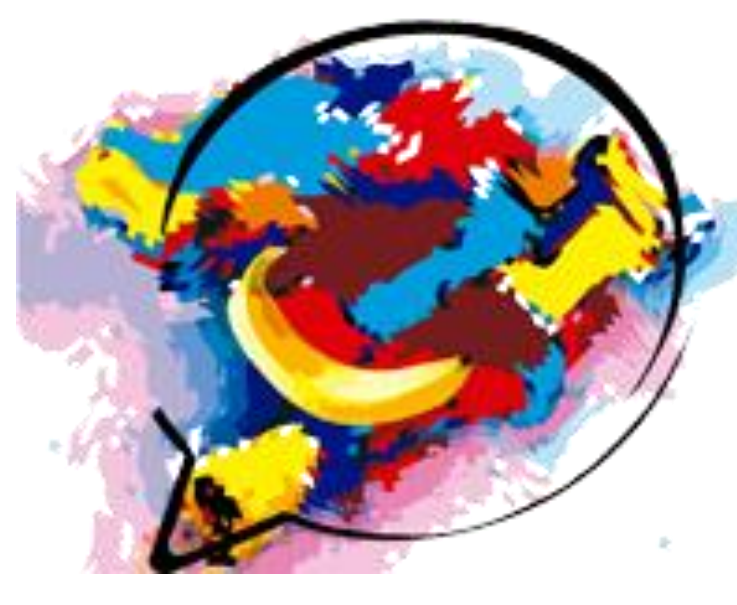

Livro de Anais do

\title{
Scientiarum Historia X
}

CONGRESSO DE HISTÓRIA DAS CIÊNCIAS E DAS TÉCNICAS E EPISTEMOLOGIA PROGRAMA DE PÓSGRADUAÇÃO EM HISTÓRIA DAS CIÊNCIAS E DAS TÉCNICAS E EPISTEMOLOGIA/HCTE - UFRJ

8 a 9 de novembro de 2017

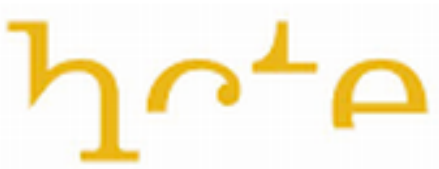




\section{FICHA CATALOGRÁFICA}

Congresso Scientiarum Historia X (2017: Rio de Janeiro: RJ).

Congresso Scientiarum Historia X: 08 a 10 de Novembro de 2017,

Rio de Janeiro, Brasil - 2017

596 p.: II. ; $28 \mathrm{~cm}$.

Livro de anais do Congresso Scientiarum Historia $X$ promovido pelo Programa de PósGraduação em História das Ciências das Técnicas e Epistemologia - HCTE / Universidade Federal do Rio de Janeiro/UFRJ, Centro de Ciências Matemátics e da Natureza/CCMN.

ISSN 2675-7559 (on-line)

ISSN 2176-123X 1 (impresso).

1. Epistemologia. 2. História da Ciência. I. Universidade Federal do Rio de Janeiro. II. Centro de Ciências Matemáticas e da Natureza. III. Título.

CDD: 509 


\section{SCIENTIARUM HISTORIA X}

Filosofia, Ciências e Artes: Conexões Interdisciplinares Criatividade é a saída!

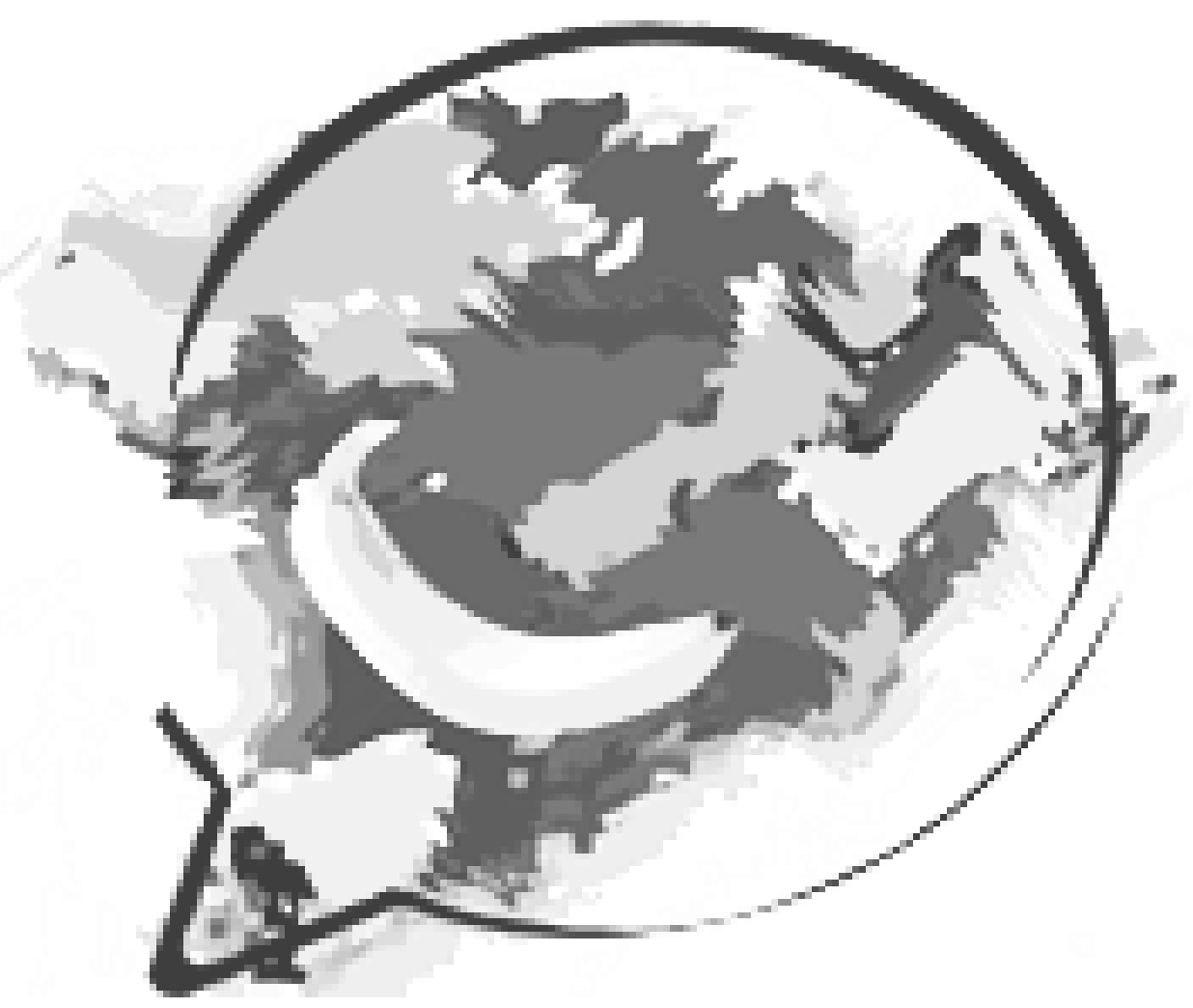

SH X -2017

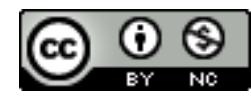

\section{CREATIVE COMMONS}

Os artigos publicados nesses anais recebem a licença Creative Commons - Atribuição Não Comercial (CC BY-NC). Com essa licença, os trabalhos podem ser utilizados e mencionados por qualquer pessoa, desde que seja para fins não comerciais e sejam citados o autor e a fonte. 


\section{INSITUCIONAL}

\section{REITOR}

PROFESSOR ROBERTO LEHER

\section{VICE-REITORA}

PROFESSORA DENISE FERNANDES LOPEZ NASCIMENTO

\section{PRÓ-REITORIA DE PÓS-GRADUAÇÃO PESQUISA/PR2}

PROFESSORA LEILA RODRIGUES DA SILVA

\section{ORGANIZAÇÃO E COORDENAÇÃO}

PROFESSOR MÉRCIO PEREIRA GOMES

\section{UNIVERSIDADE FEDERAL DO RIO DE JANEIRO}

Pró-Reitoria de Pós-Graduação e Pesquisa

Av. Pedro Calmon, 550. Prédio da Reitoria

8o andar - sala 801 - Cidade Universitária

Rio de Janeiro - RJ - Brasil

CEP 21941-901 - Caixa Postal: 68581

www.pr2.ufrj.br 
APOIO
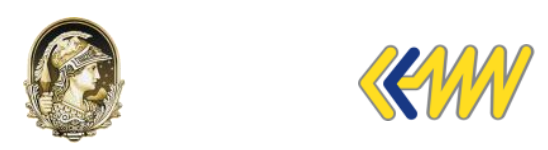

(n)

KCOPPE @FAPER

圆CNPq

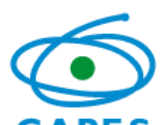

GOVERT

CAPES

REALIZAÇÃO

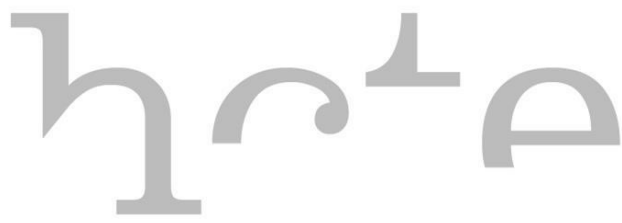

www.hcte.ufrj.br 


\section{COMISSÃO RESPONSÁVEL}

\section{COMISSÃO EXECUTIVA}

Mércio Pereira Gomes - HCTE/UFRJ - Presidente

Robson da Silva Borralho - secretário/HCTE

Alexandre Valença Teixeira - HCTE/UFRJ

Amélia Abigail Rosário de Almeida - NCE/UFRJ

Ana Paula Gonçalves - HCTE/UFRJ

Anna Cristina Cardoso da Fonseca - HCTE/UFRJ

Cláudia Santos Turco - HCTE/UFRJ

Cléber de Souza Filho - HCTE/UFRJ

Daniel Maia Amaral - HCTE/UFRJ

Dorival Rodrigues da Rocha Junior - HCTE/UFRJ

Esteban Lopez Moreno - Fundação Cecierj e HCTE/UFRJ

Fernanda Gonçalves Arcanjo - HCTE/UFRJ

Jéssyca Cordeiro Morier - HCTE/UFRJ

Jussimar de Vasconcelos Reis - HCTE/UFRJ

Kátia Correia Gorini - HCTE/UFRJ

Lilia Dias Marianno - HCTE/UFRJ

Marcelo dos Santos Azevedo - HCTE/UFRJ

Marcelo Pinheiro da Silva - HCTE/UFRJ

Marcelo Raphael Rocha Bichara - HCTE/UFRJ

Marcia Cristina de Andrade Soeiro - HCTE/UFRJ

Marcos Fialho de Carvalho - HCTE/UFRJ 
Maria Cristina de Oliveira Cardoso - HCTE/UFRJ

Maria Letícia Galluzzi Bizzo - HCTE/UFRJ

Mário Afonso da Silveira Barbosa - HCTE/UFRJ

Nelson Job - HCTE/UFRJ

Nivaldo Carneiro - HCTE/UFRJ

Palmira Margarida Ribeiro da Costa Ribeiro - HCTE/UFRJ

Raquel de Melo Porto - HCTE/UFRJ

Suzana Queiroga - HCTE/UFRJ

Thiago de Melo Ferreira - HCTE/UFRJ

Wallace Gonçalves Pereira - HCTE/UFRJ

\section{COMISSÃO CIENTÍFICA}

Luiz Pinguelli Rosa - COPPE/HCTE/UFRJ - Presidente

Mércio Pereira Gomes - HCTE/UFRJ

Ricardo Kubrusly - HCTE/UFRJ

Carlos Benevenuto Guisard Koehler - HCTE/UFRJ

César Gordon - IFCS/UFRJ

Evandro Vieira Ouriques - ECO/HCTE/UFRJ

Esteban Lopez Moreno - Fundação Cecierj e HCTE/UFRJ

Francisco Caruso Neto - CBPF/RJ

Francisco Antonio Doria - COPPE/HCTE/UFRJ

Gregory Chaitin - University of Maine/USA

Henrique Luiz Cukierman COPPE/HCTE/UFRJ

José Carlos de Oliveira - Politécnica/HCTE/UFRJ 
Nísia Trindade Lima - Pres. FIOCRUZ

Maira Fróes - NCE/HCTE/UFRJ

Maria Amélia Mascarenhas Dantes - USP

Ildeu de Castro Moreira - PRES. SBPC

Regina Costa Dantas - HCTE/UFRJ

Maria Letícia Galluzzi Bizzo - NCE/HCTE/UFRJ

Oscar Toshiaki Matsuura - USP

Virgínia Chaitin - HCTE/UFRJ

José Antônio Borges NCE/HCTE/UFRJ

Tatiana Sampaio - CCS/UFRJ

Tatiana Roque - IM/UFRJ

Ronald Shellard - Dir. CBPF/RJ

\section{SECRETARIA}

Robson da Silva Borralho

Secretário do HCTE/UFRJ

\section{DESIGN GRÁFICO}

Kika Motta (Produção de Logo) 


\section{SUMÁRIO}

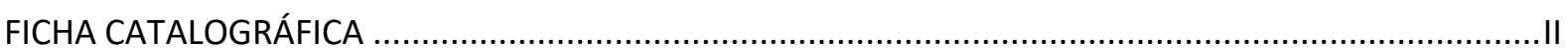

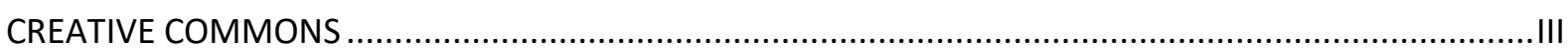

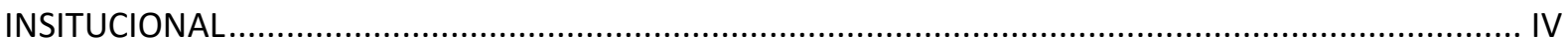

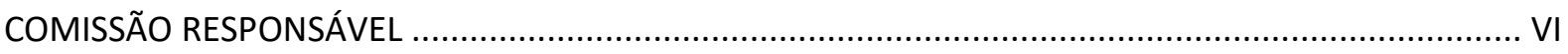

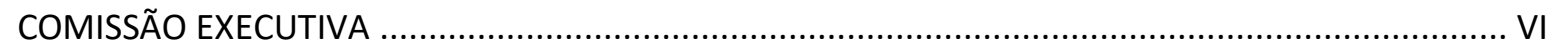

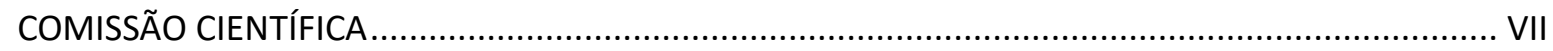

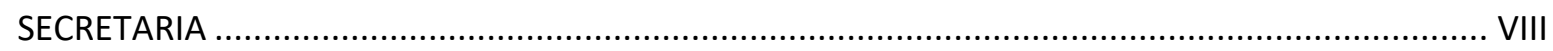

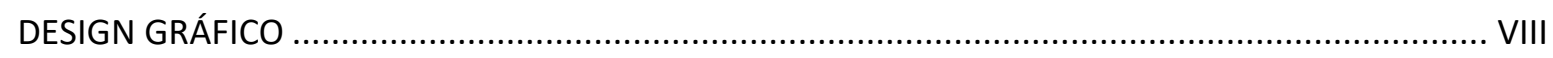

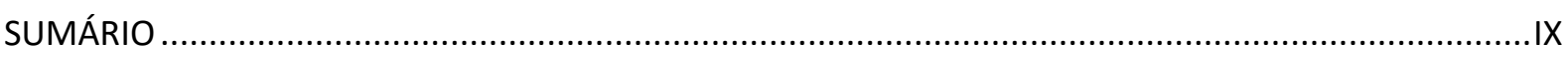

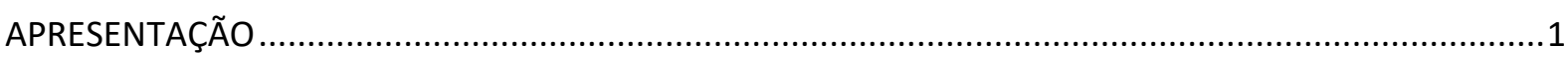

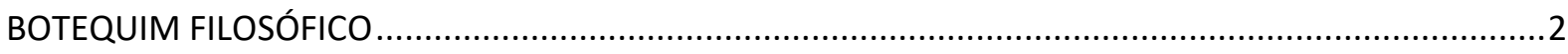

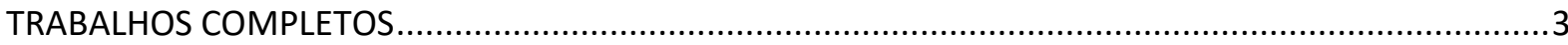

ASSOCIAÇÕES CRIATIVAS ENTRE QUADRINHOS E PINTURA

MEMÓRIAS TECNOLÓGICAS - LEVANTAMENTO DE TRABALHOS DAS DUAS PRIMEIRAS EDIÇÕES DO SIMPÓSIO DE HISTÓRIA DA INFORMÁTICA NA AMÉRICA LATINA E CARIBE (SHIALC) ......................

UMA NOVA PERSPECTIVA DA UTILIZAÇÃO DO DOSVOX NO TRATAMENTO DAS DEFICIÊNCIAS

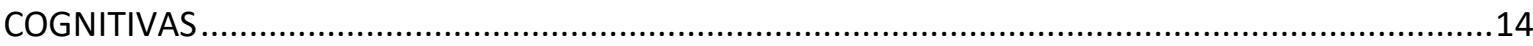

SOBRE PADRÕES DE DISTRIBUIÇÃO E ÁRVORES EVOLUTIVAS NO TRABALHO DE FRITZ MÜLLER ....18

ASTRONOMIA, HISTÓRIA DA CIÊNCIA E ENSINO DE FÍSICA: UM PROJETO INTERDISCIPLINAR .........23

ARTE CONTEMPORÂNEA E UNIVERSIDADE: REFLEXÕES SOBRE AS INFLUÊNCIAS DO AMBIENTE

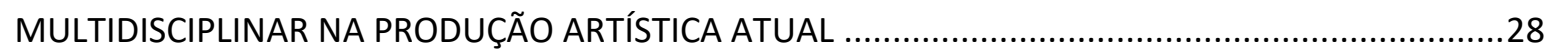

REFLETINDO A ECONOMIA DA FELICIDADE ATRAVÉS DO SISTEMA LÓGICO HIPERDIALÉTICO DE

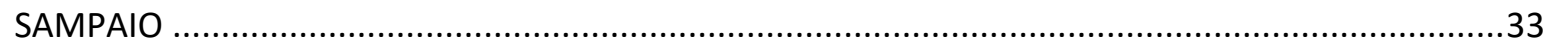

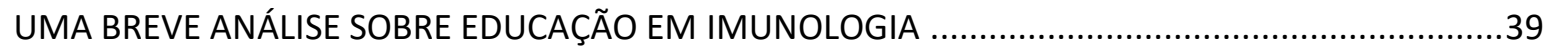

A DEFESA DA BAIA DE GUANABARA NO INÍCIO DO SÉCULO XVIII: O EPISÓDIO DA RESISTÊNCIA NO

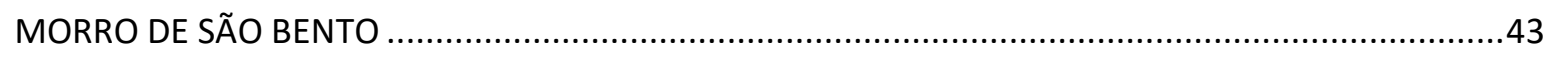

A história da ciência em Popper e Bachelard: o caso da teoria da pangênese darwiniana ...............49

PROJETO ARTE E EDUCAÇÃO: UMA VISÃO CONTEMPORÂNEA DO ENSINO DA ARTE NO BRASIL....56 RABISCOS TRIDIMENSIONAIS: IMPLANTAÇÃO DE ESCULTURAS DE ÉPURAS CONTENDO PLANOS PARTICULARES NA ILHA DO FUNDÃO

CONSTRUÇÃO E DESESTABILIZAÇÃO DO “PROJETO NACIONAL” DO PETRÓLEO ................................64

ANÁLISE DO PERFIL DOS ALUNOS INGRESSANTES NO CURSO DE LICENCIATURA EM DESENHO DA UFRJ NO ANO DE 2017

A MATEMÁTICA ATRAVÉS DA RESOLUÇÃO DE PROBLEMAS: UMA EXPERIÊNCIA NA SEEDUC-RJ ....74 
"NAVEGAR É PRECISO, VIVER NÃO É PRECISO": NARRATIVAS E MEMÓRIAS EM REDE NO PROCESSO DE AFILIAÇÃO DE ESTUDANTES BRASILEIROS NA UNIVERSIDADE DE COIMBRA .............................. 80

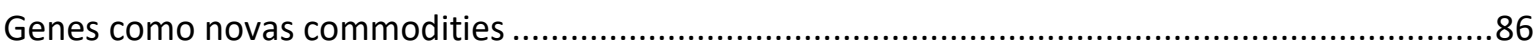

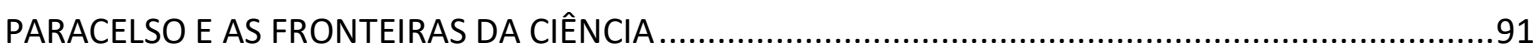

O PROGRAMA DE HILBERT E A JUSTIFICAÇÃO FINITISTA DO INFINITO ATUAL: UMA BREVE HISTÓRIA SOBRE AS JUSTIFICATIVAS E FUNDAMENTAÇÕES DO INFINITO ENQUANTO OBJETO

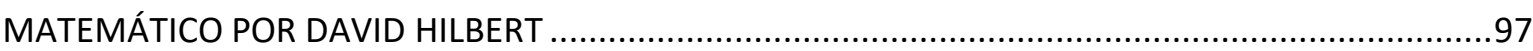

EQUATORIAL PAZOS DO OBSERVATÓRIO DO VALONGO: ORIGEM E TRAJETÓRIA.........................102 CORRUPÇÃO “PRESENTE” NO RJ: É POSSIVEL UMA ANÁLISE ANTROPOLÓGICA HIPERDIALÉTICA?

CORRUPÇÃO E JBS: Há POSSIBILIDADE DE UMA ANALISE ANTROPOLOGICA HIPERDIALÉTICA COM ELEMENTOS DE CIÊNCIA, TÉCNOLOGIA E SEGURANÇA ALIMENTAR? ............................................

PROJETO MÉTODOS DE ENSINO DA ARTE: UMA VISÃO DE THIERRY DE DUVE ..............................123

MARIANNE NORTH: UMA “CAÇADORA” DE PAISAGENS NA MATA ATLÂNTICA BRASILEIRA (1872 -

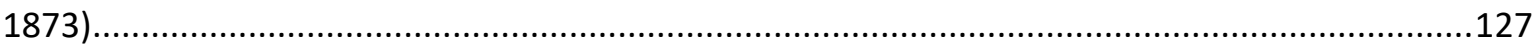

MORCEGOS PODEM DOAR SANGUE? A MALANDRAGEM, A CONFIANÇA E O BRASIL .....................133

ENFRASCANDO OS CHEIROS: A IMPORTÂNCIA DO OLFATO COMO OBJETO DE PESQUISA ............139

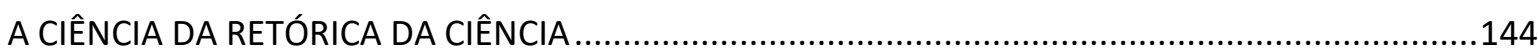

As práticas do laboratório de Manguinhos nos primórdios do século 20 (perduram?...) ..............154

Reflexões sobre as contribuições de um guarda-parques para os estudos do comportamento animal no século XVIII

Partituras imagéticas do corpo: um experimento transdisciplinar em neurociência e arte contemporânea

Problemas na aprendizagem de matemática: uma proposta de ensino usando videoaulas .........179

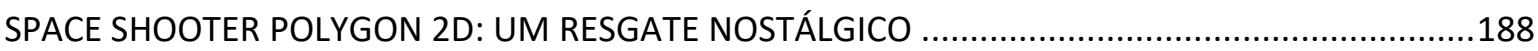

A música na Exposição Internacional do Rio de Janeiro (1922): contribuições da ciência ..............194

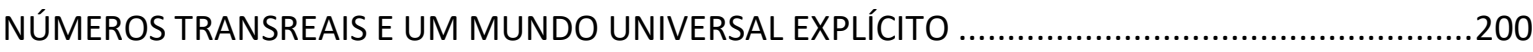

Literatura judaico-cristã e a escrita de si no tratamento de usuários de substâncias psicoativas na

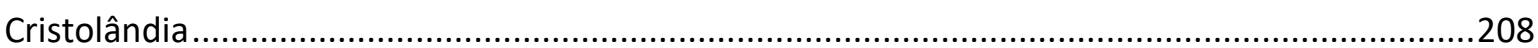

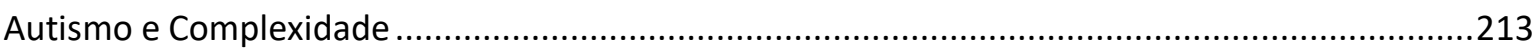

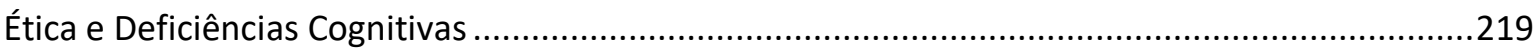

Anatomia das Paixões: Teatro como método de cuidado em saúde mental: experiência na rede de saúde mental e sistema prisional com as práticas de cuidado e ressocialização ............................224

A Estética enquanto interseção entre Arte e Ciência - uma proposta...........................................228

Rastreando a produção de casos clínicos: um estudo etnográfico de uma divisão de psicologia

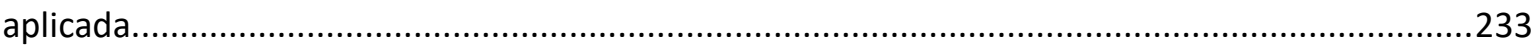

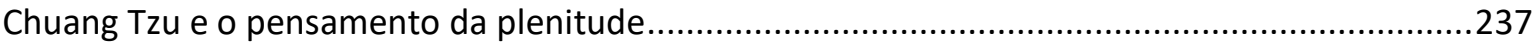

A Territorialidade na Visão Lógica-cultural Hiperdialética ..........................................................246 
Cannabis Cnidoscolus - Uma Proposta de Reserva para o Comércio Legalizado da Maconha

NOTAS DE CONTAS E FONTE HISTÓRICA: ESTUDO DOS QUIMONOS DE MARIA AUGUSTA RUI BARBOSA

Metodologias Transdisciplinares em História das Ciências: Mineração de Dados em Documentos Históricos

DAS PÁGINAS DO DIÁRIO ÀS PÁGINAS DO BLOG: DEFICIÊNCIA E CORPO NA NOVELA VIVER A VIDA

COLORINDO O ENSINO DE QUÍMICA: O EFEITO DA COR NO APRENDIZADO DE QUÍMICA

Novas ideias exigem uma nova escola de engenharia: o contexto de fundação da EFE sob o pensamento de seu primeiro diretor.....

Diversidade de gênero e o pensamento evangélico brasileiro : Análise dos conflitos pela ótica da Antropologia Hiperdialética

Evolução da Política em Ciência, Tecnologia e Inovação: Considerações sobre Internacionalização, Interação Ciência-Sociedade e Desafios para o financiamento da Pesquisa no Brasil

A performance do direito à saúde no Brasil: da Constituição à morte? 299

Projeto Resgate da memória visual das ruínas do Sahy em Mangaratiba Rio de Janeiro .304

Sócrates, Platão, Popper e a Tradição Crítica 309

Alimentação Coletiva

Os prontuários e leis psiquiátricas como fonte historiográfica e etnográfica da Reforma

Psiquiátrica Brasileira: novos modos de governamentalidade?

A História não ensinada

O Mundo Novo é de fato novo: análise comparativa das descrições da flora das Américas feitas por Bartolomé de Las Casas e Gonzalo Fernandez de Oviedo

CONHECIMENTO CIENTÍFICO E INFORMAÇÃO: SOCIEDADE, INDIVÍDUO E FALSAS NOTÍCIAS CIENTÍFICAS

Reflexões sobre as indisciplinaridades.

“OUVINDO COM OS OLHOS”: CINCO SÉCULOS DE CAMINHOS E DESCAMINHOS PELO MUNDO OUVINTE

Literatura e Teologia Natural: História e Filosofia das Ciências à luz da epistemologia de Ludwik Fleck

Criando Pensamentos sobre o Viver com Edgar Morin

SUBJETIVIDADE, ÉTICA E COMPLEXIDADE NA EDUCAÇÃO: ENTRELAÇAMENTOS PARA UMA NOVA COMPREENSÃO DA REALIDADE

A periferia da periferia - a ciência do cotidiano desenvolvida pelos laboratórios regionais dos

"mundos corporativos": Um estudo de caso.....

Criatividade servindo linhas de fuga em duas histórias de invisíveis - um estudo CTS

O GÊNIO CRIATIVO DE MAX PLANCK E O NASCIMENTO DA FÍSICA MODERNA: do desespero à revolução quântica 
Tecnologias da Informação para Fins Sociais - Pesquisa-ação no estudo da vigilância digital sofrida

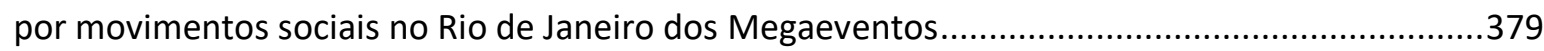

O direito à cidade e mobilidade social: um estudo sobre os trilhos que cortam uma cidade .........385

O pensamento de Edgar Morin através de seu livro: Meus filósofos ............................................390

Sistemas digitais de navegação e a inovação no plano da linguagem cartográfica advinda dos

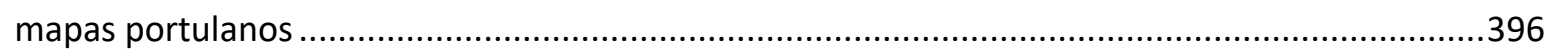

Atendimento psicológico online: acompanhando a construção de uma prática ............................402

CIDADE: RELAÇÕES PSICOGEOGRÁFICAS E TRANSGRESSÕES PSICOPOLÍTICAS NA ARTE...............408

Os malandros cariocas : profissionais da boêmia brasileira ..........................................................414

No meio do caminho: o Desenho Geométrico e Projetivo entre as "Duas Culturas".....................418

Seria o vácuo quântico Diraqueano do século XX: uma releitura da vacuidade Búdica do século V

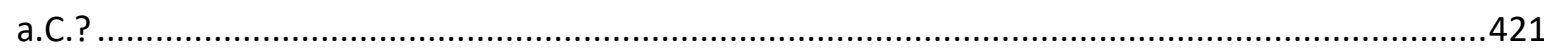

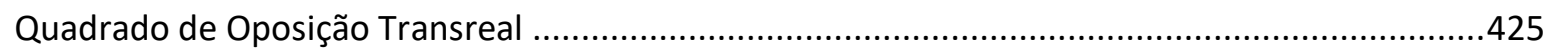

As interações complexas do milieu técnico na hominização e evolução humana .........................430

A HISTÓRIA DA MATEMÁTICA COMO AUXÍLIO NO PROCESSO DE RESOLUÇÃO DE PROBLEMAS

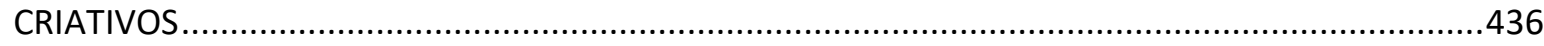

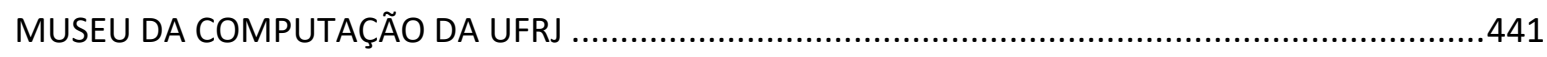

O PAPEL DA MATEMÁTICA NA RELAÇÃO DO HOMEM COM A REALIDADE: ALGUMAS QUESTÕES E

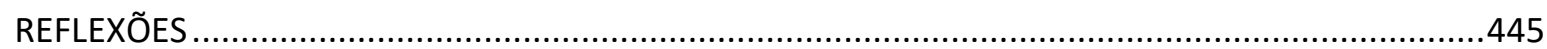

Um olhar sobre acesso, pertencimento e permanência da mulher como pesquisadora no Brasil

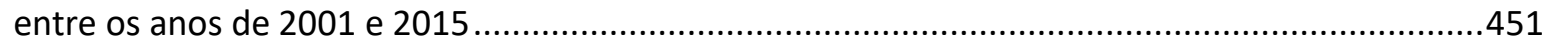

O ENSINO DE CIÊNCIAS NO EMCCF: ATIVIDADES DE UMA EQUIPE MULTIDISCIPLINAR ................459

BITCOIN: MATERIALIDADES, LIBERDADES E INTERAÇÕES DE UMA MOEDA-REDE ….....................463

NO PALCO DA CIDADE: O RIO DE JANEIRO QUE A MODERNIDADE TENTOU ESCONDER ...............469

O Olhar do Visitante: O Caso do Museu Espaço Memorial Carlos Chagas Filho .............................475

A Construção do conhecimento matemático por meio do teatro - DESENVOLVIMENTO DO CLUBE

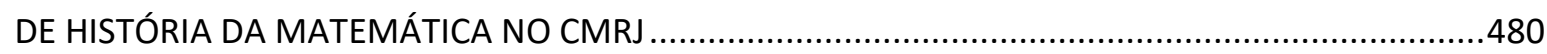

A GUERRA ENTRE HOMENS E MOSQUITOS: O LEGADO DA CAMPANHA DE ERRADICAÇÃO DA

MALÁRIA PARA O COMBATE ÀS EPIDEMIAS DE DENGUE, ZIKA E CHIKUNGUNYA ........................487

SUPER-HERÓIS, HISTÓRIA DOS QUADRINHOS E A POPULARIZAÇÃO DAS CIÊNCIAS ........................492

Como se produz um usuário de saúde mental? Breves considerações de uma etnografia em um

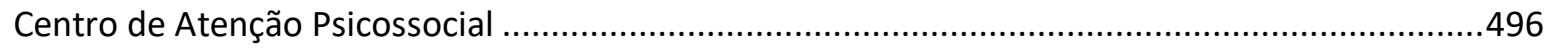

CRIATIVIDADE, HISTÓRIA E O SURGIMENTO DE UM ESPAÇO SINÉRGICO: o papel da imaginação na quebra de paradigmas institucionais.

A Educação financeira NO ENSINO BÁSICO - UMA PROPOSTA PARA Trabalhar o conceito de

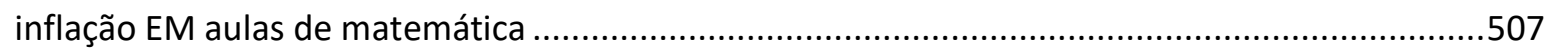

RIO DE JANEIRO: NATUREZA, BIODIVERSIDADE E O REGISTRO DOS VIAJANTES ...........................515

RIO DE JANEIRO: NATUREZA, BIODIVERSIDADE E O REGISTRO DOS VIAJANTES ...........................523 
EXPLORANDO AS OFICINAS DE SÓLIDOS

SONHOS LÚCIDOS: METODOLOGIA, DESENVOLVIMENTO DE HABILIDADES, prevalência E INDUÇÃO

Joaquim Monteiro Caminhoá: Um Médico llustrado do Império do Brasil (1858-1896)

A importância da criatividade computacional para a literatura generativa: reflexões sobre arte,

ciência e tecnologia na ciberliteratura.

MANOEL BOMFIM E CELSO FURTADO: PENSADORES ORIGINAIS DO BRASIL

Os arquivos pessoais e a história da ciência: a ornitologia brasileira no Arquivo de Helmut Sick..555

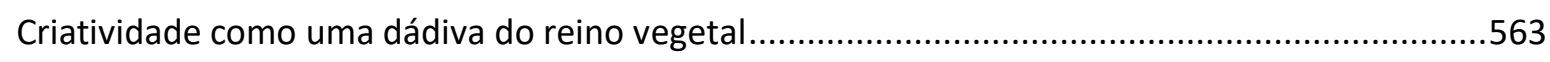

Museópolis: um jogo como caso de colaboração para a História e Filosofia da Ciência .................569

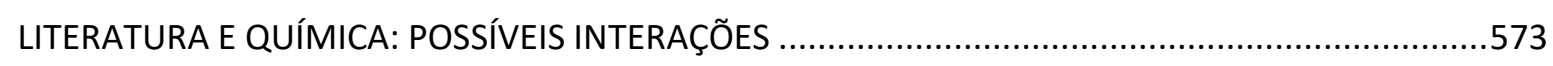

Historicidade do conceito da Consciência Quântica ...................................................................577 


\section{APRESENTAÇÃO}

Em qualquer circunstância humana a criatividade é sempre o melhor ponto de vista. Ser criativo permite entender, inclusive, o quê não é criativo, o corriqueiro. Nunca o contrário. Eis porque festejamos a criatividade como a arma cognitiva mais apropriada para os nossos tempos.

O brasileiro gosta de se fazer criativo. É a posição a partir da qual ele tenta entender o mistério de ser brasileiro. Está na hora de provar que o brasileiro é criativo.

Nesses tempos de muita perplexidade no país, estamos comemorando a 10 a edição do Congresso Scientiarum História, uma realização do nosso Programa de Pós-Graduação em História das Ciências, das Técnicas e Epistemologia (HCTE).

O que é ser criativo nas ciências, nas artes e na ética no Brasil? Nossa pergunta não é retórica. Ela requer uma exposição de ideias, discussão, debates, como forma de vencer alguns dos nossos grandes problemas da atualidade.

O 10 Congresso Scientiarum História se realizou nos dias 8, 9 e 10 de novembro de 2017, nas dependências do CCMN-NCE-UFRJ, no campus Fundão. Convidamos a todos os alunos, professores, intelectuais e brasileiros em geral para participar das mesas de debate, das exposições de ideias, nas modalidades orais, nos pôsteres e no Botequim HCTE.

Refletimos sobre o Brasil, sobre as ciências, sobre as artes e sobre a nossa ética. Queremos sempre participar da (re)construção do Brasil.

No Xo Congresso realizamos uma reflexão límpida e interdisciplinar acerca do Brasil e do mundo em que vivemos, como chegamos até aqui nos ramos do conhecimento, das artes e da ética, e quais são os desdobramentos possíveis. Para isso, contamos com inúmeros pesquisadores e agentes oriundos dos diversos campos de atuação: filósofos, matemáticos, físicos, biólogos, antropólogos, artistas, espiritualistas etc.

Nosso motor e inspiração é a CRIATIVIDADE. Por ela focamos nos temas ciências, artes e ética. Entretanto, o SH X se abriu para comunicações em outros temas, tais como, o papel da universidade na construção de avanços nas ciências e nas artes, a produção de conhecimento, a ética brasileira, as experiências em ensino e produção de conhecimento, a pulsante ciberesfera, com seus hackers e bitcoins, e, finalmente, uma discussão acerca dos rumos da interdisciplinaridade, tanto no contexto específico do HCTE, como na produção intelectual brasileira e mundial.

Todas essas questões são discutidas nos formatos tradicionais de mesas de debate, comunicações orais e pôsteres dialogados. Acrescentamos uma nova modalidade, o Botequim Filosófico HCTE. Aqui, em cinco minutos, em linguagem simples cada participante expõe sua ideia o mais claramente possível. Por tudo isso fizemos do SH X um evento marcante e diversificado que se engradeceu engrandecido pela participação de professores, estudantes e demais interessados. $O$ espaço físico de realização do evento se deu nas dependências do CCMN e do NCE no campus do Fundão da UFRJ.

Este Livro de Anais é o produto de nosso Congresso.

\section{Merciof. Gans.}

Presidente do 10 을 Congresso Scientiarum Historia Coordenador do HCTE 


\section{BOTEQUIM FILOSÓFICO}

A Comissão Executiva do nosso Congresso retoma uma modalidade de apresentação das contribuições orais, criada no SH8 de 2015, com grande sucesso. Essa modalidade, chama-se Botequim Filosófico.

A ideia do Botequim Filosófico é ter um grupo de quatro a cinco pessoas sentadas em volta de uma mesa, como se estivessem num botequim bebendo cerveja e comendo tira-gosto e conversando sobre a vida. Só que a vida aqui é um tema, o tema de suas ideias e de suas pesquisas. Cada mesa terá um tempo de 2 horas para conversar. Os membros decidem a ordem da falação, como falar e quanto tempo falar. Não pode gritar nem falar alto demais; nem usar nenhum auxílio tecnológico para sua apresentação. Ou seja: nada de Datashow ou notebook; só a fala e os tradicionais de guardanapos de boteco.

Não há líderes nem instrutores de fora. A ideia é auto-organização, espontaneidade nas falas, junto com capacidade de síntese e abertura para as ideias dos outros. Os temas serão variados. É um desafio novo e um treinamento para quem deseja transmitir suas ideias com clareza em pouco tempo.

Essa nova modalidade de comunicação é importante e instigante - também -, reunirá em uma mesma mesa do Botequim alunos/pesquisadores da graduação e os da pós-graduação.

Inscrevam-se marcando a caixa de diálogo presente na área de inscrição. Temos 20 vagas, que serão escolhidas entre os trabalhos selecionados para o SHX, nas modalidades de comunicação oral e pôster dialogado.

A apresentação de trabalho no "Botequim Filosófico" fará jus a um certificado extra, específico, de participação.

\section{EXPERIENTIA 2017}

Telepatia ionizante: a arte em ressonância entre o material e o sutil

Cila MacDowell - PPGAV. EBA

A artista e pesquisadora Profa. Cila MacDowell é nossa convidada para o Experientia.5, nesta 10a. edição de nosso congresso anual Scientiarum Historia X.

Cila nos traz o cerne experimental e inspiracional de sua pesquisa de doutorado em andamento, pelo Programa de Pós-Graduação em Artes Visuais PPGAV, da Escola de Belas Artes/UFRJ, e que vem sendo realizada sob a orientação do Prof. Guto Nóbrega (NANO, EBA/UFRJ). Segundo a autora artista pesquisadora, "...cada ínfima partícula e todos os corpos estariam a produzir efeitos por ligações sensíveis e sutis...Haveria algo em seus pensamentos que não sejam propriedades individuais?" Traremos à experimentação in loco e à discussão as questões endereçadas pela artista concernentes a uma meta ou extra sensorialidade no humano.

Apoio: PR-5 UFRJ - Realização: HCTE/UFRJ, PPGAV/UFRJ, Anatomia das Paixões/RUA 2017 


\section{ASSOCIAÇÕES CRIATIVAS ENTRE QUADRINHOS E PINTURA}

Lucas Almeida de Melo - Graduando em Educação Artística com Habilitação em Artes Plásticas pela EBA, UFRJ Imelo496@gmail.com

Matheus Nascimento da Silva - Graduando em Educação Artística com Habilitação em Artes Plásticas pela EBA, UFRJ - matheus.jadejishi@hotmail.com

Marcus Vinícius de Paula - Doutor em Design pela PUC/RJ. Professor da Escola de Belas Artes - UFRJ -

depaulamarcusvinicius@gmail.com

\section{Resumo}

O cartaz é resultado da parceria entre dois trabalhos de iniciação científica que fazem parte do projeto de pesquisa "Arte e Comunicação Visual: A linguagem dos quadrinhos e a questão da narrativa na pintura acadêmica", coordenado pelo professor Marcus Vinícius de Paula (EBA-UFRJ). Vamos analisar e comparar as relações entre duas experiências que associam a história da pintura à linguagem dos quadrinhos. Em primeiro lugar apresentaremos o álbum "Au Fil de l'Art" de Gradimir e Ivana Smudja, e, em seguida, a "História em Quadrões" por Mauricio de Sousa. Por fim, procuraremos demonstrar suas semelhanças e particularidades criativas.

Palavras-chave: História em Quadrinhos. Pintura Acadêmica. Au Fil de l'Art. História em Quadrões. Criatividade.

Introdução

Pretendemos mostrar duas experiências criativas que lidam com o diálogo entre as linguagens dos quadrinhos e da pintura. Ambos os trabalhos que apresentaremos lidam com essa questão, mas de maneiras bem distintas. O primeiro apresenta o álbum "Au Fil de l'Art", um quadrinho francês, que narra, com muito humor, episódios da história da pintura. O segundo, por sua vez, lida com as publicações e exposições denominadas História em Quadrões, do artista brasileiro Mauricio de Sousa, que transporta os icônicos personagens da Turma da Mônica para telas inspiradas em pinturas célebres da história da arte.

Metodologia

A raiz metodológica utilizada nesta pesquisa baseia-se na noção de iconologia. Esse método de abordagem da imagem foi instituído por Aby Warburg e Erwin Panofsky na primeira metade do século XX. Mais recentemente William Mitchell estabeleceu um novo marco e reformulou esse conceito por meio dos livros "Iconology, image, text, ideology" (MITCHELL, 1987) e Picture Theory (MITCHELL, 1995) criando o que ele denominou como iconologia crítica. O método iconológico que utilizaremos aqui, apesar de partir das diretrizes estabelecidas por Mitchell, será mais comparativo. Os fundamentos dessa iconologia 
comparativa (ou do que denominaremos também como intericonicidade) estão definidos pelo orientador desta pesquisa no artigo A Fratura Iconológica (DEPAULA, 2012).

A análise se apoiou em três fundamentos bibliográficos: em primeiro lugar estão, como já mencionamos, as diretrizes iconológicas; em seguida utilizamos também autores especializados na análise da linguagem em quadrinhos, como Scott McCloud, Will Eisner, Thierry Groensteen e Umberto Eco. Para analises das pinturas, usamos os livros da editora Taschen sobre a vida e obra de artistas renomados, vários deles citados no quadrinho europeu "Au Fil de l'Art" e no material brasileiro "História em Quadrões".

Au Fil de l'Art

"Au Fil de l'Art" foi produzido pela editora francesa Decourt, em 2012 (ainda não existe tradução para português) e é composto por dois volumes com lombada quadrada, capa dura e com aproximadamente duzentas páginas cada um. Narra, através da linguagem dos quadrinhos, pequenas passagens fictícias da vida de grandes mestres da história da arte europeia.

A narrativa é costurada por meio das aventuras da jovem Luna e seu gato falante Vicente (é Vicente ou Vincent?), uma possível homenagem a Vicent van Gogh ou Leonardo da Vince. Tudo começa quando esses personagens tropeçarem em uma linha vermelha e caem em um buraco que os leva às cavernas de Lascaux, no sudoeste da França. Essa linha vermelha é um importante meio gráfico que aparece e desaparece em diversas cenas.

A cada mudança de época e de pintores, nos deparamos com duas páginas, em tom de sépia, destinadas a uma breve biografia do artista. Nessas páginas, a linha vermelha se destaca e constrói um fio que perpassa todo o álbum e estimula as conexões entre os artistas.

A seriedade do discurso teórico e crítico da história da arte é substituída por uma narrativa brincalhona e descontraída, típica da linguagem dos quadrinhos. Questões complexas relativas à visão monocular de Leonardo às contorções maneiristas de Michelangelo são tratadas com o humor tópico da gag.

História em Quadrões

A ideia do livro "História em Quadrões" surgiu da necessidade de expor trabalhos que o autor, Mauricio de Sousa, realizou com a intenção de "incentivar a criatividade e divulgar a arte de um jeito divertido" (SOUSA, 2001, p. 9). Essa edição contou com 47 obras, incluindo uma escultura em isopor com revestimento em resina dentre as telas em tinta acrílica e foi publicada no ano de 2001 junto da exposição de mesmo nome.

Segundo Jacqueline Mouradin, curadora da exposição, "História em Quadrões" seguiu o seguinte itinerário desde o lançamento, conquistando quase um milhão de visitantes e dois prêmios no HQ Mix (Categoria de Melhor Exposição do Ano e Categoria Valorização das Histórias em Quadrinhos):

- 2001 - Pinacoteca do Estado de São Paulo

- 2002 - Museu Nacional de Belas Artes - Rio de Janeiro

- 2002 - Conjunto Cultural da Caixa - Salvador

- 2002 - Museu Metropolitano de Arte - Curitiba

- 2003 - Conjunto Cultural da Caixa - Brasília

- 2004 - Palácio do Planalto - Brasília

- 2004 - Palácio das Artes - Belo Horizonte

- 2004 - Museu de Arte de Goiânia - Goiânia

- 2004 - Instituto Ricardo Brennand - Recife 
Junto de uma segunda edição, publicada em 2010 com 45 obras sendo 14 delas esculturas, em 2014 as obras foram para a Coreia do Sul, tendo sido até o presente momento sua 13a exposição no Iksan Art Center Museum (27 de maio a 20 de agosto de 2017).

\section{A criatividade em Aul Fil de L'Art}

No capítulo referente a Leonardo da Vinci utiliza a "Última Ceia" para explorar outro modo de representação, típico do Renascimento: "A perspectiva da Renascença é do tipo monocular uma vez que todas as linhas convergem para um só ponto" (SMUDJA, 2011, p.12). Neste famoso afresco, o espaço foi "construído de acordo com as regras de perspectiva central. As linhas de perspectiva encontram-se no olho direito de cristo, o que por si só enfatiza a sua posição central tanto na posição atual como na da representação" (ZÖLLNER, 2000, p.50) Esse olhar renascentista pode ser também associado à contemplação prolongada e ao processo de reprodução calmo e vagaroso que atribuem a Leonardo. Em oposição a essa tranquilidade, Ivana e Gradimir Smudja colocam Luna e seu gato observando o artista num momento de grande agitação, pois não pode terminar a Última Ceia porque precisam recuperar os doze modelos que representam os apóstolos, que se encontram embriagados numa taberna. Porém, a anedota jocosa inventada por Smudja acaba por remeter ao processo artístico, na medida em que Leonardo procurou exaustivamente por modelos específicos para representar cada apóstolo. Frank Zöllner diz que: "Leonardo não poupou esforços para conseguir uma variedade de gestos e expressões faciais fortes que pudesse usar cada um dos discípulos: procurou mesmo modelos apropriados para as mãos" (ZÖLLNER, 2006, p. 54).

Já no capítulo referente a Michelangelo, o artista se viu forçado a aceitar o convite do Papa Júlio II para decorar com afrescos a abóboda da Capela Sistina. Em "Au Fil de L'Art", Michelangelo está justamente envolvido com esse problema. Ele orgulhava-se de ser escultor e desprezava os pintores. Questionado por Luna, o casal Smudja usa de maneira inovadora o recurso do balão de fala para apresentar a solução compositiva (Figura 1). Estabelece uma conexão entre a linguagem da pintura e os quadrinhos, na medida em que a estrutura narrativa do teto é composta pelo emparelhamento de quadros. A esse respeito, Will Eisner comenta que o traçado do requadro é criado de acordo com a ação dada pelas exigências da narrativa e pelas dimensões da fala. (EISNER, 2001, p.51).

Figura 1 Ei! Mas não está mal de maneira alguma!

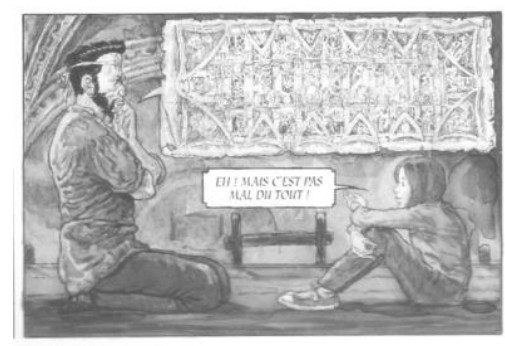

A criatividade das Histórias em quadrões

Com o intuito de atrair o público infantil para os museus, Mauricio fez uso de seus personagens em releituras dos mais famosos quadros do mundo querendo que as crianças aprendessem mais sobre a história da arte e os autores das obras originais, para isso, junto das paródias estavam cópias dos originais.

No quadro Mônica no Nascimento de Vênus, a personagem principal do original Vênus (deusa do amor e beleza) em O Nascimento de Vênus, é substituída por uma sereia que aparece em Mônica no9, Ed. Abril: 1971 e num longa metragem em 1986. Anjinho e Mônica, como os deuses do vento e da floresta, respectivamente, ajudam a trazer a sereia para a terra, assim como fazem os outros na obra de referência. Curioso a escolha da personagem de Mauricio 
para ser a atenção principal da imagem, sendo que ela é secundária em suas histórias. Ambas as personagens são originadas na água e tem beleza/charme capaz de seduzir qualquer homem no mundo. O real motivo poderia estar na sexualização que a deusa de Botticelli naturalmente carrega por estar despida e preocupada com o fato, tentando ainda esconder as partes íntimas ao máximo que pode, não querendo o autor brasileiro sexualizar uma de suas personagens principais.

Em A Criação do Cebolinha (Figura 2), assim como na pintura de Michelangelo "A Criação de Adão" Mauricio brinca com a temática da criação-criador retratando a si mesmo como criador e um de seus personagens como a criatura da criação. Algo importante a ser apontado é que no estudo do desenho antes de passar para a tela, Mauricio havia rascunhado o personagem Franjinha juntos dos outros próximos a si, entretanto ele foi retirado como é possível ver na arte finalizada. Para compreender o que aconteceu, deve-se entender primeiro que na parte direita do quadro, junto do autor, os personagens retratados como os anjos do Senhor ainda não existiam no mesmo plano que Cebolinha, naquele momento. Ou seja, eles estavam no plano das ideias, enquanto o Franjinha já existia com seu cachorro Bidu, sendo ambos os primeiros personagens criados. Logo, na criação do Cebolinha, Franjinha não poderia estar no plano das ideias.

Cebolinha ainda traz consigo outro aspecto importante que o torna o personagem perfeito para estar no lugar de Adão (primeiro homem de Deus), sendo o personagem do quadrinista o primeiro principal da Turma da Mônica a ser criado.

Figura 2 - A Criação do Cebolinha

\section{Conclusão}

Iremos fazer uma comparação entre as duas experiências: Tanto "Au Fil de I'Art" quanto História em Quadrões estabelecem de modo criativo e divertido um diálogo entre quadrinhos e pintura. Podemos verificar inicialmente que "Au Fil de l'Art" é um álbum em quadrinhos que tem como temática a história da pintura. Já na História em Quadrões, por sua vez resulta da produção de telas emolduradas que foram expostas em museus (de acordo com os códigos institucionais da pintura acadêmica). História em Quadrões gerou também dois livros que seguem o modelo dos catálogos de exposição de arte. Portanto, poderíamos a princípio deduzir, então, que enquanto "Au Fil de l'Art" é uma experiência dos quadrinhos que remete à pintura, "História em Quadrões" é uma experiência da pintura que remete aos quadrinhos. Talvez a resposta não seja tão simples assim, pois a linguagem da pintura não é apenas um pano de fundo temático para "Au Fil de l'Ar"t e os personagens de Mauricio de Sousa não são apenas uma mera referência iconográfica para "História em Quadrões".

Vamos utilizar como estudo de caso para concluir esse trabalho o modo como cada uma destas experiências associou a pintura de Michelangelo à linguagem dos quadrinhos: Tanto "Au Fil de l'Art" quanto "História em Quadrões" brincam com as diferentes estratégias figurativas difundidas pela história da pintura e pelos quadrinhos, entretanto Mauricio de Sousa estabelece as relações na aproximação de quadrinhos em pintura já em "Au Fil de l'Art" a pintura que é transformada em quadrinhos. Além disso, o recurso transmidiático em "Au Fil de l'Art", no qual o projeto (disegno) da Capela Sistina é exposto dentro de um balão de fala, entrelaça as linguagens dos quadrinhos e da pintura induzindo reflexões gráficas no eleitor. Não é preciso utilizar uma obra em quadrinhos feita sobre a história da pintura para tratar da relação entre essas duas mídias. Isso porque é possível encontrar essa interseção em diversos 
quadrinhos onde essa relação não é evidente. Isso significa que pode-se utilizar quadrinhos comerciais para o ensino de história da pintura como no exemplo encontrado.

Assim, é interessante perceber que tanto Ivana e Gradimir Smudja quanto Mauricio de Sousa produzem uma "intericonicidade" entre as duas linguagens, porém criadas para diferentes tipos de reflexões entre as associações criativas entre quadrinhos e pintura.

\section{Bibliografia}

DEPAULA, Marcus Vinicius. A Fratura Iconológica. In: Revista Poiésis 20, 2012.

A Pintura Histórica Degenerada: fundamentos da intericonicidade crítica da obra de arte. Rio de Janeiro: UERJ. Revista Concinnitas ano 17, vol. 1, n. 28 (p. 298-324), 2016.

ECO, Umberto. Apocalípticos e Integrados. São Paulo: Perspectiva, 1993.

EISNER, Will. Quadrinhos e arte sequencial. São Paulo: Ed. Martins Fontes, 2001.

GASCA, Luís. MENSURO, Asier. La pintura en el cómic. Madrid: Editiones Cátedra, 2014.

GROENSTEEN, Thierry. O Sistema dos Quadrinhos. Nova Iguaçu: Ed. Marsupial, 2015.

McCLOUD, Scott. Desvendando os quadrinhos. São Paulo: M. Books do Brasil Editora, 2004.

MITCHELL, W.J.T. Iconology, image, text, ideology. Chicago: The University of Chicago Press, 1987.

Picture Theory. Chicago: The University of Chicago Press, 1995.

MOZDZENSKI, L.; VAZ, A.; SILVA, M. C. H. Da obra-prima ao pastiche: multimodalidade e intericonicidade nos "Quadrões" de Mauricio de Sousa. 1. ed. Anais Eletrônicos. Recife: Universidade Federal de Pernambuco, 2008. Disponível em http://www.ufpe.br/nehte/simposio2008/anais/Leonardo-Mozdzenski-e-Ana-Vaz.pdf.

PANOFSKY, Erwin. O significado nas artes visuais. Lisboa: Ed. Presença, 1989

SMUDJA, Ivana, SMUDJA, Gradimir. Au Fil de l'Arte, volume 1. Paris: Delcourt, 2012.

SOUSA, Mauricio de. História em Quadrões - Pinturas de Mauricio de Sousa. São Paulo: Ed. Globo, 2001.

SOUSA, Mauricio de. História em Quadrões com a Turma da Mônica, 2. São Paulo: Ed. Globo, 2010. ZÖLLNER, Frank. Leonardo. Lisboa: Taschen, 2006. 


\title{
MEMÓRIAS TECNOLÓGICAS - LEVANTAMENTO DE TRABALHOS DAS DUAS PRIMEIRAS EDIÇÕES DO SIMPÓSIO DE HISTÓRIA DA INFORMÁTICA NA AMÉRICA LATINA E CARIBE (SHIALC)
}

\author{
Lucas de Almeida Pereira - Professor EBTT do Instituto Federal de São Paulo, Campus Suzano - \\ lucas.pereira@ifsp.edu.br \\ Marcelo Vianna - Instituto Federal de Educação Ciência e Tecnologia do Rio Grande do Sul, Campus Osório. \\ Alberto Jorge Silva de Lima - Professor do CFET Celso Sukow da Fonseca e doutorando em Informática e \\ Sociedade da COPPE/UFRJ - alberto.lima@cefet-ri.br
}

\section{Resumo}

A presente comunicação teve por objetivo apresentar uma revisão bibliográfica das duas primeiras edições do Simpósio de História da Informática na América Latina e Caribe (SHIALC). No total foram compilados 38 artigos, oriundos de sete países (Argentina, Brasil, Chile, Colômbia, Costa Rica, Uruguai e Venezuela. Foram estabelecidos três eixos para a organização das pesquisas que permitem identificar algumas identidades do evento, tais como experiências locais de formação de redes técnico-científicas, redes educacionais e memórias dos agentes envolvidos. A intenção é contribuir para além da compilação de memórias do evento, possibilitando reflexões sobre as características do simpósio e sua contribuição para um pensamento regional a partir das experiências tecnológicas locais.

Palavras-chaves: Anais acadêmicos. Experiências locais. História da Informática latinoamericana. Memórias.

\section{Introdução}

Até meados dos anos 2000 a bibliografia sobre a história da ciência da computação/informática na América Latina era escassa. Uma pesquisa do primeiro período da revista argentina de história da ciência Quipu ${ }^{1}$ (1984-2000), por exemplo, resultou em apenas dois artigos sobre tal temática. Embora se possa reconhecer exceções a esta constatação em alguns países, especialmente o material produzido no Brasil dedicado à reflexão sobre a Política Nacional de Informática desenvolvida em meados da década de 1970 e nos anos 1980, é certo reconhecer, até então, a inexistência de um espaço de reflexão conjunta e sistemática que reunisse pesquisadores do continente interessados em desenvolver e fortalecer este campo.

Em 2007, o projeto SAMCA (Salvando a Memoria da Computação Argentina) surgiu na Universidade de Rio Cuarto (UNRC), Argentina. No ano seguinte, a SAMCA propôs uma mesa de trabalhos sobre História da Informática na programação do congresso "Ciências, Tecnologias e Culturas na América Latina e no Caribe" (USACH - Santiago de Chile). Uma divulgação quase aleatória conseguiu angariar a presença de 15 pesquisadores de 5 países que apresentaram 22 artigos. De lá, emergiu a iniciativa de criar uma rede de trabalho e de compilar um livro com as pesquisas apresentadas. Ambos os objetivos começaram a ser alcançados em 2009. Neste ano, foi combinado com a direção do Centro Latino Americano de

\footnotetext{
${ }^{1}$ Dados compilados pelo professora Márcia Regina Barros da Silva no artigo "Para que fazer história da informática" apresentado no SHIALC Medellín.
} 
Estudios en Informatica (CLEI) a realização de um evento associado à conferência da CLEI que foi intitulado Simpósio de História da Informática na América Latina e Caribe (SHIALC). Desde 2010, quatro edições do SHIALC foram realizadas, nas cidades de Assunção (2010), Medellín (2012), Montevidéu (2014) e Valparaíso (2016), com 67 artigos aprovados, originários de oito países (Argentina [21], Brasil [29], Chile [7], Colômbia [(1)], Costa Rica [5], República Dominicana [1], Uruguai [2], Venezuela [1]), embora mais de $70 \%$ tenham sido produzidos no Brasil e na Argentina. Uma seleção dos primeiros artigos apresentados no SHIALC foi publicada em 2015, sob o título Historias de las TIC en América Latina y el Caribe (CARNOTA e LEAL, 2015).

Como evento interdisciplinar, o SHIALC vem se destacando não somente como espaço para o fortalecimento de uma comunidade de historiadores da informática latino-americanos e caribenhos, mas como espaço aberto a contribuições das mais diversas áreas do conhecimento e de práticas profissionais dedicadas também à pesquisa sobre as relações entre informática e política, economia, trabalho, universidade, educação, mudança social, negócios, meio-ambiente, políticas públicas, ciência e tecnologia, cultura, artes e humanidades. Uma prova desta abertura pode ser percebida pela chamada de trabalhos, aberta também a testemunhos e publicações de materiais que pudessem constituir uma espécie de acervo da experiência dos diversos países do continente com a informática.

O objetivo desta apresentação é estruturar as memórias do evento, bem como ressaltar a diversidade de temas e modos de abordagem que vem sido aplicados à área da história da informática na América Latina e Caribe por meio de uma revisão bibliográfica dos trabalhos aceitos nas duas primeiras edições do evento em 2010 e 2012. Foram compilados 38 artigos, oriundos de sete países (Argentina, Brasil, Chile, Colômbia, Costa Rica, Uruguai e Venezuela), a grande maioria provenientes de áreas das engenharias. Foram estabelecidos três eixos para a organização das pesquisas que permitem identificar algumas identidades do evento: Redes Técnico-Científicas (RTC), Redes educacionais (RE) e Testemunhos e Exposições de Memórias².

SHIALC - Assunção, 2010

Após a mesa realizada no Chile em 2008 os organizadores perceberam a importância de ampliar o espaço de debate em torno das experiências latino americanas em relação à implantação e desenvolvimento das práticas de processamento de dados. Após a associação com a CLEl em 2009 o Simpósio de História da Informática na América Latina e Caribe teve sua primeira edição programada para a cidade de Assunção no Paraguai. Essa edição do congresso teve 19 trabalhos apresentados, provenientes de sete países da América Latina e Caribe (Argentina, Brasil, Chile, Colômbia, Costa Rica, Uruguai e Venezuela).

No caso das RTC as pesquisas versam sobre a formação de redes técnicas em diferentes períodos e países e, em geral, abordam a formulação de políticas públicas e desenvolvimento autônomo de tecnologia. Podemos enumerar, neste sentido, os trabalhos envolvendo formação de grupos técnicos e/ou políticas públicas:

- - Raul Carnota e Carlos Borches: análise das experiências ligadas à Sociedade Argentina de Cálculo - SAC (1960-1962), um órgão que pretendia estabelecer contatos entre a produção científico-acadêmica no campo da informática e as empresas de tecnologia, tendo como fonte básica de dados os boletins produzidos pela SAC.

\footnotetext{
2É importante destacar que essa divisão tem caráter meramente expositivo, até porque não seria possível enquadrar rigidamente os artigos. Por exemplo, os-testemunhos em geral se referem às RTC ou às RE.
} 
- - Rodney Ferreira de Carvalho: análise das políticas publicadas de informática brasileira da década de 1980 e sua relação com a formação de Redes Locais (LAN), tendo como enfoque a questão de uso de softwares estrangeiros em um período de nacionalização da tecnologia.

- - Luís Amil, Carlos Gera, Carlos Beiro y Juan Piaggio: estudo sobre o grupo Jornadas de Informática de la Administración Pública (JIAP), atualmente denominados Jornadas de Informática del Uruguay, evento gratuito que oferece cursos de capacitação e intercâmbio de tecnologias de informação.

- - Aldo D. Migliaro: análise sobre o papel institucional da Pontifícia Universidade Católica do Chile na criação da Conferência Latino-Americana de Informática (CLEI) no início da década de 1970.

- - Marcelo Sávio R. M. de Carvalho; Henrique Luiz Cukierman; Ivan da Costa Marques: análise dos conflitos de interesses envolvidos na definição de padrões de protocolos de redes de computadores localizada no Brasil no final do Século XX.

- Raúl Carnota e Ricardo Rodríguez: análise do primeiro plano argentino de desenvolvimento autônomo de tecnologia fomentado pela Universidade Nacional del Sur, projeto que a despeito de suas condições iniciais favoráveis acabou não sendo levado à cabo em razão de limitações materiais, tanto financeiras quanto de aquisição de equipamentos e peças.

- - J. F. Marinho de Araújo, G. C. Rodrigues, D. F. Takano: descrição de dois equipamentos de hardware para redes locais desenvolvidos no Núcleo de Computação Eletrônica (NCE) da Universidade Federal do Rio de Janeiro no início da década de 1980.

- Com relação às Redes Educacionais destacam-se as análises e memórias sobre fundação e atividades de departamentos e cursos de informática na América Latina e Caribe. Destaque para o expressivo número de textos sobre a presença feminina em tais processos ( 5 de 23 artigos):

- Marta Eunice Calderón: análise da fundação da Escola de Ciências de Computação da Universidade da Costa Rica em 1981 e da relação do departamento com o então emergente mercado de informática no país.

- - Marta Sananes: exposição acerca da fundação do Departamento de Computação da Universidade Central da Venezuela em 1961 a de memórias da própria autora, participante deste processo.

- - Jorge Aguirre: o cientista argentino utiliza bibliografia e suas experiências pessoais para narrar uma série de viagens realizadas no início da década de 1970 para diversas instituições Argentinas e seus centros de cálculo. O autor destaca as ferramentas utilizadas antes da chegada dos computadores nessas instituições, bem como os impactos de sua adoção.

- - M. E. Urquhart, L. Bermudez y J. J. Cabezas: análise do perfil de egressos do curso de computação eletrônica da Universidade da República (Uruguai). O enfoque são os estudantes de pós-graduação (Maestrías) do período 1998-2007, destacando que a maioria (57\%) dos egressos dos cursos de engenharia da universidade são da área de computação, e destes cerca de $25 \%$ são mulheres (curso com a maior proporção de engenheiras diplomadas).

- Maria Izabel Cavalcanti Cabral: análise dos sistemas de avaliação dos cursos de informática em universidades brasileiras com ênfase no período 2004-2008. A autora destaca as ferramentas e políticas públicas de avaliação da área. 
- - Carlos Parra: análise do uso de TICs em instituições de ensino colombianas entre o final da década de 1970 e início de 1990. O artigo enfatiza as disputas e debates ligados à adoção de novas práticas e conceitos e meio ao perfil mais tradicionalista das instituições.

- - Juan Alvarez e Claudio Gutierrez: análise do processo de introdução, expansão e consolidação da informática no Chile, tendo como ponto de partida a chegada do primeiro computador no país, um IBM 1620 em 1961, e ponto de chegada as políticas públicas de informática conduzidas pelo governo ditatorial de Pinochet.

O SHIALC I também contou com a apresentação de relatos de memória de atores do campo da informática:

- Marta Eunice Calderón, Gabriela Marín: as autoras apresentam as trajetórias profissionais de três importantes cientistas da área da informática na Costa Rica: Clara Zomer, fundadora do Centro de Cálculo Eletrônico da Universidade da Costa Rica (UCR); Sílvia Chavarria Costa, primeira professora do Departamento de Computação da mesma instituição; Marta Calderón, primeira engenheira formada no Departamento de Computação da UCR. Destaque para a metodologia de história oral adotada pelas pesquisadoras;

- - Manuel Imaz: apresentação da trajetória profissional de Norma Lijtmaer, protagonista do processo de criação da Escola Superior Latino-americana de Informática (ESLAI) na Argentina. O artigo retrata a formação de Norma na Universidade de Buenos Aires em 1963, sua trajetória profissional e o papel fundamental desempenhado pela cientista na fundação da ESLAl em 1984;

- - Jorge Monteiro Fernandes: exposição de memórias acerca da participação do autor na formulação de ações ligadas ao campo da informática no Brasil, especialmente no contexto de desenvolvimento da Politica Nacional de Informática (PNI) entre as décadas de 1970 e 1980;

- - Ivan da Costa Marques: exposição de entrevistas realizadas com três empresários de empresas brasileiras fabricantes de tecnologia de informática atuantes durante o período da reserva de mercado da área no Brasil.

SHIALC - Medellín, 2012

Em 2012 foi realizada a segunda edição do Shialc na cidade colombiana de Medellin. Destacam-se nesta edição os relatos de memórias e trajetórias de vida de personalidades influentes no desenvolvimento da informática no continente, bem como as análises sobre a implantação de redes locais e da internet na Argentina. Também estiveram presentes análises sobre desenvolvimento de tecnologia e formação de redes técnicas.

Em relação às redes técnicas e desenvolvimento de produtos destacamos:

- - Marilza de Lourdes Cardi; Jorge Muniz Barreto: exposição sobre a evolução do uso de computadores no Brasil, enfatizando as primeiras experiências do país no campo da informática na década de 1960. Destaque para a apresentação de três protótipos de computador desenvolvidos no Brasil: Zezinho, feito por uma turma de formandos do ITA de 1962; Lourinha, feito por uma turma de formandos do IME; Patinho Feio, primeiro computador digital funcional desenvolvido no país por técnicos da USP;

- - J. F. Marinho de Araújo: análise acerca das dificuldades e caminhos trilhados por empresas brasileiras desenvolvedoras de software em conquistar mercados para exportação. O autor analisa o papel do Programa Nacional de Software para Exportação - SOFTEX 2000, criado em 1993 pelo CNPq, neste processo; 
- - Gustavo del Dago: proposta de criação de um "ecossistema" que permita rodar um software da década de 1960, abordagem que o autor intitula de "arqueologia computacional". A base do artigo é a análise da criação da linguagem e compilador COMIC, desenvolvido no Instituto de Cálculo da Universidade de Buenos Aires entre os anos 1965 e 1966;

- - Henrique Luiz Cukierman: análise dos debates e controvérsias parlamentares que permearam a aprovação de quatro leis para a informática (1984, 1991, 2001, 2004). Além da comparação entre os quatro debates o artigo também busca rastrear os grupos de influências e seus interesses mobilizados em torno da formulação das leis;

- - Federico Novik: análise das circunstâncias e modelos que estruturaram o sistema de redes teleinformáticas na Argentina antes do advento da Internet como tecnologia comercial. $\mathrm{O}$ autor se cerca de ampla documentação para examinar este processo entre os anos de 1985 e 1994;

- - Pablo A. Fontdevila: análise de uso de processamento de dados na Argentina a partir de três instituições de diferentes períodos: o Centro Único de Processamento de Dados (CUPED), criado em 1968; a Administração Nacional da Segurança Social (ANSES), criada em 1991; o Programa Conectar Igualdade, criado em 2010.

- Em relação às redes educacionais podemos destacar:

- - Guillermo A. Rojo: análise dos primeiros anos do Centro de Computação da Universidade Nacional de Rio Cuarto, Argentina, no ano de 1979. O artigo busca ressaltar o contexto da fundação de um departamento de informática em uma universidade do interior argentino.

- - V. Cotik; M. Jenik: análise da evolução do uso de Tecnologias da Informação e Comunicação nas escolas de nível médio na Argentina ao longo dos últimos 50 anos;

- Márcia Regina Barros da Silva: análise da relevância da história da informática para os estudos de ciências e tecnologias na América Latina. Trata-se de uma revisão bibliográfica voltada para a historiografia tomando por base a "Revista Latinoamericana de Historia de las Ciencias y la tecnologia - Quipu";

- - Juan Alvarez; Claudio Gutierrez: análise da instalação do primeiro computador para fins universitários do Chile. Em meados de 1962 o Departamento de Ciências da Física e Matemática da Universidade do Chile adquiriu um computador modelo ER-56 Standard Elektrik Lorenz (apelidado de "Lorenzo");

- - Margarida de Souza Neves e Silvia E Byington; Arndt von Staa: apresentação do processo que envolveu a compra, instalação e uso do primeiro computador instalado em uma universidade brasileira; modelo Burroughs B-205 em 1961;

- - Paula Maria Abrantes Cotta: O artigo apresenta um relato da história da informatização das bibliotecas da UFRJ, do final dos anos 1960 até a primeira década dos anos 2000. Apresenta os sistemas desenvolvidos e utilizados pelas bibliotecas ao longo desses anos, bem como as experiências vivenciadas pelas equipes de analistas e bibliotecários.

Em relação aos testemunhos e exposições de memórias e destacamos:

- Marta Eunice Calderón: exposição da trajetória de vida e profissional de Jorge González Martén, pioneiro do campo da informática na Costa Rica. $\mathrm{O}$ artigo apresenta desde a formação acadêmica de Martén, sua trajetória como administrador com a criação da empresa MAl e seu papel como desenvolvedor de tecnologia ao participar em 1971 da criação do minicomputador Basic Four e sua ação de implantação de computadores em escolas ao longo dos anos 1970 e 1980; 
- - Ivan da Costa Marques: o artigo associa pesquisa bibliográfica e referências das memórias do autor para analisar a proibição por parte do regime ditatorial militar brasileiro de uma apresentação de slides intitulada "história do índio" em 1979. O autor utiliza este evento para evidenciar a crescente influência do órgão de informação do regime militar a Secretária Especial de Informação (SEI) na formulação de políticas públicas da área;

- - Jorge Aguirre: exposição das memórias do autor em relação à criação de cursos de informática na Universidade Nacional de Rio Cuarto. $\mathrm{O}$ autor narra as circunstâncias particulares que o aproximaram da instituição e a criação de uma escola de verão de Ciências Informáticas em 1994;

- - Raúl Carnota; Ricardo Rodriguez: exposição da trajetória profissional de Antonio Monteiro (1907-1980) matemático português que teve atuação destacada na implantação da informática no país. Os autores buscaram articular as ações de Monteiro ao contexto político do país no período;

- - Julián Dunayevich: exposição das memórias do autor acerca de seu papel na criação de redes locais de teleinformática na Argentina. A partir de seu trabalho na Faculdade de Ciências Naturais e Exatas da Universidade de Buenos Aires Dunayevich retraça sua participação em órgãos e grupos de destaque no desenvolvimento de redes na Argentina, bem como da chegada da internet ao país.

\section{Considerações finais}

A maior parte dos artigos se refere a experiências locais de formação de Redes TécnicoCientíficas que agiam na formulação de políticas públicas ou desenvolvimento de produtos. Tais artigos nos permitem refletir de modo mais amplo sobre a experiência da informática na América Latina como uma constante disputa entre desenvolvimentos autônomos e sistemas de dependência. O segundo eixo com mais apresentações são as Redes Educacionais, que abordam o desenvolvimento da informática nas universidades Latino-Americanas, com ênfase nos cursos de engenharia. Por fim, o terceiro eixo é composto pelos depoimentos e exposições de memórias de indivíduos ligados à história da informática na América Latina. Destaque, nesse caso, para os relatos sobre a presença feminina no desenvolvimento regional da informática, com exposição de memórias de algumas pioneiras e da presença feminina em carreiras da engenharia. Também é destaque a relação entre informática e política nos contextos ditatoriais das décadas de 1970 e 1980.

Para além de uma compilação de memórias de evento, o presente levantamento também é relevante para refletir acerca de desafios futuros do simpósio, como uma presença maior de trabalhos oriundos das áreas de ciências humanas, a aproximação com pesquisadores de países que ainda não estiveram presentes no simpósio, bem como o início do estabelecimento de um pensamento mais regional a partir do conjunto dessas experiências locais.

\section{Referências bibliográficas}

CARNOTA, Raúl; LEAL, Luís Germán Rodríguez. Histórias de las TIC em América Latina y el Caribe: incios, desarrollos y rupturas. Barcelona: Ariel, 2015. (Contém os anais do I e II SHIALC (2010, 2012). 


\section{UMA NOVA PERSPECTIVA DA UTILIZAÇÃO DO DOSVOX NO TRATAMENTO DAS DEFICIÊNCIAS COGNITIVAS}

Flavia Ernesto de Oliveira da Silva Alves. Aluna Ouvinte Doutoranda HCTE - flaviaernersto@gmail.com Denise Cristina Alvares Oliveira. Aluna Ouvinte Mestranda HCTE - denisecaoliveira@hotmail.com

Resumo

Este trabalho apresenta a experiência na aplicação de tecnologia utilizada para pessoas com deficiências visuais em uma nova abordagem. Na seção de introdução são apresentadas as motivações que levaram ao seu desenvolvimento. Nas seções seguintes, além de apresentar as teorias que encadearam a realização da atividade, bem como o público alvo em questão, é apresentada uma reflexão sobre a complexidade do pensamento, para a contextualização e definição da proposta: a aplicação do Sistema DOSVOX como recurso para o tratamento de pessoas com deficiências cognitivas. Em seguida é apresentada a teoria ator-rede que permite a conexão entre os diversos atores desse contexto. Na seção resultados são pontuadas as principais observações acerca do trabalho.

Palavras-chave: AVC. Cognição. DOSVOX.

1 Introdução

No decorrer da disciplina Deftas (Deficiência, Tecnologia Assistiva e Sociedade-1), onde foram apresentados diversos sistemas voltados ao tratamento de pessoas com deficiência, percebeu-se a possibilidade da utilização do Sistema DOSVOX, criado para pessoas com deficiência visual, ser utilizado sob uma nova perspectiva, atendendo também às pessoas com déficits cognitivos. Essa atividade foi construída a partir da parceria formada entre duas profissionais: uma Terapeuta Ocupacional e uma Analista de Sistemas e Pedagoga, que juntas iniciaram a elaboração de jogos terapêuticos voltados as necessidades do tratamento das alterações cognitivas relacionadas ao Acidente Vascular Cerebral (AVC).

\section{Percurso Metodológico}

2.1 Acidente Vascular Cerebral ( AVC).

O Acidente Vascular Cerebral (AVC) descreve uma variedade de distúrbios caracterizados pelo início súbito de déficits neurológicos causados por lesão cerebral. A lesão vascular interrompe o fluxo sanguíneo, limitando o suprimento das células e induzindo a morte ou infarto do tecido cerebral. (TROMBLY \& RADOMSKI,ano). O mecanismo, a localização e a extensão da lesão determinam os sintomas e o prognóstico do paciente. Dentre as disfunções que se apresentam e que interferem na recuperação da pessoa afetada estão as alterações cognitivas. (TROMBLY \& RADOMSKI,ano)

\subsection{Cognição}

O termo cognição reflete o empreendimento mental relacionado a absorver informação, pensamento e ação dirigida a um objetivo. Esta consiste em uma hierarquia interativa que inclui as capacidades de orientação, atenção, memória, raciocínio, formação de conceitos e solução de problemas. Os objetivos do tratamento e os recursos utilizados para abordar os déficits devem ter um propósito claro e ser significativos para o paciente (TROMBLY \& RADOMSKI,ano). Dentre os recursos possíveis que visam favorecer a recuperação da pessoa pós AVC, temos a tecnologia assistiva / computação eletrônica na forma de jogos 
terapêuticos, os quais devem atender individualmente as necessidades do paciente em questão, favorecendo o seu desempenho ocupacional nas atividades cotidianas. (TROMBLY \& RADOMSKI,ano)

\subsection{O Raciocínio}

Pensar em uma atividade que seja diferente do seu propósito inicial, nos remete à articulação entre novas e diferentes possibilidades, ocorrendo intrinsecamente um processo de reformulação do pensamento. Morin (2001).

A proposta deste artigo contempla uma reformulação de ideias ao descortinar uma nova possibilidade de utilização para um jogo, que traz consigo inúmeras possibilidades, e em corolário, propor a utilização sob uma nova vertente. É bem verdade, que existe uma enorme diversidade de softwares e aplicativos no mercado que foram produzidos para serem utilizados com deficientes visuais, deficientes auditivos, deficientes cognitivos, etc. O que está sendo apresentado nada mais é do que uma nova roupagem para uma tecnologia criada em princípio para outro fim.

\subsection{Tecnologia Assistiva}

A tecnologia criada para apoiar pessoas com deficiência é chamada Tecnologia Assistiva (TA) - um termo utilizado para identificar todo o arsenal de recursos e serviços que contribuem para proporcionar ou ampliar habilidades funcionais de pessoas com deficiência e consequentemente promover vida independente e inclusão (BERSCH, 2006). Em um sentido mais amplo, a TA tem por objetivo proporcionar à pessoa com deficiência uma maior independência, qualidade de vida, inclusão social, ampliar a comunicação, mobilidade, habilidades de seu aprendizado e trabalho, permitindo ao deficiente a diminuição de sua deficiência.

"Para as pessoas sem deficiência a tecnologia torna as coisas mais fáceis. Para as pessoas com deficiência, a tecnologia torna as coisas possíveis". (RADABAUGH, 1993).

\section{$3 \mathrm{~A}$ atividade em ação}

\subsection{Sistema DOSVOX}

No site do NCE é possível encontrar a definição do DOSVOX como sendo: "um sistema computacional, baseado no uso intensivo de síntese de voz, desenvolvido pelo Instituto Tércio Paciti (antigo Núcleo de Computação Eletrônica (NCE) da Universidade Federal do Rio de Janeiro (UFRJ), que se destina a facilitar o acesso de deficientes visuais a microcomputadores. Através de seu uso é possível observar um aumento muito significativo no índice de independência e motivação das pessoas com deficiência visual, tanto no estudo, trabalho ou interação com outras pessoas. Atualmente o projeto conta com mais de 80.000 usuários espalhados pelo Brasil, Portugal e América Latina."

A ideia de criação do DOSVOX surgiu a partir da necessidade de Marcelo Pimentel, aluno do Curso de Informática da UFRJ em 1992, em estudar matérias que favorecessem o uso do computador. Na época, em 1993, não existia ainda nenhum sistema com síntese de voz para língua portuguesa disponível para uso em microcomputadores IBM PC, que eram aqueles utilizados por todos os alunos de informática na UFRJ. Desse modo o Professor Antônio Borges, informático da UFRJ e Doutor em Engenharia de Sistemas e Computação criou um sistema que fizesse o computador interagir com o usuário através da voz, pois entendeu a importância de favorecer o aluno no processo de inclusão.

3.2 O Jogavox 
O Jogavox é um editor de jogos educacionais contido no DOSVOX, cuja proposta central é possibilitar o desenvolvimento de jogos, permitindo a criação de estratégias a serem usadas na abordagem proposta.

Oferece uma simplicidade operacional muito grande, principalmente se comparado a outros softwares com o mesmo fim, o que possibilita que pessoas possam desenvolver seus próprios jogos através do uso dessa formidável ferramenta.

A Utilização do DOSVOX / Jogavox como recurso para o tratamento de pessoas com deficiência cognitiva.

A ideia de criação deste artigo surgiu a partir da apresentação do DOSVOX aos alunos da disciplina DEFTAS 1, quando foi solicitada a elaboração de jogos voltados às pessoas com deficiência visual, editando jogos educacionais na modalidade Jogavox. A construção dos jogos propostos trouxe a percepção de que outras modalidades de jogos poderiam ser criadas, estendendo os benefícios à outras pessoas com deficiências. Tratando-se de uma turma heterogênea, com experiências profissionais distintas, percebeu-se que a associação dos esforços e competências promovia os melhores resultados. Foi assim que a experiência da Terapeuta Ocupacional no tratamento de pessoas com deficiências se somou à experiência profissional Professora de Informática e Estudante de Pedagogia. Nesta perspectiva, os jogos foram planejados, construídos e aplicados pela Terapeuta Ocupacional no atendimento de pacientes com disfunções neurológicas e déficits cognitivos em tratamento em Centro de Reabilitação. Alguns jogos que acompanham o programa Jogavox foram também utilizados. Foram pensadas e organizadas diferentes atividades, sempre tendo como pensamento a necessidade cognitiva que cada paciente precisa explorar: memorização, sequência lógica, sempre através de diferentes formas de desafios que são inseridos como proposta motivadora para reinserção dos pacientes na sociedade. Na (Figura 2) é apresentado o exemplo de um Jogo, onde o paciente é convidado a reconhecer a partir de um determinado som, que instrumento o reproduz, com isso trabalhar a percepção auditiva e a memória de maneira lúdica e criativa. Na Figura 3)é apresentado um jogo onde o paciente tem como desafio identificar uma sequência lógica a partir do que é apresentado, sendo trabalhado a memorização e a percepção auditiva. Cabe ressaltar que o jogo apresentado na Figura 2 já estava na biblioteca do JogaVox e o jogo apresentado na Figura 3 foi utilizado como exemplo do que foi construído para disciplina e aplicado entre os pacientes.

3.3 Teoria do Ator-rede.

Diante da proposta apresentada podem-se perceber vários atores envolvidos neste cenário multidimensional, de cunho profissional e reflexivo. Para tal, foi utilizada a teoria ator-rede, onde Latour (2001) recoloca o lugar da natureza e das coisas, bem como dos humanos e seus artefatos, desfazendo a divisão moderna entre natureza e cultura ou ainda entre sujeito e objeto, reafirmando o lugar das controvérsias no modo de operação de todas as entidades que em algum momento se associam delimitando formas vivas e prontas a se conectarem em novas associações compostas heterogeneamente.

O ator - rede é aquilo que "é induzido a agir por uma vasta rede, em forma de estrela, de mediadores que entram e saem" (LATOUR, 2012, p. 312). Logo, o ator - rede é feito para agir, ou seja, para induzir outras entidades a fazerem coisas, através de movimentos e deslocamentos.

Faz-se necessário visualizar simetricamente o contexto sócio-técnico, onde não se trata de separar o conhecimento exato sobre a natureza do exercício do poder entre os homens, mas de seguir a rede que liga constantemente homens e coisas que permite a construção de nosso coletivo. Esta rede não é construída através de discursos ou representação, ela vai além, sendo descortinados através dos objetos que ainda não encontraram seu lugar ou que simplesmente não possuem lugar nessa divisão tradicional, os híbridos. 
As redes que o autor nos ensina a seguir são ao mesmo tempo reais como a natureza, narradas como o discurso e coletivas como a sociedade, daí o enredamento para reformulação do pensamento complexo através da vivência social e cotidiana dos diferentes atores envolvidos no processo.

4 Resultados

A utilização do Sistema DOSVOX/JogaVox possibilitou a criação de jogos compatíveis com às necessidades de tratamento de pacientes com déficits cognitivos relacionados ao AVC, favorecendo a estimulação das capacidades de orientação, atenção, memória, raciocínio, formação de conceitos e solução de problemas. Os pacientes envolvidos nas referidas atividades relataram satisfação na execução dos jogos apresentados, demonstrando interesse durante as atividades propostas e referindo sentirem-se motivados à realização das mesmas. A avaliação dos resultados permitiu observar que após a aplicação dos jogos construídos no Jogavox, foram observadas a melhoria das funções cognitivas em geral. A aplicação dos jogos foi bem aceita pelos pacientes durante as diferentes fases do tratamento.

Cabe ressaltar que este trabalho se encontra em processo de construção e que os atores envolvidos no processo continuam em acompanhamento.

Referências bibliográficas:

BERSCH, R. Tecnologia assistiva e educação inclusiva. In: Ensaios Pedagógicos, Brasília: SEESP/MEC, p. 89-94, 2006.

BORGES, J. A. DOSVOX - Uma nova realidade educacional para Deficientes Visuais. Revista Benjamim Constant, Rio de Janeiro, n. 3. 1996. Disponível em:

intervox.nce.ufrj.br/dosvox/textos/artfoz.doc. Acesso em 07 de outubro de 2017

BRASIL. SDHPR - Secretaria Nacional de Promoção dos Direitos da Pessoa com Deficiência - SNPD. 2009. Disponível em: http://www.pessoacomdeficiencia.gov.br/app/publicacoes/tecnologia-assistiva. Acesso em 07 de outubro de 2017.

CUNHA, E.E.- JogaVOX: Ferramenta e Estratégias para Construção de Jogos Educacionais para Deficientes Visuais. Rio de Janeiro, 2007.

GRIEVE, J.; GNANASEKARAN, L. Neuropsicologia para Terapeutas Ocupacionais - Cognição no Desempenho Ocupacional. Terceira Edição. Editora Santos, São Paulo - SP - 2010.

LATOUR, B. Esperança de pandora, Bauru, SP: EDUSC. 2001.

LATOUR, B. Reagregando o Social. Bauru, SP: EDUSC/ Salvador, BA: EDUFBA. 2012.

NCE UFRJ. Projeto DOSVOX. Núcleo de Computação Eletrônica da Universidade Federal do Rio de Janeiro. Disponível em: <http://intervox.nce.ufrj.br/dosvox>. - Acesso em 07 de outubro de 2017

MORIN, E. Introdução ao pensamento complexo . 3. ed. Porto Alegre: Sulina, 2005

RADABAUGH, M. P. NIDRR's Long Range Plan - Technology for Access and Function Research Section Two: NI DDR Research Agenda Chapter 5: TECHNOLOGY FOR ACCESS NA D FUNCTION

TROMBLY, C.A.; RADOMSKI, M.V. Terapia Ocupacional para Disfunções Físicas. 5a . Edição. Editora Santos. São Paulo, 2005. http://intervox.nce.ufrj.br/dosvox/ - acesso em -7 de outubro de 2017. 


\section{SOBRE PADRÕES DE DISTRIBUIÇÃO E ÁRVORES EVOLUTIVAS NO TRABALHO DE FRITZ MÜLLER}

Flavia Pacheco Alves de Souza - Doutoranda - Universidade Federal do ABC - flavia.pacheco@ufabc.edu.br Charles Morphy D. Santos - Professor da Universidade Federal do ABC - charles.santos@ufabc.edu.br.

Resumo

Fritz Müller (1822-1897) foi um naturalista alemão que viveu no Brasil no século XIX. Ele foi um dos primeiros darwinistas e imediatamente se dedicou à disseminação da teoria evolutiva, logo após a publicação de A origem das espécies de Darwin, publicado em 1859. Em seu trabalho, encontramos referências a duas das principais evidências usadas por Darwin para apoiar a evolução: padrões de distribuição geográfica e relacionamentos genealógicos ou evolutivos, representados por árvores ramificadas. Aqui, discutiremos esses elementos presentes nos estudos de Müller e analisamos como este autor usou o conceito de declaração de três itens para iluminar suas hipóteses sobre a origem e a diversidade dos seres vivos.

\section{Introdução}

Em 1859, o naturalista britânico Charles Robert Darwin publicou sua obra principal sobre a origem das espécies por meio da seleção natural ou a preservação das raças favorecidas na luta pela vida. Um ano antes, em 1858, o também britânico Philip Lutley Sclater, um ornitólogo, propôs uma classificação zoogeográfica para a Terra com o objetivo de explicar a distribuição das aves no artigo "On the general geographical distribution of the members of the class" (SCLATER, 1858). Sclater discute a importância de comparar duas áreas mais próximas com uma terceira, um conceito conhecido como declaração de três itens, isto é, "A e B estão mais estreitamente relacionadas entre si que com C" (ZARAGUETA-BAGILS \& BOURDON, 2007). Esta é a base do pensamento filogenético de Willi Hennig, publicado pela primeira vez na Alemanha (HENNIG, 1950) e mais tarde divulgado em inglês (HENNIG, 1966) sob o título de "Phylogenetic systematics". Em termos kuhnianos, a "Origem das Espécies" de Darwin e as obras de Sclater e Hennig trouxeram rupturas epistemológicas e propuseram um novo tipo de campo de pesquisa experimental e teórico em ciências naturais.

Darwin (1859) não apresentou apenas um discurso científico com fortes evidências materiais que a evolução ocorria, mas também explicou por que os fenômenos da natureza e dos seres vivos não seriam subjugados a nenhuma força inferencial sobrenatural (como é considerado, por exemplo, pelos criacionistas). Ao contrário da teoria lamarckiana da evolução (MAYR, 2006), que tratou a evolução como um processo vertical, Darwin (1859) propôs que a evolução biológica é um processo horizontal. Consequentemente, a origem da biodiversidade deve ser analisada à medida que as formas mudam no tempo, considerando a dimensão espacial - que seria profundamente discutida um século depois por Croizat (1964). Como o modelo de especiação geográfica de von Buch (PAPAVERO et al., 1997), Darwin percebeu que espécies novas ou incipientes surgem quando as populações se movem para novos nichos ambientais, sendo isoladas e, portanto, divergindo separadamente (BOWLER, 2009; MAYR, 2006; NELSON \& PLATNICK, 1981). Esse raciocínio biogeográfico explicando eventos de especiação - ou seja, divergência - é congruente com o conceito darwinista de descendência comum, como representado por uma árvore ramificada.

Sclater dividiu a Terra em seis regiões zoogeográficas distintas, nomeadamente Neotropical, Neártica, Paleártica, Etiópia, Indiana e Australiana, de acordo com a distribuição de famílias e gêneros de aves (SCLATER, 1857) - essa proposta foi posteriormente prolongada por Alfred 
Russel Wallace para incluir outros vertebrados e plantas (WALLACE, 1876). Sclater considerou o hábito das espécies como fatores importadores de distribuição, opondo-se ao Atlas físico de fenômenos naturais de Johnston, que classifica os pássaros em dezesseis regiões de acordo com as diferenças de latitude e longitude (JOHNSTON, 1856). Como dito antes, Sclater foi o primeiro a descrever a declaração de três itens para discutir questões geográficas.

Henning desenvolveu seu método sistemático filogenético com base na história evolutiva dos grupos. $\mathrm{O}$ conceito darwiniano de ascendência comum era essencial à proposição de grupos monofiléticos e à representação das relações de parentesco. O método criado por Hennig reconstrói as relações do grupo-irmão como declarações de três itens (o táxon A está mais relacionado ao táxon $\mathrm{B}$ do que $\mathrm{a} \mathrm{C}$ ). Este conceito também foi a base da biogeografia cladística (NELSON \& PLATNICK, 1981), um conjunto de métodos utilizados para construir hipóteses de relações de área com base na história das rupturas de uma certa área ancestral.

Apesar da proeminência dos referidos Darwin, Sclater e Hennig, o foco principal de nosso trabalho é Fritz Müller, naturalista alemão que morou no Brasil a partir de 1852 até sua morte em 1897 (SOUZA, 2017). Ele foi um dos primeiros darwinistas e imediatamente se dedicou à disseminação da teoria evolutiva após a publicação da Origem das espécies (DARWIN, 1859). Durante sua carreira, Müller tratou de duas das maiores evidências que sustentam a evolução biológica: padrões de distribuição geográfica e relações evolutivas, como as árvores ramificadas. Aqui, vamos discutir como esses elementos estão presentes nos estudos de Müller, analisando como ele usou o conceito de declaração de três itens para iluminar suas hipóteses sobre a origem e diversidade dos seres vivos. Nosso foco principal será a correspondência trocada entre Müller e Darwin, bem como seu livro "Für Darwin" (1864) e seu artigo "Descrição de Elpidim bromeliarium", publicado em 1879 na revista Archivos do Museu Nacional do Rio de Janeiro.

Padrões de distribuição na obra de Fritz Müller

Em "Origin", Darwin dedica dois capítulos à distribuição geográfica das espécies. Ele propõe uma distribuição disjunta dos organismos, resultante de uma dispersão a longa distância. Os organismos se dispersariam dos centros de origem para ocupar novas áreas atravessando barreiras pré-existentes, sendo que as modificações viriam através da seleção natural (DARWIN, 1859, p. 350). Os fatores para essa dispersão poderiam ser geológicos, climáticos ou acidentais (DARWIN, 1859, p. 350-356).

Ao contrário de Darwin, Fritz Müller não publicou nenhum artigo específico sobre os padrões e processos que envolvem a distribuição geográfica dos organismos. Analisando suas correspondências com Darwin, podemos observar que Müller mostrava-se cauteloso em discutir o assunto, conforme excerto:

O senhor L. Agassiz neste momento pesquisa o rio Amazonas; como deduzo de uma de suas cartas publicadas em um jornal do Rio, ele espera que a distribuição geográfica dos peixes naquele rio, venha a proporcionar decisivas provas contra a teoria da transformação (Umwandlungstheorie). Parece-me impossível que um conhecimento relativamente completo da distribuição geográfica dos peixes naquele imponente rio e seus numerosos afluentes, possa ser obtida em um par de anos, e não consigo imaginar que se possa derivar alguma decisiva objeção de um conhecimento incompleto" (Carta de Müller a Darwin, 05, novembro de 1865, ZILLIG, 1997, p. 126).

Para Müller a construção de uma hipótese biogeográfica era um trabalho árduo e de muitos anos, que não se alcançaria em pouco tempo.

Há também um trecho de carta remetida por Müller a Max Schultze (carta de 11 de março de 1865), em que ele questiona a elevação da ilha de Santa Catarina e demonstra estar curioso em saber se outros indícios da elevação serão encontrados. Darwin, por sua vez, responde a 
Müller que não sabe se a ilha se elevou recentemente e sugere a Müller que este colete dados e envie a algum jornal de geologia, o que ele nunca fez (ZILLIG, 1997, p. 128).

Porém, analisando os trabalhos de Müller nos Archivos do Museu Nacional do Rio de Janeiro (SOUZA, 2017), observamos que ele se utiliza de padrões de distribuição quando sugere a ocupação de novos habitats em resposta à seleção natural. Este é o caso, por exemplo, de Elpidium bromeliarium, um crustáceo da família dos Cytherideos. A família é representada por fósseis e espécies viventes que habitam água salgada e doce. Müller, no entanto, descreveu a nova espécie como habitante de bromélia, porém não se preocupou em discutir profundamente sobre os padrões e processos que levaram tal espécie a se dispersar e atingir outro nicho ambiental.

Os cladogramas na obra de Fritz Müller

Um dos principais pontos de "Origin" é o conceito de ancestralidade comum. Este conceito produz relações hierárquicas de semelhanças entre os seres vivos, um padrão de grupos dentro de grupos, conforme o próprio Darwin sugeriu (RIDLEY, 2011, p. 511).

Müller buscou estabelecer padrões e relações para os diversos grupos de animais que estudou, através de comparação e de classificação. O conceito de ancestralidade comum de Darwin é utilizado por ele em diferentes situações em "Für Darwin" e em diversos artigos (SOUZA, 2017).

No capítulo dois de "Für Darwin" (MÜLLER, 2009, p. 29-33), podemos observar que Müller busca estabelecer uma relação hierárquica entre espécies de crustáceos com a utilização de um cladograma simples (2009, p. 32), o primeiro a ser publicado antes do conceito proposto por Hennig.

Estudando espécies de Amphipoda do gênero Mellita, Müller citou quatro espécies: Melita valida, $M$. setipes, $M$. anisochir e $M$. fresnelii. Porém, havia ainda uma nova espécie de Santa Catarina, que ele incluiu no mesmo gênero, Melita exillii. Como as demais espécies do gênero, esta última também tem, no segundo par de pernas, de um lado uma pequena "mão" (conforme a nomenclatura original do autor) de estrutura normal e no outro uma enorme pinça

Para Müller, a pinça diferia totalmente do que ele já havia observado no grupo dos Amphipoda, porém se assemelhava a pinça das outras quatro espécies descritas do gênero, o que para ele deveriam ter evoluído de ancestrais comuns.

Nesse sentido, o autor nos apresenta um cladograma organizando as espécies com estrutura de pinça e com presença ou ausência de flagelo secundário no primeiro par de antenas. Este flagelo era considerado um caráter distintivo de gêneros, pelos especialistas em crustáceos. Para ele, a ausência do flagelo secundário de modo algum poderia ser motivo para se duvidar do parentesco existente entre $M$. freneslii e as demais (representadas no cladograma como $M$. exilii etc.). Mesmo que $M$. freneslii não tenha o flagelo na antena anterior, ela compartilha com as demais espécies o caráter distintivo que é pinça, e isto torna o gênero um grupo natural, ou seja, evoluído de ancestrais comuns (MÜLLER, 2009, p. 31).

O que podemos observar é que Müller considerou hipóteses filogenéticas distintas para tentar explicar a diversidade encontrada no gênero. Quanto à importância taxonômica do flagelo, ele discute com base na sua ocorrência em gêneros não aparentados, assim como na simultânea presença de flagelo completo em algumas formas larvais e apenas rudimento nos respectivos adultos; ou seja, trata-se de uma estrutura presente em muitos anfípodes não aparentados e sem a importância taxonômica que lhe era atribuída (MÜLLER, 2009, p. 32). Müller realizou uma distinção clara entre os caracteres primitivos e derivados utilizando o que podemos denominar atualmente de sinapomorfia, isto é, um caráter derivado compartilhado 
por duas ou mais espécies. Outro ponto interessante é a comparação de Müller entre as três espécies (A estaria mais próximo de B em relação a C), utilizado por Sclater e Hennig.

Em suporte à sua interpretação sobre o parentesco das espécies de Mellita, Müller adianta a análise (autor,2009, p. 30) que virá em detalhes no capítulo cinco (autor, ano,p. 57-64), sobre a evolução dos mecanismos de respiração aérea nos caranguejos terrestres. Conforme ele explica resumidamente,

Esses caranguejos, que se tornaram mais ou menos alheios à água, pertencem às mais diversas famílias: Raninidae (Ranina), Eriphinae (Eriphia gonagra), Grapsoidae (Aratus, Sesarma etc.), Ocypodidae (Gelasimus, Ocypoda) etc. Sem dúvida, a separação dessas famílias deve ser referida a um período muito anterior ao hábito de alguns de seus membros de deixar a água. $O$ equipamento relativo à respiração aérea, por isso, não poderia ser herdado de um ancestral comum e, portanto, dificilmente poderia ser construído de maneira idêntica (MÜLLER, 2009, p. 58 ).

Nesta explicação podemos observar que a separação das famílias não poderia ser atribuída a um ancestral comum, tratando-se de uma apomorfia própria de cada família, visto que a separação do ancestral comum deveria ter sido bem antes das espécies individuais evoluírem às novas adaptações, e isto se reflete nos diferentes mecanismos de respiração terrestre, que apareceu independentemente em cada família.

Considerações finais:

Apesar dos assuntos biogeográficos estarem em ampla circulação no final do século XIX, Müller não ousou discutir ou pesquisar amplamente o tema. Antes, mostrou-se cauteloso por entender que os padrões e processos que levavam à diversificação das espécies era um assunto complexo, carente de pesquisas mais exaustivas e que não poderia ser respondido de forma simples. Porém observamos que Müller admitia, através da seleção natural, a diversificação das espécies e a ocupação de novos nichos ambientais, ainda que ele não tenha discutido este assunto de forma mais aprofundada.

Quanto à proposição dos cladogramas, a publicação de Müller, apesar de simples, foi pioneira e publicada muito antes de Hennig, com conceitos similares. Müller inovou ao comparar três grupos, postulando o parentesco de dois deles e comparando com o grupo externo, exatamente conforme proposto por Hennig após quase um século. Ele demonstrou magistralmente o conflito filogenético, ao apresentar dois cladogramas, para ilustrar a dificuldade em se obter uma análise mais parcimoniosa das relações de parentesco dos táxons por ele analisados.

Referências bibliográficas

BOWLER, P. J. Evolution: the history of an idea. Berkeley: University of California, 2009, 464 p.

DARWIN, C. On the origin of species by means of natural selection or the preservation of favoured races in the struggle for life. London: John Murray, Albermarle street., 1859. 556p.

HENNIG, W. Phylogenetic systematics. Urbana: University of Illinois Press, 1966.

HENNIG, W. Grundzugeeinertheorie der phylogenetischen Systematics, Deuscher Zentralverlag, Berlin, 1950.

JOHNSTON, A.K. The physical atlas of natural phenomena. A new and enlarged edition. William Blackwood and Sons, Edinburgh and London, MDCCCLVI. Disponível em: http://www.davidrumsey.com/maps93003924723.html. Acesso: 19 set. 2017.

MAYR, E. Systems of ordering data. Biology and Philosophy, v. 10, n. 4, p. 419-434, 1995. 
MAYR, E. Uma ampla discussão: Charles Darwin e a gênese do moderno pensamento evolucionário. Ribeirão Preto-SP: Funpec Editora, 2006. 195p.

MÜLLER, F. Descripção do Elpidium bromeliarum Crustaceo da Familia dos Cytherideos. Archivos do Museu Nacional, v.4, n.1, p.27-34, 1879a.

MÜLLER, F. Para Darwin. Tradução de Luiz Roberto Fontes e Stefano Hagen. Florianópolis: Editora da UFSC, 2009. 280p.

NELSON, G.; PLATNICK, N, I. Systematics and biogeography: Cladistics and vicariance. New York: Columbia University Press, 1981.

PAPAVERO, N.; TEIXEIRA, D.M.; LLORENTE-BOUSQUETS, J. (1997). História da Biogeografia no período Préevolutivo. São Paulo, Plêiade/Fapesp. Posadas, P., Crisci, J.V. e Katinas.

RIDLEY, M. Evolução. 3ạ ed. Porto Alegre: Artmed, 2006. 752p.

SCLATER, P. F. On the general Geographical Distribution of the Members of the Class Aves. Zoological. Journal of the Linnean Society. p. 130-136.

SOUZA, F.P.A. Notas de uma naturalista do sul do Brasil. NO PRELO. 2017

WALLACE. A. R. The geographical distribution of animals: with a study of the relations of living and extinct faunas as elucidating the past changes of the earth's surface. London: Macmillan \& Co, 1876. 2 vols.

ZARAGÜETA BAGILS R. \& BOURDON E. Three-item analysis: Hierarchical representation and treatment of missing and inapplicable data. - C. R. Palevol, n. 6, p. 527-534, 2007.

ZILLIG, C. Dear Mr. Darwin: a intimidade da correspondência entre Fritz Müller e Charles Darwin. São Paulo: Sky Anima comunicação e design, 1997. 163p. 


\title{
ASTRONOMIA, HISTÓRIA DA CIÊNCIA E ENSINO DE FÍSICA: UM PROJETO INTERDISCIPLINAR
}

\author{
Gil Alves Silva - HCTE/UFRJ - gilalvessilva@yahoo.com.br
}

\section{Resumo}

A astronomia é provavelmente a mais antiga de todas as ciências. Observar o céu sempre incitou a curiosidade e a busca por explicações para os fenômenos da natureza. Infelizmente, as temáticas que envolvem essa ciência ainda são pouco exploradas ao longo da vida escolar, com seus conteúdos sendo abordados por professores de ciências no ensino fundamental e física durante o ensino médio. Tratar o tema astronomia no ensino médio se apresenta como uma questão crucial para os professores dessa disciplina. Como a atual legislação estabelece que as aulas devem atender a quesitos como contextualização e interdisciplinaridade, propõe-se que conteúdos envolvendo História da Cciência (HC) possam tornar essas aulas mais atrativas. Nesse trabalho, dessa forma, inserimos conteúdos astronômicos nas aulas de física via $\mathrm{HC}$ visando a obtenção de um ensino mais rico e integrado.

Palavras-chave: Astronomia. Ensino de Física. História da Ciência.

\section{Introdução}

Frequentemente, a História daCiência (HC) aparece em apêndices (ou seção denominada "curiosidades") em alguns capítulos de livros didáticos. Dessa forma, a HC é apresentada ao estudante como algo completamente desconexo em relação ao conteúdo trabalhado (GUTTMANN; BRAGA, 2015). Porém, sua utilização pode transformar a maneira como se trabalha a física em sala de aula, rompendo com o paradigma vigente, no qual os fenômenos físicos são descritos, predominantemente, pela linguagem matemática. Assim, através da interdisciplinaridade ${ }^{3}$, a física pode se reinventar, apresentando-se como uma disciplina capaz de dialogar com as outras, ultrapassando o tradicional e mostrando que não está limitada apenas à matemática (GUTTMANN; BRAGA, 2015).

Nesse caso, nossa proposta de interdisciplinaridade visa inserir conteúdos astronômicos nas aulas de física via HC. O tema escolhido foi Leis de Kepler do movimento planetário. Antes que o astrônomo alemão Johannes Kepler determinasse tais leis, no começo do século XVII, a tarefa dos astrônomos praticamente se resumia a elaborar um sistema cosmológico que explicasse as trajetórias aparentes dos planetas no céu como uma combinação de movimentos circulares uniformes - um dogma com mais de dois milênios que remonta aos filósofos gregos Pitágoras, Platão e Aristóteles. Baseado na cosmologia desse último o astrônomo grego Claudio Ptolomeu criou um sistema onde a Terra ficava posicionada no centro do universo, imóvel, com a Lua, o Sol e os outros planetas girando ao seu redor. Esse modelo de cosmo geocêntrico esteve em evidência até a metade do século XVI, quando foi rivalizado pelo sistema heliocêntrico do astrônomo polonês Nicolau Copérnico, que colocou todos os astros - inclusive a Terra - orbitando ao redor do Sol, que ocupava o lugar do nosso planeta como centro do universo. No final desse século também foi alvo de discussão um

\footnotetext{
3 "Compreender a ciência como um empreendimento humano, construído histórica e socialmente.". Este é um dos objetivos gerais da área de ciências da natureza na educação básica que consta na Base Nacional Comum Curricular (BNCC), do Ministério da Educação (MEC). A componente curricular de física do 10 ano do ensino médio deixa implícito, nos tópicos que abrangem o conhecimento conceitual, que serão abordados conteúdos relativos à astronomia, entre eles as leis do movimento planetário - mais conhecidas como Leis de Kepler.
} 
sistema híbrido - um misto de geocentrismo com heliocentrismo - criado pelo astrônomo dinamarquês Tycho Brahe, onde a Terra permanecia estática no centro do universo, com a Lua e o Sol em sua órbita - embora os planetas girassem ao redor do Sol, como no cosmo copernicano. Baseado nas observações de Tycho, Kepler revoluciona a astronomia, libertando-a de seus velhos dogmas ao descrever as órbitas planetárias como elipses com movimentos não uniformes - uma total ruptura com a harmonia divina dos antigos.

O brevíssimo resumo proposto acima se refere a como mais de dois milênios de história do pensamento astronômico foram sintetizadas naquilo que, para a posteridade, ficou conhecido como sendo as Leis de Kepler do movimento planetário. Seguem seus enunciados segundo Oliveira \& Saraiva (2004):

- 1a Lei: A órbita de cada planeta é uma elipse, com o Sol em um dos focos. Como consequência da órbita ser elíptica, a distância do Sol ao planeta varia ao longo de sua órbita.

- 2a Lei: A reta unindo o planeta ao Sol varre áreas iguais em tempos iguais. O significado físico desta lei é que a velocidade orbital não é uniforme, mas varia de forma regular: quanto mais distante o planeta está do Sol, mais devagar ele se move.

- 3a Lei: O quadrado do período orbital dos planetas é diretamente proporcional ao cubo de sua distância média ao Sol. Esta lei estabelece que planetas com órbitas maiores movem-se mais lentamente em torno do Sol e, portanto, isso implica que a força4 entre o Sol e o planeta decresce com a distância ao Sol. Sendo P o período sideral do planeta, a o semieixo maior da órbita (igual à distância média do planeta ao Sol), e K uma constante, podemos expressar a 3 a lei como: $\mathrm{P} 2=\mathrm{K}$ a3.

Lançados num livro didático, esses enunciados até podem atingir seu propósito - a compreensão e utilização dessas leis para explicar a cinemática planetária, mas provavelmente terão pouco apelo junto aos estudantes do ensino médio. Nosso trabalho propõe uma abordagem diferente ao inserir uma contextualização histórica no tema, ou seja, identificar um problema - como explicar o movimento dos planetas e por que suas velocidades variam ao longo de suas órbitas, e reconhecer alguns dos impactos e mudanças socioculturais oriundos da tentativa de solucioná-lo. Através da HC temos a oportunidade de visualizar essa descoberta de outra forma, levando em consideração não somente o aspecto científico da descoberta, mas também os aspectos sociais, políticos, econômicos, culturais, religiosos e filosóficos. Visto dessa maneira, não há dúvida que alguns pontos dessa história chamarão a atenção dos estudantes, propondo reflexões sobre a vida e as ideias dos personagens principais - ponderações que muito provavelmente não ocorreriam sem o uso da HC.

Nosso objetivo, portanto, é traçar um breve panorama histórico dos principais sistemas cosmológicos ocidentais - dos gregos até Kepler, mostrando como refinamentos nesses sistemas e novas observações levaram à elaboração das leis do movimento planetário. À parte da maneira como são tradicionalmente apresentadas no ensino médio (enunciados, fórmulas etc.), nosso propósito é chegar às Leis de Kepler via história da cosmologia, estimulando uma reflexão de como a $\mathrm{HC}$ pode ser usada como ferramenta pedagógica para o ensino de física.

2 Público alvo

\footnotetext{
${ }^{4}$ Enquanto a astronomia de sua época estava preocupada somente em descrever os movimentos dos objetos celestes, Kepler procurou encontrar as causas desses movimentos, acreditando que deveria haver alguma espécie de força - alguma interação entre o Sol e os planetas que seria responsável pelas suas órbitas.
} 
A sequência didática destina-se a estudantes do nível médio que estejam cursando a disciplina de mecânica clássica ou equivalente. O material também pode ser usado/adaptado para a formação de professores de ciências/física em cursos de licenciatura, conforme se vê na Seção 4.

\section{Sequência didática}

O trabalho está programado para ser desenvolvido ao longo de dois tempos de quarenta e cinco (ou cinquenta) minutos cada. Será entregue um texto didático (SILVA, 2016) aos estudantes antecipadamente, para que este possa ser lido em casa e também fornecer apoio para o acompanhamento das aulas, onde se inclui a apresentação de slides. No texto, os estudantes terão acesso a todas as Referências bibliográficas aqui citadas e poderão ainda consultar outras (livros e sites). O primeiro tempo será uma apresentação de slides onde será exposto o tema "Leis de Kepler: um breve panorama de como a história da cosmologia mostra sua descoberta". No tempo seguinte haverá uma discussão do tema com a turma de como o conhecimento científico se desenvolve num contexto sociocultural e é influenciado por fatores extrínsecos à ciência. Para finalizar será feito um exercício escrito de verificação da aprendizagem, onde serão abordados aspectos quantitativos relacionados às distâncias e períodos de revolução dos planetas em relação ao Sol (3a Lei de Kepler).

\subsection{Descrição sumária da sequência didática}

É importante destacar que o uso da HC tem como principal propósito transmitir ao estudante - que está em processo de construção do conhecimento - que as ideias aceitas atualmente são um produto de muitas experiências e observações que foram aceitas pela comunidade científica e outras que fracassaram. Assim, o texto utilizado foi elaborado com o objetivo de apresentar, dentro de um contexto histórico, como se desenvolveu nosso pensamento acerca do movimento dos astros. Embora o recorte cronológico pareça muito extenso (da antiguidade até o começo do século XVII), o recorte espacial é bem mais definido (apenas Europa). Na impossibilidade de reprodução de todo o período histórico estudado, o texto mostra os episódios considerados relevantes para alcançar nosso objetivo. Assim, o texto utilizado está dividido em cinco etapas, cujas principais características descreveremos a seguir.

Nas duas primeiras etapas (itens 1 e 2) foram destacadas as qualidades da ciência grega, que apareceram pela primeira vez com Tales de Mileto (circa 624-546 AEC). Nessa linha também estão Anaximandro de Mileto (c. 610-547 AEC), contemporâneo mais jovem de Tales; Pitágoras de Samos (c. 570-495 AEC), quem primeiro tentou explicar o movimento do Sol e dos planetas pela combinação de movimentos circulares uniformes; Filolau de Croton (c. 470385 AEC), discípulo de Pitágoras; Platão (c. 427-348 AEC), discípulo de Sócrates e considerado uma das figuras mais importantes do mundo grego; Aristóteles (384-322 AEC), aluno de Platão e considerado um dos mais influentes filósofos gregos; Aristarco de Samos (c. 310-230 $A E C$ ), o primeiro astrônomo a propor um sistema heliocêntrico (com o Sol estacionário no centro do universo); Hiparco de Nicéia (c. 190-125 AEC), considerado por muitos o maior observador celeste da antiguidade, e Claudio Ptolomeu (c. 100-178) - o ápice e último grande nome científico da antiguidade grega, cujo modelo geocêntrico do cosmo dominou a astronomia por quatorze séculos.

O texto revela que os pensadores gregos começaram como filósofos que quiseram dar sentido ao mundo físico em que viviam. Utilizaram círculos e esferas em cosmologia - inovações fundamentais. Antes deles as cosmovisões não tinham nenhum compromisso com a razão, e as explicações para os fenômenos da natureza tinham causas sobrenaturais ou teológicas. Parece que coube aos gregos refutar todas as lendas e folclores, e, mesmo com as limitações 
de suas cosmologias, começam a surgir esquemas coerentes da criação, onde hipóteses sustentadas por leis naturais começam a substituir as mitologias anteriores.

Na terceira etapa (item 3) é apresentado o modelo heliocêntrico de Nicolau Copérnico (14731543). Assim como Aristarco, Copérnico achava que o cosmo perfeito surgiria se o Sol fosse colocado no centro do universo e a Terra passasse a ser vista como um planeta percorrendo uma órbita em torno dele. Ao longo do texto vamos notar que o principal objetivo de Copérnico não era subverter a astronomia, mas retomar o principal preceito platônico: a crença no movimento circular uniforme como o mais adequado para descrever as trajetórias dos astros. Iniciada mais de meio século após a sua morte, sua revolução surgiu justamente por ele ser um conservador, e seu maior mérito reside no fato de ter incitado astrônomos posteriores (como Kepler e Galileu) a imaginar um cosmo heliocêntrico.

Nas duas últimas etapas (itens 4 e 5) apresentamos os astrônomos Tycho Brahe (1546-1601) e Johannes Kepler (1571-1630), cujas vidas e obras estão intimamente ligadas. Resumidamente, podemos dizer que Tycho possuía as melhores observações da era prételescópio. Acreditando que nosso planeta estava imóvel no centro do cosmo, formulou sua própria cosmovisão, onde a Terra permanecia fixa no centro do universo, com a Lua e o Sol em sua órbita - embora admitisse que os planetas pudessem orbitar ao redor do Sol. Enquanto Tycho se dedicou exclusivamente às observações astronômicas, Kepler buscou a ordem cósmica através de religiosidade e matemática. Utilizando as observações de Tycho mostrou que as leis do movimento planetário tinham que ser revistas: em vez do movimento circular uniforme em torno da Terra, estava claro que os planetas se moviam em órbitas elípticas ao redor do Sol (e a velocidades variáveis). Essa sensacional combinação entre teoria e prática proporcionou um dos mais extraordinários e proveitosos encontros da história da astronomia. Tycho e Kepler conviveram pouco, mas o suficiente para trazer ao mundo o verdadeiro embrião da ciência moderna.

\section{Atividade complementar}

O presente projeto também pode fortalecer a formação de professores dos cursos de licenciatura - ou o aperfeiçoamento daqueles já formados, particularmente aqueles cujas áreas permitem que seja abordada a temática astronômica. A fim de atingir esse objetivo seria criada uma disciplina para ser dada na graduação, por exemplo, Tópicos em astronomia ou Introdução à astronomia, onde seriam alternadas aulas e atividades em espaços de educação não formal, como planetários ou museus de ciência, e o conteúdo visto em sala de aula seria articulado com palestras junto aos licenciandos e observação do céu com instrumentos e a olho nu.

Nesse sentido, as temáticas das aulas/palestras seriam focadas em: reconhecer ordens de grandeza de medidas astronômicas (ou seja, se familiarizar com dimensões e distâncias dos astros), conhecer as relações entre os movimentos do sistema Sol-Terra-Lua para a descrição de fenômenos astronômicos (duração do dia/noite, estações do ano, fases da Lua, eclipses etc.), noções de esfera celeste, movimento diurno dos astros, constelações etc. Os aspectos históricos precederiam todos os tópicos supracitados.

Ao final do curso espera-se que os estudantes sejam capazes de desenvolver textos e/ou metodologias de ensino de astronomia que possam ser utilizados em sala de aula dentro de suas respectivas disciplinas (por exemplo, as condições para a formação de moléculas orgânicas complexas no meio interstelar e a origem da vida, assuntos que envolvem disciplinas como a química e a biologia), e que, preferencialmente, tenham uma abordagem histórica (por exemplo, estudar a história do desenvolvimento dos telescópios, as contribuições de Galileu e Kepler nesse processo e a física presente na formação de imagens por instrumentos ópticos, assunto da óptica geométrica). 


\section{Considerações Finais}

Então, embora as Leis de Kepler tenham sido lançadas e estabelecidas no princípio do século XVII, a montagem do cenário ocorreu bem antes: começou com a geometrização da esfera celeste pelos gregos, prosseguiu ao longo do século XVI com o desenvolvimento e (gradual) aceitação da teoria copernicana, e culminou com as meticulosas observações de Tycho Brahe. Esses foram apenas alguns dos ingredientes que permitiram a Kepler elaborar suas leis do movimento planetário.

Nesse sentido, espera-se que o estudante possa reconhecer o estudo da física como um processo cuja construção ocorreu ao longo da história da humanidade, impregnado de contribuições culturais, econômicas e sociais. A inclusão de história da ciência é necessária para se evitar a ideia de o conhecimento científico ser um sistema fechado de verdades absolutas. Abordagens históricas no ensino de física e de ciências podem ajudar no processo de mudança conceitual dos estudantes sobre os temas em questão e estimular o pensamento crítico, elucidando melhor a atividade científica em si e sua relação com os contextos sociais e culturais onde esta se dá.

\section{Referências}

GUTTMANN, G.; BRAGA. M. Universo dinâmico e Big Bang: uma outra forma de se abordar o Cosmo no Ensino Médio. In: Ana Paula Bispo da Silva, Andreia Guerra. (Org.). História da Ciência e Ensino: Fontes Primárias e propostas para sala de aula. São Paulo: Editora Livraria da Física, 2015, p. 137-147.

MOURÃO, R. R. F. Kepler: a descoberta das leis do movimento planetário. São Paulo: Odysseus Editora, 2003.

OLIVEIRA, K.; SARAIVA, M. F. Astronomia e astrofísica. 2. ed. São Paulo: Livraria da Fisica, 2004. Disponível em: http://astro.if.ufrgs.br/index.htm. Acesso em: 13 jul. 2017.

SILVA, G.A. Leis de Kepler do movimento planetário: um breve panorama de como a história da cosmologia mostra sua descoberta. In: 15옽INÁRIO NACIONAL DE HISTÓRIA DA CIÊNCIA E DA TECNOLOGIA, 2016, Florianópolis. Anais eletrônicos... São Paulo: SBHC, 2016. Disponível em:

http://www.15snhct.sbhc.org.br/site/anaiscomplementares\#G. Acesso em: 13 jul. 2017. 


\section{ARTE CONTEMPORÂNEA E UNIVERSIDADE: REFLEXÕES SOBRE AS INFLUÊNCIAS DO AMBIENTE MULTIDISCIPLINAR NA PRODUÇÃO ARTÍSTICA ATUAL}

Ítalo Bruno Alves - Professor Adjunto do Departamento de Arte da UFF - italobruno@id.uff.br

Resumo

Este artigo pretende levantar algumas reflexões sobre a condição atual da arte, cada vez mais próxima do ambiente universitário, e as influências que este ambiente acadêmico vem exercendo sobre a produção artística contemporânea em seu forte caráter conceitualista. A aproximação da produção artística, bem como de sua teoria imanente, com outros campos de conhecimento vem promovendo atividades de ensino, pesquisa e extensão que, de forma cada vez mais intensa, criam conexões inter e transdisciplinares. Embora este fenômeno nos Estados Unidos venha sendo observado desde meados do século XX, no contexto brasileiro ele começa a se tornar evidente a partir dos anos 1990 quando universidades brasileiras começam a criar linhas de pesquisa específicas voltadas para formação de artistas.

Palavras-chave: Artes visuais. Arte Contemporânea. Conceitualismo no Brasil.

1 Arte contemporânea, conceitualismo e universidade.

O início do período que convencionamos chamar de arte contemporânea está muito próximo do surgimento da arte conceitual e de seu maior legado, o conceitualismo, ou seja, um conjunto de fatores práticos e teóricos que aproximam a arte de um entendimento ideativo e a afastam da tradição técnica e morfológica que se desdobrou desde a antiguidade clássica. A arte conceitual por ser uma manifestação diretamente ligada à linguagem verbal parece ter sido favorecida pelo acesso a informação possibilitada pelas universidades. $O$ fenômeno de fortalecimento e delimitação da área de arte aconteceu em diversos países na segunda metade do século XX. Embora não se possa afirmar que exista uma relação de causa e efeito entre universidade e arte conceitual, certamente se pode perceber o quanto a especialização do público de estudantes e professores viabilizou a verticalização das problematizações características da arte conceitual como manifestação. O aprofundamento de reflexões na universidade pôde ser favorecido pela especialização de seu público, pelos recursos tecnológicos disponíveis e ainda pela disseminação de autores comuns, dentre eles Marcel Duchamp. Thierry De Duve aproxima o conceito de atitude estética com a reputação crescente de Duchamp como primeiro artista conceitual. Por esta razão, De Duve associa a arte conceitual e uma espécie de tendência disseminada nas escolas de arte que aproxima arte de outras áreas:

Linguísticas, Semiótica, Antropologia, psicanálise, marxismo, feminismo, estruturalismo e pós-estruturalismo, em resumo, "teoria" (ou comumente chamada teoria francesa) invadem as escolas de arte e sucedem em deslocar - as vezes substituir- a prática do ateliê enquanto renovavam o vocabulário crítico e as ferramentas intelectuais a fim de aproximar o fazer do apreciar a arte $^{5}$.

\footnotetext{
${ }^{5}$ DE DUVE, Thierry. Quando a forma se transformou em atitude e além. Tradução Clarissa Campello. In.: Arte \& Ensaios n.10. Rio de Janeiro, Programa de Pós Graduação em Artes Visuais/ Escola de Belas Artes, UFRJ, 2003 p. 102.
} 
Comparando a afirmativa de Thierry de Duve sobre esta aproximação da arte conceitual com teorias exógenas e, portanto, diferenciadas às tendências autorreflexivas modernas com a caracterização de pós-modernismo, encontramos muitas concordâncias entre fenômenos de alterações na natureza da arte nos anos posteriores a década de 1960 por contaminações de ordem teórica.

Hal Foster associa a arte pós-moderna com o desenraizamento da arte em relação às utopias autorreflexivas modernas. Nos trechos a seguir poderemos observar a direta associação entre a produção dos artistas e a relação com teorias de outras áreas de conhecimento, evidenciando uma mudança profunda na ideia de arte com sua consolidação como saber institucional nas universidades. Vejamos Hal Foster: Se a essência do modernismo é usar os métodos de uma disciplina para "enraizá-la mais firmemente em sua área de competência", a essência do pós-modernismo é fazer o mesmo, mas exatamente para subverter a disciplina ${ }^{6}$. Foster, ainda, aponta "Em geral, a arte pós-modernista está preocupada não com a pureza formal dos veículos artísticos tradicionais, mas com a "impureza" textual - as interconexões de poder e de conhecimento nas representações sociais" $"$.

De forma convergente com as afirmações de Foster, Howard Singerman destaca que por volta dos anos 60 o que mais caracterizava a Universidade para a convivência dos artistas era a linguagem e por outro lado aponta que nos escritos de Rosalind Krauss, Douglas Crimp e Craig Owens junto com as mais influentes teorias do pós-modernismo também tinham a linguagem como teoria central ${ }^{8}$.

Esta mudança de paradigma por sua vez esteve diretamente ligada à influência exercida pela dinâmica de transmissão, articulação e desenvolvimento do pensar estabelecido pela convivência universitária. A propósito da disseminação desta renovação de vocabulário de outras teorias Therry de Duve cita alguns focos:

Então apenas para citar alguns exemplos proeminentes, a Nova Scotia College of Art and Design em Halifax teve seu período mais prolífico, Cal Arts estava lançando uma geração de alumni bem-sucedidos, e Goldsmiths era o lugar onde se deveria estar?

Charles Harrison em seu texto "O ensino da arte conceitual", resultado de sua apresentação no Louvre em 2003 no ciclo de conferências Peut-on enseigner l'art aux artistes? [Pode ensinar arte aos artistas?] cita casos de associações diretas entre escolas e movimentos na arte dos anos 60 em diante.

A Pop Art britânica surgiu em Londres, principalmente no Royal College of Art, a escultura abstrata dos anos 60 na St. Martin também em Londres; as raízes inglesas do movimento da arte conceitual foram lançadas no Coventry College of Art, no final dos mesmos anos 60 e a Brit Pop ou Jovem Arte Inglesa (YBA) dos anos 90 associada ao Goldsmiths' College ${ }^{10}$.

2 Produção artística no contexto da universidade

Charles Harrison questiona se o fato de estas manifestações ter surgido na universidade não seria mais por conta do carisma de algum professor que pelo regime educacional. Nas entrelinhas de sua reflexão sobre as articulações entre os meios de ensino e as alterações na arte pós-modernista pode-se ler, no entanto, a profunda relação estabelecida entre os vínculos universitários e o desenvolvimento de obras, conforme vimos no capítulo anterior.

\footnotetext{
${ }^{6}$ FOSTER, Hal. Recodificação. São Paulo: Casa Editorial Paulista, 1996, p.178.

${ }^{7}$ FOSTER, op. cit., p.178.

${ }^{8}$ S. SINGERMANN, Howard. Making artists in american university. London: university of California press, 1999,p. 155.

${ }^{9}$ DE DUVE, op. cit., p. 102.

${ }^{10}$ HARISON, Charles. $\mathrm{O}$ ensino da Arte conceitual. Tradução Prof. Dr. Milton Machado. In.: Arte \& ensaios n.10. Rio de Janeiro, Programa de Pós Graduação em Artes Visuais/ Escola de Belas Artes, UFRJ, 2003, p. 115.
} 
Então se por um lado os sistemas educacionais per si não podem gerar manifestações, por outro lado, podem gerar atitudes de transgressão profundas o bastante para naquele momento ser designadas como arte. Um exemplo particularmente sintomático desta relação entre arte e o meio universitário foi a obra "Arte e Cultura" de John Latham de 1966. Observemos a descrição do trabalho por Paul Wood:

Em agosto de 1966, o artista inglês John Latham, professor adjunto da St. Martins School of Art, em Londres - escola cujo ensino o modernismo tinha ampla influência, tomou emprestada, da biblioteca da faculdade, uma cópia do livro "Arte e cultura" de Greenberg. Convidou então artistas e alunos com ideias parecidas às suas para uma "mastigação" (parodiando as aulas e palestras daquele tempo) - que envolvia escolher uma página, arrancá-la, mastigá-la e cuspir o resultado em um receptáculo preparado para aquele fim. Latham em seguida decompôs a pasta em um líquido com uma mistura de produtos químicos aos quais acrescentou lêvedo. Quando a biblioteca requisitou de volta o livro, foi-Ihe entregue um tubo de ensaio contendo álcool: Latham tinha "destilado" Arte e Cultura. ${ }^{11}$

Latham foi demitido tão logo seu "Arte e Cultura destilado" foi devolvido a biblioteca da universidade. A carta de demissão passou então a fazer parte da maleta onde se guardavam os recipientes da destilação. Paul Wood chama atenção para o fato de tal retaliação institucional ter em poucos anos deixado de fazer sentido, e a obra ter sido exibida na entrada da exposição dedicada ao final do século XX no Museu de Arte Moderna de Nova York. Sendo, portanto, absorvida no sistema de arte por uma transgressão ao sistema universitário.

$\mathrm{O}$ trabalho de Latham foi naquele momento tido como agressivo às normas institucionais porque talvez se encontrasse distante demais em sua prática do que houvera sido definido pelos departamentos estabelecidos pela área das ciências naturais. Tornou-se uma adaptação necessária para inserção da área, em seu caráter de pesquisa no sistema universitário gerando assim um novo paradigma. O sistema, o próprio sistema universitário, não poderia ter ficado isento da análise e intervenção de artistas. De Duve comenta que hoje, ele [Latham] poderia ter feito a mesma performance com a benção dos diretores, e os bibliotecários nem se incomodariam em ter de reencomendar "Art and Culture".

É assim que a Bauhaus como modelo de ensino, em seus pressupostos educacionais, abriu caminho para um determinado tipo de obra de arte desenvolvida no ambiente universitário que aqui denominamos como integrantes do binômio arte-universidade. Quando Lazlo Moholy Nagy em 1925 organiza atividades com sua turma em um mural, o fotografa e passa a considerá-lo como obra sua, inaugura ali mais que um novo habitat para arte, mas também esta espécie característica de trabalhos que surgem no cotidiano escolar.

Se a Bauhaus foi até agora indispensável para contarmos o capítulo arte e tecnologia, faremos aqui a abordagem da Bauhaus como também precursora disto que denominaríamos como arte e universidade.

Comparando o mural de Moholy Nagy com a pintura conceitual de Kosuth, podemos observar a construção clara de uma genealogia onde a palavra muito além de um elemento alegórico do conhecimento, apresenta uma estrutura visual que preza pelo pensamento textual. E esse pensamento textual é enquanto texto entendido como dado original para visualidade. Colocase aqui então uma relação de imanência entre o que é visto e o que pode ser escrito.

Desta forma podemos perceber na Bauhaus a gênese de uma fusão entre a produção da arte e a influência de seu estudo sistematizado e institucional que se expressará na geração conceitual americana, pela contaminação deflagrada pela Black Mountain [vide entrevista com Carlos Zílio no capítulo 1] Poderemos observar também o surgimento e o desdobramento

${ }^{11}$ WOOD, Paul. Arte conceitual. Tradução Betina Bischof. São Paulo: Cosac \& Naify, 2002 p. 32. 
de meios que estarão ligados à pratica universitária, ou ao menos serão favorecidos por ela, como é o caso dos meios do happening e da performance.

Henri Flynt definindo o Fluxus aponta que arte conceito seria a arte onde o material seriam os conceitos e uma vez que os conceitos são estritamente ligados à linguagem, a arte conceitual seria a arte na qual o material é a linguagem. Esta caracterização aumenta as possibilidades de ocorrer trabalhos centrados na linguagem e próximos ao território textual intrínseco às exigências acadêmicas.

Esta dissociação entre arte e objetos levou a década de 60 a uma outra manifestação particular: os happenings. Fruto da mesma ânsia anti-objeto, os happenings se proliferam de forma tão volátil quanto a arte conceitual. É neste momento que Howard Singermann afirma que:

Há um nexo entre espaços alternativos e os departamentos de arte em universidades. As mídias não tradicionais que estes espaços mostram têm parte de sua emergência produzida pela universidade: vídeos, filmes, performances precisam de um espaço e uma tecnologia e uma audiência específica ${ }^{12}$.

No Brasil, poderemos observar a preocupação na adaptação da arte ao sistema universitário por uma publicação de Silvio Zamboni, consultor do CNPq, denominada Pesquisa em Arte. O trabalho inédito no que diz respeito ao estabelecimento de normas de conduta na pesquisa possui implicações muito mais abrangentes dentre elas a migração de conceitos das ciências naturais para a investigação em arte.

O autor aponta que a necessidade da publicação vem desde 1984, quando a área de arte ainda não era oficializada na instituição [CNPq] e não havia consultores específicos para análise de projetos que pretendiam subsídios. Não havia naquele momento critérios claros e objetivos para o julgamento de projetos que tratassem da pesquisa em artes.

Se por um lado a publicação de Silvio Zamboni revela uma necessidade sintomática da estruturação da arte no sistema universitário brasileiro, por outro lado, revela os balizamentos exógenos estabelecidos para esta inserção. Aponta um caminho a ser seguido que de forma alguma difere do processo ocorrido nos Estados Unidos e Europa conforme apontados anteriormente por Edgar Morin e por Thierry De Duve no que diz respeito às comparações aos departamentos consolidados nas universidades.

O processo de sistematização da arte no habitat universitário, da mesma forma, estará vinculado aos processos estabelecidos secularmente para as pesquisas científicas. Zamboni afirma que:

\footnotetext{
A existência de um caráter racional em arte se revela inegável quando se promove a interposição e a comparação entre arte e ciência enquanto formas de atividades do conhecimento humano. Daí o método de abordagem da pesquisa em artes ser feito sempre comparativamente ao da pesquisa em ciências e o uso desse modelo comparativo ocorre, principalmente, em razão da existência de um grande arsenal teórico destinado ao entendimento da pesquisa em ciências ${ }^{13}$.
}

A publicação, e particularmente o pressuposto de Zamboni, refletem de forma clara, a aproximação e o desenvolvimento das artes visuais no contexto brasileiro de forma análoga ao contexto norte-americano, expresso por Singermann, se aproximando e sendo fomentada pelo contexto universitário. Este fenômeno recente pode ser muito revelador se não for naturalizado.

\section{Considerações finais}

12 SINGERMANN, op. cit., p. 157.

${ }^{13}$ ZAMBONI, Silvio. A pesquisa em arte: um paralelo entre arte e ciência. Campinas: autores associados, 2001, p.9. 
Embora as particularidades da produção artística na segunda metade do século XX e no início do século XXI venham, em grande parte, sendo desenvolvidas por artistas que buscam a formação universitária, este fenômeno é extremamente recente se observado na perspectiva de uma área secular como as artes visuais. Assim, vale observar quais são os aspectos produtivos e libertadores na produção acadêmica prática e teórica dos artistas, mas, também, quais aspectos poderiam ser enriquecedores para os outros campos de conhecimento. Poderíamos dizer que esta influência seja recíproca? Os campos de conhecimento que tomam contato com as artes visuais também vêm se beneficiando com conexões originais? Estas questões compõe um amplo campo de investigação que integra esta nova relação, um campo particular intrínseco a arte contemporânea que persistiremos em investigar: o binômio arteuniversidade.

\section{Referências bibliográficas}

DE DUVE, Thierry. Quando a forma se transformou em atitude e além. In.: Arte \& Ensaios n.10. Rio de Janeiro, Programa de Pós Graduação em Artes Visuais/ Escola de Belas Artes, UFRJ, 2003.

FOSTER, Hal. Recodificação. Tradução Duda Machado. São Paulo: Casa Editorial Paulista, 1996 The anti-aesthetic: essays on postmodern culture. Washington, Bay press, 1995.

HARISON, Charles. O ensino da Arte conceitual. Tradução Prof. Dr. Milton Machado. In.: Arte \& ensaios n.10. Rio de Janeiro, Programa de Pós Graduação em Artes Visuais/ Escola de Belas Artes, UFRJ, 2003.

HARVEY, David. A condição pós moderna. São Paulo: Loyola, 1992.

KAPROW, Allan. A Educação do A-Artista. S/T. Rio de Janeiro: Malasartes, 1976.

LUCIE-SMITH, Edward. Art Now. New York: Willian Morrow and company, 1977

MALDONADO, Tomás. O problema da educação artística depois da Bauhaus. In.: Projeto construtivo na arte (supervisão, coordenação geral e pesquisa: Aracy A Amaral) Rio de Janeiro: Museu de Arte Moderna; São Paulo: Pinacoteca do Estado, 1977.

MORIN, Edgar. A cabeça bem feita: repensar a reforma reformar o pensamento. Tradução Eloá Jacobina. Rio de Janeiro: Bertrand Brasil, 2001.

RESENDE, José. A formação do artista no Brasil. Arte \& Ensios n. 7. Programa de pós graduação em Artes Visuais/ Escola de Belas Artes, UFRJ, 2000

SINGERMANN, Howard. Making artists in American university. London: university of California press, 1999.

WOOD, Paul. Arte conceitual. Tradução Betina Bischof. São Paulo: Cosac \& Naify, 2002.

ZAMBONI, Silvio. A pesquisa em arte: um paralelo entre arte e ciência. Campinas: autores associados, 2001. 


\section{REFLETINDO A ECONOMIA DA FELICIDADE ATRAVÉS DO SISTEMA LÓGICO HIPERDIALÉTICO DE SAMPAIO}

Marcelo de Carvalho Azevedo Anache - Doutorando HCTE/UFRJ; Coordenador do Curso de Ciências Econômicas da Faculdade Presbiteriana Mackenzie-Rio - anache1976@gmail.com

Resumo

Com o intuito de abrir caminho para os estudos de transdisciplinaridade, o presente artigo contempla como a Economia da Felicidade pode ser abordada e raciocinada a partir dos elementos do Sistema Lógico Hiperdialético de Luiz Sérgio Coelho de Sampaio. Por reunirem elementos que possibilitam uma nova forma de pensar os aspectos da felicidade, pretendese, através destes dois campos de conhecimento, apresentar uma visão não ortodoxa para a compreensão da satisfação dos agentes econômicos.

Palavras-Chave: Lógica Hiperdialética. Economia da Felicidade. Utilidade.

Sistema Lógico Hiperdialético (SLH)

Segundo Luiz Sérgio Coelho de Sampaio, podemos entender lógica como tudo aquilo que serve ao pensar na tradição filosófica, mas também na vida corriqueira dos homens. O modo de pensar humano atende ao objeto pensado, em todas as suas dimensões constitutivas. Daí que, para Sampaio, este modo constitui um sistema coerente de formas de pensar que define os fenômenos pelas suas cinco dimensões.

As lógicas básicas do Sistema Lógico Hiperdialético são: Lógica da Identidade (lógica I), Lógica da Diferença (lógica D), Lógica Dialética (I/D) e Lógica Clássica (D/D). Sobre elas reina a Lógica Hiperdialética (lógica I/D2), que dá sentido a todo o conjunto.

Para Luiz Sérgio Coelho de Sampaio, as representações culturais das lógicas podem ser percebidas em diversas situações. Na antiguidade, podemos perceber as diferentes lógicas nos cinco elementos de Empédocles - ar (I), água (D), fogo (I/D), terra $\left(D /{ }^{2}\right)$ - e estendidas por Aristóteles, com a inclusão de uma quinta essência $\left(\mathrm{I} / \mathrm{D} /{ }^{2}\right)$, que serviria precisamente como marca distinta da humanidade; nas cores da bandeira francesa: Liberté, azul (I); égalité, branca (D); fraternité, vermelha (I/D) (BARBOSA, 1998).

A lógica para Sampaio é considerada como um saber que teoriza qualquer tipo de pensamento, e tantas serão as lógicas quantas forem as formas de pensar. A partir desse raciocínio, Sampaio cria um sistema lógico quinquitário, chamado por ele de Sistema Hiperdialético. De forma bastante objetiva, o sistema hiperdialético pode ser compreendido a partir da figura de um sistema composto por cinco partes, representado por uma pirâmide, cuja base compreenderia as quatro lógicas básicas: Lógica da Identidade, Lógica da Diferença, Lógica Dialética e Lógica Clássica, em cujo vértice superior estaria a Lógica Hiperdialética.

Figura 1 - Sistema Lógico hiperdialético ou Quinquitário

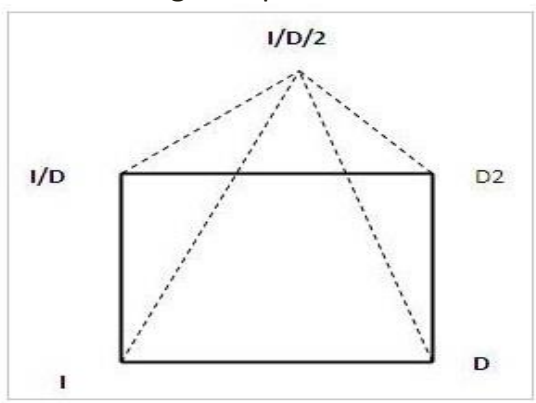


Fonte: GOMES, 2011, p. 16.

As primeiras duas lógicas são lógicas autônomas e fundamentais, enquanto as outras três são formadas por construções sintéticas e ascendentes da interação entre as duas lógicas fundamentais. A lógica hiperdialética subsume e sintetiza as quatro lógicas prévias e, consequentemente, comanda todo o sistema. Tomando, por sua vez, o Ser como o homem, a lógica pode ser entendida como o próprio modo de pensar do homem para apreender um objeto, seja em parte ou em sua totalidade. Considerando o mundo momentaneamente como o Ser, cada uma das cinco lógicas, e todas elas juntas como um todo, representam a estruturação do mundo, desde as partículas atômicas e as forças do universo até a configuração da cultura através da história (GOMES, 2015).

Em breves palavras, podem-se resumir as origens das lógicas e seus principais atributos, ou a que objetos cada uma delas visa, da seguinte forma:

- Lógica da Identidade (I): Parmênides (530-460): Consciência, temporalidade, determinação. "Pensar e ser são o mesmo". Existe uma só resposta para tudo. "Não há mudanças no mundo. Só existe o todo no seu absoluto. Todo o resto é ilusão". Lógica do ser em si. Isso quer dizer que é pela lógica da identidade que o homem sabe de si, quem tem consciência de si e que se afirma no mundo;

- Lógica da Diferença (D): Heráclito (540-470): Inconsciência, fuga da identidade. "Nenhum homem atravessa o rio duas vezes. Ser e não ser são o mesmo e não são o mesmo". Em suma, a lógica da diferença representa tanto a permanente continuidade do Ser quanto sua inconsistência, mutabilidade e ainda seu caráter paradoxal;

- Lógica Dialética (I/D): Platão (428-348 a.C.). Supera o dilema entre o ser e o não ser, entre o um e o múltiplo, entre verdade em si e a opinião de cada um. Surge a ideia, ou seja, o conceito, que agrega em si a unicidade do ser e sua multiplicidade. É, portanto, a fusão ou síntese das duas lógicas básicas precedentes ( e D). A dialética é a lógica que totaliza, por um processo de síntese, por um instante que seja, o Um e o múltiplo, tese e antítese, o diverso em coexistência, formando uma nova entidade;

- Lógica Sistêmica (D/2): Aristóteles (380-315): É a lógica das ciências. Agrega a filosofia grega e dá um salto à frente, o que vai gerar a ciência. Ela cria a lógica dos predicados (categoria), que criará a parte da ciência que permite a sistematização. Criação das bases do conhecimento científico. Verdade por adequação. Verdade estática que se adéqua ao objetivo; verdade por convencionalidade. Em suma, a lógica sistêmica abriga em si as três lógicas anteriores, o que significa que ela leva em conta a coisa em si e sua temporalidade (I), sua alteridade e espacialidade (D), seu conceito e sua historicidade (I/D), e, por fim, seu caráter sistêmico $\left(D /{ }^{2}\right)$;

A partir dessas quatro lógicas formadoras da base da pirâmide se formaria uma quinta lógica, chamada de Lógica Hiperdialética (I/D/2), ocupando o vértice de seu topo. Dessa forma, o Sistema Lógico Hiperdialético incorpora as lógicas da base e a lógica do topo, permitindo todas as potencialidades do homem; sentido superior de autoconsciência, de propósito e intencionalidade, que dá sentido não apenas ao indivíduo, como também à sociedade. De acordo com o pensamento de Sampaio, a hiperdialética é inata ao ser humano, que pensa com todas as propriedades lógicas, embora nem sempre isso aconteça em todos os momentos ou em igual competência individual.

Felicidade: Contextualização Histórica

A renovada atenção atual sobre o tema da felicidade na economia pode erradamente julgálo como uma nova moda na disciplina, quando na realidade, Adam Smith já demonstrava em 1776, quando escreveu A Riqueza das Nações, que havia constatado que todos procuram a 
felicidade. Ao nível microeconômico o tema é tratado no que se denomina Teoria do Bem Estar Social (VARIAN, 2003).

Aristóteles foi o autor da primeira fonte escrita da ideia de que toda ação humana é diretamente ou indiretamente motivada pelo desejo de aumentar o bem estar subjetivo. Para ele, o objetivo final de qualquer atividade realizada pelo ser humano seria ter felicidade, mas apenas as ações éticas conseguiriam esse objetivo. O bem estar dependeria da virtude das pessoas e das suas ações (ARISTÓTELES, 1984).

Antes de Adam Smith publicar A Riqueza das Nações em 1776, a recém-criada Economia Política tinha como objetivo assumido a felicidade pública, sobretudo nas tradições latinas francesas e italianas. O italiano Ludovico Antonio Muratori foi o primeiro autor a usar a expressão pubblica felicitá (Felicidade Pública) em 1749, sendo seguido por vários economistas conterrâneos como Giuseppe Palmieri (Riflessioni sulla felicitá pubblica) e Pietro Verri (Discorso sulla felicità).

Alguns anos mais tarde na França, personalidades como Rousseau, Condorcet e Sismondi davam igualmente um lugar central ao estudo da felicidade nas suas obras e a felicité publique foi uma das ideias chaves do iluminismo francês. O iluminismo europeu acreditava que o aumento exponencial da produtividade e da riqueza material eram fatores fundamentais para a felicidade (NIZA, 2007).

Já Adam Smith ocasionalmente incluía em seus estudos uma pesquisa muito interessante sobre as causas que afetam a felicidade das nações, apesar do seu objeto de estudo ser a causa e a natureza da riqueza das nações.

Malthus concordava com Smith que as causas que tendem a aumentar a riqueza de um estado também tendem em geral a aumentar a felicidade. Mas, segundo Malthus, talvez Adam Smith considerasse essas duas questões como ainda mais ligadas do que realmente são, enquanto que, para Malthus, a riqueza não é sinônimo de felicidade.

Smith acaba se dedicando mais tarde apenas aos fatores determinantes da riqueza das nações. Esta mudança é interpretada por alguns autores como o desejo de melhorar a qualidade da vida material das nações de uma forma global e não de buscar a felicidade através da riqueza excessiva e desnecessária.

O inglês Jeremy Bentham foi um dos principais filósofos da escola utilitarista, escola herdeira do iluminismo europeu, contemporânea da revolução industrial e até hoje um dos quatro principais campos de reflexão sobre ética e justiça econômica. A visão de sociedade justa para essa escola é simples: uma sociedade justa é uma sociedade feliz, por isso o objetivo dos utilitaristas é maximizar a felicidade dos seres humanos.

Em 1789, Bentham publicou a obra Uma Introdução aos Princípios da Moral e da Legislação, que se tornou a obra base do utilitarismo e na qual ele caracteriza os indivíduos como seres que agem esperando ganhar prazer e evitar a dor e define a felicidade "social" como nada mais do que a soma das felicidades individuais. Os atos humanos seriam consequências de decisões racionais, nas quais o ser humano agiria colocando em uma balança os prazeres e as dores que seriam sofridos por esse ato, sempre escolhendo o que maximizasse o excesso de prazer sobre a dor (HUNT, 1981).

O prazer resultante, Bentham chamou de utilidade, que era a palavra chave da sua teoria e assumidamente o objeto fundamental da sua obra de 1789. Para ele, as pessoas poderiam atingir seu objetivo de maximização da utilidade tanto via ações éticas quanto não éticas, divergindo da visão Aristotélica. A utilidade de Bentham se baseava diretamente em prazeres físicos e psicológicos.

Autores como Jevons, Walras, Edgeworth, Hicks, dentre outros, trabalharam com o conceito de utilidade, seguindo as ideias de Bentham. Se baseando no desenvolvimento da Física, reformularam a abordagem de Bentham, tratando-a com formulações matemáticas. Algumas 
relações foram traçadas entre os componentes físicos e questões econômicas. Por exemplo, energia, força e posição estavam para Física assim como os conceitos de utilidade, utilidade marginal e consumo estavam para a Economia. Consideravam que essa abordagem tinha transformado a Economia numa ciência, buscando derivar as leis econômicas da lei universal da natureza: maximizar a utilidade (HUNT, 1981)

$\mathrm{O}$ conceito de felicidade de Bentham parece ter seu significado modificado à medida que se passou a dar valor apenas para o que era objetivo e quantificável. Então, a utilidade pareceu ser mais apropriada à abordagem metodológica empregada na Economia e a felicidade foi abandonada enquanto conceito econômico.

John Stuart Mill se baseou nas ideias de Bentham para escrever sua visão sobre utilidade e felicidade. Ele foi um grande estudioso de Bentham desde jovem, acreditava que o bom era ter prazer e que o correto a se fazer era maximizá-lo. Concordava com a visão de utilidade como prazer, mas achava essa visão muito superficial e limitada. Os estados de prazer e dor não forneciam elementos suficientes para distinções sutis acerca de juízos de valor sobre a qualidade desta felicidade (MILL, 2000).

Mill fazia distinção entre prazeres superiores e inferiores, distintos em grau e natureza e acreditava que o ser humano possuiria virtudes superiores a alcançar. Um prazer superior (intelecto, sentimentos morais) será sempre superior a um inferior (sentidos, necessidade biológica), mesmo que seja de menor intensidade e duração (MILL, 2000).

A felicidade, por ser uma noção mais complexa e mais subjetiva do que os estados de prazer e dor, englobaria motivações humanas mais virtuosas. Mill adapta o utilitarismo, propondo modificar o princípio da utilidade, substituindo os estados de prazer e dor pela felicidade como motor das ações humanas.

Os economistas neoclássicos utilizavam diversos conceitos subjetivos nas análises econômicas, como nível de satisfação de vida, utilidade marginal, felicidade, prazer e dor. A partir de 1930, com a utilização das curvas de indiferença, os economistas se tornaram avessos a esses conceitos subjetivos, e avessos especialmente à utilidade cardinal e a comparações interpessoais de utilidade; passaram a adotar conceitos mais objetivos, como preferência e escolha (NG, 1993).

Essa mudança de abordagem propiciou um avanço metodológico na Economia. Apesar de ser uma abordagem limitada no sentido de não refletir os porquês das ações individuais, ela se colocou como uma aproximação simples, porém eficiente, do que ocorre na realidade. No entanto, alguns autores acreditam ter sido excessiva essa busca pela objetividade, pois não permite que muitos problemas importantes sejam analisados adequadamente. (NG, 1993; FREY; STUTZER, 2004).

Jevons e Edgeworth concretizaram o projeto ideológico de Bentham. A chamada revolução marginalista substituiu a Economia Política Clássica e o seu interesse pelos elementos objetivos e concretos da realidade econômica pelo sujeito e sua experiência subjetiva. Para Edgeworth, felicidade significava prazer e maximizar felicidade era maximizar prazer. Jevons definia a Economia como a ciência da utilidade, aceitando a filosofia de Bentham, e caracterizava a disciplina como o cálculo dos prazeres e das dores (DENIS, 1978).

Analisando a história da Ciência Econômica, Gustavo Franco (2012) conclui que o animal humano se transformou em uma criatura composta a partir de axiomas definidores de "racionalidade", e o assim criado homo economicus tornou-se um paradigma, uma entidade maximizadora de seus próprios interesses e a disciplina amadureceu sob o signo do egoísmo e do paradoxo. Para ele, existe uma espécie de vício de origem, desde que Adam Smith escreveu que os seres humanos eram motivados apenas pelos seus próprios interesses. 
Pode-se constatar que o desenvolvimento de uma Economia da Felicidade evoluiu e foi pensada de muitas maneiras. Dentro desse desencadeamento de ideias, é possível, ainda que de uma perspectiva um tanto incipiente, notar um modo de pensar, utilizando as cinco lógicas do Sistema Lógico Hiperdialético de Sampaio.

O conceito de Utilidade, utilizado por Bentham se insere na lógica I, pois esta é a lógica do ser em si, da verdade simples. Em seguida, Stuart Mill critica a abordagem de Bentham sobre as qualidades dos estados de prazer e dor. É aí que parece incorporada a lógica $D$, aquela que trata da ambiguidade das coisas do evento humano, regendo os fenômenos inconscientes, múltiplos, instintivos, os paradoxos e as inconsistências.

Enquanto os economistas clássicos partem do caráter social do ato de troca, e veem o valor de troca como um elo objetivo entre os proprietários (produtores) de diferentes mercadorias, os marginalistas partem do caráter individual das necessidades, e veem o valor de troca como um elo subjetivo entre o indivíduo e a coisa. É neste sentido que se observa a Lógica I/D, ou seja, ocorre uma síntese entre a questão da utilidade do indivíduo e o valor que se pode atribuir a ela.

Em seguida, a escola neoclássica com seus avanços metodológicos, elaborou a utilização das curvas de indiferença, fazendo com que os economistas se tornassem avessos a conceitos subjetivos, e avessos especialmente à utilidade cardinal e a comparações interpessoais de utilidade. Com isso, passaram a adotar conceitos mais objetivos, como preferência e escolha. Esta concepção sistêmica faz a Economia se rotular como ciência e se remeter a Lógica $D / 2$, que é a lógica própria da ciência, que permite definir o objeto, pesquisar suas propriedades e classificá-lo como um ser entre outros seres.

Por fim, ao se dar conta de que a felicidade não poderia ser reduzida a uma avaliação de prazer e dor e equiparada à utilidade retirada do consumo de bens, bem como compreender que o desenvolvimento humano, as relações interpessoais e virtudes deveriam ser considerados na perspectiva da felicidade, o tema passou a ser observado com outras "lentes". A investigação sobre a felicidade auxilia na compreensão de como os seres humanos valorizam os bens e os serviços, assim como a forma como eles valorizam as condições sociais. Essa forma renovada de tentativa de substituição do conceito de utilidade incorpora a forma da Lógica $\mathrm{I} / \mathrm{D} /{ }^{2}$, a lógica hiperdialética, que abarca as demais e as transcende, elevando o pensar humano para buscar a compreensão do que está acima dos constrangimentos, das estruturas, ou das necessidades. Essa lógica aponta para um plano além, ou seja, o plano da criatividade como formulação de resolução de problemas.

Referências bibliográficas

ARISTÓTELES. Ética a Nicômaco. Tradução Leonel Vallandro e Gerd Bornheim. São Paulo: Abril Cultural, 1984.

BARBOSA, Marcelo Celani. As lógicas: As lógicas ressuscitadas segundo Luiz Sérgio Coelho de Sampaio. Rio de Janeiro: Makron Books,1998.

DENIS, Henri. História do pensamento econômico. Lisboa: Livros Horizonte, 1978.

FRANCO, Gustavo H. B. Índices de felicidade e desenvolvimento econômico. 2012. Disponível em: http://www.economia.puc-rio.br/gfranco/Economia\%20e\%20felicidade\%20-\%20o\%20ensaio.pdf. Acesso em: 26 de julho. 2017.

FREY, S.B.; STUTZER, A. Happiness research: State and Prospects. Zurich, Working Paper n 190, June 2004. 
GOMES, Mércio Pereira. Todo homem é uma ilha, cada cultura é um continente, e o processo histórico é hiperdialético, 2015. Disponível em:< http://www.inter-cultural.com/wp-

content/uploads/2015/07/Todo_Homem_MercioGomes.pdf>. Acesso em: 17 de jul. 2017.

HUNT, E.K. História do Pensamento Econômico. Rio de Janeiro: Campus, 1981.

MILL, John Stuart. A Liberdade: Utilitarismo. São Paulo: Martins Fontes, 2000.

NG, Yew-Kwang; WANG, Jianguo. Relative Income, aspiration, environmental quality, individual and political myopia. Mathematical Social Science, v.26, p.3-23, 1993.

NIZA, Cláudia Fernandes. Economia da felicidade e política social: contributos da ciência comportamental para orientação da ação pública com vista ao desenvolvimento humano. 2007. 122f. Dissertação (mestrado em economia e política social). Instituto Superior de Economia e Gestão. Universidade Técnica de Lisboa.

VARIAN, Hal. Microeconomia: Princípios básicos. Ed. Campus, 2003. 


\section{UMA BREVE ANÁLISE SOBRE EDUCAÇÃO EM IMUNOLOGIA}

Janaiara Araujo Cunha - Licenciatura em Química IQ-UFRJ, Cederj -jana_1789@yahoo.com.br Priscila Tamiasso-Martinhon - pris-martinhon@hotmail.com

Angela S. Rocha - angela.sanches.rocha@gmail.com

Célia Sousa - sousa@iq.ufrj.br

\section{Resumo}

O Brasil ocupa o 11일 lugar em pesquisas em imunologia. A Sociedade Brasileira de Imunologia, $\mathrm{SBI}$, representa os imunologistas brasileiros e, para incentivar a produção científica na área, organiza reuniões científicas anuais com trabalhos abrangendo 13 áreas, uma delas educação em imunologia. Para analisar a área de educação em imunologia (EI), foi realizado um levantamento dos resumos apresentados nos Congressos da SBI, na área de EI nos últimos 5 anos. Há uma predominância de trabalhos voltados para estudantes de nível superior e profissionais. Predomina a abordagem de uso de recursos didáticos/estratégias de ensino, evidenciando uma tendência em tornar o aprendizado mais significativo, porém é necessário um planejamento para que auxiliem de fato a construção do conhecimento.

Palavras chave: Imunologia. Educação. Recursos Didáticos

Introdução

A imunologia é uma das áreas das ciências biomédicas que abrange o estudo da resposta do nosso organismo em contato com diversos patógenos, células neoplásicas, transplantes, além de diversos tipos de moléculas estranhas ou próprias do indivíduo. Essa especialidade aborda tanto o funcionamento do fisiológico do sistema imune do organismo, tanto em estado sadio quanto não sadio, como em desordens imunológicas (hipersensibilidade, doenças autoimunes e imunodeficiência, por exemplo). Os estudos em imunologia possuem outros objetivos que incluem o desenvolvimento de imunoterápicos protetores, novos métodos e reagentes para imunodiagnóstico laboratorial (USP).

Imunologia no Brasil

O Brasil é um dos países que se preocupa bastante com o desenvolvimento de pesquisa na área de imunologia, ocupando o 11일 lugar na produção de pesquisas na área. 0 estudo de Rumjanek e Leta (1996) mostrou que a produção da imunologia brasileira, apesar de comparativamente pequena na época, era de alta qualidade, pois contribuía com $12,4 \%$ de todos os cientistas brasileiros mais citados, em todas as áreas. $\mathrm{O}$ trabalho de Santos e Rumjanek (2001) evidencia um crescimento na produção e uma mudança no perfil da imunologia brasileira. Houve um salto quantitativo da produção de trabalhos, que passou de 42 artigos/ano (1985-1990), para 111 artigos/ano (1991-1995), crescendo 17\% ao ano, desde 1991. Em 1990, a Imunologia correspondia a 5\% da produção total da área biomédica, em 1995, este valor passava para 9\%. Em um estudo realizado em 2007, Barral e Barral-Netto, utilizando algumas publicações para análise, mostram uma diminuição nas publicações de pesquisadores brasileiros na área de imunologia em revistas de baixo valor de impacto e um aumento de publicações em revistas de médio e alto impacto, ainda que em menor intensidade. Como nas demais áreas biomédicas, a produção está concentrada nos estados de SP, RJ, MG e BA, representando $85 \%$ de toda produção nacional. 
Sociedade Brasileira de Imunologia (SBI)

A Sociedade Brasileira de Imunologia, fundada em 1972, representa a comunidade de imunologistas brasileiros e tem como objetivos promover o desenvolvimento da imunologia, facilitar o contato entre as pessoas interessadas e tornar acessível a população em imunologia. A fim de incentivar a produção científica na área, a SBI organiza reuniões científicas anuais alternando Congressos de interesse geral na Imunologia e Reuniões Temáticas desde 1973. Os trabalhos apresentados, tanto na forma de apresentação oral como de pôsteres, englobam 13 áreas: alergia, autoimunidade, imunologia celular, quimiocinas e tráfego, imunologia clínica, educação em imunologia, imunidade humoral, imunologia de infecções e doenças parasitárias, imunofarmacologia, imunorregulação, imunidade inata, imunologia molecular, neuroimunoendocrinologia, transplantação e imunogenética, imunologia tumoral e vacinas.

Produção científica em educação em imunologia

Para compreender os mecanismos envolvidos na imunologia é essencial o conhecimento básico de outras áreas como: Microbiologia, Parasitologia, Bioquímica, Genética, Biologia Molecular, Farmacologia e Fisiologia. O conteúdo de imunologia é extenso, complexo e possuem muitos termos específicos tornando o ensino e aprendizagem dessa ciência um desafio. A fim de analisar as vertentes na área de educação em imunologia, foi realizado um levantamento dos resumos apresentados nos Congressos da Sociedade Brasileira de Imunologia, na área de Educação em Imunologia (EI) nos últimos cinco anos.

Uma análise entre os anos de 2012 e 2016 Tabela 1), mostra que foram apresentados 25 trabalhos na área de El, sendo que entre 2012 e 2015 foi mantido a apresentação de 4 ou 5 resumos. No entanto, em 2016 houve um aumento para 8 trabalhos. O aumento foi proporcional ao total de trabalhos publicados. Enquanto entre os anos de 2012 e 2016 a porcentagem de resumos na área de El em relação do numero total de resumos oscilou entre 0,36\% (2012) e 0,73\% (2013), em 2016 a proporção aumentou para 1,36\%.

Em relação aos trabalhos publicados nas outras áreas observa-se que a área "Imunologia de infecções e doenças parasitárias" predomina com maior número de trabalhos em quase todos os anos analisadas reafirmando a parasitologia como uma das principais áreas de atuação em imunologia no país.

Quanto a distribuição regional da produção dos trabalhos, ocorre uma predominância de instituições do estado de Minas Gerais envolvidas (7), seguido de Rio de Janeiro (4), São Paulo (3) e Ceará (2), Rio Grande do Norte, Rio Grande do Sul e Acre (1 instituição cada) e 1 instituição estrangeira (New York University - New York, EUA). Nota-se que ainda que o estado da Bahia seja um dos estados com maior contribuição para a produção na área de imunologia no país, não houve participação de nenhuma instituição desse estado na área de El nos últimos 5 anos.

Em relação ao público alvo ou objeto do trabalho, há uma predominância dos estudantes de nível superior, pesquisadores e profissionais (18 resumos), seguido, a partir de 2015, da população em geral (4 resumos) e apenas 2 trabalhos voltados para o Ensino Médio, evidenciando a necessidade de mais estudos e projetos para ensino de imunologia voltados para esta etapa do ensino.

Tabela 1: Número de resumos apresentados nos Congressos da SBI entre os anos de 2012 e 2016.

\begin{tabular}{lrrrrrr}
\hline & \multirow{2}{*}{ ÁREAS } & \multicolumn{5}{c}{ ANOS } \\
\cline { 2 - 6 } & 2012 & 2013 & 2014 & 2015 & 2016 \\
\hline Alergia & - & 39 & - & - & -
\end{tabular}




\begin{tabular}{lrrrrr} 
Autoimunidade & - & 40 & - & - & - \\
Imunologia celular & 97 & 109 & 75 & 60 & 104 \\
Quimiocinas e tráfego & 11 & 27 & 7 & 8 & 4 \\
Imunologia clínica & 54 & 54 & 40 & 39 & 30 \\
Educação em imunologia & 5 & 4 & 5 & 4 & 8 \\
Imunidade humoral & 18 & 22 & 12 & 2 & 10 \\
Imunologia de infecções e doenças parasitárias & 184 & 217 & 212 & 146 & 156 \\
Imunofarmacologia & 55 & 245 & 48 & 49 & 33 \\
Imunorregulação & 63 & 77 & 80 & 79 & 55 \\
Imunidade inata & 74 & 120 & 81 & 131 & 67 \\
Imunologia molecular & 27 & 42 & 31 & 45 & 25 \\
Neuroimunoendocrinologia & - & 33 & - & - & - \\
Transplantação e imunogenética & 17 & 18 & 18 & 11 & 10 \\
Imunologia tumoral & 46 & 54 & 54 & 32 & 33 \\
Vacinas & 38 & 22 & 49 & 25 & 54 \\
\hline Total de resumos & 689 & $\mathbf{1 1 2 3}$ & $\mathbf{7 1 2}$ & $\mathbf{6 3 1}$ & $\mathbf{5 8 9}$ \\
\hline
\end{tabular}

Nota: Sinais convencionais utilizados:

- Dado numérico não disponível

Para avaliar os temas dos resumos apresentados, estes foram separados em 4 categorias, conforme Tabela 2: uso de recursos didáticos/estratégias de ensino, análise de currículo/material didático, processo de ensino aprendizagem, filosofia/divulgação científica.

Tabela 2: Categorias de resumos apresentados nos Congressos da SBI entre os anos de 2012 e 2016.

\begin{tabular}{lrrrrr}
\hline \multirow{2}{*}{ CATEGORIAS } & \multicolumn{5}{c}{ ANOS } \\
\cline { 2 - 6 } & $\mathbf{2 0 1 2}$ & $\mathbf{2 0 1 3}$ & $\mathbf{2 0 1 4}$ & $\mathbf{2 0 1 5}$ & $\mathbf{2 0 1 6}$ \\
\hline Recursos didáticos/estratégias de ensino & 3 & 2 & 3 & 2 & 8 \\
Análise de currículo/material didático & 1 & & 1 & & \\
Processo de ensino aprendizagem & 1 & 1 & 1 & & \\
Filosofia/divulgação científica & & 1 & & 2 & \\
\hline
\end{tabular}

Nota: Sinais convencionais utilizados:

- Dado numérico não disponível

Os estudos envolvendo recursos didáticos e/ou estratégias de ensino predominam totalizando em 18 dos 25 trabalhos apresentados em todo o período analisado, sendo que em 2016 todos os trabalhos apresentados abordavam essa temática. Isso mostra que nos últimos anos os grupos de pesquisa vêm buscando estratégias para melhorar o ensino de imunologia para torná-lo mais significativo.

Avaliando os recursos didáticos/estratégias de ensino utilizadas (Tabela 3), nota-se a predominância de diversos recursos multimídia como vídeo, podcasts e AVA evidenciando uma tendência a incluir novas tecnologias no ensino de imunologia. Mas se observarmos individualmente, o jogo é o recurso mais utilizado.

Tabela 3: Recursos didáticos e/ou estratégias de ensino abordados nos resumos apresentados nos Congressos da SBI entre os anos de 2012 e 2016.

\begin{tabular}{|c|c|c|c|c|c|}
\hline \multirow[t]{2}{*}{ RECURSO /ESTRATÉGIA DE ENSINO } & \multicolumn{5}{|c|}{ ANOS } \\
\hline & 2012 & 2013 & 2014 & 2015 & 2016 \\
\hline Mapas conceituais & 1 & & 1 & & 1 \\
\hline Podcast & 2 & & & & \\
\hline Ambiente virtual de aprendizagem (AVA) & & 1 & & & \\
\hline Atividades interdisciplinares & & 1 & 1 & & \\
\hline Monitoria & & & 1 & & \\
\hline Modelos tridimensionais & & & & 1 & \\
\hline Sistema de votação interativa & & & & 1 & \\
\hline Programa de vocação científica (PROVOC) & & & & & 1 \\
\hline Vídeo & & & & & 1 \\
\hline História em quadrinhos & & & & & 1 \\
\hline
\end{tabular}


Nota: Sinais convencionais utilizados:

- Dado numérico não disponível

O uso de atividades lúdicas em sala de aula constitui uma metodologia alternativa, que possibilita a interação dos estudantes com o conhecimento de forma simples em que o aluno passa a ser o sujeito da ação. De fato, a utilização de jogos e outros recursos lúdicos são sempre bem recebidos pelos alunos. Esses recursos se bem planejados, associados ao conteúdo da disciplina e bem aplicados tornam-se grandes aliados dos professores na sua prática docente (Vargas, 2009). Podem ajudar os alunos por serem atrativos e divertidos, por facilitar a compreender os conteúdos nas disciplinas de Ciências, inclusive em uma disciplina complexa como a imunologia, mas também por ajudar a desenvolver habilidades como trabalho em equipe, criatividade, capacidade de discutir tão importante em todos os níveis de ensino.

No entanto, para atingir o objetivo pedagógico o jogo não pode ser apenas divertido, também deve ter conteúdo, deve ser educativo. Seja qual for o recurso didático ou estratégia de ensino utilizada, deve ser bem planejada e aplicada pelo professor para que auxilie de fato na construção do conhecimento e não venha a ser apenas um veículo de informação.

\section{Considerações finais}

Por meio de um levantamento sobre os trabalhos apresentados nos congressos promovidos pela SBI nos últimos 5 anos, foi possível realizar uma breve revisão e análise do interesse dos pesquisadores brasileiros em pesquisas na área de ensino de imunologia. Ficou evidente que o desenvolvimento de materiais didáticos como ferramentas auxiliares no ensino de imunologia é muito importante como estratégia de tornar o processo de ensinoaprendizagem mais significativo.

Referências bibliográficas

BARRAL A.; BARRAL-NETO M. Uma breve perspectiva da imunologia no Brasil e na Bahia. Gazeta Médica da Bahia. v. 77, n.2; 241-244. 2007.

RUMJANEK VM, LETA J. An evaluation of immunology in Brazil. Brazilian Journal of Medical and Biological Research. n. 29; 923-931, 1996.

SANTOS, N.F.; RUMJANEK, V.M.; Brazilian immunology: 100 years later. Scientometrics. n. 50; 405-418, 2001.

SOCIEDADE BRASILEIRA DE IMUNOLOGIA. Sobre a SBI. Disponível em: http://sbi.org.br/sobre-a-sbi/. Acesso em: 07 out 2017.

UNIVERSIDADE DE SÃO PAULO. Instituto de Ciências Biomédicas. Graduação/Departamento de Imunologia. Disponível em: http://www.icb.usp.br/ imunoicb/?page_id=15. Acesso em: 07 out 2017.

VARGAS, C. Jogos Didáticos no Ensino de Biologia: uma proposta metodológica baseada em módulo didático. In: IX Congresso Nacional de Educação (EDUCERE), III Encontro Sul Brasileiro de Psicopedagogia. Anais... PUCPR, de 26 a 29 de outubro de 2009. 


\section{A DEFESA DA BAIA DE GUANABARA NO INÍCIO DO SÉCULO XVIII: O EPISÓDIO DA RESISTÊNCIA NO MORRO DE SÃO BENTO}

Miguel Arcanjo-Filho - Doutorando do HCTE-UFRJ - m.arcanjofilho@gmail.com Nadja Paraense dos Santos - Professora do HCTE- UFRJ - nadja@iq.ufrj.br

\section{Resumo}

No início do século XVIII, precisamente na manhã do dia 12 de setembro de 1711, o Rio de Janeiro sofreu o que podemos chamar, de forma pouco precisa, sua terceira grande tentativa de invasão por parte de franceses. Esse ataque foi liderado pelo nobre bretão René Du GuayTrouin que conseguiu romper as defesas da entrada da Baia de Guanabara realizando uma ocupação em solo carioca que durou até o dia 13 de novembro desse mesmo ano. Este trabalho pretende ser uma breve releitura do papel do Mosteiro de São Bento no episódio da invasão perpetrada por Du Guay-Trouin, no sentido de mostrar que o Mosteiro, para além de suas atividades religiosas, desempenhou durante o século XVIII a importante missão de participar da efetiva defesa da cidade do Rio de Janeiro.

Palavras-chave: Invasões Francesas. Mosteiro de São Bento. Defesa do Rio de Janeiro.

\section{Introdução}

Rigorosamente o uso do termo invasão não deve ser aplicado, sem alguma reserva, no que diz respeito às três expedições francesas que ocorreram no Rio de Janeiro colonial. A primeira, comandada por Nicolas de Villegagnon (1510-1571), ainda no século XVI, somente poderia ser definida como invasão se naquele momento Portugal já estivesse estabelecido na região da Baia de Guanabara uma colônia com todo o aparato legal, administrativo e militar devidos, caracterizando com isso o efetivo status de território português para a região. O núcleo administrativo de todo o território estava na capitania de São Vicente, numa distribuição de poderes que apenas possuía validação interna, isto é, para os estrangeiros, a região da Baia de Guanabara ainda era terra a ser explorada e os relatos da presença de franceses comerciando com os naturais, sem nenhuma intervenção portuguesa, confirma esse ponto de vista. Quanto às outras duas expedições posteriores, a de 1710 comandada por Jean François Du Clerc (?-1711) e a de 1711 liderada por René Du Guay-Trouin (1673-1736), podese também relativizar sua condição de invasão a um território estrangeiro, por motivos bem diversos. Os ataques franceses devem ser analisados do ponto de vista de ações beligerantes entre nações em guerra declarada, uma vez que Portugal, historicamente aliado da Inglaterra, estava em guerra com a França. Não existiu, por parte dos franceses, a intenção de ocupar definitivamente território estrangeiro, mas a de cortar linhas de suprimentos que abasteciam a coroa portuguesa.

Dentro desse contexto geopolítico a defesa de toda região, ao longo dos anos, foi evoluindo de ações que garantissem apenas o reconhecimento da territorialidade portuguesa, para uma efetiva incorporação de um território, que no início do século XVIII já fazia parte das bases de sustentação de Portugal. O Rio de Janeiro era uma das mais importantes cidades do Império Português, pois de seu porto era escoado o ouro das capitanias de Minas Gerais, além de tabaco, açúcar e outros produtos. Portanto, era de se esperar que a preocupação com as defesas da cidade fosse crescendo ao longo do tempo, tanto com respeito às dificuldades 
impostas em uma possível e previsível penetração inimiga através da Boca da Barra - com o aparelhamento da Fortaleza de Santa Cruz da Barra (1612) e do Forte de São João (1618) quanto com os fortes que defendessem internamente a cidade.

A investida de Du Guay-Trouin contra a cidade, após sua passagem pelas defesas de Santa Cruz e São João, se iniciou, já no dia seguinte, 13 de setembro, com a tentativa de tomada da Ilha das Cobras e do Morro dos Beneditinos, de onde veio resistência desproporcional ao que parecia ser uma fácil presa. O relato do tenente francês Louis Chancel de Lagrange descreve a linha de defesa interna da cidade e comprova ser o Mosteiro de São Bento um dos primeiros objetivos estratégicos de Du Guay-Trouin:

O primeiro dos fortes acima assinalados, o de Santiago, situa-se em pequena ponta de terra, proeminente e estendida para o mar; é abobadado e guarnecido com dez bocas de fogo. $O$ que se lhe segue, o de S. Sebastião ou o Castelo, que cognominamos o Forte Vermelho ou dos Jesuítas, fica no alto de uma colina que domina a cidade, a várzea, o ancoradouro e a barra. É quadrado em sua configuração, possuindo um fôsso e dez peças de poderosos canhões de ferro fundido, de sorte que passa por ser um dos elementos de maior eficácia na defesa local. O terceiro afastado destes dois tiros de fuzil, sobressai sobre a planície e a barra, sendo denominado de Santa Luzia; oferece o aspecto de um quadrilongo, com doze canhões e uma bateria rasa, à flor d'água, de seis peças. Finalmente, o quarto e último, é o de S. Bento, que está em um outeiro e se reduz, apenas, a uma bateria de oito canhões localizados em trincheiras. Defende, não só o próprio mosteiro, mas também, o porto e a barra, tendo sido por aí que iniciamos o ataque à cidade propriamente dita. (LAGRANGE, 1967, p.57).

O morro dos Beneditinos sempre foi considerado importante pela sua posição estratégica de última unidade de defesa interna da cidade que, pelo relato acima, começava com o forte de São Thiago da Misericórdia (1567). Ainda existem vestígios bem visíveis e de fácil identificação de parte da muralha do Forte de São Thiago da Misericórdia. Na fotografia abaixo (Fig.1) vemos alguns canhões posicionados na muralha remanescente do forte, no local outrora conhecido como Ponta do Calabouço, no Centro da Cidade do Rio de Janeiro, onde atualmente está localizado o Museu Histórico Nacional.

Figura1 - Forte de São Thiago da Misericórdia -

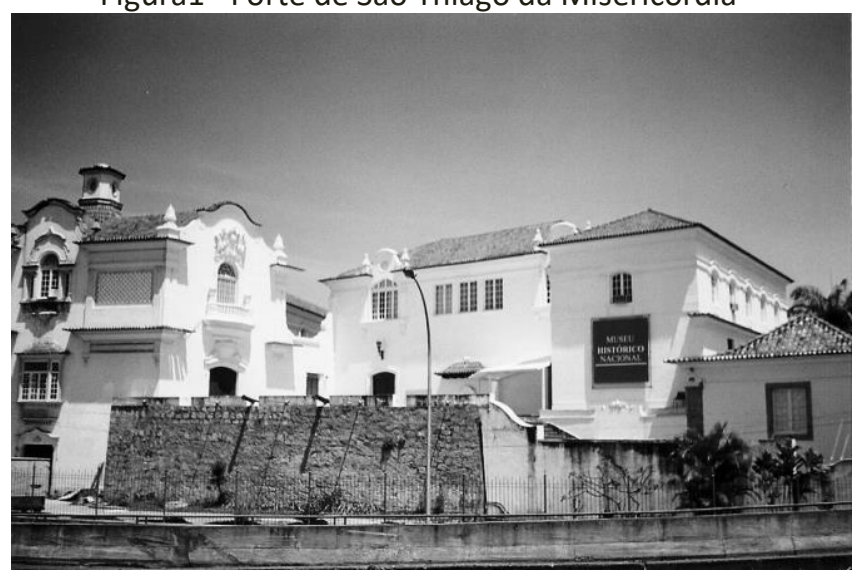

Fonte:- Carlos Luis M.C. da Cruz (2010). A foto foi tirada da atual Avenida Alfred Agache.

Outro fator relevante, com respeito ao Mosteiro de São Bento, apesar do seu acanhado poder defensivo, comparativamente às outras unidades fortificadas, é o fato de a llha das Cobras, de propriedade dos Beneditinos até 1696, situar-se bem próxima da encosta do morro do Mosteiro. Essa ilha era um ponto ideal para uma possível base bem abrigada para o escoamento de suprimentos e munições que garantiriam uma possível ocupação da cidade. ( $A$ escada de pedra que dava acesso ao antigo cais ainda hoje é utilizada pelos funcionários do Mosteiro). O historiador Vivaldo Coaracy relata que a construção do atual Arsenal da 
Marinha tem início anterior ao ataque de 1711, o que prova a importância estratégica do local onde se encontra o Mosteiro:

Tendo obtido dos frades de S. Bento a cessão de terrenos na base do morro onde se ergue o Mosteiro da ordem, Castro Caldas começou a construir ali um arsenal de guerra e marinha. Esta foi a origem do atual Arsenal de Marinha que, muito ampliado, ainda hoje está situado no mesmo local. (COARACY, 1965, p.235)

Os registros dão como sendo o ano de 1696 o início da construção do arsenal anexo ao Mosteiro pelo então governador da cidade Sebastião de Castro Caldas (Coaracy, 1965), o mesmo que posteriormente seria muito criticado pela permissão de livre circulação pela cidade do Rio de Janeiro, por mais de um mês, da tripulação francesa da esquadra do almirante Gennes que, em outubro de 1695, passava pela cidade com a missão de estabelecer uma feitoria no Estreito de Magalhães. Esses marinheiros a par de muitas informações sobre a cidade, suas defesas e o calado de seu porto tomaram parte nas expedições de Du Clerc e de Du Guay-Trouin o que favoreceu muito a logística e os planos de ataque do comandante francês em 1711.

\section{A Defesa do Morro de São Bento}

O Mosteiro de São Bento foi fundado em 1590. Existem relatos sobre uma contribuição popular que permitiu que os monges beneditinos, mesmo antes da fundação do Mosteiro, comprassem de João Fonseca, em 11 de setembro de 1589, a llha das Cobras (ERMAKOFF \& FRAGOSO, 2016). Portanto, a privilegiada situação geográfica do Mosteiro, em conjunto com sua ilha anexa, deve ter sido percebida desde o início de sua fundação, como ponto de defesa estratégico da cidade. Passados exatos 122 anos os atacantes franceses surgem e dominam a ilha, depois de breve peleja com os portugueses que se retiram da mesma após afundarem dois navios em frente ao morro do Mosteiro. Uma vez domina da a Ilha das Cobras os franceses iniciam no dia 16 de setembro o ataque ao Mosteiro. Nas palavras do próprio comandante: No dia 16, devido ao avanço de um de nossos destacamentos, os inimigos armaram uma mina com tamanha precipitação, que não nos causou nenhum mal. No mesmo dia, encarreguei o Sr. De Beauve e o Sr. De Blois da instalação de uma bateria de dez canhões numa península que atacasse pela retaguarda as baterias e parte das trincheiras do morro dos beneditinos. (DU GUAY-TROUIN, 2002, p.146)

O que parecia ser a tomada de uma simples bateria de canhões com algumas trincheiras de defensores, se revelou uma luta demorada e com muitos revezes de lado a lado. A principal razão para isso deve-se ao fato de o comandante das forças de defesa no morro dos beneditinos ser o oficial Gil Hedois du Bocage (avô materno do poeta português), um francês da Normandia naturalizado português que conhecia diversas técnicas utilizadas pelo inimigo (FRANÇA, 2000). Bocage atuou durante anos como corsário francês com experiência em comando de tropas e, portanto, conhecedor das artimanhas militares e estratégias de combate típicas dos seus antigos compatriotas que naquela altura atacavam a guarnição que ele defendia ao redor do Mosteiro. A figura 2 mostra o Mosteiro no alto da Colina e a Ilha das Cobras bem em frente ao mesmo. 


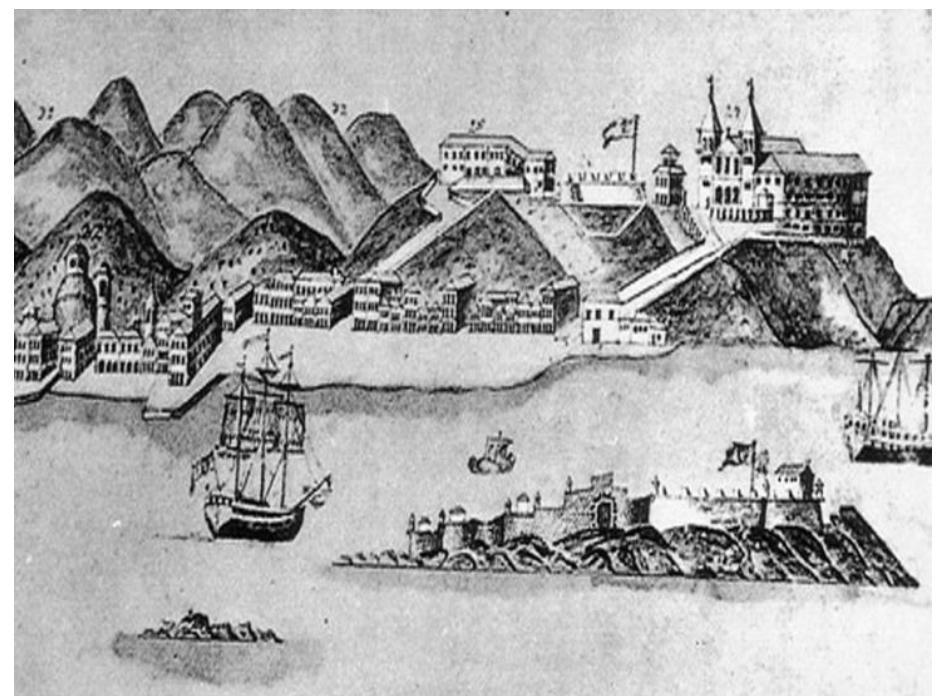

Fonte: Acervo da Fundação Biblioteca Nacional. A atual Praça Mauá, situa-se atrás da colina onde está localizada a igreja do mosteiro.

Um fator adicional para entender como foi difícil a tomada do Mosteiro beneditino é o seu formato de construção. O edifício principal é guarnecido de muralhas que não perdem em nada para uma verdadeira fortaleza militar. O oficial francês Guillaume François de Parscau, integrante das forças de ocupação de Du Guay-Trouin, descreve a construção sem disfarçar sua admiração pela obra realizada pelos portugueses inimigos:

Quanto ao convento dos beneditinos, não é tão espaçoso quanto o dos Jesuítas, mas sua igreja é maior e mais notável, formando um conjunto nada inferior ao outro. Sobe-se aí por uma bela ladeira, bem mais suave e mais curta que a dos Jesuítas. Do alto, tem-se, igualmente, uma bela vista. A construção, mais regular no todo que a sua congênere, não é menos sólida, pois, apesar do grande número de tiros de canhão disparados em cheio, da llha das Cobras que se encontra, por assim dizer, à queima-roupa - somente a muralha fronteiriça da ilha ficou consideravelmente danificada. E isso não obstante a sua grossura e os blocos de pedra que a atravessam quase que completamente. Foi essa muralha que poupou o resto das edificações de maiores avarias. (FRANÇA, 2000, p.129)

É interessante essa descrição quase poética de um indivíduo que naquele momento participava diariamente de sangrentos combates.

A figura 3 mostra a posição dos três fortins dentro da cidade citados no presente trabalho. Tomando como referência a Rosa dos Ventos da figura, temos a sudeste o Forte de São Thiago da Misericórdia na Ponta do Calabouço. Ao norte encontramos a llha das Cobras que em 1713 já possuía uma ponte que a ligava do continente a um pequeno cais no sopé do Morro de São Bento. A partir da Rosa dos Ventos, a noroeste, encontramos precisamente o Mosteiro de São Bento. 


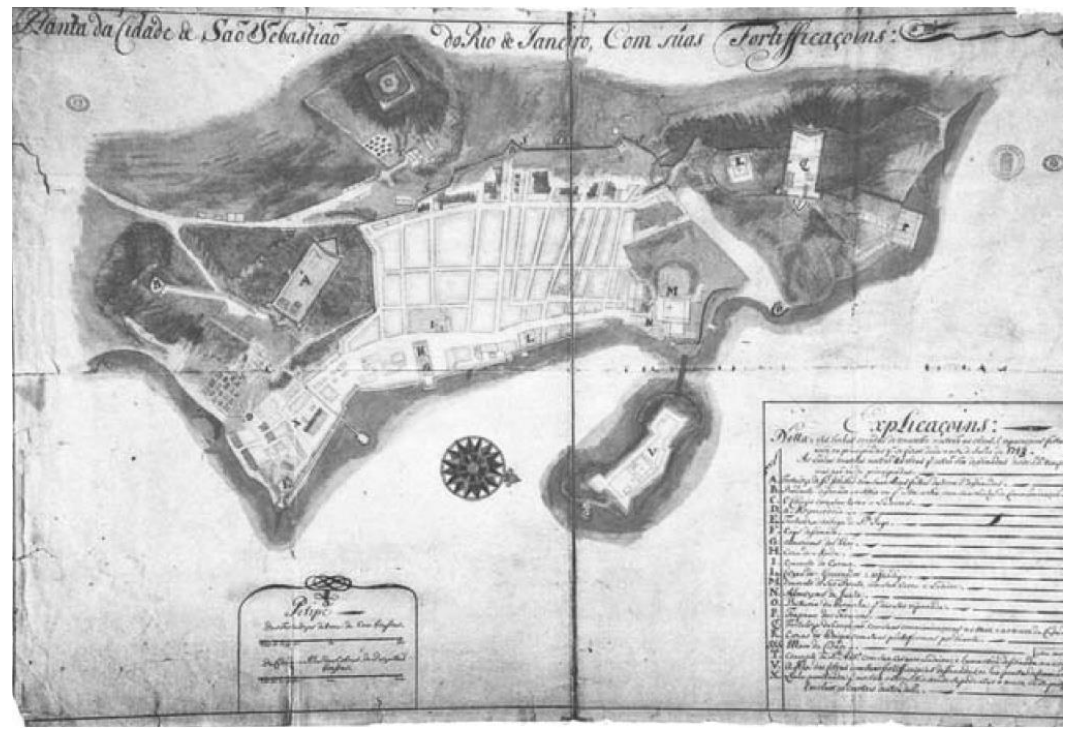

Figura3 - Planta da Cidade de São Sebastião do Rio de Janeiro, de 1713, com suas principais fortificações.

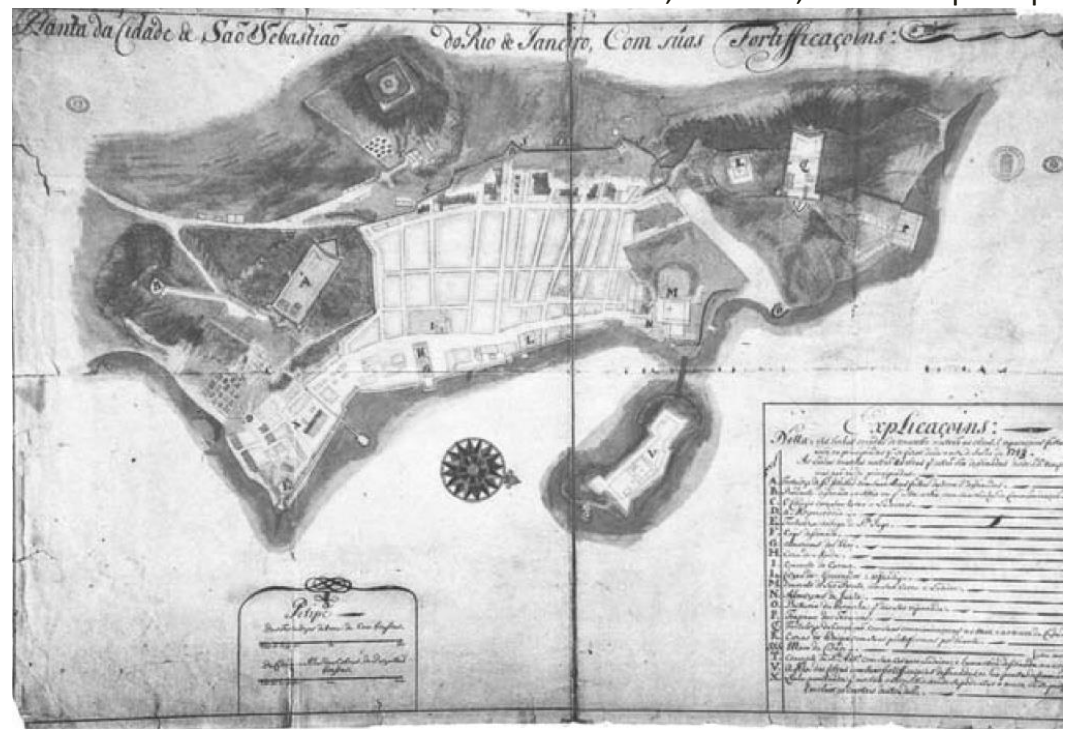

Fonte: Serviço de Documentação Geral da Marinha. Autoria de Jean Massé

No dia 19 de setembro Du Guay-Trouin resolve intimidar o governador Francisco de Castro Moraes enviando-Ihe mensagem que, entre outras exigências, além da capitulação, solicitava a entrega aos franceses dos responsáveis pelo assassinato de Du Clerc, comandante das forças que atacaram o Rio de janeiro no ano anterior. Com a recusa do governador em ceder uma rendição, Du Guay-Trouin resolve intensificar os ataques. No dia 20, dois navios franceses, o Mars e o Brillant em conjunto com as baterias já instaladas na llha das Cobras somaram fogo contra as trincheiras beneditinas. Já no início da noite se apresentava a formação de uma terrível tempestade que com o clarão de seus relâmpagos, mais tarde, revelaram a movimentação das tropas francesas que se preparavam para o ataque no raiar do dia seguinte. Com essa revelação, as baterias do Mosteiro abriram fogo contra os franceses, que responderam com toda a carga (DU GUAY-TROUIN, 2002). O que deveria ter sido a tradicional trégua noturna se transformou numa batalha ao mesmo tempo sangrenta e pavorosamente barulhenta.

\section{Conclusão}

De posse da Ilha das Cobras e bombardeando constantemente o Mosteiro, os franceses finalmente no dia 21 conseguiram eliminar as baterias de defesa e tomar as trincheiras 
beneditinas de assalto. Quando rendida, a praça do Mosteiro se transformou em acampamento militar francês. Suas acomodações foram utilizadas como alojamento de oficiais e praças de maior patente, o que trouxe prejuízos vários com depredações e roubos de peças valiosas (CRULS, 1965). Após a tomada do Mosteiro, uma vez que a população da cidade e o restante das tropas portuguesas empreenderam a evacuação do seu núcleo urbano, Du Guay-Trouin inicia as negociações, com os governantes portugueses, dos termos de rendição e as condições para retirar-se da cidade. Portanto, o Mosteiro de São Bento pode ser considerado o último reduto das defesas cariocas no episódio da "invasão" francesa de 1711. Seu lugar de destaque nesse episódio está assegurado para a posteridade e deve ser considerado importante objeto de estudos para futuras explorações históricas e arqueológicas que podem revelar tecnologias utilizadas na defesa da cidade durante o século XVIII como também em séculos anteriores.

Referências bibliográficas

COARACY, V. O Rio de Janeiro no século 17. Rio de janeiro: Livraria José Olympio Editora. 1965.

CRULS, G. A aparência do Rio de Janeiro Vol. 1. Rio de Janeiro: Livraria José Olympio Editora. 1965.

DU GUAY-TROUIN, R. O Corsário. Uma invasão francesa no Rio de Janeiro. Dário de bordo 2ạ Edição. Rio de Janeiro: Bom Texto Editora e Produtora de Arte Ltda. 2002.

ERMAKOFF, G. \& FRAGOSO, M. Mosteiro de São Bento do Rio de Janeiro 425 anos. Rio de Janeiro: Edições LumenChristi. 2016.

FERREZ, G. O rio de Janeiro e a defesa de seu porto. Rio de Janeiro: Serviço de Documentação Geral da Marinha. 1972.

FRANÇA, J.M.C. Outras Visões do rio de Janeiro Colonial. Antologia de Textos 1582-1808. Rio de Janeiro: Editora José Olympio Ltda. 2000.

LAGRANGE, L.C de. A Tomada do Rio de Janeiro por Duguay-Trouin. Rio de Janeiro: Departamento de Imprensa Nacional. 1967. 


\section{A história da ciência em Popper e Bachelard: o caso da teoria da pangênese darwiniana}

Fernanda Gonçalves Arcanjo, Mestranda pelo HCTE-UFRJ - fgarcanjo@gmail.com

\section{Resumo}

O objetivo deste trabalho foi comparar a relação entre as epistemologias de Karl Popper, da vertente anglo-saxônica, e de Gaston Bachelard, da vertente francesa, com a história da ciência e, posteriormente, abordar suas serventias para a análise de um caso particular da história da biologia, o da Pangênese de Charles Darwin. Concluiu-se que, uma vez que a teoria de Popper está estruturada num modelo lógico, ela acaba se restringindo a contar uma história da ciência demasiada homogênea, que não comporta a pluralidade das ciências. A teoria bachelardiana, por outro lado, concede foco exatamente à pluralidade e às contradições da atividade científica.

Introdução

"A filosofia da ciência sem a história da ciência é vazia; a história da ciência sem a filosofia da ciência é cega" (Lakatos, 1983).

"Pensamentos sem conteúdo são vazios, intuições sem conceitos são cegas." (KANT, 1987, p. 75) Esta frase célebre de Immanuel Kant (1724-1804) resume a empreitada de sua filosofia em defesa da síntese entre as perspectivas racionalista e empirista como explicação para o desenvolvimento do conhecimento, perspectivas que, na época, eram tomadas como contraditórias. Como afirma Lang (2002), esta frase poderia ser reescrita sobre a seguinte forma:

\footnotetext{
“A razão sem a experiência é vazia; a experiência sem a razão é cega”. Em 1983 o filósofo da ciência Imre Lakatos (1922-1974) parafraseia Kant ao escrever que "a filosofia da ciência sem a história da ciência é vazia; a história da ciência sem a filosofia da ciência é cega" (p.107).
}

Dificilmente pode-se dizer que a intenção de Lakatos com esta paráfrase era fazer uma comparação crua entre história da ciência e experiência. No entanto, ele parece querer afirmar que a filosofia da ciência não é senão a racionalização da história da ciência enquanto tida como o conjunto de fatos históricos que se apresentam ao historiador. Deste modo, ao mesmo tempo em que "história e filosofia da ciência" não se configura em um campo único e homogêneo, história da ciência e filosofia da ciência, como dois campos de estudo, jamais podem estar completamente apartados.

Dito isso, o objetivo deste trabalho é travar uma discussão sobre as diferentes formas em que a filosofia da ciência se relaciona com a história da ciência. Utiliza-se como exemplos as epistemologias de Karl Popper, amplamente reconhecido pela sua teoria das conjecturas e refutações (POPPER, 1980) e principal nome da vertente epistemológica anglo-saxônica, e de Gaston Bachelard, a grande referência daquela que chamamos a vertente epistemológica francesa; sua teoria do racionalismo aplicado é, ainda hoje, uma das mais expressivas marcas da lógica não aristotélica na epistemologia. Embora ambas as teorias de Popper e Bachelard sejam reconhecidas como racionalistas, suas abordagens são notoriamente diferentes. O que segue é uma breve revisão destas diferenças, pois muito a respeito disto já foi estudado. Nossa ênfase será identificar e definir a diferença da relação entre as teorias de Popper e de Bachelard com a história da ciência e, posteriormente, abordar a sua serventia para a análise de um caso particular da história da biologia. 
A epistemologia lógica de Popper versus a epistemologia histórica de Bachelard A epistemologia popperiana se sustenta sob uma perspectiva realista absoluta uma vez que afirma que o status científico de uma teoria é determinado por sua capacidade de ser refutada pelos os dados empíricos, ou seja, com o contato direto com o mundo real. $\mathrm{E}$, mais que isso, a ciência só progride na medida em que se reproduzem estes testes, estes contatos "diretos" com a realidade. Enquanto isso, Bachelard afirma que a noção de que o conhecimento é refratário do mundo real é uma noção ingênua advinda da ideia de que enxergamos o mundo como ele realmente é. Bachelard entendia não ser possível algo como um acesso ao real absoluto. Enxergamos o mundo através de recortes ou lentes e a lente do cientista, em particular, seria a teoria racionalmente produzida.

A epistemologia de Popper, arquitetada sobre a lógica aristotélica clássica, assume, portanto, que a realidade na qual se baseia a ciência é estática: aquilo que é real é sempre real e só real. Já aquilo que não é real, nunca foi nem nunca será real. A epistemologia de Bachelard, fundamentada numa lógica não aristotélica, assume uma realidade científica dinâmica. As proposições elementares que, em determinado momento, se tem como verdade são justamente aquelas que o cientista deve estar sempre apto a recusar. Assim, aquilo que é, nem sempre é.

A questão do modo como se dá o progresso na ciência é outra diferença crucial entre as duas epistemologias e expõe de maneira clara como ambas estão relacionadas com a história da ciência. O método lógico de propor conjecturas e buscar refutações da epistemologia popperiana pressupõe que, desde o primeiro enfrentamento com o conhecimento de senso comum até as seguintes substituições de teorias científicas, há sempre uma contínua melhora de respostas para as mesmas perguntas e um acúmulo de respostas para novas perguntas. Embora jamais se chegue a todas as respostas corretas, à verdade ou à realidade plena, a ciência promove um aumento do conteúdo de verdade das teorias. Ou seja, a ciência, para Popper, evolui no sentido de trabalhar diretamente sobre o real e daí resgatar recortes cada vez mais amplos e claros do mundo como ele é.

Enquanto interpretação da história, o modelo popperiano traz, portanto, uma exposição clara dos elementos que devem ser identificados. É necessário saber, para um determinado período, quais são as teorias que foram refutadas, a correta continuidade em que estas teorias foram refutadas e quais as razões destas refutações. É importante também identificar a teoria que prevalece até o momento o qual se estuda e o que ela trouxe de novo, num sentido de progresso, em relação às teorias anteriores.

É a principal consequência deste modelo, portanto, que a história da ciência passe a ser interpretada de uma maneira homogênea. Seria papel da história da ciência enfatizar os períodos que, hoje, são reconhecidos como os mais notáveis da história, pois foram estes que moldaram a ciência, e apenas eles vão nos revelar o caminho pelo qual a ciência avança. As condições específicas sobre as quais cada evento científico se sucedeu ou sobre as quais cada conceito foi proposto são deixadas de lado no intuito de recortar uma continuidade das teorias científicas e evidenciar um progresso científico que é, visivelmente, inquestionável.

Em oposição a este continuísmo popperiano, temos que a epistemologia de Bachelard é rupturista. Para ele, o conhecimento científico é sempre a reforma de uma ilusão e a primeira ilusão é a do primeiro contato com o mundo, o contato sensível. É necessário romper com o senso comum para construir conhecimento científico. E no desenvolvimento da ciência, o novo conhecimento sempre diz não ao conhecimento anterior. É tal ruptura que promove não uma simples mudança das respostas, mas uma mudança das próprias questões a serem perseguidas: há uma eterna mudança de racionalização. Ou seja, não há garantia de que 
sempre aumenta o recorte da realidade a que se atém o cientista, apenas que este recorte se altera.

Isso não significa dizer que Bachelard propõe que a ciência não avança, apenas que o progresso científico assume propriedades dialéticas. Bachelard acredita que este progresso se evidencia no amadurecimento da perspectiva filosófica com a qual a ciência enxerga a realidade. Esse amadurecimento se dá, de acordo com Bachelard, de uma perspectiva realista para uma racionalista. Segue que o conhecimento produzido num determinado intervalo da história da ciência não é, necessariamente, descartado. Na dependência de como e onde este conhecimento é aplicado, ele será compreendido por diferentes óticas filosóficas.

É característica essencial da epistemologia de Bachelard, portanto, o fato de que ela não é elaborada na forma de um modelo, como a teoria de Popper e dos demais epistemólogos da vertente anglo-saxônica. Bachelard simplesmente sugere uma realidade muito mais plural do que aquela exibida na epistemologia popperiana. Sua conclusão mais óbvia é de que não é possível resgatar uma homogeneidade na história da ciência, ela deve ser estudada caso a caso. Cada conceito, cada problema, cada teoria tem seu desenvolvimento único. E a história aponta nada mais do que a definição de conhecimento como a produção de uma realidade sob as leis da razão. A epistemologia bachelardiana é, portanto, denominada histórica, pois ela é um reflexo da história ao mesmo tempo em que bebe da fonte da lógica dialética. Enquanto, por outro lado, a epistemologia de Popper é inteiramente tributária da lógica clássica e pretende formatar a própria história da ciência à luz de sua lógica.

É importante, neste momento, lembrarmo-nos da paráfrase de Lakatos. Segue dela que uma história da ciência é sempre contada de modo a se adequar à filosofia que lhe é imposta. Esta história, ou melhor, esta versão jamais será absoluta ou sequer suficiente. Por outro lado, a epistemologia também é sempre desenvolvida de modo a se adequar a história na qual ela, a princípio, se baseia. Dizemos isso, pois Popper, assim como a grande maioria dos filósofos de seu período, baseou sua epistemologia em exemplos da história da física e da matemática. Bachelard foi um dos poucos que trabalhou, também, com a história da química. Portanto, transpassar quaisquer destas epistemologias para uma análise da história de uma nova ciência é sempre um exercício filosófico que deve se manter aberto e feito com cautela.

Permanece, ainda, relativamente obscurecido até que ponto estas epistemologias têm poder explanatório para a história da biologia. No intuito de fomentar esta polêmica, fazemos um questionamento a respeito das interpretações popperiana e bachelardiana para uma teoria pouco discutida: a teoria darwiniana da pangênese.

Analisando epistemologicamente a teoria da pangênese

Charles Robert Darwin, conhecido pela publicação de sua teoria para a evolução biológica no livro icônico "A Origem das Espécies" (1859), foi também autor do livro "A Variação de Animais e Plantas sob Domesticação" (1868), onde publicou sua segunda teoria biológica geral: a teoria da pangênese. Muito menos reconhecida que a teoria evolutiva, a "Hipótese Provisória da Pangênese", como Darwin a nomeou, era uma teoria para explicar o fenômeno da herança biológica (hereditariedade) e o desenvolvimento ontológico dos seres vivos. A pangênese (do grego pan- todo e genesis- origem/nascimento) estava baseava na proposta de que toda a organização do corpo é capaz de reproduzir a si mesmo através de suas partes. Cada parte do corpo, possivelmente cada célula, seria capaz de liberar minúsculas gêmulas (de proporção similar aos átomos), que carregariam a informação herdável das características daquela parte. Estas gêmulas seriam liberadas ao longo de toda a vida do indivíduo e se multiplicariam e circulariam ao longo do corpo durante certo período até que se acomodassem nos órgãos reprodutivos. Durante a reprodução sexual, o conjunto de gêmulas 
de ambos os parentais seria unido, formando um embrião, ou seja, um novo ser vivo com as características de ambos os parentais.

O objetivo explícito de Darwin com a teoria da pangênese, portanto, era fornecer uma explicação unificada e universal para o maior número de fenômenos, até então, não esclarecidos, mas que ele acreditava estarem envolvidos tanto com a herança biológica como com o desenvolvimento dos indivíduos. Dentre os diversos fenômenos os quais Darwin elucidou com sua teoria estava o fenômeno da herança de caracteres adquiridos (HCA). Popularizada pela teoria de Jean Baptiste de Lamarck, a HCA era, na realidade, senso comum na comunidade científica até o século XIX. E foi Darwin, e não Lamarck, que desenvolveu um mecanismo fisiológico, na pangênese, para explicá-la, inclusive em coerência com a sua teoria evolutiva.

Hoje sabemos que a teoria na pangênese não apresenta valor heurístico algum para a fisiologia ou para a biologia do desenvolvimento. No entanto, na época de sua publicação ela teve uma recepção acalorada com diversos adeptos, assim como opositores. Francis Galton, primo de Darwin, mais conhecido por seus trabalhos em estatística, foi um dos grandes adeptos da teoria da pangênese logo que foi publicada. Sua confiança e excitação em relação às promessas heurísticas da pangênese o levaram a elaborar um experimento baseado nas hipóteses de Darwin. Tal experimentação se deu no intuito de identificar a presença de gêmulas na corrente sanguínea de ratos, afinal Darwin havia proposto que as gêmulas, antes do repouso nos órgãos sexuais, permaneceriam circulando pelo organismo durante certo tempo.

O experimento não gerou resultados positivos, decepção que levou Galton a publicar, na revista Nature, um ensaio relatando e lamentando o insucesso de seus experimentos que, inclusive, o levariam a propor posteriormente uma nova teoria para herança. Darwin, no entanto, rebateu a publicação de Galton, através de uma resposta na Nature, afirmando que jamais havia dito que as gêmulas circulariam especificamente na corrente sanguínea.

Sob a perspectiva epistemológica de Popper, são três as mais óbvias conclusões que se pode tirar deste breve relato a respeito da teoria da pangênese:

Claramente, a pangênese darwiniana não teve papel relevante na história da teoria evolutiva como a conhecemos e, portanto, não teve papel relevante na história da biologia. Deste modo, pouco tem a oferecer para uma compreensão da lógica do desenvolvimento desta ciência.

A teoria da pangênese, sequer pode ser considerada como uma teoria genuinamente científica. Isto porque ela é dificilmente refutada, talvez não haja nenhuma maneira de refutála, como indica a resposta de Darwin aos experimentos de Galton. Darwin elaborou com a pangênese uma "teoria" extremamente abstrata, que, a primeira vista, não proíbe nenhum acontecimento logicamente previsível.

A teoria da pangênese estaria, portanto, melhor definida como uma teoria pseudocientífica e é consequência disso a baixa relevância que tal "teoria" apresentou para os desenvolvimentos seguintes da biologia.

Estas são conclusões, a princípio, sensatas. Afinal, quem hoje ouve falar sobre a teoria da pangênese, senão como um devaneio de Charles Darwin? É comum, inclusive, ver a pangênese retratada como um deslize de um grande cientista (BIZZO, 2004). Estas conclusões são, certamente, coerentes com a visão popperiana de que as condições nas quais a teoria é formulada não são relevantes para se compreender a história da ciência. No entanto, esta visão também empobrece o entendimento do lugar da pangênese em sua época enfatizando o lugar da pangênese hoje, em que temos a genética como explicação atual, e muito bem sucedida, para a hereditariedade. Esquece-se que, no século XIX, os fenômenos relacionados com herança eram completamente incompreendidos e ignora-se do exercício de Darwin em 
condensá-los quase todos numa única explicação fisiológica, de caráter materialista e mecanicista e que estava, ainda, em total harmonia com a sua teoria evolutiva, a teoria mais relevante atualmente do campo da biologia; de um novo ponto de vista, o empreendimento darwiniano com a pangênese talvez esteja sendo muito facilmente menosprezado ao ser categorizado como pseudocientífico.

Da mesma maneira que Popper diz que é relativamente fácil encontrar verificações que corroborem a sua teoria, também é relativamente fácil reconhecer nas teorias atualmente estabelecidas motivos para seus estabelecimentos. Certamente mais simples do que reconhecer em teorias ultrapassadas valores que foram sepultados. Não seria papel da história da ciência compreender o valor das teorias em seu tempo? Não teria este exercício algo a nos dizer, também, sobre o empreendimento científico?

Como não existe um modelo na teoria da Bachelard, apenas proposições a respeito de características da ciência, é mais complicado interpretar a história de uma teoria específica, como a pangênese, sobre uma abordagem bachelardiana. No entanto, algumas questões são claras. Bachelard assume que todo conceito ou ideia na ciência apresenta um espectro nocional, ou seja, a realidade de uma ideia está fracionada em diversas perspectivas filosóficas. Foi o que ele desenvolveu em sua noção de perfil epistemológico. Deste modo, seria correto supor que Bachelard defenderia uma análise mais profunda da teoria para extrair de sua história o que ela tem a dizer sobre o empreendimento científico.

Neste sentido, algo curioso em relação à teoria da pangênese é que ela era fundamentada na ideia de que o desenvolvimento é a base para as mudanças evolutivas e, portanto, era seu pressuposto que o estudo dos mecanismos do desenvolvimento desvendaria os mistérios da origem e natureza da variação das espécies. É possível dizer que a teoria da pangênese era um projeto de Darwin para sintetizar o estudo da evolução com o estudo do desenvolvimento, de modo a conferir uma linha heurística experimental para o estudo das variações na evolução.

Tal noção de desenvolvimento como base para a origem da variação foi suprimida, em meados do século XX, pelo desenvolvimento da Teoria Sintética da Evolução (TSE) - a síntese entre a teoria evolutiva darwiniana e a genética mendeliana. A abordagem genecentrista da TSE para o estudo da evolução - definindo-a como a mudança das frequências de genes ao longo das gerações - substituiu a tradição de estudo do desenvolvimento no campo da evolução. No entanto, eis que no final do século XX surge a disciplina Biologia Evolutiva do Desenvolvimento (Evo-devo) que, como defende Hall (2003), teria como origem a publicação da "Origem das Espécies". O trabalho de Darwin teria sido um marco para o início da tradição do estudo de evolução através da embriologia comparativa que, associada às inovações da biologia molecular no final do século $\mathrm{XX}$, definiu o início da produção da Evo-devo como disciplina.

Embora não seja possível entrar em detalhes, o fato é que uma ideia que no século XIX era amplamente defendida e que foi quase completamente rejeitada após o advento da genética no século XX, volta, no século XXI, com toda força. Este tipo de reviravolta não é comportado pelo modelo continuísta de Popper, especialmente porque não é possível identificar, nesta história, nenhuma refutação passada que tenha se mostrado claramente equivocada e explicasse o retorno de uma ideia anteriormente abandonada.

A perspectiva bachelardiana já nos permite entender este evento de uma maneira diferente. Tendo em vista a relação dialética que Bachelard supõe existir entre o real absoluto e o real científico, enquanto a realidade em si é inacessível, o real científico tem de ser dinâmico e mutável, e sua mutabilidade teria de se mostrar não em um, mas em diversos sentidos para compor tal relação dialética. Uma vez que não temos acesso ao mundo real e trabalhamos com seus recortes, uma mudança na racionalização pode levar a um resgate de ideias 
anteriormente rejeitadas com propriedade, mas que devido a esta conversão de racionalização passam a ser compreendidas de uma nova maneira (BACHELARD, 1984).

É possível compreender esta volta dos estudos em desenvolvimento e evolução desta maneira, levando em consideração que o advento da genética e a chamada revolução molecular na biologia, provocaram verdadeiras mudanças de racionalização - uma teórica e outra experimental - no estudo do campo da biologia como um todo. $\mathrm{E}$, de alguma maneira, estas novas espécies de evidências permitiram um resgate de uma ideia tão claramente defendida no corpo da pangênese, mas que não teve meios de se difundir naquele momento. Deve estar claro que não defendemos aqui valores heurísticos para a teoria da pangênese. Não defendemos a pangênese como explicação para a herança nem propomos que se volte a procurar gêmulas nos fluidos corporais de organismos multicelulares. Desde o início da genética moderna, novos conhecimentos surgiram e as técnicas e a linguagem dos estudos em herança e evolução sofreram mudanças dramáticas. Portanto, o resgate ingênuo de velhas ideias não faz sentido. Porém, reconstruindo historicamente o desenvolvimento das ideias de herança (mesmo que apenas parcialmente), percebemos que hipóteses e teorias antes ignoradas podem ser ressignificadas à luz dos conhecimentos atuais.

Segue disto que teorias como a pangênese darwiniana, uma vez bem adequadas ao seu tempo, não podem, nem devem ser menosprezadas por sua incongruência com conhecimentos subsequentes, principalmente quando muito do seu foco ressurge nas mais recentes produções da área. Defendemos, portanto, que há valor histórico e há valor epistemológico numa teoria que, numa análise lógica e positivista, é facilmente descartável. Neste sentido, a perspectiva bachelardiana da ciência parece fazer mais jus aos pormenores filosóficos da história da ciência, inclusive ao se tratar da história da biologia.

Considerações finais

Neste ensaio concluímos que, uma vez que a teoria de Popper está estruturada num modelo lógico bem definido, tal modelo acaba se restringindo a contar uma história da ciência demasiada homogênea, que não comporta a pluralidade das ciências e seus diversos desenvolvimentos. A teoria bachelardiana, por outro lado, concede foco exatamente à pluralidade epistemológica da atividade científica. Nem só de positivismo, nem só de racionalismo se desenvolve uma ciência. $E$, neste sentido, não temos dúvidas de que ele está correto, as revoluções que vemos ocorrer nas ciências não poderiam estar desassociadas de conversões filosóficas na compreensão da natureza. Portanto, tudo muda. Se tudo muda, uma só viseira filosófica pode não ser suficiente para contar a história de toda uma ciência, muito menos de todas as ciências.

Não afirmamos, no entanto, que a epistemologia bachelardiana tenha preenchido todas as lacunas da epistemologia. Há algo que nenhuma das duas parece, igualmente, dar conta. Afinal, quais as influências concretas do desenvolvimento econômico e social sobre a atividade científica? O modelo lógico de Popper facilmente se livra dessas preocupações ao eclipsar os meios irracionais de desenvolvimento de teorias pelos meios racionais, críticos e objetivos do método de refutações. Menos aristotélico que Popper, Bachelard ainda questiona n'A Filosofia do Não:

Perguntaremos, pois, aos cientistas: como pensais, quais são as vossas tentativas, os vossos ensaios, os vossos erros? Quais são as motivações que vos levam a mudar de opinião? Por que razão vocês se exprimem tão sucintamente quando falam das condições psicológicas de uma nova investigação? (BACHELARD)

Bachelard, diferente de Popper, assume que há fatores suprarracionais atuando no empreendimento científico. No entanto, não é possível dizer que ele avança sequer um passo 
em relação à perspectiva popperiana no sentido de responder às suas próprias questões. Em sua epistemologia Bachelard se abstém de entrar neste aspecto da ciência.

Portanto, a conclusão final deste trabalho é de que, tomando como exemplo a comparação entre as abordagens popperiana e bachelardiana para a história da teoria darwiniana da pangênese, a análise bachelardiana parece expor características do empreendimento científico muito mais interessantes e frutíferas do que a análise popperiana. Dito isso, resta uma lacuna que Bachelard não preencheu, embora parecesse estar ciente: qual a influência da cultura, religião e demais valores sociais sobre o empreendimento científico. Sendo assim, se faz necessário um novo modelo, de inspiração bachelardiana, mas que se aproprie racionalmente das influências de elementos concretos e sociológicos no estabelecimento de conceitos, teorias e tradições científicas, isto no intuito de compor uma filosofia da ciência que tome não apenas um, mas todos os ângulos da história da ciência de maneira racional e plural.

\section{Referências}

BACHELARD, G. 1984. A Filosofia do Não: Filosofia do novo espírito científico. Lisboa: Editorial Presença.

BIZZO, N.; MOLINA, A. 2004. El mito darwinista en el aula de classe: un analisis de fuentes de informacion al gran publico. Ciência \& Educação 10(3): 401-416.

DARWIN, C.R. 1868. The Variation of Animals and Plants Under Domestication. London: John Murray.

HALL, B.K. 2003. Evo-Devo: evolutionary development mechanisms. International Journal of Biological Sciences 47: 491-495.

KANT, I. 1987. Crítica da razão pura - Os pensadores. Vol. I. São Paulo: Nova Cultural.

LAKATOS, I. 1983. History of science and its rational reconstructions. In: Haking, I. (org.). Scientific Revolutions. Hong-Kong: Oxford University.

POPPER, K. 1975. Conhecimento Objetivo. São Paulo: EDUSP.

POPPER, K. 1980. Ciência: Conjecturas e Refutações. In: Conjecturas e Refutações. Popper, K. (autor) Pp. 63-88. Coimbra: Almedina. 


\title{
PROJETO ARTE E EDUCAÇÃO: UMA VISÃO CONTEMPORÂNEA DO ENSINO DA ARTE NO BRASIL
}

\author{
Giovanna Rita Rabelo de M. S. Arruda - Graduanda em Educação Artística - Licenciatura em Desenho - \\ giovannarita@ufrj.br \\ Adherbal Artigini Neto - Graduando em Educação Artística - Licenciatura em Desenho - \\ neto_artigiani@hotmail.com \\ Aleph Lana da Costa Archanjo - Graduanda em Educação Artística - Licenciatura em Artes Plásticas - \\ lana.arch@hotmail.com \\ Douglas do Nascimento Suzano - Graduando em Educação Artística - Licenciatura em Desenho - \\ douglasdesenhado@gmail.com \\ Flávia Lucia da Silva Fontes - Design de produto - flavia-fontes@live.com \\ Gabrielle Carvalho Ferreira - Graduanda em Educação Artística - Licenciatura em Artes Plásticas - \\ gabrielle.carvalhof16@gmail.com \\ José Leandro Lopes Araújo - Graduando em Educação Artística - Licenciatura em Desenho - jlla.ze@gmail.com \\ Marcelle Lateefah Simões - Graduanda em Educação Artística - Licenciatura em Desenho - \\ majulateefa@gmail.com \\ Mariana Daltro Meliande - Graduanda em Educação Artística - Licenciatura em Desenho - \\ marianameliande@gmail.com \\ Mariana Silva Rodrigues - Graduanda em Educação Artística - Licenciatura em Desenho - maribuffy@gmail.com \\ Poliana da Silva Paixão - Graduanda em Educação Artística - Licenciatura em Desenho - \\ polianaspaixao@gmail.com
}

Resumo

A pesquisa aborda o tema Arte e Educação cujo objetivo é realizar um estudo prático e teórico de sua evolução no Brasil. A teoria abrange o estado da arte, destacando: os principais autores de arte educação e legislações pertinentes. A prática apresenta as vivências acadêmicas de profissionais arte-educadores e os conteúdos programáticos no ensino fundamental de duas escolas públicas federais do Rio de Janeiro. A metodologia incluirá a realização de entrevistas e visitas técnicas possibilitando a análise dos parâmetros curriculares da disciplina de artes visuais no quinto e sexto anos do ensino fundamental. Os resultados da pesquisa serão divulgados na jornada de iniciação científica 2017 da Escola de Belas Artes da UFRJ e em um blog.

Palavras-chave: Arte e Educação. Parâmetros curriculares. Artes visuais.

\section{Introdução}

A presente pesquisa busca desenvolver um estudo sobre a aplicabilidade dos parâmetros curriculares da disciplina artes visuais nas turmas de quinto e sexto anos das escolas públicas federais, CAP- UFRJ e Colégio Pedro II Campus São Cristóvão.

\footnotetext{
"Alguns se referem à arte-educação como ensino da arte. O que tem sido bastante criticado pelos estudiosos, segundo os quais ensino da arte é, simplesmente... ensino da arte, uma vez que trata-se de uma área do conhecimento, conforme veremos mais adiante. Se não falamos, por exemplo, matemática educação, história-educação, por que arte-educação?" (VILLAÇA, 2014).
}

A arte vem se desenvolvendo desde os primeiros registros de arte rupestre, os homens iniciaram a representação do seu cotidiano, através de desenhos nas cavernas como forma simbólica de linguagem, explorando e estimulando sua capacidade criadora em seu cotidiano. A arte tem a sua presença na vida e pode ser identificada pelas histórias que revelam o conhecimento do cotidiano. Com passar do tempo, os registros iconográficos divulgam as 
experiências vivenciadas para diversas interpretações da sociedade. A linguagem iconográfica, deste modo, demonstra a construção e propagação da arte, nos diferentes meios sociais, através da observação, da interpretação e do aprendizado.

No aprendizado educacional, a linguagem iconográfica também apresenta características peculiares em determinados momentos, evoluindo de acordo com as transformações sociais e culturais. Desta maneira, as artes atendem às demandas de reorganizações de áreas de conhecimento plurais, ou seja, na: geografia, história, filosofia, língua portuguesa, matemática, música, dança etc.

Através da aprendizagem, a Arte educação propulsiona a educação, tanto no ensino infantil, básico, fundamental e médio. A arte apresenta espaço na formação cultural e acadêmica dos estudantes que tem a oportunidade de frequentar os seus cursos.

Deste modo, observa-se que a Arte educação alcança um espaço muito mais além na formação do indivíduo e articula-se com as demais áreas do conhecimento, para além dos estereótipos compreendidos como continuísta: não é mais só um conteúdo, preso a uma grade curricular dentro da escola, a fim de ocupar o tempo vago dos estudantes ou a utilização dos mestres desta disciplina para montar painéis informativos ou comemorativos na escola, ou organizar atividades sociais e festivas neste recinto.

A pesquisa compreenderá a evolução Arte educação no Brasil, com a coleta dos dados, a partir de levantamento do referencial bibliográfico, entrevistas semi estruturadas e visitas técnicas, para elaborar material de consulta aos estudantes e futuros educadores da área através de um blog acessado no LAMIE.

\begin{abstract}
“A escola, na sociedade letrada, é uma instituição voltada para o desenvolvimento do ser individual, quanto para promover o encontro daquilo que é universal no ser humano. Toda compreensão, por mínima que seja, da expressão artística é uma construção social e histórica"(ALVARES, 2012, p. 44).
\end{abstract}

Esta pesquisa se justifica, pois trarão assuntos direcionados a Arte educação e vivências da área para os profissionais da área e para estudantes de licenciatura em artes da EBA/UFRJ.

2 Objetivos e metas a serem alcançados:

Compreender a arte educação no que tange a evolução Arte educação no Brasil, o estado da arte sobre o assunto, destacar os principais nomes da arte educação, as legislações pertinentes, as vivências acadêmicas de profissionais de arte educadores e conteúdos programáticos no ensino fundamental.

Os seguintes objetivos podem ser destacados:

- Criar um Blog com a apresentação dos dados coletados;

- Apresentar os resultados dos temas pesquisados em publicações e eventos acadêmicos;

- Realizar mostras de trabalhos desenvolvidos no projeto.

3 Metodologia

A metodologia será dividida em quatro fases, a saber:

- 10 Fase: Levantamento do referencial bibliográfico;

- 2 o Fase: Entrevistas semiestruturadas com professores, técnicos e especialistas;

- 3o Fase: Revisão das fases anteriores;

- Finalização da contextualização e confecção de mídias digitais e impressas;

- 4을 Fase: Elaboração do Blog, anexo ao site LAMIE (Laboratório de Meios Eletrônicos Interativos em Arte e Arquitetura);

- Divulgação do trabalho. 
4 Conceituação Teórica:

Na visão de Araújo (2015) a manifestação artística acompanha a própria evolução do homem. Ele descreve que é na escola que o jovem e o adulto irão socializar suas experiências, desenvolver novas habilidades e aprender novos conceitos e teorias que os acompanharão ao longo de suas vidas. Através de seu estudo ele descreve o fato de a maioria desses estudantes já ter uma larga experiência de vida, terão a possibilidade de trocar experiências uns com os outros, socializando e construindo conhecimento. (ARAÚJO, 2015).

Barbosa (1989) entende que as Artes têm sido uma matéria obrigatória em escolas primárias e secundárias (1ํ e 2 o graus) no Brasil já há 17 anos. Segundo e mesmo autor, isto não foi uma conquista de arte-educadores brasileiros mas uma criação ideológica de educadores norteamericanos que, sob um acordo oficial (Acordo MEC-USAID), reformulou a Educação Brasileira, estabelecendo em 1971 os objetivos e o currículo configurado na Lei Federal no 5692 denominada "Diretrizes e Bases da Educação" (BARBOSA, 1989).

Ainda na visão de Barbosa (1989) os professores de arte conseguem os seus diplomas mas eles são incapazes de prover uma educação artística e estética que forneça informação histórica, compreensão de uma gramática visual e compreensão do fazer artístico como autoexpressão"(BARBOSA, 1989).

Pontes (2001) traz a visão dos cursos de formação para professores contribuem para que as linguagens artísticas sejam concebidas apenas como instrumentos, pois, em sua maioria não atribuem a Arte o mesmo tratamento que atribuem às demais áreas, isto é, não veem na Arte uma área de conhecimento que possui peculiaridades que poderiam ser o foco das reflexões e articulação de situações de ensino por professores" (PONTES, 2001).

5 Resultados e contribuições esperadas.

- Disponibilizar material sobre o tema para a comunidade acadêmica em meios digitais e impresso;

- Contribuir para o crescimento da Escola de Belas Artes na área das artes;

- Publicação de artigos e/ou capítulos de livros especializados sobre o tema da pesquisa;

- Participar em eventos técnico-científicos a fim de divulgar os resultados.

6 Impactos previstos:

Ampliar o interesse da comunidade acadêmica sobre a relevância da arte no sistema educacional contemporâneo brasileiro.

\section{Referências}

BARBOSA, A. M.; COUTINHO, R. "Arte/educação como mediação Cultural e Social". São Paulo. Editora UNESP, 2009

" Arte/ educação Contemporânea: Consonâncias Internacionais". São Paulo. Cortez, 2005

BARBOSA, Ana Mae. Arte-Educação no Brasil: realidade hoje e expectativas futuras. Estudos Avançados.

Revista USP, Capa n. 2. São Paulo. 1989. Acesso em: 11 jan. 2017.

DUARTE JR., J. F. "Por que Arte-Educação?" Campinas. Papirus, 1983

HERNANDEZ, F. "Cultura visual, mudança educativa e projeto de trabalho". Porto Alegre. Artes Médicas Sul, 2000

PENNA, M. "É esse o ensino da arte que queremos?" Uma análise das propostas dos parâmetros curriculares nacionais". João Pessoa. CCHLA/PPGE, 2001 
PONTES, Gilvânia Maurício Dias de. A presença da arte na educação infantil: olhares e intenções. 2001.

Disponível em: http://www.ufrgs.br/gearte/dissertacoes/dissertacao_gilvania.pdf. Acesso em: 11 jan. 2017.

VILLAÇA, lara de Carvalho. ARTE-EDUCAÇÃO: A ARTE COMO METODOLOGIA EDUCATIVA. 2014. Acesso em: 11 jan. 2017. 


\title{
RABISCOS TRIDIMENSIONAIS: IMPLANTAÇÃO DE ESCULTURAS DE ÉPURAS CONTENDO PLANOS PARTICULARES NA ILHA DO FUNDÃO
}

\author{
AdherbalArtigiani Neto \\ Aleph Lana da Costa Archanjo \\ Alessandra da Silva Nascimento \\ Douglas do Nascimento Suzano \\ Gabrielle Carvalho Ferreira \\ Giovanna Rita Rabelo de Matos Silva Arruda \\ José Leandro Lopes Araújo; Lucas Almeida de Melo \\ Mariana Daltro Meliande; Marina Silva Rodrigues. \\ Professor Dr. Aurélio Antônio Mendes Nogueira.
}

Resumo

O Projeto de Iniciação científica, Rabiscos Tridimensionais, dá sequência ao projeto anterior Rabiscos Urbanos, e visa estudar os efeitos da arte pública no ambiente a partir de análises de desenhos de esculturas de Épuras ${ }^{14}$. Usando como base desenhos de ambientes específicos da Ilha do Fundão feitos por alunos da Escola de Belas Artes da UFRJ durante seus estudos na disciplina Perspectiva de Observação, foram inseridos de forma gráfica, simulações das esculturas e os efeitos da iluminação sobre elas durante diferentes horários do dia utilizando, em conjunto, os conhecimentos na matéria Geometria Descritiva. O novo trabalho tem como objetivo tornar essas simulações físicas, construindo e implantando-as nesses mesmos lugares. A ideia se baseia em misturar os conceitos de site-specific, estudados porZalinda Cartaxo, visando analisar o espaço em que as criações serão colocadas e, com finalidade artística e performática a ideia possui também, a função didática gerada pela interação do espectador com tais elementos, remetendo aos conceitos de antiarte de Hélio Oiticica. Para alcançar tais objetivos será necessária à integração dos autores do trabalho com estudantes e professores dos diversos cursos da Escola de Belas Artes, por meio de entrevistas, a fim de buscar informações para confeccionar desenhos de plantas, gerar maquetes, especular materiais e assim construir esses Ícones Geométricos.

Palavras-Chave: Arte. Interdisciplinaridade. Épuras.

Introdução (Técnica, objeto, justificativa e relevância social)

Analisando os conceitos observados no periódico, "ARTE NOS ESPAÇOS PÚBLICOS: A cidade como realidade" de Zalinda Cartaxo, foram pensadas esculturas de épuras como objetos de arte a partir da sua questão como conceito de visualização e integração com o ambiente, e pelo caráter didático, apresentando um assunto estudado nas salas de aula. As épuras serão observadas como site-specific analisados no periódico de Zalinda Cartaxo por se encaixarem como intervenções caracterizadas pela indiscernibilidade entre a obra e o lugar.

O espaço onde a obra se mantém em conjunto com as condições dos locais no entorno como o clima e como ambas se influenciam em reciprocidade, também se tratam de site-oriented, um subgênero do site-specific. Tal situação ocorre uma vez que as obras estarão presentes

\footnotetext{
${ }^{14}$ A épura é uma representação, num plano, de qualquer entidade geométrica, mediante projeções ortogonais. Ela é muito usada em geometria descritiva e em desenho técnico para a representação de modelos e resolução de problemas. Disponível em: https://pt.wikipedia.org/wiki/\%C3\%89pura. Acesso em 23 jan. 2017.
} 
em um lugar institucional denunciando um problema relacionado à distribuição de conhecimento, pois as épuras são conceitos visuais utilizados no educar visual, mas, infelizmente, só são trabalhados antes do ensino superior em algumas escolas. O objetivo será alcançado e concluído quando os espectadores de fato reagirem à obra, validando as ideias sobre antiarte de Hélio Oiticica ${ }^{15}$.

A importância geral desse trabalho se deve ao compreender da integração de alunos e professores da Escola de Belas Artes da UFRJ, gerando a partir da criação e exposição de tais objetos de arte, a possibilidade de contato entre estudantes e funcionários com a construção tridimensional, seus desencadeamentos e com os conceitos estudados em diversas disciplinas ministradas na Escola.

Objetivos e metas a serem alcançados:

O objetivo do projeto é criar esculturas de épuras em três dimensões que problematizam conceitualmente o espaço e consequentemente sejam fonte de estudo e aprendizado. Para produzir essas obras físicas se fará necessário o uso da interdisciplinaridade entre alunos e professores da Escola de Belas Artes, considerando todos os conceitos artísticos, técnicos, teóricos e práticos visando à produção de conhecimento. Os seguintes objetivos podem ser destacados:

- Com a Criação desses objetos de arte, problematizar arte publica e sua relação com o espaço;

- Criar mais um objeto de apoio ao ensino sobre épuras e planos particulares auxiliando assim, a visualização geométrica e descritiva do espaço;

- Apresentar os resultados dos temas pesquisados em publicações e eventos acadêmicos;

- Realização de mostras de trabalhos realizados no projeto.

3. Metodologia:

Como alunos de Licenciatura valorizando a pesquisa e o embasamento para a execução dos trabalhos, e a exemplo do projeto anterior que contou com organização e uso das disciplinas do curso de Licenciatura em Desenho e Artes plásticas é necessário expor alguns passos metodológicos para a realização dessa produção artística e científica:

a) Utilizar os estudos executados no projeto anterior;

b) Pesquisa bibliográfica com livros e artigos sobre desenho de arquitetura e arte pública;

c) Entrevistas com professores e alunos de cursos diversos a fim de adquirir conhecimento sobre plantas e planejamento além da construção de esculturas.

d) A partir das pesquisas, adquirir materiais, fazer maquetes de testes e com a aprovação, construir as esculturas implantando-as em lugares utilizados para estudo na disciplina Perspectiva de observação. As obras servirão de estudo para as disciplinas da Escola de Belas Artes, envolvidas em tais conceitos.

4 Conceituação Teórica:

"A arte nos espaços públicos é, simultaneamente, meio de reflexão e lugar". (CARTAXO,2001.p.15).

\footnotetext{
${ }^{15} \mathrm{Anti}$-arte é considerada uma arte que busca uma abertura ao participador e do participador,ou seja, são obras de arte que rompem com a ideia de contemplação estática e propõem uma apreciação sensorial mais ampla, por meio do tato, do olfato, da audição e, até mesmo, do paladar. Disponível em:

https://educacao.uol.com.br/disciplinas/artes/helio-oiticica-a-antiarte.htm. Acesso em:26/01/2017.
}

HCTE-UFRJ 
Em 2016 o projeto "Rabiscos Urbanos" propôs estudar Arte Pública e seus efeitos no ambiente, essa proposta executada obteve nota 9.1 ao ser apresentada na Jornada Giulio Massarani de Iniciação Científica. A aplicação consistia em idealizar e projetar obras de arte em locais específicos da ilha do fundão e investigar as deformações visuais com relação à luz e sombra utilizando desenhos gerados por alunos. O projeto Rabiscos Tridimensionais segue o projeto Rabiscos Urbanos e pretende construir fisicamente as esculturas antes idealizadas. A primeira questão a ser respondida no projeto anterior aos Rabiscos Tridimensionais era o que trabalhar. A resposta nos foi dada enquanto investigávamos os estudos da Doutora e Professora Zalinda Cartaxo, na qual ela insere na arte pública os conceitos de Sites-specifics, estabelecendo relações dialógicas e dialéticas com o espaço e, a partir do entorno da obra, o analisa evidenciando suas condições físicas, constituindo-o pela participação do público. Segundo Cartaxo (2009) o site-Oriented é uma forma de site-specific e tem em seu prevalecer às dimensões socioculturais. Por estar acima das dimensões físicas criam-se questões sobre a organização político-social da arte redefinindo seus valores tradicionais. São autênticos pela sua capacidade de recriar e, diferente das obras de site-specific, estas podem ser mudadas de lugar livremente.

Diante desses conceitos, as Épuras serão compostas de planos particulares, ou seja, planos extras que também podem ser enxergados nesse sistema. Esses conjuntos são ideais para se tornarem objetos de arte pública uma vez que estarão fora das instituições e expostos a realidade, contextualizando os conceitos de site-specifice de site-oriented de Zalinda Cartaxo. Considerando também as ideias de antiarte de Hélio Oiticica, especificamente com sua obra "Magic Square 5\#" (OITICICA, 1977) estudada pelos autores desse trabalho em visita técnica ao Museu Inhotim em Minas Gerais e idealizada por Hélio Oiticica, é um de seis trabalhos pertencente à série Penetráveis. A obra coloca o espectador em contato com a forma, a cor, com os materiais que a constituem por meio da interação com grandes quadrados vazados e, sendo localizada em uma praça, ao ar livre, contém ainda um trocadilho com a palavra em inglês square, que significa tanto praça, quanto quadrado.

As interpretações das ideias de Oiticica são somadas ao conceito de site-funcional de Zalinda Cartaxo que aponta as questões funcionais das obras de arte públicas e sua localização direcionada a seu significado. (CARTAXO, 2001 p. 15) As épuras possuem uma ligação direta com a universidade, tendo em vista que muitas disciplinas trabalham com tais conceitos e, infelizmente, muitos alunos só venham a conhecê-los ao ingressar no ensino superior. A instalação de tais elementos permitirá direta ou indiretamente um questionamento visual e uma interação com a obra ao transitarem pelo campus da universidade.

O tema Épuras e seus planos particulares foi escolhido com a intenção de colocar no espaço algo funcional tanto tecnicamente quanto conceitualmente. As construções serão úteis para alunos que estudam a disciplina Geometria Descritiva pois possibilita uma noção em três dimensões de um conceito visual utilizado no estudo em duas dimensões e, ao mesmo tempo, explora os questionamentos da aplicação de objetos de arte no espaço público. Utilizando a pesquisa de Marli Terezinha Quadri Simões da Silva que defende o uso de maquetes no ensino de desenho geométrico em seu escrito "Geometria Descritiva: Uma Experiência Didática", de acordo com a autora a habilidade de visualização dos que estudam a Geometria Descritiva é mais bem desenvolvida com apoios didáticos baseados em materiais concretos, ou seja, tridimensionais. (TEREZINHA, 2007. p.2) A pesquisa disponibiliza gráficos comparativos de aprendizagem com e sem maquetes.

5 Resultados e contribuições esperadas.

A interação entre disciplinas durante o processo de pesquisa para a execução dos produtos de arte. 
Criar um recurso didático que ajudará na investigação dos conceitos tanto de arte pública, principalmente por sua localização e discussão social, artística e espacial, quanto aos de Geometria Descritiva por se tratarem de personificações físicas de conceitos gráficos e visuais bidimensionais.

Disponibilizar entrevistas e materiais bibliográficos para a comunidade acadêmica.

Contribuição para o crescimento da Escola de Belas Artes, na área das artes públicas e da Geometria Descritiva.

Publicação de artigos e/ou capítulos de materiais escritos especializados sobre o tema da pesquisa;

Participação em eventos técnico-científicos a fim de divulgar os resultados.

6 Impactos previstos:

Criar uma espécie de material didático funcional e ao mesmo tempo obra de arte pública em meio aos locais utilizados para estudo na disciplina Perspectiva de Observação da Ilha do Fundão, ampliando o interesse geral da comunidade acadêmica que transita no local pelo desenho e pela Geometria Descritiva.

\section{Referências}

[1] ARNHEIM, Rudolf. Arte e percepção visual. Uma psicologia da visão criadora. 2. ed. São Paulo: Ed. da Universidade de São Paulo, 1980.

CARTAXO, Zalinda. ARTE NOS ESPAÇOS PÚBLICOS: a cidade como realidade. 2009. O percevejo, Periódico do programa de Graduação.

FERREIRA, Patrícia. Desenho de Arquitetura. Editora Imperial Novo Milenio,2001.

NOGUEIRA, Aurélio Antônio Mendes, Perspectiva de Observação, Apostila de aula. Departamento BAR/EBA/UFRJ, Rio de Janeiro, 2013.

DA SILVA, Marly Terezinha Quadri Simões. GEOMETRIA DESCRITIVA - UMA EXPERIÊNCIA DIDÁTICA UFPR Universidade Federal do Paraná, Departamento de Desenho, 2007.

JOSE, Álvaro Rodrigues de Lima. Apostila de Geometria descritiva Escola de Belas Artes Universidade Federal do Rio de Janeiro, 2002.

Links importantes:

http://www.revistadehistoria.com.br/secao/perspectiva/o-quadro-virou-

pracahttp://www.arte.seed.pr.gov.br/modules/galeria/detalhe.php?foto=419. Acesso em: 05/01/2017

http://www.inhotim.org.br/inhotim/arte-contemporanea/obras/invencao-da-cor-penetravel-magic-square-5de-luxe/. Acesso em: 07/01/2017

https://pt.wikipedia.org/wiki/Espa\%C3\%A7o_tridimensional. Acesso em: 07/01/2017 


\section{CONSTRUÇÃO E DESESTABILIZAÇÃO DO "PROJETO NACIONAL" DO PETRÓLEO}

João Sérgio S. Assis - Doutorando do HCTE e pesquisador do NCE/UFRJ -Joao@nce.ufrj.br

Resumo

Antes de ser encontrado no subsolo brasileiro, o petróleo foi se configurando em um caminho promissor para o desenvolvimento econômico. O "Projeto Nacional" de encontrar e explorar petróleo foi durante muito tempo prejudicado pela dependência do país de conhecimentos técnicos e equipamentos estrangeiros. A criação da Petrobras enfrentou com muito sucesso esses dois problemas, porém a delimitação de um território onde transitavam apenas a própria empresa e o governo desestabilizou parte dos vínculos que uniam o resto da sociedade ao "Projeto Nacional". Isso se torna aparente pela análise do primeiro Programa de Capacitação em Águas Profundas (PROCAP), cujos resultados já refletem uma mudança de orientação da empresa em relação aos rumos da política pública de petróleo.

Palavras-Chaves: Petrobras. Petróleo. PROCAP. Tecnologia local.

Introdução

Ao longo do século XX, o petróleo foi se configurando no Brasil como um "Projeto Nacional"16, um objeto de desejo, um caminho para um sonhado desenvolvimento econômico que libertaria o país de seu tradicional "atraso". Mesmo a demora em encontrar o "líquido precioso" 17 no subsolo do país já era considerada um atraso, cujos culpados deveriam ser nomeados: os cientistas estrangeiros contratados para achar o produto, as multinacionais que dominavam a exploração dos derivados ou mesmo o governo que dava a concessão de exploração e fornecia os equipamentos.

Discussões giravam em torno de quem investiria na busca de petróleo e, consequentemente, seria o principal beneficiário da riqueza encontrada: o capital estrangeiro através das multinacionais do petróleo (os trustes), o capital nacional ou o governo. Muito pouco, ou nada, se falava a respeito da origem dos conhecimentos técnicos e dos equipamentos de busca e produção de petróleo, como se fosse da "natureza" que ambos viessem do estrangeiro.

\section{Conhecimentos e Equipamentos}

Em relação aos conhecimentos geológicos houve algumas iniciativas governamentais para criar conhecimento nacional acerca das potencialidades do subsolo do país. Geralmente estas iniciativas eram precedidas pela vinda de um estrangeiro contratado para estudar o Brasil e ensiná-lo aos brasileiros. Entre estas iniciativas destacam-se a criação da Escola de Minas de Ouro Preto, em 1875, pelo cientista francês Henry Gorceix, a Comissão White de 1904, chefiada pelo geólogo americano Israel C. White, contratado para estudar a geologia da Bacia

\footnotetext{
${ }^{16}$ Projeto Nacional, neste texto, não deve ser entendido como um projeto definido no sentido estrito da palavra, mas sim um objetivo (ou conjunto de objetivos) adotado por grupos com algum poder de decisão (ou de pressão sobre quem tem poder decisório) e que mobilize setores da população nacional por um tempo considerável, pelo menos até que algum (dos) objetivo(s) seja atingido.

17 “Petróleo Nacional”. Jornal do Brasil, 17 de janeiro de 1936. p. 5 Disponível em http://memoria.bn.br/DocReader/030015 05/60991. Acesso em : 15/09/2017,
} 
do Paraná, e a criação do Serviço Geológico e Mineralógico do Brasil (SGMB), em 1907, pelo geólogo americano Orville A. Derby.

Estas iniciativas não conseguiram livrar o país da necessidade de "importar" técnicos estrangeiros, mas após a descoberta de petróleo no país, em 1939, estas importações passaram a não ser totalmente bem vistas. Foi o que aconteceu com a contratação dos técnicos americanos, Everett L. DeGolyer e Lewis W. MacNaughton, em 1943, para atuarem como consultores das decisões do Conselho Nacional de Petróleo (CNP). A participação destes técnicos na formulação da Lei do Petróleo, proposta pelo presidente, foi um motivo de indignação que alimentou o movimento "O Petróleo é Nosso" (MIRANDA, 2004, p. 37).

Quando aos equipamentos para procurar petróleo, não havia investimento em produzir no país estes equipamentos, nem há indícios que houvesse algum interesse nisso. Os primeiros equipamentos de exploração de petróleo eram sondas que utilizavam o chamado método de percussão e foram dominantes na exploração de petróleo até o final do século XIX, quando foram sendo substituídas por sondas que utilizam o método rotativo (PEYERL, 2014, p.44). As sondas de percussão não deixaram de existir, mas, no caso do petróleo, o método rotativo é mais desejável por permitir cavar poços mais profundos, numa velocidade maior. No Brasil, porém, "a maioria das sondas utilizadas era de percussão (National Supply Co. e Keystone) e rotativas (Ingersoll Rand, entre outras), importadas dos Estados Unidos, em grande parte já usadas" (PEYERL, 2014, p. 44), até, pelo menos, a década de 1940. Devido à falta de conhecimentos técnicos e recursos materiais, no Brasil se realizavam poucas perfurações, muitas vezes interrompidas sem que se atingisse uma grande profundidade.

Os Interesses no Projeto Nacional do Petróleo

A Primeira Guerra Mundial (1914-1918), com a larga utilização de veículos movidos por combustíveis derivados de petróleo, mostrou a importância de os países terem acesso a fontes deste produto como forma de garantir sua independência (SMITH, 1978, p. 26). O Brasil, mesmo distante do teatro de guerra e com pequena participação nas operações, sofreu seus efeitos econômicos. O atraso geral do país e, particularmente, o atraso das forças armadas, sensibilizou o meio militar, marcando a década de 1920 com várias rebeliões.

Com a revolução de 1930 a questão do petróleo ganhou uma nova importância. De início foram formadas diversas companhias de pequenos investidores privados que tentaram, através de venda de ações, captar dinheiro para exploração de petróleo. Monteiro Lobato foi um destes investidores e porta voz deste grupo, defendendo a exploração do petróleo por brasileiros e atacando as multinacionais e o governo como culpados pela dificuldade em encontrar petróleo. Suas polêmicas difundidas por artigos de jornais e livros popularizaram a questão do petróleo, agregando novos setores da sociedade. Por outro lado, o efeito das acusações de inação e a nova guerra que se aproximava fizeram o governo assumir com mais firmeza a tarefa de buscar petróleo.

Até esta época, as empresas multinacionais não demonstravam interesse em procurar petróleo no Brasil, pois, segundo se alegava, as perspectivas geológicas não eram favoráveis. Além disso, estas empresas já dominavam a importação e distribuição de combustíveis desde 1912 e tinham suas próprias fontes de combustível. Quando finalmente se encontrou petróleo pela iniciativa estatal, estas empresas antes indiferentes passaram a atuar abertamente para modificar a legislação de forma a atender seus interesses.

A partir de 1943, houve uma mudança de orientação na política nacional de petróleo, onde se começou a buscar uma maior abertura para o capital estrangeiro. A derrubada do governo Vargas e a eleição do general Eurico Gaspar Dutra acentuaram esta mudança, com o novo governo propondo uma lei do petróleo que não apenas abriria o setor, como ofereceria vantagens para as empresas estrangeiras (MIRANDA, 2004, p. 38-39). Debates se seguiram no 
Clube Militar, culminando na criação do movimento "O Petróleo É Nosso", agregando, além de militares, estudantes e intelectuais, e culminando na criação da Petrobras em 1953, já no novo governo de Getúlio Vargas.

\section{A Petrobras}

A criação de uma empresa com a dupla função de planejar a política nacional de petróleo e a exploração deste produto e seus derivados teve como efeito a criação de um território, a delimitação de um espaço quase autônomo. OProjeto Nacional de Petróleo atingiu um momento de maior força e estabilidade, porém ao preço de romper algumas das relações que haviam sido criadas com a sociedade e que garantiam esta mesma força. A função de produtora da política pública de petróleo permitiu que a Petrobras ultrapassasse a fronteira empresarial, o que limitaria sua atuação à busca estrita de lucratividade (imediata ou futura) para seus acionistas, podendo se dedicar a atividades que beneficiariam o país e a economia nacional.

Sendo assim, aPetrobras pôde investir na formação de profissionais especializados, o que levou a criação, em 1955, do Centro de Aperfeiçoamento e Pesquisa de Petróleo (CENAP) com o objetivo de oferecer cursos de treinamento em geologia e engenharia do petróleo, que serviram de base para a abertura destes cursos nas universidades brasileiras, permitindo ao país começar a se livrar da dependência de técnicos estrangeiros. Posteriormente, com a criação de seu Centro de Pesquisa e Desenvolvimento Leopoldo Américo Miguez de Mello (CENPES), "a Petrobras torna-se o carro-chefe da economia e da pesquisa científica, tecnológica e de inovação do país relacionados às Geociências" (PEYERL, 2014, p. 3).

Em 1966 a Petrobras começou a procurar petróleo no mar, uma empreitada arriscada, mas que já vinha sendo tentada em diversas partes do mundo ${ }^{18}$. Apesar de não ter total autonomia, pois o governo escolhia seu presidente e diretores, podendo influir em suas decisões, o monopólio e as receitas provenientes da exploração do setor permitiram à empresa assumir este risco.

Em 1968 foi encontrado o primeiro poço no mar de Sergipe numa lâmina d'água de 28 metros e cuja produção começou em 1973 (MORAIS, 2013, p. 111-113). Segundo Assayag (2009, p. 20), o general Ernesto Geisel, como presidente da Petrobras (1969-1973), determinou que o campo fosse explorado mesmo sem a certeza de que a produção seria rentável, pois serviria para o país adquirir experiência na exploração marítima. Todos os equipamentos foram comprados no exterior a "porta fechada" e "tudo foi projetado pelos estrangeiros, até o aço era importado, porque nós não tínhamos conhecimento" (ASSAYAG, 2009, p. 20).

A partir da década de 1980, o petróleo passou a ser encontrado em grandes quantidades, em local inacessível para a tecnologia da época, e o investimento em desenvolvimento tecnológico tornou-se mandatório. Porém, os anos de governo militar, em que as decisões de política energética ficaram restritas à Petrobras e setores das forças armadas, enfraqueceram os elos desta política em relação ao resto da população. O petróleo como projeto nacional foi se desestabilizando e perdendo espaço para outras preocupações como o preço da gasolina, a inflação, a estabilização da economia e a dívida externa. Travou-se então uma batalha pública que opôs a necessidade de investir em tecnologia (longo prazo) à possibilidade de comprar petróleo barato (curto prazo). Naquela ocasião, as reservas já descobertas, um plano de estabilização econômica e a discreta influência militar garantiram a manutenção dos investimentos, permitindo à Petrobras instituir o Programa de Capacitação Tecnológica em Águas Profundas (PROCAP).

\footnotetext{
${ }^{18} \mathrm{Na}$ Califórnia desde 1897, na Venezuela a partir de 1924, no Golfo do México desde 1938 e no Mar do Norte a partir de 1962 (MORAIS, 2013, p. 97,98,106)
} 
O PROCAP contou com 116 projetos envolvendo, além do CENPES, diversas universidade e empresas nacionais e estrangeiras. Este programa é considerado um caso de sucesso de investimento em inovação e não há dúvidas que trouxe muitos benefícios à Petrobras, que pôde dar prosseguimento a um aumento constante de sua produção, batendo recordes mundiais de profundidade e garantindo o domínio sobre uma tecnologia estratégica para a empresa e o país. Porém, diversos projetos desenvolvidos por cientistas brasileiros foram considerados inviáveis, sendo substituídos por similares estrangeiros, por vezes especificados pela Petrobras com base em conhecimentos adquiridos nas pesquisas nacionais.

Segundo Furtado e Freitas (2004, p. 63-71), foram vários os motivos para o não aproveitamento destes projetos: as empresas nacionais não conseguiram se adequar às especificações, não se interessaram pela produção ou os custos eram muito altos; o conceito desenvolvido se tornou obsoleto em função da demora de projeto; o novo conceito enfrentou obstáculos de transferência e de passagem para a escala industrial; o Departamento de Produção da Petrobras não se interessou ou se desentendeu com o CENPES; ou simplesmente a Petrobras até hoje não optou por essa tecnologia em nenhum de seus desenvolvimentos em offshore.

Apesar destas explicações, não devem ser desprezadas as transformações pelas quais passou o país e o setor de petróleo durante a execução do PROCAP. No governo Fernando Collor de Mello (1990-1992) foi se estabilizando a ideia de que as empresas, mesmo as estatais, deveriam ser "eficientes" (sem que se discutisse o que é eficiência) e "lucrativas" (sem que se discutisse onde seriam aplicados estes lucros). A Petrobras foi perdendo o interesse de agir como órgão responsável pela política de petróleo do país, em favor de se tornar mais eficiente em produzir lucros para seus acionistas. Posteriormente, o governo Fernando Henrique Cardozo (1994-2002), acentuou este processo (FURTADO, 2004, p. 232).

Investiduras

Segundo Marques (2002, p. 24), as relações econômicas têm passado por um processo de "informacionalização", que consiste num "aumento da quantidade de trabalho sobre a informação em relação à quantidade de trabalho sobre a matéria". Ao participar das pesquisas, a Petrobrás adquiriu conhecimentos que permitiram a ela influir nas especificações de produtos ou mesmo impor modificações em seus projetos. Muitas vezes, a própria Petrobrás fez em parte, ou totalmente, o trabalho de informacionalização, entregando para outras empresas um projeto pronto ou quase pronto.

Furtado e Freitas (2004, p. 55-56), ao realizar um estudo sobre os "impactos econômicos resultantes de diversas formas de aprendizado que derivaram da execução de projetos tecnológicos" do PROCAP, chegaram à conclusão que "os impactos econômicos superaram em mais de sete vezes os custos dos projetos". Porém, ao se utilizar o conceito de "investidura informacional", proposto por Marques (2002, p. 87-88), como complementar ao conceito de investimento, percebe-se que, se a Petrobras for gerida como uma empresa privada de petróleo, sem se preocupar com seu papel no desenvolvimento do país e voltada apenas para sua própria viabilidade econômica e lucratividade, ela pode restringir seus investimentos à "investidura de uso" (a simples utilização de uma tecnologia importada). Neste caso, o país corre o risco de voltar à situação de usuário de sondas e equipamentos importados e, por vezes, obsoletos.

Porém, a lógica envolvida na criação da Petrobras e na criação do PROCAP foi outra. O PROCAP foi concebido não só para dotar a Petrobras de "investidura de virtualização" (relação completa com a tecnologia, do projeto à materialização), como para utilizar esta empresa para capacitar outras empresas nacionais e universidades a adquirir esta investidura. 


\section{Considerações Finais}

A pressa por obter resultados, que atuou para induzir o desenvolvimento tecnológico, passou a atuar contra os investimentos à medida que outros países adquiriram tecnologias similares (muitas delas financiadas pelas compras da Petrobras). A crescente hegemonia das teses econômicas monetaristas e neoliberais nos países centrais, aliada a crises econômicas persistentes, decorrente dos choques do petróleo e da crise da dívida, foram mudando o foco das manchetes de jornais, modificando as prioridades do país e desestabilizando o projeto nacional do petróleo.

A redemocratização do país e a progressiva perda de influência política dos militares serviram para associar as políticas desenvolvimentistas a desequilíbrio econômico, protecionismo a autoritarismo. Empresas públicas passam a ser associadas à ineficiência, difundindo a ideia de que empresas estatais devem atuar segundo os mesmos critérios de eficiência das privadas. O PROCAP, com seus projetos em pleno desenvolvimento, foi atingido profundamente por estas mudanças, o que fez com que os investimentos em desenvolvimento de tecnologia não resultassem em produtos efetivamente utilizados pela companhia. Os ganhos com o desenvolvimento de tecnologia própria foram sendo diluídos com o tempo à medida que as influências que garantiram este desenvolvimento foram perdendo força.

\section{Referências bibliográficas}

ASSAYAG, M. I. [Depoimento ao Museu da Pessoa]. São Paulo, 2009. Entrevista publicada no Museu da Pessoa, 08 de dezembro de 2009. Disponível em: <http://dualtec.museudapessoa.net/_index.php/historia/11311marcos-isaac-assayag/texto>. Acesso em: 10 fev. 2017.

FURTADO, A. T. Mudança Institucional e Inovação na Indústria Brasileira de Petróleo. In: Anita Kon; Guilherme de Oliveira. (Org.). Pesquisas em Economia Industrial, Trabalho e Tecnologia. São Paulo: EITT/PUCSP, 2004, p. 232-262.

FURTADO, A. T., FREITAS, A. G. Nacionalismo e Aprendizagem no Programa de Águas Profundas da Petrobras. Revista Brasileira de Inovação. Vol. 3 N. 1. Janeiro / Junho 2004. P. 55-86

MARQUES, I. C. O Brasil e a abertura dos mercados: o trabalho em questão. Rio de Janeiro: Contraponto. 2a Ed. 2002.

MIRANDA, M. A. T. O petróleo é nosso: a luta contra o entreguismo. Pelo monopólio estatal, 1947-1953, 1953 1981, 1982-2004. São Paulo: Editora IPSIS. Ed. 2. 2004. 576 p.

MORAIS, J. M. Petróleo em águas profundas: uma história tecnológica da Petrobras na exploração e produção offshore. Brasília: Ipea: Petrobras, 2013. 424 p. ISBN: 978-85-7811-159-5

PEYERL, D. A contribuição do Conselho Nacional do Petróleo e da Petrobras na formação de profissionais para a exploração do petróleo no Brasil. Tese de Doutorado. Campinas: Instituto de Geociências da Unicamp. 2014. $290 \mathrm{p}$.

SMITH, P. S. Petróleo e política no Brasil moderno. Rio de Janeiro: UNB: Editora Artenova S.A. 1978. 276 p. 


\section{ANÁLISE DO PERFIL DOS ALUNOS INGRESSANTES NO CURSO DE LICENCIATURA EM DESENHO DA UFRJ NO ANO DE 2017}

Mariane Brito Azevedo Borges - Doutoranda do HCTE, professora e coordenadora da Licenciatura em Ed. Artística da EBA-UFRJ - mariane.azevedo@eba.ufrj.br

Resumo

O curso da Licenciatura em Educação Artística - Habilitação Desenho da UFRJ oferece 36 vagas ao ano através do Exame Nacional do Ensino Médio (ENEM). O presente artigo tem por objetivo analisar o perfil dos alunos ingressantes no ano de 2017, em relação as suas expectativas e conhecimento sobre a disciplina a qual estarão aptos a lecionar no final do curso. Esta análise, feita através de questionário, é o ponto de partida de um estudo que busca valorizar tal disciplina que, muitas das vezes, é desconhecida ou aparece camuflada em outras.

Palavras-chave : Licenciatura. Desenho. Currículo.

\section{Introdução}

Os currículos escolares estão voltados para a produção do conhecimento, ou seja, as escolas depositam informação nos alunos e este se tornam meros receptores dessa informação. Outra característica marcante na maior parte dos currículos escolares é a separação das disciplinas, estas são dadas de forma independente, como se não correlacionassem com as outras.

Atualmente, observa-se um movimento por parte das escolas em pautar o ensino oferecido para o preparo específico para inserção do aluno nas universidades. Dessa forma ocorre uma hierarquia dentro do currículo, onde disciplinas são consideradas muito importantes, necessárias ou irrelevantes.

Os requisitos de entrada na universidade pressionam os currículos dos outros níveis educacionais, (assim) esses currículos refletem a mesma ênfase no 'conhecimento técnico'. É esse tipo de conhecimento que acaba sendo visto como tendo prestígio, em detrimento de outras formas de conhecimento, como o conhecimento estético e artístico, por exemplo. (SILVA,ano)

A formação do aluno não é o principal aspecto dos currículos atuais, observa-se assim o desaparecimento de disciplinas com teor artístico, estético, moral, ético etc. A disciplina Desenho, como ainda é conhecida por poucos devido quase não aparecer nas grades curriculares, vem a ser o foco do estudo do trabalho de tese. Neste artigo, avalio através de questionário, o perfil dos alunos que ingressaram, através do Exame Nacional de Ensino Médio (ENEM), para o curso de Licenciatura em Educação Artística na Habilitação Desenho da UFRJ em 2017. Estes serão os futuros professores desta disciplina que se torna cada vez menos encontrada nas grades escolares.

O objetivo deste questionário é ver se os alunos escolheram o curso com conhecimento do que é Licenciatura e do que é a disciplina Desenho; saber se os mesmos já tiveram contato com a disciplina em si ou se tiveram apenas alguns conceitos dela como parte de outra disciplina "mais importante", bem como o contato com os materiais de desenho. Assim, pode ser avaliado o perfil dos alunos quanto ao conhecimento prévio e sua escolha, bem como o perfil das escolas que ainda lecionam esta disciplina. 
Perfil dos alunos ingressantes em 2017

O questionário foi realizado com os calouros dos dois semestres de 2017 (março e junho) dentro do seu primeiro mês de aula; escolhe-se a aula de Desenho Geométrico Básico para sua realização, pois se pensou que haveria uma maior associação a temática do questionário. O que foi observado, de maneira informal em anos anteriores, é que na maioria das vezes o aluno não vinculava o curso escolhido com o seu conteúdo e o fato de ser um curso mais técnico.

Na primeira questão, procurou-se conhecer o porquê da escolha pela Licenciatura e também pela habilitação Desenho. A pergunta gerou dois grupos distintos de respostas. Dentre os ingressantes de março de 2017 é citado a aptidão e o apreço pela docência, outra resposta comum é a proximidade com a Arquitetura. Por outro lado, nos respondentes de junho de 2017, não aprece o interesse pela docência, somente o fato de gostarem ou terem habilidade com o Desenho e a proximidade com a carreira que tinham em primeira opção.

A pergunta seguinte quer saber se o curso em questão foi sua primeira opção e qual seria em caso de resposta negativa. A resposta aparece ilustrada no Gráfico 1, nele se observa que dos vinte e três alunos que responderam ao questionário, apenas cinco optaram pela Licenciatura em Desenho como primeira opção. Sendo que deste, dois haviam perdido o Teste de Habilidade Específica para os cursos de Desenho Industrial e de Comunicação Visual.

Gráfico 1 - Mostra a primeira opção dos entrevistados.

\section{1a opção no ENEM}
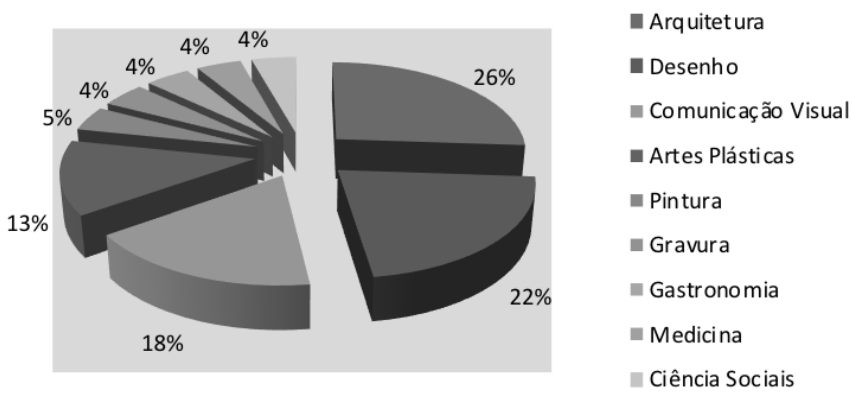

Arquitetura

Desenho

- Comunic ação Visual

- Artes Plásticas

- Pintura

- Gravura

- Gastronomia

Medicina

Ciência Sociais

Fonte própria

O questionário segue indagando sobre o Ensino Básico dos respondentes, com o objetivo de conhecer o grau de interação deles com a disciplina analisada. O gráfico 2 mostra se o Ensino Básico - Ensino Fundamenta (EF) e Ensino Médio (EM) - destes alunos foi obtido na esfera pública ou privada. Pedia-se também o nome da instituição com o propósito de, posteriormente, saber quais escolas lecionam a disciplina.

Gráfico 2 - Ensino Fundamental e Ensino Médio obtidos em escola pública ou particular 


\section{Ensino Básico}

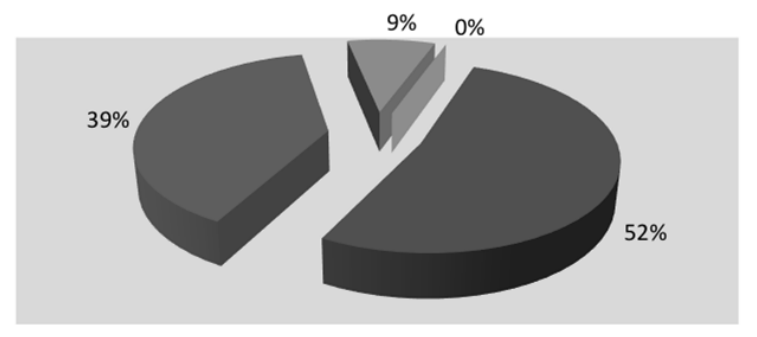

- EF e EM públicos EF e EM particulares

= EF particular e EM público = EF público e EM particular

Fonte própria

Posteriormente, são indagados quanto a terem tido o conteúdo de Desenho na escola como uma disciplina específica ou entremeada em outras ciências. OGráfico 3 nos mostra que apenas $30 \%$ dos alunos tiveram a matéria Desenho e $26 \%$ o conteúdo contido em artes ou matemática. O gráfico 4 ilustra em quais anos, estes alunos, tiveram o conteúdo de desenho em sua escola.

Gráfico 3 - Conteúdo de desenho no Ensino Básico

\section{Contato com o Desenho no Ensino Básico}

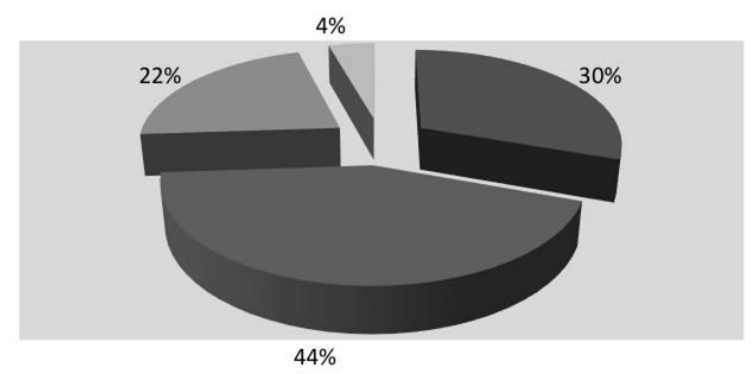

- Sim Não Em Matemática $\|$ Em Artes

Fonte própria

Gráfico 4: Anos que tiveram o conteúdo de desenho

\section{Anos de contato}

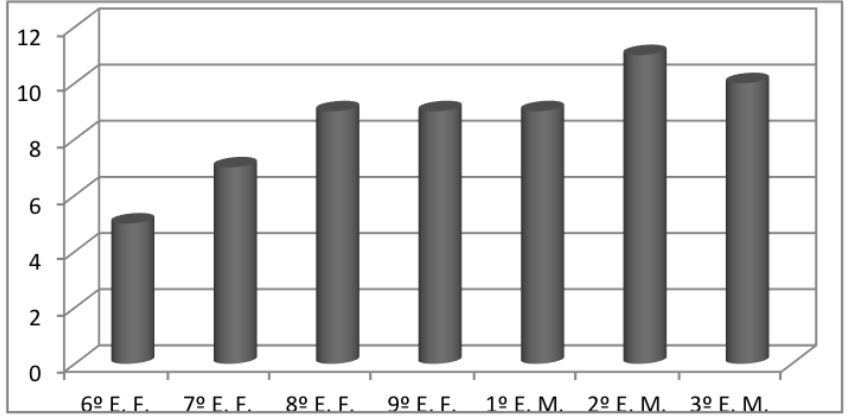

onte própria

Abaixo, noGráfico 5, observa-se o contato dos alunos com os instrumentos de Desenho: régua, compasso, par de esquadros, transferidor, escalímetro e curva francesa; independente de terem sido utilizados para o Desenho ou não. 
Gráfico 5 - O contato dos alunos com os instrumentos de Desenho no Ensino Básico

Materiais utilizados no Ensino Básico

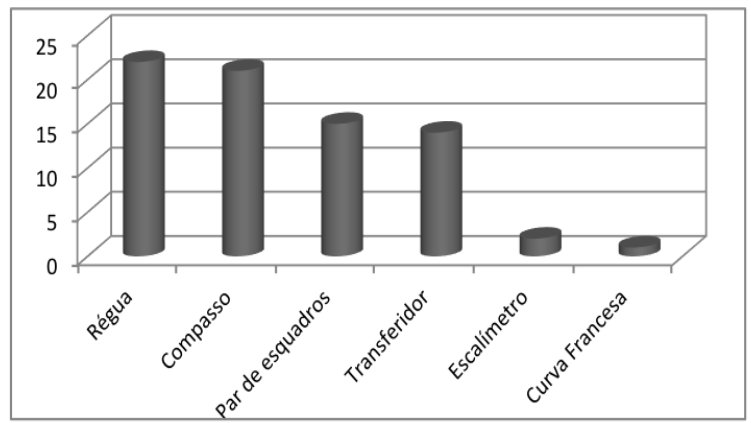

Fonte própria

Na parte final do questionário, indago sobre o que esperam do curso e observa-se que muitos não estão muito certo quanto à diferença entre as Habilitações Artes Plásticas e Desenho e que, infelizmente, estão planejando mudar de curso. Em seguida, eles avaliam a importância do conhecimento prévio do Desenho para cada área de saber como apresenta o Gráfico 6. Analisando este gráfico, comprova-se que a ligação entre Desenho e a Engenharia é facilmente percebida, o que não ocorre nas demais áreas.

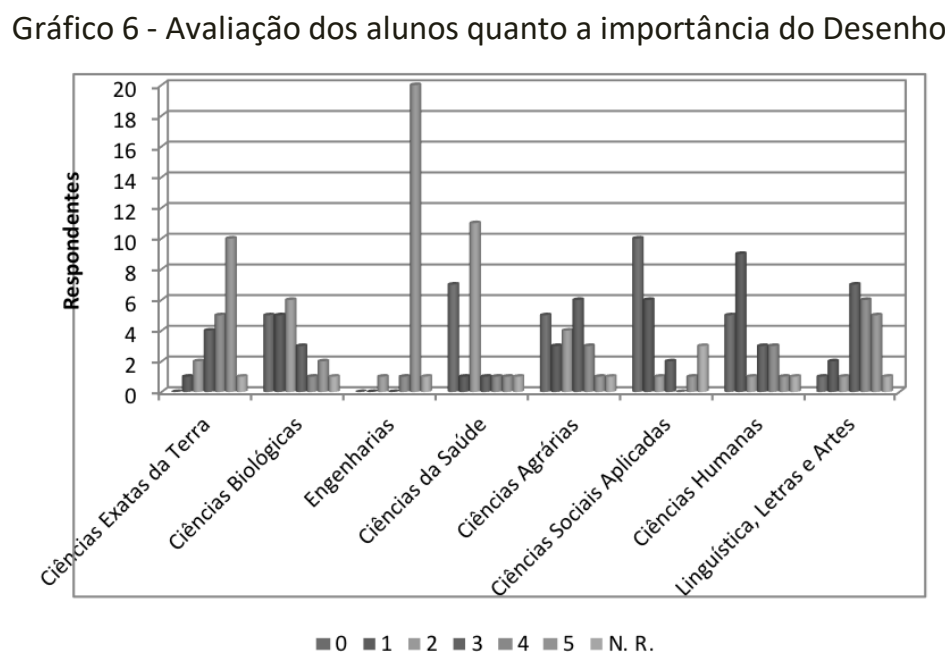

Fonte própria

\section{Conclusão}

Este estudo acredita que - pela pouco valor que é dado a este saber na maioria dos currículos e, principalmente, pelo desconhecimento do conteúdo desta disciplina - os futuros professores de Desenho não vêm à importância e a interdisciplinaridade do Desenho como um saber básico.

Como foi visto noGráfico 6, a relação entre o saber e a Engenharia e áreas exatas são percebidas; entretanto, na área médica, por exemplo, a ligação não é vista com tanta facilidade. Contudo, este conhecimento técnico está presente na anatomia humana, na forma dos vírus e como esta pode nos infectar, bem como nas tomografias, ressonâncias, raios-X, 
etc. Podem-se observar erros de diagnóstico e de literatura em diversas áreas, pautados no desconhecimento dos conceitos básicos de desenho.

Esse estigma que se pretende rebater em trabalhos futuros, com a comprovação do valor deste saber. Sendo assim, será mostrado que este conteúdo deveria estar presente em todos os currículos escolares de forma interdisciplinar. Uma vez que, acredito que o currículo não deva ser tratado como uma coleção de disciplinas, mas sim de forma integrada, sem nítidas distinções. Conforme a perspectiva culturalista sobre o currículo citada por Silva.

Nessa visão, o conhecimento não é uma revelação ou um reflexo da natureza ou da realidade, mas o resultado de um processo de criação e interpretação social. Não se separa o conhecimento supostamente mais objetivo das Ciências Naturais e o conhecimento supostamente mais interpretativo das Ciências Sociais ou das Artes. Todas as formas de conhecimento são vistas como resultado dos aparatos - discursos, práticas, instituições, instrumentos, paradigmas - que fizeram com que fossem construídas como tais. As implicações dessa perspectiva não devem ficar restritas à análise. É impossível pensar num currículo que enfatizasse precisamente o caráter construído e interpretativo do conhecimento.

Uma vantagem de concepção de currículo inspirada nos Estudos Culturais que as diversas formas de conhecimento são, de certa forma, equiparadas. (SILVA,ano)

\section{Bibliografia}

SILVA, Tomaz Tadeu da. Documentos de Identidade: uma introdução às teorias do currículo. 3. ed. 1. reimpressão. Belo Horizonte: Autêntica, 2010. 156 p. 


\title{
A MATEMÁtica ATRAVÉS DA RESOluÇÃO DE PROBLEMAS: UMA EXPERIÊNCIA NA SEEDUC-RJ
}

\author{
Darlan Azevedo Gomes - Professor da Rede Estadual do Rio de Janeiro - profdag@gmail.com \\ Augusto César de Castro Barbosa - Professor Associado do IME/UERJ - accb@ime.uerj.br \\ Cláudia Ferreira Reis Concordido - Professora Associada do IME/ UERJ, - concordido@ime.uerj.br
}

\section{Resumo}

O objetivo deste trabalho é abordar algumas concepções acerca da Resolução de Problemas, em especial, no âmbito da Secretaria de Estado de Educação do Rio de Janeiro (SEEDUC). Analisamos a disciplina Resolução de Problemas Matemáticos (RPM), lançada pela SEEDUC em 2012, apresentando a visão da Secretaria e a de um grupo de professores pertencentes à rede estadual de ensino. Para isso, foi discutido o documento da secretaria que norteia a implantação da disciplina RPM e foi realizada uma breve pesquisa de perfil e opinião com esse grupo de professores.

Palavras-chave: Ensino Fundamental. Ensino Médio. Resolução de Problemas.

\section{Introdução}

Um ponto importante relativo ao baixo desempenho escolar, em especial em Matemática, é a dificuldade em lidar com situações que exijam um raciocínio lógico aprimorado. Nesse sentido, é papel do professor propiciar condições para o desenvolvimento do raciocínio lógico e da capacidade de abstração e análise, em suma, o de fazer pensar.

Uma das maneiras de proporcionar essas condições é a utilização da resolução de problemas como metodologia de ensino, pois ela é capaz de criar mecanismos que propiciam aos alunos um ambiente de descobertas. De acordo com os Parâmetros Curriculares Nacionais (PCN) Matemática (BRASIL, 1997, p. 32), no "processo de ensino e aprendizagem, conceitos, ideias e métodos matemáticos devem ser abordados mediante a exploração de problemas, ou seja, de situações em que os alunos precisem desenvolver algum tipo de estratégia para resolvêlas".

Atenta ao fato de que a resolução de problemas é considerada como um recurso ao ensino da Matemática e tendo por objetivo melhorar o desempenho nas habilidades cognitivas relacionadas à resolução de problemas, SEEDUC criou no ano de 2012, através da Resolução $n^{\circ} 4843$ (RIO DE JANEIRO, 2012), a disciplina Resolução de Problemas Matemáticos (RPM). Essa é disciplina à parte da Matemática e começou a ser lecionada já no início do ano letivo de 2013.

Após algum tempo de existência da disciplina RPM, era de se esperar que as atividades desenvolvidas pelos professores em sala de aula já estivessem em consonância com as orientações dadas pela SEEDUC. Assim, o nosso objetivo com esse trabalho foi verificar se a disciplina RPM vinha cumprindo as metas traçadas pela SEEDUC.

Para tanto, foram analisados os documentos da SEEDUC que tratam da RPM e foi aplicado um questionário a um grupo de professores que lecionam em escolas situadas no entorno de Campo Grande, bairro da Zona Oeste do município do Rio de Janeiro. A partir das informações coletadas desse questionário, obteve-se um indicativo do que pensam e de como alguns professores da rede estadual do Rio de Janeiro trabalham essa disciplina.

\section{A Resolução de Problemas em Matemática}


Para Polya (1995), uma pessoa está diante de um problema quando ela se depara com uma questão que não pode responder ou resolver usando os conhecimentos que detém. Dante (1991) afirma que problema "é qualquer situação que exija o pensar do indivíduo para solucioná-la". Segundo Van de Walle (2001, apud ONUCHIC; ALLEVATO, 2005), “[...] um problema é definido como qualquer tarefa ou atividade para a qual os estudantes não têm métodos ou regras prescritas ou memorizadas, nem a percepção de que haja um método específico para chegar à solução correta". Concordamos com Onuchic (1999) que um problema pode ser caracterizado como sendo tudo aquilo que não se sabe fazer, porém se está interessado em resolver.

A escolha do problema a ser trabalhado desempenha um papel de fundamental importância, na medida em que é necessário despertar no aluno não apenas o interesse pelo assunto envolvido no problema, mas também o interesse na busca de sua solução. Dessa forma, nos resta pensar de que maneira podemos fazer uso de problemas em sala de aula para desenvolver habilidades e competências matemáticas em nossos alunos.

Polya (1995) sugere quatro etapas principais para a resolução de um problema. A primeira consiste em compreender o problema. Nesta etapa se elaboram perguntas a fim de descobrir o que é solicitado: quais os dados e as condições, que algoritmos podem ser utilizados, etc. A segunda etapa é a construção de uma estratégia de resolução, que demanda que se estabeleçam relações entre os dados do problema e o que nele se pede, que se busquem algoritmos ou mesmo problemas parecidos já resolvidos. Na terceira etapa, em que ocorre a execução da estratégia, deve-se verificar cada passo dado e efetuar as operações necessárias para se chegar ao resultado esperado. Finalmente, na quarta etapa faz-se o retrospecto ou verificação do resultado. Nesse ponto avalia-se o limite de validade da solução encontrada e também a possibilidade de se chegar ao resultado por um caminho diferente.

Para Dante (1991), a resolução de problemas não deve constituir-se de experiências repetitivas, cabendo ao professor sugerir diferentes maneiras de solucioná-los, destacando sempre que não há uma forma única, ideal e infalível para alcançar a resolução. É necessário que o aluno perceba que pode solucionar diferentes problemas utilizando a mesma estratégia, bem como pode utilizar estratégias diversas para a solução de um único problema. Mendonça (1993, p. 260) destaca três dimensões para a resolução de problemas, a saber, ensinar sobre resolução de problemas, ensinar para a resolução de problemas e ensinar através da resolução de problemas. Na primeira concepção, a resolução de problemas é vista como um processo, como "um meio para desenvolver o potencial heurístico do aluno". A segunda tem a resolução de problemas como um objetivo, como uma meta final. Já na terceira, a resolução de problemas é um ponto de partida, que dispara um processo de construção do conhecimento matemático. Acreditamos que a terceira concepção, em que o conteúdo matemático seja introduzido por uma situação-problema, permite que fique mais clara a necessidade de se construir os conceitos matemáticos desejados.

A resolução de problemas é uma metodologia que oportuniza aos estudantes a possibilidade de fazer Matemática, isto é, ao buscarem uma solução para o problema proposto, eles são levados a exercitar as suas habilidades intelectuais. Desse modo, a resolução de problemas estreita a distância entre uma Matemática mais intuitiva, mais experimental e uma Matemática formal.

No entanto, conforme Onuchic e Allevato (2011), trabalhar com a resolução de problemas exige que professores e alunos tenham novas posturas e atitudes com relação ao trabalho desenvolvido em sala de aula. O professor deve escolher os problemas adequados ao conceito que vai ser construído. Por outro lado, os alunos passam a ter maior participação e responsabilidade no processo de aprendizagem. 
Dante (2011, p. 14) afirma que "ensinar a resolver problemas não é um mecanismo direto de ensino, mas uma variedade de processos de pensamento que precisam ser cuidadosamente desenvolvidos pelo aluno com o apoio e incentivo do professor".

\section{A Disciplina Resolução de Problemas Matemáticos}

O principal objetivo da disciplina RPM, na visão da SEEDUC, é o desenvolvimento da capacidade dos alunos em resolver situações-problema relacionadas ao seu nível escolar, de modo que o raciocínio matemático desenvolvido auxilie o professor da disciplina do curso regular na abordagem dos conteúdos. A RPM não deve representar uma ampliação da carga horária da disciplina Matemática, mas ser uma disciplina independente, com planejamento próprio e que não introduza conceitos e sim os retome.

Desde 2013 a disciplina RPM vem sendo oferecida do 6으 ao 9을 ano do Ensino Fundamental e no 20 ano do Ensino Médio. Ela também visa desenvolver habilidades e competências que contribuam às demais disciplinas, possibilitando assim a formação de um cidadão em condições plenas de lidar, em seu cotidiano, com situações em que o raciocínio lógico esteja presente.

O documento elaborado pela SEEDUC leva em consideração a análise de diferentes abordagens para a resolução de problemas, o Currículo Mínimo de Matemática do Ensino Regular e as habilidades e competências relativas à Matemática que são fundamentais para outras disciplinas.

A fim de verificar o conhecimento e visão dos professores sobre os objetivos e habilidades da disciplina RPM determinados pela SEEDUC, aplicamos um questionário para um grupo de 40 professores de Matemática lotados em escolas estaduais no entorno do bairro de Campo Grande, Rio de Janeiro - RJ.

O questionário foi composto de questões relativas ao perfil profissional e à prática docente desse grupo de professores. Esse levantamento mostrou que a maioria dos professores possui idade entre 40 e 49 anos e que terminou a graduação entre 2000 e 2003 , com uma média de 8,5 anos de prática docente.

Em relação à formação acadêmica, a mais alta titulação obtida por esse grupo é a de especialização. Percebe-se nas respostas a importância dada à continuidade dos estudos, pois quase $70 \%$ possuem algum curso de pós-graduação.

Quanto à carga horária semanal de trabalho, obtivemos a seguinte distribuição: $13 \%$ lecionavam mais de $40 \mathrm{~h}, 20 \%$ de $30 \mathrm{~h}$ a $40 \mathrm{~h}, 13 \%$ de $20 \mathrm{~h}$ a $30 \mathrm{~h}, 20 \%$ de $12 \mathrm{~h}$ a $20 \mathrm{~h}$ e $34 \%$ até $12 \mathrm{~h}$. Quanto às horas semanais dedicadas ao planejamento das atividades de sala de aula, os resultados obtidos foram: $13 \%$ dedicam mais de $8 \mathrm{~h}, 20 \%$ de $4 \mathrm{~h}$ a $8 \mathrm{~h}, 60 \%$ até $4 \mathrm{~h}$ e $7 \%$ não planejam.

Quanto à prática docente, 21 professores já tinham lecionado ou estavam lecionando a disciplina RPM. No entanto, 24 deles a consideraram uma ampliação da carga horária de Matemática - o que contraria as orientações da SEEDUC.

Foi solicitado que os professores indicassem qual seria o principal objetivo da disciplina RPM definido pela SEEDUC, dentre vários objetivos elencados. Uma grande parcela conhecia o objetivo principal da disciplina. Isso pode ser considerado um aliado ao desenvolvimento da prática docente, pois conhecer os objetivos proporciona maior segurança ao professor quanto à escolha dos meios mais apropriados para atingi-los. Os resultados dessa questão aparecem no Gráfico 1. 


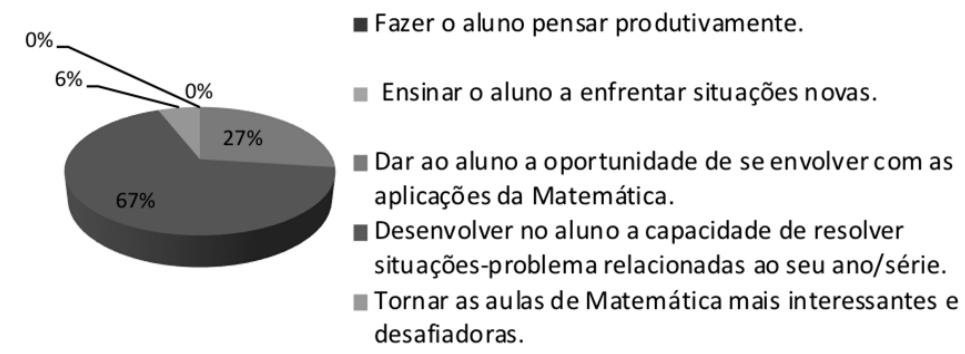

Fonte: Os autores.

A pergunta seguinte objetivou descobrir quais vantagens as atividades desenvolvidas durante as aulas de RPM trariam aos alunos (Gráfico 2). Uma das respostas com maior percentual afirma que as atividades têm possibilitado aos alunos gravar as regras que permitem obter respostas certas dos cálculos e problemas, porém essa afirmação não se enquadra na metodologia da resolução de problemas nem tampouco nos objetivos propostos pela SEEDUC para a disciplina. Esse fato vai de encontro à resposta dada à questão representada pelo Gráfico 1. Cabe destacar que apenas neste questionamento mais de um item poderia ser sinalizado.

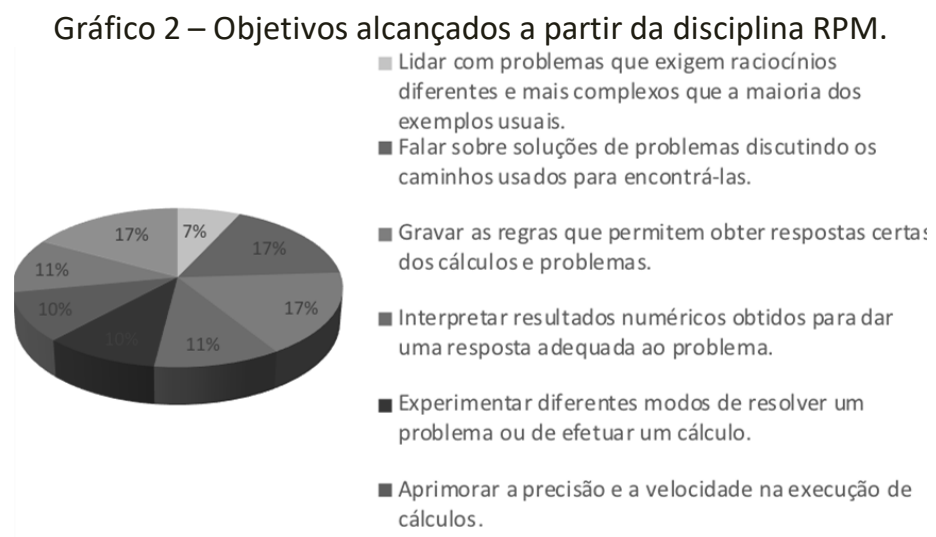

Fonte: Os autores.

Por fim, foi destinado um espaço para que os professores pudessem opinar sobre as abordagens que a disciplina RPM poderia ter. Dentre as respostas obtidas, podemos destacar: abordagem mais contextualizada com a realidade do aluno, aplicação da Matemática em projetos interdisciplinares, necessidade de maior autonomia do professor para trabalhar outros temas além dos instituídos pela SEEDUC, trabalhar conteúdos presentes em provas de concursos, explorar melhor os conceitos matemáticos e inserção da RPM no laboratório de Matemática.

Ficou evidenciado ainda que alguns dos professores desconhecem as orientações curriculares fornecidas pela SEEDUC, apesar de a maioria indicar corretamente o principal objetivo nela descrito e de o início da disciplina RPM ter ocorrido no começo do ano letivo de 2013. É importante destacar que em momento algum a SEEDUC capacitou ou criou meios para que os professores pudessem tirar dúvidas, trocar experiências ou conhecer essa disciplina.

Vale ressaltar que a matriz curricular publicada no Diário Oficial do Estado do Rio de Janeiro, do dia 11 de maio de 2016, não trouxe a obrigatoriedade da oferta da disciplina RPM para o ano letivo de 2017.

\section{Considerações Finais}

Ao implantar a disciplina RPM, entendemos que a SEEDUC esperava tornar os alunos cidadãos aptos a encarar as diversas situações do dia a dia nas quais o raciocínio matemático fosse 
fundamental. A Secretaria definiu ainda um currículo mínimo, integrado ao currículo de Matemática, para orientar os professores de RPM quanto aos objetivos a serem alcançados. A partir das informações coletadas do questionário aplicado ao grupo de 40 professores, verificou-se que 37 deles dedicam algum tempo ao planejamento de suas aulas e, portanto, eles deveriam saber quais são esses objetivos. Porém, para 13 desses professores, gravar as regras que permitem obter respostas certas dos cálculos e problemas é um dos objetivos a serem alcançados, o que evidencia desconhecimento das orientações da SEEDUC sobre a disciplina.

É possível afirmar que a resolução de problemas, seja na forma de uma disciplina específica, como a proposta pela SEEDUC, seja como metodologia adotada nas aulas regulares de Matemática, é uma ferramenta útil no processo de construção do conhecimento. Assim, para o seu correto desenvolvimento, é necessário que o professor dedique parte do seu tempo ao planejamento/seleção de atividades que estimulem a curiosidade, a intuição, o interesse em buscar diversas soluções para o problema apresentado, bem como atender ao conteúdo programático estabelecido.

Ao nos depararmos com a não obrigatoriedade da disciplina RPM, surge a seguinte pergunta: e agora? A fim de que não se percam nem tenham sido em vão as propostas definidas pela SEEDUC à RPM, seria salutar adotar as seguintes medidas: inserção da metodologia de resolução de problemas nas aulas de Matemática a partir do sexto ano do Ensino Fundamental; oferecimento, num ambiente virtual de aprendizagem, de capacitações sobre as perspectivas da resolução de problemas; criação de um canal eficaz de comunicação entre os diversos professores de Matemática pertencentes aos quadros da SEEDUC com grupos de pesquisas já estabelecidos na área de resolução de problemas; realização de seminários sobre o tema em questão.

\section{Referências bibliográficas}

BRASIL. Secretaria de Educação Fundamental. Parâmetros Curriculares Nacionais: Matemática / Secretaria de Educação Fundamental. Brasília: MEC / SEF, 1997.

Secretaria da Educação Média e Tecnológica. PCN+ Ensino Médio: Orientações Curriculares Complementares aos Parâmetros Curriculares Nacionais. Ciências da Natureza, Matemática e suas Tecnologias. Brasília: Ministério da Educação, 2002.

DANTE, L. R. Didática da resolução de problemas de Matemática. 2. ed. São Paulo: Ática, 1991 Formulação e resolução de problemas de matemática: teoria e prática. São Paulo: Ática, 2011.

MENDONÇA, M. C. D. Problematização: Um caminho a ser percorrido em Educação Matemática. 1993. 307 f. Tese (Doutorado em Educação) - Faculdade de Educação, Universidade Estadual de Campinas, Campinas, 1993.

OCDE. Organização de cooperação e de desenvolvimento econômico. Programme for International Student Assessment (PISA). Results from PISA 2015. 2016. Disponível em: < http://www.oecd.org/pisa/PISA-2015Brazil-PRT.pdf>. Acesso em: 02 mar. 2017.

ONUCHIC, L. R. Ensino-Aprendizagem de Matemática através da Resolução de Problemas. In: BICUDO, M. A. V (Org.). Pesquisa em Educação Matemática: Concepções e Perspectivas. São Paulo: Ed. UNESP, 1999.

ONUCHIC, L. R.; ALLEVATO, N. S. G. Novas reflexões sobre o ensino-aprendizagem através da Resolução de Problemas. In: BICUDO, M. A. V.; BORBA, M. C. (Orgs.). Educação matemática: pesquisa em movimento. São Paulo: Cortez, 2005. 
Pesquisa em Resolução de Problemas: caminhos, avanços e novas perspectivas. Boletim de educação Matemática, Rio Claro, SP, v. 25, n. 41, p. 73-98, dez. 2011. Disponível em:

<http://www.redalyc.org/articulo.oa?id=291223514005>. Acesso em: 29 abr. 2015.

POLYA, G. A arte de resolver problemas: um novo aspecto do método matemático. Tradução e adaptação de Heitor Lisboa de Araújo. 2. reimpressão. Rio de Janeiro: Interciências, 1995.

RIO DE JANEIRO. Secretaria de Estado de Educação. Resolução Seeduc N 4843 de 03.12.2012 - Diretrizes Implantação Matrizes Curric. Educação Básica. Rio de Janeiro: SEEDUC, 2012. 


\title{
"NAVEGAR É PRECISO, VIVER NÃO É PRECISO": NARRATIVAS E MEMÓRIAS EM REDE NO PROCESSO DE AFILIAÇÃO DE ESTUDANTES BRASILEIROS NA UNIVERSIDADE DE COIMBRA
}

\begin{abstract}
Antonio José Barbosa de Oliveira - Faculdade de Administração e Ciências Contábeis - Curso de Biblioteconomia e Gestão de Unidades de Informação - CBG/FACC-UFRJ - antoniojose@facc.ufrj.br Regina Dantas - Programa de Pós-Graduação em História das Ciências, das Técnicas e Epistemologia HCTE/UFRJ - regina@hcte.ufrj.br
\end{abstract}

\section{Resumo}

O trabalho busca analisar as variáveis que atuam no processo de afiliação de estudantes brasileiros na histórica Universidade de Coimbra. Diante das novas configurações da educação superior no Brasil e no mundo observa-se que há uma diversidade de perfis de estudantes que buscam a complementação ou a plena realização de seus estudos superiores na universidade lusitana. Tendo como proposta metodológica a etnometodologia, contemplando aspectos da etnografia e da netnografia, busca responder a questões como as variáveis composicionais do fluxo comunicacional dos estudantes em rede, as interações no processo de afiliação, as relações memorialísticas entre Brasil e Coimbra e as relações entre memória e mídias digitais na construção do "desejo de Coimbra".

Palavras chave : Memória. Redes. Universidade.

Despertando o Olhar para a Pesquisa

Em setembro de 2015, foi amplamente divulgado na mídia, o caso de um jovem estudante brasileiro, filho de costureira, aprovado nos exames de seleção em diversas universidades. Pela matéria, somos informados de que o jovem, morador de São Fidélis, no norte do estado do Rio de Janeiro, foi aprovado em 8 instituições, sendo 3 estrangeiras e 5 brasileiras, das quais 3 públicas e 2 particulares. Sua opção foi pelo curso de Engenharia Civil da Universidade de Coimbra (UC). Seus 813 pontos em Matemática foram decisivos para sua aprovação para o mesmo curso nas universidades federais da Bahia (UFBA) e Espírito Santo (UFES), além da Universidade do Norte Fluminense (Uenf) e na PUC-MG. Em Portugal, o jovem também teria sido aprovado nos exames de acesso às universidades de Algarve, Coimbra e Beira do Interior. Para realizar o sonho de estudar na UC, instituição pública, mas não gratuita, o jovem precisou encontrar meios para obter recursos para sua inscrição e viagem. Graças à solidariedade dos amigos, vizinhos e professores, os recursos foram obtidos. As ajudas "pontuais", no dizer do estudante, foram decisivas para sua viagem: das passagens, às roupas e malas, tudo foi conseguido por doações. Três pessoas da cidade teriam se comprometido com depósitos mensais para custear as mensalidades ("propinas") da universidade bem como as despesas de estadia e alimentação. Por intermediação da própria UC, o estudante também já fazia contato com outros 2 jovens estudantes de engenharia, a fim de obter informações e "dicas práticas" para sua ambientação na nova realidade. O caso não é único e, não raramente, notícias são veiculadas sobre os jovens brasileiros bem classificados no Exame Nacional do Ensino Médio (ENEM), que, a despeito das aprovações em renomadas universidades públicas brasileiras, optam pelos estudos na Universidade de Coimbra, a despeito dos valores das propinas cobradas para estudantes brasileiros serem muito superiores àqueles praticados 
para estudantes portugueses e europeus. Para além da propina, atualmente em torno de 7.000 euros anuais (que podem ser divididos em 10 parcelas), os custos com alojamentos, alimentação e despesas acadêmicas oscilam em torno de 250 euros mensais.

Enforques/Eixos para o Desenvolvimento da Pesquisa

A presente pesquisa está sendo desenvolvida em três eixos:

1. A instituição Universidade de Coimbra e suas relações com a "memória acadêmicocientífica brasileira";

2. As relações entre memória social e interações nas mídias digitais, bem como os processos de interação social na vida cotidiana dos estudantes;

3. A construção e vivência do que chamamos de "desejo por Coimbra" e sua correspondência no processo de afiliação dos estudantes na UC.

O pesquisador realizou pesquisa de campo na cidade de Coimbra, fazendo 8 entrevistas semiestruturadas com estudantes brasileiros que estão desenvolvendo suas atividades acadêmicas na Universidade de Coimbra (licenciaturas ou intercâmbio).

Sobre o Processo de Afiliação

Segundo Coulon (2008), o desejo e a importância de pertença são explicitados no processo pelo qual o estudante passa, podendo culminar na afiliação, quando ele se apropria dos conceitos inerentes ao campo universitário e incorpora o habitus academicus. De uma forma geral, isso ocorre progressivamente entre o primeiro e segundo semestre do seu ingresso na universidade. Quando isso não acontece, ele tende a abandonar os estudos logo no início, ou troca de curso ou de instituição. Assim, o processo de afiliação estudantil requer do estudante sua adaptação às exigências universitárias, em termos de conteúdo intelectual, de métodos de exposição do saber, e de adequação aos habitus estudantis, incluindo a percepção e domínio do novo espaço geográfico; identificação das atribuições dos mesmos e da maximização do uso de seu tempo; compreensão dos códigos e regras do jogo no campo social e intelectual universitário. Essas novas experiências são fundamentais e impactantes na formação do aluno/estudante como sujeito de sua própria história estudantil/acadêmica. Assim, quanto maior for sua prontidão para responder positivamente a essas mudanças e quanto maior for seu grau de resiliência para superar problemas, mais capaz ele será de aproveitar as oportunidades proporcionadas pela e na vida universitária como pessoa e como graduando.

Nery (2011, p.37), com base em Coulon, também sintetiza esse processo e suas etapas da seguinte maneira:

1. Tempo de estranhamento: Em que o estudante está diante de um universo desconhecido, em que se operam as rupturas com o seu passado. Nele as rupturas institucionais começam a ser instaladas, através do processo de escolha das disciplinas a serem cursadas, da matrícula, da localização do número de créditos necessários para o semestre, ou seja, da organização da vida acadêmica. Muitos estudantes vivenciam esse momento como traumatizantes, angustiantes, revoltantes e inquietantes;

2. Tempo de aprendizagem: Em que se inicia uma adaptação progressiva e uma conformação se produz. Nele o estudante começa a esboçar respostas para perguntas como quem sou eu em relação a esse grupo de pessoas? Qual a minha função aqui? E que relação eu tenho com essa instituição? Para responder essas questões, os jovens rompem com seu passado recente e entram em um estado de latência, em que não dispõem mais de referências estáveis. Eles progressivamente elaboram estratégias para lidar com as contingências que lhe são apresentadas através de um método de ensaio e erro. A falta de orientação e de informação pode levar o jovem a organizar 
sua vida acadêmica de maneira totalmente contrária à lógica da universidade. Quando isso acontece, o abandono [ou a retenção sucessiva] é eminente e o mal causado pela desorientação do primeiro contato talvez não seja desfeito.

3. Tempo de afiliação: Nele, o estudante torna-se definitivamente membro da universidade. Isso significa que ele compreende o manejo de uma quantidade grande de regras que organizam sua vida social e intelectual nessa instituição. São dois momentos: no primeiro, o estudante compreende e categoriza um conjunto de regras institucionais que irão organizar sua vida acadêmica - Afiliação Institucional; no segundo momento, ele percebe o que realmente se espera dele no plano intelectual e irá tentar corresponder demonstrando, cotidianamente, que possui algumas das competências requisitadas - Afiliação Intelectual.

Este, por sua vez, é um processo que nunca é totalmente finalizado, porque o estudante sempre estará requisitando confirmações para as competências que demonstra em tarefas universitárias. (NERY, 2011, p.37)

Desejamos destacar, dentre outros fatores influentes no caminho para a afiliação estudantil, dois por sua importância no processo de superação e de empoderamento pelo qual os alunos passam para atuar como estudantes universitários: a identificação entre os pares e o desenvolvimento da autonomia. A partir das trocas de experiências e ajudas mútuas na realização das tarefas universitárias e uso dos espaços de convivência; pelo enfrentamento dos mesmos problemas, ou semelhantes, compartilhado entre os pares; pela utilização do mesmo vocabulário e das mesmas expressões; enfim, pelo compartilhamento no e do mesmo mundo, os estudantes são levados a um processo de identificação e sentimento de grupo. Esse sentimento ocorre mesmo que eles pertençam a vários subgrupos pontuais: das disciplinas cursadas; das atividades esportivas e culturais; dos projetos e programas acadêmicos e não acadêmicos; do alojamento ou residência estudantil; dentre outros. Esses fatores são impactantes no sentido de incentivarem e propiciarem a afiliação acadêmica do aluno ingressante, bem como na sua inclusão social no contexto universitário.

\section{Um Olhar para a Histórica Relação entre Brasileiros e Coimbra}

Em seus textos sobre a história da educação no Brasil, Anísio Teixeira (2005) já se referia à característica dos colégios destinados aos filhos da nossa elite colonial, sobretudo aqueles administrados por jesuítas, que ministravam a educação clássica medieval europeia, não se distanciando, em termos de conteúdo e qualidade, daqueles existentes na metrópole. Segundo o autor, não havia diferenças significativas entre Metrópole e Colônia quanto ao nível ou conteúdo da educação intelectual, se considerarmos que toda a educação local ministrada pelos jesuítas iria completar-se com a educação universitária na Europa. No entanto, Anísio nos aponta um fato que precisa ser destacado: não havia ainda, pelo menos até o século XIX, uma consciência, ou uma identidade específica de "brasileiro". A elite que aqui vivia era considerada (ou se considerava) como "portugueses nascidos no Brasil". Este sentimento de identidade lusitana, certamente, estava vinculado a parte da elite latifundiária, escravista e comercial da América portuguesa, a partir do compartilhamento de uma rede de memórias construtoras de discursividades que se alinhavam a Portugal, fazendo com que tal elite se sentisse parte integrante (e não externa), não só da Universidade de Coimbra, como também das demais instituições lusitanas.

Embora tal aspecto mereça maiores estudos e cuidados, a fim de melhor percepção das interdiscursividades e compartilhamentos de memórias pelas ideologias comuns que perpassavam portugueses e "brasileiros", a menção de Anísio a este "compartilhamento de identidades" pode nortear nossa linha argumentativa: 
O brasileiro da Universidade de Coimbra não era um estrangeiro, mas um português nascido no Brasil, que poderia mesmo se fazer professor da universidade. O reitor Francisco de Lemos de Faria Pereira Coutinho, membro da Junta de Providência Literária, constituída para estudar e projetar a radical reforma universitária no tempo de Pombal e, depois, o executor da reforma e reitor por cerca de trinta anos, era um brasileiro nascido nos arredores do Rio de Janeiro; José Bonifácio de Andradai, o brasileiro considerado Patriarca da Independência do Brasil, foi, antes, professor da Universidade de Coimbra. Como estes, vários outros "brasileiros" foram ali professores. (TEIXEIRA, 2005, p.137. grifos nossos).

Sendo assim, podemos considerar a Universidade de Coimbra como uma força unificadora, aglutinadora e homogeneizadora do próprio Império Português, exercendo importante papel de convergência entre as diversas elites portuguesas espalhadas pelas várias e vastas áreas de colonização da metrópole lusitana, construindo o que podemos designar como "discursividade de fenômenos sociais homogêneos" (OLIVEIRA, 2011, p. 107). Este breve olhar histórico aponta para as inegáveis relações que perpassaram a formação educacional/intelectual da elite de "brasileiros" em Coimbra ao longo dos séculos passados. Servirá de subsídio para verificação de traços que ainda possam perdurar nas configurações discursivo-memorialísticas dos atuais estudantes brasileiros naquela universidade, atualizadas e perpassadas pela recente discursividade institucional, que se vale, constantemente, da nossa histórica aproximação.

Redes Sociais e Memória Discursiva nas Relações entre Univerisdade Coimbra e Estudantes Brasileiros. A Comunicação Digital em Rede: Etnografia e Etnometodologia

Esta pesquisa, em fase de execução, combina procedimentos etnográficos (com base nos estudos de Etnometodologia propostos por Coulon (1995), e netnográficos, conforme esquemas abaixo:

\section{ALGUMAS PREMISSAS TEÓRICAS DA ETNOMETODOLOGIA (EM)}

A EM é uma abordagem radicalmente praxiológica sobre o problema da ordem social.
As ações dos membros são definidas pela EM como sendo fundamentadas
culturalmente, e não cognitivamente, isto é, elas expressam o saber cultural em vez de
serem determinadas pela psicologia individual.
A "cultura" é vista na EM não apenas como ordem moral (valores, normas etc.), mas
também (e fundamentalmente) como um corpus de conhecimentos leigos, com alguns
locais especiais e limitados para o saber dos especialistas, mas que tem suas raízes no
conhecimento leigo.

Em geral, os métodos dos membros envolvem um processo ativo e concatenado de produção de sentido.

O domínio da linguagem natural dos membros (seja português, japonês ou quechua) é fundamental para a produção metódica de sentido.

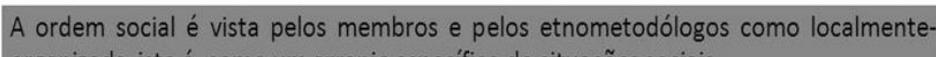
organizada, isto é, como um arranjo específico de situações sociais.

Para a EM, a sociologia clássica é pouco mais do que "senso comum teorizado". 


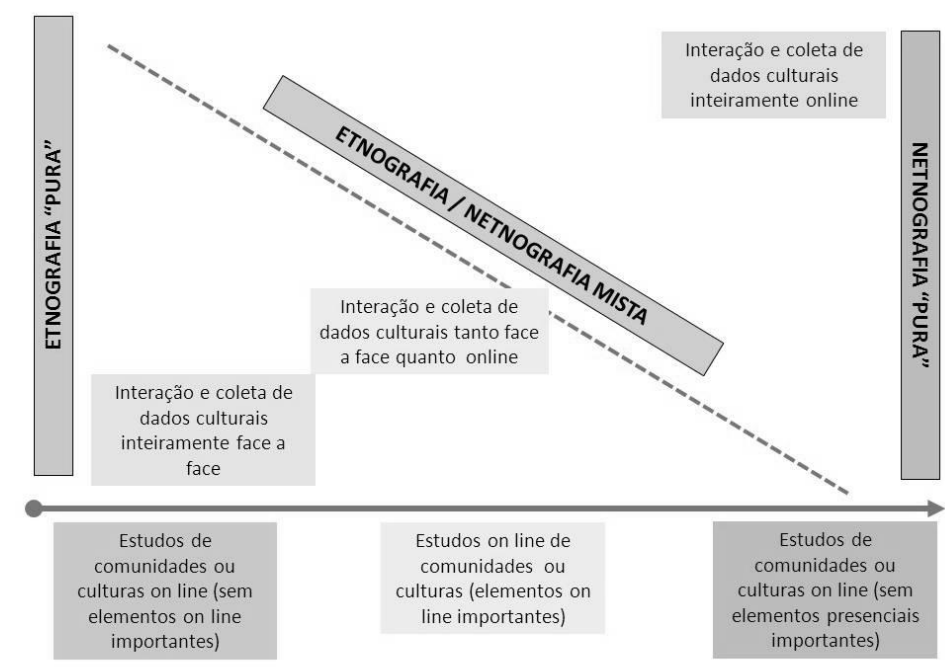

KOSINETS, 2014, p. 68

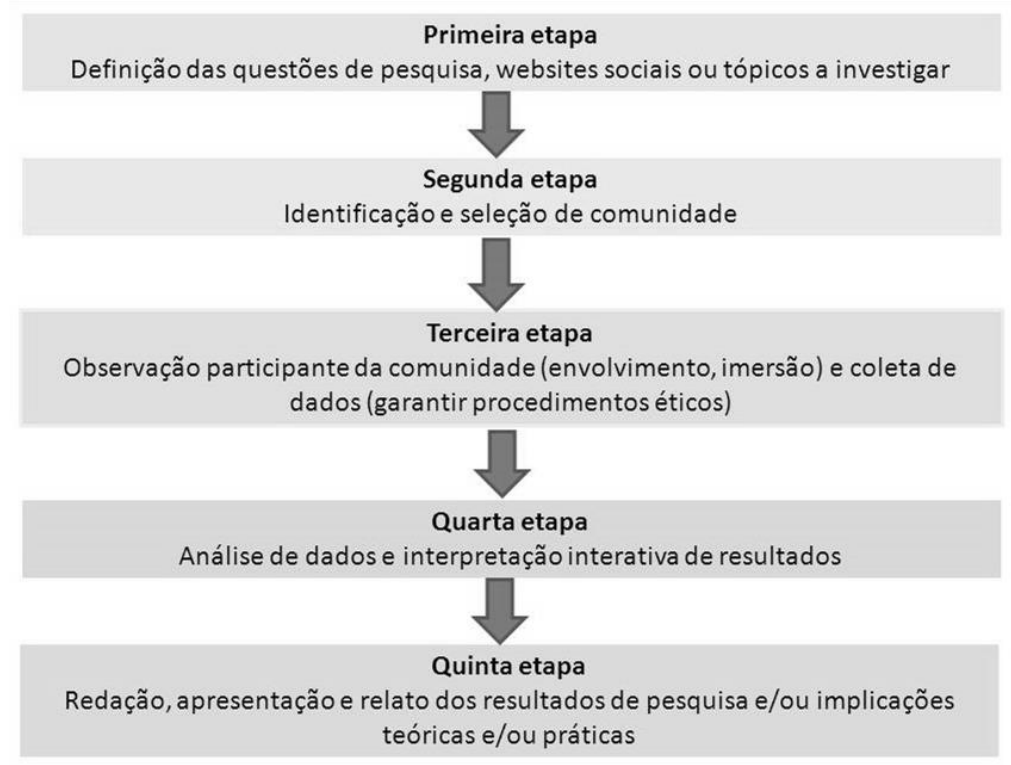

KOSINETS, 2014, p.63

Além da pesquisa de campo, de caráter etnográfico, estão sendo analisados conteúdos postados em páginas da Rede Social Facebook, particularmente na comunidade virtual "Amigos Brasileiros em Coimbra" e na página "Universidade de Coimbra - Graduação para Brasileiros". Tais análises serão feitas com base na perspectiva netnográfica, proposta por Kosinets (2014). Busca-se, por meio das postagens, observar os processos de construções memorialísticas, por meio de compartilhamentos de informações, bem como dos processos de sociabilidade e interações promovidos por intermédio das redes e da vivência na cidade de Coimbra. Entendemos que "os dispositivos tecnológicos para a interação ser humanomáquina são incorporados à vida humana como uma segunda natureza. A história, a economia, a política, a cultura, a percepção, a memória, a identidade e a experiência estão todas elas hoje mediadas pelas tecnologias digitais. Estas penetram em nosso presente não só como um modo de participação, mas como um princípio operativo assimilado à produção humana em todas as suas áreas." (SANTAELA, 2013, p. 33).

As redes sociais também exercem papel importante a se considerar nas construções intersubjetivas. Santaela (2013) nos adverte que: 
"saber o que fazemos com as redes sociais digitais não é tão importante quanto saber o que as redes estão fazendo conosco. O que estão fazendo com a nossa subjetividade e sociabilidade, com a nossa memória, com as nossas expectativas, anseios e desejos, o que estão fazendo com nossos modos de receber informação, de nos darmos conta dos fatos, de adquirir conhecimento, de perceber e representar o mundo, enfim, o que estão fazendo com os nossos processos de aprendizagem e, possivelmente, com as nossas maneiras de ensinar e educar." (SANTAELA, 2013, p.34).

No que se refere às conversações, Recuero (2013) nos aponta que estas servem para proporcionar a interação entre os atores sociais e que estes se valem da conversação para "construir valores e ter acesso a recursos do grupo, tais como a legitimação de impressões a respeito de si mesmo, o acesso a informações, o suporte e o apoio social etc."(RECUERO, 2013, p.56). Estes elementos são chamados de capital social. O capital social é, assim, constituído de valores negociados e embebidos na estrutura dos grupos sociais, aqueles associados a 'fazer parte' desses grupos. As negociações entre os valores que definem o capital social é uma das motivações mais importantes para qualquer ação social e, para a afiliação dos estudantes brasileiros na UC, constituem elemento imprescindível nas análises que estão em andamento na presente pesquisa.

\section{Referências bibliográficas}

ALBERTI, Verena. Ouvir contar: textos em história oral. Rio de Janeiro: FGV/CPDOC, 2004.

BAKHTIN, Mikail. Marxismo e filosofia da linguagem. São Paulo: Hucitec, 2009.

Estética da criação verbal. São Paulo: Martins Fontes, 2010.

COULON, A. A condição de estudante: a entrada na vida universitária. Salvador: EDUFBA, 2008.

. Etnometodologia. Petrópolis, RJ: Vozes, 1995.

KOZINETS, Robert V. Netnografia: realizando pesquisa etnográfica on line. Porto Alegre: Penso, 2014

NERY, Matheus Batalha Moreira. O processo de afiliação emocional entre estudantes do programa Permanecer da UFBA. Salvador, 2011. Tese (Doutorado em Psicologia) - Universidade Federal da Bahia (UFBA).

OLIVEIRA, Antonio José Barbosa de. A casa de Minerva: entre a ilha e o palácio - os discursos sobre os lugares como metáfora da identidade institucional. Tese. Doutorado em Memória Social. Programa de Pós Graduação em Memória Social. Universidade Federal do Estado do Rio de Janeiro, 2011.

RECUERO, Raquel. Atos de ameaça à face e à conversação em redes sociais na internet. In: PRIMO, Alex (org.). Interações em rede. Porto Alegre: Sulina, 2013.

SANTAELA, Lucia. Intersubjetividade nas redes digitais: repercussões na educação. In: PRIMO, Alex (org.). Interações em rede. Porto Alegre: Sulina, 2013.

TEIXEIRA, Anísio. Ensino superior no Brasil: análise e interpretação de sua evolução até 1969. Ed. UFRJ, 2005. 


\section{Genes como novas commodities}

Gabriel Bianconi Fernandes ${ }^{19}$ - Doutorando HCTE-UFRJ - biefernandes@gmail.com José Carlos de Oliveira - Professor Doutor HCTE-UFRJ - jcarlos@dee.ufrj.br

Resumo

Este artigo trata do desenvolvimento de inovações biotecnológicas, especificamente sementes transgênicas, como parte da globalização neoliberal. Para tanto, apoia-se nas noções teóricas da razão indolente e da sociologia das ausências, de Boaventura de Souza Santos, e de tecnociência, de Hugh Lacey. Analisa o discurso da racionalidade técnicocientífica que promove os organismos geneticamente modificados como solução para a agricultura, anulando quaisquer alternativas para o desenvolvimento agrícola. Conclui-se que essas sementes representam continuidade do padrão industrial agroalimentar, não se configurando como caminho para a sustentabilidade agrícola. Ao mesmo tempo, a modificação genética por meio da transgenia converteu os genes em nova commodity.

Palavras chave: Sementes Transgênicas. Tecnociência. Globalização.

Introdução

As economias que lideraram o processo de industrialização puderam utilizar os recursos naturais de mais fácil acesso e controlar grande parte dos recursos não renováveis que se encontram nos países subdesenvolvidos (FURTADO, 1974). Os ciclos econômicos do Brasil Colônia são exemplos desse processo. Essa busca por riquezas externa segue até os dias de hoje, sendo que, numa fase mais avançada, a expansão do capitalismo singularizou-se pela crescente utilização de riquezas - sob a forma de bens ou de conhecimento - na produção de novas mercadorias e numa forte concentração social da renda (PORTO-GONÇALVES, 2011). A prospecção, a manipulação e o patenteamento de genes para a criação de organismos geneticamente modificados ilustram perfeitamente essa tendência.

O paradigma das sementes transgênicas emerge com a expansão da globalização como uma forma de reprodução do capital (MACAFEE, 2003). Nesse mesmo período perde força a perspectiva do bem-estar coletivo e as corporações, dispondo de mais recursos para investir externamente, passam a orientar suas ações no sentido de acentuar a divisão geográfica do trabalho conforme a diversidade da dotação de recursos naturais e/ou a diversidade de remuneração da mão-de-obra, além da derrubada de barreiras tarifárias, recrutando recursos produtivos em escala global de sorte a combinar mão-de-obra de baixo preço com trabalho altamente especializado, minimizando custos financeiros e maximizando a remuneração do capital (FURTADO, 1999).

Para Hugh Lacey, não surpreende o fato de as plantações com sementes transgênicas terem tido um crescimento explosivo nos últimos anos:

\footnotetext{
"As sementes transgênicas (TG) contêm genes tirados de organismos de diferentes espécies, inseridos diretamente em seus próprios materiais genéticos, com a finalidade de gerar plantas com as específicas qualidades "desejadas", tais como as capacidades de resistir a inseticidas para seus criadores, as sementes TG incorporam conhecimento científico e trazem a marca da ciência. Elas também trazem a marca da economia política da "globalização", uma vez que seu desenvolvimento tem sido visto tanto como um objetivo da economia neoliberal global quanto como um meio de fortalecer suas estruturas. Tais marcas gêmeas emprestam uma aura de

${ }^{19}$ Elaborado a partir da dissertação de mestrado "Genes como mercadoria: o caso da introdução das sementes transgênicas no Brasil”, de Gabriel Bianconi Fernandes. HCTE-UFRJ, 2015.
} 
inevitabilidade à "revolução" agrícola prometida com o advento das sementes TG: a ciência definiu a rota, a economia global fornece as estruturas para sua efetiva implementação (LACEY, 2000).

Neste sentido, após quase 20 anos de uso comercial dessas sementes, pode-se argumentar que a novidade trazida pelas plantas transgênicas não reside em suas novas características adquiridas pela transferência de genes entre organismos de diferentes espécies e sim no fato de que a técnica permite que as sementes sejam patenteadas e garante direitos monopólicos a seus detentores (MELGAREJO; FERRAZ; FERNANDES, 2013, 2013b; GUERRANTE, 2004).

$\mathrm{O}$ caso do Brasil é emblemático. Cultivam-se aqui variedades de soja, milho e algodão transgênicos ${ }^{20}$. As primeiras variedades de soja e milho geneticamente modificadas entraram ilegalmente no País e foram posteriormente legalizadas (LISBOA, 2007; AS-PTA, 2005; MARINHO; MINAYO-GOMEZ, 2004).

\section{Entre otimistas e pessimistas}

A forma como está configurada a polêmica ligada às plantas transgênicas, que é uma parte do debate sobre o futuro da alimentação, pouco ou quase nada inovou nos últimos duzentos anos em termos de estrutura de pensamento. Waren Belasco (2009) identificou nesse período três principais correntes que movimentam essas discussões, previsões e apostas: otimistas (ou abundandistas), pessimistas e igualitaristas, respectivamente representados por Condorcet (1743-1794), Malthus e Godwin (1756-1736). Thomas Malthus foi o teórico que, em 1798, alertou para o fato de que a população mundial vinha crescendo em progressão geométrica enquanto a produção global de alimentos crescia apenas em progressão aritmética. Malthus criou assim um clima de temor da escassez e alertava então para uma grave crise alimentar e um quadro de fome que resultariam desses ritmos desencontrados, propondo ações de controle de natalidade como forma de evitar o pior. A naturalização da fome foi usada como uma judiciosa forma de regulação demográfica, como forma de seleção natural. Malthus contribuiu para a visão fatalista da história, segundo a qual a fome seria flagelo insuperável e contra ela os homens nada poderiam fazer (ZIEGLER, 2013).

O ensaio de Malthus foi uma resposta "às especulações" do matemático Francês Condorcet e do "radical" inglês Willian Godwin (BELASCO, 2009). A partir das teses e visões desses outros autores conformaram-se as demais correntes abordadas por Belasco: os técno-otimistas ou abundandistas inspirados por Condorcet, para os quais a ciência sempre poderá aportar soluções milagrosas para os dilemas humanos; e os igualitaristas motivados por Godwin, que defendem que as pessoas podem encontrar caminhos para compartilhar a generosidade da natureza e viver de forma mais equilibrada. Condorcet, por exemplo, chegou a prever que a pesquisa científica aumentaria indefinidamente a produção agrícola.

\footnotetext{
"O otimismo democrático de Godwin foi elaborado tanto pelos socialistas quanto pelos liberais do século XIX, que promoviam a redistribuição dos recursos como solução para a fome. [Já] "os abundandistas de Condorcet no Banco Mundial e na Monsanto mantêm essa esperança por meio do capitalismo de livre mercado e da biotecnologia". (p. 21)

"se toda essa história parece repetitiva é porque o debate de três vias se mantinha e perdurou no decorrer das décadas: questionando a ciência e a razão, os malthusianos previram ainda mais fome; desafiando Malthus, os abundandistas tomavam medidas para produzir mais alimentos; apontando para os excedentes que se acumulavam, os igualitaristas criticavam um sistema econômico e político que
}

${ }^{20} \mathrm{~A}$ lista das sementes transgênicas aprovadas comercialmente está disponível em: http://ctnbio.mcti.gov.br/documents/566529/1684467/Tabela+de+Plantas.pdf/e9d66306-bc49-4595-bd8a805b727e7750. Acesso em: 01 out. 2017. 
engordava os ricos com carne barata enquanto privava os pobres dos grãos básicos e esgotava o solo" (p. 91)

Belasco afirma que "para uma discussão pública de qualidade, precisamos resistir ao uso de velhos clichês que obscurecem a razão principal da luta sobre o futuro: o poder" (ANO, p. 26). Inspirados no enfoque abundandista, os promotores dos transgênicos e da agricultura industrial também lançam mão do recurso retórico de que, ainda que possam reconhecer os impactos negativos gerados por esse modelo, nada há a fazer dado que não existem alternativas críveis ao sistema posto.

A esse modelo de racionalidade Boaventura de Souza Santos dá o nome de razão indolente, que manifesta-se, entre outras formas, no modo como se resiste à mudança das rotinas e na forma como se transforma interesses hegemônicos em conhecimentos verdadeiros (SANTOS, s/d). O caminho para enfrentar essa lógica passa pela sociologia das ausências, que visa demonstrar que o que não existe é, na verdade, ativamente produzido como tal, isto é, como alternativa não credível ao que existe (idem). No caso em questão, há a racionalidade que contrai o presente, afirmando que o modelo é este e que nada fora dele tem condições de substituí-lo, e ao mesmo tempo expande o futuro, projetando avanços e modernidades dentro do próprio modelo. Ao buscar reconhecer o valor e o potencial das experiências nãoexistentes, a sociologia das ausências trata de ampliar o presente e contrair o futuro, transformando em presente as ausências. Para tanto, organiza a sua forma de investigação em torno de cinco lógicas (ibidem):

A primeira deriva da monocultura do saber e do rigor do saber. É o modo de produção da nãoexistência mais poderoso, que consiste na transformação da ciência moderna e da alta cultura em critérios únicos de verdade e de qualidade estética, respectivamente. Ambas se arrogarem ser, cada uma no seu campo, cânones exclusivos de produção de conhecimento ou de criação artística. Tudo o que o cânone não legitima ou reconhece é declarado inexistente. A nãoexistência assume a forma de ignorância ou de incultura.

A segunda lógica está baseada na monocultura do tempo linear, na ideia de que a história tem sentido e direção únicos e conhecidos, que têm sido formulados de diversas formas nos últimos duzentos anos: progresso, revolução, modernização, desenvolvimento, crescimento, globalização. Esta lógica produz não-existência declarando atrasado tudo o que, segundo a norma temporal, é assimétrico em relação ao que é declarado avançado. É a tônica do discurso que associa, por exemplo, agricultura familiar à produção de subsistência ou o uso de sementes crioulas à baixa produtividade (BUENO, 2013).

A terceira lógica é a da classificação social, que naturaliza as diferenças e distribui as populações em categorias que naturalizam as hierarquias. Para Boaventura, as classificações raciais e sexuais são suas mais salientes manifestações.

A quarta lógica da produção de inexistência é a lógica da escala dominante. Nos termos dessa lógica, a escala adotada como primordial determina a irrelevância de todas as outras possíveis escalas. A globalização é a escala que nos últimos vinte anos adquiriu uma importância sem precedentes nos mais diversos campos sociais.

Trata-se da escala que privilegia as entidades ou realidades que alargam o seu âmbito a todo o globo e que, ao fazê-lo, adquirem a prerrogativa de se designar entidades ou realidades locais como rivais. É o que se ouve a respeito da Agroecologia e da agricultura orgânica, por exemplo, quando se afirma que funcionam só em pequena escala ou em projetos demonstrativos. Assim, as entidades ou realidades definidas como particulares ou locais estão aprisionadas a escalas que as incapacitam de serem alternativas credíveis ao que existe de modo universal ou global. 
A quinta lógica de não-existência é a lógica produtivista, baseada na monocultura dos critérios de produtividade capitalista (máxima produção por unidade de capital investida). Nos termos dessa lógica, o crescimento econômico é o critério de produtividade que mais bem serve a esse objetivo (importa-se mais com quantidade do que qualidade).

A produção social destas ausências resulta na subtração do mundo e na contração do presente e, portanto, no desperdício da experiência. Como forma de superação dessa tendência Boaventura propõem a caminho da sociologia das emergências.

\section{Produtos da tecnociência}

Há uma espécie de circuito fechado entre o discurso científico que legitima a tecnologia, a ciência que a desenvolve, a que avalia seus potenciais riscos e finalmente a que propõe soluções tecnologias para mitigar esses riscos (BECK, 2011). São, no geral, resultantes de uma mesmo enfoque de pesquisas conduzidas a partir de estratégias descontextualizadas: teorias e hipóteses limitadas de modo que são capazes de representar coisas e fenômenos como sendo gerados a partir de suas próprias estruturas subjacentes, de seus processos e interações entre seus componentes, e das leis que os governam (LACEY, 2017).

Os dados empíricos gerados são predominantemente quantitativos. Sendo a ciência é limitada ao emprego dessas estratégias descontextualizadas, e considerando que esse mesmo enfoque é o que dá origem aos procedimentos de avaliação de risco dos organismos transgênicos, então não há evidências científicas de que os organismos geneticamente modificados não possam causar danos. Não obstante, essa ciência não alcança avaliar nenhuma alternativa que não seja oriunda de estratégias descontextualizadas de pesquisa. Há razões para descrer que a análise e a gestão de riscos no cerne das avaliações de biossegurança sejam elas próprias atividades meramente técnicas e cabalmente confiáveis (LEITE, 2007). Como os danos ao Humano, nesta contemporaneidade multifatorial, é extremamente difícil, se não impossível, relacionar males à saúde a um fator isolado, no caso, a transgenia.

Para Laymert dos Santos, ao transformar um processo ecológico de reprodução em processo tecnológico de produção, a biotecnologia retira a semente das mãos do camponês e do habitante da floresta, colocando-a nas mãos das corporações. Para estes, a semente é tanto produto quanto meio de produção, é seu capital a ser investido no processo produtivo. 0 biotecnólogo quebra este círculo em dois movimentos verticais. O primeiro, ascendente, canaliza o fluxo de germoplasma do campo e das florestas para os laboratórios das corporações e dos institutos de pesquisa. O outro, descendente, canaliza o fluxo de produtos uniformemente "beneficiados" e transformados em mercadorias, que parte das corporações para o campo e a floresta. No processo, a semente deixa de ser produto e meio de produção para tornar-se matéria-prima (SANTOS, 2003).

As sementes estão na essência da autonomia do agricultor e devem ser vistas como fatores determinantes dos sistemas agrícolas (FERNANDES, 2017). Tradicionalmente, eram recursos regenerativos renováveis, fonte e parte dos produtos colhidos, reproduzidas e selecionadas pelo uso de métodos desenvolvidos e aprimorados pelos agricultores ao longo do tempo (LACEY, 2017). A modernização agrícola transformou as sementes commodities cujo cultivo depende de outras commodities (agrotóxicos, fertilizantes etc.).

Referências bibliográficas

AS-PTA (2005) Deputado Frei Sérgio Görgen (PT-RS) denuncia na Assembleia Estadual venda ilegal de sementes de milho transgênico. Boletim n. 279, 18 nov. 2005. Disponível em: <http://aspta.org.br/campanha/boletim279-18-de-novembro-de-2005/>. Consulta em: 01 out. 2017. 
BECK, U. Sociedade do Risco. Rumo a uma outra modernidade. São Paulo: Editora 34, 2011.

BELASCO, W. O que iremos comer amanhã? Uma história do futuro da alimentação. São Paulo: Editora Senac, 2009. 415 p.

BUENO, s. Produtores de transgênicos miram agricultura familiar. Valor Econômico, 21 jan. 2013.

FERMENT, G.; MELGAREJO, L.; FERNANDES, G.B; FERRAZ, J.M.G. Lavouras transgênicas: riscos e incertezas Mais de 750 estudos desprezados pelos órgãos reguladores de OGMs. Brasília: Ministério do Desenvolvimento Agrário, 2015. 450p. (Nead Debate; 26).

FERNANDES, G. B. Sementes crioulas, varietais e orgânicas para a agricultura familiar: da exceção legal à política pública. In: Regina Helena Rosa Sambuichi; Iracema Ferreira de Moura; Luciano Mansor de Mattos; Mário Lúcio de Ávila; Paulo Asafe Campos Spínola; Ana Paula Moreira da Silva (Org.). A política nacional de agroecologia e produção orgânica no Brasil: uma trajetória de luta pelo desenvolvimento rural sustentável. Brasília, DF: IPEA, 2017, p. 327-357

FURTADO, C. O Mito do Desenvolvimento Econômico. Rio de Janeiro: Paz e Terra, 1974. 117 p. . O Longo Amanhecer: reflexões sobre a formação do Brasil. Rio de Janeiro: Paz e Terra, 1999. 2a Ed. $116 \mathrm{p}$.

GUERRANTE, R. S. O comportamento estratégico das grandes empresas do mercado de sementes geneticamente modificadas. Impulso. Piracicaba. 15(36). 59-76, 2004.

LACEY, H. As sementes e o conhecimento que elas incorporam. São Paulo em Perspectiva. 14(3), 2000. p. 53 59.

LACEY, H. The life and times of transgenics. In: BENSUADE-VINCENT; B. LOEVE, S.; NORDMANN, A.; SCHWARZ, A (eds.) Research Objects in their technological setting. London: Pickering\&Chato, 2017.

LEITE, M. Os arautos da razão: a paralisia no debate sobre transgênicos e meio ambiente. Novos Estudos. Cebrap. 78, julho de 2007. p. 41-47.

LISBOA, M. (2007). Transgênicos no governo Lula: liberdade para contaminar. PUCviva Revista, 29, p. 26-46

MACAFEE, K. Neoliberalism on the molecular scale. Economic and genetic reductionism in biotechnology battles. Geoforum 34 (2003) 203-219.

MARINHO, C.L.C.; MINAYO-GOMEZ, C. Decisões conflitivas na liberação dos transgênicos no Brasil. São Paulo Perspec., São Paulo, v. 18, n. 3, 2004.

MELGAREJO, L.; FERRAZ, J.M.F; FERNANDES, G.B. Dez anos de cultivos transgênicos no Brasil: um balanço crítico. Resumos do VII Congresso Brasileiro de Agroecologia. Porto Alegre-RS, 25 a 28 de novembro de 2013.

(2013b) Transgênicos no Brasil: a manipulação não é só genética. Agriculturas: Experiências em Agroecologia. v. 10, n. 1, mar. 2013. p. 14-21. ISSN 1807-491X

PORTO-GONÇALVES, C. W. A globalização da Natureza e a natureza da globalização. Rio de Janeiro: Civilização Brasileira, 2. Ed., 2011. 461 p.

SANTOS, B. S. Para uma sociologia das ausências e uma sociologia das emergências. s/d. 52 p.

SANTOS, L. G. Politizar as novas tecnologias: o impacto sociotécnico da informação digital e genética. São Paulo: Ed. 34, 2003. 319 p.

ZIEGLER, J. Destruição em massa: geopolítica da fome. São Paulo: Ed. Cortez, 2013. 336 p. 


\title{
PARACELSO E AS FRONTEIRAS DA CIÊNCIA
}

\author{
Marcelo Bichara - Doutorando pelo HCTE/UFRJ - marcelorrbichara@gmail.com
}

Resumo

A obra e a biografia do médico renascentista suíço Philip Theophrastus Bombast Von Hohenheim, mais conhecido pelo pseudônimo de Paracelso (1493 - 1541), ainda permanece obscura aos olhos do pensamento moderno. Este artigo traça um esboço da sua importância filosófica para as ciências médicas, bem como tenta buscar em autores contemporâneos indícios de uma possível relevância atual para o desenvolvimento da ciência. Nosso objetivo está em analisar a importância histórica da medicina paracélsica, buscando entender sua relevância crescente para o momento atual, em especial para as ciências da vida e da saúde.

Palavras-chave: psique; mecanicismo; holismo

\section{Introdução}

A historiografia tradicional costuma mencionar a obra de Nicolau Copérnico e os estudos de anatomia humana de Andreas Vesalius como os grandes marcos da ciência renascentista. No entanto, segundo Ball (2009), nenhum desses autores são representativos do meio acadêmico e intelectual daquele tempo, apesar da óbvia contribuição que proporcionaram para as gerações seguintes. A obra de Paracelso, por outro lado, nos apresenta uma visão mais precisa do ponto em que estava o desenvolvimento da ciência em meados do século XVI:

Foi sua visão, mais do que as reformas de Copérnico e Vesalius, que desafiou as certezas equivocadas e enrijecidas de fins da Idade Média, com suas interpretações dogmáticas e tacanhas das idades clássicas sobre o universo.

[...] Se quisermos compreender o que, de fato, os filósofos debatiam naqueles tempos, e medir a temperatura real da fermentação intelectual da época de Lutero e da Contrarreforma, é melhor investigar a vida de Paracelso. Podemos genuinamente toma-lo como um prisma do seu tempo: decompondo diante de nosso olhos, como eram de fato, os paradoxos, horrores e tensões que existiam entre a filosofia natural, a religião, o humanismo e a política. (BALL, 2009, p. 2)

Paracelso é conhecido como um dos grandes magos e pensadores místicos do renascimento, ao mesmo tempo em que é celebrado como o pai da farmacologia moderna e um dos pioneiros da medicina ocidental. É precisamente este aparente paradoxo que o torna um personagem tão interessante na história da ciência, um ícone marcante do processo radical e paulatino de transformação da mentalidade europeia. Tendo um pé na magia e outro na ciência, nem bruxo nem médico, um puro vir a ser em estado de metamorfose - Paracelso "ainda é um animista [...] e, no entanto, já é um materialista" (JUNG, 2011, p. 7).

Ele é um embaraço porque debocha da convicção já profundamente arraigada tanto em cientistas como historiadores, de que a história das ideias deve ser colocada em uma narrativa ordenada e unidirecional.

[...] Se lutamos contra ele é porque não conseguimos evitar uma luta contra a sua época, em que pessoas faziam perguntas diferentes e enfrentavam dilemas diferentes dos nossos. Essas lutas nos dizem que o nascimento do mundo moderno não foi fácil e nem indolor, mas turbulento, violento, confuso. (BALL, 2009, p. 12)

Rompendo com o pensamento antigo e medieval, onde explicações pontuais para fenômenos particulares eram suficientes, Paracelso inaugura a busca da ciência moderna de tentar a construção de um sistema integrado da natureza, de onde o conhecimento médico e suas 
aplicações poderiam ser deduzidos naturalmente (BALL, 2009, p. 7). Devido ao complexo emaranhado de contradições e conflitos em que está enredado, Paracelso continua sendo o único, entre os maiores pensadores da revolução científica, que não foi absorvido pelo conhecimento moderno, permanecendo iconoclasta e marginal (BALL, 2009, p. 11).

O animismo de Paracelso e a medicina holística:

Um estudo das controvérsias passadas é particularmente esclarecedor, se os argumentos e as objeções forem analisados em termos do nosso conhecimento atual (MAYR, 1998, p. 25). Um dos autores mais importantes para guiar nossa investigação da obra de Paracelso é o psiquiatra Carl Gustav Jung (1875 - 1961). Suíço como Paracelso, Jung considera-se herdeiro da medicina do mestre renascentista e dedicou décadas de estudo à sua obra, tecendo uma vasta pesquisa sobre o empreendimento teórico dos alquimistas e sua relevância para a medicina contemporânea. Segundo Jung (2011, p. 11), Paracelso viu nascer de perto uma nova medicina à medida que as universidades tomavam para si "a arte dos barbeiros e cirurgiões de campanha, junto com a das parteiras, bruxas, feiticeiras, astrólogos e alquimistas". Sendo ele próprio um dos pioneiros nesta nova fase do conhecimento médico erudito, Paracelso aplicou seus conhecimentos de alquimia na fabricação dos primeiros remédios químicos da história (que não eram à base de plantas ou animais), o que lhe rendeu fama e respeito internacionais. "Se o sonho químico da alquimia se tornou realidade, PARACELSO então realmente previu a medicina química de hoje" (JUNG, 2011, p. 21)

Mas o motivo pelo qual o médico alquimista extraía remédio das pedras e metais não era porque acreditava, como os modernos, que o corpo humano fosse tão material quanto o "mundo inanimado", mas justamente o contrário: em sua visão de mundo toda a natureza era viva, animada por um "espírito" que podia ser extraído das coisas, conservado numa garrafa, num comprimido ou num unguento, sendo transportado assim com maior facilidade. Ao invés de uma matéria inerte e passiva, concepção que predominaria na mentalidade europeia nos séculos seguintes a partir de Descartes, Paracelso propõe uma versão materialista do pampsiquismo primitivo, onde toda a natureza é vista em seu conjunto como um agregado de matéria viva, animada por uma substância invisível e sutil, o mysterium magnum do cosmos que ele chama de anima mundi - o princípio inteligente que conecta as partes ao todo. Uma ideia já presente entre os estoicos e os pré-socráticos e que ganha vida nova nos escritos do médico.

Além de sua inegável contribuição para a ciência farmacológica, Jung atribui a Paracelso uma inovação filosófica de extrema importância clínica, que permaneceu marginal na história da ciência até meados do século XIX, quando o romantismo alemão redescobriu suas teorias e conferiu a ele um lugar de destaque entre os grandes nomes da Renascença.

Para ele, homem e mundo são um agregado vivo de matéria, uma concepção que mantém afinidade com o ponto de vista científico do final do século XIX. Há, porém, uma diferença: Paracelso ainda não pensa mecanicamente, em termos de matéria química inerte, mas de maneira animista primitiva. A natureza, para ele, ainda é povoada de bruxas, íncubos, súcubos, diabos, sílfides e ondinas. Para ele, a vivência psíquica é, ainda, uma vivência da natureza. A morte psíquica do materialismo científico ainda não o atingiu, mas ele está preparando o caminho para esse fim. (JUNG, 2011, p. 7) [grifos do autor])

\section{A ascensão do mecanicismo e o esquecimento moderno}

O sucesso estrondoso do paradigma mecanicista arrastou para debaixo do tapete todas as visões de mundo alternativas que estavam em disputa na revolução científica, obscurecendo e distorcendo até mesmo autores fundamentais como Isaac Newton, cuja visão dinamicista não se encaixava na ideologia dominante, apesar da eficácia avassaladora de seus modelos 
matemáticos (WESTFALL, 1989). Curiosamente, foi justamente o sucesso da física newtoniana que selou a vitória do pensamento mecanicista, extirpando da matéria qualquer propriedade mental, reservando a mente apenas aos processos do pensamento humano, único ente dotado de "alma", no sentido cristão (ABRANTES, 1998).

A filosofia moderna é fundada assim numa passagem do paradigma animista pagão para o paradigma mecanicista tipicamente cristão, ignorando "de maneira generalizada, nas discussões sobre ciência daqueles séculos, que outras ciências também já existiam. Em vez disso, essas outras ciências foram espremidas para dentro do quadro conceitual da física" (MAYR, 2005, p. 30).

O fisicalismo extremo (incluindo o determinismo e o extremo reducionismo), que prevalecia no pensamento ocidental após a revolução científica, influenciou fortemente a formação teórica em biologia, por vários séculos, muitas vezes, inclusive exatamente contra aquilo que hoje é evidente (MAYR, 1998, p.18).

É nesse sentido que Thomas Kuhn (2001) chama atenção para os perigos de um compromisso paradigmático de nível elevado. O apego excessivo a determinadas crenças e visões de mundo, difundidas no meio científico numa dada época, embora ajude a manter o foco do desenvolvimento científico, pode levar a comunidade científica a descartar acriticamente toda uma gama nova de possibilidades.

No entanto, é inadmissível adotar a posição de Kuhn (2001) a respeito da incomensurabilidade dos paradigmas e a definição de ciência madura pelo critério de adesão a um único paradigma. Nesses pontos concordamos com Lakatos (1979), que defende a maturidade científica como a competição ferrenha entre diferentes paradigmas. Em seus próprios termos, o progresso científico dependeria assim da constante concorrência entre diferentes programas de pesquisa.

Entendemos que a história da medicina e das ciências da vida podem ser descritas como a competição entre dois programas de pesquisa distintos, um de viés mecanicista, que pensa o corpo de forma exclusivamente material, e outro mais holístico ou psíquico, que insere a mente no processo da vida.

Nossa hipótese é que o programa de pesquisa que leva os processos mentais e simbólicos em consideração tem, nos termos de Lakatos (1979), maior poder heurístico que a medicina mecanicista, pois não descarta ou exclui as causas mecânicas (físico-químicas), somando a essas novos fatores que são negligenciados no outro programa.

É evidente que duas teorias podem pertencer a dois corpos de racionalidade diferentes e que se podem opor em determinados pontos, permanecendo válidas individualmente no seu próprio corpo de racionalidade. Esse é um dos aspectos do pluralismo racional que só pode ser obscuro para os filósofos que se obstinam em acreditar num sistema de razão absoluto e invariável. (BACHELARD, 1991, p. 140 [grifo nosso])

Ernest Mayr (1998), um dos pais da síntese moderna da biologia, critica a imposição da física como paradigma de ciência por autores como Popper e Kuhn, argumentando que todas as tentativas de circunscrever o mundo vivo às leis da física e descrevê-lo matematicamente falharam porque os organismos vivos são sistemas complexos auto-organizados, afetados durante bilhões de anos por processos históricos onde o acaso e a aleatoriedade desempenham papel fundamental.

Nos termos de Maturana e Varela (1995), os organismos vivos possuem um determinismo estrutural, onde uma alteração no meio não contém necessariamente uma especificação de seus efeitos no ser vivo, mas sim é a sua própria estrutura que determina sua mudança frente a tal perturbação. Segundo os autores, o traço característico dos seres vivos é a autopoiese, isto é, a produção de si mesmo numa estrutura que determina uma estrutura que determina uma estrutura... numa rede de relações entre relações. As chamadas máquinas autopoiéticas, 
diferente dos corpos mecânicos, são autônomas, na medida em que constantemente subordinam suas mudanças à conservação de sua própria organização, realizando mudanças internas para compensar as perturbações externas e mantendo assim sua identidade e individualidade.

De modo semelhante, o biólogo Gregory Bateson, um dos pais da cibernética, propõe a criação de uma nova epistemologia para pensar o mundo vivo. Segundo o autor, para pensar a vida é necessário levar em conta o fluxo de informação que conecta os seres entre si com o ambiente, o que permite a formação de um ecossistema complexo e auto-organizado. Segundo Bateson (1986), o materialismo e o mecanicismo tendem a ignorar as conexões de um sistema vivo, apostando numa clara separação entre as partes. Ele defende que fomos educados a pensar essas conexões como estáveis e invariáveis, como num relógio mecânico, mas que elas são na verdade como uma dança de partes que se interagem, num imbricado processo de transformações que dependem do contexto para existirem e significarem Quando se investiga a vida, a atenção deve estar na relação entre as partes e seu contexto, não nas coisas em si.

Outro autor fundamental para repensar o papel da mente na natureza é o químico russo llya Prigogine, conhecido por sua pesquisa dos processos termodinâmicos longe do equilíbrio. De acordo com Prigogine (2002), mesmo nas ciências do mundo dito "inanimado", como a física, os sistemas estáveis de cunho determinista há muito tempo deixaram de ser uma regra universal, para ser apenas um caso especial de uma dinâmica estatística onde prevalece o indeterminismo, a múltipla escolha e a criatividade, fatores que não tinham lugar na física determinista e que constituem a imensa maioria dos casos no universo. "As leis da Física em sua formulação tradicional, descrevem um mundo idealizado, um mundo estável e não o mundo instável, evolutivo em que vivemos" (PRIGOGINE, 1996, p. 29).

Ser e estabilidade dão lugar à evolução e à mudança. Nos sistemas termodinâmicos longe do equilíbrio (como aqueles em que a vida é possível), condições iniciais muito próximas divergem imensamente, as perturbações sofrem amplificações ao longo do tempo, o que permite o aparecimento de estruturas complexas e auto-organizadas, onde a matéria adquire novas propriedades: uma "sensibilidade da matéria a si mesma e a seu ambiente" (PRIGOGINE, 1996, p. 71), onde as flutuações permitem que o sistema "escolha" uma das situações possíveis. A matéria em equilíbrio é "cega, ao passo que longe do equilíbrio ela começa a 'ver'." (PRIGOGINE, 1996, p. 71).

Como bem adverte Mayr, a Física atual não mais se restringe aos princípios da mecânica de Galileu e Newton, que sem dúvida constituíram os fundamentos das ciências físicas. Vastos campos da Física Moderna admitem processos estocásticos. O indeterminismo dos processos biológicos já não está em agudo contraste com as previsões probabilísticas de vários processos do mundo inanimado. [...] O que há de relevante nesta discussão é que estes fenômenos não são, nem de longe, deterministas, reducionistas, ou essencialistas. [...](autor, ano) De fato, para um grande número de sistemas, inanimados ou vivos, isolar todas as partes, mesmo as menores, não é suficiente para uma explicação completa. É necessário também entender a relação entre as partes, ou seja, faz-se necessária uma abordagem mais holística. (MOREIRA \& MASSONI, 2011, p. 191-192)

\section{Considerações finais}

Gaston Bachelard (1971) defende que é necessário realizar uma "psicanálise da razão", expondo os valores e as condições psicológicas inconscientes que atravancam o progresso científico, isto é, revelando as noções obstáculo. Segundo o autor, esses obstáculos epistemológicos atuam inconscientemente no cientista, como uma espécie de instinto pela conservação do pensamento - uma preferência pelas respostas e não pelas questões. $\mathrm{O}$ autor 
enfatiza o fato de que o critério do que é "conhecimento científico" é sempre construído histórico e socialmente, sendo setorial às diferentes ciências. Por isso é preciso analisar o passado com base nos valores do presente, pois o valor de uma ideia não depende apenas da ideia em si, mas da relação desta ideia com as outras ideias presentes no momento.

Para explicar a existência de uma enfermidade, por exemplo, é preciso considerar as relações históricas e sociocognitivas que influenciaram seu conceito. O pensamento é condicionado histórico-culturalmente. [...] Este está impregnado pelo estágio do conhecimento da época e pelo meio cultural e acaba resultando em um estilo de pensamento, ou seja, uma maneira "dirigida" de interpretar os fatos (MOREIRA \& MASSONI, 2011, p. 194 [grifo dos autores]).

Ao comparar a medicina tradicional africana com a chinesa e a indiana, Freitas (2014) argumenta que os conceitos de saúde e doença são sempre vistos como atores de um processo simbólico, onde a individualidade do paciente é tão importante na definição do diagnóstico e da terapêutica quanto a universalidade de sua condição humana. É essa singularidade do processo histórico e subjetivo de cada paciente que se perde numa medicina unicamente mecanicista, onde o corpo é dotado apenas de órgãos, células e de uma estrutura universal sem "alma" individual.

A medicina moderna não pode mais entender a alma como simples apêndice do corpo e por isso começa a levar cada vez mais em consideração o assim chamado "fator psíquico". Aproxima-se de certa forma novamente da concepção paracélsica da matéria animada pela psique, resultando daí que todo o fenômeno espiritual do próprio PARACELSO aparece sob nova luz. Como PARACELSO foi outrora o pioneiro da ciência médica, parece-nos que hoje se tornou o símbolo de uma importante modificação em nossa concepção sobre a natureza da doença e sobre a essência da vida em si. (JUNG, 2011, p. 9)

Referências bibliográficas:

ABRANTES, P. C. C. Imagens de natureza, imagens de ciência. Campinas: Papirus, 1998.

BACHELARD, G. A filosofia do não. Lisboa: Editorial Presença, 1991.

. Epistemologia. Barcelona: Editorial Anagrama, 1971.

BALL, P. Médico do demônio: Paracelso e o mundo da magia e da ciência renascentista. Rio de Janeiro: Imago Editora, 2009.

BATESON, G. Mente e natureza: uma unidade necessária. Rio de Janeiro: Francisco Alves, 1986.

FREITAS, V. M. A. Olhar Sobre a Recorrência da População aos Recursos Afro-Brasileiros na Saúde. Belo Horizonte: Anais Eletrônicos do 14o Seminário Nacional de História da Ciência e da Tecnologia, 2014.

JUNG, C. G. Paracelso. O espírito na arte e na ciência. Obras completas, vol. XV. Petrópolis: Vozes, 2011.

KUHN, T. A estrutura das revoluções científicas. São Paulo: Perspectiva, 2001.

LAKATOS, I. O falseamento e a metodologia dos programas de pesquisa científica. In: LAKATOS, I. e

MUSGRAVE, A. (org.) A crítica e o desenvolvimento do conhecimento. São Paulo: Cultrix, 1979.

MATURANA, H.R.; VARELA, F. A árvore do conhecimento: as bases biológicas do entendimento humano. Campinas, SP: Psy II, 1995.

MAYR, E. O desenvolvimento do pensamento biológico: diversidade, evolução e herança. Brasília: Editora da UnB, 1998. 
Biologia, ciência única. São Paulo, Editora Schwarcz Ltda., 2005.

MOREIRA, M. A.; MASSONI, N. T. Epistemologias do século XX. São Paulo: Editora pedagógica e Universitária Ltda., 2011.

PRIGOGINE, I. O fim das certezas - Tempo, caos e leis da natureza. São Paulo: Editora UNESP, 1996. . As leis do caos. São Paulo: Editora UNESP, 2002.

WESTFALL, R. S. The construction of modern science: mechanisms and mechanics. Cambridge: Cambridge University Press, 1989. 


\section{O PROGRAMA DE HILBERT E A JUSTIFICAÇÃO FINITISTA DO INFINITO ATUAL: UMA BREVE HISTÓRIA SOBRE AS JUSTIFICATIVAS E FUNDAMENTAÇÕES DO INFINITO ENQUANTO OBJETO MATEMÁTICO POR DAVID} HILBERT

Sicleidi Valente dos Santos Britto - Doutorando no HCTE-UFRJ - Sicleidi@gmail.com Valessa Leal Lessa de Sá Pinto - Doutorando no HCTE-UFRJ - valessaleal@ hotmail.com Ricardo da Silva Kubrusly - Professor do HCTE-UFRJ - risk@hcte.ufrj.br

\section{Resumo}

Na sua famosa conferência "Sobre o Infinito", David Hilbert defende a teoria dos números transfinitos de Georg Cantor das duras críticas que sofre e afirma que tal teoria lhe parece "o mais refinado produto do gênio matemático". Entretanto, ele também afirma que não há razão alguma, a partir das teorias físicas do universo, para se acreditar que exista alguma coisa no mundo que corresponda a uma coleção infinita. Pretendemos mostrar como Hilbert justifica a utilização do conceito de infinito atual a partir de uma epistemologia estritamente finistista. Bem como, apontar as implicações ontológicas e epistemológicas do chamado "Programa de Hilbert" no que diz respeito ao infinito enquanto objeto matemático, o que está inserido numa questão maior, que é a busca da fundamentação da matemática.

Palavras-chaves: Programa de Hilbert. Infinito Atual. Fundamentos da Matemática.

Introdução

\footnotetext{
"Ninguém nos expulsará do paraíso que Georg Cantor criou para nós" (David Hilbert)
}

No texto "Sobre o Infinito" que foi uma conferência proferida em 1925, no congresso da Sociedade Matemática de Westfalia, em homenagem a Karl Weierstrass, Hilbert lança as bases de sua teoria que se desdobraria em um programa, que hoje conhecemos por "Programa de Hilbert". Tal teoria seria capaz de substituir os métodos dedutivos baseados no infinito por procedimentos finitos que produzissem exatamente os mesmos resultados matemáticos. Desse modo, se evitariam os paradoxos relativos à existência e à utilização do infinito na teoria de conjuntos, na análise e em outras áreas do conhecimento. Para isso, era necessário elucidar a natureza do infinito. Que segundo ele é o conceito de infinito atual, desenvolvido sistematicamente por Georg Cantor. Em contraposição ao conceito de infinito enquanto conceito-limite, desenvolvido por Weierstrass, que era o conceito de infinito potencial, o qual ele afirmava não ser a natureza do infinito. Na passagem abaixo, ele deixa isso claro:

Alguém que desejasse caracterizar brevemente a nova concepção do infinito que Cantor introduziu, poderia afirmar que em análise lidamos com o infinitamente grande e o infinitamente pequeno somente como conceitos-limite, como algo a acontecer ou vir a ser, isto é, como infinito potencial. Mas este não é o verdadeiro infinito. Encontramos o verdadeiro infinito somente quando consideramos a totalidade dos números $1,2,3,4, \ldots$ como uma unidade completa, ou quando tomamos os pontos de um intervalo como uma totalidade 
que existe, de uma só vez. Este tipo de infinito é conhecido como infinito atual. (AUTOR,1925, p. 373)

Ele afirma que não há razões, a partir das teorias físicas do universo, para acreditar na existência do infinitamente grande, do infinitamente pequeno, ou mesmo de qualquer coisa no mundo que corresponda a uma coleção infinita. Em suas palavras,

Nosso resultado geral é que o infinito não se encontra em lugar algum na realidade. Não existe na natureza e nem oferece uma base legítima para o pensamento racional.

(...) O papel que resta ao infinito é somente o de uma ideia - se entendemos por uma ideia, na terminologia de Kant, um conceito da razão que transcende toda experiência e que completa o concreto como uma totalidade - uma ideia em que podemos confiar sem hesitar graças ao quadro conceitual erigido por nossa teoria. (AUTOR, 1925, p.392)

Entretanto, para Hilbert, o fato de não existir alguma coisa no mundo que corresponda a coleções infinitas, não implica que a sua utilização na matemática não esteja justificada. A introdução de um conceito em uma teoria é justificada se:

Pudermos provar a consistência da teoria. Isto é, se pudermos demonstrar, por meio de regras de inferências, que dos axiomas não se pode derivar uma contradição;

Produzir uma teoria fecunda

O fato de não existir (na realidade) não é condição para a não introdução de um determinado conceito na matemática para Hilbert. Isto é, não é pelo fato de não existirem números imaginários, que não está justificada a teoria dos números complexos. Além da consistência da teoria, a condição para utilizar o conceito de números imaginários ( $\mathrm{i}=\sqrt{-}-1)$ é a fecundidade. A aplicabilidade dos números complexos é vasta. Na matemática, por exemplo, os números imaginários garantem a determinação das raízes das equações do 20 grau que possuem o discriminante (delta) negativo e permitem a representação e as operações de vetores no plano. Os números complexos também são muito úteis na aerodinâmica. A teoria das funções complexas permitiu calcular a força de levantamento responsável pela sustentação do voo de um avião, o que permitiu um rápido progresso aeronáutico. Dessa forma, o fato de números imaginários não serem empíricos não pode ser determinante para a não introdução desse conceito na teoria. Da mesma forma, a introdução do conceito de infinito na matemática está justificada somente se, tal conceito não produz contradições dentro da teoria e se a introdução do mesmo for fecunda. E obviamente ela é fecunda, dada a enorme riqueza de resultados obtida em diversos ramos da matemática, tais como análise, topologia, geometria projetiva, etc.

A solução proposta por Hilbert independe da realidade ontológica que se atribua ao infinito, uma vez que as teorias matemáticas que supõem um infinito atual são representadas por sistemas formais. Nesse sistema, uma proposição é considerada verdadeira ou falsa em função da sua forma e não do seu conteúdo. Como não existem coleções infinitas no mundo, basta representar as proposições que Ihes fazem referência por fórmulas vazias de sentido e encadeadas por regras explícitas. Essas proposições que fazem referências ao infinito, destituídas de qualquer significado empírico, são as "proposições ideais" de sua teoria, pois se referem a "elementos ideais". A proposta de Hilbert retira a questão do âmbito semântico e a coloca no âmbito sintático.

Segundo Hilbert,

"podemos conceber a matemática como uma coleção de fórmulas de duas espécies: primeiramente aquelas às quais correspondem as comunicações de asserções finitárias com sentido e, em segundo lugar, outras fórmulas sem significado e que são a estrutura ideal de nossa teoria". (AUTOR, 1925, pág. 380) 
Os elementos ideais de sua teoria dariam conta da introdução de objetos não empíricos, tais como o infinito e os números imaginários, como objetos matemáticos. Contudo, para legitimar a utilização de tais objetos pela matemática, é necessário mostrar que esse conjunto de fórmulas é consistente. Isto é, temos que demonstrar que o conjunto formado pelas asserções ideais, que fazem referências ao infinito como totalidade atual, e pelas asserções finitistas, que fazem referência a elementos presentes na experiência, é um conjunto consistente. Ou seja, que dele não podemos derivar contradições.

Na seção seguinte, vamos mostrar a restrição que Hilbert faz a raciocínios finitários em seu programa. Segundo ele, "o direito de operar com o infinito só pode ser assegurado através do finito" (AUTOR, 1925, p.392).

\section{O Finitismo}

Segundo Hilbert, "é possível, de uma maneira puramente intuitiva e finitária - do mesmo modo como obtemos as proposições verdadeiras da teoria dos números - conseguir as intuições que garantam a confiabilidade do aparato matemático" (AUTOR, 1925, p. 377). Para ele, a matemática não pode ser fundamentada somente na lógica, como pretendiam Frege e Dedekind, "... encontramo-nos de acordo com os filósofos, sobretudo com Kant. Já Kant havia ensinado que a matemática dispõe de um conteúdo consolidado independente de toda lógica e que por isso jamais poderá ser fundada apenas sobre a lógica, motivo pelo qual os esforços de Frege e de Dedekind deveriam malograr" (Autor, 1925, pág. 376). Para Hilbert, as deduções e as operações lógicas devem considerar objetos concretos, de natureza não lógica, que seriam dados à intuição através da experiência imediata, independente do pensamento. $\mathrm{Na}$ teoria finitária dos números, esses objetos consistem nos próprios símbolos concretos, cuja estrutura é imediatamente clara e reconhecível: $1,11,111,1111, \ldots$ Apreendemos tais objetos concretos pela intuição, essa percepção é dada de forma imediata, isto é, não é mediada por conceitos, definições e nem por qualquer tipo de raciocínio. Eles não possuem um aspecto semântico, mas sintático. Ou seja, esses objetos, ao mesmo tempo que exibem o elemento intuitivo, também têm a propriedade de ser símbolos para um sistema formal, pois são esvaziados de sentido.

Junto a esses símbolos, temos outros que possuem significado e que facilitam a manipulação e a comunicação dos elementos básicos. Por exemplo, o símbolo 3 é usado como uma abreviação para o símbolo 111, o símbolo 4 como uma abreviação para o símbolo 1111 . Portanto, o símbolo concreto 111 é facilmente reconhecível pela intuição imediata, enquanto que o símbolo 3 não, pois esse é uma abreviação do símbolo concreto.

Temos ainda símbolos como,$+=$ e $>$ que são utilizados para comunicar proposições. Por exemplo, ao afirmar que $2+3=3+2$ - o que Hilbert chama de asserção real ou finista, pois se refere a objetos concretos - pretendemos comunicar que $2+3$ e 3+2, levando em conta as abreviações, são o mesmo símbolo, a saber, o símbolo numérico 11111. Ao afirmar que $3>2$, pretendemos comunicar que o símbolo 111 é mais longo que 11. Isto é, que 11 é uma parte própria de 111. A utilização de letras como variáveis também é admitida. Isto é, afirmar que $a+b=b+a$ é comunicar que essa igualdade se verifica sempre que as variáveis forem substituídas por numerais.

Podemos assim caracterizar o raciocínio finitista pelo fato de os seus objetos serem concretos e não apenas hipoteticamente postulados. E, também porque a legitimidade dos processos de cálculo ou definição só se dá quando se garante que os mesmos terminem em um processo finito de passos.

Notamos a importância que a intuição tem na teoria de Hilbert. Entretanto, ele não se restringe à intuição e afirma que tal restrição significaria desmembrar e mutilar nossa ciência, correndo o risco de perder alguns dos nossos tesouros mais valiosos, tais como o conceito 
geral de número irracional, de função e os números transfinitos de Cantor. E afirma: Lembremo-nos de que somos matemáticos e de que, como matemáticos, muitas vezes nos encontramos em situações difíceis, das quais fomos salvos pelo método engenhoso dos elementos ideais. (AUTOR,1925, p.379)

Obtemos asserções ideais quando continuamos de maneira óbvia e natural o desenvolvimento que a teoria dos fundamentos da matemática já traçou. Como o que Cantor fez ao desenvolver a teoria dos números transfinitos, mostrando que os números inteiros finitos e os números inteiros transfinitos são formados pelo mesmo princípio.

Hilbert concebe a matemática como um conjunto de asserções finitárias e asserções ideais. Entretanto, as operações e deduções lógicas só produzem resultados confiáveis quando aplicados à primeira:

(...) alguma vez a inferência lógica contextual nos decepcionou ou abandonou quando a aplicamos a objetos reais ou eventos? Não, a inferência lógica contextual é indispensável e ela somente nos decepcionou quando aceitamos noções arbitrárias, em particular aquelas sob as quais um número infinito de objetos está subsumido. (AUTOR,1925, p. 376)

Na próxima seção, vamos mostrar o método proposto por Hilbert que seria capaz de estender o ponto de vista finitista a todos os enunciados matemáticos.

\section{A Axiomatização Formal}

O método proposto por Hilbert para a fundamentação da matemática é o axiomático. Isto é, os axiomas são os primeiros elementos estipulados na teoria, que são aceitos sem a necessidade de demonstração. Com base nos axiomas, os teoremas e suas demonstrações são desenvolvidos. Cada axioma deve ser independente dos demais e o corpo dos axiomas deve ser capaz de gerar toda matemática existente, sem contradições. Entretanto, Hilbert rompe com a tradição, que fazia uso do paradigma do método axiomático desenvolvido por Euclides para a fundamentação da geometria, o método axiomático no sentido do conteúdo. E elabora o método axiomático no sentido da forma.

O método axiomático no sentido do conteúdo, segundo Hilbert e Bernays ${ }^{21}$, é quando, "em relação a um corpo de doutrina estabelecida, se tenta idealizar os conceitos nela contidos e individualizar um pequeno número de proposições das quais todo corpo da doutrina pode ser logicamente derivado" (LOURENÇO, 2004, p. 18).

De maneira diferente, o método axiomático no sentido da forma "é a construção de uma teoria abstrata, desligada de qualquer corpo conhecido de doutrina, propondo conceitos primitivos e proposições arbitrárias, não dependendo de qualquer referência a um sentido para as expressões que a representam" (LOURENÇO, 2004, p. 18). Isto é, uma teoria sintática, esvaziada de sentido, em um primeiro momento. Num segundo momento, é necessário especificar uma interpretação na qual todos os axiomas resultem em proposições verdadeiras, ou seja, é necessário encontrar um modelo para tal teoria.

A justificação dos elementos ideais em sua teoria se dá, se conseguimos demonstrar que o domínio dos enunciados matemáticos (proposições finitárias + proposições ideais) é uma extensão conservativa do domínio das proposições finitárias. Isto é, se pelo método da axiomatização formal, demonstramos que do conjunto de proposições finitárias não se podem derivar contradições, ao incluirmos às proposições ideais também não iremos derivar contradições. O método proposto por Hilbert é o único capaz de introduzir os elementos ideais de sua teoria, mantendo o rigor que ele almeja. A axiomatização formal acomoda perfeitamente as proposições ideais, uma vez que as trata no seu aspecto sintático. Isto é,

${ }^{21}$ Discípulo de Hilbert. 
como uma sequência de símbolos, esvaziada de semântica, que as formaliza numa determinada linguagem formal. Eis o sentido finitista que as proposições ideais devem possuir segundo Hilbert.

\section{Considerações Finais}

A questão da justificação do infinito enquanto objeto matemático está inserida numa questão maior, que é a da fundamentação da matemática. Hilbert desenvolve o seu programa, que segundo Bernays: A grande vantagem do método de Hilbert é que os problemas e as dificuldades que se apresentam nos fundamentos da matemática podem ser transferidos do domínio epistemológico-filosófico para o domínio matemático" (AUTOR, 1922, p. 1118).

Hilbert desenvolveu um programa meticuloso com a finalidade de fundamentar toda a matemática. Entretanto, para garantir a consistência do programa, era necessário demonstrar matematicamente, em bases finitistas, a consistência e a completude da aritmética. $\mathrm{O}$ que Gödel demonstrou não ser possível.

Apesar de o teorema da incompletude de Gödel ter demonstrado que o Programa de Hilbert fracassou no que diz respeito a uma prova finitista da consistência e da completude da aritmética, o método axiomático formal, tal como desenvolvido por David Hilbert, é o que hoje utilizamos nas demonstrações matemáticas. Isto é, apesar de ter sido matematicamente refutado, o programa de Hilbert possui uma grande relevância filosófica. Pois, apesar de o programa ter fracassado no seu objetivo maior, ele obteve êxito enquanto uma ferramenta poderosa para construir as bases da matemática clássica.

\section{Bibliografia}

CANTOR, G. Foundations of a General Theory of Manifolds: A Mathematical-Philosophical Investigation into the Theory of the Infinite (1883). IN: EWALD, W (Ed.) From Kant to Hilbert, A Source Book in the Foundations of Mathematics. Volume II. Oxford: Clarendon Press, 2000.

HILBERT, D. On the Infinite (1925). IN: van HEIJENOORT, J. (Ed.), From Frege to Gödel, A Source Book in Mathematical Logic, 1879 -1931, Harward U. P., 1981.

. As novas fundamentações da matemática (1922). IN: EWALD, W (Ed.) From Kant to Hilbert, A Source Book in the Foundations of Mathematics. Volume II. Oxford: Clarendon Press, 2000.

LOURENÇO, M. Os Elementos do Programa de Hilbert. Centro de Filosofia da Faculdade de Letras de Lisboa, 2004.

VIERO, A. Sistemas axiomáticos Formalizados: A questão da desinterpretação e da formalização da axiomática. Centro de Lógica, Epistemologia e História da ciência. Unicamp, 2011. 


\section{EQUATORIAL PAZOS DO OBSERVATÓRIO DO VALONGO: ORIGEM E TRAJETÓRIA}

José Adolfo S. de Campos - Observatório do Valongo, UFRJ - Adolfo@astro.ufrj.br

\section{Resumo}

O telescópio equatorial Pazos do Observatório do Valongo tem um inestimável valor histórico, porque se acredita que tenha sido o primeiro telescópio construído no Brasil, feito pela Casa Pazos, do Rio de Janeiro. Este artigo demonstra que a sua origem, dada como pertencente à Escola Politécnica do Rio de Janeiro, está equivocada. Na realidade, o instrumento foi comprado pela Escola Militar em 1880 para treinamento em prática astronômica de seus alunos e teve importante participação nas observações do trânsito de Vênus pelo Sol, feitas pela missão brasileira na ilha de Saint Thomaz, no Caribe, em 6 de dezembro de 1882.

Palavras-chave: Equatorial Pazos. Observatório da Escola Politécnica. Escola Militar. Observatório do Valongo.

\section{Introdução}

O Observatório do Valongo da Universidade Federal do Rio de Janeiro, sucessor do antigo Observatório Astronômico da Escola Politécnica do Rio de Janeiro, fundado em 5 de julho de 1881, possui uma coleção de instrumentos astronômicos e artefatos óticos antigos ${ }^{22}$, guardados num pequeno museu que se localiza no seu campus. Em especial, um dos objetos tem um inestimável valor histórico, pois se trata do que teria sido o primeiro telescópio astronômico construído no Brasil e até onde se saiba o único.

O telescópio com montagem equatorial teria sido feito em 1880, para a Escola Politécnica, pela "Officinas de Optica e Instrumentos Scientificos", conhecida como "Casa Pazos" por causa de seu proprietário José Hermida Pazos ${ }^{23}$. Estas informações têm como fonte duas placas de identificação, afixadas no pilar do telescópio.

Figura 3 - Telescópio Pazos do Observatório do Valongo, UFRJ

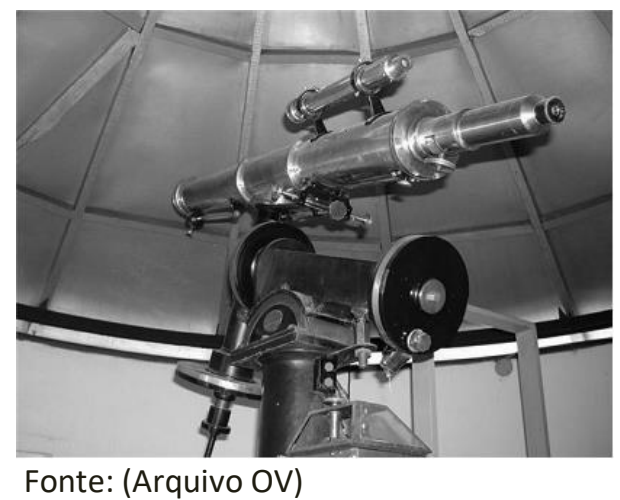

Ao analisarmos com mais atenção estas informações, surgem algumas dúvidas que precisam ser esclarecidas. As dúvidas referem-se à questão da data da fabricação (1880) e do seu proprietário, pois o Observatório da Escola Politécnica só foi oficialmente criado em 5 de julho

\footnotetext{
${ }^{22}$ Coleção de Instrumentos Científicos do Observatório do Valongo, 2010. Silvia Lorenz Martins (Org), Editora UFRJ, Rio de Janeiro.

${ }^{23}$ Sucessor do fundador José Maria dos Reis.
} 
de 1881 por doação feita por particulares à Escola. Antes desta data havia solicitações de instrumentos não atendidas e a busca por locais para instalação do observatório, descritas com mais detalhes em Campos (2012). Portanto, trata-se de identificar a origem do telescópio que ou não teria sido fabricado em 1880, ou não teria sido destinado primeiramente à Escola Politécnica, tendo sido incorporado ao seu patrimônio posteriormente.

\section{A Origem do Telescópio Equatorial Pazos}

Durante os trabalhos para a tese de doutorado do autor (CAMPOS, 2012) foi feita uma minuciosa varredura dos documentos relativos à Escola Politécnica no Arquivo Nacional e em outras fontes de documentação, não se tendo encontrado nenhuma menção à compra de telescópio equatorial de pequeno porte por parte da Escola Politécnica ou de seu Observatório.

Mais recentemente, realizou-se uma busca em novas fontes de documentação e encontrouse uma referência surpreendente no jornal a Gazeta de Notícias, do Rio de Janeiro, dando pistas sobre a possível origem da Equatorial como pertencente à Escola Militar. Na notícia era anunciada a chegada da Equatorial ${ }^{24}$, pertencente à Escola Militar e que ficaria em exposição na loja de José Hermida Pazos.

Astronomia. - Acaba de chegar ao antigo estabelecimento de optica e instrumentos scientificos de José Hermida Pazos, antiga casa de José Maria dos Reis, rua do Hospício n. 61. Um magnifico equatorial com todos os últimos melhoramentos, círculos horários. Aparelho de relojoaria e todos os acessórios para observação da astronomia. Este instrumento é destinado a aula de astronomia da Escola Militar e acha-se em exposição.

Agora, a pergunta natural seria por que a Escola Militar teria a necessidade de comprar um telescópio?

Até 1874, a formação dos engenheiros militares, oficiais do exército e engenheiros civis era feita de modo unificado em uma escola (Escola Central na época), sob o comando do Ministério da Guerra. A cadeira de "Astronomia e Geodésia" era obrigatória no 40 ano do curso e havia ainda a obrigatoriedade de aulas práticas de Astronomia, que ficavam a cargo do Imperial Observatório do Rio de Janeiro (IORJ). Os alunos da Academia de Marinha também tinham aulas práticas de Astronomia no IORJ. A partir de 1871, não obstante a obrigatoriedade de prática astronômica, os alunos de ambas as escolas deixaram de ter aulas práticas, quando o Imperial Observatório, agora sob o comando de Emmanuel Liais mudou seus objetivos, passando de um observatório escola para uma instituição com fins de pesquisa astronômica.

A partir de 1874 houve a separação entre o ensino militar e o civil. O Decreto $N^{\circ} 5529$ de 17 de janeiro de 1874 aprova um novo Regulamento para as Escolas do Exército, onde está escrito que "Na Escola Militar ficará exclusivamente concentrada a instrução teórica e prática, necessária e indispensável aos oficiais e praças do exército [...]". A disciplina de "Trigonometria Esférica, Óptica, Astronomia e Geodésia" era dada no quarto ano do curso e havia previsão de prática "não só das observações astronômicas compatíveis com os recursos da escola e independentes das que com maior desenvolvimento possam ser feitas no observatório astronômico, depois de terminado o ano letivo, [...]".

O Decreto $N^{\circ} 5600$ de 25 de abril de 1874 apresenta os estatutos da Escola Politécnica, instituição sob o comando do Ministério do Império, que será responsável pelo ensino de engenharia civil e formação de bacharéis e doutores em Ciências Físicas e Matemáticas. Na

${ }^{24}$ Gazeta de Notícias, edição de 13-2-1881, p.2. A notícia também foi veiculada no Jornal do Commercio,(Refazer pois é noticia de periódico) edição de 13-2-1881, p.2 e na Revista de Engenharia, n.3, p.49, 1881. 
Escola Politécnica, a Astronomia era cadeira obrigatória para o Engenheiro Geógrafo ${ }^{25}$ e para o Bacharel em Ciências Físicas e Matemáticas ${ }^{26}$, mas não para o Engenheiro Civil. O segundo ano do curso de Ciências Físicas e Matemáticas era dominado pela Astronomia e suas aplicações, respectivamente com as cadeiras de "Trigonometria Esférica, Astronomia", "Topografia, Geodésia e Hidrografia" e a aula de "Construção e desenho de cartas geográficas". A descrição das atividades da cadeira de Astronomia previa a realização de "observações astronômicas e cálculos de astronomia prática".

A Escola Militar para preencher a lacuna de instrução prática em Astronomia propõe e vê aprovada à aquisição de instrumentos para a construção de um pequeno observatório:

Sendo urgente a criação de um pequeno observatório em que possam os alunos adquirir o conhecimento dos instrumentos astronômicos e fazer as observações exigidas pelo ensino, de modo a tornar mais profícuo o estudo daquela ciência, mandou o Governo por Aviso de 22 de Março último escolher na mesma Escola um local apropriado para a construção do dito observatório, organizar o plano e orçamento da obra e proceder à aquisição dos instrumentos necessários. ${ }^{27}$

O local escolhido foi o do morro de Santo Antônio, onde Manoel Pereira Reis, professor de Topografia e Desenho Topográfico da Academia de Marinha, estava construindo um pequeno observatório com o auxílio da Marinha e de alguns professores da Escola Politécnica, e que serviria também para adestrar os alunos da Academia nas técnicas empregadas em topografia e geodésia. Tal observatório veio a tornar-se o Observatório Astronômico da Escola Politécnica do Rio de Janeiro (antecessor do Observatório do Valongo, da UFRJ). As ações que levaram a criação do Observatório da Escola Politécnica em 5 de julho de 1881 estão minuciosamente descritas em Campos (2012). A Escola Militar comprou da "Casa Pazos" um telescópio com montagem equatorial para equipar o novo local, no morro de Santo Antônio. Em 26 de agosto de 1882 foi solicitado, através de ofício do Ministro do Império Pedro Leão Veloso ao Ministro da Guerra, o empréstimo da pequena equatorial da Escola Militar para a Comissão do Trânsito de Vênus que iria para as Antilhas.

Havendo necessidade, para completar o material de que necessita a comissão que breve segue para as Antilhas a observar a passagem de Vênus de uma luneta auxiliar, rogo a V. Exa. se digne de providenciar a fim de que seja emprestada ao Imperial Observatório a pequena equatorial pertencente à Escola Militar. ${ }^{28}$

Efetivamente a equatorial foi usada pelo capitão-tenente Francisco Calheiros da Graça (18491906) para a observação da passagem de Vênus, no dia 6 de dezembro de 1882, na sua estação de observação situada em Saint Thomas, Ilhas Virgens dos Estados Unidos, na expedição que tinha como chefe o Barão de Tefé (1837-1931). Através do relato da Comissão ${ }^{29}$ fica-se sabendo que a "excelente equatorial" tinha uma abertura de $11 \frac{1}{2} \mathrm{~cm}$ e que "repousa sobre uma coluna de ferro de 6 pés de altura e dotada de todos os movimentos característicos".

Após reclamações da Direção da Escola Militar quanto à demora da devolução da equatorial, o Ministro da Guerra envia o aviso de 14 de abril solicitando à devolução ao Ministro do

\footnotetext{
${ }^{25} \mathrm{O}$ título de Engenheiro Geógrafo era concedido a quem cursasse os dois anos do curso geral e os dois primeiros anos do curso de ciências físicas e matemáticas.

${ }^{26} \mathrm{O}$ bacharel tinha que cursar os dois anos do curso geral e os três anos do curso de ciências físicas e matemáticas.

${ }^{27}$ Relatório apresentado à Assembleia Geral Legislativa na Terceira sessão da décima sétima legislatura pelo Ministro e Secretário de Estado dos Negócios da Guerra, Visconde de Pelotas, 1880, pg.12.

${ }^{28}$ Arquivo Nacional, Série Educação, IE ${ }^{193}$.

${ }^{29}$ Annales de L'Observatoire Impérial de Rio de Janeiro, tomo 3, 1887.
} 
Império Pedro Leão Velloso, que manda ofício ao Diretor do Imperial Observatório no dia 18 de abril de 1883 solicitando à devolução:

Sirva-se V.S. providenciar a fim de que seja remetida para o observatório do morro de Santo Antônio, a equatorial pertencente à Escola Militar e que foi cedida a este Observatório para as observações da passagem de Vênus pelo disco do Sol. ${ }^{30}$

E também encaminha ao Ministro da Guerra o ofício comunicando as providências tomadas:

Comunico a V.Exa., em resposta ao seu Aviso de 14 do corrente mês, que nesta data expeço ordem a fim de ser restituída ao observatório do morro de Sto. Antônio, onde se achava a equatorial pertencente à Escola Militar e que foi cedida ao Imperial Observatório para a observação da passagem de Vênus pelo disco do Sol. Oportunamente V.Exa. se dignará a remeter a este Ministério a fim de se ordenar o respectivo pagamento à conta da despesa que se fizer com a colocação da dita equatorial no primeiro dos referidos observatórios. ${ }^{31}$

Em 26 de setembro de 1883 foi remetida a conta da instalação e conserto da equatorial ao Diretor do Imperial Observatório ${ }^{32}$.

No inventário dos instrumentos do Observatório da Escola Politécnica realizado pelo preparador da cadeira de Astronomia, Orozimbo Lincoln do Nascimento em 1911, consta a existência em bom estado, de "luneta equatorial, objetiva de $12 \mathrm{~cm}$ e 1,83 m de distância focal, sobre pilastra de ferro e mais acessórios" 33 .

\section{A Trajetória da Luneta Pazos}

A trajetória da equatorial Pazos mostra que ela teve importantes participações no treinamento de alunos da Escola Militar, da Escola Politécnica e da Academia de Marinha, além das observações científicas feitas no trânsito de Vênus.

Quando da transferência das instalações do Observatório da Escola Politécnica do morro de Santo Antônio para o morro da Conceição em 1924, onde se encontra atualmente o Observatório do Valongo, seu sucessor, foi o único dos telescópios a ser instalado numa cúpula, permanecendo assim até a década de 1950, quando o Telescópio Refrator Cooke\&Sons de $30 \mathrm{~cm}$ de abertura foi instalado.

Em 1957, as instalações abandonadas do Observatório da Escola da Politécnica no morro da Conceição foram cedidas ao Centro Brasileiro de Pesquisas Astrofísicas, uma entidade particular, e o telescópio Pazos foi a causa principal do rompimento do convênio feito com a Universidade do Brasil, pelo seu uso indevido como instrumento para a recreação, instalado que foi na Praça da Cinelândia ${ }^{34}$.

Em 1958, com o rompimento do convênio, as instalações do Observatório foram cedidas à Comissão de Astronomia, da Faculdade Nacional de Filosofia, para uso dos alunos do Curso de Graduação em Astronomia, criado em 1958. O telescópio Pazos foi usado pelos alunos para observação de fenômenos astronômicos e treinamento até a década de 1970, quando chegaram os novos telescópios comprados pelo convênio com a República Democrática Alemã. Atualmente, ele é uma peça do Museu do Observatório do Valongo, fazendo parte do circuito de visitação.

\section{Conclusões}

\footnotetext{
${ }^{30}$ Arquivo Nacional, Série Educação, IE ${ }^{1} 98$. A nota também foi publicada na Gazeta da Tarde, edição de 20-41883, p.2.

${ }^{31}$ Arquivo Nacional, Série Educação, IE ${ }^{1} 98$

${ }^{32}$ Arquivo Nacional, Série Educação, $\mathrm{IE}^{1} 101$.

33 Inventário da Escola Politécnica, 1911, arquivo do Observatório do Valongo.

${ }^{34}$ Edição do Jornal do Brasil de 10-7-1958 p.3.
} 
A questão que se apresenta é se seria a Equatorial da Escola Militar a Equatorial Pazos do Observatório do Valongo? As evidências apontam que sim, sem sombra de dúvidas, como será demonstrado através das diversas "coincidências".

Ao examinar-se com atenção a Equatorial Pazos, não se encontra nenhum sinal de identificação do fabricante em lugar algum, a não ser duas placas afixadas no pedestal, uma de cada lado, com a inscrição "Escola Polythecnica - 1880" e "J. H. Pazos - Rua do Hospício 63 - Rio de Janeiro", dando a entender que José Hermida Pazos seria o fabricante ou importador e 1880 a data da fabricação do telescópio de propriedade da Escola Politécnica. Como foi relatado anteriormente, a Equatorial da Escola Militar teria sido encomendada à Casa Pazos em 1880 e ficou em exposição no início de 1881.

Conforme a troca de ofícios, a Equatorial da Escola Militar estava instalada no morro de Santo Antônio, quando foi requisitada pelo Imperial Observatório em 1882, tendo retornado ao mesmo lugar depois. O morro de Santo Antônio foi o primeiro lugar onde foi instalado o Observatório da Escola Politécnica e que permaneceu como sua sede até meados de 1924, quando houve a sua transferência para a atual localização, no morro da Conceição (CAMPOS, 2012). O nome da Escola Politécnica associado à data de 1880 seria uma inscrição indevida acrescentada depois, porque em 1880 não existia observatório na EP, pois sua doação feita por Manuel Pereira Reis e outros só ocorreu em 5 de julho de 1881.

O que se sabe das especificações técnicas da Equatorial da Escola Militar é que teria uma abertura de $11,5 \mathrm{~cm}$ e sua montagem equatorial estaria sobre um pilar de ferro com 6 pés de altura (aproximadamentre $1,83 \mathrm{~m}$ ). Não se tem informação sobre a sua distância focal ${ }^{35}$. As medidas precisas feitas na Equatorial Pazos apontam para abertura de 11,5 cm (4,5 polegadas, aproximadamente $12 \mathrm{~cm}$ ), distância focal de $183 \mathrm{~cm}$ (72 polegadas), montados sobre um pilar de ferro com 1,82 $\mathrm{m}$ de altura.

A prova final seria a comparação da imagem da Equatorial da Escola Militar (Figura 2) na expedição da Passagem de Vênus, tendo o capitão-tenente Calheiros da Graça ao seu lado, com a Equatorial Pazos (Figura 1) atualmente existente no Observatório do Valongo. Elas são idênticas nos detalhes como se pode verificar.

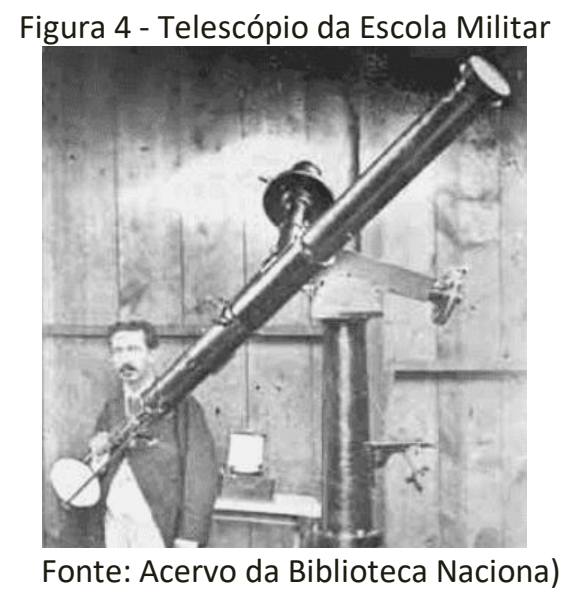

Referências bibliográficas

CAMPOS, J.A.S. de. Tese de Doutorado "Engenheiros e Astrônomos: O Ensino de Astronomia aplicada e a prática de Astronomia observacional na Escola Politécnica / Escola Nacional de Engenharia do Rio de Janeiro (1874 - 1965)", 2012. Disponível em: http://objdig.ufrj.br/10/teses/790826.pdf.

\footnotetext{
${ }^{35}$ Supondo que as medidas do inventário de 1911 se referem à equatorial da Escola Militar, a distância focal seria de $183 \mathrm{~cm}$.
} 
MARTINS, Silvia Lorenz (Org.). "Coleção de Instrumentos Científicos do Observatório do Valongo", CoordCOM/UFRJ, Rio de Janeiro, 2010. 


\section{CORRUPÇÃO “PRESENTE” NO RJ: É POSSIVEL UMA ANÁLISE ANTROPOLÓGICA HIPERDIALÉTICA?}

Mário Cordeiro de Carvalho Jr. - Mestrando HCTE e Professor da FAF-UERJ

Resumo

$\mathrm{O}$ artigo tenta responder se é possível fazer uma análise antropológica hiperdialética para a corrupção "presente" no RJ. A resposta é positiva, pois esta análise busca um entendimento não necessariamente harmônico, mas adequado a cada momento histórico . A singularidade da antropologia hiperdialética é que torna possível uma análise "aplicada desse método" à corrupção "presente" no Rio de Janeiro, lembrando que esta abordagem transdisciplinar única é desenvolvida somente no HTCE.

\section{Introdução}

Desde que entramos no segundo quinquênio da segunda década do século XXI, a sociedade brasileira vem sendo quase diariamente informada por todos os meios de comunicação - TV, jornal e revistas, rádio, internet, etc. - sobre atos e processos de corrupção. Qual então o arcabouço teórico e metodológico capaz de dar conta deste fenômeno. Gupta (2005) coloca ser esse tema - corrupção - fascinante. Ele o é por que: "se o fenômeno da corrupção não pode ser apartado da narrativa da corrupção; isto tem implicações não só nos métodos de investigação, mas no objeto de análise do estudo. A experiência de corrupção de todas as partes envolvidas nessa transação ocorre num campo sobre-determinado por estórias desses atos, e reiteradas estórias particulares dos atores participantes passa a dar um sentindo as suas ações nesse drama social. A reflexividade das ações e de suas narrativas torna a analise da corrupção um fenômeno complexo que tem sido pouco apreciado na literatura acadêmica (AUTOR, p. 174)."

Por isso, a antropologia hiperdialética é apropriada para analisar a corrupção "presente" no Rio de Janeiro. Segundo Gomes (2011), esta busca sintetizar a perspectiva cultural, econômica, política e social numa síntese que unifica todos esses pontos de vista e busca um entendimento não necessariamente harmônico, mas adequado a cada momento histórico visto ou circunstância social. A pergunta que se busca responder nesse trabalho segue a sugestão econômica de Baumol, Litan e Schramm (2010). O empreendedorismo esta presente em todas as sociedades, mas ele se manifesta de forma diferente dependendo do contexto. Empreendedorismo produtivo corresponde à criação e a expansão de novas firmas. Empreendedorismo não produtivo corresponde à presença de atividades de lobby e/ou outras formas de ação para a obtenção de quase rendas (rent seeking). Empreendedorismo destrutivo corresponde a tráfico, contrabando e descaminho de pessoas e/ou bens. Essas três formas de empreendedorismo criam atividades econômicas; entretanto só há progresso e avanço das instituições e sociedades quando os retornos do empreendedorismo produtivo superam e excedem os custos causados pelo empreendedorismo destrutivo e o não produtivo.

À esta perspectiva econômica se junta a visão política de corte legal de Rose-Ackerman (2010) em que aponta o papel da ambição ( $g r e e d)$, contrastando a visão cultural e a perspectiva legal do Estado. Isto, mais a tipologia pragmática de corrupção proposta por Bussell (2015) podese definir como foco de análise a grande corrupção com ambição. Na seção seguinte se busca expor o caso de grande corrupção com ambição do estado do Rio de Janeiro sob a perspectiva 
hiperdialética - econômica, política, social e antropológica. Na terceira seção se mostra a vantagem dessa abordagem por unificar pontos de vista diferentes, adequado ao presente.

\section{Grande Corrupção e Ambição no Rio de Janeiro}

Singular, única e sofisticada é a corrupção observada no Estado do Rio de Janeiro. Para entender é preciso compreender a ambição e a distinção do casal composto pelo exgovernador Sérgio Cabral e sua segunda esposa na gestão da coisa pública em proveito próprio. Sinais de consumo conspícuo abundam nos noticiários; joias em profusão foram adquiridas em Ipanema na matriz de multinacional de luxo controlada pelo capital nacional, bem como aquisição de casa e lancha na Costa Verde foram recentemente abertas ao público em geral para eventual leilão pela Justiça. Há (ou havia) ainda o apartamento do Leblon, viagens constantes de helicóptero e à Paris. Sem dúvida, uma vida de ostentação! A questão a responder é como indivíduos com traços para empreender focam as suas habilidades e dispendem o seu tempo e energia para malversar a coisa pública?

Ao lado de todo grande homem, há uma mulher - diz o ditado popular. Com Cabral não foi diferente, só que para nós normais o traço cultural comum é chamarmos a esposacompanheira-amante de princesa. Não Cabral! Segundo os jornais, ele a chamava de riqueza. Porque? Em qualquer família se pressupõe que haja alguma divisão de trabalho. Quando um casal - governador e primeira dama - assumem o governo estadual, em condições democráticas, como as observadas no Brasil, estes sabem que podem permanecer no mínimo, quatro anos, e no máximo oito, se reeleito.

Para gerir o estado do Rio de Janeiro, o governador tinha de olhar, acompanhar e determinar as despesas (os chamados gastos públicos) e as receitas (impostos, taxas e emolumentos recolhidos). Em situação normal, o estado poderia se endividar se pudesse emitir um título público estadual ou se tivesse acesso ao sistema financeiro para obter financiamento e assim se endividar. Poderia ainda expandir ou contrair moeda caso tivesse um banco estadual. Ao assumir o cargo pela primeira vez em 2003, Sergio Cabral não tinha sob o seu poder banco estadual, pois o antigo Banerj (Banco do Estado do Rio de Janeiro) já havia sido extinto pelo Governo Federal, não tinha acesso ao mercado financeiro nacional e internacional para tomar empréstimos, e todos os títulos públicos estaduais de dívidas anteriores estavam nas mãos do Tesouro Nacional. Mais ainda, as despesas eram maiores que as receitas e tinha restos de exercícios anteriores a pagar do governo anterior, bem como precatórios a quitar.

Sanear as contas era preciso naquele momento. Para isso trouxe de Brasília o então secretário do tesouro nacional, após ter combinado com então novo Presidente Lula essa transferência. Ser austero, saber cortar despesas e abrir espaços para novo acesso ao sistema financeiro era a reputação desse novo gestor do tesouro estadual. Este obteve carta branca de Cabral para fazer o ajuste necessário, cabendo a Cabral e sua equipe estruturarem os planos, projetos e a gestão pública pós-ajuste. Duas medidas são dignas de notas: i) a revisão, renegociação ou revogação da maioria dos contratos de compras governamentais, o que propiciou uma economia no combalido cofre público estadual, e isso gerou uma significativa poupança positiva e afluxo de recursos financeiros líquidos no caixa estadual; e ii) e com esses recursos poupados se pagou parte da dívida anteriormente contraída com a União, o que viabilizou o gradual acesso ao sistema financeiro nacional e internacional para se obter empréstimos, desde que houvesse projetos bem elaborados.

Nesse sentido foi criado um Escritório de Projetos no âmbito da administração pública, bem próximo do "núcleo duro" de decisão do governo estadual. Foram estruturados ali os projetos que necessitavam inversões financeiras para a construção de instalações físicas ligadas à Olímpiada, o arco rodoviário, Segurança, Saúde e Educação, etc. Com projeto elaborado, o governo podia se aproximar de bancos públicos (BNDES, BANCO DO BRASIL, CEF) e/ou 
instituições financeiras internacionais (BIRD, BID, CAF, entre outras). Isso obrigou que o Governador tivesse, a partir da metade do seu primeiro mandato, de se relacionar com empreiteiros, sendo emblemática a sua relação com a Delta Engenharia.

Cumpre destacar que, à medida que se abria espaço fiscal no governo do estado, graças à redução dos custos dos contratos anteriores e suas despesas, novos contratos para aquisição de bens e serviços começaram a ser negociados. Dois são importantes a serem ressaltados: i) o de alimentação dos presos e da merenda escolar; e ii) o de material de saúde, notadamente de próteses. Essas compras, dado nível de superfaturamento dos preços observado nos novos contratos firmados, é que foram objeto do início de denúncias de corrupção no Governo Cabral. Se essa denúncia já foi transitada e julgada não é o relevante, o que interessa é o surgimento de duas figuras - "Rei" Arthur e Sergio Cortes - que se tornarão figurinhas fáceis nos jornais no passado recente, e, sobretudo, mostra o embrião da formação de um oligopólio e uma rede de empresas aptas e habilitadas a prestar serviços antigos - alimentação - e "novos" - gestão de imagens médicas - ao Governo do Estado. Em outras palavras, há uma especialização por parte de empresários e firmas em fornecer bens e serviços associados a gastos de custeio para o Estado. Obviamente, isso não só se restringe à área de saúde, e segurança de presídios, mas gradualmente se expande a outras áreas como polícia, bombeiros, e até na educação. Resultado: a estrutura de custos e os preços de aquisição de bens e serviços para os gastos com custeio ao final do primeiro governo Cabral é mais cara vis-à-vis ao observado nos outros estados da Federação.

Grosso modo, poder-se-ia argumentar que os preços são mais elevados visto que o Governo do Rio de Janeiro não tinha credibilidade, pois não pagava em dia! Isso não ocorreu no Governo Cabral. Ao contrário, além de quitar as compras anteriores e abater parte do principal da dívida com o Governo Federal, o Governo Cabral pagou parte dos precatórios, dívidas basicamente contraídas por governos anteriores. A singularidade neste pagamento é que cabia ao Tesouro Estadual estabelecer uma ordenação dos títulos de precatórios a serem resgatados e um eventual cronograma a ser pago, sendo este débito quitado na justiça. Vale dizer que caso fosse pago esse débito extinguiria o processo de não pagamento de alguma coisa que corria contra o Estado, e o também o "precatório".

Neste contexto, quem tiver informações sobre as duas listas - o que o Tesouro intenciona pagar e os processos em cursos na esfera da justiça - pode montar operações de arbitragem triangular de títulos e haveres. Fundamental para isso é ter um (a) advogado(a), aliás, a profissão da então primeira dama! Ter um precatório "julgado" é um haver de direito certo, mas de liquidez incerta. Juntar as pontas, sabendo a quem se deve, e, a quem se quer realmente pagar, enseja a montagem dos mais variados tipos de operações de compra-vendacessão-empréstimo que a história e a inovação nas finanças permite montar. Não é preciso muito capital, talvez sala, telefone, contatos e advogado. Ou seja, com pouco investimento se gera riqueza, mas esta depende do volume de precatórios e do diferencial obtido em cada negociação. O apelido de "Riqueza" da ex-primeira dama começa a se tornar público devido à desenvoltura do seu escritório, talvez pela sua capacidade de inovação em finanças, quase no fim do primeiro mandato do Governador Cabral.

Com vistas a viabilizar as inversões de custeio de capital para a realização das obras de estradas, estádios, reformas de prédios públicos, hospitais, etc.; a equipe de Cabral elabora e submete projetos às instituições financeiras nacionais e internacionais. Aprovados os projetos, cumpre destacar dois modus operandi distintos em função da política operacional desses organismos. No caso dos empréstimos internacionais, esses eram recursos para setores - sem necessidade de definição prévia em que se deveriam aplicar os recursos obtidos. Por exemplo, entrando no site do Banco Mundial se encontrará tanto o(s) projeto(s) submetido(s) pelo Governo do Estado do RJ, quanto a avaliação dos resultados dos 
empréstimos. Durante os dois governos de Cabral foram vários os empréstimos obtidos no Banco Mundial para modernizar as secretárias de fazenda, de saúde, de educação e de segurança, entre outras. As avaliações feitas por organismo independente apontam impacto sofrível nas ações realizadas. Em resumo, um verdadeiro desastre na formulação e elaboração de política pública (policy failure).

Este recurso internacional foi dispendido não em "novas" instalações físicas, pois estas eram majoritariamente contrapartidas a serem aportadas pelo Estado do Rio de Janeiro, mas sim em modernos e novos equipamentos para a área de saúde e segurança pública. Foram adquiridos modernos aparelhos de imagem e diagnóstico, bem como outros equipamentos computadorizados. Esses são únicos em termos tecnológicos, com número de ofertante internacional reduzidíssimo, sendo de reconhecida dificuldade de comparação de preços, cuja aquisição era de responsabilidade de Sergio Cortes, o secretário da Saúde, e sua equipe. Ao contrário do resto do Brasil, esses equipamentos foram instalados. Mas, a sua gestão ficou a cargo incialmente de empresa de capital nacional, controlada por Arthur Cesar de Menezes Soares Filho, conhecido como "Rei Arthur", vendida posteriormente para uma empresa internacional localizada em um paraíso fiscal. Resultado: a estrutura de custos e os preços de aquisição de bens e serviços para os gastos custeio na saúde tornou-se mais cara vis-à-vis ao observado nos outros estados da Federação.

Na segurança pública se assistiu a renovação da frota de veículos, sendo que foram acoplados em cada carro equipamentos computadorizados - sem inicialmente serem do conhecimento dos policiais - que permitiam acompanhar o trajeto, localização, quilometragem, e informações básicas para manutenção preditiva dos carros. Os policiais só começaram a ter ciência desse dispositivo depois de um incidente na UPP da Rocinha que resultou numa violação de direitos humanos. A questão aqui é que há custos a serem pagos a uma empresa prestadora desses serviços para fazer esse monitoramento. O problema não é o custo visível per si, mas o fato de que os policiais não sabiam formular os pedidos para gerar base de dados. E nem sabiam o que fazer com esse big data! Logo, o resultado foram gastos elevados e baixa efetividade da politica de tecnologia de informação na área de segurança pública.

Naquela época, as grandes obras públicas do governo Cabral foram o Metrô, o Arco Rodoviário e o Maracanã. Nesse caso se tem por norma operacional dos bancos expor a aplicação dos recursos. Segundo o noticiário, em todas essas obras houve problemas de superfaturamento e corrupção. Do ponto de vista de engenharia civil há inovação na maneira de fazer cada obra. Provar e auditar se as obras foram superfaturadas será difícil num contexto de inovação. Se isso é plausível, o ponto a discutir vem ser a elaboração e análise do projeto econômico. Dadas as ofertas e demandas estimadas de pessoas - no metrô - e veículos - no Arco Rodoviário - previstas antes das obras e observadas depois delas, constatase que não se gera fluxo financeiro para pagar os empréstimos contraídos junto aos bancos oficiais. Logo, os modelos de oferta e demanda de transportes de veículos e pessoas foram erradamente desenvolvidos. Quem seria o culpado? Algum engenheiro ou economista! Mas, o verdadeiro culpado são os técnicos do BNDES, CEF e Banco do Brasil que não sabem analisar projetos econômicos. Resumo; se a obra está de acordo com os objetivos não-econômicos de Brasília, esta será feita. E assim o foi! Logo, o único problema é a exclamação do exGovernador Cabral de ter cobrado apenas $5 \%$ de propina nessas obras!

Nesse ponto aparece a questão da ambição. Por que esse percentual é pouco? Isso está associado aos problemas pessoais enfrentados e mudança de padrão de consumo conspícuo. Para o grande público, o que se tornou emblemático da corrupção cabralina foi a festa em Paris, feita em conluio com alguns empresários da construção civil. Entretanto, o relevante é que além de estabelecer relações perigosas com esses empresários, Cabral estabeleceu relações amorosas com uma parente do então dono da empresa Delta Engenharia, sem o 
conhecimento da primeira dama. Esta só vem a saber deste affair quando ocorre um acidente aéreo entre o heliporto da Lagoa e a sua casa em Mangaratiba. Quando ela toma ciência da traição, o palácio cai! Segundo a imprensa, aí ela faz uma viagem a Paris para pensar sobre o quê fazer da vida. Cabral, por sua vez, faz de tudo para reatar e voltar para sua "Riqueza", lembrando ser esta a forma afetuosa de tratamento carinhoso dado por ele. Não a perder é fundamental para quem tinha perdido a primeira mulher para outra do mesmo gênero. Para isso começa a presenteá-la com todos os tipos de joias.

Para manter o novo padrão de vida, Cabral monta uma tesouraria particular para gerir o dinheiro religiosamente arrecadado com propinas, chegando a alugar por meio de laranjas transportadoras de valores. Esse ganho fácil foi fruto de extração de renda de contratos com o governo ou quase renda econômica, e reflete a sua ambição e seu projeto de poder. Fez o ajuste no primeiro governo, fez obras para posteridade no segundo governo - maracanã, arco metropolitano, hospitais modernos, metro, etc. - e, no segundo governo implantaria uma nova gestão "moderna" com gastos de custeio mais elevados que o observado no resto do país. Esta nova gestão viabilizaria a entrada contínua de recursos, assegurando um fluxo positivo no caixa. Exemplificando, através de convênios entre governo do estado e município do Rio de Janeiro, fruto daqueles empréstimos do Banco Mundial, montou-se clinicas da família na Zona Oeste, só que um médico servidor público custa por mês R\$ 4.000,00, enquanto o de uma Organização Social (OS) (custa R\$ 22.000,00, lembrando que isso não é despesa estadual.

Interessa perceber que a estratégia adotada por Cabral é ímpar e singular visto que forja uma rede de interesses distintos. De acordo com o divulgado e documentado no blog do exgovernador Garotinho, Cabral incentivou antes de sua saída do governo a montagem de empresas de serviços diversos capaz de atender simultaneamente a educação, saúde e serviços gerais para o Estado. Esta era controlada pelo Rei Arthur num paraíso fiscal, sendo que este soberano está em Miami. O relevante é que essa estrutura foi montada para durar enquanto o partido politico do governador estivesse no poder

Ainda que se observe uma engenhosidade do gerenciamento desse modelo de negócios de achaque público, a sua ambição e o seu novo jeito de ser de "novo rico" não colou junto à população. Sua rejeição só crescia, chegando ao ponto de haver pequenas manifestações contrárias na porta de seu apartamento no Leblon. Inclusive, seus vizinhos de classe média alta começam a expressar indignação por ele e contra sua família por morarem naquela nobre região. Para que o grupo politico se mantivesse no poder, Cabral renuncia antes do fim do seu mandato, faz Pezão seu sucessor, e vai viver a boa vida! Só não contava com a operação lava Jato, e a crise fiscal do Rio de Janeiro.

Por ser o Rio de Janeiro a sede da Petrobrás, da Transpetro, e do Comperj nas denúncias sempre aparece o nome de Cabral. Busca dali, busca daqui o MPF instaura processo que leva a primeira prisão e condenação, em primeira instância, de um ex-governador. Sua remoção do Leblon ao presidio de Bangu, além de passar em TV aberta, foi comemorada por po pulares no seu trajeto. Segundo os noticiários, face as condições prisionais vivenciadas, a sua autoestima foi para baixo. No presídio, nesse momento inicial de "depre" visitas foram várias, desde o Presidente Picianni da Assembléia Estadual, um dos donos de inovadora empresa de inseminação de gado num estado não vocacionado para esta atividade, políticos menores, até advogados. Só não rolou visitas íntimas, pois riqueza também estava presa. Dizem as más línguas que ele estava atemorizado e aterrorizado com as possíveis maldades dos outros presos, seja em relação a sua integridade física ou a sua hombridade! Às pressas, o Governo do Estado reformou o presídio de Benfica, especializado para receber presos de nível superior, e, assim Cabral foi removido. Lá é perto do estádio do Vasco, seu clube de coração, e nesse novo local até reabriu a sua página do Facebook! 
Essa melhoria psicológica é fruto da confiança de que seu modelo de negócio ainda funciona, sob outro formato, mas gerido pelo grupo político que detém agora o poder no Estado do RJ. E, isso apesar da crise fiscal do Estado. Mesmo com a queda do preço do petróleo que reduziu os repasses dos royalties e do ICMS estadual não há sinais de esforços no sentido de reduzir os gastos de custeio da máquina estadual, com vistas a ajustar o setor público. Ou seja, não se faz algo parecido com o que foi feito em 2003.

Pode-se constatar que isso é uma estratégia explicita de postergar o necessário ajuste econômico, de um lado aguardando a negociação com o governo federal, e, de outro lado, postergando pagamento de obrigações, principalmente de salários. Mas, aqueles gastos de custeio elevados ainda continuam, tendo saído a turma do Rei Arthur e entrado outra galera próxima do mesmo grupo político. A lei de recuperação fiscal só saiu porque Pesão acampou no Congresso Nacional, e negociou com o mundo, e Raimundo. O senado votou essa lei no dia que eclodiu o escândalo Temer-JBS. Ponto para o governador. Agora, o mesmo toureia com o segundo escalão do governo federal, que lhe dá um chá de cadeira nas salas de espera em Brasília. Lá se questiona a vírgula do papel, protela-se decisão, e por isso o governador Pesão precisa realmente de um avião de carreira para se deslocar a toda hora para Brasília. Cada vez que chega lá, lhe exigem sempre mais alguma coisa. Por isso o mesmo confidencia que era feliz quando era prefeito, e não sabia disso!

Agora a imprensa começa a desvelar as conexões de Cabral com a prefeitura do Rio no período da preparação das Olimpíadas. Africano negocia qualquer coisa, logo a compra de voto para a escolha do Rio é algo comum nas negociações internacionais. Isto ocorre em toda escolha de sede, e não seria diferente aqui. Importa ressaltar aqui é a aproximação de Cabral com dois empresários judeus - Barat e Nuzman -, ainda que se diga que o primeiro renegou a religião. Ambos já tinham uma trajetória de sucesso de trabalho árduo, mas por mera ambição de lucro fácil se envolvem em ilícitos por se terem se inserido na "turma" do ex-governador.

Na medida em que se chegar mais próximo à eleição vindoura, o acordo com a União sairá. Mas os pagamentos estão sendo direcionados para os grupos de fornecedores de interesse do atual grupo politico, e os salários que importam ser pagos; segurança e saúde. Saúde e segurança atuam bem ou mau direto com a população. Se há violência ou faltam remédios se culpa a crise maior do país (ou do ministério da saúde que não fez o repasse). Deliberadamente atrasam os salários dos professores da secretaria de ciência e tecnologia (UERJ, UEZO, UENF, CEFET, etc.). Estes atuam com alunos diretamente, que via de regra não votam em quem esta no governo. No calculo eleitoral valem zero. Para o grupo que está no poder, o melhor seria reduzir esses custos no futuro, desgastando e minando a importância desse ensino publico junto à sociedade. Isso esta ocorrendo na medida em que se reduziu o numero de alunos que prestam vestibular nas universidades estaduais. Porém, os professores - ao invés de fazerem uma guerra de movimento como propugnada por Gramsci para quebrar a hegemonia de um partido, preferem fazer uma guerra de posição, com palavra de ordem: UERJ RESISTE! Feito o acordo com a União, o ajuste será feito por quem ganhar a eleição futura, e haverá cortes na educação, mas os serviços serão ainda adquiridos a preços altos. Essa inércia é uma junção de mau uso do dinheiro público observada de forma comum na África, junto com a inflexibilidade do regime politico constatada no Sudeste Asiático, nos idos dos anos noventa, antes da crise asiática. Resultado: o povão do RJ sofre com o desmantelamento das funções do Estado, fruto da ambição de um grupo de empreendedores não produtivos e destrutivos. Essa singularidade é única quando se associa e analisa ambição e corrupção, principalmente sob a antropologia.

Considerações Finais 
Face ao exposto se constata que é possível fazer uma analise antropológica hiperdialética para a corrupção presente no RJ. A partir do trabalho de Gomes (2011) se buscou olhar o fenômeno corrupção no Rio de Janeiro sob as perspectivas culturais, econômicas, politicas e sociais e fazer uma síntese sob a visão de antropologia hiperdialética. O passo seguinte foi identificar autores que trabalhassem sobre cada uma das perspectivas para fundamentar cada ângulo e identificar um traço comum pequeno, preferencialmente cultural, para servir de fio condutor da análise. A tipologia da grande corrupção e ambição, mais a questão dos incentivos econômicos se tornaram apropriadas aos objetivos do presente trabalho.

Ao se definir a pergunta a ser respondida partiu-se para o trabalho de campo. Dois métodos foram usados: (i) coleta de dados por meio de leituras especificas; (ii) pesquisa participativa, vivendo as consequências do processo sob um olhar antropológico interno/externo, aonde se ouviu e leu relatos de modo a descrever a teia e a rede de atores sociais e suas práticas, conforme descrito na segunda seção. A principal conclusão do trabalho é que o povão do RJ sofre com o desmantelamento das funções do Estado fruto da ambição de um grupo de empreendedores não produtivos e destrutivos. Essa singularidade é única quando se associa e analisa ambição e corrupção, principalmente na antropologia.

\section{Bibliografia}

BAUMOL, William J., Robert E. Litan, and Carl J. Schramm. (2007). Good Capitalism, Bad Capitalism, and the Economics of Growth and Prosperity. New Haven, CT: Yale University Press.

BUSSELL, Jennifer (2015) Typologies of corruption: a pragmatic approach; capítulo 2 de Greed Corruption and the modern state de Sue Rose Ackerman e outros. El Agar.

GUPTA, A (2005) Narrating The State of Corruption, em Corruption: Anthropological perspectives, Haller, D. e outros, Pluto Press.

GOMES, M. P( 2011) Antropologia Hiperdialética, São Paulo: Contexto, 2011.

Rose-Ackerman (2010) Corruption: Greed, Culture and State. The Yale Law Journal online, 125 


\section{CORRUPÇÃO E JBS: HÁ POSSIBILIDADE DE UMA} ANALISE ANTROPOLOGICA HIPERDIALÉTICA COM ELEMENTOS DE CIÊNCIA, TÉCNOLOGIA E SEGURANÇA ALIMENTAR?

Mario Cordeiro de Carvalho Junior - Mestrando do HTCE e Professor da FAF-UERJ

\section{Resumo}

Este artigo busca analisar desenvolver uma análise especifica de forma transdisciplinar sobre um assunto específico: corrupção e a empresa de carne JBS. Com base em conhecimentos de ciência e tecnologia alimentar, e práticas e abordagens oriundas da antropologia hiperdialética. Exposto os conhecimentos subjacente á análise se fez uma análise associando corrupção e a maior abatedouro do mundo - a JBS. Do exposto no artigo se pode afirmar que se pode analisar o tema corrupção e JBS de forma positiva, pois relacionar antropologia e tecnologia alimentar permite chegar a uma síntese cujo entendimento, apesar de não harmônico é adequado ao momento histórico presente.. Vale lembrar que este artigo buscar de forma criativa refletir na prática a perspectiva transdisciplinar única, desenvolvida no HTCE.

\section{Introdução}

Analisando os fatos noticiados por todos os tipos de meio de comunicação a partir de fevereiro de 2017 pode-se dizer que nunca antes na história desse país se desvelou e se revelou a todos a fratura da relação pública-privada mostrando a existência de um anel de corrupção entre políticos (e seus partidos), empresas (e seus grupos econômicos), e, eventualmente, a burocracia pública. Naquele mês, o país teve a surpresa do início da operação "Carne Fraca", em que, seguindo a linha investigatória e da prática de delação presente no momento atual no Brasil, se denunciou à questão de qualidade e adulteração da carne brasileira de quase todas as empresas do setor de carnes. Por ser um dos maiores exportadores de carne bovina do mundo, e ser sede da maior empresa de abate de carnes do mundo -a JBS -, inicialmente a imagem do país no tocante ao padrão, confiabilidade e integridade do produto foi abalada, no Brasil e no exterior.

Sem dúvida, o assunto food fraud, carne, corrupção e visões e interpretações do Brasil tem ( ou teria) tudo a ver como um eventual objeto de estudo e pesquisa no HTCE. Entre diversas linhas de pesquisas e cadeiras, duas podem se conectar com esses assuntos atuais: a de ciência, tecnologia, e segurança alimentar; e a de lógica e antropologia hiperdialética. A primeira linha é de cunho interdisciplinar, que procura desenvolver debates de múltiplas questões, que se entrelaçam, envolvendo a produção, comercialização e consumo de alimentos e cujos desenvolvimentos, e implicações, revelam, formas distintas de alimentar o ser humano. Dentre as diversas sub-linhas de pesquisa descritas no programa três podem ser relacionadas ao tema: a) fraudes na sua produção e comercialização; b) processos de conservação dos alimentos que afetam sua qualidade e introdução de aditivos para possibilitar maior tempo de comercialização, mas que alteram seus atributos alimentares; e c) também questões concernentes a produção de carnes e seus reflexos no meio ambiente. Por sua vez, a linha de pesquisa de antropologia hiperdialética busca sintetizar as seguintes perspectivas; (i) cultural; (ii) econômica, fundamental para entender produção, distribuição e 
consumo; (iii) política, e (iv) sociedade como um todo aonde "as ambições pessoais são moduladas por regras coletivas." Ela tem como proposta que qualquer ponto da história deve ser visto pelos elementos que o constituíram e pelo que produziram nos anos seguintes. Por essa heurística dá para entender por que as coisas fazem sentido hoje. Segundo Gomes (2011), essa síntese unifica todos esses pontos de vista e busca um entendimento não necessariamente harmônico, mas adequado a cada momento histórico. O problema específico a ser respondido neste artigo como é como num contexto de política de campeão nacional conectar se interpenetra (ou não) a corrupção e food fraud, de um lado, e a visão e a interpretação de uma empresa ou setor num determinado momento histórico. Sabe-se que para analisar essa interpenetração se tem que ter um ator - a empresa JBS e sua trajetória de crescimento e acumulação (e sua holding JIF); seus agentes (principais acionistas e executivos); sua organização técnica e do trabalho em cada uma das suas fábricas para fazer um bom produto ( ou fraudá-lo se isso for possível); as razões e as motivações da corrupção; e a relação público-privada entre empresa e governo. O elo comum aos dois campos de estudos é a corrupção e a fraude, de um lado, e, a escolha do método de análise para formular e responder a pergunta desejada, do outro lado.

Nesse sentido, na segunda seção, se busca definir o problema de corrupção num abatedouro, de modo geral, e como analisá-la sob à ótica de fraude e corrupção no processo produtivo. Cabe ressaltar que se buscará mostrar que a tecnologia e segurança alimentar e a antropologia hiperdialética juntas como podem abordar esse assunto. $E$, na terceira seção com base nessa perspectiva se apresentará que ao se adotar procedimentos técnicos e gestão do processo produtivo, seguindo normas e regulamentos nacionais e internacionais a questão de food fraud e de corrupção nas empresas de carnes, e, em especial na JBS não ocorreu. Na quarta seção, o contrário será mostrado, ou seja, será analisado a relação publica-privada, ressaltando o viés da relação com a política, de um lado, e o viés da relação com a burocracia pública com vistas a atender aos objetivos de se tornar campeão nacional.

Por fim, na nesta quarta seção à luz de uma leitura direta de Sampaio (1999) - pensador brasileira que formula a noção de lógica hiperdialética - se obtém pistas para uma trajetória de saída desse beco sem saída atual. Especificamente na pagina 32, ele indaga "que poderíamos dizer acerca da situação brasileira atual e de suas perspectivas, tanto em relação à modernidade quanto a nova cultura? Para ele o rompimento dessa incompatibilidade passa por compreender o sujeito do projeto, e como se poderia e alterar a trajetória e o comportamento do ator - JBS -, e seus agentes.

\section{Il Abatedouro de Carnes: Organização do trabalho, da técnica, e Estratégia Empresarial}

A história e a evolução da empresa JBS começa nos anos cinquenta, quando o pai dos principais acionistas atuais inicia o abate de bovinos no interior de Goiás para revender no seu açougue. Na época, dado o desenvolvimento econômico observado, qualquer abatedouro de carnes ficava na entrada ou na saída da cidade, e as condições de abate seguiam os padrões daquele momento de industrialização. A maior parte da carne era consumida fresca, normalmente na cidade aonde havia o abatedouro. Ou seja, produção e consumo eram próximos, e o gado chegava vivo - em pé - ao local de abate. Na medida em que se difundiu a eletrificação, a carne passou inicialmente a ser resfriada e depois congelada. Por sua vez, o consumidor brasileiro começou a poder adquirir geladeira, e espaçar as suas compras de carne quando tinha renda para adquirir esse alimento. Nesse sentido a integridade do produto foi aumentada graças ao uso do frio. Isso fez com que a produção( abate) pudesse se localizar longe do consumo.

Isso mais um consumo crescente permitiram a modernização gradual dos abatedouros. Do ponto de vista da organização e da técnica importa destacar cinco pontos: i) o primeiro é o 
aumento do tamanho da unidade de abate, e da sua linha de produção para processar um maior numero de bois, lembrando que dada à conformação típica do boi, os cortes serão "uniformes" propiciando a mecanização e a geração de economias de escala; ii) o segundo é ao estabelecer um sistema de entrada de insumo - boi - e saída de carne fria e congelada bem final - se tornava possível controlar a olho nu as condições de higiene e sanitização do processo de transformação produtiva, e também medir a produtividade física do processo produtivo - peso de carne produzida na saída / peso de boi na entrada; iii) as condições de patógenos, micróbios e possibilidades de contaminação química não observadas a olho nu puderam começar a ser controladas - por meio de análise laboratorial - feita quase ao mesmo tempo do abate e/ou depois do produto processado; iv) todos esses dados começam a ser coletados e parametrizados - de olho nu e de laboratório - começam a ser coletados, analisados e organizados de modo tal que se denomina isso tempos depois de "Manual de Boas Práticas de Produção", e "HACCP" analise de pontos críticos e riscos do processo de abate. Cumpre destacar que todos os dados e análises a serem executados são oriundos do saber da engenharia de alimentos e da química. E, v) há conflito entre a gerência e a linha de produção no tocante ao cumprimento das condições de higiene e o ritmo de trabalho a ser imposto na linha de produção.

Para esse sistema funcionar é preciso ter capital para adquirir o insumo, comprar "bem e barato" esse boi, conseguir financiar as atividades até a venda da carne e o seu recebimento. Saber comprar o boi, então, é uma arte. Na JBS isso passou de pai para filho, ao ponto, que o pai voltou recentemente á empresa para desempenhar esse item do core business do negócio. Tendo estabelecido a aquisição do insumo, só fica a definir o ritmo da linha de produção, a integridade do produto e a entrega. Esse processo pode ser aberto ao cliente final - a depender do volume de aquisição - e a inspeção e a vigilância sanitária do governo. Ai surge o primeiro ponto de uma relação pública-privada de qualquer abatedouro com o governo: a vigilância sanitária e a fiscalização agropecuária. A seguir, em função da necessidade de capital e da necessidade de recolher as obrigações e tributos que qualquer empresa incorre surgem mais duas relações público-privadas: a) com as instituições fiscais federais e municipais; e b) com os bancos oficiais e/ou de regulação de comércio exterior.

Desde o final da década de 1970, o Brasil se transformou gradualmente num exportador de carne. Hoje, o país é um dos maiores produtores agrícolas e um dos mais competitivos do mundo. E, é uma ameaça concreta e potencial para os principais exportadores de carnes, que são os EUA e a União Europeia. O surgimento do Brasil como principal comerciante agrícola mudou o status de potencia emergente e permitiu que o país assumisse um papel mais proeminente na governança global. $\mathrm{O}$ ativismo do Brasil foi inovador e ajudou a tirar o poder dos EUA e o que se deve buscar a interpretar é que o boom do carne na exportação não resultou de vantagem comparativa natural, mas de vantagem construída. A extensa intervenção estatal - lei agrícola, melhoria logística, e acesso a financiamento para aquisição e internacionalização de empresas, no caso a JBS - permitiu que houvesse uma alteração do Brasil no mundo da carne, se tornado player internacional e global. A experiência do Brasil desafia assim os pressupostos de modelos tradicionais de desenvolvimento na economia política global: contrariamente aos princípios do neoliberalismo, a vantagem comparativa do Brasil foi reformulada com êxito como resultado de uma intervenção ativa do Estado brasileiro.

Esse exercício de política de "poder" - no caso da carne - vem de uma politica de administração da Cota Hilton nos anos 90. Naquele tempo, a União Europeia permitiu que o Brasil exportasse seletos cortes de carne. Para cumprir essa corte - administrada pelo Governo mediante o MDIC - só se permitia produtos de qualidade, e abatedouros idôneos. Para ter bom produto se tinha de ter controle de qualidade, e se necessitava de politica de 
boas práticas de fabricação e HACCP. Do exposto até aqui há uma nítida e necessária organização do trabalho e da técnica numa empresa, incluindo a possibilidade de conflito ente gerência e trabalho. Corrupção e fraude no processo produtivo dependem de alteração nos relatórios e/ou na composição dos produtos. Isso deveria ser em parte checado pela regulação do Estado, se esta não estiver em conluio com o setor privado. Caso não se tenha acesso livre a esses dados, uma possibilidade é usar as técnicas de antropologia para analisar essa possibilidade.

O fato é que com a organização da técnica e do trabalho no chão de fábrica se qualificou a oferta exportável dos abatedouros. O regulamento passa a ser obrigatório a partir do fim dos anos noventa, e mandatório a partir de 2004. Além disso, os bancos oficiais e privados e ofertava linhas de trade finance para viabilizar o ciclo de produção e venda para exportação. Esse boom exportador induziu a uma modernização produtiva dos abatedouros, e uma concorrência entre os abatedouros para exportação. E o setor crescia de forma saudável, ao se construir a sua vantagem comparativa, que é saber processar bovinos com qualidade nos abatedouros. Tudo começa a mudar quando se introduz a politica de campeões nacionais. A partir desse momento começa a surgir os casos de corrupção no setor de carnes.

A antropologia passa a ser então uma candidata para servir de instrumento de análise do fenômeno corrupção. Em texto contratado e feito para a união europeia, Torsello (2014) analisa a corrupção como uma troca social, mostrando a visão da antropologia. Estudar esse assunto obriga um olhar á la Mauss, que envolva troca e reciprocidade, de um lado, e , de outro lado, assumir um ator burocrático racional com base em Max Weber. Fica difícil desenvolver assim uma análise consistente com esses elementos. Isso não ocorre com na perspectiva da antropologia hiperdialética. Essa parte das observações e fatos que permitam sintetizar e compreender o momento histórico. Naquela época, o que importava para os gestores de politica de governo é que os irmãos Batista tinham "animal spirits".

Segundo Akerlof e Shiller (2009), dois prêmios Nobel de economia, " para compreender como as economias funcionam e como se pode administra-las, se deve ter claro conhecimento sobre os padrões que animam as ideias e os sentimentos das pessoas, ou seja, os seus "animal spirits". O papel do governo, nesse caso é dar o tom do estágio. Dar o tom significa incentivar fortemente a criatividade do capitalismo. Mas, significa coibir com firmeza os excessos que ocorrem no sistema devido a existência do animal spirits" (AUTOR,ano, p. 13 e 14). Para esses autores a corrupção causa dois custos negativos na economia: a primeiro o dano especifico a transação especifica á corrupção, e, um outro maior devido á decepção generalizada das pessoas com relação á economia, e, sobretudo ao aumento da desconfiança entre os agentes econômicos. Medir isso para eles é difícil, pois "as estórias não mais explicam apenas os fatos econômicos, estes são os fatos" (autor, ano, p. 54). À esta perspectiva econômica se junta a visão a análise transdisciplinar de Janicks (2014) que estabelece que a corrupção ocorre entre atores desiguais e a dinâmica do poder é um componente das trocas. Com base nesses argumentos se pode escrever estórias sobre as causas e os efeitos da corrupção a partir do caso da JBS.

III Corrupção na Base Técnica e da Segurança Alimentar no Abatedouro

Restringindo-se à operação "Carne Fraca" e seus desdobramentos, esta começou a desvelar eventual fraude na produção de carne e de seus derivados (food fraud), e, buscou revelar um anel de corrupção entre a burocracia estatal teoricamente responsável por regular as condições sanitárias a serem prevalecidas no processo de abate dos animais bovinos com gerentes responsáveis pela produção e qualidade, tanto de médios quanto de grandes grupos empresariais brasileiros. Isto abalou a confiança do consumidor brasileiro, e, sobretudo o 
estrangeiro acerca da integridade e da qualidade do produto produzido em cada fábrica, e, no Sistema de Proteção Federal (SIF) do Ministério da Agricultura.

Passados um pouco mais de oito meses dessas graves denúncias que abalaram a credibilidade da carne brasileira, principalmente no mercado internacional, se observa uma grande capacidade de resiliência do setor de carnes frente a choques adversos e a desastres de gestão de comunicação e de acusação das autoridades públicas. Grosso modo, o resultado foi: a) dois frigoríficos pequenos - não exportadores - foram fechados no Paraná, por apresentarem problemas fitossanitários decorrentes do não cumprimento das normas e regulamentos; b) paralização temporária de abatedouros ligados e dedicados às vendas externas; c) suspensão das exportações de carnes frescas bovinas para os Estados Unidos devido ao mal estar causado no boi vivo pela vacinação contra febre aftosa; d) exigência de testes físico químicos para verificação de $e$. colli (cofa analysis) para $100 \%$ por cento de toda produção exportada de carne de frango para a União Europeia; e) não autorização para credenciar novos abatedouros para exportação para este bloco econômico; e f) proibição de venda de carne congelada de muares, jumentos e cavalos para países europeus.

Do ponto de vista legal, no Brasil, todo aquele empreendedor ou empresa que queira atuar na atividade econômica e no negócio de abater bovinos têm de seguir e cumprir esse "regulamento". Cabe destacar que caso se procure na legislação nacional não se encontra um "regulamento único". Este deveria estabelecer de forma clara - o que, como, quando, aonde - as obrigações e deveres que o empreendedor e a empresa devem seguir e cumprir. Neste, seriam apostos os princípios e o "espírito" para que servidor público - o " fiscal" - controle, monitore, audite e autue o estabelecimento industrial quando houver desvios de conduta. De fato, mediante uma pesquisa "bibliográfica" preliminar se encontrará um conjunto de normas legais esparsas que - por terem sido emanadas do poder público em momentos históricos distintos - podem ficar sujeitas a interpretações diversas.

Face ao inerente desejo de acumulação de capital do empreendedor, de um lado, e do poder discricionário do "fiscal" - em que cabe à ele interpretar e julgar a condutar segundo as normas e regulamento, do outro, é o que dá margem ao conluio e a formação de "anéis burocráticos espúrios" entre estamentos gerenciais da grupos econômicos e os fiscais "servidores" públicos objeto da operação "Carne Fraca". Analisar isso é preciso para compreender a relação público-privada no âmbito da interação de assunto e saber técnico normas e regulamentos - tanto, em nível, do espaço de produção, bem como a auditoria e controle dos mesmos por gerentes e trabalhadores num mesmo espaço produtivo.

Nesse sentido deveríamos dirigir o nosso olhar para o exterior para uma melhor compreensão da realidade produtiva atual no setor de carnes. Apesar dos temores acerca de um colapso da confiança e da percepção do consumidor estrangeiro quanto à carne brasileira face à operação Carne Fraca, o "fim do mundo não ocorreu". Inicialmente, houve especulação e renegociação de preços e quantidades entre exportadores e importadores, e ameaças de rejeição de lotes já embarcados para o exterior. Em parte essa resiliência ao impacto desses choques adversos decorre do fato das empresas brasileiras - para exportarem - terem de adotar, no mínimo, o procedimento de ter HACCP ( analise de pontos críticos) especifico para carnes, conforme o "Codex Alimentarus", norma internacional acordada na a FAO-OMC.

Cabe destacar que esse códex é eminentemente técnico. E ai incide sobre a história e a geografia da criação e processamento do gado, sobre a técnica do abate; sobre a análise físicoquímica, sobre as técnicas de conservação, do layout da fabrica, da gestão de produção desde o abate até a refrigeração, aos controles de qualidade, e à gestão da logística, e a sua interpenetração com a gestão de comércio internacional. Dada à capacidade de resiliência da produção de carnes face aos choques decorrentes da fratura da relação pública-privada, se têm que sob a ótica da segurança alimentar buscar aprofundar e detalhar dois pontos, a saber. 
O primeiro é compreender que a adoção de uma de uma regulamentação internacional CODEX e HACCP - aplicados ao setor de carne com base em técnicas e tecnologia oriunda das engenharias de alimentos, agronomia, produção e nutrição é isso que redundou nas vantagens comparativas construídas em nível de cada abatedouro. Ter isso bem aplicado é que determinou o não fechamento das vendas externas de carnes. As restrições impostas não têm nada a ver com a produção e o abate no caso dos bovinos. As medidas tomadas são de precaução. Teste sobre lote de produção de carne de frango, e de observações fora do chão de fabrica. E, as recomendações vão muito em direção a forma de controle do governo, especialmente ao Ministério da Agricultura (MAPA). Inclusive, este tem de decidir finalmente controlar a qualidade na produção, e não no porto de saída do produto do território nacional. Isso é feito para imitar a prática da Receita Federal.

O segundo é destacar a importância da implantação do HACCP e de suas normas e procedimentos num espaço produtivo cujo foco é a segurança do alimento. Demais, esse método associado a uma gestão de gestão de riscos e de uma gestão de sistema como forma para permitir a condução técnica do processo produtivo aumenta a resiliência da produção de carne. Mas, a fratura da relação pública privada no caso da operação Carne Fraca está calcada na forma de fiscalização do Governo Federal, pois este quer fiscalizar no Porto, ao invés de monitorar a fabrica exigindo acompanhamento de HACCP. Logo, o sistema de controle de qualidade no processamento da carne é superior ao exigido pelo Governo. Isso explica que as criticas e as barreiras impostas não foram em cima direto dos abatedouros, e sim ao Governo e a situações tópicas. Ou seja, nada que afetasse a competitividade do produto carne no mercado internacional.

Agora, a resiliência observada no setor face ao choque externo é oriunda da "gestão do conhecimento (knowledge management) oriundo de umas questão. A segurança alimentar e sua qualidade - expressa na adoção do saber oriundo da engenharia de alimentos, sua analise físico química, e congelamento do produto. Esse saber, em tese, está codificado na prática de HACCP e outras certificações do tipo ISO adotadas voluntariamente ou mandatoriamente pelos abatedouros. Se isso não existisse, com certeza, os danos seriam maiores. Isso não ocorreu por que há organização do trabalho em nível de chão de fábrica, condições de controle e gestão da mão de obra - por gerentes - de modo que os objetivos diários de produção não se conflitem com a necessidade da qualidade, apesar de haver outras áreas aonde há corrupção.

\section{Corrupção da Gestão e dos Controladores e Saídas Possíveis}

No mesmo período, os executivos da JBS - que no bojo da operação Carne Fraca tiveram suas unidades paralisadas pelo pedido de hold on ou suspensão da ordem de compra de carne para exportação, fizeram uma delação premiada à Justiça envolvendo uma relação públicaprivada mostrando, de um lado, uma típica de acumulação patrimonialista deles e de parte de altas autoridades da nação, tão bem descrita por Raimundo Faoro, em "Os Donos do Poder"(ano), clássico intérprete nacional; enquanto, de outro lado, desvela a dificuldade histórica dos bancos oficiais nacionais, principalmente o BNDES, de saber analisar e aprovar projetos que apoiem e incentivem o surgimento e o florescimento de uma burguesia nacional, muito bem exposta nas obras dos jovens Fernando Henrique Cardoso e Luiz Calos Bresser Pereira, clássicos do pensamento nacional, ainda que nos tempos atuais, burguesia por ser um adjetivo pejorativo seja chamado de campeões nacionais.

A questão fundamental é que na medida em que se observou uma contínua expansão da oferta das empresas que abatiam carne, o animal spirits dos empresários do setor, e, em especial da JBS, cresciam exponencialmente. E, a fonte de recursos para inversões e financiamentos de longo prazo, no Brasil, existente só existia no BNDES. Dois são os pontos 
fundamentais para entender a disponibilização de recursos por parte do BNDES à JBS, em particular, e as demais empresas nacionais. Para isso é preciso compreender usos e fontes dos recursos a serem captados pelo BNDES, e o outro é a forma de empréstimo desses recursos captados. O recurso tradicional de captação do BNDES é o FAT (Fundo de Amparo do Trabalhador). Esse é um recurso carimbado que só poder ser usado e disponibilizado para financiar bens e serviços nacionais. Ou, se pode usar esses recursos para capitalizar empresas via operações no mercado bursátil.

Por sua vez, de forma inteligente e correta, no primeiro Governo Dilma, o Tesouro nacional fez aportes via títulos de divida ao BNDES para fazer frente a demanda por empréstimos e financiamentos de modo a atender aos animal spirits nacionais. Neste caso se incluiria a expansão do setor de carnes, mais infraestrutura, e outros.

Cabe destacar que desde o governo de Fernando Henrique Cardoso já havia intenção de financiar a internacionalização das empresas brasileiras, entendida como expansão comercial e logística no exterior. Dado que não se podia por lei fazer empréstimos diretos, se começou a estruturar operações de internacionalização com base na emissão de ações ou debentures. Ao Lula chegar ao poder, e principalmente, no segundo mandato de lula e no primeiro de Dilma Rouseff essas operações se tornaram corriqueiras, agora para viabilizar a fusão e aquisição de ativos no Brasil, e no exterior. A JBS se tornou uma das maiores tomadoras do BNDES.

O problema dessa política ocorre em 2009, ao eclodir a crise do sub-prime nos EUA, quando um grande frigorifico - Independência - quebrou e o BNDES não envidou esforços para reestruturar as unidades existentes. Aqui não se tratava do BNDES se tornar num "hospital de empresas em crise", mas no fato de que ao não intervir e resolver a insolvência externa do abatedouro tornou a JBS como a compradora única de cerca de $60 \%$ dos bovinos brasileiros. Logo, ela tem condições de influenciar o preço da arroba de boi oferecida nas diversas praças do Brasil. Não precisa mencionar a posição dos ruralistas em relação a essa política.

Do exposto até aqui não surge de forma aparente a questão da corrupção, e a origem da relação publica-privada entre JBS e governo. O problema fundamental no caso atual é que a burocracia encastelada no BNDES - recente e passada - por serem desprovidos de "esprit de finesse", ficam seguidamente a buscar e a identificar e a ajudar a uma burguesia nacional. Na época da ditadura foi o tempo da Villares e Bardella. Depois foram os Olacyr de Moraes e Aracracruz Celulose. Nos tempos atuais apoiou-se a JBS, e amanhã será outro o escolhido.

O problema está nas relações do conselho de administração. Por ser o principal acionista, a União tem assento majoritário nesse conselho e leva a observância ou não de tráfico de influência. Na delação premiada dos irmãos Batista há trechos aonde são expostas essas tratativas. Em tese, há um problema de provar. Nos tempos da ditadura, as reuniões do conselho e de diretoria do banco eram gravadas, hoje isso não ocorre, e se teria que olhar projeto a projeto que é submetido a apreciação de decisão de diretoria e conselho. O fato é que muitas vezes não se tem justificativa econômica para apoiar a fusão e aquisição de empresas do setor de carne, como o apoio de outros setores como telecomunicações, como o caso da OI, que hoje entra na conta de devedores duvidosos, ainda que o BNDES não tenha essa figura no seu balanço. Esse processo cinzento atende aos interesses dos animal spirits de empresários nacionais, contribuindo efetivamente com uma maior concentração de riqueza nas mãos de poucos. Existe outro caminho? Sim. Um choque de Capitalismo numa linha indicada por Sampaio(1999) como maior racionalidade do ator, típica de sociedade norteamericana. Dado o ator - empresa - se poderia mediante operações estruturadas se pulverize via mercado de capitais as ações nas mãos do BNDES, se faça chamada de capital na JBS e das empresas envolvidas que já tenham firmado os acordos de leniência, muda o nome das empresas, e estabelece-se gestão profissional e conselho atuante. 


\section{V - Bibliografia}

AKERLOF, George e SHRILLER, Robert ( 2009), Animal Spirits

JANECICS, David (2014), "Interdisciplinary Perspectives on Corruption". CUNY Academic Works.

GOMES, M. P. (2011), Antropologia hiperdialética. São Paulo: Contexto, 2011.

SAMPAIO, Luiz Sergio (1999) Notas de Antropo-logia - mimeo

TORSELLO, Davide ( 2014), "Corruption as social Exchange: the view from anthropology", EU grant agrément number 290529. 


\section{PROJETO MÉTODOS DE ENSINO DA ARTE: UMA VISÃO DE THIERRY DE DUVE}

Giovanna Rita Rabelo de M. S. Arruda - Graduanda Educação Artística - EBA/UFRJ giovannarita@ufrj.com.br Adherbal Artigini Neto - Graduando Educação Artística - EBA/UFRJ neto_artigiani@hotmail.com Aleph Lana da Costa Archanjo - Graduando Educação Artística - EBA/UFRJ lana.arch@hotmail.com Douglas do Nascimento Suzano - Graduando Educação Artística - EBA/UFRJ douglasdesenhado@gmail.com Flávia Lucia da Silva Fontes - Graduanda Design de Produto - EBA/UFRJ flavia-fontes@live.com Gabrielle Carvalho Ferreira - Graduanda Educação Artística - EBA/UFRJ gabrielle.carvalhof16@gmail.com José Leandro Lopes Araújo - Graduando Educação Artística - EBA/UFRJ jlla.ze@gmail.com Marcelle Lateefah Simões - Graduanda Educação Artística - EBA/UFRJ majulateefa@gmail.com Mariana Daltro Meliande - Graduanda Educação Artística - EBA/UFRJ marianameliande@gmail.com Mariana Silva Rodrigues - Graduanda Educação Artística - EBA/UFRJ maribuffy@gmail.com Poliana da Silva Paixão - Graduanda Educação Artística - EBA/UFRJ polianaspaixao@gmail.com

\section{Resumo}

Esta pesquisa se baseia no livro de Thierry de Duve, Fazendo Escola (ou refazendo-a?), no qual o autor faz uma abordagem sobre de ensino na atualidade e introduz uma reflexão inovadora e ao mesmo tempo surpreendente do universo da formação artística como a conhecemos hoje, a partir de suas experiências de ensino, mas com a visão crítica de quem conhece profundamente o sistema artístico. Além de trazer experiências à margem do circuito internacional de publicações. Deste modo, a pesquisa, baseada no livro, pretende desenvolver uma coletânea de informações, a fim de atingir 4 finalidades (construir um o estado da arte sobre o tema, métodos de ensino da arte, conteúdos programáticos aplicáveis na nossa realidade e uma coletânea de referências bibliográfica). Ao final da pesquisa, os resultados serão divulgados na iniciação científica /2017 da Escola de Belas Artes da UFRJ e em um blog, de modo, a contribuir como referencial para os estudantes e profissionais da área de Licenciatura em Desenho e Arte Plástica.

Palavras-chave: Arte e Educação. Educação. Thierry de Duve.

1 Introdução (Objeto, técnica, justificativa e relevância social)

"A distância entre os campos artístico e educacional coloca os indivíduos em uma situação à margem da produção artística, envolvidos unicamente com o funcionamento do mundo escolar. Uma realidade da qual não tem culpa. Do outro lado está a comunidade artística que raramente se envolve em problemas de cunho social, - afinal artistas que apresentam em sua poética o embate com o social não necessariamente o transformam em ações práticas de campo - e pouco compreende da educação e dos dilemas da profissão docente em arte, esperando da professora, do professor ou da escola, uma prática que abandone a tradição, a corda que os segura, e se atualizem absorvendo a produção atual" (BUCHMANN, 2013).

Thierry de Duve ${ }^{36}$ é o autor do livro "Fazendo Escola (ou refazendo-a?)", no qual descreve e apresenta uma profunda reflexão sobre o estágio em que se encontra o sistema de ensino na atualidade. $\mathrm{O}$ autor realiza uma reflexão inovadora e ao mesmo tempo surpreendente do universo da formação artística como a conhecemos hoje, a partir de suas experiências de

\footnotetext{
${ }^{36}$ Thierry De Duve, teórico da arte contemporânea, vive em Bruxelas e é professor na Universidade de Lille 3. É autor de vários livros, incluindo Kant after Duchamp (Cambridge: MIT Press, 1996). Foi curador de "Voici 100 ans d'art contemporain" no Palais des Beaux-Arts, Bruxelas, 2000, e do pavilhão da Bélgica na Bienal de Veneza de 2003, com Sylvie Eyberg e Valérie Mannaerts.
} 
ensino, mas com a visão crítica de quem conhece profundamente o sistema artístico (DUVE, 2013).

O livro traz aos leitores a possibilidade de ter acesso a um título à margem do circuito internacional de publicações. Seu impacto está na análise rigorosa dos modelos de ensino estabelecidos, fundamentalmente os modelos acadêmicos e o modelo Bauhaus, ambos obsoletos na perspectiva do autor. Como alternativa, propõe outra relação de aprendizado baseada em uma abordagem de "transmissão", cujo caráter seria essencialmente antiacadêmica. $\mathrm{O}$ autor reivindica o retorno à tradição artística como um mergulho em um repertório de ferramentas para a reflexão sobre o ensino, entre elas a história da arte e a estética. Trata-se de um texto de relevância para os profissionais envolvidos no campo da arte tais como críticos, curadores, historiadores de arte, artistas e todos aqueles que desejam refletir sobre a experiência artística em sua totalidade.

\footnotetext{
"Indiferente à classe social, hoje os alunos estão inseridos numa cultura pósmoderna, mediada pelos avanços tecnológicos, constituindo-se através das redes sociais de comunicação, interagindo com diferentes linguagens, contextos e intertextos que rompem com o paradigma moderno construído em torno de narrativas fixas, lineares e históricas. Quase todas as informações estão disponíveis e são acessadas pelos meios tecnológicos de comunicação". (LEDUR, 2012)
}

O objeto principal desta pesquisa é desenvolver uma coletânea de informações, a partir da leitura do livro "Fazendo Escola (ou refazendo-a?)", de modo, que atinjam 4 finalidades: construir um o estado da arte sobre o tema, formular métodos de ensino da arte, elaborar conteúdos programáticos aplicáveis na realidade brasileira através de cruzamento de dados das Referências bibliográficas. Ao fim e ao cabo, o objetivo maior será a formulação de um blog com contextualização e imagens coletadas durante a elaboração do projeto, dando uma relevância social a pesquisa e seus resultados.

Justifica-se a realização da pesquisa por trazer novas experiências de ensino para nossos estudantes de arte, através de uma visão crítica de quem conhece profundamente o sistema artístico à margem do circuito internacional de publicações.

2 Objetivos e metas a serem alcançados

O objetivo do projeto e compreender e identificar métodos para o ensino da arte educação com as experiências transmitida por Thierry de Duve em seu livro "Fazendo Escola (ou refazendo-a?)".

Os seguintes objetivos podem ser destacados:

- Criar um Blog com o conteúdo formulado para atender ao público interessado em arte e educação;

- Apresentar os resultados dos temas pesquisados em publicações e eventos acadêmicos;

- Realização de mostras de trabalhos desenvolvidos no projeto.

3 Metodologia

A metodologia será dividida em três fases, a saber:

- 10 Fase:

- Leitura do livro e decupagem dos tópicos de interesse para pesquisa;

- Levantamento do referencial bibliográfico;

- 2o- Fase:

- Cruzamento de dados,

- Revisão das fases anteriores; 
- Finalização da contextualização e confecção de mídias digitais e impressas;

- 3을 Fase:

- Elaboração do Blog, anexo ao site LAMIE (Laboratório de Meios Eletrônicos Interativos em Arte e Arquitetura);

- Divulgação do trabalho.

\title{
4 Conceituação Teórica
}

\begin{abstract}
"Nos Parâmetros Curriculares brasileiros, por exemplo, pode-se ler: "a estética da sensibilidade, que supera a padronização e estimula a criatividade e o espírito inventivo, está presente no aprender a conhecer e no aprender a fazer, como dois momentos da própria experiência humana, superando-se a falsa divisão entre teoria e prática»18. Combinação das faculdades inatas da percepção e da imaginação, da sensibilidade e da imaginação19, criatividade implica originalidade e inventividade, duas categorias da modernidade artística" (FAVARETTO, 1989).

"Daí surgiram, como se sabe, as proposições sobre dispositivos que materializam-se no processo de ensino, focado em "competências» e "habilidades», estes verdadeiros postulados subjacentes ao ensino de arte, pois esta concepção viria a substituir a tradicional, ou acadêmica, que focava a possibilidade do ensino de arte no "talento» individual, porque a ideologia da criatividade é democrática, igualitária, é efeito de uma concepção da arte aberta a todos, pois a criatividade seria um potencial universal" (FAVARETTO, 1989).

"A colocação de Thierry De Duve, sobre o estudante de arte ideal e o artista do futuro ideal: "ser idealizado como um infante cujas habilidades naturais de ler e escrever o mundo visual precisavam, apenas, ser corretamente monitoradas" complementa a ideia" (DUVE ,2003, 3 p. 94).

"A criatividade era uma regra, e o conceito de arte como expressão tornou-se forte, levando o ensina da arte, a educação artística, a enfatizar o "livre fazer". A expressão era parte do espírito criativo, que não poderia ser cortada, invadida, tolhida ou contaminada.
\end{abstract}

Como disse Thyerry de Duve (2003, p. 94), "uma criança e um primitivo tinham mais criatividade do que um adulto desenvolvido", apoiando-se na ideia de pureza ligada à infância ou à cultura não evoluída" (BUCHMANN, 2013).

5 Resultados e contribuições esperadas.

- Disponibilizar material sobre o tema para a comunidade acadêmica em meios digitais e impresso;

- Contribuir para área valorizar o profissional das artes visuais, sobretudo os professores desta área que são os disseminadores dos conteúdos para a formação educacional básica crítica, criativa e autônoma;

- Publicar de artigos e/ou capítulos de livros especializados sobre o tema da pesquisa;

- Participar em eventos técnico-científicos a fim de divulgar os resultados.

\section{Impactos previstos}

- Ampliar do interesse da comunidade acadêmica pela Arte através da educação como proposições relevantes ao sistema de arte contemporânea brasileira.

\section{Referências bibliográficas}

BUCHMANN, Luciano Parreira. O ENSINO E A ARTE NA CONTEMPORANEIDADE. 2013. Disponível em:

ttp://bienaldecuritiba.com.br/2013/pdf/O-ensino-da-arte-na-contemporaneidade-Luciano-Buchmann.pdf.

Acesso em: 11 jan. 2017. 
DUVE, Thierry. Palestra e lança livro Fazendo Escola (ou refazendo-a?), Porto Alegre, 2013. Disponível em: < http://www.cultura.rs.gov.br/v2/2013/03/thierry-de-duve-um-dos-grandes-nomes-da-historia-da-arte-naatualidade-realiza-palestra-e-lanca-livro-em-porto-alegre/>. Acesso em: 11 jan. 2017.

DUVE, Thierry. Quando a forma se transformou em atitude - e além. In: Ferreira, Glória, VENÃNCIO, Paulo F. (org. ). Arte \& Ensaios n. 10. Rio de Janeiro, Programa de Pós-graduação em Artes Visuais. Escola de Belas Artes, UFRJ, 2003.

FAVARETTO, Celso Furtado. ARTE CONTEMPORÂNEA E EDUCAÇÃO. 2015. Disponível em: <file://C:/Users/aa.portugal.000/Downloads/rie53a10.pdf>. Acesso em: 11 jan. 2017.

LEDUR, Rejane Reckziegel. ARTE CONTEMPORÂNEA E EXPERIÊNCIA ESTÉTICA NO ENSINO DA ARTE. 2012. Disponível em:

http://www.portalanpedsul.com.br/admin/uploads/2012/Educacao_e_Arte/Trabalho/07_12_15_1966-74071-PB.pdf. Acesso em: 11 jan. 2017. 


\section{MARIANNE NORTH: UMA “CAÇADORA” DE PAISAGENS NA MATA ATLÂNTICA BRASILEIRA (1872 - 1873)}

Renata Cesar de Oliveira - Museu de Astronomia e Ciências Afins - MAST - renataoliveira@mast.br

\section{Resumo}

Este artigo analisa um pequeno corpus composto de quatro das 112 pinturas de paisagens brasileiras pintadas por Marianne North acompanhadas de narrativas retiradas dos seus livros de memórias, editados postumamente, por sua irmã, intitulados "Recollections of a Happy Life: Being the Autobiography of Marianne North" (1892, 2 volumes) e "Some Further Recollections of a Happy Life: Selected from Journals of Marianne North" (1893). Aqui, utilizamos a tradução feita por Júlio Bandeira em "A viagem ao Brasil de Marianne North (1872-1873)" para facilitar a compreensão. Verifica-se na trajetória desta viajante e na cultura científica do oitocentos, como operam as influências teórico-científicas e artísticas que subjazem histórica e socialmente na viagem ao Rio de Janeiro e às Minas Gerais e, posteriormente, na exposição de sua coleção na Galeria Marianne North, no Royal Kew Gardens, em Londres, em 1882, monumentalizando um registro da paisagem da mata atlântica brasileira, que segundo relato de North, já se encontrava em degradação.

Palavras-Chave: Marianne North. pintura de paisagem. arte-ciência.

\section{Introdução}

Não se pode dizer que os viajantes naturalistas que vieram ao Brasil durante os séculos XVII ao XIX são um grupo homogêneo. Botânicos, zoólogos, coletores, artistas de diversas nacionalidades fizeram parte deste conjunto, os quais participaram de um processo de construção do conhecimento foram em sua grande maioria homens. Nos oitocentos, contudo, registramos três mulheres viajantes ao Brasil: Maria Graham (1785 - 1842), Elizabeth Agassiz (1822 - 1907) e Marianne North (1830 - 1890). É sobre a última viajante que este artigo vai se debruçar.

Marianne North (1830 - 1890) nasceu em Hastings e faleceu em Alderley, ambas cidades inglesas. Filha do meio de uma família da aristocracia inglesa; estudou poucos anos em colégio para moças, não se adaptando aos costumes vitorianos. O matrimônio era, para North, uma instituição que levava "a uma experiência terrível, na qual a mulher era transformada numa espécie de criada eminente" (autor, ano, p.11); portanto, sua formação foi no seio familiar e, sobretudo, por meio das viagens com o pai (membro do parlamento, pelo Partido Liberal e apaixonado por botânica).

A residência dos North era frequentada por políticos, intelectuais e artistas Faziam parte do círculo familiar dos North, o pintor australiano Robert Hawker Dowling (registrava grupos aborígenes e europeus em grandes telas e introduziu em North o desejo por paisagens extra europeias), William e Joseph Hooker (diretores do Royal Kew Gardens, pai e filho respectivamente) e Charles Darwin (1809-1882).

Marianne North faz duas viagens de circum-navegação, atravessando oito vezes o Oceano Atlântico e duas vezes o Índico e o Pacífico. Visitou os Estados Unidos, Chile, Brasil, Canadá, Índia, Jamaica, Japão, Java, Cingapura, África do Sul, Tenerife, Ilhas Seichelles, Tasmânia, Sri Lanka, Java, Bornéu (Sarawak), Singapura, Havaí, Austrália e Nova Zelândia. Viajava sozinha e utilizava uma rede de relacionamento pessoal para indicações e cartas de recomendação aos 
países e especificamente às cidades para onde viajaria, assim, contava com apoio local, tradutores para o idioma, transporte, hospedagem, entre outros.

Descobriu um novo gênero e quatro novas espécies de plantas, as quais foram batizadas em sua homenagem postumamente devido à precisão de suas pinturas e à identificação de William Hooker através delas, a saber: a) Northea seychellana - uma árvore das ilhas Seychelles; b) Nepenthes northiana - a maior das plantas insetívoras de Bornéu; c) Crinum northiana - uma das Amarílis; d) Areca northeana - palmeira do gênero Plumeria; e e) Kniphofia northiana - da família das lilácias africanas.

Viagem ao Brasil (1872 - 1873)

Depois de visitar os Estados Unidos e o Chile, tendo o casal Agassiz Ihe falado sobre suas experiências no Brasil, ela decidiu preparar a viagem. Marianne North partiu a bordo do Marinha Real Neva da Inglaterra para Lisboa, passando pela ilha da Madeira, Pernambuco e Bahia até chegar ao Rio de Janeiro, em 1871. O roteiro inicial da viagem incluía a Amazônia, contudo um surto de febre amarela naquela região a impediu de ir. Ao longo de oito meses, Marianne percorreu as cidades do Rio de Janeiro, ilha de Paquetá, de Juiz de Fora, de Barbacena, de Morro Velho, de Congonhas, de Ouro Preto, de Mariana, de Caeté, de Curvelo, de Cocais, de Santa Luzia, de Sabará, de Lagoa Santa, de Petrópolis e de Teresópolis, voltando ao Rio de Janeiro.

A extensa rede de contatos, a influência do império britânico no Rio de Janeiro e no mundo facilitou sobremaneira sua estadia e atividades aqui. Obteve carta de recomendação ao comandante do navio Marinha Real Neva; hospedou-se no Hotel dos Estrangeiros, que ficava na Praça José de Alencar. Contatou o diretor do Jardim Botânico, Carl Glasl, o qual Ihe permitiu deixar seus instrumentos de trabalho em sua residência, em Botafogo, e até pintar de sua casa. Mr. J. N. Gordon, superintendente-chefe da mina inglesa de Morro Velho Saint John Del Rey Mining Company, o Barão do Morro da Glória, foram intermediários. O Imperador D. Pedro II concedeu-Ihe dois encontros, conforme seus relatos a seguir:

"Foi-me gentilmente concedida uma audiência especial pela manhã, durante a qual passou mais de uma hora examinando minhas pinturas e tecendo comentários sobre elas, dizia-me os nomes que eu mesma desconhecia. Ele, então, pegou aquilo tudo (um volume nada leve) em seus braços e, dizendo-me que o seguisse, levou para mostrar à imperatriz..."(AUTOR, ANO)

\begin{abstract}
...Na minha segunda visita ao palácio, o imperador foi muito generoso e me mostrou o seu museu, no qual existe uma coleção magnífica de minerais. Ele teve um prazer especial de mostrar-me as amostras de carvão vindas da província do Rio Grande do Sul, que promete ser uma fonte de riquezas para o país...Ele mostrou-me depois, livros preciosos de sua biblioteca, algumas vistas do rio São Francisco. Um lugar me atraiu sobremaneira: era onde um dos antigos companheiros de Humboldt tinha se estabelecido em um modesto chalé. Ele havia cultivado todos os tipos de plantas raras, como palmeiras, à sua volta, e a mata virgem original descia até o seu quintal (AUTOR, ANO, p. 195).
\end{abstract}

É raro encontrar nos relatos de viagens citação do nome dos mateiros, daqueles que tinham o conhecimento popular das plantas. Marianne North é um destes casos. Ela faz questão de registrar o nome de José Luis Corrêa, quando da passagem por Petrópolis, já voltando para o Rio de Janeiro.

“...faz merecedor do nome de registro. Ele foi o melhor guia que se podia desejar para uma viagem dessas e tinha um conhecimento maior que o ordinário sobre plantas e outras coisas da região, muito lamentei não compreender melhor a língua para usufruir de suas informações. (autor, ano, p. 197) 
Influências na Arte

Marianne North teve contato com diversos pintores, desde os que foram seus professores até aqueles que admirava. A holandesa Magdalena van Fowinkel (1785- - 1875), sua professora de pintura de flores, arranjo de cor e de conjunto; Valentine Batholomew (1799 - 1879) foi seu professor em técnica floral em aquarela; Edward Lear (1812 - 1888) pintor a óleo de influência Pré-Rafaelita; Frederic E. Church (1826-1900), pintor norte-americano de paisagem, com quem teve encontro em Nova York e Martin Johnson Heade (1819 - 1904), também pintor, ambos da Escola do Rio Hudson; Robert Hawker Dowling (1827-1886), pintor australiano, ensinou a técnica da pintura a óleo para retratar costumes e pessoas; o pintor inglês Willian Hunt (1827-1910) que, em 1848, fundou a Irmandade Pré-Rafaelita, um grupo artístico entre o espírito do romantismo e as novos revivalismos do século XIX, sobre quem Marianne disse admirar o estilo.

Na parte brasileira de relatos de viagens Marianne, não encontramos uma definição específica de natureza. Marianne usa adjetivos para qualificar e pontuar o dia, descreve minuciosamente as plantas, o clima, às vezes, animais e costumes locais. A impressiona ver que os brasileiros não dão importância à natureza como ela dá e em várias passagens registra queimadas e a destruição da mata, como a seguir:

"Meu amigo Mr. Hinchcliff, me dera minuciosas instruções, por escrito, sobre como achar um dos seus passeios favoritos, onde, prometia ele, eu veria o mais perfeito emaranhado tropical. Caminhei pela lama e debaixo de chuva para encontrar e, hélas!, apenas o carvão e as cinzas do que fora"(AUTOR, ANO)

Concepção de Ciência: entre Humboldt e Darwin

Alexander von Humboldt (1769 - 1859) influenciou grande parte dos naturalistas viajantes. Considerado pai da biogeografia, fez três viagens de circum-navegação e publicou obras como "Cosmos: projeto de uma descrição física do mundo" e "Quadros da Natureza", entre outras. Humboldt concebia uma união compensatória entre intuição, pensamento racional e experimentação com o objeto externo (natureza). Portanto, arte e ciência eram complementares. Deveria existir um movimento de construção de uma direção históricohumanista para a tarefa científica. Usa uma linguagem poética que evocaria uma comunicação perfeita; para alguns utopia, para outros, romantismo. Humboldt não acreditava numa ciência autônoma, auto-reguladora e autocontida. Para ele, o progresso cognitivo da humanidade só avançaria quando o intelecto e a sensibilidade atuassem de modo indissoluvelmente unido. Este saber holístico postulou a unidade indissolúvel entre estética, moral e ciência (RICOTTA, ANO, p 44). Humbold morre exatamente quando Charles Darwin publica o livro "Da origem das espécies por via da seleção natural ou a preservação das raças favorecidas na luta pela vida" (1859).O naturalista e amigo da família North certamente influenciou-a.

Segundo Ricotta(ano), quando as viagens são assimiladas na sua totalidade pode haver um efeito de estetização do mundo provocado pela sua realização simbólica. O mundo interno se expande como se imitasse a "majestade" da vegetação tropical, o prazer do belo se intensificasse gradativamente e o isolamento de outrora, agora fosse transcendência. Com isso, a totalidade é experimentada nessa intensidade e expansão. A coleção de quadros de Marianne North musealizada em Kew torna esse percurso um monumento-estético. Permite ao espectador uma viagem, um conhecimento e um reconhecimento de si, do outro e de si no outro. É também um tipo de vulgarização da ciência.

A natureza que se depreende das obras de Marianne North está também relacionada ao conceito humboldtiano, quando não isola a espécie, e sim a insere no todo, integrando-a e aproximando-a do expectador. Para Humboldt, a natureza era: "ora totalidade, ora força 
interna que move, ora protótipo secreto de todos os fenômenos e se manifesta ao sentido e ao sentimento simples do homem como algo terreno de preferência, algo que lhe é aparentado bem de perto." (autor, ano)

A seguir, algumas imagens e narrativas de Marianne North, por ocasião da viagem ao Brasil: Imagem 1 - Vista do Morro do Corcovado, perto do Rio de Janeiro (Botafogo), 24,8 x 35,6 cm (original) - Anexo

"A cada dez minutos, os bondes puxados por mulas passavam pela porta do hotel, e todos os dias às seis horas me levavam para o famoso Jardim Botânico, a cerca de quatro milhas dali. Todo o caminho é deleitoso, contornando as bordas de duas enseadas, ambas parecendo pequenos lagos, com as estradas escondidas, as montanhas ao seu redor têm um formato bastante estranho, acabando de um lado geralmente num precipício e, do outro, cobertas de florestas até o topo... e que florestas! Não os bosques monótonos da Europa, mas infinitas variedades de formas e cores, do branco das grandes folhas das trombeteiras até a delicadeza das palmeiras e quaresmeiras cor de coral, púrpura e lilases. ...Em seguida, vinham os jardins dos casarões, longo da estrada, cheios de árvores nobres, flores e frutas luxuriantes, em um dos trechos, uma espécie de pântanos com touceiras de bambu indiano proporcionava aos olhos um descanso agradável após a queima provocada pelo ardor do viço berrante dos jardins. Esse percurso era sempre encantador e alegre para mim e eu queria que as mulas não passassem com tanta pressa. Esses jardins perto de Botafogo eram para mim uma delícia sem fim e, como o bondoso diretor austríaco permitiu-me manter meu cavalete e outras coisas em sua residência, sentia-me completamente em casa ali. ....(AUTOR, ANO,p. 158)

Imagem 2 - Pândanos e alameda de palmeiras-reais no Jardim Botânico do Rio de Janeiro, 25 $x 35 \mathrm{~cm}$ (original)- Anexo

...É claro que meu primeiro trabalho foi a tentativa de fazer um esboço da grande
avenida de palmeiras-reais, tantas vezes descrita. Ela tem pelo menos meia milha de
cumprimento e, apesar de só terem 30 anos, as árvores chegam a 100 pés de altura.
Elas se assemelham à couve-palmeira das Índias Ocidentais, embora menos graciosas,
com as mesmas grandes bainhas verdes em seus caules, que se descascam e caem
com as folhas maduras, se desprendendo cerca de cinco por ano, cada uma deixando
um anel distinto sobre o troco liso. A base do tronco era muito proeminente,
parecendo um bulbo gigante." (AUTOR, ANO,p. 159)

Imagem 3 - Vista do Jardim do Dr. Lund em Lagoa Santa - cacto (Cereus), arácea (Philodendron), palmeira (Acrocomia) e orquídea (Cattleya) - $35 \times 25 \mathrm{~cm}$ (original) - Anexo

“.... Dr. Lund tinha uma boa biblioteca. Como lia muitos jornais estrangeiros, parecia bem informado sobre assuntos gerais e sobre o que estava acontecendo na Europa. Seu jardim era cheio de curiosidades e espécimes raros, colecionados e plantados por ele. O tronco de uma enorme tamareira estava coberto com uma quantidade de flores lilases Laelia e um cacto lindo, de florescência noturna e este caía em festões como imensas grinaldas de uma outra árvore, ou subia por uma das paredes como uma centopéia gigante, lançando suas patas ou raízes, dos dois lados para melhor se agarrar a ela parecendo mudar completamente suas características por forças das circunstâncias. Pela manhã tinha feito uma pintura de uma rara pontederiácea azul que o doutor havia conseguido, com grande esforço, que crescesse em seu lago; ele ficou muito feliz...."(AUTOR, ANO)

"O Philodendron lundii era outra de suas plantas deveras curiosas, um tipo de copode-leite de folhas cortadas e trepadeira, cujas folhas, que mostravam a hora do dia por meio da temperatura, eram quase tão eficientes quanto um relógio de sol." (AUTOR, ANO,(p.185) 
Imagem 4 - Vista do Colégio Lazarista no Caraça, Minas Gerais com a flor-de coral - (Erithrina corallodendron) em primeiro plano - $25 \times 35 \mathrm{~cm}$ (original) Anexo

\begin{abstract}
“Padre Superior Júlio levou-me para ver a Biblioteca e o jardim, dizendo que, em 17 anos, eu era a primeira mulher que ali entrava. Havia cerca de 250 alunos nesse colégio e, além do meu amigo, nove padres; mas que diferença existia entre estes homens! Foi-me dito que havia outro padre pelo qual eu me interessaria, já que era um naturalista, mas estava ausente. O padre Julio me falou de sua vontade de começar um museu e dar aulas de história natural, mas os brasileiros não viam que vantagem isso traria e não gostavam de estudar essas coisas."(AUTOR, ANO,p.191)
\end{abstract}

\title{
Conclusão
}

Entendemos Marianne North e seu trabalho artístico-científico como um legado de registro de experiência da natureza, uma vez que ao final de todas as suas viagens, ela doou suas mais de 800 obras para o Royal Kew Gardens, instalando-os a partir de um projeto museográfico e reforma da galeria que levou seu nome. Desta forma, todas as imagens da natureza ficariam disponíveis nesta "galeria-monumento" numa espécie de vulgarização daquela que foi a sua empreitada: apreender a natureza num continuum arte - ciência - vida feliz. Sua narrativa e iconografia são também formas de apreender e conhecer a natureza. Destacamos o seu reconhecimento de saberes locais, como o de um guia de Petrópolis a quem registra o nome em seu diário José Luis Corrêa e também do uso da rede de influência inglesa e real, ao conseguir dois encontros com o Imperador D. Pedro II.

\author{
Bibliografia e Fontes \\ BANDEIRA, Julio. A viagem ao Brasil de Marianne North (1872 - 1873). Rio de Janeiro: Sextante, 2012.
}

BELUZZO, A. M. M. O Brasil dos Viajantes. 2a ed. Rio de Janeiro: Objetiva, 1999.

BERGER, John. Modos de Ver. Rio de Janeiro: Rocco, 1999.

COSTA, Kássia Pereira da. A arte de Marianne North:entre tempos e histórias do século XIX. (Dissertação de Mestrado - Programa de Pós Graduação em História Social UNIRIO). Rio de Janeiro: UNIRIO, 2015.119f.

CAVALCANTI, Ana Maria T. et al. (Org.). Oitocentos: A arte brasileira do Império à Primeira República. Rio de Janeiro: EBA: UFRJ, Dezenovevinte, 2008.

DIAS, Elaine. Paisagem e Academia: Félix-Émile Taunay e o Brasil (1824 - 1851). Campinas, Unicamp, 2009. DICKENSON, John. Marianne North: uma naturalista do século dezenove no Brasil?. Cadernos Pagu. Vol. 15. N 7. Jul-dez/2000. P 145-164.

GLADSTON, Lynne Helen. The hybrid work of Marianne North in the context of nineteenth century visual practice(s). Nottinghan: University of Nottnghan ((PhD thesis). 2012.

HEIZER, Alda et al. (Orgs.). Ciência, Civilização e Impérios nos Trópicos. Rio de Janeiro: Access, 2001.

HODGE, Geoff. Botânica para jardinistas: A arte e a ciência do jardinismo explicadas e exploradas. São Paulo: Ed. Europa, 2014.

KURY, Lorelai. Homens de ciência no Brasil: impérios coloniais e circulação de informações (1780-1810). História. Ciências. Saúde. Saúde Manguinhos. Vol 11. Suplemento 1. 2004. p. 109 -129.

As artes da imitação nas viagens científicas do século XIX. In: ALMEIDA, Marta de e VERGARA, Moema (Org. ). Ciência, História e Historiografia. São Paulo/Rio de Janeiro: via Lettera/MAST, 2008, p. 321-333.

NORTH, Marianne. ADDINGTON, John (Org.). Recollection of a happy life. Being the autobiography of Marianne North. Volume I e II. London \& New York: Macmillan \& Co. 1892 
Some Further Recollections of a happy life: selected from the journals of Marianne North. London \& New York: Macmillam \&Co, 1893.

RICOTTA, L. Natureza, Ciência e Estética em Alexander von Humboldt. Rio de Janeiro: Mauad, 2003

WULF, Andrea. A invenção da natureza. A vida e as descobertas de Alexander von Humboldt. São Paulo: Crítica, 2016.

KURY, Lorelai (Org). Usos e Circulação de Plantas no Brasil - Séculos XVI - XIX.1a Edição. Rio de Janeiro: Andrea Jakobson, 2013.

LATOUR, Bruno. Ciência em Ação. São Paulo: UNESP, 2011.

LOPES, Maria M., e HEIZER, A. (Orgs). Colecionismos, práticas de campo e representações. Campina Grande: EDUEPB, 2011. 280 p.

M. B. W. "A Notable Woman Flower Painter". In: The Art Amateur, Vol. 7, No. 6 (Nov., 1882), p. 117. Disponível em: http://www.jstor.org/stable/25627760.

MILLER, David Philip; REILL, Peter Hans (Orgs.). Vision of empire: voyages, botany and representations of nature. Cambridge: CUP, 1996.

PAYNE, M. Marianne North: a very intrepid painter. Richmond: KPRBG, 2011. 


\section{MORCEGOS PODEM DOAR SANGUE?

José Costa Júnior - Instituto Federal de Minas Gerais - Professor de Filosofia e Sociologia - UFMG -

jose.costajunior@yahoo.com.br

Resumo

A partir do samba "Quando o Morcego Doar Sangue", abordamos a possibilidade da compreensão naturalista do humano e dos processos sociais, com o objetivo de pensar o Brasil e o brasileiro a partir de novos pressupostos. Num segundo momento, visitamos possibilidades evolutivas para o desenvolvimento da cooperação entre as formas de vida. Por fim, tratamos de possibilidades de ampliação das relações de confiança e cooperação em nossa sociedade.

Palavras-Chave: Brasil. Sociedade. Cooperação.

Introdução

Em 1990, os letristas Cosme Diniz e Rosemberg compuseram a canção Quando o Morcego Doar Sangue, que ficaria famosa na voz do sambista Bezerra da Silva. Identificado com o que se denomina como "malandragem" nas definições dos tipos sociais do Brasil, Bezerra da Silva interpretava a letra de viés crítico à situação política do Brasil à época. A crítica alcançava também, de uma forma mais geral, o próprio modo de ser do brasileiro, ou, numa concepção mais ampla, que somos e o que podemos ser, configurando uma ética do Brasil. Cabe aqui a íntegra do samba:

\section{Quando o Morcego Doar Sangue}

Para tirar meu Brasil dessa baderna

Para tirar meu Brasil dessa baderna

Só quando o morcego doar sangue

E o saci cruzar as pernas

Só quando o morcego doar sangue

E o saci cruzar as pernas

Toda nossa esperança é somente lembrança do passado

A alta cúpula vive contagiada pelo micróbio da corrupção

O povo nunca tem razão, estando bom ou ruim o clima

Somente quem está por cima é a tal dívida externa

E o malandro que faz aquele empréstimo

E leva os vinte por cento dela para tirar!

Já não há alegria de noite e de dia a tristeza não para

A vida custando os olhos da cara

E não temos dinheiro para comprar

Quem governa o país é muito feliz, não se preocupa

Tem tudo de graça, não esquenta a cuca

E o custo de vida só sabe aumentar 
Antigamente governavam decente, sem sacrilégio

Hoje são indecentes, cheios de privilégio

É só caô caô pra cima do povo

Promessa de um Brasil novo

E uma política moderna

Mas só quando o morcego doar sangue(AUTOR, ANO)

Há na composição uma descrição crítica do comportamento tradicional da moralidade do nativo brasileiro, principalmente daquele que busca lidar com a coisa pública. No entanto, há também uma compreensão histórica e sociológica do brasileiro e de como esse lida com a realidade e a estruturação de sua polis, de modo a buscar a manutenção de estruturas sociais que beneficiam a poucos ao custo de muitos. Há também um pessimismo sobre as possibilidades de se sair dessa situação, uma vez que é impossível reestruturar aquilo que somos e o que podemos ser ("Só quando o morcego doar sangue"). Aqui, é possível identificarmos uma leitura histórico-sociológica de senso comum, que identifica o nativo brasileiro como alguém que não se enquadra totalmente em modelos e padrões, como num possível "processo civilizatório", conforme a definição de Norbert Elias (1939) sobre a padronização e organização da vida social nos últimos séculos. Essa leitura do brasileiro como elemento que escapa à conformações e regramentos, seja pela sua ginga oriunda da hibridez cultural, seja pelo "jeitinho brasileiro" inerente à sua condição, são comuns e tipificadas na cultura popular e no senso comum: "isso é coisa de brasileiro".

As hipóteses lançadas pela sociologia brasileira dos séculos XIX e XX, buscaram compreender a sociedade brasileira, abordando de maneira indireta seus traços. Podemos observar variados quadros e exemplos, como o caso de Euclides da Cunha (1866-1909), sob forte inspiração da ciência pretensamente determinista de progressista, dá a "Os Sertões" (1902) um tom de questionamento sobre a mestiçagem. Seria esse traço bom ou ruim? Já Gilberto Freire (1900-1987), ao analisar a formação da sociedade brasileira, vê características curiosas na relação entre os habitantes dos locais diferentes da colônia, "Casa-grande \& Senzala", relações que estruturaram o modo diferenciado sob o qual o brasileiro existe. Sérgio Buarque de Holanda (1902-1982) vai além e nomeia essa característica distintiva e essencial do brasileiro, a "cordialidade", conforme lemos em suas Raízes do Brasil (1936). Darcy Ribeiro (1922-1977) atesta o caráter completamente novo dessa sociedade que surge nesses trópicos, uma "Nova Roma", na sua descrição do "Povo Brasileiro" (1995), formada por variadas origens e relações. Um último exemplo é a proposta de Roberto Damatta (1936), que busca nas nossas diferenças a explicação de "O que faz o brasil, Brasil?" (1984). O que podemos ver em tais hipóteses, de maneira geral, é uma explicação que compreende o brasileiro como algo diferente, seja por causa da formação da sua história, seja por causa do modo como se dá a estruturação de sua sociedade.

A compreensão de senso comum ("brasileiro malandro e de malemolência"), explicitada na letra cantada por Bezerra da Silva se aproxima da compreensão da tradição sociológica brasileira, que, conforme Jessé de Souza (2015), insiste em nos retratar como diferentes em relação a algum aspecto de outras sociedades, numa análise a partir de algum padrão e/ou expectativa social e moral. No entanto, uma questão se coloca: será que os brasileiros são tão negativamente diferentes assim? Se for assim, só podemos pensar em mudanças na vida brasileira somente quando houver uma alteração brusca na natureza, um milagre. Ou, conforme retratado na canção de Bezerra da Silva, só "quando morcego doar sangue"? 
Antes de seguirmos, é necessária uma discussão de fundo sobre os modos de compreensão do humano. O filósofo Francis Wolff desenvolveu um trabalho comparativo de considerável relevância antropológica e filosófica, intitulado "Nossa Humanidade" (2010). Ali, Wolff lista quatro modelos antropológicos-filosóficos que atravessam a tradição ocidental, e que, de algum modo, enquadram o escopo da condição humana - o que somos e o que podemos.

O primeiro modelo é o "humano racional", que podemos identificar como platônicoaristotélico, capaz de lidar com a realidade de forma clara e direta. Esse humano racional descobre verdades sobre a realidade e sobre si, possui o mundo a seu dispor e possui o controle sobre o próprio eu. Já o segundo modelo, moderno e cartesiano, pode ser descrito pela relação entre mente e corpo, onde continua sujeito de si, porém, agora esclarecido sobre sua condição e sobre os limites de sua corporeidade. Oriundo da ciência moderna, esse sujeito pensa, investiga sua própria subjetividade e luta contra si, mas já não é mais pleno como o modelo anterior. O terceiro modelo é nomeado por Wolff como "humano estrutural", modelo típico das ciências humanas, envolvido por estruturas que definem sua visão da realidade e sua existência. No dito atribuído a Karl Marx: "Os homens fazem sua história, mas sob condições determinadas e impostas." Esse é o modelo das ciências humanas e sociais, onde se inscreve a tradição sociológica brasileira. Nessa concepção, a humanidade varia, conforme sua situação, história, modos de produção da vida e circunstâncias.

Por fim, oriundo do desenvolvimento da hipótese darwiniana sobre o desenvolvimento da vida, temos o modelo do "humano neuronal", uma compreensão da condição humana a partir de um quadro naturalista e evolucionista, sem pretensões racistas, progressistas e de superioridade, mas enquadrando a humanidade no mundo natural. A razão e a mente não são aqui atributos especiais, mas sim capacidades desenvolvidas naturalmente, que surgiram ao longo de processos de adaptações que não envolvem progresso nem perfeição. Há uma natureza humana comum, observada através de uma unidade psicológica da humanidade, que faz com os povos não sejam tão diferentes assim uns dos outros. O animal humano, surgido há algo entre 100 e 200 mil anos, muda pouco. Wolff aborda também as consequências políticas e morais de cada um dos modelos, como os riscos da exacerbada razão ocidental, levantada pelo modelo do humano-racional, o dualismo metafisicamente questionável do modelo cartesiano, o conflito entre agência livre e estrutura do terceiro modelo e a animalização humana inerente à visão darwiniana do modelo neuronalmaterialista.

Para nossos objetivos, podemos abordar uma transição do modelo antropológico-filosófico estrutural para o naturalista-neuronal e suas consequências. Nesse movimento, o ritmo da compreensão da estruturação e do funcionamento das sociedades e agrupamentos humanos também muda. Compreenderemos o humano como fruto do processo natural de desenvolvimento da vida, conforme a compreensão de Charles Darwin e seus desenvolvimentos posteriores, com nossas capacidades originadas evolutivamente. Esse debate sobre a natureza da compreensão humana e os meios para abordá-la ainda se encontra em aberto, mas nos propomos a fazer algumas reflexões, principalmente a partir da compreensão naturalista da condição humana, e os fenômenos que podemos observar no agrupamento humano que encontramos no Brasil.

\section{Morcegos doando sangue?}

Conforme adiantamos, a compreensão comum do comportamento de morcegos, levou os compositores a afirmarem, em "Quando o Morcego Doar Sangue", que a estruturação política e social do Brasil só mudaria se tais organismos egoístas compartilhassem seu principal alimento. Assim, dada a sua natureza, seria impossível que morcegos doassem sangue e que brasileiros mudassem. No entanto, o biólogo Gerald Wilkinson (1984) observou que morcegos 
hematófagos, que se alimentam do sangue das feridas de animais de grande porte, doam sangue. Devido à dificuldade de acesso ao seu alimento, tais animais regurgitavam pequenas quantidades do sangue que traziam em seus companheiros, com os quais não compartilhavam nenhum laço de parentesco, mas que não conseguiam alimento. Havia uma repetição do fenômeno dentro dos grupos, situação que mostra indícios de memória de reciprocidade entre os indivíduos, conforme Wilkinson (1985).

Essa descrição do comportamento dos morcegos, que vai contra a noção comum envolvida no ditado "farinha pouca, meu pirão primeiro", própria das relações entre organismos egoístas, foi definida por Robert Trivers como altruísmo recíproco (1971). Na análise de Trivers sobre as possibilidades de explicação evolutiva do traço altruísta em diversos organismos, para além do altruísmo entre criaturas aparentadas entre si, uma nova modalidade de altruísmo pode evoluir, onde há uma memória mínima entre os indivíduos envolvidos. Assim, a reciprocidade é um traço observável entre alguns organismos vivos, como no caso dos morcegos e humanos. Identificado como comportamento cooperativo, este traço pode trazer benefícios para a sobrevivência e manutenção das formas de vida, para além da preocupação do organismo consigo próprio.

Além da maior complexidade das dinâmicas do mundo humano, a evolução permeou nossa espécie com uma flexibilidade comportamental muito mais vasta do que a de morcegos - ou qualquer outra forma de vida. No entanto, ainda somos animais, oriundos do processo natural de desenvolvimento da vida. Nesse contexto, diversas investigações sobre as dinâmicas evolutivas da condição humana têm sido desenvolvidas nas últimas décadas. E muitas deles envolvem também a preocupação com a evolução do traço social entre humanos. Um exemplo é a análise de Yuval Harari (2011), que envolve uma série de elementos evolutivos, principalmente as análises sobre a cooperação. Seu argumento principal defende que a nossa espécie domina o mundo pois é a única forma de vida capaz de desenvolver cooperação flexível de larga escala, condição que torna possível o desenvolvimento de crenças em elementos inexistentes no mundo natural, como deuses, nações, dinheiro, instituições e direitos humanos. A cooperação humana em larga escala produziu todos os elementos que formam a vastidão da cultura humana, porém, nem sempre para o bem-estar de todos, já que nossa espécie produziu a Capela Sistina, mas também construiu o campo de concentração.

Segundo a posição de Harari, a cooperação social é a nossa chave para a sobrevivência e a reprodução "Não basta que homens e mulheres individuais conheçam o paradeiro de leões e bisontes. É muito mais importante para eles saber quem, no seu bando, odeia quem, quem está a dormir om quem, quem é honesto e quem é trapaceiro." (HARARI: 2011). Nesse sentindo, conforme o argumento da psicologia evolucionista, ao longo do tempo do desenvolvimento da evolução humana, as dinâmicas das relações cooperativas estruturaram nossa psicologia social. Nosso senso moral foi moldado por tais circunstâncias e podemos observar tais traços na desconfiança que sentimos frente à falhas e traições nas dinâmicas das relações sociais. No entanto, nem sempre as dinâmicas cooperativas dentro das relações humanas possibilitam resultados positivos para todos. Estruturações e dinâmicas sociais específicas podem fazer com que tais relações não se efetivem, assim como outras possibilidades podem favorecer as dinâmicas de cooperação. Mesmo que seja um fenômeno possível entre os indivíduos da nossa espécie, não é sempre que ocorre, assim como no caso dos morcegos hematófagos observados por Wilkinson. Felizmente, algumas circunstâncias produzem ambientes de ampliação da confiança e dos laços de cooperação entre humanos.

\section{Reforçando laços}

De acordo com as observações do epidemiologista Richard Wilkinson, nossa espécie esteve exposta a dinâmicas evolutivas onde estabeleceram-se conflitos de interesse, relações e 
amizade, aprendizagem, ajuda e proteção, sempre permeados pela cooperação. As sociedades desiguais contemporâneas são marcadas por interações competitivas entre seus membros, com menos oportunidades para a interação cooperativa. As consequências biológicas de ambientes sociais desiguais são as associadas ao "estresse", que surgem através da exposição prolongada do corpo a respostas para os constantes "combates" da vida contemporânea, onde vigoram desafios e dificuldades constantes. Desse modo, "as consequências graves para a saúde surgem quando a ansiedade e a estimulação fisiológica são prolongadas ou se repetem com certa frequência, ao longo de semanas, meses ou anos." (WILKINSON, 2001). Em tais circunstâncias, a qualidade da coesão social tende a deteriorarse, com a diminuição das interações e da confiança entre os indivíduos, juntamente com a queda na participação da vida comunitária, e o aumento da hostilidade e da violência comum entre as pessoas.

As instituições presentes em um estado também possuem um papel nas relações entre os indivíduos. Uma estruturação social que contenha construções coletivas às quais todos os indivíduos demonstrem cuidado mínimo, ampliam a confiança e a cooperação nas dinâmicas sociais. Segundo o argumento de Harari (2011), o que nomeamos como "instituições" é fruto da crença comum de uma coletividade, já envolvida num empreendimento cooperativo. $A$ crença comum de indivíduos num "primado da lei", juntamente à limitação das ações com base nessa crença serve como exemplo. Nesse sentido, a confiança e a estruturação de instituições contribuem para o florescimento das relações sociais. Um argumento próximo foi desenvolvido por Daron Acemoglu e James Robinson (2010) em Por que as nações fracassam. Tais autores defendem que muito do desenvolvimento de estados se deve à presença de instituições inclusivas, que possibilitam que a população tenha acesso à oportunidades e recursos, promovendo assim desenvolvimento coletivo. Porém, se as instituições forem extrativistas, erguidas com o propósito de favorecer um grupo ou parcela de indivíduos, não envolverá a todos e o desenvolvimento comum não acontecerá. Uma possibilidade de compreensão desse quadro é que, historicamente, a organização social brasileira não tenha fomentado uma sociedade igualitária e possuidora de instituições confiáveis, de estímulo à confiança entre os indivíduos, onde a lógica da "farinha pouca, meu pirão primeiro", de caráter exploratório e pouco cooperativo se incrustou nas nossas relações sociais, em seus mais variados âmbitos. Isso não é um traço exclusivo de nossa gente, mas sim uma possibilidade à qual todas as relações humanas estão abertas. Um agrupamento mais igualitário, que promova oportunidades e recursos de forma mais distribuída, juntamente a construções institucionais "maiores que todos nós" e que sejam promotoras da confiança e estabilidade podem contribuir para a ampliação da confiança e cooperação coletivas.

5 Malandragem de verdade

Aberta a possibilidade de morcegos doarem sangue, tanto metaforicamente quanto factualmente, surge a possibilidade de ampliação do ritmo da confiança para além de relações exploratórios e pouco cooperativas. Nesse contexto, podemos pensar na manutenção da identidade brasileira a partir de outras frentes. Eduardo Giannetti (2016) nos alerta para a possibilidade da estruturação de "trópicos utópicos", estabelecendo a alegria com a existência própria de nossas terras, junto com preocupações mais ampla com a existência, que não é o nosso forte. $O$ "jeitinho" e a "malandragem" tradicionalmente atribuídos, o pouco cuidado com o outro e com a coisa pública, caracterizado pelo dito "levar vantagem em tudo", demonstram as dificuldades de nossas dinâmicas de confiança. Por outro lado, nossa luta constante contra as dificuldades do subdesenvolvimento, junto ao modo espontâneo e convidativo através dos quais lidamos com os desafios, são riquezas de nossa cultura. Não é necessário jogar fora o bebê junto com a água do banho. Morcegos podem doar sangue, 
podemos ser indivíduos confiáveis e cooperativos, envolvidos em projetos de comum desenvolvimento, com ambientes que contribuam para isso, melhorando nossa convivência conjunta. Nada que Mano Brown e os Racionais MC's já não tenham cantado, em sua "Fórmula Mágica da Paz": "Demorou mas hoje eu posso compreender, que malandragem de verdade é viver."

\section{Referências}

ACEMOGLU, Daron; ROBINSON, James. Por que as nações fracassam. Rio de Janeiro: Elsevier, 2011

CUNHA, Euclides. Os Sertões. Rio de Janeiro: Record, 2003.

DAMATTA, Roberto. O que faz do Brasil, Brasil? Rio de Janeiro: Rocco, 1989.

ELIAS. Norbert. O processo civilizador. (2 Volumes). Rio de Janeiro: Zahar, 1993.

FREYRE, Gilberto. Casa-Grande \& Senzala. Rio de Janeiro. Global Editora. 2005.

GIANNETTI, Eduardo. Trópicos Utópicos. São Paulo: Cia. das Letras, 2016.

HARARI, Yuval. Sapiens: História breve da humanidade. Lisboa: Vogais, 2015. (2011)

RIBEIRO, Darcy. O povo brasileiro: A formação e o sentido do Brasil. São Paulo: Cia. das Letras, 1995.

TRIVERS, Robert. “The evolution of reciprocal altruism”. In: Quarterly Review of Biology. Vol. 46, pp. 35-57, 1971.

WILKINSON, Gerald. "Reciprocal food sharing in the vampire bat." In: Nature, Vol. 308, N. 5955, pp. 181-184, 1984.

WILKINSON, Gerald. "The social organization of the com-mon vampire bat." In: Behavioral Ecology and Sociobiology, Vol. 17, N. 2, pp. 123-134, 1985.

WILKINSON, Richard. Mind the Gap: Hierarchies, Health, and Human Evolution. Yale: Yale University Press, 2001. WOLFF, Francis. Nossa Humanidade. São Paulo: Unesp, 2011. 


\section{ENFRASCANDO OS CHEIROS: A IMPORTÂNCIA DO OLFATO COMO OBJETO DE PESQUISA}

Palmira Margarida Ribeiro da Costa Ribeiro - Doutoranda HCTE-UFRJ - pmargarida@ie.ufrj.br

Nadja Paraense dos Santos- Professora do HCTE-UFRJ - nadja@iq.ufrj.br

Resumo

Este trabalho tem como objetivo propor o estudo da historiografia dos cheiros, através das perspectivas das sensibilidades e da História das Ciências e, nesta, para além a interação com o tema saúde. O sentido olfativo como objeto de estudo é permeado por preconceitos e, muitos desses, fomentados pela própria história e avanço do homem na era da razão. Os cheiros são tratados como irrelevantes ou frivolidades e, por isso mesmo, de menor importância coletiva ou social. Os cheiros exalam histórias e costuram narrativas e memórias, já que, de todos os sentidos, o olfato é o que está relacionando diretamente e biologicamente à memória. A re-negação do sentido olfativo nos estudos historiográficos e nas ciências (por um longo período) levanta questões pertinentes sobre nossa cultura e comportamento no Brasil. Diante do silenciamento dado aos aromas sua apresentação de forma material e menos sublimar faz-se necessária. Aqui, uma tentativa de enfrascar ser tão etéreo a fim de analisar sua importância que se faz, silenciosamente, presente em nossas vidas e concepções.

Palavras-chave: Olfato. Sensibilidade. Sensoridade. História. Arte. Emoções.

Introdução

O olfato foi marginalizado porque é percebido como ameaça ao regime abstrato e impessoal da Modernidade, em virtude de sua radical interioridade, de sua propensão para a transgressão de fronteiras e de sua potência emocional (CLASSEN, 1996, p.15).

No período do lluminismo (século XVIII), o sentido olfativo foi subjugado, a fim de assinalar mais uma distinção afirmativa da superioridade do homem sobre outros animais. O sentido da visão foi celebrado como de maior importância ao homem racional, sendo o ato de cheirar julgado como algo indigno de seres civilizados. A visão, a audição, o paladar e o tato sobrepujaram-se, enquanto o olfato foi ocultado ao lugar do que é inferior, bestial, sem cognição, não racional e não contribuinte para o processo civilizatório ${ }^{37}$.

De fato, o sentido olfativo é considerado o mais primitivo, já que ele possui ligação direta com o hipotálamo, não tendo acesso ao tálamo, como todos os outros sentidos. O tálamo, que é uma parte do sistema límbico, reorganiza todos os outros estímulos sensoriais, transpondoos para as suas devidas áreas corticais a fim de serem interpretados. Apenas os sinais do olfato são enviados diretamente ao córtex cerebral sem que cheguem a ser decodificados (filtrados) pelo tálamo. Ou seja, o que se cheira é o que se leva ${ }^{38}$ e tudo isso ocorre em menos de um segundo, não há como fugir e não é possível escolher parar de respirar.

Os sentidos da visão, do tato, do paladar e da audição são controláveis, o olfato não, ele é fugaz. Se o cheiro não é "filtrado", ele precisaria, diante de um processo civilizador que se

${ }^{37}$ Referência aos estudos de Norbert Elias sobre o processo civilizador dos modos e comportamentos na Europa. ELIAS, Norbert. O processo civilizador: Uma história dos costumes. Rio de Janeiro: Jorge Zahar Ed., 1994

${ }^{38}$ Estudos recentes como do pesquisador Fábio Papes (UNICAMP) aponta que "A construção celular e molecular do epitélio olfatório depende de instruções genéticas e também se altera conforme a experiência de vida". Retirado de http://revistapesquisa.fapesp.br/2017/05/23/variacoes-do-olfato/ acessado em 22/09/2017 
esforçava para conter e disciplinar as emoções, ser equilibrado ou silenciado. Até o final do século XVIII, os perfumes e produtos corporais eram em maioria de base animal ou pujantes, quentes, resinoides e raízes que exalavam aromas viscerais, herbáceos e telúricos junto aos corpos humanos, já que, acreditava-se, esta junção de cheiros entéricos contribuía para o vigor, a virilidade e a energia.

No entanto, o uso dos aromas com tonalidades animais/ entéricas passou a ser reprovado junto ao crescimento dos debates higienistas e dos avanços da química, constatou-se que a utilização de material orgânico nos corpos humanos era prejudicial à saúde. Algália ${ }^{39}$, almíscar $^{40}$, e âmbar cinzento ${ }^{41}$, aromas retirados de fezes e vísceras de animais, passaram a ser condenados. No entanto, não era apenas a saúde que estava em jogo e a questão higiênica servia mais como tempero ideológico. Não que o estamento da higienização não estivesse em evidência, mas ele não vinha somente como salvaguarda da saúde, mas também da moralidade, do comportamento civilizado e do silenciamento/controle das emoções, das 'paixões' (HUME, 1739), pois os cheiros de origem animal aguçavam, por ressonância, a condição de bicho, as vísceras, fezes e sensações emocionais mais animalescas e primitivas. O comportamento emocional e as sensibilidades passam a ser questão de civilidade e não exatamente de saúde.

Era preciso separar em dois mundos: ócio - sujeira e higiene - moralidade. Era necessário, por exemplo, ter o pudor com o corpo em relação ao toque da água e da sublimidade sedutora dos aromas no corpo. Antes da domesticação do olfato fomentada pela nova concepção de aromas através da industrialização (Último quartel do século XIX), sentir os cheiros das fezes, dos corrimentos vaginais ou do hálito oferecia indícios da saúde do intestino, do estômago e do órgão reprodutor feminino e, para além da saúde, reconhecer a paixão ou dissabor por alguém através de seus cheiros.

Todavia, sentir cheiro de fezes ${ }^{42}$ e vísceras não cabia mais entre os modos do homem moderno, sendo necessário padronizar os odores, catalogar quais representariam limpeza, frescor ou beleza, tornando os odores animais e viscerais um universo fora da conduta esperada de um cidadão civilizado e com o seu lado farejador completamente mudo e domesticado.

\section{A indústria da concepção olfativa e os aromas no Brasil}

A partir do pós-Segunda Guerra, no Brasil, a industrialização do cheiro lançou mão de estratégias para transformar o aroma natural do corpo em algo repugnante e motivo de inaceitação social. Os aromas industriais, então impregnados nas casas e nos corpos, pelo crescimento do consumo de produtos de limpeza e cosméticos, tornaram-se regra de adequação social e boa conduta. A partir da década de 1950, as indústrias estrangeiras, conjuntamente, a um projeto de modernização e apoio publicitário, firmou o consenso de que exalar os odores naturais do corpo seria sinônimo de pobreza (KOBAYASHI,2015), sujeira e falta de higiene. Sentir o cheiro do corpo tornou-se, pela nova sensibilidade olfativa, produzida socialmente junto às "sugestões" do processo industrial e modernizador, algo imoral. Era preciso regrar os corpos, seus cheiros, os odores que vinham das vísceras, do sexo, que saíam dos orifícios e suavam a pele. Os odores deveriam ser equilibrados, escondidos, dissimulados, calados. Era urgente silenciar os narizes.

\footnotetext{
${ }^{39}$ Aroma retirado da urina do gato algália

${ }^{40}$ Aroma de forte odor retirado da secreção de glândulas do cervo almiscarado.

${ }^{41}$ Aroma retirado de material viscoso do estômago das baleias.

${ }^{42}$ Atualmente há inúmeros produtos químicos, com grande apelo publicitário e aceitação de público,que neutralizam os odores de fezes. Eles são comercializados sob a forma líquida e devem ser borrifados pelo indivíduo antes de fazer as necessidades básicas fisiológicas a fim de "tapar" o cheiro das fezes.
} 
Nesse período, a limpeza com artefatos de fabricação caseira e natural, prática da medicina popular brasileira ${ }^{43}$, ainda perdurava. Após a Segunda Guerra Mundial e conjuntamente ao processo de modernização do país, os hábitos e costumes populares de limpeza passariam a ter, como fomentado pelas publicidades das indústrias estrangeiras, aspecto de atraso. . Kobayashi e Gilberto Hochman (2015) apontam que as mudanças de hábitos de limpeza corporal foram resultado de um processo social e cultural de transformação de funções fisiológicas naturais, principalmente no referido período.

Em meio aos produtos naturais largamente utilizados, no Brasil, como práticas de limpeza do organismo, destacam-se os sabões à base de carvão e gordura, águas e banhos de ervasaromáticas, uso este que não esboçava, contudo, a pretensão de ocultar processos corpóreos, que jamais cessariam. Banhos diários mantinham a limpeza do corpo, mas não era regra que o "perfume" natural do mesmo deveria ser exterminado. Pelo contrário, era avaliado como condição natural, fazendo parte da preservação da saúde do organismo. Afinal, no interior das práticas da medicina popular ${ }^{44}$, sentir e vigiar os cheiros originados nas vísceras do corpo era uma forma de observar a sua boa funcionalidade, o conhecimento pessoal sobre o corpo por meio do cheiro era fundamental para a percepção do bom funcionamento do organismo. Esse conhecimento pode ter sido prejudicado com a propagação de uma nova conduta social onde cheirar-se não era mais permitido, somando-se a esse fato a perda de percepção olfativa diante de um grupo de aromas artificiais presentes nos produtos industriais, que destreinaram o olfato. A utilização dos produtos industriais, dotados de aromas artificiais, silenciavam os odores fisiológicos passando o indivíduo a ter dificuldades para identificar o mau funcionamento de algum órgão do corpo e a sensações negativas com o próprio organismo como nojo das fezes, urina e suor acarretando, este comportamento, um distanciamento do indivíduo com o próprio corpo e suas percepções sensoriais não só sobre saúde, mas sobre o conhecimento da própria sensibilidade.

Neste aspecto, analisando a padronização dos corpos, Le Breton (2003), discerne sobre o corpo como lugar acessório. Para esse autor, a existência corporal está infundida no contexto sociocultural e é o canal por onde as relações sociais são concebidas e experimentadas. Com isso, é possível investigar as representações e imaginários, tanto do individual, como do coletivo, através das construções que os indivíduos apresentam acerca do corpo e como este representa o homem na coletividade, já que "o processo de socialização da experiência corporal é uma constante da condição social do homem" (LE BRETON, 2003: p. 8).

Para Corbin (1987), a sensibilidade olfativa modifica-se através do tempo e recebe diversos formatos ou associações nos múltiplos segmentos da sociedade. Consequentemente, todo este novo aparato aromático industrial viria a modificar as tonalidades e percepções sociais olfativas dos indivíduos.

\section{Conclusão}

O Brasil, segundo a Agência Brasileira de Desenvolvimento Industrial (ABDI), já é o terceiro maior mercado consumidor da indústria de Higiene Pessoal, Perfumaria e Cosméticos (HPPC),

\footnotetext{
${ }^{43}$ Para a bióloga Fátima Branquinho (2007, p.10), a medicina popular refere-se a um paradigma específico e "uma visão de corpo - anatomia e fisiologia - e da natureza que lhes é própria e que não é possível de ser abordada conceitualmente pela biologia".

${ }^{44}$ Antônio Carlos Diegues (1999) considera que medicina tradicional é parte da cultura de comunidades tradicionais que podem ser quilombolas, indígenas, populações ribeirinhas, etc. Já a medicina popular seria uma gama de transformações e junções de vários signos de medicinais tradicionais, praticada por comunidades não necessariamente tradicionais como rurais, interioranas ou até mesmo urbanas periféricas.
} 
45 a China lidera o mercado por questão quantitativa. Na historiografia brasileira há estudos sobre a introdução dos produtos industriais de higiene pessoal no país e de como esse fator está em consonância com o movimento de modernidade e o processo civilizatório nacional. Todavia, há poucos trabalhos de historiografia inclinados, diretamente, à questão dos odores, na mudança da sensitividade olfativa e de sua perda sensorial.

Cheiros ainda estão presos ao aspecto higiênico sendo preciso transpor essa barreira no mundo acadêmico brasileiro. Linda B. Buck e Richard Axel ganharam o prêmio Nobel(qual), em 2004, ao mostrarem que a cadeia de receptores olfatórios pertencem a uma família de genes composta por oitocentos genes humanos, a maior até agora já estudada. Como um estudo de tamanha importância ainda é apenas alocado à saúde quando o assunto é ciência? Assim, esta pesquisa pretende analisar e compreender como o olfato industrializado influenciou não apenas o aspecto modernizador nacional, mas também as questões inerentes ao imaginário, aos modos e comportamentos, o que pode ser observado pelas transformações nos hábitos que vão desde limpeza corporal até categorizações, por exemplo, sobre o corpo da mulher ${ }^{46}$ ou a forma como lidamos com nossas fezes.

Essas questões de cunho sensível e inerentes ao cheiro podem ser analisadas junto à arte e à literatura brasileira, sendo essas fontes para seguir o rastro dos aromas. Elas podem auxiliar a esmiuçar como ocorreu a amplificação do mercado de consumo da indústria de perfumaria/ higiene de uma população que tornou-se, no século XXI, um dos maiores mercados consumidores do ramo. Usam demasiadamente produtos "silenciadores" de cheiros do banheiro, mas apresentam dificuldade em absorver obras como do artista Tunga que trazem a tona o desejo e o extinto através da estética de matéria bruta, dentre elas, as fezes. Afinal, nossos excrementos não são considerados civilizados e até os dias atuais, em franco processo de desnaturalização dos cheiros do corpo humano, as experiências relacionadas à manifestação, observação ou admissão desses aromas ganham um status de oposição aos ideais de saúde e higiene, mas, principalmente de inadequação social e moral. Não é à toa que obras artísticas e literárias que trazem a pungência do erotismo, dos excrementos, dos instintos são barrados por nossos olhos, ouvidos e boca e retirados dos museus. 0 nariz civilizado, tristemente, aceita.

Referências bibliográficas

BRANQUINHO, Fátima. O poder das ervas na sabedoria popular e no saber científico. Rio de Janeiro: Mauad X, 2007.

CLASSEN, Constance; HOWES, Davis e SYNNOTT, Anthony. Aroma: a história cultural dos odores. Trad. Álvaro Cabral. Rio de Janeiro: Jorge Zahar, 1996.

\footnotetext{
${ }^{45}$ O Brasil manteve em 2013 o título de terceiro maior mercado consumidor do mundo. A venda de produtos de HPPC no país somou US\$ 43 bilhões neste ano, a preço praticado no varejo, conforme dados do Instituto Euromonitor. O Brasil participa com $9 \%$ no consumo mundial de HPPC e com 54\% na América Latina. Somos também o primeiro mercado consumidor em desodorante e fragrâncias; o segundo em banho, cabelos, depilatórios, infantis, masculino e proteção solar; o terceiro em maquiagem e higiene oral; e o quinto em pele. Destaque para duas categorias de produtos, desodorante e condicionadores de cabelo, ambos com cerca de $22 \%$ de participação no consumo mundial. Disponível em: http://www.abdi.com.br/PublishingImages/HPPC/2014-NEWSLETTER\%20PDS, acessado em 12 de outubro de 2015.

${ }^{46}$ Atualmente, a indústria de cosmética junto a um discurso sobre higiene criou um parâmetro de que a vagina precisa ter cheiro de baunilha ou doces sintéticos. Há perfumes, sabonetes e lenços perfumados exclusivos para a região, todos com cheiros sintéticos que lembram doces fomentando a ideia de que o cheiro natural vaginal é ruim ou sujo e que para ser considerada limpa e saudável necessita exalar aromas sintéticos.
} 
CORBIN, Alain. Saberes e Odores: o olfato e o imaginário nos séculos dezoito e dezenove. São Paulo: Companhia das Letras, 1987.

DIEGUES, A. (org). Os saberes Tradicionais e a Biodiversidade no Brasil. IPHAN, São Paulo, 1999.

ELIAS, Norbert. O processo civilizador: Uma história dos costumes. Rio de Janeiro: Jorge Zahar Ed., 1994, v I.

HUME, D. Tratado da natureza humana. Trad. Déborah Danowski. São Paulo: Editora UNESP/Imprensa Oficial do Estado, 2001.

KOBAYASHI, Elizabete, HOCHMAN, Gilberto. O "CC" e a patologização do natural: higiene, publicidade e modernização no Brasil do pós-Segunda Guerra Mundial. An. mus. paul. [online]. 2015, vol.23, n.1, pp. 6789.ISSN 1982-0267.

LE BRETON, David. Antropologia do corpo e modernidade. Petrópolia, Ed. Vozes, 2011.

MALNIC, Bettina. O cheiro das coisas: o sentido do olfato: paladar, emoções e comportamentos. Rio de Janeiro: Vieira \&Lent, 2008. (Ciência no bolso).

TUNGA. Cooking Crystals Expanded. Museu de Inhotim, 2010.

VIGARELLO, Georges. O limpo e o sujo, uma história da higiene corporal. São Paulo: Martins Fontes, 1996.

ZANARDI, Oscar José. O perfume em sua possibilidade de ser uma obra de arte. 2014. 168 p. Dissertação UFSC. Orientador, Celso ReniBaida. 2014. 


\section{A CIÊNCIA DA RETÓRICA DA CIÊNCIA}

Juliana Coutinho Oliveira - Doutoranda HCTE - UFRJ - jucoutinhooliveira@gmail.com

Resumo

Trata-se de uma reflexão sobre os campos das retóricas e das ciências e sobre algumas possibilidades e controvérsias presentes nas relações que aí se estabelecem. $\mathrm{O}$ artigo busca os conceitos e definições de retórica ao longo dos tempos e avalia sua utilização com propósitos de difusão científica. Para compor este trabalho foram chamados para a conversa nomes de peso do cenário dos estudos sociotécnicos como Bruno Latour, John Law e Donna Haraway.

Palavras-Chave: Retórica. Ciência. Sociotécnica.

Introdução

"O doce perguntou pro doce: qual é o doce mais doce dos doces? O doce respondeu pro doce que o doce mais doce dos doces é o doce de batata doce." Assim como nessa antiga parlenda o título desse artigo traz em seu jogo de palavras uma repetição circular, que nos remete a uma análise bem aos moldes de Bruno Latour: entrando pela porta de trás e analisando a ciência em construção e não a ciência pronta. Então perguntamos: Haverá uma retórica da ciência? Poderá essa retórica ser também uma ciência?

Uma rápida pesquisa no Google nos oferece de cara uma definição de retórica: "a arte da eloquência, a arte de bem argumentar, arte da palavra". Ora, se é arte, então não pode ser ciência. Ainda via Google nos aprofundamos e encontramos na Wikipédia uma definição mais elaborada, e entre outras coisas lá está:"A retórica é uma ciência (no sentido de um estudo estruturado) e uma arte (no sentido de uma prática assente numa experiência, com uma técnica)."

Esse é o tipo de controvérsia perfeito para o campo de estudos CTS (Ciência, Tecnologia e Sociedade), onde os estudiosos divergem até da existência do próprio campo. No clássico "Ciência em Ação", Latour apresenta as duas faces de Jano, que ao mesmo tempo divergem e se complementam. Quando falam sobre o conceito de verdade dizem: "O que é verdade sempre se sustenta." e "Quando as coisas se sustentam elas começam a se transformar em verdade.".

Muitos ainda acreditam que a ciência pura não requer uma retórica, já que a ciência seria a prova empírica de uma verdade absoluta. Afinal, o discurso científico deve estabelecer fatos. Entretanto sabemos que os cientistas precisam em algum momento sair dos laboratórios em busca de aliados e assim "contaminar" a ciência. Do contrário, a ciência não teria nenhuma utilidade. Nesse momento são feitas escolhas sobre os modos de difusão das informações e quais aliados se quer convencer, o que em comunicação se chama de público-alvo. E depois de alistar, ainda é preciso manter a rede de atores - com seus componentes tão diversos estável.

Nos laboratórios, inscrições traduzem em números, gráficos ou palavras o que se observa nos microscópios. Os inscritores seguem uma orientação coerente de interpretação dos dados, devem ter a arte da persuasão e são valorizados quando tornam suave a transição do trabalho manual às ideias. Esse trabalho de tradução através das inscrições é de suma importância para a busca de financiamentos (LATOUR \& WOOLGAR, 1997). Segundo Del Re (2000), coisas muito pequenas ou muito grandes são complexas para uma observação direta, por isso as ciências 
precisam trabalhar com representações e padrões. Em níveis de realidade não visíveis para nossos olhos o uso de modelos e analogias é indispensável.

Hesse (1966) é uma das estudiosas que afirmam serem as analogias e os modelos essenciais para a difusão do pensamento científico, possibilitando identificação e interpretação dos dados. Hoffman (1985) corrobora e afirma que quando o assunto é difícil a metáfora é crucial. Os modelos são capazes de ilustrar e demonstrar, promovendo a correspondência e a interação do público com os dados científicos. O autor aponta os argumentos dos que são contrários ao uso das analogias. Para esses, a ciência deve ser literal e precisa, sem excessos; postulados científicos precisam ser lógicos, com proposições e definições operacionais que possibilitem testes às teorias. Esses "higienistas linguísticos" buscam explicações científicas puramente lógicas e racionais e sugerem que os discursos científicos devem evitar as vulgaridades, as ambiguidades e a imprecisão da língua ordinária (HOFFMAN,1985).

Já para os que são a favor, as metáforas e os modelos têm um papel importante na teoria científica. E defendem os que acusam as metáforas de não terem lógica, afirmando que as metáforas não são racionais e que, portanto, estão além de uma análise filosófica (HOFFMAN, 1985). A retórica usa a linguagem como arte, mas baseada em um corpo de conhecimento organizado (Enciclopédia Britânica, 1969 - apud PERELMAN, 1979), e assim sendo, as figuras de linguagem e os silogismos não estão desprovidos de lógica.

A metáfora não é uma apenas figura ornamental, mas cognitiva, expressiva e praxiológica. Cognitiva, por aproximar o não similar por meio da transferência de certos predicados de um objeto ao outro. Expressiva, ao expor o desejável ou o indesejável para um grupo social. Praxiológica, por orientar o que deve ser feito. Uma vez admitida uma metáfora, estabelecese um acordo que determinará o vínculo de raciocínio (CHARBONNEL, 1991).

O termo retórica vem da Grécia Antiga e passou por vários pensadores com algumas variações de sentido. Para Platão, o grande objetivo do argumento era atingir a verdade mais pura. Isócrates chamava de retórica um discurso civilizado e vem daí a eloquência até hoje presente nas definições de retórica. Já uma retórica ao estilo sofista, onde o orador pretende convencer uma platéia passiva, pode ser considerada assimétrica com um orador dotado de saber influenciando uma platéia ingênua e passiva (SISMONDO, 2010).

O filósofo Górgias de Leontini, um sofista da Grécia Antiga, já nos alertava para a força da retórica: "A arte da persuasão ultrapassa todas as outras, e é de muito a melhor, pois ela faz de todas as coisas suas escravas por submissão espontânea e não por violência.". Mas palavras não são capazes de realizar por inteiro a comunicação, já que o outro apreende a informação segundo seus próprios quadros conceituais. A palavra tampouco tem o poder de modificar os ouvintes, há limites para ação do orador. Um conhecimento verdadeiro sobre o mundo parece ser impossível e o discurso persuasivo sempre será uma réplica do que já é sabido (MAZZOTTI, 2015).

Conforme os estudos CTS enfatizam, as diferentes escolhas geram diferentes efeitos (SISMONDO, 2010). Ao se propagarem as informações, ruídos e interferências ocorrem nas diferentes traduções (e traições) das retóricas. Quantas vezes vemos profissionais de comunicação - publicitários, jornalistas, editores - sendo acusados de manipular a "verdade"? Na retórica está presente uma política que permite a coexistência de verdade e ideologia (SISMONDO, 2010).

Mas parece não haver possibilidade de ter acesso independente ao mundo. De fato, já nascemos rodeados por discursos, retóricas, argumentos que constroem nossas futuras verdades. As experiências sensoriais e as informações que recebemos, nossas interações com outras pessoas são mediadas por objetos de um tipo ou de outro (LAW, 1992). Segundo Latour (2005), escrever ou transmitir uma ideia requer habilidades tão difíceis como fazer uma 
reação química e, para que o conhecimento se propague é necessário que relações se estabeleçam.

A retórica tem a função de comunicar de forma clara e transmitir ideias com conviç̧ão. Nesse sentido, ela é fundamental para que os cientistas possam convencer as pessoas de suas afirmações. Muitas vezes os artigos científicos não são compreendidos e é preciso usar uma comunicação alternativa. No fim das contas a retórica mais forte vence e leva consigo a ciência.

$\mathrm{O}$ artigo científico tem a função de difundir a ciência e é um importante veículo retórico. Nas referências, por exemplo, estão presentes os aliados - outros estudiosos que sustentam a ideia do artigo. Há também o uso de gráficos e legendas, que tentam traduzir para os leigos o que "dizem" os experimentos. O uso da voz passiva é recorrente nos textos científicos e buscam fazer os atores não humanos encenarem (LATOUR, 1988).

Mas o que explica a fé nos artigos científicos? Por que as argumentações dos cientistas tem tanta credibilidade, mesmo quando são apenas assertivas sem provas? Nos habituamos a acreditar nas ciências e a visão corrente e intuitiva é de que as proposições científicas são verdades inquestionáveis (DEL RE, 2000). Latour \& Woolgar (1997) sugerem que o histórico das citações e as referências fortalecem os artigos científicos e um retroalimenta o outro, mas Del Re (2000) lembra que as classificações são verdades limitadas.

Conhecer é um processo de afetação recíproca que pressupõe a necessidade de se interessar, estar entre e fazer link (MORAES, 2014). Uma tradução implica em uma transformação e possibilita equivalência, onde uma coisa representa outra (LAW, 1992). Mas tradução também significa deslocamento, traição, ambiguidade, então o que se propaga é ao mesmo tempo confiável e não-confiável (LAW, 1998). Existe ação no encontro dos atores, nas mediações e traduções que acontecem nos agenciamentos (LATOUR, 1988). E, entre escolher um intermediário, que supostamente não interfere no conteúdo do que se propaga e um mediador, que transforma, traduz, distorce e muda o conteúdo, Latour (2005) fica com o segundo. Segundo o autor, o intermediário apenas representa a si mesmo ou nem isso, enquanto o mediador representa muitos, representa redes.

Na vida - e então também na ciência - não existem intersecções tão claras entre as coisas, por isso a discórdia está sempre nos rondando. As fronteiras são zonas de contatos acinzentadas, onde as diferenças emergem. Nesse momento eis que surge a figura do discordante, alguém com quem haverá embates argumentativos. No fundo, o discordante é um fator estimulante da retórica (LATOUR, 1988).

A retórica vem, desde o império romano, sendo acusada de promover um discurso artificial através de palavras ornamentadas, tendo em um sentido pejorativo a ideia de trazer à tona uma discussão inútil ou uma presunção de verdade. Perelman (1979), entretanto, propõe um novo conceito de retórica, que ele chama de nova retórica. Nessa proposta, a retórica passa a ser uma teoria da argumentação, capaz de popularizar as ciências com suas analogias. A retórica convence ao promover um "encontro das mentes" através de uma linguagem comum (PERELMAN, 1979).

Donna Haraway (1976), com sua potente retórica e imensa credibilidade, sabe que as metáforas são necessárias. São elas que, segundo a autora, ajudam os cientistas a ultrapassar os limites que os separam dos não-cientistas, usando uma linguagem real e inteligível. Com a paixão e a emoção características da retórica, Perelman (1979) alerta para o equívoco de se pensar em uma base científica puramente lógica e racional. O autor lembra o valor pedagógico das analogias presentes em nosso dia a dia como: a mente ser um computador, o átomo um sistema solar, as moléculas dançarem e linhas de força explicarem conceitos da física. Law (1999) nos recorda que o diferencial da teoria-ator-rede é a possibilidade de dissolver-se em outras formas de ver, escrever e fazer. Esse artigo não pretende ser uma 
"fábrica de discursos", nem "atacar ou defender" a retórica. Trata-se de uma proposta de "abertura" de nossas mentes para "focar", "refletir" e - quem sabe? - "introspectar" a potência da retórica em nossas vidas e entende-la como mais um dos "atores" da ampla "rede" que envolve as ciências.

Finalizo trazendo uma fala desse forte aliado de minha doce retórica, que ressalta a impossibilidade de se pensar em uma ciência pura. John Law (1992) diz: "o conhecimento científico e as tecnologias não se desenvolvem no vácuo. Antes, participam do mundo social, sendo formados por ele e, simultaneamente, formando-o.".

\section{Bibliografia}

CHARBONNEL, N. "Les aventures de la métaphore". Strasbourg: Presses Universitaire de Strasbourg, 1991.

DEL RE, Giuseppe, "Models and analogies in science", Nápoles, Itália, 2000.

HARAWAY, Donna "Crystals, Fabrics, and Fields: Metaphors of Organicism in 20th Century Developmental Biology", New Haven: Yale University Press, 1976.

HESSE, Mary B. "Models and Analogies in Science", Notre Dame, IN: University of Notre Dame Press, 1966.

HOFFMAN, Robert R. "Some Implications of Metaphor for Philosophy and Psychology of Science" In W. Paprotté and R. Rirven, eds, The Ubiquity of Metaphor: Metaphor in Language and Thought. Amsterdam: John Benjamin, 1985.

LATOUR, Bruno "Ciência em Ação - como seguir cientistas e engenheiros cidade afora", Editora Unesp, 1988.

LATOUR, Bruno, "Reassembling the social - an introduction to actor-network-theory", Oxford University Press, NY, 2005.

LATOUR, B. \& WOOLGAR, S. "A vida de laboratório - a produção de fatos científicos", Relume Dumara, Rio de Janeiro, 1997.

LAW John, "Notes on the Theory of the Actor-Network: Ordering, Strategy, and Heterogeneity". Systems Practice, v. 5, n. 4., 1992.

LAW, John, "Keynote Speech: On Recalling ANT", In: LAW, John; HASSARD, John (eds) Actor Network Theory and After. Oxford: Blackwell, 1998.

LAW, John, "Traduction/Trahison: Notes On ANT" published by the Department of Sociology Lancaster University, UK, 1999.

MAZZOTTI, Tarso B. "Retórica, a ciência da educação", Educação em Foco, volume 20, Juiz de Fora, 2015. MORAES, Marcia "Da extorsão de testemunhos aos mal entendidos promissores: redesenhando as fronteiras entre pesquisador e pesquisado", In: ARAÚJO, José Fábio Marinho \& VALENTE, Cristina de Melo (organizadores) "Ator-rede e além... no Brasil - as teorias que aqui gorjeiam não gorjeiam como lá?", Editora da Universidade Estadual da Paraíba, Campina Grande, 2014.

PERELMAN, Chaim "The new rethoric: a theory of practical reasoning", Springer, 1979.

SISMONDO, Sergio "An introduction to science and technology studies", Blackwell Publishing, 2010.

TODA MATÉRIA "Górgias", Disponível em: https://www.todamateria.com.br/gorgias/. Acesso em:, 2017.

WIKIPÉDIA, verbete “Retórica”, Acesso em: Agosto 2017 


\section{INDUTIVISMO - UMA ANÁLISE CRÍTICA ACERCA DESTA VISÃO DE CIÊNCIA}

David Crisostomo da Silva

Prof. Dr. Carlos Benevenuto Guisard Koehler

Resumo

Segundo Chalmers (1993), o conceito de indutivismo é pautado no raciocínio indutivo, ou seja, na ideia de que a partir de afirmações singulares ou particulares, chega-se a afirmações universais ou gerais. O indutivismo é uma visão de senso comum, bastante presente na sociedade e daí a importância de elucidar seus fundamentos, seu histórico, suas virtudes e suas falhas.

Palavras-chave: Filosofia da Ciência, O Problema da Demarcação e Indutivismo.

Introdução

"Questionar é o atributo de um filósofo, porque não há outro início para a filosofia além desse".

Platão

Segundo Losee (2000), a Filosofia da Ciência é uma área fascinante, que possui algumas finalidades, tais como: uma área na qual teorias e conceitos são avaliadas, de modo a esclarecer as definições de diversos conceitos e seus usos em diversas áreas do conhecimento; avaliação entre o que é ciência e o que não é ciência (problema da demarcação) etc.

Breve histórico dos termos "ciência" e "cientista"

A palavra ciência, do latim scientia, sofreu mudanças de significado ao longo do tempo. Segundo Harrison (2017), Alberto Magno e São Tomás de Aquino compreendiam ciência (scientia) como hábito da mente ou "virtude intectual", necessário para o aprimoramento das potências que as pessoas possuem.

"Todos os homens têm, por natureza, desejo de conhecer" Aristóteles

Segundo Harrison (2017), São Tomás de Aquino propôs três virtudes intelectuais: o entendimento (intellectus); ciência (scientia) e a sabedoria (sapientia). Para São Tomás de Aquino, o entendimento (intellectus) estava associado com a aquisição de princípios primeiros, enquanto que ciência (scientia) relaciona-se com a obtenção de verdades a partir destes princípios primeiros, e o conceito de sabedoria (sapientia) estava associado com o conhecimento das causas superiores, tal como a causa primeira, Deus.

Segundo Securis (2007, apud HARRISON,2017), a concepção de ciência de São Tomás de Aquino persistiu até o fim do século XVII, conforme se via nos escritos do médico John Securis, com sua definição de que ciência era um hábito ou disposição para se fazer qualquer coisa já confirmada por longos estudos. Já o filósofo racionalista René Descartes definia ciência como a capacidade ou habilidade de solucionar problemas.

Segundo Harris (2005, apud HARRISON,2017), no passado não havia a função do cientista da forma como é conhecida atualmente, sendo os estudiosos dos fenômenos naturais conhecidos como filósofos naturais (physici).

O termo "cientista", embora amplamente disseminado na sociedade comtemporânea, só veio a ser implementado há cerca de 200 anos, quando William Whewell (1794-1866), um professor de mineralogia do Trinity College em Cambridge, que aceitou o uso deste termo como sugestão dum participante numa reunião em Cambridge, em que ele afirmou que seria melhor tratar as pessoas ali presentes por cientistas, pois eles eram práticos demais e o termo filósofo era demasiado abrangente (XAVIER, 2015). 
Figura 1: William Whenwell

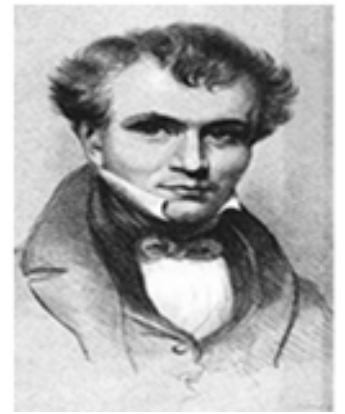

"Toda falha é um degrau para o sucesso. Toda detecção que é falsa nos direciona em direção ao que é verdadeiro: toda teste esgota algumas tentadoras formas de erro."

William Whenwell

Fonte: (Whewell's Gazette: Year 2, Vol. \#42, 2016)

Concepção Indutivista de Ciência

Segundo Chalmers (1993), O conceito de indutivismo é pautado no raciocínio indutivo, ou seja, na ideia de que a partir de afirmações singulares ou particulares, chega-se a afirmações universais ou gerais.

O empirismo (empiria, que significa experiência), consiste na ideia de que o conhecimento é obtido a partir da experiência sensorial. Um exemplo clássico de empirista foi o filósofo ateniense Aristóteles. Aristóteles (384-322 a.C.) foi o terceiro do triunvirato dos grandes filósofos de Atenas, tendo sido estudante na Academia de Platão até a morte de seu mestre em 347 a.C. Ele é considerado o primeiro filósofo da Ciência, pelo fato de seus estudos estarem intimamente relacionados com os problemas do discurso de caráter científico.

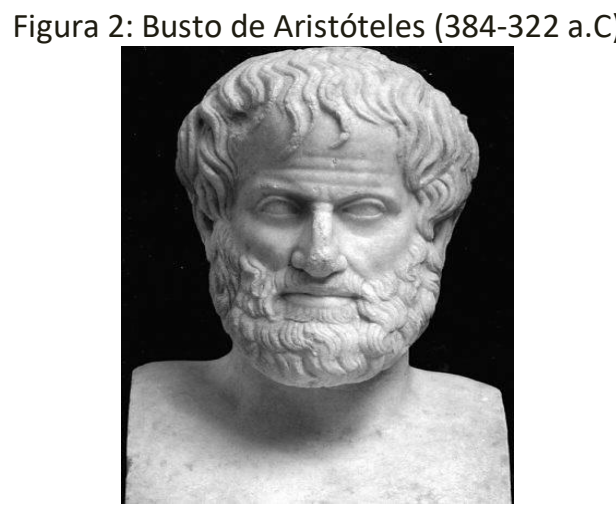

Fonte: (Strathern, 2002, p. 28)

Aristóteles caracterizava o discurso científico segundo o método indutivo-dedutivo, que é pautado em observações ou afirmações singulares progredindo a afirmações ou princípios mais gerais, voltando novamente às afirmações singulares, com todo o arcabouço teórico necessário pra explicar e prever fenômenos mais simples.

Figura 3: Método indutivo-dedutivo 


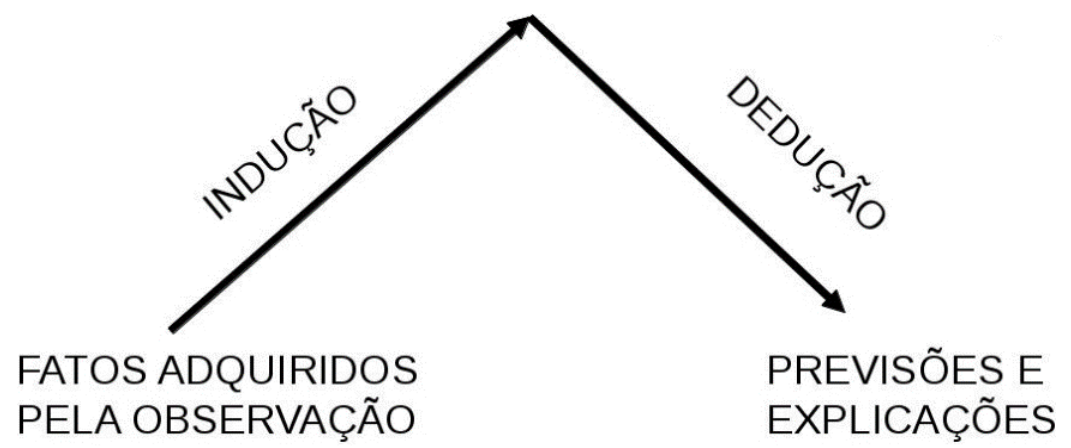

A1 tem a propriedade $P$;

A2 tem a propriedade $P$; A3 tem a propriedade $P$; An tem a propriedade $P$.

Fonte: (Chalmers, 1993, p. 27) $\therefore$ Todos os A's têm a propriedade $\mathbf{P}$. Fonte: (Losee, 2000)

A indução intuitiva é um tipo de raciocínio indutivo bastante presente em taxonomistas, pois eles têm maior habilidade de distinguir as peculiaridades entre diversos seres. A indução intuitiva não é muito frequente em todas as pessoas, pelo fato de que ela vem da experiência que o sujeito adquiri ao longo de sua vida.

Aristóteles possuía alguns requisitos para a explicação do discurso científico, dentre eles a importância de que as premissas devem ser sempre verdadeiras e as leis mais gerais ou princípios primeiros autoevidentes, dispensando demonstração. Um requisito extra muito importante era o discurso de interpretação científica acompanhado duma explicação que leve em conta as quatro causas: formal, material, eficiente e final.

As obras de Aristóteles voltaram a surgir no oeste latino por volta de 1150, época em que muitos textos dos filósofos gregos surgiram no ocidente, principalmente os textos de Aristóteles, que foram traduzidos do árabe ou grego para o latim, desmistificando a concepção que o latinos daquele período tinham de Aristóteles como um lógico. No fim do século XII a principal obra aristotélica de filosofia da ciência "Analítica Posterior" já estava traduzida e disponível para os latinos, de maneira que os grandes estudiosos passaram a ter acesso a novas facetas de Aristóteles e, daí surgem dois grandes nomes do método aristotélico na Idade Média: Robert Grossteste e Roger Bacon.

Robert Grossteste e Roger Bacon, os dois autores mais influentes sobre o método científico no século treze, adotaram o padrão indutivo-dedutivo de Aristóteles. Grosseteste referiu-se ao estágio indutivo como uma "Resolução" dos fenômenos em seus elementos constitutivos, e ao estágio dedutivo como uma composição na qual estes elementos acham-se combinados a fim de reconstruir os fenômenos originais. (LOSEE, 2000, p. 43)

Segundo Bacon (1962, apud LOSEE,2000), o aprendiz de Robert Grosseteste, Roger Bacon, forneceu também algumas contribuições importantes em relação ao método indutivodedutivo de Aristóteles, com ênfase no fato de que o arcabouço duma ciência pode ser ampliado por meio duma experimentação sistemática, sendo este conceito conhecido por "Segunda Prerrogativa" da Ciência Experimental de Bacon. 


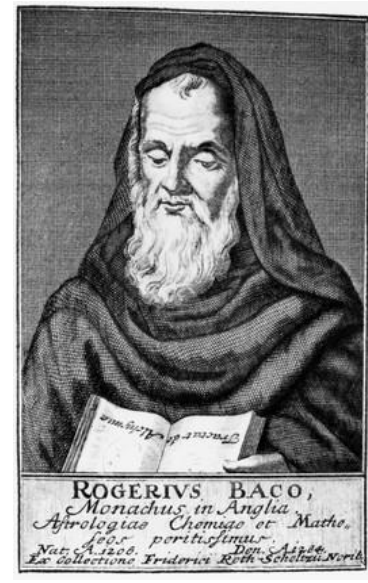

Fonte:Talens, 2001

Em relação a Robert Grosseteste, vale a pena destacar seu conceito de falsificação de hipótese mediante o fato que, se as consequências duma hipóteses são falsas, logo a hipótese será falsa e, portanto rejeitada. Este tipo de raciocínio é conhecido por modus tollens, ou a negação do consequente, por exemplolnvalid source specified..

Quadro X - Esquema do raciocínio "modus tollens

Se $H$, então $C$

não C

$\therefore$ não H

Fonte: LOSEE, 2000, p. 48

Na Idade Moderna surgiram outros nomes importantes a tratar do empirismo e a explorar os problemas da lógica indutiva etc., dentre eles os empiristas ingleses Francis Bacon e David Hume etc.

Segundo Losee (2000), Francis Bacon discordava do método indutivo aristotélico, conforme escrevera em sua mais famosa obra de filosofia da ciência, Novum organum, que faz menção direta à obra Organon, conjunto de textos de lógica escritos por Aristóteles. Francis Bacon teceu críticas a Aristóteles, pois seu método acabava por reduzir a ciência à lógica dedutiva, bem como apontou falhas no método aristotélico indutivo-dedutivo, tais como as generalizações precipitadas e o problema da indução por enumeração que, às vezes, acaba por levar a conclusões falsas.

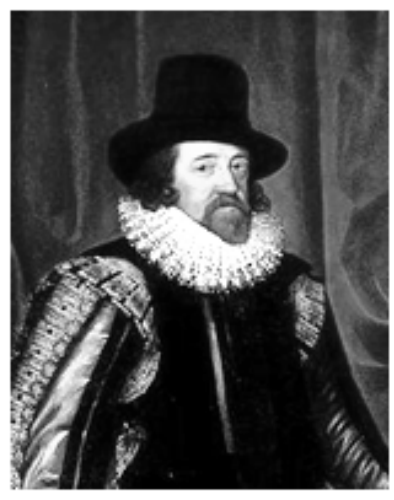

Figura 6: Francis Bacon (1561-1626)

"Quem não quer pensar é fanático; quem não pode pensar é idiota; quem não ousa pensar é covarde. "

"O conhecimento é em sim mesmo um poder."

Francis Bacon

Fonte: ROBERTS, 2015

Na obra "Novum Organum"(ano), Francis Bacon faz uma reflexão sobre os três tipos de filósofos da ciência, comparado os filósofos racionalistas com a aranha, que tece a teia a partir de si mesma; os filósofos empiristas com a formiga, que acumulam muita experiência, porém 
são incapazes discernir acerca delas. E o terceiro tipo de filósofo é comparável à abelha, que colhe o néctar das flores e o administra na produção de mel, sendo este tipo de filósofo capaz de discernir corretamente acerca das experiências que vivencia.

Figura 7 - Bacon e a alegoria sobre ciência e métodos

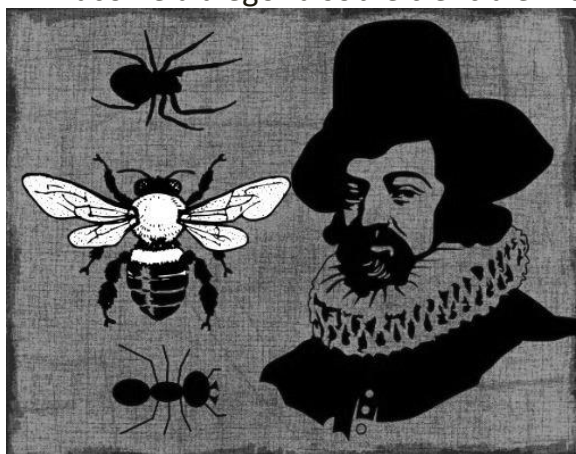

Fonte: VANNUCCHI, 2016

Os problemas por trás do indutivismo

Segundo Chalmers (1993), a respeito da validade da generalização das proposições de observação no indutivismo, é legítimo generalizá-las, desde que a quantidade de proposições de observação seja grande, sendo as proposições testadas numa ampla variedade de condições, de modo que nenhuma proposição conflite com uma lei geral derivada a partir dum processo indutivo.

A indução possui problemas de justificação lógica, podendo levar o cientista a cometer erros, pois caso as premissas sejam verdadeiras, a conclusão será verdadeira. Por isso o indutivismo não pode apoiar-se em bases lógicas porque há casos em que, mesmo que as premissas sejam verdadeiras, a conclusão pode ser falsa, sem que haja contradição envolvida no problema.

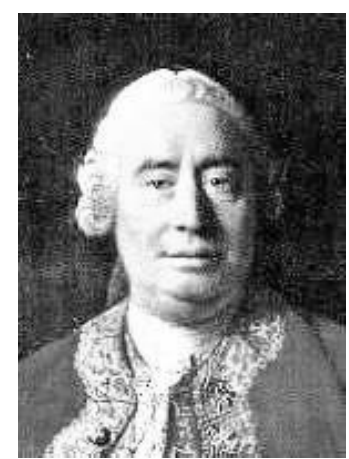

Figura 8 - David Hume (1711- 1776),

O filósofo empirista David Hume também argumenta a questão de que a experiência não é capaz de justificar a indução, pelo fato de que não há garantia de que a observação futura estará de acordo com as observações anteriores, admitindo que o hábito é o grande guia, pois somente ele diz se tal fato é provável ou não. 
Há outros problemas no indutivismo, tal como a imprecisão no número de observações necessárias, bem como a especificação das condições etc. Também é importante ressaltar a necessidade que a experiência tem da teoria, fato este que contrapõe o conceito do observador não preconceituoso do indutivismo mais ingênuo.

\section{Conclusão}

A primeira parte do trabalho visou mostrar um pouco do histórico dos termos scientia, filósofo natural e cientista. Já a segunda parte priorizou fundamentar o que é o indutivismo, seu histórico e seus principais proponentes ao longo do tempo. Conforme foi visto, o indutivismo possui muitas falhas de justificação e não leva em conta argumentos históricos e/ou sociais em suas narrativas de ciências. O presente estudo se limitou a tratar das críticas clássicas ao indutivismo, porém há outras de cunho mais atual. Desta forma, é muito importante o estudo de outras epistemologias, tais como o falsificacionismo (Karl Popper), a estrutura das revoluções (Thomas Kuhn) etc., que mostra quão complexo é caracterizar o que é ou não ciência.

\section{Bibliografia}

BURNHAM, W. B. D. et al. O Livro da Filosofia. Tradução de Douglas Kim. 1. ed. São Paulo: Globo Livros, 2016. CHALMERS, A. F. O que é ciência afinal? Tradução de Raul Fiker. 1ạ. ed. São Paulo: Brasiliense, 1993.

CONTE, J. David Hume-UFSC. Jaimir Conte-UFSC. Disponível em: <http://conte.prof.ufsc.br/hume.html>. Acesso em: 19 de maio de 2017.

HARRISON, P. Os Territórios da Ciência e da Religião. Tradução de Djair Dias Filho. Viçosa, MG: Ultimato, 2017.

LOSEE, J. Introdução Histórica à Filosofia da Ciência. Tradução de Borisas Cimbleris. Belo Horizonte: Itatiaia, 2000.

MASSONIR, N. T. Epistemologias do século XX. Porto Alegre: UFRGS, Instituto de Física, Programa da Pósgraduação em Ensino de Física, v. 16.n.3, 2005.

POMBO, O. Bertrand Arthur William Russel. Faculdade de Ciências de Lisboa. Disponível em: <http://webpages.fc.ul.pt/ ommartins/seminario/russell/index.htm>. Acesso em: 19 de maio de 2017.

ROBERTS, M. D. Francis Bacon. UNIÓN HISPANOMUNDIAL DE ESCRITORES. UHE, 2015. Disponível em: <https://unionhispanomundialdeescritores.ning.com/m/blogpost?id=2659438\%3ABlogPost\%3A3213951>. Acesso em: 19 de maio 2017.

STRATHERN, P. O Sonho de Mendeleiev-A Verdadeira História da Química. Tradução de Maria Luiza X.de A.Borges. 1a. ed. Rio de Janeiro: Zahar, 2002.

TALENS, J. R. G. La Pólvora Negra. Avancarga, 2001. Disponível em: $<$ http://www.avancarga.com/4_interesante/polvora_negra/polvoranegra.html $>$. Acesso em: 19 de maio de 2017.

VANNUCCHI, J. http://www.acervofilosofico.com/francis-bacon-a-formiga-a-aranha-e-a-abelha/. Acervo Filosófico, 2016. Disponível em: <http://www.acervofilosofico.com/francis-bacon-a-formiga-a-aranha-e-aabelha/>. Acesso em: 26 de maio de 2017.

WHEWELL'S Gazette: Year 2, Vol. \#42. Whewell's Ghost, 2016. Disponível em: <https://whewellsghost.wordpress.com/2016/06/01/whewells-gazette-year-2-vol-42/>. Acesso em: 10 de setembro de 2017. 


\title{
AS PRÁTICAS DO LABORATÓRIO DE MANGUINHOS NOS PRIMÓRDIOS DO SÉCULO 20 (PERDURAM?...)
}

\author{
Henrique Cukierman - Professor do HCTE/UFRJ - PESC/COPPE/UFRJ - hcukier@cos.ufrj.br
}

\section{Resumo}

O artigo trata do dia-a-dia do Instituto de Manguinhos nos primórdios do século 20, com destaque para as relações de trabalho no interior dos laboratórios. Aquele cotidiano revela que, apesar de sua pequenez, o quadro técnico-científico derivava sua extraordinária produtividade da diversidade de suas atividades. Tratava-se de pessoal dotado de excepcional flexibilidade tanto na ação quanto na eleição de seu objeto de estudo. Dito em bom português, o cientista de Manguinhos era um faz-tudo. O artigo investiga essa sua característica a partir do exame das relações que se estabeleceram entre os cientistas e seus 'subalternos', os ajudantes de pesquisa, nas quais o rigor e o formalismo das práticas científicas de laboratório conviveram com relações patriarcais tipicamente brasileiras.

Palavras-chave: História da Ciência nNo Brasil. Manguinhos. Práticas Institucionais Brasileiras

\section{Introdução}

Uma primeira investida para se estudar as práticas do laboratório de Manguinhos no início do século 20 revela, com a unanimidade de todas as fontes consultadas, que, apesar de sua pequenez, o quadro técnico-científico derivava sua extraordinária produtividade da diversidade de suas atividades. Não havia divisão técnica entre os trabalhos de pesquisa, de ensino e de produção, de forma que cada pesquisador ocupava-se, simultaneamente, da preparação de produtos biológicos, da investigação de um leque diversificado de temas, da orientação aos doutorandos que freqüentavam o Instituto e das aulas dos cursos de especialização. Portanto, era um pessoal dotado de excepcional flexibilidade tanto na ação como na eleição de seu objeto de estudo. Dito em bom português, o cientista de Manguinhos era um faz-tudo.

Uma segunda investida se torna possível graças aos arquivos de história oral da Casa de Oswaldo Cruz reunidos sob o título de 'Memórias de Manguinhos'. Elas contêm depoimentos que permitem vislumbrar com extraordinária clareza as situações cotidianas do Instituto, e, embora se refiram em sua grande maioria ao período posterior a 1920, são descrições que servem tranqüilamente para igualmente representar a vivência dos anos anteriores. No presente trabalho utilizarei somente o artigo de Jaime Benchimol [1989] "Retratos do Cotidiano em Manguinhos", no qual o autor apresenta os resultados de sua leitura dessas 'Memórias de Manguinhos'.

A "maioridade" do laboratório de Manguinhos viria como um desdobramento do primeiro lugar alcançado pelo Brasil na XIV Exposição de Higiene e Demografia, realizada em Berlim de setembro a outubro de 1907, trazendo modificações substanciais para os destinos de Manguinhos, "... conferindo ao Instituto a estatura institucional que lhe faltava. Finalmente, Manguinhos deixaria a aba da saia do órgão federal de saúde pública - a DGSP - para encetar seus passos autônomos à luz do dia, trocando a velha identidade de Instituto Soroterápico Federal pela de Instituto de Patologia Experimental de Manguinhos, conforme estabelecido 
pelo Decreto no 1.812, sintomaticamente promulgado em 13 de dezembro de 1907, ou seja, logo após o anúncio do prêmio na Alemanha" (CUKIERMAN, 2007, p. 333) ${ }^{47}$.

Um dos primeiros problemas do laboratório de Manguinhos teve sua origem no quadro de pessoal previsto pelo decreto 1.812, que o dividiu em três grupos: o técnico-científico (um diretor, dois chefes de serviço, seis assistentes), o administrativo (um zelador, um almoxarife, um arquivista, um escriturário e um desenhista) e o pessoal subalterno (um chefe de cocheira, quatro serventes de primeira classe, quatro serventes de segunda classe, cinco ajudantes, um mestre, dois maquinistas e dois foguistas). Não havia nenhuma vaga para auxiliares de laboratório, de forma que estes foram recrutados pelos cientistas entre o pessoal subalterno. Assim, era corriqueiro que um técnico de laboratório fosse exímio em suas funções apesar de analfabeto. Um dos 'subalternos', William Hamlet Aor, conta em seu depoimento que "o Dr. Costa Cruz, no Pavilhão da Peste, tinha um servente, um senhor totalmente analfabeto. Ele só comprava jornal quando tinha fotografia. (...) Mas tinha uma coisa: o que o homem quisesse, um meio de cultura, um repique, uma semeadura, podia confiar porque saía dentro do figurino" (BENCHIMOL,1989, p. 24).

Pode-se imaginar, portanto, o tipo de relação hierárquica que se estabelecia entre o cientista e seu 'subalterno', onde o rigor e o formalismo prussianos das práticas de laboratório eram forçadas a conviver e a contrastar com relações patriarcais típicas dos trópicos. "Eu não era nada, mas era um auxiliar dileto. Isso já me satisfazia, compreendeu?" [idem:23], revela em seu depoimento outro 'subalterno', Attílio Borrielo, deixando evidente a obediência e a hierarquia estabelecidas no cotidiano dos laboratórios do Instituto. Esta situação torna-se ainda mais explícita pelo que ele mesmo declara em outro ponto a respeito dos uniformes e do ritual das refeições em Manguinhos: "Até o avental era de cor diferente. $O$ indivíduo tinha um avental pardinho era servente. Depois, quando ia subindo de posição, passava a usar um avental branco. E isto era um orgulho! Era uma categoria média. Tinha o refeitório dos humildes e o carramanchão. Eu saí daqui comendo no carramanchão. Era uma vaidade tola, mas a gente sentia-se bem ..." [idem:23] Atuando em conjunto com a obediência, subjaziaIhe o temor que impunha a figura do cientista em seu jaleco branco: "os cientistas só falavam com a gente quando tinham interesse num certo serviço. Fora disso, mão tinham razão de falar nada. E a gente quando via um homem daquele, tomava todo o cuidado" [idem:23], é o que se ouve do testemunho de William Hamlet.

A visão do 'subalterno' a respeito daquilo que se passa com o seu superior hierárquico nos é oferecida por Francisco Gomes, para quem "os pesquisadores da época eram formidáveis. Eles chamavam a gente, ensinavam o porquê, o como era, o como se fazia (...) eles tinham orgulho de que a gente aprendesse e se tornasse bons técnicos (...)" [idem:25]. Desenvolvida nesse ambiente de vínculos intensamente afetivos, a formação do 'subalterno', a exemplo do que ocorria com os cientistas, também contava com a extrema diversificação de suas atividades: "A formação do técnico era feita nos próprios laboratórios, porque revezávamos de laboratório para laboratório e se aprendia então todas as coisas, da microbiologia para a imunologia, da imunologia para a protozoologia, a entomologia, a bioquímica, a fisiologia ... assim a gente acabava formando um técnico de conhecimento mais ou menos geral. Mas não havia curso assim específico para a formação de técnico de laboratório" [idem:24], é o que nos conta Francisco Gomes, revelando que, ao invés de um curso formalizado, operava em Manguinhos uma escola tácita, informal e altamente eficiente para os seus técnicos de laboratório. Uma eficiência construída sobre o plano puramente afetivo e informal!

${ }^{47} \mathrm{O}$ Instituto de Patologia Experimental de Manguinhos foi rebatizado, em março de 1908, como Instituto Oswaldo Cruz para render as devidas homenagens ao representante máximo da ciência brasileira vitoriosa em Berlim. 
A contratação dos subalternos, de livre arbítrio do diretor do Instituto segundo facultava-lhe o Decreto $\mathrm{n}$ - 1.812, ensejava relações extremamente pessoais entre contratantes e contratados. Uma vez contratado um primeiro 'subalterno', este usufruía do compadrio com o seu chefe para tentar introduzir sua parentela, de forma que, com o passar do tempo, estabeleceram-se várias linhagens familiares entre os serventes de Manguinhos. Portanto, o recrutamento dos 'subalternos' ocorria sob a chancela de alguma forma de predileção pessoal. O recrutamento de Francisco Gomes, 'descoberto' por Carlos Chagas em Lassance, interior de Minas Gerais, quando este pesquisava o ciclo da doença que mais tarde tomou o seu nome, é um exemplo típico deste processo. Com apenas sete anos e muito magrinho, Chico foi levado ao acampamento de Chagas por um tio para que pudesse melhorar seu estado de saúde ao 'mudar de ares'. Um dia, ao subir em uma árvore para laçar uma gambá que lhe atrapalhava o sono na rede, o garoto foi surpreendido pelo cientista, que ao mesmo tempo que pedia todo o cuidado com o bicho, rogava ao menino que não o deixasse fugir. “'Tem jeito de pegar?' 'Tem'. Aí foi quando ele correu para a barraca, foi apanhar a bandeja com o material - lâmina, tesoura, etc. Imprensei a cabeça do gambá com a forquilha no chão, consegui segurar as patas traseiras e ele veio correndo e deu um pique na orelha, tirou uma gota, botou na lâmina, saiu correndo para a barraca e foi para o microscópio. Quando olhou no microscópio, deu um tremendo berro, que aquilo ecoou, a ressonância, por aquele campo afora ... Foi o segundo animal que tinha descoberto como hospedeiro do Trypanosoma Cruzi. O primeiro era o tatu, ele já tinha descoberto, e o segundo foi esse gambá" [idem:254].

A identidade de um novo hospedeiro, assunto tão vetusto da ciência universal, ocorria a partir da destreza de um garoto magrinho aboletado numa árvore. Como prêmio, Chagas 'contratou' o garoto, comprometendo-se a ensinar-lhe a ler, a escrever e a levá-lo mais tarde ao Instituto (para onde foi com apenas doze anos). Em seguida, ainda seguindo seu depoimento, o recrutamento de Francisco Gomes mergulha fundo na ambiência afetiva e na invocação da estrutura familiar, levando ao limite a magnificação da figura do cientista como pai, às custas do minguamento de sua estatura profissional.

\footnotetext{
"Então começou a me ensinar a ler de noite (...) Isso tudo com aquele espírito paternal, porque como eu perdi meu pai muito cedo, fui fazendo transferência de afeto para ele, né? Ele me ensinava, com aquela delicadeza de sempre, como sempre foi, uma delicadeza tremenda" [idem:24].
}

Outro 'subalterno', Venâncio Bonfim, o Venancinho, sobrinho do lendário Joaquim Venâncio Fernandes, auxiliar de Adolpho Lutz e tido como o guru dos 'subalternos', dá um depoimento que não deixa margens a dúvidas quanto aos traços da existência ciência cordial ${ }^{48}$. Suas observações, extraídas das comparações entre as práticas locais e as norte-americanas, introduzidas em Manguinhos pela Fundação Rockfeller, dispensam maiores comentários: “(...) o auxiliar, ele não era assim tão importante que não pudesse limpar o piso, por exemplo. Coisa que o americano achou estranho. O auxiliar de laboratório da Rockfeller tinha um uniforme todo branco, sapato de borracha. Se não fosse assim, não podia. Deu para sentir que o povo lá tinha mais, assim, gabarito. Agora, de conhecimento intrínseco, isso é que o americano estranhou. Como é que um homem que está aqui limpando o piso, daqui a pouco pega aí uma lâmina, olha e vai dizer o que é? Porque lá o afiador de navalhas para a área de cortes só fazia isso. 0 esterilizador de material só esterilizava material" [idem:27].

Se retornamos ao faz-tudo de Manguinhos, nosso ponto de partida, é sinal de que está mais que na hora de concluir. Outras histórias ainda poderiam ser aqui mencionadas, nas quais as mãos do pesquisador aparecem encarnadas nas de seus serventes, e em profundo contraste com as mãos 'taylorizadas' dos seus 'similares' norte-americanos. Em todas elas, por este ou

${ }^{48}$ A referência é ao "homem cordial” de Sérgio Buarque de Holanda (1996). 
aquele motivo, abundam os traços de práticas cordiais, as quais, se estão longe de fundamentar a plena existência de uma ciência cordial, ao menos indicam que a modernidade à brasileira distingue-se significativamente da modernidade moderna da ciência. Concluo com a evidência neste sentido oferecida por outro dos 'subalternos', José Cunha, que, ao esboçar a autoridade do cientista de Manguinhos, utiliza uma reveladora metáfora religiosa, de fundo patriarcal e nobiliárquico: "Cada chefe era um deusinho. (...) Pequenos deuses, todos eles eram. Quase sem exceção” [idem:30].

Referências bibliográficas

BENCHIMOL, Jaime, 1989, "Retratos do Cotidiano em Manguinhos", Cadernos da Casa de Oswaldo Cruz, v.1, n.1(novembro).

CUKIERMAN, Henrique, 2007, Yes, nós temos Pasteur - Manguinhos, Oswaldo Cruz e a história da ciência no Brasil. Rio de Janeiro, Relume Dumará - FAPERJ.

HOLANDA, Sérgio Buarque de, 1996, Raízes do Brasil. 26a. ed. Rio de Janeiro, José Olympio. 


\section{IMPORTÂNCIA DO MARQUES DO LAVRADIO, O VICE-REI, NA DIVULGAÇÃO DA HISTÓRIA NATURAL DO BRASIL SETECENTISTA}

José Mario d`Almeida - Pós-Doutorando HCTE-UFRJ

Claudia Alves d`Almeida - Mestre em História Social (USS)

\section{Resumo}

Com o presente trabalho espera-se demonstrar a importância do Vice-Rei Marques do Lavradio no desenvolvimento da História Natural no Brasil. Para embasar a pesquisa, foram analisadas algumas cartas, escritas pelo Marques, envolvendo assuntos ligados à História Natural. Como também, as atividades da Academia de Ciências do Rio de Janeiro, criada por Lavradio em 1772, nas suas sessões eram discutidos e apresentados trabalhos ligados a História Natural, Medicina, dentre outros. Salienta-se que o envolvimento do Marques era tão intenso, que ele acompanhava as sessões da Academia. O Marques do Lavradio, no final do seu governo preparou um detalhado relatório para o seu sucessor sobre assuntos variados referentes à Colônia, que também foi usado no embasamento do presente trabalho.

Palavras-chave: Marques do Lavradio. Colônia. História Natural.

Introdução

A colonização portuguesa nas terras americanas, visava basicamente o enriquecimento da metrópole (CARDOSO et al.,1985) no entendimento das Ciências no Brasil Colônia, relata que seria necessário uma detalhada avaliação da formação social da colônia nos primeiros séculos de sua existência. Contudo, ocorreram administrações setecentistas que se destacaram na área científica, mesmo sendo incipientes, dentre elas, ressalta-se a do Marquês do Lavradio e a de D. Luiz de Vasconcelos e Souza. Com o presente trabalho espera-se demonstrar a importância do vice-reinado do Marquês do Lavradio (1769-1779) para a divulgação da História Natural no Brasil setecentista, utilizando-se para tal finalidade, as cartas enviadas para diferentes destinatários, que abordavam temas ligados às Ciências; a criação da Academia de Ciências do Rio de Janeiro associada ao Horto Botânico. Também utilizou-se um relatório escrito pelo Marques do Lavradio, endereçado ao seu sucessor, D. Luiz de Vasconcelos e Souza.

\section{Fundamentação teórica}

Até meados do século XVIII o desenvolvimento científico e tecnológico da Colônia ainda era incipiente, como também o de Portugal. Com a coroação de D. José I e a ascensão do Marques de Pombal, várias mudanças foram instituídas na Metrópole. O espírito iluminista que imperava em vários países da Europa, nessa época, também contaminou Portugal, gerando muitas mudanças no desenvolvimento científico, que acabaram repercutindo nas colônias e, em especial no Brasil. Contudo, segundo Filgueiras (1998), a ciência brasileira setecentista apresentava certas particularidades, que, "avaliada como uma busca desinteressada de conhecimento da natureza, praticada de forma contínua ou regular, com o patrocínio do estado ou de mecenas particulares, era inexistente".

Em 1763, a capital do Vice-Reino do Brasil, foi transferida de Salvador para o Rio de Janeiro, devido ao elevado crescimento da nova capital, motivado pelo ouro e pedras preciosas, oriundas de Minas Gerais, que encontravam no Rio de Janeiro um porto escoador bem melhor para o envio dessas riquezas para a Corte. O Marques do Lavradio, personagem alvo da presente pesquisa, foi nomeado, inicialmente, como governador da Bahia, depois de uma rápida administração, foi renomeado Vice Rei do Brasil e transferido de Salvador para a capital da colônia, em 1769, onde demonstrou o seu interesse pelas Ciências Naturais. É interessante 
ressaltar que a vinda de Lavradio para o Brasil, teria sido uma estratégia política usada pelo, então ministro Marques de Pombal, para afastá-lo da Corte, por desavenças familiares (SANTOS, 2017).

D. Luiz de Almeida Portugal Soares Alarcão Eça e Melo Silva e Mascarenhas da varonia dos Almeida, 50 Conde de Avintes e 20 Marques de Lavradio, título obtido após a morte de seu pai em 1760 na Bahia. Nasceu em 26 de junho de 1729 na Quinta da Conceição em Lisboa, aos doze anos ingressou nas Forças Armadas, na infantaria de Elvas. Seguiu para Madri em 1749 e depois para Paris, onde estudou artes militares (SANTOS, 2017).

Segundo Aizen (2006) a administração do Marques do Lavradio (1769-1779) foi marcada pelas seguintes realizações: investimento na defesa militar, já que pela formação militar de Lavradio, ele se preocupava muito com possíveis invasões da cidade; aterramento de pantanais e abertura de ruas, inclusive a rua que tem o seu nome, que ligava o Róssio (Praça Tiradentes) ao caminho de Mata-Cavalos (rua do Riachuelo); afastou do centro da cidade para - Valongo o mercado de escravos, como também deslocou o cemitério dos Pretos-Novos para a Gamboa; construiu o chafariz da Glória; incrementou a produção pecuária na Fazenda Real de Santa Cruz, tema muito abordado no relatório e entregue ao seu sucessor; exerceu maior controle na escolha dos vereadores da Câmara. Do ponto de vista cultural, pode-se destacar a criação do Teatro Casa da Ópera e a construção da Igreja Nossa Senhora da Candelária.

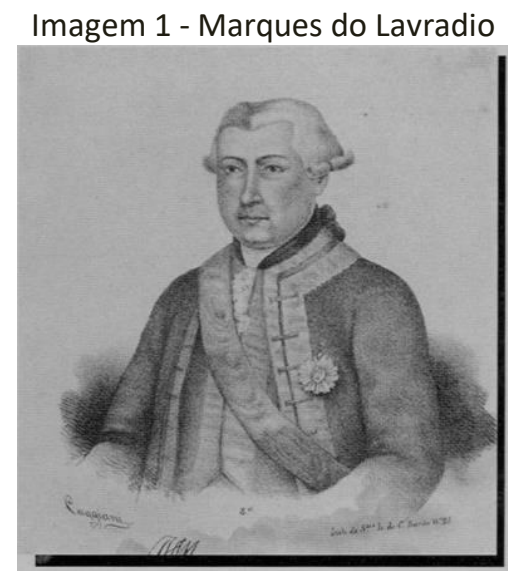

Fonte: Fundo Marques do Lavradio (Inventário, Arquivo Nacional, 1999 )

Dentre as realizações que envolviam as Ciências, em especial a História Natural, destaca-se a criação da Academia Científica do Rio de Janeiro, associada a um Horto Botânico. Contudo, mesmo com a formação especializada em artes militares, os problemas políticos externos se agravaram, ocorrendo invasões de fronteira e guerras no sul da colônia (AIZEN, 2006).

Com a coroação de D. José I e a ascenção do Marques de Pombal, o governo português, nas Ciências Naturais, viu saída para a crise de reordenamento de suas estruturas políticas e econômicas (BARBATO, 2009). Pombal, imbuído nesse espírito do iluminismo, prevalescente na Europa, convidou o naturalista Domenico Vandelli para lecionar na Universidade de Coimbra, onde foi lente de química e história natural, como também foi diretor do Jardim Botânico da Ajuda, instituição cuja principal função era a aclimatação de plantas úteis (KURY, MUNTUEL FO, 1995). Essas ideias iluministas que fervilhavam na Europa, podem ter influenciado o Marques do Lavradio, no seu interesse pela História Natural, visando, principalmente o desenvolvimento econômico da Colônia.

Segundo Torres \& Santos (2009), nas cartas de D. Luiz de Almeida, estava clara uma elevada preocupação com a carência de conhecimentos dos brasileiros sobre a fauna e flora, mesmo em se tratando de plantas de uso medicinal. Lavradio também ressalta a falta de comunicação dos letrados sobre assuntos relativos às Ciências Naturais. Esses mesmos autores, Torres \& 
Santos (2009), assinalam que, nas cartas, o Marques demonstrava preocupação com a falta de interesse da Corte em promover estudos botânicos, que além dos lucros, trariam benefícios para a população. Por meio dessas cartas, Lavradio divulgava decisões administrativas que seriam tomadas, como foi a criação da Academia de Ciências do Rio de Janeiro, pode-se observar na carta enviada ao seu amigo o Marques Angeja:

Resolvi-me a fazer um ajuntamento de médicos, cirurgiões, botânicos, farmacêuticos e alguns curiosos, aqui desta capitania, formando com eles uma assembleia ou academia para se examinarem todas as cousas que se puderem encontrar neste continente pertencentes aos 3 reinos: vegetal, animal e mineral. (LAVRADIO, 1769-1776, P 97)

Na publicação do Arquivo Nacional, de 1999, intitulada "Fundo Marques do Lavradio Inventário", além das cartas, também constam dissertações de letrados, envolvendo plantas de interesse econômico, dentre elas: 2 obras envolvendo o algodão; 4 o anil; 1 a amora; 4 a cochonilha, 3 o tabaco e, em uma delas, Lavradio demonstra preocupação com a caça predatória de baleias.

Outra realização importante do Marques do Lavradio foi a criação da Academia de Ciências do Rio de Janeiro em 18 de fevereiro de 1772. No Brasil Colônia as Academias tiveram duração efêmera, e a maioria dos seus trabalhos foram de cunho literário, dentre elas, destaca-se a Academia Brasílica dos Esquecidos, criada em 1724. Segundo Marques (2005), ainda no século XVI várias academias científicas foram criadas, Alemanha, Itália, Inglaterra, França, dentre outras. Para a criação da Academia de Medicina e História Natural do Rio de Janeiro, denominada Academia de Ciências do Rio de Janeiro, o Marques do Lavradio contou com a participação ativa do filósofo e seu médico particular Dr.José Henriques Ferreira, primeiro médico do Hospital Real. A Academia de Ciências do Rio de Janeiro congregava nove academicos, dois médicos, quatro cirurgiões, dois boticários e um prático em agricultura (KOURY \& MUNTEAL-FILHO, 1995). Na primeira sessão, em 28 de fevereiro de 1772, foram eleitos: presidente e secretário - José Henriques Ferreira; e o cirurgião Luis Borges Salgado, respectivamente. Nessa primeira sessão, o boticário Antonio Ribeiro de Paiva, responsável pela História Natural, discorreu sobre as divisões da História Natural, em especial a Botânica e ressaltou o proveito que a Colônia poderia obter com esse tipo de exploração. Os encontros ocorriam às quintas feiras na sede da Academia e aos sábados no Horto Botânico. Com a criação da Academia de Ciências do Rio de Janeiro, Lavradio, vislumbrando a necessidade de comprovações práticas, criou um horto botânico, em área do antigo Colégio dos Jesuítas. (MARQUES, 2005, p. 44).

As primeiras contribuições da recém criada Academia de Ciências do Rio de Janeiro começaram a aparecer, causando orgulho ao seu criador, o Marques do Lavradio:

Já se fizeram duas descobertas sobre alguns simples que aqui se acham e se costumam vir de fora como é o cacto e o mechoação, o primeiro vem da Ásia e verdadeiramente não se sabia o de que era composto, uns diziam ser de certa quantidade de terra, outros ser da mesma terra, com a mistura de algumas plantas, outros da dita terra com uma fruta que só havia na Ásia. Examinou-se o caju, extraído na conformidade que V. Exa. verá da dissertação sobre esta matéria, e deu o cacto mais perfeito. O professor da farmácia fez a extração e a levou à Academia junto com o que vem da Ásia, e não dizendo qual deles era o extraído por ele, examinando a Academia, um e outro, aquele que a Academia aprovou por melhor e mais perfeito, era o que, tinha extraído o dito acadêmico (LAVRADIO, 1769-1776, p. 97).

Convém destacar que a Academia de Ciências do Rio de Janeiro mantinha vínculos com a Academia de Ciências da Suécia, portanto, os assuntos analisados e discutidos nas sessões chegavam a Europa e consequentemente aos ouvidos de botânicos e zoólogos, dentre eles Carl Von Linné. (KOURY \& MUNTEAL-FILHO, 1995). 
Segundo Santos \& Torres (2012), dentre os diferentes temas tratados, pode-se destacar: Ação purgativa da mecoacã, planta originária do México. Os cientistas da Academia do Rio de Janeiro testaram a batata de purga (Operculina sp.) e outras espécies encontradas no Brasil, com o mesmo efeito da planta mexicana; Experiências com o anileiro (Indigofera sp), matéria prima para a produção do corante azul anil; Outro tema muito discutido na Academia foi a cochonilha, da qual é feito um importante corante (FERRAZ, 2007). Os letrados da Academia conseguiram, no Horto Botânico, estudar o inseto, que se desenvolve em algumas espécies de cactos. Do exoesqueleto das fêmeas isolaram um corante, o vermelho carmin. Sobre esse assunto foi escrita uma dissertação, sob os auspícios da Academia de Ciências do Rio de Janeiro, denominada Memória sobre a cochonilha e o methodo de a propagar, offerecida aos lavradores Brazileiros, por hum patriota zeloso e amante da felicidade publica". Foi escrita por Jacinto José da Silva Quintão e publicada na seção Agricultura edição de outubro de 1813 (O PATRIOTA, 1814, p. 14).

As pesquisas efetuadas na Academia de Ciências do Rio de Janeiro, além de incentivar trabalhos sobre os três reinos e promover debates científicos, também visavam atender os males que afetavam a população.

.... se podem fazer mais perduraveis as vidas, remediando-se muitas moléstias e achaques, por efeito das admiráveis plantas, raízes, óleos, bálsamos e gomas de que é cheio todo este continente.... (LAVRADIO, 1769-1776, p. 97)

Com o fim da administração do Marques do Lavradio, em 1779, a Academia de Ciências do Rio de Janeiro termina, também, os seus trabalhos. Em 1786, sob a administração do Vice-Rei D. Luiz de Vasconcelos e Souza, foi criada Sociedade Literária do Rio de Janeiro, não diríamos que veio substituir a Academia de Ciências do Marques de Lavradio, porque o enfoque era mais literário, contudo, foi uma grande conquista, realizada por um outro grande administrador. Com término do vice-reinado de D. Luis de Vasconcelos, em 1790 e a nomeação do Conde de Resende, a Sociedade Literária é extinta (KURY \& MUNTEAL-FILHO, 1995).

Para o embasamento do presente trabalho, também foi utilizado o relatório entregue ao sucessor do Marques do Lavradio, onde ele menciona a importância da Academia Científica do Rio de Janeiro, para o desenvolvimento da História Natural setecentista, como também, enfatiza a necessidade de estudos de Botânica, em especial aqueles voltados para as áreas agrícola e médica. É bem verdade, que em aproximadamente $90 \%$ do relatório, o Marques aborda temas militares (MARQUES DO LAVRADIO, 1863, p. 474). Apesar da importância da Academia Científica do Rio de Janeiro, pouco foi analisado, pela ótica da historiografia científica colonial, talvez pela sua efêmera existência, apenas sete anos (1772-1779).

\section{Conclusão}

Com este artigo, constata-se, a necessidade de um aprofundamento desses estudos, com maior abordagem na verificação das fontes.

Referências bibliográficas

AIZEN, Mario. Rio de Janeiro - A cidade dos vice-reis: 1763-1808. Revista do Instituto Histórico e Geográfico Brasileiro, Rio de Janeiro, v.167, n.432, p.201-207, 2006

ARQUIVO NACIONAL (Brasil). Coordenação de Documentos Escritos. Seção de Arquivos Privados. Fundo Marquês do Lavradio: inventário/Arquivo Nacional--Rio de Janeiro: Arquivo Nacional, 1999.

BARBATO, Luis Fernando Tosta. “Natureza, Ciência e Progresso: A natureza brasileira no debate letrado do IHGB (1839-1845)" In.: Aedos. Revista do Corpo Discente do Programa de Pós-Graduação em História da UFRGS. v. 2, n. 3, 2009 
CARDOSO, Walter.; NOVAIS, Fernando.; D'AMBRÓSIO, Ubiratan. Para uma história das ciências no Brasil colonial. Revista Brasileira de História da Ciência, n. 1, p. 13-17,jan./jun. 1985.

FERRAZ, Márcia Helena Mendes.. A rota dos estudos sobre a cochonilha em Portugal e no Brasil no século XIX: caminhos desencontrados. Química Nova, v.30, p.1032-1037, 2007

FILGUEIRAS, Carlos A. L. Havia alguma Ciência no Brasil setecentista ? Química Nova, v.21, n.3, p.351-353, 1998 KURY, Lorelai Brilhante; MUNTEAL-FILHO, Oswaldo. Cultura científica e sociabilidade intelectual no Brasil setecentista: um estudo acerca da Sociedade Literária do Rio de Janeiro. Acervo, Rio de Janeiro, v.8, n.1-2, p. 105-121. 1995

LAVRADIO, Marques Cartas do Rio de Janeiro (1769-1776). Rio de Janeiro: Instituto Estadual do Livro, 1978.

LAVRADIO, Marques. Relatório do Marquês de Lavradio, vice-rei do Rio de Janeiro entregando o governo a Luís de Vasconcellos e Sousa, que o sucedeu. Revista do Instituto Histórico e Geográfico Brasileiro, tomo 4, 1863

MARQUES, Vera Regina Beltrão. Escola de homens de ciências: a Academia Científica do Rio de Janeiro, 1772 1779. Educar, Curitiba, n.25, p.39-57.2005

O PATRIOTA. Sumário da história do descobrimento da cochonilha no Brazil, e das observaçoens, que sobre ella fez o Dr. José Henriques Ferreira. O Jornal o Patriota - Jornal literário, político, mercantil. Edições janeirofevereiro de 1814

SANTOS, Fabiano Vilaça dos. O Marques do Lavradio e os rumos da colonização na América portuguesa: notas sobre o vice-rei e sua ação administrativa (1768-1779). Arquivo Nacional/História Colonial - Comentários. 2017

SANTOS, Araci Alves; TORRES, José Celso. Produtos Naturais de Origem Vegetal no Brasil sob uma Perspectiva História. Perspectivas da Ciência e Tecnologia, v.4, n.1/2, p.33-42. 2012

TORRES, José Celso; SANTOS, Araci Alves. A Ciência e os Produtos Naturais nas Cartas do Marques do Lavradio. Anais da 320 Reunião Anual da Sociedade Brasileira de Química. p.930-2. 2009 


\section{REFLEXÕES SOBRE AS CONTRIBUIÇÕES DE UM GUARDA-PARQUES PARA OS ESTUDOS DO COMPORTAMENTO ANIMAL NO SÉCULO XVIII}

Carolina Alves d'Almeida - doutoranda HCTE/UFRJ caroldalmvegan@gmail.com Regina Dantas - professora (orientadora) - HCTE/UFRJ. regina@hcte.ufrj.br

\section{Resumo}

Pretendemos discutir as contribuições de Charles Georges Leroy (1723-1789) para o estudo do comportamento animal. Leroy foi um guarda-parques que, no auge do lluminismo francês, produziu conhecimentos sobre comportamento dos animais nos parques naturais. O cargo que exercia lhe proporcionava muitas oportunidades de observar e acompanhar os animais. Leroy apresentava críticas aos estudos do comportamental animal realizados por filósofos ou naturalistas de gabinetes, que não possuíam experiências de campo, fundamentais para se conhecer os mundos animais. Indo mais além, Leroy, diferente da maioria dos intelectuais da época, era contrário às ideias mecanicistas cartesianas e antropocêntricas, reconhecendo, nos animais, capacidades como inteligência e sensibilidade.

Palavras-chave: Etologia. História das Ciências. Guarda-Parques. Experiências Intersubjetivas.

Introdução

O presente trabalho é um recorte do projeto de doutorado que consiste em uma análise das dissoluções de fronteiras ontológicas e epistemológicas no desenvolvimento da etologia, com ênfase nas redes de conexões e controvérsias em torno das contribuições dos conhecimentos locais para o desenvolvimento da disciplina.

Em termos gerais, do ponto-de-vista darwiniano ${ }^{49}$, a etologia consiste no campo de estudos e experiências científicas sobre a dimensão evolutiva e filogenética do comportamento animal. Seus principais fundadores e responsáveis por sua consolidação como disciplina científica no século XX, foram Konrad Lorenz (1903, 1989), Nikolaas Tinbergen (1907-1988) e Karl Von Fritz (1886-1982), especialmente o primeiro, quem definiu a etologia como a ciência do comportamento animal que ocorre em contextos ecológicos realistas (LORENZ, [1981]1993). Lorenz e Tinbergen, influenciados por Oskar Heinroth, entendiam a etologia como o estudo comparado do comportamento animal (SARAIVA, 2003). Para o ecólogo Eugene Odum (1988, p.397), "a etologia, tornou-se uma ciência interdisciplinar importante que procura mais ou menos interligar a fisiologia, a ecologia e a psicologia". A partir dessas ideias, a etologia evolucionista foi constituída como disciplina científica, um ramo da biologia que reúne um conjunto de metodologias científicas para o estudo do comportamento animal comparado (ZUANON, 2007). Segundo Soczka (2003), etologia nasceu, portanto, baseada num método (a observação naturalista) e numa teoria (a teoria sintética da evolução). No entanto, uma multiplicidade de perspectivas e localidades, desde as mais vitalistas até as mais

\footnotetext{
${ }^{49}$ É importante ressaltar que o naturalista Charles Darwin, no final do século XIX, antes da etologia iniciar seu percurso como disciplina científica, já esboçara claramente seu projeto, através das conhecidas obras: “A Origem das Espécies" (particularmente no capítulo VIII, cujo o título é "Instinto"), e "A Expressão das emoções no Homem e nos Animais". Darwin, portanto é considerado, pela maioria dos etólogos, como o pai da etologia, visto que sua definição é a que mais se aproxima da definição atual da disciplina.
} 
evolucionistas, se confrontavam, conectavam ou atravessavam afim de definir os rumos e conceitos da disciplina.

Diante dessa pluralidade de perspectivas e localidades em tensão ou conexão, na história da etologia, pretendo destacar aqui um "naturalista" peculiar, considerado como um dos maiores precursores ou, pelo menos, "inspiradores" da etologia. Para o etólogo britânico William Thorpe (1982), a etologia, tal como é definida em termos gerais, surgiu antes do século XIX, antes mesmo de seu oficial "precursor", Charles Darwin (1809-1882) com sua Teoria da Evolução, bem como antes de seus possíveis "inspiradores", os naturalistas transformistas, catastrofistas ou criacionistas: Georges Cuvier (1769-1832), Jean-Baptiste de Lamarck (1744-1829), Etienne Geoffroy- Saint Hilaire (1772-1844) e Isidore Geoffroy-Saint Hilaire (1805-1861), Jean-Henri Fabre (1823-1915), entre outros. A etologia, segundo Thorpe, surgiu ainda no século XVIII, com o naturalista francês Charles Georges Leroy (1723-1789), que, diferente dos outros inspiradores e precursores da disciplina, não era naturalista nem cientista, mas uma pessoa com um status mais humilde, que exercia o posto de tenente das caças reais nos Parques de Versalles e de Marly, em outras palavras, um guarda-parques da nobreza. Leroy havia sucedido seu pai nesse posto.

Leroy era um homem de grande inteligência e excelente educação, e como parte de seu trabalho como guarda-parques, ele estudou minuciosamente o comportamento animal. Segundo o próprio Leroy, o cargo que exercia lhe proporcionava muitas oportunidades de observar os animais, mais do que se fosse um filósofo natural ou intelectual (THORPE, 1982). Uma de suas principais obras é A Inteligência e Afetabilidade dos Animais desde um Pontode-vista Filosófico, com umas poucas palavras sobre o Homem, publicada em 1764, na França, mas pouco conhecida entre os etólogos atuais.

Leroy conheceu Denis Diderot (1713-1784), Jean Le Rond d'Alembert (1717-1783) e ClaudeAdrien Helvetius (1715-1771), e foi convidado pelo primeiro para escrever vários dos artigos da Enciclopédia sobre o comportamento dos animais nos parques, bem como um artigo sobre a moralidade do homem (MARTÍNEZ-CONTRERAS \& MONTIEL-CASTRO, 2013). Dentre esses, se destaca o artigo "instinto", que refletia as crenças filosóficas e metafísicas expressas em seu livro Lettres sur les animaux, de 1978 (MARTíNEZ-CONTRERAS \& MONTIEL-CASTRO, 2013). O guarda-parques também conheceu os principais filósofos e representantes do Iluminismo, e se destacava, dentre eles, por sua independência de pensamento, demonstrada por suas ideias anti-mecanicistas (THORPE, 1982). Era um profundo conhecedor dos livros de Buffon (1707-1788) ${ }^{50}$, com o qual pouco se identificava. Talvez o fato de Leroy ter atuado de fora - porém mais dentro do que os que se encontravam dentro do ambiente científico da época, dos gabinetes e bibliotecas - tenha contribuído para sua independência de pensamento e liberdade de pensar os animais segundo suas experiências e relações com eles. É controverso o modo que seu livro Lettres sur les animaux foi escrito, em formato de cartas dirigidas a uma tal Madame d'Angiviller, de quem era amigo íntimo. O prólogo do livro era uma carta-dedicatória a Madame $* * * * * * *$, na qual Leroy fingia não ser ele mesmo, adotando o pseudônimo de "Naturalista de Nuremberg"51 (ou "Médico de Nuremberg"). O uso do pseudônimo pode ser explicado pelo fato do intelectual ter ocupado um posto menos prestigiado que o dos outros intelectuais, e, por isso, considerado pela sociedade intelectual

\footnotetext{
${ }^{50}$ Georges-Louis Leclerc ou Conde de Buffon (1707-1788) foi um renomado naturalista francês que influenciou grandes naturalistas como Jean-Baptiste de Lamarck e Charles Darwin. Suas concepções filosóficas e estudos das espécies, contribuíram significativamente para o desenvolvimento da biologia, tornando-o um dos maiores biólogos do seu tempo. Buffon, segundo Darwin, foi um dos pioneiros no estudo científico da origem das espécies, sugerindo que os animais precedem de outros animais.

51 Physicien de Nuremberg.
} 
da época como possuindo um perfil inferior (MARTíNEZ-CONTRERAS \& MONTIEL-CASTRO, 2013).

Os ricos e profundos conhecimentos sobre comportamento dos animais nos parques naturais, adquiridos por Leroy através de seu trabalho como guarda-parques, que, segundo Thorpe (1982), muitos dos renomados intelectuais e naturalistas da época, como Buffon, não possuíam, acabaram possibilitando seu ingresso nos círculos de intelectuais a partir da metade do século XVIII (MARTÍNEZ-CONTRERAS \& MONTIEL-CASTRO, 2013).

Leroy acreditava que a experiência e trabalho de campo eram fundamentais para conhecer os mundos animais e afirmava que ninguém, exceto um cavaleiro, poderia apreciar completamente a inteligência dos animais, pois para conhecê-los profundamente era preciso estar em contato com eles, condição que não cumpria a maioria dos filósofos (THORPE, 1982). É importante ressaltar que a observação do comportamento animal em seus ambientes "naturais" faz parte da definição de etologia, tal como foi difundida no século XX, pelo menos pela corrente europeia. Indo mais além, a valorização do trabalho de campo, da importância das experiências de contato direto com os animais em seus "nichos" ou "mundo-próprios" por longos períodos, afim de conhecê-los mais profunda e intimamente foram reinvindicações da etologia que se destacaram principalmente na metade do século $X X$, com a emergência dos primeiros estudos de longa duração. Tais estudos de longa duração também se iniciaram com "atores" considerados de baixo prestígio e importância pela comunidade científica predominantemente machista da época, a saber: as mulheres, já que os cientistas homens passavam maior parte do tempo nos gabinetes.

Nas palavras de Leroy, o Naturalista de Nuremberg é "como eu mesmo, um cavaleiro decidido que assistiu a seu curso de filosofia nos bosques". O naturalista, então, criticava o ponto-devista dos filósofos sobre o comportamento animal, sua localidade desconectada dos mundos animais, a partir de onde eles narravam, ressaltando a importância de se deslocar para o campo.

Coincido com ele, em pensar que no estudo dos animais devem excluir-se os fatos isolados. O que constitui o verdadeiro campo de observação é sua conduta diária, o conjunto de seus atos, com suas modificações de acordo com as circunstâncias, colaborando todos eles para os objetivos que necessariamente devem ter presentes, cada um de acordo com sua natureza. (LEROY, 1764 apud THORPE, 1982:28)

Leroy também enfatizava o estudo dos animais com os quais temos alguma afinidade, seja em estrutura ou em hábitos. Neste sentido, o guarda-parques já reconhecia a importância das experiências intersubjetivas e de identificação com os animais para a compreensão de seus comportamentos e modos de vida. Ao escolhermos os animais com os quais nos identificamos, estamos mais abertos a compreender e atravessar os seus mundos. Se olhamos com curiosidade e expectativa temos mais chances de perceber um comportamento, sem obstáculos e preconceitos, como já dizia o etólogo egípcio naturalizado brasileiro Cesar Ades (1943-2012).

Segundo Leroy (1764), "a república dos coelhos, a associação dos lobos, as precauções e astúcias características das raposas, a sagacidade que demonstram os cachorros com suas variadas reações até nós, tudo isso é muito mais instrutivo que a indústria das abelhas, sobre a qual se insiste tanto". É mais fácil se colocar no lugar de uma espécie com a qual nos identificamos, filogeneticamente mais próxima, para compreender seus mundos e comportamentos, do que se colocar no lugar de espécies muito diferentes e distantes, embora sejam igualmente importantes a apreensão de suas diferentes alteridades e o reconhecimento de seus mundos quase incognoscíveis. Penso que as afirmações de Leroy acerca da escolha dos animais que temos mais afinidade, não tem um caráter antropocêntrico, de considerar que o comportamento das espécies mais distantes e 
diferentes dos seres humanos são inferiores ou irrelevantes, mas sim que ressaltam uma relação de identificação animal e reconhecimento de semelhanças.

Thorpe (1982) afirma que na primeira carta de Leroy já se pode notar uma conexão com a etologia moderna. Além disso, o naturalista reconhecia nos animais, capacidades para além das satisfações imediatas de suas necessidades, como a inteligência, emoções, sentimentos, resolução de problemas e engenhosidades. Muitos filósofos contemporâneos de Leroy, ou que o precederam, como Montaigne no século XVI, também já reconheciam essas capacidades nos animais, mas não de um ponto de vista naturalístico.

Por exemplo, eu gostaria de ter uma biografia completa de cada animal. Meu desejo é que depois de estudar seu caráter individual, apetites naturais e modos de vida, o observador procurasse vê-lo em todas as situações que podem opor-se a satisfação imediata de suas necessidades - situações cuja natureza variável rompe a regularidade de seu proceder cotidiano e lhe força a recorrer a novas engenhosidades. (LEROY, 1764 apud THORPE, 1979: 29)

Thorpe (1982) constata que Leroy estava exigindo o que hoje conhecemos por etograma de cada espécie. Entretanto, acreditamos que Leroy, muito além de um etograma, buscava uma compreensão dos animais como sujeitos, atores e agentes, com vida e capacidades complexas, que para além de meras observações e descrições antropocêntricas, necessitavam ser descritas através de uma biografia completa de cada um.

As diferentes cartas de Leroy são como típicos trabalhos de etologia sobre o comportamento de diferentes espécies de animais e sobre questões como instinto, sensibilidade e inteligência, porém enriquecidas com questionamentos filosóficos e epistemológicos. A carta II, tratava da raposa e do lobo. A carta III, comparava carnívoros e herbívoros, como o cervo, a lebre e o coelho, e, em seguida, discutia acerca da polêmica questão do instinto versus a sensibilidade (THORPE, 1982), que perdurou e se destacou até o desenvolvimento da etologia como disciplina científica no século XX.

Leroy, como a maioria dos etólogos, criticava a ideia cartesiana dos animais como autômatos insensíveis. Para ele, um sistema de automatismo é obscuro e perigoso (Thorpe, 1982). O naturalista, que reconhecia as emoções e os sentimentos dos animais, se indagava se não era mais natural e satisfatório considerar a sensibilidade "como difundida, em geral, através de todo o reino animal, exercitando-se em graus diferentes e sob uma infinita variedade de formas em harmonia com as necessidades que incitam cada indivíduo a entrar em ação e com a organização que coloca o limite a cada espécie" (LEROY, 1764 apud THORPE, 1982:29)

Devemos dar preferência aos argumentos de uma falsa filosofia que nos ensina a considerar estes seres como se atuassem sem motivos e governados simplesmente por impulsos cegos? (...). Eu prefiro observar cada indivíduo movido por sua sensibilidade, obedecendo às suas próprias inclinações peculiares, e contribuindo assim para a perfeição do conjunto e para a justa proporção que deveria reinar entre as espécies. Me surpreende o mesmo espetáculo na ordem da sociedade; a crença em uma sensibilidade geral e difundida faz, com certeza, ainda maior o espetáculo, e se me rendo de acordo com essa ideia é porque temos visto quantos problemas e quantas suposições ininteligíveis e gratuitas nos custaria a opinião contrária. (LEROY, 1764 apud THORPE, 1982:30)

Leroy, portanto, demonstrava em grande parte de seu trabalho, fortes críticas e argumentos contra a teoria de que os animais são autômatos, particularmente quando compara o comportamento de animais domésticos e selvagens (THORPE, 1982). Leroy, na carta IV, criticava também a postura antropocêntrica de Buffon de não reconhecer a inteligência dos animais, que não condizia com suas brilhantes observações e descrições das vidas animais, demonstrando uma contradição entre argumentos e fatos. 
Juntos lemos com frequência, Senhora, as excelentes histórias que M. de Buffon nos tem dado de muitos animais. Temos admirado a eloquência deste grande naturalista. A agudeza com que capta os caracteres que distinguem cada espécie mostra a verdade de suas descrições, e seu brilhante colorido. Ao descrever aqueles animais que ele mesmo havia observado, ou daqueles dos que tinha informes confiáveis, os detalhes de suas inclinações e ações, de sua sagacidade e de sua habilidade, são expostos com uma exatidão e um encanto que deixam muito atrás todos os seus predecessores. Enquanto mantém o fio da observação em sua mão, seu caminho é seguro: penetra nas intenções dos animais, e, pela maneira de descrever suas ações, decifra para o leitor todos seus movimentos com a habilidade de um professor.

Mas poderíamos supor? O autor das histórias do cervo, o cachorro, a raposa, o castor, o elefante, parece ignorar completamente os fatos quando chega o momento de argumentar; então se torna um dos maiores detratores da inteligência dos animais. Sem dúvida tem mais títulos que seus companheiros a considerar a sua própria espécie como uma espécie a parte, mas, depois de tudo, ao ser homem, é falível, e devemos permitir-nos o direito de comprovar suas opiniões, sempre que se faça com o devido respeito a sua pessoa, e aos seus eminentes talentos. (LEROY, 1764 apud THORPE, 1982, p. 30)

Para Leroy, poderíamos conhecer mais de nós mesmos através do estudo do comportamento dos animais, não importando as nossas limitações em compreender a natureza de suas mentes (THORPE, 1982). Tal afirmação, que pressupõe o reconhecimento do homem como animal, acaba precedendo indiretamente as ideias evolucionistas biológicas de que compartilhamos características, comportamentos e um ancestral comum com os demais animais. Desse modo, Leroy foi considerado um dos principais precursores, se não o fundador, da análise comparada do comportamento na Europa - alicerce da etologia (THORPE, 1982). Enquanto Thorpe (1982), destacava a sua peculiar ênfase etológica, P.H. Gray (1968), ressaltando a proximidade entre o naturalista e a etologia moderna, afirmava que "Leroy teria se sentido em casa em qualquer de nossos modernos laboratórios de comportamento" (GRAY, 1968). Entretanto, acreditamos que Leroy não se sentiria à vontade confinado em laboratórios científicos de comportamento animal, mas sim no trabalho de campo, em relação e convivência direta com os animais em seus nichos (particulares, híbridos ou compartilhados), talvez inserido nas práticas científicas dos estudos de longa duração, interagindo com outros atores-locais, técnicos, guarda-parques e ajudantes, que integram essa complexa rede sociotécnica de produção de conhecimento etológico.

As atividades e os conhecimentos "situados" de Leroy na localidade de um guarda-parques possibilitaram a produção de novos argumentos e conhecimentos sobre o comportamento dos animais, decorrentes das vivências e convivências com os animais no campo e na natureza, da aproximação e das experiências intersubjetivas proporcionadas, que não teriam sido possíveis a partir da posição de um filósofo natural ou naturalista de gabinete. Essas importantes contribuições o transformaram, posteriormente, em um naturalista de grande importância para o desenvolvimento da etologia como disciplina científica. Como já dito, o próprio Leroy reconhecia a contribuição do ponto-de-vista que seu cargo lhe proporcionava, suscitando questionamentos epistemológicos sobre os estudos do comportamento animal realizados em sua época, que não valorizavam a pesquisa de campo e o contato com a natureza. Seu caso particular pode explicitar como a etologia se constituiu a partir de dissoluções de fronteiras institucionais e epistemológicas, entre diferentes perspectivas e localidades.

A história da etologia pode ser literalmente construída e narrada a partir do ponto-de-vista dos atores-locais, guarda-parques, tratadores, ajudantes de pesquisa, mateiros, entre outros atores que, para muito além de invisíveis colaboradores ou veiculadores das práticas científicas, também eram e são peças fundamentais na viabilização e na produção de 
conhecimento científico. Esses atores, até os dias de hoje não tem a visibilidade merecida dentro da comunidade científica.

Através de Leroy, podemos refletir sobre a dinâmica das práticas científicas da etologia, nos primórdios do Naturalismo e das Instituições Científicas. As fronteiras entre o fora e o dentro da ciência se confundiam, e permanecem se mesclando, por debaixo do tapete da modernidade, embora atualmente essa dinâmica esteja mais visível através dos estudos sociais e culturais das ciências e dos estudos CTS (Ciência, Tecnologia e Sociedade) que vem questionando a epistemologia moderna universalista.

O reconhecimento de que a localidade dos atores que adquiriam conhecimento através do contato direto e convivência com os animais era tão ou mais privilegiada do que a dos filósofos naturais confinados em seus gabinetes e bibliotecas, que nas narrativas da modernidade, eram os detentores das verdades e dos conhecimentos sobre a natureza, contribuiu para questionamentos e reconfigurações posteriores das práticas científicas da etologia. Uma das principais contribuições de Leroy foi, portanto, ter produzido conhecimentos sobre o comportamento animal, bem como questionamentos epistemológicos e metodológicos, através do ponto-de-vista de um guarda-parques que estudava nos bosques. Muitos casos, como os de Leroy, existiram em diferentes épocas até os dias atuais, porém possuem pouca visibilidade e espaço nas grandes narrativas da história das ciências.

Referências bibliográficas

GRAY, P.H. Early Animal Behaviourists: Prolegomenon to Ethology. Isis: 59. 1968.

LORENZ, Konrad. Os Fundamentos da Etologia. Trad: Pedro Mello Cruz e Carlos C. Alberts, São Paulo: Editora da UNESP. [1981] 1995.

MARTÍNEZ-CONTRERAS, J. \& MONTIEL-CASTRO, A. J. “Charles-Georges Leroy y los orígenes de la etología ilustrada", México, CEDARpublicaciones, 2013.

ODUM, E. P. Fundamentos de ecologia. Lisboa, PT. Calouste Gulbenkian.1988.

SARAIVA, Rodrigo de Sá-Nogueira. Mundos animais, universos humanos: Análise comparada da representação do ambiente. Lisboa: Fundação Calouste Gulbenkian. 2003.

SOCZKA, Luis. A Companhia dos Lobos: O Imperativo da Vinculação. Ensaios de Etologia Social. 2a Ed. Atualizada e Aumentada. Prefácio de António Bracinha Vieira. Lisboa: Fim do Século. 2003. THORPE, W.H. Breve historia de la etologia. Ed. Cast.: Alianza Editorial, S. A. Madrid, 1982.

ZUANON, Átima Clemente Alves. "Instinto, etologia e a teoria de Konrad Lorenz". Ciênc. educ. (Bauru) [online]. Vol.13, n.3, pp. 337-349.2007. 


\section{PARTITURAS IMAGÉTICAS DO CORPO: UM EXPERIMENTO TRANSDISCIPLINAR EM NEUROCIÊNCIA E ARTE CONTEMPORÂNEA}

Dandara Dantas - Doutoranda HCTE-UFRJ - dantas.dandara@gmail.com

Maira Fróes -Professora do HCTE-UFRJ-froes.maira@gmail.com

\section{Resumo}

O objetivo deste artigo é disparar uma reflexão acerca de um experimento que mistura uma poética contemporânea com metodologias e pensamentos em neurociência na produção de processos e objetos híbridos. O trabalho pregresso que suscitou esta pesquisa consistiu em uma poética de tradução de informações musicais em imagens por meio de uma remodelagem gráfica de partituras de piano. Posteriormente, em um laboratório de neurociências, em vez de informações musicais, essa poética recebeu como input dados de condutância de pele, relativos à engajamento emocional, com o fim de desenvolver um processo gerador de novas visualizações para dados de emoção. Este artigo se propõe a analisar esse experimento de acoplamento processual e seus resultados transdisciplinares.

Palavras-chave: Imagem. Música.Neuroepistemologia.

Introdução

Esse artigo consiste em um recorte da qualificação de minha pesquisa de doutorado teóricoprática "Partituras Imagéticas trans formadas" que tem como objetivo pensar e criar objetos transdisciplinares a partir da aplicação do método artsci na poética contemporânea intitulada "Partituras imagéticas".

A partir da aplicação desse método, que será apresentado adiante, no Laboratório de Métodos Avançados e Epistemologia (LAMAE/HCTE), coordenado pela professora e orientadora desta pesquisa Maira Fróes, obtivamos um primeiro experimento dessa interface processual, que nos permitiu observar e analisar diferentes níveis de imbricação entre arte e ciência, o qual intitulamos Partituras Imagéticas do Corpo.

Junto da neurocientista Celia Hedin e do musicista contemporâneo Eufrasio Prates, tivemos a chance de submeter ao edital da Internatinal Brain Research Organization (IBRO) uma proposta de extensão desse primeiro experimento no evento que chamamos Conversando sobre o código neural na interface arte e ciência. O objetivo foi abrir nosso processo em uma exposição laboratório, um espaço lúdico de experimentação e conversa com o público acadêmico e leigo, para além das fronteiras da universidade. Vencedores do edital, levamos para a Galeria Modernistas (Santa Teresa, Rio) o acervo de objetos e experimentos desenvolvidos até esta etapa da pesquisa: quadros-esculturas, móbiles, instalações, uma performance interativa e, sobretudo, as Partituras Imagéticas do corpo para discutir sobre modelos científicos a partir da poética contemporânea Partituras Imagéticas.

De volta ao laboratório, foi possível refletir sobre os resultados práticos, conceituais e epistemológicos dessa experiência de abertura do processo para um público diverso, aprimorar pesquisa e fortalecer o método artsci. Essas são as reflexões que pretendemos desenvolver neste artigo.

Partituras imagéticas: uma poética interdisciplinar em um laboratório de neurociências 
No âmbito do mestrado, tive a oportunidade de confrontar texto e imagem por meio da representação musical. Esta pesquisa até então intitulada "Partituras Imagéticas", que chamaremos de poética $\mathrm{Pl}$, nascia no território das artes visuais contemporâneas, à luz da análise do filósofo tcheco Vilém Flusser (2007) acerca das linhas textuais e superfícies imagéticas no que tange suas diferenças de (de)codificações.

O então experimento PI consistiu em uma poética de tradução de música em imagem a partir da problematização da linguagem hermética textual das partituras musicais. Tratou-se de uma remodelagem na estrutura da partitura de piano com o objetivo de subverter seu propósito textual, informativo, linear e simbólico, e dar lugar à um novo arranjo visual com intenção de imagem: não linear e predominantemente estético e subjetivo.

As escolhas visuais dessa remodelagem partiram de uma analogia visual com minha experiência musical, principalmente, no que se refere à sensação permanente da pausa e à percepção de tempo não linear tal como ocorre no nível imagético. Com isso, obteve-se uma nova visualização da música: circular, sem início, meio ou fim, e sem o intuito de ser objetivamente decodificada. O objetivo era criar uma representação imagética da fruição musical, suprimindo a carga simbólica da representação musical em forma de texto. As superfícies resultantes, carregadas de dados musicais, foram redimensionadas para imagens virtuais, incluindo projetos de performances e protótipos de esculturas.

Ao apresentar esta poética de imagem e música à neurocientista Maira Fróes, levantou-se as seguintes questões: Poderiam as Partituras Imagéticas revelar estruturas orgânicas fisiológicas? Qual seria a visualização resultante da inserção de dados de emoção no processamento PI?

Tais perguntas se tornaram questões endereçáveis tanto às neurociências quanto às artes e nos motivou a experimentar a utilização de dados de condutância de pele na poética $\mathrm{PI}$ e, juntas, analisar este processo híbrido e seus resultados.

Uma perspectiva sobre o método artsci na imbricação entre neurociência e arte contemporânea

Na premissa de que a arte seja a maior ferramenta tecnológica disparadora da imaginação humana, e ao considerar justamente que a imaginação sirva tanto às artes quanto às ciências, a pesquisadora Maira Fróes defende a introdução das artes contemporâneas no cotidiano dos laboratórios científicos:

\footnotetext{
Tendo as artes optimizado a imaginação em graus de liberdade sem precedentes, pois não necessariamente comprometida com arcabouços lógicos pré-moldados como os obedecidos dentro da prática e narrativa científicas, seu processo criativo deveria ser de grande interesse para a ciência, sobretudo quando se considera o quanto a ciência é alimentada e potencializada por perspectivas e modelos interpretativos essencialmente dependentes de criatividade e imaginação (FRÓES, 2015b).
}

Além de considerar a relevância do estímulo à imaginação nas ciências através da arte, para Fróes (2015a) e colaboradores, a própria figura do cientista é também alargada no sentido de considerar suas emoções e subjetividades no seu fazer científico. Para Fróes, por dentro da figura do cientista, existe um sujeito sensível, pleno em afeto e imaginação, recursos humanos rejeitados na visão hegemônica da ciência contemporânea ocidental, mas que, conforme seu grupo vem defendendo e demonstrando nos últimos anos, deveriam ser estimulados na produção das ciências.

Para experimentar a aplicação de suas premissas, Fróes realizou sessões de discussões entre artistas e cientistas, disparadas por obras de arte no Instituto Inhotim de Arte contemporânea. A finalidade era estruturar um formato não hierárquico de troca e produção 
de conhecimento envolvendo esses três territórios: artistas, cientistas e obras de arte. Após esses experimentos por ela referidos como "triangulações artsci", Fróes afirma que essa problematização híbrida provocada pela experiência estética é capaz de transformar o pensamento científico convencional.

Apesar de as ciências trabalharem com modelos universais e as artes com poéticas subjetivas, o método artsci aposta na possibilidade de migração de conhecimento do campo artístico para o científico através de associações conceituais, metáforas e isomorfismos entre padrões de ambas as áreas. Mais do que a emergência de uma ciência sensível, em que se reconhece a presença de realidades subjetivas, acredita-se que a abstração e o conhecimento das artes possam potencializar e antecipar o conhecimento científico.

Nesse contexto, surgia então o convite inusitado para experimentar a poética PI como potencial revelador de novos padrões nos dados científicos. Nascia assim o embrião da tese, disparada por uma residência artística em um laboratório de neuroepistemologia experimental.

Essa investigação encontrou inicialmente apoio na neuroestética, corrente contemporânea criada pelo neurocientista turco Semir Zeki (2014), defensora de que as investigações artísticas e científicas têm questões em comum, apenas buscam caminhos diferentes para respondê-las. No entanto, apesar de as perguntas que motivam a produção de conhecimento e de expressão humana em artes e ciências serem semelhantes e já reconhecidas em áreas como a neuroestética e correntes na arte contemporânea, existe uma desconexão entre essas áreas, sobretudo, em termos de processo.

A arte pode ser objeto de estudos das ciências assim como dados e ferramentas científicas costumam já ser utilizados nas artes, porém, em ambas as áreas, é recorrente observar que seus arcabouços teóricos, que sustentam seus processos e reflexões, continuam sem sofrer interferência da chamada outra área. As zonas de conforto epistemológicas permanecem protegidas contra qualquer alteração nas suas bases teóricas. Os resultados são diversos, porém os pensamentos que envolvem os processos que lhes resultam continuam isolados.

Mas e se esses processos pudessem se misturar e se fortalecer mutuamente? Existiriam metodologias acopláveis capazes de contribuir tanto para as artes quanto para as ciências?

A hipótese levantada por esta pesquisa, portanto, é uma aposta na possibilidade de uma poética artística contemporânea desvelar, através de isomorfismos, estruturas de ordem neurofisiológicas que os sistemas de análise científicos não estão aparelhados conceitual e tecnologicamente para enxergar. Acreditando que a imbricação entre poéticas artísticas e processos científicos possam contribuir para ambas as áreas, o objetivo geral desta investigação tornou-se a aplicação do método artsci na poética Partituras Imagéticas para desenvolver objetos híbridos, em uma imbricação de processos entre neurociências e artes contemporâneas.

Além de produzir conhecimento nos macro campos da arte e da ciência sob novas perspectivas, uma consequência imediata desta investigação é a discussão epistemológica em torno da visão da neuroestética em relação à arte, uma base para a pesquisa inicialmente, que ao longo da investigação, começou a ser problematizada.

A neuroestética busca entender os mecanismos neurais que permitem ao ser humano experimentar a beleza (ZEKI, 2014). Investiga, portanto, o impacto da obra sobre o espectador com interesse no resultado estético da arte tendo como parâmetro conceitos como "o belo". Assim, apesar de consistir em um ramo contemporâneo da neurociência, utiliza-se de conceitos tradicionais da arte, hoje já desconsiderados pela arte contemporânea.

A relevância desta investigação está, portanto, em propor uma atualização da neuroestética segundo o pensamento, também contemporâneo, da arte, sobretudo, ao considerar a obra de arte como processo. 
O trabalho se torna relevante, ainda, ao considerarmos o papel social do artista contemporâneo segundo o pensamento de Vilém Flusser (2008). De acordo com o filósofo tcheco, o artista de hoje deve subverter os meios de criação disponíveis, o computador e tecnologias relacionadas, na busca deliberada pelo imprevisível. Para ele, os que operam os programas sem conhecer seus processos seriam apenas seus funcionários. Nesse sentido, o artista deveria ser como um jogador, que joga um jogo contrário ao estabelecido, com o fim de subverter automatizações em busca do imprevisto, da informação nova. Nessa perspectiva, os processos e tecnologias utilizados na neurociência podem ser considerados um território de trabalho e subversão para o artista contemporâneo.

Partituras imagéticas do corpo

O primeiro experimento intitulado Partituras Imagéticas do corpo tinha como fim criar imagens e sons da poética PI a partir de dados de condutância de pele ${ }^{52}$.

Partiríamos dessa primeira etapa de medição de dados para a circularização do tempo e geraríamos gráficos equivalentes às partituras imagéticas (resultantes do experimento pregresso de tradução de partituras musicais em imagens). No entanto, nos deparamos com a necessidade de dar um passo atrás, antes mesmo de medir e trabalhar os dados gerados por esta experimentação, pois as seguintes questões axiais encontravam-se em aberto: como parametrizar dados originais e/ou atributos biofísicos calculados a partir do processamento destes dados dentro de um universo de atributos sonoros/musicais? Como relacioná-los à estrutura visual das Partituras Imagéticas?

Toda essa lógica de tradução e equivalências estava por ser construída dentro de um universo de partida que não mais consistia de partituras musicais, mas de traçados fisiológicos. Por exemplo, considerando que o modelo poético PI traduz informações musicais, como notas nas claves de sol e fá, foi preciso decidir que dados/informações coletados pelo $Q$ sensor seriam traduzidos como esta ou aquela função sonora/musical, e por quê. É o que Manovich (2004) chama de escolhas de mapeamento justamente para não estabelecer relações visuais arbitrárias, o que enfraqueceria a metodologia. Quais seriam então as escolhas para dar visualidade aos dados, relacionando-os a informações musicais do modelo PI?

Para isso, foi preciso estabelecer uma ponte entre atributos das medidas de condutância da pele e atributos musicais a partir de discussões em várias rodadas sobre cognição e fruição musical, tanto do ponto de vista poético subjetivo quanto do ponto de vista científico, respectivamente, levantados por mim, a artista criadora da PI e, Maira, neurocientista e orientadora desta pesquisa.

Da proposta preliminar de um sistema de chaveamento de informações de condutância de pele em uma poética imagético-musical, seguimos para a próxima etapa: preparar os dados para servir de input nas Partituras Imagéticas. Maira sistematizou a parametrização dos dados através de cálculos de derivadas e filtros matemáticos, contando com recursos algorítmicos desenvolvidos pelos colaboradores Murilo Moura (estudante IC LAMAE - HCTE, NCE/UFRJ) e Estevão Ferrão (Engenheiro, LAVI, COPPE/UFRJ). Após essa etapa, os dados foram estruturados para coincidir com a estrutura circular da poética PI.

Considerando o trabalho dessa equipe interdisciplinar, pode-se dizer que a metodologia do experimento contou com ferramentas e processos em artes e ciências. Notamos também que a interdisciplinaridade de uma etapa atuava sobre resultados da etapa anterior, também de natureza hídrida. Esse hibridismo esteve presente, portanto, de forma reiterada em todos os

${ }^{52}$ Medidas elétricas obtidas a diminutos intervalos de tempo através de um sensor galvânico ( $Q$ Sensor, Affectiva) localizado na superfície da pele - parte interna do pulso -, proporcionais à dinâmica de produção de suor pelo voluntário. 
momentos do experimento: desde a co-problematização do objeto (chaveamento dos dados de condutância de pele com os parâmetros sonoros/musicais), passando pelo processo (utilização de metodologias e ferramentas em artes e ciências) e finalmente também na análise de resultado (pela dupla artista/neurocientista), representado no nível 3, o que nos possibilitou enxergar e elaborar um sistema de três diferentes níveis de imbricação entre arte e ciência.

Considerando diferentes áreas do conhecimento, no contexto de um trabalho interdisciplinar, no nível 1 , apenas dados seriam compartilhados entre as essas áreas. A problematização do objeto, metodologias, bibliografia e análise de resultados permanecem inalterados. No nível 2, um pouco mais aprofundado, além de dados, compartilham-se também informações entre as diferentes áreas, por meio de bibliografias e ferramentas, permitindo a geração de um resultado híbrido que, reconhecivelmente, contém partes de ambas as áreas.

No nível 3, a hibridização já teria início desde a problematização do objeto por diferentes áreas, de maneira conjunta. Em seguida, o objeto co-problematizado se desenvolve em um processo híbrido que inclui dados, ferramentas e bibliografia de diferentes áreas. Dessa maneira, os processos e os conhecimentos interferem-se entre si, se alteram, não mais se preservam enquanto áreas delimitadas, e produzem um resultado transdisciplinar, em que não se pode mais mensurar até onde está a influência clara de uma área ou outra, se instaura uma terceira ordem.

\section{Conclusões}

Ao considerar as sucessões de interferência de ambas as áreas (artes visuais e neurociências) ao longo das etapas, entendemos que não é mais possível delimitar as fronteiras entre arte e ciência no resultado final. Esses limites não estariam mais visíveis. O produto do experimento Partituras imagéticas do corpo vai além do híbrido, trata-se de um objeto transdisciplinar.

Esse pensamento fez estalar a hipótese inicial da tese, de que criaríamos objetos híbridos. A nova hipótese defendida por esta pesquisa é que, dependendo da extensão e profundidade de imbricação entre arte e ciência em um processo de pesquisa e produção de artefatos, pode-se criar objetos transdisciplinares, que estariam além da interface nítida entre arte e ciência.

\section{Bibliografia}

FLUSSER, V. O mundo codificado: por uma filosofia do design e da comunicação. Rafael Cardoso (org). São Paulo: Cosac Naify, 2007.

FRÓES, M. Mais que a razão do belo: uma ciência sensível. In: Polêm!ca, v. 10, p. 1-6, 2011. Disponível em: <http://www.e-publicacoes.uerj.br/index.php/polemica/article/view/2864> Acesso em: 10 de mar. 2015.

An Artsci Science. Technoetic Arts: A Journal of Speculative Research, v. 13, n. 1 \& 2, p. 203-217, 2015.Disponível em:

<http://www.ingentaconnect.com/contentone/intellect/ta/2015/00000013/F0020001/art00015> Acesso em: 20 Jul. $2015 b$

MANOVICH, L. A visualização de dados como uma nova abstração anti-sublime. Revista do Programa de PósGraduação em Artes Visuais EBA/UFRJ, 2004. p.135-143.

ZEKI, S. Neurobiology and the Humanities. In: Neuron no 84, 2014. Disponível: <http://www.cell.com/neuron/pdf/S0896-6273(14)00836-8.pdf>. 


\section{MUSEU DE ANATOMIA, A CRIATIVIDADE É A SAÍDA!}

Juliana Dantas-Graduanda de Enfermagem e Obstetrícia - UFRJ julianadantas.g@hotmail.com

Gustavo Pestana - Graduando de Educação Física - UFRJ pestanagust@ufrj.br

Ana Beatriz Ferreira Graduandos de Educação Física - UFRJ - abmmf@hotmail.com

Ayrton Lima - Graduando de Dança - UFRJ ayrlimba@hotmail.com

Nathalia Nascimento - Graduanda de Ciências Biológicas - UFRJ

Ludmila Ribeiro - Técnica de Laboratório - ICB/CCS-UFRJ - ludmila@icb.ufrj.br

Daniela Uziel - Docente - ICB/CCS-UFRJ - daniuzi@icb.ufrj.br

\section{Resumo}

A curiosidade é uma característica importante em crianças e adolescentes, que buscam conhecer o próprio corpo e o mundo a sua volta. Experiências educacionais mostram que este público tem grande capacidade de lidar com temas de ciência e que a forma criativa é ideal para cativá-lo e estimulá-lo na busca do conhecimento. Museus exploram a curiosidade natural e são veículos de popularização científica. Com esta proposta nasce o Museu de Anatomia "Por dentro do Corpo" (ICB-CCS/UFRJ), cujas vitrines expoem as peças anatômicas humanas e de animais de forma criativa e didaticamente organizada através dos sistemas orgânicos do corpo. O museu recebe grupos escolares em visitas mediadas por alunos de graduação e proporciona a vivência do trabalho realizado em laboratórios de pesquisa do ICB.

\section{Palavras chave: Museu De Anatomia. Visitação.Corpo Humano}

\section{Museus como Espaços de Educação}

Museus são espaços culturais e educativos. Para Pereira et al (2007), pretendem educar por meio da sensibilização e cultivam a comunicação e produção de significados a partir de seus objetos, exposições, propostas educativas e outras. Ao longo dos anos, tanto a pesquisa quanto as práticas educacionais relacionadas às exposições, bem como às atividades em museus têm se intensificado, tornando-se cada vez mais um campo de produção do conhecimento. Atualmente os museus são reconhecidos como locais que possibilitam intensa interação social entre os visitantes, exploração ativa e ricas experiências afetivas, culturais e cognitivas (MARANDINO, 2009).

Museus de ciências são de grande relevância no âmbito da educação e da popularização da ciência para os cidadãos. Tal fato pode ser evidenciado pelas políticas internacionais e nacionais que enfatizam os museus enquanto espaços educativos, tanto por meio de financiamentos, quanto na perspectiva de incorporá-los em projetos de educação nacional (MOREIRA, 2006).

Museus mudam a vida das pessoas. Eles contribuem para que as comunidades sejam mais resilientes e ajudam a criar uma sociedade mais justa. Museus, em retorno, são imensamente enriquecidos pelas capacidades e criatividade de seus públicos"53. Eles não são espaços neutros e podem apresentar coleções que desafiem pressupostos e estimulem pessoas a pensar sobre o mundo de hoje e sobre como ele poderia ser diferente no futuro. Museus reciclam seu compromisso com a sociedade sem abandonar seu compromisso com a conservação e ressignificação dos acervos sob sua guarda, buscando formas de maximizar o seu impacto social.

As possibilidades culturais e didáticas desses espaços, aliadas a políticas governamentais de fomento e educacionais de formação profissional, têm ajudado a compor um panorama em que os museus são parceiros da instituição escolar. Para Marandino (2001), os museus se

\footnotetext{
${ }^{53}$ Pesquisa sobre o propósito dos museus na sociedade, produzida pelo Britains Think for the Museums Association em 2013.: http://www.museumsassociation.org/museums2020.
} 
caracterizam como espaços de produção, educação e divulgação do conhecimento. Além disso, o relacionamento entre museus e escolas configurou-se de forma quase permanente ao longo dos anos, o que faz, deste público, prioritário em muitas instituições museais.

Neste contexto educacional, o Museu de Anatomia "Por dentro do Corpo" nasce do processo criativo de uma equipe de docentes, técnicos e alunos dos diversos cursos de graduação da UFRJ. A variedade de formações acadêmicas e saberes desta equipe configura a diversidade e criatividade existente nesta empreitada. O Museu de Anatomia é constituído por vitrines que expõem peças anatômicas humanas e de animais de forma criativa e didaticamente organizada através dos sistemas orgânicos do corpo.

O principal público do museu são os grupos escolares em visitas pré-agendadas e mediadas pelos alunos de graduação da equipe. Com o foco no aproveitamento didático dos escolares na visita a museus, foram realizados estudos com o intuito de fomentar essa parceria. Educadores de museus estudiosos do tema vêm estabelecendo parâmetros acerca dos possíveis caminhos dessa relação, salientando sempre a necessidade do equacionamento de um denominador comum que possibilite o aprimoramento do diálogo entre as escolas e os museus (ALLARD e LEFEBRVE, 1995). Nascimento (2008) e Marandino (2005) constataram que instituições escolares têm reconhecido a importância dos museus nos processos educacionais e o seu potencial em promover uma educação integral e continuada às populações.

Desta forma, a proposta de educação em museus é de que, através das exposições, há possibilidade de conhecer conceitos, conteúdos, procedimentos, valores, concepções e políticas científicas. Os objetos e a forma como são apresentados são ricas estratégias didáticas para o ensino de Ciências.

\section{O Ensino sobre o Corpo Humano no Ensino Básico}

Os PCNs para o Ensino Fundamental determinam os objetivos gerais e um destes é: "conhecer o próprio corpo e dele cuidar, valorizando e adotando hábitos saudáveis como um dos aspectos básicos da qualidade de vida e agindo com responsabilidade em relação à sua saúde e à saúde coletiva".

Os PCNs organizam o conhecimento escolar em área e temas transversais, havendo, dentre as áreas, a de Ciências Naturais. Cada área tem seus conteúdos divididos em eixos temáticos, e na área de Ciências Naturais, há o eixo intitulado "Ser Humano e Saúde". Nele, observa-se

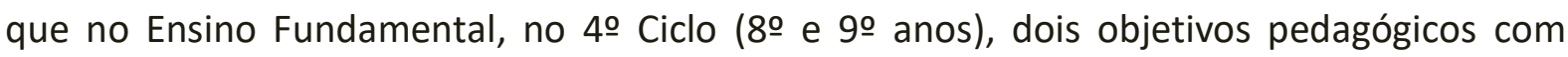
relação aos conteúdos do corpo humano são destacados: "Compreender o corpo humano e sua saúde como um todo integrado por dimensões biológicas, afetivas e sociais, relacionando a prevenção de doenças e promoção de saúde das comunidades a políticas públicas adequadas, compreender as diferentes dimensões da reprodução humana e os métodos anticoncepcionais, valorizando o sexo seguro e a gravidez planejada" (PCNs, 1998, p. 90). Todavia, os PCNs foram declarados facultativos pela Câmara de Educação Básica (CEB) do Conselho Nacional de Educação (CNE) do Ministério da Educação (MEC).

Já nas DCNs, estas "visam estabelecer bases comuns nacionais para a Educação Infantil, o Ensino Fundamental e o Ensino Médio, bem como para as modalidades com que podem se apresentar, a partir das quais os sistemas federal, estaduais, distrital e municipais, por suas competências próprias e complementares, formularão as suas orientações assegurando a integração curricular das três etapas sequentes desse nível da escolarização, essencialmente para compor um todo orgânico" (DCNs, 2013, p. 8). Assim, as DCNs garantem certa autonomia nas redes públicas municipal, estadual, federal e distrital em construírem e seguir suas próprias orientações curriculares.

Baseado nesses descritores, os alunos do 8o ano do Ensino Fundamental de escolas públicas e particulares do Rio de Janeiro podem ser considerados como alvo para a aplicação das 
técnicas experimentais propostas neste trabalho, visto que eles podem correlacionar o conteúdo teórico que estão aprendendo em sala de aula com as práticas que serão desenvolvidas dentro dos laboratórios e através da visitação e participação nas atividades do nosso Museu de Anatomia.

Aulas Práticas como Estratégia de Ensino

No Brasil, o Ministério da Educação e as redes públicas de educação priorizam o ensino do tema "corpo humano" em três momentos da vida escolar do aluno. Na Educação Básica: no 5o ano do Ensino Fundamental, quando são introduzidos conceitos fundamentais sobre o organismo e seu funcionamento, com analogias mais lúdicas e acessíveis as crianças. No 8o ano do Ensino Fundamental, os alunos têm uma visão um pouco mais aprofundada sobre os conteúdos, abordando estruturas celulares, tecidos, estruturas teciduais e seus respectivos funcionamentos. Finalmente, no Ensino Médio, o tema já é abordado com mais complexidade em cada parte, cujo grande diferencial em relação ao 8 o ano é o ensino sobre processos bioquímicos metabólicos e sobre genética. Como no Ensino Médio as disciplinas de Química e Física são lecionadas separadamente e de forma mais aprofundada do que no 9o ano do Ensino Fundamental, torna-se mais viável abordar processos bioquímicos do metabolismo humano no Ensino Médio do que no Ensino Fundamental.

A utilização de animais em aulas práticas escolares já foi muito frequente para se analisar aspectos da biologia e fisiologia de seres vivos que fazem parte do programa curricular das escolas. No entanto, esta atividade tem sido muito discutida por várias razões, obrigando os profissionais da educação a debaterem sobre a moralidade e eficácia dela (STRAUSS; KINZIE, 1994). Em primeiro lugar, tem-se a ética no uso de animais para ensino. É questionável a necessidade de se sacrificar seres vivos para fins didáticos (VILLIERS; MONK, 2005). Além disso, muitos alunos podem não estar psicologicamente preparados para lidar com animais mortos. A dissecção é uma atividade não muito agradável para muitos alunos, porém não pode ser retirada do ensino.

Para assegurar as boas práticas de uso de animais em ocasiões realmente necessárias foi sancionada em 2008 a Lei no 11.794/08 (Lei Arouca), que restringiu o uso de animais do filo Chordata, subfilo Vertebrata ao Ensino Superior e a educação profissional técnica de nível médio da área Biomédica.

Desta forma, as atividades de dissecção, antes utilizadas na Educação Básica, tiveram que ser abandonadas, o que levou os professores a buscar constantemente formas alternativas de atrair o aluno para o ensino de Ciências, pois cabe a estes "facilitar a construção do sistema de formação, motivando o aluno a desenvolver a aprendizagem, utilizando recursos didáticopedagógicos" (CASTOLDI; POLINARSKI, 2009; KUBO; BOTOMÉ, 2001 apud SILVA et al., 2011, p. 25). Tais recursos consistem em ferramentas que demonstrem o conteúdo a ser ensinado e aprendido, que sejam lúdicas, dinâmicas e que estimulem a participação do aluno na aula, tirando-o da posição de espectador.

Como sugere Lunetta (1991 apud SILVA et al., 2011, p. 26) as aulas práticas devem aproximar o aluno do mundo real, buscando conhecer seus problemas e encontrar soluções para os mesmos. Estes recursos podem ser de grande valia, não só por trazerem uma vivência real ao aluno, mas também por ajudarem no processo de interação e desenvolvimento de conceitos científicos.

Há várias formas de aulas práticas, com diferentes objetivos, mas nos concentramos neste projeto naquelas que "utilizam técnicas e peças anatômicas como uma estratégia motivadora para a construção do conhecimento nas aulas práticas" (ZABALA, 1998; MONTES;SOUZA, 2008 apud SILVA et al., 2011). 
Desta forma, os grupos escolares que nos visitam, além de contemplarem toda a exposição e poderem manipular alguns de nossos exemplares, têm a oportunidade de visitar um dos laboratórios de pesquisa do ICB, parceiros de nosso projeto, vivenciando a rotina de um ambiente laboratorial, conhecendo suas variadas linhas de pesquisa e o relacionamento do cientista e seu trabalho. Proporcionar aos alunos do Ensino Básico esta experiência, amplia os horizontes e possibilidades de carreira, muitas vezes não vislumbradas por este público.

\section{O Processo de Plastinação e sua Utilização no Ensino}

A plastinação é uma técnica criada na Alemanha (VonHAGENS, 1979) que consiste em remover líquidos biológicos de órgãos, segmentos ou corpos inteiros através de banhos sucessivos em acetona em diferentes concentrações, e impregná-los com um polímero que tem a capacidade de endurecê-lo, mantendo-o íntegro, resistente, durável, e se manipulado corretamente, pode se manter conservado por anos (VonHAGENS et al., 1987, DOUGLASS; GLOVER, 2003).

Além disso, esta técnica apresenta outras vantagens que possibilitam sua utilização para diferentes públicos: a coloração, as relações entre órgãos e sistemas, nervos e vasos são mantidas intactas (DOVAL et al., 2011); as peças ficam secas, inodoras, e atóxicas, o que permite sua manipulação sem luvas; os órgãos e tecidos podem ser dissecados e abertos, mostrando estruturas e relações difíceis de serem observadas; permite a comparação entre órgãos saudáveis ou não; podem ser transportadas para a sala de aula; possibilita o uso de rótulos com nomes e diagramas para que facilitem o aprendizado de alunos; podem ser usadas com imagens e programas educacionais; facilita a logística do material, podendo ser guardadas em recipientes plásticos (DOUGLASS; GLOVER, 2003), além de serem mais semelhantes ao modelo in vivo (DOVAL et al., 2011). As peças plastinadas possibilitam que alunos Portadores de Necessidades Especiais (PNEs), com deficiência visual, por exemplo, possam perceber as formas e texturas de órgãos tateando-as sem usar luvas.

Segundo Jones \& Whitaker (2009), "a plastinação representa um grande acontecimento no ensino de anatomia e vem crescendo como uma ferramenta útil de pesquisa". Desta forma, o uso de peças plastinadas em aulas se mostra como uma ferramenta para substituir a dissecção de animais, uma vez que esta última prática é proibida por lei no Ensino Básico, além de ilustrar os conceitos apresentados e de ser um elemento palpável para os alunos.

Capacitação dos Graduandos - Integração entre Ensino, Pesquisa e Extensão Universitária Além do curso de capacitação sobre as técnicas de plastinação e repleção, os alunos do projeto são capacitados a atuarem como mediadores nas visitas ao museu. O papel do mediador em uma visita é de suma importância. Marandino (2008) descreve que o mediador, ao planejar suas ações e ao realizar a mediação com o público, deve considerar que "este não deve ser exposto a longos períodos de exposição oral, não deve ser submetido à leitura de textos imensos, mas deve, sim, saber se localizar, se sentir à vontade para interagir, podendo dialogar com seus pares e com o mediador". O mediador deve atuar como um decodificador das informações contidas na exposição.

$\mathrm{Na}$ mediação entre o conhecimento exposto e o público, o saber apresentado sofre transformações com objetivo de se tornar compreensível ao público (ALLARD et al.,1996). Para isso, o mediador deve obter informações sobre o visitante, buscando estabelecer pontes entre os conhecimentos que trazem - conceitos, vivências, idéias - e aqueles apresentados nesses locais. Elaborar estratégias eficazes e estimulantes, que articulem processos educativos e comunicativos adequados e os objetivos esperados nas ações que participam, é um momento de criação e de produção de conhecimento próprio dos mediadores. 
Todos os cursos do Centro de Ciências da Saúde apresentam disciplinas de Anatomia em seu currículo, sendo o aprendizado deste tema essencial às carreiras da área da Saúde. Assim, neste projeto, os alunos tem a oportunidade de utilizar os conhecimentos adquiridos em sala de aula na elaboração de material a ser utilizado no ensino básico. Em paralelo, nesta linha de pesquisa sobre a utilização destas peças no ensino básico, estuda-se seu emprego e sua aceitação em aulas práticas do Ensino Fundamental. Desta forma, integra-se perfeitamente Ensino, Pesquisa e Extensão.

\section{Referências bibliográficas}

ALLARD, Michel; LEFEBVRE, Bernard. Le musée, un lieu éducatif. Montréal: Musée d’Art Contemporain de Montréal, 1995.

BONELLA, A. E. Animais em laboratório e a lei Arouca. Scientia e Studia, 2009.

BRASIL. Constituição (1988). Artigo 210. Constituição da república Federativa do Brasil: promulgada em 5 de outubro de 1988. Disponível em http://www.planalto.gov.br/ccivil 03/Constituicao/Constituicao.htm. Acesso em:

BRASIL. Lei no 11.794, de 8 de outubro de 2008. Diário Oficial [da] República Federativa do Brasil, Poder Legislativo, Brasília, DF, 9/ 10/ 2008.

BRASIL, DIRETRIZES CURRICULARES NACIONAIS, Min. da Educação. Brasília, 2013.

DOUGLASS, C.; GLOVER, R. Plastination: Preservation Technology Enhanses Biology Teaching. BioOne. v. 65, n. 7, p. 503-510, 2003.

DOVAL, M. C.; VALE, A. L. M.; GODOY, J. R. P. Técnicas de conservação de peças anatômicas para o estudo e ensino da anatomia humana. Journal of Morphological Sciences. v.28, Supl, p.39. In: II ENCONTRO INTERN. DE ENSINO EM ANATOMIA DO ICB/USP, São Paulo: USP, 2011.

JONES, D. G; WHITAKER, M. I.; Engaging With Plastination and The Body Worlds Phenomenon: a Cultural and Intellectual Challenge for Anatomists. Clinical Anatomy. v. 22, p. 770-776, 2009.

MARANDINO, M. Interfaces na relação museu-escola. Cad. Cat. Ens. Fís., v. 18, n.1: p.85- 100, abr. 2001.

MARANDINO, M. (org.) Educação em museus: a mediação em foco. São Paulo, SP: Geenf / FEUSP, 2008.

MARANDINO, M. Museus de Ciências, Coleções e Educação: relações necessárias. Revista Eletrônica do Programa de Pós-Graduação em Museologia e Patrimônio - PPG-PMUS Unirio - v.2 n.2 - jul/dez de 2009

NASCIMENTO, S.S. In: Garcia, N. (Org). Atas do XI Encontro Nacional de Pesquisa em Ensino de Física. CEFET-PR e SBF: Curitiba. 2008.

PARÂMETROS CURRICULARES NACIONAIS. Terceiro e Quarto Ciclos do Ensino Fundamental, Ciências Naturais. Min. da Educação, Brasília, 1998.

PEREIRA, J.S; SIMAN, L.M.C; COSTA, C.M.; NASCIMENTO, S.S. Escola e Museus: diálogos e práticas. Belo Horizonte: Secretaria de Estado e Cultura/ Superintendência de Museus; PUC de Minas Gerais/Cefor,2007.

RIO DE JANEIRO (Município). Orientações Curriculares: Áreas Específicas (Ciências). Secretaria Municipal de Educação. Rio de Janeiro, 2013.

SILVA, R. K. A. et al. Vantagens e desvantagens das técnicas de preparação de materiais didáticos para as aulas práticas de morfologia. Revista Didática Sistêmica. v. 13, n. 2, p. 24-41, 2011.

VON HAGENS, G. Impregnation of Soft Biological Specimens with Thermosetting Resins and Elastomers. Anat. Rec. v. 194, p. 247-256, 1979. 


\section{PROBLEMAS NA APRENDIZAGEM DE MATEMÁTICA: UMA PROPOSTA DE ENSINO USANDO VIDEOAULAS}

FARIA, Ive Sá de Pina - C. E. República de Cabo Verde - IME/UERJ - ivepina@gmail.com CONCORDIDO, Cláudia - IME-UERJ, IBMEC - concordido@ime.uerj.br BARROS, Jeanne - IME-UERJ, Projeto Fundão - IM/UFRJ - jeanne@ime.uerj.br

\section{Resumo}

O objetivo deste trabalho é divulgar uma atividade de recuperação paralela de estudos inovadora que utiliza videoaulas, tema de dissertação de mestrado profissional de Ive Faria, em 2017, não publicada ainda. Foi aplicada para os alunos do 3ํano do Ensino Médio do C. E. República de Cabo Verde, de forma semipresencial, sobre o conteúdo de Análise Combinatória, e teve a plataforma YouTube como a principal ferramenta de disseminação do conteúdo. De acordo com os bons resultados obtidos com essa prática, conclui-se que as videoaulas são excelentes instrumentos pedagógicos para o processo de recuperação paralela de estudos.

Palavras-chave: Videoaulas. Recuperação Paralela de Estudos.Lacunas De Aprendizagem.

Introdução

Em geral, as lacunas de aprendizagem são problemas decorrentes de fatores extrínsecos. Portanto, podem ser pensadas como uma dificuldade escolar (DE), a priori. Afinal, a DE tem origem extrínseca, ou seja, relaciona-se com fatores ambientais somados a fatores internos. Esses fatores podem ter origens pedagógicas, socioculturais, econômicas, familiares e/ou emocionais (CARVALHO, CRENITTE, CIASCA, 2007, p. 231). Portanto, a DE pode ser corrigida pedagogicamente. Isso não significa que outras dificuldades escolares nunca mais vão aparecer em outro momento, mas que aquele problema de aprendizagem pontual foi resolvido.

Diante disso, um conjunto de atividades foi criado com o objetivo de atender aos alunos que possuem problemas de aprendizagem (FARIA, 2017). Essas atividades foram aplicadas, mediante a criação de um Plano Especial de Estudos para a recuperação paralela de estudos do 1 o bimestre de 2017, para os alunos do 3a ano do Ensino Médio do C. E. República de Cabo Verde, localizado em Irajá, na cidade do Rio de Janeiro. Esses alunos obtiveram grau abaixo da média estabelecida no Projeto Político Pedagógico da escola, ou seja, obtiveram pontuação inferior a cinco pontos. Uma dessas atividades consistia em assistir às videoaulas do conteúdo de Análise Combinatória preparada com base nos PCNEM e em técnicas que dariam suporte a quem possuía problemas de aprendizagem. A gravação e edição das videoaulas usaram recursos tecnológicos simples e de amplo acesso a todos os professores que desejam reproduzir o processo. O conjunto de técnicas de cunho teórico e os recursos tecnológicos de cunho técnico utilizados são apresentados para fundamentar as atividades de recuperação paralela de estudos.

\section{Teoria e Prática}

A construção teórica das aulas de Análise Combinatória baseou-se no papel da Matemática para o Ensino Médio descrita nos PCNEM objetivando resolver os problemas de aprendizagem dos alunos. Para exemplificar essa construção, a Figura 1 mostra um slide de uma das videoaulas. Nessa aula, a primeira, é explicada como se processa a Análise Combinatória, através de suas várias etapas. 0 que é, quais são suas possíveis representações, estratégias 
de resolução dos problemas combinatórios, as relações combinatórias que podem estar envolvidas e os métodos de contagem que auxiliam a resolução desses problemas.

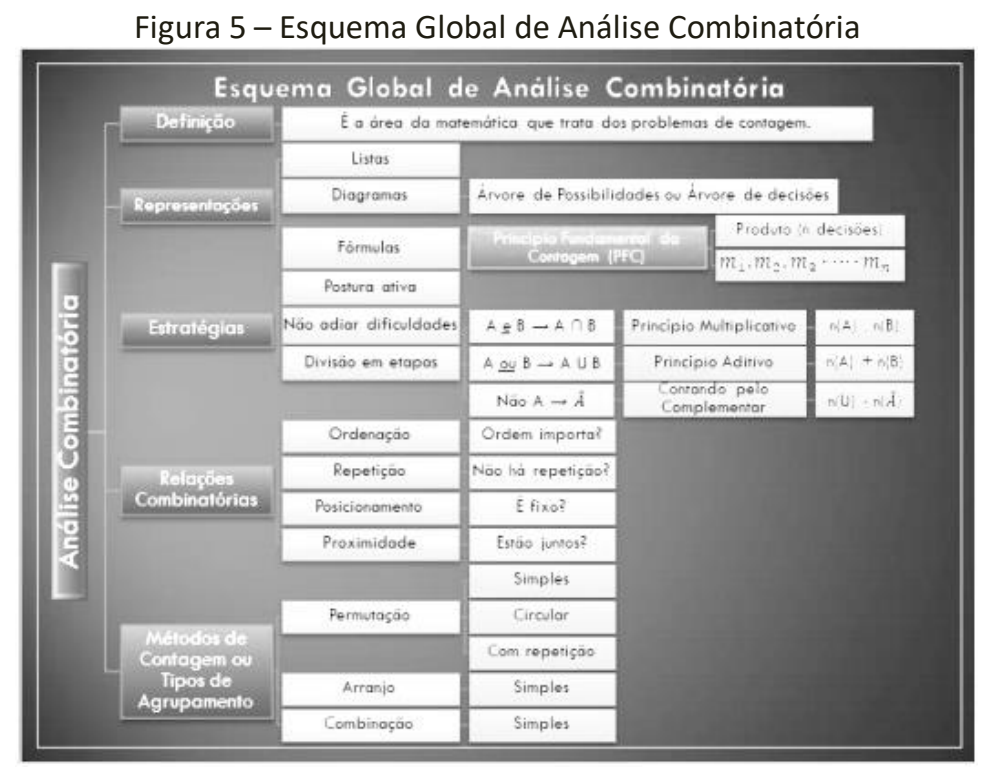

Fonte: As autoras

Os recursos tecnológicos que viabilizaram a gravação e edição das videoaulas foram:

- 1 computador de mesa da marca Positivo, com processador i5, 6 GB de memória, 1 TB de HD, Windows 10, 64 bits;

- 1 notebook da marca LENOVO, com processador i3, 4 GB de memória, 1 TB de HD, Windows 10, 64 bits;

- 1 netbook da marca LG, com processador Intel Atom CPU N270, 2 GB de memória, Windows 7, 32 bits;

- 1 microfone de lapela estéreo, que foi substituído por um microfone de mesa da marca Bright;

- 1 software livre de captura de vídeo chamado de aTube Catcher;

- 1 software livre de edição de vídeo conhecido como Windows Movie Maker, editor de vídeo da Microsoft;

- 1 software livre de tratamento de áudio chamado de Audacity.

Todas as videoaulas estão disponibilizadas na plataforma YouTube no canal Prof Mat321, cujo endereço eletrônico é <https://www.youtube.com/channel/UCv1LAkhGMbbXs2UxXp69WeQ>. E a divulgação ocorreu mediante link que foi enviado para os alunos pelo WhastApp e, também, ficou disponível na página "Aprenda a estudar matemática" do Facebook (https://www.facebook.com/aprendaaestudarmatematica) além de estar no Blog "Aprenda a estudar matemática", no endereço elrônico $<$ http://aprendaaestudarmatematica.blogspot.com.br/>.

Recuperação Paralela de Estudos

O C. E. República de Cabo Verde é um colégio de Ensino Médio, de formação geral, localizado em Irajá, no Rio de Janeiro, por isso, segue a Portaria SEEDUC/SUGEN no 419/2013. Essa portaria descreve que as ações para a recuperação paralela de estudos devem ser realizadas mediante Plano Especial de Estudos (PEE) a ser disposto nos regimentos da escola. Isto é, as ações de recuperação de estudos são subsidiadas através de material didático específico 
construído para esse fim, formando um conjunto de atividades pedagógicas diversificadas (RIO DE JANEIRO, 2013, art.8).

Assim sendo, as cinco videoaulas de Análise Combinatória constituem o principal material didático construído para auxiliar as ações de recuperação paralela de estudos desse conteúdo. Além desse material, questionários objetivos foram criados com a finalidade de verificar se os alunos estavam assistindo de fato às videoaulas. $E$, em cada videoaula, há questões para serem realizadas como tarefas. Essas ações (de assistir às videoaulas, resolver as tarefas presentes nas videoaulas, responder aos questionários e fazer uma reavaliação) foram pontuadas e constituem o conjunto de atividades pedagógicas diversificadas do PEE que poderá integrar o Projeto Político Pedagógico (PPP) do C. E. República de Cabo Verde (FARIA, 2017, p. 33).

A reavaliação, uma avaliação discursiva semelhante a que foi aplicada no primeiro bimestre, foi o principal instrumento de avaliação de desempenho para todos os alunos que ficaram em recuperação. O objetivo de mantê-la é verificar a recuperação de conteúdo efetiva dos alunos nesse tipo de avaliação. Porém, nem todos os alunos foram obrigados a participar dessas atividades de recuperação de estudos usando as videoaulas. Alguns optaram por fazer a recuperação paralela de estudos da forma tradicional, presencial, através de revisão do conteúdo e reavaliação, conforme previsto no PPP atual da instituição de ensino.

Por essa razão, nove alunos assistiram às videoaulas para rever o conteúdo de Análise Combinatória e participaram das atividades propostas (Grupo A) e dez alunos optaram pela forma tradicional de recuperação de estudos (Grupo B). Com isso, foi possível comparar os resultados desses dois grupos. Todos do Grupo A recuperaram suas notas, um deles obteve melhoria de $800 \%$ da nota. Antes da prática de recuperação a nota era 0,5 e passou a ser 4,5 , após o processo de recuperação de estudos usando as videoaulas. Enquanto que, no Grupo $B$, apenas quatro alunos melhoraram seu desempenho, alguns tiveram uma queda de nota que chegou a 66,7\% abaixo da nota antes da recuperação de estudos (FARIA, 2017, p. 61).

\section{Conclusões}

Os resultados obtidos com a aplicação das atividades mostram que as videoaulas foram eficientes instrumentos de recuperação paralela para os alunos do 3 ㅇ ano do $E M$, pois os alunos que realizaram todas as atividades propostas obtiveram melhoria do desempenho acadêmico. Isso foi comprovado pela recuperação de suas notas, através do somatório da pontuação atribuída às tarefas presentes nas videoaulas, aos questionários com perguntas sobre o que assistiram nas videoaulas e à reavaliação discursiva aplicada. Assim, a experiência passou a ser referência para outros professores, além de ser um legado para o colégio, pois nos próximos anos, podem usar essa atividade com essa finalidade. E, por último, essa forma de recuperação de estudos permite que os alunos do colégio que não obtiveram êxito no processo de recuperação de estudos, possam refazê-lo em um outro momento. Tornando este projeto um processo contínuo de aperfeiçoamento. Portanto, conforme os bons resultados obtidos com essa prática, conclui-se que as videoaulas são excelentes instrumentos pedagógicos para o processo de recuperação paralela de estudos.

Referências bibliográficas

CARVALHO, F. B. de; CRENITTE, P. A. P.; CIASCA, S. M. Distúrbios de aprendizagem na visão do professor. Revista psicopedagogia. São Paulo, v. 24, n. 75, p. 229-239, 2007. Disponível em:

<http://pepsic.bvsalud.org/scielo.php?script=sci_arttext\&pid=S0103-84862007000300003\&lng=pt\&nrm=iso>. Acesso em: 08 out. 2017. 
FARIA, I. S. de P. Problemas na aprendizagem de matemática: uma proposta de ensino usando videoaulas. $93 f$. Dissertação (Mestrado Profissional em Matemática em Rede Nacional - PROFMAT) - Instituto de Matemática e Estatística, Universidade do Estado do Rio de Janeiro. Rio de Janeiro: 2017. A publicar.

RIO DE JANEIRO. Secretaria Estadual de Educação. Avaliação interna da aprendizagem: Manual de orientações para operacionalização da Portaria SEEDUC/SUGEN № 419/2013. Rio de Janeiro: SEEDUC, 2013. Disponível em: <http://www.rj.gov.br/c/document_library/get_file?uuid=34cf5121-9cea-44f3-

a484ad472e151547\&groupld=91317>. Acesso em: 08 out. 2017. 


\section{APROFUNDANDO O CONCEITO DE QUALIDADE DO ALIMENTO (BOM, LIMPO E JUSTO)}

Thiago José Ferraz Mourão - Doutorando no HCTE-UFRJ - tjfmourao@gmail.com José Carlos de Oliveira - Professor do HCTE-UFRJ - jcarlos@dee.ufrj.br

\section{Resumo}

Partindo da definição de qualidade proposta por Carlo Petrini (Slow Food,1986), este artigo faz reflexões sobre pesquisas gastronômicas num viés interdisciplinar almejando motivar a responsabilidade profissional, do gastrônomo, na postulação de uma nova concepção de gastronomia. Ademais, discorre sobre a complexidade dos alimentos que suplanta sua importância nutricional, serva das descobertas tecnológicas do século XIX, proclama sua dependência dos interesses políticos e econômicos do último centenário e por fim, sugere reconciliar o alimento com sua natureza de ser bom, limpo e justo, características que se imbricam de forma recursiva e como predicados salutares ao ser humano.

Palavras-chave: Gastronomia. Alimentação. Qualidade. Complexidade. Sustentabilidade.

\section{Introdução}

Em 1986, na Itália, Carlo Petrini, inicia uma fantástica condensação de pensamentos gastronômicos e procura comunicar uma nova prática alimentar a que denomina Slow Food, ou seja, trata-se de nova reflexão complexa sobre nossos meios de produção, distribuição, comercialização e consumo de alimentos. Isso tudo face a uma crescente e acelerada industrialização, degradação do meio ambiente, permanência da fome e paradoxalmente da obesidade, proliferação de doenças advindas de estilo de alimentação fundado, não no bem nutrir e sim na obtenção de lucro em sua produção. Como contraponto, tem ocorrido em diversos segmentos sociais, ressurgimento da necessidade do homem em se aproximar da Natureza, para resgatar o que havia de bom em formas pregressas de se alimentar. Trouxe em decorrência, também, para se pensar numa "boa" alimentação, pontos de vistas ecológicos; a produção de alimentos saudáveis tem relação com: a terra, com o clima, com as condições de trabalho, com o tipo de técnica, com o transporte e com a distribuição. Há que se repensar nossos modos, nossos fins, a conquista do conhecimento tecnocientífico, o caminhar da humanidade nesse contexto de notáveis mudanças climáticas e crescente concentração de riquezas.

O movimento Slow Food, preconiza a produção de alimento de qualidade e ressalta como ponto de partida a religação do indivíduo com a terra. E ao enfatizar o conceito de qualidade, busca aproximar a gastronomia das ciências e fazer dela própria, uma ciência estabelecendo a pesquisa científica gastronômica - vista de uma forma mais ampla - como essencial para o desenvolvimento humano. Esta intervenção aproveita então o precedente deixado pelo próprio criador do Slow Food - Carlo Petrini-, extrata seletivamente e reorganiza algumas de suas ideias, procurando difundi-las por acreditar que possam contribuir para oferecer caminho para o bem-estar humano através da gastronomia e evidencia como as interpretações de qualidade alimentar se relacionam com as questões sociais, políticas e econômicas de forma global.

\section{A qualidade de Petrini - bom, limpo e justo.}

Criticar o pensamento de Petrini sobre os critérios de qualidade do alimento. $O$ significado de "bom", "limpo" e "justo", em sua essência, é relevante à sobrevivência humana. Um forma criativa de interpretar esses pontos, adicionando uma bagagem cultural e intelectual, próprias 
de cada região, pode garantir a solução de problemas relacionados à nutrição, sustentabilidade e soberania alimentar.

\begin{abstract}
"Esses três critérios [bom, limpo e justo] da qualidade se conjugarão de modos diferentes nas diversas partes do mundo, mas permanecem os três pontos essenciais sobre os quais devemos construir, passo a passo, com instrumentos novos e com atitude neogastronômica, um novo modelo de crescimento." (PETRINI, 2009, p.141-142)
\end{abstract}

Questiona-se a primazia do "gosto" como condição natural de uma boa alimentação. Até que ponto um produto pode ser considerado natural?

\begin{abstract}
"Em gastronomia, para o produto ser bom, ele deve atender a duas condições: se pode ser vinculado a certa naturalidade que respeite ao máximo suas características originais e se oferece sensações reconhecíveis (e agradáveis) que permitam julgá-lo em determinado momento e lugar numa determinada cultura." (PETRINI, 2009, p.98).
\end{abstract}

Porém, ampliando nossa preocupação à nível planetário, há de se ressaltar que o respeito ao direito à alimentação deve ser o pilar que equilibra esta tríade de qualidade. Temos o dever de abrandar o sofrimento do outro, o que pressupõe uma distribuição de alimentos justa.

\footnotetext{
“Dolorosa é a morte pela fome. A agonia é longa e provoca sofrimentos insuperáveis. Ela destrói lentamente o corpo, mas também o psiquismo. A angústia, o desespero e um sentimento de solidão e de abandono acompanham a decadência física." (ZIEGLER, 2013, p. 32)
}

A proposição de novos conceitos e parâmetros de qualidade do alimento "limpo" geram consequências no modo como os humanos desbastam a natureza.

É em torno da palavra "sustentável" que gira toda a definição de limpo. (PETRINI, 2009, p.114)

2 A responsabilidade do gastrônomo - homem, terra e ética.

Entendendo a responsabilidade em relação a sua atuação profissional, o gastrônomo dará início ao processo de confecção de uma nova realidade alimentar. A qualidade desta atuação está intrinsecamente ligada a sua responsabilidade para o homem bom, a terra limpa e a ética justa. Não cabe definir por onde começa ou termina esta associação, a responsabilidade circula por todas elas e se nutri de todos os seus produtos.

Assumir a responsabilidade por buscar o conhecimento necessário para pensar no futuro da alimentação considerando o impacto ambiental e as necessidades do homem. Para que a continuidade da espécie não seja apenas prolongada, permitindo que o ambiente e as condições sociais sejam favoráveis, de forma que a evolução do homem como espécie não seja uma adaptação às péssimas condições do planeta, caso um sistema econômico capitalista e degradante seja o regente do futuro da alimentação.

Uma ética profissional gastronômica precisa ser debatida e institucionalizada nas universidades. Pensar na formação técnica destes profissionais separada de uma consciência ética justa, torna-os mão-de-obra para o mercado, mas não indivíduos cientes da importância do seu papel social e político.

O conhecimento a adquirir para que estejamos aptos a produzir ciência aplicável na sociedade, leva à necessidade de inclusão do pensamento transdisciplinar no ensino universitário, formando base histórica, antropo-social e cultural indispensáveis ao tema "alimentação". Associar os conhecimentos culturais e nutricionais para garantir a propagação da sabedoria popular e científica a um estudo da implicação de mudanças alimentares na sociedade, conforme enuncia Petrini: “... o dever do novo gastrônomo será chamar a atenção 
para esse comportamento no ato da aquisição, além de favorecer o conhecimento, para que o sistema recupere o equilíbrio e retorne a seus limites." (PETRINI, 2009, p. 140)

O gastrônomo precisa ampliar seu campo de atuação para as áreas das ciências humanas e da saúde. Religar os conhecimentos imprescindíveis ao estudo da alimentação. Resgatar a importância que a técnica (preparo e cozimento) sempre ocupou na evolução da espécie.

As preocupações do gastrônomo devem ir além da cozinha. Do homem que trabalha no campo, às técnicas que manejam a terra e a ética de servir alimentos com qualidade e com isso abraçando sua responsabilidade à existência da humanidade.

3 Alimento pilar da vida - nutrição, capital e poder.

Identificar as forma antagônicas, contraditórias, muitas vezes dialógicas, como são expostos e divulgados os alimentos no mercado capitalista, como tratam com a situação alimentar, que mexem com a essência vital é um passo fundamental. Há que se imaginar outros conjuntos de ações, isto é de técnicas, de reforma da natureza que não sejam de monocultura e aplicação de agrotóxicos para a produção de alimentos. Para viver melhor o homem precisa modificar a técnica não alterando a natureza profundamente, tirando-a de um equilíbrio milenar. É evidente que não é possível viver sem técnica, mas podemos "modificar" a natureza de forma diversa, procurando não molestá-la tirando do seu equilíbrio que nos garante a vida. A opção de todos por viver em comunidade, socialmente bem, em si, implica em reforma da natureza para nos atender, mas devemos de fazer escolhas técnicas que preserve a vida da espécie no futuro. A escolha inicial por viver não é nossa, é de quem nos concebe. Neste momento ocorrem preparações, modificações, reformas na natureza e nos seres que conscientemente escolheram se reproduzir. A partir desta escolha, eles são responsáveis pela aplicação das técnicas que viabilizam a chegada desse novo ente incapaz de decidir entre a vida e a não-vida. Por onde chegamos a afirmação de Hans Jonas sobre o primeiro imperativo: "A existência da humanidade significa simplesmente que vivam os homens. Que vivam bem é um imperativo que se segue ao anterior." (JONAS, 2006, p. 177)

Assim como o homem tem o dom técnico, ele tem também o da vida, gerar vida. Existe na sociedade, a plena consciência de que ao decidir criar, produzir vida, o homem assume a responsabilidade pela modificação da natureza que este ato exige? Diante disto é imprescindível reconhecer que:

\footnotetext{
“... o homem, graças a seu dom técnico, faz com que se encontre sempre em seu derredor o que é preciso - cria, pois, uma circunstância nova mais favorável, segrega, por assim dizer, uma sobrenatureza adaptando a natureza a suas necessidades." (ORTEGA Y GASSET, 1963, p. 17)
}

De fato, a natureza pura permite ao animal que se reproduza. Tendo este animal se tornado o humano que somos hoje, dotados de intelecto, consciência e livre arbítrio, seríamos capazes de mensurar o impacto que a reprodução tem no crescimento do que Ortega y Gasset chama de sobrenatural? Entendendo por sobrenatural, a natureza modificada pelo homem de forma irreversível e que afasta-nos de nossa natureza humana.

Nos primórdios, as tarefas de sustento das tribos ou civilizações eram divididos pelos membros da sociedade e de forma coletiva atingiam o objetivo de prover o necessário para a sobrevivência e crescimento da população. As técnicas agrícolas aplicadas de acordo com os ciclos climáticos, permitindo planejamento de entressafras e períodos de escassez. Tudo era diretamente dependente da natureza.

A evolução técnica tornou o homem dependente do próprio homem para se alimentar. Passamos de uma relação natural para uma relação comercial, de coletores e caçadores a consumidores. 
Um sistema vital de alimentação da espécie transformou-se em um sistema capital. Todas as etapas da produção até o consumo dos alimentos são baseados em trocas monetárias. Os limites criados pelos proprietários de terras impedem a migração natural dos animais em busca de alimento, e assim o foi com o ser humano. Impedido de se deslocar, se viram obrigados a fixar-se ao solo, cultivando quando possível e trocando seus produtos e força de trabalho por comida. No decorrer da história, o alimento foi transportado de item primário de sobrevivência a produto comercial, perpassando por diferenciador social, identificador cultural, símbolo de poder, remédio, sentimento e objeto de prazer (CONTRERAS e GRACIA, 2011).

4 Interesses planetários - educação, ecologia e necessidade.

Para atender tais interesses deve-se refletir e buscar uma consciência planetária. Entender nossas necessidades, defender métodos agroecológicos e difundir amplamente os estudos sobre alimentação. A alimentação é direito e princípio básico para sobrevivência de qualquer ser. Sem ela, negam-lhe o direito de viver. $O$ ato alimentar faz parte do circuito da vida em todas as suas etapas, limitadamente descritas como nascer, crescer, reproduzir e morrer. 0 alimento é a malha que integra e organiza; integra porque não há crescimento sem nascimento, nem reprodução sem alimento e sem ele a morte se aproxima do nascido. Disto discute-se que a essencialidade do alimento:

"Não é, pois, o alimentar-se necessário por si, é necessário para viver. Terá, pois, tanto de necessidade quanto seja necessário viver se se há-de viver." (ORTEGA Y GASSET, 1963, p. 9)

A falta de alimentação desorganiza esse ciclo e por isso é fundamental que o "alimentar" seja o princípio condutor e organizador da vida. Conjugando a necessidade alimentar com a provedora natureza, entramos no campo da reflexão ecológica. Aceitar que a produção de alimentos incorre em uma transformação de energia irreversível é condição sine qua non para avançar em direção à sustentabilidade, por mais relativo que seja a inexistência de um completo sustentável.

\section{Considerações finais}

Novas reflexões e descobertas científicas levam a crer que o desgaste da Natureza ocorre de forma irreversível durante o processo civilizatório. Esta irreversibilidade entrópica pode também se aplicar ao sistema qualitativo no qual vivemos, onde todas as ações humanas para satisfazer nossas necessidades com qualidade e quantidade adequada, resultam da utilização de produtos criados e cedidos pela natureza. Sendo o troco dado pela humanidade em outra moeda, que não pode ser convertida nem negociada: dejetos. Uma moeda que não é aceita naturalmente. É urgente que pensemos nas implicações de nossas ações em toda a sua complexidade.

Trazendo à luz as definições de Petrini e atualizando com literaturas e conceitos técnicos pôde-se notar que a proposta de qualidade do alimento deve ser vista sempre a partir da natureza, englobando todos os critérios de bom, limpo e justo e a ela retornando. De forma que minimamente possa aproveitar os detritos para se auto reconstruir. Esse é o sentido mais amplo de sustentabilidade material. Os hábitos de consumo em si, não são o único problema, porquanto os modos de produção e comercialização também precisam ser observados. Este ato deve ser também responsabilidade do gastrônomo, o respeito pela terra, pelo produtor e uma ética profissional ao servir, pensar e replicar conhecimento.

Referências bibliográficas

CONTRERAS, J. GRACIA, M. Alimentação, sociedade e cultura. Tradução: Mayra Fonseca e Bárbara Atie Guidalli. Rio de Janeiro: Fundação Oswaldo Cruz, 2011. 
JONAS, H. O princípio responsabilidade: ensaio de uma ética para a civilização tecnológica; Tradução: Marijane Lisboa, Luiz Barros Montez. - Rio de Janeiro: Contraponto: Ed. PUC-Rio, 2006.

MORIN, E. O método 1: a natureza da natureza; Traduzido por llana Heineberg - Porto Alegre: Sulina, 2016.

MORIN, E. O método 6: Ética; Tradução Juremir Machado da Silva - Porto Alegre: Sulina, 2011.

PETRINI, C. Slow food: princípios da nova gastronomia; Tradução de Renata Lucia Botini. - São Paulo: Editora Senac, São Paulo, 2009.

POLLAN, M. Em defesa da comida: um manifesto; Tradução de Adalgisa Campos da Silva - Rio de Janeiro: Editora Intrínsica Ltda, 2013.

ORTEGA Y GASSET, J. Meditação da técnica; Tradução Luis Washington Vita - Rio de Janeiro: Livro Ibero Americano Limitada, 1963.

ZIEGLER, J. Destruição em massa: geopolítica da fome; Tradução de José Paulo Netto - 1.ed. - São Paulo: Cortez, 2013. 


\section{SPACE SHOOTER POLYGON 2D: UM RESGATE NOSTÁLGICO}

Thiago de Melo Ferreira - Mestrando Ouvinte HCTE-UFRJ - thiago.ferreira@nce.ufrj.br

\section{Resumo}

Os jogos de nave ou shoot'em ups influenciam os videogames desde o início da história dos jogos eletrônicos até hoje. E sua presença tem sido considerada fundamental na ascensão dos denominados indies: desenvolvedores independentes de jogos digitais, compostos por pequenos grupos ou mesmo uma pessoa. A apresentação do jogo-título deste trabalho, seus layouts, mecânica básica (gameplay) e sua obtenção via game engines, objetivam uma proposta de resgate nostálgico do gênero - por muito tempo esquecido pelas grandes produtoras, sobretudo, graças à estagnação do mercado japonês de games. Possíveis melhorias e futuras versões são ainda discutidas estimulando assim, uma interessante concorrência entre indies e gigantes do setor.

Palavras-chave: Nave. Navinha. Space Shooter. Game. Shump.Shooter. Shoot'em Up.

Introdução

O shoot'em up (conhecido também como shump, shooter, jogos de nave ou navinha) mostrase como um gênero popular de videogame desde os primeiros fliperamas. Sua história se integra com a história dos games e sempre teve fãs. Por sua popularidade, fator de replay (SERAFIM, 2017) e alto grau de desafio; muitas produtoras investiram pesado neste gênero durante muito tempo. Todavia, os indies, abraçaram o gênero, suprindo uma escassez destes jogos desde o fim da década de 2000. Visando trazer uma proposta gráfica "retro", inspirada no fim dos anos 90, este trabalho apresenta de forma concisa o jogo "Space Shooter Polygon 2D". Um shooter simples, visando resgatar a nostalgia dos shoot'em ups clássicos. Será mostrado um breve histórico do gênero, além de um pequeno panorama do processo de construção um jogo. Finalmente, uma explicação sobre o layout, as funcionalidades do jogo e seu gameplay serão mostrados. Bem como eventuais melhorias e versões a serem feitas.

\section{Histórico}

A história dos jogos de navinha se interliga intrinsecamente com a história dos games. Impulsionando-os no meio acadêmico e no mercado de entretenimento. Os dois jogos que exemplificam estes aspectos de forma clara são Spacewar e Space Invaders. Lançados, respectivamente, em 1961 e 1978; estes jogos foram marcantes para a história dos jogos eletrônicos, sobretudo para a consolidação do gênero shoot'em up. De acordo com Smith (2014), Spacewar foi um dos primeiros jogos criados para computador. Concebido por Steve "Slug" Russel no MIT (Massachusetts Institute of Technology) em 1961, como um programa de demonstração de hardware para o computador PDP-1. Devido ao seu elevado custo, Russel não tinha intenção comercial. Porém, Spacewar obteve relativo sucesso no meio acadêmico e chamou a atenção fora dele. Nove anos depois, surge após a primeira grande crise comercial dos games em 1977, o "Space Invaders" através da japonesa TAITO e foi um sucesso de vendas tanto nos fliperamas, quanto nos consoles caseiros e arrecadou estrondosos 600 Milhões de dólares. O jogo consistia em controlar uma nave, separada por quatro barricadas, que precisava enfrentar hordas de naves alienígenas, visando evitar uma iminente invasão 
terrestre. O sucesso foi tão grande, que alguns o consideram os Beatles dos videogames (THE GAMES ROOM COMPANY, 2014).

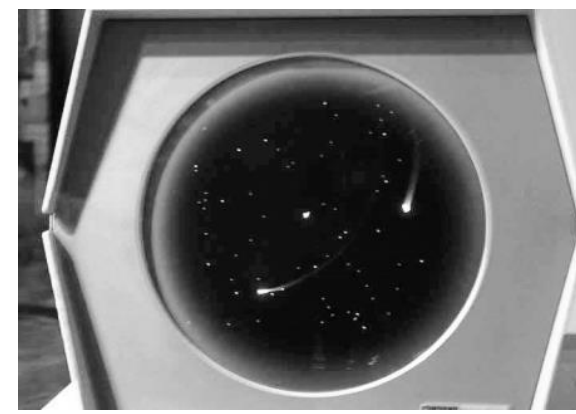

(A)

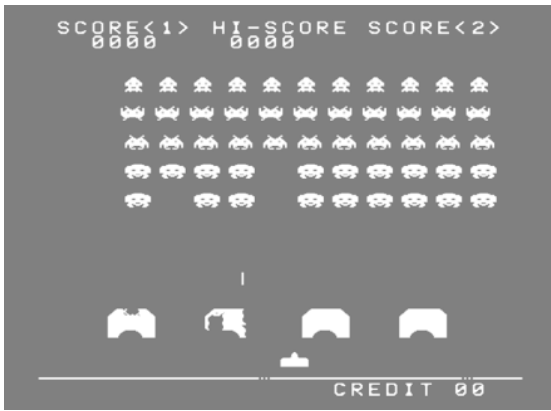

(B)

Figura 1 - (A)Spacewar no PDP-1 e (B)Jogo Space Invaders

\section{Ascenção e Queda dos Shoot'em Ups}

Entre os anos 80 e 90, o mercado de games teve uma leva notável dos jogos de nave. Muitos deles tiveram destaque de público e de crítica. Jogos como Galaga (NAMCO, 1980), Gradius (KONAMI, 1985), R-Type (IREM, 1987) e Thunder Force (TECHNOSOFT, 1983) tornaram-se ícones do gênero Shoot'em Up. A maioria usava o espaço como tema. Todavia, alguns como 1942 (CAPCOM, 1984) e Sonic Wings (VIDEO SYSTEM, 1992) utilizam temáticas militares; respectivamente a segunda guerra mundial (WEISS, 2009) e a inspiração nas guerras modernas dos anos 90 (RETROBITS, 2007). Ainda houve os ícones de inovação dentro do Shoot'em Up, como Do Don Pachi (CAVE, 1997) consolidando o subgênero Bullet'em Hell (HARDCORE GAMING 101, 2014), e Radiant Silvergun (TREASURE, 1999) que modernizou a estética usando o estilo gráfico 2,5D, refinando o sistema de gameplay tradicional dos jogos de nave; além de utilizar-se de elementos até então incomuns para este tipo de jogo como narrativa concisa, recursos de animação japonesa e sistemas de evolução da nave, inspirados em jogos de RPG (MC MILLAN et al., 2010).

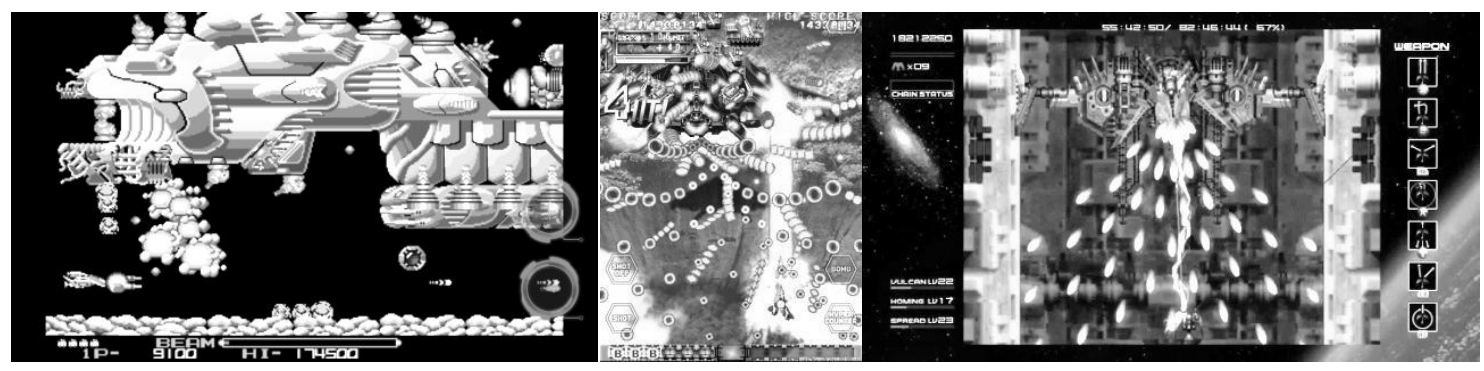

Figuras 3,4 e 5: Da esquerda para direita: R-Type, DoDonPachi e Radiant Sivergun.

Muitos dos jogos citados foram desenvolvidos por produtoras japonesas, graças à demanda existente neste mercado. Entretanto, este mesmo mercado começou a fechar-se para o mundo e, consequentemente, sofreu um processo de isolamento e engessamento; acarretando na estagnação do shump ao redor do mundo (COSMIC EFFECT, 2010) (JOGABILIDADE, 2016). A evidência mais clara deste processo de estagnação é a quantidade 
de coletâneas e relançamentos durante o ciclo de vida do console Playstation 2, um dos videogames mais populares de todos os tempos (VEJA, 2013), como observado na tabela a seguir:

Tabela1: Os melhores shoot'em ups para Playstation 2 (*.
\begin{tabular}{|r|l|r|}
\hline & \multicolumn{1}{|c|}{ Título do Jogo } & Nota do Site \\
\hline 1 & Gradius V & 8,4 \\
\hline 2 & R-Type Final & 8,1 \\
\hline 3 & Castle Shikigami 2 & 7,8 \\
\hline 4 & After Burner II & 7 \\
\hline 5 & Slipheed: The Lost Planet & 6,8 \\
\hline 6 & Scramble & 6,4 \\
\hline 7 & Raiden III & 6,3 \\
\hline 8 & Gradius III and IV & 6,2 \\
\hline 9 & Chaos Field & 6 \\
\hline 10 & Triggerheart Exelica &
\end{tabular}

Fonte: GAMESPOT, 2017)

\section{Os "Indies" abraçam o Gênero}

Denominados como produtores independentes, compostos por equipes de uma ou poucas pessoas que possuem um orçamento bem menor em relação às grandes produtoras, para investir em suas produções (LADISLAU, 2016); os indies foram os grandes responsáveis pelo resgate do gênero entre o final da década de 2000 até hoje, sustentando o gênero. 0 fácil acesso a ferramentas de desenvolvimento de jogos (game engines), a divulgação e distribuição dos jogos indies (LADISLAU, 2016) foram substancialmente importantes para o ressurgimento dos jogos do gênero. Alia-se o fato que o ainda restrito mercado japonês, está descobrindo o mercado dos jogos indies devido aos incentivos da comunidade de desenvolvedores indies ocidentais e até mesmo dos gigantes das games engines na indústria de jogos digitais; chamando a atenção dos doujins (os desenvolvedores indies japoneses) (JOGABILIDADE, 2016). Muitos desses desenvolvedores são fãs do gênero shoot'em up, o que pode sugerir a forte presença do gênero nos jogos indies. Jogos como Superstardust HD e Resogun (HOUSEMARQUE; 2007, 2013) são grandes exemplos desta notável ascensão. A capacidade criativa de inovação em elementos importantes para o sucesso de um jogo como a jogabilidade, narrativa e mecânica, sem ter os recursos das grandes produtoras de jogos (LADISLAU, 2016) foram determinantes para o sucesso dos indies. Como exemplo criativo, alguns desses desenvolvedores desenvolveram jogos para o Dreamcast (SEGA, 1999), um console lançado pela Sega no ano de 1999 e que, apesar do relativo sucesso comercial e de público, foi descontinuado meses após o lançamento do Playstation 2, causando a saída da Sega do mercado de videogames (ENTERTAINMENT WEEKLY, 2015). Este fenômeno acontece em outros consoles descontinuados, onde o desenvolvimento destes Jogos são chamad os de Homebrews*. A estética diferenciada sem grandes recursos gráficos, a facilidade de programação e o apelo nostálgico deste console fazem dele um alvo em potencial para os desenvolvedores indies. O jogo Redux: Dark Matters (KTX Software, 2014) é um bom case de sucesso, arrecadando o dobro da quantia necessária para seu custeio em sites de financiamento coletivo (POLYGON, 2016).

\footnotetext{
* Nota: O resultado apresentado na tabela foi obtido através dos seguintes parâmetros de busca disponíveis no site Gamespot: Sort by (Gamespot Score: High to low), Platform (Playstation 2), Genre (Shoot'em up), Minimum Score (No minimum), Theme (All Themes), Region (All Regions), Publishers (em branco), Developers (em branco), Find by letters (All Letters). Alguns títulos foram omitidos por não se enquadrarem na categoria dos shoot'em ups.

*Traduzindo livremente, significa "feito em casa". São programas desenvolvidos de forma caseira, sem própósito comercial a nível industrial (LIFEWIRE, 2016).
} 


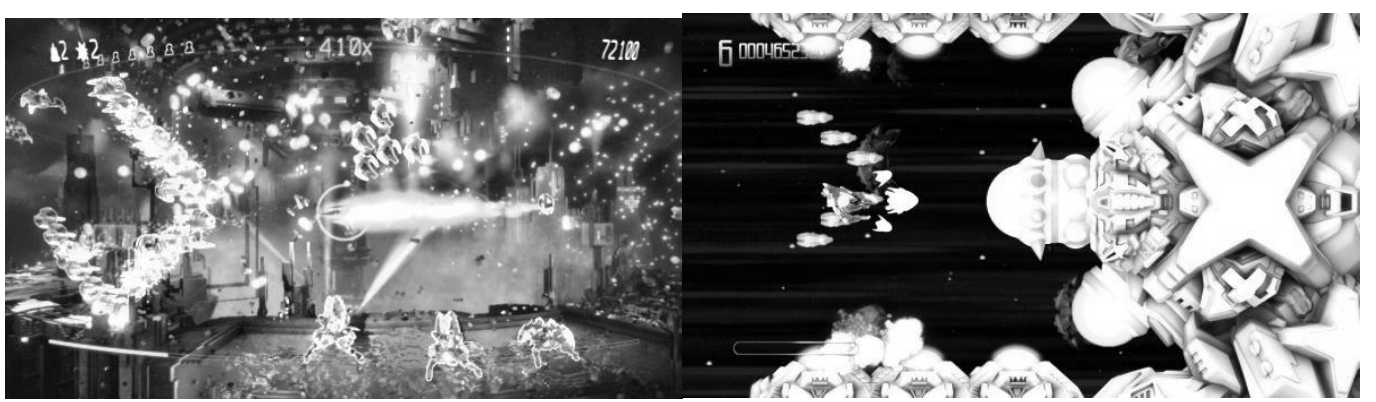

Figuras 6 e 7: Resogun (à esquerda) e Redux: Dark Matters (a direita).

\section{SPACE SHOOTRER POLYGON 2D}

Homenageando os jogos de nave dos anos 80 e 90, aliado a uma proposta "retro" e simplificada, Space Shooter Polygon 2D procura proporcionar o entretenimento simples e direto. Possui gráficos básicos em 2.5D sob vista de cima. O jogador movimenta uma nave vermelha e precisa destruir todos os objetos que estão vindo na direção oposta. Cada inimigo conta um ponto na contagem do jogo. $O$ jogador conta com três vidas e o jogo acaba quando estas são perdidas. O jogo possui duas telas: A tela de Menu e a Tela de Jogo. A tela de Menu, possui dois botões: o botão start, onde o jogo é iniciado, e o botão exit que saí do jogo. Logo abaixo dos botões, encontram-se as definições de controle da nave e de como atirar. Na tela de jogo, temos o cenário do jogo; no qual possui a nave vermelha, controlada pelo jogador, os elementos inimigos vindos na direção contrária da nave vermelha e que irão ser destruídos pelo jogador e três rótulos: Enemies: mostra a quantidade de inimigos destruídos. Record: Maior quantidade de inimigos destruídos até momento. Quando o jogador supera esse número durante o jogo, este rótulo fica igual ao item enemies. Life: Quantidade de vidas disponíveis. $\mathrm{O}$ jogo termina quando este número chega à zero. Atualmente, este game está disponível para computadores com os Sistemas Operacionais Windows, Linux e MacOSx, através da plataforma de jogos indies itch.io.

Figuras 8 - (A) Tela de Menu e (B) Tela de Jogo

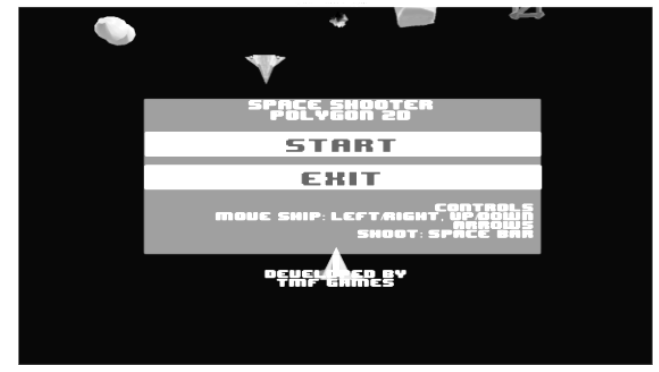

(A)

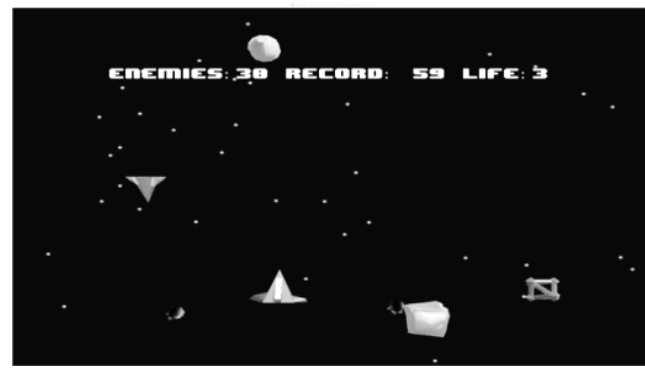

(B)

Um pouco sobre Game Engines

De uma forma geral, a criação de um game envolve diversos processos multidisciplinares. Sobretudo na parte artística (música, roteiro, sons e desenhos ou modelos 3D), técnica (programação de um jogo) e humana (história, narrativa, transmissão de lições) . Atualmente, a concretização do processo criativo de um jogo é efetuada, através das "game engines". Estes, por definição, são programas destinados à produção de jogos eletrônicos, que centralizam recursos, facilitando o acesso as ferramentas necessárias para o desenvolvimento do jogo (COTELLI, 2013). O uso dessas ferramentas "dão a liga" entre a arte e a técnica, concretizando o jogo. Os jogos atuais são desenvolvidos através das "game engines", pois permitem que o jogo seja desenvolvido de forma mais rápida e inteligente, além de facilitar a distribuição para diversas plataformas. As engines mais utilizadas no mercado até então são 
a Unreal Engine (EPIC GAMES, 2017), Unity (UNITY TECHNOLOGIES, 2017) no qual este jogo foi feito, Source Engine (VALVE, 2017) e Cry Engine (CRYTEK, 2017).

Figura 10: Interface de desenvolvimento do game engine Unity.

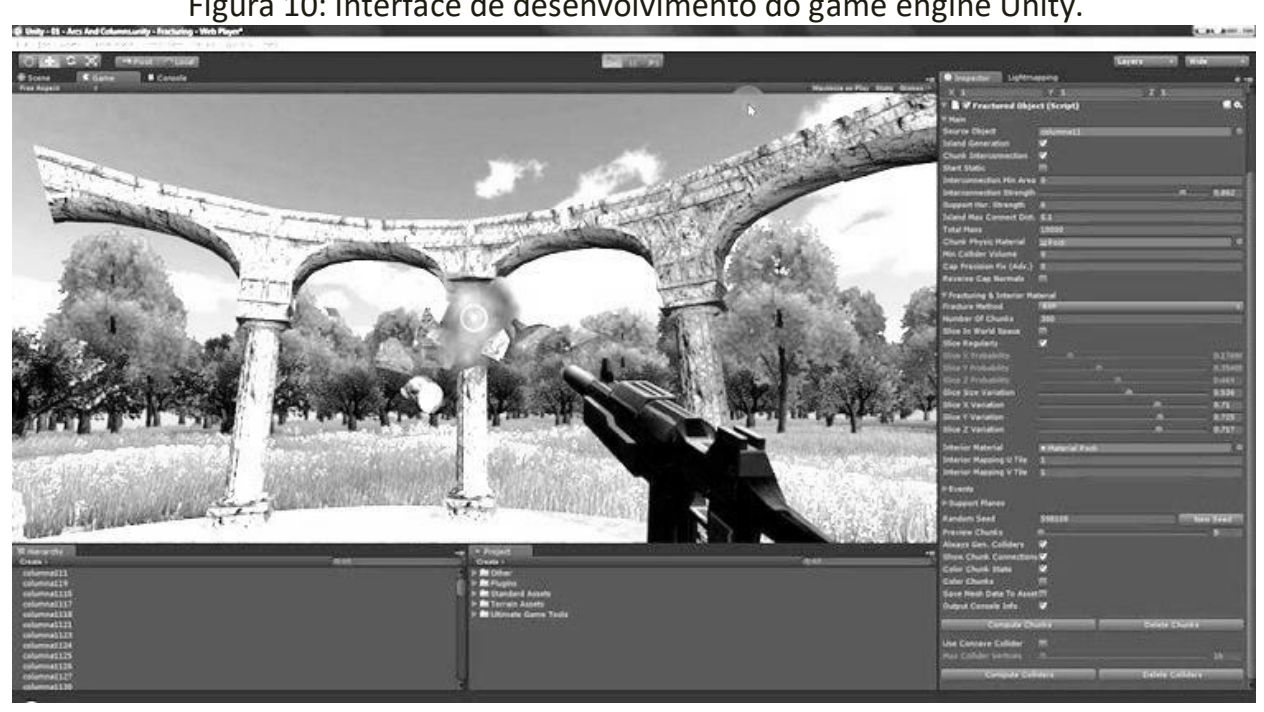

Fonte:

Possíveis Melhorias e Eventuais Próximas Versões

$\mathrm{O}$ jogo ainda está em fase inicial. Algumas melhorias precisam ser feitas. As mais urgentes, passam pelo aprimoramento da IA (Inteligência artificial) dos inimigos, novos níveis e itens de jogo, além dos chefes de fase, vislumbrando os smartphones android e o Xbox One. A versão mobile objetiva alcançar um número maior de pessoas e uma vocação natural para a plataforma. Através de adaptações de controles e touts, integração com o serviço Google Play games para os records e um sistema de anúncios menos invasivos na versão gratuita, o jogo ficará atrativo os smartphones. A segunda versão visa o Xbox One, graças ao programa "Xbox Live Creators Program" (GAMEBLAST, 2017). A facilidade de adaptação e conversão do jogo, aliado a boa visibilidade proporcionada em publicar um jogo para consoles são os grandes atrativos que incentivam esta versão.

\section{Conclusão}

Os shoot'em ups tiveram seu auge entre os anos 90 e 90, graças aos inovadores títulos japoneses. O mercado daquele país influenciou consideravelmente o auge do gênero. Em contraste, a estagnação da cena nipônica, contribuiu para o declínio do gênero. Procurando encaixar-se nestes aspectos, o jogo Space Shooter Polygon 2D, procura resgatar os tempos áureos dos jogos de nave. Com jogabilidade simplificada, divertida e gráficos simples. Ao atingir o público e, num futuro próximo, o mercado, espera-se que este jogo traga a sensação de nostalgia e diversão para seus jogadores. Uma vez que a grande indústria parece demonstrar cada vez mais, sinais de cansaço e queda criativa. Servindo até mesmo de inspiração e incentivo para que o mercado de jogos volte a produzir jogos deste gênero que sempre atraiu um grande público de jogadores e que vem, basicamente, sendo sustentado pela cena indies. O que, de toda maneira, é notável; sendo interessante ver certa concorrência entre tipos diferentes de mercado, dentro da cena de jogos digitais (FERREIRA, 2017).

Referências bibliográficas

COSMIC EFFECT. Os Shoot'em Up Estão Acabando? https://cosmiceffect.com.br/2010/06/16/os-shootem-upestao-acabando. Acesso em 02/08/2017. 
COTELLI, André. ESTUDO DA VIABILIDADE DO USO DE REALIDADE VIRTUAL NA CRIAÇÃO DE UMA FERRAMENTA DE APOIO AO PLANEJAMENTO DE SEGURANÇA FÍSICA EM INSTALAÇÕES NUCLEARES. 2013. 92f. Dissertação (Mestrado em Ciências em engenharia Nuclear), Instituto de Engenharia Nucelar, Rio de Janeiro, 2013.

ENTERTAINMENT WEEKLY. Sega Dreamcast Anniversary Retrospective. [online] Disponível em: < http://ew.com/article/2015/09/09/sega-dreamcast-anniversary-retrospective/> Acesso em 03/10/2017. FERREIRA, Thiago de Melo. Space Shooter Polygon 2D: Um Resgate Nostálgico. 2017. $81 f$. Trabalho de Conclusão de Curso (Especialização em Jogos e Animação Digital), Centro Universitário Carioca, Rio de Janeiro, 2017.

GAMEBLAST. Xbox Live Creators program. Seja um game Designer. [online] Disponível em: <http://www.xboxblast.com.br/2017/08/especial-xbox-live-creators-program-seja-game-designer.html>. Acesso em 02/10/2017.

GAMESPOT[online]. Disponível em: https://goo.gl/HSrQAG.. Acesso em 04/08/2017.

HARDCORE GAMING 101. Dodonpachi (怒首領蜂) - Arcade (February 5, 1997) [online]. Disponível em:<http://www.hardcoregaming101.net/dodonpachi/dodonpachi2.htm>.Acesso em 02/08/2017.

JOGABILIDADE! A Cena Indie Japonesa[Podcast]. Disponível em:< http://jogabilida.de/2016/11/dash-74/>. Acesso em: 03 ago. 2017.

LADISLAU, Thiago. A Estética do Videogame: Um design de experiências. 2016. 10f. Artigo apresentado ao evento Scientiarum História IX Universidade Federal do Rio de Janeiro, Rio de Janeiro, 2016

LIFEWIRE. What Is Homebrew? [online] Disponível em: <https://www.lifewire.com/what-is-homebrew2792748 Acesso em 03/10/2017.

MCMILLAN, Luke et al. All of Your Base Are Belong to Us? Shmups as a Source for Better Game Design. 2010.526f. Tese (Doutorado em Música), Griffith University, Brisbane (AUT), 2010.

POLYGON. The Dreamcast could be immortal, thanks to homebrew. [online] Disponível em: https://www.polygon.com/2016/9/9/12863124/dreamcast-new-games-homebrew-vmu. Acesso em 03/10/2017.

RETROBITS. Sonic Wings - Os aviões nunca foram tão poderosos em um game! [online] Disponível em http://www.retrobits.com.br/analises/sonic-wings-os-avioes-nunca-foram-tao-poderosos-em-um-game. Acesso em 02/08/2017.

REVISTA VEJA. O Adeus a um Gigante dos Videogames: O Playstation 2. [online] Disponível em: http://veja.abril.com.br/tecnologia/o-adeus-a-um-gigante-dos-games-o-playstation-2/. Acesso em: $28 \mathrm{de}$ setembro de 2017].

SERAFIM, Matheus. GAME VIBE: Por que estou jogando isso de novo? - Fator Replay. [online].Disponível em: http://ucegamers.com.br/siteuceg/game-vibe-por-que-estou-jogando-isso-de-novo-fator-replay/. Acesso em 13/07/2017.

SMITH, Alexander. One, Two, Three, Four I Declare a Space War. [online] Disponível em: https://videogamehistorian.wordpress.com/2014/08/07/one-two-three-four-i-declare-a-space-war/. Acesso em 02/10/2017.

THE GAMES ROOM COMPANY. The History of Space Invaders. [online] Disponível em: http://www.gamesroomcompany.com/blog/blog/history-space-invaders/. Acesso em 02/10/2017.

WEISS, Bretory. Classic Home Video Games, 1985-1988: A Complete Reference Guide. Jefferson(USA): Mc Farland \& Company, Inc., Publishers, 2009, $277 f$. 


\section{A MÚSICA NA EXPOSIIÇÃO INTERNACIONAL DO RIO DE JANEIRO (1922): CONTRIBUIÇÕES DA CIÊNCIA}

Anna Cristina Cardozo da Fonseca - Doutoranda no HCTE-UFRJ - annacrisfonseca2015@gmail.com Nadja Paraense dos Santos - Professora no HCTE-UFRJ

Resumo

O presente trabalho é parte de pesquisa de doutorado ora em andamento pelo Programa de Pós-graduação em História das Ciências e das Técnicas e Epistemologia da Universidade Federal do Rio de Janeiro e que objetiva apresentar o vínculo entre música, ciência e modernidade na Exposição Internacional do Centenário da Independência, realizada na cidade do Rio de Janeiro, em 1922. Nesse artigo, destaca-se a contribuição da ciência para a divulgação e a popularização da música por meio da transmissão e da amplificação de espetáculos, alavancada pelas comemorações de então.

Palavras-Chave: Ciência. Exposição Internacional. Modernidade. Música; Radiofonia.

Introdução

A Exposição Internacional do Rio de Janeiro, realizada nessa cidade no período de 7 de setembro de 1922 a 2 de julho de 1923, constituiu-se a principal efeméride das festividades comemorativas do Centenário da Independência Política do Brasil e deveria apresentar ao país e ao mundo, o caminho de progresso que a nação havia trilhado naquele primeiro século de autonomia política, bem como sua riqueza e capacidade de trabalho.

A República instaurada no Brasil em 1889 como uma promessa de renovação natural e de superação de nosso atraso colonial, e que seria conquistada por meio da reforma e da modernização das estruturas políticas e sociais, vinha sofrendo sérias dificuldades ao longo dos primeiros decênios de existência, dadas as divergências de pensamento entre os grupos que haviam sustentado a mudança de regime e que lutavam, cada qual, para fazer valer as próprias ideias.

Apoiado, por um lado, pelas oligarquias que professavam um liberalismo conservador, e, por outro, pelos militares positivistas, o novo regime ainda não conseguira se institucionalizar e entregar, a toda a sociedade, a tão almejada modernização que, prometeu-se, conduziria o Brasil a integrar o 'concerto das nações civilizadas'.

Em vista de um cenário de forte instabilidade política, com um número considerável de revoltas e rebeliões por todo o território nacional; de desequilíbrio econômico, resultado de uma política equivocada do ponto de vista cambial; e de condições de vida e de trabalho sofríveis para boa parcela da população, e a pretexto de uma data representativa para o país, o governo federal optou por comemorar o Centenário da Independência do Brasil com a realização de uma Exposição Internacional.

Constituíam-se as exposições internacionais eventos de caráter mercantil, que celebravam as maravilhas da ciência e do progresso que dela advinha, e que ocuparam lugar de destaque no universo da modernidade, caracterizando-se como um espaço de celebração, de divulgação e de popularização de feitos científicos e de conhecimento e promovendo a circulação e a circularidade de mercadorias e de ideias.

A realização de tais eventos se coadunava com o pensamento de parte do grupo que havia sustentado a mudança de regime, em 1889, e que defendia a ciência como o caminho a seguir para a superação de um passado do qual queriam se desvencilhar. "Neste processo, [os 
intelectuais] (...) creditavam à ciência um poder ilimitado, capaz de guiá-los ao caminho mais adequado para alcançar o bem-estar moral e material da sociedade nacional" (COSTA, 2012, p. 27).

Palco de conceitos e ideologias e da ciência como expressão da modernidade, como convinha a eventos daquela magnitude realizados desde o século XIX, a Exposição Internacional do Rio de Janeiro tornou-se lócus de performances científicas, algumas delas inéditas em território brasileiro, como aquelas relativas à transmissão do som - em particular, a radiotelefonia e o telefone alto-falante -, e que se fizeram apresentar inovadoras, não só pelo avanço tecnológico em si, mas principalmente pelo alcance formidável de público que os novos equipamentos permitiam.

No tocante à radiotelefonia, a Companhia Radiotelegraphica Brasileira requereu à Comissão Executiva da Comemoração do Centenário da Independência política do Brasil ${ }^{54}$ (BRASIL, 1921), em março de 1922, "a possibilidade do estabelecimento dos serviços sem fio, radiotelegraphico e radiotelephonico, (...), para a Exposição Commemorativa do mesmo Centenario", para o quê seria necessário "estabelecer uma estação radiotelegraphica, (...), para a Exposição communicar com outras estações, (...), que estabelecerá em São Paulo (Capital) e em Bello-Horisonte" (ARQUIVO NACIONAL, 1922, p. 113).

Por meio de documento datado de 19 de abril de 1922 e endereçado ao Prefeito do Distrito Federal, Carlos César de Oliveira Sampaio (1861-1930) ${ }^{55}$, e, nessa qualidade, integrante da Comissão Executiva, a Rio de Janeiro and São Paulo Telephone Company ${ }^{56}$, "desejando concorrer á Exposição do Centenario da Independencia", solicitou "autorização para fazer funccionar uma estação de telephone sem fio, durante o prazo da Exposição", propondo-se "installar uma estação transmittidora no Rio de Janeiro, e estações receptoras em diversas localidades dos Estados do Rio de Janeiro, São Paulo e Minas Geraes" (ARQUIVO NACIONAL, 1922a , [s.n.]).

Sob esse mote, foram montadas estações transmissoras por radiotelefonia na Praia Vermelha, "em pavilhão restaurado da Exposição de 1908, em uma dependência da [Exposição] Internacional do Centenário (Gazeta de Notícias, 1922.p. 2)" e no Morro do Corcovado, a partir das quais transmitiram-se programas musicais, e um estúdio, no segundo andar do Palácio Monroe, localizado no centro da cidade e sede dos trabalhos da Comissão Executiva da Comemoração do Centenário e um dos pavilhões da Exposição,

onde [a Rio de Janeiro and São Paulo Telephone Company] organizou numerosos concertos vocaes e instrumentaes, que eram dali mesmo divulgados pela radiotelephonia e reproduzidos em varios lugares do recinto da Exposição por meio dos apparelhos Public Adress System (telephones alto-falantes). (BRASIL, 1926, v. II, p. 251)

Também um sistema de telefone alto-falante foi utilizado no recinto da Exposição Internacional. Em 15 de junho de 1922, Perminio Carneiro Leão e Flavio Queiroz Nascimento, militares e também professores da Escola Militar, encaminharam correspondência ao

${ }^{54}$ Conforme disposto no art. 1ํ do Decreto $\mathrm{n}$ - 15.066, de 24 de outubro de 1921, a Comissão Executiva da Comemoração do Centenário da Independência política do Brasil, instância responsável pela organização dos eventos em homenagem àquela data e doravante citada como Comissão Executiva, era integrada pelo Ministro da Justiça e Negócios Interiores; pelo Ministro da Agricultura, Indústria e Comércio; e pelo Prefeito do Distrito Federal.

55 O engenheiro Carlos César de Oliveira Sampaio foi Prefeito do Distrito Federal de 7 de junho de 1920 a 15 de novembro de 1922.

${ }^{56}$ Empresa de sociedade anônima, com sede na cidade de Toronto (Canadá) e capital canadense e norteamericano, a Rio de Janeiro and São Paulo Telephone Company, denominação adotada a partir de 1915 quando incorporou a Interurban Company Limited, atuava no ramo da telefonia, tendo se originado da incorporação de outras empresas de capital estrangeiro que vinham operando serviços de energia elétrica, iluminação e transportes por tração elétrica no Brasil. 
Presidente da República, Epitácio Lindolfo da Silva Pessoa (1865-1942) ${ }^{57}$, e ao Prefeito do Distrito Federal, solicitando autorização para instalação e adoção de sistema alto falante na sala em que aconteceriam as conferências no recinto da Exposição Internacional, durante o tempo de funcionamento do certame.

Tal sistema, que previa a instalação de tubos metálicos em forma de corneta no alto de mastros para a amplificação do som, permitiria ser ouvido com clareza "o orador, ou, conferencista que esteja fallando da tribuna, (...), de modo perfeitamente synchrono e unisono, por todos os pontos no salão que se dezejar" (ARQUIVO NACIONAL, 1922b:,[s.n.]), além de possibilitar a irradiação de discursos, conferências e espetáculos para espaços distantes do local de origem desses eventos, permitindo o acesso de outros públicos àqueles conteúdos e atividades.

Tendo em vista o elevado montante orçamentário necessário para cobrir as despesas de material e mão de obra de instalação e manutenção do serviço de telefonia alto-falante durante um prazo inicial de três meses ${ }^{58}$, a Comissão Executiva não autorizou a proposta, que somente pôde ser desenvolvida, e a título precário, por terem sido as ditas despesas assumidas por agentes exógenos - a Rio de Janeiro and São Paulo Telephone Company e a International Western Electric Company ${ }^{59}$-, sem ônus para os cofres da Exposição.

A instalação da aparelhagem necessária ao funcionamento do sistema de telefone altofalante se deu, então, em alguns dos principais palácios da Exposição Internacional ${ }^{60}$, a partir dos quais foram irradiados não só os discursos pronunciados em solenidades e cerimônias oficiais que neles tinham lugar, mas também eventos e espetáculos musicais.

Juntas, as vivências proporcionadas pela radiotelefonia e pelo telefone alto-falante foram responsáveis por importante nota de modernidade no âmbito da Exposição Internacional, tendo a música, pelo objeto de que se formava - o som -, como produto veiculado e material primário a esse empreendimento.

Em virtude dessa combinação engenhosa, o publico que circulava no recinto [da Exposição] podia ouvir não só os concertos e as audições organizados no 'studio', como as operas cantadas no Theatro Municipal, os discursos pronunciados nas solemnidades e nos banquetes, os concertos do Instituto Nacional de Musica, etc.

Devido ainda á mesma combinação, os concertos realizados e discursos pronunciados no recinto eram divulgados pela estação irradiadora, montada, nessa occasião, no alto do Corcovado. (BRASIL, 1926, v. II: 252)

A movimentação em torno do funcionamento de aparelhos de telefone alto-falante e das transmissões radiofônicas repercutiu de forma efusiva nos periódicos da época como uma das principais atrações da Exposição Internacional, utilizando-se essas publicações de palavras como 'sucesso', 'progresso', 'original', 'magnífica' e inédita' para referirem-se àquelas experiências e divulgando conteúdos que descreviam, de maneira objetiva e sucinta, as características, os usos e o funcionamento daquela novidade da ciência para a sociedade brasileira.

57 O Presidente Epitácio Pessoa governou o Brasil de 28 de julho de 1919 a 15 de novembro de 1922, durante o qual foi organizada e inaugurada a Exposição Internacional.

58 Naquele momento, previa-se que Exposição funcionasse por um período de três meses.

${ }^{59}$ Empresas constituídas por investidores canadenses e norte-americanos que atuavam no Brasil desde o final do século XIX e que exploravam inicialmente serviços de iluminação pública e particular, de fornecimento de energia elétrica e de transportes por tração elétrica, alcançando, mais tarde, os serviços de telefonia e de linhas de ônibus urbanos.

${ }^{60}$ Citam-se aqui o Palácio Monroe, o Palácio das Festas, o Parque de Diversões, o Palácio dos Estados e a torre do Palácio das Grandes Indústrias. 
O discurso do Presidente Epitácio Pessoa, por exemplo, proferido quando da abertura da Exposição Internacional, em 7 de setembro de 1922, inaugurando também os serviços de transmissão radiotelefônica no Brasil, e a apresentação da ópera O Guarany, do compositor brasileiro Antônio Carlos Gomes (1836-1896), executada em espetáculo de gala na noite daquela mesma data no Theatro Municipal, foram descritos nos jornais locais como "o grande successo do dia de hontem" (CORREIO DA MANHÃ, 1922, p. 1).

Uma nota sensacional no dia de hontem foi o serviço de radio-telephonia e telephone altofalante, grande attractivo da Exposição.

O discurso do Sr. presidente da Republica, inaugurando o certamen foi, assim, ouvido no recinto da Exposição, em Nichteroy, Petropolis e em S. Paulo, graças á installação de uma possante estação transmissora no Corcovado e de apparelhos de transmissão e recepção, nos logares acima (A Noite, 1922: 8).

O mesmo periódico chamava a atenção para o ineditismo daquele acontecimento para o público e informava que a "opera 'Guarany', de Carlos Gomes, que estava sendo cantada no Theatro municipal, foi, ali [na Exposição Internacional], distinctamente ouvida, bem como os aplausos aos artistas. Egual cousa succedeu nas cidades (...) [de Nichteroy, Petropolis e S. Paulo] (A Noite, 1922, p. 8).

As transmissões radiofônicas de solenidades e de eventos musicais se sucederam ao longo dos meses subsequentes, sempre divulgadas de maneira entusiástica pelos periódicos que delas se ocupavam. Em 15 de setembro de 1922, por exemplo, realizou-se um evento especial no Palácio das Indústrias, a convite da Rio de Janeiro and S. Paulo Telephone Company, no qual o público convidado pôde presenciar a aplicabilidade do sistema de telefone alto falante ali instalado. Tal experiência consistiu na transmissão, aos convidados reunidos no Palácio das Indústrias, de obras musicais que estavam sendo executadas por artistas, naquele mesmo momento, no salão do segundo andar do Palácio Monroe.

Para um publico selecto e distincto, constituido por engenheiros industriaes, representantes da imprensa e outras pessoas gradas, o Rio de Janeiro and São Paulo Telephone Company fez funccionar hontem, ás 4 horas da tarde, o telephone auto falante (Public Address System), instalado no Palacio das Industrias, no recinto da Exposição Internacional do Centenario, pela Western Electric Company, em collaboração com a Companhia Telephonica.

Foi este um espectaculo inedito e original que impressionou vivamente a todos quantos lá se achavam presentes, e que, por isso mesmo deixaram-se empolgar por esse novo systema de telephone, (...) (GAZETA DE NOTÍCIAS, 1922, p. 2).

Em 9 de novembro de 1922, teve lugar, no estúdio montado no Palácio Monroe, uma apresentação de música regional do grupo Turunas Pernambucanos ${ }^{61}$, "especialmente para ser reproduzida e ampliada por intermedio do telephone alto-fallante da Companhia Western Electric, e irradiada pelo telephone sem fio, da Companhia Westinghouse, por intermedio da estação do Corcovado", sobre o qual noticiou o periódico Illustração Brasileira:

Musica brasileira pelo telephone sem fio. (...).

O programma (...) foi ouvido simultaneamente, no recinto da Exposição, por todos que se achavam entre o Mercado Municipal e o Parque de diversões, por intermédio das trompas do telephone alto falante, e por todos que possuam receptores radio telephonicos, aqui no Rio, e nas cidades visinhas, Petropolis, São Paulo, Juiz de fora, Bello Horizonte, etc." (ILLUSTRAÇÃO BRASILEIRA, 1922, p. 170).

${ }^{61}$ Criado em Recife (PE), em 1920, esse grupo vocal e instrumental chegou ao Rio de Janeiro em 1922 e ajudou a divulgar a música regional do Nordeste do Brasil. 
Nos dias 9 e 10 de dezembro de 1922, concertos realizados na Estação Radiotelefônica da Praia Vermelha foram transmitidos em tempo real para o recinto da Exposição Internacional e ouvidos "ao ar livre, no Pavilhão de Musica da Exposição, e no Palacio das Festas, pelo altofalante da Companhia Western Electric" (ILLUSTRAÇÃO BRASILEIRA, 1922, p. 170).

Nos meses de fevereiro e março de 1923, realizaram-se concertos na Estação Radiotelefônica do Corcovado, a partir da qual foram transmitidos para o recinto da Exposição Internacional, em tempo real. Lá, reproduzidos pelos alto-falantes, podiam ser ouvidos desde o Palácio das Festas até a esplanada do Mercado, bem como no posto telefônico instalado no Palácio das Indústrias e puderam ser também captados por estações localizadas em terra ou no mar que estivessem a uma distância de até 400 quilômetros do Rio de Janeiro.

O concerto realizado em 31 de março de 1923 seria o último a ser "irradiado pela Estação do Corcovado, a qual encerrará, assim, o serviço de demonstração de Radio-Telephonia que ha cerca de sete mezes vem conduzindo" (O JORNAL, 1923, p. 3).

Em abril de 1923, o periódico "A Noite" relatou "exhibição experimental de transmissão e recepção de discursos e musica" (A NOITE, 1923, p. 4) que a International Western Electric Company fez realizar na estação radiotelefônica da Praia Vermelha. Constava o evento de estabelecer contato com a estação instalada por aquela companhia na cidade de Buenos Aires (Argentina) e contou com a presença de figuras importantes dos meios técnico e político e também de alunos da Associação Brasileira de Canto. Ainda que com problemas técnicos, que afetaram a nitidez da transmissão dos sons, a novidade animou os cantores presentes a entoar canções ao microfone.

Essas primeiras experiências de transmissão radiofônica no Brasil constituíram-se importante ponto de tangência entre música, ciência e modernidade naquele início de século. Em um cenário que era a própria representação da modernidade - uma exposição internacional -, sob os auspícios das comemorações do centenário da autonomia política da nação, a música, transformada em mercadoria e utilizando-se das novidades tecnológicas que a ciência lhe apresentou, viu ser alterada para sempre a forma como a sociedade passou a consumi-la e executá-la, fosse pelo meio utilizado - a radiofonia e o alto-falante -, fosse pelo alcance extraordinário que esse meio permitiu a públicos antes impensáveis.

Referências bibliográficas

ARQUIVO NACIONAL (Brasil). Comissão Executiva da Comemoração do Centenário. Ofício n. 113. Cx n. 2389, 10/04/1922.

. Comissão Executiva da Comemoração do Centenário. Correspondência [s.n.]. Cx n. 2389, Rio de Janeiro, 19/04/1922a.

15/06/1922b.

Comissão Executiva da Comemoração do Centenário. Correspondência [s.n.]. Cx n. 2389,

AS GRANDES invenções. Gazeta de Notícias, Rio de Janeiro, 16 set. 1922. A commemoração do Centenario, p. 2.

BRASIL. Decreto no 15.066, de 24 de outubro de 1921. Dá execução ao Decreto Legislativo no 4.175, de 11 de novembro de 1920. Coleção de Leis do Brasil, Poder Executivo, Rio de Janeiro, 1921, v. 1, p. 395. Disponível em:< http://www2.camara.leg.br/legin/fed/decret/1920-1929/decreto-15066-24-outubro-1921-516267publicacaooriginal-1-pe.html>. Acesso em: 27 jan. 2016.

- Ministerio da Justiça e Negocios interiores. Relatorio dos Trabalhos da Exposição Internacional do Centenário. Rio de Janeiro, 1926. 2 v.

COSTA, Patrícia Coelho da. Educadores do radio: concepção, realização e recepção de programas educacionais radiofônicos (1935-1950). Tese apresentada à Faculdade de Educação da Universidade de São Paulo como 
requisito parcial à obtenção do título de Doutor em Educação. Área de concentração: História da Educação e Historiografia. São Paulo: 2012.

ESTAÇÃO da Praia Vermelha. Gazeta de Notícias, Rio de Janeiro, 29 nov. 1922. Melhoramentos nos telégrafos, p. 2.

A MúSICA na exposição. Illustração Brasileira, Rio de Janeiro, 25 dez. 1922. Movimento musical, p. 170.

RAIO das mil milhas (O). A Noite, Rio de Janeiro, 9 abr. 1923, p. 4.

SUCESSO do dia (O). Correio da Manhã, Rio de Janeiro, 8 set. 1922, p. 1.

RIO DE JANEIRO. O livro de ouro - Comemorativo do Centenário da Independência e da Exposição Internacional de 1922. Anais do Conselho Municipal, Editora Annuário do Brasil/Almanak Laemmert, Rio de Janeiro, 1923. Disponível em:< http://docvirt.no-ip.com/docreader.net/DocReader.aspx?bib=mhn\&pagfis=26504\&pesq>. Acesso em: 19 fev. 2015.

SILVA, Kalina Vanderlei; SILVA, Maciel Henrique. Dicionário de Conceitos Históricos. São Paulo: Contexto, 2009.

ÚLTIMO concerto de radio-telephonia e alto-falante. O Jornal, Rio de Janeiro, 31 mar. 1923. A Exposição Internacional, p. 3.

SUCCESSO da radio-telephonia e telephone alto-falante (UM). A Noite, Rio de Janeiro, 8 set. 1922. O Centenário, p. 8. 


\section{NÚMEROS TRANSREAIS E UM MUNDO UNIVERSAL EXPLÍCITO}

Filipe Esteves De Freitas - Graduando do IFRJ - filipesteves95@gmail.com

\section{Resumo}

A transmatemática é uma nova área da ciência que está, atualmente, em desenvolvimento. Ela consiste na matemática que surge a partir dos números transreais, que são um novo conjunto numérico onde divisão por zero é permitida. A partir de seu desenvolvimento, conceitos que se estudavam dentro da lógica se tornaram objetos matemáticos através de estruturas matemáticas bem definidas. Alguns desses conceitos foram objetos de estudo do presente autor em seu projeto de iniciação científica, tais como: espaço lógico, espaço dos mundos possíveis e mundos universais. O citado projeto teve como resultado uma construção explícita de um mundo universal. O objetivo do presente texto é apresentar os conceitos acima citados e resultados do projeto.

Palavras-chave: Transmatemática. Divisão Por Zero. Números Transreais. Espaço Lógico. Mundo Universal.

Introdução

Pelas definições da aritmética que usamos no dia a dia, sabemos que a divisão por zero é inviável. Ao longo da história nunca houve um esforço geral, dos matemáticos principalmente, para que pudessem, de alguma forma, resolver esta questão. Como houve, por exemplo, no Último Teorema de Fermat, sobre o qual matemáticos do mundo inteiro se mobilizaram na tentativa de encontrar uma resolução, sendo até proposta uma premiação para quem demonstrasse tal teorema. De uma forma geral, só há busca pela resolução de uma determinada questão, se houver alguma necessidade. A divisão por zero surge a partir de uma necessidade prática.

Um computador, em seu processamento, gera diversos cálculos a serem realizados e as divisões estão incluídas nestes cálculos. Com o aprimoramento das tecnologias, a falta de definição para a divisão por zero se tornou um problema. Pois, quando, em sua programação, o computador encontra alguma divisão por zero, este retorna mensagens de erros, ocasionando problemas tanto no hardware, quanto no software (ANDERSON, 2014).

Propor uma solução para a divisão por zero se tornou um desafio, a partir da necessidade que surgiu através das tecnologias. É interessante notar, que tal necessidade aparece em meio a uma situação prática e não em uma situação puramente matemática.

Então, na década de 2000, James Anderson - professor e pesquisador na School of Systems Engineering, University of Reading, na Inglaterra - em busca de uma solução para os erros do processamento nos computadores, introduziu o conjunto dos números transreais aplicandoos à programação (ANDERSON, 2005). Neste conjunto a divisão por zero é permitida, além das quatro operações básicas (adição, subtração, multiplicação e a própria divisão) serem totais, ou seja, o resultado de qualquer uma destas operações entre números transreais é um número transreal. A matemática que surge a partir da divisão por zero é denominada de transmatemática (REIS; GOMIDE; ANDERSON, 2016).

A transmatemática é, portanto, uma ciência nova, gerando possibilidades de diversos estudos dentro da área. O próprio Anderson publicou diversos artigos sobre o assunto (ANDERSON,2005, 2006, 2007, 2008, 2014, 2015). Ele mais Gomide e Reis têm desenvolvido 
o tema. Vale ressaltar que esses dois últimos apresentaram trabalhos sobre o tema em edições anteriores do Scientiarum História: "Números transreais. mais uma etapa na história dos números" (REIS, GOMIDE, KUBRUSLY, 2013), "O que tem sido pesquisado em transmatemática no HCTE" (REIS, 2014), "Números Transreais e o Espaço Lógico" (REIS, 2015b) e "Um pouco de transmatemática: números transcomplexos" (REIS, 2016). E, além dos trabalhos acima mencionados, a transmatemática foi o tema da tese de doutorado de Reis orientado por Kubrusly (REIS, 2015a) no HCTE (Programa de Pós-graduação em História das Ciências e das Técnicas e Epistemologia).

Este trabalho tem o objetivo de divulgar o tema e os resultados obtidos em um projeto de iniciação científica do presente autor sob a orientação do professor Tiago Reis. 0 projeto trata de uma continuação do estudo de Reis sobre espaço lógico e teve como resultado final uma construção explícita de um mundo universal. No decorrer do texto, o presente autor expõe o tema em questão para que o leitor possa compreender do que se trata o trabalho.

\section{O Espaço Lógico}

Em (REIS, 2015a), um modelo matemático para uma semântica total e um espaço lógico foi proposto. Definiu-se uma semântica total, um sistema que contem os valores clássicos de veracidade e falsidade; um valor de contradição; valores de graus de veracidade e falsidade; e um valor indeterminado. Este sistema ainda possui os conectivos lógicos de negação, disjunção e conjunção. Desta forma, seguindo a ideia de que os elementos deste espaço são as proposições e que as interações entre elas são os conectivos, definiu-se o conjunto dos valores semânticos como sendo o conjunto dos números transreais, 62 (conjunto dos números racionais unidos ao propósito.

Figura 1 - Matriz infinita de vetores de coordenadas racionais ou nullity.

$$
\text { / }
$$

Os elementos da primeira linha da matriz, , são elementos de, reciprocamente, todos elementos de estão na primeira linha da matriz. Ou seja, a primeira linha é uma enumeração dos números racionais unidos ao nullity. Os elementos da segunda linha da matriz, , são elementos de, reciprocamente, todos elementos de

Após a construção do vetor descrito acima, foi demonstrado, utilizando-se a métrica transreal, que, de fato, ele é um vetor que aproxima qualquer outro. Desta forma, chegamos ao resultado do projeto de iniciação científica do presente autor, que é a construção explícita de um mundo universal, indicando exatamente quais são seus elementos.

\section{Referências bibliográficas}

ANDERSON, J. A. D. W. Perspex machine II: Visualisation. Vision Geometry XIII Proceedings of the SPIE, v. 5675, p. 100-111, 2005. Disponível em <http://bookofparagon.com/Mathematics/PerspexMachinell.pdf> Acesso em 02 de junho de 2015.

ANDERSON, J. A. D. W. Perspex machine VII: The universal perspex machine. Vision Geometry XIV Proceedings of the SPIE, v. 6066, p. 1-17, 2006. Disponível em <http://bookofparagon.com/Mathematics/PerspexMachineVII.pdf> Acesso em 02 de junho de 2015.

62 Definido pelo Dicionário Brasileiro de Terminologia Arquivística como "Esquema estabelecido para o arranjo dos documentos de um arquivo, a partir do estudo das estruturas, funções ou atividades da entidade produtora e da análise do acervo. Expressão adotada em arquivos permanentes" (ARQUIVO NACIONAL, 2005). 
ANDERSON, J. A. D. W. Perspex machine IX: Transreal analysis. Vision Geometry XV Proceedings of the SPIE, $v$. 6499, p. 1-12, 2007. Disponível em <http://bookofparagon.com/Mathematics/PerspexMachinelX.pdf>Acesso em 02 de junho de 2015.

ANDERSON, J. A. D. W. Perspex machine XI: Topology of the transreal numbers. In: INTERNATIONAL MULTICONFERENCE OF ENGINEERS AND COMPUTER SCIENTISTS, 2008. Hong Kong. Anais... International Association of Engineers, 2008. p. 330-338. Disponível em <http://bookofparagon.com/Mathematics/PerspexMachineXI.pdf> Acesso em 02 de junho de 2015.

ANDERSON, J. A. D. W. Trans-floating-point arithmetic removes nine quadrillion redundancies from 64-bit IEEE 754 floating-point arithmetic. In: INTERNATIONAL CONFERENCE ON COMPUTER SCIENCE AND APPLICATIONS, 2014. San Francisco. Anais... International Association of Engineers, 2014, p. 80-85. Disponível em <http://www.iaeng.org/publication/WCECS2014/WCECS2014_pp80-85.pdf> Acesso em 02 de junho de 2015

ANDERSON, J. A. D. W. Transmathematical Basis of Infinitely Scalable Pipeline Machines. In: Slawomir Koziel, Leifur Leifsson, Michael Lees, Valeria V. Krzhizhanovskaya, Jack Dongarra and Peter M.A. Sloot (editores), INTERNATIONAL CONFERENCE ON COMPUTATIONAL SCIENCE, ICCS 2015 Computational Science at the Gates of Nature, Procedia Computer Science, v. 51, 1828-1837, 2015. Disponível em http://www.sciencedirect.com/science/article/pii/S1877050915012168. Acesso em 01 de março de 2016.

REIS, T. S. dos. Operadores Hipercíclicos. 2012. 87 f. Dissertação (Mestrado) - Instituto de Matemática da Universidade Federal do Rio de Janeiro, Rio de Janeiro, 2012.

REIS, T. S. dos. O que tem sido pesquisado em transmatemática no HCTE. In: SCIENTIARUM HISTORIA: VII CONGRESSO DE HISTÓRIA DAS CIÊNCIAS DAS TÉCNICAS E ESPISTEMOLOGIA, 2014. Rio de Janeiro. Anais... Universidade Federal do Rio de Janeiro, 2014.

REIS, T. S. dos. Transmatemática. 2015. 124 f. Tese (Doutorado em História das Ciências, das Técnicas e Epistemologia) - Universidade Federal do Rio de Janeiro, Rio de Janeiro, 2015a.

REIS, T. S. dos. Números Transreais e o Espaço Lógico. In: SCIENTIARUM HISTORIA: VIII CONGRESSO DE HISTÓRIA DAS CIÊNCIAS DAS TÉCNICAS E ESPISTEMOLOGIA, 2015. Rio de Janeiro. Anais... Universidade Federal do Rio de Janeiro, 2015b.

REIS, T. S. dos. Um pouco de transmatemática: números transcomplexos. In: SCIENTIARUM HISTORIA: VIX CONGRESSO DE HISTÓRIA DAS CIÊNCIAS DAS TÉCNICAS E ESPISTEMOLOGIA, 2016. Rio de Janeiro. Anais... Universidade Federal do Rio de Janeiro, 2016.

REIS, T. S. dos; GOMIDE, W.; ANDERSON, J. A. D. W. Construction of the Transreal Numbers and Algebraic Transfields. IAENG International Journal of Applied Mathematics, v. 46, n. 1, 11-23, 2016.

REIS, T. S. dos.; GOMIDE, W; KUBRUSLY, R. Números transreais. mais uma etapa na história dos números. In: SCIENTIARUM HISTORIA: VI CONGRESSO DE HISTÓRIA DAS CIÊNCIAS DAS TÉCNICAS E ESPISTEMOLOGIA, 2013. Rio de Janeiro. Anais... Universidade Federal do Rio de Janeiro, 2013.

ROLEWICZ, S. On orbits of elements. Studia Mathematica 32 (1969), 17-22. 
MÚSICA \& CRIATIVIDADE: transdisciplinaridade e transversalidades no debate sobre drogas com discentes da EAD

Rosana Lima Gerpe - Especialista em Ciências do Laboratório Clínico, pela Universidade Federal do Rio de Janeiro (UFRJ) - (rosanagerpe@gmail.com)

Francisco José Figueiredo Coelho - Doutorando em Ensino em Biociências e Saúde (IOC/ Fiocruz/ RJ) -

(ensinodeciencias.ead@gmail.com)

Priscila Tamiasso-Martinhon - Docente do Departamento de Físico-Química, IQ/ UFRJ - (pris-

martinhon@hotmail.com)

Célia Sousa - Coordenadora do Curso de Licenciatura em Química, na modalidade EaD (UAB/UFRJ/ CEDERJ/

CECIERJ) - (sousa@iq.ufrj.br)

\section{Resumo}

No que se refere ao consumo de drogas, estudos apontam para uma iniciação precoce entre os jovens, resultado de estímulos diversos, do fácil acesso e da dificuldade de espaços de diálogo sobre o tema. Diante disso, reconhecemos a relevância das discussões sobre os diversos fatores envolvidos no uso de drogas diversas. Falar de drogas não é algo fácil. A universidade tem potencial para criar espaços de diálogo e aprendizagem sobre as motivações e implicações do uso dessas substâncias. Nessa aposta, acreditamos no potencial da arte - em especial a música - como estratégia de ensino para iniciar ou complementar debates sobre diferentes drogas na sociedade, estimulando novos olhares e posicionamentos juvenis que corroboram com um processo preventivo mais dialógico e democrático. No contexto das ferramentas artísticas, este estudo discute o uso da música Quinta-feira, do compositor Chorão, do grupo Charlie Brown, como estratégia educativa promotora de debates mais dialógicos sobre as drogas. Esse evento ocorreu numa comunicação oral da VI Semana acadêmica e II Semana de Ciências da Natureza entre alunos do curso EaD do Consórcio CEDERJ, polo Nova Iguaçu. O que foi observado na breve discussão com os participantes foi que a música é vista pelos discentes como ferramenta potencial para alimentar debates abertos, críticos e participativos nas salas de aula.

Palavras-chave: Drogas. Educação sobre drogas. Educação à distância. Música no ensino.Ensino de química.

Introdução

No que se refere ao consumo de drogas, incide uma iniciação precoce do uso entre os jovens, decorrentes de estímulos diversos (ACSELRAD, 2015). Tal recorte se justifica pelo acesso e uso de drogas, principalmente o álcool, entre jovens e pelo despreparo dos docentes para abordar o tema drogas no contexto escolar. O fácil acesso e o consumo de diferentes tipos de drogas fazem parte do cotidiano dos jovens, seja na escola, na família, nos contextos de sociabilidade e nos principais meios de comunicação (televisão, redes sociais e mídia impressa).

Pesquisas indicam que a droga continua sendo uma ameaça onipresente, é o que confirma a Pesquisa Nacional de Saúde do Escolar (PeNSE), realizada pelo IBGE em 2015, para os escolares que já usaram drogas ilícitas alguma vez na vida, o consumo atual de maconha foi de 46,1\% (BRASIL, 2016). Além de fazer parte do cotidiano de muitos jovens, como tem sido sugerido desde a década de 1990 pelos Parâmetros Curriculares Nacionais (PCNs) sobre Saúde (BRASIL, 1998). Constata-se, que o grau de informação sobre o assunto está longe da realidade na qual vivemos. Faz-se necessário buscar estratégias alternativas de enfrentamento do problema, de forma educativa. Nesse sentido, ao utilizar a música em sala de aula, temos um elemento favorável à concentração da atenção do educando e da comunidade, podendo resgatar valores éticos, sociais e culturais de forma dinâmica e coletiva. 
Com uma das referências para o uso das músicas como estratégia educativa, citamos o estudo de Barros e colaboradores (2013). Para os autores, as músicas e suas letras podem estreitar o diálogo entre discentes, docentes e conhecimento científico, uma vez que abordam temáticas com grande potencial de problematização que estão presentes de forma significativa na vida do discente. Nesse sentido, o tema drogas pode ser beneficiado por essa estratégia.

Os atuais debates sobre a formação de futuros professores englobam e estimulam a Educação a Distância (EaD), algo que não era comum há pouco tempo. Estudos apontam que, após vários ajustes, a EaD está cada vez mais disseminada e muitas pessoas têm optado por esse tipo de formação (ALMEIDA et al., 2012; OLIVEIRA, 2014). Contribuem para o crescimento do uso da modalidade $\mathrm{EaD}$ as constantes inovações tecnológicas, sobretudo com o desenvolvimento da inclusão digital. Assim, a relação entre educação e tecnologia tem se estabelecido como recurso eficaz na formação de futuros professores. (SALVADOR et al., 2010). Estudos são otimistas no potencial da EaD e no desenvolvimento de processos formativos sobre drogas, como proposto pelos estudos de Coelho e Monteiro "Educação sobre Drogas: Possibilidades da EaD na Formação Continuada de Professores. EaD em FOCO". Nessa linha, pensamos que a proposta pode ser pensada também para a formação inicial, no curso de formação de professores da $\mathrm{EaD}$, utilizando o tema drogas e o uso da arte como potencial na estratégia de ensino.

Nessa perspectiva, reconhecemos a relevância das discussões sobre os diversos fatores envolvidos no uso de drogas. Falar de drogas não é algo fácil. A universidade tem potencial para criar espaços de diálogo e aprendizagem sobre as motivações e implicações do uso dessa substância. Em face ao oferecimento destes espaços de discussão, acreditamos no potencial da arte (em especial a música) como estratégia de ensino para iniciar ou complementar debates sobre diferentes drogas na sociedade, estimulando novos olhares e posicionamentos juvenis que corroboram com um processo preventivo mais dialógico e democrático. (COELHO; MONTEIRO, 2017).

Nossa premissa é de que a estratégia propicie um debate aberto, crítico e participativo em torno do uso recreativo e abusivo das drogas. Dessa forma, buscamos desenvolver o senso crítico e o esclarecimento científico desses estudantes da graduação, centrando-se na abordagem de Redução de Danos como modelo educativo de prevenção. Tendo assim como objetivo: explorar os diferentes pensamentos dos licenciandos em torno das drogas e mediar um debate aberto sobre o uso recreativo e abusivo dessas substâncias a partir da música "Quinta-feira", do compositor Charlie Brow, discutindo as potencialidades pedagógicas dessa estratégia para estimular ações preventivas com alunos da licenciatura em química.

Preparando e Organizando o debate para a inclusão do tema drogas

A partir do acolhimento aos discentes em círculo, sondamos sobre o que eles pensam sobre as drogas. Com a letra da música "Quinta-feira," composta pelo Chorão, do grupo Charlie Brown Jr. o uso da letra da música tange por ser familiar aos alunos e a letra da música tem mitos para serem desmistificado (ANEXO). A atividade constava de 15 minutos para apresentação e após 10 minutos para o debate. Foi realizado debates com 26 discentes da EaD e 2 docentes/tutores da área da pedagogia. Os discentes apresentam faixa etária diferenciada e diferentes cursos (pedagogia e turismo). A atividade foi desenvolvida durante a VI SEMANA ACADÊMICA E II SEMANA DE CIÊNCIAS DA NATUREZA - CEDERJ / Polo Nova Iguaçu. Foi uma possibilidade de abordar as drogas lícitas e ilícitas interditas de uma forma mais interativa, de forma que os participantes se pronunciassem por meio de um debate aberto e participativo.

Foram feitas algumas representações, principalmente no que diz respeito aos mitos, e nesse contexto a música e o debate geraram estratégias para promover um ensino informativo, que 
propicie a reflexão. Acselrad (2015) demonstra desagrado com a abordagem de duelo às drogas dentro do ambiente escolar. A autora acredita ser adequada uma perspectiva crítica do mundo, sustentada pelo conhecimento das realidades dos alunos e sem conhecimento assustador, punitivo e proibitivo. Nesse argumento, refletirmos uma discussão sobre drogas num contexto democrático, que todos possam participar e se posicionar de forma igualitária. Sobretudo, a partir de suas experiências, sobre como os riscos do consumo de drogas pode influenciar a saúde individual e coletiva das pessoas.

Após a apresentação da música Quinta-feira achou-se conveniente trabalharmos algumas questões norteadoras, para que o debate não se perdesse. Assim, foram pensados três tipos de debates. Na primeira questão foi um instaurado um debate sobe o tema norteador: Será que toda pessoa que experimenta um tipo de droga acaba tendo um uso problemático, ou seja, cai num uso abusivo? Na segunda questão seria possível ressaltar o caráter preventivo: Como você enxerga os trabalhos de prevenção sobre drogas realizadas nas escolas? Eles estão mais preocupados em proibir e punir ou em esclarecer para formar jovens democráticos e capazes de tomar decisões favoráveis a saúde? E na terceira abordaremos a discussão sobre as drogas em relação à violência: Você enxerga alguma relação entre o aumento da violência em nosso estado e o consumo das drogas?

Com a palavra os licenciandos da EaD

Nessa premissa, os resultados foram divididos em três blocos de acordo com três questões norteadoras.

1) Será que toda pessoa que experimenta um tipo de droga acaba tendo um uso problemático, ou seja, cai num uso abusivo?

No que tange a discussão sobre as drogas foi possível notar que todos concordavam que pode ocorrer que a pessoa não consiga parar de consumir a droga, porque o organismo acostumouse com a substância e sua ausência provoca sintomas (síndrome da abstinência), ou porque a pessoa acostumou-se a viver sob os efeitos da droga, sentindo um grande impulso de usá-la com frequência, citaram também vários exemplos de drogas lícitas (cigarro, álcool, café, etc), além disso, acreditam que se a droga fosse legalizada, teríamos sérios problemas para fiscalizar o uso.

Quando falamos em adolescentes e drogas, torna-se relevante o questionamento sobre os motivos que levam um jovem a se drogar e outro não, mesmo que ambos tenham orientação e acompanhamento desde cedo sobre este assunto. Vários fatores estão envolvidos neste processo e não se sabe se existe um fator mais importante que o outro. O que se sabe é que o trabalho preventivo é mais eficiente.

Uma aluna de pedagogia, voluntária em uma igreja com reforço escolar, relatou que família estruturada pode minimizar as características negativas ou aperfeiçoar as potencialidades de cada indivíduo; em contrapartida, as desestruturadas podem levar a problemas sérios, principalmente na adolescência, onde o jovem é muito influenciado pelo grupo social.

O tutor do curso de Pedagogia alegou que não existe família estruturada, todas as famílias possuem diversos problemas, o importante é conversar e a prevenção.

Uma aluna de Turismo descreveu seu encontro com quatro jovens no Rock in Rio, que utilizavam "bala" para curtir a noite, quando a mesma os interpelou sobre o porquê deles usarem drogas, alegaram que "de cara limpa" não tinha graça se divertirem.

Todos concordaram quanto aos diversos motivos que levam o adolescente ao uso da droga e como exemplo usou a novela da Glória Perez, a força do querer, que o filho pede uma bola ao pai por mais de uma semana e o mesmo não lhe dá atenção, os discentes alegaram que um dos maiores motivos dos adolescentes terem o contato com as drogas, é a solidão. 
2) Como você enxerga os trabalhos de prevenção sobre drogas realizados nas escolas? Eles estão mais preocupados em proibir e punir ou em esclarecer para formar jovens democráticos e capazes de tomar decisões favoráveis a saúde?

Quanto ao trabalho de prevenção, alguns discentes relataram conhecer o programa PROERD, e alegaram que não concordam com a abordagem que os voluntários apresentam com os adolescentes, pois é mais de punição e proibitiva, do que preventiva. Foram unânimes quanto a necessidade de programas de prevenção esclarecedores.

3) Você enxerga alguma relação entre o aumento da violência em nosso, estado e o consumo das drogas?

Em relação à violência e o consumo de drogas, a maioria afirma que o comércio e a distribuição das drogas existe para servir a uma necessidade de mercado, buscando suprir a demanda de consumo dos seus usuários. Estes consumidores específicos, chamados de usuários, movimentam um mercado cada vez mais crescente. Nessa vertente, o tráfico de drogas aponta para lucros, proveniente desse comércio. O tráfico de drogas fortaleceu os sistemas de controle social, enraizou seu caráter genocida. O número de mortos na 'guerra do tráfico' está em todos os lugares. A violência policial é imediatamente autenticada se a vítima é um suposto traficante. Logo, o mercado de drogas ilícitas propiciou uma concentração de investimentos no sistema penal, uma concentração dos lucros decorrentes do tráfico e, principalmente, ações contra as classes sociais vulneráveis: sejam eles jovens negros e pobres das favelas do Rio de Janeiro.

\section{Considerações finais}

Essa apresentação oral, apesar de seu curto tempo de exposição, nos fez conhecer algumas representações dos alunos da EaD no que tange o tema drogas, usando a música para desenvolver um debate, desmistificando o assunto e corroborando para a criticidade desses futuros docentes. Assim, essa estratégia pode ser adequada para estimular o exercício do diálogo em equipe com os futuros alunos, desenvolvendo a autonomia e o senso crítico entre os discentes. Enquanto eu lia a letra da música, observei que os alunos mesmo conhecendo a música, não tinham feito uma analogia da letra com o tema drogas, após essa referência eles perceberam o uso da arte (música) como um instrumento de iniciação para o debate, até mesmo para desmistificar o mito que gera na letra da música "parece inofensiva, mas te dominou", onde perceberam que nem todas as drogas são inofensivas e muito menos te dominam.

Nesse viés, essa experiência pode ser favorável, podendo entender que a arte (neste caso a música) utilizada como estratégia, pode promover espaços para o debate entre docentes e discentes. Vale ressaltar que se o debate se não for bem planejado, organizado e mediado pelo professor, apresentará danos ao senso crítico, aos mitos e até mesmo prejudicar o jovem que não obteve um esclarecimento e uma abordagem cientifica correta. $\mathrm{O}$ debate sobre drogas permite uma educação preventiva pautada no diálogo e na aprendizagem científica de valores e atitudes acerca do uso abusivo de substâncias e menos centrada nas políticas que exclusivamente proíbem e punem.

Referências bibliográficas

ACSELRAD, G. Quem tem medo de falar sobre drogas? Falar mais para se proteger. Rio de Janeiro: Ed. FGV, 2015. p.164.

ADADE, M.; MONTEIRO, S. Educação sobre drogas: uma proposta orientada pela redução de danos. Educação e Pesquisa, São Paulo, v. 40, n. 1, p. 215-230, jan./mar. 2014.

BRASIL. Ministério da Educação e do Desporto. Secretaria de Educação Fundamental. Parâmetros curriculares nacionais terceiro e quarto ciclos do ensino fundamental: Saúde. Brasília, DF: MEC/SEF, 1998. 
Instituto Brasileiro de Geografia e Estatística. Pesquisa Nacional de Saúde do Escolar 2015. Rio de Janeiro: IBGE, 2016.

COELHO, Francisco José Figueiredo; MONTEIRO, Simone. Educação sobre Drogas: Possibilidades da EaD na Formação Continuada de Professores. EaD em FOCO, [S.I.], v. 7, n. 2, set. 2017. ISSN 2177-8310. Disponível em: <http://eademfoco.cecierj.edu.br/index.php/Revista/article/view/577>. Acesso em: 22 Set. 2017. doi:http://dx.doi.org/10.18264/eadf.v7i2.577.

COELHO, Francisco José Fiigueiredo; MARTINHON, Priscilla Tamiasso, SOUZA, Célia. História, Ciência e Reflexões: Uma proposta transdiciplinar da inclusão de debates sobre drogas nas escolas. Scientiarium História IX, $9^{\circ}$ Congresso em História das Ciências e das técnicas e Epistemologia, 9 - 11, nov. 2016.

COELHO, Francisco José Figueiredo. Entre o lícito e o interdito: Relatando uma aula de Ciências a partir da letra da música Cachimbo da Paz. IV Erebio 2017. Universidade Federal de Uberlandia, 24- 26, ag. 2017.

Anexo

Letra da música Quinta-feira de Charlie Brown Jr.

Ainda me lembro bem daquela quinta-feira

Cinco malandro em volta da fogueira

Ouvi o grito de dor de um homem que falava a verdade mas ninguém se importava

Botando pra fora tudo o que sentiu na pele

Mas ninguém lhe dava ouvidos, não

Deixou a marca da fogueira que acendeu pra se livrar do frio que mata

Miséria impune, notável, sincera não acaba nunca

Parecia inofensiva, mas te dominou, te dominou, te dominou, dominou

Difícil é desviar de quem ta sempre querendo

Ela mantém a porta aberta ela te faz de instrumento,

Vai te dominar, se já não dominou

Ouvi o grito de dor de um homem que falava a verdade

Mas ninguém se importava

Botando pra fora tudo o que sentiu na pele

Mas ninguém lhe dava ouvidos não

Deixou a marca da fogueira que acendeu pra se livrar do frio que mata

Miséria impune, notável, sincera não acaba nunca

Parecia inofensiva mas te dominou, te dominou, te dominou, dominou.

Disponivel em: HYPERLINK "https://www.vagalume.com.br/charlie-brown-ir/quintafeira.html" https://www.vagalume.com.br/charlie-brown-ir/quinta-feira.html. Acesso em: 


\title{
LITERATURA JUDAICO-CRISTÃ E A ESCRITA DE SI NO TRATAMENTO DE USUÁRIOS DE SUBSTÂNCIAS PSICOATIVAS NA CRISTOLÂNDIA
}

\author{
Elizeu Gomes da Rocha (Unigranrio) \\ Daniele Ribeiro Fortuna (Unigranrio / FAPERJ) - drfortuna@hotmail.com \\ Renato da Silva (Unigranrio) -
}

\section{Resumo}

Este texto pretende apresentar o projeto de pesquisa de doutorado "Literatura judaico-cristã e a escrita de si no tratamento de usuários de substância psicoativas na Cristolândia", desenvolvido no Programa de Pós-Graduação em Humanidades Culturas e Artes da Universidade Unigranrio, em Duque de Caxias, Rio de Janeiro. A proposta é analisar a aplicação da literatura e das escritas de si como ferramentas terapêuticas no tratamento de dependentes químicos.

Palavras-chave: Biblioterapia.Dependência química.Escritas de si.

\section{Introdução}

Este texto pretende apresentar o projeto de pesquisa de doutorado "Literatura judaico-cristã e a escrita de si no tratamento de usuários de substância psicoativas na Cristolândia", desenvolvido no Programa de Pós-Graduação em Humanidades Culturas e Artes da Universidade Unigranrio, em Duque de Caxias, Rio de Janeiro. A proposta é analisar a aplicação da literatura e das escritas de si como ferramentas terapêuticas no tratamento de dependentes químicos.

Diversos autores, como Marc-Alain Ouaknin (1985), Maria Mesquita Guedes Pereira (1996), Eva Maria Seitz (2000), Caroline Schorodes (1949), Louise Varin (1995), Gilberta Acsolrad (2000) e outros abordam os impactos positivos da literatura na qualidade de vida e na saúde mental dos indivíduos, bem como os resultados relacionados a hábitos de vida, na baixa prevalência de depressão, em abuso ou dependência de substâncias e na diminuição da ideação de comportamento suicida.

Dalgalarrondo (2000), destaca que, nas últimas décadas, cresceram as pesquisas que apontam a espiritualidade como recurso protetivo para o abuso do álcool ou drogas. O uso de estratégias cognitivas ou comportamentais ligadas à espiritualidade através da leitura da literatura judaico-cristã tem contribuído para a reabilitação do uso e abuso de drogas por indivíduos em crise.

Portanto, foi a partir do levantamento inicial de alguns dados e do cruzamento de informações relacionadas a outras pesquisas que surgiu o interesse em aprofundar este tema, tornando possível a elaboração do presente projeto de pesquisa. Segundo o "Observatório Crack é possível vencer", em 2015, existiam no Brasil 7.541 vagas em 336 centros de recuperação, e a previsão era de chegar a dez mil ao final de 2016. Mas, segundo a Secretaria Nacional de Políticas sobre Drogas, como afirma Perrone (1985, p. 575), existiam entre 2.503 centros de recuperação no país atendendo a 60.000 pessoas por ano sem registro. O desencontro de informações aponta para o fato de que existem muitos centros terapêuticos sem qualquer fiscalização ou apoio do governo.

Como exemplo e foco para pesquisa, observamos a Cristolândia, projeto mantido pela Convenção Batista Brasileira, que se estende em todo o território nacional, mantido 
financeiramente pelas igrejas batistas e seus membros. Como objetivo principal, tais instituições desejam transformar as cracolândias de todo o país em Cristolândias, recuperando dependentes químicos. Possuem sua sede no estado de São Paulo, centros de triagem para o acolhimento e sítios para a internação dos dependentes em alguns estados do Brasil. Destacam-se por não utilizarem medicamentos, mas a abordagem da logoterapia (resgate da existência) e a biblioterapia (terapia com literatura).

Desenvolvida por Viktor Emil Frankl, diplomado médico pela Universidade de Viena em 1930, a logoterapia apresentou resultados positivos para prática clínica na utilização da antropologia como fundamento da terapia, na qual o "ser eu" significa ser consciente e responsável, apresenta a retomada de lugar do paciente, enquanto homem ativo, diante de sua situação. Também conhecida como "psicoterapia dos sentidos", pode ser desdobrada em várias áreas de aplicação como na psicologia, nas ciências médicas, pedagógicas e dirigida ao contexto terapêutico de reabilitação de dependentes químicos. Inclui também a Espiritualidade como uma esfera que contribui para o indivíduo encontrar um sentido para a vida.

Em relação à biblioterapia, este conceito foi formulado por Shrodes (1949), como sendo o processo dinâmico de interação entre a personalidade do leitor e a literatura imaginativa. Possibilita a extração das emoções do leitor para o uso consciente e produtivo do ser.

Para autora, a leitura funcional é o melhor caminho para experimentar a emoção, resgatando sentimentos perdidos com as experiências negativas. Para Quaknin (1985, p. 102) a biblioterapia é uma filosofia existencialista, uma filosofia do livro. Desta forma, o homem, relacionando-se com o livro, pode compreender o texto e se compreender. Ao se interpretar, passa a fazer parte do texto interpretado.

Ao focar a leitura da literatura com objeto de estudo e também como uma das ferramentas utilizadas nos centros terapêuticos, defende-se o texto literário como instrumento de reflexão psicológica ou intelectual.

Objetivos da pesquisa

O projeto tem como objetivo geral analisar os efeitos e os resultados comportamentais de dependentes químicos a partir da utilização da literatura (judaico-cristã e autobiográfica) e das escritas de si em centros terapêuticos de dependentes químicos no Rio de Janeiro e Baixada Fluminense.

Como objetivos específicos, buscamos discutir o papel da leitura e da escrita como ferramenta terapêutica e a construção da memória sobre traumas e experiências emocionais na dependência química. Pretendemos ainda colher narrativas escritas em diários experiências de indivíduos recuperados e em tratamento, que sofrem ou sofreram impactos da leitura terapêutica.

\section{Quadro teórico}

A fundamentação teórica para o desenvolvimento deste projeto de pesquisa terá como base, além dos procedimentos operacionais, a formulação do "corpus documental". Assim, o alinhamento documental e a coleta de dados se constitui como parte da fundamentação teórica. Em termos a formulação do corpo documental, o projeto foi constituído a partir de três ordens de fontes: primeira refere-se à fundamentação bibliográfica, em particular aos textos que exploram a perspectiva histórica e prática da biblioterapia, ou seja, livros que relatam desde o processo teórico à prática e experimental de campo os efeitos e resultados em várias frentes e grupos sociais diferentes. A segunda linha de estudo incide sobre os conceitos implicados na análise das histórias e experiências vividas por indivíduos que passaram pela abordagem terapêutica da literatura. Neste quesito, figuram conceitos de 
experiências, traumas e adaptações a realidades. Para tanto, será de fundamental importância bibliografia que aborde as escritas de si, principalmente, os diários. Como principal suporte teóricos, trabalharemos com Lejeune (2014), Arfuch $(2010,2013)$ e Kingler (2012). O terceiro bloco remete aos estudos sobre os textos da literatura judaico-cristã e das escritas de si. Serão valorizados o sentido dos textos e a sua utilização e aplicação no ambiente terapêutico. Assim, serão escolhidos textos autobiográficos - diários -, com os quais os participantes do projeto de pesquisa possam se identificar.

A fim de possibilitar uma breve amostra dos textos escolhidos e do efeito pretendido na fundamentação teórica, procede-se a uma rápida revisão historiográfica, com o propósito de iluminar os caminhos trilhados para a composição do projeto. De acordo com Marc-Alain Quaknin (1996, p. 97), a tese central da biblioterapia é que o ser humano, como criação contínua e em movimento constante, "encontra suas forças no processo narrativointerpretativo da atividade da leitura.

A leitura implica em interpretação - que é em si mesma uma terapia, posto que evoca a ideia de liberdade -, pois permite a tributação de vários sentidos ao texto. O leitor possui a liberdade de guardar o que the agrada e descartar o que não the convém, dando vida e movimento às palavras. A biblioterapia contempla não apenas a leitura, mas também o comentário que lhe é adicional. Desta forma, as palavras produzem sentidos, oralidade, afirmações e a negação, o fazer e o desfazer, o ler e o falar; produzem a reflexão, ao encontro de escolhas e caminhos, e que curar se configura com o abrir-se a uma outra dimensão.

Para Ouaknin (1996, p. 198), “a biblioterapia (terapia com literatura) é primariamente uma filosofia existencial e uma filosofia do livro", que sublinha que o homem é um "ser dotado de uma relação com o livro". Nesta relação com o livro, o indivíduo compreende o livro e passa a ser compreender. Ao interpretar, passa a fazer parte do texto.

L.H. Tweffort (apud Shrodes, 1949) conceitua biblioterapia como sendo um método subsidiário da psicoterapia; um auxílio no tratamento que, através da leitura, busca a aquisição de um conhecimento melhor de si mesmo e das relações dos outros, resultando em um melhor ajustamento da vida. A introspecção para o crescimento emocional; melhor entendimento das emoções; verbalizar e exteriorizar os problemas; ver objetivamente os problemas, afastar a sensação de isolamento; verificar falhas alheias semelhantes às suas; aferir valores; realizar movimentos criativos e estimular novos interesses.

Para Kenneth Appel (apud Shrodes, 1949), biblioterapia é o uso de livros, artigos e panfletos como coadjuvantes no tratamento psiquiátrico. Elenca como objetivos: adquirir informação sobre a psicologia e a fisiologia do comportamento humano; capacitar o indivíduo a se conhecer melhor; criar interesse em algo exterior ao indivíduo; proporcionar a familiarização com a realidade externa; provocar a liberação dos processos inconscientes; oferecer a oportunidade de identificar e compensação.

Louise Rosenblatt (apud Shrodes, 1949) analisa a literatura ficcional como ajuda para o ajustamento social e pessoal. Sua teoria é de que a literatura imaginativa é útil para ajustar o indivíduo tanto em relação aos seus conflitos íntimos como em conflitos com outros. Para a autora, pensamento e sentimento estão interligados. Por isso, a leitura produz pensamento que, automaticamente, gera sentimento.

Segundo Ouaknin (1996, p. 98-99), "para a biblioterapia a identidade é um não lugar", pois o "ser humano é um ser de caminhos, um homem em marcha". Assim, ao lado da identidade estável, as marcas distintivas do homem-caráter, nome, profissão, posição social, existe a identidade construída pelas identificações adquiridas nos modelos, heróis ou valores nos quais a pessoa se reconhece, que poderia ser chamada de identidade dinâmica. As histórias, contadas ou lidas, propõem ao ouvinte ou leitor a possibilidade de "mudança de direção da trajetória inicial de sua história". 
Metodologia da pesquisa

A metodologia proposta será bibliográfica e pesquisa de campo. Pretende-se interagir com os centros terapêuticos que praticam a biblioterapia, buscando dados e informações para o levantamento da tese, através de coletas de dados, procedimentos e avaliações de dados encontrados em cada centro terapêutico.

Em um primeiro momento, serão definidos os centros terapêuticos onde será desenvolvido o projeto. Em seguida, serão selecionados os indivíduos que participarão da pesquisa. Um dos critérios para a participação - além da anuência - é que estejam em tratamento há, no mínimo, quatro meses. Isso porque, nesse período, as chances de desistência são menores. Em seguida, serão escolhidos os livros - literatura judaico-cristã e diários - a serem trabalhados. Ao longo de três meses, os participantes lerão estes livros e, paralelamente, registrarão suas impressões sobre as obras, sobre o tratamento e sobre suas próprias vidas em diários. Por fim, estes diários serão lidos e analisados, com o objetivo de confirmar ou não as hipóteses do projeto.

Cabe ressaltar que, antes de ser realizado, o projeto com os dependentes químicos, será submetido ao Comitê de Ética da Unigranrio e que todos os participantes deverão assinar o termo de consentimento livre e esclarecido. Serão respeitadas a privacidade e confidencialidade dos pacientes, familiares e funcionários dos centros terapêuticos.

Serão necessárias visitas aos centros terapêuticos da baixada fluminense e em alguns casos em outros estados. O processo de observação se faz necessário para colher informações das práticas de leitura e dos resultados positivos e/ou negativos através de depoimentos tanto dos pacientes, como de funcionários que atuam diretamente com a biblioterapia.

Considerações finais

A dependência química se transformou, nos últimos 30 anos, em um dos principais problemas de saúde pública em diversos países do mundo, inclusive no Brasil. Esse mesmo período foi marcado pelo desenvolvimento significante das neurociências e pela implementação positivas de modelos de políticas públicas, tanto para a saúde mental quanto para o consumo de substâncias psicoativas.

A relação entre psique humana e literatura não é nova. Foi, inicialmente, alicerçada pelas emblemáticas observações psicanalíticas de Freud (1969) sobre a escrita como arte poética. A leitura teria um caráter compensatório, ideia de que os textos literários mudam, em um sentido terapêutico, o estado psíquico do leitor que pode assim descobrir o verdadeiro significado do ser. (ISER, 1999).

Neste sentido, a literatura judaico-cristã e as escritas de si colaboram com este processo ao apresentar em sua literatura histórias de traumas, perdas, conquistas, reviravoltas e tramas identificados na vida humana em toda a sua história. Esta identificação deixa aberta a possibilidade de o leitor se transportar para dentro da história contada. Permite a interação entre a personalidade do leitor e a literatura, atraindo as emoções do leitor e o inconsciente do comportamento. Com isso, a literatura pode se transformar em uma importante ferramenta no tratamento e (re)socialização de dependentes químicos.

Referências bibliográficas

ARFUCH, Leonor. O espaço autobiográfico: dilemas da subjetividade contemporânea. Rio de Janeiro: Eduerj, 2010.

2013.

Memoria y autobiografia: exploraciones en los límites. Buenos Aires: Fondo de Cultura Económica, 
ACSELRAD, Gilberta. Avessos do Prazer: drogas, AIDS e direitos humanos. Editora Fiocruz, 2000.

DALGALARRONDO, Paulo. Psicologia e Semiologia dos Transtornos Mentais. São Paulo: Ed. Artmed, 271 p. 2000.

FREUD, Sigmund. Os chistes e suas relações com o inconsciente. Tradução de Margarida Salomão. Rio de Janeiro: Imago, 1969.

ISER, Wolfgang. O Ato de Ler, Vol.2. São Paulo, Editora:34, 1999.

KLINGER, Diana. Escritas de si, escritas do outro: o retorno do autor e a virada etnográfica. Rio de Janeiro: 7Letras, 2012.

LEJEUNE, Philippe. O pacto autobiográfico - De Rousseau à internet. Belo Horizonte: Editora UFMG, 2014.

OUAKNIN, Marc-Alain. Biblioterapia. Tradução de Nicolás Niymi Campanário. São Paulo: Loyola, 1996.

PEREIRA, Marília Mesquita Guedes. Biblioterapia: proposta de um programa de leitura para portadores de deficiência visual em bibliotecas públicas. João Pessoa: Ed. Universitária, 1996.

PERRONE, Pablo Andrés Kurlander. A comunidade terapêutica para recuperação da dependência do álcool e outras drogas no Brasil: mão ou contramão da reforma psiquiátrica? Ciênc. saúde coletiva [online]. 2014, vol.19, n.2, pp.569-580.

SEITZ, Eva Maria. Biblioterapia: uma experiência com pacientes internados em clínica médica. 2000. 79 f. Dissertação (Mestrado em Engenharia de Produção)- Universidade Federal de Santa Catarina, Florianópolis.

SHRODES, Caroline. Bibliotherapy: a theoretical and clinical-experimental study. 1949. $344 \mathrm{f}$. Dissertation (Doctor of Philosophy in Education) - University of California, Berkeley.

VARIN, Louise; AUBIN, Robert. Les livres qui font du bien. Documentation et bibliothèques, v. 41, n.2, p. 95-100, avr./juin 1995. 


\section{AUTISMO E COMPLEXIDADE}

Jomar Gozzi - Doutorando do HCTE/UFRJ - jomargozzi@hotmail.com

José Carlos de Oliveira - Professor da Poli/HCTE/UFRJ - jcarlos@dee.ufrj.br

Resumo

Abordam-se diversos aspectos relativos à síndrome do autismo, tomando como base conceitos do paradigma da complexidade. São comentadas hipóteses relativas às suas possíveis causas e os tratamentos decorrentes, assim como as formas comportamentais de manifestação nas pessoas autistas. De um lado pessoas com formas mais brandas de autismo formaram o movimento da neurodiversidade que entende o autismo como um jeito de ser; de outro lado pais de filhos autistas de condição mais severa apoiam a busca de uma cura e métodos terapêuticos adequados. Mostra-se a importância da coexistência dialógica dessas duas posturas.

Palavras-chaves: Autismo. Complexidade. Neurodiversidade

Introdução

Para Edgar Morin (2011, p. 6), "a complexidade surge onde o pensamento simplificador falha. Enquanto o pensamento simplificador desintegra a complexidade do real, o pensamento complexo integra o mais possível os modos simplificadores de pensar, mas recusa as consequências mutiladoras, redutoras, unidimensionais e finalmente ofuscantes de uma simplificação que se considera reflexo do que há de real na realidade." Morin propõe o que denomina "paradigma da complexidade" para a análise dos problemas complexos, e assinala que "a consciência da complexidade nos faz compreender que jamais poderemos escapar da incerteza e que jamais poderemos ter um saber total". Assim, Morin não acredita numa totalidade que seja capaz de traduzir em si uma explicação completa de grandes questões complexas. Para ele, há que se conviver com as incertezas inerentes aos grandes problemas, com abertura às distintas interpretações e ideias que surgem. Valoriza o que chama "princípio da dialógica", variante da dialética, pelo qual os conceitos que se opõem podem conviver sem serem superados por um terceiro, síntese.

\section{Autismo}

Dentre as deficiências cognitivas figura o autismo como uma condição extremamente complexa. O autismo foi descrito pela primeira vez por Leo Kanner em 1940. Atualmente, o diagnóstico clínico do autismo se dá pela ocorrência, desde tenra idade, de prejuízo significativo e persistente de comunicação e interação social, aliado à presença de comportamentos estereotipados e repetitivos (GRANDIN, 2015). A par disso, a pessoa autista costuma apresentar extraordinária memória e hiperfoco em assuntos de seu interesse obsessivo. O autismo apresenta-se em um espectro, indo de casos severos, com ausência de fala e automutilação, até casos mais brandos, em que a pessoa autista pode trabalhar e formar família. Porém em todo o espectro ocorrem falhas significativas na comunicação e interação social, o que conduz a isolamento, o que leva à denominação "autismo". Diferentes teorias tentam explicar o autismo, o qual apresenta várias formas de comprometimento e recebe distintas abordagens terapêuticas. Reconhecendo a complexidade do autismo e as incertezas em sua interpretação, observa-se aqui o autismo evitando desprezar as diversas teorias que tentam abordá-lo e explicá-lo, e justamente reunindo as visões, em princípio 
conflitantes, que podem conviver no sentido de serem encontrados os melhores caminhos para as pessoas autistas.

\section{Hipóteses e Tratamentos Decorrentes}

Sob influência da teoria psicanalítica, a hipótese de uma causa psicológica supostamente originada numa possível frieza dos pais, da mãe em particular, largamente predominou durante mais de duas décadas. A prevalência absoluta dessa hipótese acarretou um atraso de mais de 20 anos na pesquisa sobre o autismo (GRANDIN, 2015). A fixação absoluta numa só hipótese aumenta o risco de se tomar uma direção falsa: foi o que aconteceu com a adoção praticamente exclusiva do enfoque psicanalítico por muito tempo. Por uma confusão entre causa e efeito, pais foram injustamente estigmatizados por uma falsa culpabilidade quanto ao autismo de seus filhos. Não mais prevalece essa hipótese. Porém em alguns círculos psicanalíticos ainda persiste a abordagem psicogênica do autismo. Não para explicar o autismo, mas para tentar minorar os efeitos do isolamento de pessoas autistas não se deve afastar de todo as possibilidades potenciais da psicoterapia. Como tratamentos psicoterapêuticos baseiam-se fortemente no discurso do paciente, essa possibilidade fica prejudicada para os casos graves de autismo. Mas nas formas mais brandas de autismo, quando a pessoa autista pode ter um emprego formal e formar família, seu nível de discurso pode buscar o benefício do acompanhamento psicoterapêutico, dentro de limites próprios da condição autista. Assim, não se deve negar a abordagem psicológica de todo, mas restringindo-a aos casos mais favoráveis dentro do espectro.

Desde os anos 1960 tem predominado a hipótese biológica, de causa orgânica ou causa genética, para o autismo. Estatísticas sugerem a importância da genética, possivelmente associada a algum gatilho ambiental. Famílias onde ocorre um caso de autismo têm bem maior chance de nova ocorrência do que em famílias sem nenhum caso. Mas há uma multiplicidade de genes suspeitos de possuírem relação com o autismo, assim como pode haver múltiplos possíveis gatilhos ambientais. A pesquisa continua. Esse desconhecimento em relação às causas determinantes do autismo abre espaço para a proliferação de teorias que se propõem explicá-lo, daí sendo propostos tratamentos decorrentes dessas teorias.

Durante algum tempo foi muito divulgada a teoria do gatilho supostamente acionado pela vacinação tríplice MMR. Esse estudo mais tarde revelou-se fraudulento (TASCHNER, 2017). A crença nessa hipótese acabou conduzindo a que muitos pais não vacinassem seus filhos, o que acabou gerando uma desnecessária exposição de crianças às doenças que seriam prevenidas pela vacina. Mas essa suposição se insere em uma hipótese mais geral de atribuição do autismo a uma possível intoxicação dos organismos dos indivíduos autistas por certos metais. Daí decorreu o tratamento por quelação, que consiste em desintoxicar o organismo pela introdução de substâncias especiais que procuram neutralizar os supostos agentes tóxicos.

Há outras propostas para tratamento do autismo com base em hipóteses sobre suas causas, como dietas alimentares (eliminação de glúten e caseína) e suplementações vitamínicas (megadoses de vitamina B6 em associação com magnésio). Em (MARCELINO, 2010) a mãe de um jovem autista relata a aposta que fêz na dieta livre de glúten e caseína, e relata, não a cura, mas a melhora dos sintomas autísticos de seu filho. Há defensores e detratores de cada forma de tratamento.

O surgimento dessas variadas propostas sempre traz esperanças, mas elas não têm sido validadas em testes científicos extensivos e controlados. Os pais ficam divididos entre somente esperar pela ciência médica oficial ou depositar suas esperanças em tratamentos alternativos. O fato é que há uma "indústria" do autismo prometendo soluções por diferentes métodos de discutível validade. Não se deve desprezar o fato de que algumas dessas 
propostas rendem grandes lucros a seus promotores e oneram famílias de pessoas autistas. Mas o desespero de pais leva a que precisem apostar em algo, mesmo que não cientificamente comprovado. Pesquisas apontam que nos Estados Unidos $75 \%$ das famílias estejam lançando mão dessas terapias alternativas sem que sejam encontrados resultados positivos consistentes (SHUTE, 2010).

Paralelamente, na via tradicional, a indústria farmacêutica cria drogas que são aplicadas no sentido da diminuição de sintomas-alvo, por exemplo, ansiedade, obsessividade, etc. Muitas vezes, sem que haja uma elucidação segura do porquê do eventual benefício obtido, essas drogas apresentam eficácia na diminuição de sintomas-alvo, produzindo efeitos positivos em uma fração de casos (e efeitos negativos colaterais), mesmo que temporariamente. Mas as mesmas drogas podem não ter eficácia alguma quanto à diminuição dos mesmos sintomasalvo numa outra parte dos casos. Os pais, diante de graves sintomas de seus filhos autistas, são compelidos a apostar no emprego dessas drogas e ficar vigilantes quanto aos seus efeitos. A utilização de medicação para redução de sintomas autísticos é controversa. Quem lê uma bula fica assustado com os possíveis efeitos colaterais e pouco seguro quanto aos índices estatísticos que relatam os resultados obtidos. Drogas que reduzem sintomas autísticos em algumas pessoas não funcionam para outros, e não é fácil acertar a dosagem adequada. A sucessão de novas drogas sempre traz esperanças de maior diminuição de sintomas-alvo com redução de efeitos colaterais negativos. Ao mesmo tempo não se pode desconhecer os fortes interesses econômicos da indústria farmacêutica, para a qual a administração contínua de drogas é a fonte de seus lucros (ANGELL, 2004).

Independentemente das incertezas quanto à real causa biológica, pesquisas têm se realizado no sentido de se entender como funciona a mente da pessoa autista, uma vez presente o quadro. Ou seja, se não se sabe bem o "porquê" biológico, tenta-se descobrir o "como" a mente em funcionamento se manifesta. Foram propostos modelos explicativos muito interessantes para os comportamentos estranhos de pessoas autistas, como a hipersensibilidade sensorial, o prejuízo da teoria da mente (FRITH, 2003) (dificuldade em atribuir estados mentais ao interlocutor), a falta de coerência central (fixação em detalhes desimportantes) e a fraqueza nas funções executivas (dificuldade de planejamento). Esses modelos se coadunam com a tendência ao isolamento social, a vulnerabilidade nas relações sociais, o hiperfoco em detalhes e as falhas na contextualização. Quanto a esse aspecto, conforme Uta Frith (2003), a falta ou prejuízo de uma "teoria da mente", inata nas demais pessoas, revela-se a falha fundamental que mostra maior coerência com as dificuldades de interação social. Essa falta ou prejuízo de uma teoria da mente ocorre juntamente com um grande deficit de comunicação. Isso torna particularmente difícil a inserção da pessoa autista na sociedade, pois a humanidade se desenvolveu justamente sobre a comunicação entre os seres humanos. A falta ou prejuízo de uma teoria da mente praticamente impede o entendimento de intenções ocultas no discurso de um interlocutor, o que fragiliza a pessoa autista. Isso gera a necessidade de sua proteção e representação por alguém responsável. Um subproduto notável dessa característica é que a pessoa autista parece jamais mentir, mesmo em seu benefício.

Com base nesses modelos, esforços têm sido desenvolvidos quanto ao manejo do comportamento de pessoas autistas. É preciso que a pessoa autista seja minimamente aceita de início, para em seguida poder angariar empatia do grupo onde deva ser inserida. Embora encontrem críticas quanto a uma suposta robotização das pessoas autistas, as técnicas de modificação de comportamento têm se mostrado muito importantes para o alcance de um mínimo de comportamento aceitável de modo a permitir o convívio social necessário à escolaridade. Isso não tira a importância de se abrir espaço para momentos de isolamento e 
manifestação de estereotipias que parecem ser necessários para diminuição de ansiedade e alívio de sobrecargas sensoriais (ATTWOOD, 2008).

Necessidade de Proteção e a Neurodiversidade

Sendo a condição autista muito variada, deve-se tomar cuidado com tentativas de generalização. $O$ autismo apresenta vários graus de severidade, indo desde casos gravíssimos - como já apontado - da ausência de fala e presença de automutilação, até os casos mais brandos, quando a pessoa pode se sustentar pelo trabalho, formar família e levar uma vida com razoável nível de independência. Porém em todos os casos há importantes problemas de comunicação e interação social, justamente o que leva à denominação "autismo". Não é possível se falar das necessidades das pessoas autistas em sua totalidade, sem fazer algum recorte. Apesar da ampla variação, e mesmo reconhecendo o que lhe é comum, um aspecto pode fornecer um ponto para recorte: trata-se da capacidade ou não da pessoa autista necessitar de constante supervisão. Essa necessidade de supervisão deriva da eventual incapacidade de avaliar o melhor para si em relações sociais e/ou da eventual necessidade de apoio em atividades básicas da vida diária. Esse subconjunto mais comprometido carece de proteção e cuidado (KITTAY, 2002).

O conceito de neurodiversidade preconiza como natural haver diferenças neurológicas entre as pessoas, do que derivariam diferentes modos de raciocínio. As pessoas autistas da parte mais favorável do espectro, com suficiente autonomia e independência, têm lutado pelo reconhecimento de suas peculiaridades como decorrentes de variações neurológicas naturais. Delas emergiu o movimento da neurodiversidade (SINGER, 2016). Esse movimento é auspicioso por afirmar a importância do respeito em relação às diferenças entre os seres humanos. Esse movimento tem sustentado que o autismo deve ser encarado como um "modo de ser", resultado de uma variação natural do cérebro e mente humanos, e não um transtorno estigmatizado como anomalia. O movimento da neurodiversidade combate o rótulo de "deficiência" atribuído ao autismo e tem inclusive se posicionado contra abordagens terapêuticas que tentam "corrigir" o autismo, alegando que isso significaria uma negação do princípio da neurodiversidade.

Por outro lado, associações de pais de filhos autistas advogam o reconhecimento do autismo como deficiência, têm empenhado esforços em apoio a pesquisas que visem uma "cura" do autismo, ao mesmo tempo em que buscam procedimentos terapêuticos para correção de comportamentos indesejáveis e medidas de proteção a seus filhos por parte do Estado.

Não se devendo adotar um modelo único para representação da pessoa autista, a complexidade do autismo sugere uma abordagem cuidadosa reunindo dois aspectos: De um lado, o reconhecimento de que os comportamentos peculiares das pessoas autistas correspondem a diferenças que são próprias da variedade humana, como bem defendido pelo movimento da neurodiversidade. De outro lado, o reconhecimento de que o autismo é uma deficiência cognitiva grave, e que exige todos os esforços no sentido de minorar suas consequências negativas através da proteção das pessoas autistas necessitadas de supervisão constante.

Não é possível se falar em nome das pessoas autistas em sua totalidade, já que não há um modelo que se possa conceber como representativo de todo o espectro. Para pessoas autistas com alto grau de comprometimento as medidas de proteção obviamente devem ser muito mais abrangentes do que para as pessoas com formas mais brandas de autismo na parte mais favorável do espectro. Um aspecto fundamentalmente positivo do princípio da neurodiversidade é que ele reforça uma identidade autista, e com isso contribui para elevar a autoestima das pessoas autistas. $O$ respeito ao princípio da neurodiversidade interessa a todas as pessoas autistas independentemente da gravidade de sua condição. Até mesmo as 
pessoas autistas de condição mais adversa podem ser mais bem aceitas considerando-se esse princípio. É importante demarcar o tipo de autismo caracterizado por necessidade de supervisão constante, flagrante prejuízo da teoria da mente e incapacidade da pessoa de se cuidar sozinha. Há necessidade da criação de condições especiais em apoio à superação das limitações de pessoas autistas nas diversas atividades (educação, trabalho, etc), até mesmo em qualquer parte do espectro autista. Assim, o autismo, perpassado pelo problema fundamental da interação social, abrange pessoas com características de autonomia de um lado, mas de absoluta necessidade de supervisão de outro.

\section{Conclusão}

A complexidade do autismo sugere uma abordagem que reconheça a inexistência de uma totalidade para a condição autista, as incertezas que se apresentam, e a coexistência dialógica entre distintas teorias. Não há um modelo prototípico, havendo de um lado pessoas com formas brandas de autismo com razoável autonomia e em outro extremo pessoas com autismo severo necessitadas de constante supervisão. A atitude da sociedade deve realizar esse diálogo: de um lado o reconhecimento de que o autismo é uma deficiência grave que exige todos os esforços no sentido de minorar suas consequências negativas, seja através de intervenções de tratamento, seja através de sua proteção em todos os aspectos; de outra parte e ao mesmo tempo, o reconhecimento de que as pessoas autistas devem ser todas respeitadas em suas diferenças, o que significa compreender e aceitar seus modos peculiares de ver e agir no mundo. A postura da sociedade de reconhecimento da neurodiversidade interessa inclusive às pessoas autistas mais comprometidas, mas não se deve negar-lhes a devida proteção e as melhores condições para sua adequação ao convívio social. E também a postura da sociedade de proteção às pessoas com autismo também deve interessar inclusive àquelas pessoas com formas brandas de autismo, de suficiente grau de autonomia, pelo menos de modo que suas diferenças em relação às pessoas neurotípicas não Ihes privem de oportunidades. Essas duas posturas da sociedade são fundamentais e se somam em um todo, podendo e devendo coexistirem pelo bem das pessoas autistas.

\section{Referências bibliográficas}

ANGELL, Marcia. A Verdade Sobre os Laboratórios Farmacêuticos: Como Fomos Enganados e o que Podemos Fazer a Respeito. Editora Record, 2004

ATTWOOD, Tony. The Complete Guide to Asperger's Syndrome. London: Jessica Kingsley Publishers, 2008

FRITH, Uta. Autism: Explaining the Enigma. UK: Blackwell Publishing, 2nd Ed., 2003

GRANDIN, Temple \& PANEK, Richard. O Cérebro Autista: Pensando Através do Espectro. Rio de Janeiro: Editora Record, 2015

KITTAY, Eva Feder \& FEDER, Ellen K. (org.) - The Subject of Care: Feminist Perspectives on Dependency Rowman \& Littlefield Publishers, 2002, eBook Kindle

MARCELINO, Claudia. Autismo: Esperança pela Nutrição. Rio de Janeiro: M. Books do Brasil Editora, 2010

MORIN, Edgar. Introdução ao Pensamento Complexo. Porto Alegre: Editora Sulina, 2011

SHUTE, Nancy. Desperate for an Autism Cure. Revista Scientific American Brasil, edição 102, novembro 2010

SINGER, Judy. Neurodiversity: The Birth of an Idea. EBook Kindle, 2016. 
TASCHNER, Natalia Pasternak. Vacina e Autismo - A História de uma Fraude. Disponível em: <http://cafe-nabancada.com.br/index.php/vacinas-e-autismo-historia-de-uma-fraude/>. Acesso em 23 de maio de 2017. 


\section{ÉTICA E DEFICIÊNCIAS COGNITIVAS}

Jomar Gozzi - Doutorando do HCTE/UFRJ - jomargozzi@hotmail.com José Carlos de Oliveira - Professor do HCTE/UFRJ - jcarlos@dee.ufrj.br

Resumo

As éticas fundadas no conceito do indivíduo racional, autônomo, livre e proprietário não reconhecem as pessoas com deficiências cognitivas. São exemplos a ética utilitarista e a ética contratualista. Em contraste, a ética da alteridade e a ética do cuidado propõem uma radical mudança de foco, com centralidade na relação com o próximo diferente e na responsabilidade por ele, representando posturas éticas que consideram e respeitam profundamente as pessoas com deficiências cognitivas.

Palavras-chave: Deficiência. Alteridade. Cuidado.

Introdução

A evolução do pensamento filosófico acompanha as transformações da sociedade. Essa evolução se reflete na maneira como são consideradas as pessoas com deficiências cognitivas. $\mathrm{Na}$ Grécia antiga o pensamento filosófico enxergava o mundo como fixo, e refletia sobre a relação entre o homem e o cosmos, não havendo consideração favorável às pessoas com deficiências cognitivas (ou outras deficiências graves), consideradas sub-humanas. Com o advento do cristianismo, o pensamento filosófico passou a refletir sobre a relação entre o homem e Deus, reconhecendo as pessoas com deficiências cognitivas como também criaturas de Deus, embora fossem desvalorizadas no cotidiano e vivessem da caridade. Com o crescimento do capitalismo mercantil, ganhou maior relevância a investigação da natureza, e começou lentamente a prevalecer a razão em lugar dos dogmas sobrenaturais de origem religiosa ou mística (PESSOTTI, 1984). O desenvolvimento do capitalismo gerou para o capital a necessidade de trabalhadores livres para venderem sua força de trabalho e consumirem os produtos gerados pela indústria e comercializados no mercado. Dessa estrutura econômica surgiu a ideologia liberal, a qual veio produzir contribuições de filósofos que teorizaram tanto sobre o conhecimento, agora empregado no desenvolvimento material da sociedade, como sobre a ética entre os indivíduos.

Ética Utilitarista e Ética Contratualista

Ideólogo do liberalismo clássico, o filósofo Jeremy Bentham (1748-1832), a partir da idealização do indivíduo autônomo, propôs uma ética baseada no "Princípio da Utilidade" (BENTHAM, 2000 [ 1781]), o qual implica em se "aprovar ou desaprovar toda ação de acordo com sua tendência a aumentar ou diminuir o bem-estar daqueles cujos interesses estejam em jogo".

A presença de uma pessoa com deficiência cognitiva grave em uma família impõe enorme pressão emocional e econômica sobre seus familiares, assim como gera pressões sobre o Estado quanto a políticas compensatórias. A prevalência de uma visão "quantitativa" de bemestar, de "interesses" em jogo, conforme a "ética utilitarista" de Bentham, tende a conduzir à rejeição de pessoas com deficiências cognitivas graves pela sociedade, e até mesmo por suas famílias.

O elemento legal que materializa as relações liberais é o "contrato". Segundo a visão liberal, os indivíduos possuem habilidade para negociar contratos, examinam suas opções e fazem escolhas racionais. O filósofo John Rawls (1921-2002) propôs uma "ética contratualista", 
baseada na liberdade, independência e autonomia do indivíduo em busca de renda e riqueza como os bens primários a perseguir, e baseada na cooperação social fundada na busca de vantagens mútuas (RAWLS, 2000).

As pessoas com deficiências cognitivas não se enquadram nesses pressupostos. Como desdobramento das proposições acima, somente seriam devidos deveres morais àqueles que podem assumir obrigações morais, o que ameaça pessoas com deficiências cognitivas graves. Essas propostas éticas clássicas não prevêem lugar para as pessoas com deficiências cognitivas acentuadas.

O Sujeito Autônomo e Independente ou o Sujeito Vulnerável?

Para Martha Fineman (2008), em política social o conceito de "sujeito vulnerável" deve suplantar e substituir o conceito de "sujeito autônomo e independente" da tradição liberal, pois considera o conceito de sujeito vulnerável muito mais representativo da verdadeira experiência vivida e da condição humana.

A abordagem da vulnerabilidade reconhece que os indivíduos são marcados, em cada extremo de suas vidas, pela dependência e pela ausência de capacidades importantes. Obviamente, entre esses extremos, perda de capacidades importantes e dependência podem também ocorrer, temporária ou permanentemente, como resultado de deficiências ou doenças. Os seres humanos vivem com a sempre presente possibilidade de que suas necessidades e as circunstâncias que os envolvem possam mudar.

No nível individual, o conceito de vulnerabilidade (em vez da autonomia liberal) capta esse potencial de cada ser humano se tornar dependente baseado na persistente susceptibilidade ao infortúnio. Por outro lado, o sujeito liberal, tal como previsto, somente pode se apresentar como um adulto, parecendo situar-se não somente à margem da passagem do tempo, mas também fora da experiência humana. A construção do sujeito adulto liberal capta somente um estágio possível do desenvolvimento, o menos vulnerável dentre os muitos possíveis estágios ao longo da vida normal. A abordagem com base no sujeito vulnerável faz o que a abordagem liberal não faz: abrange o fato de que a realidade humana envolve um amplo espectro de indivíduos diferentes e interdependentes interagindo ao longo da vida (FINEMAN, 2008).

Pessoas com Deficiências Cognitivas

A pessoa com deficiência cognitiva é um exemplo claro do sujeito vulnerável. Essa vulnerabilidade se estende à família, onde surge em decorrência uma vulnerabilidade emocional e econômica. Para que a sociedade respeite a dignidade dessas pessoas fragilizadas há que ter um padrão ético dominante baseado no reconhecimento e aceitação das diferenças. Como visões éticas que melhor se coadunam com o respeito à pessoa com deficiência cognitiva figuram a ética da alteridade e a ética do cuidado.

\section{Ética da Alteridade}

Emmanuel Lévinas (1906-1995), filósofo judeu nascido na Lituânia e naturalizado francês, foi discípulo de Martin Heidegger (1889-1976), de quem se afastou quanto este se engajou no nazismo. A proposta ética de Lévinas é conhecida como "ética da alteridade". Embora inicialmente influenciado pela ontologia de Heidegger, Lévinas propôs uma mudança de foco da subjetividade centrada no Mesmo para uma alteridade centrada no Outro, a partir do encontro face-a-face. Enquanto Heidegger coloca a ética em segundo lugar, Lévinas a coloca em primeiro plano, propondo uma radicalidade ética no sentido mais profundo da relação entre seres humanos. Para ele, a originalidade da filosofia encontra-se no solo da ética, com o Mesmo se reconhecendo pelo encontro com o Outro, a responsabilidade do Mesmo em 
relação ao próximo importando mais que a própria liberdade. Conforme HADOCK-LOBO (2006, p. 38), para Lévinas "o problema da filosofia não é mais a relação ontológica do homem com o ser, mas a relação ética do homem com o Outro, com seu Outro, com a alteridade absoluta."

O pensamento de Lévinas vai muito além da simples relação com o próximo, trata-se de uma relação com o próximo "diferente". Não se trata da simples tolerância, de compreender a diferença. Trata-se de reconhecer a diferença, a radicalidade da diferença, e de querer que essa diferença tenha seu espaço e tempo respeitados.

A ética da alteridade é um caminho que contém o reconhecimento e o respeito a todos os seres humanos em suas diferenças, assim como o necessitam e merecem as pessoas com deficiências cognitivas.

\section{Ética do Cuidado}

A autonomia do indivíduo é absolutamente valorizada em nossa sociedade, mas efetivamente corresponde a um mito e a um ideal. De fato, o ser humano nasce frágil e completamente dependente dos cuidados de uma mãe, isto é, com deficiência em alguma medida; vive diferentes graus de dependência ao longo da vida, pode ter intervalos maiores ou menores de não deficiência, e tende a caminhar no sentido da deficiência à medida que entra na velhice. As pessoas com vulnerabilidade grave, incluídas as pessoas com deficiências cognitivas, que tenham pouca ou nenhuma autonomia, necessitando supervisão constante, dependem de cuidado. Nesse sentido considera-se aqui a chamada "ética do cuidado". A posse de cidadania tem sido condicionada à capacidade de autonomia. As pessoas com deficiências cognitivas graves, que necessitam supervisão, não dispõem dessa autonomia, por isso necessitam um tratamento especial que contenha o cuidado a lhes ser oferecido.

O cuidado é um conjunto de práticas e valores que configuram uma ética. O foco central da ética do cuidado está no atendimento e no suprimento das necessidades daqueles sob nossa responsabilidade. A ética do cuidado contrasta com as teorias morais baseadas na autonomia do indivíduo, e valoriza e incorpora a emoção humana em seus fundamentos.

Segundo Virginia Held (2006, p. 10), as teorias morais baseadas na imagem do indivíduo independente, autônomo e racional ignoram a realidade da dependência humana. Segundo ela, a ética do cuidado valoriza a emoção humana, não a rejeita; "não qualquer emoção, mas, em contraste com as abordagens racionalistas dominantes, as emoções da simpatia, empatia, sensibilidade e responsabilidade [...], que precisam ser cultivadas".

Por sua vez, Eva Kittay, filósofa americana, mãe de uma filha com deficiência intelectual grave, critica os conceitos de cidadania de clássicos pensadores do passado (KITTAY, 2002). Ela nos lembra que, para Aristóteles, "a posse da faculdade deliberativa e a capacidade de agir a partir de deliberação racional representavam a condição sine qua non para cidadania, uma capacidade que ele atribuía somente aos homens livres, não às mulheres e não aos escravos". Se nem às mulheres cabia cidadania, muito menos caberia às pessoas com deficiência cognitiva.

Eva Kittay interpreta que para Kant "a dignidade dos humanos derivava de sua capacidade de assumir deveres de acordo com a lei que eles mesmos elaboravam. A capacidade que elevava humanos ao status de agentes morais [...] era a racionalidade pela qual nós julgamos se podemos universalizar as máximas que escolhemos para nossas próprias ações" (KITTAY, 2002, p. 262). Para Kant, é necessário que, para que o homem tenha obrigação moral para com outrem, esse outro indivíduo seja capaz de apresentar deveres morais. Ou seja, não se exigiria obrigação moral de um indivíduo em relação a outro que não pudesse observar deveres morais por não dispor de plena capacidade cognitiva. 
Eva Kittay aponta ainda que para Rawls "a justiça é devida àqueles que entram com outros em associação baseada em adequados termos de cooperação" (KITTAY, 2002, p. 262). O pensamento de John Rawls exclui o dever de justiça a quem não pode cooperar, o que atinge as pessoas com deficiência cognitiva.

Para o liberalismo tradicional, a noção de participação política depende de que a pessoa seja independente, racional e capaz de autossuficiência. O exclusivo foco nas limitações das pessoas com deficiências cognitivas graves as colocaria fora das definições liberais de personalidade e cidadania, que são fixadas plena capacidade racional, na independência e na produtividade.

Para o individualismo liberal a sociedade é constituída por sujeitos independentes que perseguem seus próprios fins, e cooperam somente quando enxergam vantagens mútuas. As teorias morais com origem no individualismo liberal vêem as pessoas como agentes autônomos ou indivíduos movidos por seus próprios interesses. Por seu turno, a ética do cuidado baseia-se nas pessoas em relação. O fundamento da ética do cuidado é a relação de interdependência entre as pessoas, uma interdependência que não tem que ser simétrica entre as pessoas, a assimetria sendo natural e variante no tempo.

São os vínculos de dependência que estruturam as relações humanas, visto que a dependência é algo inescapável à história de vida de todas as pessoas. A respeito, diz HELD (2006, p. 13): "A ética do cuidado vê as pessoas em relação e interdependentes, moral e epistemologicamente. Todos nós surgimos como crianças dependentes daqueles que nos provêm cuidado, e continuamos interdependentes com os outros de modo fundamental ao longo de nossas vidas. O que nos faz pensar e agir como se fôssemos independentes depende de uma rede de relações sociais que o tornem possível. E nossas relações são parte de nossa identidade".

Por outro lado, da parte de setores insensíveis à questão da deficiência produz-se pressão permanente no sentido de que se mantenha restrita às famílias a responsabilidade por suas pessoas com deficiências, fora do âmbito do Estado. O Estado, com sua economia fundada na competição do mercado, tem relutado em reconhecer a responsabilidade pelo cuidado das pessoas como questão social. Subsídios públicos para suporte ao capital têm sido apresentados como essenciais ao Estado e ao mercado, e indiretamente às famílias. Mas subsídios públicos para o suporte do cuidado têm sido apresentados como opostos aos interesses do Estado e do mercado, relegando-se a responsabilidade do cuidado apenas à esfera privada familiar.

A ética do cuidado é um valor a cultivar numa sociedade necessariamente interdependente. A prática de uma ética do cuidado deve ser estimulada como um valor de cidadania, não devendo se restringir ao âmbito familiar, mas devendo também embasar políticas de Estado.

\section{Conclusão}

Teorias morais clássicas basearam-se na autonomia e independência do sujeito, desconsiderando as pessoas com deficiência cognitiva. De modo distinto, outras abordagens filosóficas e éticas postulam princípios fundamentais quanto à relação com as pessoas vulneráveis, como aquelas com deficiências cognitivas. São exemplos a ética da alteridade e a ética do cuidado. Para a sociedade estabelecer uma relação de reconhecimento e respeito em relação às pessoas com deficiências cognitivas, vulneráveis e incapazes de cuidar de si mesmas, são fundamentais a promoção, a valorização e a prática de uma postura com foco no próximo diferente. A ética da alteridade e a ética do cuidado representam suportes éticos para essa atitude.

Referências bibliográficas 
BENTHAM, Jeremy. An Introduction to the Principles of Morals and Legislation. Ontario: Kitchener, Batoche Books, 2000 (originalmente publicado em 1781).

FINEMAN, Martha Albertson. The Vulnerable Subject: Anchoring Equality in the Human Condition. Yale Journal of Law and Feminism. Volume 20, Issue 1, Article 2, 2008

HADOCK-LOBO, Rafael. Da Existência ao Infinito: Ensaios sobre Emanuel Lévinas. São Paulo: Edições Loyola, 2006 HELD, Virginia. The Ethics of Care: Personal, Political, and Global. New York: Oxford University Press, 2006 KITTAY, Eva Feder \& CARLSON, Licia (org.). Cognitive Disability and Its Challenges to Moral Philosophy - WileyBlackwell, 2010

LÉVINAS, Emanuel - Entre Nós: Ensaios sobre a Alteridade - Petrópolis: Editora Vozes, 1991

PESSOTTI, Isaías. Deficiência Mental: da Superstição à Ciência. São Paulo: Editora da Universidade de São Paulo, 1984

RAWLS, John. Uma Teoria da Justiça. São Paulo: Martins Fontes, 2000 


\section{ANATOMIA DAS PAIXÕES: TEATRO COMO MÉTODO DE CUIDADO EM SAÚDE MENTAL: EXPERIÊNCIA NA REDE DE SAÚDE MENTAL E SISTEMA PRISIONAL COM AS PRÁTICAS DE CUIDADO E RESSOCIALIZAÇÃO}

Kadosh Olive - Universidade das Quebradas, Programa Avançado de Cultura Contemporânea (PACC), Universidade Federal do Rio de Janeiro, Rio de Janeiro, Brasil kadosholive@gmail.com

\section{Resumo}

Partimos de reflexões sobre a natureza do encontro terapêutico na perspectiva de nossa experiência desenvolvida desde 2013 na rede de laboratórios LAMAE- Anatomia das Paixões, Centro de Ciências Matemáticas e da Natureza (CCMN)- HCTE, na Cidade Universitária no Rio de Janeiro. Damos especial atenção à experiência e os princípios onde apresentaremos, referenciando nossos filmes documentários e fotografias publicadas na rede virtual, nossa experiência com teatro e promoção da saúde mental, constituindo método de cuidado com resultados publicados e documentados que constituíram política pública bem sucedida de promoção da saúde, restando, o desafio de comunicar sobre esses métodos e teorias de forma adequada a sua reprodução nos territórios e nas comunidades.

Palavras-chave: Anatomia das Paixões. Universidade das Quebradas. ParatodosUFRJ. Instituto Arte Viva. Cinema. Documentário. Psiquiatria Transcultural. Promoção da Saúde Mental.

A experiência da cirandas da vida e práticas de cuidado

A Oficina de Ação Expressiva e Teatro Ritual é um espaço educativo coletivo com foco em debates no campo da Extensão Popular e nas trocas de experiências entre diferentes atores e iniciativas das mais diversas áreas. Constitui uma oportunidade para que profissionais, estudantes, professores, técnicos, gestores e representantes do movimentos sociais e populares dêem visibilidade as suas ações e socializem o jeito de fazer das práticas de educação popular, que não demarcam uma área específica, mas um referencial teórico e metodológico que conduz essas práticas, norteando o diálogo entre os trabalhadores, professores e estudantes com os sujeitos dos movimentos e práticas populares por meio de roda de cuidado.

É um espaço de circulação ampla, onde acolhe rodas de conversa e expressões diversas da arte popular, momentos para troca e discussão sobre Educação Popular, debates e exposição de filmes, além de místicas e vivências artísticas e culturais. Construída coletivamente, é realizada de modo integrado podendo ser integrando a eventos e sua programação oficial. Já uma marca do movimento de educação popular, articulando práticas que se constitui em espaço importante para a troca de saberes com a comunidade na construção de conhecimentos em saúde, tanto individuais como coletivos.

O contexto que envolve a temática das práticas deve ser abordados na saúde integral das pessoas, o que envolve necessariamente a dimensão cultural e interpessoal do público frequentador de espaços alternativos. Como os relacionamentos e as trocas concretas ocorrem, ao mesmo tempo, nos planos objetivo e subjetivo, individual e coletivo, os investimentos em intervenções com foco multidimensional aplicados nestes ambientes trazem resultados rápidos, efetivos e mais coerentes com o propósito educativo de organizações culturais. A oferta de ações que possibilitam a manifestação da identidade, o 
reconhecimento das escolhas profissionais e o resgate da autonomia quanto ao bem viver (consigo mesmo e com o outro) traz ao campo prático o valor da sensibilidade e do cuidado afetivo, repercutindo positivamente na vinculação mais saudável dos agentes de saúde em suas rotinas e nas relações sociais. Como os serviços culturais geralmente trazem embutido o cuidado das pessoas pela via do lazer, elas costumam aderir aos investimentos propostos sempre que se sentem acolhidas em seus desejos de diversão e prazer. Ou seja, quanto mais adequado for o respaldo para o exercício de seu bem estar, o respeito aos seus gostos e modos de viver, maior tende a ser a satisfação e o potencial de conquista de bons retornos práticos nas experiências adquiridas com as atividades ofertadas. Sendo assim, ao invés de tratar de restrições, perdas ou obrigações sofridas que envolvem as doenças ou os contextos de adoecimento, pode-se viabilizar uma programação para abordá-lo pelo viés de algo que simbolicamente soe mais agradável: o Cuidado, por exemplo. Afinal, uma das vias de adoecimento é o descuido, em suas inumeráveis Cultura do Cuidado em potências viáveis de cura na cidade. A perspectiva da promoção de saúde, com estratégias e práticas culturais de cuidado. Desta imensa riqueza cultural da resistência dos povos ancestrais, emergiram esses três grandes artistas do teatro, da poesia e da medicina. Junio Santos, Vera Dantas e Ray Lima desenvolveram a linguagem do diálogo e do teatro verdadeiramente público, que trabalha com a cantiga e a dança, com o diálogo entre as linguagens, o método da construção coletiva na arte e na cultura, segundo Ray Lima numa CENOPOESIA (DANTAS, 2014). Podemos afirmar que o Movimento Escambo Livre de Rua e a linguagem cenopoética foram e são inspirações e ferramentas úteis na construção do espetáculo teatral e a melhoria do nível de saúde mental dos atores em treinamento. (DANTAS, 2009). A psiquiatria transcultural, que assume a história, a cultura, a linguagem, as imagens e a arte, e da qual a experiência de Nise é um dos exemplos mais brilhantes e significativos, estuda também a história dos traumas. Grandes traumas históricos como a inquisição, os genocídios indígenas e africanos, ainda em curso, repetem-se inconscientemente, como se a tragédia fosse inescapável.

A comunicação é o desafio para a saúde mental

O proponente utiliza o princípio de que "todo ser humano é ator e cuidador" e se apoia na ideia da livre participação de crianças, jovens, adultos, idosos, terapeutas, estudantes de qualquer área do conhecimento, usuários dos serviços de Saúde Mental, população em situação de rua, trabalhadores e demais cidadãos, sem restrições.

O trabalho é baseado no reconhecimento dos saberes populares dos mestres da cultura, ratificando que todo ser humano possui capacidade criativa e curativa a ser exercida, de modo a estimular o protagonismo dos agentes sociais e a conquista da autonomia no reestabelecimento da saúde individual e coletiva. Isso se dá a partir da prevenção de distúrbios econômicos, culturais, sociais e históricos que assolam e adoecem as comunidades, em processos que envolvem as linguagens artístico-culturais como ferramentas/recursos ou meio democrático participativo, efetivado na apresentação de oficinas, filmes, cursos, debates, palestras, rodas de conversa, eventos científicos ou de caráter político e outras manifestações, em troca direta com o público presente. $O$ viés das ações transversais propostas é fundamentalmente educativo e afetivo, ao mesmo tempo. Nesta perspectiva, as questões que dizem respeito à Saúde e à Cultura integram fatores políticos, socioeconômicos e institucionais, sendo trabalhadas pelo Anatomia das Paixões durante o compartilhamento prático de atitudes e posturas éticas e técnicas que estimulam a participação de pesquisadores, estudantes, educadores populares e demais pessoas ao longo da imersão nos processos ativados. O teatro é utilizado em resgate da linguagem ancestral do corpo e inconsciente coletivo, possibilitando a conexão com o campo morfo genético, sutil e causal, 
que favorece a capacidade de expressão dos indivíduos, emancipação, afeto e diálogo, em um processo de construção de diferentes identidades interdependentes.

Quanto às especificidades sobre questões da saúde mental, o foco é colocado em diretrizes que abrem espaços para criações funcionais e reflexivas, auxiliando o desenvolvimento dos relacionamentos saudáveis e da maturidade política dos participantes quanto aos desafios no processo de autonomia social e reequilíbrio da sanidade. Assim, pode-se questionar e exercer tipos de metodologias a serem implementados nos sistemas políticos vigentes, de modo a contribuir com o fortalecimento das relações entre a Arte e a Ciência. Os referenciais adotados para isso se ancoram nas contribuições de Shakespeare, Goethe, Nise da Silveira, Baruch de Spinoza, Humberto Maturana, Nelson Vaz, Amir Haddad, Paulo Freire, José Pacheco, Carl Jung, Heloisa Helena Drummond, Júnio Santos, Vera Dantas, Ray Lima, Vitor Pordeus, Mana Bernardes, Maria Teresa Vieira dentre outros, por iluminarem caminhos e/ou ousarem viver a proximidade com a experiência da loucura, da Arte e da Ciência. A participação inclusiva e o diálogo entre pessoas de diversificados saberes são diretrizes e meios para criar e manter a saúde integral, como exercício de respeito amoroso às ideias e opiniões alheias, fundamentais à manifestação da potencia criativa e coletiva, diferentemente do quadro voraz de medo, egoísmo e competição, preponderante na sociedade capitalista atual.

Saúde e cultura com doçura

As ações propostas para o Intercâmbio de Saúde, Educação e Cultura serão organizadas de modo a integrar pessoas com interesse em dinâmicas de atuação transversais, reunindo com grupo de educadores e atores que visa um ponto de encontro para conversas e vivências sobre o bem-estar o bem alimentar-se, o bem cuidar-se e o bom convívio em grupo. Dentro da "Tenda Doces Cuidados", serão realizando rodas de conversas, danças circulares, vivências corporais de dança, sensibilizações e jogos dramáticos. Saúde e cultura juntas para vivenciar o corpo e a natureza. Com grupo de educadores e atores sociais de diversas iniciativas que congreguem entre si e potencialize as ações.

Promoção de saúde integral associada a estratégias educativas, para ampliar o conhecimento, a percepção e o repertório de ações. Aspectos saudáveis e iatrogênicos do cotidiano, de modo a potencializar atitudes afetivas e prazerosas na prática de ensino-aprendizagem, instrumentalização para o desenvolvimento de ações éticas e estéticas de valorização do cuidado coletivo.

\section{Conclusões}

Pudemos verificar através de nossa própria experiência com teatro e doenças mentais graves que através de linguagem especificada segundo nosso método, desenvolvida segundo os princípios de Nise da Silveira e Amir Haddad, Junio Santos, Ray Lima e Vera Dantas, também alinhadas com a revolução científica contemporânea na biologia de Humberto Maturana.

Referências bibliográficas

DANTAS, M.J. Cenopoesia: abrindo diálogos sobre a poética de saberes entrelaçados, Qualificação de Mestrado, 2014. Disponível em:

\&lt;https://sigaa.ufpb.br/sigaa/public/docente/producao.jsf?siape=268015\&gt;. Acesso em ago. 2016.

DANTAS, V. L. A. ; LINHARES, A. M. B. Dialogismo e arte na gestão em saúde: a perspectiva popular nas cirandas da vida em Fortaleza-CE. Tese de Doutorado na Universidade Federal do Ceará. 2009. Disponível em: \&lt;http://repositorio.ufc.br/handle/riufc/3282\&gt;. Acesso em ago. 2016.

FREIRE, P. Pedagogia do Oprimido. São Paulo: Paz e Terra, 1970. 218p. 
MELLO, L.C. Nise da Silveira: caminhos de uma psiquiatra rebelde. 1a ed. Rio de Janeiro: Automática Edições, 2014. 367p.

SILVEIRA, N. Jung: vida e obra. 22 a ed. Rio de Janeiro: Paz e Terra, 2003. 173 p.

Figura 1- Conferência Arte Salva Vidas produzida pelo Instituto Arte Viva, realizado nos dias 23 e 24 de setembro de 2017 no Complexo Cultural Clube dos Diários, Teresina- Piauí.

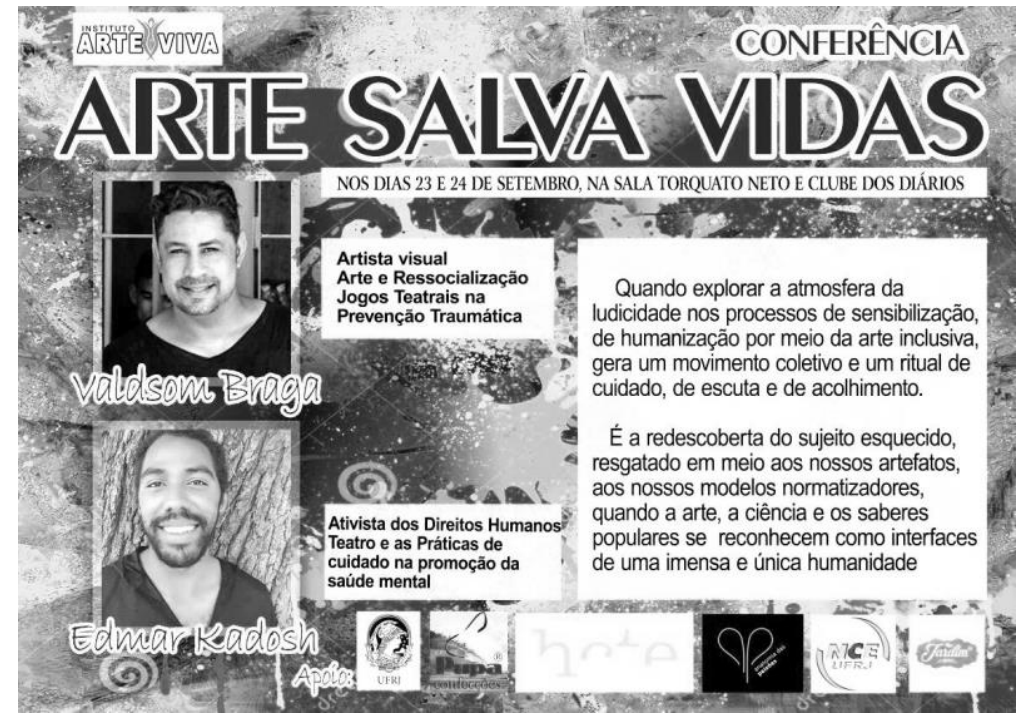

Fonte: Autores

Figura 2 -Oficina de práticas de cuidado na promoção de saúde mental no projeto Mulheres de Aço e de Flores, Penitenciária Feminina de Teresina, Sejus- Secretaria de Justiça e Cidadania.
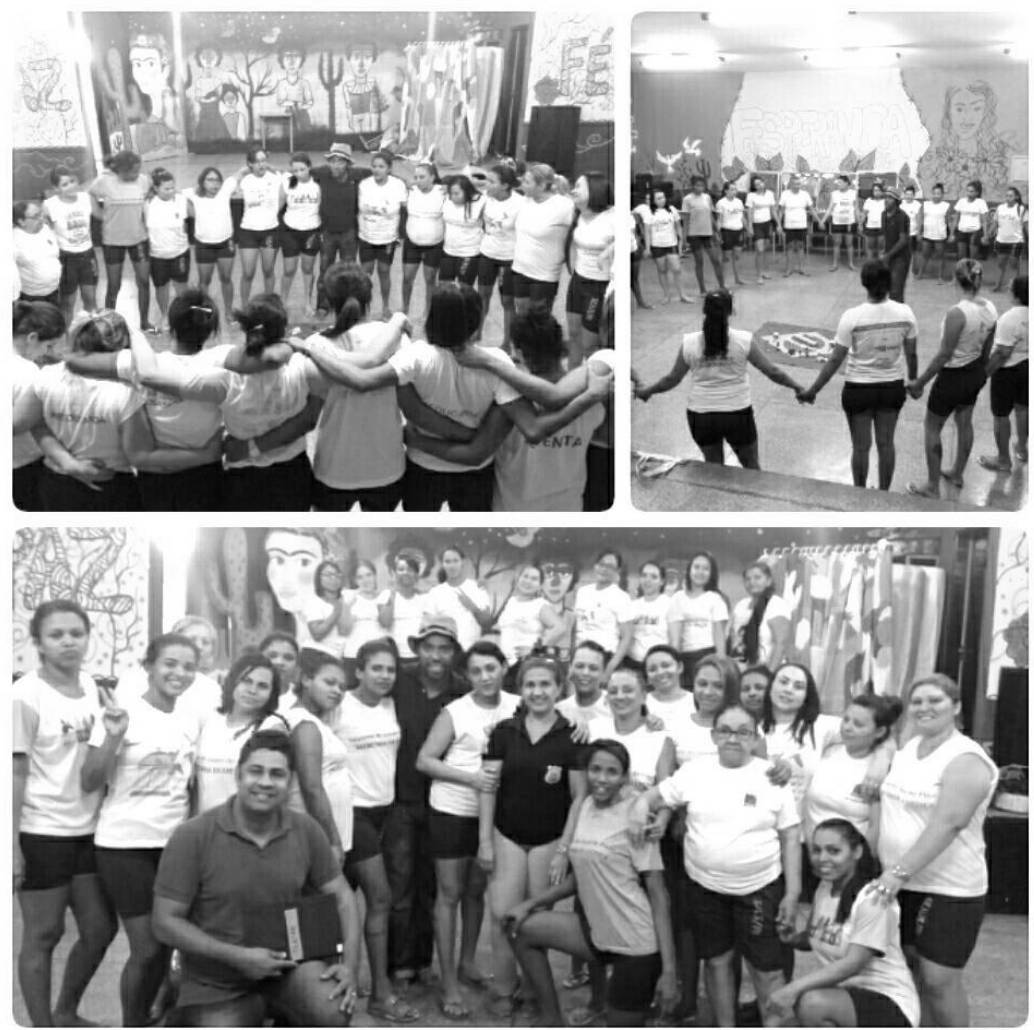

Fonte: Autores 


\section{A ESTÉTICA ENQUANTO INTERSEÇÃO ENTRE ARTE E CIÊNCIA - UMA PROPOSTA}

KOEHLER, Carlos Benevenuto Guisard, HCTE/UFRJ, cbgk@uol.com.br HELAYEL-NETO, José Abdalla, CBPF/MCTI, josehelayel@gmail.com

WIENSKOSKI, Paula, HCTE/UFRJ, paulawienskoski@gmail.com

\section{Resumo}

Este trabalho apresenta uma proposta de pesquisa em andamento que tem o intuito de estudar a hipótese de que o conceito de beleza possa ser considerado parte de um processo epistemológico na construção de teorias científicas no século XX. Para isso, está sendo estudado o papel do conceito de beleza da forma como é empregado tanto na Estética quanto pelas teorias da Física Moderna e que relevância exerce no processo de construção das teorias científicas. No campo da Física a pesquisa apontará alguns exemplos históricos de pensadores que, desde os primórdios do conhecimento grego, já conectavam beleza e ciência na busca pelo entendimento do universo.

Palavras-chave: Estética. Beleza. Epistemologia.

A Estética está culturalmente muito mais relacionada, para nós, à prática artística do que à científica. Mas certamente o belo não é uma exclusividade da arte. A maioria de nós aprende a reconhecer a beleza, em primeiro lugar, na relação entre o belo e as formas humanas e da natureza (vivenciadas ou representadas), antes desse conceito ser atribuído a qualquer outro objeto ou prática cultural. Por isso mesmo, segundo Gombrich "a maioria das pessoas gosta de ver nas imagens as coisas que eles gostam de ver no mundo real. E é uma preferência bastante natural." É uma espécie de "estética a priori", não cultivada, não aprendida, intrínseca do ser humano. E essa ocorrência também se reflete no meio científico. Existem critérios aos quais podemos recorrer para pensar na beleza que elas podem conter, porque estamos lidando com imagens e, ainda que algumas possam sejam abstratas, transitamos por um universo familiar, graças à preocupação humana em estudar, compreender e valorar a estética. Para os físicos teóricos isso também está presente em seu trabalho, embora talvez de uma forma diferente do que estamos habituados. Segundo Anthony Zee (2007, p.3),

\footnotetext{
“(...) we like to think that we too search for beauty. Some physics equations are so ugly that we cannot bear to look at them, let alone write them down. Certanly, the Ultimate Designer would use only beautiful equations in designing the universe! we proclaim. When presented with two alternative equations purporting to describe Nature, we always choose the one that appeals to our aesthetic sense."
}

Esse senso estético de que ele trata se refere à uma estética abstrata, que avalia a beleza de uma teoria, de uma equação, a partir de um conhecimento matemático, e ela começa muito longe na história. Voltemos por alguns instantes aos gregos, em suas investigações acerca da Physis. Quando a matemática pitagórica ("o mundo é número") se uniu aos poucos a outros conceitos como o Belo platônico ("o Belo é verdadeiro e bom"), a geometria euclidiana e a teoria sobre o universo aristotélico-ptolomaico, eles criaram uma visão cosmológica onde as órbitas dos corpos celestes em torno da Terra eram circulares, pois o círculo era considerado, dentre todas as formas, a mais esteticamente perfeita, conceito com o qual a arte também está de acordo quando trata da perfeição estética.

Esta visão de mundo era tão perfeita, tão bela, que dominou o modelo astronômico por quase dois mil anos, até que o heliocentrismo Copernicano, embora ainda propondo trajetórias 
homocêntricas dos planetas, derrubou o mito do geocentrismo e abriu caminho para as ideias de Johannes Kepler e Isaac Newton que romperam de vez com o modelo cosmológico aristotélico-ptolomaico de órbitas circulares. A nova ordem proposta por esses astrônomos também seguia uma visão estética de formas harmônicas, porém não mais dentro do círculo perfeito, mas com uso de elipses e parábolas, que são formas retiradas de projeções do círculo na cônica.

Galileu Galilei, entre suas inumeráveis contribuições ao nascimento da ciência clássica moderna, tem como uma de suas principais características a utilização e união de dados empírico-observacionais com argumentos lógico-matemáticos. De certa forma, podemos dizer que Galileu complementa na cinemática dos movimentos terrestres aquilo que Kepler havia conseguido na descrição do sistema planetário, ou cinemática dos corpos celestes. Ambos partem de pressupostos platônicos, que os levam à utilização das cônicas - elipses em Kepler e parábolas em Galileu - após terem confrontado seus pressupostos a priori com os dados observacionais (levantados pelo próprio Galileu e, no caso de Kepler, por Tycho Brahe). Isaac Newton unificou as até então separadas "Física Celeste" (assim exemplificada pela cinemática celeste de Kepler), com a "Física Terrestre" (tal como descrita pelos estudos galileanos sobre a queda dos corpos e o movimento dos projéteis). Ambas as sínteses são geometrizadas através de trajetórias cônicas (elipses keplerianas e parábolas galileanas) e formam a base sobre a qual Newton vai edificar suas sínteses.

A busca por uma Teoria de Unificação Geral na Física Moderna contém essas mesmas características e até hoje, tenta-se encontrar uma Grande Teoria a ser expressa por equações de beleza ímpar. Essa beleza abstrata que se encontra nessa harmonia do funcionamento do universo corresponde perfeitamente ao sentimento da beleza abstrata clássica da representação harmonicamente proporcional dos corpos humanos na arte.

Com a multiplicação de pesquisas e análises mais recentes, tanto historiográficas como epistemológicas, considera-se que o problema é mais complexo e o processo de criação envolve múltiplos aspectos. Este é o ponto de vista central adotado nesse trabalho: como a estética se tornou um meio através do qual se conduziram pesquisas científicas na área da Física Moderna - desde o início do século XX até hoje, divulgada por cientistas como o físico Murray Gell-Mann.

Ao lidar conceitos estéticos abstratos, diferentes do que estamos habituados a lidar na arte, podemos formular repostas para questões como, por exemplo, qual a beleza existente na equação $E=M . C^{2}$ e como descrever o que a faz bela. Ou quais critérios são empregados para julgar a beleza de uma teoria ou de uma equação e o que esses critérios têm ou não em comum com o que estamos acostumados a lidar no nosso cotidiano.

Nem tudo que é belo é arte, nem tudo que é arte é belo, mas de que maneiras o Belo se transformou ao longo dos tempos e como podemos enxergar sua presença em manifestações aparentemente díspares como uma obra de arte e uma equação matemática? Esses conceitos de beleza, independente de dialogarem ou não entre si, vão constituir um instrumental na criação e desenvolvimento de projetos em ambos os saberes.

Conceitos teóricos e formais

Na Estética, identificamos como principais os seguintes elementos definidores da Beleza:

Proporção - comparação dos objetos em si e na obra como um todo, através de uma razão entre os elementos que compõe o objeto, noção de perspectiva e/ou de ambientação da imagem.

Ordem - hierarquia dos elementos.

Coerência - relação entre os elementos, entre significantes e significados, ideia e representação. 
Simetrias - disposição dos elementos segundo conceitos de simetria.

Verdade - relação entre o que está representado e sua contraparte no mundo real e no mundo ideal, bem como a correspondência com valões éticos.

Contrastes - elementos que se destacam ou se anulam pelo contraste de cores, ideias, estilos, proporção.

Equilíbrio - disposição balanceada dos elementos formais da obra.

Utilidade / Finalidade - motivo pelo qual a obra é feita. Valoração da obra segundo sua utilidade para um fim social, político, econômico.

Elegância - harmonia entre todos os elementos que formam o conjunto pistórico: forma, disposição, coerência, ordem etc.

Gosto - conformidade com uma estética pessoal ou definida por agentes culturais.

Na Física, identificamos os seguintes conceitos aplicados como critério de escolha e validação de teorias através da Beleza:

- Sentido de unificação - capacidade de colocar sob as mesmas condições matemáticas diferentes fenômenos físicos. Expressão máxima da Beleza.

- Simplicidade - qualidade de ser facilmente entendida ou explicada, de possuir clareza, visibilidade. O contrário de complicado e não de complexo.

- Coerência - consistência lógica da teoria como um todo. Estar em conformidade com os experimentos ou provas.

- Simetria - apacidade de alteração da ordem dos elementos em uma equação ou teoria sem que o resultado final sofra modificação.

- Elegância - refino. Combinação do maior número de elementos possíveis em uma dada teoria ou equação para obter o máximo do conceito de beleza.

- Dualidade - equivalência de teorias ou modelos que aparentemente são muito distintos.

- Universalidade - fator que minimiza ao máximo o número de parâmetros de uma teoria. Propõe uma mesma intensidade de interação entre partículas de um sistema.

- Concisão - permite a expressão de teoremas e equações com notações mais simplificadas.

A Beleza em relação às formas de pensar e compreender o mundo

Como se dá a apropriação da Beleza como ferramenta pelos cientistas além de ferramenta de criação? E em que casos a Estética também pode ser empregada como instrumento de validação? Ou como método para certas escolhas?

Poderia a estética assumir uma nova forma de se estudar a geração de conhecimentos, um novo campo de estudos na epistemologia, uma espécie de "epistemologia estética"?

De uma derivação direta de ideias do Empirismo clássico, o contexto de descoberta - que determina o que é inventado ou descoberto e de que forma isso se deu - e o conceito de justificação - que vai determinar como uma teoria vai demonstrar a sua "cientificidade" -, propostos por Reichenbach, vão ser avaliados por Karl Popper. Em oposição aberta ao verificacionismo, ele sugere um novo critério de demarcação científica baseado no conceito de falseabilidade: proposições não precisariam ser verdadeiras, mas teriam que poder ser falseadas. Esta capacidade de uma teoria de ser testada ou refutada é o critério que demarcaria uma proposição como científica. E até que fosse falseada, toda teoria científica seria considerada uma hipótese válida. Com isso, Popper abre novos caminhos para o contexto de criação/descoberta, visto que não é relevante a forma como uma teoria surge, 
mas sim a possibilidade de ser falseada. Ele propõe em sua obra (autor, 1972) que se façam "ousadas conjecturas" a serem confrontadas por "rígidas refutações".

É interessante observar o quanto a Estética ganha espaço de atuação nesse momento em que se rompe com ideias engessadas acerca do processo de criação, por tanto tempo considerado fruto da observação e da indução. E não apenas no contexto de criação, mas também a mudança da validação das proposições científicas, com o conceito de falseamento, vai permitir que novas formas de criação se tornem justificáveis, estimulando uma proliferação de teorias. A Física Moderna provê Popper de inúmeros exemplos de teorias criadas a partir de especulações e experimentos mentais, que passaram pelo teste de falseamento em momentos e situações completamente diferentes de sua criação, muitas vezes décadas depois de propostas ou por cientistas interessados em desprová-las.

\section{Conclusão}

Estudar esta relação entre elementos, sua relevância e os critérios com que são aplicados é fundamental não apenas para entendermos melhor esse processo de criação dentro da cultura científica que, baseados em considerações de ordem estética, recuperou seu valor e consolidou sua presença entre os Físicos Modernos.

O físico Paul Dirac tinha como método para criação de suas teorias o conceito da beleza matemática: um método que, na sua opinião, ainda não era completamente bem sucedido, mas que se tornaria uma ferramenta poderosa para as campos da matemática e da física na busca pelas teorias da unificação. Para ele (1939), "the method is to begin by choosing that branch of mathematics which one thinks will form the basis of the new theory. One should be influenced very much in this choice by considerations of mathematical beauty." Ou seja, para ele a beleza da matemática deveria ser o próprio método.

Faz-se necessário o aprofundamento desse estudo que poderá ser útil no auxílio à pavimentação de um novo caminho para a epistemologia no século XXI, no que tange à compreensão clara dos instrumentos que são empregados pela Estética na Física para a formação do conhecimento

\section{Bibliografia}

BAYER, Raymond. História da Estética. Lisboa: Editorial Estampa, 1979.

ENGLER, Gideon. Einstein and the most beautiful theories in physics. In: International Studies in the Philosophy of science, v.16, n.1, p.27-37. New York: Routledge, 2002. **

GOMBRICH, Ernst H. The story of art. London: Phaidon, 1995. HADAMARD, Jacques. Psicologia da invenção na matemática. Rio de Janeiro: Contraponto,

HOLTON, Gerald. A imaginação científica. Rio de Janeiro: Zahar, 1978.

HOLTON, Gerald; BRUSH, Stephen. Thematic elements and styles in science. In: Physics, the human adventure: from Copernicus to Einstein and beyond. Cap. 33, pp. 517-530. New Brunswick: Rutgers University Press, 2001.

KOESTLER, Arthur. The act of creation. London: Hutchinson, 1964.

LACOSTE, Jean. A filosofia da arte. Rio de Janeiro: Zahar, 1986.

LÀKATOS, Imre. O falseamento e a metodologia dos programas de pesquisa científica. In: \& MUSGRAVE, Alan. A crítica e o desenvolvimento do conhecimento. p.109-243. São Paulo: Editora Cultrix, 1979. LOEB, Arthur L. Structures and patterns in science and art. In: Leonardo, v.4, n.4, p.339-346. Cambridge: Pergamon Press, 1971. 
MCALISTER, James W. Beauty and revolution in science. Ihtaca: Cornell University Press, 1996. Dirac and the aesthetic evaluation of theories. In: Methodology and Science, n.23, p.87-102, 1990.

MOURÃO, Ronaldo Rogério de Freitas. Kepler: A descoberta das Leis do Movimento Planetário. São Paulo: Odysseus Editora, 2008.

OSTROWER, Fayga. Criatividade e processos de criação. Rio de Janeiro: Ed. Vozes, 1977.

POPPER, Karl R. Conjecturas e refutações. DF: Ed. UNB, 1972.

A lógica da pesquisa científica. São Paulo: Editora Cultrix, 1972b.

STEWART, Ian. Uma história da simetria na matemática. Rio de Janeiro: Zahar, 2012.

WÖLFFLIN, Heinrich. Conceitos fundamentais da história da arte. São Paulo: Ed. Martins Fontes, 1996.

ZEKI, Semir; ROMAYA, John Paul; BENINCASA, Dionigi M. T.; ATIYAH, Michael F. The experience of the mathematical beauty and it's neural correlates. In: Frontiers in Human Neuroscience, v.8, art.68, p.1-12. Lausanne: EPFL, 2014.

COOPER, David. A Companion to aesthetics. Blackwell Companions to Philosophy. Oxford: Blackwell Publishers, 1995.

DANCY, Johathan; SOSA, Ernest. A (eds). A Companion to epistemology. Blackwell Companions to Philosophy. Oxford: Blackwell Publishers, 1992.

DICIONÁRIO DE BIOGRAFIAS CIENTÍFICAS (DSB). Charles C. Gillispie (ed.). Rio de Janeiro: Editora Contraponto, 2007.

NEWTON-SMITH, W.H. A Companion to the philosophy of science. Blackwell Companions to Philosophy. Oxford: Blackwell Publishers, 2000.

OCVIRK, Otto G.; STINGSON, Robert E. et al. Fundamentos de arte - teoria e prática. Porto Alegre: McGraw Hill Education/Bookman, 2014

OSTROWER, Fayga [sobre intuição, criação e beleza] Depoimento não incluído no filme documentário Janela da Alma, de JARDIM, João; CARVALHO, Walter, 2001. Disponível em:

https://www.youtube.com/watch?v=M4p0ORnWI2E. Acesso em: 8 de junho de 2015. 


\title{
RASTREANDO A PRODUÇÃO DE CASOS CLÍNICOS: UM ESTUDO ETNOGRÁFICO DE UMA DIVISÃO DE PSICOLOGIA APLICADA
}

\author{
Arthur Arruda Leal Ferreira - Professor Adjunto do Instituto de Psicologia da UFRJ arleal@superig.com.br \\ Rafael de Souza Lima -Me strado de Psicologia na UFRJ - rdsl.1989@gmail.com \\ Davida Lima Brita - Graduando de Psicologia na UFRJ bolsista Faperj davidlimab15@gmail.com \\ Thaíssa Rosa Alves Almada - Graduanda de Psicologia na UFRJ - tatarosaaa@yahoo.com.br \\ Isabella Gomes Freire - Graduanda de Psicologia na UFRJ - isabellagomesfreire@gmail.com \\ Paulo Henrique Mendas da Cunha - Graduando de Psicologia na UFRJ \\ paulomea29@gmail.com \\ Karina da Silva Vieira - Graduando de Psicologia na UFRJ - karinadsvieira@gmail.com \\ Pedro Luís Sydenstricker Alvares - Graduando de Psicologia na UFRJ - pedrosydenstricker@gmail.com
}

Resumo

Este trabalho visa trazer à cena os diferentes modos em que se deram singulares relações de trabalho etnográfico numa pesquisa que busca observar as diferentes formas de produção de subjetividades engendradas pelas práticas psicológicas clínicas, propostas na Divisão de Psicologia Aplicada (DPA) da Universidade Federal do Rio de Janeiro (UFRJ), tendo como base conceitual a Epistemologia Política de Isabelle Stengers e Vinciane Despret e a Teoria AtorRede de Bruno Latour e John Law. Para estes autores, o conhecimento científico se produz não como representação da realidade, mas como modos de articulação entre pesquisadores e entes pesquisados, portanto, importa aqui discutir como os pesquisadores se articulam com o campo investigado, e os resultados decorrentes disso.

Palavras-chave: Etnografia. Teoria Ator-Rede. Divisão de Psicologia Aplicada.

\section{Introdução}

Como tentativa de abarcar diversas questões relacionadas à produção de um campo clínico psi, desenvolvemos uma pesquisa que busca observar as diferentes formas de produção de subjetividades engendradas por práticas psicológicas clínicas, analisando-as em determinadas redes produzidas por diferentes orientações terapêuticas na Divisão de Psicologia Aplicada (DPA) da Universidade Federal do Rio de Janeiro (UFRJ). Tendo como referencial teórico a Teoria Ator-Rede de Bruno Latour e John Law, e a Epistemologia Política de Isabelle Stengers e Vinciane Despret, nossa pesquisa concebe o conhecimento científico como sendo produzido por uma articulação entre pesquisadores, técnicas de inscrição, aliados e entidades investigadas e como sendo politicamente diferenciado entre más e boas articulações. Para ser mais específico:

[...] desejamos estudar como estas práticas clínicas são performadas, como elas se articulam entre si (ou não), que controvérsias surgem de seus modos de atuação e que mundos e modos de subjetivação são aí produzidos entre pacientes, estagiários, coordenadores, setting clínicos e grades curriculares. (FERREIRA et al., 2013, p. 373)

Tal acompanhamento seguiria alguns parâmetros da Teoria Ator-Rede e da Epistemologia Política:

Os participantes da pesquisa serão tomados como experts no tema, sem qualquer divisão entre saber comum e científico; 
Enquanto experts, serão demandadas definições sobre a psicologia, sobre os psicólogos, mas igualmente sobre o que os conduz ao serviço, as expectativas e leituras que fazem da sua demanda.

Para investigar os modos de articulação produzidos por práticas psicológicas, são observadas na DPA algumas redes produzidas por diferentes abordagens psicoterápicas:

- Psicanálise,

- Psicanálise Existencial,

- Terapia Cognitiva-Comportamental,

- Gestalt-Terapia,

- Análise Institucional Francesa.

Além da realização de entrevistas com supervisores, estagiários e pacientes, estão sendo acompanhadas pela pesquisa, através do método etnográfico, as supervisões de cinco equipes - cada uma correspondendo a uma abordagem já citada. Neste acompanhamento, busca-se entender de que maneiras nestas diferentes redes são produzidos pacientes, supervisores, estagiários e sobretudo pesquisadores, já que os mesmos também são afetados na medida em que se articulam a esses mundos singulares investigados. Desse modo, pretende-se estudar os modos como esses acompanhamentos de supervisões são realizados pelos pesquisadores e as ressonâncias produzidas nos mesmos, sabendo que neste trabalho de campo eles não apenas interferem nas dinâmicas que observam (e das quais participam), como também são interferidos por elas.

Dedicamo-nos ao estudo do acompanhamento das supervisões de duas das cinco equipes já mencionadas, para a apresentação do presente trabalho. Aqui, optamos por identificar os pesquisadores nos seus respectivos acompanhamentos, Rafael na equipe de Psicanálise, e David na de Gestalt-terapia. Nosso interesse se volta para os modos de articulação dos pesquisadores com as equipes investigadas, e para as consequências disso no fazer etnográfico, já que o conhecimento é uma construção que decorre da articulação do pesquisador com os entes pesquisados.

Antes de abordarmos esses acompanhamentos, vale esclarecer sucintamente o que é uma supervisão: trata-se de uma reunião que envolve estagiários e supervisor de estágio, para a discussão principalmente de atendimentos psicoterápicos realizados individualmente pelos estagiários, que são estudantes do curso de psicologia da UFRJ. O supervisor é um psicólogo que pode ou não ser professor do mesmo curso. Outras questões podem ser discutidas nas supervisões, como as referentes à realização de triagens ou ao funcionamento da instituição em geral.

Rafael começou a acompanhar a equipe de Psicanálise no início do primeiro semestre letivo de 2015. É importante constar que o pesquisador já fez parte desta equipe como estagiário, durante o ano de 2013, sendo que ainda havia ali pessoas que estagiaram com ele na ocasião, e que permaneceram no estágio. Com isso sua inserção no campo investigado foi facilitada, ou melhor, ele não habitava um local desconhecido, sentia-se a vontade em permanecer em um lugar "familiar". Levado isso em conta, o pesquisador deparou-se com o desafio de produzir uma descrição etnográfica que implicasse um certo grau de estranhamento daquilo que ele já conhecia da equipe e da clínica psicanalítica.

A supervisão de Psicanálise acontece numa sala pequena com uma mesa grande, e os participantes se posicionam ao redor dela. O supervisor sempre senta no mesmo lugar, deixando um lugar à sua direita para o estagiário que no momento estiver realizando a leitura do seu relato de atendimento. Para a discussão dos são produzidos relatos de cada atendimento realizado, em forma de transcrição. Os relatos são lidos e após a leitura ocorre 
a discussão do atendimento. O acompanhamento de Rafael foi marcado por dois momentos, que são caracterizados por modos distintos de articulação com o campo investigado. No momento inicial, nas primeiras supervisões acompanhadas, Rafael se sentava sempre na mesma cadeira, que ficava distante da mesa. Ele não participava da supervisão como todos os outros presentes, discutindo os "casos"; se dedicava a observação daquela dinâmica e a escrita do diário de campo. Mas a equipe não era indiferente ao seu posicionamento, ele era perguntado sobre o que estava escrevendo, e eram constantes as brincadeiras, tendo recebido o apelido de espião. Comentários do tipo: "é, ele só fica aí anotando!", "ele fica anotando as besteiras que a gente fala aqui!" eram comuns, estando sempre presentes nos mesmos o humor. Isso mudou quando ele foi convidado gentilmente pelo supervisor: "você não prefere se sentar aqui na mesa com a gente?". Aceitou o convite, e teve seu trabalho modificado com esse deslocamento, que marca o segundo momento do seu trabalho, onde foi privilegiado a sua participação na dinâmica da supervisão. Quando já se encontrava na mesa, junto aos outros, passou a interagir mais dentro do que eles se propunham: participava da discussão dos casos, fazia intervenções, perguntava. Sentiu, com isso, uma modificação no seu modo de estar ali e de participar da supervisão, deixou de ser um observador distanciado para ser um participante menos distinto dos estagiários, pelo menos no momento da supervisão. Ele passou a estabelecer maior contato visual com os outros, de modo a incluirse na conversa, levando-se em conta a contrapartida, ou seja, o fato dos participantes terem incluído ele, dirigindo seus olhares também para ele quando falavam.

David, por sua vez, começou a acompanhar a supervisão da equipe de Gestaltterapia no início de 2016. Tendo em vista que não conhecia a maioria das pessoas que faziam parte da equipe, havendo apenas uma estagiária com quem possuía algum vínculo de amizade, ele não encontrou tanta facilidade como Rafael para se situar ali. Sua entrada se deu em um mundo desconhecido. Desconhecido por vias da equipe, pela abordagem que era trabalhada, já que David não tivera nenhum contato com Gestaltterapia antes, e por ser o primeiro trabalho etnográfico feito pelo mesmo. Então suas primeiras descrições giraram em torno desse novo mundo no qual entrava, descrevendo os desafios e dificuldades de se portar como pesquisador em relação com esse campo.

Esse acompanhamento foi marcado também por dois momentos, na relação com o campo. Nos primeiros encontros, David se ateve com diversas preocupações em relação a sua posição e atuação naquele espaço e naquela dinâmica. Mantinha o seu corpo ereto, estava sempre voltado para o seu pequeno caderno de campo, se preocupando e se mantendo atento a tudo que se dizia. Optava por se manter quieto, e o ato de anotar o deixava muito receoso por ser visto fazendo-o. Sua postura dura e nervosa e sua posição distanciada em relação a dinâmica produziu uma certa relação com a equipe nesse primeiro momento. Isso aparecia pela equipe em jogos de olhares que não o incluíam, e também em um fala que não o incluía, tendo em vista que ele era o único homem presente e sempre utilizavam coletivos no feminino. Diante da percepção desta não inclusão na fala e nos olhares, aceitou o risco da adoção de uma outra postura, um outro modo de se estar naquele campo. Descentrou-se do caderno de campo, ao qual tanto se prendia, relaxou sua postura na cadeira e se permitiu participar de algumas conversas, principalmente as das discussões sobre as situações contemporâneas, as quais são sempre presentes. Essa nova postura que se arriscou a adotar se fez produzir uma nova relação com o campo, no qual a equipe o incluía e dava espaço tanto nos olhares quanto nas falas, ditando assim um segundo momento nesse acompanhamento.

Em decorrência dessas mudanças de participação nas supervisões, os dois pesquisadores passaram a produzir descrições diferentes das iniciais. Rafael, antes, se ocupava com a descrição do que ocorria na supervisão, das falas ali presentes, das atitudes dos estagiários e supervisor diante dos "casos". Depois, sua narrativa passou a incluí-lo, pois importava dizer o 
que ele também fazia ali, de que modo se comunicava com os outros, intervinha... já não falava apenas o que via, mas o que sentia, o que fazia, dentro daquela dinâmica. E David abandonou o seu desconforto e apresentou descrições referentes ao modo como aqueles encontros, na supervisão acompanhada, modificaram a sua relação com o próprio corpo.

\section{Referências bibliográficas}

CAIAFA, J. Aventuras das cidades. Rio de Janeiro: Editora FGV. 2007

DESPRET, V. A leitura etnopsicológica do segredo. Revista Fractal de Psicologia, Niterói, v. 3, n. 1, p. 5-28, jan./abr. 2011. Dossie Despret.

FERREIRA, A. A. L. et al. A produção de subjetividades em rede: seguindo as pistas de uma divisão de psicologia aplicada. Universitas Humanística, Bogotá, v. 76, p. 371- 392, jul./dez. 2013.

LATOUR, B. Como terminar uma tese de sociologia: pequeno diálogo entre um aluno e se professor (um tanto socrático). Cadernos de Campo, São Paulo, v. 14/15, p. 339- 352, 2006.

LATOUR, B. How to talk about the body. Body \& Society, London, v. 10, n. 2-3, p. 205-229, 2004.

LAW, John. After method: mess in social science research. Londres: Routledge, 2004.

STENGERS, I. Quem tem medo da ciência?. São Paulo: Siciliano, 1989. 


\section{CHUANG TZU E O PENSAMENTO DA PLENITUDE}

André Lira - IFTO/UFRJ - andreobranco@ufrj.br

Resumo

Neste trabalho, será interpretado o pensamento de Chuang Tzu com ênfase nas questões da felicidade e da liberdade, em dois de seus textos: "A grande sabedoria" e "Vida ativa". A obra de Chuang Tzu, fora a distância cronológica de mais de vinte séculos, apresenta bastantes dificuldades para o leitor ocidental por integrar a tradição oriental de pensamento. Trabalharse-á com versões de Thomas Merton. Será estabelecido um confronto entre a visão poética de Chuang Tzu, que remete a uma desfuncionalização da vida e do ser humano, e a percepção corrente na sociedade globalizada, que gira em torno da utilidade e funcionalidade, ponto máximo da tradição metafísica do Ocidente.

Palavras-chave: Chuang Tzu. Hermenêutica. Poética. Tecnologia.

O que Chuang Tzu nos diz a respeito da felicidade e da liberdade? Em "A Grande Sabedoria"(ano), provoca:

A grande sabedoria vê tudo num só.

A pequena sabedoria multiplica-se entre as muitas partes.

(...)

O prazer e a raiva

A tristeza e a alegria

Esperança e perdão

Fraqueza e firmeza

Impaciência e preguiça:

Todos são sons da mesma flauta,

Todos são cogumelos do mesmo úmido mofo.

Dia e noite seguem-se uns aos outros e vêm

Até nós, sem vermos como eles brotam! (MERTON: 1984, pp. 54-56)

O ser pequeno e o ser grande indicam vários modos do mesmo ser. Dessa forma sempre incluem o mistério por que o pensador pode se interrogar. A sabedoria, portanto, é a mesma. Suas duas qualificações ("grande e pequena") não lhe acrescentam nada, como adjetivos, apenas di-mensionam uma perspectiva de movimento: A grande se torna pequena e a pequena se torna grande. Elas necessitam uma da outra para se constituírem como sabedoria: da mesma forma, o tudo reúne a singularidade de cada parte num todo. O tudo é a parte que é todas. Vendo tudo num só, cada parte pode participar do todo, se multiplicando em muitas. A sabedoria é pequena por se multiplicar entre partes, não por ser inferior. Ela apenas situa o ponto da parte. Como a sabedoria não é só pequena, mas também é paradoxalmente grande, ela habita entre as partes, isto é, na distância misteriosa entre as partes que as aproxima na união do todo. Cada parte só pode ser parte se aquilo que as separa também for o mesmo que as une. O que separa também recolhe: sabedoria.

A conjunção " $\mathrm{e}$ " une duas coisas discretas conceitual e graficamente, como prazer e raiva, tristeza e alegria. Entretanto, essa concepção já pressupõe que são duas coisas distintas e excludentes que podem ser tomadas juntamente pela conjunção que apontamos. A partir da interpretação da sabedoria, o " $\mathrm{e}$ " torna-se o vazio entre as muitas partes, a pequena sabedoria que permite à grande ser grande, ou ver tudo num só: é o que o som não diz que 
configura as músicas, é também todas as músicas ainda por vir, reunidas no silêncio da flauta. Cada momento musical é singular pelo "e" que se multiplica entre os sons e as músicas. Na escuta, na busca, se dá a sabedoria tanto em sua grandeza quanto em sua pequeneza. Não precisa haver diferentes flautas para haver diferentes sons. O músico é sábio, pois faz com a mesma flauta diferentes sons, que na realidade são os mesmos, compondo diferentes músicas. Que também são a mesma, uma e sempre a mesma música que uma flauta tocará. E todo cogumelo, por mais que seja entendido como à parte do outro ou dos outros, se origina de um mesmo mofo. $O$ úmido nos remete à água, que dá as condições tanto do mofo, quanto dos cogumelos. O úmido do mofo dá vida aos cogumelos. A fluidez e o incerto movimento da água, o silêncio da flauta e o entre das partes são também o mesmo se doando de diferentes formas.

O mesmo compartilhar de um princípio vemos na articulação de dia e noite. De acordo com nossa interpretação, também dia e noite seriam partes conjugadas num todo. Esse todo, em noite e dia, se dá não pela sucessão das partes, ou a maneira como cada um segue ao outro, cronologicamente. Percebe-se que noite e dia se manifestam ao homem, vêm até nós. Contudo, pensemos no verbo "vir", um verbo de movimento que em si conjuga o trecho com que dialogamos. Tendemos a tomar a manifestação da claridade do dia e da obscuridade da noite como sucessividade, como alteridade excludente. Quando nos interrogamos de onde vêm noite e dia, ou pelo seu originário em comum, um deixa de ser tomado em função do outro, mas apenas em si mesmo e no lugar singular como um-no-todo. Cada dia e cada noite passam a ser únicos. Há esse princípio, esse lugar de onde brotam e se dão à visão do homem. É o originário in-visível que não vem, que sempre escapa ao homem, mas está sempre presente (ainda que na ausência) nas suas partes, doações de dia e noite. Se cada dia é um novo dia, ainda que brote do mesmo lugar misterioso, o inesperado e o inexplicável podem também fazer brotar o extraordinário no panorama humano.

O exercício de se desnudar, de questionar os limites de doutrinas, recompensas e percepções é doloroso. Esse exercício, porém, não se origina de uma decisão consciente do sujeito. É por isso que, se Chuang Tzu aponta para esse sentido poético de ser, ele precisa também levantar a questão do método. Se não se decide ser sereno e unido ao universo, como é que isso se alcança? Criticando a funcionalidade das classes e dos utilitarismos, Chuang Tzu diz, em "Vida Ativa"(ano):

\footnotetext{
Onde estaria o jardineiro se não houvesse mais erva daninha? O que seria dos negócios se não existisse o mercado dos tolos? Onde estariam as massas se não houvesse pretexto para aglomeração e barulho? O que seria do trabalho se não houvesse objetos supérfluos a fabricar? Produza! Obtenha resultados! Faça fortuna! Faça amigos! Faça inovações! Ou morrerá de desespero!(autor, ano)
}

Os que se aprisionam na maquinaria do poder não se alegram, a não ser na atividade e na modificação - o estridar das máquinas! Quando uma ocasião para agir se apresenta, são impelidos à ação; não se podem ajudar mutuamente. São movidos inexoravelmente, como a máquina de que constituem uma peça. Prisioneiros no mundo dos objetos, não têm escolha, a não ser se submeterem às exigências da matéria! São pressionados e esmagados por forças externas, pela moda, pelo mercado, pelos acontecimentos, pela opinião pública. Nunca, em toda a sua vida, recuperam o bom-senso! A vida ativa! Que lástima! (MERTON: 1984, p. 179180)

O jardineiro cuida do jardim. Nesse cuidado, a erva daninha, a erva estrangeira a um determinado jardim, é evitada e combatida. Dessa forma, o jardim rende e produz mais, ou se torna ele mesmo um produto que possa ser mais bem valorizado pelo mercado de negócios. Dentro dessa articulação hierárquica, Chuang Tzu questiona: por que ficamos com 
a impressão de se perder o sentido de um jardineiro se um jardim não possuir uma erva daninha? Exatamente porque a ação de cuidar do jardim se deixou possuir pela atividade, pelo controle do jardim e de sua singularidade (incongruências que se tentam controlar). Em outras palavras, não lemos "jardineiro" como o homem que habita o jardim ou dele cuida, mas como aquele que trabalha ou tem por emprego a função de, por critérios estéticos e/ou mercadológicos socialmente estabelecidos, tratar objetivamente de um jardim. A imagemquestão da erva daninha, então, torna-se importante, porque é ao mesmo tempo o que impede a atividade de se consumar totalmente (a adequação dos jardins), mas o que também incita e motiva a jardinagem.

Esse co-pertencimento vemos também na linha seguinte: onde repousa a essência, isto é, a utilidade que motiva a existência dos negócios, senão no mercado de tolos e tolices? A fragilidade das construções sócio-econômicas leva Chuang Tzu a apontar que o sentido de nossa existência não se situa nesse plano, não se reduz a ele nem é por ele determinado. Os negócios precisam assegurar o mercado dos tolos e a tolice do mercado. Os negociantes precisam revolver em torno de seus produtos e de suas técnicas, na objetivização de coisas a serem consumidas por quem verdadeiramente nunca quis ou precisou. Isso porque os produtos se negociam, mas nunca uma própria coisa, ou antes, o seu sentido. Não se negocia a coisidade da coisa. Fora do mercado dos tolos, só há o inegociável para se negociar, o nada para ser dado, e o homem pode pensar e viver livremente. Se dermos valor aos produtos e aos negócios, obviamente daremos menos valor a tudo aquilo que não se situa nessa escala. É uma escolha. O que não existe como produto e como negócio? O homem pode ser negociável? Perguntas difíceis. Ora, supor o homem inteiramente negociável soa absurdo. Tudo seria claro e manifestado para que o homem com ele possa operar e nesse mundo finalmente se situar. Essa impossibilidade está dada, entre outros, pelo simples dado de que o homem, tolo que seja, se insatisfaz com seus produtos consumidos, indican do que há algo mais radical e urgente a que não se está respondendo: seu sentido. A necessidade de negociar, de valorar e de possuir riqueza material vai perdendo o sentido, porque se vê nesses caminhos um sentido que não é o essencial. Dá-se falta do sentido dos sentidos. Da mesma forma, são criticadas as massas e o trabalho. O falatório da vida alheia, cheio de juízos calcados nos preconceitos e nos medos de cada homem, afasta o coletivo do pensamento e da percepção da insuficiência desses sistemas que criaram para si mesmos. $O$ trabalho perde a simplicidade da co-laboração com os outros homens. A necessidade dos produtos reduz o trabalho à produção e exploração. Essa produção parte da objetivação do mundo e insere critérios externos e universais para o fazer e o coabitar no mundo de cada homem.

No segundo trecho citado, a obsessão pela produção se torna a voz que fala, em vez de ser o ponto de vista criticado. As exclamações chamam atenção para como tais ordens se introduzem nos homens e eles mesmos as repetem e agem em função delas. É, aliás, o que dá título ao conto: "Vida ativa"(ano). Que resultados são esses que devemos obter? Será que precisamos genuinamente deles, são um apelo nosso?

Todas essas perguntas estão articuladas nos imperativos do segundo trecho. Elas se focam na última e mais importante pergunta: morreremos de desespero ao não conseguir realizar as outras ordens? O que é o morrer? Inversamente, seria legítimo supor que plenifiquem a vida se cumpridas?

Vemos aí duas dimensões: a que diz que se morrerá de desespero, e a que diz que não se morrerá. O que ocorre é que a vida, quando tem por horizonte as obrigações e as metas, se sufoca e se desespera. Diante da frustração de não alcançar esse horizonte, o desespero pode levar o homem a, espiralmente, se angustiar mais e mais. Dessa forma, vai morrendo para a vida; a busca da felicidade e da liberdade se torna confusa e sem sentido. O brilho de cada dia e de cada noite é deslocado para as supérfluas liberações momentâneas dessa angústia, e 
mais uma vez não se percebe como brotam dia e noite. Por outro lado, pode-se deixar de esperar, se des-esperar, e ver como a montanha de compromissos no horizonte é pequena. Quando a urgência de tudo ver, cumprir e saber é ungida pelos óleos da paciência, a montanha de areia se desfaz, e a cada passo na caminhada o horizonte se faz e se refaz, e todo momento é novo e acontece. Nesse sentido, é preciso se des-esperar para aprender a esperar; é preciso morrer desesperando-se para aprender a viver esperando. Não mais esperar as coisas de antes, mas aprender consigo e com o mundo, com a calma do camponês que cultiva e colhe seu destino no lavrar. Os imperativos nesse trecho também têm lugar nesse renascimento: as produções, os amigos, as inovações. Entretanto, eles surgem mais como uma parte, uma dádiva graciosa do viver, do que algo que surge a partir de um desempenho social, como a diferença entre ser um jardineiro e cuidar do jardim.

A seguir, Chuang Tzu diz: "Os que se aprisionam na maquinaria do poder não se alegram, a não ser na atividade e na modificação - o estridar das máquinas"(autor, ano). Seria essa, de fato, a alegria do homem, condicionada ao "estridar as máquinas", dos objetos à sua volta? Como se diz logo depois, a alegria do homem é tanto identificada com as máquinas que ele mesmo se torna uma, ou parte de uma. Vira prisioneiro dos próprios objetos que concebeu e se assenhoreou, acabando por se tornar um. Essa prisão não concede felicidade e liberdade ao homem. Tudo nessa prisão é claridade: não há barras e nem para onde ir, apenas para frente e sempre adiante. Essa liberdade do sujeito não o liberta de ser um sujeito, ou não se permitir ver como parte de um todo, ou todo em partes. Aqui está se tratando do poder: não há nada maior do que ele mesmo. Não há lugar para os mundos míticos e sagrados: são transfigurados para o homem e intelectualizados, arquetipizados.

Trata-se de um caminho para tentar alcançar a felicidade e a liberdade pelas reduções ou pelas generalizações. Os dogmas religiosos erigem um guia de felicidade e liberdade que todos seus discípulos devem seguir, na tentativa de superar a morte na vida. Supõe-se que: a) haja um sistema que valha para qualquer homem; b) a morte não possa proporcionar liberdade e felicidade; c) vida e morte sejam dissociáveis (CASTRO, 2007). Tais assunções são as mesmas dos sistemas políticos, que de antemão determinam o que um homem possa ou deva fazer. O que a busca e acumulação do poder proporcionam é uma via distinta da "iluminação" religiosa: se antes a humanidade do homem era vista em suas falhas e se tentava abstrair delas numa vida superior, agora o espírito modificador e dominador é que sobressai, resvalando na vida material, na acumulação de riquezas. Ambos os pontos de vista partem de um primeiro, em comum: o homem está cindido, e jamais é visto como um. Para tal, deve cumprir uma série de exigências e tomar decisões que o conduzam, finalmente, a este termo de plenitude. Esse ponto de vista em comum vê a liberdade e a felicidade na distância e a fazem uma meta a ser atingida. A partir do momento em que a felicidade e a liberdade ficam confinados no escopo dos objetivos a serem cumpridos, os homens só se alegrarão "na atividade e na modificação - o estridar das máquinas!", porque só permitirão um tipo de alegria maquinal surgirem nas suas vidas, já que será sempre oriunda dos resultados, dos prazeres, dos objetos.

Como se pode querer ser feliz e livre sem que efetivamente se transformem em objetivos em cujo prol se deva trabalhar? Isso supõe que já não somos felizes, e que ainda precisamos fazer algo para ser. O caminho para ser feliz não se sabe. Contudo, o que Chuang Tzu indica é como os caminhos propugnados normalmente para tal não nos fazem felizes, apenas nos frustram mais. Por isso, "Vida ativa" (autor, ano) vai deixar surgir, no inaudito, o mistério de ser feliz. Então, poderíamos nós conceber que Chuang Tzu está nos falando de uma vida "não-ativa"? Não, se entendermos "não-ativo" como a contemplação destacada dos fenômenos do mundo. O sentido de não-ativo que persegue toda nossa interpretação é o de reconduzir o homem ao seu lugar, de cessar os juízos e atividades e permitir nesse silêncio plantar e colher 
sua libertação. Apresenta-se outra vez a questão do tamanho do homem, articulado entre uma grande e uma pequena sabedoria; do jardineiro que não quer transformar o jardim, mas ajudar a deixá-lo surgir. Esse deixar surgir é alimentar suas possibilidades, revelar o terreno de aquilo que já se destinava ser. Nesse agir que não-age, busca-se o princípio principiante, ou o mistério da vida que conjuga limite e não-limite. Assim, tanto jardim e homem se realizam. Sua singularidade caminha una ao Tao, ao misterioso paradoxo de que tudo se compõe. O Tao se perfaz reunindo tudo o que jaz distinto, e ilumina o espaço singular de cada distinção. É como se a grande e a pequena sabedoria fossem a mesma, pois do Tao, do mesmo-diferente (LAO TSE, 1977). Quando essa singularidade se destaca da sua união, se anulando ou afirmando sobre sua medida, a felicidade e a liberdade também se destacam e ficam distantes, como fantasmas de um outro tempo. É por isso que o vazio do Tao se dá como o lugar em que cada uma de suas manifestações se manifesta e permite manifestar, isto é, toda música sempre acontece no silêncio de uma flauta.

O não-agir, então, dá a todo agir seu sentido e movimento (CASTRO, 2006). Ele Ihes dá seu espaço-tempo e sua dimensão poética. Esse é aquele "bom-senso" de "Vida ativa" (autor, ano) que Chuang Tzu diz ficar oculto na vida maquinal do homem. O bom-senso sente bem o lugar próprio de cada fazer humano em seu percurso de realização. Como não situa a felicidade nos objetos e nos fatos, mas no acontecer poético de si a todo momento, o bom-senso não permite revolver em torno de informações e objetos. Com bom-senso, o poder pode pouco; os objetos não têm sujeitos e se radicam outra vez na unidade. É ao movimento da unidade a que o bom-senso presta atenção. Como pode haver unidade se todo homem não é tido como irmão, pela diferenciação do poder? Um irmão não é igual a outro, é mais sempre um do mesmo, da mesma mãe, do mesmo universo, do mesmo solo. O todo sempre nos lembra da simplicidade e necessidade do movimento no gesto de um abraço fraterno. $\mathrm{O}$ abraço genuíno sempre abraça o familiar, mas ao mesmo tempo o não-abraçado. $\mathrm{O}$ abraço abraça para soltar. Sempre e nunca juntos: é o que diz um abraço. A verdade das verdades está na sola do sapato dos homens do saber a pular para alcançar suas idéias. O solo amassado, embaixo, se deforma e reforma cuidadosamente e sempre de novo, humilde e sem preocupações. A perfeita harmonia.

Referências bibliográficas

CASTRO, M. A. de. A ação e a caminhada de vida. Internet. 2006. Disponível em:

http://travessiapoetica.blogspot.com.br/2006/08/ao-e-caminhada-de-vida.html. Acesso 05 out. 2017.

CASTRO, M. A. de. A leitura e os paradigmas. Internet. 2007. Disponível em:

http://travessiapoetica.blogspot.com/2007/08/leitura-e-os-paradigmas-prof_15.html. Acesso 05 out. 2017.

HEIDEGGER, Martin. A caminho da linguagem. 2ae ed. Petrópolis: Vozes, 2004.

LAO TSE. Tao Te King. Lisboa: Editorial Estampa, 1977.

MERTON, Thomas. A via de Chuang Tzu. Petrópolis: Vozes, 1984. 


\title{
CULTURA E OPULÊNCIA: RELEITURA E ILUSTRAÇÃO
}

\section{Resumo}

Pretende-se representar graficamente cenas contextualizadas e decupadas do livro "Cultura e Opulência do Brazil por suas drogas e minas" de André João Antonil, 1711. O livro não contém nenhuma ilustração e foi redigido no século XVIII, em uma literatura que é rica em descrições da cultura material. Serão utilizadas técnicas de ilustrações para compor as cenas decupadas, tornando a compreensão do livro mais acessível do ciclo da cana de açúcar no litoral brasileiro.

Palavras chave: Ilustração. Linguagem. Memória Histórica.

1. Introdução (Objeto, técnica, justificativa e relevância social):

\begin{abstract}
"Entre os textos produzidos por Andreoni, constam cartas entre outros escritos como a tradução da Synagoga Desenganada e o panegírico do Arcebispo da Bahia. Em 1711, foi publicada em Lisboa uma obra de sua autoria intitulada Cultura e Opulência do Brasil por suas drogas e minas. Na ocasião, o padre Andreoni utilizou o pseudônimo, André João Antonil" (CANABRAVA, 1967:9-112).
\end{abstract}

Cultura e Opulência no Brasil por suas drogas e minas, livro escrito por André João Antonil (nome adotado quando veio morar no Brasil, seu nome verdadeiro é Giovanni Antônio) é considerado uma das melhores narrativas a respeito da produção açucareira e o fabrico do açúcar no Brasil em meados do séc. XVII/XVIII (Referência). O livro relata detalhadamente a forma do cultivo da cana, a estrutura do engenho e a fabricação do açúcar. O autor baseouse nos engenhos que aconteciam na Bahia, em pleno final do séc. XVII e início do séc. XVIII, cheio de grandes méritos pela abundância, riqueza e sinceridade dos informes. $\mathrm{O}$ autor teve sua publicação inacessível, aureolado pela perseguição colonial, aonde chegou a ser confiscado por ordem do Senhor Rei D. João V. Vale salientar que o autor também relata sobre outras técnicas de produção, como tabaco, mineração e criação de gados.

\footnotetext{
"A escrita de Antonil se assemelha ao de um manual do homem do século XVIII, pois descreve além de todo o processo do cultivo do açúcar, aconselha o leitor como escolher o terreno mais apropriado para uma fazenda e como administrá-la, como deve ser a relação com a família e seus subordinados e a função de cada um naquele contexto" (SANTOS, 2014).
}

Deste modo, este projeto tem como proposta uma representação ilustrativa dos relatos, cenas contextualizadas e memórias da forma como ocorria a produção e fabricação do açúcar, dos engenhos, senhores de terra e escravidão no Brasil no século XVII/XVIII, como cada qual influenciava um ao outro.

Nos dias atuais, editoras estão adaptando grandes obras literárias em forma de histórias em quadrinhos. Onde eles misturam as ilustrações com a adaptação da obra . Assim sendo, o leitor consegue fazer uma analogia entre a escrita e a ilustração, conseguindo compreender o que está escrito através da âncora da imagem ilustrada. Com isso, a técnica da ilustração trará o que está contextualizado para uma linguagem diferente, a linguagem de imagem/ilustrações, com o intuito de facilitar o entendimento do livro.

Justificasse a realização deste projeto pela relevância de traduzir as narrativas escritas com ilustrações, a fim de um melhor entendimento das narrativas apresentadas pelo autor, deixando-o assim mais acessível visualmente e mais clara a compreensão aos leitores. Destarte, a meta será revelar iconograficamente os procedimentos do sistema de produção da cana de açúcar e do engenho da época referida. 


\section{Objetivos}

Os objetivos e premissas principais desse projeto são:

- A clareza no entendimento e compreensão das cenas descritas, que retratam um dos ciclos econômicos do Brasil colonial: a cana de açúcar, como fator enriquecedor do país. Além dos outros tipos de engenho retratados no livro, tabaco, mineração e as criações de gados.

- Gerar metodologia visual para compreensão, através do desenho, da pintura, de gráficos e de outros meios para contribuir na leitura, evitando perda de algum conteúdo narrativo.

- Destaque para objetivos: Criação de um material físico de um livro paradidático Ilustrativo que apoie o texto e dinamize a assimilação do conteúdo histórico; Realização de exposições oferecendo ao público a manipulação do material e a criação de um blog.

\section{Fundamento teórico}

"O ser senhor de engenho é título, a que muitos aspiram, porque traz consigo, o ser servido, obedecido e respeitado de muitos. E se for, qual deve ser, homem de cabedal, e governo; bem se pode estimar no Brasil o ser senhor de engenho, quanto proporcionalmente se estimam os títulos entre os fidalgos do reino. Porque engenhos há na Bahia, que dão ao senhor quatro mil pães de açúcar, e outros pouco menos, com cana obrigada à moenda, de cujo rendimento logra o engenho ao menos a metade, como de qualquer outra, que nele livremente se mói; e em algumas partes ainda mais que a metade" (ANTONIL, 1711, p. 19).

"Discursando sobre a lavoura da cana, não só escreveu Antonil um manual do agricultor da preciosa gramínea que foi a base da riqueza nacional, até meados do século XIX, como ainda um código do critério e do bom tom, sobremodo proveitoso àquelas épocas atrasadas. Assim o vemos começar expondo "que cabedal deveria ter o explorador de um engenho real", para depois ministrar os mais minudentes conselhos a quantos quisessem, no Brasil, estabelecer-se como fabricantes de açúcar. Surgem os conselhos para a compra das terras, de modo a não adquirir o novel plantador chãos estéreis ou sequer inferiores por massapés, a famosa terra negra, adocicado por excelência do caldo sacarífero." (autor, ano))

"Quem chamou as oficinas, em que se fabrica o açúcar, engenhos, acertou verdadeiramente no nome. Porque quem quer que as vê, e considera com reflexão, que merecem, é obrigado a confessar, que são uns dos principais partos, e invenções do engenho humano, o qual com pequena porção do Divino, sempre se mostra no seu modo de obrar, admirável. Dos engenhos uns se chamam reais, outros inferiores vulgarmente engenhocas. Os reais ganharam este apelido, por terem todas as partes, de que se compõem, e todas as oficinas perfeitas, cheias de grande número de escravos, com muitos canaviais próprios, e outros obrigados à moenda; e principalmente por terem a realeza de moerem com água, à diferença, de outros, que moem com cavalos e bois, e são menos providos e aparelhados; ou pelo menos com menor perfeição, e largueza, das oficinas necessárias, e com pouco número de escravos, para fazerem como dizem, o engenho moente e corrente" (ANTONIL, 1711, p. 13-14).

"Se é verdade que a Coroa portuguesa viu nas linhas do jesuíta um verdadeiro mapa para as minas de ouro do Brasil, não com menor riqueza o historiador consegue vislumbrar-la. As prescrições e indicações de técnicas, caminhos e assuntos vinculados à produção, beneficiamento e comércio de gêneros aqui encontrados podem ser lidas como um verdadeiro panorama das relações sociais de outrora: através das descrições do funcionamento do engenho e dos centros mineradores, acaba por imprimir sua ótica não só da economia, mas das gentes do Brasil. Em 
português, francês ou inglês, a obra permanece como ponto de apoio e referência incontornável para os que se debruçam sobre a história econômica, do cotidiano, do trabalho, dos escravos..." (VIOTTI, 2013).

\section{Metodologia}

O livro, quando foi escrito, tinha uma finalidade diferente da que encontramos hoje em dia. O autor de "Cultura e Opulência do Brazil"(ano) tinha como meta escrever um manual que pudesse auxiliar outros senhores que se encontravam na mesma situação, os que estavam envolvidos diretamente com a produção açucareira e nos tipos de engenho daquela época. Hoje, esse mesmo livro é uma referência histórica que contém diversas informações detalhadas de uma época. Atualmente, diversos teóricos, artistas e escritores vêm realizando trabalhos de releitura dos livros considerados clássicos. Um exemplo é a coleção "Literatura Brasileira em Quadrinhos"(ano) onde livros marcantes da literatura são transformados em quadrinhos para entreter e ensinar de forma divertida. Como pesquisadores, acreditamos que uma releitura de "Cultura e Opulência no Brazil" seria de suma importância para que esse livro não seja perdido com o tempo. E para tanto, será necessário o levantamento bibliográfico e iconográfico de outros autores do período. Com isso, destina-se a partir da decupagem de partes do livro, a experimentação de diversas técnicas de ilustrações da época.

A metodologia será dividida em 4 (quatro) fases, a saber:

- 1을

- Levantamento do referencial teórico e iconográfico dos conceitos e fatos históricos;

- Pesquisar sobre o tema lendo mais profundamente sobre o livro, o autor e a época;

- Decoupagem narrativa;

- 2o Fase:

- Estudo de técnicas que poderão ser utilizadas na produção das ilustrações;

- Entrevista semiestruturadas com professores e especialistas;

- 3을 Fase:

- Revisão das fases anteriores;

- Finalização das ilustrações e confecção de mídias digitais e impressas;

- 4o Fase:

○ Divulgação do trabalho.

5. Resultado esperado

Os resultados esperados são os seguintes:

- Criação de um material que auxilie no estudo da história do Brasil, dentro e fora das salas de aula;

- Divulgação por meios tecnológicos, on-line, através de blogs e páginas na internet;

- Resgate da memória Nacional.

- Preservação de um patrimônio cultural brasileiro.

6. Impactos previstos

Espera-se que a comunidade interessada valorize e divulgue este patrimônio literário tão rico, percebendo os detalhes das entrelinhas do livro através das ilustrações, preservar o patrimônio cultural brasileiro, trazer à luz este material precioso e evitar o esquecimento e o 
desuso do mesmo por professores, estudantes e interessados em história representativa do nosso país.

\section{Referências bibliográficas}

ABREU, Capistrano de. Capítulos de história colonial: 1500-1800. Rio de Janeiro, M. Orosco \& C., 1907. (Capítulo V).

AMARAL, Luís. História geral da agricultura brasileira no tríplice aspecto: político-social-econômico - vol.1. 2a ed, São Paulo, Companhia Editora Nacional, 1958.

ANTONIL, André João. Cultura e Opulência no Brazil, por suas drogas e minas, Ed. Lisboa: Oficina Real de Slandesiana, 1711. $214 \mathrm{p}$.

CANABRAVA, Alice P. "João Antônio Andreoni e sua obra". In: ANDREONI, João Antônio (André João Antonil). Cultura e opulência do Brasil. São Paulo: Editora Nacional, 1967, pp. 9 -112.

SANTOS, Bruna Rodrigues dos A Cultura e Opulência do Brasil por suas drogas e minas: qual sua natureza?. Disponível em: <

http://www.encontro2014.rj.anpuh.org/resources/anais/28/1400082707_ARQUIVO_anpuhartcorr.pdf>. Acesso em: 11 jan. 2017.

TAUNAY, Affonso D’Escragnolle. Antonil e sua obra, São Paulo, jan. 1922. Disponível em: $<$ http://www.culturatura.com.br/obras/Cultura\%20e\%20opul\%C3\%AAncia\%20do\%20Brasil.pdf $>$ Acesso em: 11 jan. 2017.

VILAR, Leandro, SEGUINDO OS PASSOS DA HISTÓRIA. O engenho e o fabrico do açúcar no Brasil colonial. Disponível em: <http://seguindopassoshistoria.blogspot.com.br/2013/12/o-engenho-e-o-fabrico-do-acucarno.html>. Acesso em: 09 jan. 2017.

VIOTTI, Ana Carolina de Carvalho. Resenhas-História (São Paulo), 2013. Disponível em: <http://www.scielo.br/scielo.php?script=sci_arttext\&pid=S0101-90742013000100025 >.Acesso em: 09 jan. 2017.

Cultura e opulência do Brasil. Vol. 70 da Coleção "Riquezas do Brasil", Livraria Itatiaia Editora,1982, dirigida por Mário Guimarães Ferri, da Universidade Federal de São Paulo.

Açúcar e Álcool - ontem e hoje. Coleção Canavieira no 4, Hamilton Fernandes, 1971.

História de usos e costumes do Brasil - 500 anos de vida cotidiana . Hernâni Donato, Editora Melhoramentos, 2005.

iteratura Brasileira em Quadrinhos, Editora Escala. 


\section{A TERRITORIALIDADE NA VISÃO LÓGICA-CULTURAL HIPERDIALÉTICA}

Esteban Lopez Moreno - PEQUI/UFRJ e Fundação Cecierj - estebanImoreno@gmail.com Mércio Pereira Gomes - HCTE/UFRJ - merciogomes@gmail.com

Resumo

O objetivo deste trabalho é buscar um entendimento acerca da territorialidade dentro da perspectiva do Sistema Lógico Hiperdialético (SLH), que permita mapear o processo de formação dos agregados humanos ao longo da história e assim abrir um novo horizonte de compreensão sobre o modelo real da cidade brasileira e suas possibilidades de transformação. A construção de uma cultura hiperdialética só alcançará a sua plenitude depois de passar pelas diversas dimensões pregressas, reconhecendo-as e integrando-as em suas particularidades. Para tal, será necessário exigir muito mais do ser humano.

Palavras chave: Lógica hiperdialética. Territorialidade. Organização do território. Cidades hiperdialéticas.

\section{Introdução}

Luiz Sérgio Coelho de Sampaio foi um filósofo brasileiro que desenvolveu um novo sistema lógico-filosófico que denominou de Sistema Lógico Hiperdialético (SLH), ou simplesmente, Hiperdialética. Por esse sistema lógico-filosófico, o mundo é entendido como uma trama calculável, ainda que não absolutizada, nem de todo consciente ao sujeito, de visões complementares e ascensionais. Sobre as quatro lógicas básicas - a da identidade ou transcendental; a da diferença; a dialética; e a lógica sistêmica ou clássica - rege a lógica hiperdialética, que dá sentido aos modos como cada uma delas opera e aos objetos que cada uma delas visa e dá sentido (SAMPAIO, 2000).

Segundo as palavras de Sampaio, "as lógicas não são "res cogitans", nem substâncias, nem coisas, nem aparelhos, nem suscetíveis de localizações, elas produzem, fazem surgir um "modo de ser" ou "aspecto da realidade"" (SAMPAIO, 2000, p.117). Com efeito, Sampaio desenvolve o seu sistema lógico para compreender e ressignificar diferentes dimensões da realidade, da filosofia à psicologia, da matemática à física quântica, chegando a prever, neste último campo, propriedades de subpartículas que ainda estão por serem descobertas.

No campo da territorialidade, Sampaio nos deixou um campo a ser explorado. A ideia de territorialidade nasce da atitude instintiva dos animais - incluindo a nossa espécie - que promove a ocupação e defesa do território que serve como seu campo de atuação. Trata-se de um conceito que interfaceia diversos campos do saber, como a sociologia, a psicologia social, as ciências jurídicas, no caso do ser humano está profundamente arraigada com a cultura.

Numa linguagem introdutória, podemos dizer que a base lógica diferenciadora (D) de nossa organização territorial está em sua codificação por meio das trocas e da linguagem, em seus diferentes modos e aspectos, e mais além, por tudo aquilo que permite a percepção do espaço entre uma coisa e outra. A Lógica $D$, portanto, é que nos dá o senso de espaço e territorialidade. É a res extensa, tal como pensada por Descartes. Por outro lado, a operação da identidade (I) se alicerça na homogeneidade da comunicação no que diz respeito aos processo de formação da matriz da cultural humana que é comum a todos nós. A Lógica I nos dá o senso do tempo. As resultantes topológicas referentes à interação destas duas lógicas 
básicas (I e D) irão criar os espaços de territorialidade por meio do embate entre a homogeneização e a diversificação cultural.

O conceito de territorialidade tem um uso mais amplo do que se propõe a ser explorado neste artigo. Por ora, vamos nos contentar em aplicá-lo a organização das habitações humanas, de seus primeiros agregados, desde as aldeias nômades ou vilas indígenas, até as grandes cidades modernas e aquilo que seria ou será a cidade hiperdialética.

Além das cinco lógicas, Sampaio, propôs duas pré-lógicas associadas à culturas que ainda não teriam alcançado o nível de representação lógica em sua concepção cosmológica. Ao todo, duas pré-lógicas e são cinco lógicas, e sua aplicação sintetizadas a seguir (GOMES, 2011; SAMPAIO, 2000, 2001, 2002).

Advertimos que, a despeito da proposta de criação de uma inteligibilidade lógica no uso da territorialidade, em nenhum momento ela pode se apresentar de forma absoluta, há sempre associações de uma lógica com outra de forma que o que se mostra é apenas aquela que possui maior evidência, seja por contingências naturais (clima, geogŕafia) ou culturais (historicidade). Cabe também ressaltar que o ser humano é hiperdialético e se desvela por igual na humanidade, não importa o estágio lógico ou pré-lógico em que se encontra.

Aplicação do SLH à Territorialidade

Pŕe-lógica I - A humanidade iniciou sua trajetória histórica como caçadores-coletores, aqueles primevos Homo sapiens que evoluíram na África há mais de 200 mil anos. Neste estágio nômade, nossa espécie cria uma visão animista do mundo, há um sentimento de mútua reciprocidade com a natureza, homens e animais encontram-se em íntimo relacionamento. Esta cultura vive mais no tempo do que no espaço, sua ocupação territorial dá-se pelo imperativo da sobrevivência, e são internamente pouco diferenciadas ou hierarquizadas. Há, por exemplo, os que são excelentes caçadores ou ainda aquele que canta melhor, porém todas as atividades são igualitárias e a própria sociedade cria impedimentos para não existam privilégios. Deste modo, todas as habitações apresentam padrões semelhantes - ainda que em seu íntimo se diferenciem - e são construídas com materiais de pouca durabilidade e robustez (e.g.: galhos de taquaras, troncos de árvores, palhas, folhas, couro). A disposição das habitações segue frequentemente um padrão circular, de forma a homogeneizar os espaço de troca.

Elas são exemplificadas, na atualidade ou desde o século XVI, pelas comunidades de caçadores e coletores de diversas regiões do mundo, como o sul da África, os pigmeus Ndembu das florestas da África Central, os Aborígenes Australianos, os Ona e Alacaluf do sul da América do Sul, os Esquimós do Círculo Ártico, bem como por povos que praticam uma agricultura itinerante, de pouco excedente, tal como os povos que habitavam e ainda habitam o território brasileiro, para exemplificar casos mais próximos, sem esquecer os agricultores africanos e indonésios e tantos mais. No momento em que esses povos encontram meios econômicos e ambientais de aumentar suas populações, suas habitações adquirem maior robustez e permanência, o que coincide com desenvolvimento de uma agricultura mais permanente, em geral de regadio, e uma intensificação de criação de animais domésticos, começa a emergir a função diferenciadora de segmentos populacionais em proto-classes, característica da prélógica $\mathrm{D}$.

Pre-lógica D - Nesta nova etapa a sociedade passa a ter apego à terra e a desenvolver uma nova forma de religião na qual a natureza e os homens já não caminham juntos, ainda que permaneçam nostalgicamente relacionados por meio de deuses, temidos e idolatrados, com qualidades de animais. Nas culturas ameríndias, surge uma nova forma político-social conhecida na literatura antropológica como cacicato, onde emerge um sistema social baseado em proto-classes e um controle político de ordem teocrática. O trabalho não é mais exclusivo 
à produção para o grupos familiar ou social mais próximo, mas passa a se tornar um trabalho para outrem, em outras palavras, alienado do seu propósito original, e começa a ser explorado em uma hierarquia social bem demarcada.

As novas organizações sociais refletem-se em sua territorialidade. Em oposição à pré-lógica anterior, as habitações passam a possuir uma estrutura robusta com uso de materiais diversificados e de maior permanência - como adobe, argamassa e pedra - adquirindo também formatos diferenciados conforme a hierarquia e o grau de especialização. Emerge uma clara divisão do trabalho e as primeiras especialidades artísticas.

Com o distanciamento cada vez maior entre as elites político-religiosas e a população, vão surgindo os primeiros grandes impérios, como egípcios, babilônicos, maias, incas e chineses. Os primeiros grandes estados apoiavam-se na presença de seus múltiplos deuses - com a predominância de um ou outro, por vezes por animais fabulosos que tornam imperiosa a obediência - para justificar o controle da população, de forma a impedir a luta de classes e aceitar a desigualdade econômica e social. Esta imposição imagética levou à construção de estruturas suntuosas, como os grandes templos do Egito ou os opulentos palácios da China antiga.

O desenvolvimento da escrita, que ocorre ao final deste período pré-lógico, da matemática, da crescente variação das atividades sócio-econômicas, e a sacralização extremada da desigualdade social evoca o nascimento da primeira lógica, a da identidade.

Lógica da Identidade (Lógica I) - Entramos no limiar do simbólico, no nascimento da primeira lógica básica. Aqui o sentimento de identidade faz-se de novo presente, no entanto a consciência agora volta-se para a auto-reflexão, da identidade e da autodeterminação. É nesta lógica que se origina o alfabeto, as letras passam a não se referenciar a coisas ou sons, mas abstrações irredutíveis em si. É a lógica do ser em si, primeiro evocada pelo filósofo grego Parmênides, e na era moderna por Descartes, com o sujeito pensante da ciência, a res cogitans, bem como pelo sujeito transcendental de Kant. Nesta lógica a verdade se apresenta cristalina como uma revelação, uma coisa em si, que se opõe ao falso. Parmênides revela esta lógica ao declarar que "o ser é". Antecipando em muitos anos as bases da verdade e da epistemologia que outros filósofos iriam criar, Parmênides enunciou que "ser e pensar são o mesmo".

A lógica da identidade se manifesta em culturas de baixa intensidade e desigualdade social, formada por uma pequena elite de teólogos, pastores, agricultores ou comerciantes que transitam nos interstícios dos grandes impérios clássicos, ora submetidos a eles, ora desafiando-os em busca de sua autonomia. Em seu primeiro estágio, a territorialidade desta lógica se constrói entre as primeiras cidades, como o assentamento neolítico de Çatalhöyük (Figura 1), na Ásia Menor, sem ruas separando as habitações, todas simples e pouco diferenciadas, e regidos sob a idealização de uma deusa mãe unificadora, ainda com elementos da transição do pré-D. 
Figura 1 - Çatalhöyük, uma das primeiras grandes cidades do mundo (9.000 a.C.)

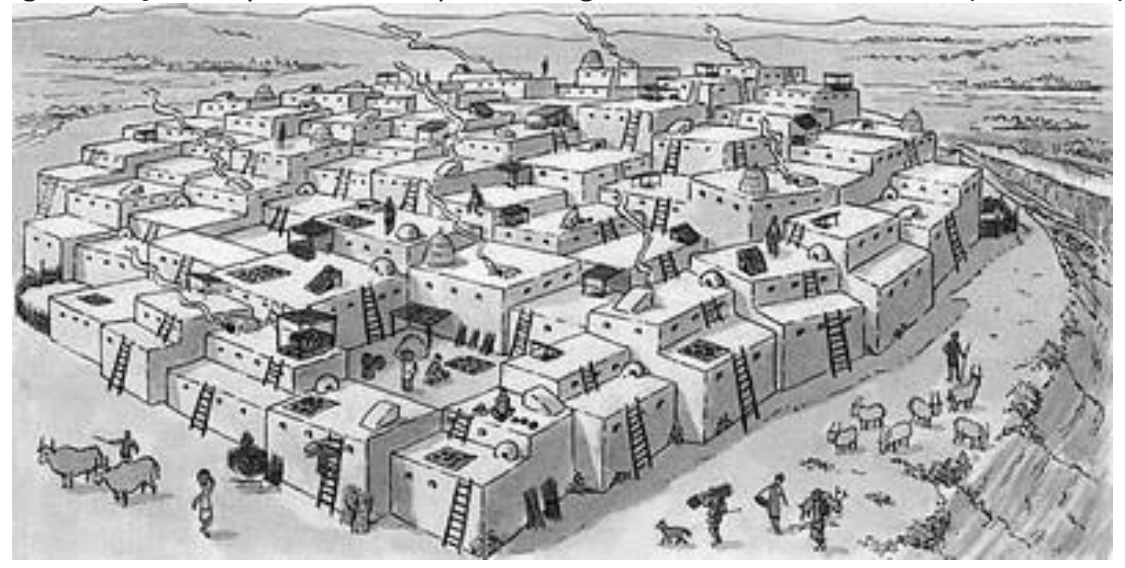

Fonte: https://www.thinglink.com/scene/576157568150274049

Aos poucos as comunidades oriundas desta visão lógica tornam-se muradas, como a cidade bíblica de Jericó, que demarca de forma clara a sua identidade territorial. Além de seus muros, não há nada que importa senão apenas aquilo que for necessário à sobrevivência. Esta organização se manifesta de forma mais clara na formulação do deus único, no monoteísmo hebraico na medida em que se declaram como um ser simbólico autorreferenciado, não personificado, nada existindo fora dela. É ela, por isso, que evoca que se destruam as imagens dos animais, as estátuas e o seus ícones, passando-se a referenciar o Ser único como o ente simbólico. Em sua expressão mais avançada, temos as antigas cidades árabes, como Damasco e Toledo, com sua arquitetura e desenhos geométricos de elaborada beleza e harmonia.

Em séculos posteriores, a lógica transcendente vai concretizar os kibutz judaicos - eles próprios pertencentes à lógica I -, pequenas comunidades economicamente autônomas caracterizadas por uma organização igualitária e democrática, sob inspiração socialista. Ou nas feitorias portuguesas criadas à pulso em sua busca da implantação do identidade (I/D) sobre um território ocupado pelos povos indígenas brasileiros (pré-I). Ou ainda, dentro dos governos imbuídos de uma modernidade avassaladora, que constrói contingentes de casas populares sem qualquer instinto diferenciador, como se nela fossem habitar autômatos desalmados.

Lógica da Diferença (lógica D) é a lógica que se refere ao "outro", o não-conhecido e o nãoidentificável. Ao direcionar o ponto de vista do "outro", ela se indaga sobre a validade do "mesmo". Isto é, a Lógica da Diferença confronta e desafia a Lógica da Identidade, bagunça as suas certezas imanentes e transcendentais. A Lógica da Diferença é a lógica própria do inconsciente, da dúvida, consequentemente da indagação, e também do coletivo, do corpo, do descontínuo, enfim, da res extensa. A lógica $D$ junto com a lógica I constituem as duas lógicas básicas sobre o qual se derivam todas as outras.

A organização territorial gestada a partir da lógica da diferença não é imediatamente apreensível, não segue a rigor qualquer padrão prévio de planejamento de um sujeito, de governo ou de alguma lógica estruturante. A irregularidade de suas ruas e conformações é a materialização física de seu inconsciente social e não simbolizam, necessariamente, caos ou desordem, mas sim alguns dos elementos necessários para um sistema de crescimento urbano flexível e que mais facilmente responde às demandas sociais, funcionais daquela população.

As cidades da antiga Grécia e Roma eram bons exemplos. Muitas delas eram pontos avançados de conquista de territórios e consolidação de seu império, porém fisicamente a estratégia de garantia de posse passava pela fagocitose das culturas locais sem que o encontro representasse graves perdas, assumindo como resultado final uma mescla de estruturas 
físicas e práticas culturais. Com efeito, cada cidade grega (ou romana) tinha o seu próprio deus protetor, por vezes oriundos de culturas muito distantes da sua, adquirindo idiossincrasias locais, antes de Heródoto e Tucídides tentar lhes dar um sentido comum. Um bom exemplo desses arranjos nos tempos atuais estão presentes em nossas favelas, com seu amálgama multifacetado de culturas - sons, cores, cheiros, paladares - intercalados de construções que recebem maior destaque, como a igreja, a UPP, a casa do chefe do tráfico. Lógica Dialética (lógica I/D) é a lógica da temporalidade, sendo constituída como uma lógica derivada da síntese das lógicas da Identidade (I) e da Diferença (D), que necessariamente a precedem. Nesta lógica, a verdade é o todo que se forma pela integração dos contrários ou dos diversos, sendo estes apenas instâncias em busca de devir. Platão, com sua concepção da ideia, que é o conceito em si, é o primeiro a usar dessa lógica com clareza. A verdade não está nem na aparência multifária do ser, nem na sua unicidade percebida, mas na síntese lógica dessas duas instâncias, numa forma ideária só apreensível pelo intelecto.

O desenvolvimento da lógica I/D deu-se notadamente na Europa, com o domínio do cristianismo como religião do Império Romano, e envolvimento de todo o período medieval. Sua arquitetura característica notabiliza-se pela centralidade das estruturas que representam o poder religioso, como as imponentes catedrais e igrejas, cercada e protegida de um poder múltiplo, disperso e organizado dentro de seus muros e fronteiras. Estas agora se tornaram mais fluidas do que a fortaleza da lógica I - especialmente receptivas ao mercantilismos crescente - , ao mesmo tempo menos tolerantes que a organização $D$ na medida em que valorizam suas própria historicidade.

$\mathrm{Na}$ medida em que o capitalismo torna-se a força unificadora, são os grandes prédios de escritórios na forma de arranha-céus que vão ocupar os locais de centralidade, dessacralizando os antigos espaços de poder unificador da igreja. A emergência desta nova força produtiva irá desaguar na próxima lógica estruturante.

Lógica Clássica ou Formal (lógica D2) é a lógica da sistematicidade do ser, dos conjuntos autosuficientes, da funcionalidade e da estrutura. É a lógica que permitiu a classificação da natureza em classes, categorias, ordens, grupos, subgrupos etc. É também conhecida como lógica do terceiro excluído, a lógica que abarca a todos os componentes de um sistema por categorização de identidade, contrariedade, síntese e proximidade, deixando de fora apenas aquilo que não faz parte de modo algum do sistema, um terceiro qualquer, até que possa ser incluído por novo processo de totalização. Essa nova totalização é feita por incorporação de similitude, não por síntese com na lógica I/D pregressa.

É no capitalismo pleno que está lógica encontra seu território de multiplicidade, ao mesmo tempo que a consciência da vontade humana é obscurecida por um deus movido pelo dinheiro, por um ideário mecânico, invisível, amoral. Neste sistema de estruturas multifacetadas de prédios e territórios, à semelhança de um organismo vivo, todos cabem, ao mesmo tempo que alguns cabem mais do que outros, por meio de leis, regras e classificações operadas por outras lógicas, não necessariamente justas e coerentes. É o território das grandes cidades, que abriga do pobre morador dos guetos ao rico empresário, intercalado por estamentos intermediários.

Lógica Hiperdialética (lógica I/D2) é a lógica que subsume todas as demais num conjunto integrado com um novo fator: a intersubjetividade e a intencionalidade do ser a superar a sua condição de prisioneiro da estrutura e da sistematicidade característica da lógica anteriores. Não se trata de um novo operador exógeno que faz o sistema funcionar, mas é ele próprio um motor de ação. Este fator está inserido como parte constitutiva da nova lógica, que se move por si mesma. A Lógica Hiperdialética corresponde ao sentido integral do ser humano, seu modo próprio superior de ser-pensar. Todo e cada ser humano pensa ou pode pensar hiperdialeticamente. 
Em termos culturais, as cidades hiperdialéticas são aquelas nas quais as pessoas convertemse em protagonistas do espaço público, tornando-se mais tolerantes quando as diferenças culturais (D), ao mesmo tempo que reconhece a sua unidade (I), sua historicidade (I/D) e os dinamismos próprios da modernidade (D2), sendo permeado do sentimento de uma compreensão amorosa e ética. A cidade hiperdialética reconhece-se em sua incompletude, mas tampouco desacredita no valor de tudo que já foi conquistado pelas culturas anteriores. Uma cidade hiperdialética não se define tanto pelo seu território, mas pelas pessoas que a habitam em seu diálogo pela cidadania. A construção de uma cultura hiperdialética só alcançará a sua plenitude depois de passar pelas diversas dimensões pregressas, reconhecendo-as e integrando-as em suas particularidades. Para tal, será necessário exigir muito mais do ser humano. Cabe a nós construir este futuro e ele começa aqui e agora.

Referências bibliográficas

SAMPAIO, L. S. C. de. Lógica Ressuscitada: Sete Ensaios. Rio de Janeiro: EdUERJ, 2000. . Lógica da diferença. Rio de Janeiro, EdUERJ, 2001 . Filosofia da cultura - Brasil, luxo ou originalidade. Rio de Janeiro, Ágora da Ilha, 2002.

. Física Moderna - partículas e forças, buracos negros, constantes universais, princípio antrópico, história e destinação da física, a partícula de Higgs, a física como recôndito desejo da modernidade, Rio de Janeiro, 2005, Editora H. P. Comunicação.

GOMES, M. P., Antropologia Hiperdialética, Editora Contexto, 2011. 


\section{CANNABIS CNIDOSCOLUS - UMA PROPOSTA DE RESERVA PARA O COMÉRCIO LEGALIZADO DA MACONHA}

Esteban Lopez Moreno - Pós-Doutorando no HCTE/UFRJ e Fundação Cecierj - estebanlmoreno@gmail.com Mércio Pereira Gomes - Professor do HCTE/UFRJ - merciogomes@gmail.com

\section{Resumo}

O mundo caminha aparentemente a passos largos, para a regularização do consumo recreativo da maconha. Já vimos isso acontecendo na Europa, nos Estados Unidos e no Uruguai. O consumo medicinal já é legal em muitos outros países. Subjaz nesta passagem uma oportunidade histórica singular de proporcionar às comunidades de baixa renda, as nossas favelas -- que, de tão carentes em serviços urbanos, abrem-se para a formação de grupos de jovens que se vinculam diretamente a este comércio, o qual, por ilegal, cria ambientes de violência e criminalidade -- uma vantagem comercial que lhes traria benefícios diretos e, por extensão, consequências sociais e econômicas positivas para toda a sociedade brasileira. Neste artigo apresentamos para debate acadêmico uma proposta de reserva de mercado e analisamos alguns dos desafios e consequências que traria para a sociedade.

Palavras-chave: Legalização da maconha. Inclusão social. Favelas. Comunidades de baixa renda. Justiça social.

\section{Introdução}

Se há um tema que causa debates acalorados em nossa sociedade é a demanda pela legalização da maconha. Apesar da proibição, a maconha ainda é a droga ilícita mais usada no mundo e no Brasil (GALDUROZ J.C., 1997). Diversos estudos corroboram que esta planta é prejudicial à saúde, especialmente na adolescência (SOARES-WEISERS et al., 2003), no agravamento de quadros de esquizofrenia (VAN OS, 2012) ou no prejuízo do processo de aprendizagem (POPE et al., 2001), entre outras, o que no entanto tem sido questionado pela própria comunidade científica (RIBEIROS et al 2005).

Por outro lado, há fortes indícios demonstrando efeitos benfazejos da maconha na prevenção e tratamento de Alzheimer (CURRAIS et. al., 2006), o que permitiu sua legalização como uso medicinal em diversos países, inclusive no Brasil (Resolução da Diretoria Colegiada da Anvisa - RDC 17/2015 ). O uso desta planta corrobora também com resultados positivos no tratamento de dores (analgésico), glaucoma, depressão, ansiedade (KALANT, H., 2001; BONFA, 2008) e até na cura de dependência de outras drogas, como crack e cocaína (LABIGALINI, 1999). Ademais, com o fim da proibição da produção e comércio da maconha haverá uma enorme redução dos custos econômicos e sociais para a manutenção do aparelhamento policial e da justiça, beneficiando outros setores, como a saúde e educação (MARIZ, 2016; MORAES, 2015), ainda que pesem argumentos contrários (Azevedo, R., 2014) ou problematizadores (LARANJEIRA, 2010; BESSA, 2010).

Devemos também considerar que não há qualquer caso na literatura científica que comprove que há algum dano ao organismo no consumo ocasional ou moderado da maconha (SOARESWEISER et al., 2003) e não faltaram esforços para que se o encontrassem. Para muitos autores, o motivo principal ou o único para a proibição da maconha é ideológico, conforme sintetizado por Burgierman \& Nunes (2016): 
A guerra contra essa planta foi motivada muito mais por fatores raciais, econômicos, políticos e morais do que por argumentos científicos. E algumas dessas razões são inconfessáveis. Tem a ver com o preconceito contra árabes, chineses, mexicanos e negros, usuários frequentes de maconha no começo do século XX. Deve muito aos interesses de indústrias poderosas dos anos 20, que vendiam tecidos sintéticos e papel e queriam se livrar de um concorrente, o cânhamo. Tem raízes também na bem-sucedida estratégia de dominação dos Estados Unidos sobre o planeta. E, é claro, guarda relação com o moralismo judaico-cristão (e principalmente protestante-puritano), que não aceita a idéia do prazer sem merecimento.

Assim é que, resguardadas as surpresas históricas que porventura emerjam desse nosso confuso tempo, o mundo hoje caminha para a regularização da maconha. No Brasil, a legalização do consumo recreativo não tem previsão para ocorrer, mas seguindo a tendência mundial, como a regulamentação gradual em países como Holanda, EUA, Portugal, Uruguai e em breve o Canadá, é possível que ocorra nos próximos 10 ou 20 anos. Soma-se a este movimento o interesse de grandes corporações financeiras, que veem como uma possibilidade de ampliar o leque de seus produtos e locupletar enormes somas de capital. Não por menos, muitos ou, provavelmente, a maioria dos economistas (MORAES, 2015) tem posições favoráveis à legalização e regulação de um mercado que anualmente movimentaria somente no Brasil R\$ 5,7 bilhões ao ano, com perspectiva de gerar uma arrecadação de $\mathrm{R} \$ 5$ bilhões somente em impostos (MARIZ, 2016). Entretanto, até o momento não se apresentou uma maneira clara e precisa de como seria feita a mudança.

Dada a possibilidade de legalização recreativa da maconha no Brasil, eis aqui algumas considerações sobre a implantação de um modelo de comercialização criativo e beneficente para as comunidades carentes brasileiras,

- Será garantida pelo prazo mínimo de 20 anos a exclusividade do comércio da maconha nas favelas e demais comunidades carentes, tradicionalmente já envolvidas em seu comércio;

- os representantes comerciais serão selecionados a partir de livre concorrência entre os moradores ou representantes da comunidade, após ampla discussão pública;

- em contra-partida, os novos empreendedores deverão oficializar o seu comércio seguindo todas as prerrogativas da lei, esmerando-se pela qualidade e a idoneidade de seus produtos e serviços;

- ao governo caberá estabelecer as leis e os mecanismos necessários para fiscalizar e garantir a qualidade, a concorrência pacífica entre os empreendedores, a limitação da venda dos produtos para jovens ou pessoas em situação de risco, campanhas educativas e a cobrança de impostos;

- os impostos arrecadados devem ser dirigidos preferencialmente para a saúde e a melhoria do capital humano dessas comunidades;

- após o período de concessão e durante intervalos intermediários, serão avaliados por uma comissão própria os benefícios e prejuízos desta proposta.

Quais são os desafios dessa política?

Os desafios são imensos, elencamos a seguir alguns dos principais, começando pela ponderação apresentada pelo jurista $\mathrm{M}$. A. Bessa ao analisar o que poderia vir a acontecer com a legalização da maconha: "A simples legalização das drogas não alterará em nada as condições que fazem com que esses jovens tenham no tráfico, muitas vezes, a única alternativa de trabalho e de renda. (...)" (BESSA, 2010)

Nos simples termos de uma legalização, com efeito, nada muito diferente acontecerá de positivo para os grupos de jovens que vendem o produto de modo ilegal. No entanto, a liberação do uso recreativo da maconha em conjunto com a regularização de seu comércio 
nas favelas deverá atrair mais consumidores para este mercado, trazendo maior oportunidade de emprego e benefícios àquele jovem que opte por sair do tráfico. A forte injeção de recursos nas favelas deve proporcionar diversos outros benefícios para o jovem. Outras formas de criminalidade continuarão presentes nos morros, incluindo o comércio de outras drogas que permanecerão como ilícitas, como o crack, LSD etc.

Sim, continuarão. Mesmo drogas legalizadas como o cigarro e o álcool possuem uma indústria ilegal paralela que escapa da tributação e do controle sanitário. A legalização da maconha do Uruguai, tampouco, até o momento, diminuiu o tráfico naquele país. O que se espera é que a violência como um todo diminua na medida em que ocorra um maior sentimento de pertencimento da parcela menos favorecida da população, junto com uma política de melhoria de acesso ao saneamento, transporte coletivo, bons hospitais e escolas. O fortalecimento do comércio local seria efetivamente um dos fatores mais importantes para a diminuição da criminalidade (JACOBS, 2011).

"A abolição das leis teria um efeito maior nas pessoas que comumente não consomem drogas, potencialmente levando um maior número a experimentar e a se tornar usuário regular ou esporádico". (Laranjeira, 2010)

Considerando-se o cenário aqui proposto, o aumento do consumo da maconha com a legalização é provável e, para alguns propósitos, indesejável. Não obstante, os principais danos decorrentes do consumo da maconha são causados pela forma como a sociedade lida com esta planta, não pelo uso em si. Ademais, com o fortalecimento da presença do Estado nas comunidades que antes eram dominadas pelo tráfico, espera-se um efetivo aumento do conhecimento consciente da população usuária ou potencialmente usuário, o que pode ser reforçada em campanhas, como já ocorrem em relação ao uso do tabaco e do álcool. O Estado estaria também mais apto a oferecer um tratamento público digno aos usuários dependentes de todos os tipos de drogas.

E quem produziria e beneficiaria a maconha?

Não temos clareza neste ponto. Nosso ensejo até o momento é que estas etapas de produção sejam livres, seja em ambiente urbano ou rural, apenas regulamentadas pelo Estado e sem qualquer reserva para comunidades, como já ocorre com o tabaco. De outra sorte, caso a produção seja monopolizada pelo Estado ou por empresas privadas, incorrerá fatalmente em uma forte produção clandestina. Por outro lado, a livre produção, ainda que regulamentada, provocará o aumento da concorrência e a diminuição do preço e dos lucros, enfraquecendo o interesse dos empresários pelo comércio da maconha. A venda das drogas ilícitas se tornaria, por isso, mais lucrativa. Há ainda uma série de variáveis imprevisíveis nesta questão. Trazendo de novo as ponderações de Bessa:

\footnotetext{
"Será que se pode imaginar que a simples legalização afastará as facções do crime organizado que desempenham essas funções de atividade ilícita e fará com que eles apareçam à luz, legalizem-se e se tornem respeitáveis cidadãos, pagantes de impostos, tementes a Deus e às leis? Transformem-se do dia para a noite em empresários sérios, participativos de campanhas beneficentes, patrocinadores de ações sociais solidárias voltadas especialmente às crianças e jovens carentes? Terão o mesmo comportamento nobre e desinteressado que seus colegas das indústrias do tabaco e das bebidas alcoólicas tiveram ao longo da história e mantêm em nossos dias? “ (BESSA, 2010)
}

É muito difícil afirmar com total convicção que tal efeito ocorra, entretanto foi assim que aconteceu em alguns países. A Austrália é um bom exemplo. Durante sua colonização no século XVIII uma parcela significativa de sua população era composta de réus condenados e deportados da Inglaterra. A partir do momento que a sua economia tornou-se mais inclusiva, 
permitindo a participação ativa desses criminosos, este país se tornou uma dos mais prósperos do planeta. O mesmo ocorreu por diferentes mecanismos com os EUA, Canadá e Nova Zelândia e tem sido hoje considerada como a melhor estratégia para melhorar a situação de países pobres, ao invés da simples transferência de recursos por meio de ações sociais. 0 que certamente nunca ocorreu foi o "comportamento nobre e desinteressado" das indústrias de álcool e tabaco, trata-se naturalmente de uma ironia.

É preciso considerar que os resultados das ações aqui propostas podem ser imprevisíveis. Para que se potencialize os efeitos desejados, é necessário que o comércio legalizado seja inicialmente implantado de modo experimental em algumas poucas comunidades, de porte pequeno, como o Morro Dona Marta, na Zona Sul do Rio de Janeiro. Ao menos por algum pouco tempo, esse experimento servirá como um laboratório de estudo cujos resultados podem vir a ser multiplicados, com os devidos cuidados, em outras comunidades.

Palavras finais

A Cannabis sativa, nome científico da maconha, é um arbusto da família das Moraceae que cresce em diversas partes do planeta, nas regiões tropicais e temperadas. É provável que suas sementes tenham sido trazida para o Brasil por escravos africanos, a partir de cuja prática lúdica e cerimonial se fez corriqueiro o seu uso entre a população pobre, livre ou cativa, pelo interior do Brasil. No Rio de Janeiro, boa parte de seu comércio dá-se nas "favelas". Este nome, por sua vez, é oriundo de um arbusto de flores brancas, com espinhos e sementes em forma de "favas", cujo nome científico é Cnidoscolus Quercifolius, e é endêmica em regiões áridas do Brasil. Os soldados que retornaram ao Rio de Janeiro após participarem da guerra que destruiu a comunidade messiânica de Canudos, talvez o último reduto da resistência indígena-mestiça aos poderes estabelecidos, sem terem um merecido local para construir suas casas e morar, foram ocupando principalmente os morros da cidade, construindo barracos e casebres, constituindo comunidades, e acabaram por designar essas novas formas de moradia e vivência pelo nome da planta que tanto os havia impressionado em sua terrível passagem pelos sertões baianos. Será que houvera aí alguma identidade escondida?

No imaginário de nós, autores, estas duas plantas enquanto isoladas têm representado preconceito, violência e injustiça; no entanto se tratadas juntas e misturadas, i.e., como Cannabis Cnidoscolus, simbolizam um encontro que nos leva a uma perspectiva de apaziguamento e a uma tão desejada justiça social. Trata-se, pois, de uma proposta criativa e original, bem ao estilo de nossa brasilidade.

\section{Bibliografia}

AZEVEDO, Reinaldo, Um manifesto contra a legalização das drogas no Brasil; se concordar, assine, revista Veja, publicado em 24 jun 2014. http://veja.abril.com.br/blog/reinaldo/um-manifesto-contra-a-legalizacao-dasdrogas-no-brasil-se-concordar-assine/ Acesso em 4 de outubro de 2017.

BESSA, M.A.; Contribuição à discussão sobre a legalização de drogas. Ciência e Saúde Coletiva, vol. 15 (3): pp. 632-636, 2010

BURGLERMA, D. NUNES, A., A verdade sobre a maconha, Revista Superinteressante, 2016. Disponível em: https://super.abril.com.br/ciencia/a-verdade-sobre-a-maconha/, acesso em 5 de setembro de 2017.

BONFA, Laura; VINAGRE, Ronaldo Contreiras de Oliveira; FIGUEIREDO, Núbia Verçosa de. Uso de canabinóides na dor crônica e em cuidados paliativos. Rev. Bras. Anestesiol., Campinas, v. 58, n. 3, p. 267-279, jun. 2008.

KALANT, H. Medicinal use of cannabis: history and current status. Pain Res Manag, 2001; 6:80-91. 
CURRAIS, Antonio \& QUEHENBERGER, Oswald \& ARMANDO, Aaron \& DAUGHERTY, Daniel \& MAHER, Pam \& SCHUBERT, David. Amyloid proteotoxicity initiates an inflammatory response blocked by cannabinoids. npj Aging and Mechanisms of Disease. 2. 16012, 2016. DOI: 10.1038/npjamd.2016.12.

LABIGALINI, Eliseu, RODRIGUES, Lucio Ribeiro, DA SILVEIRA, Dartiu Xavier, Therapeutic Use of Cannabis by Crack Addicts in Brazil, Journal of Psychoactive Drugs Vol. 31 , Iss. 4, 1999

GALDURÓZ J.C., NOTO, A.R., CARLINI, E.A. IV Levantamento sobre o uso de drogas entre estudantes de 10 e 20 graus em 10 capitais brasileiras. São Paulo: Centro Brasileiro de Informações sobre Drogas Psicotrópicas (CEBRID); 1997.

JACOBS, Jane. Morte e Vida de Grandes Cidades, São Paulo, Wmf Martins Fontes, 3a ed., 2011.

LARANJEIRA, Ronaldo. Legalização de drogas e a saúde pública. Ciênc. saúde coletiva, Rio de Janeiro , v. 15, n. 3, p. 621-631, May 2010.

MARIZ, Renata, Comércio formal de maconha movimentaria R\$ 5,7 bilhões no Brasil. Estudo de consultores da Câmara avalia impacto econômico da legalização. Revista Veja. 09/06/2016, disponível em https://oglobo.globo.com/sociedade/comercio-formal-de-maconha-movimentaria-57-bilhoes-no-brasil19468621\#ixzz4uZJp3rT6

MORAES, Pedro Rocha de. A proibição da maconha no Brasil e suas implicações econômicas: uma análise dos custos incorridos e evitados. 2015. 77 f., il. Monografia (Bacharelado em Ciências Econômicas)_Universidade de Brasília, Brasília, 2015. Disponível em:

http://bdm.unb.br/bitstream/10483/11445/1/2015_PedroRochadeMoraes.pdf

POPE H.G. Jr, GRUBER AJ, HUDSON JI, HUESTIS MA, YURGELUN-TOSS D. Neuropsychological performance in long-term cannabis users. Arch Gen Psychiatry 2001;58:909-15.

RIBEIRO, Marcelo et al . Abuso e dependência da maconha. Rev. Assoc. Med. Bras., São Paulo, v. 51, n. 5, p. 247-249, Oct. 2005 .

SOARES-WEISER, Karla; WEISER, Mark; DAVIDSON, Michael. Uso de maconha na adolescência e risco de esquizofrenia. Rev. Bras. Psiquiatr, São Paulo , v. 25, n. 3, p. 131-132, Sept. 2003.

Van Os J1, BAK M, HANSSEN M, BIJL RV, de GRAAF R, VERDOUX H.. Cannabis use and Psychosis: a longitudinal population based study. Am J Epidemiol 2002; 156: 319-27. Disponível em:

https://www.ncbi.nlm.nih.gov/pubmed/12181101 


\section{NOTAS DE CONTAS E FONTE HISTÓRICA: ESTUDO DOS QUIMONOS DE MARIA AUGUSTA RUI BARBOSA}

Gabriela Lúcio de Sousa - Fundação Casa de Rui Barbosa - gabriela.luciio@gmail.com Anna Gabriela Pereira Faria - Fundação Casa de Rui Barbosa - gabriela@rb.gov.br

Resumo

Em busca de novas fontes de pesquisa para investigar os quimonos de Maria Augusta Rui Barbosa, os cadernos de contabilidade, ou notas de contas de Rui Barbosa foram consultados. A partir desse material, informações significativas sobre compras, hábitos e preferências de lojas da família foram descobertas. Um estudo interdisciplinar, reunindo os campos de museologia, conservação, história e arquivologia foi essencial para realização do trabalho que mostrou-se singular, eficiente e criativo, evidenciando que a análise de arquivos pessoais possibilitou acesso a dados diferentes dos esperados, mas igualmente relevantes.

Palavras-chave: Arquivos pessoais. Maria Augusta Rui Barbosa. Pesquisa Histórica.

Introdução

Ao iniciar as pesquisas do projeto Os quimonos de Maria Augusta Rui Barbosa: pesquisa, conservação e acesso ao público, identificou-se uma disponibilidade de fontes bastante limitada sobre o tema. Buscou-se então aplicar a metodologia relacionada a cultura material proposta por Lou Taylor, em seu livro "The study of dress history" (2002), investigando minuciosamente os detalhes e as possibilidades. Decidiu-se, então, consultar novos dados sobre o objeto de estudo em questão nos arquivos pessoais de Rui Barbosa. Operando entre os campos da cultura material - já que as buscas foram realizadas com o propósito de compreender melhor dois trajes do acervo do Museu Casa de Rui Barbosa - a partir das pesquisas em arquivos históricos, relacionando com as ciências da museologia e da conservação, áreas correlatas preocupadas com a preservação de acervos e, portanto, resgatando a memória para realizar tal ação de modo eficiente, a interdisciplinaridade foi chave para a realização desse trabalho.

Por meio dos cadernos de contas, obtivemos informações referentes a certos hábitos de compra e consumo do grupo familiar: lojas onde roupas eram adquiridas, suas preferências, costumes e comportamentos de Rui com dinheiro, principalmente quando este era direcionado a terceiros. A decisão pela consulta a estas fontes mostra-se consideravelmente inovadora, visto que estes documentos são, comumente, entendidos como meros objetos de curiosidade e, por vezes são desconsiderados pelos pesquisadores, e no decorrer deste trabalho ganham protagonismo e destaque incomum para os campos de conhecimento acima descritos. O principal referencial usado para direcionar as observações sobre os cadernos de contabilidade de Rui Barbosa foi o livro já citado de Lou Taylor, uma reconhecida referência para o estudo da cultura material. Outra autora de relevante para o campo é Rita Moraes de Andrade, que será comentada através do seu artigo Indumentária nos museus brasileiros: a invisibilidade das coleções (2016). Além dessas fontes, também foram usados o projeto original dos quimonos de Maria Augusta Rui Barbosa, de Anna Gabriela Pereira Faria (2016), também comentado anteriormente, e o livro "Parc Royal": um magazine na modernidade carioca (2013) de Marissa Gorberg e sites com informações sobre as lojas citadas. No decorrer da pesquisa, os cadernos poderão ser definidos como 'cadernos de contabilidade' ou 'notas de contas'. 
Os quimonos de Maria Augusta Rui Barbosa

O Museu Casa de Rui Barbosa (MCRB) é uma divisão da à Fundação Casa de Rui Barbosa (FCRB), instituição federal vinculada ao Ministério da Cultura. Afirma-se como missão do órgão 'o desenvolvimento da cultura, da pesquisa e do ensino cumprindo-lhe, especialmente, a divulgação e o culto da obra e da vida de Rui Barbosa' (Lei 4.943, 1966, art. 4ㅇ). De modo a reiterar esse objetivo, em 2016 é instaurada uma bolsa de pesquisa no programa iniciação cientifica (PIC), denominada "Os Quimonos de Maria Augusta Rui Barbosa": pesquisa, conservação e acesso ao público que elenca como objetivos:

- Classificar e identificar os modelos, as matérias primas e as técnicas empregadas na confecção dos quimonos;

- Pesquisar a origem dos tecidos usados a fim de averiguar sua nacionalidade;

- Estabelecer uma relação entre o comportamento e o pensamento de Maria Augusta Rui Barbosa e a "roupa de casa" do momento sócio-cultural em que viveu até 1948;

- Promover a conservação dos dois quimonos em novo acondicionamento;

- Propor condições ambientais de guarda dentro das limitações de uma casa do século XIX, bem como dentro de um projeto de novo prédio contemporâneo, exclusivo à guarda de indumentária histórica;

- Promover a divulgação e a fruição virtual dos exemplares; Participação em eventos acadêmicos para divulgação da pesquisa. (FARIA, 2016, p. 6).

As pesquisas preliminares do estudo se deram a partir do direcionamento dos objetivos e com base no método da historiadora Lou Taylor, que sugere uma investigação minuciosa, buscando os 'mínimos detalhes' de um artefato. Taylor afirma ainda que 'seguir todas as pistas possíveis a serem encontradas nas roupas sobreviventes é, portanto, essencial nos processos de identificação. As datas podem ser rastreadas, por exemplo, através das etiquetas dos fabricantes' (TAYLOR, 2002, p. 13). Ainda sobre o método adotado, a autora aconselha alguns preceitos, que envolvem 'localizar, identificar, conservar, exibir e finalmente interpretar o objeto' (TAYLOR, 2002, p. 13).

Os objetos a serem pesquisados a partir da metodologia descrita são dois quimonos que pertenceram Maria Augusta Rui Barbosa, esposa de do patrono do museu e da fundação. Segundo a ficha de catalogação das peças, ambos teriam sido presentes de seu filho, João, que os trouxe de uma viagem realizada pelo Japão. As fichas também fornecem uma breve descrição de cada peça.

Os quimonos foram analisados como fontes de informação, pois, o 'artefato - quando este sobrevive - pode ser um ponto de partida privilegiado na metodologia de investigação' (ANDRADE, 2016, p. 10), porém as peças não possuíam qualquer tipo de etiqueta. Sua forma e materialidade ainda estão em análise, a partir do apoio de profissionais qualificados e específicos dessas áreas.

O primeiro quimono tem coloração azul, sendo identificado e descrito como sendo 'em seda azul marinho, bordado nos tons, branco, vermelho, verde, ocre e azul claro. Mangas curtas e faixa para amarrar na cintura. Decorado por dragões, nuvens, árvores e quiosques' (PIRES, 1998, p. 2). A peça pode ser vista na figura 1.

Figura 1: Quimono azul de Maria Augusta Rui Barbosa 


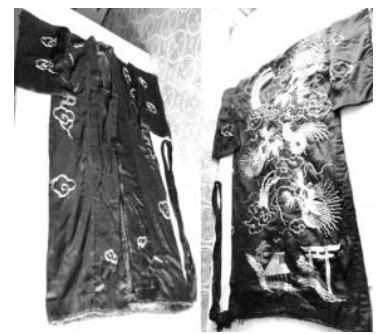

Fonte: Gabriela Lúcio de Sousa, 2016.

O outro é preto, e por sua vez, caracterizado da seguinte forma: 'quimono em seda preta, mangas curtas e faixa para amarrar na cintura. Decorada por galhos, folhas, flores, montanhas e barcos bordados em linha branca' (PIRES, 1998, p. 2), conforme ilustra a figura 2.

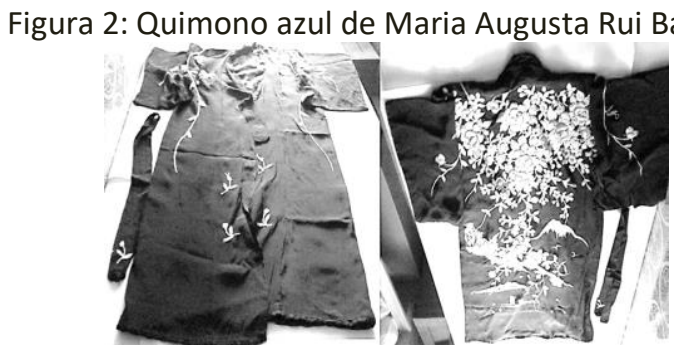

Fonte: Gabriela Lúcio de Sousa, 2016.

Além das fichas de catalogação, poucas fontes de informações direcionadas aos quimonos de Maria Augusta foram localizadas, resumindo-se à publicação Indumentária: Estudos sobre o Acervo do Museu Casa de Rui Barbosa, produzida pela museóloga Cláudia Barbosa Reis.

Dada à carência de informações específicas sobre os quimonos, outras fontes foram buscadas na própria instituição. E, após consultas no Arquivo Institucional da Fundação Casa de Rui Barbosa, as notas de contas de Rui Barbosa foram localizadas.

Os cadernos de contabilidade de Rui Barbosa

Em quatro meses, a coleção completa de notas de contas de Rui Barbosa foi pesquisada, totalizando 23 cadernos acondicionados em 5 caixas distintas. Neles, Rui anotava todos os gastos já realizados em um determinado período.

A partir destas investigações, informações relevantes e interessantes sobre Rui Barbosa e sua família, bem como sobre o acervo de têxteis do MCRB, foram coletadas. É importante salientar que os apontamentos descritos não são absolutos, alguns livros foram escritos com tintas metaloácidas, o que dificultou a leitura, e a caligrafia também causou alguns inconvenientes, por isso, foram anotados os itens compreendidos plenamente. No geral, compras relacionadas ao vestuário foram registradas quase em sua integralidade.

Os cadernos apresentam uma quantidade considerável de registros com costureiras e alfaiates. Algumas vezes estão especificados que o valor é para o conserto de alguma peça (geralmente chapéus) e em outras consta apenas como um pagamento ao profissional responsável, mas poucos eram nomeados. Mas um detalhe interessante está relacionado à compra de colarinhos, que são obtidos em grandes quantidades. Em 26/03/1884 Rui adquiriu 12 colarinhos em uma única transação.

A família Rui Barbosa comprava roupas de lojas de certo prestígio, no período, e alguns magazines nacionais e internacionais são especificados. Os nacionais são: Casa Raunier, Casa Clark (principalmente para o caso de botinas e chapéus de feltro), Casa Torres, Parc Royal. Os internacionais listados são Grands Magasins du Louvre, Le Bon Marché, John Barker \& Co Ltd e William Whiteley - The Universal Provider.

A Casa Raunier foi uma loja que vendeu roupas para homens e mulheres e consta em um dos cadernos através da anotação " 24 marcas de roupa 'Raunier'". É notada a grande quantidade 
de roupas, compradas de uma só vez na loja. Já o Parc Royal foi 'uma loja de departamentos que existiu no Rio de Janeiro entre 1873 e 1943' (GORBERG, 2013, p. 6.). O magazine mostrouse muito próximo as tendências europeias, como por exemplo, o orientalismo:

O estilista francês Paul Poiret (1879-1944) captou as tendências de vanguarda e afrouxou os contornos da silhueta feminina, acenando com uma forma mais fluida e solta, em vestes retas e alongadas, impregnadas de elementos orientais; suas criações estabeleceram novos parâmetros que ecoaram na moda em âmbito global. Numa observação comparativa entre anúncios do Parc Royal de 1908 e 1912, é possível perceber a flagrante mudança no estilo e nos contornos da roupa feminina; da cintura marcada pelo collete, usado com saia de roda ampla, aos chamados "Costumes de Tussor", mais retos, a mulher parece ganhar espaço para se mover. (GORBERG, 2013, p. 116.)

O Grands Magasins du Louvre foi uma loja de departamentos francesa, aparentemente uma concorrente do magazine Le Bon Marché, construída em meados de 1855 . O estabelecimento vendia robes de chambre, incluindo masculinos, como ilustra uma parte do catalogo da figura 3. O Le Bon Marché também é uma loja de departamentos e ainda está ativa, sendo a única da lista de comércios citados que existem até hoje. O magazine foi construído em meados de 1838. Atualmente, o estabelecimento vende uma grande variedade de produtos, muito além de roupas e acessórios.

Figura 3 - Parte do catálogo do Grands Magasins du Louvre, 1913-1914.

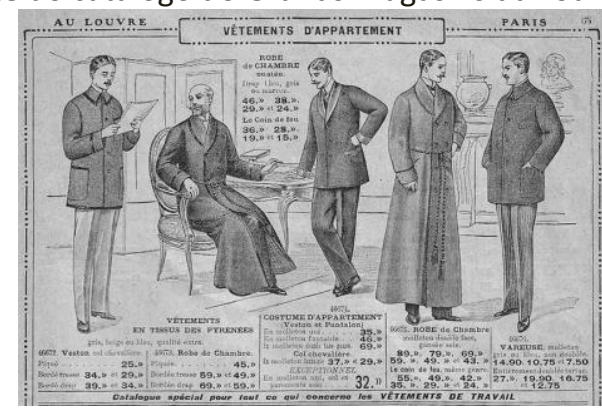

Fonte: Vieilleries et Antiquailles, 2016.

Já as histórias dos comércios John Barker \& Co Ltd e William Whiteley - The Universal Provider estão ligadas. Em 1870, John Barker deixou William Whiteley, seu parceiro nos negócios, para fundar um pequeno armazém de cortinas. Em 1871, ele mudou de endereço e fundou uma pequena alfaiataria e um área, dentro do comércio, dedicada ao vestuário juvenil. A loja continuou a crescer e, em 1894, tornou-se oficialmente John Barker \& Co Ltd. Seu funcionamento estendeu-se até 1988. O estabelecimento William Whiteley - The Universal Provider existiu entre 1863 e 1974, o nome de The Universal Provider (O provedor universal) foi concedido pelo próprio William Whiteley, para reafirmar a agilidade de sua entrega e a variedade de suprimentos, segundo Whiteley, ele poderia fornecer um alfinete para um elefante em um curto prazo (Time Out Guides, 172, 2005.).

\section{Considerações finais}

As pesquisas sobre os quimonos de Maria Augusta Rui Barbosa continuam e seguem de maneira plena e satisfatória, obtendo resultados significativos sobre a historicidade das peças. Seguindo o método de Lou Taylor, todas as fontes possíveis podem e devem ser pesquisadas, evidenciando assim a importância da interdisciplinaridade nesse trabalho. Em muitas situações, as investigações apontam para caminhos que, aparentemente, não se relacionam com o objetivo inicial, mas, as informações obtidas através dos cadernos de contabilidade de Rui Barbosa mostraram o seu interesse e o de Maria Augusta em adequarse à moda vigente no período. Esta por sua vez, quando moça, 'cosia os seus próprios vestidos' 
(REIS, 1999, p. 9), e, já mais velha e casada, adquiria uma quantidade razoável de chapéus de diferentes materiais, além dos dois quimonos estudados na pesquisa.

As notas de contas confirmaram um certo interesse de Maria Augusta e Rui Barbosa por moda, além de uma aparente independência da esposa em relação a seu marido no que dizia respeito às suas compras, já que Rui entregava quantias de dinheiro em suas mãos. Sem dúvida, a inovação no uso desses cadernos de contabilidade como uma fonte de pesquisa apresenta uma nova e criativa oportunidade para o estudo das tipologias de acervos presentes no Museu Casa de Rui Barbosa.

\section{Referências bibliográficas}

ANDRADE, Rita Morais de. Indumentária nos museus brasileiros: a invisibilidade das coleções. Musas - Revista Brasileira de Museus e Museologia. Brasília. V.: il., n. 7, p. 10-31, 2016.

Etrust Wiki. Market Gardeners Factsheet: William Whiteley. Disponível em:

<http://etrustwiki.co.uk/et/images/8/89/William-whiteley.pdf>. Acesso em: 13 jun. 2016.

FARIA, Anna Gabriela Pereira. Projeto - Os Quimonos de Maria Augusta Rui Barbosa: pesquisa, conservação e acesso ao público. Disponível em:

$<$ http://www.casaruibarbosa.gov.br/arquivos/file/bolsistas16/h_Os_Quimonos_Maria_Augusta_Rui_Barbosa_ 2016.pdf>. Acesso em: 11 jun. 2016.

GORBERG, Marissa. Parc Royal: um magazine na modernidade carioca / Marissa Gorberg. 2013. 148f.

Dissertação (Mestrado em História, Política e Bens Culturais) - Centro de Pesquisa e Documentação de História Contemporânea do Brasil - CPDOC, Fundação Getúlio Vargas, Rio de Janeiro, 2013.

LE BON MARCHÉ. About us. Disponível em: <http://www.lebonmarche.fr/>. Acesso em: 11 jun. 2016. Presidência da República (Casa Civil). Lei № 4.943, de 6 de abril 1966. Disponível em: <http://www.planalto.gov.br/ccivil_03/leis/1950-1969/L4943.htm>. Acesso em: 11 jun. 2016.

PIRES, José Manoel de Andrade. Ficha de catalogação - 50.810A - Quimono (Relatório MARC). Museu Casa de Rui Barbosa, Rio de Janeiro, 1998.

PIRES, José Manoel de Andrade. Ficha de catalogação - 66.881A - Quimono (Relatório MARC). Museu Casa de Rui Barbosa, Rio de Janeiro, 1998.

REIS, Cláudia Barbosa. Indumentária: Estudos sobre o Acervo do Museu Casa de Rui Barbosa - II. Edições Casa de Rui Barbosa: Rio de Janeiro, 1999.

SAN-MILLÁN, Pedro Barbáchano. Las tintas metaloacidas y su conservacion. In: Decimo congreso de estudios vascos., 1987. Pamplona. Anais do Decimo congreso de estudios vascos - Archivos, bibliotecas y museos. Donostia-San Sebastián, 1988, p. 411-412.

TAYLOR, Lou. The Study of Dress History. Manchester: Manchester University Press, 2002.

Time Out Guides. Time Out London Walks, Volume 2: 25 Walks by London Writers. Londres: Time Out Guides, 2005.

THE HOUSE OF FRASER ARCHIVE. Company: John Barker \& Co Ltd. Disponível em:

$<$ http://www.housefraserarchive.ac.uk/company/?id=c0537>. Acesso em: 11 jun. 2016.

THE NATIONAL ARCHIVES. William Whiteley, Department Store, Queensway. Disponível em: <http://discovery.nationalarchives.gov.uk/details/rd/a9a31d39-c40d-402d-9a98-94af2b598abe>. Acesso em: 11 jun. 2016.

UNIVERSITY OF GLASGOW ARCHIVE SERVICES. The story of John Barker \& Co Ltd, Kensington, London. Disponível em: <http://www.gla.ac.uk/media/media_91174_en.pdf>. Acesso em: 11 jun. 2016. 
VIEILLERIES ET ANTIQUAILLES - LA MALLE AUX TRÉSORS. Grands Magasins du Louvre, hiver 1913-1914 - 14. Disponível em: <http://www.dzoing.fr/antiquailles/article69/grands-magasins-du-louvre-hiver-1913-191414>. Acesso em: 11 jun. 2016. 


\title{
METODOLOGIAS TRANSDISCIPLINARES EM HISTÓRIA DAS CIÊNCIAS: MINERAÇÃO DE DADOS EM DOCUMENTOS HISTÓRICOS
}

\author{
Daniel Maia - Doutorando do HCTE-UFRJ - danielmaia@hcte.ufrj.br \\ Regina Maria Macedo Costa Dantas - Professora do HCTE-UFRJ - regina@hcte.ufrj.br
}

\section{Resumo}

O presente artigo faz parte de um trabalho em desenvolvimento contínuo referente à constituição de uma rede de agenciamentos informacionais, extraída de documentos históricos, notadamente periódicos científicos especializados. É o recorte da dissertação de mestrado apresentada anteriormente pelo autor, tratando de modelagem e análise computacional-imagética de dados, tendo como base a Teoria dos Grafos e a Teoria de Redes, tema de crescente interesse na Ciência da Informação e abordagem recente no campo da Metodologia da História. Visa fortalecer a área de História das Ciências e as conexões transdisciplinares como parte de uma renovação das políticas científicas em procedimentos de inovação como elementos indispensáveis das políticas de Estado para as Ciências e as Tecnologias.

Palavras-chave: Teoria de Redes. História das Ciências no Brasil. Transdisciplinaridade.

\section{Introdução}

O desenvolvimento da microeletrônica e as potencialidades que os computadores trouxeram para as ciências nos proporciona hoje um novo horizonte de aplicações sociotécnicas, até mesmo para a ciência histórica, o que requer maior atenção de historiadores profissionais na aquisição de habilidades além do seu campo de atuação, provocando também uma mudança nas mentalidades institucionalizadas das ciências e dos cientistas. Concentrados na formalização e afirmação disciplinar da História desde o século XIX, os historiadores estabeleceram fronteiras epistemológicas mais seguras para analisar o processo de desenvolvimento das civilizações no tempo. No entanto, com o desenvolvimento científico e tecnológico, mudanças profundas surgiram no seio das sociedades que se encontravam num processo de modernização. Passados mais de cem anos, tendo adentrado em um novo milênio, a comunidade científica se vê na necessidade de reformular processos metodológicos no que diz respeito às pesquisas documentais, em particular no âmbito da História.

A partir de uma abordagem quali-quantitativa, tendo o documento como base discursiva, é possível transcrever a linguagem escrita em uma outra, híbrida, indexável e dinâmica, produzindo uma nova categoria de fonte, capaz de revelar novas relações, que de outro modo não seria possível, ou mesmo custoso para o pesquisador de identificar. Um modo de fazer historiográfico que considera um conjunto de fontes que perpassa diversos domínios teóricometodológicos, e ao tratar a documentação como uma série de dados, tem-se no software de computador um instrumento indispensável na construção de análises mais sofisticadas que utilizam teorias matemáticas para a visualização de dados históricos.

Assim, o estudo de caso realizado na dissertação de mestrado se utilizou do periódico Archivos do Museu Nacional, disponível digitalmente e parte do acervo da Seção de Memória e Arquivo (SEMEAR) do Museu Nacional/UFRJ, como fonte primária para a extração e classificação de dados a serem utilizados na modelagem por software para a criação de um 
novo tipo de fonte documental: um grafo. O software Gephi foi desenvolvido para visualização e exploração de dados, podendo o pesquisador interagir com a representação visual, manipular as estruturas e suas propriedades para revelar padrões ou relações que de outro modo seria difícil de se estabelecer.

As capacidades computacionais do referido software traduzem o esforço epistemológico dessa proposta de modelagem, visto que é dotado de algoritmos capazes de criar layouts e métricas a partir da transcrição dos dados trabalhados ao longo da pesquisa. A representação espacial da informação então pode ser visualizada de uma forma inovadora enquanto proposta teórico-metodológica, produzindo, como dito anteriormente, uma fonte de pesquisa híbrida e dinâmica, algo novo e necessário diante dos problemas ainda enfrentados por profissionais que lidam com documentação não-indexada. O uso do Gephi é bastante apropriado, visto que o modo operacional por trás de suas funções tem como base a teoria de grafos, o que produz uma leitura sobre as redes na historiografia e metodologia da História ainda pouco trabalhada no campo.

A teoria dos grafos é um ramo da matemática que estuda as relações entre os objetos de um determinado conjunto. Tais objetos são denominados nós, e as relações entre eles, arestas. Estruturas que podem ser representadas por grafos estão em toda parte e muitos problemas de interesse prático podem ser formulados como questões sobre certos grafos. Na pesquisa em questão estabeleceu-se uma analogia conceitual entre as características dos elementos de um grafo e os elementos textuais dos documentos analisados. Tais elementos abrangiam referências à pessoas, lugares ou mesmo objetos, graus de influência ou acontecimentos.

Tal abordagem demonstra as potencialidades da pesquisa transdisciplinar, como também revela novos desafios e problemas. A Teoria de Redes tem também nos fornecido análises cada vez mais precisas sobre as relações entre entidades, aqui especialmente as relações sociais entre indivíduos e instituições dentro de uma cultura científica em desenvolvimento. A formação de agrupamentos ou clusters traduz as crises paradigmáticas dos campos do conhecimento, a dinâmica da transmissão de conhecimento e a formação e desaparecimento de comunidades científicas e seus agentes.

Mapear o conhecimento científico parece ocupar, já há algum tempo, o campo intelectual de uma pequena parcela de especialistas (BERNAL, 1946, LEYDESDORFF, 2001). Ainda assim, é de fato o desvelamento de novos resultados e perspectivas inovadoras. Ademais do fato que a linguagem que usamos para descrever as ciências é repleta de metáforas espaciais, como "campo" e "área" de pesquisa, quando tentamos verdadeiramente criar um mapa das ciências, logo percebemos que os procedimentos usados para fazer mapas de conotação espacial estão se tornando insuficientes.

Devemos lidar com as associações e relações abstratas entre entidades como ideias científicas, especialidades, campos ou disciplinas cujas próprias existências podem estar abertas à crítica. Chaomei Chen lança a pergunta em Mapping Scientific Frontiers (CHEN, 2013, p. vi): faz sentido procurarmos uma representação espacial de tais entidades abstratas, ou mesmo hipotéticas? Nossos cérebros estão programados para considerar o que é relacional e projetar isso no espaço real? Considerando o desenvolvimento tecnológico na criação de interfaces que estendem as capacidades de representação da cognição humana, ao projetar abstrações num espaço virtual cheio de pixels, podemos dizer que sim. Ainda segundo Chen, a apreensão do mapeamento científico pode parecer difícil devido a três estágios conceituais requeridos para dar sentido ao processo como um todo. Primeiro, uma unidade de análise deve ser escolhida para abranger as partículas elementares do universo científico. Segundo, uma medida de associação entre as unidades deve ser definida. Terceiro, um meio deve ser encontrado para retratar as unidades e suas relações num espaço dimensional perceptível, geralmente duas dimensões. 
Críticos da cientometria (HARRIS, 2006; STYHRE, 2003; WILSON, 2002) alegam que o foco na literatura científica como sua fonte primária limita severamente os dados cujos estudos de ciências podem ser baseados. Por outro lado, a crescente disponibilidade de textos completos de artigos científicos, em formatos que podem ser lidos por computador, abre muitos novos tipos de dados para análise os quais, quando usados em conjunto com os bancos de dados online padronizados vão muito além do que tem sido possível usando apenas os índices padronizados.

Os agenciamentos do processo cartográfico das ciências, entre as várias escolhas para unidades de análise como palavras, referências, autores, periódicos, e os meios de associá-los como palavras relacionais, citações cruzadas ou diretas e coautoria parecem se reduzir aos tipos de estruturas e níveis relacionais que queremos observar.

Outra questão importante é a interpretação dos mapeamentos. É sabido que os agenciamentos em rede que são representados em mapas são hiperdimensionais, e que a projeção em duas dimensões é inevitavelmente uma aproximação que pode colocar duas unidades pouco relacionadas muito próximas. Isso requer a necessidade de prestar bastante atenção aos agenciamentos propriamente ditos, os links, o que faz surgir a solução bidimensional em primeiro lugar, ao tentar visualizá-los como rede neural.

Apenas sabendo o que os agenciamentos significam teremos uma melhor compreensão do que o mapeamento representa. Isso envolve olhar mais profundamente para o contexto do plano de forças atuando no espaço desses agenciamentos, e procurar novos modos de representação e categorização dessas relações, se tem função causal, lógica, social, hipotética ou metafórica. Em última instância, tais análises visuais têm como objetivo servir de suporte para decisões estratégicas, particularmente no que diz respeito às políticas científicas.

A particularidade do mapeamento científico é perceber o horizonte constantemente mutável, em que, ano após ano, uma nova leva de artigos publicados, provocam mudanças estruturais e fazem surgir novas áreas, evoluem outras tantas, e algumas acabam por sucumbir. $\mathrm{O}$ acaso é inerente às ciências, assim como seu mapeamento. Não se sabe se as descobertas podem ser previstas, se existem antecedentes reconhecíveis ou condições, se podem ser programadas para acontecer antecipadamente.

Mas, como as descobertas ficam aparentes nos mapas após sua ocorrência, também há a possibilidade de estudar os mapeamentos de períodos antecedentes e procurar por suas estruturas fundacionais. É nesse sentido que se abre espaço para a abordagem da teoria dos grafos enquanto abstração matemática para a elaboração do modelo computacionalimagético proposto na pesquisa.

Para ilustrar o problema proposto no presente artigo, apresento três situações possíveis na extração de dados de documentos históricos. Considerando a utilização de softwares que podem ou não automatizar o processo de construção de mapas relacionais, isso definirá a precisão do modelo e da própria análise das informações.

Como demonstrado na Figura 1, o processamento de informações em documentação histórica pode sofrer inconsistências dependendo da técnica aplicada. Na primeira coluna, temos o documento em estado bruto, apenas escaneado; na segunda coluna, o documento passa por um processo de reconhecimento óptico de caracteres (OCR), o que ainda não garante cem por cento de precisão, mas já permite a seleção de textos; e por fim, um texto que já se origina em seu formato digital possibilita a transcrição direta de informações na construção de um modelo computacional-imagético. 
Figura 1 - Possibilidades e restrições para mineração de dados textuais. 
Agardh (G. H.)

Baillon (Henrique).

Barboza du Bocage. (J. V.)

Beaurepaire Rohan

(Henrique de)

Beneden (Ed. Van).

Benthan (Jorge).

Bom Retiro (Visconde do)

Braun (Alexandre).

Bureau (Eduardo).

(Candolle (Affonso de).

Coelho d'Almeida (Thomas

J.)

Darwin (Carlos).

Decaisne (José).

Delpino (F.)

Duchartre (Pedro).

Eichler (A. W.)

Exner (Mauricio).

Fenzl (Ed.)

Ferreira Penna (D. S.)

Fries (Elias).

Glaziou (A. F.)

Gorceix (Henrique). 
A problemática da representação de agenciamentos, quando estes se manifestam como associações subjetivas, na esfera do social e do mental, requer a construção de metáforas visuais que traduzam o espaço de fluxo de modo a validar o não-dito. "Atributos visuais de configurações topológicas e geométricas tem de transformar o conhecimento intangível e invisível em algo concreto e significativo" (CHEN, 2013).

O processo de transcrição do documento histórico textual em uma fonte híbrida, constituída de camadas de informação digital e visual, é o modo como esse método transdisciplinar de modelagem pode construir um novo entendimento sobre o conhecimento. Torna legível as infinitas associações visuais subjetivas, onde, em "isolamento" o texto acaba por permanecer numa linearidade inescapável. Enquanto estudo histórico das instituições científicas, podemos compreender mais facilmente a dinâmica entre os sujeitos, onde o processo cognitivo classifica os caminhos, os clusters, as relações, como um organograma fluido. Quanto mais associações são feitas no espaço de fluxo, melhor nossa compreensão sobre sua dinâmica e suas transformações estruturais.

O pensamento visual é uma fonte peculiar de estruturação e processamento de conceitos, onde voltamos nossa atenção para o campo como um todo, depois partindo para os detalhes. No processo da abstração o indivíduo pode reestruturar ou mesmo transformar os conceitos, resultando disso uma experiência concreta agora visível. A modelagem computacionalimagética realizada a partir da extração de informações textuais de cunho histórico nos oferece caminhos para uma análise transdisciplinar como complemento da visualização da informação complexa. Trata-se da constante comunicação entre métodos analíticos e processos cognitivos, que juntos geram insights visuais para revelar novas interpretações. São construções metafóricas, muitas vezes implícitas, que a informação textual isolada não é capaz de revelar.

O uso do software Gephi apresenta, para um pesquisador fora da área da computação, uma curva de aprendizagem bastante acentuada. Ainda assim, o programa apresenta recursos de visualização e manipulação de dados que se adéquam as necessidades do usuário. Uma das características utilizadas no software foi a filtragem de dados e a construção da topologia de rede. Dentre inúmeras possibilidades de filtragem, foi escolhida a Rede Egocentrada com a indicação manual de um nó específico da rede, nesse caso, o Museu Nacional. Quanto a topologia da rede, o software disponibiliza layouts que organizam a distribuição de acordo com o número de arestas e nós interconectados, ou para usar o vocábulo mais presente na pesquisa, de acordo com os agenciamentos estabelecidos entre sujeitos, instituições e a produção científica.

A Figura 2 demonstra o resultado da modelagem feita a partir da extração manual dos dados textuais do periódico Archivos do Museu Nacional, e assim é possível verificar a formação de padrões de agrupamento, como também o grau de influência de determinados nós da rede, não apenas pelo número de conexões que se atravessam mas também pelo seu papel na topologia da rede. 
Fig.2.: Grafo da Rede de Relações Científicas Institucionais do Museu Nacional.

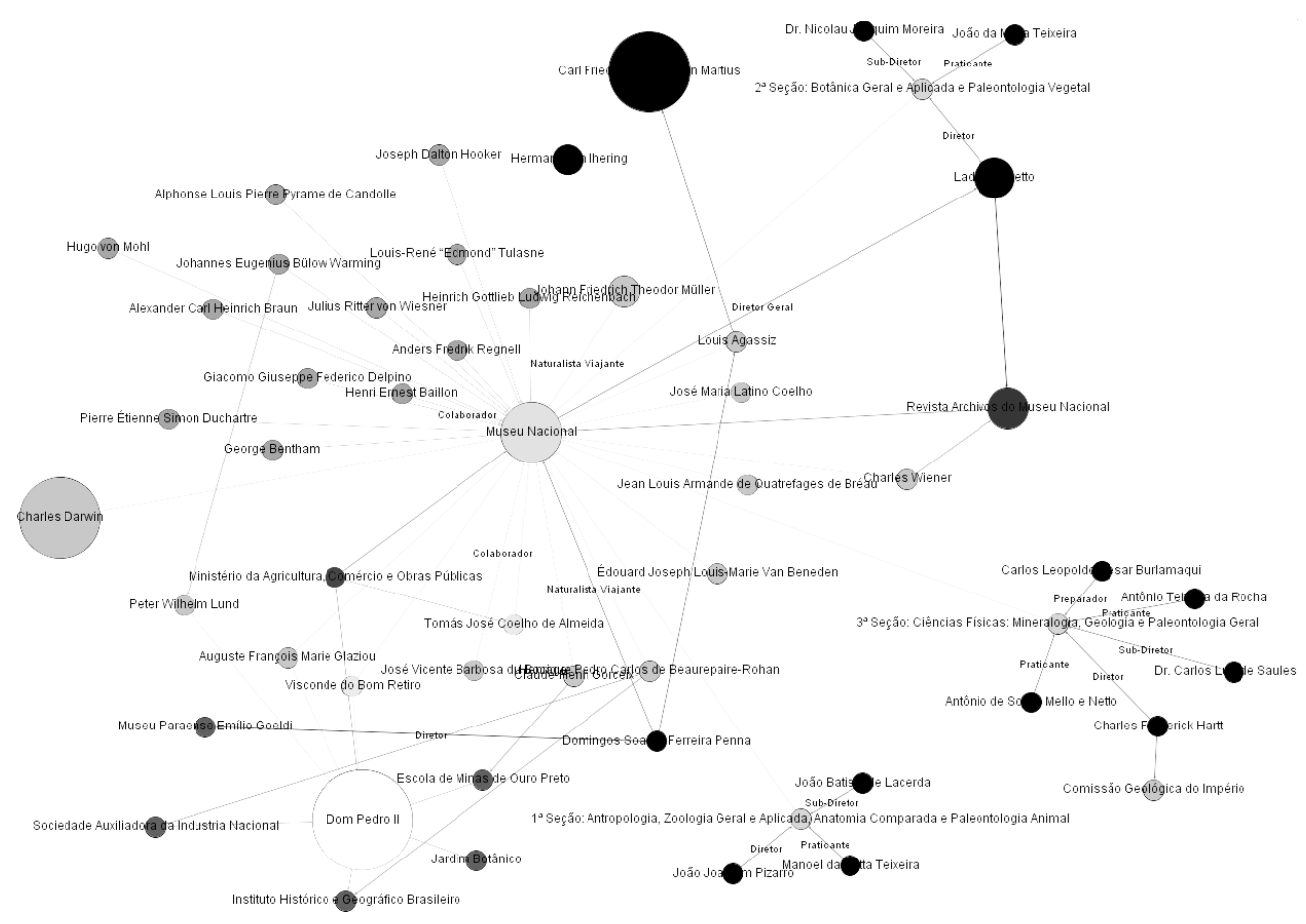

O exemplo emblemático dessa modelagem foi a interpretação do espaço ocupado por Dom Pedro II (destacado em rosa claro) na Rede: apesar de ser um elemento de grande influência na formulação de políticas científicas do Império ele não era um elemento central da estrutura comunicacional em análise. Já o Museu Nacional, por meio de seu periódico (destacado em vermelho), determina as capacidades comunicacionais entre os demais elementos da rede, visto que era a partir da instituição que se produzia a revista e também por meio dela, se estabelecia o vínculo com pesquisadores brasileiros e estrangeiros, com destaque para Charles Darwin (destacado em verde claro).

\section{Conclusão}

Sobre as dificuldades da pesquisa, o primeiro obstáculo observado na análise documental, levando-se em consideração a preocupação com a eficácia da extração dos dados, foi a impossibilidade da identificação automática dos termos sensíveis na elaboração de um banco de dados relacionais. No trabalho historiográfico, a análise documental representa uma grande parcela do tempo de dedicação à pesquisa. Ainda assim, tendo hoje disponível tecnologia capaz de reconhecer padrões de escrita, conhecida como OCR (Optical Character Recognition), tal recurso não pôde ser utilizado com eficácia devido o tempo que levaria para corrigir a imprecisão do próprio procedimento, fazendo com que fosse descartado para a presente pesquisa.

Isso gerou uma dificuldade na precisão da coleta de dados e a própria construção dos grafos, visto que o software poderia ser alimentado de forma automática com o output do processo de reconhecimento de caracteres. Em conformidade com as condições de coleta e extração de dados, a pesquisa prosseguiu também com uma bibliografia complementar de origem eletrônica, a partir de livros e artigos encontrados na Rede Mundial de Computadores. Isso nos traz ao final dos questionamentos da pesquisa no que diz respeito não só a elaboração de novos métodos e sobre a criatividade individual do cientista, mas também sobre as políticas científicas elaboradas no seio das instituições governamentais e das comunidades acadêmicas e os custos financeiros restritos a um modelo de política protecionista que não proporciona 
acesso à informação, à própria comunidade científica e ao público em geral. A questão da acessibilidade científica está presente desde antes do surgimento dos periódicos especializados, e sendo a presente pesquisa centrada justamente nesse tipo de fonte como objeto, foi possível perceber como a dinâmica das descobertas científicas se modifica quando estas são disponibilizadas abertamente por meio do agenciamento de redes de sujeitos e instituições.

\section{Bibliografia}

ARCHIVOS DO MUSEU NACIONAL. Museu Nacional: Imprensa Industrial, v. 1, 1876.

BERNAL, J. D. The Social Function of Science. London: G. Routledge \& Sons Ltd, 1946.

CHEN, Chaomei. Mapping Scientific Frontiers. 2. ed. Pennsylvania: Springer, 2013.

HARRIS, K. Knowledge management enables the high performance workplace. Gartnet Inc, 2006. Acesso em 08 jan 2017. Disponível em: https://www.gartner.com/doc/489448/knowledge-management-enableshighperformance-workplace.

LEYDESDORFF, Loet. The Challenge of Scientometrics: the development, measurement, and self-organization of scientific communications. 2.ed. Florida, USA: Universal Publishers, 2001.

MAIA, D. Uma Cartografia de Redes Institucionais: método transdisciplinar e modelagem computacionalimagética da História das Ciências no Brasil. Rio de Janeiro: 2017. Dissertação (Mestrado em História das Ciências, das Técnicas e Epistemologia) - Universidade Federal do Rio de Janeiro.

STYHRE, Alexander. Understanding knowledge management: Critical and postmodern perspectives. Copenhagen: Copenhagen Business School Press, 2003.

WILSON, T. D. The nonsense of 'knowledge management'. Information Research, 8(1), 2002. 


\title{
DAS PÁGINAS DO DIÁRIO ÀS PÁGINAS DO BLOG: DEFICIÊNCIA E CORPO NA NOVELA VIVER A VIDA
}

\author{
Vanessa Nogueira Maia de Sousa - Doutoranda do PPG em Humanidades, Culturas e Artes da UNIGRANRIO - \\ UNIGRANRIO - vanessousa@yahoo.com.br \\ Daniele Ribeiro Fortuna - Professora do PPG em Humanidades, Culturas e Artes da UNIGRANRIO - \\ drfortuna@hotmail.com \\ Márcio Luiz Correa Vilaça - Professor do PPG em Humanidades, Culturas e Artes da UNIGRANRIO - \\ professorvilaca@gmail.com
}

\section{Resumo}

O presente trabalho apresenta projeto de pesquisa de doutorado desenvolvido no programa de Pós-Graduação em Humanidades Culturas em Artes da Universidade Unigranrio. Propõe o debate sobre o corpo da pessoa com deficiência retratado na novela "Viver a Vida". Esta telenovela traz não só um tema sempre necessário e atual, como a deficiência, mas inova na comunicação: a mensagem é transmitida não somente pela TV, mas também por um blog. Este projeto busca entender como a mídia retrata social e culturalmente esta deficiência.

Palavras-chave: Corpo, Deficiência, Mídia, Novela, Blog

Introdução

Este texto apresenta o projeto de pesquisa de doutorado "Das páginas do diário às páginas do blog: deficiência e corpo na novela Viver a vida", desenvolvido no programa de PósGraduação em Humanidades, Culturas e Artes da Universidade Unigranrio, em Duque de Caxias, no Rio de Janeiro.

Nesta pesquisa, procuramos entender, através da comunicação transmídia, transmitida pela telenovela "Viver a vida", como a deficiência física é abordada e representada. O problema que permeará a tese é verificar como a deficiência física é apresentada pela mídia, mais especificamente pela telenovela global "Viver a vida" e o blog "Sonhos de Luciana", um diário virtual escrito pela personagem Luciana durante a novela, mas que contava com interação real dos espectadores, estabelecendo uma estratégia que era diferenciada na integração entre mídias para aquele momento.

Criada pelo autor Manoel Carlos, e com a colaboração de Ângela Chaves, Cláudia Lage, Daisy Chaves, Juliana Peres e Maria Carolina, a novela Viver a vida foi transmitida pela Rede Globo no horário nobre da emissora, às $21 \mathrm{~h}$, no período de 14 de setembro de 2009 a 14 de maio de 2010.

Dividida em 209 capítulos, esta novela traz a primeira "Helena" negra dentre as tramas já escritas pelo autor. Conforme abordado em reportagens e programas de televisão, Manoel Carlos é conhecido pelas suas personagens protagonistas batizadas como "Helena". A história se passa nas cidades do Rio de Janeiro e Búzios, ambas localizadas no Estado do Rio de Janeiro. Toda esta análise só se faz possível a partir da discussão do papel da telenovela no cenário sociocultural brasileiro. A novela está inserida em um contexto social concreto, atual. Entretanto, deve-se levar em consideração que suas narrativas buscam a expressão de uma realidade ficcional. De acordo com Lopes (2003, p.18).

A televisão oferece a difusão de informações acessíveis a todos sem distinção de pertencimento social, classe ou região. Ao fazê-lo, ela torna disponíveis repertórios anteriormente da alçada privilegiada de certas instituições socializadoras tradicionais como a escola, a família, a igreja, o partido político, a agência estatal. 
Nesse sentido, a novela "Viver a vida" apresenta à sociedade a questão da deficiência física, mas, cabe ressaltar, de uma maneira que não retrata exatamente a realidade. Durante a trama, a modelo Luciana, personagem representada pela atriz Alinne Moraes, sofre um grave acidente de carro, no deserto de Wadi Rum, na Jordânia, que a deixa tetraplégica. $\mathrm{O}$ acidente acontece quando Luciana e Helena - também modelo - estão a caminho do aeroporto de Amã, capital da Jordânia, depois de terem participado de um trabalho na cidade. Luciana como a maioria dos personagens criados por Manoel Carlos - é de classe média alta e, portanto, tem acesso aos melhores tratamentos.

Após a tragédia, angustiada por causa de sua situação, Luciana resolve escrever um blog para relatar as dificuldades pelas quais passava. O blog "Sonhos de Luciana" não fez parte apenas da ficção. Ele foi de fato publicado na internet, e os espectadores comentavam os posts de Luciana, criando a possibilidade de interação entre a realidade e a ficção.

Com o acidente, o corpo de Luciana mudou, segundo suas primeiras impressões expressas nos capítulos subsequentes ao acidente, para um corpo preso, sem expressão, sem a liberdade e a alegria tão presentes no corpo da modelo até então.

De acordo com Le Breton

\begin{abstract}
, "é difícil a ritualização da parte do desconhecido: como abordar esse homem na cadeira de rodas ou com o rosto desfigurado? Como reagirá o cego à eventual ajuda para atravessar a rua, ou o tetraplégico que tem dificuldades para descer da calçada com sua cadeira?" (LE BRETON, 2007, p. 74):
\end{abstract}

Diante do desconforto de uma deficiência não sutil, este corpo se torna incômodo, sem atenuações para a aceitação social. Torna-se difícil negociar uma definição mútua de inserção fora das referências costumeiras. O homem que dispõe da integridade física tende, então, evitar passar por um mal-estar desagradável.

Esta foi a primeira novela que utilizou uma ferramenta online como extensão de sua narrativa - o blog, como extensão da própria telenovela. No site de "Viver a vida" - ainda online - há também a opção de receber torpedos no celular sobre informações a respeito dos capítulos, além da seção da loja virtual com os produtos que foram usados na novela, como bolsas, por exemplo. Ainda sobre o site, estava disponível também um especial chamado "Portal da superação". Este último não está mais disponível desde a data da nossa última consulta, em 12 de setembro de 2017.

De acordo com Ayres (2015, p.71), "o termo blog deriva de weblog que significa diário na web". Para Luciana, o blog era, sim, um diário, no qual ela poderia registrar suas vivências e suas lembranças. Desde o início da novela, a personagem é mostrada com seu diário nas mãos, sempre escrevendo e lendo poesias. No capítulo 51, quando o acidente no deserto ocorre, Luciana estava com seu diário registrando suas experiências.

É importante registrar que o conteúdo de cada post era selecionado por Luciana; ela, em muitos capítulos, é mostrada escrevendo no blog, falando sobre ou mostrando algum assunto que queria abordar.

Segundo Ayres,

\footnotetext{
"estes posts não são um resumo do capítulo da telenovela, assim como não necessariamente tratam sobre os assuntos que estiveram em pauta em um determinado capítulo. Os textos também não seguem uma ordem sequencial. Não é preciso ler as diferentes postagens em uma ordem específica para compreender o relato". (AYRES, 2015, p.72),
}

O que difere o blog e o diário é a questão do conteúdo compartilhado: enquanto aquele pode ser secreto, o segundo será lido por todos. O autor do blog que outros o lerão, e o objetivo é 
este, que este material seja compartilhado. O blog busca uma troca, segundo afirma Ayres (2015): quem escreve espera um comentário.

E no blog Sonhos de Luciana foram postados milhares deles - 13.021, no total. Cada uma das postagens recebeu centenas de comentários. Vale ressaltar que estes relatos eram feitos por pessoas com deficiência ou não, também por crianças, jovens, idosos, pessoas de todas as regiões do país e também de outros países. Até hoje o blog está online, seu conteúdo e os comentários estão disponíveis para o acesso.

Todo o conteúdo dos posts foi desenvolvido pelas colaboradoras de Manoel Carlos, e as temáticas abordadas eram variadas, não somente em torno da deficiência, mas também temas como poesia, música, viagens, dilemas sentimentais etc. eram abordados.

A primeira postagem no blog ocorreu em 8 de fevereiro de 2010 e o último post em 15 de maio de 2010. No total, foram 84 posts (postagens), divididos entre as seguintes categorias: acessibilidade, rotina, tecnologias, cuidado, amor, gravidez, música, poesia, casamento, filhos, família, cadeira de rodas etc.

Convém apresentar algumas considerações sobre blogs, de forma a possibilitar melhor compreensão de questões metodológicas e sobre o funcionamento básico de blogs, apesar de que estes tenham seus usos modificados ao longo do tempo.

O blog é uma ferramenta popular da chamada web 2.0, marcada por forte interação entre os usuários, que deixam de ser predominantemente consumidores de conteúdos e passam também a ser autores e coautores em diferentes proporções. Usado como estratégia de interação não apenas entre pessoas, os blogs passam gradualmente a serem usados como um canal de interação entre marcas e clientes ou consumidores. Se na sua origem os blogs eram vistos como o equivalente online dos diários pessoais, com o tempo passaram a ser usados, entre outros usos, como ferramenta para colunas de leigos, jornalistas e especialistas de diferentes áreas.

Os blogs são organizados basicamente em dois tipos de conteúdos: as páginas e os posts (ou postagens). O mais comum é o post, que geralmente, é organizado por ordem cronológica de publicação, da mais recente para as mais antigas. Os blogs permitem que os visitantes publiquem comentários. $O$ administrador do blog pode definir quais conteúdos podem ser comentados e se os comentários são moderados antes de ficarem visíveis para público. A moderação pode ser inviável em blogs de elevada visitação por causa do número muito grande de comentários que as publicações podem gerar. Os conteúdos são basicamente classificados ou organizados por categorias (de forma semelhante a temas ou tipo de conteúdos) e por tags (semelhante a palavras chave). As categorias e as tags possibilitam filtrar os conteúdos e localizar publicações mais específicas. Um post pode ser participar de várias categorias, assim como também não há um número específico de tags que podem "marcar" aquele conteúdo específico. Os "nomes" das categorias e tags podem coincidir. Em geral, o número de categorias é reduzido, enquanto as tags podem variar muito.

\section{Objetivos}

O objetivo geral do projeto é analisar se há a possibilidade de inclusão da pessoa com deficiência através da novela referida e do blog. Como instrumento para aferir tal objetivo, analisaremos a trama e os comentários realizados pelos leitores do blog.

Como objetivos específicos, pretendemos:

- identificar se a pessoa com deficiência se sente mais à vontade de se abrir no ambiente digital por não ter sua identidade revelada;

- analisar quais são as perspectivas para a mídia/transmídia em relação à pessoa com deficiência; 
- em relação ao blog, pesquisar a relação de uma personagem com deficiência e autora fictícia do mesmo, com a interação deste público; como se dá esta nova comunicação?

Metodologia:

A pesquisa é qualitativa, de análise documental. Como define Gil

\begin{abstract}
"O desenvolvimento da pesquisa documental segue os mesmos passos da pesquisa bibliográfica. Apenas há que se considerar que o primeiro passo consiste na exploração das fontes documentais, que são em grande número. Existem, de um lado, os documentos de primeira mão, que não receberam qualquer tratamento analítico, tais como: documentos oficiais, reportagens de jornal, cartas, contratos, diários, filmes, fotografias, gravações etc". (GIL, 2008, p.51):
\end{abstract}

Assim, pretendemos atingir os objetivos citados anteriormente por meio da análise da novela e também dos comentários realizados pelos leitores do blog "Sonhos de Luciana". Serão selecionados posts, de acordo com a classificação das categorias e tags mais citadas.

Após esta filtragem, serão selecionados os textos em que pessoas que se classificam "deficientes" estejam esboçando sua história, seu relato. O objetivo é "ouvir" esta voz, é analisar este texto, verificando se há identificação, ou não, com a personagem da novela.

A metodologia inclui uma tabulação dos comentários. Dentre os 84 posts, as seguintes tabulações foram realizadas: por número total de comentários, pelos mais comentados, pelas categorias e pelas tags. Abaixo, a Tabela 1 com os 20 posts mais comentados:

Tabela $1-20$ post mais cometados

\begin{tabular}{|c|c|c|}
\hline Post & Mais comentados & Categoria/Tag \\
\hline 55 & 436 & Preconceito / Ingrid \\
\hline 54 & 371 & Coisas que amo/lista \\
\hline 58 & 347 & O que faço/hanbike \\
\hline 57 & 275 & Fisioterapia/felicidade \\
\hline 78 & 271 & Casamento/núpcias \\
\hline 56 & 258 & Poesias/poesia \\
\hline 26 & 252 & Amor/amor \\
\hline 33 & 250 & Amor/Miguel \\
\hline 41 & 245 & Pensamentos/superação \\
\hline 79 & 233 & Lua de mel/Paris \\
\hline 65 & 231 & O que faço/saúde \\
\hline 42 & 224 & Amor/música \\
\hline 61 & 222 & Amor/Miguel \\
\hline 52 & 219 & Amor/sexualidade \\
\hline 76 & 205 & Amor/casamento \\
\hline 84 & 201 & Amor/gravidez \\
\hline 22 & 197 & Praia para todos \\
\hline 53 & 197 & Comentários/Portugal \\
\hline 27 & 193 & Entrevista/Camila \\
\hline 59 & 193 & Poesias/Chacal \\
\hline
\end{tabular}


Tabela 2 - Categorias mais citadas

\begin{tabular}{|l|l|}
\hline Categoria & Frequência \\
\hline Amor & 15 vezes \\
\hline Poesias & 9 vezes \\
\hline Casamento & 8 vezes \\
\hline Gente que amo & 8 vezes \\
\hline Acessibilidade & 5 vezes \\
\hline Pensamentos & 5 vezes \\
\hline Projetos bacanas & 3 vezes \\
\hline Música & 3 vezes \\
\hline
\end{tabular}

A partir das Tabelas 1 e 2, serão escolhidos os posts mais comentados e, a partir daí, será feita uma análise, que buscará perceber de que forma os internautas percebem o corpo e a deficiência da personagem Luciana.

Considerações finais:

Voltando o olhar para o cenário brasileiro, ao nos referirmos às pessoas com deficiência, estamos falando de uma extensa e significativa parcela da população. De acordo com o censo realizado pelo IBGE, em 2010, mais de 46 milhões de indivíduos - 24\% - se classificaram com algum tipo de deficiência.

É importante ressaltar que a temática deficiência gera muitas inquietações, mas estamos cientes de que, mesmo com o afinco dedicado a esta pesquisa, estas mesmas inquietações não se esgotarão. Entretanto, o debate e a pesquisa sobre o tema tornam-se cada vez mais fundamentais na academia.

\section{Referências bibliográficas}

AYRES, Melina de la Barrera. As representações da deficiência física na telenovela viver a vida. Uma etnografia de tela da intimidade: cuidado, corpo e sexualidade. Universidade Federal de Santa Catarina, Centro de Filosofia e Ciências Humanas, Programa de Pós-Graduação Interdisciplinar em Ciências Humanas, Florianópolis, 2015

BLOG SONHOS DE LUCIANA. Blog da personagem Luciana, da novela "Viver a vida". Disponível em < http://gshow.globo.com/novelas/viver-a-vida/sonhos-de-luciana/platb/>. Acesso em: jan 2017

BRASIL. Lei Brasileira de Inclusão. Lei № 13.146 de 06 de julho de 2015. Disponível em: <http://www.planalto.gov.br/ccivil_03/_Ato2015-2018/2015/Lei/L13146.htm>. Acesso em: jul 2015

GIL, Antônio Carlos. Métodos e técnicas de pesquisa social. São Paulo: Atlas, 2008.

GLOBO. Site globo.com . Matéria sobre o censo demográfico das pessoas com deficiência no Brasil. Disponível em: <http://g1.globo.com/brasil/noticia/2012/04/239-dos-brasileiros-declaram-ter-alguma-deficiencia-dizibge.html>. Acesso em: maio 2012

LE BRETON, David. A sociologia do corpo. Petrópolis, RJ: Vozes, 2a ed. 2007.

LOPES, Maria Immacolata. Revista USP. Telenovela brasileira: uma narrativa sobre a nação. Disponível em: < http://www.revistas.usp.br/comueduc/article/view/37469/40183> . Acesso em: set 2017

MEMÓRIA GLOBO. Informações sobre o autor Manoel Carlos. Disponível em <http://memoriaglobo.globo.com/perfis/talentos/manoel-carlos.htm>. Acesso em: jan 2017. 
NOVELA VIVER A VIDA. Site da telenovela da Rede Globo. Disponível em < http://viveravida.globo.com/>. Acesso em: jan 2017. 


\section{COLORINDO O ENSINO DE QUÍMICA: O EFEITO DA COR NO APRENDIZADO DE QUÍMICA}

Ariana L. Maia - Instituto de Química UFRJ - (arianaliporace@gmail.com)

Priscila Tamiasso-Martinhon - (pris-martinhon@hotmail.com)

Angela S. Rocha - (angela.sanches.rocha@gmail.com)

Célia Sousa - (sousa@iq.ufrj.br)

\section{Resumo}

As ciências exatas são interpretadas por muitos como sendo distantes do saber cotidiano e difíceis de serem compreendidas. Mas, e se os conhecimentos relacionados a elas fossem passados de outro modo? Se o ensino tivesse como principal foco os aspectos que comumente despertam o interesse das pessoas? Dentro dessa perspectiva, a temática cor é adotada como instrumento criativo para o aprendizado de química. $O$ objetivo deste trabalho é mostrar como o efeito das cores na química pode ser um aliado no aprendizado desta área das ciências exatas, estimulando o interesse dos alunos e, consequentemente facilitando o processo de ensino e aprendizagem.

Palavras chave: Cor. Química. Aprendizado.

Introdução

A cor pode ser definida como sendo a propriedade de uma radiação eletromagnética, com comprimento de onda pertencente ao espectro visível, capaz de produzir no olho, uma sensação característica (LONDERO, 2016; DENIS, 2009, p.12).

Para o entendimento completo das cores, é preciso compreender, antes de mais nada, o que é luz. A luz são ondas eletromagnéticas com propriedades que dependem da faixa de comprimento de onda que apresentam e se propagam através dos diferentes materiais. Desta forma, as ondas eletromagnéticas possuem duas características que a descrevem: a frequência e o comprimento de onda. O conjunto de ondas eletromagnéticas que compreendem todas as faixas de comprimentos de onda observados na natureza definem o que chamamos de espectro eletromagnético (LUZZI, 2017; NETO, 2007; UFF, s.n.).

A luz visível ou o espectro visível, é uma parte do espectro eletromagnético cujos comprimentos de onda são identificados como cores pelos nossos olhos, sendo cada cor referente a uma faixa estreita de comprimento de onda específico. Então, os olhos humanos são capazes de detectar apenas a luz visível, não enxergando por exemplo a radiação ultravioleta e a infravermelha, que são muito nocivas para nosso organismo. O espectro visível inicia-se no vermelho, com comprimento de onda em torno de $700 \mathrm{~nm}$ e termina no violeta, cujo comprimento de onda característico está em torno de $400 \mathrm{~nm}$ (MARTINS et al., 2015). Neste trabalho, são apresentados e discutidos como o uso de transformações químicas, envolvendo mudanças de coloração, são potencialmente interessantes para facilitar o ensino de química de uma forma criativa e atraente para os alunos.

A cor como instrumento de medida

A visão pode ser considerada o sentido mais utilizado pela espécie humana, por proporcionar a absorção de uma grande quantidade de informações em um intervalo muito curto de tempo, além do que, é através desse sentido que a maioria dos seres humanos analisa inicialmente o ambiente no qual está inserido (KANASHIRO, 2003). O olho, além de possibilitar a análise do ambiente mesmo que de longe, permite discriminar os objetos quanto a suas 
formas, se estão perto ou longe, se estão em movimento e, em alguns casos, se são coloridos. Além da construção visual sobre o ambiente onde se encontram, as imagens são utilizadas como elementos de comunicação (NISHIDA, 2012).

É através da visão que somos capazes de enxergar as cores. E das muitas informações trazidas pelos nossos olhos, a cor tem um efeito especial. Ela é capaz de provocar várias sensações, dentre elas podemos destacar a curiosidade e a imaginação, que são essenciais quando vamos aprender algo. A cor e a química andam quase sempre juntas. Portanto a cor por despertar o interesse e manter nossa atenção, se torna um instrumento criativo, mutável e eficiente no aprendizado de química.

\section{A cor na química}

Na química, não é difícil cruzarmos com as cores, isto é, encontrarmos sistemas com coloração típica que os nossos olhos são capazes de observar, vários compostos químicos são coloridos de modo que é possível verificar que uma reação química está ocorrendo por meio de mudança de coloração do meio reacional.

Essas reações em que ocorrem mudanças de coloração podem ser utilizadas para elucidar e facilitar a compreensão de inúmeros conceitos químicos. Por exemplo, a mudança de cor pode indicar o ponto de neutralização em titulações ácido-bases nas quais se usa indicadores que mudam de coloração quando o pH do meio é alterado. Também pode caracterizar o estado de oxidação de um determinado elemento presente em uma substância, ou mesmo seu grau de hidratação, por exemplo o sulfato de $\mathrm{Cu}(\mathrm{II})$, sulfato cúprico, quando anidro tem coloração branca ou cinzenta, mas é um sal muito solúvel e, na forma hidratada apresenta coloração azul intensa.

A estrutura cristalina dos materiais também pode ser avaliada por meio de coloração, o carbono na forma de diamante é incolor, mas como grafite é escuro e opaco. Impurezas também conferem coloração a substâncias, o que é comum nas pedras preciosas e semipreciosas. É possível obter informações sobre solubilidade, equilíbrio químico, cinética de reação e muitas outras informações com o uso de sistemas coloridos.

As reações oscilantes são um exemplo de reações químicas nas quais podemos observar mudança de cor repetidas vezes em um curto intervalo de tempo. Apesar da pratica dessas reações no ensino de química não ser comum, elas são extremamente atraentes e interessantes quimicamente, pois as reações ocorrem num sentido e depois no outro sentido, sem que se tenha alterado nenhum parâmetro da reação, e se isto ocorrer com mudança de coloração, torna-se fácil detectar as mudanças reacionais, causando expectativa nos alunos que observam as transformações e, consequentemente despertando seu interesse.

Na reação de Briggs-Rauscher, por exemplo, a mudança de coloração é consequência das reações de oxidação e redução que ocorrem no sistema reacional, de modo que são misturadas soluções incolores, que se tornam âmbar, depois azul e depois incolor novamente, sendo que estas mudanças ocorrem sucessivamente várias vezes em intervalos que aumentam até se tornar azul em definitivo.

Acredita-se que, por meio destas reações podemos explorar conceitos de número de oxidação, agentes oxidantes e redutores, estequiometria de reações redox, velocidade de reação e fatores que a influenciam, equilíbrio químico entre outros. $O$ apelo visual é grande e espera-se de fato que os alunos fiquem interessados no fenômeno que está ocorrendo e assim queiram entender o que está ocorrendo e porque, sendo um mecanismo de quebra da barreira que comumente se forma entre professor e aluno, facilitando a aprendizagem (ARROIO, 2006).

E se pudéssemos usar exemplos ainda mais comuns ao nosso dia a dia envolvendo cores para explicar conceitos químicos? Quem nunca ficou fascinado com os letreiros luminosos nas 
fachadas de lojas nas ruas e quis saber qual o motivo daquele fenômeno ou como montar um sistema daquele tipo?

Pois bem, a química também está ali e por meio de seu conhecimento podemos entender e controlar este tipo de aparato que desperta tanto interesse de todos. Trata-se da emissão de luz devido a um processo de excitação eletrônica, que pode ocorrer na forma de fluorescência, em que a emissão de luz cessa quando a fonte de energia é desligada, ou como fosforescência, que pode durar horas, mesmo depois de desligada a fonte de luz (NERY; FERNANDEZ, 2004).

Esses fenômenos podem ser reproduzidos utilizando-se tubos de vidro contendo algum gás com baixa pressão e passando-se correntes elétricas através deles, por exemplo. Se o tubo for incolor e contiver gás neônio puro a baixa pressão, quando os elétrons são excitados devido à corrente elétrica, este emite luz de comprimento de onda relativo à cor vermelhoalaranjada (PEIXOTO, 1999). As cores ainda podem ser alteradas tanto pela mistura de gases, como por exemplo adicionando pequena pressão de hélio, argônio e materiais fluorescentes, quanto pelo uso de vidro colorido.

Deste modo, utilizando esses experimentos de lâmpadas coloridas torna-se possível explorar conceitos de estrutura atômica, transições eletrônicas, interação da radiação eletromagnética com a matéria, dentre outros, que muitas vezes são enfadonhos para os alunos quando vistos por meio de aulas puramente expositivas, mas que podem se tornar mais atraentes se for usado um exemplo do cotidiano e que tem o apelo visual.

\section{Considerações finais}

Com base nas reflexões contidas neste trabalho, pudemos destacar que a cor tem grande relevância na química, na interação do homem com o meio no qual está inserido e também em sua capacidade de comunicação, por meio da construção visual e de inúmeras informações que a visão traz. Portanto o uso criativo de exemplos e experimentos envolvendo transformações químicas que ocorrem com mudança de coloração, bem como da investigação de sistemas químicos coloridos, pode contribuir para aumentar o interesse dos alunos no estudo da Química, sobretudo em assuntos que por muitas vezes são de difícil compreensão. Pensamos que isto é possível porque, ao estarmos mais interessados, mais atentos e com a imaginação estimulada, produzimos mais. $\mathrm{O}$ aprendizado pode ser lúdico, se realizar por meio de atividades que deem prazer, o que naturalmente ocorre quando entendemos melhor o ambiente ao nosso redor, aprender é estimulante. Foi discutido como a cor na química pode tornar o aprendizado mais interessante. Portanto, colorir é também aprender!

Referências bibliográficas

ARROIO, A.; HONÓRIO, K. M.; WEBER, K. C.; HOMEM-DE-MELLO, P.; GAMBARDELLA, M. T. P.; DA SILVA, A. B. F. O show da química: motivando o interesse científico. Química Nova, v. 29, n. 1, p.173-178, 2006.

DE CARVALHO, L. P.; REZENDE, H. C.; DA SILVA, R. M. G.; COELHO, N. M. M. Reações Oscilantes no Ensino de Química. In: Reunião Anual da Sociedade Brasileira de Química, 29a., 2006. Águas de Lindóia - SP. Anais... Águas de Lindóia, 2006. Disponível em http://sec.sbq.org.br/cd29ra/resumos/T1402-1.pdf. Acesso em: 30, set, 2017.

DENIS, C. Metodologia de seleção de tomates para processamento industrial por meio da visão computacional e redes neurais. 2009. 117f. Dissertação (Mestrado em Engenharia de Processos Químicos e Bioquímicos) Centro Universitário do Instituto Mauá de Tecnologia, São Caetano do Sul, 2009.

KANASHIRO, M. A Cidade e os Sentidos: Sentir a Cidade. Desenvolvimento e Meio Ambiente, n. 7, p. 155-160, 2003. 
LONDERO, F. T. Estimativa de orientação com uma bússola visual baseada em cores. 2016. 80f. Dissertação (Mestrado em Ciências da Computação) - Universidade Federal de Santa Maria, Santa Maria - RS, 2016.

LUZZI, F. O. Óptica da fotografia: Abordagem CTS sob a perspectiva da Aprendizagem Significativa. 2017. 192f. Dissertação (Mestrado Profissional em Ensino de Ciências) - Universidade Federal de Ouro Preto, Ouro Preto MG, 2017.

MARTINS, G. B. C.; SUCUPIRA, R. R.; SUAREZ, P. A. Z. A Química e as Cores. Revista Virtual de Química, v. 7, n.4, p. 1508-1534, 2015.

NERY, A. L. P.; FERNANDEZ, C. Fluorescência e Estrutura Atômica: Experimentos Simples para Abordar o Tema. Química Nova na Escola, n.19, p. 39-42, 2004.

NETO, J. D. M. Química da cor. In: Semana da Química do Departamento de Química da UFPR, XIV., 2007. UFPR. Anais... UFPR, 2007. Disponível em http://www.quimica.ufpr.br/quim/img/minicursos/Cores2007/Cor1.pdf. Acesso em: 30, set, 2017.

NISHIDA, S. M. Sentido da visão. Apostila do Curso de Fisiologia, Departamento de Fisiologia, Unesp-Botucatu, 2012. Disponível em: <http://www.ibb.unesp.br/Home/ Departamentos/Fisiologia/Neuro/08.sentido_visao.pdf>. Acesso em: 30, set, 2017.

PEIXOTO, E. M. A. Neônio. Química Nova na Escola, n.9, 1999. Disponível em: <http://qnesc.sbq.org.br/online/qnesc09/elemento.pdf>. Acesso em: 30, set, 2017. UFF. Espaço UFF de Ciências. Percepção do Ambiente. Disponível em http://www.uff.br/espacouffciencias/percepcaodoambiente.htm. Acesso em: 30, set, 2017. 


\title{
NOVAS IDEIAS EXIGEM UMA NOVA ESCOLA DE ENGENHARIA: O CONTEXTO DE FUNDAÇÃO DA EFE SOB O PENSAMENTO DE SEU PRIMEIRO DIRETOR
}

\author{
Elias da Silva Maia - MAST - eliasmaia@mast.br
}

Resumo

Observando as mudanças que o ensino de engenharia passou ao longo do século XX no Brasil, propomos uma abordagem que considere as novas ideias que permearam a criação de uma instituição de ensino. A comunicação fará um resgate da criação da Escola Fluminense de Engenharia (EFE) ocorrida em 1952, partindo da documentação pessoal do engenheiro Octavio Cantanhede sob a guarda do AHC-MAST. Tentou-se explorar a relação entre os aspectos da vida do cientista, sua perspectiva em relação ao ensino de engenharia e a história da instituição de ensino que ajudou a criar e dirigiu. Cantanhede e a EFE se inserem em uma realidade social ampla, onde suas aspirações se materializaram nas atividades da escola, entendendo sua criação fazendo parte de um projeto de desenvolvimento e exploração econômica.

Palavras-Chave: Octavio Cantanhede. Escola Fluminense de Engenharia. Ensino de Engenharia.

Introdução

Profundas transformações ocorreram no ensino de engenharia após a intensificação do processo de industrialização experimentado pelo Brasil na década de 1930. Observamos iniciativas para aumentar o número de instituições de ensino de engenharia, que cresceram ainda mais nos anos que precederam à Segunda Guerra Mundial. Junto com essas mudanças, nota-se também uma nova forma de ver o ensino de engenharia, visto a partir dai, com objetivos mais definidos e funções atreladas ao desenvolvimento econômico. Para realizar essa abordagem, partimos da documentação pessoal de um engenheiro que esta sob a guarda do Arquivo de História da Ciência do MAST. Tentou-se explorar a relação entre os aspectos da vida do cientista, sua perspectiva em relação ao ensino de engenharia e a história da instituição de ensino que ajudou a criar e dirigiu.

Pretendemos abordar as ideias do engenheiro Octávio dos Reis Cantanhede e sua atuação no início da década de 1950 que levou a criação da Escola Fluminense de Engenharia (EFE), vendo a existência de um vínculo entre a visão desse cientista e os primeiros passos dados pela Escola. As aspirações de Octavio Cantanhede em relação a sua área de atuação no que tange ao seu papel no desenvolvimento, se identificam com a função da instituição no desenvolvimento do ensino e pesquisa nesse período. Entendemos que Cantanhede se insere em um contexto social amplo, que envolve o conhecimento e interpretação de suas redes de relações e obrigações. Contudo, não desconsideramos que sua atuação se fez presente num sistema social e político culturalmente e socialmente determinado, que limitavam suas ações, mas possibilitava brechas para suas pretensões.

Octavio dos Reis Cantanhede, nasceu em abril de 1913 e faleceu em dezembro de 2004, na cidade do Rio de Janeiro. Era de uma família tradicional de engenheiros, sendo neto do renomado engenheiro Aarão Reis, referência no urbanismo no Brasil, responsável pelo traçado de Belo Horizonte. Cantanhede estudou no Colégio Pedro II, completando os estudos 
no final dos anos 1920, formou-se em Engenharia Geográfica em 1932, e em Engenharia Civil em 1935, pela Escola Politécnica do Rio de Janeiro. Logo após a formatura, passou a trabalhar na Divisão Técnica da Companhia Estrada de Ferro Central do Brasil, onde, no ano de 1938, concluiu o curso de Topografia.

No mesmo ano criou com dois amigos a Empresa de Topografia, Urbanismo e Consultoria LTDA, (ETUC), que executava levantamento topográfico, de loteamento e urbanismo, entre eles a locação da Ponte Rio Niterói e da Usina Getúlio Vargas em Volta Redonda, além de trabalhos no setor rodoviário. Na área de urbanização, realizou as plantas cadastrais de várias cidades do Brasil, tendo ao longo de sua vida atuado no ensino, em projetos de infraestrutura urbana e associações de classe. Em 1942, com 29 anos, tornou-se com uma tese inovadora sobre a Aviação Civil (aerofotogrametria), professor catedrático de Topografia da Escola Nacional de Engenharia, período em que fazia parte do Conselho Técnico-administrativo da Escola.

No ano de 1945 foi eleito diretor da Escola Nacional de Engenharia da Universidade do Brasil para um mandato de três anos, deixando a direção em 1948, mas permaneceu exercendo diversas funções, além de professor, até 1973. Ao longo das décadas de 1950 e 1960, teve atuação no MEC e foi membro de diversas comissões culturais e convênios técnico-científicos, além de conselhos de diversas associações como o Conselho Regional de Engenharia e Arquitetura, o Conselho Federal do mesmo órgão. Foi presidente do Clube de Engenharia, do Conselho Federal de Engenharia e Arquitetura, bem como do CREA-RJ, onde em 2000 ocupou pela 10a vez o mandato de conselheiro.

No começo da década de 1950 se envolveu na criação de uma escola de engenharia, recebendo o convite do Governador Amaral Peixoto e do Secretário de Educação, José de Moura e Silva, para estudar e implantar o que viria a ser a Escola Fluminense de Engenharia. No final de 1952 a escola começa suas primeiras atividades, ainda subordinada ao Secretário de Educação e Cultura. Ainda em 1952, Cantanhede foi nomeado diretor da Escola, ficando encarregado de implementar o curso de Engenharia Civil na instituição. Nesse mesmo ano foi nomeado Chefe do Departamento de Engenharia Geográfica, da Escola Nacional de Engenharia, e em 1953 foi membro da Comissão de Finanças da mesma instituição. Esteve envolvido na área de planejamento das cidades, tendo ainda uma ligação com o desenvolvimento da infraestrutura urbana, integrando bancas de concurso para a carreira de engenheiro do Departamento Nacional de Estradas de Ferro.

II

Optamos por abordar a história de um indivíduo, porque entendemos que estamos observando um sujeito envolvido em uma realidade, não como individuo autônomo, livre, mas como uma pessoa que experimentou situações e relações determinadas pelas necessidades e interesses antagônicos. Consequentemente, essa experiência permeou sua consciência e sua forma de ver sua realidade, isso certamente ocorreu de maneira particular na vida de Octavio Cantanhede, porém sua atuação estava sujeita ao exercício limitado de sua função. Consta que, quando Cantanhede ocupara nos anos de 1945 e 1948 o cargo de diretor da Escola Nacional de Engenharia, havia indicado algumas mudanças no seu regimento para a congregação. Essas mudanças visavam transformar sua estrutura, que era considerada por ele ultrapassada e merecedora de atualizações, inclusive algumas até radicais. Foi sucedido por um professor mais conservador que modificou as ideias mais modernas e renovadoras do projeto aprovado na gestão anterior.

Em uma conferência proferida no Clube de Engenharia em 1949, tratou das ideias propostas para a Escola Nacional de Engenharia na época que foi seu diretor. Apontou a necessidade de modernizar e atualizar os cursos no Brasil, aplicando um ensino mais objetivo e prático, 
estimulando o interesse pela profissão. Era contra o professor orador, mestre nas aulas com forma, com explanações, mas sem demonstração. Na segunda parte do seu discurso, observou que era importante mudanças no ensino da engenharia no Brasil, que segundo ele, necessitava de uma modificação profunda, pois não tinha acompanhado as transformações radicais no progresso técnico e nas exigências das indústrias. Pregava uma reformulação na estrutura dos cursos, considerando a moderna conceituação do ensino da engenharia. Criticava que a Escola não podia mais "perder-se em devaneios, conservando um academicismo exagerado, ou demasiadamente elevado de especulações científicas." Completava esse pensamento afirmando que o "ensino de Engenharia assume hoje aspectos, que não apresentava outrora, exigindo assim nova estruturação, novos métodos de ensino e maior objetividade nos diferentes cursos ministrados." (CANTANHEDE, 1949, p. 6-7).

Cantanhede tinha grande experiência no ambiente universitário e nas entidades de classe, e vinha planejando com mais dois amigos da turma de 1935 da Escola Politécnica do Rio de Janeiro (Arthur Cardoso de Abreu e Zózimo Menna Gonçalves) trabalhar para uma melhor e mais moderna educação para os futuros engenheiros. Outro personagem importante nesse processo inicial foi um funcionário de elevado cargo técnico do Departamento de Estadual de Estradas e Rodagem, que conhecendo o governador Amaral Peixoto, ficou de apresentar as pretensões dos três amigos.

Muitos anos depois, Octavio Cantanhede escreveu sobre os acontecimentos que antecederam a criação da Escola Fluminense de Engenharia, indicando as primeiras iniciativas para a criação do seu primeiro curso. Foi seu diretor do momento de sua criação, passando pela incorporação dessa escola à atual Universidade Federal Fluminense, até 1971, quando deixou de ocupar esse cargo. Nas palavras de Cantanhede, a instituição foi pensada já em seus primeiros passos em mudar alguns conceitos clássicos do ensino de engenharia. Relata que essa intenção, embora causasse dúvidas, todos os envolvidos entendiam aonde ela iria os levar, "sabendo que iriam concorrer, decididamente para modificar e alterar conceitos inaceitáveis, bem como para criar novas perspectivas para o ensino de Engenharia." (CANTANHEDE, 2002, p. 13)

No primeiro encontro com o governador, fizeram críticas ao sistema atual de ensino de engenharia que era muito conservador, não havendo coragem de inovar e criar novas estruturas. Segundo Cantanhede, o governador incentivou a criação de uma "escola modelo, atualizada e sempre aberta ao diálogo e à percepção dos acontecimentos tecnológicos e científicos de vanguarda." (CANTANHEDE, 2002, p. 16) Após essa reunião novas propostas foram apresentadas e sempre recebiam incentivos por parte do governador, que conforme frisado, não interferiu na implementação e contratação de pessoal que trabalhou nos primeiros anos. $\mathrm{O}$ imediato interesse do governo provocou agilidade nos estudos e preparo da documentação da nova escola, pois era preciso aproveitar o momento de reconhecimento de um novo cenário para o ensino de engenharia.

A criação da EFE veio através da solicitação feita pelo Governador do Estado do Rio, e refletiu a organização de uma escola de Engenharia em moldes modernos. Uma lei baseada nessa proposta, marca a criação da instituição, que dois meses depois recebeu outra, onde nomeou Octavio Cantanhede como seu diretor e estabeleceu algumas diretrizes. O primeiro artigo da lei aponta seu fim específico de capacitar profissionais mediante formação e aperfeiçoamento para a preparação científica e técnica, e para a realização de pesquisas nesses dois domínios. No segundo indicava sua subordinação a Secretaria de Educação e Cultura, porém com autonomia administrativa, financeira, didática e pedagógica.

Seu terceiro artigo previa um processo progressivo de instalação, que se daria de acordo com as necessidades da formação básica da graduação, aperfeiçoamento, especialização, extensão cultural e doutoramento. Traz em seu parágrafo único, a intenção de criar após o 
curso de Engenharia Civil, outros na área de Elétrica, Metalurgia e indústrias, observando a necessidade do setor produtivo. No documento ficava decidido que o chefe do poder executivo nomearia uma comissão com três membros para elaborar em trinta dias um regulamento provisório e submeter a sua apreciação, sendo que um representante obrigatoriamente deveria ser do CNPq. Segundo Cantanhede:

esses primeiros passos foram dados com muita cutela e atenção, pois o que se pretendia apresentar não era uma aventura inconsequente, mas, sim, medidas e procedimentos lastreados em estudos sérios e abrangentes, calcados na experiência e capacidade já demonstradas em outras oportunidades. (CANTANHEDE, 2002, p. 20)

Após uma campanha de divulgação foi realizado um vestibular aos moldes dos realizados pelas escolas de engenharias existentes, com bancas compostas por praticamente os mesmos professores qualificados, com o mesmo sistema aplicado nas outras. Foram selecionados 35 alunos homens, que no primeiro contato com a direção da Escola, foram informados das intenções de ajustar e alterar alguns procedimentos da estrutura didática e pedagógica existentes em outras instituições, e que tinham o apoio do governador. Dos 35 alunos ingressados em 1953, 21 deles se formaram em 1956, nos quatro anos previstos. Foi a primeira instituição de ensino a adotar matrícula por disciplina, e previa a instalação de cursos de aperfeiçoamento, extensão, e doutorado.

Já com a experiência de dois anos a frente da nova instituição, Cantanhede mostra mais uma vez que a formação profissional era uma preocupação constante do cientista. Considerava que seu papel era fundamental para o desenvolvimento do país, onde o engenheiro.

no mundo moderno, assume proporções gigantescas e a rápida evolução dos problemas nacionais, exigem cada vez mais, profissionais competentes e altamente qualificados, devendo ser abolida inteiramente a improvisação e o empirismo, no preparo dos técnicos, ou na resolução dos nossos problemas." (CANTANHEDE, 1954, p. 2)

Essa capacitação se insere em uma dinâmica que envolve a tecnologia e a sociedade fazendo parte de um conjunto formado pela base educacional, estrutura industrial e comercial. Não podemos esquecer a organização dos financiamentos e do papel das instituições que gerenciam os elementos que envolvem a capacitação social dos países. Afinal, a capacitação social e o estágio em que a tecnologia se encontra estão relacionados. Esses fatores determinam o futuro de qualquer país, principalmente dos mais atrasados, quando partem para negociações com países mais desenvolvidos. (ABRAMOVITZ, 1989)

Anos mais tarde continuava a criticar o caráter administrativo que permeava as instituições de ensino, sobrando pouco tempo para pensar no ensino. Segundo ele, as escolas se interessavam mais por questões burocráticas, finanças e contratos de serviços, estes, julgava importantes, quando voltado para o ensino. Criticava que apenas $5 \%$ do orçamento da união eram destinados para a educação, lembrando que não fazia muito tempo o volume destinado era de $10 \%$, esse fator que estava desvirtuado a verdadeira função da universidade. Previa o crescimento da década de 70 , e seu condicionamento aos suportes científicos e tecnológicos adequados, formação e aperfeiçoamento de engenheiros, tecnólogos e pesquisadores, além de investimentos em ensino e pesquisa. O investimento evitaria a dependência tecnológica, defendendo o controle do processo de desenvolvimento, participação do engenheiro na indústria, nos serviços públicos, e a integração da escola com a indústria para a formação profissional. (CANTANHEDE, 1971)

A lei de 31 de dezembro de 1952 especificou as primeiras ações da EFE em relação aos aspectos de financiamento. Indicavam formas diversas como dotações orçamentárias, créditos regulares, especiais e extraordinários, a escola arrecadava com taxas de matrículas, cursos, exames, certificados. Previa recursos oriundos de análises e perícias, uso de seus 
laboratórios e patrimônio da universidade, rendas de serviços prestados a entidades públicas e privadas, também previa rendas eventuais e as que viessem a ser criadas por lei. $\mathrm{O}$ desempenho da economia foi visto pela produção do conhecimento científico que traz consigo o aumento na produtividade do trabalho, principalmente nos setores industriais. $\mathrm{O}$ desenvolvimento científico dentro ou fora das instituições de ensino contribui para formar trabalhadores mais preparados para a execução das tarefas nos laboratórios de P\&D industrial e nas novas funções trazidas com a incorporação dos conhecimentos fundamentais para a realização de tarefas antes não conhecidas. (PAVITT, 1991)

Em um texto de 1976 cita um estudo realizado por ele em 1958, onde já informava que a educação era um elemento decisivo para superar o atraso no desenvolvimento, e que a ligação entre a escola - fábrica/universidade - indústria era crucial para suprir a defasagem entre o número de engenheiros que temos e o número de engenheiros necessários para nosso desenvolvimento. A ação governamental, que atuava quase isoladamente, estava se mostrando incapaz de propor bons resultados sozinha. A formação dos engenheiros, jamais acompanhou a expansão industrial vivida pelo Brasil nos últimos anos, acarretando um déficit que cresce anualmente. Esse estudo tinha como objetivo orientar o governo para olhar com mais atenção à formação de técnicos nacionais. A oferta de vagas não cresceu, o aumento só veio por conta das novas escolas abertas. Das 36 escolas existentes em 1963, se graduaram 1800 engenheiros, tendo em media formado 200 alunos em cada uma das sete escolas espalhadas pelo Rio de Janeiro, São Paulo e Minas Gerais. Finalizava problematizando que as outras escolas espalhadas pelo país, formavam 20 alunos por turma, o que era considerado por ele antieconômico. (CANTANHEDE, 1976)

III

Os apontamentos brevemente expostos acima sobre as ideias de Cantanhede e as propostas para o ensino de engenharia na recém-criada EFE, servem para indicar um contexto específico, pois expõem ideias de um ambiente que estava se constituído. Teve forte ligação e foi estimulada por solicitação de uma autoridade, e sua criação indicou o diálogo e a vinculação que deveriam ter com órgãos reguladores do Estado, mostrando a ligação das instituições com o poder político institucional. Foi destacado o reconhecimento e necessidade de capacitar os alunos para funções importantes, visando à aplicabilidade e a racionalidade do conhecimento ensinado. Esse pensamento era completado com o estímulo da aproximação e interação da atividade da escola com as empresas e indústrias.

As mudanças ocorridas após a Segunda Guerra Mundial, não só na economia, mas também sociais, como a introdução de uma nova ideologia, induziram novas políticas e ajudaram a ver um novo rumo para o ensino de engenharia. Novas funções surgiram para as escolas e faculdades de engenharia, configurando novas formas e visões para o ensino e pesquisa, mais adequados às necessidades do setor industrial. Passou-se a valorizar aspectos práticos em contraposição as ensino enciclopédico que predominava na educação como um todo, se adequando então a certos objetivos específicos.

A intenção foi ver Octavio Cantanhede e a Escola Técnica do Exército em uma realidade social ampla, onde as aspirações do cientista serviram de referência para se materializarem nas atividades das escolas. Entendemos a criação da Escola, fazendo parte de um projeto de desenvolvimento e exploração do potencial econômico, com o objetivo de integrar indústria e pesquisa. Esse processo fez parte de uma política educacional com critérios de racionalidade, eficiência e produtividade.

O surgimento de instituições e comunidades científicas com credibilidade e escopo para sustentar projetos e crescimento de longo prazo, só poderia ser alcançado quando a sociedade passasse a reconhecer e aceitar a ciência como uma profissão. Importantes 
elementos passam a existir nesses novos tempos para a ciência, onde os próprios cientistas começaram a valorizar sua atividade, e por sua vez, introduziram uma visão mais clara de seu papel e do seu lugar na sociedade. Esse papel foi começando a tomar forma em suas mentes e os cientistas passaram a trabalhar para obter o reconhecimento da sociedade.

\section{Referências bibliográficas}

ABRAMOVITZ, Moses. Thinking about growth: and other essays on economic growth and welfare. Cambridge: Cambridge University, 1989.

CANTANHEDE, Octavio dos Reis. Conferência sobre o ensino de engenharia na ENE-UB proferida no Clube de Engenharia, 1949. AHC-MAST.

CANTANHEDE, Octavio dos Reis. Conferência sobre a profissão do engenheiro proferida no Sindicato da Confederação Civil, 1954. AHC-MAST.

CANTANHEDE, Octavio dos Reis. Conferência sobre as reformas do ensino ocorridas no final da década de 1960 proferida no Clube de Engenharia, 1971. AHC-MAST.

CANTANHEDE, Octavio dos Reis. Universidade e Indústria: estudo preliminar. 1976. AHC-MAST.

CANTANHEDE, Octavio dos Reis. A Escola Fluminense de Engenharia - Sua Criação e Sua Obra - 1952/2002. Rio de Janeiro, EDUFF, 2002.

PAVITT, Keith. What makes basic research economically useful? Research Policy, v.20, n.2, 1991. 


\section{DIVERSIDADE DE GÊNERO E O PENSAMENTO EVANGÉLICO BRASILEIRO : ANÁLISE DOS CONFLITOS PELA ÓTICA DA ANTROPOLOGIA HIPERDIALÉTICA}

Lília Dias Marianno - Doutoranda do HCTE- UFRJ - lilia.marianno@gmail.com

Resumo

Quando trabalhamos com gestão de conflitos entre a militâncias LGBTQ e as lideranças evangélicas no Brasil, enfrentamos uma complexidade de ideologias que esgota rapidamente a paciência da maior parte dos interessados em solução. Competências interdisciplinares e transdisciplinares na práxis de negociação, nunca foram tão urgentes. Em quinze anos laborando nesse campo minado, constatamos que a permeabilidade de conhecimentos neurocientíficos, genéticos, sociológicos, antropológicos e linguísticos na produção de argumentações e de uma educação para o trato da questão tem produzido bons resultados. O que nos inspira nesta caminhada é o Pensamento Processual de Alfred North Whitehead, com o qual muito se alinhou, posteriormente, a Lógica Hiperdialética de Luis Sérgio Sampaio.

Palavras-chave: Antropologia. Hiperdialética. Transdisciplinariedade. Pensamento Processual. História.

Introdução

Este trabalho é um recorte de um ensaio mais extenso que produzimos no primeiro semestre de 2017, como conclusão da disciplina Filosofia e Antropologia Hiperdialética e que se encontra publicado na íntegra na mencionada referência. Recorreremos ao texto maior aqui sempre que preciso for a fim de respeitar o limite de páginas desta comunicação (MARIANNO, 2017).

Um sistema filosófico nunca é rejeitado; é apenas abandonado. (...) depois de realizada a sua crítica, os sistemas deixam de apresentar apenas deficiências lógicas. Passam a sofrer de inadequação e de incoerência. A falta de inclusão de alguns elementos óbvios da experiência no âmbito do sistema é ultrapassada com a negação descarada dos factos. Além disso, enquanto um sistema filosófico mantém o charme da novidade, as suas faltas de coerência gozam de uma indulgência. Mas depois de um sistema ter adquirido ortodoxia, e de ser ensinado com autoridade, sofre uma crítica mais severa. As suas negações e incoerências tornam-se intoleráveis, instalando-se uma reação. (WHITEHEAD, 2011, p. 26).

1. Ciranda de ciências para interpretar o fenômeno: É senso comum em nossa história, que os mais de quinhentos anos desde o descobrimento foram marcados por uma colonização exploratória muito extensa que permeou a maior parte de nossa existência enquanto país. Nosso sentimento nacional é frágil e debilitado. Até compreendermos de maneira saudável e positiva a nossa mestiçagem indo-africana como nosso traço étnico-cultural mais marcante ainda temos muito caminho a percorrer.

Somente nos séculos XIX e XX é que nos tornamos independentes e republicanos, mesmo assim, com lacunas impressionantes no senso de democracia, já que ambos os eventos foram demarcados por intervenções de militares no poder, um traço muito recorrente em nossa história, por mais triste que seja. Uma angústia inconsciente sobre este estado suspensão ideológica, por não encontrarmos ideologias que nos representem, perpassa inúmeras 
instâncias da nossa cultura. De maneira mais conflitiva perpassa a formação do pensamento evangélico no Brasil, fenômeno que nada tem de autóctone ou original, mas que foi clonado de ideologias estadunidenses. E aqui, a História, enquanto ciência que nos estabelece linearidade lógica entre os eventos nos ajuda em muito, sendo a primeira das Ciências que cooperam neste exercício de transdisciplinariedade que nos propomos a fazer.

2. A formação dos modelos mentais evangélicos no Brasil: Em nosso ensaio mais extenso (MARIANNO, 2017) roteirizamos detalhadamente a chegada do cristianismo no Brasil, desde as caravelas de Cabral, com seus sacerdotes católicos, as tentativas frustradas de instalação do Protestantismo Histórico, a dominação Jesuíta no sistema educacional dos séculos XVI até XVIII até a chegada dos missionários estadunidenses nos séculos XIX e XX, no modo como a participação destes últimos foi determinante consolidação do modo atual como evangélicos se relacionam com a política.

Neste roteiro também mostramos que no campo da sexualidade, a homossexualidade, o lesbianismo, e os travestimos eram comuns aos índios quando fomos "achados" pelos europeus. Não havia constrangimentos, punições nem exclusão destes praticantes do seio de uma tribo. Fomos ensinados a tratar estas práticas com conotações negativas e pecaminosas por nossos educadores europeus. A Linguística nos ajuda a perceber esta questão, pois nos primeiros glossários indígenas redigidos no Brasil as práticas eram associadas com o "pecado nefando da sodomia." Sobre estes atos foi construído um glossário repleto de noções criminais sobre estes atos, o que os levou, posteriormente a castigar e matar índios pegos nestas práticas. Mais tarde, com os protestantes de tradição puritana estas noções só foram reforçadas.

Qualquer análise destes conflitos sem considerar a formação do pensamento evangélico no Brasil é, no mínimo, incompleta, prejudica até mesmo a nossa compreensão do Censo 2010 sobre o crescimento dos evangélicos no Brasil. Ao ancorarmos qualquer argumentação apenas na definição de Estado Democrático de Direito e Laico há que se levar em conta que este mesmo Estado invoca a proteção de Deus para exercer a justiça e o direito no preâmbulo de sua Constituição, pois é formado por sujeitos religiosos, que aprenderam a ser religiosos por meio da catequese missionária de alguma tradição religiosa estrangeira. No caso dos evangélicos esta influência é, predominantemente estadunidense. As Ciências Autuariais são as que ajudam a História e a Linguística na hermenêutica mais profunda destes dados bem como as Ciências Jurídicas, pois ao pesquisarmos a história de nossas constituições nos estudos de Direito Constitucional, notaremos que pensamento religioso constou na elaboração de todas as nossas cartas constitucionais. (LENZA, 2012, p. 100-131)

3. A História ajuda a entender o conflito: Segundo o mapa da Diversidade Religiosa do Censo 2010, o Brasil possui atualmente 148 religiões classificadas. Caiu o percentual de brasileiros que se declaravam Católicos Romanos, manteve-se inalterado o percentual de Evangélicos de Missão. Aumentaram em número de fieis os segmentos: Sem religião, Outras religiosidades (Judeus, Muçulmanos, Budistas e Hinduístas, Candomblecistas, Umbandistas, etc.), Espíritas, Evangélicos Pentecostais/Neopentecostais e Evangélicos não determinados. Este levantamento estabelece que 87,3 \% da população brasileira se denomina religiosa de tradição cristã. No caso dos não-católicos, é preciso conhecer as seguintes divisões: Protestantes Reformados de tradições Calvinistas, Luteranas e Anglicanas que chegaram ao Brasil provenientes da Europa, em levas diferentes do século XVI ao XVIII, estes segmentos sempre defenderam separação entre Igreja Estado. Protestantes de Missão: Tem matriz estadunidense e, embora na teoria, separe Igreja e Estado, na prática isso sempre foi muito difícil porque sua tradição reformada é Estatal, deriva de Henrique VIII na Inglaterra e de sua 
reforma Anglicana, ocorrida por motivos muito diferentes dos primeiros reformadores. Marcados por um robusto conservadorismo vitoriano que se reflete em todas as instâncias da vida.

Desses grupos derivam os atuais evangélicos que, herdeiros de esforços missionários no Brasil tão intensos quanto o dos Jesuítas da Contra-Reforma. Com o tempo ficam conhecidos como Evangélicos de Missão e a partir da segunda metade do século XIX, trouxeram as igrejas Batistas, Metodistas, Presbiterianas, construído para elas sólidas instituições de educação teológica que formaram a maioria dos pastores evangélicos não pentecostais por mais de cem anos.

As Igrejas Pentecostais derivam de um movimento missionário estadunidense, à parte dos anteriores, ocorrido na primeira metade do século XX. Aqui se inscrevem igrejas como as Assembleias de Deus, Evangelho Quadrangular, Nova Vida, Nazareno, O Brasil Para Cristo e Deus é Amor. Pentecostalismo é produto de uma realidade carismática de avivamentos ocorridos nos Estados Unidos e nunca exigiu que seus líderes tivessem formação teológica. 0 idealismo puritano ou conservador é muito levado a sério nestas instituições. O Neopentecostalismo e suas igrejas, é um fenômeno não exclusivo do Brasil, mas em nossas terras ganha contornos muito singulares, até mesmo de franquias empresariais que arrecadam muitos recursos. Suas igrejas são dissidentes do pentecostalismo e dos evangélicos de missão, aplicando certos comportamentos religiosos que boa parte dos segmentos evangélicos não se permite ser associado a elas. O caso mais polêmico é o da Igreja Universal do Reino de Deus, objeto amplamente estudado nas Ciências da Religião por não ter muitas das características de uma igreja, mas de movimentos sectários/seitas.

4. Co-dependência de ideologias estrangeiras: Foucault $(1999$, p.9) responsabiliza a Mentalidade Vitoriana como a responsável por esta mudança de comportamento para um retrocesso moralista. Esta mentalidade predominava o imaginário dos missionários estadunidenses. Eles viam a nudez indígena e africana, natural de nossa gente era vista como pecado carnal. O uso de instrumentos musicais e de músicas indígenas e africanas nas liturgias também não era permitido. As Assembleias de Deus quebraram o paradigma do uso de pandeiros e palmas nos cultos, mas porque chegaram ao Brasil num diferente momento das crises ideológicas estadunidenses. Esta dependência patológica de ideologias estadunidenses é fenômeno em outras áreas da vida brasileira como no campo das artes, economia, política e também dos estudos de gênero. Estas ideologias mantinham distanciamento e estranhamento em relação ao pensamento religioso mais liberal produzido na Europa, principalmente na França e Alemanha, Inglaterra.

O antropólogo Luiz Mott, da UFBA, é quem está, há mais tempo no Brasil, mapeado o progresso das ações afirmativas e de inclusão LGBTQ. Aqui e como no restante do trabalho, mais uma ciência colabora na gestão deste conflito: a Antropologia. Seu trabalho é indubitavelmente valioso, mas seus pronunciamentos refletem a grande dificuldade que a militância LGBTQ possui com a Ética da Compreensão (MORIN, 2007). Não há esforço histórico nem antropológico na compreensão desta formação do pensamento evangélico e os pronunciamentos evidenciam forte preconceito quando declara leis judaico-cristãs como ridículas (MOTT, 2014). Tais declarações depreciam a utilidade das Ciências Autuariais, que contabiliza mais de $87 \%$ de população seguindo esta tradição e que traz a tona a relevância deste dado, muito facilmente absorvido por gestores de marketing e produtores comerciais. Um parte da militância LGBTQ adota este mesmo comportamento depreciativo da espiritualidade do outro. Em nosso texto mais amplo roteirizamos toda a trajetória dos movimentos de ação afirmativa elencados pelo professor Mott (MARIANNO, 2017). 
É aqui que a Lógica Hiperdialética do Prof. Luiz Sérgio Sampaio se alinha com o Pensamento Processual de Whitehead e nos permite uma forma mais ampla e holística, mais respeitosa em relação à ideologia do outro. Podemos não concordar com a ideologia do outro, mas respeita-la é o mínimo que devemos fazer se pretendemos nos representar como civilizados. A lógica hiperdialética contribui para o delineamento de uma linha de ação para gestores de conflito neste campo.

4. A lógica hiperdialética na gestão de conflitos: Edgar Morin (2007) nos propõe uma Ética da Compreensão, que requer escuta atenta da realidade do outro, compreendendo-o em sua própria realidade. Mas é Sampaio $(2000 ; 2005)$ quem mapeia os sistemas lógicos dos comportamentos e que depois Gomes $(2008 ; 2011)$ o introduz como Epistemologia para uma antropologia brasileira, permitindo a entrada de mais um saber científico em nosso diálogo. Sampaio descreve cinco diferentes lógicas em sua densa proposta filosófica. A Lógica da Identidade ( $\log$ I) é a lógica transcendental, uma lógica do Uno que também pode ser teocêntrica. Regula a vida por meio do princípio de Deus e do que agrada a Deus. Ela "visa a dimensão da autoconsciência do ser humano (...) que se projeta no mundo como autodeterminação" (GOMES: 2011, p. 17). Uma das lógicas mais antigas na existência humana, e anterior a ela somente o que ele chama de Lógica Pré-I, que torna o sujeito identificado com a natureza ao invés e identificado com o Uno. A segunda é a Lógica da Diferença $(\log D)$. Nesta lógica o Uno reconhece a existência de outro ser, diferente dele próprio, mas admite o outro como partícipe da mesma sociedade que ele, embora seja diferente. Se o Uno é um sujeito A, o outro é um sujeito Não-A, mas existe junto com o Uno. Essa lógica acontece quando aceitamos o princípio da contradição que governa o inconsciente e abre possibilidade para o duvidoso, incoerente e paradoxal. $\mathrm{O}$ inconsciente coletivo é orientado por esta lógica. (GOMES, 2011, p. 19-21). A terceira é a Lógica Dialética (Log I/D): "a fusão ou a síntese das duas lógicas básicas precedentes: a Lógica da Identidade e a Lógica da Diferença. (...) No processo dialético, a entidade resultante desintegra as anteriores, mas (...) de algum modo, conserva um tanto de cada uma." (GOMES: 2011, p. 21-22). A quarta é chamada de Lógica da Dupla Diferença (Log D/2), também conhecida como Lógica Sistêmica "A Lógica Sistêmica, ao contrário da lógica D, não admite inconsistências, paradoxos e determinações." (GOMES: 2011, p. 23) ela praticamente força o entorno a funcionar dentro de sua lógica.

Neste ponto em que já descreveu as quatro lógicas subjacentes aos comportamentos humanos, antes de descrever a hiperdialética, Sampaio sugere o cruzamento de duas lógicas que ligam a Log I com a Log ID/2 e a Log I/D com a Log D/2. Usando categorias lacanianas de análise dos comportamentos feminino e masculino, Sampaio denomina estes cruzamentos como Pseudo-dialética Masculina e Pseudo-dialética Feminina, sendo esta a do discurso profundo, que para Sampaio, trata-se dos "únicos modos possíveis de inserção no discurso." (SAMPAIO, 2000, p. 31 e 41). Conforme discussões em classe, na visão de Gomes, esta lógica feminina fornece esperança para solucionarmos conflitos, pois insere, na análise do discurso profundo a dimensão do afeto e do amor.

Finalmente, Sampaio propõe a Lógica Quinquitária ou Lógica Hiperdialética Log I/D/2, uma lógica que abarca todas as outras sem desconsiderar nenhuma delas, respeitando-as nos seus momentos de manifestação identitária, inserindo inclusive a dimensão do afeto e do amor (da Pseudo-dialética feminina) nos processos de negociações ideológicas. Se atentarmos bem para os fatos elencados há pouco, veremos que todas estas lógicas são inerentes aos diversos movimentos de formação do pensamento, são geradoras desta comunicação e sempre provocam, também os conflitos. Há presença da Log I na forma como os missionários cristãos incutiram sua ética vitoriana na nossa cultura, convencendo-nos de um paganismo 
impensável sobre nossa nudez indígena e africana. Igualmente, quando as Leis de Higiene (Lv 17,22 e 20,13 ) dos judeus, que os preservou de epidemias de sífilis e gonorreia quando estas doenças surgiram em seus formatos ainda vetoriais (MARIANNO, 2011), são chamadas de ridículas e ultrapassadas por um segmento acadêmico, leis que para o Séc V AEC foram um enorme avanço no controle de doenças infecciosas. Há presença da Log Pré-I na forma natural como os Tupinambás se relacionavam com a sexualidade, não excluindo nem os tibiras (homossexuais) nem as caçoaimbeguiras (lésbicas). Há presença da Log $D$ quando colonizadores portugueses reconhecem os indígenas brasileiros como os habitantes originais da terra. Também quando, segundo o relato de Mott, os brasileiros não oferecem qualquer hostilidade na exaltação histórica de personalidades públicas homossexuais como Santos Dummont, João do Rio ou Mário de Andrade.

Há presença da Log I/D quando a Constituição Brasileira define nosso país como um Estado Laico, pedindo proteção de Deus para assegurar o cumprimento dos direitos e deveres de todos os cidadãos brasileiros independente de fé ou de orientação sexual. Reconhece que tanto o religioso fundamentalista quanto o militante LGBTQ possuem direitos iguais diante de Deus e da nação. Há presença da Lógica Sistêmica Log $D / 2$ quando os estadunidenses, misturando a teologia protestante com o espírito do capitalismo e estabelecendo coerções políticas em benefício próprio, pressionam os brasileiros com boicotes econômicos como ocorreu na Era Vargas, com a entrada do Brasil na IIGM, lutando por um lado que contrariava as inclinações dos governantes de então, e também posteriormente, na Revolução de 1964, associando os homossexuais com comunistas, levando o Brasil a oprimir pessoas que jamais se pensaria. Os estadunidenses não estavam preocupados com nosso bem-estar, queriam apenas evitar que um país com território gigantesco como o nosso, os ameaçasse como uma segunda Cuba, por isso era interesse deles nomear comunistas entre os brasileiros para serem punidos. (TAVARES, 2014)

Apesar de todos estes trâmites, o movimento de afirmação LGBT conseguiu vitórias inegáveis de consolidação em momentos marcados por inegável autoritarismo. 30 grupos de ação afirmativa LGBTQ surgiram durante o regime militar, o que só é possível pela presença da Pseudo-dialética feminina, que traz à memória uma essência Pré-I dos Tupinambás que aceitavam a naturalidade da homossexualidade.

Quando os neopentecostais na atualidade querem impor seu pensamento religioso sobre a gestão pública no Brasil incorrem naquilo que Sampaio chama de recaída para a Log I estabelecendo o cruzamento da Pseudo-logica masculina. Assombrações do tal "destino manifesto" presente no imaginário coletivo dos estadunidenses, e metaforizado na coleção de seus super-heróis, a começar pelo Capitão América. Sampaio chama este movimento de "cumprimento de uma destinação" (SAMPAIO, 2000, p. 173). Na instância quinquitária I/D2, ou Hiperdialética ele mostra que só faz sentido lidar com esses assuntos integrando à lógica do discurso, o amor e o respeito pelo outro, a vontade de ser partícipe com ele das instâncias naturais da vida. Estes articuladores de diálogo aumentam a cada dia, assim como aumenta o número de religiosos intolerantes com a intolerância, e que se agregam a eles. Não há espaço para desmerecer tradições de povos milenares sob o risco de sermos anti-científicos. Neste sentido a transdisciplinariedade exerce papel de extrema relevância. Resta aos cientistas se permitirem dialogar, e aos pesquisadores transdisciplinares, usar amplamente tais epistemologias.

Referências bibliográficas

FOUCAULT, Michel. A história da sexualidade. Vol 1: vontade de saber. Rio de Janeiro: Graal, 1999. 
GOMES, Mércio Pereira. Antropologia: ciência do homem, filosofia da cultura. 2å. ed. São Paulo: Contexto, 2015.

. Antropologia hiperdialética: ciência do homem, filosofia da cultura. São Paulo: Contexto, 2011. LENZA, Pedro. Direito Constitucional Esquematizado. 16a ed. Revista e Atualizada Ampliada. São Paulo: Saraiva, 2012.

MARIANNO, Lília Dias. Diversidade de gênero versus intolerância religiosa. O conflito sob as lentes da Lógica e da Antropologia Hiperdialética. [Monografia]. Rio de Janeiro: HCTE. Julho de 2017, 31p. Disponível em: https://ufrj.academia.edu/L\%C3\%ADliaMarianno

. Impureza: Sexualidade e saúde pública no judaísmo do Período Persa. Em: Revista Vértices. São Paulo: DLO - FFLCH - USP. ISSN: 2179-5894. N. 11. Publicado em 2011. Disponível em: <http://www.revistas.fflch.usp.br/vertices/article/view/68> Acessado em 15/07/2017.

Sexo, sexualidade e reflexão teológica: onde é que eles se. Rio de Janeiro: Programa de PósGraduação em Ciências da Religião FATERJ/IBEC. ISSN: 1980-2579. Ano 2, N.3. Publicado em 2S2007. Acessado em 15/07/2017. Disponível em: https://ufrj.academia.edu/L\%C3\%ADliaMarianno

MORIN, Edgar. O método (6) - Ética. 3ạ. ed. Trad. Juremir Machado da Silva. Porto Alegre: Sulina, 2007.

MOTT, Luiz. História da homossexualidade no Brasil. Cronologia dos principais destaques. Publicado em: Acessado em 13/07/2017. Disponível em:

http://www.ggb.org.br/cronologia_movimento_homossexual.html

MOTT, Luiz. Homossexualidade e contexto histórico. Entrevista Publicada em: 08/04/2014 Acessado em 13/07/2017 Disponível em: https://www.youtube.com/watch?v=Aq1a1730hsw

SAMPAIO, Luis Sergio Coelho de. Lógica ressuscitada: sete ensaios. Rio de Janeiro: EdUERJ, 2000. . Lógica da diferença. Rio de Janeiro: EdUERJ, 2001.

SANTOS, Breno Machado. Os primeiros jesuítas e o trabalho missionário no Brasil. Anais do I Colóquio do Laboratório de História Econômica e Social. Juiz de Fora: LAHES, Publicado em: Junho de 2005. Disponível em: http://www.ufjf.br/lahes/files/2010/03/c1-a7.pdf. Acessado em 14/07/2017.

TAVARES, Camilo. O dia que durou 21 anos. Documentário. Publicado em 24/09/2014. Acessado em 15/07/2017. Disponível em: https://www.youtube.com/watch?v=QJCugIKcWNs

WHITEHEAD, Alfred North. Processo e Realidade. Ensaio de cosmologia. Trad. Maria Teresa Teixeira. Lisboa. Centro de Filosofia da Universidade de Lisboa, 2010. 


\title{
EVOLUÇÃO DA POLÍTICA EM CIÊNCIA, TECNOLOGIA E INOVAÇÃO: CONSIDERAÇÕES SOBRE INTERNACIONALIZAÇÃO, INTERAÇÃO CIÊNCIA- SOCIEDADE E DESAFIOS PARA O FINANCIAMENTO DA PESQUISA NO BRASIL
}

\author{
Valéria Lima Marques de Sousa; Fernanda de Moura Borges; Biana Mota Penelva de Andrade; Ana Lúcia de \\ Oliveira Carvalho; Mônica Antunes das Chagas. Mestrado Profissional em Educação, Gestão e Difusão em \\ Biociências - Instituto de Bioquímica Médica Leopoldo de Meis/UFRJ \\ Contatos: valerialms@gmail.com,fernanda_mborges@yahoo.com.br, bianaufrj@globo.com, \\ alocarvalho2013@gmail.com, mchagas.uerj@gmail.com
}

Resumo

Esta contribuição baseia-se em estudos realizados na disciplina Fundamentos e Metodologias da Gestão em Ciências ao abordarmos a evolução da política científica, tecnológica e de inovação a partir da interface ciência-sociedade. Discutimos a temática no Brasil, considerando conceitos de ciência, fontes de recursos financeiros, além de outros fatores que proporcionaram a internacionalização da produção de conhecimento e mudanças na relação entre ciência e sociedade. Tendo como ponto de partida a abordagem de VELHO (2011), verificamos que diferentes fontes de financiamento em CTI e P\&D são empregadas atualmente. Contudo, entendemos ser necessário refletir sobre os benefícios e riscos desse novo modelo de investimento para a produção de conhecimento e seus possíveis impactos socioambientais.

Palavras-chave: CTI. Internacionalização. Ciência-Sociedade.

Introdução

Diversos países compartilham objetivos e estratégias semelhantes nas políticas em Ciência, Tecnologia e Inovação (CTI). Velho (2011) destaca que a tendência ao isomorfismo ou imitação dessas políticas, a princípio, não representava um problema, entretanto, observa que apesar dos objetivos comuns, cada país deve considerar a cultura nacional e seu nível de desenvolvimento econômico no intuito de traçar estratégias de crescimento adequadas à própria realidade.

A produção de conhecimento científico no Brasil está essencialmente vinculada às universidades públicas, instituições financiadas majoritariamente pelo Estado, através de uma estrutura complexa constituída por programas de pós-graduação e agências de fomento, e ligada tanto ao Ministério da Educação (MEC) quanto ao Ministério de Ciência, Tecnologia, Inovação e Comunicação (MCTIC) (MARQUES, 2017). Gradativamente, fortaleceu-se o interesse em não restringir o conhecimento gerado ao meio acadêmico e contribuir para o desenvolvimento econômico e social, percepção que assumiu caráter global a partir do processo de internacionalização das políticas de Ciência, Tecnologia e Inovação (MOREIRA, 2006) e da mudança na visão da sociedade sobre a ciência, que cada vez mais se volta para questões globais como avanços tecnológicos, meio ambiente, economia, saúde, fome e justiça social (THE ROYAL SOCIETY, 2010). 
Neste trabalho, desenvolvido a partir de estudos e reflexões na disciplina Fundamentos e Metodologias da Gestão em Ciências, acompanhamos a trajetória histórica dos paradigmas de ciência que influenciaram as políticas de interna-cionalização em CTI, considerando aspectos da interação entre ciência e sociedade e fontes de financiamento em pesquisa e desenvolvimento, com atenção ao Brasil.

Trajetória dos paradigmas e das fontes de financiamento da ciência

Diversas formas de conhecimento foram construídas ao longo da história, sendo o conhecimento científico um dos que mais sofreu mudanças, passando a ser entendido como necessário em qualquer sociedade pelos benefícios trazidos com relação à melhor interpretação da natureza e melhoria na qualidade de vida (PORTO, 2011). Apesar da visão social de ciência benevolente, avanços científicos e tecnológicos nem sempre estiveram diretamente ligados a processos sociais.

Para essa compreensão, partimos da análise da evolução dos quatro paradigmas de ciência descritos por Velho (2011) de acordo com a origem histórica e o perfil do financiamento atribuído à pesquisa. Sobre o paradigma da "ciência como motor do progresso" (1945-1960), a autora apresenta a autonomia da ciência:

A comunidade científica proclama a ciência fora dos processos sociais e, consequentemente, libera a si própria de qualquer responsabilidade, pelo uso dado aos resultados de pesquisa [...] Nessa fase, o Estado, como principal financiador da ciência, delegava esta tarefa aos conselhos de pesquisa e essas delegavam as principais decisões aos próprios cientistas - os únicos juízes competentes. A necessidade de prestar contas à sociedade perdia sua importância quando confrontada com o argumento de que o sistema de revisão por pares estava selecionando a melhor pesquisa, e isto era o que o governo (e a sociedade) desejava (ou deveriam desejar). A comunidade científica, então, tinha grande autonomia na distribuição de recursos, prestava contas apenas a si própria e não se sujeitava a qualquer controle social direto. [...] A avaliação se fazia, exclusivamente, pelo processo de revisão por pares, tanto pelo controle da qualidade quanto do sistema de recompensa (VELHO, 2011, p. 136-139).

Em seguida, a autora apresenta o paradigma da "Ciência como Solução e Causa de Problemas (1960-1970), no qual os governos e a sociedade passaram a questionar ideologias, riscos econômicos e impactos sociais e ambientais da ciência e, em contrapartida, as empresas privadas entraram no cenário do desenvolvimento científico e tecnológico, passando a atuar com credibilidade para julgar, identificar e articular novas demandas de mercado, influenciando ou até mesmo determinando os rumos da pesquisa científica:

A relação entre ciência e tecnologia ainda era concebida como linear, mas agora com ênfase na demanda. (...) as necessidades dos usuários que puxam o desenvolvimento científico (demand pull). Nessa relação entre ciência e tecnologia, as empresas eram tidas como possuidoras de capacitação e habilidades para julgar as demandas do mercado, identificar oportunidades tecnológicas e articular necessidades e demandas. (...) o foco da política era o de conceber incentivos para que os pesquisadores trabalhassem em problemas relevantes para o setor produtivo e o de criar oportunidades para transferência de tecnologia. (Ibid., p. 140).

Exemplos dessa visão de ciência foram os avanços das tecnologias agrícolas, que apesar de terem promovido grande aumento na produção de alimentos, a partir de uma perspectiva de ciência rural econômica e globalizada, também levou à perda de diversidade biológica e cultural, causou problemas ambientais, de segurança alimentar e saúde pública; assim como o aumento na produção de resíduos sólidos (LEFF, 2009). 
A partir da década de 1980, o panorama da globalização econômica e da comunicação fez surgir um novo paradigma que Velho (2011) denominou "Ciência como Fonte de Oportunidade Estratégica", vista como um elemento socialmente construído, ultrapassando os limites da academia, dos países e das empresas, a ciência é então financiada e produzida em ambientes diversos. Esse novo paradigma é cada vez mais aceito pela sociedade e pela comunidade científica em geral, embora ainda existam polêmicas sobre prejuízos que o direcionamento de pesquisas possa acarretar para a produção de conhecimento. No contexto do século XXI, vivemos a construção de um novo paradigma, que é denominado por Velho (2011) como "Ciência para o Bem da Sociedade", no qual:

A empresa deixa de ser o foco principal de escolha tecnológica, (...) cabe à política pública de CTI o papel de articulador, regulador e facilitador, garantindo a conectividade dos múltiplos atores. Desenvolvem-se instrumentos para garantir a participação social na definição de objetivos e instrumentos de política, assim como na disseminação de resultados (papel da mídia). A definição de políticas deve ocorrer não apenas no nível nacional, mas também nos níveis regionais e locais. (Ibid, p. 146).

Diante do exposto, percebemos que os conceitos dominantes de ciência, assim como as estratégias de financiamento e a atitude de pesquisadores e sociedade em diversos países guardam semelhanças relevantes, sendo assim soluções e políticas estabelecidas por países desenvolvidos passaram a ser aplicadas em caráter global, desencadeando um processo de internacionalização e popularização das ciências que será discutido a seguir.

Internacionalização da Política CTI: considerações sobre estratégias e desafios para diversificação dos investimentos

O processo de internacionalização científico-tecnológico envolve representantes de governos, pesquisadores, diplomatas, jornalistas, políticos e líderes empresariais no esforço de enfrentamento de um conjunto de questões globais como as alterações climáticas, a segurança alimentar, a redução da pobreza, a saúde e o desarmamento nuclear (ARROZ; MENDONÇA, 2016).

Especialistas da Comissão Europeia (CE) elaboraram um relatório com propostas para reverter a redução nos índices de crescimento da ciência europeia. Segundo o documento, este cenário se deu devido à transformação nas políticas de CTI nos países desenvolvidos, impulsionada por crises econômicas, pelo desenvolvimento industrial e pelos avanços nas tecnologias de informação, formando um panorama internacional multipolar, em que países emergentes passaram a adotar novas estratégias e investimentos. Dessa forma, a escassez de recursos e a demanda por competitividade implicaram redução de gastos públicos com ciência e fomentaram estratégias para manutenção da credibilidade e relevância de instituições de pesquisa de renome, especialmente em países europeus e norte-americanos. (EUROPEAN COMISSION, 2012).

Neste cenário, segundo o mesmo relatório, os especialistas propuseram a aproximação de empresas privadas com as universidades e a cooperação científica com outros países, inclusive emergentes e não pertencentes à União Europeia. A CE propôs a abertura dos projetos de pesquisa, além da redução de custos e enfrentamento de desafios globais a partir de prioridades estabelecidas estrategicamente por seus membros - abordagem top-down -, considerando iniciativas de pesquisadores ou instituições, denominadas bottom-up.

Dentro deste contexto, observamos que temas prioritários predefinidos por programas e editais na abordagem top-down proporcionam desenvolvimento socioeconômico e impulsionam pesquisas científicas para produzirem tecnologia de aplicação social, ao mesmo tempo em que promovem cooperação entre redes mundiais de agências financiadoras e instâncias de governo, valorizando também as iniciativas de pesquisadores locais, seguindo, 
portanto, a lógica de internacionalização da ciência, ao considerar também as abordagens bottom-up.

Iniciativas denominadas "Grand Challenges" representam criatividade e diversificação no campo dos investimentos, com fundações de apoio a pesquisas nas áreas social, ambiental e de saúde que se destacam no cenário brasileiro e internacional: MacArthur Foundation, com projetos focados no combate à corrupção, promoção de justiça social e desenvolvimento sustentável, este último objetivo juntamente com a proteção ambiental mobiliza várias outras organizações de apoio à pesquisa como Amazon Conservation Association; Fundação $\mathrm{O}$ Boticário; Fundação Amazonas Sustentável; Fundação de Apoio à Pesquisa Agropecuária e Ambiental (FUNDAPAM); SOS AMAZÔNIA; na área das ciências biomédicas destacam-se os financiamentos da Gates Foundation, TWAS e INSERM.

Do ponto de vista do capital humano, o volume 72 da International Higher Education (2013) traz artigos apontando que a relação dos países ricos com as estratégias de internacionalização favoreceu o surgimento de alguns fenômenos como "fuga de cérebros", "migração" e "diáspora científica", que consistem respectivamente: a) na atração definitiva de cientistas para países estrangeiros com efetiva perda de referência e contato com seus países de origem; b) na permanência de cientistas e estudantes por curto período, permitindo a aquisição de conhecimento e consolidação de redes de colaboração científica; c) na atração de cientistas de forma permanente ou por longo período, porém mantendo-se o contato com o país de origem e garantindo a colaboração científica com seus pares (BALBACHEVSKY; SILVA, 2011).

Concordamos com a ideia de que essas iniciativas proporcionam a atuação de instituições públicas, empresas privadas, indústrias, organizações internacionais e universidades em acordos que resultam na diversificação dos investimentos e na transferência de tecnologias inovadoras cujo impacto no desenvolvimento social e econômico se reflete em esfera local e global, contribuindo também para consolidar a cooperação científica, evidenciada pela coautoria de publicações reconhecidas mundialmente, conferindo visibilidade e valorização da ciência de países em desenvolvimento, inclusive do Brasil (MARQUES, 2017), o que sustenta a necessidade de observação atenta às questões éticas e práticas que envolvam a ciência e a sociedade, como as políticas de divulgação científica e as pesquisas de público, e permitam mensurar os interesses sociais em CTI.

Interação Ciência-Sociedade e Produção de Conhecimento

É necessário pensar na influência das políticas de educação e difusão científica, pois escolaridade e divulgação científica interferem na capacidade de uma sociedade compreender os múltiplos contextos, tomar decisões e fazer reivindicações que permitam demandas sociais, assim como socioambientais, serem norteadoras de políticas públicas e pesquisas, acadêmicas ou não (VELHO, 2011). Moreira (2006) defende que a popularização da ciência revela-se tanto como um elemento de inclusão social quanto de aprimoramento da cultura científica. Do mesmo modo, Caldas(2011) afirma que o conhecimento é uma forma de emancipação social essencial para a conquista da cidadania, pois, é através de uma educação e uma cultura científica que os sujeitos sociais desenvolvem a capacidade crítica para melhor compreender a realidade e, dessa forma, se posicionar sobre ela.

No Brasil, nos anos 1980, o então Ministério da Ciência e Tecnologia (MCT) iniciou as pesquisas de interesse e percepção pública sobre Ciência e Tecnologia (C\&T). Desde então, percebeu-se maior interesse público por questões ambientais e de saúde (BRASIL, 2010). Em 2015, o Centro de Gestão e Estudos Estratégicos (CGEE), a pedido do então Ministério da Ciência, Tecnologia e Inovação (MCTI), realizou nova pesquisa, obtendo como resultado $42 \%$ interessados e $36 \%$ muito interessados no tema meio ambiente. É razoável assumir que as 
questões ambientais se tornaram de maior domínio público pela percepção dos impactos na realidade e pelo grande apelo midiático que tais discussões alcançam através da fácil difusão, não só em mídias convencionais, mas também pela Internet, uma das principais fontes de informação sobre C\&T mencionadas pelos entrevistados.

Já para C\&T, a pesquisa do CGEE aponta $36 \%$ interessados e $26 \%$ muito interessados, e muitos acreditam que benefícios da C\&T superam possíveis malefícios. Este é também um posicionamento ideológico defendido no documento "The Scientific Century - securing our future prosperity", que coloca o esforço científico como uma das conquistas da humanidade, destacando a contribuição para sua cultura e civilização (THE ROYAL SOCIETY, 2010).

Essa percepção dos brasileiros é ratificada no relatório "Global Trends 2014: Navigating the New" (IPSOS MORI, 2014), que avaliou o que o cidadão tem pensado e escolhido, em especial, com relação aos avanços tecnológicos e melhoria na qualidade de vida. Nesse relatório, o Brasil apresenta um cenário positivo quando comparado a países desenvolvidos, mesmo em um cenário mundial de crise, pois a população brasileira parece ter uma visão mais otimista da economia, da ciência e seus benefícios, e do futuro de sua juventude; e sugere-se que os níveis de otimismo estão correlacionados com a possibilidade de controle e o alcance dos indivíduos para influenciar seu ambiente e o futuro, apontando para uma necessidade das organizações de pensar e agir na esfera local.

Contudo, o atual cenário brasileiro para o desenvolvimento de CTI e as políticas ambientais tem sofrido mudanças drásticas. O contingenciamento de recursos destinados ao $\mathrm{CNPq}$, à Capes e às universidades públicas afeta diretamente laboratórios, centros de pesquisa e programas de pós-graduação (SBPC, 2017), fazendo o país caminhar na contramão dos países desenvolvidos e emergentes que, mesmo em momentos de crise econômica, investem em CTI, priorizando ações de internacionalização científica e políticas para a educação. Assim, entendemos que a definição de prioridades para investimentos requer uma reflexão crítica sobre a importância da ciência no Brasil e suas perspectivas futuras.

\section{Considerações Finais}

Ao dialogarmos com as ideias aqui apresentadas, concluímos que participação social, a influência internacional e a crescente demanda pela popularização da ciência são realidades atuais e inevitáveis. Concordamos que o desafio do Brasil nos próximos anos será agir estrategicamente para ampliar seus acordos de cooperação científica internacional e fazer com que ocorra significativo aumento do investimento privado em CTI, assim como acontece nos países com maior reconhecimento e desenvolvimento científico.

Nas universidades brasileiras alguns caminhos nos parecem ser possíveis para garantir que pesquisadores comprometidos com a sociedade, com seu tempo e com questões éticas continuem produzindo conhecimento e sejam reconhecidos, tais como: divulgação científica, projetos de extensão, inovação, parcerias interna-cionais e acesso a recursos financeiros de fundações nacionais e internacionais.

Por fim, é importante ressaltar que além de gerar desenvolvimento local, a captação de recursos internacionais por países em desenvolvimento reflete na produção e transferência de conhecimento sem que o capital humano de alta qualificação seja atraído de forma permanente para outros países. Entendemos que essas medidas devem considerar a divisão equilibrada de custos entre os países, sem desprezar o investimento público em ciência básica e aplicada, evitando assim o direcionamento das pesquisas pela lógica do mercado.

Referências bibliográficas

ARROZ, Sónia; MENDONÇA, Sandro. Diplomacia de ciência: razões, justificações e abordagens na intersecção da investigação e internacionalização. Parcerias Estratégicas, v. 21, n. 42, p. 117-136, 2016. 
BALBACHEVSKY, Elizabeth; SILVA, Eduardo do Couto e. A diáspora científica brasileira: perspectivas para sua articulação em favor da ciência brasileira. Parcerias Estratégicas, v. 16, n. 33, p. 163-176, 2011.

BRASIL. Pesquisa Nacional: Percepção Pública da Ciência e Tecnologia. Ministério da Ciência e Tecnologia. 2010.

CALDAS, Graça. O valor do conhecimento e da divulgação científica para a construção da cidadania. Comunicação \& Sociedade, v. 33, n. 56, p. 7-28, 2011.

CGEE. Percepção pública da C\&T no Brasil 2015. Brasília: Centro de Gestão e Estudos Estratégicos. 2015. Disponível em <percepcaocti.cgee.org.br>, acesso 20 set. 2017.

EUROPEAN COMISSION. International Cooperation in Science, Technology and Innovation: Strategies for a Changing World: Report of the Expert Group established to support the further development of an EU international STI cooperation strategy. Luxembourg: Publications Office of the European Union, 2012. IHE (International Higher Education), v. 72, 2013. Disponível em <http://www.revistaensinosuperior.gr.unicamp.br/edicoes/ihe/IHE72original.pdf>, acesso 20 set. 2017

IPSOS MORI. Global Trends 2014 - Navigating the New. London: Ipsos MORI Social research Institute, 2014.

MARQUES, Fabrício. Financiamento em crise. Revista Pesquisa Fapesp, ano 18, n. 256, p. 20-29, jun. 2017.

MOREIRA, Ildeu de Castro. A inclusão social e a popularização da ciência e tecnologia no Brasil. Inclusão Social, v. 1, n. 2, p. 11-16, abr./set. 2006.

LEFF, Enrique. Ecologia, Capital e Cultura: a territorialização da racionalidade ambiental. Petrópolis: Vozes, 2009.

PORTO, Cristiane de Magalhães. Um olhar sobre a definição de cultura científica. p. 93-122. In: PORTO, Cristiane de Magalhães; BROTAS, Antonio Marcos Pereira; BORTOLIERO, Simone Terezinha (Orgs.). Diálogos entre ciência e divulgação científica: leituras contemporâneas. Salvador: EDUFBA. 2011.

SBPC. Associadas da SBPC se manifestam contra os cortes à CT\&I. 2017. Disponível em <http://portal.sbpcnet.org.br/noticias/associadas-da-sbpc-se-manifestam-contra-os-cortes-a-cti/ >, acesso 20 set. 2017.

THE ROYAL SOCIETY. The Scientific Century - securing our future prosperity. London: The Royal Society. 2010.

VELHO, Léa. Conceitos de Ciência e a Política Científica, Tecnológica e de Inovação. Sociologias, v. 13, n. 26, p. 128-153, jan./abr. 2011. 


\section{A PERFORMANCE DO DIREITO À SAÚDE NO BRASIL: DA CONSTITUIÇÃO À MORTE?}

Daniele Martins dos Santos - Doutoranda UFRJ-HCTE - danielesantos@hcte.ufrj.br

Resumo

Vamos refletir sobre o direito à saúde, desde o período de redemocratização do Brasil que antecedeu a Constituição de 1988 até os dias atuais. Nos interessa refletir sobre os fatores que desencadearam a forma final que esse direito se materializou na Constituição. Nos interessa também saber se a maneira como se conformou esse direito influenciou sua caminhada, para ao final chegarmos aos dias atuais. Vamos passar pela audiência pública realizada no STF que tratou do tema da "judicialização" do direito à saúde, e chegar a discussão do projeto "planos de saúde acessíveis", criada pelo Ministro da Justiça Ricardo Barros, que traz uma nova leitura no conceito de "universalização da saúde", e pode significar a morte do SUS.

Palavras-chaves: Direito. Saúde. Constituição. STF.

1. Introdução

O artigo 196 da Constituição Federal de 1988 define saúde da seguinte forma: "A saúde é direito de todos e dever do Estado, garantido mediante políticas sociais e econômicas que visem à redução do risco de doença e de outros agravos e ao acesso universal e igualitário às ações e serviços para sua promoção, proteção e recuperação".

Pensando nas inúmeras ações que existem no nosso sistema judiciário e que tem como objeto a concretização do direito à saúde, nos interessa saber porque há tanto litígio em torno dessa temática. Será que a dificuldade é puramente orçamentária?

Para essa reflexão teremos que retornar à década de 80, períodoem que se construiu a ideia da "saúde para todos", mais tarde implementada através do Sistema Único de Saúde. Ao pesquisar o período, percebemos que essa mudança que culminou na regra constitucional não foi alcançada sem muita controvérsia.

Passaremos também por outro marco importante, a audiência pública $n^{\circ} 4$ realizada no Supremo Tribunal Federal, em que diversas pessoas, representantes de órgãos públicos e privados, assim como usuários do Sistema Único de Saúde foram chamados para falar sobre questões técnicas referentes a prestações de saúde, a fim de auxiliar o STF nas decisões subsequente.

Ao fim chegaremos ao ponto em que nos encontramos: 2017, para fazermos mais uma vez uma análise do direito à saúde. Com uma nova composição política, esse direito pode alcançar uma nova ontologia, que é o que nós pretendemos analisar.

2. Saúde. Que direito é esse?

Voltamos à década de 80 , período de redemocratização brasileira. A década de 1980 é marcada pelo movimento conhecido como a reforma sanitária. Nesse período formou-se o projeto de seguridade social, que incluiria a saúde, a previdência social e a assistência social. Nesse primeiro momento, para falar de saúde teremos que falar de seguridade social.

O ideário da seguridade social, no âmbito da reforma sanitária, buscou um distanciamento de um modelo de cidadania atrelado a relação reguladora do Estado e no vínculo formal de 
produção do trabalho. Até então, poderia se dizer que só seria cidadão aqueles que ocupassem uma das atividades reconhecidas por lei. No novo modelo, pretendia-se estabelecer um compromisso mais efetivo do Estado na formulação de políticas na área "social", de forma que se reconhecessem direitos iguais a todos os cidadãos - "cidadania plena" -, independentemente de serem ou não contribuintes do sistema.

Esse foi um dos pontos mais sensíveis da proposta. Muitos daqueles que efetivamente contribuíam para o sistema não estavam dispostos a dividi-lo com aqueles que antes eram excluídos. E havia uma forte propaganda no sentido de que o sistema não suportaria tal inclusão.

Um primeiro ponto que percebemos ao pesquisar o período, é que, como se pode prever, essa mudança não foi alcançada sem muita controvérsia. Até porque o princípio universalista estendia os benefícios para toda a população, mas não previa outras fontes de financiamento, de maneira que os custos permaneceriam concentrados nas folhas de salários dos trabalhadores.

Até a Constituição de 1988, duas entidades eram responsáveis pela saúde dos brasileiros. O Instituto Nacional de Assistência Médica da Previdência Social (Inamps) e o Ministério da Saúde. O Inamps era uma autarquia filiada ao Ministério da Previdência e Assistência Social. Tinha estabelecimentos próprios, apesar de a maioria dos atendimentos acontecerem em hospitais da rede privada. Era responsável pela assistência médica aos trabalhadores que contribuíam para a previdência social. Dessa maneira, aqueles que não contribuíam não podiam acessar esse serviço.

O Ministério da Saúde era responsável pelas atividades de promoção de saúde e prevenção de doenças. Essa atividade era prestada em caráter universal, já que o Inamps era focado no tratamento de doenças. Outra atividade do Ministério da Saúde era o tratamento de indigentes, ou seja, aqueles que não tinham acesso ao Inamps.

Podemos identificar, naquele momento, dois grandes grupos: um primeiro que defendia a unificação do setor da saúde no âmbito federal em um único organismo que unisse as funções de assistência médica individual e as ações de saúde coletiva; e um segundo que pretendia a modernização da máquina previdenciária com o objetivo de fortalecimento do Inamps, que continuaria a ser o responsável pelas decisões acerca das políticas de saúde.

No período que antecedeu a aprovação da Constituição, o que percebemos é que o debate acerca da seguridade social era uma questão polêmica de difícil consenso.

A falta de consenso entre os setores envolvidos - saúde, previdência e assistência social comprometeu a criação de uma política integrada e compromissada na área social (WARGAS, 1998). As duas estratégias percorreram uma caminhada de traduções, desvios e composições até alcançar a forma que conhecemos da Constituição de 88.

A forma final do Sistema Único de Saúde, tal como estabelecida pela Constituição de 88, foi resultado de toda essa caminhada de conflitos. A presença de grupos conservadores na assembleia constituinte fez surgir um texto cheio de linhas gerais e imprecisas, bem diferente do que foi idealizado a princípio.

Após a promulgação da Constituição, principalmente nos primeiros anos, ficou evidente a fragilidade e o elevado grau de abstração das negociações políticas que acabaram por conformar a saúde no Brasil. A saída de alguns atores de cargos estratégicos do Governo, e que participaram ativamente da performance dos acordos durante esse período, provocou um enfraquecimento no momento subsequente. As disputas por recursos tornaram as negociações entre saúde, previdência e assistência acirradas, criando impasses principalmente no financiamento da saúde.

O que aconteceu em seguida, foi uma enxurrada de leis que tinham como objeto regulamentar a competência comum dos três entes federativos (União, Estados e Municípios) 
para formular e executar políticas de saúde. Essa competência foi estabelecida de forma anacrônica, de maneira que se iniciou no Brasil um fenômeno que acabou tornando-se muito comum, conhecido como "judicialização". Na falta de entendimento e cumprimento das determinações constitucionais na esfera executiva e legislativa, os usuários passaram a recorrer de forma repetitiva a esfera judiciária.

Em 2009, o Ministro Gilmar Mendes, então Presidente do Supremo Tribunal Federal, determinou realização de audiência pública para subsidiar o julgamento de inúmeros processos que discutiam a concretização do direito à saúde, tal qual estabelecido pelo artigo 196 da Constituição Federal. A discussão se daria em torno de diferentes pedidos de prestações de saúde pelo SUS (fornecimento de medicamentos, suplementos alimentares, órteses e próteses; criação de vagas de UTI; contratação de servidores de saúde; realização de cirurgias; custeio de tratamentos fora do domicílio e de tratamentos no exterior, entre outros).

Sobre saúde na Constituição de 1988, o Ministro Gilmar Mendes, na abertura do primeiro dia de audiência pública afirmou o seguinte:

\begin{abstract}
"A Constituição de 1988, aprovada num contexto econômico e social difícil, faz clara opção pela democracia e sonora declaração em favor da superação das desigualdades sociais e regionais. Precisamos expandir a capacidade do Estado social de se desenvolver e buscar a concretização efetiva dos direitos sociais por meio da afirmação das liberdades. "
\end{abstract}

Mas será que estava tão clara assim a opção efetuada pela Constituição? Será que o instituto da saúde, tal qual consagrado no artigo 196 citado acima, restou robustamente configurado na constituição? Talvez aí esteja o imbróglio, ou o motivo para tantas ações judiciais requerendo efetivação desse direito. Se estivesse "tão clara a opção pela democracia" e "tão sonora" a declaração em favor da superação de desigualdades sociais e regionais, não haveria tantos embates judiciais.

3. O direito à saúde em xeque. Mais uma vez.

A saúde que tratamos aqui, construída após muito debate e muitas concessões na Constituinte de 1988, está sempre em xeque. É preciso movimentar continuamente aliados se se deseja ampliar suas dimensões e assim alcançar a realização dos assim chamados "direitos sociais". Quando lemos o artigo 196 da Constituição Federal podemos ter uma ideia do que se trata a saúde. Mas quando passamos para as decisões judiciais, vemos que há outros artefatos em jogo. Na audiência pública surgem ainda muitos outros. Recentemente entraram na arena outros jogadores.

O atual Ministro da saúde, Ricardo Barros, nomeado pelo Presidente Michel Temer após o impeachment da Presidenta eleita Dilma Rousseff, assumiu em sua pasta uma empreitada no sentido de elaborar uma proposta de "planos de saúde acessíveis", com cobertura de atendimento reduzida, para o público de menor renda. O objetivo dessa proposta é que essas pessoas façam consultas e tratamentos no sistema privado, desafogando o SUS. Há um grupo de trabalho dentro do Ministério da Saúde, que inclui representantes da indústria de planos de saúde, elaborando um novo produto a ser disponibilizado pelas operadoras.

Em entrevista à BBC Brasil, o Ministro Ricardo Barros foi perguntado acerca de uma afirmação do professor Jairnilson Paim, da UFBA, que afirmou que para o SUS, quanto mais gente utilizando, melhor seria o serviço. Vamos transcrever aqui a reposta do atual Ministro da Saúde:

"Você tem que conversar com o contribuinte. Se tiver gente disposta a contribuir para que todos demandem o SUS, eu também concordo. Então falar que tem que pôr mais gente demandando, sendo que o recurso é limitado, é uma incoerência. 
Ele está falando de uma ideologia, do pensamento, do sonho, e não está falando da realidade. Não são técnicos, nem especialistas, são ideólogos que tratam o assunto como se não existisse o limite orçamentário, como se fosse só o sonho. Não é um sonho, nós temos que administrar uma realidade aqui. "

A fala do Ministro da Saúde Ricardo Barros, diferente da fala do Ministro Gilmar Mendes, revela uma outra face performática da saúde. Enquanto Gilmar Mendes fala de "buscar a concretização efetiva dos direitos sociais", Ricardo Barros fala de "sonho" e "limite orçamentário". O ponto de partida das falas determina, sobremaneira, o curso das decisões que serão tomadas no caminho. Ricardo Barros está colocando em prática um movimento de deslocamento de pessoas para fora do SUS. Numa reinterpretação do princípio universalista aprovado na Constituição de 1988, esse princípio passa a assumir uma conotação excludente. Isso porque, tendo em vista a alegada falta de recursos financeiros, o serviço oferecido pelo SUS é exaltado como um serviço ruim e de baixa tecnologia, ou, como se costuma dizer: "para pobres". Aqueles que tem condição de não se submeter a um serviço de baixa qualidade, passam a ser estimulados a migrar para a medicina supletiva autônoma do Estado (planos de saúde). Em outras palavras, é firmada a ideia de que, ao se oferecer saúde para todos, oferece-se saúde "ruim" e para os "pobres". Ao retirar do SUS pessoas com capacidade crítica de defender um serviço público de melhor qualidade, a tendência é ele ficar cada vez mais enfraquecido. É a esse círculo vicioso que se refere o Professor Jairnilson. Mas Ricardo Barros caminha exatamente nesse sentido em sua pasta no Ministério da Saúde. Para isso ele trabalha na construção de "planos de saúde populares", que, segundo ele, visam a afastar usuários do SUS para assim concentrar os gastos com o menor número possível de usuários. Para Ricardo Barros a operação é puramente matemática: pouco dinheiro para poucas pessoas.

4. Conclusão

A realidade não está dada. Como nos indica Latour :

realidade como indica a palavra latina res, é aquilo que resiste. Mas resiste a quê? Ao teste de força. Se, em dada situação, nenhum discordante é capaz de modificar a forma de um objeto novo, então sim, ele é realidade, pelo menos enquanto os testes de força não forem modificados. (LATOUR, 2000, p.155)

Afinal, como construiremos a "realidade" do SUS? A "realidade" do SUS será includente ou excludente? Pelo que lutaremos? Parece que os Ministros Gilmar Mendes e Ricardo Barros não estão trilhando o mesmo caminho. Nada está garantido. O SUS existirá enquanto puder resistir aos repetidos testes de forças a que vem sendo submetido.

O impeachment da Presidenta, a chegada de Michel Temer à presidência e de seu plano liberal de desmonte de direitos sociais, como os trabalhistas, previdenciários e de saúde, que é o que nos interessa aqui especificamente, aumentaram a importância e a necessidade de falar sobre o assunto e ressaltar todas as coisas que vão sendo colocadas na mesa. Não é só lei. Nem é só orçamento público. Vemos assim que a controvérsia que atravessou a década de 80 e se estabilizou momentaneamente na Constituição de 88 continua em xeque. Mais do que nunca é necessário pensar o direito à saúde.

\section{Referências bibliográficas}

FIGUEIREDO NETO, Manoel Valente. Silva, Priscyla Freitas da. Rosa, Lúcia Cristina dos Santos. Cunha, Carlos Leonardo Figueiredo. Santos, Rafael. Vitor Silva Gaioso dos. O processo histórico de construção do Sistema Único de Saúde brasileiro e as novas perspectivas. Disponível em http://www.ambitojuridico.com.br/site/index.php?n_link=revista_artigos_leitura\&artigo_id=7781. Acesso em: 30 mar. 2017. 
LATOUR, Bruno. Ciência em Ação: como seguir cientistas e engenheiros sociedade afora. São Paulo: Vunesp, 2000.

PEREIRA, Carlos. A Política como Caixa de Pandora: Organização de Interesses, Processo Decisório e Efeitos Perversos na Reforma Sanitária Brasileira 1985-1989, Dados, Rio de Janeiro, v.39, n.3, p.,1996. Disponível em $<$ http://www.scielo.br/scielo.php?script=sci_arttext\&pid=S0011-52581996000300006\&lng=en\&nrm=iso>. Acesso em: 20 mar. 2017

TAVARES, Marcelo Leonardo. Previdência e assistência social: legitimação e fundamentação constitucional brasileira. Rio de Janeiro: Lúmen Júris, 2004.

SANTOS, Wanderley Guilherme dos. Cidadania e Justiça: a política social na ordem brasileira. Rio de Janeiro: Campus, 1979.

STEPHANES, Reinhold. Reforma da previdência sem segredos. Rio de Janeiro: Record, 1999.

WARGAS, Tatiana de Faria Baptista, Seguridade Social do Brasil. Revista do Serviço Público, Rio de Janeiro. V. 49, Número 3, jul.-set. 1998. . Disponível em https://revista.enap.gov.br/index.php/RSP/article/view/373/379. Acesso em: 20 mar. 2017 


\section{PROJETO RESGATE DA MEMÓRIA VISUAL DAS RUÍNAS DO SAHY EM MANGARATIBA RIO DE JANEIRO}

Giovanna Rita Rabelo de M. S. Arruda - Graduanda em Educação Artística - Licenciatura em Desenho giovannarita@ufrj.br

Adherbal Artigini Neto - Graduando em Educação Artística - Licenciatura em Desenho

neto_artigiani@hotmail.com

Aleph Lana da Costa Archanjo - Graduanda em Educação Artística - Licenciatura em Artes Plásticas

lana.arch@hotmail.com

Douglas do Nascimento Suzano - Graduanda em Educação Artística - Licenciatura em Desenho

douglasdesenhado@gmail.com

Flávia Lucia da Silva Fontes - Design de produto flavia-fontes@live.com

Gabrielle Carvalho Ferreira - Graduanda em Educação Artística - Licenciatura em Artes Plásticas

gabrielle.carvalhof16@gmail.com

José Leandro Lopes Araújo - Graduanda em Educação Artística - Licenciatura em Desenho jlla.ze@gmail.com

Marcelle Lateefah Simões - Graduanda em Educação Artística - Licenciatura em Desenho

majulateefa@gmail.com

Mariana Daltro Meliande - Graduanda em Educação Artística - Licenciatura em Desenho

marianameliande@gmail.com

Mariana Silva Rodrigues - Graduanda em Educação Artística - Licenciatura em Desenho maribuffy@gmail.com

Poliana da Silva Paixão - Graduanda em Educação Artística - Licenciatura em Desenho

polianaspaixao@gmail.com

Resumo

O projeto visa reconstruir graficamente o local onde se encontram as ruínas do Sahy, antigo distrito do Saco, Mangaratiba, Rio de Janeiro, através do desenho de observação, utilizando técnicas aplicadas na disciplina de Perspectiva de Observação, da Escola de Belas Artes da Universidade Federal do Rio de Janeiro. Deste modo, pretende-se simplificar a compreensão da história local, através da metodologia visual, representando perspectivas das plantas arquitetônicas da região. Destina-se praticar atividade do desenho de observação tecida a relevante história do patrimônio arquitetônico cultural da região, muitas vezes desconhecido da comunidade local da importância da preservação histórica e cultural de Mangaratiba. Ao final da pesquisa, os resultados serão aplicados na elaboração de um blog e de material físico, contendo referências visuais e textuais, além de um projeto, que se pretende levar à prefeitura da cidade, ansiando a preservação do local onde se encontram as ruínas do Sahy.

Palavras chave: Preservação histórica. Mangaratiba. Desenho de observação.

1. Introdução (contexto histórico; justificativa):

“A importância do complexo do Sahy no triste período da diáspora africana e do tráfico negreiro no ciclo cafeeiro ainda é desconhecido para a sociedade. É essencial construir a consciência social contra a discriminação racial e todas as formas de opressão. O Parque do Sahy e o Centro de Memória da Escravidão e contra a Discriminação têm um sério papel a desempenhar nesta missão" (LINHARES, 2016).

Numa estreita faixa de terra entre o mar e a montanha encontra-se a região de Mangaratiba, que está ligada à história de ocupação das terras da antiga cidade de São João Marcos, hoje um sítio arqueológico. O povoamento do local por volta de 1730 , originado pela necessidade de abrir uma estrada ligando o Rio de Janeiro a São Paulo e evitar o risco do transporte do ouro pelo mar, de Paraty ao Rio de Janeiro, devido à presença de piratas. Esse caminho ficou 
denominado como "Caminho Novo" e, mais tarde, transformou-se na "Estrada Real de Santa Cruz" (BREVES, 1966).

A Coroa Portuguesa incentivou a ocupação dessa região (serrana e beira mar) através de doação de sesmarias (léguas de terras), fazendo com que os colonos se embrenhassem pelas matas fechadas, construíssem suas fazendas e colaborassem na construção e segurança da estrada. Essas terras "serra acima", denominada serra do piloto, estavam compreendidas no território da freguesia de São João Marcos até meado do século XIX. A fertilidade dessa região serrana começava a se revelar no final do século XVIII, com as produções de milho, cará, feijão e café, como também com a criação de suíno.

\begin{abstract}
"Embora existam indícios de sua utilização no período anterior ao Ciclo do Café foi nesta época que o complexo se notabilizou como local de leilão de africanos escravizados. Inclusive no período pós proibição do tráfego os leilões teriam continuado, tendo sido construída uma rota alternativa para envio dos cativos a certo trecho da Estrada Imperial que ligava Mangaratiba ao Vale do Rio Paraíba e às fazendas de café" (LINHARES, 2016).
\end{abstract}

Em Mangaratiba (1808), colonos e negociantes (alguns foreiros das terras indígenas) formavam uma corrente de brancos indignados com o atraso da localidade, que culpavam os aldeados por não aproveitarem a terra que possuíam para desenvolver a freguesia. Entre esses fazendeiros, estava o padre Manuel Álvares Teixeira que produziu um documento descritivo das terras e das gentes de Mangaratiba (Tratado de 1810), sugerindo ao príncipe regente, medidas para o seu desenvolvimento.

O café começou a frutificar em Mangaratiba por volta do ano de 1780 . Posteriormente, o grande movimento de tropas carregadas de café descia a Serra do Piloto em direção aos portos Mangaratiba e levados por mar para o porto do Rio de Janeiro. Em 1810, o café já era bem negociado nos portos do Rio de Janeiro, só perdendo em qualidade e valor para o café produzido em São João Marcos.

A região de Mangaratiba tornou-se de suma importância para o contexto histórico brasileiro, tanto como produtora de café e escoadora da produção através do porto. Nesse período, o Brasil passou por diversas mudanças que afetaram diretamente a população elitista, ou seja, os donos de terras e escravos que eram responsáveis pela economia do país. O maior impacto foi, primeiramente, a abolição do tráfico negreiro e depois a lei Áurea. Neste período as terras de Mangaratiba eram de posse dos irmãos comendadores José e Joaquim Breves, que também estavam envolvidos diretamente na política do país.

Em 1847, o comendador Joaquim José de Souza Breves se associou com outro grande comerciante de escravos, o comendador Manoel Vieira de Aguiar, a fim de traficarem escravos para suas terras (ilhas próximas a Itacuruçá e áreas do Sahy) e posterior venda ilegal destes escravos para fazendeiros das áreas de São João Marcos, Rio Claro, Piraí, Barra Mansa, entre outras cidades do Vale do Paraíba (BREVES, s/d.).

$\mathrm{Na}$ área do Sahy, atual Praia do Sahy (Baía de Sepetiba), no Município de Mangaratiba, os comendadores Breves e Vieira desenvolveram o complexo conhecido como "engorda" de escravos africanos recém-chegados na restinga da Marambaia. Após a engorda, eram levados para o prédio de leilão (mercado e armazém de escravos) e posteriormente, seguiam, via serra do piloto, para trabalharem nas fazendas de café do Vale do Rio Paraíba.

Atualmente, no sítio arqueológico do complexo do Sahy é possível observarem referências ao período do café entre as ruínas a importância econômica, política e cultural do local. O espaço de engorda encontra-se deteriorado e observa-se uma destruição parcial do edifício dos leilões, que abriga um salão de festas em um condomínio de luxo.

“Materialidades como a dos vestígios arqueológicos são consideradas intermediárias e agentes nas relações sociais, incluindo nas relações entre o passado 
e o presente. Isto implica considerar não apenas a dinâmica das coisas nos contextos passados, mas também na relação entre o olhar do pesquisador e o olhar de outros agentes contemporâneos sobre as mesmas coisas de história e de ação" (AGOSTINI, 2015).

Justifica-se o desenvolvimento deste projeto para resgatar memória cultural e patrimonial, e divulgar a historiografia local, relevantes para a compreensão de um dos ciclos econômicos mais importantes na formação do Brasil. Haja vista que o diagnóstico realizado in loco detectou que parte dos visitantes ou moradores desse município desconhecem que Mangaratiba foi uma das principais portas de entrada de africanos escravos no Brasil colonial.

\section{Objetivos e metas a serem alcançados:}

Os objetivos propõem a conscientização do patrimônio histórico através do desenho de reconstrução e visa contribuir como memória visual do local. Sendo assim, pode gerar um recurso diferenciado para fortalecer a concepção do Desenho como instrumento eficaz de construção do conhecimento científico e artístico, dando maior visibilidade à produção acadêmica, através das técnicas de representação gráfica, podendo ajudar na preservação das ruínas e aplicar o método para outros locais. O projeto reforçará a importância do desenho como elemento integrante, e essencial, na formação da memória iconográfica científica. Destacaremos as metas a serem alcançadas, a conhecer:

- Produção de material físico e visual;

- Ampliação da atividade turística do local;

- Realização do estudo histórico da região;

- Divulgação de informações através de um blog;

- Preservação do patrimônio histórico;

- Criação de oficinas para a divulgação do trabalho;

- Apresentação dos resultados dos temas pesquisados em publicações e eventos acadêmicos.

\section{Fundamentação teórica:}

“...Produzir um livro de História é como montar um grande quebra cabeça onde as peças precisam ser muito bem analisadas para serem encaixadas no lugar certo. No momento em que vão se encaixando, o quadro da realidade vai se revelando. Muitas informações soltas circulam, por meio de comunicação sem serem processadas, nem tão pouco analisada. O trabalho do historiador não é o de somente divulgar informações soltas sobre os fatos históricos, (isso os meios de comunicação já fazem muito bem), nem de impor suas conclusões ao leitor. Mas sim, o de contribuir com a leitura de mundo, pesquisando bem o assunto, analisando sua importância e dispondo as informações de forma bem organizada, para que o sujeito possa não somente entendê-la, como também, compreender a montagem e desmontagem da mesma." (BONDIM, 2015).

“...uma definição bem clara sobre a utilização da perspectiva como a projeção em uma superfície bidimensional de um determinado fenômeno tridimensional. Para ser representada na forma de um desenho (conjunto de linhas, formas e superfícies) devem ser aplicados mecanismos gráficos estudados pela Geometria descritiva, os quais permitem uma reprodução precisa ou analítica da realidade tridimensional. Considerando a perspectiva como ciência que estuda a imagem aparente do objeto, será fácil concluir que, para nós, ela é de certo modo a própria ciência do belo, ou seja, a base de uma teoria estética" (NOGUEIRA, 2013)

"A passagem da escravidão para a liberdade foi marcante na memória familiar dos descendentes de escravos. Eles passaram a contar o tempo familiar com essa posição. Então, é muito freqüente ouvir depoimentos de netos de escravos 
descrevendo se sua avó era ou não escrava, se viveu antes ou depois da abolição. Essas vivências familiares permitiram que eles tivessem uma clara idéia sobre a lei abolicionista e a história da escravidão no Brasil. "Essas diferenças, remetendo a trajetórias familiares, lembrando de avós, bisavós, foram o que me empurrou a tentar compreender a dimensão dessas diferentes trajetórias nesse quadro das histórias familiares a partir do período pós-abolição. Os descendentes de escravos tiveram trajetórias de vida, ao saírem do cativeiro, muito diferentes e construíram suas vidas familiares de modos diferentes também. Alguns de maneira muito violenta, precários e dramáticos, enquanto outros com uma memória familiar do sucesso relativo, de não terem passado fome, de terem tido acesso à educação" (LUGÃO, 2007).

"A atuação de historiadores começou a ganhar mais fôlego dentro do próprio Instituto do Patrimônio Histórico e Artístico Nacional (IPHAN) e a propor, por exemplo, uma visão do patrimônio enquanto "documento" ou "testemunho", que pudesse enfim representar momentos da própria história nacional" (CHUVA, 1998).

\section{Metodologia:}

Agindo como pesquisadores e futuros educadores, acreditamos na importância de preservar a história e a arquitetura dos locais. Ao longo dos anos, é possível diagnosticar e identificar variações de utilização do espaço.

As ruínas do Sahy possuem indícios da logística do sistema escravista, detectados durante a visita técnica. Através de entrevistas semiestruturadas, foram coletados relatos de alguns descendentes de proprietários e de escravos. Estas pessoas contam histórias pertinentes sobre a memória local. Observa-se, entretanto, que o desconhecimento por parte da população transeunte, desvaloriza o patrimônio, pois as construções estão sendo desmontadas ou demolidas.

Durante a elaboração e desenvolvimento das panorâmicas, serão utilizadas iconografias das fazendas localizadas entre Mangaratiba e o Vale do Paraíba e das quarenta fazendas levantadas na bibliografia pertencentes ao Comendador Breves. Este material será fonte de referência para identificar e caracterizar os elementos arquitetônicos da época para reconstituição gráfica.

A metodologia será dividida em 4 fases, a saber:

- 1a fase:

○ Diagnóstico;

- Levantamento bibliográfico;

- Pesquisas sobre o tema; Entrevistas semiestruturadas (moradores);

- Visita técnica.

- 2a fase:

- Entrevistas semiestruturadas (professores);

- Visita técnica (Ruínas do Sahy, antigo mercado de escravos, sítio histórico da estrada imperial; bebedouro da barreira, cachoeira dos escravos);

- 3a fase:

- Levantamento fotográfico para a montagem de panorâmicas do espaço geográfico da região; "Técnica do papel vegetal";

- Montagem de panorâmicas do espaço geográfico da região;

- 4a fase:

○ Elaboração do blog; 
- Divulgação do trabalho apresentado para moradores, prefeitura e escolas de Mangaratiba; Sugestão de ilustração de placas de preservação.

5. Resultados e contribuições esperadas:

Como resultados e contribuições esperados, consideram-se os seguintes pontos, a saber:

- Ampliação e divulgação sobre a cidade histórica de Mangaratiba através do desenho das ruínas do Sahy, com o estímulo a prática do desenho de perspectiva panorâmica da Escola de Belas Artes da Universidade Federal do Rio de Janeiro;

- Elaboração de um banco de informações coletadas ao longo do projeto acerca dos estudos sobre a cidade de Mangaratiba, a ser disponibilizado tanto para a comunidade acadêmica científica, á população local e demais interessados;

- Contribuição para preservação do patrimônio arquitetônico da área das ruínas do Sahy; Participação em eventos técnico-científicos;

- Divulgação dos resultados através de periódicos, rede virtual, artigos, comunicações workshops, visitas técnicas, entre outros.

6. Impactos previstos:

Ampliação do interesse geral da população moradora de Mangaratiba e seus visitantes para o conhecimento da cidade histórica, tendo em vista a divulgação do projeto através de palestras com o material coletado e um blog. Sinalização da área das ruínas do Sahy, juntamente com a prefeitura, através de placas informativas ansiando a preservação do local.

\section{Bibliografia}

AGOSTINI, Camilla. Cultura material, memória e o lugar do outro na produção do conhecimento: histórias possíveis a partir do trabalho de campo da arqueologia. 2015. Disponível em:

<http://www.sudeste2015.historiaoral.org.br/resources/anais/9/1429972054_ARQUIVO_Textopinsc.pdf >. Acesso em: 11 jan. 2017.

BONDIM, Mirian, Resumo da história econômica e social de Mangaratiba, Apostila da Atas da Câmara Municipal de Mangaratiba, 2015. Disponível em: . Acesso em: 11 jan. 2017.

BREVES, Armando de Moraes. O Reino da Marambaia. Rio de Janeiro: Gráfica, Olímpica Editora, 1966.

BREVES, Padre Reynato, A Saga dos Breves. Sua Família, Genealogia, Histórias e Tradições. EVSA; Valença S.A, s/d.

CHUVA, Márcia. Os arquitetos da memória: a construção do patrimônio histórico e artístico nacional no Brasil (anos 30 e 40). Tese (Doutorado)-Departamento de História, Universidade Federal Fluminense (UFF), Rio de Janeiro, 1998.

LINHARES, Bruno. Histórico do Projeto de Restauração das Ruínas do Sahy. Pela criação do Parque Arqueológico do Sahy. 2016. Disponível em:. Acesso em: 11 jan. 2017.

NOGUEIRA, Aurélio Antonio Mendes, Perspectiva de Observação, Apostila de aula. Departamento BAR/EBA/UFRJ, Rio de Janeiro, 2013.

RIOS, Ana Lugão, Memórias do cativeiro: família, trabalho e cidadania no pós-abolição, LABHOI, UFF, 2005. Disponível em: < http://www.historia.uff.br/stricto/td/1367.pdf>. Acesso em: 11 jan. 2017 


\section{SÓCRATES, PLATÃO, POPPER E A TRADIÇÃO CRÍTICA}

João Ricardo Barroca Mendes - Mestre pelo HCTE UFRJ - joao.mendes@catena-ca.com.br

Resumo

O objetivo deste trabalho é produzir uma introdução a história da tradição crítica na epistemologia, ou seja, a tradição baseada na crença na capacidade da crítica intersubjetiva em aprimorar o conhecimento. Esta história é acompanhada em dois momentos principais. No primeiro, a origem desta tradição filosófica é estabelecida no uso da dialética como meio de chegar a episteme, ou conhecimento seguro, no segundo, pontos relevantes do Racionalismo Crítico de Karl Popper são abordados. Nos dois casos, são evidenciadas algumas visões dos autores sobre o que foi chamado, no trabalho, de tradição sofística. O trabalho conclui com um breve comentário sobre a adequação de cada tradição a certas visões da pesquisa científica.

Palavras-chaves: Epistemologia. Platão. Popper. Racionalismo Crítico.

\section{Introdução}

A história do que chamo de tradição crítica remonta a Sócrates e Platão, na maneira em que

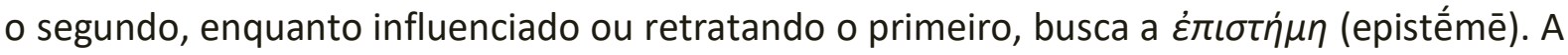

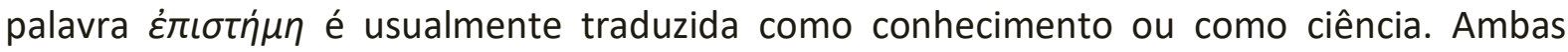
traduções podem levar a problemas. A palavra ciência deriva do latim scientia, que, até o século XIX seria uma tradução bem adequada. No entanto, o homem moderno carregou o

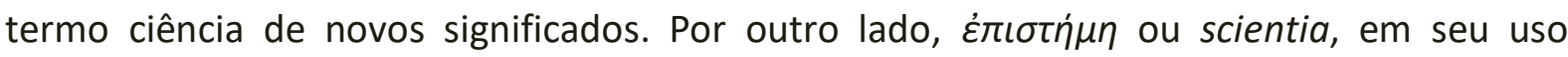
filosófico, não significam um conhecimento qualquer. Enquanto a palavra $\gamma v \tilde{\omega} \sigma \check{\varsigma}$ (gnôsis), também traduzida como conhecimento, mas menos usada por Platão, tem sua raiz em

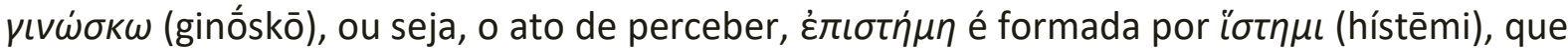
significa 'estar em pé' e ćmı̀ (epí), ou seja, 'sobre'. Hanley (2000) sugere que episteme seria, então, um tipo de conhecimento sobre o qual podemos erguer outros conhecimentos devido a sua segurança. Os diálogos de Platão, em seu conjunto, ilustram uma abordagem de como estabelecer este 'conhecimento seguro'. No entanto, em alguns deles, Platão usa sua abordagem para discutir o próprio conhecimento, e estes diálogos expressam pontos centrais que sustentam o método.

O Mênon (PLATÃO, MÊNON (OU DA VIRTUDE), 2010) é o diálogo epistemológico mais antigo.

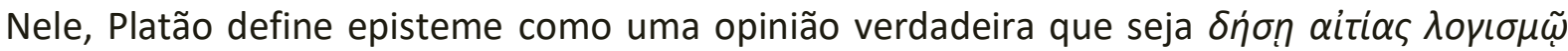
(dése aitias logismos). Segundo Gail Fine (2007) "aitias logismos" é uma expressão extremamente incomum. Platão não a explica e muitas traduções são possíveis. Uma aitia é um motivo, uma causa ou uma explicação. A expressão logismos significa um cálculo, ou um processo de raciocínio feito de forma precisa. A tradução mais comum para 'raciocínio causal' não me parece fazer muito sentido no contexto, sendo a tradução 'raciocínio em direção a uma explicação' a que me parece mais adequada. Outro componente importante na compreensão da definição é a expressão $\delta$ ńon, que significa 'amarrado'. No Mênon, então, se chega a episteme quando uma opinião (que seja verdadeira) é amarrada por um raciocínio explicativo. Sócrates demonstra o método com um escravo de Mênon. Ele conversa com o escravo, fazendo perguntas, mostrando quando uma conclusão não adere à realidade e o estimulando a resolver contradições. Na República (PLATÃO, A República, 2014), ele nomeia

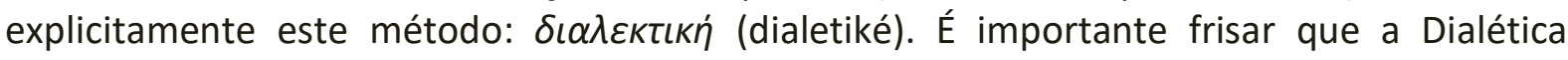
Socrática tem quase que apenas o nome em comum com outros conceitos, como a chamada 


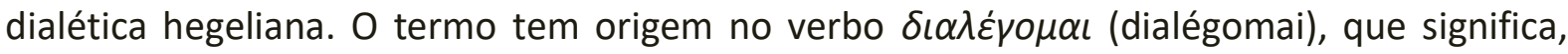
simplesmente, conversar. Em Platão ele adquire o significado técnico de um tipo especial de diálogo, em que ambiguidades são expurgadas, a precisão é exigida e qualquer contradição deve ser explicitada e resolvida. Através da dialética, as opiniões são criticadas, purificadas e amarradas de forma a chegar na episteme.

A explicação de como, exatamente, a dialética gera a episteme é um problema que Platão não conseguiu resolver. No Mênon, a explicação é que a dialética provoca a ává $\mu v \eta \sigma \iota \varsigma$ (anamnesis), ou seja, a recordação do conhecimento que a alma possui antes de se unir ao

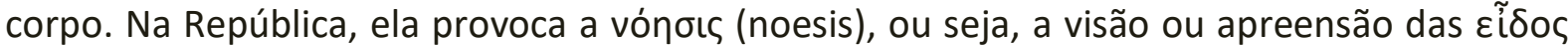
(eidos), ou seja, das formas platônicas. Finalmente, no Teeteto (Platão, Teeteto (ou Do Conhecimento), 2014), chegamos, em duplo sentido, na aporia platônica. Em primeiro lugar temos a aporia em que o diálogo termina sendo incapaz chegar a seu objetivo de definir o que é o episteme. Em segundo lugar, ele parece desistir de conseguir uma explicação de como a

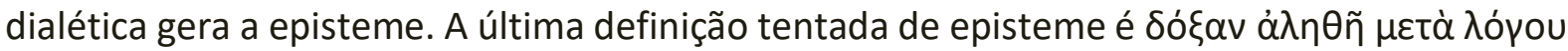

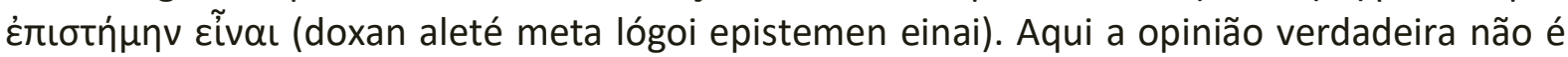
mais amarrada pelo raciocínio explicativo (lógoi). É apenas exigido que este seja oferecido antes dela ser considerada episteme. Platão continua a acreditar que a crítica dialética é o melhor caminho para o aprimoramento do conhecimento. No entanto, ele já não é mais otimista na capacidade de chegar a um conhecimento totalmente seguro, sobre o qual que possamos nos erguer firmemente. No entanto, ele continua a pensar na episteme como sendo a mais alta ordem de conhecimento e a de maior valor. Na República ele é claramente desdenhoso em relação ao conhecimento que se pode obter pela experiência.

Neste ponto, é importante falarmos um pouco sobre a alternativa à abordagem crítica dialético, que é combatida por Platão. A maior parte do Teeteto é dedicada a criticar a ideia de que conhecimento é mera opinião e os ensinamentos dos sofistas. Platão nos explica o significado da bem conhecida citação de Protágoras de que o homem é a medida de todas as coisas. Trata-se de um tipo extremo de relativismo, que podemos chamar de subjetivismo fenomenológico, em que a realidade é tal como parece a um ser humano qualquer. Mesmo claramente desprezando a absurdidade desta doutrina, ele, dentro do espírito crítico, a suplementa com a doutrina de Heráclito de que o movimento é a causa de tudo que existe enquanto o descanso é a causa da inexistência e destruição. Porém, mesmo tratada da forma mais generosa possível, a ideia de que conhecimento e verdade se igualam com opinião e percepção não resiste ao processo crítico e é finalmente descartada. Platão tem um motivo ético para atacar da forma mais forte possível estas doutrinas. Enquanto sua visão de episteme o induz a ensinar a dialética crítica aos jovens de Atenas, os sofistas se justificam na visão de que não existe verdade para ensinar retórica, a arte do discurso eloquente destinado a convencer, e erística, a forma de argumento que se destina a vencer a discursão, mesmo que isto signifique o uso de falácias e contradições. Na ausência de um conhecimento seguro e mesmo da noção de verdade, o sucesso em aprovar e realizar políticas que fossem do interesse da pessoa ou do grupo a que pertencia, passa a ser a medida da qualidade da educação. No Mênon, Platão coloca na boca de Anito a opinião de que os sofistas 'são manifestadamente os causadores da ruína e corrupção daqueles que os seguem' (PLATÃO, MÊNON (OU DA VIRTUDE), 2010, p. 91c). É contra aqueles que utilizam o engano e a manipulação, se justificando em uma suposta inexistência da de qualquer realidade objetiva que o método crítico foi primeiro empregado. Em diversas formas este embate se repete na história.

A tradição crítica, não mais na forma da Dialética Socrática, se integra, de diversas maneiras em várias etapas do pensamento científico e filosófico. Na Alta Escolástica se torna necessário colocar todos os argumentos contrários a tese proposta antes de defender a própria tese e, 
após isto, responder as objeções uma a uma. Tomás de Aquino é o expoente desta técnica. René Descartes submeteu o manuscrito de suas 'Meditações sobre Filosofia Primeira' a diversos intelectuais antes de sua primeira publicação, e incluiu as objeções, inclusive as de Thomas Hobbes, com suas respostas em sua primeira edição. Mesmo sem este tipo de preocupação explícita, o texto de muitos filósofos, de diversas eras, como David Hume, Gottlob Frege, Bertrand Russell e John Searle, são obviamente construídos de forma a expor suas ideias à crítica, evitar ambiguidades e contradições e expressar os argumentos da forma mais clara possível, tornando-os, assim, expostos ao contraditório. Para evitar polêmicas desnecessárias, não incluirei aqui exemplos da igualmente persistente tradição sofística. É, de todo modo, uma tarefa fácil encontrar textos de autores que aderem tanto a um tipo qualquer de subjetivismo em relação a verdade, quanto ao estilo de ocultar falhas e absurdos com o recurso da obscuridade ou da falácia. De qualquer forma, meu objetivo não é demonstrar a correção das palavras de Anito sobre as ideias sofistas, mas simplesmente expor alguns marcos da tradição oposta.

O mais recente importante defensor da tradição crítica foi Karl Popper. A importância de Popper está na tentativa de generalizar e atualizar esta tradição. Em sua Autobiografia Intelectual ele reporta que:

Em 1919, minha concepção principal era a seguinte: se alguém formulasse uma teoria científica, deveria dar a resposta, exatamente como Einstein havia feito, a esta questão: "Sob que condições eu admitiria que minha teoria era insustentável? ". Em outras palavras, que fatos concebíveis eu aceitaria como refutações, ou falseamentos, de minha teoria? (POPPER, AUTOBIOGRAFIA INTELECTUAL, 1986, P. 48)

Esta é a formulação do que é chamado de falsificacionismo ingênuo. A maioria esmagadora das críticas a Popper são em relação a esta formulação. No entanto, considerando que Popper nasceu em 1902, percebe-se que o combate está sendo feito a um rapaz de 17 anos. Em sua obra 'A Lógica da Pesquisa Científica' (2007), ele desenvolve sua intuição juvenil em um sistema sofisticado. Por exemplo, ele claramente nega, na seção sobre 'O Problema da Base Empírica' (POPPER, 2007, pp. 44-46) que uma experiência possa falsificar uma teoria. Ele afirma que devem existir enunciados singulares (e não experiências) que sirvam para inferências falsificadoras. Os enunciados universais de uma teoria só podem ser falsificados pela aceitação de um enunciado singular, e não se pode derivar um enunciado diretamente de uma experiência. Na seção seguinte, sobre 'Objetividade Cientifica e Convicção Subjetiva' (POPPER, 2007, pp. 46-50) ele explica que seu critério de objetividade científica reside em que proposições podem ser intersubjetivamente submetidas a teste. É possível que uma experiência crucial cause um impacto tão grande que a comunidade a aceite como base de um enunciado falsificador, mas isto está longe de ser necessário. $\mathrm{O}$ acúmulo de experiências menores, desde que feitas por diversas pessoas acaba por fazer que certos enunciados singulares sejam aceitos. De fato, até mesmo uma série de experimentos questionáveis, como no caso de Millikan e a carga do eléctron (HOLTON, 1979), podem gerar aceitação deste tipo de enunciado, seja como corroboração ou falsificação de uma teoria. Popper admite que o método de testes intersubjetivos não é perfeito. Jamais chegaremos a episteme platônica, uma vez que ele acredita que não existem enunciados definitivos em ciência. Sua proposta é que (1) não há uma alternativa superior, que ofereça certezas (2) a história parece dar credibilidade a ideia de que a crítica intersubjetiva de resultados e teorias funciona, no longo prazo, para o crescimento do conhecimento. Em seus escritos políticos 'A Sociedade Aberta e seus Inimigos' (POPPER, 1987), ele critica Platão, não por seu método crítico dialético, mas pelo seu essencialismo metodológico e sua pretensão de chegar ao conhecimento puro. 
Embora seja altamente discutível se Popper chegou, em sua 'A Lógica da Pesquisa Científica', a um sistema epistemológico estruturado que pode ser generalizado para qualquer tipo de conhecimento, ou seja, um substituto da dialética platônica como caminho para o avanço do conhecimento, o conjunto de seus escritos aborda todos os aspectos da tradição crítica. Já citei alguns destes aspectos, e posso acrescentar (1) a crítica ao 'culto da não-inteligibilidade, e de uma linguagem altissonante que impressione' (POPPER, 2004, p. 42), que remete à crítica de Platão à retórica sofista, (2) a negação da existência de observadores imparciais perfeitamente confiáveis, uma vez que não há razão para supor que mesmo 'um habitante de Marte nos veria mais "objetivamente", do que nós, por exemplo, nos veríamos' (POPPER, 2004, p. 19), (3) a importância da existência de uma comunidade cientifica que se autocritique uma vez que 'a objetividade da ciência não é uma matéria dos cientistas individuais, porém, mais apropriadamente, o resultado social de uma crítica recíproca' (POPPER, 2004, p. 23), (4) a ideia de que a 'função mais importante da pura lógica dedutiva é a se ser um sistema de crítica' (POPPER, 2004, p. 26), uma vez que expõe contradições e sofismas.

Para aqueles que a mera diversidade de opiniões tem valor, uma vez que não existe verdade objetiva, ou para aqueles que acreditam que o objetivo da pesquisa é fornecer subsídios para o avanço de alguma agenda política ou ideológica, a tradição crítica nada tem a oferecer e deve até ser combatida como danosa. No entanto, para aqueles que acreditam na possibilidade de se aproximar da verdade e que o objetivo da pesquisa é gerar conhecimento, a tradição crítica parece oferecer o caminho mais bem-sucedido deste Sócrates até Popper e os dias de hoje.

\section{Bibliografia}

CHALMERS, A. F. (1993). O que é ciência afinal? (1ạ ed.). (R. Fiker, Trad.) São Paulo: Brasiliense. CONTE, J. (s.d.). David Hume-UFSC. Acesso em 19 de Maio de 2017, disponível em Jaimir Conte-UFSC: http://conte.prof.ufsc.br/hume.html

FINE, G. (2007). Knowledge and True Belief in the Meno. Oxford studies in ancient philosophy, XXVII. HANLEY, C. (2000). Being and God in Aristotle and Heidegger - the role of method in thinking the infinite. Lanham, Md:: Rowman \& Littlefield Publishers.

HOLTON, G. (1979). A Imaginação Científica. Rio de Janeiro: Zahar Editores.

LOSEE, J. (2000). Introdução Histórica à Filosofia da Ciência. (B. Cimbleris, Trad.) Belo Horisonte: Itatiaia. PLATÃO. (2014). A República. (E. Bini, Trad.) São Paulo: Edipro.

PLATÃO. (2010). Mênon (ou Da Virtude). In: Platão, \& E. Bini, Diálogos V - O Banquete, Mênon, Timeu, Crítias (E. Bini, Trad., pp. 109-159). São Paulo: Edipro.

PLATÃO. (2014). Teeteto (ou Do Conhecimento). In: Platão, \& E. Bini, Diálogos I - Teeteto, Sofista, Protágoras (E. Bini, Trad., pp. 41-156). São Paulo, Edipro: Edipro.

POPPER, K. (2007). A Lógica da Pesquisa Científica. São Paulo: Cultrix.

POPPER, K. (1987). A Sociedade Aberta e seus Inimigos (Vol. Tomo I). São Paulo: Editora Itatiaia - EDUSP.

POPPER, K. (1986). Autobiografia Intelectual. São Paulo: Cultrix.

POPPER, K. (2004). Lógica das Ciências Sociais. Rio de Janeiro: Tempo Brasileiro.

ROBERTS, M. D. (2015). Francis Bacon. Acesso em 19 de Maio de 2017, disponível em UNIÓN

HISPANOMUNDIAL DE ESCRITORES. UHE:

https://unionhispanomundialdeescritores.ning.com/m/blogpost?id=2659438\%3ABlogPost\%3A3213951

Strathern, P. (2002). O Sonho de Mendeleiev-A Verdadeira História da Química (1a ed.). (M. L. A.Borges, Trad.) Rio de Janeiro: Zahar.

TALENS, J. R. (2001). La Pólvora Negra. Acesso em 19 de Maio de 2017, disponível em Avancarga:

http://www.avancarga.com/4_interesante/polvora_negra/polvoranegra.html

VANNUCCHI, J. (2016). http://www.acervofilosofico.com/francis-bacon-a-formiga-a-aranha-e-a-abelha/. Acesso em 26 de Maio de 2017, disponível em Acervo Filosófico: http://www.acervofilosofico.com/francisbacon-a-formiga-a-aranha-e-a-abelha/

WHEWELL'S GAZETTE: Year 2, Vol. \#42. (2016). Disponível em:

https://whewellsghost.wordpress.com/2016/06/01/whewells-gazette-year-2-vol-42/

Acesso em 10 de setembro de 2017, 


\section{ALIMENTAÇÃO COLETIVA}

Marta Moeckel - Doutoranda do HCTE-UFRJ - marta.moeckel@gmail.com HCTE/UFRJ

Jose Carlos de Oliveira - Professor do HCTE-UFRJ - jcarlos@dee.ufrj.br HCTE/UFRJ

Resumo

Para a realização de estudos sobre vários aspectos da alimentação o recorte histórico é parte ineliminável. Posta a intenção de examinar como se compõe a Alimentação Coletiva nos seus meandros, variedades, características, pois ela faz parte essencial do entendimento de como se procede a alimentação hodierna. O presente artigo procura prioritariamente resgatar alguns aspectos históricos do sistema que denominamos por "Alimentação Coletiva": como ele se organiza e os seus diversos componentes se interagem.

Palavras chave: Alimentos. Alimentação Coletiva.História Da Alimentação.

Introdução

Modernamente a Alimentação Coletiva se constitui, em uma disciplina, designando um determinado ramo do conhecimento no campo da Nutrição. Sua caraterística fundamental, no presente, se configura em formas de alimentar grupos humanos, que convivem juntos uma mesma circunstância, e/ou um mesmo espaço. São exemplos esclarecedores que mostram tanto a diversidade de situações quanto a uniformidade dos seres alimentados: exército, instituições de ensino, fábricas, grandes plantações e colheita, instituições de comércio, restaurantes, aviões, hospitais, grandes construções, grandes eventos culturais e de manifestação coletivas. Portanto é multifacetado tanto na forma quanto no tipo de participantes. E assunto vasto, cujo estudo acurado certamente exigiria interdisciplinaridade e pensamento complexo para uma mais completa elucidação, em que dever-se ia ver o contexto de cada uma das suas expressões. Além de que há que se ver, tal tema, de forma histórica: como essa ocorrência de alimentação se deu nos mais diferenciados ambientes de situações históricas, em termos de finalidades: desde a construção das pirâmides do Egito, nas grandes marchas religiosas ou não, fugas de refugiados e outros, etc. É a isso que se irá dar ênfase neste ensaio.

O fato é que se há de fornecer refeições para coletividades sejam sadias, sejam enfermas atendendo-se aos preceitos básicos do que seja uma alimentação que mantenha um nível de sanidade satisfatório. Isso requer na atualidade conhecimentos de: clínica, saúde coletiva, tecnologia e ciências matemática, biológica, química, física, estatística, etc.

Alimentação Coletiva na História

As preocupações com a alimentação coletiva sempre estiveram presentes na história dos grupamentos humanos, unidos por razões diversas. Desde os primórdios dos tempos houve monastérios, hospitais, asilos, orfanatos e forças armadas, que exigiam a produção e distribuição de alimentos em grande quantidade. Muito antes disso, os banquetes bíblicos fornecem inúmeros exemplos de como a vida antiga estava centrada em torno das refeições. Os casamentos, já no relato bíblico, tinham como função marcar uma passagem que, mais do que um laço afetivo, constituía um contrato, um negócio realizado a conselho de seus pais, tutores ou ancestrais. Por que a necessidade de marcar essa passagem contratual com comida? Oferecer e compartilhar comida, nesses casos, poderia simbolizar o desejo de criar laços. A comensalidade, então, funciona como um sinal da aceitação da participação do 
indivíduo em determinado círculo social: uma nova família, um novo povo. Os convidados são convocados a comungar deste pão como coparticipes deste jogo de interações sociais, tendo em vista a necessidade de tornar público o contrato firmado. Não se sabe ao certo o que se consumia nos banquetes de casamentos bíblicos. A exceção em termos de descrição de alimentos aparece no episódio bíblico marcado pelo milagre de multiplicação do vinho, no episódio conhecido como as Bodas de Canãa.

A alimentação do coletivo e as provisões para sustentar milhares de soldados são consideradas estratégias de guerra. A Arte da Guerra escrita pelo general chinês Sun Tzu no século VI a.C. começou a se tornar conhecida no Ocidente apenas pouco antes da Revolução Francesa influenciando o estilo de vários comandantes como Napoleão Bonaparte, Joseph Stalin, Mao Tsetung e outros. No entanto, Vegétio, escritor militar romano que viveu no século IV d.C., um grande historiador da Antiguidade observou: "A fome destrói com mais frequência que uma batalha, e é mais cruel que a espada". Vegétio cita a máxima militar de Sun Tzu: "todo aquele que não faz provisões adequadas de alimentos e outras necessidades é conquistado sem luta".

\section{A Alimentação Coletiva nos monastérios}

Além de centros de sabedoria, os grandes monastérios ou mosteiros, fundados através da Europa durante a Idade Média, eram também uma fonte de alívio para os pobres, doentes e por vezes também para os proprietários mais abastados. O modo de vida denominado "monasticismo", viver separado do mundo para dedicação total a Deus, surgiu na Ásia, muito antes da era cristã e foi marcado por regras, uma espécie de guia sobre a maneira como os monges deveriam viver. $\mathrm{O}$ que se come e o quanto se come são fatores cuidadosamente determinados pela Regra beneditina, a maior das regras.

O vinho, bebida sagrada por simbolizar o "sangue de Cristo", também deveria ser consumido em medida definida pela Regra, pois se ingerido em excesso poderia gerar o descontrole, não só do corpo, mas também do espírito. A Regra determina que um monge nunca deve comer ou beber até a saciedade e deve jejuar em vários dias do ano. A alimentação, portanto, está sempre submetida ao controle, exigindo o domínio do corpo, e consequentemente, à inexistência de pecados relacionados fundamentalmente a qualquer forma de prazer físico. Embora esse controle se apresente como uma tarefa individual, a coletividade torna-se um elemento essencial na medida em que contribui para a realização de uma vigilância mútua. A comensalidade, ato de se comer em conjunto, em horários rigorosamente definidos pela Regra, é também uma forma de se exercer um controle.

Dos monastérios aos hospitais

Comandados por sacerdotes e religiosos, os monastérios passaram a servir de refúgio para viajantes e doentes pobres. Os beneditinos, na sua faina admirável de curar os enfermos, criaram enfermarias e hospitais na Itália, na França, na Alemanha, na Inglaterra, conseguindo instalar um elevado número de casas de assistência médica. Parece que na sua primitiva organização estas enfermarias conventuais eram reservadas exclusivamente aos religiosos. Logo se estendeu, porém, a concessão aos leigos, criando-se hospitais anexos. Nessas instituições de assistência aos pobres e de segregação de doentes havia alimentação abundante e repouso. Assim sendo, a alimentação hospitalar era absolutamente fundamental. Foram esses lugares que se tornaram modelo para os hospitais modernos

\section{A invenção do Restaurante}

O alimento sai do espaço da residência e das relações pessoais imediatas e transita como mercadoria pela cidade quando surgem os mercados e feiras que obrigavam os camponeses 
e artesãos a deixarem seu domicílio, durante um ou vários dias, e se alimentarem ao mesmo tempo em que mantinham seus negócios. Desde a Antiguidade, tanto no Império Romano como na China, as estalagens, como eram assim chamadas, eram situadas nas principais estradas e, muitas vezes, em plena zona rural. Lá, os visitantes se restauravam, repousavam, alimentavam-se e divertiam-se. A ideia do restaurante - como local de alimentação - começa de diferentes formas e em diferentes locais, sem um ponto de origem comum ou necessário. Pode estar ligado às cozinhas medievais, que preparavam alimentos para as pessoas que não tinham instalações em casa e que formavam a maioria. Está associado às casas de café em Paris e Londres, no século XVII, fornecedoras de café e tabaco, locais vibrantes, onde as pessoas encontravam-se e trocavam informações. Em várias partes da Europa e Ásia, era possível tomar uma refeição fora de casa em cozinhas de bairros ou em cozinha de rua, casas de vinho e tavernas. Todos esses locais eram, de certa forma, restaurantes rudimentares, que propunham pratos simples e baratos para saciar a fome. Os restaurantes, pouco a pouco, tomaram o lugar de todas essas instituições rudimentares.

\section{Reconhecimento dos Serviços de Alimentação}

Embora a preocupação com a alimentação de coletivos permeie toda a história dos grupamentos humanos, somente no início do século XX os serviços de produção e distribuição de alimentos em grande quantidade começaram a ser reconhecidos e oficializados. Durante a Primeira Guerra Mundial a necessidade de substituição de mão de obra masculina por feminina nas fábricas é identificada como um estímulo à produção de refeições para coletividades, pelo abandono compulsório da parte das atividades domésticas, até então realizadas por mulheres. Na Inglaterra, no decorrer da Segunda Grande Guerra Mundial, houve um incremento na produção de refeições coletivas quando o governo Britânico decidiu pelo racionamento dos alimentos devido à escassez. Para que a produção existente atendesse à demanda de consumo da época, além da necessidade de alimentação das forças armadas, as cantinas e os restaurantes de hotéis existentes, foram induzidos pelo governo a produzir alimentos para toda a população, de maneira que todos os civis tivessem pelo menos uma refeição quente por dia e a partir daí, surgiram cantinas e restaurantes de todas as classes e de vários tipos, incentivados inclusive financeiramente pelo governo.

\section{A Emergência da Nutrição}

No cenário mundial, a emergência do campo da Nutrição, seja como ciência, política social e/ou profissão, é um fenômeno relativamente recente, característico do início do século XX. Entretanto, é possível sustentar que as condições históricas para a constituição deste campo científico, acumuladas ao longo da história da humanidade, foram estimuladas a partir da revolução industrial europeia, ocorrida no século XVIII, e desencadearam-se entre 1914 e 1918, quando ocorreu a Primeira Guerra Mundial. Neste sentido, no período entre as duas Guerras Mundiais, tanto em países da Europa (Inglaterra, França, Itália, Alemanha, Dinamarca, entre outros), como da América do Norte (Estados Unidos e Canadá) e, posteriormente, da América Latina (Argentina e Brasil), foram criados os primeiros centros de estudos e pesquisas, os primeiros cursos para formação de profissionais especialistas e as primeiras agências condutoras de medidas de intervenção em Nutrição.

Alimentação Coletiva e sua relação com as Políticas Públicas de Alimentação

As discussões sobre saúde do trabalhador nascem em um contexto de estudos do médico Josué de Castro, nos quais retrata o problema da fome no Brasil. Os dados do estudo As condições de vida das classes operárias no Recife, registrados na década de 1930, tiveram ampla divulgação e provocaram a realização de investigações similares. Uma delas serviu de 
base para a regulamentação do salário mínimo, quando o Estado avaliava a melhor maneira de garantir maior controle sobre a classe trabalhadora, de modo a amenizar os conflitos. A partir de então, desperta a consciência nacional para o problema da nutrição e suas implicações no processo produtivo. No final da década, o governo Vargas institui a obrigatoriedade das empresas com mais de 500 empregados destinarem local abrigado, higiênico e adequadamente aparelhado para os trabalhadores fazerem suas refeições decreto-lei $n^{\circ}$ 1228, de 02 de maio de 1939. Em 1940, com a intenção de melhorar as condições de alimentação dos trabalhadores, sua resistência orgânica e capacidade de trabalho, foi instituído o Serviço de Alimentação da Previdência Social (SAPS) - decreto-lei n 2478, de 5 de agosto de 1940. Trata-se de restaurantes populares que ofereciam refeições aos trabalhadores a preços modestos, além de promover uma política de educação alimentar. Sob o argumento de que abrigava reuniões de sindicalistas de esquerda, além de denúncias de corrupção administrativa, o regime militar de 1967 extingue o órgão.

Em 1954 teve início o Programa de Merenda Escolar, política essa na qual Josué de Castro teve grande participação em sua formulação. Uma das atribuições do SAPS nas décadas anteriores era a oferta de desjejum escolar aos filhos dos trabalhadores, medida que pode ser considerada como o embrião da merenda escolar. Hoje, o que é então denominado Programa Nacional de Alimentação Escolar (PNAE) é uma das vertentes da alimentação coletiva para o ensino no país. São atendidos pelo Programa os alunos de toda a educação básica (educação infantil, ensino fundamental, ensino médio e educação de jovens e adultos) matriculados em escolas públicas, filantrópicas e em entidades comunitárias (conveniadas com o poder público), por meio da transferência de recursos financeiros. Os Restaurantes Universitários (RUs) constituem outra vertente da alimentação coletiva para o ensino no país e tiveram início na década de 1950.

Com suas bases lançadas ainda na época do SAPS, o Programa de Alimentação do Trabalha dor (PAT) foi instituído em 1976 - lei n 6.231, de 14 de abril de 1976 - em um período em que os debates internacionais sobre a fome mundial despontavam com força e, no Brasil, a discussão girava em torno da desnutrição calórica e proteica. O programa foi criado com o objetivo de: Proporcionar disponibilidade maior e mais eficiente de energia para o trabalho do homem e, consequentemente concorrer para melhoria do estado nutricional do trabalhador.

Com a globalização, o Brasil passou a sofrer grandes influências do exterior. Redes de fast food se instalaram com os serviços de livre escolha, entre outros, o que começou a mudar os hábitos da população brasileira. A preocupação com a saúde começou a ganhar força nos restaurantes institucionais: nutricionistas e clientes passaram a buscar uma alimentação que, além de saborosa, bem apresentada e higienicamente preparada, fosse mais saudável, com redução no teor de gordura, açúcar e sal e maior ênfase no oferecimento de verduras, frutas e legumes. Os conceitos light e diet definitivamente se estabeleceram.

Em parceria com a Ação da Cidadania contra a Fome, a Miséria e pela Vida e pressionado pela sociedade civil e por diversas instituições ligadas à Nutrição, o Governo Federal criou em 1993 - Conselho Nacional de Segurança Alimentar (Consea) para auxiliar na implantação da Política Nacional de Segurança Alimentar e Nutricional. Por intermédio desse órgão foi elaborado um Plano de Combate à Fome e à Miséria, que tinha como prioridade a geração de emprego e renda, a democratização da terra, o combate à desnutrição materno-infantil, a descentralização e o fortalecimento do PNAE.

A Ação da Cidadania contra a Fome, a Miséria e pela Vida também foi fundamental na implantação dos Restaurantes Populares. O projeto foi baseado na experiência da Rede SAPS, os denominados bandejões criados no Governo Getúlio Vargas. O primeiro Restaurante Popular foi inaugurado na Central do Brasil, no centro do Rio no final do ano 2000. Hoje, os Restaurantes Populares estão espalhados por todo o Brasil. 
Em 2010, a alimentação passou a ser considerada um direito social garantido na Constituição Federal, assim como a educação, a moradia e a saúde. O novo direito contribui para a segurança alimentar e nutricional e consequentemente para a soberania alimentar. A Pesquisa de Orçamentos Familiares - POF de 2008/2009 apresentou um acréscimo significativo de pessoas acima do peso recomendado, o que tem contribuído para o aumento dos agravos à saúde principalmente das Doenças Crônicas não Transmissíveis (DCNT) como: as doenças do coração, o diabetes e a pressão alta que são, atualmente, os principais problemas de saúde pública no Brasil. Frente a este cenário o Ministério da Saúde elaborou um Guia de Boas Práticas Nutricionais para Restaurantes Coletivos que estabelecem um conjunto de medidas a serem adotadas a fim de garantir a adequação nutricional das refeições e dos produtos alimentícios às necessidades da população a que se destinam. Um dos objetivos propostos pelo Guia é a necessidade de melhoria do perfil nutricional dos alimentos, de modo a orientar os serviços de alimentação na preparação de alimentos com menores teores de açúcar, sódio, gorduras trans e saturadas.

Para o enfrentamento desse cenário, é emergente a necessidade da ampliação de ações intersetoriais que repercutam positivamente sobre os diversos determinantes da saúde e nutrição. O Guia Alimentar para a População Brasileira (GAPB), publicado em 2006, apresentou as primeiras diretrizes alimentares oficiais para a nossa população. Diante das transformações sociais vivenciadas pela sociedade brasileira, que impactaram sobre suas condições de saúde e nutrição, fez-se necessária a apresentação de novas recomendações. A segunda edição do guia passou por um processo de consulta pública, que permitiu o seu amplo debate por diversos setores da sociedade e orientou a construção da versão lançada em 2014. Tendo por pressupostos os direitos à saúde e à alimentação adequada e saudável, o guia é um documento oficial que aborda os princípios e as recomendações de uma alimentação adequada e saudável para a população brasileira, configurando-se como instrumento de apoio às ações de educação alimentar e nutricional.

\section{Conclusão}

Diante das mudanças, evoluções e expectativas, como devemos hoje conceituar a área de Alimentação Coletiva? Qual o papel do nutricionista nessa área onde se produz, transforma, distribui, transporta, compartilha, socializa a comida? Será que esse profissional poderá ter somente uma visão técnico-administrativa? A conscientização do nutricionista diante de sua posição como profissional de saúde e até mesmo de formação de hábitos é uma tarefa árdua e demorada, que requer paciência, empenho e determinação.

\section{Bibliografia}

AGUIAR, O.B.; KRAEMER, F.B.; MENEZES, M.F. G. Gestão de Pessoas em Unidades de Alimentação e Nutrição. Rio de Janeiro: Rúbio, 2013.

BRASIL. Ministério da Saúde. Guia Alimentar da População Brasileira. Brasília, DF, 2014.

GODOY et al. Transformações socioculturais da alimentação hospitalar. História, Ciências, Saúde - Manguinhos, v.14, n.4, p.1197-1215, out.-dez. 2007, Rio de Janeiro.

LUSTOSA. M. M. A. Humanidade, Desenvolvimento e Alimentação: Que Futuro é esse? 2012. 206f. Dissertação (Mestrado em Engenharia de Produção) - Programa de Pós-Graduação em Engenharia de Produção, COPPE, Universidade Federal do Rio de Janeiro, Rio de Janeiro, 2012.

PROENÇA, R. P. C. Inovação tecnológica na produção de alimentação coletiva. Florianópolis: Insular, 2000.

RIERA-MELIS, A. Sociedade feudal e alimentação (séculos XII-XIII) In: .: Flandrin J. L.; Montanari, M. História da alimentação. Tradução de: Luciano Vieira Machado e Guilherme J. F. Teixeira São Paulo: Estação Liberdade, 6. ed., pp 387-408, 1998.

SENAC. Administração na Alimentação Coletiva. São Paulo: Senac, 2007.

STANDAGE, T. Uma história comestível da humanidade. Tradução de Maria Luiza X. de A. Borges. Rio de Janeiro: Zahar, 2010. 
SUN TZU . A Arte da Guerra. Tradução de Candida de Sampaio Bastos. São Paulo. Golden Books, 2007. VITORINO et al. A ética alimentar nos banquetes bíblicos: passagem, comunhão e poder. Demetra; 211 (2); 275 296, 2016, Rio de Janeiro. 


\title{
OS PRONTUÁRIOS E LEIS PSIQUIÁTRICAS COMO FONTE HISTORIOGRÁFICA E ETNOGRÁFICA DA REFORMA PSIQUIÁTRICA BRASILEIRA: NOVOS MODOS DE GOVERNAMENTALIDADE?
}

\author{
Adriana Beatriz Molas Quintana - Professora da Facultad de Psicología/Udelar adrimolas@gmail.com \\ Arthur Arruda Leal Ferreira -Professor Adjunto do Instituto de Psicologia da UFRJ - arleal@superig.com.br \\ Rafael de Souza Lima - Estudante de mestrado de Psicologia na UFRJ - rdsI.1989@gmail.com \\ Laiz Rangel Barbosa - Estudante de graduação de Psicologia na UFRJ laizrb@gmail.com \\ Nicole Marcques - Estudante de graduação de Psicologia na UFRJ nicole.marcques@hotmail.com \\ Letícia Gomes Canuto - Estudante de graduação de História na UFRJ Igomescanuto@gmail.com
}

Resumo

A partir do trabalho genealógico de Foucault sobre as práticas de governo, abre-se um campo possível para o estudo das práticas e nos saberes psicológicos e psiquiátricos. Aqui teríamos dois marcos: 1) no século XVI, surgem técnicas de governo baseadas no disciplinamento, o "Estado de polícia"; e 2) no século XVIII novas tecnologias de governo em referências liberais. Nosso objetivo é avaliar as práticas e conceitos de cidadania e liberdade no contexto de alguns processos de Reforma Psiquiátrica Brasileira. Para tal, sustentamos que coexistem neste campo não apenas os antigos dispositivos disciplinares e a resistência a estes, mas modos liberais de gestão. Estes serão analisados nas práticas cotidianas de gestão dos usuários em saúde mental, presentes em textos, leis e prontuários.

Palavras-chave: Reforma Psiquiátrica. Governamentalidade. Práticas de Liberdade.

Introdução: Abrindo cenários

Em meados do século XX despontaram em diversos países europeus e americanos uma série de movimentos que apresentaram alternativas aos modos de abordagem da psiquiatria tradicional, centrada então na figura do asilo manicomial. Muitos destes movimentos (como a Antipsiquiatria Britânica e a Psiquiatria Democrática Italiana) produziram inclusive abordagens mais radicais, que questionaram não apenas o asilo como pedra fundamental do tratamento, mas também o estatuto da própria psiquiatria como saber e prática.

Especialmente estes últimos movimentos têm proposto palavras-de-ordem e termos-chave que até então eram incompatíveis com as práticas psiquiátricas: liberdade, cidadania e direitos humanos. Igualmente, têm aberto territórios até então impossíveis para os pacientes: ruas, assembleias, trabalho livre, consumo, responsabilidade e autogestão. Também têm permitido a entrada em jogo de outros profissionais nos serviços de atenção aos usuários: psicólogos, sociólogos, terapeutas ocupacionais e servidores sociais. Estas novidades se materializam em instituições de portas abertas, leis, políticas governamentais e principalmente em práticas cotidianas de cuidado e gestão dos usuários. Em poucas décadas, os serviços de atenção aos ditos doentes mentais se transformou de forma substancial: o asilo praticamente desapareceu como dispositivo central e a psiquiatria perdeu seu protagonismo diante do ativismo dos demais profissionais e dos pacientes.

Estes processos geralmente são celebrados como verdadeiras "revoluções" que libertaram a "loucura" das correntes da velha psiquiatria (ver por exemplo AMARANTE, 1998). O que propomos, de modo diferente, é abordar os processos de reforma psiquiátrica a partir de uma 
descrição dos dispositivos de gestão cotidiana através do conceito-operador de govenamentalidade, proposto por Foucault (2006 e 2007).

Não é nosso objetivo criticar o processo de reforma da instituição psiquiátrica, nem defender supostas propostas conservadoras que a criticam: estas, quando ocorrem, propõe geralmente um controle mais estrito dos usuários. Nosso objetivo não é pôr em questão as diretrizes gerais dos movimentos reformistas, e sim analisar seus dispositivos específicos em relação aos modos de governo aí presentes. Estudaremos primeiro o conceito de governamentalidade, introduzido por Foucault no fim dos anos 70. Este conceito pode ajudar na descrição de alguns dispositivos cotidianos presentes nos processos de reforma psiquiátrica brasileiros. Na conclusão, discutiremos o sentido das práticas de liberdade presente nestas práticas, abrindo um espaço de debate para novas formulações destes modos de gestão.

Governamentalidade e estratégias "psi"

Em dois cursos oferecidos no fim dos anos 1970 no Collège de France, Segurança, Território e População (2006) e o Nascimento da Biopolítica (2007), Foucault introduz o conceito de governamentalidade, entendido como o exercício estratégico de controle da conduta alheia. De forma mais específica este seria "o conjunto constituído pelas instituições, os procedimentos, análises e reflexões, os cálculos e as tácticas que permitem exercer esta forma específica, mesmo que muito complexa de poder, que têm por objetivo a população" (FOUCAULT, 2006, p. 136).

Conforme Foucault (2006), um momento decisivo na história das artes de governo se situa no século XVI, quando surgem os chamados "Manuais de Governo". Os autores desses manuais (por exemplo, La Perriére na França, Mayenne na Holanda, Huhental na Alemanha) são em geral completamente desconhecidos para nossa reflexão política atual. Esses manuais possuíam uma série de dispositivos pelos quais o Estado deveria administrar não somente o fluxo de mercadorias, mas também os populacionais, que assim se torna um assunto de governo. Preocupações deste tipo aumentavam conforme se evidenciava uma urbanização acelerada produzida pela migração rural e o descenso da taxa de mortalidade. Gradualmente a noção de população vai definindo seus contornos, passando a ser vista como uma entidade capaz de gerar riqueza e poderio econômico. Estes manuais surgiram ao mesmo tempo em que apareceram novas doutrinas e dispositivos relativos aos Estados, que se agrupam no Estado de Polícia, que inclui recursos para registrar e corrigir as ações dos indivíduos. Os métodos disciplinares haviam sido uma marca presente nos séculos XVI e XVII, atuando na vigilância continua e no controle dos corpos e atos em instituições como escolas e casernas. Em meados do século XVIII o movimento fisiocrata postula a necessidade de estabelecer limites quanto à atuação deste Estado de Polícia sobre os mercados. Isto devido à suposição de que os fenômenos do mercado obedeceriam a uma ordem natural e a leis inerentes a ela. Este é o deslocamento básico com que os governos liberais operam em relação aos dispositivos disciplinares do Estado de Polícia. No entanto, a esta transformação, se segue outra mais fundamental no interior das próprias estratégias liberais a partir dos séculos XIX e $X X$ : se no século XVIII o liberalismo se afirmava como uma crítica do Estado, a partir do século XIX e especialmente do XX, ele passa a oferecer técnicas positivas de governo, como o ordoliberalismo alemão e neo-liberalismo norte-americano. Foucault (2006; 2007) e Rose (1998) sugerem que o surgimento do liberalismo coloca o domínio da população como nova preocupação do governo, que necessitaria descobrir meios para dirigi-la, respeitando seus códigos naturais de funcionamento. Por tanto, se tornaria absolutamente necessário o conhecimento de seus padrões de ação, de suas regularidades, a fim de conduzir os indivíduos como sujeitos responsáveis. É este contexto onde a psicologia encontra as condições de seu 
desenvolvimento: como saber legitimado sob a promessa de cientificidade e livre condução da conduta alheia.

Para Rose (1998op. cit.), a história dos saberes psi está ligada a história do governo de uma dupla forma: 1) mediante as técnicas de inscrição que permitem que as subjetividades se tornem permeáveis às técnicas de governo; e 2) mediante a constituição de políticas múltiplas que pretendem conduzir a conduta dos indivíduos, ainda que não somente através da disciplina, mas principalmente através da liberdade e da atividade destes.

Nos trabalhos de Rose e Foucault, o liberalismo se configura como uma técnica positiva de gestão que se origina no domínio econômico, mas que se desloca pouco a pouco em direção à questão da população em geral. A psicologia possuiria especial importância nestas novas técnicas governamentais liberais, operando especialmente na construção das formas democráticas de associação, buscando estimular modos mais livres e ativos de conduta por parte dos cidadãos. No entanto, tomado numa perspectiva panorâmica a história das práticas relacionadas com o campo da saúde mental apresentaria um caminho singular: estas técnicas governamentais revelam uma passagem de dispositivos exclusivamente disciplinares (como os asilos) para os modos de governo embasados na soberania e, principalmente, nas formas liberais (gestão em espaços livres). Nosso objetivo será avaliar especificamente as práticas governamentais presentes nos discursos e práticas reformistas.

A análise das técnicas governamentais presentes nestes processos de reforma será levada a cabo através do estudo de (a) documentos oficiais (lei, normativas e resoluções) e (b) da descrição das práticas cotidianas presentes nos processos reformistas, especialmente as presentes nos prontuários.

Um novo modo de governar por meio da liberdade e da autonomia É possível dizer que o esforço central dos processos de reforma psiquiátrica no Brasil é excluir as antigas formas de governo dos ditos doentes mentais presentes nas instituições asilares. Isto abre espaço a formas de gestão calcadas na soberania, como a participação de entidades públicas na decisão das internações: o Ministério Público (BRASIL, 2002), ou ainda a lei antimanicomial brasileira decretada em 2001 (BRASIL, 2002). Porém, nossa hipótese é que junto a estas novas práticas legais surgem formas cotidianas de gestão liberal. Isto poderia ser visto de alguma forma como uma contradição, especialmente considerando a forte tendência esquerdista e contestatória presentes nos movimentos reformistas. Mas como Foucault (2006) destaca, tal contradição se resolve levando-se em conta que as práticas políticas de esquerda não têm produzido nenhuma forma nova de governamentalidade, apesar da inovação de suas teorias políticas.

Os CAPS no Brasil são dispositivos-chave para as novas práticas no tratamento das ditas doenças mentais e seus modos de funcionamento se baseiam em uma rede que conecta diversos serviços com familiares e a comunidade de entorno. O sujeito de intervenção nestes novos dispositivos deve deslocar-se livremente por esta rede, o que implicaria na obtenção de certas habilidades necessárias de autorresponsabilidade ou o autogoverno. Os pacientes seriam assim estimulados a obter um papel ativo em seu próprio tratamento e na construção de relações sociais. Estas atividades têm por objetivo desenvolver no paciente "uma forte integração social e familiar, a expressão de sentimentos e problemas, o treinamento de habilidades corporais, o trabalho em atividades produtivas, e o exercício coletivo da cidadania" (BRASIL, 2004, p. 20). Um exemplo bom e prático do reforço da atividade nos pacientes é o estimulo a participar nas assembleias coletivas. Aqui, o suposto doente mental obteria uma real possibilidade de decidir e determinar os destinos de seu próprio tratamento (BRASIL, p. 17). 
Além destas abordagens presentes nos documentos oficiais, é importante considerar narrativas etnográficas (SILVA, 2005) onde se descreve toda a rede cotidiana de práticas de responsabilidade contra a internação e a favor da liberdade dos pacientes. Estas formas de intervenção dão conta de uma rede de múltiplos atores, como profissionais (psiquiatras, psicólogos, trabalhadores sociais, técnicos de referência, etc.), familiares, a comunidade e o próprio paciente, que por meio de promessas, acordos e recompensas vão criando uma série de dispositivos locais articulados em função de um novo imperativo de liberdade. No Brasil, estas complexas negociações envolvem inclusive a criação de um especialista nas equipes multidisciplinares, o dito técnico de referência.

Uma fonte muito interessante de análise desta rede cotidiana de práticas de responsabilidade pode ser encontrada nos prontuários dos pacientes. Nestas fontes é possível observar um estilo discursivo bastante distinto entre diversos profissionais (médicos, enfermeiros, psicólogos e assistentes sociais). Mas, apesar das diferenças estilísticas (as preocupações farmacológicas dos médicos ou as descrições do entorno comunitário dos assistentes sociais) há uma narrativa comum de esforços que tangem a mudança nas relações familiares, a busca de um aprendizado profissional, a realização de cursos ou oficinas. Um caso nos chamou muito a atenção no funcionamento de um CAPS que servia a uma área próxima a de um antigo asilo psiquiátrico. No prontuário de uma paciente específica, é possível encontrar a narrativa de uma série de tentativas de internação por parte desta, sendo estas tentativas contornadas com a oferta de uma complexa rede de negociações em torno da oferta de cursos, atividades e reencontros familiares.

\section{Conclusão}

Nosso principal objetivo não é afirmar que os atores da reforma psiquiátrica brasileira têm se limitado a incluir a dita doença mental em uma forma liberal de gestão (ao menos no sentido doutrinário). O que gostaríamos de destacar é a semelhança estratégica destas formas cotidianas de governo da vida dos usuários e profissionais com técnicas como as empreendoristas (Rose, 1998), mesmo quando inseridas em distintas macropolíticas governamentais. Neste sentido, é necessário recordar que as práticas de resistência (como a luta antimanicomial brasileira dos anos 1970) podem se transformar em técnicas positivas de governo, como Foucault (2006) muitas vezes sublinhou em relação a algumas técnicas confessionais. Este caráter mutante e múltiplo das formas de governo é um aspecto ao qual todos os pesquisadores deste campo devem permanecer atentos.

À guisa de conclusão, cremos que, no atual conjunto de modos de liberdade e tutela, é crucial repensar a cidadania e a liberdade buscadas pelos dispositivos reformistas em outro sentido: seria necessário perguntar se é possível criar novos modos de cidadania e liberdade fora do horizonte das práticas de autogoverno ou da autonomia negociada. Consideramos que seria interessante tomar a palavra liberdade (tão invocada nos discursos legais e nas práticas reformistas) em modulações distintas das liberais, que a conformam a uma prática governamental de autoempreendimento, autoconstituição e autogestão. Tal como Larrosa (2000) destaca, é necessário "libertar a liberdade" de todas as práticas que fazem desta palavra algo débil. Este exercício é importante para o que Foucault (1995) denomina uma "história crítica do presente", abrindo nossa atualidade para outras possibilidades distintas do que tem sido naturalizado e cristalizado. A liberdade aqui não deve ser entendida como um atributo natural da natureza humana, e sim como um efeito de práticas críticas de resistência e problematização de nossas verdades mais cotidianas. Não seria no caso uma utopia, mas uma heterotopia. A liberdade pode não ser entendida apenas como autogestão. Ela pode implicar "um acontecimento, uma experimentação, uma transgressão, uma ruptura, e uma criação" (AUTOR, p. 331). Para concluir, gostaríamos de levantar uma posição efetiva 
para os movimentos reformistas baseada em um uso crítico e heterotópico da palavra liberdade: prestar atenção aos problemas atuais e específicos, e colocar em questão qualquer solução utópica para a loucura, incluindo qualquer solução libertadora.

\section{Referencias bibliográficas}

AMARANTE, P. Loucos pela vida. Rio de Janeiro: Fiocruz, 1998

BIRMAN, J. . A cidadania tresloucada: notas introdutórias sobre a cidadania dos doentes mentais. In: BEZERRA JR., B. e AMARANTE, P. (Eds.). Psiquiatria sem hospício: Contribuições ao estudo da reforma psiquiátrica. Rio de Janeiro, Relume-Dumará, 1992

BRASIL (. Lei n 10.216. In: Legislação em Saúde Mental. Brasília: Ministério da Saúde, 2002

FOUCAULT, M. (. Seguridad, territorio, población. Buenos Aires: Fondo de Cultura Económica, 2006. (2007). Nacimiento de la biopolítica. Buenos Aires: Fondo de Cultura Económica,2007

LARROSA, J. (. A libertação da liberdade. In G. C. Branco y V. Portocarrero (eds.), Retratos de Foucault. Rio de Janeiro: Nau, pp. 328-335, 2000

BRASIL,). Saúde mental no SUS: os centros de atenção psicossocial. Brasília: Ministério da Saúde, 2004

ROSE, N. . Inventing our selves. Cambridge: Cambridge University Press,1998

SILVA, M. B. . Atenção Psicossocial e Gestão de Populações: Sobre os Discursos e as Práticas em Torno da Responsabilidade no Campo da Saúde Mental. PHYSIS: Rev. Saúde Coletiva, Rio de Janeiro, 15(1), p.127-150. 


\section{A HISTÓRIA NÃO ENSINADA}

Janaina Morelli Dias - Universidade Federal do Rio de Janeiro morellidias@gmail.com Marta Simões Peres - Universidade Federal do Rio de Janeiro martasperes@gmail.com

\section{Resumo}

Essa análise tem como objetivo observar o conhecimento existente entre os doscentes, discentes e servidores da UFRJ (Campus Praia Vermelha) no que diz respeito ao passado do local onde os mesmos atuam. Esta investigação ancora-se no pressuposto de que esse conhecimento não é passado de geração a geração pelos professores e alunos. Volta-se, ainda, à aplicabilidade e à real função social da perpetuação desse saber, uma vez que a história nos mostra certos estigmas ligados à saúde mental. A metodologia consistiu em pesquisa bibliográfica a partir de artigos e livros e entrevista com pessoas que ocupam o local de diversas formas. As conclusões mostraram que há uma defasagem nas informações, mas existem recursos e eles devem ser pensados em prol da relação universidade-sociedade.

Palavras-Chave: História. Saúde Mental. Ocupação.

Introdução

Mais um semestre. Novos alunos e novas histórias. 50 anos da ECO e, daqui a pouco, 100 anos da UFRJ. Apesar disso, o Campus da Praia Vermelha foi palco de diversos momentos marcantes na História do Brasil, e está tendo suas origens esquecidas.

O que muitos alunos não sabem é que o Campus guarda sua origem como segredo, em particular a origem do Palácio Universitário, que mudou de nome algumas vezes desde sua construção em 1852: Até 1890 se chamava Hospício Pedro II, e foi o primeiro hospital psiquiátrico do Brasil e o segundo da América Latina, décadas depois, em 1948, foi cedido a então Universidade do Brasil.

Figura 1 - Linha do tempo Campus Praia vermelha

\begin{tabular}{|l|l|l|l|}
\hline 1852 até 1890 & 1890 até 1937 & 1937 até 1944 & 1948 \\
\hline Hospício Pedro II & $\begin{array}{l}\text { Hospício Nacional dos } \\
\text { Alienados }\end{array}$ & $\begin{array}{l}\text { Hospital Psiquiátrico } \\
\text { Praia Vermelha }\end{array}$ & Universidade do Brasil \\
\hline
\end{tabular}

No dia 10 de julho de 1841, foi publicado o decreto que ordenou a construção de um asilo no Rio de Janeiro sob o patrocínio do Imperador Pedro II, na Chácara do Vigário Geral. Este asilo foi inaugurado em 1852 e foi originalmente planejado para trezentos pacientes de ambos os sexos.

"Não sei que espírito de previdência me inspira, a Chácara do Vigário Geral há de um dia converter-se em Hospício de Alienados". D. Pedro II

Inaugurado solenemente por D. Pedro II, o Hospício que recebeu seu nome nos leva aos textos de Michel Foucault, que em obras como "História da loucura" e "Microfísica do poder" nos fala como os ditos "alienados" eram levados para longe do convívio em sociedade, como resposta a uma pressão feita pela mesma.

Apesar de Foucault afirmar que o hospital até o século VXIII assume esse papel de separação, exclusão e "morredouro"- já que não se ia para os hospitais a fim de se curar, mas apenas para se ter um local onde morrer- a localização geográfica escolhida para receber o Hospital Pedro II, no século XIX, estava a uma distância conveniente do rico subúrbio de Botafogo e do terminal das linhas de bondes que atendiam a essa área. 
Além da distância, Philippe-Marius descreveu em 1875 as condições no Hospício em seu artigo "O Hospício de Pedro II e os alienados no Brasil" e cita "os meios de contenção" utilizados:

\footnotetext{
"Os meios de repressão autorizados pelo regulamento incluem: a privação de visitas, de passeios e de outros tipos de recreação. Às vezes, a redução dos alimentos, numa proporção prescrita pelo médico, uma estadia na cela-forte e as duchas. A camisa de força é o único meio de contenção que vimos. Ela é utilizada da mesma forma que nos nossos asilos."(AUTOR, ANO)
}

Para quem viu o filme "Nise, o coração da loucura", sabe que em 1944, Nise passou a trabalhar no Hospital do Engenho de Dentro, e após se recusar a seguir o tratamento da época -que incluía choque elétrico, cardiazólico e insulínico, camisa de força e isolamento - a psiquiatra foi transferida, como "punição", para o Setor de Terapia Ocupacional do Pedro II, onde grande parte do filme se passa, e onde hoje se encontra o Museu do Inconsciente. O que não é tão enfatizado no filme, é que logo após terminar sua especialização, Nise foi aprovada em 1933 em um concurso de psiquiatria, e começou a trabalhar no Serviço de Assistência a Psicopatas e Profilaxia Mental do Hospital da Praia Vermelha, e desde essa época, já não sentia afinidade pelos tratamentos oferecidos pelos hospitais psiquiátricos. O Campus novamente faz parte da História.

Ao questionar alunos e servidores sobre o histórico do Campus, poucos souberam de seu passado. O aluno Felipe Knupp Vieira, do primeiro período do curso de administração da UFRJ, ao ser perguntado sobre a história do Campus disse que "ouvi falar que era o mais antigo do Brasil, não sei se isso é verdade, e que D. Pedro estudou aqui" também disse que não costuma ouvir os alunos conversando sobre o assunto. A aluna Guinevere Ramos Gaspari Ribeiro, no oitavo período de comunicação social, disse que "por muito tempo o Campus foi sede de um manicômio e que dizem que até hoje existem salas com aparelhos que eram usados pra tortura naquela época, e depois foi cedido a Universidade do Brasil e estamos aqui até hoje, dividindo espaço com o Pinel, com o IPUB, e acho que ainda tem muito resquício disso ai né, claro que em foramato muito diferente de como era naquela época, mas acho que ainda acontece muita coisa ruim ali dentro que é parte dessa cultura manicomial", também disse que as únicas vezes que conversou sobre o Campus foi fora de sala. $\mathrm{O}$ aluno Bruno Parisoto Lopes, no décimo período do curso de direção teatral, também sabia que ali havia sido um dos primeiros hospitais psiquiátricos do Brasil (chutando o ano de 1920 como o de inauguração) e que logo depois a UFRJ adquiriu o Campus; entretanto dá mérito ao conhecimento adquirido a uma pesquisa feita sobre a História da loucura no Rio de Janeiro. Já o servidor Sérgio Ribeiro, que trabalha no local a 14 anos, disse que "antigamente, em 1949, era o tempo dos escravos aqui do instituto". A professora e coordenadora do curso de comunicação Andréia Resende Barreto dá aulas desde 2010 e assumiu que ao entrar para a UFRJ chegou a pesquisar a história do Campus e sabe que Lima Barreto foi internado no Hospício da época; também mencionou que estava presente quando a capela pegou fogo, tendo que sair de sala durante o episódio; fora isso, afirmou não ter conhecimento de outros eventos históricos.

Cabe, portanto, mencionar que hoje o campus da Praia Vermelha acolhe o Instituto Municipal Philippe Pinel, o CAPSi-CARIM e o IPUB. Além desses, algumas iniciativas começaram por parte de alunos e professores a fim de acabar com o estigma que ainda existe a cerca dos transtornos mentais, como projetos de extensão que visam conectar os estudantes ao resto da sociedade.

Gilson Carneiro Santos participa do projeto de extensão ParaTodos, coordenado pela professora Marta Simões Peres, há cerca de quatro anos, é formado em sociologia e se trata no IPUB e no famoso "campinho", onde as aulas ocorrem. Ao ser questionado da importância da ocupação do local, o participante relata: 
"O fato mais importante do projeto, é que eu me sinto aqui respeitado, acolhido e amado. E amar e ser amado faz um bem enorme à vida e à saúde. O propósito do espaço é tentar criar um link, um laço, entre a universidade, que é pública mas que exclui a sociedade; então o projeto é justamente isso, detonar com os presídios, detonar com as prisões, detonar com os muros e trazer um diálogo, uma relação com o social. Um espaço importante porque no começo do projeto a gente tava numa espéice de campo de batalha, porque havia uma resistência, mas a gente resistiu também, heróicamente, e agora o projeto ta reconhecido em função não da determinação, mas de certa forma o nosso comportamento em ocupar esse espaço de uma forma ou de outra estimulou outras pessoas a ocupar também, democratizando a universidade."

Participando do mesmo projeto, Maria Aparecida Lopes do Nascimento também nos conta um pouco da sua sensação e dos benefícios que o projeto trouxe:

"Eu sou uma paciente do Hospital Dia, fui internada no Pinel, hoje eu faço tratamento e acompanhamento com a equipe UFRJ, que me ajuda a me controlar, e eu encontrei aqui no campinho a Marta fazendo teatro, e aquilo me cativou e trabalhando com a árvore e no "tocar na árvore" que me deu aquela força e eu já posso contar uma outra história além daquela que para mim não existiu mas eu vivi, e hoje eu to numa vida nova, eu busco a força na natureza que eu encontrei aqui no campo, e eu gostaria que esse campo não se acabasse nunca, e continuasse assim, porque é muito importante pra mim. Hoje eu não sou mais aquela, é uma extensão, me aceitaram como ser humano e meu coração creseu mais um pouco, porque coube mais gente. Essa família que eu encontrei aqui é maravilhosa e eu quero continuar brilhando, fazendo serviço com meus colegas porque aqui eu mostro a alegria que ta lá debaixo da tristeza, e eu quero continuar doando, levando praquele que não pode ter o que eu tenho: o amor, a alegria, fazer vocês sorrirem. Obrigada."

Além dos muito relatos de pacientes, também é possível encontrar aqueles feitos por pessoas que inicialmente não tinham nenhuma relação direta com o Campus, como é o caso de Berenice Xavier, que participa do projeto por acreditar na importância da relação entre as pessoas, quaisquer que sejam elas

"Eu sou Berenice Xavier, sou economista, sou artista, atriz, colaboradora do projeto ParaTodos, da Trupe DiVersos e uma coisa que eu tenho a dizer sobre o Campus e as atividades da UFRJ nesse famoso "campinho", é que o importante aqui, no meu ponto de vista, é que a gente tenha a sensação real de que a externalidade da ação da UFRJ se extende muito, muito além do que a gente pode perceber por uma simples matrícula ou participação como bolsista ou colaborador efetivo. Eu sou uma colaboradora efeitva mas totalmente informal, to aqui no projeto da Marta porque fui atraída por isso e pela sensação especial de que a externalidade universal, que é a grande pretensão da universidade, se realiza e se concretiza aqui nesse lugar, no campinho, então nós temos uma área de influência muito maior do que a gente pode perceber a primeira vista, onde os fluxos do conhecimento, da troca de conhecimento se dão com muita força, com muita eficácia, então a minha colaboração nesse projeto é que a gente permaneça funcionando aqui, porque é aqui o coração pulsante da UFRJ."

Além da importância de se conhecer a história do Campus, é necessário que se conheça o que ocorre em seu espaço hoje, para que todos possam, juntos, construir uma universidade e uma cidade melhor, sem preconceitos e com respeito a todo aquele que um dia foi tido como diferente.

\section{Referências bibliográficas}

FOUCAULT, Michel. A História da Loucura na Idade Clássica. Perspectiva, São Paulo, 1997. 
FOUCAULT, Michel. Microfísica do poder. Organizaçao e tradução de Roberto Machado. Edições Graal, Rio de Janeiro, 1979.

HOFFBAUER, Daniela Salzano Hungria. Hospício de Pedro II. Memória da Administração Pública Brasileira. Rio de Janeiro, 2016. Available from < http://linux.an.gov.br/mapa/?p=9300>.

REY, Philippe-Marius. O Hospício de Pedro II e os alienados no Brasil (1875). Rev.latinoam. psicopatol. fundam., São Paulo,v.15, n.2, p.382-403, 2012. Available from<http://www.scielo.br/scielo.php?script=sci_arttext\&pid=S1415-47142012000200012\&lng=en\&nrm=iso>.

TOLEDO, Caio Navarro de. 1964: o golpe contra as reformas e a democracia. Rev. Bras. Hist., São Paulo, v. 24, n. 47, p. 13-28, 2004. Available from <http://www.scielo.br/scielo.php?script=sci_arttext\&pid=S0102$01882004000100002 \&$ Ing=en\&nrm=iso>. 


\section{O MUNDO NOVO É DE FATO NOVO: ANÁLISE COMPARATIVA DAS DESCRIÇÕES DA FLORA DAS AMÉRICAS FEITAS POR BARTOLOMÉ DE LAS CASAS E GONZALO FERNANDEZ DE OVIEDO}

Luiz Mors Cabral - Professor Adjunto do Instituto de Biologia da UFF - luizmors@gmail.com

\section{Resumo}

Os esforços dos primeiros cronistas para descrever a realidade do Novo Mundo levaram a profundas mudanças epistemológicas. Os primeiros relatos refletem métodos empíricos de sistematização do conhecimento, contribuindo para o surgimento da história natural e da Revolução Científica. Os textos do século XVI não eram, no entanto, "científicos" no sentido moderno. A observação empírica misturava filosofia escolástica e humanística com fontes clássicas e medievais, discursos que eram combinados de maneiras distintas de acordo com as perspectivas ideológicas dos autores. Este trabalho examina as descrições de plantas nas crônicas de Bartolomé de Las Casas e Gonzalo Fernández de Oviedo, analisando o papel que tiveram na solução da crise epistemológica inaugurada com a descoberta do Novo Mundo.

Palavras chave: Epistemologia. Novo Mundo. Representações da flora.

\section{Introdução}

Nos anos que se seguiram a chegada de Colombo à América, os esforços europeus para descrever a realidade física de um hemisfério até então desconhecido levou a profundas mudanças epistemológicas. De uma hora para outra, uma série de novas descobertas deviam ser "encaixadas" em conceitos já existentes. Os primeiros relatos da natureza no novo mundo são um demonstrativo dessa tentativa de compreensão da nova realidade, e são resultado do conflito entre as diversas tradições intelectuais e artísticas que se misturavam, muitas vezes de forma desarmoniosa, com a ciência nascente ( CAÑIZARES ESQUERRA, 2006).

Neste trabalho serão analisadas e comparadas às maneiras como dois dos primeiros cronistas dos descobrimentos, Bartolomé de Las Casas e Gonzalo Fernandez de Oviedo, descrevem a flora das Américas, e o que esses relatos nos dizem sobre a solução da crise epistemológica que se iniciou com a descoberta das Américas.

O interesse de Las Casas pelo Novo Mundo começou ainda em sua infância. Com oito anos ele testemunhou o retorno de Colombo de sua primeira viagem e viu os índios, pássaros exóticos e artefatos estranhos que o almirante tinha trazido. O pai de Las Casas navegou com Colombo em sua segunda viagem, trazendo em seu retorno um jovem escravo índio que foi companheiro de Las Casas durante sua infância e adolescência. É impossível dissociar os escritos de Las Casas dessa amizade com um nativo das Américas. Bartolomé viaja ao Novo Mundo em 1502 com a idade de dezoito anos e com o objetivo de ajudar seu pai no cultivo de umas terras na ilha de Hispaniola que ele havia ganho de Colombo. Até seu retorno a Sevilha em 1506, ele foi profundamente influenciado pelas atrocidades que testemunhou no Novo Mundo. Bartolomé se ordena sacerdote em Roma em 1507, e em 1510 acompanhou Pánfilo de Narváez a Cuba como capelão, no que ele acreditava que seria uma missão sem derramamento de sangue com o objetivo de pacificar e converter a os nativos ao catolicismo. 
O que ele testemunhou, no entanto, foram as atrocidades dos homens de Narváez (PARISH, 1992).

Com a chegada das primeiras missões Dominicanas ao Novo Mundo, em 1510, cresce a idéia de que os indígenas merecem um tratamento mais humano, e Las Casas é fortemente tocado por essa ideologia. Observando a destruição da população da ilha de Cuba sob o sistema de encomienda, ele decidiu iniciar uma carreira de oposição aos métodos de exploração aplicados no Novo Mundo. Las Casas estava mergulhado nas doutrinas da filosofia natural e nos debates jurídico-teológicos da escola de Salamanca, então um centro de destaque em filosofia humanista e direito, e ficaria conhecido como por seus esforços para restringir o tratamento brutal dos espanhóis aos nativos. Por mais de cinquenta anos Las Casas contestou incansavelmente, tanto no campo político como jurídico, os métodos espanhóis de conquista das Américas. Apologética Historia Sumaria, sua obra principal, é uma defesa dos direitos dos índios que inclui farto material etnográfico e apresenta uma longa descrição da natureza do Novo Mundo (LAS CASAS, 1992).

Gonzalo Fernandez de Oviedo, por sua vez, sempre acreditou que a conquista dos ameríndios era mais que uma vontade da Corte Espanhola: era também seu direito e seu dever. Ele nunca questionou a legitimidade do papel da Espanha nas Américas, e argumentava que somente a influência espanhola poderia disciplinar um povo "preguiçoso", "inclinado à mentira", e com hábitos bárbaros que incluíam "adoração a deuses pagãos" e canibalismo. Em um trecho de seu livro mais importante, Historia Geral e Natural das Índias, ele justifica a conquista e o extermínio dos indígenas:

\footnotetext{
“...as pessoas desta região são naturalmente tão inúteis, corruptas, de pouco trabalho, melancólicas, covardes, sujas, de má condição, mentirosas, sem constância e firmeza (...) que Nosso Senhor permitiu que fossem eliminadas e banidas da superfície terrestres". (OVIEDO, 1851)
}

O envolvimento de Oviedo com a Corte espanhola começou em 1478, com doze anos, quando ele se tornou camareiro de Don Juan, filho do Rei Fernando de Aragón (MYERS, 2007). Assim como Las Casas, ele testemunhou e foi profundamente afetado pelo retorno triunfal de Colombo, mas ao contrário de Las Casas (que assistiu ao evento nas ruas de Sevilha), ele estava presente no evento como um membro da corte. Com a morte súbita em 1497 do jovem Don Juan, Oviedo passou a ocupar diversos cargos na corte, a maioria como historiador ou administrador. Em 1513 foi oferecido à Oviedo um cargo de inspector de minas e escrivão geral em Darién, onde hoje é o Panamá. A expedição que o levou às Américas, liderada por Pedrarias Dávila, foi teve sua partida bastante atrasada pela ação de defensores dos ameríndios, a tal ponto que foi nomeado um painel de teólogos para analisar o caso. A armada finalmente zarpou em 1514, após a elaboração do "Requerimiento", um documento que era para ser lido para os ameríndios antes de qualquer ação armada, exigindo que eles reconhecem a autoridade da Igreja e da Espanha, jurando fidelidade ao Papa e à Coroa. Foi durante essas negociações para a partida da expedição que Oviedo conheceu Las Casas. Em seu História geral, ele observa sarcasticamente que: “... andava por ali um reverendo... procurando falar com sua Majestade e com os membros do Conselho das Índias". (MYERS, 2007)

Esse foi o início da rivalidade histórica entre Las Casas e Oviedo. Oviedo acusa o padre de conquistar apoio na Corte com uma mentira, prometendo grandes lucros para quem investisse em uma maneira mais humana de explorar as riquezas das Américas (ARIAS; MEREDIZ, 2008). Por sua parte, em sua Historia de las Indias, Las Casas descreve Oviedo como: "muito bom orador, que sabia muito bem persuadir, além de ser um dos maiores inimigos que os índios já tiveram e que mais danos tinha feito...". (ARIAS; MEREDIZ, 2008). 
Descrições de plantas:

As descrições de plantas feitas por Las Casas devem ser sempre vistas no contexto de sua construção da ilha de Hispaniola como um paraíso terrestre. O Novo Mundo aparece como sendo sempre melhor do que a Europa. Não se percebe pelos seus escritos nada de sinistro que possa colocar as Américas como um mundo à parte, ontologicamente diferente da Europa. Las Casas condenava as ações da Espanha no Novo Mundo, e sua visão da natureza paradisíaca das Américas serviu de base para o seu argumento de que o clima do mundo novo produziu seres humanos capazes de organização social racional. Na base do argumento de las Casas estava que, embora houvesse um objetivo legítimo na conversão dos ameríndios para o cristianismo, sua escravidão não poderia ser justificada por qualquer motivo (PARISH, 1992). As descrições de Las Casas são governadas pela crença na universalidade da natureza. As leis de Deus operam da mesma forma em todos os lugares, e enquanto Las Casas não exclui o anômalo, o seu objetivo é claro no sentido de minimizar o exotismo do que observava. Nesse ponto, existe uma distinção importante entre Las Casas e Oviedo, porque Oviedo tem prazer na particularidades. Ele não nega de forma categórica a unidade do mundo natural mas suas descrições são tão cheias de maravilha e encantamento com a novidade do Novo Mundo que a noção de unidade fica em segundo plano frente ao relato de particularidades e idiossincrasias. Las Casas apresenta sua seção de plantas herbáceas com uma passagem particularmente interessante:

\footnotetext{
"Quanto às ervas, são imensas em quantidade as que existem nessas ilhas, e de espécies tão diversas, e creio que de grandes virtudes medicinais, porque são muito belas e coloridas, muitas delas como que cortadas à tesoura, que logo parecem ter sido assinaladas por sua virtude." (LAS CASAS, 1992)
}

Las Casas sugere que essas plantas parecem ter sido delicadamente cortadas com tesoura. Não há nada selvagem ou aleatório e tem-se a impressão que o que está sendo descrito é um jardim e não um território selvagem. A noção de que a mão de Deus (em funcionamento através da natureza) foi atuante em todo o mundo natural era um dos dogmas centrais da filosofia natural, cujas preocupações centrais foram a apreciação da existência de Deus, a bondade, a providência, a premeditação, generosidade e provisão de sua criação.

Um segundo ponto importante, evidente na insistência de Las Casas que a beleza das plantas deve sinalizar propriedades medicinais, é a legibilidade da natureza. A beleza não é um fator em si, mas está presente como forma de apontar para uma virtude da planta. Deus não apenas fez plantas dotadas de qualidades úteis ao homem, ele também indicou a sua utilidade com sinais que podem ser decifrados. Tanto a noção de que a natureza é obra de Deus, como a idéia de que o Criador tem estruturado seu trabalho de tal forma que ele pode ser lido por seres humanos, são componentes importantes de representação de Las Casas do mundo natural. Nesse ponto, Las Casas está sendo influenciado pela chamada "Doutrina das Assinaturas" (criada por Dioscórides por volta do ano 70), uma das primeiras tentativas de desvendar o "código" da natureza. Sendo um homem muito letrado, Las Casas certamente conhecia Paracelso e havia lido em seu livro "Plantas Mágicas":

\footnotetext{
“Não é a vontade de Deus que o que ele cria para o benefício do homem e o que ele tem nos dado deve ficar escondido... E mesmo que ele tenha escondido certas coisas, ele permitiu que nada de ficar sem exterior e sinais visíveis na forma de marcas especiais - exatamente como um homem que enterrou um tesouro marca o local para que ele pudesse encontrá-lo novamente" (PARACELSO, 1976)
}

As diferenças de tratamento dado por Las Casas e Oviedo à natureza encontrada na nova terra fica evidente quando eles descrevem a mesma árvore com pontos de vista bem distintos. A árvore em questão é chamada por Las Casas como "Guao" (LAS CASAS, 1992) e por Oviedo 
como "Manzanila" (OVIEDO, 1851). Embora não exista absoluta certeza de que se trata da mesma planta, seu uso e os efeitos descritos são bem parecidos, de forma que se acredita que seja a mesma.

Las Casas dá uma descrição muito breve da aparência da árvore, quase sem detalhes, e afirma que os índios a utilizam para fazer veneno para suas flechas. Entre as descrições dos seus efeitos, ele diz que basta que os ramos toquem alguém que anda pela floresta para que seu rosto fique inchado e haja uma forte sensação de queimação muito duradoura. Mas Las Casas é rápido em acrescentar que os efeitos só acontecem em pessoas mais sensíveis, que ele chama de "homens muito brancos e delicados". Aos "coléricos... não causa dano algum". Diz ainda que "A mim me encostaram muitas vezes as ramas no rosto e nunca me fez mal, porque não sou dos brancos e fleumáticos (LAS CASAS, 1992)". Além disso, afirma que essas árvores não se encontram por todos os lugares na llha de Hispaniola, estando concentradas em determinada região. Assim, Las Casas se esforça sempre por minimizar aspectos negativos da flora, comprometendo algum grau de veracidade em seus relatos. Ao contrário de Las Casas, Oviedo não lança mão de nenhum recurso para diminuir a malignidade da planta, e portanto um retrato mais realista emerge da narrativa. Em sua descrição Oviedo dá uma descrição detalhada de sua aparência, afirma que o veneno é irremediável (OVIEDO, 1851), e continua a dizer que aqueles que inadvertidamente adormecem próximo à fogueira de seu tronco acorda com dores de cabeça, acrescentando:

\footnotetext{
"E se acaso um ramo dessa árvore bate no rosto, é como fogo, e levanta e põe em brasa os couros de tudo o que toca; e se caem nos olhos, ou os danifica, ou cega, ou os põe em grande trabalho e perigo de os perder. A lenha dessa árvore, quando acesa, não há quem consiga ficar perto por muito tempo, porque logo causa problemas, e dá tanta dor de cabeça que quem quer que esteja nas cercanias tem de se retirar, homem ou animal." (OVIEDO, 1851)
}

Uma clara vantagem de Oviedo sobre Las Casas reside no fato deste ter adotado Plínio, O Velho, como principal referência de seu trabalho, especialmente no que diz respeito à flora. Essa referência fica clara no número de vezes que Plínio é citado, e também na própria estrutura do relato, tentando sempre classificar as plantas de acordo com categorias taxonômicas (árvores, plantas herbáceas, entre outras). Nesse ponto, no entanto, enquanto Las Casas descreve as plantas desconhecidas sempre comparando-as com os familiares já conhecidos na Europa, Oviedo percebeu que a natureza contida no novo mundo ia muito além das categorias aceitas e conhecidas, passando então a enfatizar a novidade da natureza americana. Nesse aspecto especificamente, Oviedo é, dentre a totalidade dos cronistas do novo mundo, o que vai mais longe na afirmação de que o conhecimento institucionalizado não dava conta dos novos seres, e novas categorias teriam que ser criadas.

Isso fica claro quando se observa a utilização dos nomes indígenas para muitas plantas que ele descreve. Não por um respeito a culturas ameríndias, mas sim como recurso para contornar a diferença insuperável entre o Novo Mundo e o Velho. Oviedo admite a incapacidade da linguagem Europeia para transmitir a realidade americana.

No que diz respeito à mandioca. Oviedo reconhece imediatamente a singularidade da planta, e trata de dar uma descrição o mais precisa possível. Já Las Casas descreve a mandioca tentando fazer relação de suas características com plantas que ele conhecia. Dessa forma ele descreve a parte da planta que fica acima do solo através de uma comparação com as vinhas (LAS CASAS, 1992), representando a cultura indígena com cores baseadas na cultura européia. Ao descrever o Pan Cazabi, feito de mandioca, Oviedo se mostra fascinado pela ideia de que a mandioca não tratada é um veneno mortal, e ele dedica um grande espaço de texto ao tema. Ele começa explicando nos termos mais fortes possíveis que o suco extraído da mandioca "es tan pésimo veneno, que con un sólo y pequeño trago matara o elefante o cualquier otro 
hombre o animais viviente" (OVIEDO, 1851). Para Oviedo é chocante o fato de uma cultura fazer tão largo uso de uma planta venenosa, coisa jamais vista na Europa.

Por último, vale ressaltar a descrição que Oviedo faz do abacaxi, chamando atenção de sua singularidade e diferença. São quase quatro páginas inteiras com enorme riqueza de detalhes de seu aspecto físico, fisiologia da planta e propriedades como gosto e sensações que desperta e quem experimenta:

\begin{abstract}
“E se, por falta de cores eu não chegar à dar a entender o que pretendia dizer, que se jogue a culpa em meu juízo, pois, a meu ver, é a mais bela fruta de todas as frutas que eu já vi, e a que melhor sabor tem, e em sua grandeza e cor, que é verde, brilhante, ou matizado de uma cor amarelo muito forte, e quanto mais se vai amadurecendo, mais se torna amarela e menos verde, e assim se vai aumentando a cor, e o gosto é melhor do que o gosto do mais saboroso melão, e mais suculento."( OVIEDO, 1851)
\end{abstract}

Oviedo, antes de mais nada, reconhece a incapacidade de descrever a fruta em comparação com qualquer outra conhecida na Europa: "Existe nessas ilhas espanholas uns cardos, que cada um deles leva uma pinha, posto que, por parecer-se com a pinha, assim as chamam os cristãos, mesmo sem o ser." (OVIEDO, 1851)

Oviedo sabe que se trata de uma planta distinta da pinha, mas reconhece que não existe nome apropriado na língua espanhola para representá-la. A descrição escrita de Oviedo contrastando a pinha e o abacaxi é bastante precisa, observando em primeiro lugar que as pinhas são "de madeira, ou quase", e depois falando que no abacaxi, ao contrário da pinha, as escamas "não se abrem nem se dividem através das escamas, como no caso dos pinhões". (OVIEDO, 1851)

Conclusão

O que diferencia os relatos de plantas entre Las Casas e Oviedo é o ponto de vista a partir do qual observam a natureza. Se os escritos de Las Casas sobre o mundo natural podem ser mais bem compreendidos no contexto de sua luta para defender os ameríndios, as descrições da natureza de Oviedo devem ser vistas no contexto de seu papel como um funcionário dedicado do Império Espanhol. Seu livro mais importante "Historia Geral e Natural das Índias" foi escrito de acordo com suas responsabilidades como historiador da Coroa. Embora o livro reflita sua própria curiosidade e sua capacidade de deliciar-se com a novidade da natureza americana, ele nunca perdeu de vista seu papel como cronista real. Sendo as sim, era uma de suas funções atuar na catalogação de plantas e animais para que a corte pudesse avaliar as possibilidades de exploração dos novos territórios.

Las Casas estava muito envolvido com a defesa dos nativos, e portanto seus relatos serviam a um propósito ideológico. Já Oviedo, imbuído da função primordial de catalogação, reconhece que uma nova forma de representar a flora encontrada no novo mundo deve ser criada, e que as categorias antigas sob as quais se organizava o conhecimento sobre a flora tinham que sofrer reformulações. Oviedo vai aonde Las Casas e outros cronistas não conseguiram, contribuindo com um primeiro passo para que a crise epistemológica aberta pela descoberta das Américas fosse resolvida. Os relatos de Oviedo são um divisor de águas na história das ciências naturais, dando um passo à frente no processo de descolamento de uma ciência antiga e que já não conseguia dar conta de explicar e catalogar a realidade do Novo Mundo, em direção a uma nova ciência, em um processo que acabaria por dar origem à história natural alguns séculos depois. 


\section{Referências}

Cañizares Esguerra, Jorge. Nature, Empire and Nation: Explorations of the History of Science in the Iberian World. Stanford: Stanford University Press, 2006. Print. ---. Puritan Conquistadors: Iberianizing the Atlantic, 1550-1700. Stanford: Stanford University Press, 2006. Print.

Las Casas versus Oviedo: The Polemic between the "Defender of the Indians" and the "Enemy of the Indians". Approaches to Teaching the Writings of Bartolomé de La Casas. Santa Arias and Eyda Merediz. Ed. New York: Modern Language Association, 2008. 106-116.

Parish, Helen Rand. Introduction. Bartolomé de Las Casas: The Only Way. Ed. Helen Rand Parish. Trans. Francis Patrick Sullivan, S.J. New York: Paulist Press, 1992. Print.

Bartolomé de las Casas Obras completas. Publicaciones de la Excma. Diputación Provincial de Sevilla. Editor Paulino Castañeda Delgado. Alianza Editorial, 1992

General y Natural de las Indias. El Capitan Gonzalo Fernandez de Oviedo y Valdes. Imprenta de La Academia de La istoria. Madri, 1851.

Myers, Kathleen A., and Gonzalo Fernández de Oviedo. Fernández de Oviedo's Chronicle of the Americas: A New History for a New World. Trans. of Oviedo, Nina M. Scott. Austin: University of Texas Press, 2007. Print.

As Plantas Mágicas (Botânica Oculta) - Paracelso, Filippo Teofrasto, Editora Hemus, 1976. 


\section{CONHECIMENTO CIENTÍFICO E INFORMAÇÃO: SOCIEDADE, INDIVÍDUO E FALSAS NOTÍCIAS CIENTÍFICAS}

Amanda Moura de Sousa - Doutoranda em História das Ciências e das Técnicas e Epistemologia (UFRJ) amandamoura@if.ufrj.br

\section{Resumo}

O presente trabalho discute a relação da ciência com o grande público diante do problema da disseminação de notícias falsas (fake news) com o avanço das tecnologias de comunicação e informação (TICS). São apresentadas algumas questões da história da ciência e suas relações com a tecnologia e a sociedade a partir de breve revisão bibliográfica. Ao final, é discutida a relação sujeito ciência sob a ótica Gilles Deleuze e Félix Guattari.

Palavras-chave: História da Ciência. Informação Científica. fake news. imanência.

\section{Introdução}

O conhecimento científico se estabeleceu na sociedade como instancia máxima de credibilidade de discurso ao longo se sua história. À medida que seu desenvolvimento trouxe progresso e soluções para a vida do homem, enfrentou também resistência por parte da sociedade devido às crenças preexistentes ou pela dificuldade do diálogo científico com a sociedade.

A dificuldade da ciência em dialogar com a sociedade está relacionada em parte com o rigor da linguagem utilizada na informação científica. Para reduzir a distância entre a informação científica surgiram diversas revistas especializadas na divulgação científica para o grande público se utilizando de linguagem simples, de fácil entendimento.

Com o avanço das tecnologias de informação e comunicação (TICs), a forma como a sociedade utiliza e manipula a informação sofre mudança radical, pois aumenta o volume de informação e o tempo de exposição. Outra mudança que interfere nessa relação é "descentralização" da autoria.

Diante desse panorama, o que se pretende discutir neste trabalho é relação da ciência com o grande público frente a um problema que surge com as novas tecnologias: a aceitação pelo grande público de notícias falsas, em especial, notícias falsas de informação científica.

Para essa discussão, serão apresentadas algumas questões da história da ciência e suas relações com a tecnologia e a sociedade a partir de breve revisão bibliográfica para a exposição do tema a ao final é discutida a relação sujeito x ciência sob a ótica de Gilles Deleuze e Félix Guattari.

Ciência e Sociedade

No livro "Tecnociências e humanidades", Luiz Pinguelli Rosa (2005, v.1, p. 16) apresenta a hipótese de que

\footnotetext{
"a ciência não se desenvolve de modo autônomo no plano intelectual das ideias. Seus conceitos e teorias têm uma profunda relação com o contexto histórico, tanto nos aspectos intelectual e cultural como nos aspectos econômico, social e político. Essa relação se dá em mão dupla." (AUTOR,ANO)
} 
A partir disso, é possível assumir que o desenvolvimento científico acompanha o desenvolvimento social e vice-versa.

A Física se estabelece como paradigma que influenciaria a epistemologia não só das ciências naturais como também se estendeu às humanidades. Um dos fatores que contribuíram para a hegemonia da física entre as ciências é a sua completa matematização, apresentando linguagem mais universal e menos abstrata que as ciências humanas e sociais, por exemplo. Sobre a extensão da Física à cultura humana, afirma Niels Bohr (1995, p. 29):

“Evidentemente, é impossível traçar uma distinção nítida entre a filosofia natural e a cultura humana. As ciências físicas, na verdade, são parte integrante de nossa civilização, não apenas pelo fato de nosso domínio cada vez maior das forças da natureza haver modificado tão completamente as condições materiais da vida, mas também porque o estudo dessas ciências contribuiu muito para esclarecer os antecedentes de nossa própria existência. "(AUTOR, ANO)

O reconhecimento por parte de Bohr que a ciência modificou as condições materiais da vida através de um domínio maior das forças da natureza é um dos aspectos cruciais para o desenvolvimento humano seja por aspectos positivos ou negativos. A mesma ciência que nos dá a oportunidade de controle da vida material pode, ao mesmo tempo, ter aplicações que ameaçam a vida humana, como as bombas nucleares. Sendo assim, as conquistas da ciência não são capazes de beneficiar a todos igualmente, principalmente após o estabelecimento do capitalismo como sistema econômico dominante.

O capitalismo tem suas origens na Revolução Comercial, se consolidando após a Revolução Industrial. Não se pretende aqui avaliar os sucessos e os fracassos do capitalismo enquanto sistema, porém é inegável que seu estabelecimento aumentou substancialmente o consumo e em consequência promove o esgotamento dos recursos naturais. Por outro lado, a chamada terceira revolução industrial - associada à eletrônica, à telecomunicação e à informática possibilitou a chamada revolução tecnológica da informática, que segundo Rosa (2005) marca o nosso tempo atual coroando todos os avanços anteriores alcançados pela ciência.

A tecnologia, segundo Rosa (2005, v.1, p. 368) é um dos aceleradores da globalização, embora esse processo não tenha apenas a tecnologia em sua base. A globalização, assim como quase qualquer coisa associada ao capitalismo, é experimentada segundo o capital, ou seja, abre diversas possibilidades de interação social e econômica para aqueles que têm mais poder de consumo enquanto que para a maioria é "um processo de localização no espaço". Entre as possibilidades que se abrem na globalização é a capacidade de transmissão de informação e da ampliação da comunicação científica, ainda que essa ampliação esteja condicionada a grandes impérios das telecomunicações.

\section{Informação Científica e Tecnologia}

A informação científica acompanha as descobertas e avanços da ciência, com os objetivos principais de documentar e torná-la pública. Desde os primeiros livros da antiguidade, passando pelo surgimento dos periódicos científicos e publicações de divulgação científica.

Derek de Solla Price (1965) com a sua "ciência da ciência" expõe que o conhecimento científico apresenta crescimento exponencial à medida que há mais interesse por determinado campo. Segundo Price (1965), esse maior interesse é incentivado principalmente pela capacidade de uma área do conhecimento se comunicar entre os pares. Ainda segundo Price (1965, p. 5), o aumento de sociedades científicas e publicações proporcionou a "transição da pequena ciência para a grande ciência".

A informação científica abordada até agora possui estrutura e objetivos direcionados para fortalecer a comunicação entre especialistas, documentar e tornar as pesquisas públicas. Trata-se de um instrumento importante para o desenvolvimento da ciência, porém, não é um 
instrumento capaz de aproximar ciência e sociedade, seja pelos objetivos já assinalados ou pela linguagem acessível apenas aos especialistas. Para aproximar ciência da sociedade, a divulgação científica é desenvolvida.

Para este trabalho, tomamos como marco inicial da divulgação científica a obra de Galileu Galilei "Diálogos sobre os dois sistemas máximos do mundo, ptolomaico e copernicano" (1632) escrita em diálogos, em italiano ao invés do latim (a língua ciência). Isto possibilitou que mais pessoas acessassem o texto. A partir do século XIX, a divulgação científica passa a ser estruturada através de publicações especificas para esse fim, com o objetivo de tornar a ciência um pouco mais próxima da sociedade (MUELLER; CARIBÉ, 2010). Essas ações simplificam a linguagem técnica para a compreensão por parte do público em geral.

A divulgação científica se utiliza de diversas estratégias para cumprir com seu papel. Com a aceleração no desenvolvimento das TICs a partir dos anos 1970 e mais tarde com a popularização da internet em meados dos anos 1990 houve uma mudança no acesso por parte do grande público, que já não dependia mais exclusivamente de um exemplar impresso ou se deslocar a uma biblioteca, por exemplo.

A partir da internet a divulgação cientifica é facilitada principalmente por questões de acesso e pela variedade de conteúdo disponível sem as barreiras do espaço e do tempo. Essa facilidade, no entanto, traz consigo um problema para a divulgação científica em função da facilidade na manipulação das informações: a divulgação de falsos fatos científicos.

As Notícias Falsas e a Ciência: Relações com o Indivíduo

A ciência através dos séculos ocupou lugar de destaque entre as atividades humanas. Materializada na forma de artigos, livros e demais formas de comunicação, dissemina mais que descobertas e inovações: conceitos. A definição de conceito que se emprega para discussão é a de Deleuze e Guattari (1993, p. 27):

\footnotetext{
"Todo conceito tem componentes, e se define por eles. [...] Não há conceito de um só componente: mesmo o primeiro conceito, aquele pelo qual uma filosofia "começa", possui vários componentes, já que não é evidente que a filosofia deva ter um começo e que, se ela determina um, deve acrescentar-lhe um ponto de vista ou uma razão. [...] Todo conceito tem um contorno irregular, definido pela cifra de seus componentes. É por isso que, de Platão a Bergson, encontramos a ideia de que o conceito é questão de articulação, corte e superposição."(AUTOR,ANO)
}

Ainda sobre os conceitos, Deleuze e Guattari (1993, p. 53) afirmam que eles não apresentam a essência ou a coisa em si, mas um acontecimento, tornando-se, portanto, absoluto e relativo ao mesmo tempo. Os acontecimentos, por sua vez, necessitam de um plano, um meio indivisível para se expandirem e se reservarem. Esse plano é chamado de plano de imanência: "o plano de imanência não é um conceito pensado nem pensável, mas a imagem do pensamento, a imagem que ele se dá do que significa pensar, fazer uso do pensamento, se orientar no pensamento" (DELEUZE; GUATTARI, 1993, p. 53).

A partir dessa definição, os sujeitos do presente trabalho são a ciência, a tecnologia e o indivíduo (público leigo em ciência). Cada um com sua imagem de pensamento, absoluta em si e relativa em função dos outros sujeitos. Cada um reservando seus conceitos se cruzando através de pontes, estabelecendo, assim, a ligação entre os três mundos possíveis.

Em relação ao caráter absoluto e relativo dos conceitos, e da possibilidade de vários planos de imanência, a disseminação e aceitação de falsos fatos e mitos científicos surgem como resultado de interpretações que estão relacionadas ao fazer sentido da narrativa cientifica, seja pela necessidade aproximação entre ciência e sociedade ou pelo afastamento entre esses dois planos. A tecnologia seria um terceiro plano que convive com os outros dois. 
$\mathrm{Na}$ atualidade, em função do maior acesso do grande público à informação através da tecnologia, identifica-se também, um maior número de disseminação dos mitos científicos e notícias falsas relacionadas à ciência. As razões para esse aumento devem-se em parte à facilidade de manipulação dos conteúdos de uma mensagem com o auxílio da tecnologia e em parte também à valorização das TICs como entidades principais na intermediação do conhecimento, ou seja, o desenvolvimento da internet a tornou hegemônica entre os canais de comunicação da ciência.

Apesar das notícias falsas alcançarem mais público no século XXI favorecendo a discussão sobre o tema, elas não são necessariamente uma novidade. Ao longo da história, podemos observar diversos exemplos de interpretações de fatos científicos que se converteram em informações falsas e textos apócrifos.

Como exemplo de mito científico destaca-se a o uso de apenas $10 \%$ da capacidade cerebral, que tem início no século XIX e se estende ao longo do século XX. Em meados de 2000, novos estudos derrubam este mito cientificamente, porém, não foi suficiente para desfazer totalmente a crença popular de que a só se usa $10 \%$ da capacidade cerebral.

Contextualizando no cenário brasileiro, a imprensa carioca durante a A Revolta da Vacina (1904) propagou diversos fatos que não eram comprovados cientificamente. A população do Rio de Janeiro na época assimilou diversos fatos não comprados como verdadeiros, iniciando a revolta contra a vacinação obrigatória contra a febre amarela, que assolava a cidade à época.

A partir dos dois exemplos aqui citados, nota-se que a disseminação de notícias falsas (chamados de pós-verdade na era tecnológica) é algo que acontece há algum tempo, não é uma prática contemporânea, o que ocorre é a facilidade de disseminação e aceitação de informação falsa por ocasião da tecnologia e do tempo de exposição do indivíduo à informação, principalmente com o desenvolvimento de tecnologias móveis como smartphones, tablets, etc.

A crença em um falso fato cientifico por parte do indivíduo, revela um aspecto do plano da imanência:

\footnotetext{
“a imagem do pensamento só retém o que o pensamento pode reivindicar de direito. O pensamento reivindica somente o movimento que pode ser levado ao infinito. O que o pensamento reivindica de direito, o que ele seleciona, é o movimento infinito ou o movimento do infinito. É ele que constitui a imagem do pensamento" (DELEUZE; GUATTARI, 1993, p. 53).
}

Se o indivíduo é capaz de reter conceitos falsos disseminados com o auxílio da tecnologia é porque seu plano de imanência reivindica esse movimento e o seleciona. Seus conceitos, como atos de pensamento estão conectados aos conceitos disseminados pela tecnologia e mais distantes dos conceitos disseminados pela ciência. O movimento que o indivíduo faz para buscar referência ora na ciência, ora na tecnologia está relacionado a afirmação de Deleuze e Guattari (1993, p. 55) que

“o plano da imanência não para de se tecer, gigantesco tear. Voltar-se-para não implica somente em se desviar, mas em enfrentar, volta-se, retornar, perder-se, apagar-se. Mesmo o negativo produz movimentos infinitos: cair no erro, bem como evitar o falso, deixar-se dominar pelas paixões, bem como superá-las. "

Evitar o erro é algo que busca a ciência com desenvolvimento do método. O conjunto de regras e técnicas utilizadas no método visa estabelecer um conhecimento novo, corrigir um existente. Para isso o método deve possibilitar a verificação de uma teoria científica e também a sua crítica. Se a ciência não estivesse aberta a críticas e correções, estaria se aproximando das religiões (enquanto instituições) algo que a ciência em sua essência visa se afastar. Ou 
seja, teorias científicas precisam se reprovadas algumas vezes, assim como acontece no plano da imanência:

\begin{abstract}
"Mas então "perigo" toma outro sentido: trata-se de consequências evidentes, quando a imanência pura suscita, na opinião, uma forte reprovação instintiva e natureza dos conceitos criados ainda vem redobrar a reprovação " (DELEUZE; GUATTARI, 1993, p. 59).
\end{abstract}

Considerações Finais

A discussão filosófica apresentada neste trabalho visa uma interpretação de processos que antecedem a relação direta entre os personagens ciência, tecnologia e indivíduo. É uma tentativa de explorar o problema da aceitação das notícias falsas da ciência pelo público leigo considerando os acontecimentos relativos a cada um e como estariam ligados (ou separados) entre si. O problema apresentado parte de observação empírica e não é a proposta deste trabalho solucionar o problema, mas buscar o entendimento a partir das bases filosóficas propostas por Deleuze e Guattari.

\title{
Referências bibliográficas
}

BOHR, Niels Henrik David. Física atômica e conhecimento humano: ensaios 1932-1957. Rio de Janeiro:

Contraponto, 1995. p. 29.

DELEUZE, Gilles; GUATTARI, Félix. O que é a filosofia? Rio de Janeiro: Ed. 34, 1993.

MUELLER, Suzana P.M.; CARIBÉ, Rita de Cássia do Vale. A comunicação científica para o público leigo: breve histórico. Informação \& Informação, [S.L.], v. 15, n. esp., p. 13-30, dez. 2010. Disponível em: <http://www.uel.br/revistas/uel/index.php/informacao/article/view/6160>. Acesso em: 06 jun. 2017. doi:http://dx.doi.org/10.5433/1981-8920.2010v15n1espp13.

PRICE, Derek J. de Solla. Little science, big science. New York: Columbia University Press, 1965.

ROSA, Luiz Pinguelli. Tecnociências e humanidades: novos paradigmas, velhas questões. São Paulo: Paz e Terra, 2005. v. 1. 


\section{REFLEXÕES SOBRE AS INDISCIPLINARIDADES}

Eduardo Nazareth Paiva - Professor do HCTE-UFRJ

Cláudia Santos Turco - Doutoranda do HCTE-UFRJ

\section{Resumo}

Comungando e algumas vezes parafraseando pensadores como Eduardo Viveiros de Castro, ensaiamos pensar a tecnociência como uma coisa indisciplinada buscando usá-la como estratégia para a autodeterminação de coletivos locais. Isso possui algumas diferenças daquelas estratégias que praticamente buscam ou encontram a autoextinção em troca de legados outros. Não é fácil nem normal se buscar dimensões coletivas-relacionais da realidade local sem tentar universalizá-las. Refletir sobre como elaborar pensamentos simétricos sobre conceitos em construção ou estabelecidos. Ensaiar a indisciplinaridade como uma estratégia desenvolvida à luz da pertinência, da comunhão e das potencialidades dos interesses locais, resistindo às pressões para subalterná-los diante dos conhecimentos universalizantes.

Palavras-chave: Indisciplinaridades. Traduções. CTS.

Introdução

Em palestra proferida na UFMG, Eduardo Viveiros de Castro (2005) coloca a antropologia como uma disciplina que até bem pouco tempo atrás estava voltada para o estudo de sociedades não especializadas, não separadas por esferas do saber, em suma, indisciplinares e indisciplinadas. A antropologia se definiria como a ciência da não-ciência, o que imprime à antropologia da ciência um caráter reflexivo. A antropologia da ciência traz, também um certo incômodo ao colocar os objetos da tecnociência e as ditas superstições e mitos sob um mesmo olhar, de forma simétrica.

Ao observar as práticas científicas nestas condições, percebe-se que a estabilização de fatos não é uma atividade neutra, simples ou fácil; esta envolve cooperação, não apenas entre pares mas também com outros atores; estes habitantes de múltiplos mundos sociais. É também comum que os próprios objetos de estudo habitem e circulem em diferentes mundos sociais, que sejam transdisciplinares ou ainda, nas palavras de Eduardo Viveiros de Castro, que "desrespeitem indisciplinadamente a multissecular e sacrossanta fronteira entre as ciências da extensão e as ciências do pensamento ou, para falarmos modernamente, entre as ciências da natureza e as ciências da cultura ou da alma - as humanidades" (CASTRO, 2010). No entanto, essa cooperação ou ação simultânea demanda um árduo e permanente trabalho, que envolve todos os atores implicados para que se estabeleça e se estabilize um fato científico. Este esforço de tradução e deslocamento merece algumas reflexões e este trabalho buscará percorrer alguns conceitos que ajudam a entender estas transições e passeios entremundos; conceitos que podem ser úteis para entender ou explicitar assimetrias seja entre os mundos científicos-disciplinares, seja entre estes e outros mundos, ditos leigos.

Traduções, modalidades e interessamento

"Tradução é ao mesmo tempo transcrever, transpor, deslocar, transferir e, portanto, transportar transformando." (LATOUR, 2016, p.30)

Latour (2011) apresenta a construção de fatos na tecnociência como um processo de retórica, no qual traduções e deslocamentos de significado ocorrem entre cientistas e não cientistas, o que pode levar à desistência, à aceitação ou à manutenção dos debates em torno de determinadas proposições ao longo do tempo. Neste processo, laboratórios são construídos, artigos são escritos e aliados são arregimentados. 
O problema da tradução foi colocado por Latour $(2011,2016)$ e Callon (1984) e, em suas origens, tem seu olhar dirigido para a tradução das preocupações dos cientistas para aquelas dos não-cientistas, ou seja, é o processo pelo qual cientistas buscam criar autoridade científica, através da busca de aliados de várias origens (LATOUR, 2011) e se estabelecer como pontos de passagem obrigatórios. Este é o chamado interessamento, no sentido de inter-esse, o que se situa entre duas coisas, entre os atores e seus objetivos. Neste caso, traduz interesses de diversos atores, de mundos sociais múltiplos. Segundo Latour (2016), a ciência será ou não interessante dependendo de sua habilidade de composição com outros cursos de ação, aceitando os desvios necessários, assim como de sua capacidade de se fazer reconhecer como fonte principal da proposição resultante de todo o processo de tradução.

Callon (1984) nos apresenta a sociologia da tradução como um estudo de poder e o próprio processo de tradução como nunca completamente atingido e passível de fracasso. Sua análise sobre controvérsias parte de três princípios: a imparcialidade entre os atores implicados em uma controvérsia; a simetria ao analisar diferentes pontos de vista; e o abandono da dicotomia natural/social.

A percepção da tradução ocorre quando se acompanha cientistas, seu diálogo com outros atores e as modalidades de discurso que surgem ao se elaborar, ao longo deste processo, as proposições. Todos os atores implicados no processo de tradução atuam sobre a proposição, não apenas transmitindo, mas acrescentando elementos e modificando o argumento de forma a incorporá-lo em novos contextos. Neste sentido, fatos e proposições são coletivamente construídos e compostos pelos atores. Nesta ação coletiva cada ator seleciona, entre as possibilidades e modalidades existentes, as características que os ajudem a alcançar seus objetivos, o que, ao final do processo, cria um desvio entre a proposição inicial e a final. Aí podem ocorrer traições.

Se analisarmos os discursos dos atores implicados em determinado processo de tradução, veremos que acontecem modalidades positivas e negativas. Modalidades positivas são aquelas que empurram o enunciado inicial para a estabilidade, afastando-o de suas condições de produção. As modalidades negativas já aproximam o enunciado inicial de suas condições de produção, explicitando as razões e suas forças e fraquezas. Assim, através desta construção conjunta, por vezes envolvendo intensas disputas, uma sentença flui mais da condição de fato para a ficção ou vice-versa.

O modelo traz como principais questões para análise o fluxo de objetos e conceitos através de uma rede de aliados e de mundos sociais, sua busca por enquadrar e afunilar as preocupações e os interesses de diversos atores para um único ponto de passagem. Assim, apenas seguindo as sinuosidades da ação coletiva, através dos desvios e composições, podese encontrar os diversos atores e elementos e compreender seu papel no processo de tradução.

Mundos sociais, objetos de fronteira e agentes intermediários

Clarke e Star (2008) definem mundo social como universos de discurso, espaços compartilhados de discurso que são profundamente relacionais. Inicialmente utilizado na década de 1970 em estudos de sociologia urbana nos quais a dimensão territorial era crucial, o uso do conceito foi ampliado para o entendimento de outros grupos, nacionais e internacionais, como profissões ou mesmo uma tradição teórica, por exemplo. Neste sentido, mundos sociais formam a base para uma ação coletiva, seus participantes estão comprometidos com certas atividades, compartilham objetivos e constroem suas próprias identidades.

Quando diferentes mundos sociais chegam a uma interseção e se encontram em torno de questões de interesse e compromisso mútuo, pode-se analisar como se estivessem em uma 
arena. E claro, muito esforço é também despendido em demarcar as fronteiras entre estes diferentes mundos.

O conceito de mundo social pode ser utilizado para entender a emergência de novas disciplinas ou especialidades. Diferentes disciplinas são entendidas como diferentes mundos sociais, que, em determinados momentos, podem se recombinar através de consenso ou cooperação para criar uma nova disciplina, como por exemplo, os estudos ambientais. No entanto, a interação entre atores de diferentes mundos sociais pode ocorrer independente de consenso, ou seja, atores de diferentes mundos sociais podem colocar suas diferenças de lado - mesmo que temporariamente - em prol de uma ação coletiva, dialogicamente.

O conceito de mundo social foi amplamente utilizado nos estudos CTS. Ao longo do tempo, estas análises incorporaram os conceitos de ação situada (HARAWAY, 1995) e de análise do discurso (FOULCAULT, 2009), criando o que pode ser denominado de análise situada. A análise situada é entendida como a percepção de que as condições em que a ação acontece são a própria ação, eliminando a separação ação/contexto. A situação é a própria unidade de análise, na qual são situados mundos sociais, arenas, atores e relações. Colocar a ação no centro da análise facilita a compreensão dos diversos mundos sociais, pois a partir da ação central é possível seguir os diferentes atores e interesses que dela partem.

Para a análise de diferentes mundos sociais e de suas interseções, Star e Griesemer (1989) propõem o conceito de objetos de fronteira. Esses objetos, físicos ou conceituais, seriam flexíveis o suficiente para habitar múltiplos mundos sociais, mas, ao mesmo tempo, robustos o suficiente para manter algum nível de identidade em todos eles. Os objetos de fronteira são entendidos não apenas como meio de tradução, mas também como a formação e expressão de uma identidade (CLARKE; STAR, 2008). Neste sentido, são conceitos ou objetos que auxiliam tanto a tradução e a transição entre mundos, quanto a demarcação de suas fronteiras.

Outro conceito proposto para a análise de traduções e deslocamentos entre mundos sociais é o de agentes intermediários. As pessoas participam, simultaneamente, em diferentes mundos sociais e os agentes intermediários conseguem, ao participar destes mundos, realizar conexões e coordenar possibilidades de troca. Neste sentido, sua atuação ocorre em processos de tradução e coordenação que, ao longo do tempo, podem se desenvolver em um conjunto de recursos compartilhados entre mundos sociais distintos, que se cristalizam em regras, procedimentos e, mesmo, em objetos de fronteira a serem utilizados.

O modelo de Star e Griesemer (1989) adota e amplia o modelo de interessamento de Latour $(2011,2016)$ e Callon (1984), assumindo que há vários atores, provenientes de mundos sociais diversos, que buscam fazer suas traduções simultaneamente. Portanto, o processo de tradução não pode ser entendido por um único ponto de vista - o do cientista - e sim deve ser analisado do ponto de vista ecológico, de forma não-reducionista. Assim, o modelo de Star e Griesemer (1989) implica na possibilidade de coexistência de vários pontos de passagem obrigatórios e de múltiplos conjuntos coerentes de tradução simultâneos.

Uma ciência indisciplinada, de indisciplinados para indisciplinados

Em palestra proferida em 2010, na UFMG, Eduardo Viveiros de Castro se coloca como um pesquisador que não tem uma prática transdisciplinar, que não realiza estudos antropológicos da ciência, mas de sociedades que são rotuladas, injustamente, como simples. O autor nos traz, então, a proposta de uma antropologia indisciplinada ou uma antropologia da indisciplinaridade. Uma disciplina que até bem pouco tempo atrás estava voltada para o estudo de sociedades não especializadas, não separadas por esferas do saber, em suma, indisciplinares e indisciplinadas. Portanto a antropologia se define como a ciência da não- 
ciência, o que dá à antropologia da ciência um caráter reflexivo e cuja ação traz um certo incômodo.

Viveiros de Castro (2010) coloca que a obra de Lévi-Strauss e seu estudo sobre o estilo intelectual das sociedades ameríndias permitiu entender o pensamento selvagem como um pensamento insubmisso, indisciplinado. É essa compreensão que abre a possibilidade de criar estas multiplicidades e mesmo uma forma de descriar imperialidades. Talvez um importante papel da antropologia seja criar condições para a auto-determinação conceitual dos povos. O que o autor propõe é uma supersimetria entre cientistas e outros saberes. É o abandono da noção de que, no caso da antropologia, a ciência do antropólogo é de outra ordem que a ciência do nativo. Afirmar esta diferença, para o autor seria cometer um "epistemocídio" e escapar desta divisão é entrar no "mundo do meio", no mundo relacional. O antropólogo deveria assumir que o discurso destes outros saberes fala sobre o mundo, assim como o discurso das próprias ciências. São discursos provenientes de diferentes ontologias, os verdadeiros objetos da antropologia.

As formas de compreender as interseções entre diferentes mundos sociais, os caminhos do meio e seus processos de tradução, seja entre diferentes disciplinas ou seja entre ciências e saberes leigos, de forma simétrica ou supersimétrica, afastam nossos estudos de dicotomias radicais e de fronteiras demarcadas. Esta perspectiva afasta, ainda, os estudos das acusações de irracionalidade, abrindo espaço para a multiplicidade de discursos e saberes. Talvez essas escolhas nos aproximem mais das culturas ditas simples, indisciplinadas e insubordinadas.

Finalmente, no âmbito do próprio conhecimento dito científico, estes conceitos, esta indisciplinaridade e insubordinação podem nos ajudar a superar o que Polanco (1986) denominou de fuga interna de cérebros. Por esta expressão, o autor busca explicitar a posição assumida por pesquisadores da América Latina e de outros países que, mesmo sem sair de seus países, orientam seus trabalhos de investigação e seus sistemas de avaliação em função dos problemas e programas de pesquisa definidos externamente. Melhor seria trazer a reflexão nas palavras de Darcy Ribeiro, lembradas por Sugimoto (2017).

"A crítica de Darcy Ribeiro era de que a antropologia tinha rompido seu compromisso com os povos que estudava, em especial com os indígenas. Endurecia o verbo, acusando os antropólogos, por exemplo, de terem se tornado "cavalos de santo" - aqueles que nos cultos afros são tomados por entidades que vêm falar por meio deles. "No caso, os antropólogos eram tomados por entidades do 'primeiro mundo', limitando-se a repetir em suas teses o que falavam os grandes intelectuais lá de fora"

É esta reflexão que queremos compartilhar com você, que nos leu até aqui.

Referências bibliográficas

CALLON, Michel. Some Elements of a Sociology of Translation: Domestication of the Scallops and the Fishermen of St Brieuc Bay. The Sociological Review, 32, no 1_suppl, maio de 1984, p. 196-233. doi:10.1111/j.1467-954X.1984.tb00113.x.

CASTRO, Eduardo Viveiros de. Antropologia e imaginação da indisciplinaridade. Instituto de Estudos Avançados Transdisciplinares (UFMG), Youtube, 24 de ago. 2010. Disponível em https://www.youtube.com/watch?v=ry1ykrRVqYk\&t=29s . Acesso em 4 out. 2017.

CLARKE, Adele; STAR, Susan Leigh . The Social Worlds Framework: A Theory/Methods Package, 2008. doi:10.1002/9780470377994.ch6.

FOUCAULT, Michel A Ordem do Discurso. Aula Inaugural no Collège de France, pronunciada em 2 de dezembro de 1970. 19.ed. São Paulo: Edições Loyola, 2009. 
FUJIMURA, Joan H. Crafting Science: Standardized Packages, Boundary Objects, and 'Translation'. In: PICKERING, Andrew (Org.). Science as Practice and Culture. Chicago: University of Chicago Press, 1992. P. 168211.

HARAWAY, Donna. Saberes localizados: a questão da ciência para o feminismo e o privilégio da perspectiva parcial.Cadernos Pagu, Campinas, SP, n. 5, p. 7-41, jan. 2009. ISSN 1809-4449. Disponível em: <https://periodicos.sbu.unicamp.br/ojs/index.php/cadpagu/article/view/1773>. Acesso em: 08 out. 2017.

HUVILA, Isto. The Politics of Boundary Objects: Hegemonic Interventions and the Making of a Document. Journal of the Association for Information Science and Technology, v. 62, n. 12 , p. 2528-2539, 10 de dezembro de 2011. doi:10.1002/asi.21639.

KIMBLE, Chris; GRENIER, Corinne; GOGLIO-PRIMARD, Karine. Innovation and knowledge sharing across professional boundaries: Political interplay between boundary objects and brokers. International Journal of Information Management, v. 30, n. 5, 2010. Disponível em: https://works.bepress.com/chris_kimble/10/. Acesso em: 4 out. 2017.

LATOUR, B. A ciência em ação: como seguir cientistas e engenheiros mundo afora. São Paulo: Ed. UNESP, 2011.

LATOUR, Bruno. Cogitamus: seis cartas sobre as humanidades científicas. Trad. Jamille Pinheiro Dias. São Paulo: Ed.34, 2016.

POLANCO, Xavier. La ciencia como ficción. Historia y contexto, In: Cuadernos de Quipu, El Perfil de la Ciencia en América, Saldaña, J.J. (org), n. 1. Mexico, Sociedad Latinoamericana de Historia de las Ciencias y la Tecnología, 1986.

STAR, Susan Leigh. This Is Not a Boundary Object: Reflections on the Origin of a Concept. Science, Technology, \& Human Values, v, 35, n.. 5, p. 601-617, setembro de 2010. doi:10.1177/0162243910377624.

STAR, S.L, GRIESEMER, J.R., Institutional Ecology, 'Translations' and Boundary Objects: Amateurs and Professionals in Berkeley's Museum of Vertebrate Zoology, 1907-39. Social Studies of Science, v. 19, n. 3, p.387-420, Agosto de 1989. Disponível em https://www.jstor.org/stable/285080?seq=1\#page_scan_tab_contents. Acesso em 4 de out de 2017.

SUGIMOTO, L. Um brasileiro no exílio. E um exilado no Brasil. Jornal da Unicamp, Campinas, p.12, 9a 15 abr.2007 


\section{"OUVINDO COM OS OLHOS": CINCO SÉCULOS DE CAMINHOS E DESCAMINHOS PELO MUNDO OUVINTE}

Armando Guimarães Nembri - Pós-doutorando do HCTE-UFRJ - armandonembri@hcte.ufrj.br

\section{Resumo}

Este estudo partiu da apresentação de um mini-censo inédito de um mini-segmento da sociedade que, apesar da aparente invisibilidade que o faz desconhecido pela sociedade ouvinte e hegemônica, apresenta-se com possibilidades vitoriosas em contraponto ao nenhum ou pouco apoio dado por parte do Estado. Tal necessidade de imersão se deu pela possibilidade de demonstrar o modus vivendi dessa comunidade surda, a dos doutorandos e doutores surdos, que chegou a um dos mais altos graus de escolaridade em um país pouco dado à educação. $O$ objetivo do estudo foi observar até que ponto as Universidades estão proporcionando a devida adequação de seus programas ao movimento de ampliação dos horizontes educacionais para doutorandos e doutores surdos à luz da lógica de sua L1. O estudo destaca as etapas metodológicas da observação, dando ênfase à obtenção de dados diretamente nos ambientes nos quais ocorrem os fenômenos, onde o autor da pesquisa é seu principal agente e instrumento. Desta forma, privilegiou-se a concepção dos aspectos gerais, da organização e das observações para que fossem constatadas as fragilidades e os potenciais avanços da aceitação e da recepção, por parte de algumas poucas Universidades do país, em processos seletivos aparentemente próprios, de surdos em Programas de Doutorado. Neste estudo foi possível verificar e observar que doutorandos e doutores surdos carecem de um conhecimento ainda mais aprofundado por parte das Universidades que os recebem, pois parecem desconhecer a lógica da L1 surda.

Palavras-chave: Surdos e Ouvintes. Língua Brasileira de Sinais - LIBRAS. Doutorandos e Doutores Surdos.

\section{Introdução}

Nas últimas décadas do Século XX e início deste Século, detectou-se a ampliação de estudos que privilegiam a autopercepção de sujeitos, mais especificamente aqueles com necessidades educativas e laborais especiais que, sabe-se, são chamados, hoje, de Pessoas com Deficiência - PcD, ou seja, pessoas que, entre outras, carregam estigmas, rótulos e marcas pessoais que, para elas - e para as que as rodeiam - são inconfundíveis; são estigmas, rótulos e marcas pessoais que, cotidianamente, as lembram que, fisicamente, na ausência ou deficiência de um ou mais sentidos, não são consideradas "normais", não são consideradas "iguais" (e o que é ser normal? e o que é ser igual?). Esses estudos priorizam as versões que tais pessoas possam disseminar para a sociedade; a maioria, hoje, é proveniente de experts e profissionais que, embora conheçam o tema (ampliadamente em muitas das situações), não vivem o "sentir na pele" do que, teoricamente, costumam estudar e veicular. Experts e profissionais têm seus méritos e seus estudos podem e devem fortalecer concepções hoje já disponíveis. Necessários, ainda mais, são os que, "vivendo na pele" o estigma e o rótulo, tentam expor seus testemunhos para experimentos e condições que possibilitem a melhoria das suas condições de vida.

Com base no descrito no parágrafo anterior, esta pesquisa tem, como proposta, conhecer a versão de doutorandos e doutores surdos brasileiros (o pesquisador entende que, dos surdos, estes são os mais familiarizados com a língua portuguesa em sua modalidade escrita, em razão 
dos anos a mais de estudo) e não a versão dos experts e profissionais da surdez, em sua ampla maioria ouvinte, acerca dos problemas e obstáculos advindos da longa convivência com o silêncio que nunca se acaba. Corroborando a proposta aqui formalizada, Glat (1989) enfatiza a necessidade de se "priorizar a versão dos indivíduos pertencentes ao grupo estigmatizado, em vez dos profissionais que os rotulam".

Outrossim, este autor pretende apresentar a oportunidade histórica da luta de alguns poucos doutorandos e doutores surdos, estes ainda mais engajados por questões de anos de estudo, no sentido de que, lutando por aceitação pela diferença que têm, possam transitar pela sociedade ouvinte sem os percalços vivenciados pelos indivíduos surdos que se posicionam à margem da vida educacional brasileira e, desta forma, ajudar a minimizar a enorme diferença educacional existente entre surdos e ouvintes. Suas condições, algumas a serem apresentadas nesta pesquisa, serão relatadas à luz do reconhecimento e da regulamentação da Língua Brasileira de Sinais (LIBRAS) que, a bem da verdade, mudaram a perspectiva do surdo com relação à sua vida no mundo ouvinte. Parece que para melhor. Entretanto, muito ainda precisa ser realizado - na esfera de um país que pouco privilegia a educação para o seu povo, de uma maneira geral - para que se possa imaginar, um dia, a "simbiose" entre a velha escola francesa e o método bilíngue atual, com "pinceladas" - com "cores fortes" - da escola alemã do século XIX (a "fórmula" ideal para o autor desta pesquisa), para que um novo surdo possa aparecer no cenário mundial, um surdo que "ouve" e fala.

A pesquisa relativa aos Doutorandos e Doutores Surdos do Brasil parte do princípio de que surdos e ouvintes não se conhecem e têm caminhos educacionais bastante diferentes. Para buscar as necessárias respostas - para que o arcabouço teórico ganhasse a forma desejada para possibilitar a amplitude da pesquisa, haja vista que foi realizada por um surdo de nascença em Língua Portuguesa e não em Língua de Sinais, e para apresentar o mundo dos doutorandos e doutores surdos brasileiros - evidenciou-se pela necessidade de coletar o maior número possível de doutorados nas maiores e mais importantes Universidades Federais Brasileiras por Região do País e, por conseguinte, pela urgência e pela necessidade de se conhecer o quantitativo de doutorandos surdos (o estudo revela, também, o número de doutores surdos no Brasil) que tais Universidades abrigam, haja vista que esta pesquisa encampa o fato de que a educação brasileira não privilegia, pelos números pesquisados, a sua comunidade surda.

Exceções quanto às escolhas - unicamente de Universidades Federais - se deram na Região Sudeste, mais especificamente no Rio de Janeiro e em São Paulo, vez que são cidades com duas Universidades Públicas não Federais com um número significativo de doutorados, o que gerou um aumento da probabilidade de obtenção de informações positivas sobre a possibilidade de encontrar doutorandos surdos em seus respectivos Programas de Doutoramento. Nesta condição, as exceções foram a Universidade do Estado do Rio de Janeiro - UERJ, e a Universidade de São Paulo - USP, considerada a Universidade que mais forma doutores no mundo As duas exceções, juntas, oferecem cerca de duzentos doutorados. Foram pesquisados cerca de 700 doutorados.

Optou-se por elaborar um levantamento do número de Doutorandos e de Doutores Surdos no país, por se considerar, este, o nível mais alto de escolaridade e de certificação no país.

Esse objetivo foi delineado a partir da experiência do autor como pesquisador no campo da Surdez e do ser Surdo em um país de ouvintes, principalmente na esfera educacional. Entretanto, com o objetivo, também, de sair do lugar comum que tem restringido, geralmente, a pesquisa sobre escolaridade do Surdo aos níveis fundamental e médio, o foco dessa investigação foi voltado para a Pós-Graduação, em princípio pela originalidade e também por considerar que, após 12 (doze) anos do reconhecimento da LIBRAS como a Língua Oficial do Surdo e como uma das Línguas Oficiais do Brasil, já haveria um prazo suficiente para 
que o nível de escolaridade dessa clientela tivesse ultrapassado as barreiras da educação básica.

O cerne desta pesquisa foi dar voz ao Surdo, a partir de cada uma das histórias de vida "ouvidas" por um Surdo. Foi, portanto, a visão do Surdo pelo Surdo. O pesquisador partiu de sua própria história para "dar ouvidos" e "falas" a algumas outras histórias, todas oriundas do universo do surdo.

Para este autor, faz-se imperativo ousar. O indivíduo surdo deve ousar, atrever-se a buscar um jeito inteiramente novo de caminhar por um velho e conhecido mundo; este jeito novo de caminhar pode ser a saída, já encontrada por alguns surdos, que abrirá as portas para que todos, como diria Carrancho da Silva (2012, p. 5), "sintam-se convidados a entrar e acolhidos em permanecer".

A partir do exposto, o presente estudo teve como norte as seguintes questões:

- Quantos são os Doutores/Doutorandos e onde estão?

- Qual o perfil do doutorando/doutor surdo?

- O que fez a diferença na vida deles?

Alagumas Limitações da Pesquisa

O autor encontrou algumas dificuldades para concluir seu processo de investigação nas Universidades, muito embora obtivesse, após muito custo, apoio para a empreitada. Uma delas, óbvia, a resistência para as respostas dos atores pertinentes às Universidades. Pode-se, nesta questão, elencar como possíveis razões, a originalidade da proposta, em função do protagonismo das Universidades da Região Sul, o pouco contato e "traquejo" do estudante surdo (em qualquer esfera educacional) com a Língua Portuguesa (oral e/ou escrita), a pouca empatia dos doutores surdos mais velhos e o receio que parecem sentir os atores mencionados quando em situação de sujeitos de uma pesquisa.

Em função da resistência encontrada pelo pesquisador diante do universo surdo, surgiu a maior limitação desta pesquisa, ou seja, a resistência silenciosa do surdo participante do estudo. Em outras palavras, por ser surdo e por transitar com bastante destreza também no mundo ouvinte, o pesquisador foi surpreendido pela negativa da maior parte dos participantes do estudo em fornecer informações sobre suas vidas privadas e trajetórias acadêmicas. De forma geral, a grande dificuldade desse tipo de metodologia é a transcrição dos "relatos" do oral ao escrito, pois algumas fórmulas só são utilizadas oralmente. Por outro lado, a comunicação oral não se limita ao texto; há toda uma gama de entonações, de gestos, de pausas, de eloquentes silêncios impossíveis de serem traduzidos nos limites da escrita, no caso das línguas orais. No caso específico da Língua de Sinais e da Língua Portuguesa Escrita, a dificuldade maior foi a resistência. Por inúmeras razões, algumas já conhecidas e outras que ainda demandam muita investigação, os relatos conseguidos variaram da negativa total em participar - com um simples "não" - a respostas monossilábicas ou absolutamente sintéticas. Por essas razões, o que seria, em princípio, uma história de vida detalhada e aprofundada de cada um dos poucos participantes do estudo, ficou restrito a relatos mínimos fornecidos por cada um daqueles que responderam às inúmeras tentativas de contatos realizadas pelo pesquisador. Nesta condição, essa limitação, traduzida em relatos sucintos ou até mesmo na ausência total da informação, pode ser interpretada como a "não comunicação", a "não integração", enfim, como o silêncio simbólico e concreto em que está ainda mergulhada a maior parte dos surdos brasileiros, mesmo aqueles que venceram as barreiras impostas pela educação formal.

Resultados

Doutorandos e doutores surdos? Quantos somos, quem somos e onde estamos?

HCTE-UFRJ 
O quadro a seguir mostra o panorama geral sobre os totais apurados em todas as quinze Universidades Federais pesquisadas.

Tabela 1 - Totais apurados por Universidade

\begin{tabular}{lccccccc}
\hline UNIVERSIDADES & TD & $\mathbf{R}$ & \%R & NR & SED & TDS & NTDS \\
\hline UFRJ & 82 & 44 & 54 & 31 & 07 & X & ----- \\
\hline UFRRJ & 14 & 04 & 29 & 08 & 02 & ---- & $\mathrm{X}$ \\
\hline UERJ & 37 & 21 & 57 & 13 & 03 & ----- & $\mathrm{X}$ \\
\hline UNIRIO & 07 & 03 & 43 & 03 & 01 & ----- & $\mathrm{X}$ \\
\hline USP & 164 & 82 & 50 & 70 & 12 & ----- & $\mathrm{X}$ \\
\hline UFF & 40 & 13 & 33 & 26 & 01 & ----- & $\mathrm{X}$ \\
\hline UFAM & 10 & 04 & 40 & 03 & 03 & ----- & $\mathrm{X}$ \\
\hline UFPA & 64 & 26 & 41 & 35 & 03 & ----- & $\mathrm{X}$ \\
\hline UFC & 40 & 17 & 43 & 22 & 01 & ----- & $\mathrm{X}$ \\
\hline UFBA & 48 & 18 & 38 & 30 & ----- & ----- & $\mathrm{X}$ \\
\hline UFMS & 14 & 07 & 50 & 07 & ----- & ----- & $\mathrm{X}$ \\
\hline UFG & 28 & 12 & 43 & 15 & 01 & $\mathrm{X}$ & ----- \\
\hline UFMT & 09 & 02 & 22 & 07 & ---- & ----- & $\mathrm{X}$ \\
\hline UFRGS & 80 & 48 & 60 & 30 & 02 & $\mathrm{X}$ & ----- \\
\hline UFSC & 54 & 35 & 65 & 18 & 01 & $\mathrm{X}$ & ----- \\
\hline
\end{tabular}

Notas:

TD = total de doutorados pesquisados/consultados

$\mathrm{R}=$ número de programas de doutorado que responderam

$\% \mathrm{R}=$ percentual de respostas dos programas de doutorado

$N R$ = número de programas de doutorado que não responderam

SED = site com e-mail desatualizado ou com problemas - sem recepção

TDS = alguns programas de doutorado tem doutorando surdo

NTDS = programas de doutorado não tem doutorando surdo

Os totais apurados por Universidade.

A pesquisa/consulta às Universidades mencionadas, apontou 6 (seis) Programas de Doutorado com a presença de doutorandos surdos; 4 (quatro) na Região Sul, mais especificamente na Universidade Federal do Rio Grande do Sul (UFRGS) -1 Programa) e Universidade Federal de Santa Catarina (UFSC) - 3 Programas; 1 (um) na Região Centro-Oeste, na Universidade Federal de Goiás - UFG; e 1 (um) na Região Sudeste, na Universidade Federal do Rio de Janeiro - UFRJ (o autor desta pesquisa).

Faz-se oportuno salientar que, ao atender às indicações de doutores e de doutorandos do Sul do país, o pesquisador teve acesso a mais quatro doutorandos surdos e dois doutores surdos; estes de Programas de Doutorado em Universidades fora do âmbito das elencadas nesta pesquisa. São elas: Universidade Federal de Pelotas (UFPel), Universidade Federal de Uberlândia - UFU, Universidade Federal de São Paulo - UNIFESP, Universidade Federal de Pernambuco - UFPE, Universidade Federal da Paraíba - UFPA, Universidade Federal de São Carlos - UFSCar e Universidade Tecnológica Federal do Paraná - UTFPR.

\section{Conclusões}

Em um mundo estratosfericamente tecnológico, excludente e "humanamente" enfraquecido, o papel das pessoas que "carregam a marca da surdez" assume características singulares e plurais após milênios de silêncio e cinco séculos de "preparação" para que a "capa de invisibilidade" que envolve a sua comunidade seja, de uma vez por todas, retirada e não mais 
utilizada. Neste trabalho, tal preparação de cinco séculos é resumida, de modo a comprovar que, pela "simbiose" entre a velha escola francesa e o método bilíngue atual - com pinceladas (com "cores fortes") da velha escola alemã - um novo surdo pode estar "aparecendo" no cenário mundial. Um surdo que "ouve" e fala.

\section{Referências bibliográficas}

BRASIL. Decreto no 5.626, de 22 de dezembro de 2005. Regulamenta a Lei no.10.436, de 24 de abril de 2002, que dispõe sobre a Língua Brasileira de Sinais - LIBRAS, e o art. 18 da Lei no 10.098, de 19 de dezembro de 2000. Diário Oficial da União. Brasília, DF, 23 dez. 2005. Disponível em: <http://www.planalto.gov.br/ccivil/_Ato2004_2006/2005/Decreto/D5626.htm>. Acesso em: 18 mar. 2011.

. Lei no 10.436, de 24 de abril de 2002. Dispõe sobre a Língua Brasileira de Sinais - LIBRAS e dá outras providências. Diário Oficial da União, Brasília, DF, 25 abr. 2002. Disponível em: <http://planalto.gov.br/ccivil/leis/2002/L10436.htm>. Acesso em: 18 mar. 2011.

CARRANCHO DA SILVA, A.; NEMBRI, Armando Guimarães. (2012). Ouvindo o Silêncio: Surdez, Linguagem e Educação. Porto Alegre: Mediação, 3a ed.

GLAT, Rosana. (1989). Somos iguais a vocês: depoimentos de mulheres com deficiência mental. Rio de Janeiro: Agir.

KUBRUSLY, Ricardo S.; CARRANCHO DA SILVA, Angela; NEMBRI, Armando Guimarães. (2012). O autoengajamento do novo educador: uma atitude consciente de transcendência dos modelos excludentes. Trabalho apresentado no Scientiarum Historia V. Rio de Janeiro, RJ, Universidade Federal do Rio de Janeiro UFRJ.

BRASIL, Portaria no 2.344, de 3 de novembro de 2010. Atualiza a nomenclatura do Regimento Interno do CONADE. Diário Oficial da União. Brasília, DF, 5 nov. 2010 (no 212, seção 1, pág. 4). Disponível em: <http://www.grupoepura.blogspot.com.br/2010/11/portaria-n-2344-de-novembro-de.html>. Acesso em: 28 jan 2016.

ROCHA, Solange. (2010). Memória e História: a indagação de Esmeralda. Petrópolis, RJ: Arara Azul.

ROCHA, Solange. (2008). O INES e a Educação de Surdos no Brasil: Aspectos da trajetória do Instituto Nacional de Educação de Surdos em seu percurso de 150 anos. Vol. 1, 2a edição. Rio de Janeiro: INES.

SILVA, Angela Carrancho; NEMBRI, Armando Guimarães. (2014). Em Silêncio: Avaliação do Primeiro Curso de Graduação para Surdos e Ouvintes em Língua de Sinais. Rio de Janeiro: Ed. Multifoco, 2014. 


\section{LITERATURA E TEOLOGIA NATURAL: HISTÓRIA E FILOSOFIA DAS CIÊNCIAS À LUZ DA EPISTEMOLOGIA DE LUDWIK FLECK}

Luciana Valéria Nogueira - Instituto de Biociências - USP - luinha.bio.filo@gmail.com

Resumo

O presente trabalho tem por objetivo apresentar uma análise das relações entre a Teologia Natural dos séculos XVII, XVIII e XIX e obras literárias desses períodos à luz da epistemologia de Ludwik Fleck. Considerando as ciências e a literatura como cultura, a análise ora apresentada busca salientar o caráter performativo de ambas instâncias culturais. Assim, não se trata de representação, mas, antes, de construção mútua entre o mundo e as ciências e a literatura. Os conceitos de coletivo e estilo de pensamento, da epistemologia fleckeana, são utilizados a fim de mostrar a interdependência mútua entre todas as esferas da vida humana e a impossibilidade de entender a realidade como algo da ordem dos fatos objetivos.

Palavras-chave: Teologia Natural. Literatura. Ludwik Fleck.

Introdução

Entendendo as ciências como um fenômeno cultural, portanto como constructo humano, temos que os conhecimentos produzidos por elas não são verdades da natureza desveladas pelos cientistas, mas, antes, obedecem a imperativos históricos, políticos, econômicos, crenças pessoais, entre outros. Nessa perspectiva, o presente trabalho busca trazer elementos para a reflexão acerca de certa forma de se fazer história. A saber, uma história que se conta por meio da literatura à luz da epistemologia fleckeana.

Em 1935 o médico e epistemólogo judeu-polonês Ludwig Fleck (1896-1961) apresentou os conceitos de estilo e coletivo de pensamento na obra Gênese e desenvolvimento de um fato científico (autor, 2010 [1935]). Em linhas gerais pode-se entender o estilo de pensamento como o modus operandi que é acionado pelo cientista durante a produção de conhecimento científico (FLECK, 2010 [1935], p. 149). O estilo de pensamento acaba por determinar, segundo Fleck, os instrumentos de intervenção e interpretação acerca dos fenômenos estudados. Trata-se de uma espécie de sistema de referência que orienta o pesquisador e, no mais das vezes, a respostas já preconcebidas nas perguntas a que deseja responder (idem, ibidem, p. 133).

Acreditando que os processos cognitivos envolvidos na tarefa dos cientistas é uma atividade social, não restrita ao indivíduo unitário, das ciências, como atividade social, decorrem a noção de compartilhamento de significados atribuídos ao mundo originado dentro da comunidade científica. A essa comunidade que compartilha a atribuição de significados ao mundo Fleck chama de coletivo de pensamento (idem, ibidem, p. 149 e 81-82).

Em consonância com o pensamento de Fleck, a Escola dos Annales, segundo Lucien Febvre (1878-1956), "Cada época elenca novos temas que, no fundo, falam mais de suas próprias inquietações e convicções do que de tempos memoráveis, cuja lógica pode ser descoberta de uma vez só" (FEBVRE apud BLOCH, 2001, p. 7). E mais:

"Nada mais legítimo, nada mais constantemente salutar do que centrar o estudo de uma sociedade em um de seus aspectos particulares, ou melhor, ainda, em um dos problemas precisos que levantam este ou aquele desses aspectos: crença, economia, estrutura das classes ou dos grupos, crises políticas. (...) Reconhecemos 
que, numa sociedade, qualquer que seja, tudo se liga e se controla mutuamente: a estrutura política e social, a economia as crenças, tanto as manifestações mais elementares como as mais sutis da mentalidade" (BLOCH, 2001, p. 30 e 31).

Compactuando as ideias de Fleck e Bloch, tomo a literatura como documento histórico para entender as mudanças pelas quais a Teologia Natural passou ao longo do tempo, precisamente entre os séculos XVII e XIX. A utilização da literatura como documento histórico insere-se em uma vertente da história cultural buscando, nos mais diversos tipos de texto, pensar a escrita, a linguagem e a leitura (BORGES, 2010, p. 94-95). Isso equivale a dizer que o modo de produção de textos, sejam eles literários ou não, está inexoravelmente imerso em um dado contexto social, em um Zeitgeist específico.

A literatura pode ser tomada como uma forma de expressão do mundo social em determinado período histórico. Expressão essa de mão-dupla. Defendo que a literatura, ao mesmo tempo em que fala de um dado mundo, produz esse mesmo mundo, não sendo possível estabelecer limites precisos entre causa e efeito. Assim, a literatura pode ser vista como um efeito do mundo em que foi produzida, ela deve também ser entendida como causa dele. Uma produção cultural, seja a literatura, sejam as ciências, participam de forma dupla do mundo da vida: são seu efeito e sua causa. Não compartilho, pois, da ideia de literatura como representação ou espelho de uma sociedade em uma determinada época. As ciências, bem com a literatura são dimensões mediadoras das experiências e práticas sociais não isoladas dos demais campos sociais, logo não são fixas, nem tampouco estáveis, afinal "nenhuma ilha é uma ilha" (GINZBURG, 2004, p. 42). Dessa forma, tomo a literatura e a teologia natural como expressões de mundos que são construídos ao mesmo tempo em que os constroem.

O conceito de Teologia Natural é polissêmico tendo sua definição ou seu entendimento sujeito à época em que dela se fala. No entanto, uma definição possível, da Enciclopédia Britânica de 1840, define a Teologia Natural como: "um sistema teológico formado inteiramente a partir de verdades religiosas que podem ser aprendidas a partir das fontes naturais, ou seja, da constituição da mente humana e dos fenômenos do universo mental e material. " (TOPHAM, 2014, p. 82). Logo, a Teologia Natural contaria com a razão - que é natural - sem que ocorresse qualquer auxílio relativo à revelação - ou à Teologia Revelada.

Assim, pode-se dizer que se tratava de um empreendimento intelectual que buscava conhecer a Deus e seus atributos por meio da razão, da percepção, entendimento, inferência e inquirição sobre o mundo natural. Para os teólogos naturais conhecer a Deus, de forma direta, não é possível, mas apenas por meio das coisas do mundo sensível (TWETTEN, 2003, p. 921). Há que se notar que essa possibilidade de conhecimento acerca de Deus mediada pelo mundo físico só é possível dentro de uma metafísica que estabelece uma operação de analogia entre as coisas do mundo - os entes - e o próprio Deus, na medida em que Ele é o Deus Criador desses entes. Logo, pressupõe-se não apenas que Deus existe como também que Ele é o criador do mundo e de todas as coisas nele presentes. E mais, estabelece-se uma relação de causalidade que carrega consigo o estabelecimento de uma relação que é analógica (FURRY, 2010, p. 320-324; LONG, 2012, p. 1-3; SUÁREZ, 2015, p. 159-161).

Teologia Natural do século XVII e O paraíso perdido de Milton

Dada a polissemia da noção de Teologia Natural, não é possível falar dela de forma geral. Isso significa que, ainda que seja possível elencar traços gerais desse empreendimento cultural, cada caso, cada teólogo natural possui suas especificidades. Para pensar a Teologia Natural do século XVII tomo duas obras: A sabedoria de Deus manifestada em seus trabalhos da criação (1691), de John Ray (1627-1705), importante naturalista inglês, e duas Boyle's Lectures do filósofo inglês Samuel Clarke (1675-1729) - Uma demonstração da existência dos 
atributos de Deus (1704) e As evidências da religião natural e revelada (1705). Tanto em Ray quanto em Clarke a defesa da existência de Deus e de seus atributos é feita ao modo do discurso de autoridade dentro de uma obviedade incontestável. Não se trata de argumentar, mas, antes, apenas de reafirmar algo "sabido" por todos: que Deus existe e que ele é o criador de tudo o que há no mundo. Antes de tudo é um recado contra o ateísmo e àqueles que, eventualmente, não creem.

Em O paraíso perdido (1667), John Milton (1608-1674) anuncia a queda do homem graças ao pecado original cometido pelo desejo de conhecimento traduzido em uma desobediência. Milton, homem religioso, se filiava ao pensamento de Agostinho de Hipona (354-430) para quem a infelicidade humana deveu-se à desobediência de Deus. Vejamos o que Clarke e Milton têm a nos dizer:

"A todos aqueles que são ou fingem ser ateus; quem não acredita no ser de Deus, ou tenham pensado em fazê-lo; ou que negam os principais atributos da natureza divina, e supõem que Deus seja um ser não inteligente, que atua apenas por necessidade; isto é, que, em qualquer propriedade tolerável de fala, não age de nada, mas só é atuado: a todos os homens que são ateus, eu digo, neste sentido, que isso deve ocorrer por uma dessas três razões (...) por extrema ignorância ou estupidez; (...) por ter sido corrompido por uma vida de vícios; (...) porque, no caminho do raciocínio especulativo, e sobre os princípios da filosofia, eles fingem que o argumentos usados contra o Ser ou atributos de Deus, parecem, após o mais rigoroso e inquérito mais completo, ser mais forte e conclusivo do que aqueles pelos quais nos esforçamos para provar essas grandes verdades." (CLARKE, 1704, p. 8)

"Dize primeiro, tu que observas tudo/No Céu sublime, no profundo Inferno,/Dize primeiro a causa irresistível/Que mover pôde os pais da prole humana,/Em tão próspera sina, ao Céu tão caros,/A apostatar de Deus que o ser lhes dera/E a transgredir a lei que lhes ditara,/Sendo só no objeto restringidos,/No mais senhores do universo Mundo (...)" (MILTON, 1994 [1667], p. 22).

Pode-se depreender, portanto, que o mundo do qual ambos falam é um mundo assolado pela dor porque o homem se afastou de Deus. Estar em Deus é tratado com a única possibilidade de vida feliz para os homens. Conhecer a Deus e com ele permanecer é a chave. Em John Ray, o conhecimento de Deus pode ser encontrado a partir das criaturas, isto é, conhecer o Criador só é possível por meio das criaturas. Trata-se de admirar a magnitude dos trabalhos de Deus. Trata-se de conhecer os vegetais, os animais e os corpos celestes para alcançar alguma inteligibilidade em relação a Deus, mas, antes de tudo, glorifica-lo (RAY, 1691p. 17-30).

Teologia Natural do século XVIII e Robinson Crusoé (Daniel Dafoe)

O teólogo e filósofo britânico William Paley (1743-1805) pode ser tomado como uma das principais referências de parte da Teologia Natural do século XIX. Haja vista a publicação dos oito Tratados de Bridgewater, entre os anos de 1833 e 1840 cuja inspiração fez referência direta à Natural Theology (1802) de Paley.

A escolha pela obra de Paley revela um viés racional próprio à Teologia Natural, não partindo de elementos ligados à fé, mas, sim, de fatos ou acontecimentos da natureza. O livro se inicia com o famoso "Argumento do Relojoeiro" ou "Argumento do Desígnio" (Design). Assim, para explicar a complexidade e adaptação observada nos seres vivos, Paley apresenta duas explicações possíveis: a primeira aponta para a existência de um Designer Inteligente; a segunda, para a possibilidade de que forças físicas aleatórias converteram a matéria em seres vivos (SOBER, 1996, p. 65). Partindo do princípio metodológico da Inferência da Melhor Explicação (IME), o teólogo opta pela primeira possibilidade, argumentando ser esta a explicação mais razoável. Vale notar que sua argumentação se constitui em uma operação de analogia: assumida a complexidade tanto dos artefatos humanos quanto dos seres vivos, 
atribui-se a estes a natureza de artefato; como o artefato é necessariamente produzido por um artífice, os seres vivos, analogicamente, também foram criados. Eis, portanto, a analogia entis tomista.

A operação analógica de Paley parece-me inserida em um contexto de fé e confiança em um progresso inexorável à moda de Robinson Crusoé (1719), de Daniel Dafoe (1660-1731). Tanto em Paley, quanto em Crusoé encontramos a marca do liberalismo e do individualismo na capacidade humana de dominar a natureza. A analogia empreendida em Paley não é inocente. Não se trata apenas de uma analogia, mas de uma forma de ressaltar a capacidade humana na fabricação de artefatos. A comparação entre o artefato humano (o relógio) e os "artefatos" divinos parece radicalizar duas ideias: a aproximação máxima das naturezas divinas e humana, fundada na afirmação de que o homem - único ser racional da criação - foi criado à imagem e semelhança de Deus e, consequentemente, a afirmação de que a racionalidade humana é da mesma ordem (ou natureza) que a racionalidade divina, expressa na criação. Isso pareceme em consonância com o momento histórico vivenciado por ambos autores: o início da Revolução Industrial com o triunfo das fábricas e o desejo de progresso, à moda do liberalismo de Adam Smith (1723-1790) em A riqueza das nações (1776).

Teologia Natural do século XIX e Norte e Sul (Elizabeth Gaskell)

Como representativo de parte do Teologia Natural do século XIX, tomo o Natural Theology (1891-1893), série de conferências realizadas pelas Gifford Lectures, do físico irlandês George Gabriel Stokes (1819-1903).

Em sua teologia, Stokes, diante de um mundo impactado pela teoria da evolução de Charles Darwin (1809-1882), busca conciliar ciência e religião. Ele critica duramente a ideia de ancestralidade comum de Darwin, mas aceita a ideia seleção natural. Trata-se de uma espécie de concessão, talvez, até, uma tentativa de conciliação, diante da inexorável mudança que as ideias darwinistas acabariam por empreender no mundo.

Na literatura isso não é diferente. A inglesa Elizabeth Gaskell (1810-1865) em Norte e Sul (1855) aponta para as consequências da Revolução Industrial. A miséria, as diferenças de condições sociais, a degradação das relações humanas e dos ambientes são assinaladas por sua pena sensível que busca mostrar uma realidade que não correspondeu às promessas do progresso. Sua escrita é diametralmente oposta à de Jane Austen (1775-1817) na medida em que retrata as classes sociais dos desvalidos e daqueles que perderam na luta pela sobrevivência.

Tanto em Stokes quanto em Gaskell vemos um mundo em mudança. As promessas de riqueza do progresso, as ideias de individualismo e superação pessoal tão caras ao liberalismo encontram seu contraponto na queda do homem de sua posição de criação especial, bem como na pobreza que assolava a Inglaterra.

Teologias, literatura e epistemologia fleckeana

A partir da breve apresentação das teologias naturais dos séculos XVII, XVIII e XIX e suas relações com obras literárias específicas é possível dizer que, ao longo do tempo, graças às mudanças das condições históricas, estilos de pensamento diferentes foram sendo construídos com o respaldo de coletivos de pensamento.

Não é possível imaginar que as ciências e a literatura estejam apartadas do mundo social. $\mathrm{Na}$ verdade, ambas, como integrantes da cultura, são modificadas e modificam o mundo em que se inserem. $\mathrm{O}$ que Fleck tem a nos dizer é justamente isso: não se trata de representação, de espelhamento, mas de construção mútua em um devir-mundo, à moda de Deleuze, em que o dinamismo e a interpenetração das variadas facetas da vida humana constroem uma realidade em perpétuo movimento. 


\section{Referências bibliográficas}

BLOCH, Marc. Apologia da história ou O ofício de historiador. Rio de Janeiro: Zahar, 2001.

BORGES, Valdeci Rezende. História e literatura: algumas considerações. Revista de Teoria da História Ano 1 , Número 3, junho/ 2010. Disponível em: https://www.historia.ufg.br/up/114/o/ARTIGO_BORGES.pdf. Acesso: agosto/2017.

CLARKE, Samuel. A Demonstration of the Being and Attributes of God. Inglaterra: Grand Rapids, MI: Christian Classics Ethereal Library, 1704.

The Evidences of Natural and Revealed Religion. Inglaterra: Grand Rapids, MI: Christian Classics Ethereal Library, 1705.

DAFOE, Daniel. Robinson Crusoé. São Paulo: Penguin Classics Companhia das Letras, 2011 [1719].

FLECK, Ludwig. Gênese e desenvolvimento de um fato científico: introdução à doutrina do estilo de pensamento e do coletivo de pensamento. Tradução de Georg Otte e Mariana Camilo de Oliveira. Belo Horizonte: Fabrefactum, 2010 [1935].

FURRY, Timothy J. Analogous analogies? Thomas Aquinas and Karl Barth. Scottish Journal of Theology, 63(3): 318-330, 2010.

GASKELL, Elizabeth. Norte e Sul. São Paulo: Landmark, 2011 [1855].

GIFFORD LECTURES. Disponível em http://www.giffordlectures.org/theology.asp. Acesso em:

KIDD, John. Treatise II: On the Adaptation of External Nature to the Physical Condition of Man. London, William Pickering eds., 1837. Disponível em:

https://ia600408.us.archive.org/11/items/bridgewatertreat02brid/bridgewatertreat02brid.pdf

GINZBURG, Carlo. Nenhuma ilha é uma ilha: quatro visões da literatura inglesa. São Paulo: Companhia das Letras, 2004.

LONG, Steven A. Analogia entis. On the Analogy of Being, Metaphysics, and the Act of Faith. Indiana: University of Notre Dame Press, 2012.

PALEY, William. Natural Theology. Londres, Charles Knight eds, 1802.

RAY, John. The wisdom of God manifested in the works of the Creation. Inglaterra: William Innys, 1714 [1691]. SOBER, Elliot. Filosofía de la Biología. Madrid, Alianza Editorial, 1996.

STOKES, George Gabriel. Natural Theology. Londres, Adam and Charles Black eds., 1893.

SUÁREZ, Lucero González. La doctrina de Tomás de Aquino sobre la analogia como recurso para el conocimiento de Dios. Uma meditación filosófica sobre sus limites y alcances. Perseitas, Vol. 3, No. 2, juliodiciembre/ 2015.

TOPHAM, Jonathan R. A teologia natural e as ciências. In: Ciência e religião, HARRISON, Peter (org.). São Paulo: Ideias \& Letras, p. 83-107, 2014.

TWETTEN, D. B. Theology, Natural. New Catholic Encyclopedia. 2nd ed. Vol. 13. Detroit: Gale, 2003. 921-923. Gale Virtual Reference Library. Web. 2 Oct. 2013. 


\section{CRIANDO PENSAMENTOS SOBRE O VIVER COM EDGAR MORIN}

José Carlos de Oliveira - Professor do HCTE-UFRJ - jcarlosdee.ufrj.br Matheus Henrique da Mota Ferreira - Mestrando HCTE-UFRJ - matheushmf01@gmail.com

Resumo

Edgar Morin é o autor do Pensamento Complexo e obras sobre interdisciplinaridade. Neste texto convocamos sua presença com exclusividade, para divulga-lo e construir reflexões e sugerir pontos para debates em torno de parte de suas ideias. Vamos destacar no seu pensamento a "busca da vida", um viver de forma cheia, plena, da abstração à concretude e de volta à abstração no caminho para o concreto onde se manifesta a vida.

Palavras-Chave: Pensamento Complexo. Viver.Autoecorreorganização.

Introdução

Sua obra máxima é "O método", apresenta reflexões sobre a natureza, a vida, o conhecimento, as ideias, a humanidade, e a ética. Todos enredados, emaranhados, religados em uma tessitura complexa onde o todo se manifesta, maior que a soma das partes, sem que as partes deixem de ter suas singularidades, serem mais e menos que o todo em si. Morin trabalha com conceitos e macroconceitos, indicando que a complexidade da realidade às vezes não pode ser explicitada apenas através de conceitos, requerendo, portanto, em muitas ocasiões, uma reunião simultânea, antagônica e complementar de conceitos, como os conceitos trinitários, por exemplo, ciência-politica-ideologia, que são, além de indissociáveis, sem dominância e, tampouco, que um deles esteja na origem de algum outro.

Princípios da Complexidade

O Pensamento Complexo é construído a partir de três principais princípios, que permeiam todos os conceitos, os dizeres e os saberes assim enumerados:

1. O Princípio Dialógico: é o princípio do diálogo, relacionado a e alimentado a partir da dialética de Hegel e Marx; a dialógica associa de forma simultaneamente complementar/concorrente/antagônica conceitos, ideias, instâncias, fenômenos que são conjuntamente necessários para a existência, funcionamento e desenvolvimento de uma organização. Para exemplificá-lo poderia comentar das relações entre Vida/Morte; Indivíduo/Sociedade/Espécie; Egoísmo/Altruísmo; Mercado/Estado em nosso sistema econômico; ou mesmo Ordem/Desordem na organização cósmica.

2. O Princípio Recursivo: este se relaciona à causação circular. Enquanto uma primeira cibernética evidenciou a retroação, ou seja, o resultado de um sistema interferindo sobre seus causadores, de modo a regular o sistema; em um segundo momento esta trará à tona a recursão - fenômeno pelo qual os efeitos ou produtos são, ao mesmo tempo, causadores e produtores no próprio processo que os produziu. O exemplo quase arquetípico deste fenômeno foi trazido por Maturana e Varela a partir da ideia de Autopoiese observada nos organismos vivos. Os produtos de uma organização celular viva são eles mesmos incorporados e necessitados pela estrutura que os produziu, tornando-se produtores de si mesmo em um círculo "virtuoso".

3. O Princípio Hologramático: se refere à relação entre todo e partes a partir da imagem do holograma. No holograma, cada ponto do objeto repete o todo, incorpora informações 
referentes à sua circunvizinhança, levando a (re)organizações bidirecionais entre o todo e as partes. Esse princípio refere-se, portanto, ao fato de que sistemas organizados na realidade cosmo-bio-antropossocial apresentam-se de tal modo que o todo está na parte que está no todo. Alguns exemplos poderiam ser: uma galáxia exerce força gravitacional sobre outras, compondo um cluster de galáxias, as quais, por suas resultantes gravitacionais determinam a posição e os movimentos umas das outras e de cada uma; do mesmo modo, uma célula compõe um organismo multicelular que retroage como totalidade sobre cada célula, assim como cada uma contém toda a informação genética necessária para produzir a totalidade orgânica; e nas sociedades cada indivíduo carrega em si, por sua criação, educação, enculturação, uma totalidade social que ele reproduz enquanto parte de uma grande organização sociocultural complexa emergente da atividade de centenas, milhares ou milhões de indivíduos.

\section{O Viver}

O Viver seria então o conjunto de qualidades fundamentais próprias da existência dos seres auto(geno-feno-ego) ecorreorganizadores. Este macroconceito plural, se compõe por dialógica conceitual e se manifesta em anel recursivo, no qual cada parte é geradora e regeneradora das demais. Além disso, cada parte deste fenômeno organizador vital só é capaz de se manifestar em conjunto com suas demais partes, de forma complementar, concorrente e antagônica, ou seja, estabelecendo entre si dialogias complexas.

Comecemos então pela ideia de auto-organização. Já colocada por inúmeros teóricos da cibernética, dos quais talvez pudéssemos destacar Maturana e Varela novamente com sua teoria da Autopoiese. A auto-organização é uma manifestação típica dos organismos vivos. Não se pode imaginar um ser vivo sem processos em que ele se organiza. Um ser vivo é uma criatura autônoma sem necessidade de ser criado, que não só pode se manter, conforme produz ou adquire seu alimento do meio ambiente, mas também pode se reproduzir, dando continuidade a esse sistema auto-organizador.

As primeiras organizações espontâneas não são vivas, se manifestam na natureza inorgânica em pontos fulcrais, explicado pelo seu macroconceito denominado "Tetrálogo Fundamental da Physis" composto de conceitos, em indissociáveis relações de ordem/caos/interações/organização. Esses termos, na natureza, referem-se e remetem sempre uns aos outros, de modo que do caos quântico cósmico, das mínimas flutuações primordiais durante a grande inflação, surgiram toda a complexa estrutura heterogênea do universo como hoje o conhecemos. Da caótica desordem de nebulosas cheias de gás, padrões de contração e agregação gravitacional originam expansões térmicas pontuais que, quando mantidas em cheque, em equilíbrio, complexificam a organização do universo com o surgimento de estrelas, as quais, a partir de então, originam nova ordem na produção de sistemas planetários que se organizarão em seu entorno por interações gravitacionais. Assim dialogam ordem/desordem/organização/interações conforme novas estruturas se organizam no universo, novas complexidades emergem e novos regimes de ordem se instauram, se alimentando de fluxos de matéria, energia e (nas organizações neguentrópicas computantes) informação, e acelerando a degradação total da ordem conforme amplificam a marcha irrefreável da flecha do tempo com o aumento de entropia e desordem no universo. As estruturas físicas cada vez mais complexas como estrelas ou mesmo fenômenos geológicos e meteorológicos (tectonismo e movimento de placas; ciclos da água, ventos alíseos, tornados, furacões e turbilhões de correntes aquáticas) começam a ser capazes de se manterem. Elas formam organizações que se fecham sobre si mesmas, se retroalimentando. Elas adquirem um ser, que se manifesta mais plenamente quanto mais complexa é a organização, quanto mais ela se fecha sobre si mesma e se torna capaz de auto-manutenção. Aí surge a diferença: 
enquanto esses processos, são capazes de se manterem, manifestando seu ser pouco desenvolvido e um tanto de si, eles ainda não possuem Autos, como os seres vivos. Os organismos vivos complexificam o tetragrama da physis, transformando-o em ordem/desordem/interações/auto-organização. Essa auto-organização adquire autonomia. É um indivíduo que se afirma, que se auto produz, se organiza e se move de acordo com finalidades próprias (alimentar-se, manter-se vivo, evitar a morte). O Autos é autoorganizador, autoprodutor, autorreorganização, autorreprodutor, autorreferente, conforme circula, se anela, se fechando de forma recursiva a cada vez que retoma a si mesmo nos processos de manutenção vital.

Contudo, esse fechamento que autonomiza e produz o Autos é, simultaneamente abertura para o ambiente. Todo ganho de autonomia é adquirido com aumento da dependência em relação ao meio, assim os seres vivos se autonomizam de ciclos químicos espontâneos fechando-se e, simultaneamente, tornando-se dependentes da procura de alimento, da movimentação em direção a fontes de recursos. Os animais são mais móveis, mais autônomos no seu ambiente, porém tem mais necessidades metabólicas que os vegetais, estão sempre correndo em busca da próxima refeição. Os humanos sendo mais autônomos, são mesmo mais livres em sua capacidade de imaginar e construir seus ambientes próprios em que a natureza é profundamente modificada; todavia isso se faz com uma dependência cada vez maior, tanto psicossocial com a necessidade dos infantes humanos de carinho e acompanhamento materno, familiar e comunitário para desenvolverem suas grandes potencialidades cognitivas, quanto material nas necessidades cada vez maiores das sociedades humanas de arrebanharem grandes quantidades de alimento e energia para saciarem seus sistemas socio-técnico-urbanísticos. Toda autonomia é dependente do seu meio, ou seja, quanto mais autônomo um sistema organizado, mais dependente ele se torna de seu meio.

Para complexificar ainda mais essa organização recursivamente anelada, podemos dividir a autonomia de organização dos sistemas vivos em dois níveis: o fenomênico, existencial, individual, concretamente manifesto; e o generativo, genérico e genético. O Autos refere-se, portanto, tanto à identidade transindividual, aquela inscrita nos genes, comum a uma espécie, capaz de manter os organismos através de sucessivas gerações, regenerando-os; quanto a uma identidade fenomênica individual, que atualiza essa potencialidade genética em cada organismo, em cada indivíduo que constitui uma mesma espécie. Esse nível genético, o Genos, é a manifestação reprodutiva da vida, contida no senso comum de que a vida se constituiria pelo ciclo de nascimentos, reproduções e mortes. Já o nível fenomênico, o Fenon, é a manifestação organizacional da vida, contida na ideia de que para se estar vivo, é necessário ser um organismo, um ser organizado que se mantém no tempo e no espaço. Ambos devem ser combinados de forma dialógica e recursiva, conforme as espécies não poderiam existir sem os indivíduos que as concretizam, nem os indivíduos sem os grandes, quase abstratos, ciclos reprodutivos transgeracionais. Depois de um grande domínio do gene e da genética, a biologia volta-se novamente para a valorização dos organismos; genótipo e fenótipo se entrechocam e emaranham-se, demonstrando a fluidez das fronteiras entre os dois conceitos e entre suas manifestações reais. A auto-eco-organização complexifica-se em auto(genofeno)eco-organização

Chegamos ao terceiro termo do Autos: o ego. O ego refere-se ao caráter subjetivo, individual, existencial das organizações vivas. Como dito anteriormente, estrelas e turbilhões possuem ser, isto é, possuem um certo caráter existencial, o qual é desenvolvido muitas vezes nas autoorganizações vivas. Nelas, ser e si tornam-se Autos e Individualidade. Existe um caráter de indivíduo-sujeito próprio a toda organização viva. Podemos afirmar que de toda organização emerge uma dimensão existencial, ou seja, juntamente com a complexidade lógico- 
organizacional, manifesta-se, nesse fechamento estrutural/abertura ambiental em anel recursivo, uma dimensão ontológico-existencial. Assim adquirem as estrelas ser e os organismos vivos subjetividade. A individualidade dos organismos se constitui por uma referência una/tripla, eles possuem três identidades interdependentes que definem sua individualidade: uma identidade genética (genericidade transindividual); uma identidade particular (singularidade individual); uma identidade subjetiva (egocentrismo subjetivo). 0 indivíduo é ponto de encontro de complexos processos auto(geno-feno)eco- organizacionais. O Viver é um modo de existência próprio a um Ser-Existente-Indivíduo-Sujeito; ou seja, o Viver é a manifestação emergente existencial de uma auto(geno-feno-ego)eco-organização.

Morin invoca aqui a ideia de "animus" para chegar a essa dimensão egoica. $O$ animus não é independente da physis, nem vem de sobre esta para torná-la uma realidade espiritual ou psíquica. Ele é manifestação dinâmica a partir da natureza e das complexas organizações vivas, desenvolvendo ainda mais sua complexidade e sua vitalidade. $\mathrm{O}$ animus diz respeito à toda organização computante, o que inclui os mais simples organismos unicelulares que extraem informação do seu ambiente para solucionar seus problemas relacionados à manutenção da vida; e capazes de gravar informação em seu código genético que será invocada por seus sistemas celulares em sua autoprodução e em sua autorreprodução. 0 animus tem um triplo caráter: físico (dinamismo, motricidade, produção), biológico (autoorganização, computação) e protopsíquico (cognitivo, reflexivo). De forma similar, podemos perceber nas ideias e conjecturas piagetianas o paralelismo entre a organização biológica/neurológica/epistemológica, ou seja, as semelhanças e continuidades entre a organização da vida, do cérebro e do conhecimento. Enquanto seria ridículo atribuir um espírito a uma bactéria, é possível perceber que esse caráter subjetivo proto-psíquico imanente à bactéria irá, ao longo da evolução biológica, desenvolver-se em formas mais complexas: uma subjetividade organísmica em seres multicelulares que demandam grandes organizações intersistêmicas; uma subjetividade animal nos organismos cerebrados que desenvolvem o psiquismo em um cérebro/espírito que integra sensação/computação/representação/organização/ação; e uma subjetividade humana que produz o nível qualitativamente novo da consciência reflexiva, linguística e simbólica. Compreendendo, a partir de então, o espírito em continuidade com a organização biológica mais simples, podemos, simultaneamente, percebê-lo como parte integrante de um complexo auto(geno-feno-ego)eco-organizador.

Para finalizar esse percurso analítico-sintético do Viver, ele mesmo dialógico, recursivo (em seu movimento anelado onde cada parte parece produto e produtora, causa e consequência das demais) e hologramático (pois que cada parte necessita de todas as outras para se definir, assim como contem em si a definição de todas estas), necessitamos falar do Re. O Re é o mesmo que está contido nas ideias de recursão, regeneração, reprodução, reorganização. Ele remete a si mesmo. Ele se inicia com a repetição de um processo, organizando-se e desenvolvendo-se em reproduções, recorrências, rememorações que trazem de volta o passado, a história orgânica/organizacional do vivente e a reatualizam no momento presente para prepará-lo e lançá-lo ao futuro. A organização viva torna-se reorganização viva por sua capacidade de, autorreferindo-se, ou mesmo, remetendo a seu ser passado, manter-se, (re)generar-se, (re)constituir-se, (re)produzir-se. O Re é face complementar do Autos. É na recursão em anel, onde os produtos são constitutivos dos estados iniciais em que eles mesmos são produzidos, do Re que o Autos se manifesta. Sem reorganização, o Autos vivo morre. E é também a repetição que dá a uma organização a capacidade de se fechar, de se referir a si, de organizar-se. Assim Re torna-se Se, que, nos indivíduos-sujeitos com subjetividade, torna-se a referência do sujeito a si mesmo, do Eu a Mim. Daí temos Re/Se/Me em anel, todos aspectos complementares ao Autos vivo. 
Na recursão dialógica hologramática de todos esses termos, de todos esses macroconceitos, desses paradigmas lógica e ontologicamente distintos, formamos um último anel conceitual que nos traz de volta à problemática complexa não resolvida do Viver. O anel conceitual é o da ordem/desordem/interações/auto(geno-feno-ego)ecorreorganização, processo típico e característico dos seres viventes, daqueles que vivem, do próprio Viver.

\section{Teoria Viva da Vida}

O paradigma auto(geno-feno-ego)ecorreorganizador desenvolvido pelo/no/com o pensamento complexo não se pretende uma solução final para a questão da Vida. Esta complexidadade e este paradigma não contêm toda a vida. São, sim, meios para concebê-la, para unir sua complexidade conceitual, causal e ontológica em Anel, em uma estrutura recorrente que se regenera e se reproduz, produzindo novidades qualitativamente diferenciadas, propriedades originais na globalidade, ou seja, emergências. A Teoria da Vida deve ser ela mesma viva se queremos que seja capaz de iluminar o pensamento sobre o vivo e o pensamento vivo. Ela não deve se reduzir ao micro, com conceitos e entidades como as moléculas, a informação ou os genes; nem ser simplificada pela totalidade, tendo sua complexidade explicada por um princípio vital, ou uma força especial ou um tipo de "matéria viva".

A Teoria da Vida precisa ligar o micro ao macro passando pelo meso. Ela precisa incorporar as contribuições do mecanicismo/vitalismo/organicismo e mesmo do pan-genetismo/epigenetismo/psico-genetismo, reordenando-os e reorganizando essas formas de pensar e conceber a vida segundo um fecundo e interfecundante princípio de complexidade. A Teoria da Vida precisa ser capaz de manifestar a BioLógica, lógica da vida, emergente das organizações moleculares locais, que retroage sobre elas, organizando-as. O princípio vital dos vitalistas existe como emergência da organização viva, não como entidade prévia a esta. Não só pensamento complexo do vivo deve ser a Teoria da Vida, mas também pensamento complexo vivo, em anel generativo, que a regenere e a torne capaz de produzir emergências, realidades novas a partir do sistema anelado e organizado.

Do Viver ao nosso Viver

Para que se vive? Qual é a finalidade deste processo? Morin sugere uma aparente tautologia como a resposta talvez mais rica para essa pergunta tão fundamental sobre a vida. Vive-se para viver. Vivemos por viver. Não há grandes causas, nem mesmo ausência de motivo. 0 objetivo da vida é perpetuar-se, manter-se. Assim, vive-se para viver, o que simultaneamente significa que se vive para sobreviver e, mesmo que se sobrevive para continuar vivendo. Também é real que se vive para dar a viver, para auxiliar os outros inseridos na identidade orgânica a manter suas vitalidades, ou seja, para dar continuidade ao grupo, à família, à espécie. Vive-se para sobreviver e sobrevive-se garantindo que os semelhantes sobrevivam e, assim, vivam. Viver é mesmo um trabalho, ser vivo é como ser trabalhador. É uma profissão que não se pode deixar de cumprir para a manutenção da própria vida. É função que se exerce no mundo real. Contudo, viver é também um jogo. Viver é jogar, pois agimos como jogadores que enfrentam jogo com regras e soluções de problemas. Estamos sempre tentando ganhar a vida. Ganhar a vida significa ganhar vida, não deixando-a esvair, não se deixando morrer, ou perdendo o jogo por deixar seus descendentes morrerem. A Vida é jogo de tudo ou nada e é também jogo de tudo e nada, já que tudo que temos é esse jogo, está em jogo e, ao mesmo tempo, jogamos por nada, sem motivo maior que a própria necessidade de continuar a jogar por jogar. A Vida é mesmo profissão, jogo e mistério, porque sabendo mais e mais sobre ela, ainda parece incompreensível em sua inteireza. 
Nós, humanos, desenvolvemos em graus superiores inúmeras das qualidades próprias do vivo, sem jamais deixar de sermos viventes como tantos outros. Somos hiperegocêntricos, hiperindividuados, hipersentimentais e hiperemocionais. Atingimos plenitudes existenciais nos transes místicos, psicotrópicos, orgásmicos. Somos supervivos e hipervivos. Consumimos para viver e consumimo-nos no viver.

Se nas células individuais confundem-se ser/agir/conhecer/sentir, em nós todas estas atividades-funções autonomizam-se, sem abandonar seus aspectos interdependentes. A célula conhece, porque computa. Computa por ser célula. Mantém-se, porque computa, adquirindo conhecimento que permite a ação e sente, porque é célula computante capaz de perceber as alterações sobre seus estados, capaz de conhecer-se e agir para alcançar os estados desejados, os estados standard, os estados programados em seu código padrão. Nós podemos conhecer por conhecer, sentir por sentir, agir por agir e ser aquilo que somos em toda nossa riqueza. Somos o que fazemos e procuramos conhecer o que somos assim como nos sensibilizamos com nossas ações e com as ações dos outros.

A partir do pensamento sobre a vida e de uma teoria da vida, nos tornamos por fim, capazes de pensar nossas vidas e de teorizar sobre elas. Partimos de uma ideia sobre o Viver, que acabou incorporando o humanismo que parte da experiência subjetiva e existencial da vida humana e o cientismo que parte das observações objetivas sobre a vida natural orgânica. Entre antropomorfismos, biomorfismos, cosmomorfismos e fisiomorfismos, tentamos entender o Viver formando um anel do viver para viver. Estamos todos em um circuito recursivo que produz as emergências da realidade, do nosso próprio pensamento e de nossa vida como um todo: viver/jogar/gozar/agir/ explorar/procurar/conhecer/amar. Todos interpenetram-se e nos penetram no contínuo ato de Viver.

Referências bibliográficas:

Morin E. O Método 1. A Natureza da Natureza. Edição: 3. Sulina; 2013.

Morin E. O Método 3. O Conhecimento Do Conhecimento. Edição 5. Sulina; 2015.

Morin E. O Método 2. A Vida da Vida. Edição: 5. Sulina; abril de 2015. 


\section{SUBJETIVIDADE, ÉTICA E COMPLEXIDADE NA EDUCAÇÃO: ENTRELAÇAMENTOS PARA UMA NOVA COMPREENSÃO DA REALIDADE}

José Carlos de Oliveira - Professor do HCTE/UFRJ - jcarlos@dee.ufrj.br

Renata Costa de Oliveira - Escola Oga Mitá - renatapsicomotricista@gmail.com

Resumo

De um modo geral, na área da educação predomina uma cegueira em relação à subjetividade e uma valoração da hiperespecialização, o que acarreta a fragmentação dos saberes obstruindo a visão do conjunto, ou seja, não consegue integrar o compromisso de unir os conhecimentos em prol de uma nova compreensão da realidade. A educação religada com a problemática global mostra que a barbárie das relações humanas precisa ser revertida ou todos os sujeitos ficarão imersos na selvageria. Isso envolve uma ética de religação, de alteridade e cuidado não somente consigo, mas também com o outro. É dizer não ao pensamento simplificador e considerar a complexidade na educação.

Palavras-Chave: Subjetividade. Ética. Complexidade. Educação.

Introdução

Um dos aspectos mais relevantes que envolve a educação é a sua contribuição para a formação do sujeito como cidadão. Quando se trata de democracia este cidadão se configura por se solidarizar e se responsabilizar por tudo que acontece ao seu redor e no mundo, sabendo que sua intenção e ação podem levar a consequências indeléveis e degradantes.

A complexidade pode brotar nas brechas da educação, para isso é preciso entender que mudanças se fazem necessárias para compreender o mundo em que vivemos. É indispensável reformar o pensamento e trazer à tona uma compreensão mais profunda do conhecimento. (HESSELano; MORIN 2012, p.52),

\footnotetext{
"A reforma do pensamento permitirá frear a regressão democrática que, em todos os campos da política, suscita a expansão da autoridade dos peritos, dos especialistas de todos os tipos, o que restringe ainda mais a competência de todos os cidadãos, condenados à aceitação cega de decisões que emanam daqueles que deveriam saber, mas que, de fato, praticam uma inteligência fragmentada e abstrata, a qual rompe a globalidade e contextualidade dos problemas.".
}

Estas mudanças incluem um novo olhar, um olhar complexo, não no sentido de que é complicado, mas sim do que é tecido junto. Entrelaçar os diferentes saberes, tornando-os comunicantes é ultrapassar os muros da incompreensão.

Compreender a incompreensão é complexo e exige enfrentar as incertezas do conhecimento, onde a explicação não é sinônimo de compreensão. Para Morin (2009, p.51), "Explicar é utilizar todos os meios objetivos de conhecimento, que são, porém, insuficientes para compreender o ser subjetivo." Explicar é tornar claro o que está obscuro e é um caminho para compreensão intelectual, pois a compreensão humana transcende essa parte objetiva tendo a comunicação e a capacidade de se identificar com outro sujeito como alicerces essenciais e intersubjetivos. Segundo

"Compreender comporta um processo de identificação e de projeção de sujeito a sujeito. Se vejo uma criança em prantos, vou compreendê-la não pela medição do grau de salinidade de 
suas lágrimas, mas por identificá-la comigo e identificar-me com ela. A compreensão, sempre intersubjetiva, necessita de abertura e generosidade."

MORIN (2009, p.93), .

A subjetividade ocorre na existência humana por meio das relações interpessoais e por sua reconhecença. Quando o indivíduo torna-se indiferente frente ao sofrimento do outro revelase um distanciamento, uma frieza em relação a barbárie que acontece no dia a dia. As relações ficam fragmentadas, diluídas, desconectadas. Morin (2007, p.86) diz que "O mal ético está na barbárie das relações humanas, no próprio coração da civilização. Enquanto permanecemos como somos, continuaremos bárbaros e mergulhados na barbárie."

No momento em que o indivíduo se coloca no lugar do outro se torna responsável para com ele.

\footnotetext{
"O ser que se exprime impõe-se, mais precisamente apelando para mim da sua miséria e da sua nudez - da sua fome - sem que eu possa ser surdo ao seu apelo. De maneira que, na expressão, o ser que se impõe não limita, mas promove a minha liberdade, suscitando a minha bondade" (LÉVINAS. Apud: COSTA, 2000, p. 179).
}

Assim, as relações humanas vão comportar um espelho especular em que pode reportar a imagem do outro a si próprio. A compreensão reside no reconhecimento do outro como sujeito igual a ele. Pode-se dizer que existe uma ética de religação, uma ética altruísta. Morin (2007, p.103) fala que "A ética altruísta é uma ética da religação eu exige manter a abertura ao outro, salvaguardar sentimento de identidade comum, consolidar e tonificar a compreensão do outro."

\section{Subjetividade e Ética}

O ser humano é um ser complexo. Edifica sua própria identidade para tornar-se sujeito independente e autônomo a partir das dependências que fazem partem do seu cotidiano. Segundo PEetraglia (2003, p.60) "O ser humano vive a construção de sua própria identidade, que pressupõe a liberdade e a autonomia para tornar-se sujeito, a partir das dependências que alimenta, necessita ou tolera, como por exemplo da família, da escola, da linguagem, da cultura, da sociedade, etc."

A compreensão subjetiva é a consequência de uma compreensão de sujeito a sujeito que possibilita tem um olhar acolhedor quanto aos dissabores e angústias do outro. SegundoMorin (2007, p.112), "São sobretudo o sofrimento e a infelicidade do outro que nos levam ao reconhecimento do seu ser subjetivo e despertam em nós a percepção da nossa comunidade humana". Ela faz com que a incivilidade se distancie e crie um elo entre o conhecimento subjetivo e o conhecimento objetivo. Como afirmaMorin (2007, p.123) "A compreensão que afasta a barbárie nutre-se da aliança entre a racionalidade e a afetividade.". O corpo adoece quando não há cuidado consigo e com o outro. O corpo vivo é subjetividade, de relações humanas. No momento em que o indivíduo percebe-se nos encontros a percepção que tem-se do outro se amplia. Boff salienta que

\footnotetext{
"O rosto e o olhar lançam sempre uma pro-posta em busca de uma res-posta. Nasce assim a res-ponsa-bilidade, a obrigatoriedade de dar res-postas. Aqui encontramos o lugar do nascimento da ética que reside nesta relação de res-ponsa-bilidade diante do rosto do outro..." (BOFF,1999, p.139).
}

Entrelaçar as percepções objetivas e subjetivas em relação ao outro é ter uma visão mais profunda sobre este outro. Neste sentido diz Morin (2007, p. 80) "Para conhecer o outro, certo, deve-se percebê-lo objetivamente, estudá-lo, se possível, objetivamente, mas também se deve compreendê-lo subjetivamente. O desenvolvimento de um conhecimento objetivo do mundo deve avançar junto com um conhecimento intersubjetivo do outro.". 
A subjetividade envolve afetividade e a ética que estão entrelaçados com a reforma do pensamento em que a responsabilidade é um aspecto inerente ao ser humano e possibilita trazer à tona a solidariedade. SegundoMorin (2015, p.136), "A reforma do pensamento conduz a uma reforma de vida que também e necessária para o bem-viver".

\section{Educação e Complexidade}

Muitas vezes a educação é fragmentada. O pensamento reducionista mostra que o pensamento é linear, não proporciona a comunicação e o diálogo entre os saberes. Faz-se necessário uma educação que rompa com a fragmentação das disciplinas e que a religação mostre a sua potência para uma nova compreensão da realidade. Morin nos alerta que "O mundo dos intelectuais que deveria ser mais compreensivo, é o mais gangrenado pela hipertrofia do ego, pela necessidade de consagração, de glória. As incompreensões entre filósofos são particularmente surpreendentes. Estamos incessantemente mergulhados no espaço de incompreensões mútuas e generalizadas" (MORIN, 2015, p.75). A educação com uma perspectiva complexa pode fazer a diferença. Derruba as barreiras de um pensamento simplificador, desnubla o que não é compreensível. Carvalho (2017, p.180) diz que "A complexidade não é um paradigma...Se o pensamento complexo for convertido em um paradigma, corre seriamente o risco de virar doutrina, regra, mandamento, prescrição.". Isso mostra que a complexidade é um caminho sempre em construção, de inovação, de criação não precisa ser quebrado. Petraglia $(2003$, p.86) ressalta que “...é preciso não se reduzir ao sistema. É preciso enriquecer-se pelo sistema".

Deve-se promover uma reforma em que todos envolvidos na educação tenham meios de enfrentar os problemas globais, pois com muita constância estão separados em várias disciplinas dificultando a compreensão da realidade. Hessel e Morin $(2012$, p.48) afirmam que "É de importância capital ensinar o conhecimento do momento atual vivido pela humanidade, além de suas mudanças, chances e riscos, o que inclui os problemas vitais - para cada um e para todos - de nossa época, marcada pela globalização.".

Morin (2007) enuncia sete saberes necessários à educação de fundamental importância para a reforma do pensamento, são eles: as cegueiras do conhecimento: o erro e a ilusão - A educação deve trabalhar o conhecimento que em algum nível esteja atravessado pelo erro e pela ilusão; os princípios do conhecimento pertinente - Discorrer sobre o pensamento que isola e que reduz e do pensamento que distingue e religa; ensinar a condição humana Reconhecer o sujeito no universo e não afastado dele e que traz consigo a unidualidade de ser $100 \%$ biológico e 100\% cultural; ensinar a identidade terrena - a educação deverá trabalhar a ética da compreensão planetária; enfrentar as incertezas - a humanidade é guiada por caminhos ainda não desbravados, onde o pensamento deve se municiar para enfrentar a incerteza; ensinar a compreensão - envolve a solidariedade intelectual e moral da humanidade;a ética do gênero humano - A antropoética compreende a esperança na completude da humanidade, como consciência e cidadania planetária. Envolve a comunhão, comunicação, a busca da compreensão de si e do outro.

Os sete saberes seriam os norteadores para uma compreensão da realidade e assim para uma educação de qualidade conforme contenha em si a condição humana. Assim ressalta Morin $(2009$, p.11) "...a educação pode ajudar a nos tornamos melhores, se não mais felizes, e nos ensinar a assumir a parte prosaica e viver a parte poética de nossas vidas.".

\section{Conclusão}

Pode-se dizer que a selvageria que a humanidade se encontra é uma crise planetária. A empatia se perde em meio ao apocalipse, a incompreensão supera a compreensão nas relações humanas e a indiferença é um dos empecilhos para a compreensão. É preciso que a 
solidariedade e a compreensão humana sempre intersubjetivas reinem dentro das mais variadas dimensões que a educação comporta. Romper com as barreiras de um pensamento simplificador e reducionista em que se tem uma fragmentação dos valores e dos sujeitos e dar lugar ao pensamento que religa é uma emergência. Para que as relações saiam do seu estado bárbaro é necessária à compreensão mútua entre todos os sujeitos, uma ética de religação, de compreensão humana.

Referências bibliográficas

BOFF, L. Saber Cuidar: Ética do Humano- Compaixão pela terra. Petrópolis: Vozes, 1999.

CARVALHO, E.de A. Conexões da Vida: Uma Antropologia da Experiência. Editora UNA, 2017.

COSTA, M. L. Lévinas: Uma introdução. Petrópolis: Vozes, 2000. (Coleção ética e intersubjetividade).

HESSEL, S., MORIN, E. O Caminho da Esperança. Rio de Janeiro: Bertrand Brasil, 2012.

MORIN, E. Cabeça Bem Feita: Repensar a Reforma, Reformar o Pensamento. Rio de Janeiro: Bertrand Brasil, 2009.

. Ensinar a Viver: Manifesto para Mudar a Educação. Porto Alegre: Sulina, 2015.

. O Método 6: Ética. Porto Alegre: Sulina, 2007.

. O Método 5: A Humanidade da Humanidade. Porto Alegre: Sulina, 2007.

. Os Sete Saberes Necessários à Educação do Futuro. São Paulo: Cortez; Brasília, DF: UNESCO, 2007.

PETRAGLIA, I. C. Edgar Morin: A Educação e a Complexidade do Ser e do Saber. Petrópolis: Vozes, 2003. 


\section{A PERIFERIA DA PERIFERIA - A CIÊNCIA DO COTIDIANO DESENVOLVIDA PELOS LABORATÓRIOS REGIONAIS DOS "MUNDOS CORPORATIVOS": UM ESTUDO DE CASO}

Maria Cristina de Oliveira Cardoso - Mestranda do HCTE-UFRJ - mcritinaocardoso@gmail.com Regina Maria Macedo Costa Dantas - Professora do HCTE/UFRJ - regina@hcte.ufrj.br

Resumo

Este trabalho, recorte de dissertação em desenvolvimento, propõe a trazer para a discussão a "ciência do cotidiano" desenvolvida pelas empresas, que muitas vezes não é considerada como tal, mesmo dentro das próprias empresas. As adaptações necessárias nas tecnologias e técnicas utilizadas, desenvolvidas por profissionais das empresas, são muitas vezes consideradas, nas próprias empresas e fora delas, invencionices, estudos não científicos ou mesmo consequência de processos. Sabedores de que a história contada é quase sempre pelo viés dos vencedores, pretendemos incluir na historiografia da História das Ciências a história destes cientistas invisíveis.

Palavras-chave: História invisíveis corporativo.

Introdução

Como falar de uma empresa que presta serviços no segmento de tecnologia sem apontar a importação de materiais? Como não falar das "naturalizações" necessárias destes mesmos materiais?

Os mundos corporativos são construídos por profissionais de diversas áreas, uma rede de saberes trabalhando com foco em um único objetivo. Laboratórios vivos alimentados todos os dias por novos elementos capturados das narrativas e do exercício de observação. Nos mundos corporativos, a interação com a sociedade e a rápida adaptação aos movimentos feitos pela mesma é, muitas vezes, uma questão de sobrevivência. O Projeto FIAT Mio, com o sugestivo slogan "um carro para chamar de seu", seria um exemplo de como os mundos corporativos lidam com as multiplicidades de narrativas onde contexto e conteúdo se confundem.

Dentro dos mundos corporativos seria possível vislumbrar, também, o desenvolvimento de uma ciência que aqui chamaremos de "ciência do cotidiano", ciência esta que, quase sempre, não é considerada como tal, mesmo dentro das próprias empresas. As adaptações necessárias nas tecnologias e técnicas utilizadas (em sua maioria importadas), desenvolvidas por profissionais (cientistas invisíveis) de dentro das empresas, são muitas vezes reconhecidas, nas próprias empresas e fora delas, como gambiarras, invencionices, estudos não científicos ou mesmo consequência de processos. Ainda persiste uma imagem idealizada dos países que tomamos como modelo: "buscando o esperado, não encontram o realizado" (FIGUERÔA, 1995, p.17)

Produziram assim categorias analíticas para uma "história dos vencedores", deixando de lado a "história cotidiana" das ciências, que constitui, na verdade, a maior parte do processo. Penso que é possível um novo olhar para as atividades científicas desenvolvidas no Brasil, até hoje pouco valorizadas. Sem esquecer, contudo, que sempre estiveram balizadas pelo marco da condição colonial do país(...).(FIGUERÔA, 1995, p.17).

HCTE-UFRJ 
Dentro das empresas, esta "ciência do cotidiano", realizada na sua maioria em laboratórios regionais, quando não é ignorada, se perde na burocracia. Quando o produto se estabelece, as inscrições que deram forma ao mesmo, perdem a importância (LATOUR, 2000, p.112). Informações, conhecimentos tácitos, contribuições da sociedade, desaparecem no meio dos papéis e dos lucros, e só serão resgatados, por estes mesmos cientistas invisíveis, em um próximo projeto, se forem necessários. Quase sempre, apenas parte deste conhecimento ficará na mente dos engenheiros, técnicos e colaboradores, e os mesmos darão continuidade à tradição oral de passagem de um conhecimento, ou daquilo em que ele se transformou.

Portanto, como estudo de caso, este trabalho se dispõe a dar voz a um grupo de cientistas invisíveis dos mundos corporativos, sediado no norte do Brasil. O projeto escolhido é o da travessia do rio Amazonas por um cabo subfluvial realizado por uma empresa de telecomunicações, iniciado em 2010. Este foi um projeto multidisciplinar, tendo sido necessário o envolvimento de diferentes saberes. A empresa tinha conhecimento de lançamento de cabo submarino, porém seria a primeira vez que lançaria um cabo subfluvial. Mas, sendo um projeto corporativo, as adequações, adaptações das tecnologias, não ficaram documentadas como desenvolvimento de técnicas por não serem consideradas relevantes naquele momento ou mesmo por serem consideradas consequências da implantação do projeto.

Engenheiros de diversas áreas, técnicos, ambientalistas, colaboradores e a sociedade local participaram das etapas do projeto, portanto, os saberes foram se misturando e se complementando. Pormenorizando nosso estudo, veremos aqui, uma parte do projeto, o momento da chegada à Ilha da Marchantaria, no rio Solimões (Estado do Amazonas). A pesquisa não tem a pretensão de demonstrar as técnicas de engenharia e de outras ciências utilizadas no projeto.

A ação inicial foi caracterizada pelo deslocamento de uma grande equipe da empresa para apresentar o projeto à comunidade e, para registrar a primeira dificuldade, o desafio foi chegar à ilha. Para o deslocamento foram utilizados pequenos barcos, pilotados por moradores, devido à penosa navegação nas "ruas" formadas pelos igarapés.

Cabe ressaltar que a metodologia da presente pesquisa para recuperar as informações sobre as ações do Projeto (o nosso caso), foi realizada por meio de entrevistas com um dos membros do grupo que aqui identificaremos como "Engenharia do Norte": equipe de engenheiros e técnicos sediada no norte do Brasil, funcionários da empresa de telecomunicações, que ficou responsável pela implantação do projeto de travessia. Dessa forma, foram realizadas entrevistas, onde obtivemos os primeiros depoimentos, por escrito, por e-mail, em julho de 2017.

(...) tenho o maior orgulho de ser um engenheiro do norte e de ter conseguido aplicar todo o conhecimento acadêmico que adquiri as peculiaridades da nossa região, vencendo desafios que grandes empresas, até mesmo as internacionais, não se sentiram capazes. (ENGENHARIA DO NORTE, 2017)

Durante a reunião com a comunidade, ficou claro que o projeto tinha várias "partes" dissociadas. Apesar da apresentação em conjunto na "reunião", cada equipe possuía um papel a desempenhar e um resultado a obter. O relato da Engenharia do Norte sobre a exposição para a comunidade, por exemplo, só contempla a parte técnica. Segundo Cukierman (2007, p.212), seria necessário um novo enquadramento, um novo "ângulo de aproximação do problema" para que o "técnico" e o "social/cultural" constituíssem um movimento de "co-modificação". 
As linhas gerais do projeto foram apresentadas para as comunidades da ilha em reunião em uma das escolas, com mapas com as rotas, amostras dos cabos que seriam utilizados, dos postes de fibra (...). (ENGENHARIA DO NORTE, 2017)

Durante a fase piloto do projeto, as equipes se depararam com diversas situações em que o técnico e o sociocultural não se dissociavam. Em uma delas, por exemplo, dois cabos de testes implantados com a mesma técnica dos cabos submarinos, técnica dominada pela empresa, romperam-se. A técnica utilizada (lançar o cabo no leito do rio), não se mostrou adequada, mas até aquele momento não havia causa aparente que justificasse o rompimento. Foi necessária uma aproximação com a comunidade local para se entender que uma das razões para os cabos terem rompido dava-se por uma atividade de pesca, cuja técnica utilizada causava danos ao material.

Primeiro foi executado um projeto-piloto, no qual dois cabos de teste foram implantados desde uma das margens do Rio Solimões até a Ilha da Marchantaria. Eles acabaram rompendo-se, mas o aprendizado foi fundamental para o projeto definitivo, pois observamos ofensores que deveriam ser evitados e oportunidades a serem aproveitadas: os ribeirinhos usam uma técnica de pesca onde eles fazem boias com anzóis descerem a correnteza do rio e as recolhem alguns quilômetros abaixo. Isso fez com que anzóis engatassem nos dois cabos ópticos implantados para teste. Quando as boias eram recolhidas, o cabo óptico era puxado pelos pescadores, o que causava danos ao mesmo. (ENGENHARIA DO NORTE, 2017)

Outra razão para o rompimento dos cabos foram as valas no leito do rio, resultantes do movimento das correntezas, que deixavam os cabos expostos, tais quais varais de roupas, aos galhos e vegetações arrastados pelas correntezas, nas partes mais profundas do rio.

Estas situações levaram a decisão de mudança no projeto. Optou-se por enterrar o cabo no leito do rio para a travessia. A indicação de que o cabo óptico deveria ser enterrado veio como resultado de um processo, que pode ser considerado um experimento. Primeiramente, cabos ópticos foram instalados conforme a orientação já existente na empresa; depois, foram observados os efeitos oriundos de um comportamento social (a pesca) e da natureza (correnteza). A partir destas observações é que vem a decisão final de se enterrar o cabo.

Após análise dos resultados desse teste piloto, foi elaborado um primeiro projeto onde o cabo óptico a ser usado possuiria uma armadura de aço similar a usada nos cabos submarinos e que, ao contrário desses, que são lançados sobre o leito do mar, o cabo subfluvial deveria ser enterrado no leito do rio. (ENGENHARIA DO NORTE, 2017)

Para ampliar a velocidade da rede, foi necessário transpor o Rio Solimões, o que não era possível anteriormente com a tecnologia disponível para os sistemas submarinos, por conta da correnteza e da impossibilidade de fixar corretamente os cabos de fibra óptica no leito do rio, de estrutura sedimentar. O problema foi resolvido graças ao cabo subfluvial da Embratel no Rio Solimões, que permitiu a passagem do sinal óptico. Esse feito da engenharia demandou métodos operacionais diferenciados e inovadores. (GOVERNO DO ESTADO DO AMAZONAS, 2014, p. 346).

Neste momento, destacamos um outro ponto importante: a "naturalização" que a Engenharia do Norte realizou em técnicas e tecnologias para adaptar o projeto à realidade local.

Como o cabo óptico seria enterrado no leito do rio, poderíamos implantá-lo na llha da Marchantaria diretamente enterrado no solo, mas seria uma tarefa muito difícil já que a ilha é cortada por vários igarapés. Optamos então por usar postes e cabo aéreo autossustentável pelo seguinte: a experiência das pessoas que moram na ilha revelou que as suas margens não são estáveis e sofrem um processo de desmoronamento causado pela correnteza do Rio Solimões. (...) As rotas ópticas aéreas na ilha procuraram então contornar os igarapés e usar os terrenos mais firmes para implantação dos postes, já que eram também as áreas com 
moradias dos residentes na ilha, que se ressentiam da ausência de energia elétrica. (ENGENHARIA DO NORTE, 2017)

Percebe-se que a narrativa da Engenharia do Norte já incorpora um conhecimento que, a priori, seria um conhecimento local (cheia, localização de igarapés). Tal conhecimento, na fala da Engenharia do Norte, torna-se "naturalizado" e imbricado com o próprio projeto da empresa. Ao final, ler a narrativa da equipe somente, não se consegue perceber todo o esforço necessário para a "naturalização" do conhecimento local.

A equipe de Engenharia da Embratel passou, então, a analisar a possibilidade de lançar um cabo subfluvial. Ao longo de 2009 foram realizados testes in loco (...), para avaliar a viabilidade dessa travessia. Os resultados obtidos após oito meses de experiência piloto mostraram que a experiência é viável (...).(LIMA, 2010, p.39)

Como era impossível deslocar para as margens máquinas de perfuração de dutos, em conjunto com uma empresa de Manaus instalamos uma perfuratriz em uma balsa e construímos os dutos por onde passaram os cabos, do rio para a margem, o que nunca tinha sido tentado, mas que se revelou um sucesso. (ENGENHARIA DO NORTE, 2017)

As adaptações às tecnologias foram ocorrendo naturalmente, o conhecimento universal, se misturando ao conhecimento da equipe de Engenharia do Norte, e ao conhecimento da população local.

A despeito dos desafios inerentes a um projeto de tal porte e caracterizado pelo ineditismo, a expectativa é que a travessia esteja concluída ainda em 2010. Novamente, a tarefa de operar um cabo subfluvial em condições extremas e ainda não totalmente conhecidas ou plenamente dominadas exigirá métodos operacionais diferenciados e inovadores.(LIMA, 2010, p.40)

Figuerôa (1995, p.22) aponta que no momento em que se passa a duvidar da universalidade da ciência, começa-se a admitir que este conhecimento seja "socialmente negociado".

A partir do momento que se passa a duvidar de que a ciência seja um corpus universal (espacial e temporalmente) de conhecimento que reproduz e espelha, de maneira direta, a realidade e, ainda, que se passa a admitir que tal conhecimento seja socialmente negociado, o estudo do processo de inserção e desenvolvimento de disciplinas científicas em contextos diversos daqueles nos quais floresceram originalmente reveste-se de sentido e importância. (FIGUERÔA,1995, p.22)

A criatividade foi a saída para vários obstáculos encontrados pela equipe de Engenharia do Norte. E uma destas saídas foi realizar um movimento de aproximação entre o técnico e o social. Segundo Latour (2000, p.232), "nunca estamos diante de 'ciência, tecnologia e sociedade', mas sim de uma gama de associações mais fortes e mais fracas; portanto, entender o que são fatos e máquinas é o mesmo que entender quem são as pessoas".

As empresas contratadas pela empresa foram orientadas a utilizar ao máximo possível de mão de obra local e a conduzir qualquer pleito dos moradores diretamente à Coordenação do Projeto. (...) Foram realizadas muitas modificações a partir de sugestões dos moradores. As rotas dos cabos na ilha praticamente foram definidas em conjunto com os moradores, em face da experiência que eles tinham em relação a identificação dos terrenos que alagavam nos períodos de cheia. (ENGENHARIA DO NORTE, 2017)

\section{Conclusão}

Na primeira entrevista realizada com a Engenharia do Norte, identificamos como a história dos "vencedores" pode ser contada de diferentes ângulos, desarticulando a referência hegemônica de ciência. Sair do eixo do mainstream da empresa e trazer para o centro da discussão o conhecimento local, a "ciência do cotidiano", a modernidade "estrangeira" "naturalizada" pela periferia da periferia. 
Percebe-se no discurso do membro da equipe de Engenharia do Norte o orgulho de participar do mainstream da ciência, mas, ao mesmo tempo, de fazer parte de uma história local. Acredita-se que a continuidade da pesquisa revelará experimentos e abordagens que contribuirão para apontarmos a atuação de "cientistas invisíveis" em espaços não registrados pela historiografia.

\section{REFERÊNCIAS:}

BUENO, Bruna; BALESTRIN, Alsones. Inovação colaborativa: uma abordagem aberta no desenvolvimento de novos produtos. Rev. adm. empres., São Paulo ,v. 52,n. 5,p. 517-530, Oct. 2012. Disponível em: <http://www.scielo.br/scielo.php?script=sci_arttext\&pid=S0034-75902012000500004\&lng=en\&nrm=iso>. Acesso em 17 Ago 2017

CUKIERMAN, H.L.: Abrindo mão da polarização entre o técnico e o social/cultural , Pesquisas e Práticas Psicossociais 6, n.2, São João del-Rei, agosto/dezembro 2011. Disponível em: $<$ https://www.ufsj.edu.br/portal2repositorio/File/revistalapip/volume6_n2/Cukierman.pdf>, Acesso em : 17 ago 2017.

FIGUEIRÔA, SILVIA FERNANDA M. As Ciências Geológicas no Brasil: Uma História Social e Institucional, 18751934, Hucitec, 1995.

GOVERNO DO ESTADO DO AMAZONAS: Mensagem do governador do Omar Azis à Assembleia Legislativa Balanço 2011/2012/2013, p.346. Disponível em:

<http://www.amazonas.am.gov.br/content/uploads/2014/02/MENSAGEM2014.pdf > Acesso em 30 set 2017.

LATOUR, Bruno, Ciência em Ação: como seguir cientistas e engenheiros sociedade afora. São Paulo. Ed.Unesp, 2000.

, Cogitamus: Seis cartas sobre as humanidades científicas. São Paulo: Editora 34, 2016.

LIMA, Maria Teresa A. : Banda Larga, expectativas para o Norte, Revista T\&C Amazônia, Ano VIII, Número 18, I Semestre de 2010, Fundação Centro de Análise, Pesquisa e Inovação Tecnológica (Fucapi), p.38, 2010. Disponível em: <http://tecamazonia.com.br/wp-content/uploads/2017/03/revista_tec_ed18.pdf > Acesso em 30 set 2017. 


\section{CRIATIVIDADE SERVINDO LINHAS DE FUGA EM DUAS HISTÓRIAS DE INVISÍVEIS - UM ESTUDO CTS}

Marcia de Oliveira Cardoso - LadoB/NCE/UFRJ - marcia@nce.ufrj.br

Resumo

Em 2017, dois eventos enfatizaram a importância da preservação da memória da UFRJ, convidando a comunidade para uma reflexão sobre o fazer e saber cotidiano da instituição. Muitos destes saberes e fazeres ainda são invisíveis, cotidianos do Lado B, e não fazem parte de uma chamada "história oficial" - dos gestados dentro de um mainstream. Neste grupo, estão os que, com criatividade, optam por linhas de fuga para produzir um conhecimento localizado. Portanto, em comemoração aos 100 anos da UFRJ, este trabalho traz duas histórias que envolvem elementos heterogêneos e criatividade para produzir fato e artefato. Uma, é a história de um cabo necessário para conectar um teclado musical a um computador; a outra, é a história dos malabarismos feitos para se mudar a forma de edição de vídeos.

Palavras-chave: Estudos CTS. História das Técnicas. História das Ciências. MIDI Kit. Edição Não Linear.

Introdução - por onde entrar para apresentar as histórias?

Em 2017, a Universidade Federal do Rio de Janeiro (UFRJ) foi palco de dois eventos diretamente relacionados com a história da própria instituição, que fará 100 anos em 2020. Os eventos incentivaram que os trabalhos inscritos procurassem refletir e debater sobre a construção histórica e cotidiana da UFRJ, sinalizando a importância da preservação de documentos e depoimentos, dos "lugares de memória", dos artefatos e dos saberes e fazeres no cotidiano da vida universitária e da "representação dos indivíduos que se reconhecem como parte integrante do patrimônio cultural da UFRJ".

Empolgada com estes eventos, que de certa forma buscam, nos textos escritos e inscritos, dar historicidade à UFRJ, decidi apresentar duas histórias que ocorreram no Instituto Tércio Pacitti de Aplicações e Pesquisas Computacionais (NCE). Uma vez que muitos dos saberes e fazeres cotidianos da universidade são ainda invisíveis - cotidianos do lado B, creio que estas histórias podem possibilitar um olhar para os que optaram por caminhos diferentes do estabelecido em uma chamada "historia oficial", fazendo-se perceber o momento da criação de um conhecimento localizado, experimentos de inovação e estabelecimento de novas inscrições que tornem fatos e artefatos estabilizados, mesmo que seja uma estabilidade efêmera. Ao mesmo tempo, creio que estas histórias também permitem apontar holofotes para o palco dos diversos atores humanos, quase sempre coadjuvantes e invisíveis no mainstream, encontrados ao seguirmos suas linhas de fuga. Agentes que, muitas vezes fogem de um saber e fazer universal, e enveredam por seus próprios caminhos, quase sempre localizados. São histórias onde a criatividade transborda, transforma posições e rearruma relações de poder para além de enquadramentos obtidos a priori de um caminho dito universal.

Primeira história - desenvolvendo o cabo adaptador MIDI

O primeiro relato, da década de 1990, segue a trajetória do cabo MIDI Kit, um cabo necessário para conectar um teclado MIDI a um microcomputador do modelo PC 486 da época. Esta é a história da construção coletiva deste adaptador, apresentando uma rede de atores 
heterogêneos, entre eles engenheiros, analistas de sistemas, computadores, teclados MIDI, cabos, programas, sistema operacional. Esta é uma história que procura seguir a primeira regra do método de Bruno Latour (1997, p. 13), que versa sobre a observação de fatos e máquinas durante a sua construção, sem nenhum preconceito sobre o que constitui o conhecimento, onde observamos o trabalho dos envolvidos, as incertezas e as decisões tomadas no momento.

Em 1989, consta que Moacyr de Paula Moreno estava trocando seu computador pessoal PC modelo 386 SX por um PC 486, mais moderno e ideal para seus projetos em Computação Gráfica. O problema é que ele também realizava experimentos com arquivos digitais no formato wave e MIDI, ligando teclados ao computador, e esta mudança de computador tornaria obsoleta sua interface MIDI da Roland, denominada MPU4016, um periférico de conexão dos instrumentos. Uma possível solução para o problema seria utilizar a placa de som, que estava instalada no novo computador e já incorporava a tecnologia MIDI. Porém, para fazê-la funcionar foi necessário importar dos Estados Unidos (EUA) um cabo especial.

A história poderia parar aqui: com a importação do cabo Moacyr poderia continuar com suas experiências sonoras e o cabo continuaria uma caixa-preta, um ponto estabilizado nesta rede. Porém, para Moacyr interagir com colegas músicos utilizando esta tecnologia MIDI, seria necessário mais cabos adaptadores. Desta forma, após verificar que a especificação para a montagem do MIDI Kit estava disponível na WEB, Moacyr, em uma versão de "Eu quero o que você quer", descrita por Bruno Latour (1987), recorreu a um outro funcionário do NCE, o engenheiro eletrônico Diogo Takano. Segundo Latour (1987, p. 108) a primeira e mais fácil maneira de achar pessoas que acreditem imediatamente no fato, invistam no projeto ou comprem o protótipo é construir o objeto de uma forma que atenda aos interesses explícitos destas pessoas. Neste sentido, Takano foi convencido pela possibilidade de projetar um cabo simples e de baixo custo, ainda não existente no país. E estes eram pontos que interessavam ao engenheiro, e atenderam aos interesses (LATOUR, 1987, p. 108) já manifestados por Takano, na busca de projetos de possível aceitação comercial.

No desenvolvimento do protótipo do MIDI kit, segundo o esquema original, Takano se deparou com diversos obstáculos que encareceriam o produto final. Portanto, para produzir um cabo barato, o esquema de implementação deveria ser outro. Desta forma, ele decidiu construir um novo esquema, onde efetuaria testes com componentes eletrônicos substitutos, muitas vezes obtidos no descarte tecnológico da empresa. Para Latour (1987, p. 124), escolhas devem ser feitas pois não podemos ligar elementos entre si de forma aleatória - escolher significará rearrumar as alianças e estabelecer novas relações. E no desenvolver do cabo, é possível identificar o fortalecimento e o enfraquecimento das ligações (alianças) entre os elementos, como resultante dos caminhos escolhidos: Moacyr, Takano e o esquema original, primeiramente; Takano e o esquema criado para obter baixo custo, posteriormente, e o abandono do esquema original. Assim, aos poucos, a relação de Moacyr com o esquema acaba, e uma outra associação aparece quando Takano pede para ele testar o protótipo. Desta nova associação, surgem alguns novos elementos como a confecção de uma extensão no Kit para o uso simultâneo de joystick e do cabo MIDI, tamanho ideal do cabo para uso em estúdio de gravação (onde se tem equipamentos geralmente longe dos instrumentos). Tudo isto acabou sendo considerado por Takano, desde que não encarecesse o produto final. E o cabo ficou assim, estabilizado com as escolhas de Takano, agora porta-voz (LATOUR, 1987, p. 71) do esquema.

Quer saber como termina esta história? Só posso terminá-la provisoriamente, informando que o cabo foi comercializado pela Lay-Cab. Se ele ainda é vendido, esta é outra história.

Segunda história - ensinando a edição não linear de vídeos 
Esta história ocorreu em meados da década de 1990. Ela versa sobre a adoção de computadores como ferramentas auxiliares que, aliados aos sistemas de edição não linear, estabeleceram uma mudança nos processos de produção de vídeos, incorporando elementos, humanos ou não, e linguajar da área de informática (aqui cito programadores, técnicos, arquivos de dados, formatos, compressão, digitalização) até então não utilizados na arte de edição de vídeos - as empresas produtoras de vídeos utilizavam o processo de edição linear. Se observarmos que hoje os sistemas de edição não linear estão bastante naturalizados nesta produção, nem imaginamos o quanto a introdução desta tecnologia possa ter sido complexa. Afinal, se a tecnologia estava pronta e importada não deveria ser simplesmente utilizada? E, como no artigo de Gary Lee Downey sobre a tecnologia CAD/CAM (DOWNEY, 1995, p. 83), a introdução do sistema de edição não linear, de alguma forma, auxiliou o desenvolvimento de técnicas de edição de vídeo, melhorando a qualidade do produto final. E estes fatos não bastariam?

A análise da adoção da edição não linear, sobre uma ótica construtivista (RIP et all , 1995), pode ser conceituada não como uma força independente que atuou sozinha, instalando-se sem critérios, mas como uma tecnologia que foi introduzida através de movimentos complexos, onde a sociedade interage, ajusta-se, e a dirige e modifica. Vendo sobre esta lente, perguntas sobre quem usa, quem é privilegiado, quem perde, quais as relações de poder e quais as diferenças geradas nos movimentos da introdução da tecnologia podem ser respondidas. Desta forma, na adoção de sistemas não lineares para vídeos, poderíamos levantar algumas controvérsias, quanto à forma de trabalho nas empresas produtoras, quanto à transformação na carreira dos editores, ou até mesmo o descortinar de opções implementadas pelos programas de computadores. Neste sentido, ainda podemos perguntar: como resolver as dificuldades de operar o computador? Como encarar as novas terminologias? E é este primeiro passo que apresento nesta história ${ }^{1}$.

Editar um vídeo é basicamente selecionar um determinado material gravado de algumas fitas, as fitas de material bruto, e passá-lo para uma fita denominada master. Na edição linear, os procedimentos de seleção e cópia do material bruto é feito sequencialmente ou linearmente, isto é, o primeiro segmento do material é copiado, seguido do segundo e assim por diante, o que torna quase impossível reordenar os segmentos. Se alguma modificação for necessária, deve-se efetuar a gravação da fita master novamente. Na edição não linear, o processo de seleção e cópia do material bruto começa com a digitalização das imagens, que são transferidas para o disco rígido do computador. O programa de edição não linear, recria na tela do computador alguns dos principais botões de operação dos equipamentos de uma ilha de edição linear e possui ferramentas que remontam o processo da edição de um filme. 0 programa tem como principal característica o timeline, ou janela de construção, onde o editor tem uma visão geral dos segmentos (agora chamados clips). Nesta janela é construída a sequência de vídeos que irá ser copiada para a fita master.

Uma das primeiras dificuldades da adoção da edição não linear, que deveria ser superada, seria a utilização do mouse. O profissional da edição linear possuía pouco ou nenhum conhecimento na área de informática e muitos ignoravam o computador como ferramenta de trabalho. A dificuldade no manuseio do mouse precisou ser superada através de estratégias, como a utilização de jogos de computador básicos, para convencer os editores a fazerem uso do sistema. A segunda dificuldade foi a grande variedade de verbetes em inglês e de novas terminologias (render, formato avi, formato mpeg e jpeg, entre outros). Neste caso, em seus treinamentos, as revendedoras de equipamentos optaram por ensinar apenas o significado dos verbetes geradores de alguma ação significativa na edição. É interessante também perceber que algumas destas palavras foram "aportuguesadas", como é o caso de 
render (traduzir, interpretar) que se transformou em renderizar (com o acréscimo também do substantivo renderização).

Aqui é possível resumir as mudanças em curso: além das transformações do editor, que deveria esquecer anos de refinamento técnico do mundo linear, houve também um rearranjo dos papéis dos envolvidos. Para a edição linear de vídeo, havia, em geral, especialista em vídeo, especialista em áudio e operador de caracteres. Cada um executava determinada tarefa, dirigidos pelo diretor de artes - o maestro. A adoção da edição não linear concentrou as fases de edição em um só ambiente, onde o operador do programa navegava em todos os papéis. Antes, a construção do vídeo estava centrada na qualidade dos equipamentos da ilha de edição linear e os clientes procuravam a produtora com melhores equipamentos. Com a edição não linear, a construção passou para as mãos de quem utilizava o programa, uma vez que não existem diferenças significativas na qualidade digital. E os clientes passaram a procurar as produtoras pela qualidade do editor.

Por fim, a introdução da edição não linear fortaleceu a ligação dos computadores com os vídeos e permitiu o aparecimento de um grupo especialista em informática que, apto para lidar com a tecnologia, se posicionou na rede através da oferta de cursos de edição. Na UFRJ, através dos cursos elaborados pelo Moacyr, o NCE também se posicionou neste grupo. É interessante notar que o perfil dos usuários que procuraram os cursos de edição não linear do NCE até 1999, 60\% não estavam ligados à produtoras; parte deste percentual era formado por profissionais de outras áreas (médica, biológica, química, etc) que desejavam produzir seus próprios vídeos.

E o que aconteceu com os especialistas da edição linear de vídeo? Esta é uma próxima história.

\section{Encontrando fatos e artefatos na ciência do cotidiano da UFRJ}

De acordo com Roberto Leher, "pensar a história é necessário para que possamos seguir forjando o futuro" e, hoje, "a UFRJ se une em torno da necessidade de preservação dos documentos e depoimentos que podem permitir melhor conhecimento e compreensão de sua história". De fato, se observarmos o cotidiano da instituição certamente iremos encontrar os fatos e artefatos capazes de nos fazer compreender o funcionamento atual e os caminhos escolhidos no fazer da universidade, construindo um lugar de fala (CERTEAU, 1982, p. 56), sem distinção do que constitui o conhecimento. Neste sentido, espero que poder dar voz aos que participam destas empreitadas, quase sempre invisíveis, tal qual explorado nas histórias do MIDI kit e da adoção não linear de vídeos, possa contribuir na constituição de um conhecimento localizado, adaptado e criativo.

Referências bibliográficas

CARDOSO, Maria Cristina de Oliveira, Os invisíveis da ciência no Brasil, da periferia para o centro da controvérsia. Um olhar sociotécnico - o "mundo" corporativo a frente do "mundo" acadêmico, 2017.

CERTEAU, Michel de. A escrita da história. Rio de Janeiro. Forense Universitária, 1982.

DOWNEY, Gary Lee. Steering Technology Development through Computer-Aided Design.(pp. 83 -110) in RIP, Arie, MISA, Thomas J., SCHOT, Johan . Managing Technology in Society -The approach of Constructive Thecnology Assessment. Pinter Publishers. 1995.

HORN, Delton T.. Digital Eletronic Music Synthesizers. Tab Books Inc. Second Edition.

LATOUR, Bruno. Science in action. How to follow scients and engineers through society. (1987). Harward University Press. 
RIP, Arie, MISA, Thomas J., SCHOT, Johan. Managing Technology in Society -The approach of Constructive Thecnology Assessment. Pinter Publishers. 1995. 


\title{
O GÊNIO CRIATIVO DE MAX PLANCK E O NASCIMENTO DA FÍSICA MODERNA: DO DESESPERO À REVOLUÇÃO QUÂNTICA
}

\author{
Leticia de Oliveira Castro - Licenciatura em Química da UAB - letocenator@ufrj.br \\ Priscila Tamiasso-Martinho - Núcleo de Estudos em Biomassa e Gerenciamento de Águas - NAB, UFF - pris- \\ martinhon@hotmail.com \\ Angela Sanches Rocha - Núcleo de Estudos em Biomassa e Gerenciamento de Águas - NAB, UFF - \\ angela.sanches.rocha@gmail.com \\ Célia Sousa - Núcleo de Estudos em Biomassa e Gerenciamento de Águas - NAB, UFF - sousa@iq.ufrj.br
}

Resumo

Max Planck, físico alemão, é considerado um dos pais da Física moderna, pois introduzindo o conceito de quantização para explicar o comportamento da radiação do corpo negro, abriu caminho para uma melhor compreensão dos fenômenos que até então não eram bem explicados com as bases da Física Clássica. Neste contexto, o presente trabalho faz uma breve revisão sobre o contexto histórico no qual Planck formulou e propôs a quantização de energia existente nas partículas subatômicas, com base na inventividade, conhecimento e perseverança para quebra dos paradigmas e como foi possível romper o status quo.

Palavras-Chave: Planck. Quantização. Criatividade.

Introdução

(sic) Karl Ernest Ludwig Max Planck nasceu em Kiel (norte da Alemanha), a 23 de abril de 1858, quarto filho do advogado Johann J. W. Planck e Emma née Patzig. Aos nove anos de idade mudou-se com a família para Munique, ingressando na Maximilian School, onde se destacou não só pelo bom comportamento, mas sobretudo pelo seu excelente desempenho, sendo um dos melhores alunos em matemática, linguagem e religião. Músico talentoso, cantava no coro da universidade, participava de operetas e chegou a compor uma opereta "Liebe im Wald" ou traduzido para o inglês "Love in the Woods" cujo texto se perdeu (SYMANSKI, 2017; CARDONA; MARX, s.n.). No entanto, ao se formar, aos 16 anos, foi admitido na Universidade de Munique, ainda indeciso sobre que carreira seguir, assistiu, durante o inverno de 1874, as aulas de filosofia, porém optou por fim pela Física, principalmente por gostar das aulas de matemática.

Em 1878, depois de realizar os exames na universidade de Munique, torna-se professor e assume a vaga de seu antigo professor de matemática na Maximilian School. Ainda neste mesmo ano, após uma viagem pelo norte de Itália, assiste as aulas dos físicos Helmholtz e Kirchhoff na Universidade de Berlim, cuja vaga deste último ele ocuparia anos mais tarde, em 1889, nesta mesma universidade (STUDART, 2000).

Em 1879 obtém o título doutorado com a elaboração de uma tese sobre a segunda Lei da Termodinâmica. Esta lei, em geral, tem seu primeiro enunciado associado aos estudos envolvendo máquinas térmicas, realizado pelo físico Sadi Carnot (1796-1832), assim como nos trabalhos do físico Lorde Kelvin (1824-1870) (REIS, 2012, p. 1057-1061). Contudo, vale a pena ressaltar a importância do conceito de entropia para os estudos de Planck, introduzido por Rudolph Clausius (1822-1888), quando propôs a existência de uma quantidade física "cuja variação se encontra relacionada ao sentido em que os processos [físicos] ocorrem" (REIS, 
2012, p. 1057). "Planck acreditava na veracidade absoluta do princípio proposto por Clausius em 1862" (NOBREGA, 2013).

Dois anos depois, ele consegue sua habilitação e o título de membro na Universidade de Munique, ressaltando-se que, ainda sem pagamentos, após recusar o mesmo tipo de colocação em universidades estrangeiras. Foi apenas em 1885 que obteve sua primeira oferta de trabalho remunerado na Universidade de Kiev. Neste mesmo ano, Planck publica um artigo sobre a essência da entropia. Foi então, como citado anteriormente, que em 1889, recebeu o convite para se tornar membro extraordinário na universidade de Berlin, tomando posse do cargo em abril deste ano (SYMANSKI, 2017).

Do desespero à revolução quântica

Planck publica, em 1980, dois artigos nos Annalen der Physik sobre fenômenos térmicos e elétricos em eletrólitos, artigos tão relevantes, que ainda são citados até os dias atuais (SYMANSKI, 2017). Em 1892, é promovido a membro ordinário da Universidade de Berlin. Porém, em 1897, após a publicação de trabalhos que não tiveram um bom impacto, decide se dedicar a investigação de problemas relacionados às teorias termodinâmicas e eletromagnéticas sobre a radiação do corpo negro. Pode-se dizer que este acontecimento foi exatamente o grande marco na carreira deste já reconhecido físico teórico, pois foi a partir deste ponto, que sua genialidade e criatividade se sobressaíram e ele foi além das teorias e modelos propostos até então no estudo de sistemas em nível atômico e subatômico.

Assim, em 19 de outubro de 1900 ela anuncia a lei empírica para radiação do corpo negro, lei essa, cuja derivação teórica, o levou a utilizar uma nova proposta, descrita por ele como um "ato de desespero". Para fazer com que os dados experimentais concordassem com as formulações teóricas, ele se viu obrigado a lançar a hipótese da quantização de energia, iniciando assim, uma nova era para a Física e a Química. Este trabalho é considerado por diversos historiadores, como o marco do nascimento da Física Moderna e introduziu uma das mais importantes constantes da natureza, que se encontra presente em praticamente todas as formulações da Mecânica Quântica, a constante de Planck, “" $h$ ”.

Por volta do final do século XIX, com o surgimento de novos dados experimentais que não podiam ser explicados com base na Física Clássica, que, muito embora fosse eficiente para descrever o comportamento dos sistemas macroscópicos como aqueles ao nosso redor, bem como de astros e planetas, não descrevia bem os fenômenos em nível microscópicos como, por exemplo, o efeito fotoelétrico, as linhas espectrais exibidas pelos elementos químicos e o comportamento da radiação do corpo negro. Como era de se esperar, os cientistas da época tentavam ajustar suas hipóteses de modo a descrever os fenômenos observados sempre segundo a Mecânica Clássica, pois, até este momento, se pensava que as três Leis de Newton seriam capazes de explicar, como dito anteriormente, todos os fenômenos da natureza.

Assim, a cada nova descoberta no âmbito principalmente da óptica, termodinâmica e atomística, ficava claro aos cientistas que seria necessária uma nova teoria para descrever estes fenômenos. Hoje, sabe-se que este quadro só começou a mudar com as conclusões sobre os estudos da radiação do corpo negro elaboradas por Planck.

Experimentalmente verifica-se que qualquer corpo quando aquecido emite radiação, e que esta radiação depende da temperatura a qual o corpo é aquecido. Deste modo observa-se que existe uma relação entre temperatura e radiação emitida e, para facilitar os estudos definiu-se a grandeza radiância, como sendo a quantidade de energia emitida por um corpo, por unidade de tempo e área, num dado intervalo de frequência, $R(v)$. A radiação espectral é característica de cada material e sua distribuição de absorção é igual à de emissão, portanto se um material for um bom absorvedor, ele será também um bom emissor. 
O modelo do corpo negro foi proposto para se estudar as características da radiação emitida por corpos aquecidos, a radiação térmica. $O$ corpo negro é um absorvedor ideal, que absorve toda radiação sem refletir qualquer parcela, portanto ele também é um emissor ideal. Este corpo negro deve absorver e emitir radiação em todas as frequências, dependendo apenas da temperatura em que está (McQUARRIE, 1997).

Verificava-se que a radiação do corpo negro variava com a frequência conforme gráfico apresentado na Figura 1, que tem como características o fato do valor de radiância tender a zero tanto para frequências elevadas quanto muito pequenas, e por apresentar um máximo, cujo valor de frequência aumenta com o aumento da temperatura, além de ter uma radiância que aumenta rapidamente com a temperatura.

Figura 6: Radiância espectral do corpo negro.

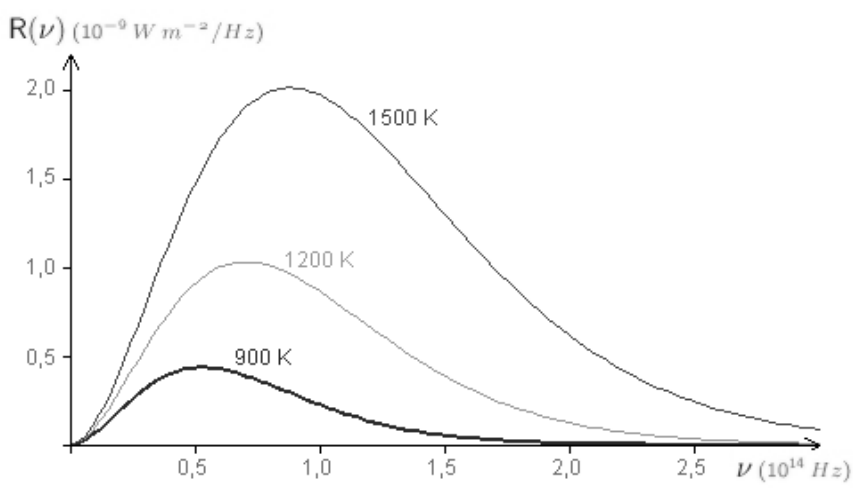

Fonte:

https://www.if.ufrgs.br/ betz/iq_XX_A/radTerm/aRadTe rmFrame.htm

Existiram duas equações fenomenológicas que explicavam de forma razoavelmente satisfatória apenas duas destas características observadas para o corpo negro, a segunda e a terceira apresentadas anteriormente em relação à radiância espectral do corpo negro, a lei de Wien e a lei de Sefan-Boltzmann. No entanto, o fato da radiância tender a zero tanto para frequências altas quanto para baixas, não podiam ser explicadas pelas teorias vigentes na época.

A radiação térmica era um fenômeno bem conhecido e que está relacionado ao fato dos corpos serem compostos por partículas carregadas que sofrem agitação térmica aleatória e, cargas em movimento emitem radiação eletromagnética. Deste modo, deveria ser possível prever o comportamento destes corpos utilizando a mecânica clássica e a mecânica estatística, que descreve o comportamento termodinâmico de conjuntos de muitas partículas. No entanto, o melhor resultado teórico obtido é comumente chamado de "catástrofe do ultravioleta", pois consegue descrever a radiância do corpo negro para baixa frequência, mas resulta numa radiância crescente com o aumento da frequência, caracterizando a falha da teoria clássica em reproduzir o resultado experimental, como apresentado na Figura 2. 
Figura 2 - Radiância espectral do corpo negro obtida experimentalmente e calculada pela teoria clássica.

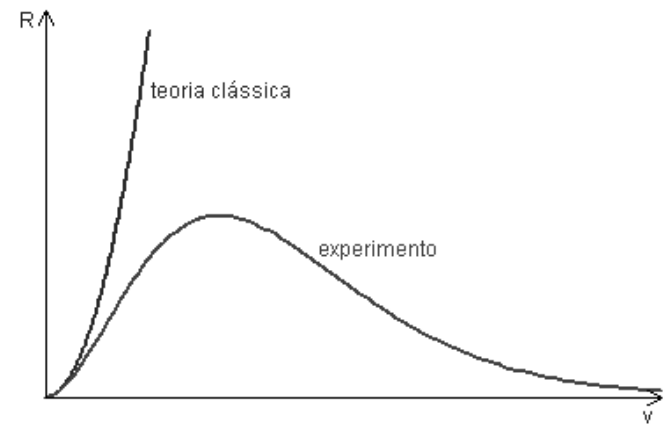

Fonte: https://www.if.ufrgs.br/ betz/iq_XX_A/ radTerm/aRadTermFrame.htm.

Alguns físicos da época, como Lord Rayleigh e James Jean, trabalhavam para desenvolver uma fórmula, seguindo os moldes da mecânica clássica, para descrever este fenômeno, porém obtiveram apenas um resultado razoável em altas frequência. Planck, porém, vendo que seus dados eram inconciliáveis, introduziu o conceito de quantização, propondo que esta distribuição de radiância não era contínua, isto é, não apresentava valores para todas as frequências, mas apenas para valores específicos que não eram contínuos. Deste modo conseguiu derivar uma fórmula simples, que conseguia prever a intensidade da radiação do corpo negro em toda a faixa de frequências, lançando assim, a pedra fundamental da Mecânica Quântica.

Pode-se dizer que muitos cientistas, e até mesmo Planck, não perceberam o quanto esta suposição era revolucionária e o quanto ela mudaria e influenciaria não só a comunidade científica, mas também a nossa sociedade moderna, tanto econômica quanto tecnologicamente, já que, com o advento da Mecânica Quântica, muitos avanços tecnológicos foram possíveis. Até a utilização por Albert Einstein do conceito de quantização para explicar o efeito fotoelétrico, eles pensavam que a equação de Planck: $E=$ hv, não passava de uma curiosidade matemática.

Planck recebeu em 1918 o Prêmio Nobel por sua contribuição para a Física e pela sua teoria quântica. Nos anos que se seguiram, continuou trabalhando na Universidade de Berlim e participando ativamente do ambiente científico, dando suporte a teoria da Relatividade de Einstein, escrevendo vários artigos sobre este tema. Tornou-se emérito desta universidade em1927 sendo sucedido por Erwin Schrödinger. Deixa Berlin apenas em 1943, fixando residência em Elba. Em seus últimos anos se dedicou a escrever sobre religião e filosofia. Max Planck veio a falecer em outubro de 1947.

Considerações finais

Max Planck foi, sem dúvida, um dos maiores físicos do século XX, sendo considerado o pai da Mecânica Quântica. Graças a uma proposta criativa e porque não, impetuosa, revolucionou profundamente o modo como se pensava que os fenômenos físicos em nível atômico e subatômico ocorriam. Introduziu o conceito de quantização para ajustar os dados teóricos aos resultados obtidos experimentalmente para a radiação do corpo negro. Construiu uma carreira sólida na física e teve sua trajetória de vida marcada por grande atividade no meio acadêmico, tendo influenciado grandes físicos, como Albert Einstein, por exemplo. Teve uma carreira reconhecida, que pode ser destacada por ter sido laureado com o Prêmio Nobel de 1918, por sua contribuição para a Física Moderna.

Referências bibliográficas 
CARDONA, M.; MARX, W. Draft: Max Planck - A conservative revolutionary. Disponível em: <http://www.tddft.org/TDDFT2008/lectures/MC5.pdf>. Acesso em: Acesso em: 29, set, 2017.

FONTANA, R. D. B.; SANTOS, I. A. Os enunciados da segunda lei da termodinâmica: Uma possível abordagem. Revista Brasileira de Ensino de Física, v. 35, n.2, p. 3601-3609, 2013.

MCQUARRIE, D. A.; SIMON, D. J. Physical Chemistry: A Molecular Approach. University Science Books. 1997.

NÓBREGA, M. L; FREIRE-JR., O.; PINHO, S. T. R. Max Planck e os enunciados da segunda lei da termodinâmica. Revista Brasileira de Ensino em Física, v. 38, n.1, 1311, 2016.

REIS, M. C.; BASSI, A. S. A segunda lei da termodinâmica. Química Nova, v. 35, p1057-1061. 2012.

STUDART, N. A invenção do conceito de quantum de energia segundo Planck. Revista Brasileira de Ensino de Física. v. 22, n. 4, p. 523-535, 2000.

SYMANSKI, M. Max Planck and his role in the Physics. Kindle Edition, 2017. 


\title{
TECNOLOGIAS DA INFORMAÇÃO PARA FINS SOCIAIS - PESQUISA-AÇÃO NO ESTUDO DA VIGILÂNCIA DIGITAL SOFRIDA POR MOVIMENTOS SOCIAIS NO RIO DE JANEIRO DOS MEGAEVENTOS
}

\author{
Arthur Oscar de Castro \\ Arthur Guilherme Souza \\ Pedro Jullian Medina Torres Graça \\ Pedro Henrique da Costa Braga \\ Camille Costa Perissé Pereira
}

\section{Resumo}

Em um contexto que cada vez mais estão presentes as interações com tecnologias da informação na sociedade garantindo uma maior qualidade e facilidade na comunicação e acesso a informação, se faz então necessário se debater essa interação. A militância de grupos políticos não escapa desse cenário, dadas diversas ferramentas que estão disponíveis para aprimorar a organização e ação, porém ao mesmo tempo aumenta sua exposição, visto que o aparelho repressivo garante cada vez mais uma vigilância massiva em rede. Este trabalho vem apresentar a forma como se organizou um curso de segurança da informação para movimentos sociais utilizando a metodologia da pesquisa-ação e como se deu sua utilização para adequar-se às condições específicas desta ação

Palavras-chave: Pesquisa-ação, TICs, Vigilância

\section{Introdução}

A comunicação é uma necessidade de movimentos sociais devido às necessidades de planejamento, debate e organização, que são cruciais para o funcionamento da militância. Com o advento das ferramentas de tecnologia da informação e da ampliação do acesso à internet, surgem novas oportunidades para otimizar a comunicação dos movimentos sociais, dando possibilidade de acesso à informação e comunicação em tempo real, de divulgar de maneira mais massiva e de superar problemas com relação à comunicação para grandes distâncias. Sob essa perspectiva, diversos grupos hoje mergulham sua militância na rede virtual, o que amplia o alcance e a velocidade da comunicação em relação às ferramentas mais arcaicas. Porém, há que se considerar que essa inserção e acesso a tais benefícios possui um revés: uma possível maior exposição a perigos de vigilância.

No Brasil, o assunto de vigilância foi tomado a cabo com muito empenho pelo Estado, tendo vista os megaeventos que tinham o pretexto de demandar melhorias de segurança, principalmente no setor de inteligência, com a justificativa de evitar atentados terroristas e outros problemas relacionados à violência, que comprometeriam a realização dos eventos, desta forma movendo grandes montantes de dinheiro para esse fim, porém as ferramentas adquiridas poderiam ser usadas com objetivos de vigiar e desarticular movimentos sociais, destruindo uma possível pluralidade política: um pilar importante para uma democracia moderna. Casos como o processo dos 23 presas e presos políticas/os de 2013 demonstram como a inteligência do poder estatal serviu para prender indivíduos por razões, a priori, meramente políticas. Dessa forma, hoje o Estado brasileiro tem ferramentas de vigilância e as usa para acompanhar e rastrear movimentos sociais. 
Assim como o aparato Estatal progrediu em sua inteligência, uma parcela dos movimentos populares, em resposta, desenvolveu métodos para resistir à vigilância, e reutilizou metodologias de segurança já historicamente testadas, visto a tradição de perseguição política perpetrada pelo Estado brasileiro. Possíveis exemplos de novas aplicações de técnicas antigas é a tentativa de comunicação por códigos, em ferramentas digitais. Existe também parte da militância que já se acautela em relação a dispositivos eletrônicos, tomando o cuidado de não transmitir informações sigilosas por meios que sabidamente são inseguros. Infelizmente, esse quadro não é o padrão, pois outros grupos ainda não se inseriram nesse debate e acabam se expondo a riscos desnecessários, o que põe em cheque sua segurança como indivíduos e organizações, e pode também até comprometer a segurança de terceiros. Ao mesmo tempo, o debate do direito à privacidade no âmbito da internet e de todos os outros direitos na web ainda está muito centrado no meio acadêmico e nas populações com maiores recursos, sendo muitas vezes um debate que não atinge nem uma linguagem popular nem os problemas populares. Há uma limitação da academia em conseguir construir um conhecimento que seja de fácil aplicação para quem realmente carece de soluções técnicas. Nesta perspectiva, o projeto Tecnologia da Informação para Fins Sociais, do Programa SOLTEC/UFRJ, vem desde 2016 atuando com a construção de um curso de formação e sensibilização sobre segurança da informação para movimentos sociais. O curso foi desenvolvido a partir da metodologia da pesquisa-ação, já que a ação da elaboração do curso seria muito mais eficiente a partir do momento em que conseguisse reunir o acúmulo de debate das organizações que já aplicam certas táticas, gerando novo conhecimento e aplicando-o através de uma adequação de programa e linguagem, que é muito facilitada graças à participação dos atores e das atrizes na construção da ação e da pesquisa. Tal metodologia permite a produção de um curso que atenda ao máximo às expectativas alçadas das atrizes e dos atores envolvidos/as.

Neste artigo, será descrita a construção do curso de extensão do projeto TIFS/SOLTEC/UFRJ com análise sobre a metodologia da pesquisa-ação e seus princípios utilizados, tendo como principal base o livro "Metodologia da pesquisa-ação" (THIOLLENT,1986). Também serão mencionados o processo da formação dos bolsistas, a execução de seminários de construção e elaboração de apostila, seguidos pela aplicação do curso. Finalizaremos com a discussão dos resultados do curso bem como uma perspectiva dos caminhos seguintes.

\section{Metodologia}

A metodologia empregada pelo SOLTEC para suas ações de extensão universitária é a pesquisa-ação. Essa linha de pesquisa surge da necessidade de uma metodologia de estudos da área social que fosse além das pesquisas embasadas no positivismo. Isso se manifesta nas diferenças das premissas entre as duas linhas metodológicas.

$\mathrm{Na}$ pesquisa-ação, o seu elemento central é a ação, construída em conjunto pelos pesquisadores com os pesquisados, e decidida de forma cooperativa. Assim, a pesquisa-ação está normalmente direcionada para movimentos da sociedade civil e para grupos marginalizados e oprimidos. Isso se dá porque uma das bases da pesquisa-ação é que a ação vá no sentido da transformação da realidade dada para que se possa compreender sobre esta. Não há como entender o mundo social sem participar dele, a pesquisa já é uma forma de intervenção.

Outro importante aspecto da pesquisa-ação é o de ser uma pesquisa própria para análises de conjuntos, uma vez que esta metodologia se ajusta entre o nível microssocial e o nível macrossocial. Pode-se evidenciar isso observando que o foco sempre está na análise de ações e não de aspectos estruturais ou psicológicos. Assim, faz sentido falar de pesquisa-ação em 
um curso ou uma ação de um dado movimento social, mas não em uma pesquisa exploratória sobre o movimento em si.

Desde o início, é muito importante ter claro qual é a ação que se pretende fazer, o que se espera ser o impacto dela e quais são os seus agentes, além de ter clareza entre os objetivos da pesquisa, os da ação e a relação entre eles. Para isso, é importante que se trate os pesquisados como atrizes e atores, diferente das pesquisas convencionais que os tratam como fornecedores de informação, ressaltando aspectos individuais.

Apesar da premissa inicial de intervenção, a pesquisa-ação mantêm algumas das exigências do ideal científico. Ela não deixa de ser um experimento semi-controlado, e, assim, é muito importante o seu caráter participativo e cooperativo, uma vez que somente através do diálogo entre o conhecimento acadêmico e o popular, a pesquisa-ação é capaz de produzir soluções melhores para problemas concretos e novos conhecimentos, mais próximos à população de forma ampla.

3 Construção do Curso de Contra-Vigilância para Movimentos Sociais

Visto a flexibilidade da pesquisa-ação frente a uma ordenação de tarefas (THIOLLENT, 1986, p. 47), desde a concepção do curso houve um planejamento flexível quanto à construção da ação, sabendo que os temas poderiam se repetir ou até mesmo se prolongarem por todo projeto. Os seminários e as hipóteses são exemplos de temas cíclicos que se prolongam por todo o processo de construção do curso.

O primeiro tema da pesquisa é a fase exploratória (THIOLLENT, 1986, p.47-72), que consiste na preparação para o início da pesquisa, sendo feitos os primeiros contatos buscando atores e atrizes interessados/as, recursos financeiros para o projeto buscados e fazendo diagnóstico dos problemas a serem resolvidos pela ação, ressaltando que este diagnóstico previsto pela pesquisa-ação não se assemelha com o modelo de diagnóstico médico, que consiste em uma simples avaliação do especialista sobre o quadro. Em contraste a este, a pesquisa-ação é capaz de produzir o diagnóstico em contato com os grupos pesquisados e com acúmulo sobre o assunto que participam ativamente neste levantamento (THIOLLENT, 1986, p. 48-49).

Paralelamente aos primeiros contatos com os movimentos, era necessário pensar na colocação de problemas, tomando as dificuldades, e assim analisar como sair da situação inicial para a situação almejada. Por conta desse debate, foi analisada a necessidade tanto de uma sensibilização acerca do tema quanto uma formação sobre Tecnologia da Informação e Comunicação (TICs). Dessa forma, foram pensados dois cursos, um mais simples com conteúdo reduzido e com foco principal na sensibilização, e um segundo modelo de curso mais longo com um aprofundamento no debate técnico. Os dois pontos seriam de suma importância, visto que as delimitações da situação atual se dão como um debate incipiente, com pouco conhecimento formal a respeito das TICs, e que o delinear da situação desejada é um debate maduro sobre a questão de segurança pelos atores e atrizes envolvidos/as na ação (THIOLLENT, 1986, p. 53-54).

Após a execução dos primeiros temas da pesquisa e de se elaborar o cronograma do curso com sua importância dada à sensibilização e formação técnica, levou-se ao campo as hipóteses para o primeiro seminário. A pesquisa-ação não busca seleção aleatória de grupos pesquisados, mas sim escolhas intencionais, baseadas nos grupos, as quais os pesquisadores considerem importantes (ALVEAR, 2014, p. 163). Convidou-se, então, representações de grupos de midiativismo, militantes de partidos que lutam por direitos na internet e militância de atuação judicial. Tais grupos foram chamados para esse primeiro seminário por serem os grupos que, a princípio, já possuíam mais acúmulo sobre o tema e poderiam contribuir de maneira notória nos primeiros passos do curso. 
No primeiro seminário, foi fortalecida a hipótese levantada pelos pesquisadores de uma necessidade de cursos com programas e didáticas variadas, pela hipótese levantada de que as ferramentas variariam dependendo do espaço de militância, pela variação de acúmulo de conhecimento formal, idade, classe social. Apesar da necessidade de uma abordagem diferente para cada grupo, foi discutido que um primeiro evento deveria ser generalista e aberto a todos aqueles que militassem, para que, através de um primeiro contato com o tema da vigilância, pudessem estreitar parcerias e elaborar cursos específicos para aquelas e aqueles com interesse.

O desafio da aplicação do primeiro curso se dava em como adaptar o discurso para alcançar uma diferente gama de atores e atrizes e assim conseguir aproximá-los do debate e estimular uma sede sobre a temática. Ficava claro que a modelagem se daria em um curso primordialmente para sensibilização ao tema. Outro desafio seria suprir a demanda de formação em TICs mais seguras que as convencionais, porém tendo tempo escasso, visto o foco na sensibilização. Dessa forma, foi reforçada a ideia da produção de uma apostila com diversos materiais registrados, a qual já havia sido sugerida por facilitar o acesso à informação dos atores e das atrizes após a ação. A apostila foi produzida pelos bolsistas e somada a outros materiais disponíveis pela internet.

Enquanto a apostila era elaborada, mantinha-se contato com as atrizes e os atores que haviam participado do primeiro seminário, mas também era feita uma busca por outros e outras, para divulgação e para auxiliarem na estrutura para aplicação do curso. Foram feitos contatos com diversos sindicatos a fim de se obter apoio com a estrutura, e se conseguiu auxílio financeiro da Sindpetro e do SENGE, este último também oferecendo local para realização.

Mediante a estrutura material acertada e o projeto do curso elaborado, se fazia necessário ainda uma divulgação que conseguisse aproximar do curso uma gama mais variada possível de militantes e que buscasse ao máximo uma paridade de gênero e cor. Foi elaborado um formulário de inscrição, onde seriam colocadas as informações pessoais sigilosas, que serviriam tanto para seleção quanto para debate futuro, o qual foi elaborado no sítio eletrônico da REPOS. Esse formulário foi espalhado por redes sociais.

O formulário tinha por finalidade, além de nos dar uma estimativa da quantidade de atores e atrizes interessados/as por meio das inscrições, fornecer uma coleta de dados dos mesmos. Como o curso foi destinado aos mais variados grupos, naquele momento ainda não tínhamos uma delimitação do campo de observação. Portanto, utilizamos o formulário, tendo em vista, inicialmente, uma larga escala.

A coleta de dados é efetuada por grupos de observação e pesquisadores sob controle do seminário central. As principais técnicas utilizadas são a entrevista coletiva nos locais de moradia ou de trabalho e a entrevista individual aplicada de modo aprofundado. [...] Ao lado dessas técnicas, também são utilizáveis questionários convencionais que são aplicáveis em maior escala. (THIOLLENT, 1996, p. 64)

Os dados obtidos pelo formulário nos forneceram uma estimativa dos perfis dos atores e das atrizes que participariam do curso, e a partir dela escolhemos os temas a serem abordados 1. Após as inscrições serem fechadas foram escolhidas/os as atrizes e os atores, analisando os fatores antes mencionados.

\section{Execução da Primeira Oficina}

O primeiro curso realizado foi denominado "1a Oficina de Segurança Digital para Ativistas". Realizamos a oficina dividindo-a em duas partes: sensibilização e ferramental. A primeira parte destinou-se a uma sensibilização da segurança da informação aos atores e às atrizes envolvidos/as, sendo este o nosso principal objetivo da oficina. 
Encontramos outras situações nas quais os objetivos são voltados para a tomada de consciência dos agentes implicados na atividade investigada. Nesse caso, não se trata apenas de resolver um problema imediato e sim desenvolver a consciência da coletividade nos planos político ou cultural a respeito dos problemas importantes que enfrenta, mesmo quando não se vêem soluções a curto prazo como, por exemplo, nos casos de secas, efeitos da propriedade fundiária, etc. O objetivo é tornar mais evidente aos olhos dos interessados a natureza e a complexidade dos problemas considerados. (THIOLLENT, 1996, p. 18)

Começamos por indagar comportamentos dos atores e das atrizes em relação à segurança e depois citamos alguns exemplos de perseguições a movimentos sociais pelos governos, empresas privadas e indivíduos com objetivos repressivos que usavam as TICs, discorremos numa rápida discussão sobre a utilização das TICs no capitalismo globalizado em uma escala macro e micro, sobre o ambiente de controle da internet e, por fim, um debate sobre a importância da utilização das TICs .

Após um primeiro contato com o assunto, introduzimos um questionário para que as atrizes e os atores respondessem às questões com suas impressões naquele momento da oficina. Denominamos tal questionário por reação. Seriam, ao todo, quatro reações introduzidas, intercalando os assuntos de forma que obtivéssemos respostas coerentes para nossas futuras avaliações.

Por estarmos tratando de um caso em que temos uma limitada quantidade de atores e atrizes por termos como principal objetivo uma sensibilização, nós consideramos que "a pesquisa deve[ria] abranger o conjunto da população que será consultada sob forma de questionários ou de discussões em grupos" (THIOLLENT, 1996, p.62), e estes dados coletados seriam usados na análise da realização da oficina.

Na primeira reação, foram pedidos dados de idade, raça, gênero e espaço de militância. Após a realização dessa, tivemos a colaboração de três palestrantes que foram atrizes e atores dos seminários que realizamos. A oficina havia sido planejada para ter quatro palestrantes convidados, entretanto um deles não pode comparecer.

Introduzimos entre o terceiro e o quarto palestrante, então, a segunda reação, na qual fizemos um mapa de ameaças, que consiste em perguntas sobre por quais grupos ou indivíduos com intenções repressivas as atrizes e os atores se sentiam ameaçados de serem vigiados, e qual deles as atrizes e os atores mais temiam.

Iniciamos, a partir de então, a segunda parte da oficina, a ferramental. Estimou-se a oferecer recomendações a atrizes e atores de como se apropriar das TICs de forma segura. Porém mesma nessa parte buscou-se fugir de uma postura professoral por parte da equipe de pesquisa e usar a discussão das ferramentas como um laboratório que alimentasse a produção de conhecimento de nossa pesquisa-ação.

Ao longo da realização da oficina realizamos mais duas reações: uma com questões relacionadas a uma descrição maior dos motivos de temer a vigilância daqueles listados na segunda reação, e outra, introduzida no final, com um caráter avaliativo da oficina.

\section{Futuros Trabalhos}

Após a realização da oficina nos detemos a avaliá-la e refletir sobre os pontos positivos e negativos da mesma, e também refletir sobre o aprendizado que tivemos com o saber das atrizes e dos atores.

Dentro da concepção da pesquisa-ação, o estudo da relação entre saber formal e saber informal visa estabelecer (ou melhorar) a estrutura de comunicação entre os dois universos culturais: o dos especialistas e o dos interessados. (THIOLLENT, 1996, p. 67)

Este projeto como um todo tem se dedicado fundamentalmente no processo de sensibilização dos atores e das atrizes, pretendendo-se a partir disso aumentar o conhecimento, ou o "nível 
de consciência", das pessoas e grupos considerados (THIOLLENT, 1996, p.16), acerca da vigilância aos movimentos sociais e políticos.

A utilização da pesquisa ação como método tem nos possibilitado mais do que a realização de ações concretas, como a execução da primeira oficina, mas trouxe "uma ampla e explícita interação entre pesquisadores e pessoas implicadas na situação investigada" (THIOLLENT, 1996, p.16), pudemos encontrar através desta interação grupos interessados em nos ajudar a construir a realização de novas ações, e fortalecer ainda mais as redes de atrizes e atores interessados em na continuidade da pesquisa-ação.

Referências bibliográficas

THIOLLENT, Michel. Metodologia da Pesquisa-ação. São Paulo: Cortez: Autores Associados, 1986.

DE ALVEAR, Celso Alexandre Souza. Sistemas de Informação e a construção de propostas coletivas para Movimentos Sociais e processos de Desenvolvimento Local. Rio de Janeiro: UFRJ/COPPE, 2014. 


\section{O DIREITO À CIDADE E MOBILIDADE SOCIAL: UM ESTUDO SOBRE OS TRILHOS QUE CORTAM UMA CIDADE}

Rosemeri da Silva Paixão - Doutoranda na UNIGRANRIO

Rosane Cristina de Oliveira - Doutoranda no Programa de Pós-Graduação em Humanidades, Culturas e Artes da UNIGRANRIO.

Jacqueline de Cassia Pinheiro Lima - Doutoranda no Programa de Pós-Graduação em Humanidades, Culturas e Artes da UNIGRANRIO.

\section{Resumo}

Este artigo tem como principal objetivo discutir a questão do direito à cidade, especificamente em relação ao direito de ir e vir, tendo como objeto de estudo o processo de urbanização e o impacto promovido pela construção da linha férrea na região do município de Duque de Caxias da Baixada Fluminense do Estado do Rio de Janeiro. Neste estudo, apresentamos o resultado de pesquisa realizada com 52 voluntários anônimos, moradores das regiões de fronteira com a linha férrea no município caxiense, através da plataforma google formulários. O formulário foi distribuído nas redes sociais, indagando sobre as vantagens e desvantagens em morar nas proximidades da ferrovia.

Palavras-Chave: Mobilidade Urbana. Direito à Cidade. Baixada Fluminense.

\section{Introdução}

O direito de ir e vir é constitucional e na formação urbana de uma cidade há a necessidade de se pensar em como a população, especialmente nos centros urbanos, se locomovem cotidianamente. Pensar em um meio de transporte público coletivo eficiente e de qualidade é uma das obrigações daqueles que estão gerindo uma Cidade ou um Estado. Neste sentido, refletir como este meio de transporte pode interferir na vida das pessoas que moram próximas às vias férreas é uma questão fundamental no que concerne a sociabilidade e o impacto econômico que atinge a população.

O trem como meio de transporte terrestre, seja ele de transporte público coletivo ou de transporte urbano de cargas, em geral é o mais rápido quando comparado com as rodovias dos grandes centros urbanos, como é o caso do Rio de Janeiro. Nas vias férreas não observamos, comumente, os mesmos problemas das rodovias, como engarrafamentos por excesso de veículos, fechamento parcial ou total por causa de acidentes, dificuldade em procurar novas rotas para chegar ao destino desejado, entre outros. O impacto ambiental também é um fator diferencial entre o transporte ferroviário e o rodoviário, uma vez que carros, caminhões, ônibus poluem mais em decorrência da queima dos combustíveis utilizados por estes veículos. Segundo Vasconcellos (2013, p. 2) "o transporte coletivo consome menos energia e emitem menos poluentes que as viagens de transporte individual. O custo médio por habitante das viagens no transporte coletivo é muito inferior ao custo da viagem no transporte individual".

Neste estudo, chamamos a atenção para o transporte ferroviário e sua importância para a mobilidade urbana, destacando os trilhos que cortam o município de Duque de Caxias, situado na região da Baixada Fluminense do Estado do Rio de Janeiro. É importante salientar o aspecto da formação urbana a partir da construção de sociabilidade e relações econômicas ao longo das ferrovias, uma vez que no meio urbano os trilhos perpassam por inúmeros bairros e, dessa 
forma, é comum uma série de transformações de ordem social e econômica ao longo destas vias.

Do ponto de vista metodológico, além do caráter exploratório e descritivo, apresentamos, brevemente, os resultados a partir da aplicação de questionários através do Google Formulários e distribuída nas redes sociais, que analisou a opinião de 52 voluntários, anônimos, sobre as vantagens e os incômodos em morar próximo a ferrovia e as estações do município de Duque de Caxias.

Direito à cidade, interdisciplinaridade e mobilidade

Os estudos acerca do direito à cidade pautam-se, na perspectiva interdisciplinar, no esforço de abordagem advindas de múltiplas áreas do conhecimento, como a antropologia, sociologia urbana, história social, planejamento urbano, administração, entre outras. Para Japiassu (1976), um estudo interdisciplinar pode ser reconhecido a partir da realização de estudos que incorporem várias especialidades, uso de metodologias e conceitos de diversas disciplinas,

\footnotetext{
"a fim de fazê-los integrarem e convergirem, depois de terem sido comparados e julgados. Donde podermos dizer que o papel específico da atividade interdisciplinar consiste, primordialmente, em lançar uma ponte para ligar as fronteiras que haviam sido estabelecidas anteriormente entre as disciplinas com o objetivo preciso de assegurar a um seu caráter propriamente positivo, segundo modos particulares e com resultados específicos". (Autor, 1976, p. 75)
}

Além da definição apresentada por Japiassu, Olga Pombo (2005), enfatiza que a interdisciplinaridade ocorre para além do diálogo entre áreas de conhecimento. Para a autora, o processo de pesquisa e elaboração de análises interdisciplinares acontece a partir da construção do conhecimento científico a partir do entrelaçamento desafiador entre várias disciplinas, cujo resultado apresenta-se advindo de múltiplos olhares e diversas possibilidades.

As discussões conceituais em torno do Direito à Cidade, questão urbana e mobilidade urbana são fundamentais. Neste estudo destacamos David Harvey no livro "Cidades rebeldes: do direito à cidade à revolução urbana" e Henri Lefebvre com o livro "O direito à cidade", onde os autores proporcionam um debate crítico sobre a urbanização. Harvey (2014), ao dialogar com conceituação de Lefebvre (2001) sobre o direito à cidade, argumenta que a cidade que se quer é resultado do entrelaçamento das relações sociais, "com a natureza, estilos de vida, tecnologias e valores estéticos". Neste sentido, o direito à cidade diz respeito à supremacia do direito comum, do poder coletivo e, dessa forma, os direitos individuais estariam em segundo plano. Portanto, para Harvey (2014, p.2), "é um direito comum antes de individual já que esta transformação depende inevitavelmente do exercício de um poder coletivo de moldar o processo de urbanização. A liberdade de construir e reconstruir a cidade e a nós mesmos é, como procuro argumentar, um dos mais preciosos e negligenciados direitos humanos".

A questão do "direito de ir e vir" em relação as vias férreas, faz parte de algumas abordagens de Jacobs (2011), em "Morte e Vida nas Grandes Cidades", mais especificamente no capítulo intitulado "A maldição das zonas de fronteira desertas". Neste estudo, a autora apresenta uma discussão importante para este artigo, pois relata como as zonas de fronteiras criam bairros decadentes e que a linha férrea é um exemplo clássico de fronteira. Segundo Jacobs (2011, p. 285) "as linhas férreas são um exemplo clássico de fronteiras, tanto que passam a significar, há muito tempo, também fronteiras sociais - 'do lado da linha do trem'” e é possível ver estas diferenças em alguns bairros "cortados" pelos trilhos.

Entre os estudos acerca da Cidade de Duque de Caxias, destacamos Souza (2014) e Lacerda (2001 e 2003), pesquisadores sobre a história da Baixada Fluminense e especificadamente a 
Cidade de Duque de Caxias. Auxiliando a pesquisa sobre a formação da estrada de ferro no Rio de Janeiro, o autor Rodriguez (2004), traz fatores históricos importantes para a construção da memória em relação aos transportes ferroviários no Estado do Rio de Janeiro. Outro referencial importante sobre a história da Baixada Fluminense é a Revista Pilares da História, que enfatiza artigos sobre a História de Duque de Caxias e da Baixada Fluminense com divulgação conjunta do Instituto Histórico da Câmara Municipal de Duque de Caxias e a Associação dos Amigos do Instituto Histórico.

\section{Os trilhos que cortam a cidade caxiense}

As ferrovias, em geral, apresentam problemas estruturais, oriundos de políticas públicas para a área de transportes que não foram bem institucionalizadas. Um bom exemplo são alguns ramais ferroviários destinados à Baixada Fluminense. Nesta localidade, ao longo de sua história, houve uma perda considerável de sua extensão quando se compara às últimas décadas do século XX, com trechos ferroviários abandonados, terminais e estações destruídos. Estas informações fazem parte dos acervos e demais pesquisas realizadas pela Sociedade de Pesquisa para Memória do Trem.

Foi realizada uma pesquisa, através do Google Formulário, no primeiro semestre de 2017, com 52 participantes, voluntários e anônimos. O objetivo principal foi compreender a formação do município de Duque de Caxias junto a ferrovia que perpassa por três distritos do município (Caxias, Campos Elíseos e Imbariê) e analisar o comportamento das pessoas que moram em torno da via férrea e como estas pessoas se adaptaram a sua travessia para que possam se locomover para estes dois lados da linha férrea utilizado as passarelas, passagens de nível etc.

Dos 52 participantes da pesquisa, $54 \%$ são do sexo masculino e $46 \%$ do sexo feminino; $79 \%$ tem idade entre 25 a 59 anos, $19 \%$ entre 16 e 24 anos e $2 \%$ entre 60 anos ou mais; $46 \%$ com ensino superior, $52 \%$ com ensino médio e $2 \%$ com ensino fundamental; e faixa salarial: $56 \%$ de 1 a 2 salários mínimos, 29\% entre 3 a 4 salários mínimos; $4 \%$ entre 5 a 6 salários mínimos e $11 \%$ acima de 6 salário mínimos.

Os participantes da pesquisa são moradores próximos as estações de trem do município de Duque de Caxias: $10 \%$ em Duque de Caxias; $11 \%$ em Corte 8; $15 \%$ em Gramacho; $6 \%$ em Campos Elíseos; 31\% em Jardim Primavera; 19\% em Saracuruna; 4\% em Imbariê com 4\%; 2\% em Manoel Belo e $2 \%$ em Parada Angélica. Não houveram voluntários moradores próximo à estação Morabi. A proximidade das residências dos participantes, perante a ferrovia foi: $0 \mathrm{~m}$ a 50m: $12 \%$; $50 \mathrm{~m}$ a $120 \mathrm{~m}$ : $21 \%$; $120 \mathrm{~m}$ a $300 \mathrm{~m}$ : $21 \%$ e $300 \mathrm{~m}$ ou mais: $46 \%$.

As vantagens sobre morar próximo a ferrovia, $67 \%$ das pessoas responderam que é vantajoso morar próximo a ferrovia, mas apenas $21 \%$ das pessoas dizem ser mais vantajoso se for próximo as estações de trem, mas $52 \%$ das pessoas acreditam que o bairro não fica mais valorizado por causa da ferrovia e $67 \%$ das pessoas acham que não há áreas de lazer em torno da ferrovia e $50 \%$ pessoas apontam que não há comércio em torno da ferrovia. Uma questão interessante abordada diz respeito às áreas de lazer e o comércio no entorno da ferrovia: apenas $10 \%$ dos que responderam o questionário declararam ser moradores próximos da estação de Duque de Caxias (o "centro de Duque de Caxias"), pois esta área possui mais espaços de lazer e comércio e o principal ponto de deslocamento para outras áreas do município caxiense.

Sobre a ferrovia ser ponto de referência para a residência, $52 \%$ das pessoas que moram mais próximos da ferrovia, responderam que sim, mas os $48 \%$ que moram mais longe da ferrovia, disseram que não, a ferrovia não é ponto de referência para a residência. $E$ isso poderia ser visto como uma vantagem de quem mora próximo a ferrovia e as estações, já que as mesmas podem servir de orientação para encontrar os endereços. 
Áreas de lazer, próximas a ferrovia e que são mais frequentadas são: praças: $58 \%$; feiras livres: 52\%; bares: $46 \%$; teatros: $29 \%$; escola de samba/bloco de carnaval e bibliotecas: $14 \%$; clubes sociais: $10 \%$; áreas esportivas: $6 \%$; feiras temáticas: $4 \%$. Já circos, parques de diversão, shoppings e cinema representaram apenas $2 \%$ de lugares frequentados pelos voluntários que responderam à pesquisa.

A mobilidade de travessia de um lado ao outro é uma questão controversa, pois em diversos pontos da via férrea (que depende de passarelas, viadutos, passagem de nível e clandestinas (são abertos buracos entre os muros da via férrea), são travessias perigosas, com iluminação precária ou nenhuma iluminação, lixo e mato alto onde a população se obriga a correr riscos de assalto e estupro. Alguns assassinatos já ocorreram nas vias férreas da cidade, devido à falta de segurança do local, com pessoas assassinadas de diversas formas, até mesmo jogadas vivas na linha férrea para que o trem as mutilassem. A cidade de Duque de Caxias tem muitas histórias de violência relatadas em vários estudos e as vias férreas também é protagonista destas histórias de violência urbana.

Os participantes da pesquisa revelaram que as formas de travessia da linha férrea utilizadas por eles são: passagens de nível: 42\%; viadutos: 10\%; passarelas: $71 \%$; passagem subterrâneas: $4 \%$; passagem clandestinas: $11 \%$ e outros $11 \%$ revelaram que não há muros entre as ruas/casas e a linha férrea, sendo assim a travessia é livre, ou seja, atravessa a linha sem nenhuma barreira.

Há passagens de nível e passagens de pedestres clandestinas, feitas pelos moradores, cuja finalidade é constituir uma forma mais rápida de atravessar a via férrea. Estes tipos de passagens, em geral, são feitas por "meliantes", e, neste sentido, observa-se que a violência é um dos agravantes relacionados a via férrea, pois estes utilizam a via para consumir drogas e cometer delitos como roubos e assaltos.

As fronteiras criadas pelas vias férreas, observadas pela paisagem urbana por vezes diferenciadas nos dois lados da via, "representam, na maioria das vezes, barreiras" (JACOBS, 2011). Por este motivo, algumas são depredadas, justamente por não serem observadas pela população como uma forma de manter a população em segurança ao atravessar a linha férrea.

As passagens clandestinas são formas mais rápidas e com menor distância para realizar a travessia da linha. A questão da insegurança, em geral, é pormenorizada pelas pessoas, seja porque a passagem regular está distante para um determinado grupo, ou, de certa forma, por um comportamento que ignora os perigos em decorrência da utilização desse tipo de passagem. Jacobs (2011), que traz exemplos de lugares com fronteiras, nos Estados Unidos da América, salienta que estes lugares, em geral, são abandonados, e, portanto, são desertos, pois nenhum empreendimento quer se estabelecer em lugares que restringem a circulação de pessoas. Mas em se tratando de lugares periféricos, como no município de Duque de Caxias, as pessoas continuam construindo residências e utilizando de um "jeitinho" para poderem ultrapassar estas barreiras e circularem de um lado ao outro da via férrea.

\section{Considerações finais}

A mobilidade urbana é fundamentalmente analisada pelo viés capitalista, onde a prestação de serviços sai do direito do cidadão para o direito do capital. A Baixada Fluminense foi palco de grandes transformações geográficas resultando em 13 municípios, formada com pessoas de origens vindas de todos os lugares do Brasil e do mundo, foi explorada para o bem o capital. A população passou e passa por problemas hegemônicos, de violência e ainda por problemas relacionados ao direito de ir e vir, relacionados as zonas de fronteiras criadas pelas ferrovias. Do ponto de vista das políticas públicas urbanas, conforme demonstrado brevemente neste 
trabalho, apresenta resultados ínfimos em relação aos problemas de segurança e estrutura ao longo da linha férrea.

Uma questão fundamental em relação à realidade urbana no entorno da ferrovia que corta a cidade caxiense diz respeito à necessidade de planejamento urbano atender a extensão ao longo da ferrovia, que está desprovida de uma acessibilidade que seja capaz de atender a população com qualidade. Dessa forma, do ponto de vista da mobilidade urbana, o planejamento deve contribuir para que a ferrovia seja vista como algo que vem a somar para as pessoas moram próximas a ela. Jacobs (2011), vê as regiões portuárias (por exemplo) como zonas de fronteiras, assim como as ferrovias, mas havendo uma transformação na qual a população local possa fazer parte do processo, através de pesquisas de opinião e/ou demais instrumentos que salientam o desejo e a necessidade daqueles que habitam a região que se quer planejar urbanisticamente.

Referências bibliográficas

HARVEY, David. Cidades rebeldes: do direito à cidade à revolução urbana. São Paulo: Martins Fontes, 2014.

JACOBS, Jane. Morte e vida de grandes cidades - 3a. Ed. São Paulo: WMF Martins Fontes, 2011.

LACERDA, Stélio. Uma passagem pela Caxias dos anos 60: fragmentos de memória e registros diversos. Duque de Caxias: ed. do autor, 2001.

LACERDA, Stélio José da Silva; VILLAR, Laury de Souza; SOUZA, Marlucia Santos de. A Emancipação Política do Município de Duque de Caxias: uma tentativa de compreensão. Textos sobre a História de Duque de Caxias e da Baixada Fluminense. Órgão de divulgação conjunta: Instituto Histórico Vereador Thomé Siqueira Barreto / Câmara Municipal de Duque de Caxias e Associação dos Amigos do Instituto Histórico. Revista Pilares da História - Ano II, no 03, dezembro de 2003. 101p.

LEVEBVRE, Henri. O direito à cidade. Trad. Rubens Eduardo Frias. São Paulo: Centauro, 2001.

RODRIGUEZ, Helio Suêvo. A formação das estradas de ferro no Rio de Janeiro: o resgate da sua memória. Memória do Trem, 2004.

SOUZA, Marlucia Santos de. Escavando o passado da cidade: história política da Cidade de Duque de Caxias. Duque de Caxias: APPH-CLIO, 2014.

VASCONCELLOS, Eduardo Alcântara de. Mobilidade urbana: o que você precisa saber. São Paulo: Companhia das Letras, 2013. 


\section{O PENSAMENTO DE EDGAR MORIN ATRAVÉS DE SEU LIVRO: MEUS FILÓSOFOS}

Gleyse Peiter - Mestranda no HCTE-UFRJ

Jose Carlos de Oliveira - Professor do HCTE-UFRJ - jcarlos@dee.ufrj

Resumo

As questões de interdisciplinaridade tem nas produções (livros e artigos) de Edgar Morin um representante rico em determinações. Ele não é amplamente discutido nas instâncias internacionais. Não há, por exemplo, edições de suas principais obras em Inglês, como "O Método" (6 volumes). No Brasil há uma extensa tradução de suas obras, em torno de 50 livros. No entanto ele tem sido mais visitado, prioritariamente, por intelectuais da área de Educação. $\mathrm{Na}$ área de Epistemologia ele tem sido considerado, mas não de forma extensiva. O presente texto é uma incursão em uma de suas obras, reveladora e esclarecedora de sua forma de pensar: "Meus Filósofos". Ou seja, a pretensão de nosso artigo é tão somente apresentar em linhas gerais seu pensamento com o intuito de torná-lo mais conhecido no âmbito universitário, pois apresenta ideias instigantes em torno da interdisciplinaridade e pensamento complexo.

Palavras chave: Pensamento Complexo. Dialética/dialógica.

Introdução

Nas páginas iniciais intenciona explicar a origem do livro, ou melhor, por que o escreveu? Em suas explicações ele dá o crédito a seu amigo e filósofo Jean Tellez, e justifica a existência dessa obra como uma revisita aos" espíritos que o formaram e o alimentaram" uma espécie de resgate de sua dívida para com eles. A seguir aponta para a concretude de suas principais preocupação subjetivas, associando a elas informações biográficas, ou ainda, contextualizando-as. Assim nos informa que tendo suas origens em uma família laica, que não Ihe transmitiram nenhuma verdade, nenhuma cultura, apenas o amor pela música - que estará presente em sua relação com a obra de Bethoveen - e não tinha nenhuma herança cultural, um sistema imunológico, que o fizesse rejeitar ideias presentes até então. Desta forma ele buscou a verdade, por conta própria, em fontes diversas, basicamente para duas questões fundamentais de sua existência: "O que posso saber?" de Kant e "O que sei eu", de Montaigne. Essas perguntas jamais o deixaram, transformando-o num vulcão sempre em erupção, explodindo pensamentos e ideias. Ao longo de sua vida, diz ele, se vê sempre preso a um "desespero irremediável e a uma esperança incontrolável", o que faz com que ele buscasse, com todas as suas forças, a compreensão de suas contradições. Para isso, ele teve que agir como "um abelha que faz o mel de diferentes flores", estudando filósofos, pensadores, músicos, escritores, em busca da verdade, em todos os domínios, cuja centralidade era a busca de si mesmo. Nesse trajeto ele entra em contato, como que chama de seus demônios: a dúvida avassaladora; a busca de uma fé; a racionalidade; o misticismo. Neste processo, o filósofo define o cerne da ideia de complexidade: "integrar simultaneamente as múltiplas dimensões de uma mesma realidade, a saber, a realidade humana, as incontornáveis contradições e as inelimináveis incertezas". Por conseguinte, o livro vai mostrar sua relação com cada um dos pensadores apenas no que diz respeito ao estabelecimento dessa complexidade, imersa em contradições. Seguem enumerados os pensadores que deixaram marcas em seu pensamento e quais foram esses pensamentos. 
Evidentemente fez-se um extrato seletivo desses pensamentos, mas que acreditamos serem suficientemente relevantes para mostrar a riqueza de seu pensar.

\section{Heráclito}

Morin tem uma identificação intensa com Heráclito: "sou profundamente heraclitiano", em quem ele encontra a compreensão sobre suas contradições, sendo que a maior parte delas não são superáveis, e portanto, são fundamentais como as seguintes: "o Bem e o Mal são uma coisa só; o caminho da ascensão e o caminho da queda são o mesmo; acordados, eles dormem". Neste sentido, inspirado em Heráclito, o autor reconhece que manter juntas duas verdades contraditórias o protege de uma visão redutora, unilateral e maniqueísta. O que faz ser contra especialistas, que se põe como donos das verdades de seus campos de atuação. Um resultado foi sua elaboração da dialógica, que liga vida e morte de modo "simultâneo e complementar, concorrente e antagônico". Esta dialógica permanece mais próxima da dialética de Heráclito e mais distante da dialética de Marx e Hegel, para quem poderia haver a possibilidade de superação das contradições. A afirmação de que as contradições estão no cerne da ciência, e que "a contradição constituiu um sinal de verdade, enquanto a lógica clássica nos dirá que a contradição é um erro". Morin cita como essencial para entender a Vida, a ideia de Logos, como uma força original, criadora e organizadora, numa metáfora com o Sol - uma bola de fogo da qual se originou o sistema solar, a Terra: a explosão do sol deu origem a um caos desorganizado de onde surgiu a organização e a ordem. Esta contradição mostra o casamento da harmonia com a desarmonia: "se só houvesse discórdia ou desarmonia, tudo se desintegraria; se só houvesse concórdia e harmonia, nada aconteceria". Para ele um dos pensamentos mais intrigantes de Heráclito é o dado por "viver de morte e morrer de vida", expressando uma contradição profunda. O organismo vive da morte de suas células substituídas por células jovens, numa regeneração permanente. Outra expressão de contradição dialógica é "acordados, eles dormem", ou seja, pode-se ter a consciência de que sonho e realidade são interligados. Além disso, não temos consciência da nossa vida, do funcionamento de nosso corpo. A verdade é que ninguém controla o funcionamento de seus órgãos, ou seja, de sua própria existência biológica, portanto cada pessoa é comandada por coisas das quais não são conscientes. A afirmação "o Bem e o Mal são uma coisa só", traz uma ideia de guerra, de conflito, e sua base está na noção de que as forças de desintegração são as forças do Mal (como por exemplo o Big Bang), cujo resultado é a organização, a junção dos átomos, das moléculas, ou seja, do Bem. Portanto o Bem e o Mal resultam da mesma ação deflagradora, como uma coisa só. Ele compara essa força desintegradora do cosmo às forças que nos povoam e que provocam o ódio e a morte. Mas, afirma que o ser humano desenvolve, ao mesmo tempo, forças religadoras, de amor, fraternidade, e com isso, as forças éticas de cada um são as forças de religação. Ao citar "sem a esperança você não encontrará o inesperado", o autor revela seu lado esperançoso - que faz parte de suas contradições dizendo que embora o planeta esteja em ritmo de destruição, descontrole, guerras, ele acredita que "o provável não é certo, mas com minhas frágeis forças, trabalho pelo improvável".

\section{Buda}

A maior lição do budismo para ele é: "nada é permanente, apenas a compaixão do Buda". E, diferentemente do mundo ocidental, esta compaixão se estende a todos os sofrimentos, de todo ser vivo, inclusive dos animais. Esta noção de impermanência, de que tudo é passageiro e não importante, traz um paradoxo: "tudo que é importante para nós, nossos sofrimentos, nossos amores, não são quase nada, mesmo que este nada para nós seja tudo". O budismo aceita o sofrimento como inerente a toda vida, e a morte é apenas um renascimento dentro 
de um ciclo. A cultura ocidental pensa na morte como um "abismo imenso e assustador, no qual no aniquilamos". Assim Morin encontra eco para suas contradições, ao ver no budismo as ideias de ser/nada, vida/morte, nada/tudo.

\section{Jesus}

A contradição não é a questão central neste "mistério que é Jesus, um xamã judeu de um tipo novo". O que atrai Morin é sentimento do perdão. Embora ele não acredite na salvação celeste, fala da necessidade de se emancipar o perdão da religião e transforma-lo numa força ética. O desafio lançado por Jesus para "aquele que jamais pecou que atire a primeira pedra" faz com que o filósofo encaminhe o pensamento para a importância de uma autoética, que significa o "autoexame, a força da dúvida para os próprios atos", que todos devem fazer antes de julgar a outros. Reconhecer o perdão como o núcleo da fé, traz a possibilidade de arrependimento, de redenção, da identificação da virtude, da valorização da ética. Resgata de Jesus a ideia da compreensão da cegueira humana, quando Jesus fala "eles não sabem o que fazem". Para Morin, isto significa que as pessoas não sabem o Mal que fazem, ou se o praticam, é involuntário.

\section{Montaigne}

Uma vez que o essencial para Morin são as contradições, ele se identifica com a tendência cética de Montaigne pois sabe que traz consigo as contradições essenciais da humanidade: a imersão em si mesmo desemboca na condição humana. Todo o sofrimento de Montaigne, como judeu pós-marrano, se reflete em seu pensamento, que desencadeou uma "prática racional e humanista do ceticismo". O respeito de Montaigne por outras culturas - aquelas que foram vítimas dos "conquistadores" -- reforça para Morin a ideia humanista da compreensão e de compaixão pelos perseguidos e pelos oprimidos, resgatando a faceta de Montaigne como pedagogo, do qual toma "emprestado", a ideia da "cabeça bem feita", que será desenvolvida em livro específico.

\section{Descartes}

A identificação de Morin se dá por conta do "penso, logo existo", pensamento de Descartes que joga luz na qualidade de "sujeito que nos torna capazes de refletir sobre nós mesmos". Mas o critica, por ele não perceber a natureza de sujeito de todo ser vivo situando-o fora de qualquer enraizamento biológico. Sua crítica é contundente sobre o "paradigma cartesiano", em que existem duas visões do mundo tragicamente separadas, entre as ciências e a filosofia, que se tornou o grande paradigma do ocidente".

\section{Pascal}

Este pensador é tão importante para Morin quanto Heráclito porque criou um "laço extraordinário e complementar entre a fé, a religião, a razão e a dúvida", com a visão da contradição, do combate e da complementaridade, o que faz com que o autor se identifique com ele desde sempre. A ideia do tetragrama de Pascal, onde estão explicitas as ligações entre fé, religião, razão, dúvida, que se alimentam um do outro, acompanha o sentido profundo da contradição, cerne da complexidade humana - questão essencial de Morin. Em resumo, essa tetralógica mostra que o indivíduo "serve-se dos limites da razão para alimentar sua dúvida; serve-se da dúvida para desvelar uma ordem de realidade superior e inacessível à razão e assim, ele alimenta sua fé e sua religião de dúvida e razão". Essas contradições apontam para uma nova antropologia social complexa, em que o homem é, ao mesmo tempo, demens e sapiens; faber e mitológico; economicus e ludens. Outra questão destacada é sobre a incerteza do conhecimento, pois "uma ciência que acredita esclarecer tudo provoca cegueira; 
a verdadeira ciência é aquela que atinge o conhecimento da ignorância". Então, a ciência tem duas extremidades que se tocam: a pura ignorância, vinda do nascimento, e a ignorância sábia, que se conhece a si mesma. Uma ideia de Pascal apreendida por Morin e essencial em sua obra é "todas as coisas são causadas e causantes, ajudadas e ajudantes, mediatas e imediatas e todas se acham entrelaçadas pó rum vínculo natural e insensível que liga as mais distantes e mais diferentes, considero impossível conhecer as partes sem conhecer o todo, bem como conhecer o todo sem conhecer particularmente as partes". Isto rompe com a linearidade e simplificação do pensamento e traz a complexidade como protagonista de uma nova forma de ação.

\section{Spinoza}

A importância deste pensador para Morin está nas ideias de uma ética que rejeita o ódio, e a profunda necessidade do amor, da amizade. Como um judeu pós-marrano que foi excomungado, Spinoza traz muito fortemente a importância da tolerância, o horror à violência e as perseguições. Neste mesmo caminho, emite uma mensagem mais profunda que liga conhecimento, compaixão, alegria e amor, dando sentido à vida humana. Contribui com a visão de um Deus como natureza, ela mesmo sendo autocriadora e criativa.

\section{Rousseau}

Morin considera este pensador romântico, inovador e profundo, autodidata que interroga sobre a relação do homem com a natureza, na busca da relação umbilical perdida com a natureza e no reencontro com a própria natureza de cada um. Ele é um pensador que conseguiu compreender a individualidade humana constituída de cultura e natureza. Um dos demônios de Morin é a misticismo, então ela fala da ideia rousseauniana de um misticismo que não está ligado à religião, mas pode ser encontrado em outros espaços e momentos, como diante do espetáculo da natureza. A visão de democracia de Rousseau está ancorada na importância do povo, ou seja, para ele, o povo é soberano. Neste sentido, a importância de uma democracia cognitiva, onde os "cidadãos despossuidos do saber" terão acesso ao conhecimento. Novamente, o autor retoma o debate sobre a ciência e a filosofia: "é essencial superar a separação entre a cultura das humanidades e a cultura cientifica". A cultura humanista tradicional e a filosofia ignoram a ciência atual, que no entanto, pode lhes fornecer a mais importante matéria para reflexão e meditação sobre o universo, a vida, o ser humano".

\section{Hegel}

A capacidade de enfrentar as contradições é que joga luz sobre Hegel. Ao se aproximar da obra de Hegel, em plena 2a Guerra Mundial, Morin tem revelado para si mesmo as questões de suas próprias contradições - a fé, a dúvida, a esperança, o desespero - e seus questionamentos nos anos de guerra, a participação na resistência: "é somente com o risco da própria vida que se conserva a liberdade". Morin aceita o pensamento hegeliano da "razão dialética", que "incorpora as contradições que se desenvolvem no antagonismo permanente das ideias" e na dialética pode integrar a "dialógica espontânea", que assume, ao mesmo tempo, as dúvidas e contradições como verdades e forças positivas. Ao aceitar suas contradições, mesmo sem superá-las, Morin adere ao comunismo stalinista e aceita as injustiças provisórias e circunstanciais do regime. Assim que o faz, ele se apropria do conceito hegeliano da "astúcia da razão", em que se age em função de um objetivo, sem saber que se está agindo em prol de algum outro objetivo, e então, pode-se chegar a resultados contrários daqueles que se havia previsto. Após a guerra, Morin não aceita mais a dialética hegeliana, afirmando que há contradições que são insuperáveis e cria, então, o conceito da dialógica, 
para a qual "as contradições são simultaneamente antagônicas, conflitantes e complementares" e é possível enfrentá-las sem superá-las.

10. Marx

Embora reconheça a genialidade de Marx, Morin afirma que o marxismo não o desviou de outras escolas de pensamento, ou seja, ele não se considera um convertido: "Marx não é minha Bíblia, é uma estrela numa constelação". É neste capítulo que o autor mais se refere ao seu livro "Autocrítica", com suas reflexões e críticas ao pensamento marxiano. Morin retoma o conceito do "homem genérico", ligado a uma Antropossociologia - antropologia fundada sobre a individualidade humana, onde estão juntas a natureza e a cultura. Para o autor, o talento maior de Marx está na práxis, que associa a filosofia, a ciência e a ação, sustentada por uma "visão dialética da história humana". Esta mesma práxis seria capaz de "provocar o salto histórico para uma nova sociedade na qual seria abolida a exploração do homem pelo homem, na qual o homem se liberta de suas alienações". Após sua adesão ao comunismo soviético e o posterior reconhecimento de todas as questões inerentes ao regime, Morin promove uma "revisão do seu marxismo", perde a fé na missão histórica do proletariado e adquire novamente a "consciência do caráter problemático de toda ação inserida em contradições entre a utopia e a realidade, o improvável e o provável".

\section{Dostoievski}

Em vários de seus escritos, o autor traz a importância da cultura das humanidades para a vida e a compreensão da condição humana. Ao estudar o humanismo russo em Dostoievski, ele valoriza o primeiro pensamento filosófico que emana das obras deste escritor: "a compaixão pelo sofrimento humano, da tragédia humana, da humilhação, da infelicidade". Morin encanta-se com o escritor russo, pois ele "possui um sentido profundo da contradição, da complexidade e das multiplicidades humanas" e ele revela as virtudes dos malditos e a possibilidade de redenção dos marginais, de resgate dos excluídos.

\section{Proust}

Além de filosofia, música e ciência, Morin considera a literatura muito importante para a construção de seu pensamento, em especial quando ele encontra eco nas contradições e na complexidade. Em Proust, ele destaca a complexidade que aparece em sua obra, que apresenta duas dimensões que parecem exclui-se, ou seja, são contraditórias: a extrema precisão da palavra e a tradução da vida da alma e sentimento. Além disso, ele destaca que o escritor também demonstra um sentido de compreensão humana.

\section{Freud e as psicanálises}

Para o pensamento de Morin a visão de Freud como antropólogo é muito mais importante do que como médico. Ele entende a psicanálise como a "ciência do sujeito que sabe abrir-se à alma humana e à complexidade dos indivíduos". A complexificação do sujeito, do ego, traz à tona o pensamento de Morin sobre indivíduo / sociedade / espécie, sobre o que ele discorrerá no "Método I". Dentre os destaques da obra freudiana, Morin mostra as reflexões sobre a consciência/ inconsciência da morte - como dois opostos, duas ideias contraditórias porem caminhantes do mesmo trilho. Embora faça outras reflexões sobre as análises de Freud sobre religião, mitos, etc.

\section{A Escola de Frankfurt}

Diversos pensadores são aqui citados, dentre eles Adorno, de quem Morin toma a ideia (que ele vai usar em outros livros) "a totalidade é a não verdade", ou seja, a "verdade está no 
dilaceramento, nas contradições, no fim de todas as sínteses afortunadas". Neste capítulo Morin critica a razão instrumental e mostra as diferenças entre a racionalidade - a razão é aberta e reconhece a presença do mistério - e a racionalização, cuja lógica é fechada e nega o real. Outra menção interessante é sobre Marcuse, no que se refere à cultura de massa, mídia e comunicação, o que tem muito a ver com a importância que ele dá ao cinema.

\section{Heidegger}

Com este pensador, Morin apreende as questões sobre o progresso técnico e seus poderes de manipulação e sobre a ampliação da forma de pensar os problemas da humanidade planetariamente. $\mathrm{O}$ autor coloca a importância de Heidegger que o obriga a "repensar, reconsiderar, recomeçar a pensar" e junta ideias essenciais de outros pensadores como Pascal, Rousseau, Marx. Uma das belas ideias de Heidegger, que Morin cita como muito importante para ele é: "o começo não se constrói atrás de nós, mas diante de nós". Ele fala, então, sobre o desafio de nossa capacidade de resistir à crueldade do homem, sobre as possibilidades de metamorfose das pessoas.

16. Os pensadores da ciência e os cientistas pensadores

Neste capítulo, Morin fala sobre a influência dos filósofos e pensadores que souberam ultrapassar a disjunção ciência/filosofia, sempre presente nas questões que ele trata em outras obras suas. Ele cita filósofos que souberam pensar a ciência, filósofos da lógica e dos limites da racionalidade, pensadores polidisciplinares e epistemológicos e cientistas que souberam ser filósofos. Destaque deve ser dado às ideias trazidas da "revolução californiana", onde estão os primórdios do pensamento de seu livro Método 1, que trata da ordemdesordem-organização. Este período em que viveu na Califórnia foi muito inspirador para Morin, e muitos pensamentos são primorosos e fundantes de suas teorias, principalmente sobre a complexidade.

\section{O surrealismo}

A ideia principal aqui é a importância dada à cultura, pela poesia, prosa, cinema, literatura e a música. Morin fala da relevância política deste movimento cultural revolucionário, que nasceu não só contra o mundo prosaico, mas também contar os horrores da 2a Guerra Mundial e da importância do sonho para a vida. Depois disso, Morin ainda cita outros pensadores como Ivan Illich, Kant e finalmente Bethoveen e dizer como a música foi importante para sua formação.

Bibliografia

Morin, Edgar. Meus Filósofos. Porto Alegre. Ed. Sulina, 2014. 


\section{SISTEMAS DIGITAIS DE NAVEGAÇÃO E A INOVAÇÃO NO PLANO DA LINGUAGEM CARTOGRÁFICA ADVINDA DOS MAPAS PORTULANOS}

Wallace Gonçalves Pereira - UFRJ - wallacegpereira@gmail.com

Erica Cristina da Silva Gomes - Doutoranda HCTE-UFRJ - assessoraerica@yahoo.com.br

\section{Resumo}

As cidades possuem um sistema complexo rodoviário, por onde milhões de indivíduos trafegam todos os dias. Como resultado desta intensa circulação de pessoas, há a ocorrência de congestionamentos, incidentes e acidentes de trânsito. Com tais problemas relacionados à mobilidade urbana e o avanço das TICS, o mercado de aplicativos para smartphones encontra uma oportunidade para minimizar tais inconvenientes. Cartógrafos da Idade Média e da Renascença desenvolveram técnicas e produziram elaborados mapas portulanos com a finalidade de guiar e informar os navegadores e os exploradores contemporâneos. Os fundamentos deste conjunto de métodos e procedimentos utilizados nestes mapas, com a implantação de signos, também são empregados nos modernos aplicativos de navegação com sistema de localização.

Palavras-chave: Cartografia. Navegação. Waze.

Introdução

A mobilidade urbana é fator essencial na sociedade moderna, influenciando, deste modo, a qualidade de vida e a eficiência de processos de planejamento das metrópoles e cidades em todo o mundo. Para atender às necessidades complexas e crescentes dos sistemas de transporte urbano, o uso de sistemas digitais representa uma das mais promissoras inovações tecnológicas neste campo. Mas, uma das bases de conhecimento para tal empreendimento não é recente. Este artigo propõe demonstrar que as aplicações para smartphones com sistemas de localização (Location Based Services - LBS), dando destaque ao aplicativo Waze, apropriam-se de técnicas desenvolvidas para produção de mapas medievais e renascentistas nos séculos XV e XVI.

A navegação no século XVI com mapas portulanos

Relatos de viajantes sobre as áreas exploradas pelas navegações aliados à tradição oral e à própria experiência dos cartógrafos foram fundamentais para a produção de mapas medievais e renascentistas nos séculos XV e XVI. Segundo Woodward e Campbell (1987 apud NOGUEIRA E BIASI, 2015, p. 2), 'o gênero cartográfico portulano desenvolveu-se entre os séculos XIII e $\mathrm{XIV}$, sendo considerado a base do aperfeiçoamento técnico para a cartografia científica renascentista'. Continuando,

o padrão denominado Portulano é descrito como uma representação gráfica em escala e de maneira realista da bacia Mediterrânea, feita sobre uma superfície plana (geralmente pergaminho) cruzada por uma rede de linhas construídas a partir das direções dos ventos, sendo sua finalidade facilitar a navegação e determinar com precisão a localização dos portos existentes em torno desta bacia a partir da utilização de bússola e compasso como instrumentos de navegação. (NOGUEIRA;BIASI, 2015, p. 2). 
A princípio, os mapas portulanos foram utilizados para descrever o Mar Mediterrâneo. No entanto com a expansão marítima ibérica tal representação gráfica passou a retratar também a costa ocidental africana, a costa oriental africana e a Índia, e o Novo Mundo (DUTSCHKE, 1989; MELO et al., 2013; KILDUSHEVSKA, 2002).

No século XVIII houve uma mudança na elaboração dos mapas, que tornaram as ilustrações em elementos substancialmente decorativos, sem uma relevância maior nos aspectos cartográficos. Apesar de muitas vezes manterem alguma relação com o espaço geográfico representado, os motivos escolhidos podem assumir independência, havendo numerosos casos de metáforas e composições com variadas figuras mitológicas, bem como, 'representações de caráter histórico destinadas a ressaltar o poderio de um determinado ator político' (TEIXEIRA, 2009, p. 147). Cabe destacar, entretanto, que este gênero cartográfico tem um papel inovador no plano da linguagem cartográfica. Nele são introduzidos símbolos procurando uma padronização para sua interpretação como, por exemplo, atribuição de escalas, linhas de rios esboçados suavemente em azul, nomes dos principais portos e cidades em vermelho, perpendicular à costa, nome dos mares dentro de moldura colorida, desenhos uniformizados de cadeias de montanhas, rotas, vilas e cidades indicadas por ícones e bandeiras, além de bancos de areia e outros acidentes geográficos.

\section{Simbologias}

Todos os mapas são repletos de signos ou símbolos e a escolha destes signos na cartografia não é aleatória. Ela obedece a uma lógica previamente sistematizada. De acordo com Archela \& Théry (2008), 'o signo é constituído por um significante e significado'. Conforme estes autores (2008), há três modos diferentes de implantação de símbolos em mapas:

A primeira é a implantação pontual, quando a superfície ocupada é insignificante, mas localizável com precisão. A segunda é a implantação linear, quando sua largura é desprezível em relação ao seu comprimento, o qual, apesar de tudo, pode ser traçado com exatidão. Por último, a implantação zonal, quando cobre no terreno uma superfície suficiente para ser representada sobre o mapa por uma superfície proporcional correspondente (ARCHELA; THÉRY, 2008).

É possível exemplificar a implantação pontual com as figuras de âncoras simbolizando os portos, a implantação linear por trajetos de rodovias e a implantação zonal pela área de lagoas ou florestas em mapas.

De modo geral, os signos de um mapa precisam estar em consonância com o que é representado. Exemplificando, não é adequado utilizar a figura de um trem para simbolizar um aeroporto. É o que ratifica Oliveira \& Baranauskas (1998, p. 15) quando afirmam que 'um ícone é uma forma de representação através da aproximação formal do signo com o objeto representado'.

Sendo assim, 'os signos são construídos basicamente, com a variação visual de forma, tamanho, orientação, cor, valor e granulação para representar fenômenos qualitativos, ordenados ou quantitativos nos modos de implantação pontual, linear ou zonal' (ARCHELA; THÉRY, 2008).

Mesmo com a utilização das Tecnologias de Informação e Comunicação (TICS) para a exibição de mapas através de telas sensíveis ao toque, os signos continuam a ser utilizados para navegação e orientação. Tais signos, aprimorados através do User Interface Design, permitem não apenas que o usuário os veja e entenda seus significados, mas garantindo uma 
experiência user-friendly, ou seja, uma experiência de utilização amigável da aplicação, que não lhe cause desapontamentos e que não limitada a aparência que esta possui.

Além das variações visuais possíveis, também é viável que os sistemas aos quais tais telas são parte integrante emitam sinais sonoros e/ou orientação por uma voz humana previamente gravada.

A navegação no século XXI com aplicativos para smartphones

Conforme Maziero (2007, p. 3), 'até a década de 1960, os mapas eram apresentados no formato analógico. A partir de então, com a disponibilidade dos recursos computacionais, os mapas passaram a ser apresentados no modo digital'. Com a unificação dos problemas relacionados à mobilidade urbana e o avanço em sistemas digitais cria-se um mercado de aplicativos para telefones celulares com componentes de posicionamento. Os smartphones com sistema de localização (Location Based Services - LBS) 'fornecem aos usuários a capacidade de associar os dados obtidos no exato momento, dividindo-os com todos os outros usuários que possuem o mesmo sistema, tornando-os ativos' (FIRE et al., 2012).

Location-Based Service (LBS) são 'serviços acessíveis com a utilização de dispositivos móveis através da rede móvel de dados e utilizando a capacidade de fazer uso da localização dos terminais' (VIRRANTAUS et al., 2001).

A maioria dos LBS é baseada no Sistema de Posicionamento Global (GPS - Global Positioning System) ou similar. Quando um aparelho habilitado com GPS se conecta a eles, o sistema analisa alguns fatores como tempo de sinal e potência e, depois, utiliza a triangulação para determinar a localização do dispositivo com base na distância e direção dos satélites.

Em um LBS, os compartilhamentos das informações da localização dos usuários são identificadas e monitoradas automaticamente. A operação de LBS envolve diversos atores como operadores de rede, serviços e provedores de conteúdo que, com o intercâmbio de informações entre eles em tempo real, fornecem uma ampla gama de possíveis utilizações.

De acordo com Nowakowski, Green \& Tsimhoni (2003), um sistema de navegação bem projetado pode evitar manobras erradas, reduzir o tempo de viagem e, com esperança, aliviar alguma carga de trabalho do motorista. Entretanto, má usabilidade pode colocar os motoristas na direção errada, aumentar sua carga de trabalho e levá-los a fazer manobras não seguras (NOWAKOWSKI; GREEN; TSIMHONI, 2003).

Existem algumas aplicações para smartphones com sistema de localização, como o Here, o Google Maps e o Sygic, mas para exemplificar, neste artigo são esboçadas algumas reflexões a respeito do Waze, aplicativo gratuito para dispositivos móveis com sistemas Android e iOS. O app, criado em 2008 em Israel e adquirido pelo Google em 2013, 'contava em 2016 com mais de sessenta e cinco milhões de usuários ao redor do mundo' (EXAME, 2016). Enquanto a aplicação está em uso, o software recolhe dados dos smartphones e utiliza-os para cálculo de velocidade nas vias e condições de tráfego. $O$ app oferece aos seus usuários alertas prédefinidos, incidentes como engarrafamentos e acidentes, ampliando assim as informações sobre condições do tráfego.

\section{Os perigos}

Apesar de quinhentos anos de desenvolvimento de mapas e instrumentos auxiliares para navegações, e um pouco mais de vinte anos do avanço das novas tecnologias de informação e comunicação, seja no mar ou em terra firme, perdas de vidas humanas continuam a acontecer por possíveis falhas nesses sistemas de navegação. Admite-se que 'nos séculos XVI e XVII naufragou um navio em cada cinco dos que partiram com destino à Índia' (KOISO, 2004, p. 1). 'Naufrágios por fatores cartográficos, como um mau levantamento do local, aconteciam' (COSTA, 1983, p. 57). Atualmente, um dos riscos é que para driblar rotas congestionadas ou 
seguir por caminho mais rápido, o algoritmo destas aplicações possivelmente trace as rotas passando por áreas perigosas e alguns destes casos terminam em morte (GRAEL, 2015; MOREIRA, 2016; SILVA, 2017).

Há também os registros de naufrágios relacionados a 'fatores humanos, que ocorrem desde os primórdios da navegação, devido a falhas do próprio homem, ou propositalmente' (LIMA, 1975, p. 64-65 apud RIOS, 2011, p. 119).

Mesmo com os problemas relatados, o Google trabalha para minimizar estes problemas, com os alertas de riscos de crime (BARRETO FILHO, 2016). Um ícone vermelho com um ponto de exclamação é exibido na tela do smartphone quando o destino ou o trajeto passe por um caminho com uma incidência maior de crimes. No caso do Rio de Janeiro, o Waze utiliza a base de dados do Disque-Denúncia, um serviço que recebe telefonemas de cidadãos para reportar crimes, e de uma empresa de marketing digital, a fim de definir quais áreas são perigosas. Outra medida é a implementação de barreiras de defesa que detectam se o alerta foi dado em movimento e se na via destacada há o tráfego de diversos motoristas sem redução de velocidade. 'Caso seja constatada fraude, posteriormente, a empresa bane os usuários que fizeram mau uso do sistema' (ZURUARRAIN, 2016).

\section{Considerações Finais}

Cinco séculos depois da criação dos primeiros mapas renascentistas, os pergaminhos foram trocados por telas de LED, os astrolábios por sistemas GPS, os relatos dos navegantes contados aos cartógrafos foram substituídos por LBS, em um ambiente colaborativo. Magalhães (2009, p. 71) menciona o mapa-múndi do alemão Heinrich Hammer (1489), elaborado na Itália, como sendo 'a primeira tentativa de mostrar a passagem entre os oceanos Atlântico e Índico pelo sul da África, supostamente após receber informações dos portugueses'. O navegador Bartolomeu Dias, quase um ano antes, havia descoberto esta passagem.

Guardadas as devidas proporções e peculiaridades das motivações do desenvolvimento tecnológico em prol do deslocamento mais assertivo nos mares dos séculos XV e XVI, atuais aplicativos como o Waze, descrito mais detalhadamente neste artigo, também são projetados de modo a garantir a indicação de uma mobilidade mais informativa e preventiva nos territórios das grandes cidades. Através de conexões de internet móvel, tais apps são capazes de transmitir quase que em tempo real a outros usuários acidentes ou interdições na via. No entanto, assim como falhas humanas e imprevistos provocaram naufrágios no passado, hoje, no que se refere à garantia de segurança para os usuários dos aplicativos anteriormente citados, também há riscos de incidentes que a tecnologia ainda não conseguiu minorar ou impedir.

Sendo assim, a inovação no plano da linguagem cartográfica advinda dos mapas portulanos é fundamental para o êxito na navegação através de dispositivos móveis. A implantação de signos pontuais dinâmicos e a facilidade e rapidez em modificar símbolos lineares torna a navegação com smartphones ou qualquer outro dispositivo com sistema de navegação e conectado a uma rede móvel uma tendência para anos vindouros, a princípio como um elemento acessório e, posteriormente, como um item de série, a ser parte complementar dos computadores de bordo veiculares.

Mas, apesar de toda perspectiva otimista, a mobilidade pautada em informações obtidas através de aplicativos via internet ainda traz seus riscos e desafios, afinal a tecnologia para navegação ainda precisa lidar com esta imprecisão.

Referências bibliográficas: 
ARCHELA, Rosely Sampaio; THÉRY, Hervé. Orientação metodológica para construção e leitura de mapas temáticos. Confins [Online], v. 3, 2008.

BARRETO FILHO, Herculano. Waze Mapeia 25 áreas com risco de crime no Rio. In: O Dia < http://odia.ig.com.br/rio-de-janeiro/2016-08-03/waze-mapeia-25-areas-com-risco-de-crime-no-rio.html>. Acesso em: 08 out 2017.

DA COSTA, Francisco Augusto Pereira; DE MELLO, José Antônio Gonçalves. Anais pernambucanos: 1795-1817. Governo de Pernambuco, Secretaria de Turismo, Cultura e Esportes, Fundação do Patrimônio Histórico e Artístico de Pernambuco, Diretoria de Assuntos Culturais, 1983.

DUTSCHKE, Consuelo W. et al. Guide to medieval and renaissance manuscripts in the Huntington Library. San Marino, Calif.: Huntington Library, 1989.

EXAME. Waze chega a 3 milhões de usuários em São Paulo. In: Exame < http://exame.abril.com.br/tecnologia/waze-chega-a-3-milhoes-de-usuarios-em-sao-paulo/>. Acesso em: 08 out 2017.

FIRE, Michael et al. Data mining opportunities in geosocial networks for improving road safety. In: Electrical \& Electronics Engineers in Israel (IEEEI), 2012 IEEE 27th Convention of. IEEE, 2012. p. 1-4.

GRAEL, Fernanda. Casal entra em favela do RJ por engano e mulher morre baleada. Disponível em: Jornal Hoje < http://g1.globo.com/jornal-hoje/noticia/2015/10/casal-entra-em-favela-do-rj-por-engano-e-mulher-morrebaleada.html>, 17/06/2017.

HALÁSZ, Iwan Thomas. Handbook do radioamador. Editora da Universidade de São Paulo, 1993.

HAMMER, Heinrich. 1489. Map of the world of Christopher Columbus. In: Yale University Library <http://brbldl.library.yale.edu/vufind/Record/3435243>. Acesso em: 08 out 2017.

KILDUSHEVSKA, Liudmila. 2002. Atlas Universal de Diogo Homem. Barcelona: M. Moleiro.

KOISO, Kioko. 2004. História Trágico-Marítima: factos revelados em documentação inédita. Portugal.

MAGALHÃES, Joaquim Romero. 2009. Mundo em miniatura: aproximação a alguns aspectos da cartografia portuguesa do Brasil (séculos XVI a XVIII). Anais do Museu Paulista. v.17. n.1. 69-94. São Paulo.

MAZIERO, Lucia Teresinha Peixe. Influência dos aspectos das interfaces na comunicação dos mapas interativos e a proposição de diretrizes para o design dessas interfaces. Diss. Universidade Federal do Paraná, 2007.

MELO, Maria João et al 2013. Atlas universal de Fernão Vaz Dourado, 1571. Barcelona: M. Moleiro.

MOREIRA, Gabriela. Waze levou homens da Força Nacional à favela onde foram baleados. In: ESPN < http http://espn.uol.com.br/noticia/621336_waze-levou-homens-da-forca-nacional-a-favela-onde-forambaleados>. Acesso em: 08 out 2017.

NOGUEIRA, Magali Gomes; BIASI, Mario de. Fontes e técnicas da cartografia medieval portulano. Terra Brasilis (Nova Série). Revista da Rede Brasileira de História da Geografia e Geografia Histórica, n. 4, 2015.

NOWAKOWSKI, Christopher; GREEN, Paul; TSIMHONI, Omer. Common automotive navigation system usability problems and a standard test protocol to identify them. In: ITS-America 2003 Annual Meeting. 2003.

DE OLIVEIRA, Osvaldo Luiz; BARANAUSKAS, M. Cecília Calani. A Semiótica e o Design de Software. 1998.

SAWAYA, Márcia Regina. Dicionário de informática \& Internet. Nobel Editora, 1999.

SILVA, Ânderson. Turista gaúcha é morta ao entrar por engano em comunidade do Norte da Ilha, em Florianópolis. In: Diário Catarinense <http://dc.clicrbs.com.br/sc/noticias/noticia/2017/01/turista-gaucha-e- 
morta-ao-entrar-por-engano-em-comunidade-do-norte-da-ilha-em-florianopolis-9033609.html>. Acesso em 08 out 2017.

TEIXEIRA, Dante Martins. Todas as criaturas do mundo: a arte dos mapas como elemento de orientação geográfica. Anais do Museu Paulista: História e Cultura Material, v. 17, n. 1, p. 137-154, 2009.

VIEIRA, Vaninha et al. The UbiBus project: Using context and ubiquitous computing to build advanced public transportation systems to support bus passengers. Anais do VIII Simpósio Brasileiro de Sistemas de Informação, p. 7, 2012.

VIRRANTAUS, Kirsi et al. Developing GIS-supported location-based services. In: Web information systems engineering, 2001. Proceedings of the Second International Conference on. IEEE, 2001. p. 66-75.

ZURRIARRAIN, José Mendiola. Os 'sabotadores' do Waze. In: El País < http://brasil.elpais.com/brasil/2016/06/13/tecnologia/1465831215_171961.html>. Acesso em: 08 out 2017. 


\title{
ATENDIMENTO PSICOLÓGICO ONLINE: ACOMPANHANDO A CONSTRUÇÃO DE UMA PRÁTICA
}

\author{
Marcelo Pinheiro da Silva - Doutorando no HCTE - UFRJ - marcelo@igt.psc.bt
}

Tema

O ritmo da evolução do desenvolvimento tecnológico tem se acelerado em progressão geométrica. A velocidade desta evolução impacta diretamente o modo de vida contemporâneo. Artefatos tecnológicos têm ampliado de forma marcante as possibilidades de comunicação entre humanos.

$\mathrm{Na}$ atualidade, inegavelmente, o instrumento de comunicação mais poderoso que tem invadido os lares e as vidas de forma avassaladora é a Internet. Esta janela para o mundo vem ocupando espaço em grande parte dos eletrodomésticos, e este processo tende a se intensificar cada vez mais.

Tal qual o peixe, que não tem como entender a água sem sair dela, é bem difícil compreender a intensidade do impacto destas transformações, sem olhar com muita atenção para as mudanças performadas por este dispositivo. Estamos presenciando um dos períodos da história da humanidade em que as transformações sociais estão se dando de forma mais veloz. Nas últimas décadas, o desenvolvimento da grande rede, a Internet, tem mexido com hábitos, costumes e principalmente com as relações humanas como atesta Lima:

\footnotetext{
Vivemos uma revolução em todos os aspectos da vida, sem precedentes na história. A grande transformação que as novas tecnologias de informação e comunicação promovem nas categorias de espaço e de tempo, possibilitando a emergência de uma comunicação em tempo real num espaço virtual, tem produzido efeitos nas mais diversas áreas, ajudando a derrubar barreiras que, historicamente, separam os elementos da identidade nacional dos povos, como a língua, as tradições, os costumes, etc. (LIMA, 2012)
}

A Internet se mostra como um importante meio de comunicação pela facilidade de acesso, pela rapidez com que as informações se propagam na rede, pelo poder que confere a cada usuário. Hoje uma pessoa anônima, sem muito investimento financeiro, pode criar uma mensagem interessante, que consiga gerar mobilização e com isso atingir um número astronômico de pessoas com este conteúdo, em um tempo extremamente curto. Estas características geram uma mudança extraordinária na possibilidade de comunicação entre os cidadãos comuns. Ocorre uma redistribuição na capacidade de comunicação de uma forma geral.

A grande rede se mostra capaz de conectar as pessoas quase que de forma contínua. Um exemplo disso pode ser observado quando examinamos a rotina de uma parcela bem razoável dos estudantes de classe média de ensino fundamental e ensino médio. Eles se mantêm conectados, mesmo nos períodos em que não estão em seus ambientes escolares. Fazem isso utilizando os celulares, as redes sociais e os programas de comunicação direta via Internet como o Skype, Whatsapp, Viber, MSN, Facebook, entre outros. É evidente, que, para o bem ou para o mau, isso gera grandes mudanças no tipo de relação estabelecida entre estes estudantes, quando comparamos com gerações anteriores. Propicia uma intimidade muito maior entre eles, muda, entre outros aspectos, a importância da distância geográfica no contato entre pessoas, promove transformações em quase todos os âmbitos relacionais. Cabe ressaltar que este fenômeno tão perceptível quando observamos essas novas gerações também se faz presente em vários outros âmbitos das relações sociais desenvolvidas em nosso tempo. 
Dentro desse contexto o psicólogo se vê desafiado a acompanhar estas transformações, sem, contudo, abrir mão dos cuidados éticos necessários à construção de uma nova prática. Atualmente, o Conselho Federal de Psicologia - CFP, através da Resolução CFP № 011/2012, regula a atuação do psicólogo no que se refere a práticas que utilizem recursos associados à virtualidade. São reconhecidos e autorizados, através desta resolução, como serviços psicológicos de comunicação à distância as atividades descritas no fragmento abaixo:

I. As Orientações Psicológicas de diferentes tipos, entendendo-se por orientação o atendimento realizado em até 20 encontros ou contatos virtuais, síncronos ou assíncronos;

II. Os processos prévios de Seleção de Pessoal;

III. Aplicação de Testes devidamente regulamentados por resolução pertinente;

IV. A Supervisão do trabalho de psicólogos, realizada de forma eventual ou complementar ao processo de sua formação profissional presencial;

V. O Atendimento Eventual de clientes em trânsito e/ou de clientes que momentaneamente se encontrem impossibilitados de comparecer ao atendimento presencial.

VI. Parágrafo Único: Em quaisquer modalidades destes serviços a(o) psicóloga(o) está obrigada(o) a especificar quais são os recursos tecnológicos utilizados para garantir o sigilo das informações e esclarecer o cliente sobre isso.(Resolução CFP № 011/2012)

$\mathrm{O}$ atendimento psicoterapêutico online ainda não é uma prática aceita pelo CFP (Conselho Federal de Psicologia). Atualmente ele só pode ser realizado com fins de pesquisa. Será necessário o desenvolvimento de estudos cuidadosos que comprovem a validade desta forma de atuação para que ela seja considerada definitivamente uma prática aceita para a atuação do psicólogo. A Resolução № 011/2012 explicita:

Art. $9^{\circ}$. O Atendimento Psicoterapêutico realizado por meios tecnológicos de comunicação a distância pode ser utilizado em caráter exclusivamente experimental, desde que sejam garantidas as seguintes condições:

I. Apresentar certificado de aprovação do protocolo em Comitê de Ética em Pesquisa, conforme os critérios do Conselho Nacional de Saúde do Ministério da Saúde.

II. Respeitar o Código de Ética Profissional da(o) psicóloga(o);

III. É vedado ao participante pesquisado, individual ou coletivamente, receber qualquer forma de remuneração ou pagamento;

IV. A(o) psicóloga(o) deve se comprometer a especificar quais são os recursos tecnológicos utilizados no seu trabalho e buscar garantir o sigilo das informações;

V. As informações acima citadas deverão constar de forma visível e com fácil acesso no site que realiza a pesquisa.

Parágrafo Único: Nos casos de atendimentos psicoterapêuticos em caráter experimental, o número de sessões corresponderá ao que estiver estabelecido no protocolo aprovado pelo Comitê de Ética em Pesquisa. (Resolução CFP № 011/2012)

Acredito que estamos diante de um processo de consolidação no que se refere ao atendimento psicoterapêutico online. A caixa preta ainda está aberta. Esta é uma excelente e rara oportunidade para acompanharmos as controvérsias típicas deste tipo de movimento. As discussões acerca de aspectos básicos desta forma de atuação ainda estão em andamento, buscaremos acompanhar de perto este enredamento em suas derivas. Não temos dúvidas de que mais cedo ou mais tarde o atendimento psicoterapêutico online se consolidará como uma prática reconhecida no âmbito da psicologia. Definimos como nosso tema o acompanhar o processo de construção e consolidação desta prática. 
Fundamentação teórica

Neste trabalho utilizaremos a teoria Ator-rede e a Epistemologia Política de Isabelle Stengers e Vinciane Despret como referenciais teóricos norteadores de nossas pesquisas. A perspectiva Ator-rede vem sendo desenvolvida especialmente por Bruno Latour e seus colaboradores. Tem sido estudada em várias partes do mundo, inclusive no Brasil. Azambuja contextualiza: O sociólogo francês Bruno Latour (1994), em "Jamais Fomos Modernos", apresenta a ele e a seu grupo de amigos como estudiosos de situações estranhas que a cultura intelectual não consegue classificar. Também se autodenominam "sociólogos, historiadores, economistas, cientistas políticos, filósofos, antropólogos [...] acrescentando sempre o genitivo: das ciências e das técnicas" (LATOUR, 1994, p.9). No interior de instituições científicas, buscam descrever as tramas atravessadas por acontecimentos ligados a ciência, política, economia, direito, religião, técnica, ficção e a toda mistura responsável por tecer as teias do corpo social. Seguem as tramas aonde elas os levem, tomando como meio de transporte a noção de tradução ou de rede. (AZAMBUJA, 2012)

O grupo de amigos ao qual Latour se refere no fragmento relatado acima como nos traz Azambuja (2012) é composto por: "Michel Callon, Steve Woolgar, John Law, Madeleine Akrich, Vinciane Despret, Isabelle Stengers, Annemarie Mol, entre outros pesquisadores que compõem o campo de estudo chamado "Ciência, Tecnologia e Sociedade (CTS)". Latour (1994) explica que um dos aspectos fundamentais que traz identidade a este grupo é a busca incessante de reatar a conexão indesatável que separa os conhecimentos exatos e os exercícios de poder; aspectos da natureza e aspectos da cultura. Este grupo atua examinando minunciosamente e de forma recorrente as relações existentes entre estas dimensões, entendendo-as como componentes híbridos, imbricados e indissociáveis. Estes buscam descrever os rastros deixados no fluir desta espécie de rede.

Dentro da perspectiva ator-rede, a deriva cultural humana pode ser compreendida a partir da dinâmica de uma rede que envolve humanos e não humanos. Segundo esta forma de olhar, tanto os humanos como os não humanos têm um papel ativo na performação da construção social. O homem transforma e também é transformado na relação que estabelece com os não humanos. Segundo Freire (2006), Bruno Latour define ator como "tudo que age, deixa traço, produz efeito no mundo, podendo se referir a pessoas, instituições, coisas, animais, objetos, máquinas, etc". Como nos traz Márcia Moraes:

\footnotetext{
A noção de rede de atores diz respeito a um plano de conexões heterogêneas a partir do qual emergem tanto as ciências quanto as crenças, as religiões, etc. Podemos dizer que ela se caracteriza por estabelecer um campo de tensões heterogêneas no qual a síntese não é um resultado necessário. Latour (1994) afirma a rede como uma ontologia de geometria variável, isto é, como um plano ontológico marcado por múltiplas entradas. Nesse sentido, a análise das ciências é apresentada sem partir de pólos privilegiados, como o sujeito e o objeto, o acerto e o erro. O princípio de simetria generalizada proposto por Latour é uma conseqüência dessa ontologia de múltiplas entradas e conexões. Trata-se de analisar simetricamente não apenas o erro e o acerto, mas antes, todo e qualquer efeito das negociações em rede, dentre eles, a natureza e a sociedade. (MORAES, 2003)
}

Essa perspectiva que valoriza a relação, a interação entre os atores na construção social humana, busca uma posição de sensibilidade no que se refere a percepção do poder interpretativo dos vários fatores que definem os caminhos da dinâmica sociotécnica, o que Bruno Latour chama de princípio de simetria generalizada. Esta postura também resgata, o papel dos não humanos que não vinham sendo incluídos de forma tão marcante como atores por outras perspectivas. A partir deste contexto, o estudo da atuação dos não humanos passa a ter um novo sentido. 
Bruno Latour e seus colaboradores têm trazido uma contribuição de grande importância para o desenvolvimento de metodologias de pesquisa que sejam capazes de captar as sutilezas de seus campos de pesquisa nas mais diversas áreas. Esta linha de pensamento (ou forma de pesquisar) tem se esmerado no sentido de construir caminhos de aproximação que não ofusquem as nuances dos campos de pesquisa em função do peso exercido pelos aparatos de pesquisa e pelos preconceitos dos pesquisadores. "A paixão, as teorias ou os preconceitos não são maus em si mesmos; apenas se tornam maus quando não oferecem ao fenômeno ocasiões para diferir." (LATOUR, 2008). Acreditamos que essa perspectiva nos possibilitará uma aproximação das sutilezas que envolvem o tema de nossa investigação, de forma consistente e rigorosa.

A palavra rigor se encaixa bem para definir esta metodologia de pesquisa, não por se referir a uma rigidez cega em seguir um determinado caminho metodológico pré-estabelecido, mas sim pelo cuidado no sentido de que o caminho do conhecimento a ser desenvolvido seja indicado, dentro do possível, pelo próprio campo em especial no que se refere a nuances que independem do pesquisador. Desta forma o produto final da pesquisa fala mais das inúmeras nuances do campo e menos de aspectos específicos do pesquisador, como poderia ocorrer em uma pesquisa em que a metodologia do pesquisador falasse mais alto do que as outras vozes do campo. Este cuidado sensível, esta busca de não ofuscar as vozes das diversas nuances do campo, de acompanhar o campo em suas dobras é que nos aproxima desta forma de investigação. Azambuja confirma:

Em outras palavras, a própria forma de retirar essas informações, de pensar e percorrer os caminhos metodológicos, já estabelece na figura do pesquisador o sujeito em constante diálogo com o campo de pesquisa. O que encontra apoio na concepção de que não existe um modelo único de pesquisa participante, cada caso deve ser adequado às condições particulares de expressão. As ferramentas de pesquisa social são, portanto, vivas em seu contexto, pois afetam e são afetadas. Nem elas, nem o próprio pesquisador entram em campo livres ou isentos de influenciar e serem influenciados. Na verdade, ao invés de seguir regras metodológicas capazes de iluminar objetos pré-existentes, os autores aqui utilizados propõem analisar as condições de possibilidades suscetíveis às múltiplas formas de expressão. Por exemplo, este viés metodológico exige mudança nas práticas de narrar. A isso, soma-se a possibilidade de estratégias metodológicas abertas ao heterogêneo. (AZAMBUJA, 2012)

Esta forma de olhar aposta, entre outros aspectos, na criatividade do investigador, dando liberdade a que este se permita construir formas sob medida para a aproximação de seu campo de pesquisa. Convida a que o pesquisador se deixe conduzir a partir do que surge das interlocuções decorrentes de sua investigação. Moldando sua forma de aproximação de acordo com as recalcitrâncias e peculiaridades encontradas em seus campos de estudo. Como nos traz Ferreira:

Ao contrário das teses epistemológicas clássicas, o conhecimento científico é aqui concebido na articulação e co-afetação entre entidades, na produção inesperada de efeitos, e não no salto representacional dado na identidade entre uma sentença ou hipótese prévia e um estado de coisas a ser progressivamente desvelado. Tomado como articulação, o conhecimento científico não se distinguiria mais entre boa e má representação, mas boas e más articulações. No primeiro caso, há uma situação em que a articulação é extorquida ou condicionada a uma resposta pontual, conduzindo os seres pesquisados a um lugar de "docilidade". No segundo, há uma articulação na qual o testemunho iria além da mera resposta, abrindo-se ao risco de invalidação das questões e proposições do pesquisador e à colocação de novas questões pelos entes pesquisados. Esta seria uma relação de recalcitrância. (FERREIRA, 2011) 
O campo de pesquisa não se resume apenas a uma região geográfica/social, envolve também praticamente tudo o que se refere ao tema investigado, incluindo-se aí os aspectos ligados ao pesquisador (SPINK, 2003). Sendo assim, envolve também o pesquisador com toda sua história, expectativas e necessidades. Abrange inclusive, o leitor, isto é, para quem o pesquisador escreve sua pesquisa. Encerra, ainda, as instituições de ensino, os órgãos de fomento, a pretensão de publicação posterior do material produzido e as relações políticas que envolvem todos esses personagens. Spink certifica:

\begin{abstract}
O campo-tema não é um aquário que olhamos do outro lado do vidro; é algo do qual fazemos parte desde o primeiro momento em que dissemos, "estou trabalhando com....". A investigação em ação, portanto, se refere à ação da investigação; sua localização como parte do tema. Conversar sobre o que entendemos, ampliar argumentos, narrar e publicar o que parece importante narrar ou publicar, não são atividades eventuais e opcionais. Estamos no campo-tema porque disciplinarmente achamos que podemos ser úteis e é sempre bom lembrar que, ao contrário da posição confortável da separação de problema e solução na famosa frase atribuída ao Lenin - se somos parte da solução, provavelmente somos também parte do problema. Lugares, eventos, pessoas, rostos, artefatos, documentos, impressões, recortes, anotações, lembranças, fotos e sons em partes e em pedaços (muitos pedaços); um confronto de saberes uma negociação de sentidos numa busca de ampliar possibilidades de transformar práticas. Só o mal avisado pode pensar que isso é uma atividade neutra. (SPINK, 2003)
\end{abstract}

Quanto maior a clareza sobre os fatos que geram a conexão entre o pesquisador e o assunto abordado, maior o entendimento em relação ao que estará sendo produzido. Todas as nuances significativas no que se refere a nossa implicação no tema deste trabalho serão, dentro do possível, oportunamente explicitadas. Coerente como que nos traz Despret, se referindo ao trabalho da etnopsicóloga Catherine Lutz.

O fato de eu privilegiar, desde as primeiras linhas, o contexto no qual a pesquisadora cresceu para abordar os problemas da passagem de uma cultura para outra não atende a qualquer exigência narrativa ou biográfica. Eu o faço porque esta especificação aparece ao longo de seus próprios escritos, e da qual ela não é inocente.

Podemos a princípio traduzir essa especificação como uma precaução metodológica que se tornou bastante usual no domínio da antropologia. Essa precaução corresponde àquela que se chama "exigência reflexiva". Em antropologia, essa maneira de proceder se tornou inerente à própria pesquisa: lembrar de onde se vem, de onde se fala, faz parte atualmente do caderno de encargos do trabalho do antropólogo: toda pesquisa é uma pesquisa "situada". (DESPRET, 2011)

À medida em que busco explicitar dentro do possível de onde estou falando permito que meus interlocutores identifiquem os limites e possibilidades de meu discurso. Em uma pesquisa que envolve aspectos ligados à uma prática profissional, estar atento a como se constrói nosso olhar é uma questão de responsabilidade.

Vale aqui ressaltar minha posição inicial no que se refere a esta investigação. Como psicólogo, gestalt-terapeuta, não tenho como questão a efetividade ou não da psicoterapia online. A perspectiva gestáltica é uma abordagem que aposta na relação entre pessoas como terra fértil para o processo de desenvolvimento humano. É coerente com o entendimento de que psicólogos são profissionais da comunicação e que qualquer forma de comunicação tem potencial para gerar mudança, isto é, toda forma de comunicação é possibilidade de transformação.

Estamos nesta pesquisa acompanhando um processo de validação de uma prática. Em outras palavras: a questão desta investigação não passa pela verificação eficácia desta prática, não temos dúvidas em relação a este ponto. A questão desta pesquisa se restringe ao 
acompanhamento das controvérsias que vem se desenvolvendo ao longo deste processo de validação. Para tanto tenho acompanhado o processo de discussão a respeito das futuras mudanças na legislação a respeito deste tema, que serão implementadas a partir de uma nova resolução, que será publicada em breve pelos CFP (Conselho federal de psicologia).

\section{Referências bibliográficas}

AZAMBUJA, P. K. Cognição e Mediação Técnica: passagem analógico-digital da recepção de TV sob a ótica da Teoria Ator-rede. - Tese (Doutorado) - Universidade do Estado do Rio de Janeiro. Instituto de Psicologia. 2012.

CONSELHO FEDERAL DE PSICOLOGIA. RESOLUÇÃO CFP Nº 011/ 2012. Disponível em: http://site.cfp.org.br/wpcontent/uploads/2012/07/Resoluxo CFP nx 011-12.pdf. Acessado em 19/05/2017

DESPRET, V. As ciências da emoção estão impregnadas de política? Catherine Lutz e a questão do gênero das emoções. Fractal: Revista de Psicologia, v. 23 - n. 1, p. 29-42, Jan./Abr. 2011 31. Disponível em: http://www.uff.br/periodicoshumanas/index.php/Fractal/article/view/647. Acesso em: 20/08/2016

FERREIRA, A. A. L et al. Psicologia como um Dispositivo de Produção de Subjetividades: Um Percurso pelos Métodos Quantitativos. Pesquisas e Práticas Psicossociais 6(2),São João del-Rei,agosto/dezembro 2011. Disponível em: http://www.ufsj.edu.br/portal2-repositorio/File/revistalapip/volume6_n2/Ferreira_et_al.pdf Acesso em: 29/10/2016

FREIRE, L. de L. Seguindo Bruno Latour: notas para uma antropologia simétrica. Comum, Rio de Janeiro, v. 11, n. 26, p. 46-65, 2006. Disponível em: <http://www.facha.edu.br/publicacoes/comum/comum26/artigo2.pdf>. Acesso em: Acesso em: 27/09/2016

LATOUR, B. Jamais Fomos Modernos: ensaio de antropologia simétrica [Trad. De Carlos Irineu da Costa]. Rio de Janeiro: Editora 34. 1994.

Como falar do corpo? A dimensão normativa dos estudos sobre a ciência in João Arriscado Nunes e Ricardo Roque Objectos Impuros: Experiências em Estudos sobre a Ciência - Edições Afrontamento I Port, Portugal, 2008

LIMA, N. L.;SOUZA, E. P.; REZENDE, A. O.; MESQUITA, A. C. R. Os adolescentes na rede: uma reflexão sobre as comunidades virtuais. Arquivos Brasileiros de Psicologia; Rio de Janeiro, 64 (3): 2-18, 2012. Disponível em: http://seer.psicologia.ufrj.br/index.php/abp/article/view/772/728 Acessado em 03/09/15

MORAES, M. A Psicologia como reflexão sobre as práticas humanas: da adaptação à errância. Estudos de Psicologia 2003, 8(3), 535-539. Disponível em: http://www.slab.uff.br/textos/texto16.pdf Acesso em: $27 / 09 / 2016$

SPINK, P. K. Pesquisa de campo em psicologia social: uma perspectiva pós-construcionista. Pontifícia Universidade Católica de São Paulo. 2003. Disponível em: http://www.scielo.br/pdf/psoc/v15n2/a03v15n2 Acesso em: 20/08/2016. 


\section{CIDADE: RELAÇÕES PSICOGEOGRÁFICAS E TRANSGRESSÕES PSICOPOLÍTICAS NA ARTE}

Ana Prado - Doutoranda no HCTE/UFRJ

Evandro Vieira Ouriques - Professor do HCTE/UFRJ

Resumo

Este artigo busca trazer à luz algumas questões que atravessam as cidades contemporâneas, mediante as transformações de diversas ordens instauradas por vários atores que resignificam espaços, através de intervenções de natureza artística, sociocultural, política e ou urbanística. Procura-se identificar possíveis relações, transgressões e ou conflitos instaurados pelas fortes pressões econômicas na vida psicogeográfica do cidadão, seus estados mentais, relacionando-as com a potência psicopolítica emancipatória de ações de arte no ambiente urbano, ou seja, na cidade mergulhada no autismo neoliberal.

Palavras-chave: Arte. Cidade. Espaço Urbano. Psicogeografia.Psicopolítica.

Introdução

A rua nasce como o homem, do soluço, do espasmo.Hásuor humano na argamassa do seu calçamento.Cada casa que se ergue éfeita de esforço exaustivo de muitos seres(...)

A rua sente nos nervos essa miséria da criação,e por isso é a mais igualitária, a mais socialista, a mais niveladora das obras humanas.

Como premissa para se entender de que ambiente estamos falandoabordamos um conceito utilizado pela Faranak Miraftab, quenos parece bastante apropriado para o reconhecimento no ambiente de dois tipos deespaços existentes, no contraponto daquilo que surge por iniciativa do habitante ou por iniciativa do poder público: "espaços inventados"são aqueles espaços e dinâmicas sociais produzidos na recriação dos lugares, mediante a inventividade artística, que colocam em questão, pela contestação ou pelo amoldamento os chamados "espaços convidados"aqueles espaços concebidos e mediados pelas instituições, dentro dos moldes da promoção de uma participação social controlada e planejada nas instânciasgovernamentais, no âmbito das políticas urbanas voltadas aos espaços públicos( MIRAFTAB, 2009, p.35).

Nos espaços inventados se delineiam várias ações de ordem sociocultural ou artística, e atémesmo política como foi o caso do OcupaMinC, que em 2016 foi um exemplo de colaboração participativa por iniciativa de artistas, músicos, ocupantes, que desencadeou um processo de economia viva jamais visto atéentão nos últimos tempos, tudo em defesa e da manutenção Ministério da Cultura, que havia sido desmontado pelo governo golpista após o impeachment da Presidenta Dilma. Ivana Bentes em um artigo publicado na Rede Brasil Atual vai dizer o seguinte sobre esta ação no MinC:

Trata-se de uma experiência radical de economia colaborativa, governança e cogestão (em nenhum momento as funções administrativas do MinC foram interrompidas!), um "case" de desmonetização das ações culturais. Uma aula de gestão pública (BENTES, 2016)

Essas experiências não são isoladas e vem no rastro dos acontecimentos no mundo todo, nas ocupações de espaços como forma de protesto e de reivindicação pelos direitos de diversas natureza num contexto sócio político e cultural, ocorridos desde meados da década passada. 
Aqui é importante voltar um pouco mais atrás para entender e lembrar que existe uma transformação que vinha se operando no indivíduo, que é marcada pelo sujeito pós-moderno e que segundo Stuart Hall se torna um sujeito de identidade fragmentada, fruto de um processo que se desloca desde o sujeito do lluminismo, aquele sujeito dotado da razão, consciência e de ação, passando mais tarde pelo sujeito sociológico que no mundo moderno percebe que o seu núcleo interior do sujeito não era auto suficiente, mas formado pela relação com as outras pessoas, num diálogo continuo com os mundos culturais (HALL, 1992, p. 10,11).

É interessante observar que hoje este sujeito vive numa estrutura de metrópole, e que sua capacidade de diálogo passa pela base psicológica do tipo metropolitano que consiste na intensificação de estímulos nervosos. Segundo Georg Simmel o homem é uma criatura que se faz diferente perante sua mente, que é estimulada pela diferença entre a impressão de um dado momento e aquele que precedeu. Este fato num ambiente urbano mobiliza uma série de sensações que obriga o indivíduo a se proteger das discrepâncias ameaçadoras de sua movimentação externa, levando-o a reagir, dada à tradição platônica que ainda prevalece, com a cabeça ao invés com o coração (SIMMEL,1973, p. 12,13).

Aprofundando um pouco mais sobre este sujeito e trazendo para o campo das artes, o artista instaurado nestes sistemas ao longo da história vai desenvolver capacidades de percepção que irão atuar profundamente no seu estado de ser e como ele se coloca diante do mundo, aos quais são determinantes na sua relação com o outro.

Jacques Poulain nos lembra que a experiência da arte é a mais potente criadora de figuras de felicidade que um ser humano busca ao longo de sua vida, pois são da ordem da experiência da escuta da voz da mãe, neste abrigo, neste habitat, no qual ele se institui no estado mental de solidariedade, em sua condição comunicacional. O diálogo com ele mesmo e o diálogo artístico com o mundo exige um julgamento coletivo contínuo que questiona o sentido de felicidade que se tinha no passado, uma vez que é este julgamento da verdade que anima a criatividade artística e nossa vida mental e social, e que isto constitui a cultura (POULAIN, 2016, p. 6).

O artista contemporâneo neste sentido vai ser um profundo ativador desse processo de diálogo do ser humano consigo mesmo e com o outro, caminhando para diferentes formas de atuação no fazer artístico, que a partir da década de 90 do século passado, através de suas práticas vai dar ênfase às relações sociais, e como destaca Marisa Florido se tornar um mediador social, ativando mesmo que temporariamente o convívio, em alguns casos como um etnógrafo de micro estratégias de territorialização, em outros interferindo através de pequenas táticas no habitat, evocando situações rápidas e perturbadoras, pequenos ruídos na entropia urbana (FLORIDO, 2017). No entanto estas ações não foram capazes de impedir a onda fascista que emergiu nas cidades. O que terá acontecido com a potência emancipatória do território mental desses artistas (OURIQUES, 2009)

Vejamos: nos parece que neste habitat é onde se resguardam sensações, sentimentos e tantas outras emoções, que podemos nos utilizar do conceito de Heidegger, quando ele define queresguardaré deixarmos algo entregue ao seu vigor de essência e que isto significa estar liberto, ou seja, liberto para a paz de um abrigo, na liberdade de um pertencimento, de um demorar-se dos homens sobre a terra -salvando a terra, acolhendo o céu, aguardando os deuses, conduzindo os mortais.É assim que acontece o habitar (HEIDEGGER, 1954).

$\mathrm{O}$ artista ativado pelas suas figuras de felicidade vai potencializar esse habitar com o acolhimento das suas forças interiores, dos seus questionamentos, da sua fala com os deuses, do seu encontro com o outro.Destacamos aqui um exemplo interessante: o trabalho de intervenção artística urbana "Perca Tempo"(Figura 1), desenvolvido pelo coletivo de arte Grupo Poro, que ativa questionamentos do tempo na vida da cidade através de faixas nas 
esquinas das ruas, e de distribuição de folhetos e botons indicando dez maneiras de se perder tempo. As maneiras indicadas para se perder tempo são muito simples, mas que ao fazê-las podemos estimular pequenos estados de felicidades, em meio a uma vida tão atribulada de deveres e pouco prazeres.
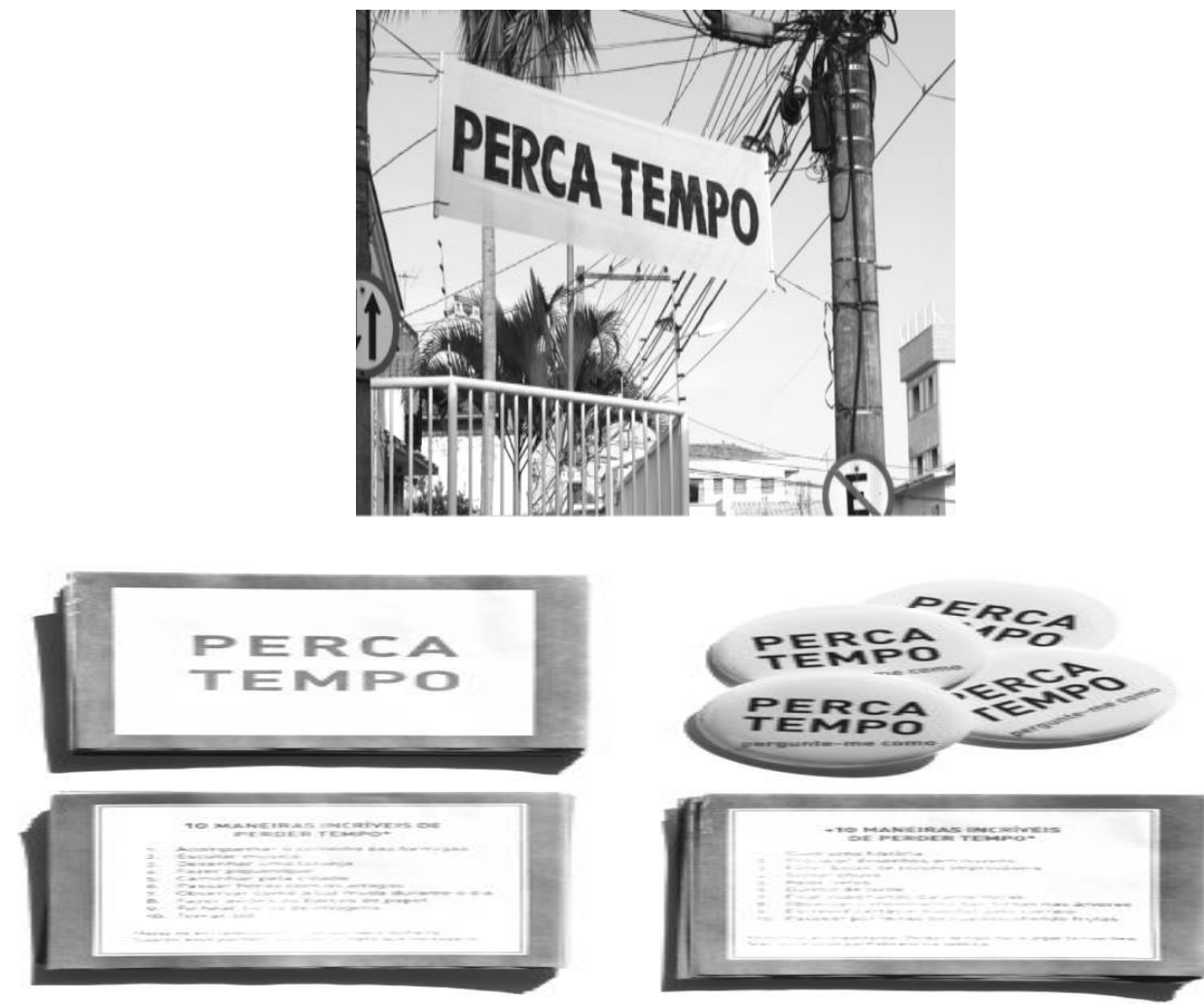

FIGURA 1 - Trabalho de Intervenção Urbana "Perca Tempo" - Grupo Poro 2010

Todo esse movimento artísticoparece-nosser uma resposta importante àsmudanças profundas na cidade, cujo conceito de governança e de poder público vão sendo investidos de novos significados.Tais transformações resignificam a cidade como sujeito/ator econômico, a passa a ser como sabemos, uma mercadoria, transformada em objeto e máquinade consumo que se apresenta na forma de grandes espetáculos.

Cabe ressaltar que críticas a espetacularização da cidade já vinham sendo feitas desde meados do século passado. No livro "A sociedade do Espetáculo"(ano) Guy Debord acentuou criticamente o significado da negação da vida que se tornou visível e da perda da qualidade ligada à forma-mercadoria, e da proletarização do mundo (DEBORD, 1997, p. 9).Numa crítica ao urbanismo a Internacional Situacionista (IS) proclamou a deriva como modo de subversão da cidade, de seus direitos e de suas ideologias. Os situacionistas (artistas, pensadores e ativistas que participaram da IS) vão propor as práticas da psicogeografia e da deriva para a vivência e para novas experiências na cidade(JACQUES, 2003, p. 65). Esta vai ser a guinada na percepção do significado do urbanismo, ativando possibilidades reais e efetivas mediante observações, caminhadas, e construção de ambiências, mesmo que momentâneas na vida, na direção de uma transformação na qualidade do indivíduo e do ambiente urbano, ou seja, da vida cotidiana.

A psicogeografia neste sentido incorpora um certo significado psíquico que pode ativar leituras ao sujeito, o qual ao contrário do que os modernistas achavam que a arquitetura e o 
urbanismo poderiam mudar a sociedade, mas que os situacionistas perceberam que a sociedade éque deveria mudar a arquitetura e o urbanismo(DEBORD, 2002, p. 19). A psicogeografia entendida como efeito no ambiente age sobre o comportamento dos indivíduos, com suas andanças e errâncias, se apropriando de olhar observador e sensível sobre seus sentimentos, nos revela uma importante contribuição na direção de uma sociedade capaz de tomar para si, a responsabilidade na mudança de forma diferencial no habitar a cidade e um intrínseco estado de ser no espaço urbano.

Sabemos que nossa vida psíquica émuito marcada pelas influências sociais e ambientais. Richard Sennett critica o fato de hoje a vida psíquica ser tratada como uma vida interior própria, e por ser considerada tão preciosa e delicada que nunca pode ser exposta, jáque ela sópoderáflorescer na medida em que for protegida e isolada. Ele aborda esta questão afirmando que o fato de estarmos tão absortos em nós mesmos faz com que nossa psique se torne privatizada, e que isto nos leva a dificuldade de sentir ou exprimir nossos sentimentos. Esta leitura aponta para uma imaginação psicológica da vida, em que o mundo exterior éimpessoal e parece rançoso e vazio (SENNETT, 1998, p. 16).

Podemos aqui perceber a importância que tem as questões de ordem psíquicase sóciopolíticas na cidade, ea teoriapsicopolíticasnos ajuda a aprofundar o conhecimento desses estados mentais do citadino e o quanto eles são determinantes na potênciaemancipatória ou não das intervenções nos territórios. As dinâmicas de socialização reais estão nas capacidades cognitivas e afetivas, portanto mentais de solidariedade inscritas na constituição antropológica do ser humano como ser de linguagem, e como tal cultura. Neste sentido se é na mente do homemque se inicia uma guerra, é nesta mesma mente que se é capaz de construir as defesas de paz (OURIQUES, 2017).

De acordo com a teoria psicopolítica, nenhuma sociedade, e, portanto, nenhum artista ou intervenção artística, pode subsistir sem que os impulsos e as emoções individuais tenham uma regulação muito concreta. A teoria social e a filosofia hegemônicas esperaram por quatro séculos que este papel fosse feito metafisicamente pelo Estado, o que não poderia mesmo ter dado certo. Está na hora de mudar, pois o sofrimento gerado por esta insistência é indescritível. Cada um que pára e reflete sobre o que está sendo falado aqui conhece este sofrimento (OURIQUES, 2017). Neste sentido, dada à condição comunicacional do ser humano implicar em sua capacidade de julgar continuamente, como dito, a antropologia filosófica, sobretudo no sentido de Arnold Gehlen, ou seja, aquela que se baseia nos resultados da ciência e prescinde da teologia e da metafísica, ajuda e muito na constituição de figuras de felicidade emancipatórias, pois faz sentido que ela seja uma "prima philosophia", como Kant originalmente a propôs.

Assim a psicopolítica entendida não apenas como um diagnóstico do que ocorre no capitalismo sob a forma neoliberal, portanto também nas cidades onde se instauram e reproduzem todos os regimes de servidão, confere a qualidade de ser a única via de emancipação dos estados mentais de ignorância (de que somos comunicação, portanto felicidade), do ódio (a presença da ausência da comunicação) e da ganância (com a qual o sujeito procura interpor objetos e situações entre ele e a lacuna sinistra na qual a ignorância transforma o fluxo vital) (OURIQUES, 2017).

Quando o sujeito, no caso o artista autoriza estrategicamente os estados amorosos como fonte de referência de sua capacidade de julgar, ele constrói figuras de felicidade, figuras de uma solidária e amorosa que possibilitam o diferencial na experiência urbana, e não os estados mentais de ignorância, servos do dualismo que recusa a possibilidades da vivência nas diferenças, portanto num ataque direto sobre o outro, se distanciando-se de uma poética que é por si só nossa própria existência. (OURIQUES, 2017). 
Os estados mentais vistos pela teoria psicopolítica e pela psicogeografia se entrelaçam na construçãodas possibilidades de vivências da vida pública e privada na cidadee são determinantes para a construção de afetos e alteridades, na capacidade de se conectarem como o outro e de percorrer uma vida em rede reconhecidamente fruto de seus desejos solidários e assim emancipados e emancipadores.

Desta maneira,a ação em rede, autopoética e auto organizadora pode potencialmente ser transformadora nestes estados mentais e o artista insere-se neste contexto com suas linguagens poéticas e com fortes trabalhos que se instauram psicopoliticamente nesta vida social. A cidade se constitui então como um palco perfeito para ativação dess es dinâmicas, no exercício de um diálogo possível nos tantos conflitos que nos tocam a cada momento, a ensejar a sua contínua superação, da qual depende o processo civilizatório.Na verdade, se olharmos com carinho, a vida é uma grande dinâmica na qual emergem, articulam-se e modificam-se potências diversas. Estar na cidade é viver numa malha psicogeográfica, onde a cada passo nos múltiplos territórios descortinam-se imagens e saberes de diferentes ordens: mas é também estar na vida com o outro,no tecido transdisciplinar da teoria psicopolítica, tornando-nos a cada respiração seres em busca de respostas, ou de vivências, em que habitam delicadezas que dissolvem regimes de servidão e estabelecem uma vida coletiva e amorosa é que faz a diferença de nossa existência.

\section{Referências bibliográficas}

BENTES, Ivana. Ocupa Tudo! Extinção, ressureição e insurreição da Cultura. Rede Brasil Atual 12/10/16. Disponível em http://www.redebrasilatual.com.br/blogs/blog-na-rede/2016/10/ocupa-tudo-extincaoressurreicao-e-insurreicao-da-cultura-9780.html. Acesso em 30/06/17.

JACQUES, Paola Berenstein. Apologia da Deriva: escritos situacionistas sobre a cidade. RJ. Ed Casa da Palavra, 2003.

BIRMAN, Joel. Arquivos do mal-estar e da resistência. RJ. Ed. Civilização Brasileira, 2017.

Debord, Guy. A sociedade do Espetáculo. RJ: Ed. Contraponto, 2002.

FLORIDO, Marisa. Seminário o artista e a cidade. Disponível em https://www.youtube.com/watch?v=f1SpEwnSD5k. Acesso em 30/06/17.

HALL, Stuart. A identidade cultural na pós-modernidade. RJ: Ed. Dp\&A, 1992

HEIDEGGER, Martin. Construir, Habitar, Pensar. [Bauen, Wohnen, Denken] (1951). Conferência pronunciada por ocasião da "Segunda Reunião de Darmastad", 1954.

MIRAFTAB, Faranak. Insurgent planning: situating radical planning in the global south. Revista Planning Theory, 2009. Disponível em: http://plt.sagepub.com/. Acesso em 11 de setembro de 2016.

OURIQUES, Evandro Vieira. Teoria Psicopolítica: A emancipação dos Aparelhos Psicopolíticos da Cultura. Coleção Teoria Psicopolítica, volume 1, 2017. Co-edição Universidad de La Fronteira, Universidade Federal do Rio de Janeiro, Universidade do Porto, Universidad Nacional de La Plata e Universidade de Groningen: Chile, Brasil, Porto, Argentina e Holanda.

PORO, Grupo. Intervalo, Respiro, Pequenos deslocamentos: Ações poéticas do Poro. São Paulo. Ed. Radical Livros. 2011

POULAIN, Jacques e CANY, Bruno. L'art comme figure du bonheur. Ed. Hermann, 2016. RIO, João do. A Alma encantadora das ruas. RJ. Ed. Companhia das Letras, 2008.

SENNETT, Richard. O Declínio do homem Público. São Paulo. Ed. Companhia das Letras, 1988. 
SIMMEL, Georg. A metrópole e a vida mental, (in) O fenômeno urbano, org. Otávio Gilberto Velho, 1973. 


\section{OS MALANDROS CARIOCAS : PROFISSIONAIS DA BOÊMIA BRASILEIRA}

Reinaldo Ramos Diniz- Professor do Laboratório de Linguagens Desenhadas e Educação - Proped/UERJ

\section{Resumo}

Este texto trata do surgimento do malandro carioca, no final do século XIX até a sua extinção, no fim do Estado Novo. Através de uma pequena cartografia dos territórios que habitava, com suas astúcias e táticas cotidianas (CERTEAU, 1994) de Zé Pilintra. O nosso herói às avessas, filho de Exu e primo de Macunaíma, foi o praticante de uma profissão de vida e de fé, no Brasil: a boêmia. Com seu deboche, vida desregrada e marginal, enfrentou os ditames da modernidade burguesa e elitista da época; viviam no fio da navalha (DEALTRY, 2009). O seu modo de viver, povoa o imaginário da população brasileira até os dias atuais, acalentando um sonho que muitos querem : ser dono do seu destino e do seu corpo, ser livre.

O malandro carioca foi tema do enredo "Opera do Malandro" do Grêmio Recreativo Escola de Samba Acadêmicos do Salgueiro, no carnaval de 2016. Logo na comissão de frente víamos este "tipo" carioca, abrindo os trabalhos da agremiação tijucana, como Exu- entidade dos cultos afro-brasileiros ligado a sexualidade e a vida mundana das ruas- com a sua roupa em vermelha e preta, cartola, capa o Zé Pilintra .Rodeado de pombagiras que saracoteavam sensualmente as suas saias, seguidas de um carro alegórico que recriava um bordel, cheio de esculturas de mulheres com seus fetiches, liberando os seus desejos sexuais e outros. 0 desfile do Salgueiro, que ficou em quarto lugar, foi uma metáfora do conflito entre os desejos de ser livre do trabalho alienante e de uma sexualidade repressora e os limites que a realidade impõe as pessoas comuns de realização desses desejos. A história do malandro carioca foi o pano desse drama vivencial.

Exemplo desse herói da metrópole carioca ,da Belle Époque até o fim do Estado Novo, foi a do travesti Madame Satã. Este era um misto de rainha e rei da Lapa de outrora. Além dela(e) temos notícias de Leopoldo "Pé de Mesa", Geraldo "Bico de Ferro", "Cupido", Soares "Caixa de Fósforos", Miguelzinho, dentre outros, são representantes dos vários malandros rufiões que cantavam e encantavam com seus violões as serenatas das noites de boêmia da cidade maravilhosa. Eram chamados pela crônica época do "povo da lira", eram grupos de "negros e mulatos capoeiristas e apreciadores, em muitos casos, de violão e cantoria" (DIAS, 1997, p. 331).

Estes eram reconhecidos, na época, por "não gostarem de trabalhar" e por aparecerem com freqüência como "guarda-costas de políticos" (Idem). Eram personagens ligados à violência e à marginalidade, sendo uma espécie de lumpemproletariado urbano. Temidos por sua destreza tática, alegria e valentia, no jogar a capoeira- uma trampolinagem.

O caricaturista Calixto Cordeiro- segundo Giovanna Dealtry era um "exímio capoeirista(autor,2010, p. 66), "formado nas rodas da Cidade Nova (autor, 2010, p. 67), e conhecedor e praticante da cultura popular carioca e suas gírias- nos legou um registro do jogo-luta nos seus desenhos e linguagens utilizados. Podemos observar nas figuras abaixo, extraídas da Revista Kosmos de março de 1906, a seqüência de golpes da capoeira e os diálogos.

"A Peneiração". Fig1 
"Com pouco vi um cabra peneirando na minha frente, dansei de velho, o typo era bom! sambou e entrou no caterêté commigo..." (Revista Kosmos, desenho de Calixto Cordeiro, 1906).

"A Cocada" fig. 2

"Fiz duas chamadas nos materiaes rodantes, de uma palma, sempre com os mirones grelados no mecco, o cabra não leu... fiz uma figuração por cima para o bruto fugir com o carão, e grampeei o individuo. Chamei o cabra na chinxa, levei a caveira de lado, e fui buscar o machinismo mastigante do poeta. O cabra engolio a lingua, damnou-se, não perdeu a scisma, ganhou tento e compareceu de novo... Não fiz questão do preço da banha... "(Revista Kosmos, desenho de Calixto Cordeiro, 1906)

"O CALÇO OU A RASTEIRA" fig.3

\begin{abstract}
"Cahi no bahiano rente a poeira, e lasquei-lhe um rabo de raia que o marreco voôu na alegria do tombo, indo amarrotar a tampa do juizo n'uma canastra, e ahi gritei: - Entra negrada! O turuna enfeitou-se outra vez... Oh! cabra cutuba!" ( Revista Kosmos, desenho de Calixto Cordeiro, 1906)
\end{abstract}

\title{
LAMPARINA " fig.4
}

Grimpei perdi a estribeira, cocei-me, dei de mão na barbeira e... ia sapecar-lhe um rabo de gallo, quando o cabra cascou-me uma lamparina que eu vi vermelho"( Revista Kosmos, desenho de Calixto Cordeiro, 1906)

METTER O ANDANTE fig.5

\begin{abstract}
"Ahi não conversei, grudei na parede, escorei o tronco, e meti-Ihe o andante na caixa de comida. O dreco bispando que eu não era pecco, chamou na canella que si bem corre, está muito longe... Eu voltei p'ro samba garganteando: "Meu Deus que noite sonorosa"
\end{abstract}

( Revista Kosmos, desenho de Calixto Cordeiro, 1906)

Podemos observar os diversos passos e jogos que essa luta apresentava, os traços de Calixto demonstram a grande agilidade e presteza que o capoeirista tinha que ter, era uma luta dançada e em muito influenciou os passos dos mestres salas atuais das escolas de samba.

O malandro era um tipo carioca- em sua grande maioria- de origem negra e mestiça, já veio ao mundo deserdado das riquezas da nossa pátria mãe gentil. Seu nascimento ocorreu no final do século XIX e o no início da criação da Cidade Maravilhosa, época de transição do Rio Antigo Colonial para o Rio Moderno da Belle Époque .Existiu e persistiu na sua vida errante de boêmio profissional, até o final do Estado Novo.

Cresceu e viveu na Gamboa, nos morros da Favela - depois chamado de Providência-, do Pinto e Nheco em suas casas de angu, onde matava sua fome física e afetiva . Em Santo Cristo, no Cais do Valongo, junto ao cemitério dos pretos novos- região que recebeu seus antepassados escravizados na África e que foi o tumulo destes. Nas revoltas da vacina e da chibata na Praça da Harmonia ,onde os malandros Prata Preta, Camisa Negra, Manduca da Praia conviveram com João Candido.Na Saúde, da Pedra do Sal ,temos João da Baiana que freqüentava o terreiro de João irmandades religiosas de Ubá. Nas ladeiras do morro da Conceição-escorrega e jogo da bola - gingou muitas danças entre elas o lundu, o batuque, a capoeira, a dança dos velhos, a gongada com suas batidas de palmas ao som de caxambus e atabaques. No Cais do Porto e nos trapiches junto com os estivadores, ganhava a vida: contrabandista. Nas ruas centrais da cidade desfilava com as zabumbas dos zé-pereiras, cantando as marchinhas nos ranchos, defendendo os estandartes como mestre-sala nos cordões, assistindo os préstitos das Grandes Sociedades e aos desfiles dos corsos na Avenida Central- a vedete principal da modernização, da cidade de São Sebastião.Na fronteira entre o Passeio Pública, a Avenida Beira-Mar e a Rua da Glória conviveu com Manuel Bandeira e os intelectuais modernistas 
cariocas. Nas pensões das ruas escuras da encosta do Morro de Santa Tereza, como a Conde Lage, a Taylor e a Joaquim Silva, tinham suas mulheres,que trabalhavam, vendendo amor, carinho e afeto para sustentar o malandro. Na Lapa- a Montmartre tropical com suas esquinas do pecado- dançava matava sua fome. Na Praça Tiradentes- a terra dos teatros de revistas e das operetas, a Broadway tupiniquim - freqüentava a vida cultural.No Campo de Santana dançava as cançonetes ,modinhas e maxixes nos cabarés, cafés-concertos, chopes-berrantes, mafuás e gafieiras. Nas festas com rodas de choro e de samba amaxixado das casas das tias negras como tia Ciata (MOURA,1995) na cidade nova, junto com Pixinguinha, Catulo da Paixão Cearense, Anacleto de Medeiros, Villa-Lobos, Sinhô, Heitor dos Prazeres, ajudaram compor com Donga e o jornalista e cronista carnavalesco Peru dos Pés Frios (COUTINHO, 2006) o primeiro samba gravado, em 1916, Pelo telefone. Os boêmios profissionais faziam parte dessa uma nova cultura, rica em sons com outras vozes que clamavam formas de representação estética baseadas na oralidade das tradições negras africanas e a dos habitantes autóctones do Brasil (SANDRONI,2001).

O malandro também tinha o seu lado espiritual: era nos terreiros das religiões da umbanda carioca e de candomblé que fechavam o corpo e recebiam seus patuais. Nas ruelas estreitas dos morros de São Carlos, da Mangueira, tocando e dançando o samba batucado ,com ritmo mais sincopado nos pontos das casas de santos (SODRÉ,2002) , com os passos da capoeiragem na companhia de Ismael Silva, Cartola, Carlos Cachaça ajudaram a fundar as primeiras escolas de samba da cidade: Deixa Falar (agosto de 1928) e Estação Primeira de Mangueira (1928).

Enfim, viveram na Festa da Penha, nos subúrbios cariocas de Vila Izabel -de Noel Rosa- e de Madureira- do jongo do quilombo da Serrinha-, na região da Leopoldina- onde mantinham seus atletas das rinhas de galos. Este imenso território era o palco para o seu gingado compassado nas artes do jogo de capoeira, com um figurino de chapéu de abas largas, paletó grande, largo e desabotoado, camisa e gravata de seda em cores vivas, calça larga de boca estreita, sapato bicolor e bico fino e sua fiel amante, inseparável: a cortante navalha.

Foram os últimos profissionais de uma boêmia que não existe mais. Essa figura, esse jeito de viver, essa identidade quase uma entidade_como foi mostrado o Exu da comissão de frente salgueirense- é um dos ícones da nossa cultura, povoa o imaginário da população brasileira como sendo um herói - as avessas- um mártir que resistiu, com seu deboche, vida desregrada e marginal, aos ditames da modernidade burguesa e elitista, viviam no fio da navalha (DEALTRY, 2009). A sua forma de viver era um acintoso desprezo a essa ordem, com suas astúcias e táticas cotidianas (CERTEAU, 1994) reinventava a sua maneira, outra modernidade carioca.

Até os dias atuais, é sedutora a idéia de ganhar a vida sem trabalhar duro_apesar de que dá trabalho ser malandro-, jogando dadinho e bilhar com muita conversa fora entre goles de cerveja, chopp, paraty-cachaça da época- petiscando torresmo, tremoços, moela, lingüiça, sardinha frita, ovo cozido- azul e rosa- e no final do expediente liberar a libido desmedida da carne, sem os limites da moral dominante, realizando o sonho desejoso de ser dono do seu destino e do seu corpo, ser livre. Este tipo carioca não existe mais, dizem até as "más línguas que ele até trabalha, mora lá longe e chacoalha num trem da central".

Referências bibliográficas

BARRETO, Lima. História e Sonhos. Rio de Janeiro: Livraria Garnier, 1990.

BUARQUE, Chico. O malandro In: “Ópera do malandro” . Rio de Janeiro: Universal, 1978.

CALIXTO, 1906. In: L. C. A Capoeira. Revista Kosmos. Ano três, no 3, mar. CERTEAU, Michel de. A invenção do cotidiano: 1. artes de fazer. Petrópolis: Vozes, 1994. 
COUTINHO, Eduardo Granja. Os cronistas de Momo: imprensa e carnaval na Primeira República. Rio de Janeiro: Editora UFRJ, 2006.

CUNHA, Maria Clementina Pereira (org). Carnavais e outras $f(r)$ estas: ensaio de história social da cultura. São Paulo: Editora da UNICAMP,CECULT,2002.

DEALTRY, G. Ginga na 'belle époque'. In: Revista de História da Biblioteca Nacional. Ano 5, no 53. Rio de Janeiro: fev, 2010 .

DEALTRY, G. No fio da navalha:malandragem na literatura e no samba. Rio de Janeiro: Casa da Palavra, 2009.

DIAS, L. S. A turma da lira. Sobrevivência negra no rio de Janeiro pós-abolicionista, Revista do Patrimônio Histórico e Artístico Nacional, Iphan, n. 25, 1997, p. 327-333.

LOPES, Ney. Mandingas da mulata velha na cidade nova. Rio de Janeiro: Língua Geral, 2009.

MOURA, Roberto. Tia Ciata e a Pequena África. Rio de Janeiro: Secretaria Municipal de Cultura. Departamento Geral de Documentação e Informação de Cultura, 1995.

PEDERNEIRAS, Raul. Geringonça carioca: verbetes para um dicionário da gíria. Rio de Janeiro: Officinas Gráficas do Jornal do Brasil, 1922.

SODRÉ, Muniz. O terreiro e a cidade - a forma social negro-brasileira. Salvador/Rio de Janeiro: Fundação Cultural do Estado da Bahia/Imago, 2002.

SANDRONI, Carlos. Feitiço Decente: transformações do samba no Rio de Janeiro. 1917 - 1933. Rio de Janeiro: Jorge Zahar Editores, Ed. da UFRJ, 2001. 


\section{NO MEIO DO CAMINHO: O DESENHO GEOMÉTRICO E PROJETIVO ENTRE AS “DUAS CULTURAS”}

Beatriz dos Ramos Pinto - Professora do Colégio Pedro II, mestranda do HCTE - bia_rp1@yahoo.com.br

Resumo

O Desenho Geométrico e Projetivo se configura como uma área do conhecimento que transita entre as artes e a matemática, perpassando saberes que se propõem dissociados entre si, salientando a questão da interdisciplinaridade presente na produção do conhecimento humano, esquecida pelo pensamento científico ocidental, que sistematiza os "saberes" e os delimita em "caixas" pré-programadas, com conteúdos pré-determinados. O que este breve artigo pretende trazer é uma tentativa de diálogo entre a questão da transitoriedade do Desenho Geométrico e Projetivo nessas duas áreas e a questão da evolução do pensamento científico no ocidente, tentando mostrar como essa evolução interferiu diretamente na separação desses conhecimentos.

Palavras chave: Pensamento Científico. Desenho Geométrico, Desenho Projetivo. Matemática. Artes. Educação.

O que seriam essas "Duas Culturas"?

O termo "entre Duas Culturas" presente neste artigo foi apropriado do livro de ROSA (2005), que apresenta o problema gerado pela cisão histórica entre humanidades e ciências naturais, trazendo a necessidade de mostrar que ambas se relacionam por meio de uma linguagem comum "associada na tradição intelectual herdada dos gregos e do lluminismo, atualizada ou transformadas pelas teorias contemporâneas." (Idem, p. 42-43)

Há uma tendência na história da evolução do pensamento científico ocidental por se determinar essa cisão. A separação dos saberes foi criada a partir do lluminismo. Antes todo saber era transdisciplinar. Nada se dissociava. Com a retomada e apropriação do conceito de taxonomia pelo método científico, as partes passam a ser não relativas, mas reais. Deste modo, o Ocidente passa a dissociar os saberes, colocando-os em caixas pré-programadas de conhecimento. Contudo essa dissociação mais prejudicou a evolução do pensamento do que ajudou, ao passo que não permite que se faça uma genealogia séria do conhecimento humano.

Este esfacelamento está enraizado na física de Newton, que fez da ciência moderna uma ciência fragmentada, acarretando consequências para todos os aspectos da sociedade, incluindo a Educação, que está em questão aqui, conforme colocam BEBRENS e OLIARI (2007, p. 59-60):

O paradigma tradicional ou newtoniano-cartesiano levou a fragmentação do conhecimento e a supervalorização da visão racional. Nesse sentido, propôs a primazia da razão sobre a emoção, especialmente, para atender a coerência lógica nas teorias e a eliminação da imprecisão, da ambigüidade e da contradição dos discursos científicos. A fragmentação atingiu as Ciências e, por conseqüência, a Educação, dividindo o conhecimento em áreas, cursos e disciplinas. As instituições, em especial as educacionais, passaram a ser organizadas em departamentos estanques, no qual emergem os especialistas, considerados pela sociedade como os detentores do saber. Neste processo reducionista, criam-se as especialidades em uma única área do conhecimento. 
As duas culturas separadas pela "peneira" do paradigma tradicional (newtoniano - cartesiano) que estão em pauta aqui referem-se à Matemática e às Artes como ambiente que comporta outro saber que transita entre elas. A disposição das artes e da matemática em "culturas" diferentes é resultado desse processo de fragmentação. Essa visão reducionista gerou currículos estanques em que essas disciplinas são ensinadas como saberes que não dialogam entre si.

Tomas Kuhn aponta em seu livro "A estrutura das revoluções científicas" (1998, p. 212) para um caráter específico de uma revolução científica, que pressupõe uma alternância de paradigmas, tratando especificamente do que ocorreu após o paradigma newtoniano, em que a especialização cada vez maior diminui a capacidade de comunicação entre grupos de conhecimento. Deste padrão que emerge da necessidade de alcançar a certeza de que um conhecimento é verdadeiro surge a questão do critério de verdade (HESSEN, 2000, p. 23), que fomenta uma consequente enculturação do mesmo.

Adiante este trabalho trata de mostrar o diálogo possível entre essas "Duas Culturas".

\section{Desenho Geométrico e Projetivo nas Artes e na Matemática}

Transita entre os dois saberes citados anteriormente, no que tange o currículo escolar, um outro saber, também dissociado dos demais, mas que consegue trazer à luz a questão da interdisciplinaridade do conhecimento humano, pois une, mesmo que inconscientemente, duas culturas separadas pela peneira do conhecimento científico. O Desenho Geométrico e Projetivo está, historicamente, ligado ao conteúdo curricular da matemática' contudo, também é abraçado pelas artes como conteúdo curricular

“(...) o ensino da geometria que valorize o artístico justifica-se pela possibilidade de despertar e desenvolver o senso estético, envolvendo simultaneamente, as quatro funções da consciência - sensação, pensamento, sentimento e intuição considerando que toda vida emerge de um mesmo padrão e que sua existência tem uma condição de unidade com o universo e o criador. (SANTOS e ORMEZZANO, In: ARAÚJO, 2012, p. 34 )"

Justamente essa facilidade de acesso à saberes que se propõe dissociados o faz perder credibilidade no cenário da educação nacional e, como visto anteriormente, esse descrédito está mais ligado à história da teoria do conhecimento do que à uma escolha burocrática, de aspecto legal, haja vista que dentro do paradigma tradicional, newtoniano-cartesiano, aquilo que não possui definição especifica fica à margem. E como o Desenho Geométrico e Projetivo perdeu esta definição com a Lei no 5.692 de 1971 (PINTO, 2013, p. 18), ele foi posto num limbo, que agora se mostra como uma via de diálogo, assumindo caráter positivo na educação, como não ocorria antes. KUHN (Idem) e HESSEN (Idem) afirmam que há uma alternância de paradigmas ao longo da história da teoria do conhecimento no ocidente. Deste modo, é provável que as questões em voga sobre a necessidade de um saber interdisciplinar e da transdisciplinaridade do conhecimento estejam relacionadas à uma nova tendência, apontando para um novo paradigma que consiga abrir espaço para um diálogo verdadeiro entre os saberes dissociados. BEBRENS e OLIARI (In: ARAÚJO, 2012, pag. 61) colocam que "a proposta da nova visão depende do avanço do paradigma da ciência que impulsiona a revisão do processo fragmentado do conhecimento na busca de reintegração do todo."

Deste modo, o Desenho Geométrico e Projetivo mostra estar um passo à frente. Repensar sua prática é fundamental para que o mesmo não acabe por perder essa característica positiva que lhe foi imposta e acabe por se tornar mais uma "cultura".

3 Conclusão: Retomar o diálogo 
A necessária brevidade deste artigo não possibilitou o esgotamento do assunto em questão, tendo se mostrado como ponto de partida para uma pesquisa mais profunda das relações da teoria do conhecimento com a educação escolar. Seguem os apontamentos que concluem o mesmo, reiterando o que foi apresentado até aqui.

Uma prova concreta de que nenhum saber se dissocia é o diálogo transdisciplinar existente entre as três áreas apresentadas. O Desenho Geométrico e Projetivo transita de forma natural entre conhecimentos separados e colocados em lugares completamente diferentes. Ele está nas Artes, no estudo da perspectiva, das projeções bidimensionais, no estudo da teoria da percepção visual, etc; está na matemática no estudo do das figuras planas, da geometria descritiva, no estudo da razão áurea, etc. E por estar no meio do caminho, acabou por ficar relegado à segundo plano no que tange a educação escolar.

Mas estar no "meio do caminho" seria um problema?

Este artigo apontou para uma resposta negativa a esta pergunta, de modo que as necessidades que emergem da própria produção do conhecimento, conforme foi visto, apontam para o caminho que foi imposto ao Desenho Geométrico e Projetivo. Retomar o diálogo é necessário. E no que trata das relações entre Artes e Matemática, o Desenho é uma via.

Se todo conhecimento é produzido com base numa perspectiva humanizada do universo, e a percepção é uma vertente única, no sentido próprio do termo, insistir na fragmentação do mesmo implica desconsiderar as necessidades que emanam da própria sociedade que produz esse conhecimento. Essa retomada de diálogo entre saberes fragmentados vai além dos que foram colocados aqui e apontam para uma verdadeira transdisciplinaridade da educação, como consequência dessa mudança. Sabe-se que é possível, mas os caminhos ainda seguem escorregadios, já que o novo precisa romper com o velho para que as mudanças aconteçam.

\section{Bibliografia}

ARAÚJO, Ana Paula Batista. Memórias do Ensino de Desenho na UFPel: Da Escola de Belas Artes ao Centro de Artes. Dissertação de Mestrado, Pelotas: UFP, 2012.

HESSEN, Johannes. Teoria do Conhecimento. São Paulo: Martins Fontes, 2000.

KUHN, Thomas S. A estrutura das revoluções científicas. São Paulo: Perspectiva S. A., 1998.

PINTO, Beatriz dos Ramos. O Desenho Geométrico e o currículo escolar: escola, atualidade e luta. (Monografia de conclusão de Especialização). Escola de Belas Artes - UFRJ, 2013.

ROSA, Luiz Pinguelli. Tecnociências e Humanidades: novos paradigmas, velhas questões. São Paulo: Paz e Terra, 2005.

SANTOS, Rosângela S.; ORMEZZANO, Graciela. Para além da geometria na escola: Antigas e novas abordagens. UPF editora. Passo Fundo, 2005.

BRASIL. Lei de Diretrizes e Bases da Educação Nacional, no 9.394, de 20 de dezembro de 1996.

BRASIL. Parâmetros Curriculares Nacionais (PCNs). Matemática. Ensino Fundamental. Brasília: MEC/SEF, 1998. Parâmetros Curriculares Nacionais (PCNs). Matemática. Ensino Médio. Brasília: MEC/SEF, 1998. 


\section{SERIA O VÁCUO QUÂNTICO DIRAQUEANO DO SÉCULO XX: UMA RELEITURA DA VACUIDADE BÚDICA DO SÉCULO V A.C.?}

REIS, Jussimar, Mestranda do HCTE/UFRJ, - joreis@hcte.ufri.br

HELAYEL-NETO, Jose Abdalla- Pesquisador no CBPF - helayel@cbpf.br

Resumo

O eixo epistêmico da Escola Oriental Budista sugere a existência de núcleos conceituais e práticos representados em diversos campos do saber, por exemplo, na física ocidental. Uma possível aproximação entre Escolas, Oriental e Ocidental, está sendo proposta a partir da combinação da Escola Diraquena - Escola do Físico Paul Dirac (1902-1984), cientista britânico, foi o mais jovem teórico ganhador do prêmio Nobel de Física (1933), e a Escola Budista Humanística Ikeda - Escola do Humanista Daisaku Ikeda (1928-) fundador da ONG Humanística Soka Gakkai Internacional (1974), traduzindo para o repertório filosófico os Ensinamentos que são colocados à luz da linguagem moderna. Dentro deste recorte, há outro: as duas tratam da "teoria do nada", do "vácuo". Contudo, estes conceitos emergem com suas respectivas assinaturas epistêmicas. O objetivo é investigar, estruturar e sistematizar elementos que apontem potencialmente para este paralelismo, construindo uma conexão narrativa em rede entre Paul Dirac e Daisaku Ikeda.

Palavras-chave: Mecânica Quântica. Budismo. Teoria do Nada. Vácuo Quântico. Ikeda.Dirac.

\section{A Física}

A busca por uma descrição sempre mais profunda da Natureza e a tarefa de se elaborar novas realidades vem, de forma sempre crescente e mais complexa, movimentando o mundo das ideias, estendendo os domínios de nossa abstração e criando linguagens e códigos altamente refinados. Tomando como ponto de partida uma das Ciências da Natureza, a Física, o desafio imposto pela investigação de fenômenos que se passam desde a escala attoscópica (milionésimo do milionésimo do milionésimo do metro) à escala cosmológica (e, aqui, se fala de centenas de milhões de milhões de milhões de quilômetros) é repensar a relação entre Natureza e Realidade, uma vez que o projeto é perscrutar o natural que se encontra a um enorme distanciamento do real. E a dialética que se estabelece entre o natural e o real estende-se aos demais setores do conhecimento humano, a todas as Ciências de nossos dias. A concepção Galileo-Newtoniana do método científico é colocada em questão quando é considerado experimentos tão complexos como aqueles realizados nos mais recentes aceleradores de partículas (o grande anel colisor de partículas sub-nucleares, o LHC de CERNGenebra, por exemplo) ou quando refere--se às medidas realizadas nos refinados telescópios, na Terra ou em plataformas espaciais. A experimentação já não é mais exploratória em seu sentido amplo, não se descobre aleatoriamente; constroem-se os mais complexos e precisos aparelhos de medição já se tendo em mente o que se deseja descobrir, ou seja, é detectado aquele objeto que já estava preparado para se ver ou detectar. Exemplos muito recentes são a descoberta do bóson de Higgs, anunciada em Julho de 2012, e a detecção da colisão de buracos negros com a consequente emissão de ondas gravitacionais, observadas em experimento terrestre, descoberta anunciada em Fevereiro de 2016.

As Ciências, nos tempos atuais, em um grande número de situações, são marcadas por um alto grau de abstração - abstração matemática também - de tal forma que o caráter 
exploratório concentra-se na fase da teoria; as explorações se dão muito no abstrato. Construído um modelo ou, em um estágio mais avançado, formulada uma teoria, passa-se à fase da experimentação, com algum aparato já desenhado de acordo com o que se quer explorar a partir daquilo que a teoria prevê, ou, de forma mais radical, daquilo que a teoria já "descobriu". É neste sentido - e a Física contemporânea é rica deste tipo de procedimento diz-se que se vivencia uma quase inversão do tradicional método Galileo-Newtoniano de se fazer Ciência. O LHC, já mencionado acima, é um experimento altamente desafiador para a Física, mas igualmente - ou, mesmo, até mais - desafiador para a Epistemologia. A complexidade está neste entrelaçamento entre modelo/teoria, geração de dados experimentais, simulação computacional a partir destes dados colhidos, e a final confirmação em laboratório de uma descoberta já anunciada teoricamente.

\section{O Vácuo teria uma estrutura? Como se chegou a esta Teoria?}

"O vácuo quântico difere do clássico, pois este é definido como sendo o espaço na ausência de quaisquer tipos de matéria, e o quântico é uma região repleta de pares de partículas e antipartículas, as chamadas partículas virtuais. Desde a antiguidade clássica até os tempos atuais, o conceito de vácuo vem sendo discutido fervorosamente e as ideias sofreram diversas mudanças." Mauro Antonio Andreata

Em fevereiro de 1929, Paul Dirac em seu trabalho "The Theory of Electrons and Protons" junta elétrons com prótons, lançando a ideia de vácuo quântico. Surge então o "mar de Dirac". Uma proposta de Dirac para o vácuo quântico: um mar infinito de elétrons livres com energia negativa. Assim o vácuo quântico é apresentado como tudo menos o nada, o vazio. Esta estrutura de conceito muito, muito microscópico, torna-se um ponto de encontro entre o que é extremamente pequeno, o mais ínfimo que há em física com o que é mais macro. Metaforicamente, imagina-se uma linha de menos a mais infinito e é o vácuo quântico que faz a junção com o que está extremamente distante a esquerda com o que está extremamente distante a direita.

Dirac afirma que o vácuo é riquíssimo, o vácuo é matéria, o vácuo tem estrutura e é protagonista que coordena tudo o que se conhece da natureza. Romper com este lugar comum da vacuidade não é uma tarefa fácil, porque além de sair do senso comum esta ideia, apesar de científica, envolve certa subjetividade.

Em 1947, aparece a primeira evidencia de que o vácuo existe, de que não é uma estrutura estática. A Física Atômica é utilizada como instrumento de alta precisão, tendo em vista o ser humano não possuir a habilidade visual de observar distâncias como um bilionésimo de metro $\left(1,0 \times 10^{-9}\right.$ metros $)$ e nem de perceber um intervalo de tempo como um trilionésimo de trilionésimo de trilionésimo de segundo, que é onde o vácuo pulsa. Portanto, a ferramenta utilizada para estas confirmações experimentais foi a chamada flutuação do Vácuo (ou flutuação de ponto-zero) conhecido como o deslocamento de Lamb (Lamb shift). No ano seguinte, o físico holandês Hendrik Casimir da Phillips previu o famoso Efeito Casimir. O efeito Casimir basicamente é causado nos efeitos vazios do vácuo entre duas placas metálicas colocadas próximas. Ele faz com que as placas se aproximem, pois há menor densidade de energia entre elas do que fora delas. E a resposta para a pergunta se a estrutura do Vácuo seria sensível à gravidade veio em 1971, 1972 sobre esta sensibilidade. Experimentos com átomos também mostraram que sim.

Neste percurso, entre Dirac e a atualidade, um ciclo de pensamento foi sendo delineado para uma postura em relação a ideia, a teoria de como seria este vácuo: existe de fato, não é estático, não é trivial, ele é matéria que pulsa.

Vácuo Budista -Teoria do Nada 
A princípio, o termo "vácuo" indica a ausência total de matéria. Mas existem graus diferentes de vazio de acordo com a aplicação técnica ou científica. No dia-a-dia, é comum embalagens com a expressão "embalado a vácuo". Trata-se de um processo industrial em que a quantidade de ar dentro da embalagem é reduzida a dez vezes menos do que a presente na atmosfera. Já no interior das lâmpadas, utiliza-se o vácuo de alta qualidade correspondente a cerca de 5 trilhões de moléculas ou átomos por centímetro cúbico. Nos grandes laboratórios especializados consegue-se alcançar a quantidade de mil moléculas por centímetro cúbico. No espaço interestelar, existe poeira e gases espalhados entre os corpos celestes. Entretanto essa quantidade de matéria é mil vezes maior que nos graus de vácuo atingidos pelo ser humano.

Segundo o budismo, o Universo é composto de cinco elementos naturais: terra, água, fogo, vento e kuu. O quinto elemento, kuu, é livre do nascimento e da morte, existe num mesmo estado e produz os outros quatro elementos. Do ponto de vista contemporâneo sobre a matéria, os quatro elementos naturais são partículas elementares, e kuu é o "campo de energia" que pode produzir partículas elementares e transformá-las (IKEDA, 2004). A Teoria do Nada pela visão budista, "kuu" em japonês, significa a natureza e o espírito de todas as coisas e que transcende a existência e a não-existência. Muito frequentemente, encontra-se este conceito budista interpretado como vacuidade, não-substancialidade ou relatividade. Há também leituras como vazio ou aniquilação, mas que é considerado pelos pensadores budistas como definições equivocadas para um estado potencial da qual todas as coisas emergem e para qual retornam. Desse Fundo sem fundo surgiram todos os seres e o inteiro universo (BOFF, 2016).

Quatro estágios cíclicos de formação, continuação, declínio e desintegração

A linha de pensamento sobre o cosmos, pela visão búdica, reside no eterno movimento de formação, continuação, declínio e kuu (desintegração, o aparente nada). Tudo se repetindo neste ciclo sem fim. A formação é o estágio em que a vida surge ou se manifesta e se desenvolve e assim a continuação corresponde à fase em que ela encerra o seu crescimento e atinge a maturidade. Na existência humana, está relacionado ao estágio em que a vida começa a envelhecer ou a declinar. E por fim, kuu é a fase em que a vida completa suas atividades no mundo e se funde com o Universo. O budismo vê o cosmos como uma grande vida que não tem começo nem fim. Não há nada no Universo que nunca mude ou permaneça como está. Tudo repete seu ciclo de formação, continuação ou desenvolvimento, declínio e desintegração (IKEDA, 1965).

\section{Conclusão}

Em última análise, o que se busca neste encontro é proporcionar a discussão sobre a interface de Física, através do físico europeu ocidental Paul Dirac, e Budismo, através do humanista oriental Daisaku Ikeda, contemplando a Teoria do Nada como mola propulsora deste primeiro encontro epistemológico.

O diálogo entre a Escola Diraquena e a Escola Humanística Ikeda pautado no conceito de vácuo quântico - sua rica e ainda não compreendida estrutura - revela-nos uma ciência viva, pulsante, e essencialmente humana. Seja pela abstração dos objetos na ciência, ou na não substancialidade de todos os fenômenos, sustentada pelas milenares culturas orientais, o nada é a grande urgência existencial, racional, contemporânea.

\section{Bibliografia}

ANDREATA, Mauro Antonio. O VÁCUO QUÂNTICO. Coletânea Interdisciplinar em Pesquisa, Pós-Graduação e Inovação - Volume 4: Ciências Exatas e Tecnológicas. Anais [livro eletrônico] / organizado por Adriana Freitas 
Neves, Idelvone Mendes Ferreira, Maria Helena de Paula, Petrus Henrique Ribeiro dos Anjos. São Paulo: Blucher, 2015.

BOFF, Leonardo. O Cristo cósmico: uma espiritualidade do universo. In: http://www.jb.com.br/leonardoboff/noticias/2016/09/26/o-cristo-cosmico-uma-espiritualidade-do-universo/ - acessado em 10/10/2016.

DIRAC, Paul Adrien Maurice. The Relation between Mathematics and Physics. In: Proceedings of the Royal Society (Edinburgh) Vol. 59, 1938-39, Part II pp. 122-129.

IKEDA, Daisaku. Vida um Enigma, uma Jóia Preciosa. São Paulo: Editora Brasil Seikyo, 2010.

IKEDA, Daisaku. A Sabedoria do Sutra do Lótus. São Paulo: Editora Brasil Seikyo, 2006.

IKEDA, Daisaku. Science and Religion. Tóquio: Soka Gakkai, 1965. 


\section{QUADRADO DE OPOSIÇÃO TRANSREAL}

Tiago S. dos Reis - Doutor pelo HCTE/UFRJ - Professor do IFRJ - tiago.reis@ifrj.edu.br

Resumo

No presente texto, divulgamos o quadrado de oposição transreal. O quadrado de oposição, oriundo da teoria das proposições categóricas de Aristóteles, é um diagrama que ilustra relações lógicas de contradição, contrariedade, subcontrariedade e subalternação entre proposições. O quadrado de oposição transreal é feito de valores semânticos baseados nos números transreais, que são uma extensão dos números reais que permite a divisão por zero.

Palavras-chave: Quadrado de Oposição. Quadrado de Oposição Transreal. Transmatemática.

Introdução

O objetivo deste texto é divulgar o tema do 5th World Congress on the Square of Opposition e, mais especificamente, o quadrado de oposição transreal apresentado no evento citado (REIS, GOMIDE e ANDERSON, 2016).

O quadrado de oposição é um tema oriundo da lógica aristotélica, que há séculos vem sendo estudado, melhorado, estendido e aplicado em diversas outras áreas do saber. Este quadrado é uma figura, um diagrama, uma ilustração, de relações lógicas entre determinadas proposições. O diagrama facilita a visualização e entendimento de tais relações. Esta visualização permitiu o aprimoramento da teoria e, mais ainda, a extensão do quadrado a outras figuras mais complexas e a aplicação destas figuras em diversas áreas.

Neste texto, apresentamos o quadrado de oposição transreal. Este é um diagrama motivado no quadrado original, no entanto, contempla os valores da semântica total. Semântica esta que é baseada nos números transreais que originaram a transmatemática.

A transmatemática é a matemática que surge a partir dos transnúmeros, números que estendem os números usuais e permitem a divisão por zero. O primeiro conjunto a permitir a divisão por zero é o dos números transreais. Outros conjuntos também são estudados na transmatemática como, por exemplo, os transnaturais e os transcomplexos. Alguns tópicos da transmatemática já foram abordados em edições anteriores do Scientiarum História (ABRAHÃO e GOMIDE, 2013),(GOMIDE, 2012),(REIS, 2014, 2015, 2016),(REIS, GOMIDE e KUBRUSLY, 2013).

\section{O Quadrado de Oposição}

O quadrado de oposição é um diagrama feito para ilustrar as relações lógicas de oposição, negação, quantificação e proposição. Ele surge a partir da teoria de Aristóteles das proposições categóricas e pode ser generalizado a outras várias situações, inclusive em suas versões extendidas, como hexágonos, octógonos e até poliedros. Atualmente ele tem sido aplicado em diversas áreas da lógica, filosofia, matemática e até das artes (5th World Congress on the Square of Opposition, 2016).

O quadrado de oposição, em sua versão mais simples, elucida as relações de contradição, contrariedade, subcontrariedade e subalternação entre proposições. Duas proposições são contraditórias se, e somente se, o fato de uma delas ser verdadeira implica que a outra é falsa; duas proposições são contrárias se, e somente se, não podem ambas ser verdadeiras, mas podem ambas ser falsas; duas proposições são subcontrárias se, e somente se, podem ser ambas verdadeiras, mas não podem ser ambas falsas; uma proposição é subalterna a outra 
se, e somente se, a segunda implica a primeira. Sejam A, E, I e $O$ as seguintes proposições: a) $A$ : Todo $S$ é $P$, b) E: Nenhum S é P.; c) I: Algum S é P.; d) e) O: Algum $S$ não é $P$.

Note que: A e O, I e E são contraditórias; A e E são contrárias; I e O são subcontrárias e I é subalterna a $A$ e $O$ é subalterna a E. Veja a Figura 1.

Para mais sobre o quadrado de oposição veja (BEZIAU, 2012a, 2012b).

Figura 1. Quadrado de oposição

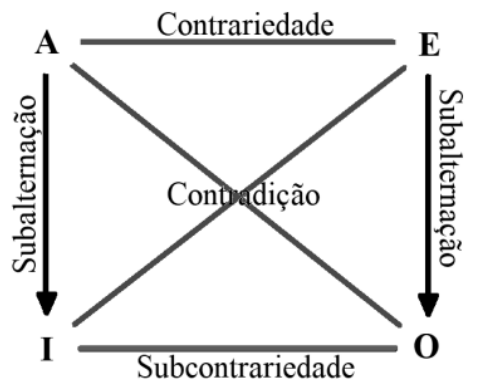

Fonte: Elaborado pelo autor

Os Números Transreais e a Semênctica Total

O conjunto dos números transreais ( $\mathbb{R}^{T}$ ) é uma extensão dos números reais que permite a divisão por zero (ANDERSON, 2005). A motivação de James Anderson foi aplicar estes novos números à programação de computadores. A aplicação da transaritmética em hardwares e softwares de computador foi discutida em (ANDERSON, 2015), dentre outros textos.

$E m \mathbb{R}^{T}$, as quatro operações básicas (adição, subtração, multiplicação e divisão) são fechadas, isto é, o resultado de qualquer uma destas operações entre números transreais é um número transreal. Em particular, divisão por zero é permitida. O conjunto $\mathbb{R}^{T}$ é formado por todos os números reais e mais três novos elementos, $-\infty, \infty$ e $\Phi$, denominados respectivamente por menos infinito, infinito e nullity. Desta forma, $\mathbb{R}^{T}=\mathbb{R} \cup\{-\infty, \infty, \Phi\}$. Por definição: $\frac{-k}{0}=$ $\frac{-1}{0}:=-\infty, \frac{k}{0}=\frac{1}{0}:=\infty$ para todo $k \in \mathbb{R} \mathrm{e} \frac{0}{0}:=\Phi$ (ANDERSON, VÖLKER e ADAMS, 2007).

Os números transreais possuem divesas propriedades aritmétcias e de ordem. As mais relevantes para o presente tema são: $-\infty<k<\infty$ para todo número real $k$, isto é, menos infinito é menor que qualquer número real e mais infinito é maior que qualquer número real; $\Phi \nless x$ e $\Phi \ngtr x$ para todo número transreal $x$, isto é, nullity é um número não-ordenado, nullity não é menor nem maior que qualquer número transreal; $\Phi$ é um ponto isolado, topologicamente falando (REIS e ANDERSON, 2015); $\Phi+x=x+\Phi=\Phi, \Phi-x=x-\Phi$ $=\Phi, \Phi \times x=x \times \Phi=\Phi$ e $\Phi \div x=x \div \Phi=\Phi$ para todo número transreal $x$, isto é, qualquer operação aritmética com nullity resulta em nullity.

A semântica total é baseada no conjunto dos números transreais, em virtude da totalidade deste conjunto (GOMIDE, REIS e ANDERSON, 2015a, 2015b), isto é, em virtude do fato de o resultado de quaisquer operações aritméticas aplicadas a números transreais ser um número transreal. Na Figura 2, a reta transreal é exibida.

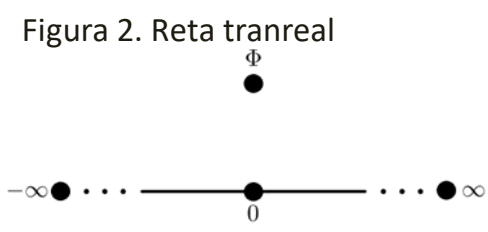

Fonte: Reis, Gomide e Anderson (2016)

O eixo é dimensionado para permitir que todos os números reais sejam definidos na figura. 0 infinito negativo situa-se à esquerda da reta real. $\mathrm{O}$ infinito positivo situa-se à direita da reta 
real. O nullity fica fora da direção da reta real. Em (GOMIDE, REIS e ANDERSON, 2015a), o conjunto dos valores semânticos é definido como $\mathbb{R}^{T}$. Na semântica total, o infinito negativo modela o Falso clássico; o infinito positivo modela o Verdadeiro clássico; o conjunto dos números reais modela os valores fuzzy; o zero modela um valor paraconsistente, que é igualmente Falso e Verdadeiro; e nullity modela um valor de indeterminação, que é nem falso nem verdadeiro. Os conectivos lógicos são definidos a partir de funções transreais. A negação é dada por $\neg(x)=-x$; a conjunção é dada por $x \wedge y=\Phi$, se $x=\Phi$ ou $y=\Phi$ e $x \wedge y=$ $\min \{x, y\}$, caso contrário; e a disjunção é dada por $x \vee y=\Phi$, se $x=\Phi$ ou $y=\Phi$ e $x \vee y=$ $\max \{x, y\}$, caso contrário.

O Quadrado de Oposição Transreal

No quadrado de oposição transreal os vértices não são proposições, mas valores semânticos. Ele estende o quadrado da lógica de quatro valores de Belnap (BELNAP, 1977). Na lógica de Belnap, os valores semânticos são dados pelo conjunto $\{\mathrm{F}, \mathrm{T}, \delta, \gamma\}$ onde $\mathrm{F}$ é Falso, $\mathrm{T}$ é Verdadeiro, $\delta$ é Falso e Verdadeiro, e $\gamma$ não é Falso nem Verdadeiro. Esse quadrado foi mostrado em (BEZIAU, 2012a) e mostrado na Figura 3.

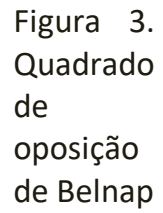

O quadrado de oposição transreal é feito a partir da semântica total, Figura 4.
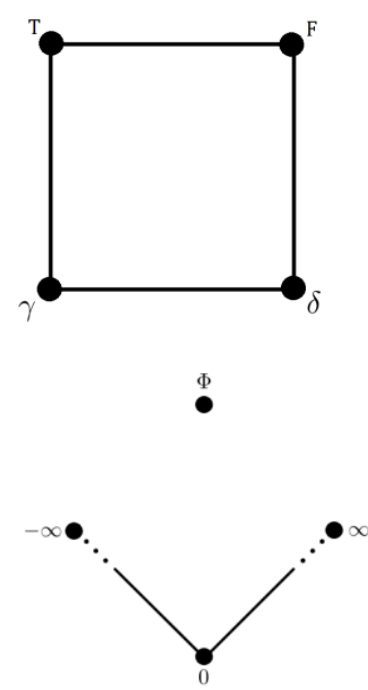

Figura 4. Quadrado de oposição transreal Fonte: Reis, Gomide e Anderson (2016)

Fonte: Reis, Gomide e Anderson (2016)

Este quadrado é contínuo em alguns pontos e descontínuo em outros. Os números (transreais) $-\infty, 0, \infty$ e $\Phi$, nesta ordem, são os vértices do quadrado. O lado entre os vértices 0 e $-\infty$ é feito de uma semi-reta que começa em 0 e vai indefinidamente com todos os 
números reais negativos para $-\infty$. Da mesma forma, o lado entre os vértices 0 e $\infty$ é feito de uma semi-reta que começa em 0 e vai indefinidamente com todos os números reais positivos em direção a $\infty$. O lado entre os vértices $-\infty$ e $\Phi$ é feito de um espaço vazio. Da mesma forma, o lado entre os vértices $\infty$ e $\Phi$ é feito de um espaço vazio. Neste quadrado, os vértices não são os únicos valores semânticos, mas a parte contínua dos lados também o são. Observe que $-\infty, 0, \infty$ e $\Phi$ desempenham o papel dos valores de Belnap $F, \delta, T$ e $\gamma$ respectivamente, o lado entre 0 e $-\infty$ desempenha o papel dos valores fuzzy de falsidade e o lado entre 0 e $\infty$ desempenha o papel dos valores fuzzy de veracidade.

No quadrado de oposição transreal, os valores opostos são as interseções do quadrado com linhas paralelas à diagonal entre $-\infty$ e $\infty$, conforme mostrado na Figura 5.

Figura 5. Valores opostos

$\Phi$

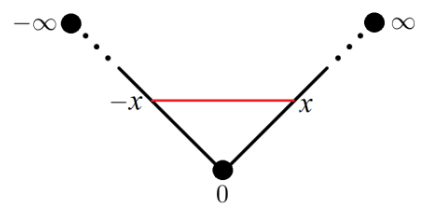

Fonte: Reis, Gomide e Anderson (2016)

Desta forma, números reais simétricos são opostos; $-\infty$ e $\infty$ são opostos; 0 é oposto a 0 ; e $\Phi$ é oposto a $\Phi$. Isto está de acordo com a negação transreal definida em (GOMIDE, REIS e ANDERSON, 2015a), onde $\neg(x)=-x$ (a aritmética transreal diz que $-0=0$ e $-\Phi=\Phi$ ). Consideremos o triângulo $-x 0 x$ cuja hipotenusa é $-x x$. Este triângulo representa a "negação paraconsistente". O "triangulo paraconsistente" poderia ser aumentado e, no limite, quando $-x=-\infty$ e $x=\infty$, nós temos o "triângulo clássico" $-\infty 0 \infty$. Desta forma, a negação é uma operação lógica que "diagonaliza" valores semânticos. Toda lógica que tenha contradição pode ser vista como uma operação em um triângulo, de modo que a operação vai da posição $x$ para a posição antipodal $-x$. A contradição deve ser definida em um triângulo cuja origem é uma dialetheia - uma verdadeira contradição.

Referências bibliográficas

5th World Congress on the Square of Opposition, 5, 2016. Ilha de Páscoa. Anais ... Handbook of Abstracts 5th World Congress on the Square of Opposition: J.-Y. Beziau, D. Jacquette (eds.), 2016.

ABRAHÃO, F.; GOMIDE, W. Teologia da informação. In: SCIENTIARUM HISTORIA:

VI CONGRESSO DE HISTÓRIA DAS CIÊNCIAS DAS TÉCNICAS E EPISTEMOLOGIA, 2013. Rio de Janeiro. Anais... Universidade Federal do Rio de Janeiro, 2013.

ANDERSON, J. A. D. W. Perspex machine II: Visualisation. Vision Geometry XIII Proceedings of the SPIE, v. 5675, p. 100-111, 2005.

ANDERSON, J. A. D. W. Transmathematical Basis of Infinitely Scalable

Pipeline Machines. In INTERNATIONAL CONFERENCE ON COMPUTATIONAL SCIENCE. Anais... Computer Science, v. 51, 2015, p. 1828-1837.

ANDERSON, J. A. D. W.; VÖLKER, N.; ADAMS A. A. Perspex Machine VIII: Axioms of transreal arithmetic. Vision Geometry XV Proceedings of the SPIE, v. 6499, p. 649903.1-649903.12, 2007.

BELNAP, N. D. A useful four-valued logic. In M. Dunn (ed), Modern uses of multiple-valued logic, Reidel, Boston, p. 8-37, 1977. 
BEZIAU, J.-Y. The New Rising of the Square of Opposition. In: J.-Y. Beziau, D. Jacquette (eds.), Around and Beyond the Square of Opposition. Basel: Birkhäuser, p. 3-19, 2012a.

BEZIAU, J.-Y. The Power of the Hexagon. Logica Universalis, v. 6, p. 1-43, 2012b.

GOMIDE, W. Uma bBreve apresentação dos números transreais e uma sugestão de aplicação em filosofia: o espaço lógico de Wittgenstein. In: SCIENTIARUM HISTORIA: V CONGRESSO DE HISTÓRIA DAS CIÊNCIAS DAS TÉCNICAS E EPISTEMOLOGIA, 2012. Rio de Janeiro. Anais... Universidade Federal do Rio de Janeiro, 2012.

GOMIDE, W; REIS, T. S. dos; ANDERSON, J. A. D. W. Transreal Logical Space of All Propositions. In: Haeng Kon Kim; Mayhar A. Amouzegar; Sio-long Ao. (Org.). Transactions on Engineering Technologies, World Congress on Engineering and Computer Science. London: Springer, 2015a, p. 227-242.

GOMIDE, W; REIS, T. S. dos; ANDERSON, J. A. D. W. Transreal Proof of the Existence of Universal Possible Worlds. In: 5th World Congress and School on Universal Logic, 2015, Istambul. Handbook of the 5th World Congress and School on Universal Logic, p. 240-241, 2015b.

REIS, T. S. dos. O que tem sido pesquisado em transmatemática no HCTE. In: SCIENTIARUM HISTORIA: VII

CONGRESSO DE HISTÓRIA DAS CIÊNCIAS DAS TÉCNICAS E EPISTEMOLOGIA, 2014. Rio de Janeiro. Anais... Universidade Federal do Rio de Janeiro, 2014.

REIS, T. S. dos. Números transreais e o espaço lógico. In: SCIENTIARUM HISTORIA: VIII CONGRESSO DE HISTÓRIA DAS CIÊNCIAS DAS TÉCNICAS E EPISTEMOLOGIA, 2015. Rio de Janeiro. Anais... Universidade Federal do Rio de Janeiro, 2015.

REIS, T. S. dos. Um pouco de transmatemática: números transcomplexos. In: SCIENTIARUM HISTORIA: IX CONGRESSO DE HISTÓRIA DAS CIÊNCIAS DAS TÉCNICAS E EPISTEMOLOGIA, 2016. Rio de Janeiro. Anais... Universidade Federal do Rio de Janeiro, 2016.

REIS, T. S. dos; ANDERSON, J. A. D. W. Transreal Calculus. IAENG International Journal of Applied Mathematics, v. 45, n. 1, p. 51-63, 2015.

REIS, T. S. dos; GOMIDE, W.; ANDERSON, J. A. D. W. Transreal truth valued square of opposition In: 5th World Congress on the Square of Opposition, 2016, Easter Island. Handbook of Abstracts 5th World Congress on the Square of Opposition 2016, p. 37-40.

REIS, T. S. dos; GOMIDE, W; KUBRUSLY, R. Números transreais: mais uma etapa na história dos números. In: SCIENTIARUM HISTORIA: VI CONGRESSO DE HISTÓRIA DAS CIÊNCIAS DAS TÉCNICAS E EPISTEMOLOGIA, 2013. Rio de Janeiro. Anais... Universidade Federal do Rio de Janeiro, 2013. 


\section{AS INTERAÇÕES COMPLEXAS DO MILIEU TÉCNICO NA HOMINIZAÇÃO E EVOLUÇÃO HUMANA}

Cleber Melo Rocha Santos - clebersantos2021@bol.com.br

\section{Resumo}

Este artigo traz anotações de pesquisas em Biologia Evolucionista a respeito do cérebro humano, e sobre a psicologia evolutiva da mente humana, de forma a provocar um circuito hermenêutico com o fenômeno técnico através da Antropologia Fundamental de Edgar Morin. Para tanto são sinalizadas aberturas, que nos aproximam da criatividade, como modus operandi da physes, da vida, e da técnica. Provocações no âmbito da Filosofia da Biologia, e da Cosmologia Moderna, favorecem as dinâmicas generativas de sentido, pois colocam em movimento, os agenciamentos coletivos de desejo que maquinam com a imanência, a espreita da criação como acontecimento.

Palavras-Chave: Complexidade. Ciência. Filosofia. Técnica. Hominização. Mente, Cérebro. Crítica. Sentido.

Introdução

A criatividade humana remete inicialmente à vida, pois "nada impede de pensar que a criatividade do homem prolongue a da natureza"(PRIGOGINE, P.23). A história natural está repleta de testemunhos disso: a versatilidade bacteriana, a explosão cambriana, a irradiação adaptativa dos mamíferos... a diáspora da arkhé sociedade. Não obstante a impossibilidade de adentrarmos aqui nesta discussão que é subterrânea - no sentido guattari-deleusiano - a uma Filosofia da Biologia ainda centrada na nova síntese; fica evidente que novos olhares apontam para outras realidades, fenomenais, que ultrapassam o erro e a aleatoriedade em genética (BOURGUINGNON,ano).

"De uma atenção limitada quase que unicamente a uma explicação baseada exclusivamente sobre o genético passa-se à pesquisa de processos epigenéticos, e à análise dos mecanismos reguladores da expressão gênica" (ATLAN,ano). A partir deste olhar, percebe-se que a expressão gênica, e, portanto, o fenótipo, são diretamente influenciadas pelo meio externo; que o fluxo de dados não corre apenas em uma única direção, como propõem o dogma central da biologia molecular. $O$ agente da hereditariedade não seria apenas o núcleo, mas também membrana e citoplasma - justamente aquilo que irá delimitar a autonomia do vivente, como meio interno, separando-o do meio.

Na verdade, através da reflexão complexa, pode-se retornar além do milieu interno de Cuvier, deixando muito para traz a incômoda questão do "progresso evolutivo", ou a desconfiança no dogma central. Rumo ao infinito, às nucleossínteses, à formação do carbono e outros elementos nas supernovas. E antes de chegar a vida, partir em direção ao Sempre, na direção de uma criatividade cosmogenésica, fruto da causação quântica provocada por modulações criadas pela mente humana, como propõem o universo participativo de John Wheller. Neste sentido, as quatro forças elementares, não constituiriam um acaso, um universo particular, entre infinitos possíveis. A partir do argumento do "princípio antrópico" o multiverso, necessariamente, estará apto a produzir a vida: "Não 'há' nada no universo manifestado até um observador ver algo. Todas as coisas permanecem como possibilidades, até coisas macroscópicas, enquanto a consciência não escolher uma dentre essas possibilidades e ocorrer um evento de colapso (GOSWAMI,ano). 
Que escolhas seriam essas, capazes de integrar as constantes universais, responsáveis pelo firmamento e pela vida? Uma coisa parece ser certa, se o universo é observado a partir de leis comprovadas pela técnica - que é o cenário da Cosmologia padrão; e sua crítica principal ter sido construída também por amadores (ARP), a criatividade humana está fazendo a sua parte através da Ciência estabelecida e de sua permanente crítica. Já a Filosofia, a Arte e a Religião possuem velocidades diferentes, que podem ser alcançadas como mundo da linguagem, alargando, através da Filosofia, as aberturas interparadgmáticas que propõem "O Método 4". Trata-se de interpelar estas paragens do pensamento para que digam algo a respeito - pois a pergunta permanece. Será que só as questões técnico-científicas integram estas escolhas? As respostas que se constroem com 0 Método são justificadas pelo mito da neutralidade científica, pela inegável depredação do ambiente natural, e sujeição da humanidade terrena pela tecnociência (ELLUL,ano) a serviço do capitalismo, sejam eles concorrenciais ou de estado (KURZ,ano).

O 'imanentismo selvagem ' guattari-deleuziano propõem o conceito e sua pedagogia frente a 'perda do mundo', que é estria e afecção e percepto e acontecimento e Antroposceno, e enquanto desejo que maquina o mundo, no mundo da linguagem e do agora, traça uma linha de fuga para Ecúmeno. Pode-se falar dessas questões ao nível de uma física que ainda é intuitiva, e que é apoderamento sobre o real enquanto sentido, donde a questão ética emerge nesta discussão.

Neste sentido, o recorte se faz fundamental. Pois dentro da amplitude de reflexões que podem ser abarcadas pela proposta do simpósio, e no amplo espaço de discussão que se desenvolve no HCTE, cumpre a elaboração de um percurso de pensamento, que apesar de curto, potencialize estas aberturas como oportunidade de criação.

A complexidade moriniana consistirá na chave de construção do recorte proposto. O tetrálogo, enquanto chave para o movimento de O Método, permite o trânsito sobre realidades construídas através de teorias e epistemes particulares, que podem ou não alcançar a fronteira interparadgmática, a partir do comum flerte com a Filosofia. O que estivemos fazendo até agora foi inserir a criatividade humana, nesta criatividade mais ampla presente na Cosmogênese e na Evolução. A natureza da natureza, observada em "O Método $1^{\prime \prime}$, trata da observação do tetrálogo no âmbito physis.

Há um grande jogo cosmogenésico da desordem, da ordem e da organização. Pode-se dizer jogo porque há as peças do jogo (elementos materiais), as regras do jogo (imposições iniciais e princípios de interação) e o acaso das distribuições e dos encontros. No início, este jogo é limitado a alguns tipos de partículas operacionais, viáveis, singulares e, talvez, a apenas quatro tipos de interação[...]

Assim continua o jogo do mundo. Como veremos ele permite desenvolvimentos locais, insulares de ordem e de organização, inseparáveis dos desenvolvimentos de diversidade. (MORIN,ano).

Sem que precisemos, partindo da cosmogênese, adentrar nos modelos que tratam do surgimento das estrelas e do sistema solar, para então observarmos a vida da vida como pretende Morin em "O Método 2"; podemos transferir, de imediato, o tetrálogo para este ambiente, no qual a mega-máquina universo é substituída pela máquina Terra, enquanto organismo vivo, marcado por imensa complexidade ecossistêmica, e em interações e retroações com os Cosmo local e não local.

Desde aí, descobrimos que a qualidade eco-organizadora mais notável não é manter sem cessar, em condições iguais, por meio de nascimentos e de mortes, o estado estacionário do clímax, mas ser também capaz de produzir ou inventar novas reorganizações a partir de transformações irreversívieis que sobrevêm no biótopo e na biocenose. Assim, aparece-nos a virtude suprema da eco-organização: não é a estabilidade, mas a aptidão para construir novas 
estabilidades; não é o retorno ao equilíbrio, mas a aptidão da organização a reorganizar a si mesma de novas maneiras, sob o efeito de novas desorganizações. Em outras palavras, a ecoorganização é capaz de evoluir sob a irrupção pertubadora do novo, e essa aptidão evolutiva é que permite à vida não somente sobreviver; mas desenvolver-se ou, antes, desenvolver-se para sobreviver (MORIN, 2005, p.51)

Esta moldura epistemológica é perfeita para pensar a irradiação adaptativa dos mamíferos, e a complexificação da cerebralização. Mas, para nos apropriarmos devidamente do nosso objeto se faz imprescindível o recurso à especialidade científica, neste caso a Biologia Evolutiva e sua episteme, própria: pensar a partir de custos e benefícios, da permanência do ancestral comum, e a partir da seleção natural.

Robert Foley, coloca a questão de forma interessante: por que os humanos são tão raros na evolução?

\footnotetext{
"Se as caracterísitcas humanas conferem tamanha vantagem, por que razão os demais animais não a possuem? É claro que a seleção teria favorecido o aparecimento frequente dessas características, possivelmente em linhagens amplamente divergentes (FOLEY,ano, p.190).
}

De fato, a humanidade é parte de um continuum seletivo, que fez convergir a cerebralização rumo ao aumento de massa encefálica, sociabilidade, e maior flexibilidade de comportamento (FOLEY,ano). E isto pode ser observado entre os mamíferos e principalmente entre os primatas, o que atenta para a presença do ancestral comum, enquanto pool genético sobre o qual trabalharão os mecanismos genéticos e epigenéticos da evolução, e também a seleção natural.

A partir daí, segundo Foley (ano), a questão fundamental da paleoantropologia passa a ser sob que condições o fenótipo humano é adaptativo? Estas são as questões da ecologia evolucionista, e versam a respeito da pirâmide trófica, o acesso a quantidades de energia que tornem a relação custo benefício favorável a uma maior cerebralização, em virtude do alto custo energético dos tecidos cerebrais.

É aí que nós começamos a entrever o nosso objeto. Como o desenvolvimento das competências técnicas, já presentes nos chipanzés especializam-se, constituindo um milieu técnico que contribuirá para o surgimento da mente do sapiens, caracterizada por aquilo que Steven Mithen chama de fluidez cognitiva.

É claro que este olhar não pretende colocar o fenômeno técnico, em uma posição de primazia no processo de hominização, tratando-se antes de observar suas especificidades e tentar observar estas interações, complementares e antagônicas, no sentido da adaptação permanente de nossa espécie; pois o fenômeno técnico cria uma evolução exossomática que retroage sobre a biologia e espirito, da humanidade - como há muito se sabe; justificando a expressão de Leroy-Gourran de um milieu técnico. Tais reflexões, a despeito de seu fascínio e importância, permanecem minoritárias, subterrâneas mesmo, fruto do trabalho de verdadeiros titãs intelectuais como André Leroy-Gourran, Marshall McLuhan, Regis Debray, Roger Chartier, Jacques Ellul, Ellias Caneti, Herbert Marcuse, Lewis Munford, e certamente alguns outros. Tais formulações devem integrar a antropologia fundamental, com a qual Morin finaliza o "Le Paradigme Perdu: La nature Humaine"(ano) que pode ser considerado o volume 0 de "O Método" (MORIN,1975)

Mas por hora, no nível em que se encontra nosso objeto, acompanhar a construção conceitual da fluidez cognitiva de Steven Mithem, no entrecruzamento da biologia e antropologia evolutivas com a teoria da cognição, partindo daí em direção ao nosso objeto, parece ser uma boa estratégia. 
Segundo Mithen (ano) a fluidez cognitiva depende de processos psicológicos que originalmente evoluíram em domínios cognitivos especializados, e tal fluidez apenas veio à tona quando esses processos puderam trabalhar integradamente. Basicamente Steven Mithen fala da integração da inteligência naturalista, da inteligência social, e da inteligência técnica, que foram se especializando, principalmente ao longo do processo de hominização. No entanto, tais inteligências partem de uma herança genética já adaptada que é a inteligência geral presente entre os mamíferos.

Esta primeira inteligência, que seria a "nave " que alicerça a "catedral da mente moderna" é, segundo Mithen, a inteligência geral, que "teria construído uma série de regras sobre aprendizado geral e tomadas de decisão cuja característica essencial é o fato de poderem ser usadas para modificar o comportamento à luz da experiência em qualquer domínio comportamental" (MITHEN,ano).

Essa inteligência geral está presente nos mamíferos, sobretudo nos superiores, principalmente na ordem dos primatas, que inclui espécies que utilizam e fabricam artefatos técnicos. Os macacos especializaram a inteligência geral permitindo a seleção de uma inteligência social, sobretudo nos grandes primatas ou símios - sendo esta inteligência largamente associada com o afloramento da consciência (MITHEN,ano; FOLEY,ano; MORIN,ano). Neste sentido, o ancestral comum entre a humanidade e os grandes símios, o chamado elo perdido, também possuía esta inteligência geral, e alguma inteligência social (MITHEN,ano). Esta inteligência especializada, calcada em uma 'psicologia intuitiva' acaba por sobrepujar a 'inteligência geral', permitindo o surgimento de novos módulos mentais: a inteligência naturalista, baseada em uma biologia intuitiva, e a inteligência técnica baseada em uma física intuitiva(MITHEN,ano).

Ao que parece, as pressões adaptativas desencadeadas durante o Miosceno tardio, levou a seleção natural a atuar sobre os indivíduos deste ramo que divergiu dos grandes macacos africanos, no sentido de transferir sua habilidade de formular e testar hipóteses ao nível do comportamento, em direção ao meio natural; aumentando o número de informações sobre o meio, enquanto memória, previsibilidade, e observação do comportamento dos outros animais; e, enquanto abstração conceitual, técnica. Como observa Mithen(ano), as experiências de laboratório com chipanzés evidenciam quais competências já constituem uma adaptação, e quais competências podem ser especializadas em virtude do estímulo do ambiente. Neste caso, os chipanzés evidenciam a existência da inteligência social, pois não há mudanças significativas no comportamento social, enquanto o estimulo os faz superar em muito suas competências técnicas.

Ainda de acordo com Steven Mithen (ano) os artefatos técnicos fabricados pelo Homo habilis, não significam uma inteligência técnica especializada, mas apenas um aumento das modulações da inteligência geral (MITHEN, ano, p.175). Para o observador da técnica, todas essas informações são importantes, e ainda mais importante é a presença indelével da indústria Olduvaiense, em suas retroações sobre o fenótipo e genótipo dos indivíduos que a desenvolveram. A partir daí podemos observar, através dessas especialidades cientificas, e da crítica ao dogma central, a existência do milieau técnico, que influenciará, de forma irreversível a constituição biológica e mental destes primeiros primatas do gênero Homo, e consequentemente sua evolução.

Importante para nós é que $H$. habilis consumia grandes quantidades de carne, se comparados aos primatas de sua época. O cérebro de $500-800 \mathrm{~cm}^{3} \mathrm{de} H$. habilis, sugere que a carne havia passado a constituir uma parte substancial de sua dieta; independente de os desafios intelectuais relacionados a rapinagem, como a localização das carcaças, ter constituído, ou não, uma pressão seletiva, para o aumento do cérebro, como sugere Steven Mithen (ano). 
Ao que parece a inteligência técnica já está sendo partejada, no âmbito da inteligência naturalista, por uma memória somática construída pelo cérebro mamífero, através de modulações advindas da experiência de um corpo organismo vivo maquinal cerebralizado aberto para o mundo e para si mesmo como evolução e inacabamento. Movimentado-se por pulsões de prazer e dor, experimentando o ambiente, rememorando a conservação, os entes a sua volta, com seus paços, respiração, e suor - corpo próprio em movimento; e, chegada a hora, reprodução.

Já ordem social complexifica a consciência, favorecendo a inteligência social, que também por sua vez desenvolve traços dessa biotécnica. Neste cenário da história natural, a memória fixa comportamentos e parece permitir um tipo de previsibilidade prazerosa de sentido - um conceito - que não é apenas corpóreo como na inteligência naturalista, mas que se externaliza como comportamento, dramatizado, imagético, total, muito atores previsíveis, transferindo para realidade algo que foi primeiramente vivenciado, pensado como estratégia e resultado e aposta.

Já neste outro gênero da ordem primatae, o gênero Homo e sua indústria Olduvaiense, o corpo se projeta sobre a ordem natural como conceito de uma virtualidade prazerosa de sentido.

Foi dito que os instrumentos - quaisquer que fossem - produzidos pelo homo habilis eram 'instrumentos biológicos', quer dizer, que potencializavam ou estendiam a morfologia do indivíduo. No entanto, desde que os caninos começaram a se reduzir no Ardipthectus ramidus, os homens não dispõem de boas ferramentas naturais para cortar a pele e a carne dos animais mortos, nem tampouco tem como fraturar os ossos para extrair o tutano, por isso os instrumentos de pedra realmente representaram a chave, ou uma delas, para abrir uma nova despensa (ARSUAGA, ano)

Parece até uma ironia mas a partir daí, deste feito e efeito semiótico do fenômeno técnico, surge uma monotonia e previsibilidade até o aparecimento da linguagem. Como se a História da técnica estivesse falando de outra coisa mesmo, além de evolução. Dentes, mãos, braços; para fora - carne para dentro. Mithen observa as modulações que encaminham a linguagem, como o gesto, e os sons. O gesto é imagético e sinestésico, táctil; e o som que é fonação e audição, sincronizam, todos juntos, o mundo do agora - natural e social - com o cérebro Homo, com o mundo, que é partilha de sentido, se enxergando dentro dele, modificando seu crânio, seu rosto, e a realidade. O movimento do maxilar libera os dentes, e o rosto a palavra. (LEROYGOURRAN,ano). Mas antes as imagens e o sentido.

A práxis da arkhé sociedade será uma tentativa obstinada de recuperar o sensórium do meio táctil, verdadeiro princípio de apoderamento sobre o mundo, que se perde com a palavra (McLUHAN,ano). E o que faz é reconstruir o mundo todos os dias, através do mito do Eterno Retorno. A práxis faz isso povoando o mundo de seres imagéticos, verdadeiros tal qual os sonhos, e os momentos de sublimação estética ou terror; e movimenta-se circularmente através dessas densidades ontológicas diferentes, para recriá-lo e encontrá-lo, como tempo forte (ELIADE,ano). Tais imagens não são apenas todo o continuum imagético do grupo, mediado pelo mundo natural; é ainda a instituição do xamã que marca os corpos, dizendo que eles pertencem terra, através da filiação a um mito fundador - a práxis maquinando, através do guardião dos segredos e da tradição a captura deste modo anterior a linguagem(DELEUSE; GUATTARRI,1976). É ainda todo um mundo sobre-natural que envolve sonhos, duplos, visagens, mistério, iniciação, e encenação dessas forças livres, para que os participantes desta trama entreguem-se sinestesicamente a elas(ELIADE,ano).

Bibliografia

ARP, H. O Universo Vermelho. São Paulo: Perspectiva, 2001.

HCTE-UFRJ 
ARSUAGA, J.L. O colar de Neandertal: em busca dos primeiros pensadores. São Paulo: Globo, 2005.

ATLAN, H. DNA: programa ou dados. In: MORIN, E. (Org). A Religação dos Saberes. Rio de Janeiro: Bertrand Brasil, 2005.

BOURGUIGNON, A. História Natural do Homem - o homem imprevisto. Rio de Janeiro: Jorge Zahar Editor, 1990.

DELEUZE. G.; GUATTARI, F. O que é a Filosofia. Rio de Janeiro: Ed. 34, 1992. O Anti-Édipo. Rio de Janeiro, Imago:1976.

ELLUL. J. A técnica e o desafio do século. Rio de Janeiro, Paz e Terra: 1968.

ELIADE, M. Imagens e Símbolos. São Paulo: Martins e Fontes: 2002.

FOLEY, R. Os humanos antes da humanidade. São Paulo: Unesp, 2003.

GOSWAMI, A. Evolução Criativa das Espécies, São Paulo: Aleph, 2009.

KURZ, R. Os Últimos Combates. Petrópolis: Vozes, 1997.

LEROI-GOURHAN, A. O gesto e a Palavra 1 - técnica e linguagem. Lisboa: Edições 70.

MCLUHAN, M. Os Meios de Comunicação como Extensões do Homem. São Paulo: Cultrix, 1999.

MITHEN,S. A pré história da mente. São Paulo: UNESP, 2002.

MORIN, E. O Enigma do Homem. Rio de Janeiro: Zahar Editores, 1975.

O Método I: A Natureza da Natureza. Porto Alegre: Sulina, 2008.

O Método II: A Vida da Vida. Porto Alegre: Sulina, 2005.

. O Método IV: As Idéias. Porto Alegre: Sulina, 2005.

PRIGOGINE, I. Criatividade da natureza, criatividade humana. In: CARVALHO, E, A.; MENDONÇA, T. (Org). Ensaios de Complexidade 2. Porto Alegre: Sulina, 2003. 


\section{A HISTÓRIA DA MATEMÁTICA COMO AUXÍLIO NO PROCESSO DE RESOLUÇÃO DE PROBLEMAS CRIATIVOS}

Dorival Rodrigues da Rocha Junior - Mestrando no HCTE/UFRJ rodrigues.dorivaljunior@gmail.com Ana Paula Gonçalves - Mestranda no HCTE/UFRJ - hanapaulag@gmail.com

Resumo

Este trabalho visa examinar e compreender o processo de resolução de problemas criativos no ensino, usando o viés histórico como motivação da criatividade. Os problemas históricas e as diversas representações e variedade de tipos de pensamento pode ajudar na elucidação. O processo criativo se dá em quatro etapas: Preparação, Incubação, Iluminação e Avaliação. Entender essas etapas, e dar tempo a elas, é uma tarefa importante na resolução criativa. Focamos em exemplos de problemas geométricos pelas características criativas e multiplicidade de resoluções. Podemos concluir que a criatividade e liberdade de pensamento deveria ser mais incentivada, e pode ser uma boa abordagem no ensino e a exposição à história da matemática colabora para isso.

Palavras-chave: História. Matemática.

Introdução

Conhecer a história da álgebra ajuda a firmar conceitos, de modo que ele apresenta outras perspectivas. A maioria das vezes o que vemos são modelos prontos, "sem falhas" e nos resta apenas aceita-los. O estudo da história nos mostra que não foi assim que o conhecimento tomou forma. É importante destacar que o conhecimento matemático sempre foi construído por erros e acertos. Desta forma, entendemos que o conhecimento histórico desta ciência, pode contribuir profundamente para a formação inicial e continuada do professor, no sentido de que o mesmo possa aceitar ideias novas com facilidade. Isso pode gerar reflexões melhores sobre o assunto e problemas. Em outras palavras, conhecer a história da álgebra, e como se deu a construção desse campo do conhecimento pode ajudar em estratégias na hora de resolver problemas.

O processo criativo requer uma análise do problema que se quer solucionar. Essa análise passa por levantamento de dados e a identificação do tipo de problema, para então mobilizar o conhecimento que se tem. Uma etapa que acaba sendo negligenciada é a incubação, que seria dar tempo para mente se acostumar com a situação, possibilitando um pensamento mais livre, num primeiro momento, sobre o problema. Devemos então registrar qualquer ideia vinda desse processo, para uma checagem posterior. Feito isso, vem a avaliação que é a checagem das ideias e a tomada de ação para resolver o problema.

Segundo Houzel,

\footnotetext{
"A criatividade depende de um esforço conjunto de uma rede de estruturas dos dois lados do cérebro (e não só do direito!) Servem cada uma a uma função específica: memória de trabalho, imaginação de ações, significados emocionais complexos, satisfação e, sobretudo, flexibilidade cognitiva: a capacidade de mudar o conjunto de regras em uso no momento". (HOUZEL,2008)
}

Existem várias formas de se resolver um único problema. O uso de vários materiais contribui para a constatação desse fato. A conjunção das habilidades dominadas pelos dois hemisférios cerebrais é que determina o processo criativo. Aparentemente o hemisfério direito é dominante para habilidades espaciais, reconhecimento de faces, visualização mental e 
música. O lado esquerdo é mais especializado em habilidades de linguagem, matemática e lógica.

A criatividade do professor é fundamental, na hora de estimular e auxiliar no processo de criação da estratégia de resolução de problema. Essa criatividade pode ser estimulada. 0 melhor forma de exercitar isso é a exposição a diferentes situações e resoluções que podem ser utilizadas em diversos problemas posteriormente.

Segundo a metodologia pluralista de Feyerabend (ano), devemos estar abertos a todo tipo de teoria na busca da solução de um problema, levando em consideração até as ideias mais contraditórias. Sua visão anárquica e não linear da ciência embasa como é necessário levar em conta, numa fase experimental, qualquer ideia que se tenha, não priorizando o modelo tradicional. Feyerabend vai dizer que os grandes saltos da ciência foram momentos de ousadia, consciente ou não, onde se rompeu com modelo vigente.

A criatividade mostra-se, então, essencial na resolução de problemas. Podendo mostrar novos caminhos de se enxergar uma resolução.

$\mathrm{Na}$ nossa pesquisa bibliográfica conseguimos identificar que os registros históricos apresentam uma grande variedade de representações para problemas vistos até hoje, enriquecendo o arsenal de um professor que pode se encontrar de frente com uma ideia não tradicional proposta pelos próprios alunos. E, ainda, esse professor estaria munido para apresentar para seus alunos diferentes pontos de vista.

O ensino ainda é, principalmente, guiado pelo livro didático. Esses livros ainda apresentam o conteúdo de forma simplificada, sem discussões aprofundadas, e não dão suporte pra prática docente, segundo Santos(2010). Essa metodologia não dá espaço para o pensamento lógico e solução criativa de problemas e ideias que possam surgir por parte dos alunos. De certa forma, processos alternativos não são vistos com legitimidade em sala de aula. Deveríamos, então, reconhecer o impacto da História da Matemática na inserção de novas ideias e modelos, como história da matemática interfere no desenvolvimento da aula, e na forma como vemos os conteúdos.

Nosso objetivo, portanto, é identificar como se dá o processo criativo, analisar problemas antigos e suas resoluções, aplicar o processo criativo, junto às observações históricas, na tentativa de resoluções de problemas.

História da Matemática

Havendo vontade de ensinar matemática, como se o entendimento sobre o objeto estivesse desprendido do entendimento e domínio de sua representação, tem-se o paradoxo cognitivo do pensamento matemático e as dificuldades que resultam para sua aprendizagem (DUVAL,1993). As dificuldades dos alunos para compreender matemática surgem por conta da diversidade e complexidade das variações entre os registros de representação. Reconhecer várias representações de um mesmo objeto está diretamente ligado à percepção do objeto. Ele não depende de uma forma de representação, portanto quanto mais representações conhecidas melhor o entendimento sobre o objeto. A representação funciona como uma forma de acesso ao objeto. Dessa troca de registros e mobilização de ao menos dois registros no fazer matemática que surge a originalidade de pensamento. É importante lidar com ambos, representação e objeto, durante as aulas, de forma clara para que os alunos consigam desenvolver uma maturidade cognitiva. A compreensão da dualidade objeto representação, permite ao alunos caminhar, no futuro, com maior facilidades entre as representações semióticas.

A existência de várias representações semióticas pode estar ligada à facilidade de tratamento, a escolha apropriada pode agilizar a resolução do problema, e proporcionar um caminho mais 
claro à solução. Por outro lado, uma representação pode complementar a outra, destacando características que antes (em uma representação anterior) permanecia oculta.

Quando você começa a descrever ações, por exemplo, mesmo que em língua corrente, esse comportamento traz características que sistemas enativos não apresentavam antes. Tall (1994) diz que o símbolo pode ser falado, ouvido, visto ou lido e é a combinação desses meios de percepção e ação sobre ele que dão ao símbolo existência como objeto matemático. Uma abordagem versátil usa o método que for melhor para cada situação.

Percebemos um pensamento geométrico na resolução babilônica. O problema era resolvido descritivamente porém o pensamento que os conduzia era geométrico. É possível perceber este fato através das palavras adotadas nas resoluções, tais como: formar o quadro, o quadrado de lado, mostrando dependência das figuras, uma característica do pensamento icônico com pensamento em cima de experimentação, e interpretação sobre as figuras ou diagramas, assim como descreve Tall (1994). Observamos com os árabes, também, uma volta do artifício geométrico nas soluções motivado pelo estudo de os Elementos, demonstrando uma atenção a problemas geométricos.

A abordagem de História da Matemática é incentivada no PCN, e autores como Katz (2007) acreditam que no processo de construção de conhecimento do aluno o professor terá uma vantagem metodológica se conhecer os processos históricos de construção do conhecimento.

\section{O Processo Criativo}

Segundo Wallas, o processo criativo se dá em quatro etapas: preparação, incubação, iluminação e avaliação. Trazendo para a resolução de problemas, podemos fazer a seguinte análise:

\begin{tabular}{|l|l|}
\hline \multicolumn{2}{|c|}{ Quadro 1 - Processo Criativo } \\
\hline 1ạ. Etapa: Preparação & Problemas dessa etapa \\
\hline Formulação do problema & Precipitar-se \\
Busca de informações & Definir muito ou mal o problema a ser tratado \\
Exploração de alternativas & Excesso de confiança \\
Deve vir acompanhada de momentos de frustração & Negligência \\
& Fracasso grupal \\
& Desistir antes do tempo \\
\hline
\end{tabular}

\begin{tabular}{|l|l|}
\hline 2a-. Etapa: Incubação & Problemas dessa etapa \\
\hline Deixar o problema “descansar" & Não temos tempo para os devaneios \\
Inconsciente - Inteligência dos sentidos e intuição & Nossa mente não descansa \\
Devaneios & $\begin{array}{l}\text { Comprometemos o período de imersão no problema, } \\
\text { não dando espaço para criação de estratégias de } \\
\text { resolução }\end{array}$ \\
\hline
\end{tabular}

\begin{tabular}{|l|l|}
\hline 3a.. Etapa: Iluminação & Problemas dessa etapa \\
\hline Estalo! & $\begin{array}{l}\text { Podemos perder a ideia, se não tivermos como } \\
\text { registrá-la no momento em que aparece. } \\
\text { Traz alegria, prazer e aumenta a autoconfiança } \\
\text { "estalo". }\end{array}$ \\
\hline
\end{tabular}

4a. Etapa: Avaliação Problemas dessa etapa

Validamos a ideia e transformamos em ação Negligência Enganar a si mesmo 
Busca de evidências que suportem a ideia /resultado gerado - Verificação

A resolução de problemas de Geometria já é um processo de criação. Porém, se forem utilizadas estratégias em que se trabalhe os dois hemisférios cerebrais, a produção será bem mais elaborada e criativa.

Alguns impedimentos do uso dessas estratégias nas aulas de Geometria pode ser a pouca concentração por parte dos estudantes. Tempo reduzido, que o professor tem, juntamente com a cobrança de um programa extenso. Alunos querem receitas prontas e imediatas. Não querem dar tempo para a incubação, que é uma das etapas mais negligenciadas e ao mesmo tempo mais importantes, para maturar o conhecimento previamente adquirido e aplicá-lo em problemas. Os alunos normalmente não querem perder tempo lendo os enunciados e dão valorização a formalidade e não ao processo. O registro do processo de pensamento pode ser um auxilio para essa estratégia.

Exemplos de formas criativas de resolver problemas em Geometria seria o uso de enunciados curiosos, materiais concretos diversos, desafios com trabalhos cooperativos, jogos e TICs.

Etapas do processo criativo na resolução de problemas geométricos:

- Leitura, interpretação, análise dos dados (Preparação)

- Elaboração da estratégia (Incubação)

- Aplicação da estratégia (Iluminação)

- Verificação (Avaliação)

Conclusão

Resolver um problema de Geometria requer ousadia. Existem várias formas de se resolver um único problema. O uso de vários materiais contribui para a constatação desse fato, depende de uma visão geométrica, que nem todos possuem de forma desenvolvida. Trabalhar com quebra-cabeças forma alunos visualizadores, dando ferramental extra na hora de analise e resolução de problemas. A criatividade do professor é fundamental, na hora de estimular/auxiliar no processo de criação da estratégia de resolução de problema pelo aluno. A exposição ao desenvolvimento histórico pode elucidar outros caminhos de resolução de um problema. Vimos como diferentes culturas tinha diferentes formas para resolver um problema de mesma natureza, isso devido aos diferentes tipos de representação. O contato com essas diferentes solução ajudaria, portanto, no processo criativo. Pois, apesar de ser um processo livre, quanto maior o arcabouço mental, melhor o ambiente no processo criativo. Seguindo Feyerabend, a liberdade de pensamento deve ser mais estimulada. Não havendo um único método correto de se pensar. Podemos notar nesse trabalho que na resolução de problemas de geometria se pode ter abordagens fora do padrão. Este tipo de liberdade de pensamento acaba ficando fora da sala de aula e reprimindo o pensamento criativo dos alunos, por uma metodologia científica, que pode ser vista como regra.

Referências bibliográficasBASTOS, José Alexandre . O cérebro e a Matemática.São Paulo: Edição do autor, 2007

CHACÓN, Inês Mạ Gomes. Matemática emocional: os afetos na aprendizagem matemática. Porto Alegre:

ArtMed, 2003

CHALMERS, A. F. O Que É Ciência Afinal?. Ed. Brasiliense. 1993.

COLEMAN, Daniel. O espírito criativo. São Paulo: Cultrix, 1992

HCTE-UFRJ 
DUVAL, Raymond; MACHADO, Silvia Dias Alcântara (Org.). Aprendizagem em matemática: Registro de representação semiótica. 7. ed. Campinas: Papirus, 2010. 160 p.

GARBI, Gabriel - Decorar é preciso. Demonstrar também é, RPM v. 68, p. 1-6, Rio de Janeiro: SBM, 2009

HOUZEL, Suzana Herculano. O que faz o cérebro criativo?. Folha de São Paulo, 2008. Disponível em: http://www1.folha.uol.com.br/fsp/equilibrio/eq0307200813.htm, Acesso em: 06 out. 2017

KALEFF, A. M et all. Desenvolvimento do pensamento geométrico: modelo de van Hiele. Bolema, v. 10, p, $21-$ 30, 1994

KATZ, Victor J. A History of MATHEMATICS An Introduction: an introdution. 3. ed. Chicago, Illinois: Pearson, 2009. 977p.

LINDQUIST, M., SHULTE A. P. (Org). Aprendendo e ensinando Geometria, Tradução de Higino Domingues. São Paulo: Atual, 1994

RAMOS, Maria Dalila Correia Pedrosa. Da Álgebra Geométrica Grega à Geometria Analítica de Descartes e de Fermat. 2013. 140 f. Dissertação (Mestrado) - Curso de da Álgebra Geométrica Grega à Geometria Analítica de Descartes e de Fermat, Departamento de Matemática, Universiade do Porto, Porto, 2013.

TALL, David. A Versatile Theory of Visualisation and Symbolisation in Mathematics. In: PROCEEDINGS OF THE 46TH CONFERENCE OF CIEAEM, 1., 1994, Toulouse, France. Plenary Presentation. Toulouse, France: University Od Warwick, 1994. p. 15 - 27.

WALLAS, Graham. The art of the thought. New York: Hartcout Brace, 1926. 


\section{MUSEU DA COMPUTAÇÃO DA UFRJ}

Ana Lucia F. C. Rodrigues - Jornalista, Instituto Tércio Pacitti de Aplicações e Pesquisas Computacionais ana_lucia@nce.ufrj.br

Claudia L. R. da Motta - Pesquisadora - Instituto Tércio Pacitti de Aplicações e Pesquisas Computacionais claudiam@nce.ufrj.br

Regina M. M. C. Dantas - Professora do HCTE - regina@hcte.ufrj.br

\section{Resumo}

O NCE está envolvido na criação do Museu da Computação da UFRJ. Este museu pretende ser um centro agregador e fomentador da preservação da história da Computação. O Jubileu de Ouro do NCE marcou a pré-inauguração desse espaço de ciência e cultura, ocasião em que convidados puderam vivenciar o ambiente e ter a experiência do Museu. O tripé ensino, pesquisa e extensão está representado no Museu através da participação de alunos de graduação e de pós-graduação. O Museu é também um espaço de apoio formal à educação voltado a práticas e experimentos que envolvem visitantes nos processos da investigação e conhecimento científico. além de ser fonte de entretenimento e cultura para a sociedade.

Palavras-Chave: História. Computação. Museu.

\section{Museus, Memória e Lugares de Memória}

Iniciamos nossa abordagem por meio da definição de "museu" na concepção do Conselho Internacional de Museus (ICOM):

"o museu é uma instituição permanente, sem fins lucrativos, a serviço da sociedade e do seu desenvolvimento, aberta ao público, que adquire, conserva, estuda, expõe e transmite o patrimônio material e imaterial da humanidade e do seu meio, com fins de estudo, educação e deleite."

Museus são lugares de memória. Segundo NORA (1993, p. 9),

\footnotetext{
"a necessidade pelos lugares de memória é indicador de que não há mais memória e sim uma necessidade de história. Se habitássemos ainda nossa memória, não teríamos necessidade de lhe consagrar lugares. Não haveria lugares porque não haveria memória transportada pela história. [...] Desde que haja rastro, distância, mediação, não estamos mais dentro da verdadeira memória, mas dentro da história."
}

A memória é sempre uma construção feita no presente, a partir de vivências e experiências ocorridas num passado sobre o qual se deseja refletir e entender. Enquanto construção, a memória está também sujeita às questões da subjetividade, seletividade e, sobretudo, às instâncias de poderes. Mesmo que (re) constituída a partir de indivíduos, a memória sempre nos remete a uma dimensão coletiva e social e, por extensão, institucional. A memória também tem a função de produção ou percepção de sentimentos de pertinência a passados comuns, o que, por sua vez, constitui-se aspecto imprescindível ao estabelecimento de identidades calcadas em experiências compartilhadas, não somente no campo histórico ou material, como também (e sobretudo) no campo simbólico. (OLIVEIRA, 2008, p. 43).

\section{O NCE e a Construção de Artefatos Tecnológicos}

No ambiente mundial efervescente de ideias e ações do início da década de 1970, como resultado dos investimentos governamentais na infraestrutura de pesquisa, o Núcleo de Computação Eletrônica (NCE) foi um dos centros universitários de ensino e pesquisa que ousou desenvolver a computação no Brasil. 
“(...) construir no Brasil uma capacidade, limitada mas significativa, de concepção, projeto e integração de produtos de informática de potencial comercializável visível, em meio às discussões do que deveria constituir o objeto de pesquisa em informática no país. (...) professores, alunos de pós-graduação e pesquisadores projetaram modens, terminais de vídeo, terminais inteligentes (precursores dos microcomputadores de hoje), processadores especializados, compiladores, protocolos de comunicação e diversos produtos de informática". (MARQUES, 2000, p. 95)

Criado como órgão suplementar para prestar serviços à Universidade, o NCE sempre teve seu perfil baseado em ensino, pesquisa, prestação de serviços e consultoria. Fortalecendo seu perfil acadêmico-científico, em 2010, o NCE se transformou em instituto especializado, passando a se chamar Instituto Tércio Pacitti de Aplicações e Pesquisas Computacionais/NCE. Por muitos anos o NCE alimentou a ideia de construir um museu e sempre se preocupou em preservar a memória de seus projetos de pesquisas \& desenvolvimento na área de Computação. Os protótipos, alguns deles repassados à indústria, foram por anos exibidos com orgulho nos corredores do NCE. Além disso, tanto o Departamento de Ciência da Computação quanto o NCE guardam acervo documental e fotográfico sobre a criação e evolução da Computação na UFRJ e no Brasil.

Hoje, no Instituto Tércio Pacitti, existe um desejo de apresentar às novas gerações esse esforço de desenvolvimento tecnológico feito no Brasil e, em especial da UFRJ, na área de Computação. Os artefatos, oriundos dessa época e das décadas seguintes, compõem o acervo do Museu da Computação da UFRJ.

\section{A Criação do Museu de Computação}

Há cerca de 4 anos, com a criação de uma comissão de implantação multidisciplinar e multiinstitucional, um novo projeto de museu foi tomando forma. Não era mais o Museu do NCE, mas o museu da COMPUTAÇÃO DA UFRJ. Esta comissão foi constituída por pesquisadores, por uma jornalista, por um arquiteto do NCE e pelas docentes do DCC/IM, do PPGI e do HCTE. Contamos também com a relevante orientação inicial de uma museóloga do Museu Nacional da UFRJ e com a consultoria da Divisão de Memória Institucional do SIBI/UFRJ.

Uma área de cerca de $400 \mathrm{~m}^{2}$ foi destinada pela direção do NCE a sediar o Museu. O espaço fica localizado próximo ao Museu da Geodiversidade do Instituto de Geociências (IGEO), criando um pequeno núcleo museológico que permite aos visitantes conhecer os dois museus numa mesma oportunidade. Com a consultoria das museólogas envolvidas, foi concebido um projeto arquitetônico adequado à exposição e à interação com os bens culturais.

A oportunidade de lançamento do Museu da Computação surgiu em 2017, como uma das iniciativas de comemoração dos 50 anos do NCE. O momento não poderia ser mais oportuno, pois o Museu busca resgatar a memória institucional e preservar uma história de pioneirismo, inovação e sucesso, apresentando artefatos tecnológicos construídos por pesquisadores, professores e alunos dentro dos laboratórios de pesquisa em um período em que o país, e, em especial a UFRJ, mostrou sua capacidade de desenvolvimento tecnológico. Beneficiados por uma política de reserva de mercado em Informática que eles mesmos ajudaram a delinear, esses pesquisadores desenvolveram equipamentos e protótipos, muitos deles repassados à nascente indústria nacional de Informática.

\section{A Exposição de Lançamento}

Mas como apresentar uma exposição de lançamento em um espaço inadequado? Como fazer se ainda não existem recursos financeiros disponíveis? A saída foi buscar a criatividade! Dessa 
forma, entrou em ação para mais uma missão a equipe do Sistema Universitário de Apoio Teatral (SUAT) da Escola de Comunicação (ECO) da Universidade Federal do Rio de Janeiro. A SUAT/ECO/UFRJ é um programa de treinamento de equipe interdisciplinar de alunos de graduação, sob orientação de um professor do curso de Direção Teatral, que vem desempenhando papel relevante no apoio às atividades artísticas e culturais na UFRJ, concretizando formalmente ações de suporte técnico como empréstimo de equipamentos, fornecimento de mão-de-obra treinada e know-how artístico a diversas Unidades.

Buscou-se na montagem da exposição de lançamento, uma interlocução entre o enfoque museográfico e o teatral, com o objetivo de não apenas expor e informar, mas de criar um cenário para exibir as peças e impressionar. Cortinas de palco e iluminação cênica, compuseram com as peças expostas e banners informativos um espaço por onde os convidados para o Jubileu de Ouro do NCE circularam e revisitaram uma parte da história da computação.

A repercussão da visita entre os que vivenciaram a experiência atestou que o objetivo inicial foi alcançado, constatando-se que a exposição “(...) constitui, de certa forma, uma experiência multidimensional, que não pode ser colocada em palavras: pois é o olhar que precede o toque e a fala, seduz o observador, provoca-Ihe os sentidos (...)" (SCHEINER, 2003).

\section{Envolvimento das Unidades Parceiras}

A atuação das quatro Unidades da UFRJ diretamente envolvidas na criação do Museu da Computação se dá com a integração do tripé ensino, pesquisa e extensão da seguinte forma: o NCE cedeu o espaço físico; as peças para exposição; apoio logístico e de pessoal; o DCC é responsável pelo desenvolvimento de aplicações computacionais para o museu e de coordenação dos alunos de graduação que atuam como guias nas visitações programadas, alunos da graduação também são estimulados a desenvolver seus trabalhos de final de curso em temas afins ao Museu; o PPGI orienta dissertações e teses sobre aplicações computacionais para o Museu; e o HCTE orienta dissertações e teses nas áreas de Ciência, Tecnologia e Sociedade, História das Ciências no Brasil e História das Instituições Científicas.

\section{Continuidade do Projeto}

A partir do registro fotográfico da exposição de lançamento, a Comissão de Implantação do Museu da Computação da UFRJ prepara um primeiro portfólio destinado a sensibilizar possíveis parceiros e patrocinadores, que possam fazer algum aporte financeiro, pois há necessidade de se captar recursos externos para execução de obras de adequação do espaço físico.

As etapas subsequentes de continuidade do Museu envolvem o reestabelecimento dos contatos com o Museu Nacional da UFRJ e com a Divisão de Memória Institucional SIBI/UFRJ para a concepção do projeto museográfico da exposição permanente e das mostras temáticas temporárias. Além disso, a formação de uma equipe dedicada ao Museu, composta por profissionais da área de Museologia e Educação e a seleção de bolsistas permite que se pense em atividades educacionais e interativas. A acessibilidade também está entre as prioridades do Museu, visto que o NCE já desenvolve sistemas informacionais nessa área.

\section{A Integração Ensino, Pesquisa e Extensão}

O projeto do Museu da Computação da UFRJ se caracteriza como um espaço de ensino, pesquisa e extensão, pois cria um ambiente físico de apoio à educação formal, servindo como mecanismo de investigação, organização, disseminação e preservação de conhecimento sobre a história da computação, especialmente aquela referente à sua evolução no Brasil. 
Com as atividades de conservação, investigação e difusão do patrimônio, um museu auxilia o educador oferecendo novas alternativas para sua prática. Portanto, conservar a história da Computação auxiliará o ensino técnico e superior nessa área. Outrossim, no Museu pretendese desenvolver contextos para experimentos abundantes e motivadores, envolvendo os visitantes nos processos da investigação e conhecimento científico.

Além de sua importância para o ensino, o museu é fonte de entretenimento e cultura para a sociedade, é um espaço de memórias vivas e experiências dinâmicas e interativas.

\section{Conclusão}

No ano de 2017, comemorando seu cinquentenário, o NCE concretiza o sonho, acalentado há anos, de criação do Museu da Computação da UFRJ, seu lugar de memória, que contribui para a sedimentação de lembranças e para o reforço de sua identidade institucional.

Referências bibliográficas

ALBERTI, Verena. Manual de História Oral. FGV, 2012

CERTEAU, Michel de. A escrita da História. Rio de Janeiro: Forense Universitária, 2002.

HALBWACHS, Maurice. A memória coletiva. São Paulo: Centauro, 2006.

MARQUES, Ivan da Costa. Reserva de Mercado: Um mal entendido caso político-tecnológico de "sucesso" democrático e "fracasso" autoritário. Revista de Economia, Curitiba, n. 24, p. 89-114. Editora da UFPR, 2000. MARQUES, Ivan da Costa. Revisitando o discurso mobilizador da "reserva de mercado" dos anos 1970 à luz dos Estudos CTS. XL Conferencia Latinoamericana en Informatica/ XL Latin America Computing Conference, SHIALC 2014, Montevideo, Uruguay, 2014.

NORA, Pierre. Entre Memória e História: a problemática dos lugares. Projeto História. São Paulo, n.10, 1993.

OLIVEIRA, Antônio José B. de. A casa de Minerva - entre a ilha e o palácio. Tese doutorado em Memória Social UNIRIO, 2011.

OLIVEIRA, Antônio José B. de. História, memória e instituições: algumas reflexões teórico-metodológicas para os trabalhos do Projeto Memória. In: Universidade e Lugares de Memória, p. 41-62. SIBI/FCC/UFRJ, 2008.

SCHEINER, Tereza C. M. Comunicação - educação - exposição: novos saberes, novos sentidos. Semiosfera. Revista de Comunicação e Cultura, Rio de Janeiro, n. 4-5, 2003. 


\section{O PAPEL DA MATEMÁTICA NA RELAÇÃO DO HOMEM COM A REALIDADE: ALGUMAS QUESTÕES E REFLEXÕES}

Valessa Leal Lessa de Sá Pinto - Doutoranda no HCTE-UFRJ - valessaleal@hotmail.com Ricardo Silva Kubrusly - Professor no HCTE-HCTE - risk@hcte.ufrj.br Sicleidi Valente dos Santos Britto - Doutoranda no HCTE-UFRJ - sicleidi@gmail.com Angelo Santos Siqueira - UNIGRANRIO/PPGHCA/PPGEC - asiqueira@unigranrio.edu.br

\section{Resumo}

$\mathrm{O}$ artigo trata das primeiras reflexões de uma tese que tem a proposta de apresentar a matemática como uma produção da mente humana, que recebe forte influência de fatores intrínsecos ao homem, como aspectos culturais e sociais, entre outros. Para isto, trazemos algumas questões sobre o papel da matemática na relação do homem com a realidade. Neste contexto, o objetivo do presente estudo é mostrar como percebemos as interações do ser humano com matemática nos mais diferentes cenários e a posição que ela ocupa em cada um deles. $O$ trabalho destaca a matemática como uma interessante invenção do homem na busca de representação da realidade, que acabou por tornar-se associada às ideias de verdade e certeza sobre as coisas do mundo.

Palavras-chave: Homem. Matemática. Realidade. Representação.

\section{Introdução}

De modo geral, a matemática é reconhecida como uma ciência logicamente estruturada e ferramenta útil para resolver problemas da vida cotidiana. Ela também é identificada como um conhecimento abstrato, de rigor lógico e com o poder da exatidão. Acredita-se ainda que ela seja um saber estável, bem definido e de caráter universal. Costuma-se associar aos números e aos princípios matemáticos, os sentidos da verdade, da racionalidade e da certeza. O pensamento de que a matemática é o nosso saber mais técnico, fortemente estruturado e infalível é predominante entre os mais diversos grupos de indivíduos, e reproduzida, principalmente, pelos que se dizem especialistas. Assim, a matemática é cada vez mais considerada um saber puro, sólido, inquestionável e convincente, sendo sempre relacionada a uma perspectiva formal.

Por todas estas características, argumenta-se que ela permite a formação de um pensamento consistente, favorecendo a análise racional e a consciência nas ações, ou seja, é o melhor conhecimento para tratar a realidade e conhecer as coisas do mundo de maneira clara e objetiva. Dentre muitas ideias associadas à matemática, esta é a principal delas, desde o seu surgimento há milhares de anos. Assim, quando pensamos em estratégias para descrever e compreender a realidade que nos cerca, a matemática, de alguma forma, sempre está presente.

A história da matemática nos mostra que este conhecimento é fundamental para o homem em diferentes aspectos desde a Antiguidade. Ao estudar a narrativa desta trajetória, é possível identificar uma série de maneiras de como os indivíduos fazem matemática e compreendem sua natureza. Daí, como atividade ou corpo de conhecimentos, ao longo do tempo, muitas concepções e ideologias surgiram a respeito da matemática, dando origem a distintas teorias sobre o seu surgimento e o seu papel na relação do homem com a realidade. A principal questão que direciona as discussões sobre esse assunto e que guiará as reflexões deste estudo é a seguinte: "A matemática é descoberta ou inventada, isto é, ela realmente existe ou é fruto da mente humana?". Assim, outras perguntas surgem a partir desta: De onde 
vem a matemática? De uma lógica universal ou da pessoa (do corpo, da sociedade, de uma religião)? A matemática está em todo lugar ou em lugar nenhum (na cabeça)?

As respostas a estes questionamentos nos direcionam a duas ideias centrais e opostas: o realismo e o construtivismo. No realismo, os objetos matemáticos têm existência própria, sem a necessidade do homem, e como consequência, a matemática é vista como um saber imutável, certo, universal e eterno que espera ser descoberto. No construtivismo, as estruturas matemáticas são produções da mente humana e a maneira como o homem entende o mundo é a base desta criação, pois ele cria modelos para interpretar e representar o que está a sua volta.

Este trabalho segue a ideia de uma leitura construtivista da matemática. Acreditamos que a matemática foi sendo construída a partir das diferentes experiências do homem com o mundo natural e na vida em sociedade. Assim, aspectos como necessidades e interesses individuais e coletivos, lugares e épocas, entre outros, foram definindo as práticas matemáticas. Um exemplo disso é que diferentes práticas matemáticas coexistiram desde sempre, dando soluções diferentes para problemas semelhantes (ROQUE, 2012).

Pensamos também que este conhecimento é um formidável exemplo do poder de criatividade do homem diante da complexa e misteriosa realidade. Daí, acreditamos que a aplicação da matemática nas coisas do mundo se aproxima da realidade, isto é, não é a realidade em si, pois ela é uma invenção humana.

Desta forma, abordamos neste trabalho as primeiras colocações sobre os elementos que consideramos relevantes na defesa da ideia de que a matemática é construída e não descoberta.

\section{A matematização de fenômenos e coisas}

O homem, através dos seus sentidos, incluindo o pensamento, conseguiu quantificar e medir o mundo, entre outras ações. Ele foi percebendo as coisas a sua volta, captando sinais, racionalizando dados e estabelecendo uma conexão com o universo. Daí, ele começou a construir ferramentas para interagir da melhor forma com a realidade. Neste contexto, os números foram uma das mais importantes criações no processo de busca de uma conexão, pois atenderam de forma significativa ao objetivo do homem de representar suas ideias de quantificação e medição.

O ser humano também foi compreendendo que o seu conhecimento era constituído por um emaranhado de aspectos objetivos e subjetivos, estabelecidos por percepções, sentidos, experiências. Assim, concepções de ordem e regularidade surgiram, por exemplo, através da observação de fenômenos naturais, e depois, os números foram criados expressar essas ideias. GLEISER (2015) ressalta que "a "matematização" da Natureza, e a consequente ordenação dos padrões regulares em termos de leis quantitativas é um dos grandes feitos da nossa espécie".

Esta "matematização" do universo, de linguagem clara e objetiva, que gerou confiança e inspirou verdade, tornou o conhecimento matemático a melhor maneira de explicar a realidade em muitos aspectos. No entanto, é necessário destacar que embora a matemática contribua para dar sentido aos fenômenos e as coisas, ela não explica o mundo, pois nossa visão sobre este mundo é limitada.

De acordo com GLEISER (2015), o que vemos do mundo é uma ínfima fração do que existe. Como muito na Natureza permanece oculto, nossa visão é baseada apenas na fração da realidade que podemos medir e analisar. Assim, acreditamos na necessidade de questionamentos e reflexões sobre as afirmações de que a matemática seja um conhecimento imutável, eterno, fortemente estruturado, infalível e objetivo, que nos mostra a verdade quando a descobrimos, nos dando a certeza sobre as coisas. 
Diante destas especulações, podemos citar Gödel e seu Teorema da Incompletude, com a explicação de que num sistema formal que seja abrangente para comportar toda a aritmética sempre tem uma sentença que escrevemos no próprio sistema que não conseguimos provar. Desta forma, Gödel nos mostrou que a representação formal nunca é fiel a sua ideia. Assim, a matemática é uma representação da realidade, nem tão poderosa, a ponto de resolver todas as coisas. Ela não dá conta sozinha de resolver os problemas que consideramos do seu escopo, embora tenha uma configuração de saber diferenciado. Gödel constatou que sempre haverá lacunas nas certezas da matemática, mas que isso não é uma questão da matemática, e sim dos processos de representação em qualquer área da vida. Com o intuito de reforçar estas colocações, citamos GOLDSTEIN (2008):

A inevitável incompletude até de nossos sistemas formais de pensamento demonstra que não existe um fundamento sólido que sirva de base a qualquer sistema. Todas as verdades mesmo aquelas que pareciam tão certas a ponto de serem imunes a toda possibilidade de revisão - são essencialmente manipuladas. De fato, a própria noção da verdade objetiva é um mito socialmente construído. (GOLDSTEIN, 2008).

O Teorema de Gödel também nos indica que nossas mentes não funcionam como modelos computacionais, que reduzem todo o pensamento a seguir comandos, ou seja, nosso pensamento não se resume a seguir regras.

\section{As características culturais da matemática}

Há modos de pensamento que se configuram de acordo com determinado lugar, época e cultura. Por exemplo, a matemática procedimental (resolver problemas) quando chegou à Grécia se modificou pelo estilo de sociedade (mais argumentativa) e assumiu uma caráter formal.

Segundo D’AMBROSIO (2005), a educação multicultural o levou a ver o ato de criação como uma manifestação. A aquisição e elaboração do conhecimento se dão como resultados de todo um passado, individual e cultural, com vistas às estratégias de ação no presente e projetando-se no futuro, modificando assim a realidade e incorporando a ela novos fatos, isto é, "artefatos" e "mentefatos". Ele afirma também que esse comportamento é intrínseco ao ser humano e resulta de impulsos naturais para sobreviver e transcender.

Além de considerar um processo de construção de conhecimento, deve-se dar um enfoque holístico que incorpore ao racional o sensorial, o intuitivo e o emocional. Este autor comenta que "em todas as culturas e em todos os tempos, o conhecimento é gerado pela necessidade de uma resposta a problemas e situações distintas e está subordinado a um contexto natural, social e cultural" (D'AMBROSIO, 2005).

Em relação à matemática, encontramos reflexões interessantes no estudo do Programa Etnomatemática, idealizado pelo professor Ubiratan D'Ambrosio, que tem por essência a abordagem de distintas formas de conhecer. O Programa sinaliza que:

\footnotetext{
"Indivíduos e povos têm, ao longo de suas existências e ao longo da história, criado e desenvolvido instrumentos de reflexão, de observação, instrumentos teóricos e, associados a esses, técnicas, habilidades (artes, técnicas) para explicar, entender, conhecer, aprender, para saber e fazer como resposta a necessidades de sobrevivência e de transcendência (matema), em ambientes naturais, sociais e culturais (etno) os mais diversos. Daí chamarmos o exposto acima de Programa Etnomatemática. O nome sugere o corpus de conhecimento reconhecido academicamente como Matemática." (D’AMBROSIO, 2005).
}

A partir desta perspectiva, a matemática é uma etnomatemática, e não a ciência infalível, rigorosa e de extrema precisão. D’AMBROSIO (2001) acrescenta que: 
A disciplina denominada matemática é uma etnomatemática que se originou e se desenvolveu na Europa, tendo recebido algumas contribuições das civilizações indiana e islâmica, e que chegou à forma atual nos séculos XVI e XVII, sendo, a partir de então, levada e imposta a todo o mundo. Hoje, essa matemática adquire um caráter de universalidade, sobretudo devido ao predomínio da ciência e da tecnologia modernas, que foram desenvolvidas a partir do século XVII na Europa, e servem de respaldo para as teorias econômicas vigentes. (D'AMBROSIO, 2001).

As expressões matemáticas são frutos de um pensamento capaz de imaginar e abstrair, mas que sempre está vinculado à forma como se vive e se sente a realidade. D'AMORE (2012) fala da matemática, especialmente, como uma expressão humana:

\footnotetext{
"A matemática é humanismo, assim como tudo aquilo que o homem cria para suas necessidades concretas e espirituais e pelo gosto sublime e não concretamente vantajoso de criar coisas novas, é um desafio intelectual como a poesia, a física, a literatura, a química, o canto, a eletrônica, a música, a zoologia, a astronomia, a mitologia, a botânica, a filosofia, a pintura, o cinema, a história, o teatro..." (D'AMORE, 2012).
}

E assim como poetas e artistas nos oferecem muitas maneiras de expressão da beleza e da harmonia através de suas representações das coisas do mundo e das experiências humanas, teoremas, fórmulas e "formas" de calcular também podem ser consideradas "obras" que fazem parte do patrimônio cultural da humanidade.

\section{Os traços sociais da matemática}

Acreditamos que existe uma construção social em volta de todo conhecimento. Assim, a matemática pode ser vista como uma atividade social. Nesta condição, ela não é una, ou seja, existe a possibilidade de que admita mais de uma verdade, considerando diferentes realidades sociais. Sem dúvida, este olhar é radicalmente diferente da visão de uma verdade elementar contida nos símbolos matemáticos, que torna a matemática extremamente persuasiva, imutável e única.

Este olhar diferenciado tem como pano de fundo o Programa Forte da sociologia do conhecimento científico, idealizado por David Bloor na década de 1970, cujo objetivo é investigar o desenvolvimento de um campo científico e identificar pontos de contingência e flexibilidade interpretativa, ligados a fatores políticos, históricos, culturais e econômicos.

De acordo com este Programa, a ciência é tão suscetível ao interesse particular como qualquer outra instituição social. Se algo a distingue, isto deve ser buscado em sua organização, e não em alguma habilidade heroica intrínseca de se colocar fora da sociedade e, de lá, observar os fatos.

Neste contexto, Bloor não mede esforços para enfrentar um dos principais obstáculos da sociologia da ciência que diz respeito ao status da lógica e da matemática. Ele investiga e argumenta sobre o reino da objetividade, da universalidade e da impessoalidade do mais puro, abstrato e inquestionável dos conhecimentos, isto é, a matemática, buscando sua causalidade social (GOMES, 2008). Assim, Bloor afirma que a objetividade matemática pode ser entendida como uma convenção social, traçando uma semelhança entre autoridade lógica e autoridade moral.

Embora uma reflexão sobre os fundamentos da matemática transcenda o domínio da sociologia do conhecimento, as concepções apresentadas no Programa Forte podem nos levam a pensar sobre a fundamentação ontológica desses conhecimentos.

A partir destas considerações, também encontramos meios para questionar a perspectiva realista associada à prática das ciências matemáticas. Esta concepção se opõe frontalmente às ideias do Programa Forte. Então, Bloor assume a tarefa de mostrar, contra o tipo de 
fundamentação defendida pelo realismo, que existem matemáticas alternativas que se utilizam de um mecanismo essencialmente sociológico - a negociação - e que a objetividade é perfeitamente compatível com um fundamento social (GOMES, 2008).

\section{Considerações Finais}

A partir da consideração de que a matemática é uma invenção humana, acreditamos que este conhecimento foi construído a partir das necessidades, interesses e curiosidades do homem, com a influência da época, e de acordo com o tipo de cultura e características de sua sociedade. Através da análise de fatos da sua história, percebemos que as invenções matemáticas não acontecem isoladamente, ou seja, é sempre possível contextualizá-las com outros aspectos no momento da criação. Nesta perspectiva, STEWART (2014) nos aponta informações importantes:

\footnotetext{
"E assim, ao longo de quatro milênios, a estrutura elaborada e elegante que chamamos de matemática veio a existir. Ela surgiu aos solavancos, com acessos de atividade febril seguidos por períodos de estagnação; o centro de atividade moveuse ao redor do globo acompanhando a ascensão e queda da cultura humana. Às vezes cresceu de acordo com as necessidades práticas daquela cultura; outras vezes o tema assumiu sua própria direção, e os praticantes brincavam com aquilo que para todas as outras pessoas não passavam de jogos intelectuais. E, com surpreendente frequência, esses jogos acabam dando retorno no mundo real, estimulando o desenvolvimento de novas técnicas, novos pontos de vista e nova compreensão" (STEWART, 2014)
}

Neste trabalho procuramos abordar algumas questões e reflexões sobre o papel da matemática na relação do homem com a realidade, associando este conhecimento aos seguintes aspectos: a matemática como uma representação das coisas do mundo, a matemática como expressão cultural e a matemática como uma construção social. A intenção é que o estudo destes fatores contribua para a tese que tem como objetivo apresentar a matemática como uma produção da mente humana que recebe forte influência de fatores intrínsecos ao homem.

Aqui também procuramos questionar as ideias de verdade e certeza vinculadas à matemática. Sabemos que ela é estabelecida a partir de processos dedutivos, padronização, mecanismos abstratos, mas suas verdades podem são arbitrárias: basta que seja dado um conjunto de postulados e uma lógica, tudo o que é produzido por este sistema é verdade (geometria, aritmética, álgebra, análise).

Outro aspecto colocado foi a teoria dos interesses do Programa Forte que mostra que a "racionalidade" pode ser usada de várias formas, dependendo do contexto, ou seja, fatores sociais podem ajudar a entender, por exemplo, porque uma prova é considerada verdadeira ou falsa.

Por fim, esperamos que este estudo contribua para reflexões a respeito da relação do homem com a matemática e para discussões sobre seus paradigmas.

\section{Referências bibliográficas}

D’AMBRÓSIO, U. Etnomatemática: elo entre as tradições e a modernidade. Belo Horizonte: Autêntica. Coleção Tendências em Educação Matemática, 2001.

D’AMBRÓSIO, U. Sociedade, cultura, matemática e seu ensino. Educação e Pesquisa, São Paulo, v. 31, n. 1, p. 99-120, jan./abr. 2005.

D’AMORE, B. Matemática, estupefação e poesia. Tradução de Maria Cristina Bonomi. São Paulo: Livraria da Física, 2012. 
GLEISER, M. A ilha do conhecimento: os limites da ciência e a busca por sentido. 3. ed. Rio de Janeiro: Record, 2015.

GOLDSTEIN, R. Incompletude: a prova e o paradoxo de Kurt Gödel. Tradução de Ivo Korytowski. São Paulo: Companhia das Letras, 2008.

GOMES, V. P. Causalidade e hermenêutica em sociologia da ciência: uma crítica ao 'Programa Forte' de David Bloor. Tese de Doutorado. São Paulo: 2008.

ROQUE, T. História da Matemática: uma visão crítica, desfazendo mitos e lendas. Rio de Janeiro: Zahar, 2012. STEWART, I. Em busca do infinito: uma história da matemática dos primeiros números à teoria do caos. Tradução de George Schlesinger. 1. ed. Rio de Janeiro: Zahar, 2014. 


\title{
UM OLHAR SOBRE ACESSO, PERTENCIMENTO E PERMANÊNCIA DA MULHER COMO PESQUISADORA NO BRASIL ENTRE OS ANOS DE 2001 E 2015
}

\author{
Marcelo dos Santos Azevedo - Aluno Especial do Programa de Pós-Graduação em História das Ciências e das \\ Técnicas e Epistemologia (HCTE) - marcelost@aluno.unb.br
}

\section{Resumo}

A representação social da mulher é um fato discutido em toda história da humanidade. O seu locus social confunde-se com suas atividades, historicamente impostas. O objetivo deste relato é observar como as questões de gênero se refletem no acesso, no pertencimento e na permanência das pesquisadoras no Brasil, a partir de dados oficiais de distribuição de bolsas de estudo e pesquisa. Por meio da análise da distribuição quantitativa de bolsas, das agências oficiais de fomento à pesquisa no Brasil, entre 2001 e 2015, procura-se desenhar um perfil deste percurso, os descritores escolhidos para a análise foram as modalidades de bolsas e o gênero. O comportamento sugere que entre a fase de graduação e de atuação profissional existem fatores que influenciaram na diminuição da participação do gênero feminino na distribuição de bolsas.

Palavras-Chave: Gênero. Mulher. Formação. Bolsas de Pesquisa. Pesquisadoras

\section{Introdução}

A representação social da mulher é um fato antigo na história da humanidade, bem relatado na literatura. JAFFÉ (1977) discute o significado de artefatos arqueológicos com formas femininas, as Vênus pré-históricas, que suscitam debates sobre a subjetividade do papel desempenhado pela mulher naquele período. A autora sugere que desde a pré-história a mulher tem um locus privilegiado na constituição da sociedade humana. A presença de questões de gênero, em período anterior à escrita, indica que a atuação da mulher transcende, historicamente, os limites domésticos.

SANTANA (2009) procurou avaliar a inserção da mulher brasileira no ambiente educacional do século XIX. O autor observa, naquele período, que a educação feminina se inicia em ambientes domésticos. E a existência da legitimação de poder econômico e/ou historicamente estabelecido (pai ou marido), em conjunto com pressões de ordem moral e/ou religiosa, moldaram um modelo de comportamento da mulher, em especial, o da esposa, limitando sua presença ao lar. Desta forma, surge uma imagem socialmente estática da mulher, restrita ao ambiente doméstico, perante um patriarcado provedor.

Porém LEITE (1992), baseada em seu estudo sobre os relatos de 153 viajantes em visita ao Brasil, entre 1803 e 1900, propõe o conceito de "grupos de convívio" (coabitação de pessoas na mesma propriedade, unidas por atividades de sobrevivência), que rompe com essa representação passiva da mulher. Entre estes, destaca o de Madame Toussaint-Simon (1883), que descreve as atividades das mulheres como um complexo conjunto de ações ligadas ao universo doméstico. Entretanto, a mesma relata que muitas mulheres, em especial nos grandes centros urbanos, exerciam atividades comerciais, sem a supervisão de seus provedores, longe do ambiente doméstico, por meio de seus escravos, obtendo ganhos com a venda de excedentes. Os recursos obtidos eram utilizados para diversos fins, dentre eles, a aquisição de livros, o que sugere uma forma de acesso à leitura, não autorizada. 
Entre a pré-história e o período atual, como poderiam ser avaliados os caminhos percorridos pela mulher para sua participação na sociedade, em especial na ciência? LETA (2003) argumenta que a evolução da participação da mulher na ciência se dá em quatro etapas. A primeira, como interlocutora e tutora, sem nenhuma participação nas discussões científicas (séc. XV ao XVII). A segunda, em função de parentesco quando, salvo raras exceções, atuava como suporte aos trabalhos científicos (séc. XVIII). A terceira, no séc. XIX, quando surgem os colégios de mulheres, porém, mesmo com formação, essas eram marginalizadas profissionalmente. A última, na segunda metade do século $X X$, "pela necessidade crescente de recursos humanos para atividades estratégicas (LETA, 2003).

Segundo Sismondo, "As normas institucionais trabalham em combinação com recompensas e sanções, em contextos em que os membros da comunidade são socializados para responder a essas recompensas e sanções." (SISMONDO, 2004. p.24)

Por meio da argumentação acima, podem ser associados como recompensas os prêmios e o acesso às formas de financiamento para a pesquisa, em especial as diferentes modalidades de bolsas, como reconhecimento perante a comunidade cientifica. No âmbito mundial, a maior recompensa é a láurea concedida anualmente pela Fundação Nobel. Segundo a Fundação Nobel, de 911 laureados, há somente 49 laureadas. O primeiro Nobel para uma mulher deu-se em 1905, a Manya Sklodowska Curie. No Gráfico 1, pode ser observado que para o gênero feminino ocorrem quatro hiatos na premiação, destes desacatam-se dois períodos, com intervalos de mais de dez anos, de ausência de mulheres: 1914 a 1925 e 1948 1963. Estes hiatos coincidem com os períodos pós-guerra dos dois conflitos mundiais, sugerindo uma possível relação de sobreposição, nos períodos de reestruturação econômica e/ou política, em relação aos assuntos associados às questões de gênero.

Mesmo sendo multifatorial, pode ser inferido que seja um reflexo da ausência da discussão, já que estariam concentradas em outras áreas, consideradas prioritárias, naquele momento. Em âmbito nacional, o "Prêmio CAPES de Tese", anualmente, destaca as melhores teses de 48 áreas de conhecimento. As informações disponibilizadas pela CAPES (BRASIL, 2017) sobre este prêmio, nos anos de 2006 e 2015, permite delinear um perfil sobre a presença da mulher, como premiada ou orientadora. NaTabela 1 é possível observar o predomínio do gênero masculino, tanto para os prêmios quanto para as orientações. Deve-se destacar que no caso dos prêmios houve um aumento na distância percentual entre os gêneros, quando comparados os, anos de 2006 e 2015.

\begin{tabular}{lcccc}
\hline Ano & $\begin{array}{c}\text { Premia } \\
\text { das }\end{array}$ & $\begin{array}{c}\text { Premia } \\
\text { dos }\end{array}$ & $\begin{array}{c}\text { Orienta } \\
\text { doras }\end{array}$ & $\begin{array}{c}\text { Orienta } \\
\text { dores }\end{array}$ \\
\hline 2006 & $43,6 \%$ & $56,4 \%$ & $33,3 \%$ & $66,7 \%$ \\
\hline 2015 & $31,2 \%$ & $68,8 \%$ & $35,4 \%$ & $64,6 \%$ \\
\hline
\end{tabular}

Tabela 1 - Percentual dos Prêmios e orientações nos anos de 2006 e 2015

Fonte: BRASIL. CAPES. MEC. Prêmio Capes de Tese. Disponível em: http://www.capes.gov.br/premiocapesdetese. Acesso em: 02 set. 2017. 
Outro olhar pode ser feito em relação ao financiamento para formação de pesquisadoras, na forma de bolsas concedidas pelo Conselho Nacional de Desenvolvimento Científico e Tecnológico (CNPq), órgão ligado ao Ministério da Ciência, Tecnologia, Inovações e Comunicações (MCTIC), para incentivo à pesquisa no Brasil. O CNPq disponibiliza, no seu portal, os dados de todas as modalidades de bolsas no país e exterior entre os anos de 2001 e 2015. Para a análise, foram escolhidos como descritores: o período (2001 a 2015), a diferença percentual entre os gêneros a partir do número total de bolsas (independente da modalidade), e as regiões político-administrativas do Brasil, associando, com este último, as diversas características socioeconômicas e culturais, considerando que as questões de gênero também possam ter entendimento e percursos regionais diferenciados.

A partir destes critérios surgem três comportamentos para a distribuição de bolsas. Cada um deles está associado um conjunto regional (Grupo A: Centro-Oeste e Norte, Grupo B: Nordeste e Sul, Grupo C: Sudeste). No Grupo A, apresentado no Gráfico 2-A, é possível observar o comportamento de predomínio histórico do gênero feminino, sendo que, para a região Norte, nos primeiros seis anos, a diferença percentual entre gêneros é maior do que nos anos finais. Já o Grupo B, apresentado no Gráfico 2-B, é observado que a diferença percentual é negativa, o que indica que nos anos iniciais do levantamento houve o predomínio do gênero masculino. Mas, a partir do ano de 2011 o comportamento assemelha-se ao do Grupo A. Para o Grupo C, mostrado no Gráfico 3, o predomínio é historicamente masculino (valores negativos). É importante observar que este é o único grupo que é constituído por apenas uma região (Sudeste).

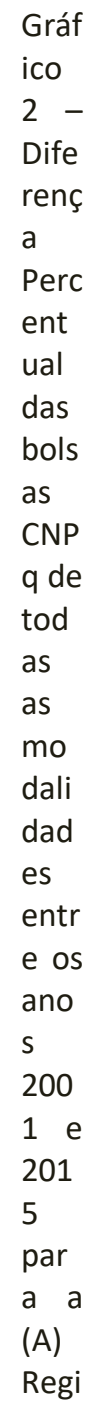


ão

Cen

tro-

oest

e e

Nor

te e

(B)

Regi

ão

Nor

dest

e e

Sul

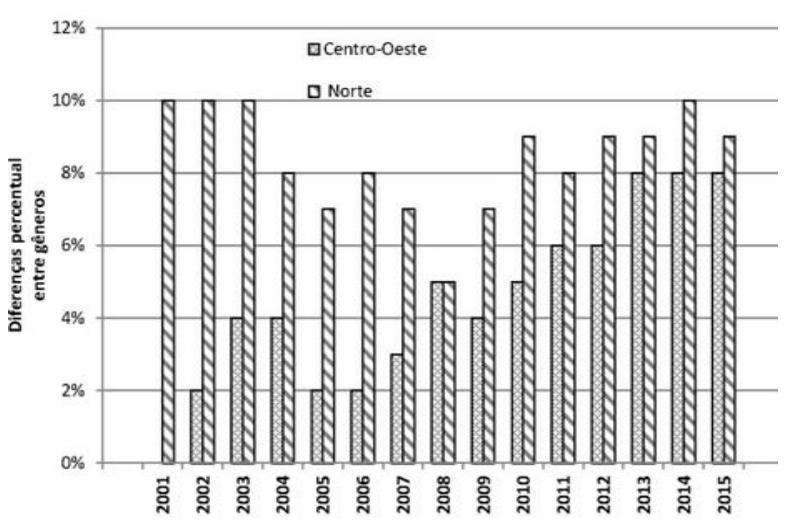

(A)

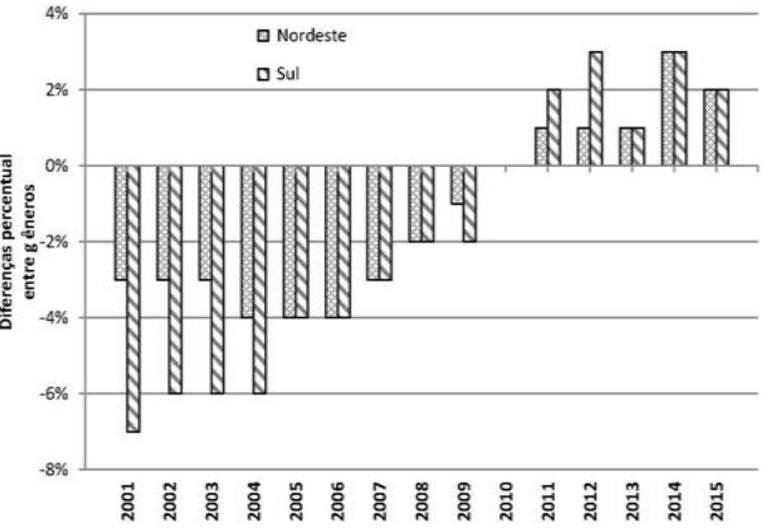

(B)

Fonte dos dados: (A) e (B) BRASIL.

MCTI. CNPq. "Estatísticas".

Disponível em:

http://cnpq.br/estatisticas1>.Aces

so em: 02 Set. 2017.

Gráf
ico
$3-$
Dife
renç
a
Perc
ent
ual
das
bols
as
CNP
q de
tod
as
as
mo
dali
dad 
es

entr

es

os

ano

200

$1 \mathrm{e}$

201

5

par

a a

Regi

ão

Sud

este

Fonte dos

dados: $(A)$ e

(B) BRASIL.

MCTI. CNPq.

"Estatísticas".

Disponível

em:

http://cnpq.b

r/estatisticas

1. Acesso em:

02 Set. 2017.
Para entender este quadro é preciso observar detalhadamente as modalidades de bolsas, a evolução cronológica de distribuição e a relação com os gêneros. Para as modalidades de bolsas, os dados foram divididos em três grandes grupos: um com as bolsas de iniciação científica (IC); outro com mestrado (M), doutorado (D) e pós-doutorado (PD); e o terceiro com as bolsas de estímulo a inovação e de produtividade. Com estes novos descritores, diferentes comportamentos são observados, em especial, em relação às modalidades de bolsas, pois a cada uma destas está associada uma titulação acadêmica e, por consequência, inferências sobre a permanência na área de pesquisa 
podem ser sugeridas. A partir desta organização dos dados, foram observados quatro comportamentos distintos: um para as bolsas de IC (Grupo 01); outro para as bolsas de M, D e PD (Grupo 02), outro para as bolsas de estimulo a inovação (Grupo 03) e último para as bolsas produtividade (Grupo 04).

O Gráfico 4 mostra três faixas de distribuição quantitativas de bolsas. O Grupo 01 ocupa a região mais alta do gráfico, seguido do Grupo 02 na região intermediária e o Grupo 03 na parte inferior. Há uma proximidade entre gêneros nos grupos 02 e 03, sugerindo um equilíbrio entre os gêneros e a permanência do gênero feminino nesta etapa de titulação. Porém, o destaque está nas bolsas de IC, pois há um percurso de predominância feminina, superando com vantagem os homens. Logo, tem-se uma aparente contradição, pelo menos nesta etapa de formação, em relação à afirmação de SISMONDO (2004).

Gráfico 4-Quantidade total de bolsas distribuída pelo CNPq entre os anos de 2011 e 2015 em função da modalidade da bolsa e do gênero do bolsista

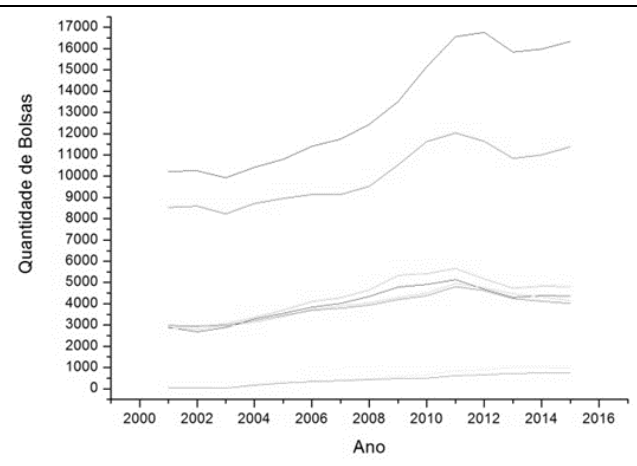

Fonte: BRASIL.

MCTI. CNPq.

"Estatísticas".

Disponível em:

http://cnpq.br/es

tatisticas1. 
Também é importante avaliar a etapa de atuação profissional, aqui relacionada especificamente à concessão de bolsas de produtividade e estímulo à inovação com o gênero. Quando estas relações são estabelecidas, dois perfis surgem, conforme o Gráfico 5-A, com bolsas de produtividade e 5-B, com as de estímulo à inovação. Para a bolsa produtividade, mesmo com o aumento substancial na quantidade de bolsas ofertadas, o predomínio do gênero masculino é constante e histórico. Para as bolsas de estímulo à inovação, este se apresenta menos pronunciado, muito próximo da equidade de gêneros, mas mantém o predomínio masculino.

Os dados mostram que a presença majoritária da mulher, na iniciação científica (bolsas de IC), no período analisado (2001-2015), inverte-se em relação às bolsas produtividade, onde há o predomínio masculino. Porém, existem semelhanças entre a distribuição de bolsas de pósgraduação e as de estímulo à inovação, com a proximidade de gêneros.

Gráfico 5 -Quantidade total de bolsas distribuída pelo CNPq entre os anos de 2011 e 2015 em função da modalidade da bolsa e do gênero do bolsista.: (A) de produtividade. (B) de estímulo a produção
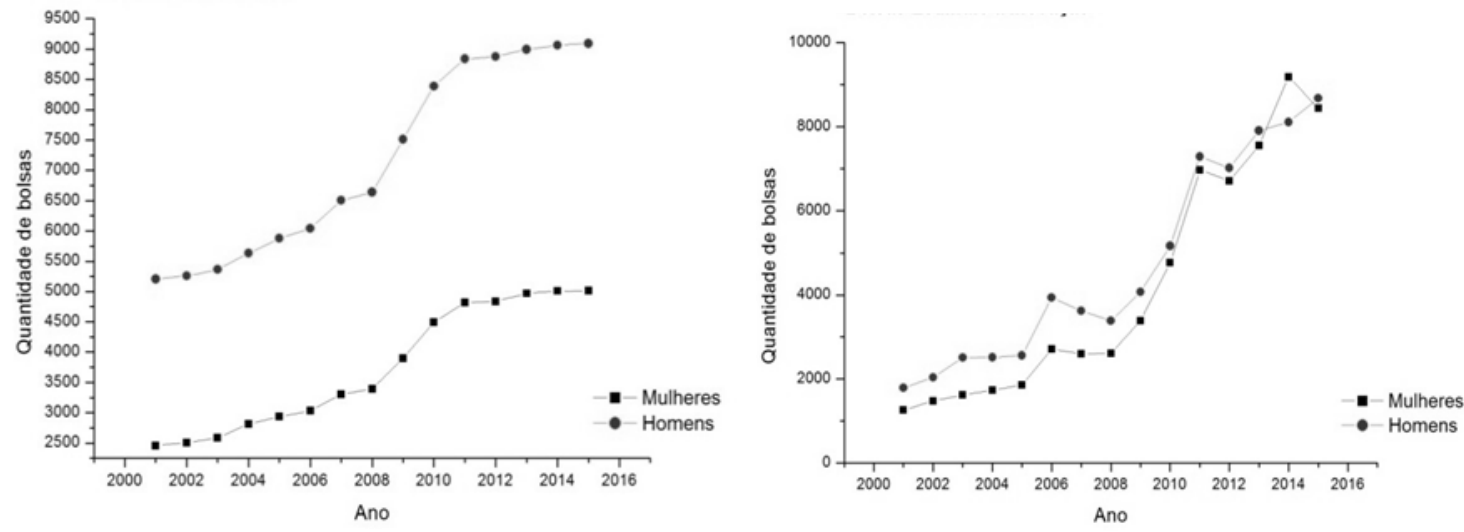

(A) (B)

Fon

te:

BRA

SIL.

MC

TIC.

CNP

q.

"Est

atíst

icas

$"$.

Disp

onív

el

em:

$<$ htt

$\mathrm{p}: / /$

cnp

q.br 
/est

atist

icas

$1>$.

Ace

sso

em:

02

Set.

201

7.

Para concluir é necessário que a avaliação dos resultados, mesmo sugerindo que fatores, de origem interna da formação e/ou exterior, reflitam na permanência da mulher nas etapas finais de formação e atuação profissional da pesquisadora, um olhar mais detalhado deve ser feito no período de 2006 a 2010, pois todas as análises indicam mudança de comportamento neste intervalo Surge, assim, um questionamento: mesmo com esta diferença inicial favorável à mulher, o que ocorre no percurso que não reflete esta vantagem nas etapas seguintes de titulação?

\section{Referências bibliográficas}

BRASIL. CAPES. MEC. Prêmio Capes de Tese. Disponível em: <http://www.capes.gov.br/premiocapesdetese>. Acesso em: 02 set. 2017.

BRASIL. MCTI. CNPq. "Estatísticas". Disponível em: <http://cnpq.br/estatisticas1>. Acesso em: 01 set. 2017.

JAFFÉ, A. 4 O simbolismo nas artes plásticas. O Homem e seus símbolos, p. 230 a 249, 1977. Disponível em: http://iO.statig.com.br/correcaodeprovas/enem2011/49555198-Carl-Jung-O-Homem-e-seus-simbolos-parte4.pdf>. . Acesso em;

LEITE, M. L. M. Grupos de convívio no Rio de Janeiro (século XIX). Psicologia USP, v. 3, n. 3(1/2), p. 13-36, 1992.

LETA, J. As mulheres na ciência brasileira: crescimento, contrastes e um perfil de sucesso. Estudos Avançados, v. 17, n. 2001, p. 271-284, 2003.

NOBELPRIZE.ORG. All Nobel Prizes. Disponível em:

http://www.nobelprize.org/nobel_prizes/lists/all/index.html). Acesso em;

SANTANA, R. F. A instrução da fêmea : a educação da mulher brasileira no século XIX. , p. 137-150, 2009.

SISMONDO, S. An Introduction to Science and Technology Studies. Blackwell, 2004. 


\section{O ENSINO DE CIÊNCIAS NO EMCCF: ATIVIDADES DE UMA EQUIPE MULTIDISCIPLINAR}

Karina Siciliano Oliva Saraiva - Historiadora e Mestre em Educação pela Universidade Federal do Rio de Janeiro (UFRJ) - karinassaraiva@gmail.com

Érika Negreiros - Pós-Doutorando em Ciências Morfológicas (ICB/UFRJ) - erikanegres@yahoo.com.br Gabriella da Silva Mendes - Graduanda em História pela Universidade Federal do Rio de Janeiro (UFRJ) gabiufrj1@gmail.com

Thaís Patrícia Mancílio - Historiadora pela UFF e Pesquisadora do Espaço Memorial Carlos Chagas Filho UFRJ/IBCCF/EMCCF - thaispat@yahoo.com.br

Pedro Henrique Boninni - Graduando em Geografia pela Universidade Federal do Rio de Janeiro (UFRJ)e Pesquisador do Espaço Memorial Carlos Chagas Filho - UFRJ/IBCCF/EMCCF - pedrohenriquebonini@gmail.com Humberto Martins de Souza - Graduando em Biologia pela Universidade Federal do Rio de Janeiro (UFRJ) e Pesquisador do Espaço Memorial Carlos Chagas Filho - UFRJ/IBCCF/EMCCF - betosouza9@hotmail.com Vinicius Valentino Maria - Graduando em Biofísica pela Universidade Federal do Rio de Janeiro (UFRJ) e Pesquisador do Espaço Memorial Carlos Chagas Filho - UFRJ/IBCCF/EMCCF - vi.valent.vm@gmail.com

Resumo

Reconhecido como Museu de História da Ciência, o Espaço Memorial Carlos Chagas Filho (EMCCF) localizado no Instituto de Biofísica Carlos Chagas Filho (IBCCF) da UFRJ é um espaço não formal de educação inserido no programa de extensão do IBCCF/PR5 e possui três projetos de extensão cadastrados. Parte integrante de uma equipe multidisciplinar, os sujeitos que atuam no EMCCF realizam práticas científicas com objetivo de ensinar ciências, adequando a linguagem e modi operandi à realidade de cada grupo. Pretendemos, portanto, inscrever esse trabalho na modalidade oral, destacando as práticas realizadas nesse espaço a suas especificidades de modo a compreender como ocorre a transmissão do conhecimento das múltiplas ciências que dialogam de forma criativa e fluida no interior desse espaço.

Palavras-chave: História da Ciência. Divulgação Científica. Ensino. Pesquisa, Extensão.

Introdução:

O Espaço Memorial Carlos Chagas Filho (EMCCF) é um museu de História da Ciência e Divulgação Científica, localizado no Instituto de Biofísica Carlos Chagas Filho (IBCCF), no prédio do Centro de Ciências da Saúde (CCS), que pretende recontar por meio da preservação, ensino, pesquisa e extensão um pouco da História de seu Instituto e da Ciência inserido no contexto nacional e internacional. Pesquisas iniciadas a priori pelo fundador do IBCCF, no ano de 1945, são recontadas por nossos mediadores que recebem os visitantes interessados em conhecer um pouco da História da Ciência no Brasil. A Divulgação Cientifica é uma das principais práticas realizadas no EMCCF, bem como a realização de três projetos de extensão que visam atender a toda comunidade acadêmica e ao público externo, como é o caso dos alunos de educação básica que visitam o EMCCF e laboratórios do IBCCF. Os projetos: "Descobrindo a Biofísica", "EMCCF: Divulgando a Ciência Brasileira" e "A História da Ciência no Brasil: o capítulo do IBCCF" estão devidamente cadastrados na pró- reitoria de extensão (PR5). A atividade "Vitrines Memoriais: recontando a trajetória de grandes pesquisadores" teve inicio em 2014 e faz parte dos trabalhos realizados pelo projeto "EMCCF: Divulgando a Ciência Brasileira", visando organizar vitrines memoriais rememorando brevemente a vida e obra de grandes pesquisadores brasileiros que fazem ou fizeram parte da história do IBCCF. Elas encontram-se montadas nos corredores do Instituto e são diariamente vistas por todos que percorrem o Instituto e visitam a universidade. 
O EMCCF, em seu andar superior, preserva o antigo escritório e o acervo pessoal de Carlos Chagas Filho, fundador do IBCCF. Ele que nos deixou uma série de trabalhos relevantes sobre Ciência e Cultura insipra todos os funcionários do espaço no que se refere à valorização da pesquisa e do ensino no interior da universidade: "Na universidade se ensina porque se pesquisa" (CHAGAS FILHO, 1956). No subsolo do EMCCF há a exposição "A História da Ciência no Brasil: o capítulo do Instituto de Biofísica Carlos Chagas Filho", que homenageia e conta a história dos primeiros pesquisadores do IBCCF. Esse "lugar de memória" segundo afirmou Chagas (2002), pode ser compreendido como um espaço híbrido, pois contempla várias temáticas e reúne diversos funcionários e bolsistas de diversas áreas. É um espaço dedicado à guarda, pesquisa e conservação de equipamentos científicos históricos, visitação escolar e de público espontâneo, bem como à realização de práticas de Física, Química e Biologia pelos mediadores e pelo próprio Dr. Elias, que utilizam os equipamentos para abordar questões das ciências da vida com os alunos e outros visitantes. Antes mesmo que ocorresse uma disputa pelo espaço onde ficaria localizado o museu, Dr. Elias, já se preocupava em fazer o mesmo que fez Bragança Gil (1999) em Portugal: "a guarda de um raro acervo bem como a preocupação de torná-lo acessível aos pesquisadores e aos visitantes". Com base no exposto acima e segundo Chagas (1999, p. 54): “[...] um ambiente dinâmico e produtor de conhecimento, uma instituição constituída por processos híbridos, que contempla múltiplas temáticas e por isso apresenta elevado potencial pedagógico", o trabalho que pretendemos apresentar nesse congresso consiste em relatar como os projetos que acontecem no interior do EMCCF podem facilitar a aprendizagem e ampliar o conhecimento ao realizar a divulgação da História da Ciência do Brasil e do mundo.

Equipe multidisciplinar do EMCCF:

A equipe do EMCCF é composta por um grupo hibrido e multidisciplinar que realiza multiplas atividades dentre elas: Extensão Universitária, mediação, organização de acervo museológico (guarda e catalogação), pesquisa em História da Ciência, Divulgação Científica, Memória, Patrimônio e organização de eventos relacionados ao museu e ao IBCCF.O espaço conta com a presença de dois funcionários da UFRJ, uma TAE (Mestra em Educação e Historiadora/UFRJ) que responde pelo setor educativo e o projeto de visitação escolar e uma técnica de laboratório que nos auxilia com a parte de secretariado. A coordenadora do EMCCF está à frente do espaço há 3 anos e é pós-doutora em Ciências Morfológicas - ICB/UFRJ, além de Especialista em Divulgação Científica e Extensão. Dr. Elias, reconhecido como uma das pessoas mais dedicadas e preocupadas em zelar pela História e Memória do IBCCF, é um senhor bastante ativo e peça fundamental no desenvolvimento da guarda, pesquisa e catalogação de todos os equipamentos científicos que fazem parte de nosso acervo. Sete bolsistas de extensão dos mais diversos cursos de graduação da UFRJ e fora dela (História, Biologia, Geografia, Biofísica, Conservação e Restauro) compõem o restante da equipe e são peça fundamental para o andamento das atividades realizadas no EMCCF. A política de aquisição segue uma norma pré-estabelecida pela coordenação do EMCCF, na qual os interessados em doar algum equipamento devem enviar um e-mail solicitando uma avaliação prévia realizada por nossa equipe e coordenada pelo Dr. Elias.

2 Prática educativa multidisciplinar: Ensino com os equipamentos científicos e as mediações escolares:

A equipe do EMCCF que atua na organização do acervo realizou a catalogação de cerca de 400 equipamentos científicos. A interação entre os estudantes visitantes e os equipamentos do século passado, associada a temáticas atuais e do nosso cotidiano, é uma especificidade do nosso museu. Equipamentos como Miliamperímetro - Weston D.C, Circuito Tesla, 
Espectroscópio e Microscópios clássicos, são alguns dos equipamentos do acerco utilizados por para abordar temas e fenômenos da natureza como luz, som, eletricidade, dentre outros temas de física. Os estudantes da educação básica interagem diretamente com cada equipamento. Sobre a mediação que ocorre durante a visitação à exposição, os bolsistas subdivididos nas áreas nas quais possuem maior domínio, interagem com os estudantes de modo a discutir as multiplas ciências. Na exposição permanente, os visitantes aprendem um pouco da nossa História atraves da observação de objetos utilizados pelo Dr Chagas Filho. A Historiadora ou o mediador da área de História se utiliza da metodologia da "Educação Patrimonial" para discutir sobre os avanços e progressos da tecnologia no Brasil, por meio de questionamentos aos visitantes. Maria de Lourdes Horta (1999), museóloga e servidora pública federal, permaneceu dezessete anos à frente do Museu Imperial e pensou uma metodologia própria a educação no museu. De acordo com essa autora, a temática deveria envolver não somente a rede escolar, mas toda a comunidade local, família e empresas que valorizassem toda a importância da preservação do nosso patrimônio. Sua inserção no currículo permite a prática da cidadania e diálogo entre gerações. Trata-se de um processo permanente e sistemático de trabalho educacional centrado no Patrimônio Cultural como fonte primária do conhecimento e enriquecimento individual e coletivo para investimento das fontes secundárias. Para que se consolide a preservação sustentável desses bens e se fortaleça o sentimento de identidade e cidadania, o currículo precisa oferecer ao aluno subsídios para que ele construa seu pensamento, seja crítico e se aproprie conscientemente do Patrimônio Cultural Brasileiro. A palavra Patrimônio significa algo que foi herdado e deve ser usufruído por todos os estudantes que um dia irão transmitir essa noção de preservação para os mais jovens. Aos professores cabe a missão de valorizar todo conteúdo e ensinamento que é oferecido ao seu aluno, para que eles encontrem diversos motivos para ler, estudar e pesquisar e para que o professor possa ensinar o real motivo de estudar. No escritório musealizado de Carlos Chagas Filho, os mediadores escolhem três objetos de seu arquivo pessoal, mas que não fazem parte do cotidiano dos alunos do século XXI e fazem perguntas baseadas nos tópicos descritos acima. Como exemplo de estudo de caso em uma das nossas pesquisas, utilizamos como objeto de análise uma máquina de calcular que pertenceu ao $\mathrm{Dr}$. Chagas, datada de 1940 e fabricada no México, e por meio da análise do mesmo é possivel destacar acontecimentos ocorridos nos anos de 1940, como a segunda grande guerra e fundação do Instituto de Biofísica. Esse panorama histórico cultural permite que o educador reflita com os alunos acontecimentos do século passado, e estes se apropriem da História com muito mais facilidade. A volta no tempo permitiu ao mediador falar não apenas dos acontecimentos, mas da cultura, dos hábitos, das roupas, da alimentação e muito mais das características desse século XX. Em um segundo momento, o mediador passou a analisar com os estudantes a máquina de escrever, da marca "Halda", que também pertenceu a Chagas Filho e data da década de 1950.

A exposição "A História da Ciência no Brasil: o capítulo do IBCCF", existente no subsolo do EMCCF, permite que os mediadores dialoguem com os visitantes a começar pela explicação do pioneirismo nas pesquisas nacionais e internacionais e os cientistas que trabalharam no IBCCF por muitos anos. Dividida em algumas subáreas, a exposição é interativa e relaciona passado e presente como forma de facilitar o aprendizado dos alunos. No módulo Bioquímica, os mediadores abordam a temática relacionada ao exame anti-dopping, o que na época das Oímpiadas nos rendeu uma série de discussões ainda mais profundas, exame este que foi feito em cavalos do Jóquei Clube Brasileiro na década de quarenta, liderado por uma mulher cientista do Instituto de Biofísica chamada Aida Hossón- Volloc. No módulo Biologia Molecular falamos sobre a evolução da pesquisa em animais, desde Chagas Filho com peixe elétrico, passando por modelos mais tradicionais como ratos e camundongos, até à utilização da 
Drosophila melanogaster, conhecida como mosquinha da fruta, as quais podem observadas através lupa de aumento. No módulo Biologia Celular e Microscopia, os estudantes têm acesso a microscópios e podem ver de perto um cérebro do camaleão em um microspio do século passado. Finalmente, no módulo Radiobiologia, os visitantes têm acesso a um vídeo que mostra o maior acidente radiológico do Brasil que ocorreu em Goiânia, através da contaminação com o Césio-137. Em uma atividade interativa que ocorre com a simulação do brilho do Césio-137, os visitantes discutem sobre como a população foi contaminada há exatos trinta anos atrás, além do destaque à importância e aos perigos da radiação, visto que ela também existe na medicina e conservação de alimentos e nos beneficia bastante, basta saber fazer um bom uso da mesma.

\section{Considerações Finais:}

Atualmente estamos desenvolvendo pesquisas relacionadas à Percepção Pública da Ciência e analisando questionários de avaliação de público e grupos focais que, em breve, comporá um artigo referente à avaliação do ensino em espaços não formais de educação. Grande parte do nosso público são estudantes advindos da periferia e zona rural, a maioria sem acesso a museus e laboratórios básicos de Ciência aplicada. O retorno das escolas ano após ano e a participação ativa dos estudantes e público visitante ao EMCCF é algo positivo para nossa avaliação e continuidade desse trabalho que se inicia desde o momento em que catalogamos e preservamos os equipamentos até à utilização dos mesmos nas oficinas e exposições de ciências. Além disso, todo o contraponto com a realidade/cotidiano dos estudantes, bem como a criatividade em expôr a temática presente nas exposições de ciências ajudam os mediadores no momento que estão realizando a mediação escolar e possibilitam a relação dialógica entre público e museu.

Referências bibliográficas

BRAGANÇA GIL, F.; M. LOURENÇO. Que cultura para o século XIX? O papel essencial dos museus e técnicas. In:

REUNIÃO DA REDE POP DO MUSEU DE ASTRONOMIA E CIÊNCIAS AFINS, 6, Rio de Janeiro. Anais... Rio de Janeiro, 1999

CHAGAS FILHO, C. Homens e coisas da ciência. Rio de Janeiro: Gráfica da Universidade do Brasil, 1956. CHAGAS, M. Museu de ciência, assim é se lhe parece. In: KOPTCKE, L. S.; VALENTE, M. E. A. (Orgs.). Caderno do Museu da Vida: o formal e o não formal na dimensão educativa do museu 2001/2002. Rio de Janeiro: Museu da Vida; Fiocruz, 2002. p. 46-59.

. Há uma gota de sangue em cada museu: a ótica museológica de Mário de Andrade. Lisboa: Universidade Lusófona de Humanidades e Tecnologias, 1999. (Cadernos de Sociomuseologia, 13)

HORTA, M. de L. P. et al. Guia básico de Educação Patrimonial. ed. Brasília: IPHAN / Museu Imperial, 2006. . Um aprendiz de ciência. Rio de Janeiro: Nova Fronteira; Editora Fiocruz, 2000.

NORA, P. Entre memória e história: a problemática dos lugares. Projeto História, São Paulo, PUC, n. 10, p. 7-28, dez. 1993. 


\section{BITCOIN: MATERIALIDADES, LIBERDADES E INTERAÇÕES DE UMA MOEDA-REDE}

Luiz Arthur Silva de Faria - UFRJ

\section{Resumo}

A Bitcoin suscita discursos de liberdade em relação a governos, bancos centrais e grandes bancos, de um lado, e críticas que aproximam a proposta de moeda do mundo da especulação financeira, de outro. Analisaremos brevemente neste trabalho alguns aspectos da recente história de tensão entre esses dois olhares sobre esta moeda suportada por diferentes elementos de tecnologias da informação, como softwares, hardwares e protocolos. Considerando que há opções inscritas nos códigos, como a quantidade de moeda disponível e uma versão particular de descentralização centrada no indivíduo, as reflexões do trabalho apontam para o reconhecimento de que a Bitcoin não está separada tanto do que poderíamos chamar de micropolítica daqueles que projetaram seus algoritmos e códigos quanto da macropolítica da governança da Internet.

Palavras-chave: Moedas Digitais. Descentralização. Política.

Introdução

Cena 1. Marcos, tido como "um hacker meio anarquista" por seus colegas de graduação em computação, finalmente chega ao FISL. Ele tinha estudado bem a grade do evento, e estava interessado em temas sobre moedas alternativas. Naquela tarde, caminhava pra mais uma palestra sobre Bitcoin. Entra no auditório, senta. De manhã já tinha ido a outra apresentação que tratava da moeda digital, mas achou "meio teoria da conspiração, falando de guerra cibernética, de bancos centrais e tal", como comentou com o rapaz ao seu lado. Auditório cheio e apertado, começa a palestra: "Gente, vocês não acreditam no sonho que tive!! Eu imaginava em fazer nossas próprias moedas, sem depender desses governos! Podíamos estabelecer nós mesmos uma regra pra criação dessas moedas. As transações seriam anônimas, ninguém tem que ficar sabendo o que eu comprei ou vendi. Talvez as pessoas pudessem ajudar a validar cada transferência da moeda, mas de uma forma que elas não poderiam saber quem faz parte da transação. E quem fizesse isso ganharia algumas moedas como prêmio. Com as possibilidades da Internet, o registro de todas as transações que rolaram na rede podia ficaria aberto, apenas sem identificar exatamente a pessoa. E sem ninguém controlando, no esquema do compartilhamento de músicas, ponto a ponto. Isso era no sonho... Mas ... não é sonho, pessoal! Como alguns aqui devem saber, um tal de Satoshi esteve trabalhando em um novo sistema de dinheiro eletrônico que é completamente ponto a ponto (P2P), sem precisar de um servidor central. Ele resolveu o problema da segurança com a rede $\mathrm{P} 2 \mathrm{P}$, não tem nenhuma instituição centralizada pra emissão de moedas e os participantes podem ser anônimos. O cara mandou o link pra um paper e tudo. Acho que tô sonhando ainda...". Nesse momento, Marcos não pôde deixar de perceber um sotaque carioca (como o dele) vindo da conversa à sua direita: "meu irmão, com isso aí, em 20 anos não vai haver mais fronteiras entre os países. Os Estados se mantém por causa das moedas... Acabou isso!! Essa é mundial, não tem como os governos controlarem". A conversa quase faz Marcos perder a intervenção de alguém insatisfeito com o discurso do palestrante: "Deixa eu falar, você não pode me impedir! Eu participei dessa comunidade do bitcoin no Brasil desde o início. Era uma alternativa lá atrás, pelo menos eu achava. Mas agora só serve pra especular 
e ganhar dinheiro. Você tem que falar disso também. Não pode deixar de falar!" Silencio no auditório, climão... Agora foi a vez de Marcos prestar atenção num rapaz sentado à sua esquerda, que não se conteve. Virou-se pra Marcos e soltou: "Véi, cada vez eu me convenço mais que essa bitcoin não resolve nada... Depois vê se passa na sala 110 . Vou apresentar daqui a pouco uma experiência com outra história de moeda digital, na economia solidária". Marcos não conhecia o rapaz, apenas percebeu que o sotaque vinha de algum ponto do nordeste brasileiro. Bateu nos ombros de Marcos, levantou e saiu da sala.

A cena 1 é fictícia, mas inspirada na realidade. O discurso de liberdade e de alternativa em relação a governos, bancos centrais e grandes bancos, controladores das moedas que circulam na maior parte dos países, de um lado, e as críticas que aproximam a Bitcoin do mundo da especulação financeira, de outro, foram observadas por este pesquisador na circulação da "primeira moeda digital descentralizada", como Kemel Zaidan (2014) caracteriza a Bitcoin, em fóruns sobre software livre e inclusão financeira. Analisaremos brevemente neste trabalho alguns aspectos da tensão entre esses dois olhares sobre esta (proposta de) moeda suportada por diferentes elementos de tecnologias da informação, como softwares, hardwares e protocolos.

Em 31/10/2008, Satoshi Nakamoto envia e-mail com white paper para uma lista de criptografia cypherpunk, lançando as bases e as primeiras implementações do Bitcoin (ZAIDAN, 2014). Suas regras são inscritas nas linhas de código dos programas que dão vida à proposta de moeda, e que funcionam em celulares, tablets, laptops etc. Segundo elas, qualquer transação realizada em Bitcoin fica registrada em uma espécie de livro caixa (public ledger) que contém todas as transações já realizadas na rede, uma de suas grandes novidades. Periodicamente, (a cada dez minutos, segundo Zaidan (2014)), a rede reúne as páginas do livro, ou melhor, os blocos da cadeia, que registra sequencialmente as transações e as torna públicas - contudo sem abrir mão do anonimato das pessoas envolvidas. Essa publicidade das transações é um forte aliado à segurança da rede (CRIPPA, 2014).

Também incorporado nos códigos, o anonimato é garantido pela criptografia e por um mecanismo de chaves assimétricas. Em resumo, cada usuário na rede corresponde a uma chave pública (conhecida pelos outros membros da rede, ou seja, computadores) e a uma chave privada, a que somente o próprio usuário tem acesso. Outra característica fundamental da moeda-rede Bitcoin é que ela utiliza uma rede de computadores cuja arquitetura pode ser caracterizada como ponto-a-ponto (peer-to-peer, ou P2P). Significa dizer que a rede não possui um servidor central, ou seja, a validação de qualquer transação em Bitcoin é feita numa rede distribuída.

Essa arquitetura é uma pista para as formas de geração e circulação da nossa moeda-rede: não há uma entidade central emissora de Bitcoin. As moedas são geradas e atribuídas, como um prêmio, aos usuários que colocam à disposição da rede um esforço computacional para validar as transações realizadas em Bitcoins (ZAIDAN, 2014). Esse processo é chamado de mineração de Bitcoins: os usuários que validam transações recebem moedas, segundo Wladimir Crippa (2014), a uma taxa na rede aproximada de 25 Bitcoins a cada 10 minutos.

Mineração, peer-to-peer e criptografia poderiam ser nomeadas, apressadamente, características técnicas da Bitcoin. Porém, mais cuidadosamente, é possível perceber que tais atores não-humanos embutem escolhas e propagam efeitos que poderíamos chamar sociais ou políticos, o que torna essa fronteira um tanto borrada. Dialogando com a antropologia da economia, vale examinar as reflexões de George Dalton (1967) ao analisar diferenças entre os usos e significados do dinheiro nas sociedades contemporâneas ocidentais e em outras muitas vezes ditas primitivas. O autor coloca que "a questão não é se - como convencionalmente colocado - (...) gados, bodes [etc.] (...) são 'realmente' 'dinheiro'?" É, ao invés disso, como as similaridades e diferenças entre tais itens [das sociedades primitivas] e 
os dólares [das atuais] se relacionam com similaridades e diferenças na estrutura sócioeconômica?"

Dalton (1967) argumenta que, ao examinar atentamente as "moedas", é possível (e necessário) ver a estrutura socioeconômica. O artefato em questão, a moeda, seria indissociável dessa estrutura. Dialogando com essa abordagem e com Bruno Latour (), podemos propor que a observação cuidadosa dos artefatos tecnológicos que circulam na rede da Bitcoin - aliados não-humanos da rede -, nos leva a noções, argumentos e teorias associados à proposição da moeda-rede Bitcoin. É o que veremos adiante, ao mesmo tempo que acompanhamos os construtores brasileiros da Bitcoin na busca por mais aliados e pela confiança do público.

Observando as apresentações sobre Bitcoin e criptomoedas no FISL e LATINOWARE, não é difícil identificar um argumento apresentado como favorável para o uso da moeda alternativa: sua pretença independência em relação a governos e sistemas políticos, por um lado, e a bancos centrais e ao sistema bancário em geral por outro. O que regulamentaria a Bitcoin seria o protocolo, e portanto a rede não dependeria de bancos ou governos pra existir, o que seria uma vantagem para Zaidan (2014). Uma das facetas de essa independência ganha a forma da defesa do anonimato, e seu tom parece guardar relação com o de Eric Hughes, programador que escreveu o "Manifesto Cypherpunk" em 1998 e que defendia o uso de criptografia para proteger a privacidade na era da informação. Ele argumenta que "[s]e eu compro uma revista de uma loja e dou dinheiro para o caixa, não há necessidade de ele saber quem eu sou. (...). Se eu peço ao meu provedor de correio eletrônico para mandar e receber mensagens, meu provedor não precisa saber com quem eu estou falando ou o que outros estão me dizendo; meu provedor só precisa saber como levar a mensagem até lá e quanto eu devo."

A preocupação com o anonimato e a privacidade é situada por Pedro Rezende (2014) na história da digitalização das moedas, que lembra da digitalização das moedas como um fenômeno não inaugurado com a Bitcoin. Os bancos, provendo operações eletrônicas já há muito iniciaram esse processo. Não somente teriam iniciado, mas também se beneficiariam de uma importante diferença que a materialidade das operações eletrônicas traz, quando comparada por exemplo com o papel-moeda: a rastreabilidade. Na visão de Rezende (2014), ela permite que os bancos ofereça mais versatilidade em troca da privacidade dos usuários (essa, compartilhada com as instituições financeiras). Uma saída possível estaria na tecnologia, que permitiu sair de uma ideia de validação centralizada das transações para um arranjo descentralizado, como vimos por conta das tecnologias P2P. Nesse novo arranjo, tendo um software como um dos protagonistas, o poder teria sido deslocado, já que nas "moedas livres" (REZENDE, 2014):

\footnotetext{
"Quem controla a emissão é um protocolo distribuído acordado por quem implementou o artigo original de Satoshi Nakamoto. Quem emite moeda é o protocolo (...). Quem pode entrar? Quem quiser. Quem pode rodar o código? Quem quiser. Quem pode examinar o código? Quem quiser." (REZENDE, 2014)
}

Anonimato, certa aversão a governos e bancos, elogio aos protocolos e tecnologias são ideias obviamente não exclusivas dos (mas presentes nos) circuitos da Bitcoin. Crippa (2014) posiciona a Bitcoin nos contextos mais amplos da revolução digital e da democracia direta. Entre os indícios de uma visão libertária, bastante comum nas discussões sobre um dos ícones da revolução digital, a Internet, está a "Declaração de Independência do Ciberespaço". Ela proclama:

"[ó], Governos do Mundo Industrial, esgotados gigantes de carne e aço, eu venho do ciberespaço, a nova morada da mente. Em nome do futuro, eu peço a vocês do passado que nos deixem em paz. Vocês não são bem-vindos entre nós. Vocês não 
têm soberania onde nos reunimos. [...] Declaro que o espaço social global que estamos construindo é naturalmente independente das tiranias que vocês querem nos impor." (BARLOW, 1996, apud CARVALHO et al., 2005, p. 58)

Parece pertinente assim situar os valores libertários que atravessam a rede da Bitcoin como estando imbricados com os discursos e visões de mundo que circulam entre militantes da Internet, do protocolo P2P e do software livre, como transparece na fala de Crippa (2014): para ele, o "Mp3 é uma porta de entrada para 'drogas mais pesadas' como Bitcoin". Contudo, vale aqui pontuar que, como discutimos em outro momento, ainda que valorizando as diversas lutas políticas por práticas democráticas relacionadas à Internet, é preciso relativizar a visão que advoga uma independência natural do ciberespaço e uma descentralização do poder na Internet, por exemplo, lembrando que a redistribuição de recursos e de poder do "modelo descentralizado de comunicação [da Internet], baseado no protocolo TCP/IP" (CARVALHO et al., 2005, p. 61) não está apartada de seu sistema de endereçamento, que define a própria existência de um computador na Internet e é centralizado (CARVALHO et al., 2005) (FARIA, 2010). Cabe lembrar assim que a Internet não existe totalmente apartada da política e dos Estados.

Importa também examinarmos nesta seção o que chamamos de "elogio aos protocolos e tecnologias" que circulam na moeda-rede Bitcoin, como uma possível alternativa às esferas políticas. Como já pontuamos, os estudos CTS demonstram a não neutralidade da ciência e das tecnologias: "todo desenvolvimento tecnológico implica escolhas, e os artefatos não nascem apartados das associações engendradas com o objetivo de produzi-los" (FARIA, 2010). No caso da Internet, "em oposição à ideia de que o ciberespaço é um território sem leis, livre - inclusive da influência dos governos - importa chamar a atenção para os códigos que permeiam a Internet: eles delimitam poderes dos usuários (CARVALHO et al., 2005), configurando as regras e empoderando mais - ou menos - aqueles que ali agem. Pode-se dizer assim que os códigos reconfiguram agenciamentos. Nas palavras de Lawrence Lessig (1999, p. 5), "o que faz o ciberespaço tão diferente é que ele é constituído por essas leis da natureza que escrevemos", os códigos dos softwares que conformam a grande rede." (FARIA, 2010)

Há política na tecnologia: há opções inscritas nos códigos, adotadas pelos construtores dos algoritmos e códigos, como a opção por delimitar a quantidade de moeda em um teto; há efeitos no uso da Bitcoin, efeitos esses relacionados com as opções e materialidades embutidas na moeda: por ser intensiva em tecnologias da informação, pode-se dizer que o uso da moeda inclui aqueles que dominam razoavelmente suas linguagens e exclui, ao menos temporariamente, os que as ignoram. De forma bastante crítica, Scott (2014) coloca: "[s]e você está na posição de sonhar com uma saída tecnológica, você provavelmente não está em uma posição de sair da sociedade mainstream. Você é sociedade mainstream."

Ainda no campo das políticas embutidas na Bitcoin, encontramos uma versão particular de descentralização. Nela, a alternativa à concentração promovida por bancos centrais e grandes bancos é substituída, em tese, pela individualidade de cada pessoa. Uma opção que desconsidera, por exemplo, o tema da proximidade, tão caro às metodologias de moedas alternativas no campo da economia solidária, como nos casos dos Bancos Comunitários de Desenvolvimento (BCDs) e das Produtoras Culturais Colaborativas, passa ao largo dos militantes brasileiros da Bitcoin. Um indicador percebido no FISL: ao ser apresentado à metodologia dos BCDs, a primeira reação de Wladimir Crippa (2015) (um de seus porta-vozes em encontros como o FISL) foi compará-la às Dotz. A comparação faz sentido no escopo desta proposta de moeda alternativa, onde uma descentralização extrema das instâncias validadoras das transações financeiras é um valor que circula tanto nos discursos quanto em seus artefatos. A própria existência de um banco comunitário como uma instância de relativo 
poder local soa estranha à "cosmologia" da Bitcoin. Contudo, Joaquim Melo, pioneiro na metodologia dos BCDs, aponta grandes diferenças das Dotz em relação aos BCDs: não possui lastro em Reais, seu espaço de circulação se estende por todo o território nacional, e não se sabe "quem é o dono, quem administra, a quem ela beneficia" (MELO NETO SEGUNDO, 2012). Por fim, cabe ressaltar que os valores que influenciam e são embutidos em um artefato tecnológico, como a Bitcoin, não são propagados necessariamente da mesma maneira. Se nos afastamos aqui de uma noção de determinismo tecnológico, também não nos aproximamos de um determinismo social: as materialidades promovem surpresas. Em nosso caso, chama a atenção que minerar Bitcoins foi progressivamente tornando-se uma tarefa árdua, para especialistas. Um usuário comum, utilizando um desktop, já não consegue mais atualmente obter muitas Bitcoins a partir da mineração (ZAIDAN, 2014). Surgiram inclusive três ou quatro pools no mundo, que "movimentam a economia Bitcoin", além das "benditas máquinas projetadas só pra minerar Bitcoin" (CRIPPA, 2014). Esta surpresa material, oferece uma vantagem para aqueles que têm condição de investir Reais em máquinas poderosas, que produzam mais Bitcoins: assim, a suposta intenção descentralizadora ganha contornos de promotora de novas concentrações.

Portanto, não se deve imaginar que, adotando uma "moeda livre" cujo funcionamento não seja determinado diretamente por governos e bancos, estaremos livres dessas institucionalidades e de suas políticas constituintes. Apesar de concordar com Zaidan (2014), quando argumenta que "não é fácil acabar com o Bitcoin (...) por ser uma rede [distribuída] P2P", e de ser fundamental lembrar que os códigos-fonte são licenciados como softwares livres (ou seja, sempre é possível modificar o código-fonte e propor construir outra rede, com outra moeda, assunto a que voltaremos adiante), melhor imaginar que as relações e os poderes podem ser reconfigurados sim pela Bitcoin, em outros termos; porém, termos esses que não serão isentos de opções, restrições, facilidades, de políticas. "Somente se escapa para um conjunto diferente de regras, não controlada por políticos, mas nas mãos de programadores e daqueles que controlam o poder computacional", como coloca (SCOTT, 2014).

As moedas de nossa sociedade ocidental estão conectadas à autoridade centralizada dos bancos centrais, e por sua vez essa está intimamente ligada aos governos. Se isso é sim verdade, é importante também reconhecer que a Bitcoin não está separada, por um lado, do que poderíamos chamar de micropolítica daqueles que projetaram seus algoritmos e códigos, nem mesmo, por outro, da macropolítica da governança da Internet.

\section{Referências bibliográficas}

CARVALHO, Marcelo. S. R. M.; CUKIERMAN, Henrique. L.; MARQUES, Ivan da C., 2005, A governança da Internet: o controle do namespace no ciberespaço. In: AFONSO, Carlos A. (Org.). Governança da Internet: contexto, impasses e caminhos. São Paulo: Peirópolis, p. 58-77.

CRIPPA, Wladimir, 2014. Bitcoin: a Revolução Digital chegou à economia. Palestra apresentada ao Fórum Internacional de Software Livre 2014. Porto Alegre, em 8 mai. 2014.

Wladimir, 2015. [Sobre o Bitcoin]. Porto Alegre. Entrevista concedida a Luiz Arthur Silva de Faria em 08 de junho de 2015.

DALTON, George, 1967. "Primitive Money." In Tribal and Peasant Economies. Readings in Economic Anthropology, edited by George Dalton, 254-81. New York: The Natural History Press.

FARIA, Luiz Arthur Silva de, 2010. Softwares livres, economia solidária e o fortalecimento de práticas democráticas: três casos brasileiros/Luiz Arthur Silva de Faria. — Rio de Janeiro: UFRJ/COPPE, 2010. JATOBÁ, Pedro H., 2013. [Sobre a moeda Conchas, o Corais.org, a Produtora Cultural Colabor@tiva.PE , e a Rede de Produtoras Colaborativas segundo a visão de um dos desenvolvedores da metodologia das Produtoras 
Culturais Colaborativas]. Entrevista concedida via skype a Luiz Arthur Silva de Faria em 06 de setembro de 2013.

LATOUR, Bruno, 2000 [1998]. Ciência em ação: como seguir cientistas e engenheiros sociedade afora. São Paulo, UNESP.

MELO NETO SEGUNDO, João Joaquim de, 2012. Uma segunda moeda agora pode? Disponível em <http://empreendedorsocial.blogfolha.uol.com.br/2012/07/11/uma-segunda-moeda-agora-pode/> Acesso em 01 jun. 2013.

REZENDE, Pedro Antonio Dourado de, 2014. Possíveis futuros para o último bastião da liberdade digital: as Criptomoedas. Palestra apresentada ao Fórum Internacional de Software Livre 2014. Porto Alegre, em 8 mai. 2014.

SCOTT, Brett, 2014. "Visions of a Techno-Leviathan: The Politics of the Bitcoin Blockchain ." Disponível em < http://www.e-ir.info/2014/06/01/visions-of-a-techno-leviathan-the-politics-of-the-bitcoin-blockchain/>Acesso em 01 jun. 2014.

ZAIDAN, Kemel, 2014. Bitcoin: o futuro do dinheiro é open source (e livre). Palestra apresentada ao Fórum Internacional de Software Livre 2014. Porto Alegre, em 7 mai. 2014 


\section{NO PALCO DA CIDADE: O RIO DE JANEIRO QUE A MODERNIDADE TENTOU ESCONDER}

Erica Cristina da Silva Gomes - Doutoranda do HCTE-UFRJ - assessoraerica@yahoo.com.br Nadja Paraense dos Santos - Professora do HCTE-IQ-UFRJ - nadja@if.ufrj.br

Resumo

No contexto da Belle Époque Carioca o jornalista e cronista, João do Rio (1881-1921), registra em seus textos uma faceta da cidade que o projeto modernizador, por meio de simulacros, desejava esconder. Graças a esta abordagem criativa, os hábitos culturais e o modo de viver da chamada "Pequena África" foram estampados nas páginas dos jornais no início do século XX. Mesmo a contragosto da elite republicana, que pretendia implantar uma "Paris nos Trópicos", o flaneur imortaliza trajetórias de vida popular em suas crônicas. Fazendo uso de uma linguagem metafórica teatral, este artigo reconstrói sucintamente tal panorama histórico-cultural.

Palavras-chave: João do Rio. Metáfora Teatral. Modernidade. Popular. Jornalismo.

Introdução

Recorrendo simbolicamente a uma metáfora teatral, no início do século XX duas "peças" disputavam a atenção da "plateia" carioca. No centro do palco havia a encenação de uma Paris nos trópicos, patrocinada pelos recursos da nascente República. No fundo da cena desenrolava-se a história dos personagens que haviam sido reprovados para participar do espetáculo "O Rio civiliza-se" (EDMUNDO, 1957, p.40).

Enquanto oficialmente montava-se a cenografia da "Europa possível", a "Pequena África" (VELOSO, 1990, p. 1) organizava sua apresentação no tablado da rua. De repente a representação popular, com seus hábitos e tradições, passou a se insinuar em meio à superprodução do Estado. O responsável por dirigir esse ato revolucionário foi João do Rio. Através dos seus textos, ele deu visibilidade ao elenco popular que o processo de modernização teimava em deixar fora de cena.

\section{O Palco da Cidade}

Nem sempre a cidade foi palco de grandes simulacros. Até o final do século XIX, a cena apresentava, sem rasuras, a história do Rio Antigo com seu passado colonial e escravocrata: becos sujos e estreitos com pouca iluminação e circulação de ar; cortiços com um número excessivo de pessoas por cômodos; um velho cais com limitações para atracar grandes navios. Os atores movimentavam-se pelo palco da populosa capital da República guiados pelo seu drama pessoal de sobrevivência e busca por empregos. A abolição e a crise da economia cafeeira no Vale do Paraíba atraíram um intenso fluxo de agricultores para o Distrito Federal em busca de oportunidades de trabalho. A falta de condições sanitárias nas habitações coletivas populares os expunha a doenças infectocontagiosas. (HERSCHMANN, LERNER, 1993, p.82).

Foi numa das ruas desse palco, a do Hospício (hoje Buenos Aires), que começou a história de João Paulo Alberto Coelho Barreto, um dos maiores cronistas do século XX. Nascido no final do Segundo Império, em 1881, durante a infância assistiu à chegada da Abolição e da República. Iniciou a prática jornalística aos 17 anos quando ingressou em A Tribuna (18901911). A partir daí, passou por diversos jornais cariocas, como: O Paiz (1884-1934), O Dia 
(1900) e Correio Mercantil (1848-1868). Nestes periódicos, produziu críticas de artes, assinando com seu verdadeiro nome, com as iniciais P. ou P.B ou ainda com o pseudônimo Claude.

Coincidentemente, foi durante os primeiros anos de sua atividade profissional que se iniciou uma grande alteração no palco da cidade. Juntamente com a chegada do século XX, surgia o cenário sobre o qual Paulo Barreto, melhor dizendo, João do Rio, nasceria. Flanando, ele reuniu os materiais que fizeram de suas reportagens, peças teatrais, contos, conferências, romances e crônicas, composições diferenciadas das produzidas até então:

\begin{abstract}
Que significa flanar? Flanar é ser vagabundo e refletir, é ser basbaque e comentar, ter o vírus da observação ligado ao da vadiagem. Flanar é ir por aí, de manhã, de dia, à noite, meter-se nas rodas da populaça, admirar o menino de gaitinha ali à esquina, seguir com os garotos o lutador do Cassino vestido de turco, gozar nas praças os ajuntamentos defronte das lanternas mágicas, conversar com os cantores de modinha das alfurjas da Saúde, depois de Ter ouvido dilettanti de casaca aplaudirem o maior tenor do Lírico numa ópera velha e má; (...)O flâneur é (...) é o eterno "convidado do sereno", de todos os bailes quer saber a história dos boleiros, admirase simplesmente, e conhecendo cada rua, cada beco, cada viela, sabendo-lhe um pedaço da história, como se sabe a história dos amigos(quase sempre mal), acaba com a vaga idéia de que todo o espetáculo da cidade foi feito especialmente para seu gozo próprio. (RIO; ANTELO, 1997, p. 50-52)
\end{abstract}

Longe de ser um espetáculo produzido para a apreciação do flaneur, o "Rio Civilizado" tinha outro público. O prefeito Pereira Passos (1836-1913) dirigia a montagem da nova cena afinado com a proposta modernizadora, que assolava o mundo, e inspirado pelas reformas do barão Haussmann na capital francesa. Ele havia sido escolhido pelo presidente Rodrigues Alves (1848-1919), em 1902, para conduzir o simulacro capaz de despertar o interesse do investimento e do comércio europeu, provando para os estrangeiros que a "cidade pocilga" havia se transformado num "Éden maravilhoso" (EDMUNDO, 1957, p.24). O desaparecimento repentino da antiga cidade trazia um aspecto fortemente teatral (BARRETO, 1956:106). Estreara uma nova peça? Quem seria seu diretor?

Era uma vez ...

Era uma vez, o Rio de Pereira Passos.... Para organizar o palco carioca, o prefeito baseou-se no seguinte pressuposto: progresso, beleza e higiene, afinados com o paradigma europeu, estariam dentro de cena, enquanto, tradições, hábitos e costumes ligados à sociedade colonial deveriam ser expulsos para fora dela. A criação simbólica da cartografia urbana foi estruturada para atender a uma idealização da modernidade:

A cidade real, por onde circulava uma rica tradição popular, não cabia na versão da "ordem", não poderia fazer parte da cena moderna. Era vista como obscena, isto é, deveria estar fora de cena, para não manchar o cenário de cidade civilizada emblematizada pela Avenida Central "(...). A encenação da orgia horripilante" não deveria borrar a cenografia da cidade ideal (...) Teria que ser empurrada para fora desta cena: é coisa obscena! (GOMES, 1996, p. 32-33)

Para implementar as mudanças de ordem econômica, espacial e social na cena da cidade, Pereira Passos contou com o auxílio de alguns ajudantes: o redesenhamento físico do Rio, que incluiu melhorias na área do porto e o "bota abaixo", foi orquestrado pelo Ministro dos Transportes e Obras Públicas, Lauro Müller, que convidou os engenheiros Paulo de Frontin e Francisco Bicalho; a parte sanitária ficou a cargo do médico Oswaldo Cruz, que assumiu a diretoria-geral de Saúde; para mudar os hábitos da população, a prefeitura decretou uma série de leis, dentre elas, a proibição da ordenha de vacas leiteiras nas ruas. Enfim, estava pronto o "palco ilusionista" (GOMES, 1994, p.104) fundamental para a representação dos tempos modernos com todos os seus aparatos. 


\title{
O Personagem Mascarado
}

Afinado com o clima de encenação da cidade, Paulo Barreto também se tornou personagem, colocando máscaras para assinar os textos. Ao longo de sua atividade profissional, ele utilizou doze pseudônimos. Na coluna "A Cidade" (1903-1904) do Jornal A Gazeta de Notícias (18751942), por exemplo, registrou quase que diariamente as incongruências do nascente projeto teatral: enchentes, falta d'água, problemas de transportes e incompetência administrativa. As matérias no periódico eram assinadas com o pseudônimo X.

Já na coluna "Cinematographo" (1907-1910), igualmente publicada em A Gazeta de Notícias, mascarou-se de Joe para fazer uma forte crítica a montagem do teatro de Pereira Passos:

\begin{abstract}
Acabou de mudar-se ontem a praça do mercado. (...) Aquela mudança era, entretanto, maior do que todas, era uma operação da cirurgia urbana, era para modificar inteiramente o Rio de outrora, a mobilização do próprio estômago da cidade para outro local. Que nos resta mais do velho Rio antigo, tão curioso e tão característico? Uma cidade moderna é como todas as cidades modernas. O progresso, a higiene, o confortável nivelam almas, gostos, costumes, a civilização (...). As cidades que não são civilizadas são exóticas, mas quão mais agradáveis. Não há avenidas, há outras cousas e quem vinha ao Rio gozava o interesse de uma cidade diferente das outras e tão curiosa no seu feitio (...). O Rio cidade nova- a única talvez no mundo - cheia de tradições, foi-se delas se despojando com indiferença. De súbito, da noite para o dia, compreendeu que era preciso ser tal qual Buenos Aires, que é o esforço despedaçante de ser Paris, e ruíram casas e estalaram igrejas e desapareceram ruas e até o mar se pôs barreira. (...) (RIO, 1909, p. 213-215)
\end{abstract}

É também no contexto das reformas urbanas, que transformaram a cidade portuguesa nos trópicos na afrancesada metrópole, que o jornalista assume a missão de representar a si mesmo enquanto representa a cidade. Abandonando de vez o nome civil, nasce João do Rio em 04 de janeiro de 1904, na página 1 de A Gazeta de Notícias.

Misturando reportagem e crônica literária, João do Rio foi o cognome que apareceu assinado embaixo das reportagens, que Ihe fizeram a fama e dinamizaram o jornalismo da época. A criatividade não estava só no estilo de texto, mas também na ida às ruas da "cidade velha" para procurar histórias (PASTURA, 1999:79).

Apesar desse interesse pelos feitos populares, João do Rio não se opôs à peça de Pereira Passos. Chegou a andar pelos espaços da Frívola-City escrevendo sobre a opulência dos salões e ambientes chiques da refinada cidade. Assim, em seus passeios, mostrou não apenas a cena, mas também a obscena da cidade partida.

Abrem-se as Cortinas ...

Com a abertura das cortinas, melhor dizendo, dos textos escritos por João do Rio, saltaram ao palco personagens não convidados para participar da encenação do Rio moderno. Trajando figurinos diferentes dos escolhidos por Pereira Passos, os tipos humanos indesejáveis tornaram-se, surpreendentemente, protagonistas da cidade. Como afirma Arthur Xexéo, no documentário João do Rio e a alma encantadora das ruas (2001), da diretora Kika Lopes:

\footnotetext{
"A originalidade de João do Rio se encontra no material que ele encontrou na rua. Ele trouxe um tipo de personagem que não frequentava a imprensa da época. Colocou nas páginas dos jornais, o outro lado da cidade partida: os macumbeiros, os ciganos, amoladores de faca, os camelôs, enfim o pessoal que andava nas ruas de madrugada nos lugares mais esquisitos." (AUTOR,ANO)
}

Ao longo da leitura de seus textos percebe-se que embora o simulacro francês estivesse montado, João do Rio compõe um quadro oposto àquele apresentado pelos agentes da modernização. Seguindo indícios, ele chegou ao palco obscuro, onde se desenrolava o teatro 
das sombras. Uma destas atuações não oficiais foi flagrada pelo flaneur em visita ao Morro de Santo Antônio. A favela abrigava barracos, que se tornaram uma das alternativas de moradia para os excluídos dos antigos cortiços:

“(...) O morro era como outro qualquer morro. Vi então que eles se metiam por uma espécie de corredor, encoberto pela erva alta e por algum arvoredo. Acompanheios, e dei num outro mundo. A iluminação desaparecera. (...) O caminho, que serpeava descendo, era ora estreito, ora largo, mas cheio de depressões e de buracos. De um lado e de outro casinhas estreitas, feitas de tábuas de caixão com cercados, indicando quintais. (...) Como se criou ali aquela curiosa vila de miséria indolente? O certo é que hoje há, talvez, mais de quinhentas casas e cerca de mil e quinhentas pessoas abrigadas lá em cima."(RIO, RODRIGUES (org),1981, p. 46-51)

E o que dizer dos atores cujo enredo se passava na prisão? João do Rio também esteve numa penitenciária, que comportava 450 detentos, dos quais 395 eram homens e 59 mulheres. 0 jornalista descreveu sua percepção após conversar com gatunos, desordeiros, incendiários, defloradores, mulheres perdidas, vítimas da sorte e criminosos por amor:

O criminoso é um homem como outro qualquer. No primeiro momento, sob o pavor dos grandes muros de pedra, com um guarda que nos mostra os indivíduos como se mostrasse as feras de um domador, a impressão é esmagadora. (...). Quando a gente se habitua a vê-los e a falar-lhes todo o dia, o terror desaparece. Há sempre dois homens em cada detento - o que cometeu o crime e o atual, o preso. Os atuais são perfeitamente humanos. (...). Conversam, contam fatos e pilhéria, arranjam o pretexto de ir lavar a roupa para apanhar um pouco de sol no lavadouro, são homens capazes até de sentimento amáveis. (RIO; ANTELO (org),1997, p. 345-346)

Outra constatação da atuação da "Pequena África" diz respeito às profissões informais, ignoradas ou exóticas que passaram a ser exercidas pelos que foram expulsos da cena. Frente aos populares, até mesmo algumas iniciativas da campanha profilática de Oswaldo Cruz representaram um meio de ganhar dinheiro. Depois que o sanitarista declarou guerra aos ratos, responsáveis pela transmissão da peste bubônica, eles não tiveram mais sossego. Com a mesma velocidade em que surgiram, os caçadores de ratos se espalharam pela cidade. $\mathrm{A}$ prefeitura dava uma recompensa por cada bicho apreendido:

A mais nova, porém, dessas profissões, que saltam dos ralos, dos buracos, do cisco da grande cidade, é a dos ratoeiros, o agente de ratos, o entreposto entre as ratoeiras das estalagens e a diretoria de Saúde. Ratoeiro não é um cavador, é um negociante. Passeia pela Gamboa, pelas estalagens da Cidade Nova, pelos cortiços e bibocas da parte velha da urbs, vai até o subúrbio, tocando uma cornetinha com a lata na mão. (...) Das rótulas há quem os chame; à porta das estalagens afluem mulheres e crianças. - Ó ratoeiro, aqui tem dez ratos! - Quanto quer? - Meia pataca. (...). (RIO, ANTELO (org), 1997, p. 94-96)

Além de trabalhar, os atores da obscena também jogavam. Apesar de o governo ter elaborado manuais de bom comportamento, que instruíam as pessoas a procurar atividades edificantes nos momentos livres, afastando-se do vício e do jogo, nem sempre isto acontecia. É assim que João do Rio descreve o lazer daqueles que se entretinham longe dos atrativos legalmente oferecidos pela França carioca. De trem, o jornalista foi a uma rinha de galo que acontecia próxima à estação de Sampaio.

Logo à entrada, impressionou-me a multidão. Eram todos homens, homens endomingados, de cara tostada de sol, homens em mangas de camisas, apesar da temperatura quase outonal (...). Atrevo-me a perguntar a um cidadão: - Quem é aquele? - É o Porto Carreiro, o diretor e o juiz. - E a balança? (...) - A balança é para pesar os galos (...). la começar uma briga. - Vou todo no Nilo, berrava um sujeito No Frei Satanaz, no Frei Satanaz! Bradavam lá longe, faço jogo no Frei Satanaz! contra qualquer outro (...). (RIO, 1909, p.103-111) 
Os personagens da "Pequena África" continuavam sua performance também nas principais vias da cidade. Em dias de carnaval o baile do povo acontecia nas ruas do próprio Centro. A folia ficava por conta dos cordões, precursores das escolas de samba, que desfilavam exibindo fantasias e estandartes. Era comum adotar títulos que indicassem a inserção na cidade ou na festa, recorrendo ao humor para caracterizar sua própria origem de classe. "Grêmio Carnavalesco Destemidos do Inferno", "Esfolados e inimigos do trabalho", "Filhos do Relâmpago do Mundo Novo", "Estrela de Vila Isabel" são os nomes de alguns dos grupos registrados pelo olhar do cronista:

(...) Serpentinas riscavam o ar; homens passavam empapados d'água, cheios de confetti; mulheres de chapéu de papel curvavam as nucas à estila do lançaperfumes(...). Ladeando o bolo, homens em tamancos ou de pés nus iam por ali, tropeçando, erguendo archotes, carregando serpentes vivas sem os dentes, lagartos enfeitados, jabutis aterradores com grandes gritos roufenhos (...). Achas tu que haveria Carnaval se não houvesse os cordões? (...). Os cordões são os núcleos irredutíveis da folia carioca, brotam como um fulgor mais vivo e são antes de tudo bem do povo, bem da terra, bem da alma encantadora e bárbara do Rio. (...). (RIO; ANTELO (org), 1997, p. 225-242)

\section{Considerações Finais}

Por mais que a França carioca tenha se empenhado para garantir exclusividade de representação no palco da cidade, o espaço ainda era invadido por silhuetas do teatro marginal. Quebrando a unidade do moderno projeto teatral de Pereira Passos, elementos, personagens e cenários da obscena saltavam do fundo do palco para a boca de cena.

O diretor que orientou esse jogo invertido tornou-se personagem e tem nome de cidade. João do Rio é um dos muitos pseudônimos que Paulo Barreto mascarou-se para assinar suas reportagens e crônicas. Adequando-se ao clima de encenação que dominava a capital federal no início do século XX, ele virou "pseudo-Paulo" enquanto a cidade tornava-se "pseudo-Rio". Depois de flanar pelos luxuosos espaços da "Europa possível", ele partiu para novos e ousados passeios. Através dos seus textos trouxe para o palco visível representações, até então, restritas ao anonimato das ruas. Favelados, apostadores de rinha de galo, foliões populares, caçadores de rato, detentos.... Enfim, protagonistas bem distintos dos selecionados para atuar no simulacro patrocinado pela República.

Ao escrever criativamente sobre costumes, cotidiano, estratégias, tradições e concepções desse elenco popular, o cronista dá visibilidade ao espetáculo da "Pequena África", ao mesmo tempo em que inova o jornalismo da época. Através dos textos de João do Rio, espaços e personagens que a peça moderna pretendia excluir do imaginário urbano foram imortalizados nas páginas dos jornais. Era a obscena em cena denunciando as incoerências do script de Pereira Passos como em um teatro de sombras.

Referências bibliográficas

BARRETO, Lima. Os Bruzundangas in Obras de Lima Barreto. São Paulo: Brasiliense, 1956.

EDMUNDO, Luiz. O Rio de Janeiro do meu tempo. Rio de Janeiro: Conquista, 1957.

GOMES, Renato Cordeiro. João do Rio: vielas do vício, ruas da graça. Rio de Janeiro: Relume- Dumará: RioArte, 1996.

Todas as cidades a cidade: literatura e experiência urbana. Rio de Janeiro: Rocco, 1994.

HERSCHMANN, Micael; LENNER, Kátia. Lance de sorte: o futebol e o jogo do bicho na belle époque carioca. Rio de Janeiro: Diadorin ed., 1993. 
PASTURA, Angela F. Perricone. Imagens de Paris nos Trópicos. Rio de Janeiro: Papel virtual editora, 1999.

RIO, João; ANTELO, Raúl(org). A alma encantadora das ruas. São Paulo: Companhia das Letras, 1997.

Cinematógrapho: crônicas cariocas. Porto: Lello \& Irmão, 1909.

RODRIGUES, João Carlos (org.) Histórias da gente alegre: contos, crônicas e reportagens da belle époque carioca. Rio de Janeiro: J. Olympio, 1981

RODRIGUES, João Carlos. João do Rio: uma biografia. Rio de Janeiro: Topbooks, 1996.

João do Rio: Catálogo bibliográfico. Rio de Janeiro: Secretaria Municipal de Cultura, Departamento Geral de Doc. e Inf. Cultural, Divisão de Editoração, 1994.

SILVA, Francisco de Assis. História do Brasil: colônia, império, república. São Paulo: Moderna, 1992.

VELLOSO, Mônica Pimenta. As tias baianas tomam conta do pedaço: espaço e identidade cultural no Rio de Janeiro. In: Estudos históricos 6: cultura e povo. Rio de Janeiro: editora FGV, 1990.

Videografia

LOPES, Kika. João do Rio e a alma encantadora das ruas. Malagueta produções artísticas, GNT/Globosat, 2001. 


\section{O OLHAR DO VISITANTE: O CASO DO MUSEU ESPAÇO MEMORIAL CARLOS CHAGAS FILHO}

Gabriella da Silva Mendes - Graduanda em História/UFRJ e Pesquisadora do Espaço Memorial Carlos Chagas Filho - UFRJ/IBCCF/EMCCF - gabiufrj1@gmail.com

Thaís Patrícia Mancílio - Historiadora pela UFF e Pesquisadora do Espaço Memorial Carlos Chagas Filho UFRJ/IBCCF/EMCCF - thaispat@yahoo.com.br

Pedro Henrique Boninni - Graduando em Geografia pela UFRJ e Pesquisador do Espaço Memorial Carlos Chagas Filho - UFRJ/IBCCF/EMCCF - pedrohenriquebonini@gmail.com

Humberto Martins de Souza - Graduando em Biologia pela UFRJ e Pesquisador do Espaço Memorial Carlos Chagas Filho - UFRJ/IBCCF/EMCCF - betosouza9@hotmail.com

Érika Negreiros - Pós-Doutorado em Ciências Morfológicas (ICB/UFRJ); Coordenação do Espaço Memorial Carlos Chagas Filho UFRJ/IBCCF/EMCCF - erikanegres@yahoo.com.br

\section{Resumo}

O Espaço Memorial Carlos Chagas Filho (EMCCF) é um Museu de História da Ciência que tem se consolidado cada vez mais desde sua criação em 2000. Atualmente recebe visitas guiadas para a exposição "A História da Ciência no Brasil: o capítulo do Instituto de Biofísica Carlos Chagas Filho". Espaços desse tipo são fundamentais para a manutenção da memória e para a extensão universitária, por isso é importante que se criem parâmetros avaliativos para perceber o impacto sobre os diferentes públicos que o frequentam, compreender seus interesses e expectativas, produzir conhecimento e se remodelar de acordo com as demandas sociais percebidas. Esperamos compreender suas expectativas para determinar o quão realizáveis são as nossas e o que devemos mudar para torna-las mais possíveis.

Palavras-chave: Museu. Divulgação Científica. Extensão.

Introdução e Contextualização

Museus e Centros de Ciências, em função da diversidade de estímulos oferecidos por suas exposições temáticas, podem ser considerados contextos privilegiados para a construção de diálogos compartilhados entre variados grupos (BONATTO et al, 2007). A bibliografia recente aponta que para a construção deste diálogo torna-se necessária a individualização do visitante, distanciando-se de um mero observador passivo e transformando-se em um ser questionador. Somente através deste processo, o visitante se torna construtor de seu próprio conhecimento e, para tanto, é muito importante o seu acompanhamento por parte de um representante institucional habilitado para auxiliá-lo nesta descoberta (MORA, 2007).

Visando esta relação indissociável entre uma aprendizagem significativa e a mediação humana em Museus e Centros de Ciências é possível observar, ao longo das últimas décadas, um aumento de investigações que abordam este tema. Estes estudos, ora relacionam-se à importância deste elemento na aproximação do público e dos aparatos tecnológicos, ora se debruçam sobre as intempéries da mediação em si, passando pela necessidade da reflexão das práticas e dos saberes específicos da mediação no contexto da educação não formal (QUEIROZ et al, 2002).

Neste contexto, este trabalho apresenta o processo de construção da identidade da mediação no contexto do Espaço Memorial Carlos Chagas Filho (EMCCF), como forma de constituir este espaço para preservação da memória de parte da História da Ciência e Divulgação Científica Brasileira.

O EMCCF é um museu de História da Ciência do Instituto de Biofísica Carlos Chagas Filho (IBCCF) da UFRJ, que conta com um escritório musealizado do Professor Carlos Chagas Filho 
além de exposições sobre temas científicos e uma reserva técnica com uma volumosa coleção de equipamentos científicos e livros. Foi fundado no ano 2000 com o objetivo principal de pesquisar, preservar e divulgar a memória do IBCCF, assim como a dos cientistas que a ele deram importantes contribuições.

O EMCCF é um museu de História da Ciência porque se preocupa com a memória e preservação de seu acervo histórico e científico, e ao mesmo tempo é um museu de Ciências pois realiza atividades interativas e de experimentação com temas de Ciências que são desenvolvidas no IBCCF. Antigamente os museus de Ciências eram espaços que passavam conhecimento para o público leigo contemplar o sucesso da ciência. Atualmente são considerados espaços que pensam em formas de aumentar a interatividade e que começam a entender que é preciso engajar o público, torná-lo protagonista do funcionamento do museu, instigá-lo a participar de debates, catalisar formas de apropriação concreta e crítica da ciência e tecnologia. Muitas pesquisas tem mostrado que o cidadão que entra no museu vai interpretando, conectando e dando sentido às mensagens com base também em seus valores morais e sai com mais questionamentos, mais dúvidas, com mais interesse do que entrou, não necessariamente com mais conhecimento. E é exatamente essa realidade que o EMCCF procura vivenciar com os visitantes que recebem e tem como importante questão seu papel em relação à divulgação científica e extensão, cujo exercício é muito mais do que a transferência de conhecimento da Ciência para o público leigo, visa democratizar o conhecimento, pois envolve diálogo e comunicação, interação entre ciência e sociedade.

\section{A Mediação no EMCCF}

A equipe do EMCCF desenvolveu a exposição "A história da Ciência do Brasil: O capítulo do Instituto de Biofísica Carlos Chagas Filho" que foi inaugurada em dezembro de 2015, em homenagem aos 70 anos do IBCCF. O tema central da exposição foi baseado no livro "Construtores do Instituto de Biofísica Carlos Chagas Filho" lançado em 2013. Este livro é uma homenagem póstuma aos primeiros pesquisadores do IBCCF que, juntamente com Carlos Chagas Filho, estabeleceram e consolidaram as pesquisas científicas desenvolvidas no Instituto. O grande objetivo deste projeto de exposição foi preservar a memória do IBCCF e popularizar o trabalho e a ciência de seus primeiros pesquisadores e construtores, promovendo o desenvolvimento e a ampliação da popularização da História da Ciência Brasileira.

Um grande desafio foi desenvolver uma exposição com densidade de conceitos e informações para um público alvo, em sua maioria, alunos da rede pública de ensino. O risco seria estabelecer uma exposição muito distante da realidade dos visitantes, com muita informação história e pouco interativa, o que não teria um impacto positivo e não despertaria interesse. Neste sentido, a exposição foi pensada com base nas áreas da Ciência e não simplesmente em contar a história de cada pesquisador isoladamente.

Ela é composta por módulos temáticos que representam áreas de pesquisas científicas desenvolvidas no IBCCF (Bioquímica, Biologia Molecular, Biologia Celular, Microscopia, Neurobiologia e Radiobiologia) sendo dispostos em ordem e divididos por cores, as quais facilitam a percepção dos visitantes na mudança de temas ao longo do translado. Cada módulo conta a história dos cientistas de forma lúdica e com atividades interativas ou expositivas, mesclando conceitos científicos com elementos de experimentação e arte, de forma a promover comunicação e interação entre os visitantes e os temas abordados.

Em todos os módulos a abordagem usada na mediação sempre pretende suscitar questionamentos sobre os temas de ciências. Nunca as respostas são dadas, pois não existem respostas prontas e certas. O que é desenvolvido é um diálogo com os visitantes para poder 
absorver suas representações sobre os temas e, a partir delas, direcionar desconstruções necessárias juntamente com os visitantes.

Esse projeto da exposição contribuiu enormemente para consolidar o papel do EMCCF como um museu de História da Ciência e Divulgação Científica dentro do IBCCF, onde pesquisa e extensão ocorrem de maneira interligada. Através do Projeto de Extensão "Descobrindo a Biofísica", que visa a integração da universidade e da escola básica, o EMCCF tem recebido alunos de diferentes escolas de ensino médio e fundamental que, além de conhecerem este espaço, visitam diferentes laboratórios do IBCCF, o que proporciona contato com o meio científico acadêmico. Desde 2008 até o ano de 2015, o EMCCF recebeu cerca de 3000 visitantes. Com a inauguração da exposição interativa, as visitações à exposição acontecem semanalmente e tanto escolas públicas quanto escolas privadas são convidadas a participar, sendo que para escolas públicas, são disponibilizados ônibus, em parceria com a UFRJ. Só no ano de 2016 foram recebidos mais que 1.600 visitantes, um número bastante expressivo e maior que as visitações dos anos anteriores.

\section{Avaliação da Exposição}

A visitação permite que os estudantes também conheçam diferentes laboratórios do IBCCF onde são realizadas práticas adaptadas para o nível de formação dos estudantes, que entram em contato com pesquisadores, alunos de graduação e pós-graduação além de conhecer a história do IBCCF e de seu fundador Carlos Chagas Filho, bem como a de outros cientistas que estão inseridos na História da Ciência no Brasil.

Como a exposição interativa precisa de mediadores, este projeto teve uma proposta de mediação com formação prévia sobre o tema da exposição e todos os instrumentos de interação. A capacitação foi baseada em uma apresentação geral do assunto, discussões sobre o tema para aguçar as argumentações e em atividades práticas que são trabalhadas durante a exposição. A mediação seguiu um roteiro que foi desenvolvido em conjunto com os mediadores que compõem a equipe multidisciplinar do EMCCF, alunos de diversos cursos de graduação da UFRJ. Há também uma importante contribuição para a formação de professores de educação básica, através de oficinas nas áreas de ciências contempladas na exposição. Os professores participaram de atividades interativas durante a visitação e receberam revistas de Divulgação Científica ("Sim, nós temos cientistas" e "Doro, a mosquinha Nobel") como ferramentas paradidáticas para serem trabalhadas em sala de aula.

É importante entender este público e suas interferências para a eficácia da divulgação e por isso torna-se fundamental entender e avaliar a eficácia da exposição através de pesquisas que visam analisar as audiências e suas percepções sobre Ciência. Por isso, estão sendo realizadas pesquisas de cunho explicativo apoiadas em uma abordagem qualitativa sobre as atividades e atitudes dos visitantes diante dos temas abordados na exposição. Os instrumentos de coleta de dados são questionários e entrevistas gravadas a partir de grupos focais. Este tipo de pesquisa, além de revelar a percepção do público, também pode dimensionar resultados da exposição e avaliar sua pertinência e eficácia.

A Avaliação inicial foi feita a partir de 178 questionários de estudantes de escolas públicas (90\%) e particulares (10\%), através da aplicação de questionários com perguntas abertas após as visitações ao EMCCF. Este tipo de pesquisa, além de revelar a percepção do público, também pode dimensionar resultados da exposição e avaliar sua pertinência e eficácia. Em uma análise preliminar, foi observado que a maioria dos alunos investigados não frequenta museus, no entanto, aqueles que o fazem, são geralmente levados pelas instituições de ensino. Este fato evidencia a importância do Projeto "Descobrindo a Biofísica", que permite aos alunos terem contato com museus e centros de ciência. Cerca de $75 \%$ dos alunos classificam o objeto da exposição como sendo: áreas da ciência, Carlos Chagas Filho, ciência 
e história. As respostas estão de acordo com os reais objetos da exposição, a não ser pelas respostas que a associam à figura de Carlos Chagas Filho (confusão compreensível em vista do fato de o início da visita acontecer no escritório de CCF). Os alunos indicam em suas considerações que as intervenções práticas tornam as visitas mais interessantes. Em análise paralela é possível traçar uma relação entre o interesse na exposição de ciências (com atividades práticas) e o desinteresse nas aulas de ciências (meramente expositivas), reflexo da falta de infraestrutura de muitas escolas visitantes. A maioria dos alunos afirmou que voltaria ao EMCCF ou a outro museu, o que confirma que a experiência foi marcante e agradável.

O próximo passo é aumentar o quantitativo de questionários e realizar grupos focais nas escolas que visitaram o museu e a exposição. Este tipo de técnica permite a interação entre os participantes do grupo sobre um tema determinado pelo pesquisador. Geralmente, os próprios participantes levantam questões que não haviam sido inicialmente previstas pelos pesquisadores, enriquecendo, portanto, o estudo. Sendo assim, os grupos focais são de grande valor para examinar como as diferentes percepções se relacionam com o contexto sócio-cultural.

\section{Considerações Finais}

Como resultado, este projeto leva para a sociedade a Ciência de forma acessível e mostra a importância da mesma para seu desenvolvimento, bem como conhecer a história do IBCCF e de seu fundador Carlos Chagas Filho e de outros cientistas que estão inseridos na história da Ciência no Brasil.

Como perspectivas futuras, será dada continuidade às visitações semanais à exposição "História da Ciência no Brasil: o capítulo do Instituto de Biofísica Carlos Chagas Filho", onde haverá a capacitação de mediadores e o exercício da mediação e todas as pesquisas que envolvem avaliação do público e da exposição.

Parte da exposição será desenvolvida em formato itinerante o que permitirá estabelecer uma articulação com outros espaços científico-culturais e de educação formal, que poderão receber essa exposição. Esse projeto já foi iniciado com oficinas interativas de demonstração de equipamentos científicos e históricos.

Outro plano é desenvolver material didático de apoio à professores dos ensinos fundamental e médio, abordando temas científicos apresentados na exposição. A formação de professores será através de oficinas com temas de Ciências e História da Ciência além da aplicação de revistas científicas em quadrinhos, como apoio paradidático.

Pretende-se também criar aplicativo para dispositivos móveis, onde o visitante terá disponíveis as informações sobre os objetos expostos, além de vídeos e textos sobre a exposição. Devido a importância da inclusão e acessibilidade em museus, espera-se gerar material impresso em Braille contando a historia da exposição e promovendo a divulgação do saber científico construído no país para deficientes visuais. A proposta prevê a aquisição de instrumentos tocadores de $\mathrm{mp} 3$, como iPods, onde visitas guiadas serão gravadas e disponibilizadas para esse público.

Em relação à extensão, haverá a continuação do projeto "Descobrindo a Biofísica" e esperamos promover atividades de divulgação da exposição e atrair o público do entorno da Ilha do Fundão, a fim de proporcionar atividades interativas de temas relativos à ciência e a saúde para populações de baixa renda que vivam nessa região.

Referências bibliográficas 
BARROS, Ana Bárbara, De Corpo e Alma: Narrativas dos Profissionais de Educação em Museus da Cidade do Porto. Dissertação de Mestrado do Curso Integrado de Estudos Pós-graduados em Museologia apresentada à Faculdade de Letras da Universidade do Porto, 2008.

BONATTO, M. P. O.; SEIBEL, M. I; MENDES, I. A. Ação mediada em museus de Ciências: o caso do Museu da Vida. In: MASSARANI, L. (Org). Diálogos \& Ciência: mediação em museus e centros de Ciência. Rio de Janeiro: Casa de Oswaldo Cruz/Fiocruz, 2007, p. 48-55.

MORA, M. C. S. Diversos enfoques sobre as visitas guiadas nos museus de ciência. In: MASSARANI, Luisa; MERZAGORA, Matteo; RODARI, Paola (orgs.). Diálogos \& ciência: mediação em museus e centros de Ciência. Rio de Janeiro: Museu da Vida/Casa de Oswaldo Cruz/Fiocruz, 2007, p. 21- 26. Disponível em: <http://www.museudavida.fiocruz.br/media/Mediacao_final.pdf> Acesso em: 10 Jan. 2015

MORAES, Roque; BERTOLETTI, Jeter Jorge; ANA, C. R. B.; ALMEIDA, Lucas Sgorla de. Mediação em museus e centros de ciências: o caso do Museu de Ciências e Tecnologia da PUCRS. In: Luisa Massarani, Matteo Merzagora e Paola Rodari. (Org.). Diálogos \& Ciência - Mediação em museus e centros de ciência. Rio de Janeiro, 2007, v. , p. 55-66.

QUEIROZ, G.; Krapas, S.; VALENTE, Maria Esther; DAVID, Erika; DAMAS, Eduardo; FREIRE, Fernando. Construindo Saberes da Mediação na Educação em Museus de Ciências: O Caso dos Mediadores do Museu de Astronomia e Ciências Afins/Brasil. Revista Brasileira de Pesquisa em Educação em Ciências, Porto Alegre, v. 2, n.2, p. 77-88, 2002. 


\title{
A CONSTRUÇÃO DO CONHECIMENTO MATEMÁTICO POR MEIO DO TEATRO - DESENVOLVIMENTO DO CLUBE DE HISTÓRIA DA MATEMÁTICA NO CMRJ
}

\author{
Daniele da Silva Motta - Aluna de Licenciatura em Matemática do IME/UERJ - daniele motta91@hotmail.com \\ Cláudia Concordido - Professora Associada do IME/UERJ, IBMEC, -concordido@ime.uerj.br \\ Jeanne Barros - Professora Associada do IME/UERJ, Projeto Fundão IM/UFRJ - jeanne@ime.uerj.br \\ Maurício Mendes - Professor do Colégio Militar do Rio de Janeiro, mauricio.mendes@uol.com.br
}

Resumo

A utilização da História da Matemática no ensino básico do Colégio Militar do Rio de Janeiro (CMRJ) através de manifestações artísticas, fazendo uso do teatro, em 2014, trouxe para os alunos envolvidos a percepção da Matemática como uma ciência contextualizada. A experiência foi tema de dissertação de mestrado profissional no IME/UERJ, culminando na fundação do Clube de História da Matemática no CMRJ. No Clube de História da Matemática as atividades são desenvolvidas atraindo alunos afeitos tanto às ciências humanas e sociais como às ciências exatas. Este trabalho apresenta as atividades deste ano, cujo tema é Pitágoras, com alunos do nono ano do Ensino Fundamental.

Palavras-chave: História da Matemática. Pitágoras. Teatro.

Introdução

A necessidade de atrair o interesse dos alunos para o ensino da Matemática não é nova. Nas séries iniciais é comum que os professores se preocupem em desenvolver atividades envolvendo jogos e brincadeiras que buscam estimulam os alunos para a Matemática. No entanto, no segundo segmento do Ensino Fundamental e no Ensino Médio, a Matemática fica na maior parte das vezes isolada do contexto social. Os fatos históricos aparecem como apêndices nos livros didáticos (quando aparecem) e são pouco atrativos, passam praticamente despercebidos. Isso acaba por afastar alunos desta ciência que, independentemente dos conteúdos nela desenvolvidos, agrega também competências e habilidades importantes para o ser social, tais como: raciocínio lógico, capacidade de concentração, poder de síntese. Isso sem considerar conteúdos comuns e úteis a todos da sociedade, como, por exemplo, porcentagem, juros, operações básicas, perímetro, área, dentre outros.

A História da Matemática pode ser o fio condutor-motivador para o ensino da Matemática como uma ciência temporal, humana e sujeita a interferências políticas e sociais. Com esse enfoque, o ensino dessa disciplina associado à história e às artes cênicas contribui para que o alunato veja com outro olhar as ciências exatas, desenvolvendo a criticidade, aumentando a sensibilidade e o senso de solidariedade.

Ao se criar o Clube de História da Matemática pretendeu-se aproveitar o envolvimento dos alunos no que concerne a apresentações teatrais para atrair o interesse em Matemática daqueles mais simpáticos às ciências sociais e humanas e, também, mostrar aos pequenos matemáticos que a Matemática não nasceu na Academia, é uma obra humana, muitas vezes fruto da necessidade e ferramenta para solução de problemas cotidianos.

Referencial Teórico

HCTE-UFRJ 
Entender a Matemática como uma ciência exata, porém contextualizada na história, é fundamental. Segundo D’Ambrosio (2012),

"[...] grupos humanos desenvolvem, ao longo da história de sua evolução cultural e de acordo com suas características culturais (etno) distintas técnicas (ticas, do grego techné, que é também raiz de arte). Dentre as inúmeras técnicas criadas, a matemática é apenas uma delas, desenvolvida a partir das culturas ao redor do Mediterrâneo." (D'AMBROSIO, 2012, p. 119)

O estudo de História da Matemática, além de fazer com que alunos busquem os fatos históricos que motivaram o desenvolvimento científico de determinado modelo matemático, vem esclarecer que na busca científica o conhecimento não vem pronto. Lorenzato (2008) considera que

Outro modo de melhorar as aulas de matemática tornando-as mais compreensíveis aos alunos é utilizar a própria história da matemática; esta mostra que a matemática surgiu aos poucos, com aproximações, ensaios e erros, não de forma adivinhatória, nem completa ou inteira. Quase todo pensamento matemático se deu por necessidade do homem, diante do contexto da época. (LORENZATO, 2008, p.107)

Por sua vez, o teatro tem o potencial de desenvolver nos alunos habilidades normalmente esquecidas nas aulas tradicionais, como sensibilidade, afeto, desinibição, comunicação (nas suas diversas formas: corporal, gestual, visual, auditiva). Por outro lado, obriga os envolvidos a pesquisar sobre aquilo que desejam manifestar. Além disso, seja na montagem ou na realização da própria peça teatral, todos precisam também abstrair, viver uma realidade que na maioria das vezes não é a sua.

Podemos dizer que o Teatro materializa ou mesmo concretiza os temas considerados abstratos na Matemática. E ainda apresenta uma vantagem superior ao do uso dos materiais didáticos, pois possibilita o contexto que vivifica o problema e dá forma aos dados, informações, conceitos, ideias ou conteúdos. (POLIGICCHIO, 2011, p. 82)

No Clube, fatos do cotidiano também podem ser explorados e representados pelos alunos. Mesmo histórias como as contadas por Malba Tahan em "O Homem que Calculava" podem ser representadas, o que certamente é um atrativo a mais. Portanto, sem o risco de ficar restrito a incentivos que se caracterizam, apenas, pela busca da Matemática ligada ao cotidiano. Giardinetto confirma a importância desses fatos na aprendizagem:

O cotidiano como o não cotidiano são produtos histórico-sociais. É preciso, pois, que o cotidiano e o não cotidiano sejam entendidos como esferas onde se dá o processo de apropriação e elaboração do conhecimento não como 'essencialidades' que antepõem a existência humana. Essas esferas são essenciais para a vida humana da sociedade altamente complexificada que se tem hoje. É preciso, porém, compreender que essas esferas foram surgindo dentro do processo de divisão social do trabalho, e como tal, refletem o processo de alienação decorrente dessa divisão social do trabalho. (GIARDINETTO, 1999, p. 122-123)

Ademais, todo esse processo envolve a pesquisa tanto de fatos históricos ligados a Matemática como também de tópicos desta ciência, o que se mostra uma ótima oportunidade de trabalho interdisciplinar.

Dessa forma, o Clube, ao mesmo tempo que incentiva a busca de novos conhecimentos, tem a função de formar criticamente o discente, apoiando-se para isso na história e nas manifestações artísticas.

O Surgimento do Clube de História da Matemática no CMRJ

O Clube foi oficialmente fundado em 2014, como produto gerado pelo mestrado profissional (PROFMAT) do professor Maurício Mendes. Nesse primeiro ano, dez alunos do $9^{\circ}$ ano do 
Ensino Fundamental do CMRJ se interessaram em participar do projeto e foram os voluntários fundadores do Clube.

O tema desenvolvido e encenado pelo grupo de alunos foi o imbróglio entre Cardano e Tartaglia. No século XVI, os dois matemáticos se envolveram em disputa pela autoria de uma fórmula para resolver equações polinomiais do 30 grau. Cardano a teria publicado em sua obra "Ars Magna" sem dar o devido crédito a Tartaglia, que alegava ter sido o primeiro a deduzir a fórmula (ROQUE, 2012, p. 270).

O grupo se encontrava semanalmente em sala de aula no contra turno e, sob supervisão do professor Maurício, pesquisou, escreveu o roteiro, desenvolveu figurino, preparou cenário e, ao final do ano, encenou a peça para um público formado por alunos e professores do $9^{\circ}$ ano (Figura 1).

Os alunos vivenciaram uma história em que os personagens, intelectuais de sua época e importantes matemáticos e desenvolvedores da ciência, são pessoas com defeitos e virtudes, passíveis de falhas de caráter e que tiveram que lidar com frustrações. Além da questão de direitos autorais, outras questões morais puderam ser trabalhadas.

\section{Figu \\ ra 1 \\ - $\mathrm{O}$ \\ dia \\ da \\ apr \\ ese \\ ntaç \\ ão}

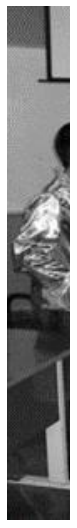

Fon

te:

Os

aut

ores

201

4.

Clube de História da Matemática em 2016: A Parceria UERJ/CMRJ

Em 2016 se iniciou um projeto de extensão do Instituto de Matemática e Estatística da Universidade do Estado do Rio de Janeiro, que visava dar continuidade ao Clube, agora também com o envolvimento de uma aluna de Licenciatura em Matemática bolsista da 
universidade. O principal objetivo desse projeto no que diz respeito à licencianda é promover sua iniciação em atividades lúdicas como metodologia para o ensino de Matemática na sua futura prática docente.

Dessa vez, como formar de deixar registrada o início da parceria, foi escolhido como tema da peça a "História do Número Zero". Para o desenvolvimento do projeto ocorreram reuniões semanais de duas horas em classe, voltadas para formação do grupo, pesquisa do tema, elaboração do roteiro da peça, ensaios e preparação dos cenários e figurinos (com pesquisa histórica em apoio). Uma das principais fontes de estudo foi Kaplan (2001).

As reuniões contavam com a participação de 16 alunos voluntários do 90 ano do Ensino Fundamental, coordenados pela licencianda da UERJ e também sob a supervisão do professor do CMRJ. Além das atividades de preparação para a encenação da peça os alunos, os alunos também fizeram testes com questões envolvendo fazer contas sem o algarismo zero, para mostrar a importância do tema.

Ao final do ano, foi encenada a peça de aproximadamente 25 minutos num dos auditórios para alunos e professores do 90 ano. Os alunos resolveram fazer um cartaz de anúncio da peça, o que atraiu um público grande (Figura 2). A peça foi encenada por quatro vezes, pois a capacidade do auditório não comportava a quantidade de alunos. 


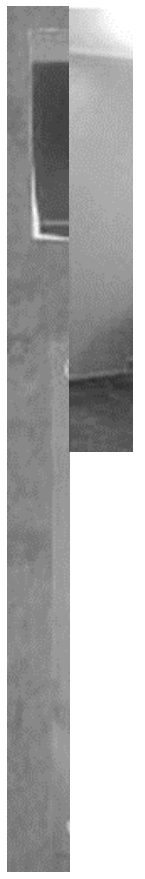

(A) (B)

Fonte: Os autores, 2016

Clube de História da Matemática em 2017: Pitágoras

Esse ano trinta e quatro alunos voluntários participam do Clube. Foram apresentados pelos professores três possíveis temas: os números irracionais, a história do número $\pi$ e Pitágoras, tendo sido esse último o tema escolhido pelos alunos.

O grupo se reúne semanalmente às quartas à tarde para discutir a elaboração do roteiro, a divisão de tarefas, a formação do elenco, os ensaios, a montagem do cenário e a criação e confecção do figurino, sob a supervisão do professor do CMRJ e da licencianda da UERJ (Figura $3)$.

Figura 3 - Parte do grupo de alunos em um dos encontros semanais

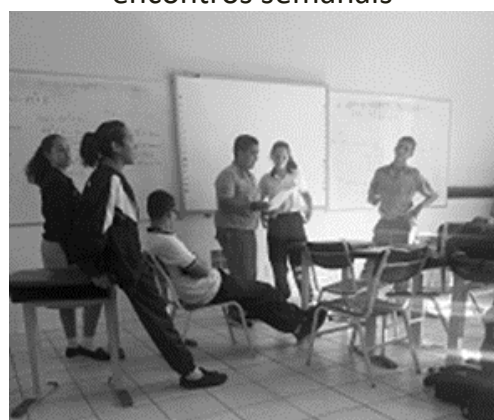

Fonte:

Os

autores,

2017

Além da encenação da peça para seus colegas no espaço do CMRJ ao final do ano, o grupo deve apresentá-la também na UERJ, como parte das atividades da UERJ SEM MUROS. Foi 
criada ainda uma página no Facebook (Coliseu da Matemática) para que os alunos e os professores envolvidos troquem informações, compartilhem os textos que encontraram, publiquem vídeos, etc. Há na página (Figura 4), por exemplo, textos sobre a escrita de roteiros teatrais, artigos sobre os pitagóricos e sua filosofia, vídeos sobre números e notas musicais, dentre outros.

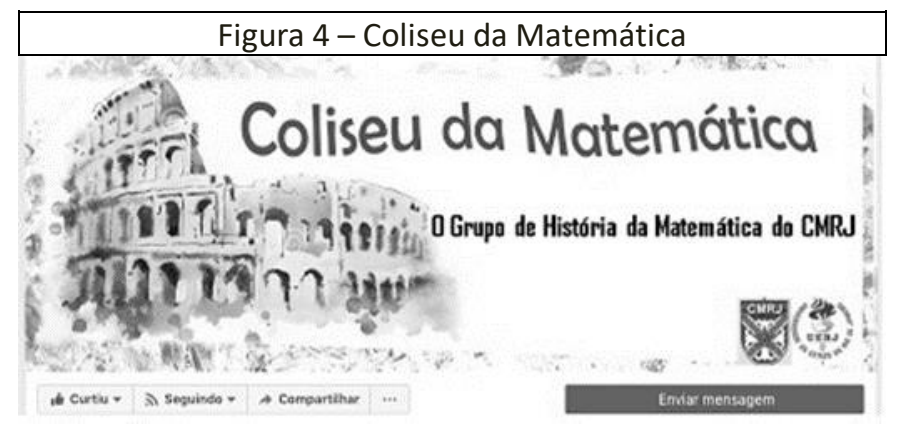
Fon
te:
Os
aut
ores
201
7

\section{Considerações Finais}

O trabalho procura mostrar que uma das ações possíveis para o aluno obter sucesso cognitivamente e desenvolver-se crítica e politicamente é permitir que ele se manifeste artisticamente. Isso por si só estimula a participação e aguça a curiosidade.

No Clube os alunos têm a oportunidade de ver a Matemática associada a um contexto histórico-social. Além disso, ddesenvolver pesquisas de fatos históricos ligados à Matemática é uma excelente oportunidade dos docentes trabalharem interdisciplinarmente, o que atualmente tem sido explorado pelo Exame Nacional do Ensino Médio (ENEM).

Esse tipo de trabalho aproveita ainda o envolvimento dos alunos no que concerne a apresentações teatrais para atrair o interesse tanto daqueles mais simpáticos às ciências sociais e humanas como também daqueles mais ligados às ciências exatas, formando um só grupo. A partir dos fatos vivenciados, ambos potencializam seu interesse pela Matemática, tornando-a mais concreta, ainda que os fatos tratem de assuntos abstratos.

Referências bibliográficas

D’AMBRosio, U. Uma História Concisa da Matemática no Brasil. 2. ed. Petrópolis: Vozes, 2011.

GIARDINETTO, J. R. B. Matemática Escolar e Matemática da Vida Cotidiana. Campinas: Autores Associados, 1999.

KAPLAN, R. O nada que existe - uma história natural do zero. Rio de Janeiro: Rocco, 2001.

LORENZATO, S. Para Aprender Matemática. 2. ed. rev. Campinas: Autores Associados, 2008.

MENDES, M.; CONCORDIDO, C. F. R.; BARROS, J. D. B. Trabalhando a História da Matemática no CMRJ. In: Congresso Scientiarum Historia VIII (In)certezas e (In)completudes. Rio de Janeiro, 2015. 
POLIGICCHIO, A. G. Teatro: materialização da narrativa matemática. 2011. 148 f. Dissertação (Mestrado - Ensino de Ciências e Matemática - USP). São Paulo, 2011.

ROQUE, T. História da matemática: uma visão crítica, desfazendo mitos e lendas. Rio de Janeiro: Zahar, 2012. 


\section{A GUERRA ENTRE HOMENS E MOSQUITOS: O LEGADO DA CAMPANHA DE ERRADICAÇÃO DA MALÁRIA PARA O COMBATE Às EPIDEMIAS DE DENGUE, ZIKA E CHIKUNGUNYA}

Renato da Silva - Professor do Programa de Pós Graduação em Humanidades, Culturas e Artes - UNIGRANRIO redslv333@gmail.com

Resumo

O objetivo do trabalho é analisar o legado da Campanha Nacional de Erradicação da Malária (1958-1965) e suas possíveis contribuições no combate às epidemias de dengue, zika e chikungunya. O conhecimento histórico das estruturas e operações de controle e erradicação da malária pode ser relevante na atual conjuntura onde somos novamente assombrados por doenças que tem como protagonistas os mosquitos. A dengue, a zika e chikungunya encontraram no espaço urbano um ambiente favorável para seu desenvolvimento em parte explicado pela ausência de informações e políticas de prevenção. Neste sentido, o estudo das lições de combate às Anopheles gambiae podemos conhecer métodos para enfrentar o Aedes aegypti.

Palavras-chaves: Mosquito. Epidemias. Malária.

Introdução

É inegável a construção de uma tradição de combate a e de controle da malária criada no país, tendo como marco histórico a erradicação do vetor Anopheles gambiae em 1940. O Serviço Nacional de Malária (SNM) e o Serviço Especial de Saúde Pública (SESP), criados respectivamente em 1941 e 1942, instituíram as ações rotinizadas de controle da malária no Brasil (HOCHMAN ET AL., 2006, p. 44). O combate ao Anopheles gambiae ocorreu na região do Nordeste brasileiro no final da década de 1930. Um dos primeiros passos para a institucionalização do combate à malária no Brasil foi a criação do Serviço de Malária do Nordeste (SMNE) em 1939, possibilitado pelo convênio entre o governo brasileiro e a Fundação Rockefeller. Este acordo aprofundava uma relação iniciada em meados da década de 1910 com a Divisão Sanitária Internacional da Fundação Rockefeller que estava preocupada desde a década de 1920 em combater a febre amarela (GADELHA; PACKARD, 1994).

A Guerra entre Homens e Mosquitos

O mosquito Anopheles gambiae foi identificado primeiramente no território brasileiro pelo entomologista Raymond Shannon do Serviço Nacional de Febre Amarela em 1930 no estado do Rio Grande do Norte. O primeiro surto de malária ocorreu em 1930, em Natal, atingindo dez mil pessoas em uma localidade de 12 mil habitantes. Em 1938, o Nordeste brasileiro sofreu a maior epidemia de malária registrada nos continentes americanos. Os estados do Rio Grande do Norte e Ceará foram os palcos dessa epidemia que deixou uma trágica marca. No primeiro, 5 mil mortes em uma população de 240 mil habitantes. No Vale do Jaguaribe, no Ceará, em julho, 63 mil casos foram registrados, sendo oito mil o número de óbitos. Em algumas localidades, o impacto sobre a população chegou ao surpreendente índice $90 \%$ de fatalidade (BENCHIMOL, 1996, p. 169). 
Em 1942 foi finalmente considerado erradicado o vetor transmissor Anopheles gambiae. Este fato teria marcado a história da malária no país e aberto uma perspectiva de erradicação da doença no mundo via erradicação de um vetor. Esta experiência foi um primeiro passo na constituição de organizações e de um grupo de especialistas no controle da malária no Brasil. O Serviço Nacional de Malária (SNM) foi criado pelo Decreto-lei no 3.171 em 1941, anexando o Serviço de Malária da Baixada Fluminense. Até 1942 o Serviço de Malária do Nordeste manteve-se vinculado à Fundação Rockefeller, sendo depois incorporado ao SNM (GADELHA et. al., 1977).

O diclorodifenil tricloroetano (DDT), inseticida do grupo dos hidrocarbonetos clorados, foi apresentado pelos cientistas como a arma mais eficaz de combate à malária após o término da Segunda Guerra Mundial. A utilização do DDT nos domicílios tornou-se um sucesso imediato em muitos países. No entanto, o inseticida teve maior impacto nos países onde as condições sanitárias eram mais desenvolvidas, isto é, em países ou regiões em que não havia nichos ecológicos alternativos para que os mosquitos pudessem desenvolver a cadeia de transmissão. Em muitas áreas do mundo a malária foi erradicada, e os resultados positivos levaram as autoridades de saúde pública internacional a acreditar que a erradicação da doença era possível (CUETO, 2007).

O ano de 1947 marcou o início da utilização em larga escala do inseticida no Brasil (Hochman, From autonomy to partial alignment...). A primeira grande campanha ocorreu no estado do Rio de Janeiro e incluía 1821 localidades em 30 municípios. A campanha, que cobriu praticamente todos os estados de norte a sul atingindo também a capital federal, serviu de modelo de ação para combater a malária no resto do país, uma ação de saúde inédita na América do Sul. O DDT foi considerado, por muitos especialistas em malária, uma arma revolucionária no combate à doença. Ele reunia qualidades que não haviam sido apresentadas em nenhuma outra droga antimalárica: alta toxidade para os mosquitos da malária, baixa toxidez para o aplicador, ação prolongada com estabilidade química satisfatória e baixo custo (PAULINI, 1962).

O diretor do SNM, Mario Pinotti observou dois fatores distintos, resultados da ação de combate à malária após cinco anos de utilização do DDT. Primeiro, em áreas onde o inseticida foi utilizado em grande escala com rigor, a redução da malária chegou a casos zero, não sendo registrados casos da doença por mais três anos nessas regiões. Segundo fator não concretizado, mas possível de acontecer, seria a resistência que os mosquitos poderiam adquirir com a utilização por longo período dessa arma. Ou seja, durante certo tempo de uso do DDT sem um planejamento eficaz e consciente, o inseticida perderia sua eficácia diante dos vetores. Mario Pinotti foi o responsável pela criação do método de controle da malária em áreas onde a utilização do DDT era inviável. Neste caso, o método incidia na combinação de um antimalárico a um alimento ou condimento de consumo diário. O denominado "Método Pinotti" usava o sal de cozinha misturado à cloroquina, um antimalárico, e foi utilizado amplamente na região amazônica. No início, o método foi pensado para uso como controle, mas foi cogitado ser utilizado também como auxiliar na perspectiva de erradicação da malária. O resultado esperado era o desaparecimento das fontes de infecção na população que utilizasse o sal cloroquinado. A transmissão seria interrompida no período de três a quatro anos, esgotando-se, assim, os parasitas nos portadores (SILVA; HOCHMAN, 2011).

Neste contexto, os principais especialistas em malária da época iniciaram uma campanha para promover a transformação dos programas de controle em programas de erradicação na década de 1950. Os estudos sobre a resistência dos vetores ao DDT seria a pauta central da XIV Conferência Sanitária Pan-Americana em 1954 em Santiago, no Chile, e a VIII Assembléia Mundial de Saúde em 1955, realizada no México. Desses encontros internacionais de saúde resultaram as propostas e as recomendações dirigidas aos países-membros para a conversão 
dos programas de controle em programas de erradicação. $O$ inseticida deveria ser a principal arma dessa empreitada, contudo, a área de malária no mundo seria enorme e em regiões heterogêneas (PACKARD, 1997). No caso do Brasil, essas regiões heterogêneas se apresentariam como um grande obstáculo não somente ao programa de erradicação, como também ao de controle. Os malariologistas brasileiros procuraram um método alternativo para combater a malária em áreas onde a utilização do DDT era impraticável. O sal cloroquinado foi apresentado como método complementar das dedetizações de inseticidas de efeito residual, e deveria ser utilizado principalmente na região amazônica.

A Campanha de Erradicação da Malária em nível global não teve êxito. A malária não foi erradicada no mundo, apenas alguns países obtiveram sucesso. As causas e os motivos que compuseram este "fracasso" não são conhecidos totalmente. Uma das causas possíveis pelo desinteresse pela erradicação por parte dos países mais ricos é que eles resolveram seus problemas relacionados à malária. Essas nações eram as principais financiadoras da campanha mundial (SILVA; PAIVA, 2015).

\section{Antigas lições e novas epidemias}

No Brasil, os mosquitos perderam para homens em grande parte do território nacional, mas continua endêmica na região amazônica, registrando momentos elevados de casos, como no ano de 2000 com mais de 600 mil infectados levando a 245 óbitos. Segundo o Ministério da Saúde em 2011, 99,7\% dos casos de transmissão estão concentrados nos estados do Pará, Amazonas, Rondônia, Acre, Amapá e Roraima. As guerras entre os homens e os mosquitos não terminaram, as transformações biológicas são quase proporcionais aos progressos científicos. As guerras entre os homens e os mosquitos, são na verdade a guerra entre o homem e a natureza.

A primeira referência à dengue no Brasil data o ano de 1846. Na década de 1986, a dengue uma doença reemergente passa a ser considerada epidemiológica, quando ocorre a epidemia no Estado do Rio de Janeiro e rapidamente atinge a Região Nordeste. Neste contexto, a dengue se tornou endêmica no Brasil, com episódios cada vez mais frequentes de epidemias, com aparecimento de novos tipos e variações da doença. Entre os anos de 1986 e 1990, as epidemias de dengue atingiram alguns Estados das Regiões Sudeste (Rio de Janeiro, São Paulo e Minas Gerais) e Nordeste (Pernambuco, Alagoas, Ceará e Bahia). Em 1990, surge um novo sorotipo da doença. A Dengue tipo 2 agrava a situação no Estado do Rio de Janeiro (BRAGA; Vale, 2007). Outros tipos de dengue vão surgindo na passagem do século XX para XXI (Dengue tipo 3- ano 2000; Dengue tipo 4- ano 2010).

Em 2003, foram registrados quase meio milhão de casos de dengue nas Américas, dos quais, aproximadamente, dez mil eram de dengue hemorrágica. Metade dos casos notificados ocorreram na América do Sul.

Em 11 de novembro de 2015, o Ministério da Saúde reconheceu a primeira epidemia do vírus Zika no Brasil. Uma doença nova no país que assombrou e assombra gestantes devido as complicações do vírus que podem ocasionar a microcefalia nos recém-nascidos (MCNEIL, 2016; DINIZ, 2016). Surtos da chikungunya na região sudeste ocorrem a partir de 2015. Se torna epidêmica no nordeste brasileiro em meados de 2016. Com 60.000 casos confirmados de chikungunya no Ceará que tem o maior índice do país (AGÊNCIA BRASIL, 2017). As epidemias de dengue, zika e chikungunya estão se tornando mais frequentes, a cada verão inicia um ciclo epidêmico que pode atravessar a estação quente. 0 embate entre os homens e mosquitos está cada vez mais mortal, com perdas significativas para os seres humanos.

\section{Considerações Finais}


Além da participação da campanha de erradicação da malária da OMS na década de 1950, o Brasil já participou também de campanhas de erradicação Aedes aegypti nas décadas de 40 e 50 do século XX promovidas pela Organização. Houve sucesso temporário em algumas regiões. Com a criação da Superintendência de Campanhas de Saúde Pública (Sucam) substituindo o Departamento de Endemias Rurais foi anunciado precocemente à erradicação do vetor da Dengue em 1973. Três anos depois a doença está de volta. Considero fundamental estabelecer relações entre as campanhas de combate à malária e a dengue, zika e chikungunya. Porque entendo que a campanha de erradicação da malária pode nos dizer muito sobre as práticas de enfrentamento da dengue, zika e chikungunya. Isto é, nas lições de combate às anófeles podemos conhecer métodos para enfrentar o aedes.

As guerras entre os homens e os mosquitos não terminaram, as transformações biológicas são quase proporcionais aos progressos científicos. As guerras entre os homens e os mosquitos, são na verdade a guerra entre o homem e a natureza. $\mathrm{O}$ discurso bélico sobre a dengue produzido pela imprensa parece enfraquecer o caráter educacional que a epidemia exige para ser tratada.

\section{Referências:}

BENCHIMOL, Jaime Larry. O combate ao Anopheles gambiae. In: ( (Coord.). Febre amarela: a doença e a vacina, uma história inacabada. Rio de Janeiro: Editora Fiocruz, 2001. p. 168-173. Cf. CUETO, M. Los ciclos de la erradicación: la Fundación Rockefeller y la salud latinoamericana, 1918-1940. In: CUETO, M. Salud, cultura y sociedad en América Latina: nuevas perspectivas históricas. Lima: Instituto de Estudios Peruanos/Organización Panamericana de la Salud, 1996. p. 198.

BRAGA, Ima Aparecida; VALLE, Denise. Aedes aegypti: histórico do controle no Brasil. Epidemiologia e Serviços de Saúde., v. 16, n.2, p. $113-118,2007$.

CUETO, Marcos. Cold War, deadly fevers: malaria eradication in México, 1955-1975. Washington, DC: Woodrow Wilson Center Press; Baltimore: The Johns Hopkins University Press, 2007.

DONALISIOI, Maria Rita; FREITAS, André Ricardo Ribas. Chikungunya no Brasil: um desafio emergente. II REV BRAS EPIDEMIOL JAN-MAR 2015; 18(1): 283-5

DINIZ, Debora. Zika: do Sertão nordestino à ameaça global. - 1a ed. - Rio de Janeiro: Civilização Brasileira, 2016.

GADELHA, Paulo E.; PACKARD, Randall. A land filled with mosquitoes: Fred L. Soper, the Rockefeller Foundation and the Anopheles gambiae invasion of Brazil, 1932-1939. Parassitologia, v. 36, 1994, passim. Cf. SOPER, Fred. L. Anopheles gambiae in Brazil. In: . (Ed.). Ventures in world health - the memoirs of Fred Lowe Soper. Washington, DC: Pan-American Health Organization, v. 355, p. 201 et seq., 1977.

HOCHMAN, Gilberto. From autonomy to partial alignment: national malaria programs in the time of global eradication, Brazil, 1941-61. CBMH/BCHM, v. 25, n. 1, 2008. p. 169.

HOCHMAN, Gilberto; MELLO, Maria Tereza Bandeira de; SANTOS, Paulo Roberto Elian dos. A malária em foto: imagens de campanhas e ações no Brasil da primeira metade do século XX. História, Ciências, Saúde Manguinhos, Rio de Janeiro: Editora Fiocruz, v. 9, p. 249, 2002. Suplemento.

MCNEIL, Donald. Zika: a epidemia emergente. -1aed. - São Paulo: Planeta, 2016.

PACKARD, Randall M. Malaria dreams: postwar visions of world. Medical Anthropology, v. 17, p. 279-296, 1997.

PAULINI, Ernest. Considerações sobre o emprego de inseticidas em campanhas contra a malária. Revista Brasileira de Malariologia e Doenças Tropicais, Rio de Janeiro: Divisão de Cooperação e Divulgação - DNERu/ Ministério da Saúde, v. 14, n. 1/2, p. 116, 1962. 
SILVA, Renato da; PAIVA, Carlos Henrique Assunção. The Juscelino Kubitschek government and the Brazilian Malaria Control and Eradication Working Group: collaboration and conflicts in Brazilian and international health agenda, 1958-1961. História, Ciências, Saúde-Manguinhos (Impresso). , v.22, p.95 - 114, 2015.

SILVA, Renato da; HOCHMAN, Gilberto. Um método chamado Pinotti: sal medicamentoso, malária e saúde internacional (1952-1960). História, Ciências, Saúde-Manguinhos (Impresso). , v.18, n.2, p.519-543, 2011. 


\section{SUPER-HERÓIS, HISTÓRIA DOS QUADRINHOS E A POPULARIZAÇÃO DAS CIÊNCIAS}

Cleber de Souza Filho - Doutorando no HCTE/UFRJ - souzac.bio@gmail.com

Evandro Vieira Ouriques - Professor da ECO/HCTE/UFRJ - evandro.vieira.ouriques@gmail.com

Resumo

Quadrinhos são vistos como objetos de entretenimento, seja em seu formato original impresso, ou em suas outras mídias como televisão e cinema. Porém, apesar de sua grande popularidade e aceitação hoje, a história dos quadrinhos no ocidente é conturbada por sua relação com profissionais especializados de diversas áreas. A reflexão acerca de suas origens históricas tem o objetivo de resgatar interlocuções com campos do conhecimento para destacar a possibilidade do uso deste objeto como uma forma de linguagem para comunicar, divulgar e popularizar as ciências, observando sua importância histórica e sua relevância na cultura popular atual.

Palavras-chave: Quadrinhos. História das Ciências. Divulgação Científica.

\section{Introdução}

Os quadrinhos, sua cultura, seus diversos formatos em diferentes meios de comunicação foram e são entendidos como meros artigos de lazer e entretenimento sem explorar o que suas potencialidades subjetivas, e principalmente o tipo de linguagem usada na formulação desses quadrinhos, podem oferecer para diversas áreas do conhecimento. Dificilmente os quadrinhos são encarados como uma forma de produção artística ou cultural, pois além de não se encaixarem nas formas de artes tradicionalmente pré-estabelecidas, seu formato de mídia em massa é comumente voltado para e consumido pelo público infanto-juvenil e jovem adulto. Inclusive esse status artístico foi muitas vezes questionado no último século por quadrinhos não serem considerados literatura (KAKALIOS, 2005), ignorando os diferentes tipos de narrativa que utilizam imagens como recurso de linguagem em suas diversas formas artísticas.

Algumas possibilidades foram sugeridas nos últimos anos por profissionais da área de comunicação visual para tentar superar esse tipo de questão, através do valor histórico desses objetos e também utilizando esse tipo de linguagem com obras mais conceituais, artísticas e acadêmicas. A motivação desse esforço pode ser atribuída às inúmeras dificuldades que diversas áreas de conhecimento têm encontrado para melhor comunicar e divulgar seus conteúdos, à recente explosão de popularidade dos quadrinhos, e suas personagens, potencializada pelo cinema nas últimas décadas e principalmente ao interesse de profissionais de diversas áreas que são influenciados pela cultura, forma de linguagem e personagens das histórias em quadrinhos.

\section{Uma Breve História das Histórias em Quadrinhos}

É uma tarefa árdua apontar com precisão quem fez a primeira tirinha em quadrinhos, quando e em qual jornal, principal meio de veiculação desse formato no ocidente. Esse desafio na verdade vem, desde a década de 40 , fortalecendo a necessidade de pesquisas e formação de profissionais para estudar esse documento histórico que é a tirinha em quadrinhos e consequentemente os quadrinhos em si. 
É possível mapear ao longo da História traços do que hoje é entendido como tirinhas em quadrinhos, que aqui se define como linguagem de justaposição (MCCLOUDS, 1993; SOUSANIS, 2012). Essa justaposição de imagens em quadros sequenciais que "transformam o estático em cinético" indica fluidez de movimento ou passar do tempo dentro da narrativa, acompanhados de linguagem textual, "um balanço entre arte e linguagem" (SOUSANIS, 2012). Will Eisner (1999) afirma que:

\begin{abstract}
A configuração geral da revista em quadrinhos apresenta uma sobreposição de palavra e imagem, e assim, é preciso que o leitor exerça suas habilidades interpretativas visuais e verbais. As regências da arte (por exemplo, perspectiva, simetria, pincelada) e as regências da literatura (por exemplo, gramática, enredo, sintaxe) superpõem-se mutuamente. A leitura da revista em quadrinhos é um ato de percepção estética e de esforço intelectual (EISNER, 1999).
\end{abstract}

Essa linguagem já era utilizada por diversos povos espalhados pelo globo em diferentes contextos com materiais variados e é possível encontrar esses vestígios através de imagens no Japão Feudal com a obra "Genji Monogatari Emaki" do século XII (cerca de 1120-1140), na idade média com a Tapeçaria de Bayeux do século XI (cerca de 1070-1080), na Roma Antiga com a Coluna de Trajano do século II (cerca de 107-113) ou, se forem permitidos aprofundamentos mais criativos, no Livros dos Mortos no Egito (cerca de 2400 AC) e nas pinturas rupestres pré-históricas das cavernas (cerca de 38.000 AC) (CAMPOS, 2015).

Desde a década de 40 a origem dos quadrinhos no formato contemporâneo é debatida na Europa e nos Estados Unidos. Como coloca Campos (2015), diversos autores de best-sellers, historiadores, jornalistas e entusiastas tentam e tentaram cunhar o grande criador ou pai dos quadrinhos, o primeiro grande autor a lançar uma tirinha amplamente conhecida em um jornal. Esse debate ocorreu como uma tentativa de garantir reconhecimento ou certo status não só para o historiador ou autor do livro sobre o assunto, mas também para quem publicava as tirinhas, para o jornal onde foram publicadas e também o local de origem do jornal e do cartunista.

Em 1996, estabeleceu-se que a tirinha Yellow Kid de 1896 por Richard Fenton Outcault seria cunhada como a primeira obra desse novo meio de comunicação, o que gera problemas porque ignora as contribuições anteriores a essa data por inúmeros autores, inclusive do próprio autor de Yellow Kid (CAMPOS, 2015).

\title{
História dos Super-Heróis
}

Os super-heróis dos quadrinhos se tornaram grandes responsáveis pela popularização global dessa forma de comunicação, "uma forma de manifestação da arte produzida nos Estados Unidos e consumida em diferentes partes do mundo" (INGE, 1990; VELOSO, 2002). Entre 1902 e 1933 foram publicadas tirinhas em quadrinhos, pulp fictions, revistas e apresentações de rádio sobre diversos personagens fantásticos, com poderes sobre-humanos normalmente de origem sobrenatural ou de ficção científica, despertando uma serialização das obras e grande curiosidade do público por contar histórias místicas de lugares distantes à realidade ocidental. Inúmeras personagens serviram como fundação para os super-heróis que conhecemos hoje. Alguns exemplos importantes são: Hugo Hercules (entre 1902-1903 no jornal Tribuna de Chicago) por Wilhelm Heinrich Detlev Körner, John Carter de Marte (1911 na revista A Princesa de Marte) por Edgar Rice Burroughs, Tarzã o Homem Macaco (1912 na revista Tarzan dos Macacos) também por Edgar Rice Burroughs, Zorro (1919 na revista All-Story Weekly) por Johnston McCulley, Buck Rogers (1928 na novela Armageddon 2419 A.D. da revista Amazing Stories) por Philip Francis Nowlan, O Sombra (1930 no rádio e 1931 na pulp fiction) por Walter B. Gibson (com pseudônimo Maxwell Grant), O Cavaleiro Solitário (1933 no rádio) por George W. Trendle, Doc Savage - O Homem de Bronze (1933 na revista Doc Savage Magazine) por 
Lester Dent (com pseudônimo Kenneth Robeson), O Besouro Verde (1936 no rádio) também por George W. Trendle e Fran Striker, O Fantasma (1936 em forma de tirinha) por Lee Falk, O Vingador (1939 na revista O Vingador) e Flash Gordon (1934 em forma de tirinha) por Alex Raymond.

Graças à inspiração dessas personagens, em especial John Carter de Marte e Tarzã - o Homem Macaco, em 1938 é lançado, pela DC Company na revista Action Comics primeira edição, o super-herói criado por adolescentes de nome Super-Homem (1934) de Jerry Siegel e Joe Shuster, invertendo a relação da narrativa (pela primeira vez não se tratava de um homem desbravando o desconhecido e sim uma personagem extraterrestre vivendo nos Estados Unidos) e revolucionando o universo da ficção científica em quadrinhos. O Super-Homem se tornaria o pontapé inicial para toda uma nova geração de heróis e muitos deles, de alguma forma, acabariam entrando em contato com certos aspectos das ciências ou contextos científicos.

\section{Divulgação Científica e Super-Heróis?}

Existem diversas pesquisas na área de educação informal sobre o uso de diferentes tipos de narrativas e mídias de ficção científica e outros temas como plano de fundo para ensinar e obter melhor entendimento dos princípios científicos. Trabalhos com essa temática têm a intenção de despertar visibilidade para um ponto chave das práticas educativas e para divulgação científica, que é a necessidade de aperfeiçoar a linguagem adotada pelos cientistas e professores de ciências a fim de traduzir o conhecimento científico para o público jovem.

Ao longo do século XX as histórias quadrinhos eram muito acessíveis para o público geral e em especial para crianças e adolescentes por causa do seu preço baixo, construindo uma relação duradoura com o público, apesar de perseguições e estigmas que as histórias em quadrinhos sofrem desde a década de 50 (KAKALIOS, 2005), como, por exemplo, no livro Seduction of the Innocent (1953) de Fredic Wertham. O escopo dos quadrinhos vem se aperfeiçoando com o passar das décadas, com suas produções artísticas e culturais transmidiáticas que atravessaram os jornais, revistas, rádio, televisão e hoje principalmente através do cinema, da internet, de jogos e dos quadrinhos em si, além de outras mercadorias (brinquedos, materiais escolares, roupas e etc.). Esses objetos demonstram um poder estrutural que influenciam todas as faixas etárias: seus produtos têm grande procura internacional e movimentam bilhões de dólares todos os anos com seus filmes, séries de televisão, parques etc.

O impacto dos quadrinhos na sociedade recente como um agente de diálogo tem sido explorado por alguns pesquisadores das áreas da comunicação visual e da pedagogia, e leva em consideração que as histórias em quadrinhos são produtos de alcance mundial, distribuídos em larga escala em diferentes línguas e se encaixam na definição de Fairclough (1995) para Mídia em massa, pois mediam a relação entre a esfera pública e o domínio privado. As histórias em quadrinhos e suas personagens nascem de uma visão ou representação simplificada do real e foram construídas nas últimas décadas documentando história e criando memórias a partir da relação dos seus autores e suas relações com acontecimentos sociais, históricos, políticos e científicos. É através desse diálogo, do seu alcance e dessas relações que as histórias em quadrinhos têm o potencial de realizar contextualizações necessárias para questões de diferentes campos do conhecimento em sala de aula, usando esses objetos lúdicos para estimular a curiosidade e despertar o interesse dos alunos na construção dos saberes científicos (MESSEDER, 2010). 


\section{Considerações Finais}

Sugere-se a realização de uma reflexão teórica sobre o uso de objetos lúdicos da cultura popular, a fim de aproveitar a notoriedade atual dos quadrinhos e todos os seus desdobramentos para promover uma melhor compreensão do conteúdo científico do ensino básico e da popularização da ciência para o público geral. É através dos objetos lúdicos (em suas diversas formas e mídias) que sejam mais próximos da realidade dos alunos que será possível obter maior facilidade para encorajar a curiosidade científica das crianças e adolescentes (MARANDINO, 2004) acerca de diversos temas. E os quadrinhos, por desenvolver conteúdo por mais de 100 anos, em especial quadrinhos de super-heróis permeando campos das ciências através da ficção científica nos últimos 70 anos, podem servir como esse objeto lúdico para diferentes áreas de ensino.

\section{Referências bibliográficas}

CAMPOS, R. Imageria: o nascimento das histórias em quadrinhos. São Paulo: Veneta, 2015.

EISNER, W. Quadrinhos e Arte Seqüencial. São Paulo: Martins Fontes, 1999

FAIRCLOUGH, N. Media Discourse. Nova lorque: Edward Arnold, 1995

INGE, M. T. Comics as Culture. Mississipi: University Press of Mississippi, 1990

KAKALIOS, J. The Physics of Superheroes. 2. ed. Nova Iorque: Gotham Books, 2005.

MARANDINO, M. et al A Educação não formal e a Divulgação Científica: O que pensa quem faz? In: IV Encontro Nacional de Pesquisa em Ensino de Ciências. Bauru, 2004

MCCLOUD, S. Understanding Comics. Northampton: Kitchen Sink Press, Inc, 1993 MESSEDER, J. C.; RÔÇAS, G. O Lúdico e o ensino de Ciências: um relato de caso de uma Licenciatura em Química Revista Ciências \& Idéias, Rio de Janeiro, v. 1, n. 1, p. 69-75, 2010.

SOUSANIS, N. The shape of our thoughts: A meditation on \& in comics. Visual Arts Research, Illinois: University of Illinois Press, v. 38, n. 1, p.1-10, 2012.

VELOSO, F. O. D. Us vs Them: A critical reading of Superman - Peace on Earth. Dissertação de Mestrado. Florianópolis: UFSC, 2002 


\section{COMO SE PRODUZ UM USUÁRIO DE SAÚDE MENTAL? BREVES CONSIDERAÇÕES DE UMA ETNOGRAFIA EM UM CENTRO DE ATENÇÃO PSICOSSOCIAL}

Rafael de Souza Lima - Estudante de pós-graduação de Psicologia na UFRJ - rdsl.1989@gmail.com

Resumo

O presente trabalho visa discutir algumas observações feitas em um estudo etnográfico realizado em um Centro de Atenção Psicossocial (CAPS) da cidade do Rio de Janeiro, utilizando como referencial teórico a Teoria Ator-Rede de Bruno Latour e a Epistemologia Política de Isabelle Stengers e Vinciane Despret. Neste, o pesquisador acompanhou, semanalmente, 2 oficinas (de culinária e literária), algumas assembleias extraordinárias e esteve presente na área de convivência da instituição. Pretende-se discutir a importância das atividades acompanhadas e das relações que se estabelecem no serviço para a produção de um modo de ser usuário de saúde mental, tratando-se de uma relação consigo e com os outros e de um tipo de articulação com o CAPS em questão.

Palavras-chave: Saúde Mental. Usuário. Etnografia. CAPS. Teoria Ator-Rede. Epistemologia Política.

\section{Introdução}

Tem sido realizado, desde maio deste ano, um estudo etnográfico em um Centro de Atenção Psicossocial (CAPS) localizado na cidade do Rio de Janeiro. Segue abaixo uma definição deste serviço, segundo o Ministério da Saúde (2004, p. 13):

"[...] um Centro de Atenção Psicossocial (CAPS) ou Núcleo de Atenção Psicossocial é um serviço de saúde aberto e comunitário do Sistema Único de Saúde (SUS). Ele é um lugar de referência e tratamento para pessoas que sofrem com transtornos mentais, psicoses, neuroses graves e demais quadros, cuja severidade e/ou persistência justifiquem sua permanência num dispositivo de cuidado intensivo, comunitário, personalizado e promotor de vida.

\footnotetext{
“O objetivo dos CAPS é oferecer atendimento à população de sua área de abrangência, realizando o acompanhamento clínico e a reinserção social dos usuários pelo acesso ao trabalho, lazer, exercício dos direitos civis e fortalecimento dos laços familiares e comunitários. É um serviço de atendimento de saúde mental criado para ser substitutivo às internações em hospitais psiquiátricos.

"Os CAPS ainda precisam contar com os seguintes recursos físicos: consultórios para atividades individuais (consultas, entrevistas, terapias); salas para atividades grupais; espaço de convivência; oficinas; refeitório; sanitários; área externa para oficinas, recreação e esportes (MINISTÉRIO DA SAÚDE, 2004, P. 14)."
}

Estes serviços oferecem um atendimento interdisciplinar, composto por uma equipe multiprofisssional que reúne médicos, enfermeiros, assistentes sociais, psicólogos, psiquiatras, terapeutas ocupacionais, entre outros especialistas de nível superior, e por profissionais de nível médio, que podem ser: técnicos e/ou auxiliares de enfermagem, técnicos administrativos, educadores e artesãos. Os CAPS contam ainda com equipes de limpeza e de cozinha (MINISTÉRIO DA SAÚDE, 2004, P. 26).

No CAPS em questão, no qual tenho realizado a presente pesquisa, venho acompanhando as seguintes atividades: as oficinas de culinária e a literária, que ocorrem semanalmente; e as 
assembleias extraordinárias. Além disso, tenho frequentado a área de convivência, que tem se mostrado um importante espaço para interação e observação para a produção de material para a pesquisa, que tem por objetivo estudar o cotidiano dessa instituição utilizando como referencial teórico a Teoria Ator-Rede de Bruno Latour e a Epistemologia Política de Isabelle Stengers e Vinciane Despret, tentando descrever a maneira como os diversos elementos presentes nela, como os citados a pouco, se articulam para produzir modos de subjetivação nos usuários desse serviço. Para o presente trabalho, vou discutir observações feitas nas assembleias e na oficina literária.

O modo como o Ministério da Saúde se refere ao público atendido pelo CAPS - "pessoas que sofrem com transtornos mentais, psicoses, neuroses graves e demais quadros" - merece nossa atenção, por se distinguir da maneira como busco me referir aos usuários do serviço em questão.

Não os penso a partir de tais categorias, por entender que "as proposições terapêuticas vão participar da maneira como as pessoas vivem a experiência do sofrimento" (DESPRET, 2011, p. 7).

Vinciane Despret (2011, p. 6) relata a história de um homem chamado Achille, que se apresentou para consulta no Salpetrière, em 1890. Era um homem de negócios, habitante de uma província francesa longínqua, que apresentava sintomas de possessão diabólica. Encontrava-se em estado de agitação furiosa, proferia blasfêmias, falava com a voz do diabo. Ele foi confiado ao psiquiatra Pierre Janet, que soube que os sintomas apareceram seis meses antes, após uma viagem do paciente. Hipnotizado por Janet, o homem contou que durante essa viagem ele foi infiel à sua esposa, tentou esquecer o ocorrido, mas se viu invadido pela culpa, pelo medo de ser condenado, e posteriormente pelo demônio. "A revelação desse segredo conduzirá lentamente Achille em direção à cura, pois ela permitirá a Janet superar o que ele chama as 'ideias fixas subconscientes' de seu paciente." (DESPRET, 2011, p. 6). Essa história, retomada por Ellenberger (1995, apud DESPRET, 2011, p. 6) se desdobra em duas, cada uma abarcando um mundo de pensamento diferente. Na primeira, Achille e o grupo de indivíduos de sua comunidade compartilham uma mesma superstição: a existência de seres invisíveis capazes de interferir na conduta dos homens e de torná-los doentes. Ele era possuído pelo demônio em um mundo onde se contava com a ação de exorcistas para a resolução dos problemas. A segunda acontece com a chegada de Achille no hospital, e é aí que ocorre uma reviravolta: se antes ele estava possuído, agora é um paciente que sofre de "ideias fixas subconscientes".

“[...] essa segunda história não é o simples prolongamento da primeira; ao contrário, ela vai retroativamente restabelecer aquilo que diferentemente, a reconstrói fazendo intervir outros elementos. A metamorfose não se traduz no epílogo da cura, ela advém da entrada de um jogo, ela se constitui na reconstrução da própria experiência do transtorno e modifica seus atores. Os invisíveis que tratavam Achille do exterior tornam-se com a teoria de Janet, aquilo que fará agir Achille do interior, a relação que se inscreveu como uma relação com a exterioridade, em direção a outras intencionalidades, é totalmente deslocada e convertida em uma relação completamente diferente. A desordem agora é instalada na psiché. O que, no primeiro mundo, podia se traduzir como punição torna-se, no segundo culpa e, portanto, totalmente acessível a uma teoria ou uma técnica da psiché." (DESPRET, 2011, p. 6)

Despret (2011, p. 7) se interessa por esse caso porque nele se percebe o modo como a cultura propõe o cuidado, mas sobretudo como também ela influencia a maneira como as pessoas experienciam os seus problemas. Em uma cultura povoada de seres invisíveis, as pessoas se deixam capturar por eles para conferirem sentido às suas experiências; naquela onde os problemas recaem sobre a psiché e a culpabilidade, elas orientam suas experiências 
referindo-as ao psiquismo, aos problemas mentais, ao desejo, etc. A cultura aqui sendo considerada em seu conjunto e incluindo nela as proposições terapêuticas.

Percebe-se nessa história, primeiro, a manifestação de sintomas em Achille condizentes com a cultura da pequena província que habita, e segundo, uma transformação dessa sua experiência a partir da incidência do tratamento psiquiátrico. Trata-se de uma nova relação estabelecida entre o paciente e o seu sofrimento, da variação de sentidos para o mesmo e de uma modificação da própria experiência: o quanto deve diferir uma punição proporcionada por demônios de uma experiência de culpa ou um sofrimento proveniente de "ideias fixas subconscientes"? Não é apenas a explicação para uma mesma experiência que muda, a própria experiência sofre uma metamorfose quando o paciente é submetido ao tratamento de Janet.

Esse caso, e as considerações levantadas a partir dele, me incitam a pensar algumas questões: Quais são, atualmente, os modos de tratamentos destinados aos usuários de serviços de saúde mental? Quais são os efeitos destas práticas? Que outros elementos, para além das intervenções terapêuticas, participam da produção de subjetividades desses sujeitos?

Como o meu interesse se dirige à produção de subjetividade dos usuários de um CAPS específico, vou a seguir esclarecer como o termo subjetividade está sendo aqui abordado: não se trata de um domínio interno, pessoal e centrado em um eu autorreflexivo submetido a leis e princípios universais, em oposição a uma realidade externa; “(...) essa dimensão subjetiva não será aqui considerada como um patrimônio inalienável de nossa natureza humana, mas sim construída através de práticas e dispositivos contingentes ao sabor da história." (FERREIRA, 2015, p. 302).

Assim, em vez de falar de "subjetivo" num sentido substantivo ou adjetivo, será discutida a produção de subjetividades em sentido processual, apontando as múltiplas formas com que se desencadeiam processos de subjetivação. Nesse ponto, é importante considerar nossas subjetividades como efeito de práticas, agenciamentos, dobras, amálgamas de termos heterogêneos em composição (mas também em conflito e muitas vezes em atrito) e através de dispositivos sociotécnicos, discursos e práticas de governança de si e de outros, sem os quais nossa experiência de subjetividade poderia ser totalmente outra, ou mesmo nem existir. (FERREIRA, 2015, p. 303).

Assim, para falar das subjetividades em questão neste trabalho, evito qualquer teoria que tenha a pretensão de explicá-las, ou mesmo aquelas que funcionem como um quadro explicativo ou um contexto para a inserção dos dados coletados no campo (LATOUR, 2006b, p. 341). Segundo Latour (2006b, p. 343-344), o principal argumento da Teoria Ator-Rede é "que os próprios atores fazem tudo, inclusive seus próprios quadros, suas próprias teorias, seus próprios contextos, sua própria metafísica, até mesmo sua própria ontologia (...)". Dentro dessas condições, o pesquisador fica encarregado de realizar descrições, e não de oferecer ao campo explicações.

Apenas descrições ruins precisam de explicação. É bem simples, na verdade. O que se entende por "explicação", na maior parte das vezes? A adição de um outro ator para prover aqueles já descritos a energia necessária para agir. Mas, se você tem que adicionar um ator, então a rede não está completa, e, se os atores já reunidos não têm energia suficiente para agir, então eles não são "atores", e sim meros intermediários, tolos ou marionetes. (LATOUR, 2006b, p. 344). Levando-se isso em consideração, eu busco não me guiar por tais categorias, mas tomá-las em conta na medida em que elas participam da produção de subjetividades dos usuários em questão. No meu trabalho de campo, tenho observado que é bastante recorrente a referência a noções como doença, doença mental, doença dos nervos, pertubação na cabeça, crises, e a categorias diagnósticas, como esquizofrenia, por parte dos usuários, que se referem a si mesmos como usuários, mas o uso de termos como pacientes e doentes também é comum. 
Escuto por vezes profissionais também se referindo a eles a partir de tal terminologia: paciente. Parece ser uma constatação óbvia, já que o CAPS é um serviço de saúde mental. Porém, o interesse aqui reside na força de tais categorias para a produção de modos de existência específicos, que implicam num certo engajamento dos usuários de um certo modo, nas propostas ali oferecidas.

Nas assembleias extraordinárias, o que tenho percebido é que a coordenadora do CAPS, juntamente com outros profissionais, se esforça para engajar os usuários nas propostas da Reforma Psiquiátrica. As assembleias se caracterizam pelo envolvimento de profissionais, usuários, familiares e outros eventuais convidados na discussão dos problemas relativos ao serviço, e na proposição coletiva de encaminhamentos e soluções. São recorrentes as convocações de todos para reuniões que ocorrem em outros lugares, como por exemplo na Superintendência de Saúde Mental, localizada na Prefeitura, assim como para manifestações de reinvidicação dos direitos em saúde. Esforça-se para promover uma mobilização coletiva, para que movimentos como estes tenham força, e para a implicação de cada um com aquilo que se torna interesse de todos os participantes. Os ideais da Reforma Psiquiátrica e do SUS aparecem sempre, e ocorre o que eu tenho chamado de uma espécie de pedagogia da Reforma: os profissionais fazem questão de explicar os detalhes, de tirar as dúvidas, de fazerem perguntas como:

"Vocês sabem o que é um Conselho Municipal de Saúde?", de falarem dos direitos dos usuários à saúde, ao serviço que é oferecido. É importante ressaltar que, quando as falas dos usuários contemplam estes mesmos ideais, ou lançam luz ao que se concebe ali como sendo problemas vividos pelo CAPS, elas são valorizadas pelos profissionais: "Olha só, isso que a Beatriz está dizendo é muito importante!".

Chama-se a atenção para isso, a atenção de todos os outros, enfatiza-se aquilo que é importante para eles.

Certa vez, diante do término do contrato com uma empresa que fornece alimento ao CAPS (não houve a renovação do contrato, e o CAPS ficou sob o risco de não poder oferecer alimentação aos usuários), um usuário sugeriu que fosse feito um rateio pelos usuários e familiares para a compra dos alimentos para serem servidos ali. Dentre os problemas colocados por uma das profissionais, surgiu o de que o serviço deve oferecer alimentação aos usuários, que a solução sugerida é boa mas não se deve remediar o problema dessa forma, deve-se lutar para garantir o direito à alimentação dos usuários ali.

Vejo nesse espaço o engajamento de alguns usuários de um modo militante. No fim de uma das assembleias, ouvi um usuário exclamar, diante da reclamação de uma das usuárias a respeito da falta de um medicamento e da possibilidade de participação em uma manifestação: "Mas não adianta só reclamar que tá faltando remédio, tem que lutar, tem que fazer alguma coisa!". Os problemas do CAPS se tornam, na prática, problemas dos usuários, no sentido mesmo do engajamento deles, de se preocuparem com tais assuntos e de discutirem os mesmos.

Na oficina literária, geralmente são produzidos textos pelos usuários a partir da leitura de algo que sirva de inspiração, como uma poesia, escolhida por eles mesmos. Mas a escrita é livre, escreve-se o que se sente vontade. Quais as vontades que se produzem ali, diante dessa liberdade? Os usuários escrevem sobre diversos temas, algumas vezes inspirados pela leitura inicial, outras não. Porém, diante dessa diversidade temática, percebo aqui também o interesse dos usuários voltados para os problemas do CAPS, ou para a importância do mesmo em suas vidas. Parece tratar-se de algo central em suas vidas. Eles muitas vezes versam também sobre os problemas que enfrentam e sobre os seus sofrimentos. Após a escrita, cada um lê o que escreveu, e a partir disso se discute os trabalhos, podendo um texto causar reverberações em outras pessoas, que tecem seus comentários. 
A oficina literária me parece um espaço propício para reforçar a importância do CAPS na vida dos usuários, a implicação destes e mais uma vez, uma identificação dos mesmos com a categoria de paciente. Em certa oficina, uma das usuárias leu o texto que produziu. Nele, ela dizia que estava se sentindo muito triste, que antes ela gostava de cantar e hoje já não canta mais. Após a sua leitura, a profissional que coordena a oficina perguntou se alguém queria comentar algo sobre o texto. Dois usuários disseram que a usuária não era assim, que ela está muito "depressiva", não ri mais. "Ela precisa de medicamento doutora!" - comentou uma das usuárias. Segundo eles, ela antes sorria mais, cantava e até brigava. Percebi que eles foram bastante cuidadosos, demonstraram preocupação com ela, que concordou com o que foi falado por eles.

Como conclusão, a partir dessas breves considerações, pode-se constatar que ocorre no serviço estudado a produção de um engajamento dos usuários, que adquire a forma de uma atuação militante e se dá também na valorização daquilo lhe eles passam a reconhecer como importante para lidarem com os seus problemas, que são concebidos como pertencentes ao campo da saúde; e uma forma de identificação dos usuários pautada pela ideia de doença (o ser paciente) e os consequentes modos de significações das experiências vividas por eles.

Referências bibliográficas:

BRASIL. Ministério da Saúde. (2004). Saúde mental no SUS: os centros de atenção psicossocial. Brasília: Ministério da Saúde. Disponível em: http://www.ccs.saude.gov.br/saude_mental/pdf/SM_Sus.pdf $\mathrm{D}$

ESPRET, V. Leitura etnopsicológica do segredo. In: Dossiê Despret. Revista Fractal de Psicologia. v. 3, n. 1, janeiro/abril. Niterói: UFF, 2011.

FERREIRA, A. A. L. Psicologia, produção subjetivante e modos políticos: pistas conceituais da Teoria Ator-Rede. Cadernos de Pesquisa, v. 45, n. 156, p. 300-313, abr./jun., 2015.

LATOUR, B. Como terminar uma tese de sociologia: pequeno diálogo entre um aluno e se professor (um tanto socrático). Cadernos de Campo, São Paulo, v. 14/15, p. 339-352, 2006 b. 


\title{
CRIATIVIDADE, HISTÓRIA E O SURGIMENTO DE UM ESPAÇO SINÉRGICO: O PAPEL DA IMAGINAÇÃO NA QUEBRA DE PARADIGMAS INSTITUCIONAIS
}

\author{
Priscila Tamiasso-Martinhon - Núcleo de Estudos em Biomassa e Gerenciamento de Águas - NAB, UFF - pris- \\ martinhon@hotmail.com \\ Angela Sanches Rocha - Departamento de Físico-Química (DFQ), UFRJ) - angela.sanches.rocha@gmail.com \\ Célia Sousa - Grupo Interdisciplinar de Educação, Eletroquímica, Saúde, Ambiente e Arte (GIEESAA) - \\ sousa@iq.ufrj.br \\ Raimundo Damasceno - Departamento de Físico-Química (DFQ), UERJ - damascen@vm.uff.br
}

\section{Resumo}

O presente trabalho resgata alguns apontamentos práticos e traça reflexões sobre o papel da criatividade e da imaginação na quebra de paradigmas institucionais. Para tal, foi feito um resgate histórico contextualizado sobre o surgimento de um espaço sinergético de pesquisa, ensino e extensão: o Núcleo de Estudos em Biomassa e Gerenciamento de Águas (NAB) /UFF. O objetivo é estabelecer uma interlocução acerca da temática criatividade dentro de conceitos sustentáveis de inovação que contemplem: viabilidade, funcionalidade, sustentabilidade, coletividade e autonomia; a partir de uma análise qualitativa e exploratória sobre a contribuição desse espaço na inter-relação entre a indústria, a universidade e a sociedade, na perspectiva de uma formação acadêmica mais autônoma.

Palavras-chave: História. Sinergismo. NAB.

Introdução

No mundo contemporâneo e globalizado, existe uma preocupação crescente em se preservar a história de centros de pesquisas, não só por meio de acervos e narrativas - baseada em fontes apropriadas - mas também pela análise da inter-relação desses com a sociedade. $A$ singularidade de tais instituições ora mostra, ora esconde, o processo de como ocorreu - e/ou ocorre - suas práxis (SANFELICE, 2006).

Por um lado, o olhar externo nem sempre permite ao observador contemplar a filosofia que forjou os alicerces de um centro de pesquisa (TAMIASSO-MARTINHON et al., 2017). Por outro, as relações entre memória e identidade, bastante exploradas nos últimos anos, tanto no campo da história como no da antropologia, têm uma conexão direta com os legados históricos institucionais (HEYMANN, 2005). Apesar disso, no Brasil ainda é muito recorrente que tais memórias - responsáveis pela identidade ideológica de muitos acervos científicos percam-se no tempo, o que contribui para caracterizar um país sem memória ou de cunho imediatista.

Segundo Sanfelice (2006), mergulhar no âmago de uma instituição de ensino ou de um centro de pesquisa é "ir em busca das suas origens, do seu desenvolvimento no tempo, das alterações arquitetônicas pelas quais passou, e que não são gratuitas", em suma, sugere uma busca também pela identidade dos sujeitos implicados, e em que contexto foram envolvidos durante sua criação. O essencial é tentar responder questões acerca do que torna uma instituição singular. Do que ela estabeleceu e/ou estabelece para si, para seus sujeitos, para a sociedade na qual está inserida, ou mais ainda, para o sentido pelo qual foi instituída e concebida. 
Assim, o presente trabalho exibe a concepção de um centro de excelência em inovação e pesquisa, pautado na filosofia da química verde - que contempla princípios de viabilidade, funcionalidade, sustentabilidade, coletividade e autonomia - desde a sua idealização, até seu plano de empreendimento, buscando compreender a relação do singular (instituição) com o geral (sociedade, empresa). Afinal, nenhum centro de pesquisa ou instituição de ensino tem o sentido da sua singularidade explicitado, quando tomada apenas em si mesma, posto que ela se projeta para dentro de um grupo social, produz memórias e/ou imaginários. Nessa perspectiva, Sanfelice (2006) pontua que essa inter-relação entre sociedade e instituição:

Mobiliza ou desmobiliza grupos de pessoas e famílias; assinala sua presença em comemorações, torna-se notícia na mídia, ou seja, é muito, mas muito mais mesmo do que um prédio que agrupa sujeitos para trabalharem, ensinarem, aprenderem etc. (SANFELICE, 2006).

Além disso, o movimento inverso também ocorre, toda instituição também é objeto de interesses contraditórios de ordem econômica, política, ideológica, cultural, dentre outras. Assim, torna-se óbvio que a história de uma instituição de ensino, ou de um centro de pesquisa, não traz o sentido que ela realmente tem, se for tomada de forma isolada de todo o contexto.

Ademais, todo centro de pesquisa que pode opinar sobre o espaço geográfico em que pode ser erguido, geralmente expõe seus valores e princípios desde a arquitetura de seu prédio, quase sempre transparecendo suas convicções e identidade, tornando-se singular para a sociedade.

\section{Espaços Sinérgicos}

Atualmente, Espaços Sinérgicos reforçam a existência de um processo contínuo de avanço e aperfeiçoamento - ou, sob outra ótica, de modernização e inovação - buscando atingir a excelência em termos de qualidade, sustentabilidade, produtividade e competitividade (HANEFELD, s.n.).

Nessa perspectiva, a globalização vem promovendo modificações representativas nos diversos seguimentos - não apenas econômico, mas também político, social, cultural, tecnológico. O que implica em dinâmicas de reavaliações das formas de se pensar e agir em prol do desenvolvimento, por parte das forças vivas da sociedade, pautadas na interação dos sujeitos envolvidos nesse processo (HANEFELD, 2003). Por isso é tão importante que os espaços sinérgicos incorporem diversos campos de pesquisa, diferentes áreas (COSTA \& SILVA, 2017) e nutram em sua equipe características como a criatividade e a autonomia, o que resulta num local mais adequado para a formação do indivíduo de uma maneira mais plena além do desenvolvimento de tecnologia.

\section{Criatividade}

A criatividade e o processo imaginativo vêem sendo cada vez mais substituídos pela observação estritamente descritiva, em que o cientista assume um perfil totalmente objetivo, deixando a subjetividade para o senso comum (OLIMPIO et al., 2016). Para muitos a imaginação é praticamente desconsiderada no processo da criação, contudo ela pode ser uma etapa importante e até mesmo crucial (ALVES, 1981). Mas afinal, será que uma ideia pode surgir sem uma história pregressa? Ou ela é a resultante da integral de nossas vivências e experiências?

A percepção e a criatividade podem ser únicas para cada sujeito, uma vez que vários fatores contribuem de maneira diferente, e combinada, para questionamentos individuais. Nessa perspectiva, a imaginação criadora é vista como a imaginação inovadora que gera algo novo, onde novos caminhos e trajetos são feitos de uma perspectiva diferente. 
O conceito por traz da palavra conhecimento vai muito além de qualquer padrão ou modelo vigente, ele é ilimitado e infinito. Atualmente encontra-se fragmentado em várias áreas e nas suas possíveis ramificações. Provavelmente tal divisão ocorreu para facilitar e organizar o processo de ensino e aprendizagem, segundo a visão de certa parcela de estudiosos.

Neste escopo, torna-se importante o uso da criatividade ou inventividade para construção de edificações mais modernas e adequadas às novas demandas das sociedades modernas. Este aspecto é importante não apenas com relação às construções familiares e comerciais, mas sobre tudo para as administrativas e acadêmicas.

O Núcleo de Estudos em Biomassa e Gerenciamento de Águas

As construções verdes e sustentáveis (green building) são edificações em consonância com os ideais de sustentabilidade. O Núcleo de Estudos em Biomassa e Gerenciamento de Águas (NAB), da Universidade Federal Fluminense (UFF), foi idealizado e concebido dentro desse conceito, sendo norteado por quatro princípios fundamentais: a viabilidade econômica, a funcionalidade, a sustentabilidade (do ponto de vista ambiental), e o design arquitetônico (TAMIASSO-MARTINHON et al., 2017). Tais preceitos estiveram presentes desde a escolha dos materiais utilizados durante a construção, até os custos ambientais e de manutenção do edifício. Além disso, também foram contempladas questões inerentes à eficiência energética, uso sustentável da água, qualidade dos ambientes internos, acessibilidade, entre outras (TAMIASSO-MARTINHON et al., 2017).

O prédio - inaugurado em 18 de março de 2014, financiado pela Petrobras e situado no campus da Praia Vermelha, em Niterói - possui uma filosofia própria baseada na generosidade e solidariedade da equipe que dá anima a sua estrutura física, e é precisamente caracterizada pelo seu símbolo, uma espiral aberta que remete ao ciclo do petróleo. O logo - elaborado por Rosa Benevento - é representado por cinco elementos: o sol, em amarelo; as plantas, em verde; a terra, em laranja; o mar, em azul; e o petróleo, em preto (CUNHA, 2014). E, como apresentada na Figura 1, a espiral não é fechada nela mesma, o que implica em dizer que o Núcleo de Estudos em Biomassa e Gerenciamento de Águas - NAB foi concebido como um espaço sinergético, com fronteiras abertas, em movimento, preparado para crescer, expandir e agregar (DAMASCENO, 2014 apud CUNHA, 2014), o que reflete o cerne de sua equipe científica.

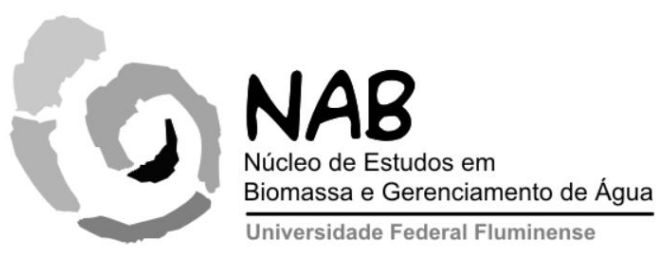

Figura 1. Logotipo do NAB/UFF

Fazem parte do Núcleo de Estudos em Biomassa e Gerenciamento de Águas - NAB onze laboratórios, os quais direta ou indiretamente adotam os princípios da química verde; duas salas multifuncionais; uma oficina de mecatrônica; um almoxarifado de reagentes químicos e um auditório com capacidade para 250 pessoas sentadas. Os laboratórios são equipados com aparelhos de última geração, de modo a promover o desenvolvimento de tecnologia de ponta tanto de interesse da academia quanto de indústrias. Os ambientes são arejados e munidos de luz natural propiciando um ambiente salubre e agradável de trabalho. A Figura 2 apresenta fotos de alguns laboratórios do Núcleo de Estudos em Biomassa e Gerenciamento de Águas NAB. 
Figura 2. Imagens de alguns laboratórios do NAB.
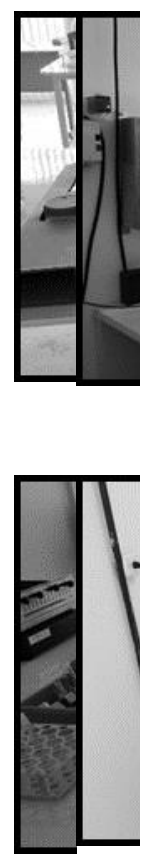

Fotos: Acervo do NAB

A presença do auditório permite que eventos de médio porte sejam realizados no prédio, como encontros, seminários, reuniões, workshops, etc. Esta característica torna esta estrutura mais útil à comunidade acadêmica e privada. Na Figura 3 são apresentadas fotos de eventos realizados neste auditório, sendo uma de um congresso, com a participação de algumas autoridades da UFF presente na mesa e participantes, e a outra de formandos no hall de entrada do prédio, localizado em frente ao auditório.

Figura 3 - (A) Formandos em solenidade realizada no auditório do NAB (esquerda) e (B) Participantes de congresso realizado no mesmo auditório).

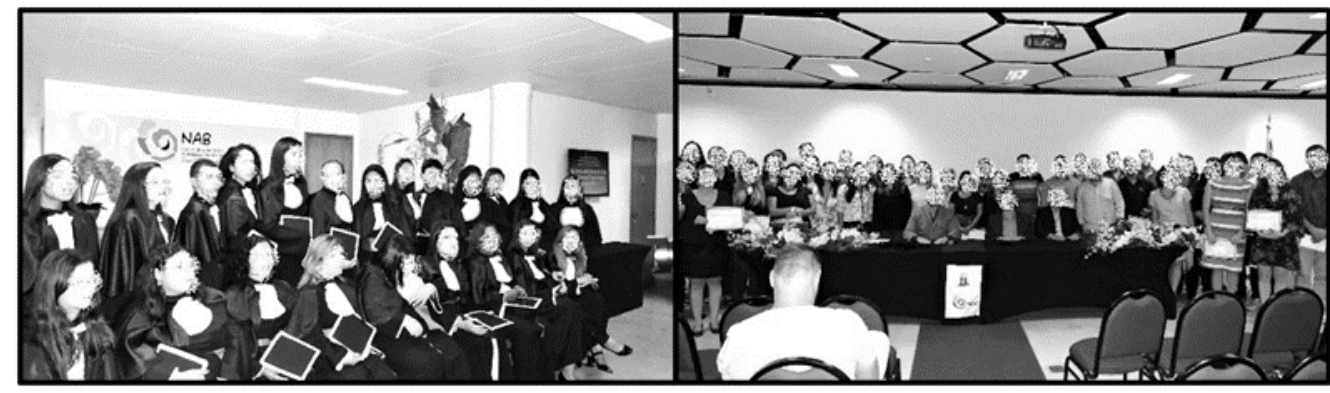

Fonte: Acervo do NAB.

A localização do Núcleo de Estudos em Biomassa e Gerenciamento de Águas (NAB) é privilegiada, com vista para a baía de Guanabara, local agradável e de fácil mobilidade. A Figura 4 mostra duas fotos do prédio, uma frontal (à esquerda) e outra de cima (à direita), 
ficando a mostra nesta última que o edifício se localiza de frente à baía, e apresenta áreas externas que podem possibilitar experimentos ao ar livre.

Em suma, o projeto arquitetônico faz uma releitura de edificação que valoriza o coletivo, integra-se com o ambiente circundante, natural e construído, assegura a acessibilidade, combinando o aspecto científico com a sustentabilidade em suas várias faces, além de propiciar um local de aprendizagem e formação de cientistas, sendo contemplado em 2014 pela revista Projeto Design - como um dos melhores projetos do Brasil da área de arquitetura e desenvolvimento em escolas e centros de pesquisa (CUNHA, 2014).

Figu

ra 4

Dois

âng

ulos

exte

rnos

do

pré

dio

do

Núc

leo

de

Estu

dos

em

Bio

mas

sa e

Ger

enci

ame

nto

de

Águ

as -

NAB
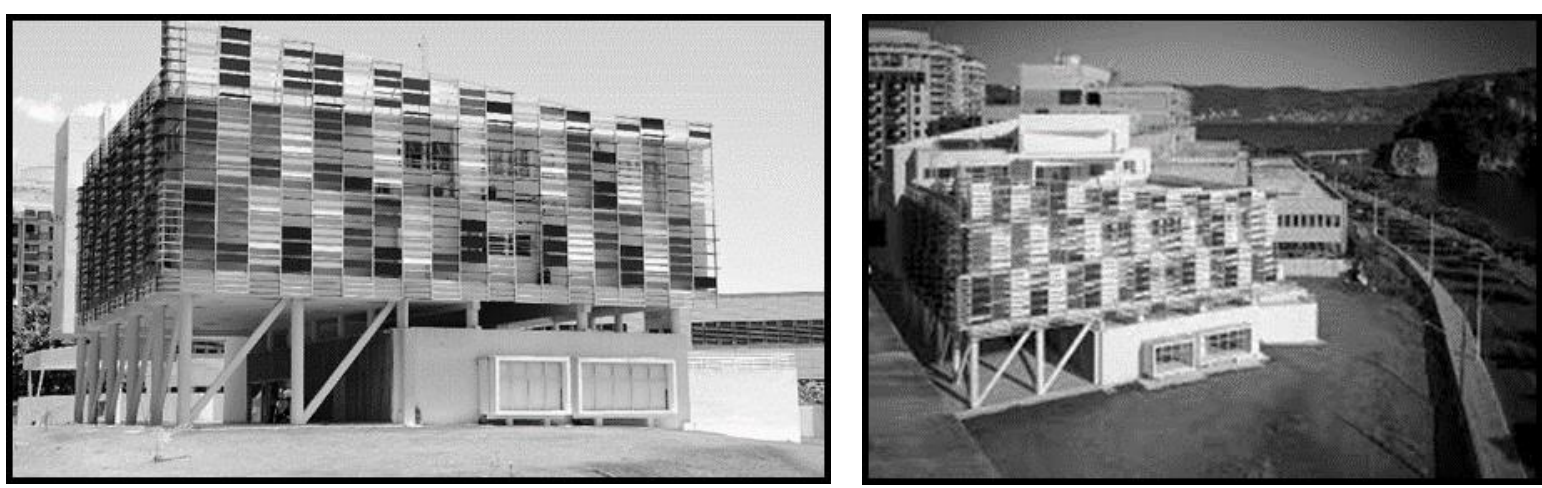

Fotos: Acervo do NAB.

Considerações finais 
As instituições de ensino e pesquisa, salvo pouquíssimas exceções, não têm a cultura que leve a uma política de preservação de fontes. O que não deixa de ser uma lástima, pois as fontes são essenciais para se fazer pesquisa historiográfica. Além disso, as fontes assumem um papel importante na relação entre memória e história, e, embora os documentos escritos oficiais sejam importantíssimos para a pesquisa historiográfica, hoje a concepção de fonte está muito ampliada, trabalha-se com fotos, com filmes, com plantas de prédios, com os apontamentos pessoais, com correspondência particular e com uma infinidade de outros materiais. Assim, torna-se necessário um empenho crescente, para que se criem condições claras e objetivas para uma política de preservação das fontes.

\section{Referências bibliográficas}

ALVES, Rubem. FILOSOFIA DA CIÊNCIA: introdução ao jogo e suas regras. São Paulo: Editora Brasiliense, 1981.

COSTA, Josué de Moura; SILVA, Ivanda Maria Martins. BIBLIOTECAS DIGITAIS NA EDUCAÇÃO A DISTÂNCIA: conexões com a percepção de estudantes. RENOTE, v. 15, n. 1, 2017.

CUNHA, Renata. UFF inaugura Núcleo de Estudos em Biomassa e Gerenciamento de águas. UFF Notícias: Superintendência de Comunicação Social, 2014. . Disponível em:

<http://www.noticias.uff.br/noticias/2014/03/nab-inauguracao.php>. Acesso em: 29 set 2017.

HANEFELD, Alexandro Oto. ECONOMIA E DESENVOLVIMENTO ECONÔMICO: 2uma experiência a partir do Pólo de Modernização Tecnológica do Vale do Rio Pardo, Rio Grande do Sul, Brasil. Disponível em: <http://cdn.fee.tche.br/eeg/1/ mesa_2_hanefeld.pdf>. Acesso em: 20 set 2017.

ORGANIZAÇÃO SOCIAL DO DESENVOLVIMENTO: a experiência do Pólo de Modernização Tecnológica do Vale do Rio Pardo/Universidade de Santa Cruz do Sul. In: JORNADAS DE HISTORIA ECONÓMICA, III., 2003. Montevideo. Anais... AUDHE: Asociación Uruguaya de Historia Económica, Montevideo, 2003. Disponível em: <http://www.audhe.org.uy/Jornadas_Internacionales_Hist_Econ/III_Jornadas/ Simposios_III/10/Hanefeld.pdf>. Acesso em: 20 set 2017.

HEYMANN, Luciana. DE "ARQUIVO PESSOAL' A "PATRIMÔNIO NACIONAL": reflexões acerca da produção de "legados". Rio de Janeiro: CPDOC, 2005.

OLIMPIO, Quelle Garcia; TAMIASSO-MARTINHON, Priscila; SOUSA, Célia. CONHECIMENTO SINÉRGICO: o papel da imaginação, dos paradigmas e da metodologia científica na formação docente. In: CONGRESSO DE HISTÓRIA DAS CIÊNCIAS DA TÉCNICAS E EPISTEMOLOGIA, IX., 2016. Rio de Janeiro. Anais... Rio de Janeiro: Universidade Federal do Rio de Janeiro, 2016.

SAITO, Fumikazu. CONTINUIDADE E DESCONTINUIDADE: O processo da construção do conhecimento. Revista da FAEBBA: Educação e Contemporaneidade, v. 22, n. 39, p. 183-194 (2013).

SANFELICE, José Luís. História, instituições escolares e gestores educacionais. Revista HISTEDBR, Campinas, $n$. especial, p. 20-27, 2006.

TAMIASSO-MARTINHON, Priscila; ROCHA, Angela Sanches; SOUSA, Célia; DAMASCENO, Raimundo. Um prédio sustentável onde se vivencia a filosofia da QV. In: Encontro da Escola Brasileira de Química, VII., 2017. Rio de Janeiro. Anais... Rio de Janeiro: Instituto Nacional de Tecnologia, 2017. 


\title{
A EDUCAÇÃO FINANCEIRA NO ENSINO BÁSICO - UMA PROPOSTA PARA TRABALHAR O CONCEITO DE INFLAÇÃO EM AULAS DE MATEMÁTICA
}

\author{
Cintia Teixeira Dias - Professora da Rede Municipal de Duque de Caxias, cintiatdias@hotmail.com \\ Cláudia Concordido - Professora Associada do IME/UERJ - concordido@ime.uerj.br \\ Ricardo Camargo Severo de Macedo - Coordenador Adjunto do Curso de Ciências Econômicas do IBMEC
}

\section{Resumo}

Esse trabalho é fruto de uma pesquisa que buscou desenvolver o tema Educação Financeira na Educação Básica, investigando como a inflação pode ser trabalhada nas aulas de Matemática. A inflação foi a escolha por ter recentemente voltado a afetar a vida dos brasileiros. A pesquisa de campo ocorreu em uma escola municipal de Duque de Caxias/Rio de Janeiro (RJ)RJ em uma turma de 8 o ano do Ensino Fundamental. São apresentadas atividades referentes ao tema inflação e avaliados os resultados, bem como a repercussão que o estudo desse assunto teve entre os alunos. São também sugeridas atividades adicionais, com o intuito de auxiliar o professor de Matemática interessado na inserção da Educação Financeira em sala de aula, como parte da formação do pensamento matemático e financeiro de seus alunos.

Palavras-chave: Educação Financeira. Inflação.Ensino de Matemática.

\section{Introdução}

A maioria das pessoas têm dificuldades para lidar com questões financeiras. Conhecer técnicas e recursos que possibilitem decidir como usar o dinheiro é fundamental. De acordo com os Parâmetros Curriculares Nacionais (PCN), "se a escola pretende estar em consonância com as demandas atuais da sociedade, é necessário que trate de questões que interferem na vida dos alunos e com os quais se veem confrontados no seu dia a dia" (BRASIL, 2000, p.64). É na escola que o aluno deve aprender a lidar com essas questões, uma vez que, nesse ambiente, ele não obtém apenas conhecimentos cognitivos, mas também a capacidade de viver em sociedade. Conforme Martins (2004, p.56).

A omissão da escola em relação a noções de comércio, de economia, de impostos e de finanças tem uma consequência perversa: a maioria das pessoas, quando adulta, continua ignorando esses assuntos e segue sem instrução financeira e sem habilidade para manejar dinheiro.

Não é de se admitir que os alunos saiam do Ensino Médio sabendo resolver problemas complicados, como aqueles que envolvem equações logarítmicas ou números complexos, por exemplo, mas não consigam decidir sobre as vantagens e desvantagens do uso do cartão de crédito ou como elaborar um orçamento doméstico ou ainda interpretar notícias referentes à inflação.

A ideia ao trabalhar em sala de aula questões matemáticas envolvendo situações que abordam esse conceito é, utilizando a Matemática, preparar o aluno para ser capaz de entender as informações que lhe são passadas pelos meios de comunicação e refletir as decisões que podem ser tomadas no futuro, e até mesmo no presente, em relação ao uso do seu dinheiro (DIAS; CONCORDIDO; MACEDO, 2016). Com esse objetivo, elaboramos diversas atividades envolvendo o tema inflação e aplicamos algumas delas em uma turma de 8 o ano do Ensino Fundamental de uma escola municipal de Duque de Caxias/RJ. Em nosso trabalho, 
além de apresentar um conjunto de atividades, damos sugestões a fim de auxiliar o professor de Matemática interessado na inserção da Educação Financeira em sala de aula.

\section{Atividades para o Ensino Fundamental}

Foram elaboradas atividades para turmas do 70 Ano do Ensino Fundamental. Indicamos que elas sejam aplicadas quando o professor abordar os conceitos de Razão, Porcentagem e Variação Percentual. No entanto, podem também ser dirigidas a turmas de 8 으 e 9 으 Ano do Ensino Fundamental.

Para a melhor compreensão dos alunos, sugerimos que, antes de iniciar a aplicação das atividades, seja feita uma sondagem com eles, perguntando-lhes o que é "inflação", para verificar se têm alguma noção sobre o tema proposto. A expectativa é que poucos saibam responder ou mesmo mostrar que têm ideia do assunto (DIAS; CONCORDIDO; MACEDO, 2016). Ao final de uma discussão com a turma sobre as respostas, deve ficar claro que inflação é o aumento generalizado e contínuo dos preços, diminuindo o poder de compra da população (GREMAUD, 2007, p.219).

Antes das atividades, sugerimos ainda a leitura de textos (CONEF, 2013) para auxiliar o aluno no entendimento desse conceito. É importante também explicar detalhadamente aos alunos na lousa como é calculado o índice de inflação de uma cesta de produtos. O professor também poderá comentar sobre o período de hiperinflação que o Brasil viveu nas décadas de 1980 e 1990, antes do Plano Real, e, como tarefa de casa, pedir aos alunos para conversarem com seus pais ou avós e colherem algumas experiências vividas nessa época.

A partir daí, deve-se dividir a turma em duplas ou em grupos de quatro para iniciar a realização das atividades elaboradas, que vivenciam situações-problemas e indagações envolvendo o tópico "inflação". Convém ressaltar que foi permitido o uso de calculadora em todas as atividades. Segue na Figura 1 um exemplo de atividade trabalhada numa classe de 29 alunos, com idades entre 13 e 15 anos.

$$
\begin{aligned}
& \text { Dona } \\
& \text { Ana } \\
& \text { está } \\
& \text { preoc } \\
& \text { upada } \\
& \text { com a } \\
& \text { inflaçã } \\
& \text { o. Ela } \\
& \text { é } \\
& \text { "boleir } \\
& \text { a" e os } \\
& \text { bolos } \\
& \text { que } \\
& \text { faz e } \\
& \text { vende } \\
& \text { não } \\
& \text { estão } \\
& \text { mais } \\
& \text { dando } \\
& \text { tanto } \\
& \text { lucro } \\
& \text { quant } \\
& \text { o } \\
& \text { davam } \\
& \text { no ano } \\
& \text { passad } \\
& \text { o. Por } \\
& \text { este } \\
& \text { motiv } \\
& \text { o, ela } \\
& \text { pesqui }
\end{aligned}
$$


sou no

Tudo

Barato

alguns

itens

que

compr

regula

rment

e para

confec

cionar

os

bolos

e

compa

rou

com o

valor

que

eles

tinha

$m$ há

um

ano.

O

quadr

abaixo

mostr

a a

cesta

dos

princip

ais

produt

os

utiliza

dos

por

Dona

Ana

com

seus

respec

tivos

preços

nos

meses

de

Julho

de

2015 e

Julho

2016:

Prod JulhoJulho Colu Colu Colu

utos de de na 1 na 2 na 3

20152016

\begin{tabular}{|l|l|l|l|l|l|}
\hline trigo & $\mathrm{R} \$ 3,00$ & $\mathrm{R} \$ 3,20$ & & & \\
\hline $\mathrm{ar}$ & $\mathrm{R} \$ 2,50$ & $\mathrm{R} \$ 3,00$ & & & \\
\hline
\end{tabular}




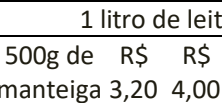

Dona Ana leu nos jornais que o IPCA, índice oficial que mede a inflação no Brasil, dos últimos 12 meses foi de aproximadamente $\mathbf{1 0 \%}$. A partir dessas informações responda às questões a seguir.

a) Compare os preços do ano passado com os atuais. Registre na Coluna 1 a diferença de preço (em Reais) de cada produto.

b) Agora, calcule o quociente entre as diferenças encontradas na coluna anterior e os preços de cada produto referente ao ano passado e registre na Coluna 2.

c) Registre na coluna 3 a taxa de aumento no preço de cada produto.

d) Quais foram os produtos cujo aumento de preço foi maior que o IPCA?

e) Sabendo que um bolo da Dona Ana custava $\mathrm{R} \$ 30,00$ no ano passado, quanto ela deve cobrar no mínimo pelo seu bolo a partir de agora, considerando um reajuste igual à inflação dos últimos 12 meses?

f) Calcule a variação, em Reais, do valor da cesta dos principais produtos comprados por Dona Ana no período considerado.

g) Baseado nessa variação, calcule o índice de inflação da cesta dos principais produtos comprados por Dona Ana no período considerado.

Discuta com o seu grupo se o preço reajustado do bolo é justo se comparado com o índice de inflação da cesta dos produtos, e o quanto vocês cobrariam no mínimo pelo bolo, considerando esse aumento dos preços. 
O tempo de duração desta atividade foi de aproximadamente 40 minutos e como prérequisitos consideramos as operações aritméticas fundamentais, razão, porcentagem e variação percentual, assuntos apresentados ou revisados em aulas anteriores.

A turma fez com facilidade a primeira parte da atividade - a construção da tabela. Não tiveram muitas dúvidas, até porque fizemos muitos exercícios de taxa de aumento durante as revisões. A maioria dos alunos conseguiu perceber que os itens $a, b$ e $c$, levavam à resposta em porcentagem da taxa de aumento de cada produto.

No item d, alguns alunos perguntaram: "Como vou comparar os preços com o IPCA? Quanto é o IPCA?" Então pedimos que lessem o enunciado novamente, evidenciando que os alunos não gostam de ler enunciados grandes, apesar de no início da aula termos lido o enunciado com eles e explicado o que deveriam fazer. No item e, novamente, alguns perguntaram qual era a inflação considerada. Depois que lemos com eles o parágrafo que fornecia o valor da inflação, conseguiram realizar a questão sem dificuldade. Dos 26 alunos presentes nessa atividade, apenas dois não conseguiram responder essa questão.

Praticamente todos os alunos conseguiram responder corretamente os itens $f$ e $g$. Porém, alguns calcularam o índice, mas não colocaram o símbolo de porcentagem na resposta, e outros colocaram o símbolo de $\mathrm{R} \$$ na resposta do índice, mostrando não compreender muito bem as grandezas envolvidas. No item $\mathrm{h}$, foi necessária a nossa intervenção para que eles chegassem à resposta desejada. Mesmo assim, alguns não conseguiram, respondendo que cobrariam $49,24 \%$, ou seja, a taxa de reajuste e não o preço, como solicitado. Apenas dois responderam corretamente.

Para a próxima atividade (Figura 2), é importante explicar previamente aos alunos o que é Poder de Compra e como calculá-lo. O Poder de Compra é a capacidade que uma pessoa ou uma população tem de adquirir bens e serviços com determinada unidade monetária (GREMAUD, 2007). Para calcular a perda ou ganho no Poder de Compra (PC) de uma pessoa devemos primeiramente escolher um bem ou objeto e verificar quantas unidades desse bem ou objeto é possível comprar com uma quantidade fixa de dinheiro em épocas diferentes. Assim, seja P1 o poder aquisitivo de obter uma quantidade de certo bem em uma época inicial e seja P2 o poder aquisitivo de obter uma quantidade desse bem em uma época final, temos:Se a resposta for positiva significa que houve ganho, se for negativa significa que houve uma perda no Poder de Compra.

O tempo de duração desta atividade foi de 20 minutos aproximadamente e foram considerados como pré-requisitos as operações aritméticas fundamentais, porcentagem e poder de compra.

Os alunos não tiveram muitas dificuldades na realização dessa atividade e, de modo geral, mostraram que conseguiram entender como calcular a perda no poder de compra. Porém, destacamos a dúvida de um aluno que perguntou qual era o preço do sanduíche antes do reajuste. Devolvemos então a pergunta para a turma e uma aluna respondeu que, se Roberto podia comprar 20 sanduíches com o valor de sua mesada que era de 100 reais, então o preço do sanduíche é 100 dividido por 20, que dá 5 reais. 
Fonte: Elaboração própria.

Roberto está muito feliz! Ele recebeu um aumento em sua mesada e ela passou a ser $\mathrm{R} \$ 100,00$. Roberto fez a seguinte reflexão: "Agora
eu tenho poder aquisitivo para comprar exatamente 20 sanduíches na lanchonete Lanche Bom durante o mês!" Mas, um dia depois,
surge a notícia de que haverá um reajuste de $25 \%$ nos preços dos sanduíches da lanchonete Lanche bom.
a) Depois do reajuste na lanchonete Lanche Bom, quanto custa cada sanduíche?
b) Como o preço do sanduíche foi reajustado, Roberto não pode mais comprar 20 sanduíches. Quantos sanduíches ele pode
comprar agora? Percebemos que o poder de compra de Roberto diminuiu. Determine qual foi a desvalorização no poder de compra da mesada de Roberto após o reajuste no preço dos sanduíches.

Alguns ao calcular a desvalorização no poder de compra da mesada de Roberto (item c), fizeram o poder de compra inicial subtraído pelo poder de compra depois do reajuste, achando um valor positivo. Aproveitamos essa dúvida para discutir com a turma a importância de se utilizar corretamente as fórmulas, mas ressaltamos também a importância de entender e interpretar os dados do enunciado e os dados que são calculados em cada item da questão. Se o aluno não tivesse voltado para os outros itens, entendido o que aconteceu antes e depois do reajuste dos preços do sanduíche e compreendido que Roberto está comprando menos agora, teria respondido que Roberto teve ganho no poder de compra por ter encontrado um valor positivo na resposta.

\section{Atividades para o Ensino Médio}

A temática inflação pode ser abordada também com turmas do Ensino Médio, onde podemos incluir assuntos mais complexos, com situações-problema que envolvam o cálculo de juros compostos e série uniformes. Para a aplicação dessas atividades, sugerimos que, assim como naquelas direcionadas para o Ensino Fundamental, antes seja feita uma revisão com exercícios acerca dos conteúdos matemáticos básicos para o entendimento das atividades assim como uma exposição do conteúdo na lousa, explicando e discutindo com a turma os temas abordados. É útil ainda fazer uso de planilhas eletrônicas.

Para a atividade apresentada na Figura 3, é necessário que a escola possua um Laboratório de Informática. É um exercício de juros compostos e o tempo estimado para sua resolução é de 30 minutos.

Figura 3 - Atividade com planilha eletrônica

\footnotetext{
Ana ganhou uma herança de seus avós no valor de $\mathrm{R} \$ 500.000,00$. Ela ainda não sabe o que fazer com essa quantia e como ainda é muito jovem, decidiu guardar a sua herança para o futuro.

a) Suponha que Ana não tenha feito nenhum investimento com o valor de sua herança e que a taxa de inflação em seu país é de $6 \%$ a.a, calcule quanto valerá o seu dinheiro daqui a 20 anos.

b) E se a taxa de inflação fosse de $1 \%$ a.a?

c) Utilizando o programa Excel, veja como se comporta o valor da herança de Ana de acordo com diferentes índices de inflação (use valores de $1 \%$ a.a até $12 \%$ a.a).

d) Observando os resultados, a qual conclusão você chegou?
}

Fonte: Elaboração própria.

Como muitos alunos não sabem manipular o software Excel, é aconselhável que, se possível, o professor agrupe os alunos em duplas onde um deles já possua tal conhecimento. Se a maioria dos alunos não souber como utilizá-lo, o professor deve iniciar a atividade com os alunos e mostrar passo a passo a atividade. Aconselhamos também que o professor se prepare antecipadamente.

A atividade ilustrada na Figura 4 é muito interessante para o aluno aprimorar a sua educação financeira, pois mostra como a inflação corrói o poder de compra das pessoas. Se não for feito um investimento compatível com a inflação, com o passar do tempo, o dinheiro perde o seu valor. É uma atividade em que podemos questionar o 
valor dos juros dos investimentos e a importância de não guardarmos o dinheiro em nosso bolso em momentos de inflação alta. Exige o conhecimento de Série Uniforme de Pagamentos, um conceito da Matemática Financeira que muitas vezes não é visto no Ensino Médio. O professor pode fazer uma explanação mostrando o que seria a Série Uniforme de Pagamentos na lousa e chegar juntamente com os alunos à fórmula utilizando Progressão Geométrica. A atividade pode ser desenvolvida com uma turma de $2^{\circ}$ ou $3^{\circ}$ ano e seu tempo de duração estimado é de 30 minutos.

Figura 4 - Atividade envolvendo séries uniformes

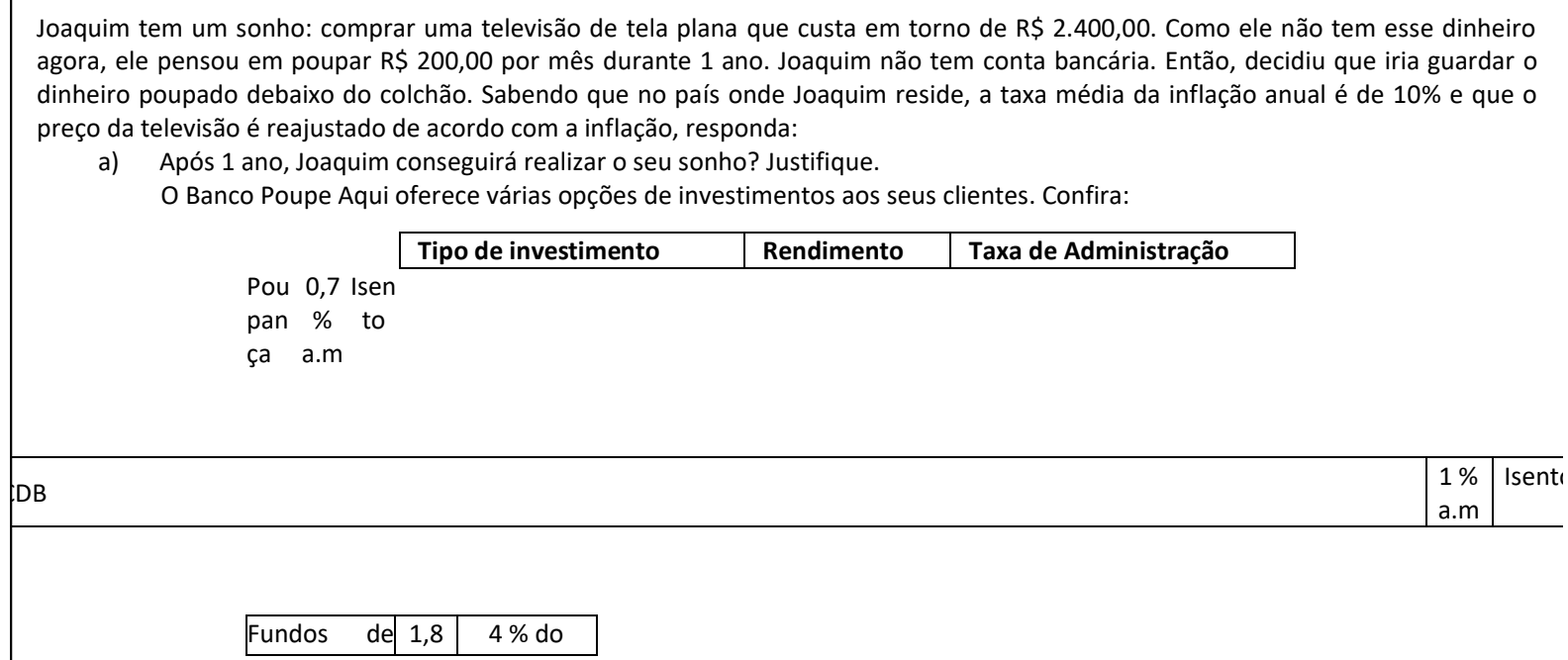

Fonte: Elaboração própria.

\section{Considerações Finais}

A escola é responsável por preparar o indivíduo para o mercado de trabalho e também para o exercício da cidadania. Com atividades como estas aqui propostas, acreditamos estar contribuindo para que o aluno relacione a Matemática com a sua prática diária, além de conhecer conceitos referentes ao mundo financeiro, como a inflação. Observamos, a partir das respostas dadas, que muitos alunos demonstraram ter melhorado sua compreensão sobre o tema. Inicialmente eles não sabiam o que era e 
afirmavam nem ter ouvido falar sobre inflação. A escola onde foi realizada a pesquisa é predominantemente de classe social baixa e o conhecimento dos alunos sobre os assuntos relacionados ao mundo das finanças se mostrou bastante precário, tanto assim que associavam a ideia de inflação a algo relacionado ao governo e à corrupção. Ao final das atividades, podemos dizer que obtiveram não somente conhecimento matemático, mas também conhecimento sobre Economia, que certamente usarão em suas vidas e poderão também transmitir para a sua família.

Percebemos também que as atividades aplicadas revelaram algumas falhas no processo ensino-aprendizagem, dentre elas destacamos a defasagem de alguns conhecimentos matemáticos básicos por parte dos alunos e a postura de alguns que por vezes não estavam muito motivados a participar da aula. Isso mostra que existem desafios ao trazermos aulas mais contextualizadas aos nossos alunos. Apesar de não ter sido um problema da escola em questão, sabemos que ainda temos também muita dificuldade em conseguir recursos adequados, como data show e até mesmo cópias, nas maiorias das escolas públicas.

Pensamos com este trabalho poder contribuir para a educação financeira dos alunos, formando cidadãos não somente conscientes e capazes de gastar o seu dinheiro, mas também, de planejar o seu futuro, administrar seus recursos financeiros de forma saudável e compreender de forma básica as questões em relação ao mundo financeiro, tomando assim decisões financeiras apropriadas.

Referências bibliográficas

BRASIL. Secretaria da Educação Fundamental. Parâmetros Curriculares Nacionais. Brasília, MEC/ SEF, 2000.

CONEF. Educação financeira nas escolas: ensino médio. Bloco 3 (livro do professor) - elaborado pelo Comitê Nacional de Educação Financeira (CONEF) - Brasília: CONEF, 2013.

DIAS, C. T.; CONCORDIDO, C. F. R.; MACEDO, R. C. S. Trabalhando o conceito de inflação nas aulas de matemática. Revista de Educação, Ciências e Matemática v.6 n.3, 2016.

GREMAUD, A. P. et al. Introdução à Economia. São Paulo: Atlas, 2007.

MARTINS, J. P. Educação Financeira ao alcance de todos: adquirindo conhecimentos financeiros em linguagem simples. 1.ed. São Paulo: Editora Fundamento Educacional, 2004.

\section{RIO DE JANEIRO: NATUREZA, BIODIVERSIDADE E O REGISTRO DOS VIAJANTES}

Maria da Gloria Tuxen - Mestranda no HCTE-UFRJ - gloriatuxen@gmail.com Nadja Paraense dos Santos - Professora do HCTE-UFRJ - nadja@iq.ufrj.br

"Sei que não são ruínas de Atenas; mas cada um mostra o que possui. 0 viajante entrou, deu uma volta, saiu e foi postar-se junto à muralha, fitando o mar, o céu e as montanhas, e, ao cabo de cinco minutos: 'Que natureza que vocês têm !' (...) A admiração do nosso hóspede excluía qualquer ideia de ação humana. Não me perguntou pela fundação das fortalezas, nem pelos nomes dos navios que estavam ancorados. Foi só natureza." (Machado de Assis, 1893)

Resumo

HCTE-UFRJ 
O presente trabalho discute a relação entre homem e natureza na cidade do Rio de Janeiro, a biodiversidade local e o efeito antrópico sobre esta. O estudo dos relatos e da iconografia que nos deixaram os viajantes do século XIX, brasileiros ou estrangeiros, tem se mostrado de significativa importância para compreendermos a relação humana com o ambiente e o papel da natureza tropical na construção de nossa id entidade.

Palavras-chave: Biodiversidade. Rio de Janeiro. Viajantes. Século XIX.

\section{Introdução}

Para o viajante do século XIX, naturalista ou não, vindo das florestas temperadas, pouco diversas e aparentemente ordenadas da Europa ou da América do Norte, a natureza tropical era fonte de deslumbramento e temor. A diversidade biológica impressionava (DIEGUES, 2001; PRESTES, 2000).

Os relatos sobre o Brasil perfazem mais de 260 obras sobre o Rio de Janeiro, cerca de 100 escritas em várias línguas. Os autores discorrem não somente sobre a flora e a fauna, mas também sobre os habitantes, a vida social, os usos e costumes, e outros aspectos. Há um incremento dos relatos principalmente durante o século XIX, depois que Dom João VI decretou abertura dos portos brasileiros, em 1808. Dos viajantes que estiveram no Rio de Janeiro, boa parte era de naturalistas que, por um lado, ampliavam seus estudos e, por outro, forneciam aos os governos que os enviavam valiosas informações sobre as riquezas das novas terras. Através das anotações, diários e iconografia dos viajantes podemos analisar a relação entre homem e natureza, bem como a perda da biodiversidade no Rio de Janeiro decorrente do processo de urbanização.

\section{A Relação entre Homem e Natureza}

Os registros dos viajantes nos ajudam a identificar o grande impacto que a chegada do europeu trouxe sobre a biodiversidade do sítio onde se instalou a urbe carioca (AMADOR, 1997). O sítio de ocupação da cidade era constituído por diversos ecossistemas muito biodiversos, característica esta que não escapou ao olhar atento do colonizador, interessado nas riquezas da terra.

$\mathrm{Na}$ medida em que a cidade se instala, os processos antrópicos de degradação ambiental se intensificam. O cuidado com o ambiente não era uma preocupação. Colocando-se em grau hierárquico superior ao dos demais seres vivos, o homem atribuiu-se o direito de usar a natureza como bem entender, sujeitando ou matando os demais seres.

O problema da legitimidade da exploração da natureza e do esgotamento dos recursos naturais já era levantado desde o Renascimento (ACOT, 1990). Posteriormente, Carl Lineu (1707-1778) postulava que “(...) a natureza inteira tende a prover a felicidade do homem, cuja autoridade se estende por toda a terra e que pode se apropriar de todo o seu produto" (ACOT, 1990). Mas o pensamento lineano também nos indica que a natureza é um sistema frágil, do qual cada parte é interdependente de outra. O processo de expansão e de ocupação das terras do Novo Mundo seguiu esse modelo. Os colonizadores buscavam nessas terras riquezas em forma de metais e pedras, mas descobriram outra riqueza: a biológica.

Por sua vez, o explorador europeu partia em busca da riqueza que não conseguira em sua terra. Seu objetivo era adquirir o bastante para uma vida melhor quando voltasse a seu país (DIEGUES, 2001). Assim o seu compromisso e cuidado em preservar a natureza eram nulos. 
Na disputa pelo domínio econômico e político, os governos enviaram a volta do globo viajantes encarregados em mapear a topografia, catalogar e registrar a diversidade local e remeter as informações aos seus governantes. Para Acot (1990), a geografia vegetal nasceu da riqueza de informações que as grandes potências marítimas, em suas intenções pré-coloniais, financiaram. Não podemos esquecer também alguns viajantes andavam pelas novas terras às suas próprias custas.

Os relatos de viagens faziam sucesso, graças à atração que o diferente, o extraordinário exercia sobre a fértil mente humana. Muitos relatos, pouco preocupados com a verdade e mais com o sucesso de vendas, apelavam para o extravagante, levando a se acreditar em absurdos. Por sua vez, descrições de alguns animais misturavam realidade e fantasia, como no caso do bicho-preguiça, chamado Aí ou Aití pelos nativos, que ANDRÉ THEVET descreve em seu livro As Singularidades da França Antártica de 1557. A descrição lembra a mitológica Mantícora:

"É do tamanho de um mono africano adulto, apresentando uma barriga tão grande que chega quase a se arrastar no chão. A cabeça lembra a de uma criança, assim como também a cara, conforme pode ser visto na gravura tirada ao natural. Quanto preso, fica suspirando como uma criança que sente dores. Sua pele é cinzenta e felpuda como a de um ursinho. Tem patas compridas, cada uma com quatro dedos, três dos quais com unhas parecendo grandes espinhas de carpa, com as quais trepa nas árvores onde fica por mais tempo do que em terra." (THEVET, 1978, p.169)

Esse entrelaçar entre fantasia e realidade era frequente nos primeiros relatos de viagens pela América do Sul. Não havia a necessidade de um levantamento amplo de dados empíricos através de observações metodológicas da natureza (PRESTES, 2000).

\section{Biodiversidasde e Efeitos Antrópicos}

Os relatos sobre a região do Rio de Janeiro e sua biodiversidade remontam a períodos tão distantes como o da construção do forte Coligny na ilha de Serigipe, hoje Villegagnon, no momento da fundação da França Antártica (1555). Já no século XIX o número de viajantes aumentou significativamente (Tabela 1) e os relatos tornam-se mais numerosos. Esses viajantes cruzavam o Brasil e, frequentemente, o ponto de partida ou de chegada era a cidade do Rio de Janeiro.

Tabela 1 - Viajantes que passaram pelo Brasil do século XVI ao XIX (início).

\section{ORIGEM}

\section{XVIIXVII XIX TOT}

I (iníc AL

io)

\section{Fonte: Elaboração própria.}

O tempo de duração desta atividade foi de aproximadamente 40 minutos e como prérequisitos consideramos as operações aritméticas fundamentais, razão, porcentagem e variação percentual, assuntos apresentados ou revisados em aulas anteriores.

A turma fez com facilidade a primeira parte da atividade - a construção da tabela. Não tiveram muitas dúvidas, até porque fizemos muitos exercícios de taxa de aumento durante as revisões. A maioria dos alunos conseguiu perceber que os itens $a, b$ e c, levavam à resposta em porcentagem da taxa de aumento de cada produto. 
No item d, alguns alunos perguntaram: "Como vou comparar os preços com o IPCA? Quanto é o IPCA?" Então pedimos que lessem o enunciado novamente, evidenciando que os alunos não gostam de ler enunciados grandes, apesar de no início da aula termos lido o enunciado com eles e explicado o que deveriam fazer. No item e, novamente, alguns perguntaram qual era a inflação considerada. Depois que lemos com eles o parágrafo que fornecia o valor da inflação, conseguiram realizar a questão sem dificuldade. Dos 26 alunos presentes nessa atividade, apenas dois não conseguiram responder essa questão.

Praticamente todos os alunos conseguiram responder corretamente os itens $f$ e g. Porém, alguns calcularam o índice, mas não colocaram o símbolo de porcentagem na resposta, e outros colocaram o símbolo de $\mathrm{R} \$$ na resposta do índice, mostrando não compreender muito bem as grandezas envolvidas. No item $h$, foi necessária a nossa intervenção para que eles chegassem à resposta desejada. Mesmo assim, alguns não conseguiram, respondendo que cobrariam $49,24 \%$, ou seja, a taxa de reajuste e não o preço, como solicitado. Apenas dois responderam corretamente.

Para a próxima atividade (Figura 2), é importante explicar previamente aos alunos o que é Poder de Compra e como calculá-lo. O Poder de Compra é a capacidade que uma pessoa ou uma população tem de adquirir bens e serviços com determinada unidade monetária (GREMAUD, 2007). Para calcular a perda ou ganho no Poder de Compra (PC) de uma pessoa devemos primeiramente escolher um bem ou objeto e verificar quantas unidades desse bem ou objeto é possível comprar com uma quantidade fixa de dinheiro em épocas diferentes. Assim, seja P1 o poder aquisitivo de obter uma quantidade de certo bem em uma época inicial e seja P2 o poder aquisitivo de obter uma quantidade desse bem em uma época final, temos: Se a resposta for positiva significa que houve ganho, se for negativa significa que houve uma perda no Poder de Compra.

O tempo de duração desta atividade foi de 20 minutos aproximadamente e foram considerados como pré-requisitos as operações aritméticas fundamentais, porcentagem e poder de compra.

Os alunos não tiveram muitas dificuldades na realização dessa atividade e, de modo geral, mostraram que conseguiram entender como calcular a perda no poder de compra. Porém, destacamos a dúvida de um aluno que perguntou qual era o preço do sanduíche antes do reajuste. Devolvemos então a pergunta para a turma e uma aluna respondeu que, se Roberto podia comprar 20 sanduíches com o valor de sua mesada que era de 100 reais, então o preço do sanduíche é 100 dividido por 20, que dá 5 reais. 
Roberto está muito feliz! Ele recebeu um aumento em sua mesada e ela passou a ser $R \$ 100,00$. Roberto fez a seguinte reflexão: "Agora eu tenho poder aquisitivo para comprar exatamente 20 sanduíches na lanchonete Lanche Bom durante o mês!" Mas, um dia depois, surge a notícia de que haverá um reajuste de $25 \%$ nos preços dos sanduíches da lanchonete Lanche bom.

c) Depois do reajuste na lanchonete Lanche Bom, quanto custa cada sanduíche?

d) Como o preço do sanduíche foi reajustado, Roberto não pode mais comprar 20 sanduíches. Quantos sanduíches ele pode comprar agora?

Percebemos que o poder de compra de Roberto diminuiu. Determine qual foi a desvalorização no poder de compra da mesada de Roberto após o reajuste no preço dos sanduíches.

Figura 2 - A Atividade 2

Fonte: Elaboração própria.

Alguns ao calcular a desvalorização no poder de compra da mesada de Roberto (item c), fizeram o poder de compra inicial subtraído pelo poder de compra depois do reajuste, achando um valor positivo. Aproveitamos essa dúvida para discutir com a turma a importância de se utilizar corretamente as fórmulas, mas ressaltamos também a importância de entender e interpretar os dados do enunciado e os dados que são calculados em cada item da questão. Se o aluno não tivesse voltado para os outros itens, entendido o que aconteceu antes e depois do reajuste dos preços do sanduíche e compreendido que Roberto está comprando menos agora, teria respondido que Roberto teve ganho no poder de compra por ter encontrado um valor positivo na resposta.

\section{Atividades para o Ensino Médio}

A temática inflação pode ser abordada também com turmas do Ensino Médio, onde podemos incluir assuntos mais complexos, com situações-problema que envolvam o cálculo de juros compostos e série uniformes. Para a aplicação dessas atividades, sugerimos que, assim como naquelas direcionadas para o Ensino Fundamental, antes seja feita uma revisão com exercícios acerca dos conteúdos matemáticos básicos para o entendimento das atividades assim como uma exposição do conteúdo na lousa, explicando e discutindo com a turma os temas abordados. É útil ainda fazer uso de planilhas eletrônicas.

Para a atividade apresentada na Figura 3, é necessário que a escola possua um Laboratório de Informática. É um exercício de juros compostos e o tempo estimado para sua resolução é de 30 minutos. 
Ana ganhou uma herança de seus avós no valor de $\mathrm{R} \$ 500.000,00$. Ela ainda não sabe o que fazer com essa quantia e como ainda é muito jovem, decidiu guardar a sua herança para o futuro.

e) Suponha que Ana não tenha feito nenhum investimento com o valor de sua herança e que a taxa de inflação em seu país é de $6 \%$ a.a, calcule quanto valerá o seu dinheiro daqui a 20 anos.

f) E se a taxa de inflação fosse de $1 \%$ a.a?

g) Utilizando o programa Excel, veja como se comporta o valor da herança de Ana de acordo com diferentes índices de inflação (use valores de $1 \%$ a.a até $12 \%$ a.a).

h) Observando os resultados, a qual conclusão você chegou?

Figura 3 - Atividade com planilha eletrônica

Fonte: Elaboração própria.

Como muitos alunos não sabem manipular o software Excel, é aconselhável que, se possível, o professor agrupe os alunos em duplas onde um deles já possua tal conhecimento. Se a maioria dos alunos não souber como utilizá-lo, o professor deve iniciar a atividade com os alunos e mostrar passo a passo a atividade. Aconselhamos também que o professor se prepare antecipadamente.

A atividade ilustrada na Figura 4 é muito interessante para o aluno aprimorar a sua educação financeira, pois mostra como a inflação corrói o poder de compra das pessoas. Se não for feito um investimento compatível com a inflação, com o passar do tempo, o dinheiro perde o seu valor. É uma atividade em que podemos questionar o valor dos juros dos investimentos e a importância de não guardarmos o dinheiro em nosso bolso em momentos de inflação alta. Exige o conhecimento de Série Uniforme de Pagamentos, um conceito da Matemática Financeira que muitas vezes não é visto no Ensino Médio. O professor pode fazer uma explanação mostrando o que seria a Série Uniforme de Pagamentos na lousa e chegar juntamente com os alunos à fórmula utilizando Progressão Geométrica. A atividade pode ser desenvolvida com uma turma de $2^{\circ}$ ou $3^{\circ}$ ano e seu tempo de duração estimado é de 30 minutos. 
Joaquim tem um sonho: comprar uma televisão de tela plana que custa em torno de $\mathrm{R} \$ 2.400,00$. Como ele não tem esse dinheiro agora, ele pensou em poupar $\mathrm{R} \$ 200,00$ por mês durante 1 ano. Joaquim não tem conta bancária. Então, decidiu que iria guardar o dinheiro poupado debaixo do colchão. Sabendo que no país onde Joaquim reside, a taxa média da inflação anual é de $10 \%$ e que o preço da televisão é reajustado de acordo com a inflação, responda:

e) Após 1 ano, Joaquim conseguirá realizar o seu sonho? Justifique.

O Banco Poupe Aqui oferece várias opções de investimentos aos seus clientes. Confira:

\begin{tabular}{|l|l|l|}
\hline Tipo de investimento & Rendimento & Taxa de Administração \\
\hline Poupança & $0,7 \%$ a.m & Isento \\
\hline CDB & $1 \%$ a.m & Isento \\
\hline Fundos de investimento & $1,8 \%$ a.m & $4 \%$ do Rendimento \\
\hline
\end{tabular}

Um amigo de Joaquim disse: "Cuidado com a inflação! Se você quiser ter dinheiro suficiente daqui a um ano para comprar a sua televisão, coloque o seu dinheiro na Caderneta de Poupança ao invés de guardá-lo debaixo do colchão".

f) Se Joaquim seguir o conselho de seu amigo, qual o valor que ele terá ao final de 1 ano aplicando mensalmente 200 reais na Caderneta de Poupança? Com esse valor, é possível Joaquim realizar o seu sonho, considerando a taxa média da inflação anual?

g) Por que as pessoas geralmente utilizam a Caderneta de Poupança como principal e/ ou único meio de investimento?

h) Com base nas informações dadas pelo Banco Poupe Aqui, qual opção de investimento você indicaria ao Joaquim para que a perda no seu poder de compra seja a mínima possível?

Figura 4 - Atividade envolvendo séries uniformes

Fonte: Elaboração própria.

\section{Considerações Finais}

A escola é responsável por preparar o indivíduo para o mercado de trabalho e também para o exercício da cidadania. Com atividades como estas aqui propostas, acreditamos estar contribuindo para que o aluno relacione a Matemática com a sua prática diária, além de conhecer conceitos referentes ao mundo financeiro, como a inflação.

Observamos, a partir das respostas dadas, que muitos alunos demonstraram ter melhorado sua compreensão sobre o tema. Inicialmente eles não sabiam o que era e afirmavam nem ter ouvido falar sobre inflação. A escola onde foi realizada a pesquisa é predominantemente de classe social baixa e o conhecimento dos alunos sobre os assuntos relacionados ao mundo das finanças se mostrou bastante precário, tanto assim que associavam a ideia de inflação a algo relacionado ao governo e à corrupção. Ao final das atividades, podemos dizer que obtiveram 
não somente conhecimento matemático, mas também conhecimento sobre Economia, que certamente usarão em suas vidas e poderão também transmitir para a sua família.

Percebemos também que as atividades aplicadas revelaram algumas falhas no processo ensino-aprendizagem, dentre elas destacamos a defasagem de alguns conhecimentos matemáticos básicos por parte dos alunos e a postura de alguns que por vezes não estavam muito motivados a participar da aula. Isso mostra que existem desafios ao trazermos aulas mais contextualizadas aos nossos alunos. Apesar de não ter sido um problema da escola em questão, sabemos que ainda temos também muita dificuldade em conseguir recursos adequados, como data show e até mesmo cópias, nas maiorias das escolas públicas.

Pensamos com este trabalho poder contribuir para a educação financeira dos alunos, formando cidadãos não somente conscientes e capazes de gastar o seu dinheiro, mas também, de planejar o seu futuro, administrar seus recursos financeiros de forma saudável e compreender de forma básica as questões em relação ao mundo financeiro, tomando assim decisões financeiras apropriadas.

Referências bibliográficas

BRASIL. Secretaria da Educação Fundamental. Parâmetros Curriculares Nacionais. Brasília, MEC/ SEF, 2000.

CONEF. Educação financeira nas escolas: ensino médio. Bloco 3 (livro do professor) elaborado pelo Comitê Nacional de Educação Financeira (CONEF) - Brasília: CONEF, 2013.

DIAS, C. T.; CONCORDIDO, C. F. R.; MACEDO, R. C. S. Trabalhando o conceito de inflação nas aulas de matemática. Revista de Educação, Ciências e Matemática v.6 n.3, 2016.

GREMAUD, A. P. et al. Introdução à Economia. São Paulo: Atlas, 2007.

MARTINS, J. P. Educação Financeira ao alcance de todos: adquirindo conhecimentos financeiros em linguagem simples. 1.ed. São Paulo: Editora Fundamento Educacional, 2004. 


\section{RIO DE JANEIRO: NATUREZA, BIODIVERSIDADE E O REGISTRO DOS VIAJANTES}

Maria da Gloria Tuxen - Mestranda no HCTE-UFRJ -

Nadja Paraense dos Santos - Professora do HCTE-UFRJ - nadja@iq.ufrj.br

"Sei que não são ruínas de Atenas; mas cada um mostra o que possui. O viajante entrou, deu uma volta, saiu e foi postar-se junto à muralha, fitando o mar, o céu e as montanhas, e, ao cabo de cinco minutos: 'Que natureza que vocês têm !' (...) A admiração do nosso hóspede excluía qualquer ideia de ação humana. Não me perguntou pela fundação das fortalezas, nem pelos nomes dos navios que estavam ancorados. Foi só natureza." (Machado de Assis, 1893)

Resumo

O presente trabalho discute a relação entre homem e natureza na cidade do Rio de Janeiro, a biodiversidade local e o efeito antrópico sobre esta. $O$ estudo dos relatos e da iconografia que nos deixaram os viajantes do século XIX, brasileiros ou estrangeiros, tem se mostrado de significativa importância para compreendermos a relação humana com o ambiente e o papel da natureza tropical na construção de nossa identidade.

Palavras-chave: Biodiversidade; Rio de Janeiro; Viajantes; Século XIX.

Introdução

Para o viajante do século XIX, naturalista ou não, vindo das florestas temperadas, pouco diversas e aparentemente ordenadas da Europa ou da América do Norte, a natureza tropical era fonte de deslumbramento e temor. A diversidade biológica impressionava (Diegues, 2001; PRESTES, 2000).

Os relatos sobre o Brasil perfazem mais de 260 obras sobre o Rio de Janeiro, cerca de 100 escritas em várias línguas. Os autores discorrem não somente sobre a flora e a fauna, mas também sobre os habitantes, a vida social, os usos e costumes, e outros aspectos. Há um incremento dos relatos principalmente durante o século $\mathrm{XIX}$, depois que Dom João $\mathrm{VI}$ decretou abertura dos portos brasileiros, em 1808. Dos viajantes que estiveram no Rio de Janeiro, boa parte era de naturalistas que, por um lado, ampliavam seus estudos e, por outro, forneciam aos os governos que os enviavam valiosas informações sobre as riquezas das novas terras. Através das anotações, diários e iconografia dos viajantes podemos analisar a relação entre homem e natureza, bem como a perda da biodiversidade no Rio de Janeiro decorrente do processo de urbanização.

\section{A Relação entre Homem e Natureza}

Os registros dos viajantes nos ajudam a identificar o grande impacto que a chegada do europeu trouxe sobre a biodiversidade do sítio onde se instalou a urbe carioca (AMADOR, 
1997). O sítio de ocupação da cidade era constituído por diversos ecossistemas muito biodiversos, característica esta que não escapou ao olhar atento do colonizador, interessado nas riquezas da terra.

Na medida em que a cidade se instala, os processos antrópicos de degradação ambiental se intensificam. $\mathrm{O}$ cuidado com o ambiente não era uma preocupação. Colocando-se em grau hierárquico superior ao dos demais seres vivos, o homem atribuiu-se o direito de usar a natureza como bem entender, sujeitando ou matando os demais seres.

O problema da legitimidade da exploração da natureza e do esgotamento dos recursos naturais já era levantado desde o Renascimento (ACOT, 1990). Posteriormente, Carl Lineu (1707-1778) postulava que "(...) a natureza inteira tende a prover a felicidade do homem, cuja autoridade se estende por toda a terra e que pode se apropriar de todo o seu produto". (ACOT, 1990). Mas o pensamento lineano também nos indica que a natureza é um sistema frágil, do qual cada parte é interdependente de outra. O processo de expansão e de ocupação das terras do Novo Mundo seguiu esse modelo. Os colonizadores buscavam nessas terras riquezas em forma de metais e pedras, mas descobriram outra riqueza: a biológica.

Por sua vez, o explorador europeu partia em busca da riqueza que não conseguira em sua terra. Seu objetivo era adquirir o bastante para uma vida melhor quando voltasse a seu país (Diegues, 2001). Assim o seu compromisso e cuidado em preservar a natureza eram nulos.

Na disputa pelo domínio econômico e político, os governos enviaram a volta do globo viajantes encarregados em mapear a topografia, catalogar e registrar a diversidade local e remeter as informações aos seus governantes. Para Acot (1990), a geografia vegetal nasceu da riqueza de informações que as grandes potências marítimas, em suas intenções précoloniais, financiaram. Não podemos esquecer também alguns viajantes andavam pelas novas terras às suas próprias custas.

Os relatos de viagens faziam sucesso, graças à atração que o diferente, o extraordinário exercia sobre a fértil mente humana. Muitos relatos, pouco preocupados com a verdade e mais com o sucesso de vendas, apelavam para o extravagante, levando a se acreditar em absurdos. Por sua vez, descrições de alguns animais misturavam realidade e fantasia, como no caso do bicho-preguiça, chamado Aí ou Aití pelos nativos, que ANDRÉ THEVET descreve em seu livro As Singularidades da França Antártica de 1557. A descrição lembra a mitológica Mantícora:

"É do tamanho de um mono africano adulto, apresentando uma barriga tão grande que chega quase a se arrastar no chão. A cabeça lembra a de uma criança, assim como também a cara, conforme pode ser visto na gravura tirada ao natural. Quanto preso, fica suspiran do como uma criança que sente dores. Sua pele é cinzenta e felpuda como a de um ursinho. Tem patas compridas, cada uma com quatro dedos, três dos quais com unhas parecendo grandes espinhas de carpa, com as quais trepa nas árvores onde fica por mais tempo do que em terra. " (THEVET, 1978, p.169)

Esse entrelaçar entre fantasia e realidade era frequente nos primeiros relatos de viagens pela América do Sul. Não havia a necessidade de um levantamento amplo de dados empíricos através de observações metodológicas da natureza (Prestes, 2000). 


\section{Biodiversidasde e Efeitos Antrópicos}

Os relatos sobre a região do Rio de Janeiro e sua biodiversidade remontam a períodos tão distantes como o da construção do forte Coligny na ilha de Serigipe, hoje Villegagnon, no momento da fundação da França Antártica (1555). Já no século XIX o número de viajantes aumentou significativamente (Tabela 1 ) e os relatos tornam-se mais numerosos. Esses viajantes cruzavam o Brasil e, frequentemente, o ponto de partida ou de chegada era a cidade do Rio de Janeiro.

Tabela 1: Viajantes que passaram pelo Brasil do século XVI ao XIX (início).

\begin{tabular}{|c|c|c|c|c|c|c|}
\hline Franceses & & 3 & 10 & 14 & 14 & 28 \\
\hline Ingleses 5 & 82 & 20 & 20 & 42 & & \\
\hline Holandeses & & & 1 & 7 & - & 8 \\
\hline Germânicos & 2 & 3 & 4 & 1 & 10 & \\
\hline Espanhóis & 1 & 3 & - & - & - & 4 \\
\hline Italianos & 1 & 4 & - & - & - & 5 \\
\hline Russos & - & - & - & - & 2 & 2 \\
\hline Sueco & - & - & 1 & 1 & - & 1 \\
\hline TOTAL & 13 & 35 & 35 & 39 & 13 & 100 \\
\hline
\end{tabular}

Fonte: FRANÇA, 2012, p. 185-186

Entre os viajantes do século XIX muitos eram naturalistas, como Carl Friedrich Philipp von Martius, Johann Baptist von Spix e Charles Darwin. Nesse momento, a preocupação com o rigor e a correção nas descrições e relatos torna-se maior. Os limites das ciências estavam sendo melhor definidos, embora os cientistas fossem vistos como meros desveladores da realidade e da ordem inalterável da natureza, a qual se chegava por observações, experimentos e dedução racional.

O viajante estrangeiro, por não fazer parte da cultura local, identificava aspectos da vida cotidiana não percebidos pelo habitante, por dá-los como naturais e permanentes. Como escreve FREIRE ALEMÃO (Mata Atlântica- 500 anos, 2000):

\footnotetext{
"As riquezas naturais do Brasil têm sido melhor examinadas e descritas pelos estrangeiros: ou porque os brasileiros em geral se dão pouco à cultura das ciências naturais; ou porque os governos, que se sucedem rapidamente e sempre agitados pelos movimentos políticos, não têm tido repouso bastante para fazer o inventário do rico legado com que a Natureza nos dotou: assim é também pela obra dos viajantes estrangeiros, que nós conhecemos a maior parte dos produtos e tesouros de nossa terra." (Autor, ano)
}

Foram muitos os viajantes que estiveram no sítio ocupado pela atual cidade do Rio de Janeiro: Johann Baptist von Spix, Carl Friedrich P. von Martius, Georg Heinrich von Langsdorff, Thomas Ender, Maria Grahan, Charles Darwin, Jean de Léry, Johann Moritz Rugendas, Auguste SaintHilaire, François Auguste Biard, John Luccok, John Mawe, Gardner, Louis Agassiz, Johann Emanuel Pohl, Oscar Canstatt, só para citar alguns.

Mesmo considerando o contexto dos relatos, observa-se o impacto da diversidade e do aparente caos da floresta tropical sobre os viajantes estrangeiros. Grande número dos viajantes europeus viveram a Era Vitoriana (1837-1901), período onde a ciência encontrava prazer estético na objetividade, na simplicidade, na harmonia e na ordem (PARADIS, POSTLEWAIT, 1981). Mas a natureza tropical, vista como infinitamente complexa e 
esteticamente ambígua, se apresentava como um grande desafio a se entender os processos e desvelar a ordem.

As duas imagens que se seguem complementam a discussão, apontando para uma questão filosófica: a sensação de insignificância do homem ante a grandiosidade das florestas tropicais, gerando simultaneamente medo e admiração. Na Figura 1, o quadro Floresta Virgem (1819) do CONDE CHARLES OTHON FRÉDÉRIC JEAN-BAPTISTE DE CLARAC, os homens, muito pequenos, valorizam por seu tamanho, a grandiosidade da floresta brasileira e de suas árvores. Na Figura 2, o quadro Brazilian Forest (1864) de MARTIN JOHNSON HEADE, a grandeza magnífica e opressiva da floresta tropical, é acentuada pelo homem minúsculo, quase invisível ante as árvores gigantescas.

Os ecossistemas do Rio de Janeiro são descritos por SCHLICHTHORST, viajante do século XIX:

“Dali, a vista é surpreendentemente bela. Floresta e serras ficam muito abaixo do pico, que domina tudo, perpendicularmente, do lado do mar. As ondulações montanhosas mostram-se em relevo com o verde mais ou menos vivo dos arvoredos que as revestem. Nos vales que se enterram profundamente entre as matas virgens, como listas de cor, a vida grulha animadíssima. Planícies e praias cobrem-se de moradias e jardins. No meio, estendem-se maravilhosas lagoas, separadas do oceano por estreita restinga que a ressaca alternadamente desfaz e renova." (SCHLICHTHORST, 2000, p. 207)

\footnotetext{
Figu Figu

ra 1. ra 2.

- M.

CONHEA

DE DE.

DE Flor

CLA esta

RACBras

ileir

Flor a. (C

esta D

virg rom

em. Mat

(CD a

rom Atlâ

Mat ntic

a $a / 50$

Atlâ 0

ntic ano

a/50 s -

0 Jardi

ano $\mathrm{m}$

s - Botâ

Jardi nico

$m$ do

Botâ Rio

nico de

do Jane

Rio iro,

de 2000

Jane )

iro,

2000

)
} 


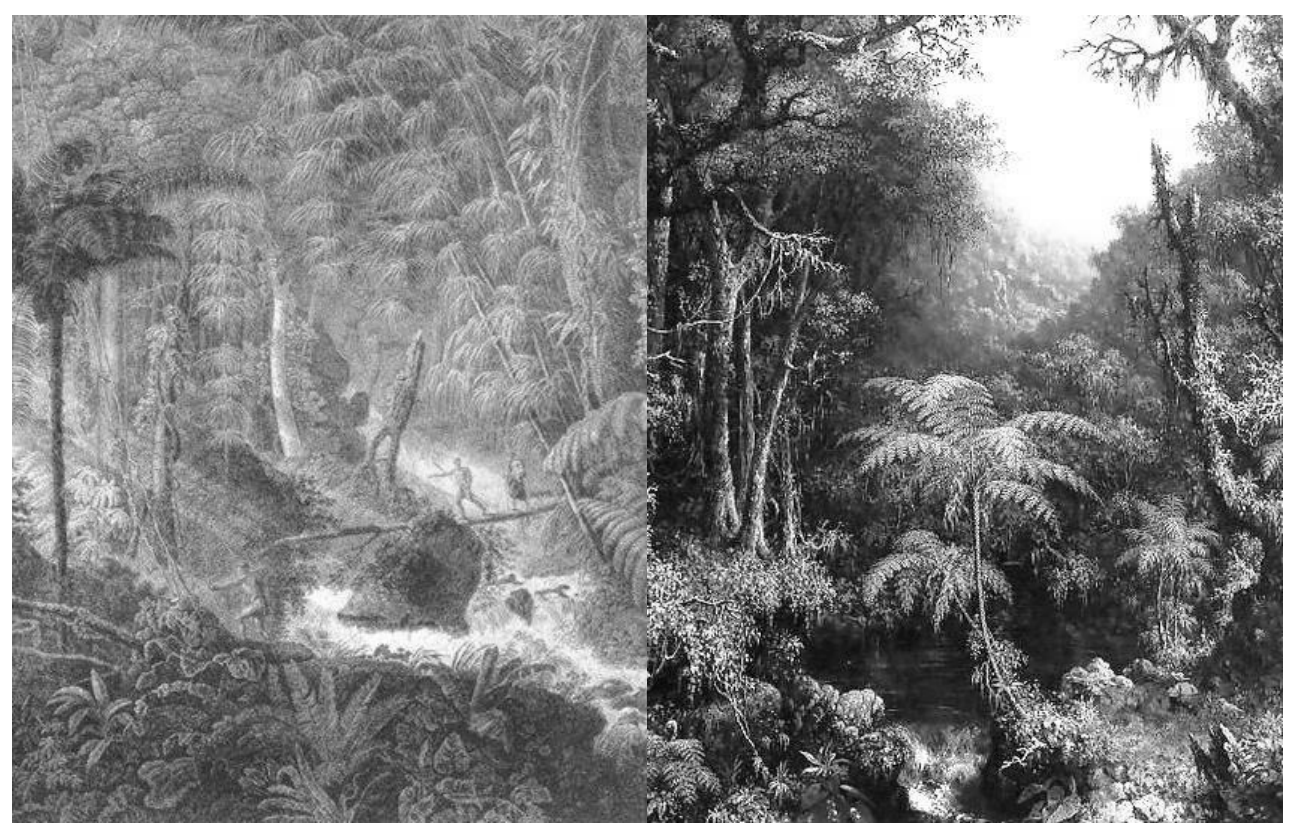

E por DARWIN, em 1832, assim:

"Seguindo uma picada, penetrei no interior de uma nobre floresta e, de uma altura de 150 a 200 metros, pude contemplar um dos soberbos panoramas tão comuns ao redor de todo o Rio. Vista dessa altura a paisagem atinge o máximo de brilho em seu colorido; e todas as formas e sombras ultrapassam de tal modo tudo quanto um europeu possa jamais ter visto em sua terra natal, que não sabe como há de expressar as emoções em seu espírito. $O$ efeito geral sempre me trazia à mente o cenário das óperas nos grandes teatros." (DARWIN, s/d, pp 52 e 53)

A iconografia também é um importante registro do impactante encontro com a natureza tropical. É o que observamos na Figura 3, onde um homem enfatiotado à inglesa, no alto do Corcovado, demonstra a surpresa que a paisagem lhe causou por

sua postura. O Velho Continente, representado pelo homem, "descobre" o Novo Mundo e a natureza é tão impactante que sobrepuja o urbano de tal forma que a cidade nem é representada. Até o Imperador Dom Pedro II, grande entusiasta da ciência e da cultura, deixou-se fotografar junto a algumas orquídeas e bromélias (Figura 4). Identificando-se com essa natureza exuberante, o imperador ganhava ainda mais majestade, grandeza e, ao mesmo tempo, avisava, ser o senhor de toda essa riqueza.

A cidade do Rio de Janeiro ocupa uma área originalmente de ecossistemas muito produtivos e frágeis (AMADOR, 1997), responsáveis por importantes serviços ambientais e que sofreu devastadora interferência com a instalação da urbe. Fundada em 1565, a cidade foi transferida para o morro do Castelo com a retirada dos portugueses da região localizada entre os morros Cara de Cão e Pão de Açúcar, após a vitória sobre os franceses. Gradativamente a cidade foi ocupando os outros três morros do Centro: Conceição, São Bento e Santo Antônio, 
formando um quadrilátero. A rua mais antiga da cidade, a rua Direita ou Direta, ligava os morros do Castelo ao de São Bento, hoje chama-se Primeiro de Março.

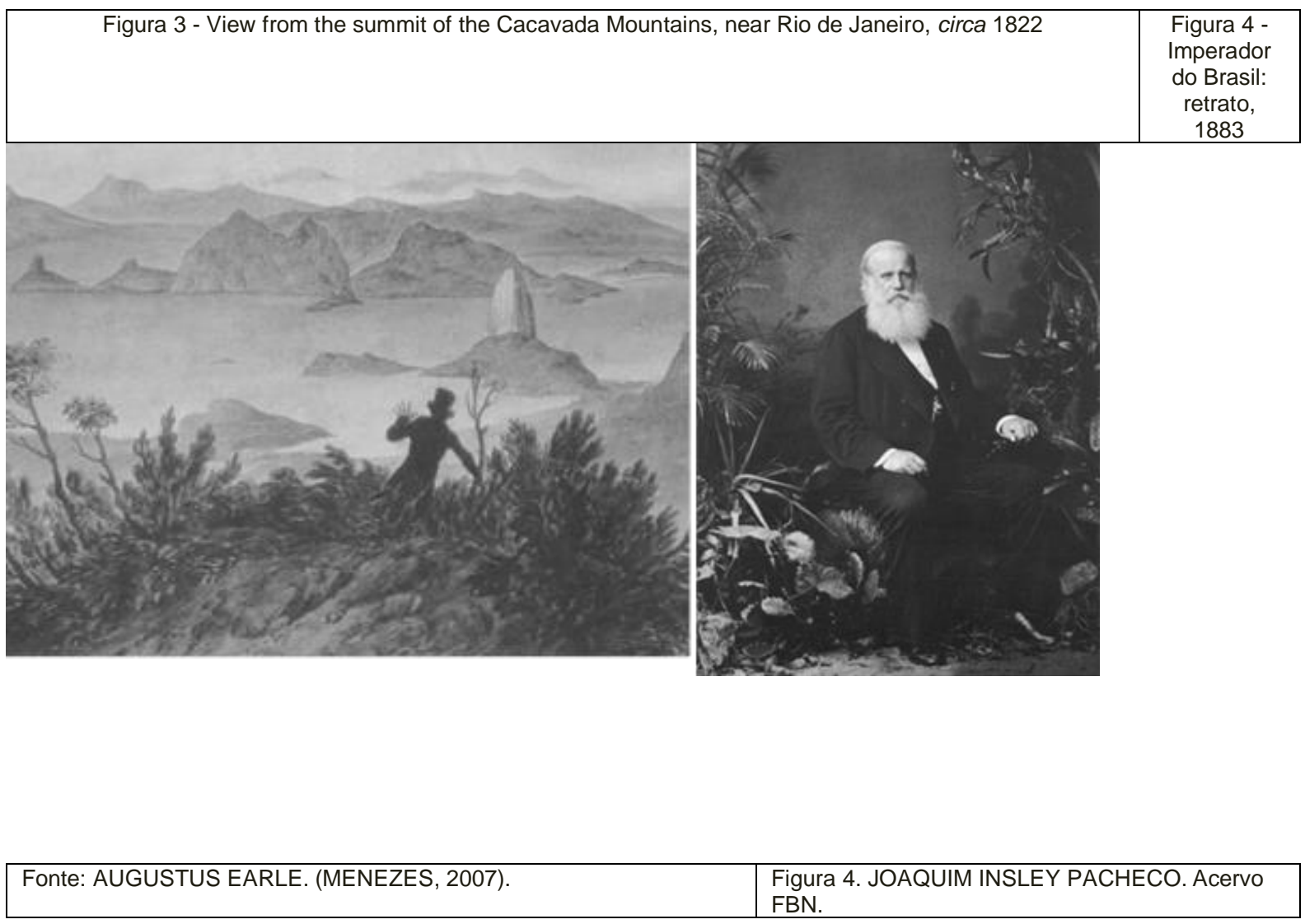

A região foi aterrada e planificada ao longo do tempo, sem preocupação com os ambientes que iam sendo arrasados. Os registros dos viajantes, no entanto, nos dão informações sobre diversidade local. Dos ecossistemas, havia muitos mangues cuja fama de serem fontes de doenças e outras mazelas lhes justificariam o aterro. As regiões entre o quadrilátero de morros do Centro e o caminho em direção a São Cristóvão apresentavam grande quantidade de lagunas e mangues.

Havia também regiões com aspecto de lagoa, como a atual rua Visconde de Inhaúma, que era inundada na preamar. As restingas, barras lagunares, eram as de Uruçu-mirim, praia do Russel, extremidade da lagoa do Boqueirão e restinga de Manoel de Brito, junto ao morro de São Bento. Esta última ficava na Prainha, atual Praça Mauá.

\section{Conclusão}

Se o sítio do Rio de Janeiro era, para os primeiros viajantes, o Paraíso, no século XX a situação tornou-se outra. Claude Lévi-Strauss (TRISTES TRÓPICOS, 1957, p. 95. apud PERRONEMOISÉS, 1996) sintetiza a situação dos ecossistemas originais da cidade do Rio de Janeiro:

“Ao redor de mim, a erosão destruiu as terras de relevo inacabado, mas é sobretudo o homem o responsável pelo aspecto caótico da paisagem. Primeiramente desmoitou-se para cultivar; mas ao fim de alguns anos, o solo, esgotado e lavado pelas chuvas, furtou-se aos cafezais. E as plantações se transportaram para mais longe (...). Aqui o solo foi violado e destruído. "(autor, ano)

Segundo Perrone-Moisés (1996), a visão desencantada de Lévi-Strauss se transforma em um aviso: "Espoliados de nossa cultura, desprovidos de valores que prezávamos - pureza da água 
e do ar, graças da natureza, diversidade das espécies animais e vegetais -, todos nós índios agora estamos fazendo conosco o que fizemos com eles". Para a maioria dos ecossistemas da região do Rio de Janeiro o que resta é só o registro feito pelos viajantes. Os importantes serviços ambientais prestados por esses ecossistemas foram aniquilados. Os que deles dependiam, ou foram eliminados ou precisaram se mudar.

No Brasil de antanho a natureza e sua biodiversidade eram a garantia do futuro progresso. $\mathrm{O}$ ambiente era avaliado tendo em vista o que dele se poderia extrair e comerciar. A visão do homem contemporâneo pouco mudou. Hoje, analisar a nossa história ambiental, entender que ela está intimamente relacionada às nossas visões de mundo e ao conceito de natureza, a quem éramos e a quem somos, é condição necessária à sobrevivência em um mundo globalizado, onde a lei do mercado gera um número crescente de excluídos social e ambientalmente falando. É preciso aprendermos com a nossa história ambiental a fim de mudarmos nossa história futura.

Referências bibliográficas

ACOT, Pascal. História da Ecologia. Rio de Janeiro: Editora Campus, 1990.

AMADOR, Elmo da Silva. Baía de Guanabara e ecossistemas periféricos: homem e natureza. Rio de Janeiro: Edição do autor, 1997.

ASSIS, Machado de. A Semana, v.1, p 365, 20 de agosto de 1893.

CRULS, Gastão. Cruls, G. A Aparência do Rio de Janeiro.1965, volume 1. José Olympio, Rio de Janeiro.

DARWIN, C. Viagem de um naturalista ao redor do mundo. Vols. 1. Rio de Janeiro: SEDEGRA, s/d.

DEL PRIORE, Mary. Esquecidos por Deus: Monstros no Mundo Europeu e Ibero-americano (séculos XVI-XVIII). São Paulo: Companhia das Letras, 2000.

Diegues, Antonio Carlos. O Mito Moderno da Natureza Intocada. São Paulo: Editora Hucitec, 2001

FRANÇA, Jean M. Carvalho. A construção do Brasil na literatura de viagem os séculos XVI, XVII e XVIII: antologia de textos (1591-1808). Rio de Janeiro: José Olympio Ed. ;SP: Unesp, 2012.

, Visões do Rio de Janeiro Colonial. RJ: Ed. José Olympio, 1999.

MACEDO, J. M. Memórias da Rua do Ouvidor - Coleção Temas Brasileiros, 63 - Documentos e Estudos - Editora UnB - 1988

MARTINS, L. de L. O Rio de Janeiro dos viajantes: o olhar britânico, 1800-1850. Rio de Janeiro: Jorge Zahar Editor, 2001.

PARADIS, J. G. \& Postlewait, T. Victorian Science and Victorian Values: Literary Perspectives. New York: The New York Academy of Sciences, 1981.

PERRONE - MOISÉS, L. Alegres Trópicos: Gonneville, Thevet e Léry. Revista USP, São Paulo (30) : 84 -93, junho/agosto, 1996

PRESTES, M.E.B. A Investigação da Natureza no Brasil Colônia. São Paulo: Annablume/FAPESP, 2000.

SCHLICHTHORST, C. O Rio de Janeiro como é (1824-1826): uma vez e nunca mais: contribuições de um diário para a história atual, os costumes e especialmente a situação da tropa estrangeira na capital do Brasil. Brasília: Senado Federal, 2000.

THEVET, André. As singularidades da França Antártica. Belo Horizonte - São Paulo, Editora Itatiaia-Editora da Universidade de São Paulo, 1978. 
WILSON, E.O. (org.) Biodiversidade. Rio de Janeiro: Editora Nova Fronteira, 1997. Mídia CD rom Mata Atlântica500 anos - Jardim Botânico do Rio de Janeiro, 2000. 


\section{EXPLORANDO AS OFICINAS DE SÓLIDOS}

Andréa Zander Vaiano - DMAT-FFP. - UFRJ - andreazanderv@gmail.com June Cunha de Araujo - Colégio MV 1, São Gonçalo, RJ - junearaujo75@gmail.com

Rosa García Márquez - DMAT-FFP. UERJ - rosagm@uerj.br

Resumo

O presente trabalho apresenta o relato de experiência na abordagem de geometria espacial realizada junto ao Curso Normal de uma escola pública de São Gonçalo/RJ. Em geral, o ensino de geometria espacial é focado exclusivamente em fórmulas, não se despertando a habilidade visual do aluno e estando desvinculado das aplicações no cotidiano e em outras ciências. A fim de potencializar a aprendizagem, buscamos articular história da geometria, lúdico e material concreto, permitindo uma melhor visualização dos elementos e suas relações, e consequentemente, uma abstração. O objetivo principal foi fazer com que os participantes repensassem e adequassem as experiências por que passaram, em suas futuras turmas, uma vez que as oficinas propostas oferecem tanto simplicidade quanto baixo custo.

Palavras-chave: Geometria Espacial. Prática Pedagógica. Teoria De Van Hiele. História Da Geometria.

\section{Introdução}

Vestígios arqueológicos mostram que o homem paleolítico já representava figuras geométricas. Acredita-se que os egípcios foram os primeiros a utilizar conhecimentos geométricos empíricos na construção de pirâmides e outros monumentos, enquanto os gregos, a utilizar o raciocínio lógico e dedutivo na tentativa de formalizar a geometria plana e espacial, sendo Tales de Mileto (624 a.C. - 558 a.C.) o precursor.

Levando-se em conta as orientações dos Parâmetros Curriculares Nacionais (Brasil, 1998), a atividade escolar não deve "olhar para coisas prontas e definitivas, mas à construção e à apropriação de um conhecimento pelo aluno" (autor, ano,p.56). Essa ideia também era defendida pelo educador suíço Johann Pestalozzi (1746-1827) quando afirmava que "a vida educa. Mas a vida que educa não é uma questão de palavras, e sim de ação. É atividade.". A construção de sólidos em sala de aula permite a sua manipulação e exploração, auxiliando a construção gradativa de conceitos geométricos de maneira recreativa, o que facilita o processo de ensino-aprendizagem. Neste sentido, através do presente trabalho, objetivamos apresentar oficinas desenvolvidas com os alunos normalistas, encontradas na literatura digital, impressa e em conhecimentos populares, tendo como base o legado de Pestalozzi, van Hiele e aportes de Gutierrez. Tal levantamento tem, além do valor da divulgação, o intuito de ser um importante instrumento de incentivo a trabalhos manuais, buscando com isso novas possibilidades pedagógicas e tipos de interações que possam estimular o estudo de sólidos.

\section{Referencial teórico}

Desde os anos iniciais é muito falado sobre a importância de tocar, observar e identificar objetos que estão à nossa volta para uma melhor exploração do espaço (Pestalozzi, 2006). A construção de sólidos geométricos feita pelos alunos descontrai o ambiente escolar, desmistifica a dificuldade que a visualização na lousa causa, ajuda na assimilação dos conceitos envolvidos, tais como o reconhecimento dos elementos e propriedades, bem como suas aplicações no cotidiano. 
A dificuldade da visualização de sólidos, assim como a sua planificação, propriedades e conceitos é o que nos motiva ao levantamento de oficinas de sólidos. Por conta disso objetivamos oferecer uma coletânea de formas diferenciadas de oficinas que possam contribuir com professores e futuros professores, para repensarem e adequarem, a fim de proporcionar uma aprendizagem mais significativa de seus alunos.

Teoria de van Hiele e Gutierrez

A teoria de van Hiele foi elaborada em 1957 na dissertação de doutorado pelo casal de holandeses Dina van Hiele e Pierre van Hiele. É uma teoria de ensino e aprendizagem da geometria em forma construtiva e didática, composta basicamente por cinco níveis graduais de pensamento: visualização, análise, classificação ou dedução informal, dedução formal e rigor (MASON, 1997).

Gutierrez (1992) estendeu os níveis de van Hiele para além das figuras no plano. Para ele, a teoria de van Hiele tendo os mesmos níveis, serve de estrutura para a compreensão dos processos de aprendizagem da geometria espacial e abrange tanto a aquisição de habilidades, quanto a compreensão das relações entre conceitos. A visualização integra habilidades de: reconhecer um objeto, independente de cor, tamanho, textura ou posição, e suas propriedades; produzir imagens mentais; relacionar e comparar objetos, identificando semelhanças e diferenças entre eles; lembrar de um objeto e de suas características, quando este é rotacionado ou escondido, parcialmente ou totalmente. Gutierrez (1996) defende ainda a necessidade de se realizarem atividades em que se observem as conexões entre o bi e o tridimensional.

Os níveis apresentados tanto na teoria de van Hiele quanto na adaptação de Gutierrez constituem um guia de aprendizagem e um instrumento de avaliação das habilidades dos alunos em geometria plana e espacial.

O professor tem um papel fundamental ao definir tarefas adequadas a fim dos alunos progredirem para níveis superiores do pensamento.

\section{Referencial histórico}

A geometria surgiu em várias civilizações antigas independentemente, de acordo com as suas necessidades, com aplicações na agricultura, arquitetura, engenharia e astronomia.

Entre 2000 a.C. e 1600 a.C. os babilônios já utilizavam seus conhecimentos geométricos, conquistados através da prática. Por ser a Babilônia um grande centro comercial entre os rios Tigre e Eufrates na época, a Matemática era mais avançada que a egípcia. Porém, inicialmente os historiadores acreditavam o contrário, pelo fato de serem encontradas tardiamente placas de argila babilônicas com conteúdos matemáticos, como por exemplo, o Plimpton 322 (aproximadamente entre 1800 e 1600 a.C.), que apresenta colunas, representando um cateto e a hipotenusa de triângulos retângulos de lados inteiros (EVES, 2002) e a tábua catalogada como YBC 7289 (1600 a.C.), que mostra o cálculo da raiz quadrada de 2, a partir das diagonais de um quadrado (STEWART, 2007).

A civilização egípcia acreditava que, quando um corpo morto fosse conservado, haveria vida após a morte. Então, a partir de suas necessidades, desenvolveram conhecimentos matemáticos avançados, bem como de engenharia, para construir túmulos. Dentre eles, se destaca a Pirâmide de Gizé, construída em cerca de 2600 a.C. para abrigar o corpo de um faraó. Em documentos egípcios antigos, tais como o Papiro de Rhind e o Papiro de Moscou, datados por volta de 1650 a.C. e 1850 a.C., respectivamente, foram encontrados problemas envolvendo volumes acompanhados de suas soluções.

Porém, tanto egípcios quanto babilônios, apesar de terem expressivos conhecimentos matemáticos, não possuíam nada formalizado. De acordo com Eves (2002), o poder desses 
povos foi diminuído por mudanças políticas e econômicas, dando abertura aos matemáticos gregos.

Os gregos melhoraram a geometria dos babilônicos, aportaram ideias cruciais para a compreensão sistemática da geometria, e uso na arquitetura, construção de navios, entre outros. Também, por serem grandes comerciantes, estavam em constante contato com os egípcios. Observando os cálculos realizados em construções de túmulos e monumentos, procuraram justificá-los através de demonstrações dedutivas rigorosas. O primeiro a fazer tentativa foi Tales de Mileto, negociante de azeite, que em 640 a.C. levou o que havia aprendido em suas viagens pelo Egito e pela Babilônia para a Grécia. Depois veio Pitágoras, discípulo de Tales, que fundou uma escola que era ao mesmo tempo semirreligiosa e semimatemática. Nesta escola se aprendia a adorar os números, pois se achava que os números eram a essência do universo. Outro importante grego que contribuiu na formalização da geometria foi Euclides, com sua obra-prima 'Elementos', onde reuniu resultados dos gregos desde Tales, representando, deste modo, o ápice da produção matemática da época.

Procedimentos metodológicos

A implementação das oficinas ocorreu em duas turmas de formação do curso normal do Colégio Pandiá Calógeras, localizado em São Gonçalo/RJ em junho de 2012, por representarem uma queixa constante dos alunos quanto às dificuldades visuais e teóricas básicas nos conceitos e propriedades de figuras planas, estudados em séries anteriores. Foram quatro encontros realizados em horário extraclasse, cada qual com duas horas de duração.

A elaboração das ações se deu em etapas: inicialmente com um relato histórico sobre as origens e desenvolvimento da geometria plana e espacial nos diferentes povos da Antiguidade. Pretendemos com tal procedimento mostrar aos participantes que tais conhecimentos foram imprescindíveis para resolver necessidades práticas desses povos. A seguir, direcionou-se para a manipulação dos sólidos que seriam construídos, com a identificação e análise de suas propriedades, a fim de se obter uma maior familiarização. Em um terceiro momento, os participantes receberam materiais e instruções para a elaboração dos sólidos propostos e foram realizadas as oficinas, que detalharemos neste trabalho: oficina de planificação, oficina de jujuba e oficina de revolução.

Oficina de Planificação

A partir de planificações feitas em cartolina, confeccionamos os sólidos, conforme mostra a Figura 1. Escolhemos essa oficina por permitir a construção de vários poliedros e corpos redondos a partir de sua planificação, levando a observação da ligação existente entre a geometria plana e espacial, e melhorando deste modo, a percepção espacial. Centenas de modelos de planificação para a construção de poliedros podem ser encontradas no site criado por Gijs Korthals Altes (2013). 
Figura 1 - Cilindro oblíquo, sua planificação e montagem final
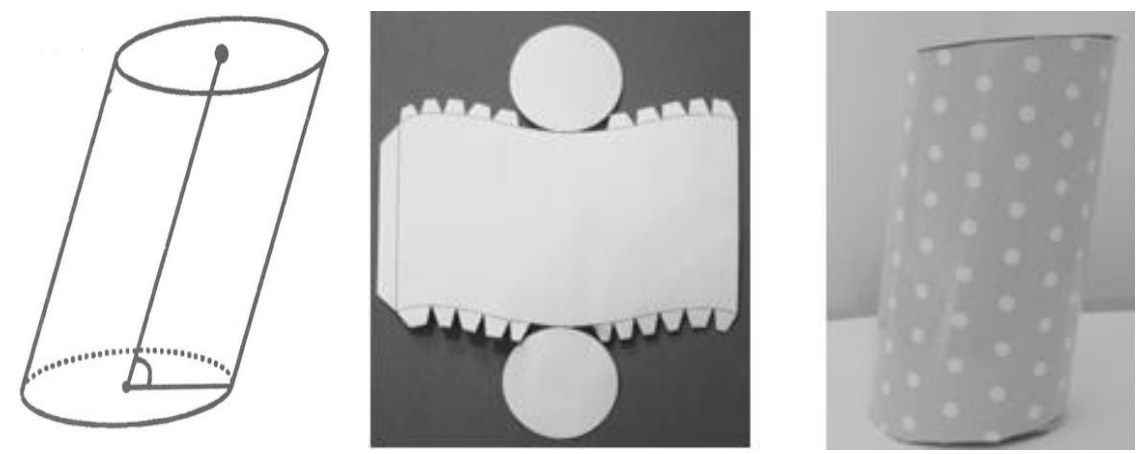

Oficina de Revolução

Essa é uma oficina que faz ligação entre a geometria plana e espacial. A ideia principal dessa oficina é trabalhar com figuras planas, que ao serem rotacionadas rapidamente em 360 graus em torno de um eixo que pode ser um palito de churrasco, por exemplo, geram um sólido (Figura 2). O destaque para essa oficina em relação às outras é a construção da esfera. Interessante também é a estimulação da criatividade do aluno, que se torna um agente construtor de seu conhecimento, no momento em que é convidado a criar as mais diversas figuras planas a serem giradas e ver a forma do sólido produzido. Essa atividade foi complementada com o software livre desenvolvido pela Unicamp/SP, o qual possibilita a construção e a visualização de um sólido de revolução no computador, disponível em http://m3.ime.unicamp.br/media/software/1230/index.html.

Figura 2 - Modelos para rotação (bandeirinhas) e seu respectivo sólido de revolução
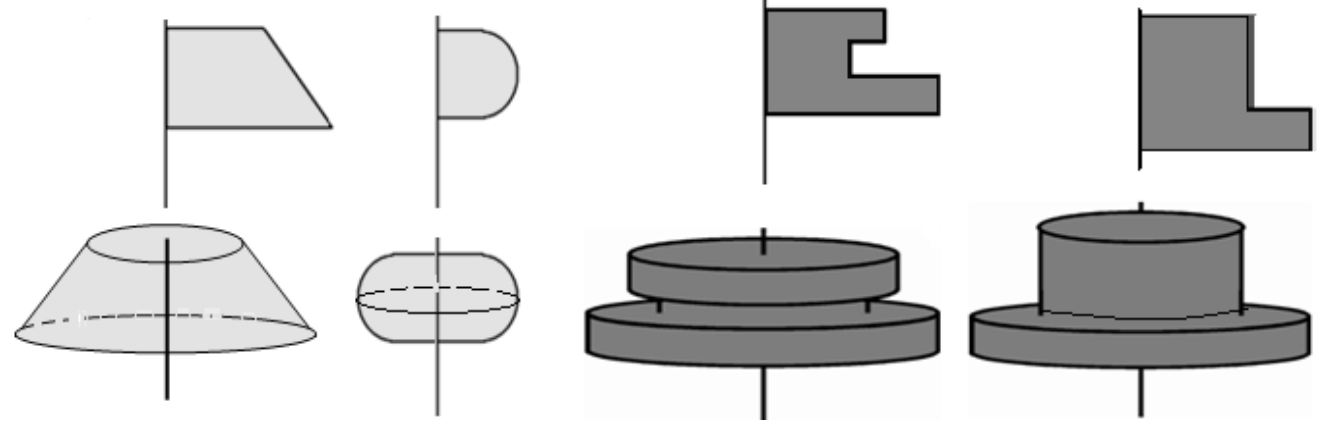

Oficina de Jujuba

Essa oficina utiliza as balas de goma e os palitos de dente como os vértices e as arestas do esqueleto do poliedro a ser construído, de acordo com a figura 3. Além de serem feitos com material de baixo custo e oferecem estabilidade aos poliedros construídos, trazem descontração ao ambiente de sala de aula pela possibilidade de saborear as jujubas ao final do trabalho. Uma desvantagem é que corpos redondos não são possíveis de serem confeccionados nessa oficina. 

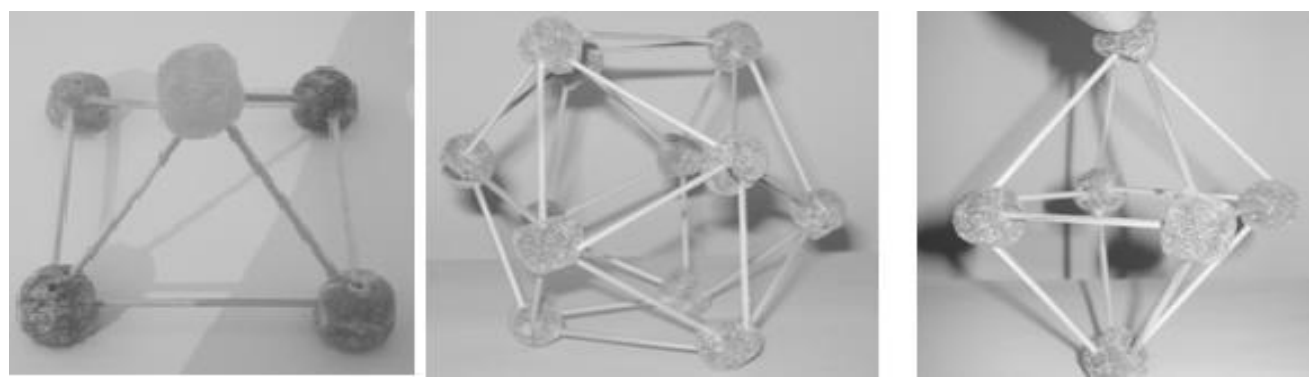

Figura 3 - estruturas de poliedros de platão com palitos e jujubas.

Durante todo o procedimento foram feitos questionamentos, desencadeando discussões e conduzindo os normalistas a descobertas/redescobertas quanto às características e relações entre sólidos.

Também, nos encontros foi observado que os normalistas não viam conexão entre a geometria ensinada em sala de aula e as situações do cotidiano. Por esse motivo, introduzimos exemplos que mostrassem a importância de seu estudo, tais como indústria, comércio, agricultura e saúde, seja na confecção de armários, caixas d'água, embalagens de produtos, e silos, bem como em tratamentos de saúde diversos, onde se utilizam volumes de fluidos.

As oficinas apresentadas e outras delas podem ser encontradas em Araujo (2012).

\section{Considerações e Resultados obtidos}

No conjunto de ações propostas, observamos que a participação ativa do grupo de normalistas sob um ambiente dinâmico e lúdico, proporcionou a construção/reconstrução do conhecimento, suprindo deficiências de conceitos geométricos e estimulando a capacidade de criar e adaptar as atividades.

Ao final das ações desenvolvidas, os participantes demonstraram certa ansiedade em aplicar o que tinham aprendido em suas futuras turmas, dando sugestões de suas aplicações de forma indireta, como por exemplo, a construção dos sólidos aprendidos em festas juninas e natalinas, percebendo que a construção destas obras de arte requerem criatividade, persistência e paciência.

O professor tem papel importante como mediador no direcionamento das ações, para que se garanta uma aprendizagem efetiva.

Referências bibliográficas

ALTES, G.K. Paper models of polyhedra. Disponível em: <http://www.korthalsaltes.com>. Acesso em: dez. 2013.

ARAUJO, J. Explorando as oficinas de sólidos. Monografia de Especialização em Ensino de Matemática. FFP/Uerj, 2012.

BRASIL. Parâmetros Curriculares Nacionais. Matemática. Ensino Fundamental - Terceiro e Quarto Ciclos. Brasília: MEC/SEF, 1998.

EVES, H. Introdução à história da matemática. 3 ed., Campinas, SP: Editora da Unicamp, 2002.

GUTIERREZ, A. Exploring the links between van Hiele levels and 3-dimensional Geometry. University of Valence, Spain, 1992. Disponível em: <http://www.uv.es/gutierre/archivos1/textospdf/Gut92a.pdf>. Acesso em: abr. 2017.

GUTIERREZ, A. Visualization in 3-dimensional geometry: in search of a framework. University of Valence, Spain, 1996. Disponível em: http://www.uv.es/Angel.Gutierrez/archivos1/textospdf/Gut96c.pdf. Acesso em: ago. 2016. 
MASON, M. The van Hiele model of geometric understanding and mathematically talented students. Journal for the Education of the Gifted 21: 38-53, October, 1997.

PESTALOZZI, J.H. Cartas sobre educación infantil. 3 ed. Madrid, España: Editorial Tecnos S.A., 2006.

STEWART, I. Historia de las matemáticas em los últimos 10.000 años. Barcelona: Editora Critica, 2007. 


\section{SONHOS LÚCIDOS: METODOLOGIA, DESENVOLVIMENTO DE HABILIDADES, PREVALÊNCIA E INDUÇÃO}

Alexandre Valença - Doutorando no HCTE /UFRJ - alexandre@hcte.ufrj.br

ResumoOs sonhos lúcidos (SL) são caracterizados como o estado no qual o sonhador está consciente que está sonhando, durante o sonho. Esse estado paradoxal, tem despertado investigações em diversos campos de saber. Nossos objetivos neste artigo são: apresentar uma proposta de unificação conceitual dos SL; identificar as contribuições dos SL, como uma "ferramenta" para otimizar os desempenhos cognitivo e motor ; identificar as taxas de prevalência dos sonhadores lúcidos. Outra questão: dado que a frequência de sonhos lúcidos na população é baixa, haveria como aumentá-la para ampliar seus benefícios? Diversas técnicas e dispositivos de indução surgem como alternativa para potencializar a frequência dos sonhos lúcidos, mas seriam eficientes? Buscaremos aqui apresentar algumas respostas.

Palavras-chave: Sonhos Lúcidos. Aprendizagem. Prevalência. Indução.

Introdução

O sonho lúcido (SL) é caracterizado como um estado mental no qual o indivíduo está consciente que está sonhando, ainda durante o sonho (LABERGE,1985; GILLESPIE, 1983). Contudo, não há um consenso amplo sobre esta definição, o que traz desdobramentos metodológicos relevantes, que retomaremos no item 2. Abordaremos aqui, ainda, algumas aplicações dos sonhos lúcidos no desenvolvimento de habilidades cognitivas e motoras, suas taxas de prevalência em diferentes países e, por fim, algumas técnicas de indução que visam favorecer a ocorrência e frequência dos SL, uma vez que suas taxas de frequência são relativamente baixas.

\section{Definições de SL e Proposta de Unificação}

Não há uma definição consensual sobre os SL. Para alguns, o sonho lúcido é caracterizado como um estado mental no qual o indivíduo está consciente que está sonhando, ainda durante o sonho (LABERGE,1985; GILLESPIE, 1983). Outros autores entendem que, além da consciência que está sonhando durante o sonho, o indivíduo deve ser capaz, também, de manipular seu conteúdo, como o cenário do sonho, seus personagens, ações e outros (VANEDEN,1913; SNYDER e GACKENBACH,1988). LaBerge e seus associados chamaram as pessoas que exploram intencionalmente as possibilidades dos "sonhos lúcidos" de "onironautas", expressão que significa "exploradores de sonhos" (LABERGE,1985).

Como existe essa questão conceitual, envolvendo a própria definição de "sonhos lúcidos", que implica em questões metodológicas relevantes, sugerimos que seja realizada uma separação conceitual entre os "sonhadores lúcidos" e os "onironautas", onde os primeiros seriam aqueles sonhadores que "apenas" estão conscientes que estão sonhando enquanto sonham; e os "onironautas", seriam aqueles que além da consciência, teriam a habilidade de controlar e manipular os conteúdos oníricos, como o ambiente, os personagens e as ações que ocorrem durante o sonho. Outra alternativa, acompanhando essa mesma ideia, seria diferenciar entre "sonhos lúcidos" e "sonhos controlados". Desta forma, haveria uma delimitação clara de cada fenômeno, explicitando suas condições necessárias. Embora, possa 
parecer, a princípio, uma questão menor, a definição conceitual clara, precisa e consensual do fenômeno SL é fundamental, pois, a divergência entre uma definição e outra produz inúmeros equívocos e diferenças importantes na interpretação de resultados como dados de ocorrência, frequência, entre outros, como veremos no item 3. Desta forma, solucionaríamos um problema conceitual, que tem desdobramentos relevantes para questões metodológicas nas pesquisas sobre sonhos lúcidos.

Neste artigo, entenderemos sonho lúcido como o fenômeno onde o indivíduo tem consciência que está sonhando, enquanto ainda experencia o sonho, durante o sonho. Compreendemos que controlar e manipular o sonho é uma habilidade a mais que, contudo, não é condição necessária para a definição de sonho lúcido, acompanhando a definição de LaBerge e de Gillespie (LABERGE, 1985; GILLESPIE, 1983),

\section{Aplicações: Desenvolvimento de Habilidades Cognitivas e Motoras}

Os sonhos lúcidos, que durante muito tempo eram vistos apenas como um fenômeno lúdico, encontraram utilização nos processos de aprendizagem e criatividade e como recurso terapêutico, especialmente nos casos de pacientes que sofrem pesadelos frequentes, oriundos de estresse pós-traumático. As aplicações nos processos de aprendizagem e no desenvolvimento de habilidades cognitivas e motoras são decorrentes, inicialmente, dos estudos envolvendo essas habilidades em sonhos não lúcidos - já amplamente verificada (RIBEIRO, 2003; MAQUET,2001; SIEGEL, 2000) e da teoria de simulação neural de Jean Decety, que aponta que as ações, sejam elas imaginadas ou sonhadas, ativam - em grande parte - as mesmas circuitarias neurais estimuladas quando da atividade realizada na vida de vigília (DECETY, 1996). Conforme Erlacher e Schredl, tanto o sonho como a imaginação são uma simulação do mundo real, em um nível cognitivo mais elevado (ERLACHER \& SCHREDL, 2008).Os sonhos lúcidos apresentariam essas mesmas características, com a vantagem do "controle" sobre o conteúdo dos sonhos, o que favoreceria o direcionamento para o desenvolvimento de habilidades específicas.

\section{Prevalência dos Sonhos Lúcidos}

O que faz o sonho lúcido ser um fenômeno relativamente raro na população em geral? Sabemos que, embora em algumas pesquisas, a maior parte da população relate já ter tido ao menos um episódio de sonho lúcido em suas vidas, esse número cai drasticamente para uma frequência que ultrapasse 20 episódios de sonhos lúcidos durante a vida inteira, como mostraremos a seguir. Haveria algumas características pessoais, que contribuiriam para sua ocorrência? Haveria algum "perfil" para sonhadores lúcidos frequentes e espontâneos?Os resultados de diversas pesquisas mostram que a prevalência de sonhos lúcidos parece variar consideravelmente entre alguns estudos e países: $26 \%$ de uma amostra de austríacos, relatou a ocorrência de sonhos lúcidos, pelo menos uma vez na vida (STEPANSKI et al,1998), enquanto na Alemanha foram 51\% (SCHREDL \& ERLACHER, 2011). Já estudantes universitários no Japão, Estados Unidos, Alemanha e China registraram prevalências de 47\% (ERLACHER et al, 2008), 71\% (PALMER, 1979), 82\% (SCHREDL \& ERLACHER, 2004) e 92\% (YU, 2008), respectivamente. Rolim, encontrou uma taxa de 76,5 \% na sua amostra, entre brasileiros (MOTA-ROLIM, 2012). Podemos observar algumas diferenças significativas quando comparamos os resultados desses estudos, que podem estar relacionadas à inúmeras variáveis não controladas e a um fator, mencionado anteriormente: a questão da ausência de uma definição clara e consensual do que é entendido como "sonho lúcido".

Outras pesquisas trazem dados de atletas amadores e profissionais, que afirmam utilizar os sonhos lúcidos, para melhorar seu desempenho no estado de vigília ,com bons resultados (ERLACHER,2010; THOLEY 1990). Um estudo realizado na Alemanha reuniu 840 atletas 
praticantes de esportes diversos, que foram questionados sobre sua experiência com sonhos lúcidos. Cerca de $57 \%$ dos atletas declararam que já haviam experimentado um sonho lúcido, pelo menos, uma vez em suas vidas; contudo, esse número cai para menos da metade, $24 \%$, quando a frequência é de pelo menos um ou mais sonhos lúcidos por mês. O estudo aponta também que, 9\% dos atletas já usaram SL para praticar habilidades esportivas e a maioria relatou a impressão de que o treino dentro do SL melhorou seu desempenho na vigília (SCHREDL \& ERLACHER,2011). A taxa de prevalência de sonhos lúcidos em atletas profissionais é semelhante à da população em geral. O percentual relativamente baixo de sonhadores lúcidos frequentes - $24 \%$ - leva-nos ao próximo ponto: como poderíamos aumentar as taxas de frequência de SL, visando ampliar as práticas e benefícios dele decorrentes?

\section{Técnicas e Dispositivos de Indução}

Embora o sonho lúcido espontâneo tenha uma frequência baixa, sendo, portanto, relativamente raro, é uma habilidade que pode ser aprendida e desenvolvida(PURCELL et al,1986, LABERGE,1985; THOLEY,1983), através de diversas técnicas de indução. Pelo termo "indução", nos referimos a qualquer meio utilizado com o objetivo de aumentar a frequência de sonhos lúcidos.

Visando aumentar a frequência de SL, foram desenvolvidas diversas técnicas e dispositivos de indução como sugestão pré-sono (LABERGE, 1980) e incubação de auditivo ou visual (LABERGE et al, 1981). Existem, ainda, a possibilidade de indução por estimulação elétrica, produzindo ondas gama diretamente no cérebro (VOSS et al, 2014); pela utilização de drogas específicas, além de dispositivos como óculos e máscaras de indução. Um estudo produziu uma revisão sistemática e buscou avaliar evidências da eficácia de técnicas de indução, através de uma pesquisa bibliográfica abrangente, Trinta e cinco estudos foram incluídos na análise, sendo alguns em laboratórios do sono e outros, estudos de campo (STUMBRYS et al, 2012). Segundo os próprios autores, nenhuma das técnicas de indução foi verificada para induzir sonhos lúcidos de forma confiável e consistente, embora alguns pareçam promissores. Um achado importante vem da estimulação cerebral direta. No experimento conduzido por Voss (VOSS et al, 2014), quando o cérebro era estimulado na frequência de ondas gama (40 $\mathrm{Hz})$, grande parte dos sujeitos , (77\%), relatou lucidez em seus sonhos, indicando que essa estimulação, quando realizada durante o sono REM, influencia a atividade cerebral e induz a consciência nos sonhos

Uma das drogas que tem sido correlacionada com o favorecimento dos SL, é a galantamina. A substância, que é vendida livremente nos Estados Unidos, no Brasil, depende de prescrição médica e, os resultados de sua utilização, carecem, também, de maiores evidências experimentais

\section{Considerações Finais}

As evidências de contribuição dos processos oníricos, para os processsos de aprendizagem e desenvolvimento de habilidades, nos levam a ideia de poder estender esses benefícios aos sonhos lúcidos, hipótese confirmada através de diversos estudos. Contudo, em relação aos insights e os processos criativos, podemos levantar uma questão: a ativação de circuitarias cerebrais, como a do cortex pré-frontal, que não ocorre nos sonhos não lúcidos, podem inibir esses processos? Como esta circuitaria cerebral tem correlação com aspectos lógicos e de linguagem, sua ativação nos SL seria um ponto negativo, visto que os insights ocorridos nos sonhos podem advir, ao menos em parte, da ausência de necessidade desses aspectos lógicos, típicos da vida de vigília?

A extrema dificuldade de reproduzir o fenômeno dos SL, em um ambiente experimental controlado, tem imposto um obstáculo para obtenção de dados mais objetivos e abrangentes. 
A técnica de indução mais bem sucedida , a de estimulação elétrica do cérebro, é, justamente, a mais complexa e de difícil acesso aos indivíduos em geral.

O fenômeno dos sonhos lúcidos, um estado híbrido de consciência (VOSS, 2009) tem produzido estudos que abragem aspectos epistemológicos da consciência, aprendizagem, memória,desenvolvimento de habilidades, além de aplicações terapêuticas para pacientes que sofreram algum tipo de lesão, os que sofrem com pesadelos frequentes, decorrentes, muitas vezes de estresse pós traumático e nos casos de depressão profunda (ARGARGUN et al, 2007; SPOORMAKER \& VANDENBOULT,2006). Esse painel, que reitera suas múltiplas aplicações, justifica a relevância das pesquisas envolvendo sonhos lúcidos que, certamente, ainda contribuirão amplamente, para nosso entendimento dos processos mentais.

\section{Referência Bibliográficas}

DECETY, J. Do imagined and executed actions share the same neural substrate? Cognitive Brain Research, 3, 8793, 1996.

ERLACHER, D.; SCHREDL, M. Time required for motor activity in lucid dreams. Perceptual \& Motor Skills, v. 99, n. 3, p. 1239-42, 2004.

ERLACHER, D.; SCHREDL, M. Cardiovascular responses to dreamed physical exercise during REM lucid dreaming. Dreaming, v. 18, n. 2, jun. 2008.

Practicing a motor task in a lucid dream enhances subsequent performance. A pilot study .The Sport Psychologist, 24 ,pp. 157-167, 2010.

ERLACHER, D., SCHREDL, M., WATANABE, T., YAMANA, J., and GANTZERT, F. The incidence of lucid dreaming within a Japanese university student sample. IJODR 1, 39-43. doi: 10.11588/ijodr.2008.2.79, 2008.

GILLESPIE,G. Memory and reason in lucid dreams: a personal observation. Lucidity Letter. 2, 8-9, 1983

LABERGE, S. Lucid dreaming: psychophysiological studies of consciousness during REM sleep. In: BOOTSEN, R. R.; KIHLSTROM, J. F.; SCHACTER, D. L. (Ed.). Sleep and cognition. Washington, D. C.: American Psychological Association, 1990.

LABERGE, S.; NAGEL, L.; DEMENT, W.; ZARCONE,V. Lucid dreaming verified by volitional communication during REM sleep. Perceptual and Motor Skills, 1981.

MAQUET, P.The Role of Sleep in Learning and Memory. Science, 2001.

PALMER J. A community mail survey of psychic experiences. JASPR 73, 221-251, 1979.

SCHREDL,M. , ERLACHER, D. Frequency of lucid dreaming in a representative German sample. Percept Mot Skills $112: 104-108,2011$

SIEGEL J. M. Brainstem mechanisms generating REM sleep. Princ. Pract.Sleep Med. 3, 112-133 , 2000.

SIRIGU A, DUHAMEL JR. Motor and visual imagery as two complementary and neurally dissociable mental processes. J Cogn Neurosci ;13 (7):910-9 , 2001.

SNYDER, T.;GACKENBACH, J. In: GACKENBACH, J.; LABERGE, S. (Ed.). Conscious mind, dreaming brain. New York: Plenum Press, 1988.

SPOORMAKER, V. I.; BOUT, J.; MEIJER J. G. Lucid Dreaming Treatment for Nightmares: A Series of Cases. Dreaming, Vol. 13, no. 3, 2003.

STEPANSKY R.; HOLZINGER, B.; SCHMEISER-RIEDER, A.; SALETU, B.; KUNZEET M.; ZEITIHOFER J. Austrian dream behavior: results of a representative population survey. Dreaming 8, 23-30, 1998. 
STUMBRYS, T., ERLACHER, D., SCHADLICH, M. \& SCHREDL, M. Induction of lucid dreams: a systematic review of evidence. Consciousness and Cognition, 21 (3), 1456- 1475. 10.1016/j.concog.2012.07.003, 2012.

THOLEY, P. Techniques for inducing and manipulating lucid dreams. Perceptual and Motor Skills, 57, 1983, pp 79-90, 1983.

VOSS, U. ;HOLZMANN, R.; TUIN, I.; HOBSON, J. A. Lucid dreaming: a state of consciousness with features of both waking and non-lucid dreaming. Sleep. 2009.

VOSS, U., HOLZMANN, R., HOBSON, A., PAULUS, W., KOPPEHELE-GOSSEL, J., KLIMKE, A. \& NITSCHE, M. Induction of self awareness in dreams through frontal low current stimulation of gamma activity. Nature Neuroscience, 17 (6), 810-812. 10.1038/nn.3719, 2014.

YU, C. K-C. Dream Intensity Inventory and Chinese People's Dream Experience Frequencies. Dreaming, 18, 94111, 2008. 


\title{
JOAQUIM MONTEIRO CAMINHOÁ: UM MÉDICO ILUSTRADO DO IMPÉRIO DO BRASIL (1858-1896)
}

\author{
Alex Gonçalves Varela - UERJ - alexvarelarj@terra.com.br
}

\section{Resumo}

Temos como objetivo recuperar a trajetória de vida do médico Joaquim Monteiro Caminhoá e a sua contribuição para a institucionalização das ciências naturais no Império do Brasil. 0 personagem foi um dos mais importantes homens de ciência que atuou no período imperial, tendo inclusive uma carreira consolidada e reconhecida internacionalmente. Contudo, sua trajetória acadêmica ainda não foi devidamente estudada, e suas produções científicas ainda não foram analisadas profundamente. Dessa forma, há lacunas que precisam ser preenchidas pelos estudiosos que se dedicam a pesquisar as relações ciências e trajetórias, e caminhos amplos e profícuos que merecem ser explorados e estimulam novas reflexões.

Palavras-chaves: Joaquim Monteiro Caminhoá. História das Ciências. História da Medicina.

\section{Introdução}

Joaquim Monteiro Caminhoá nasceu em 21 de dezembro de 1836, na cidade de Salvador, província da Bahia. Era filho de Luiza Monteiro Caminhoá e Manuel José Caminhoá, além de irmão de Luiz Monteiro Caminhoá. Considerado um dos grandes botânicos brasileiros, tornouse doutor em Medicina pela Faculdade de Medicina da Bahia (1858), Joaquim Monteiro Caminhoá foi membro do Conselho do Imperador D. Pedro II, Cavaleiro da Ordem de São Bento de Aviz, Cavaleiro de Cristo, Comendador da Ordem da Rosa e da Imperial Ordem Austríaca de Francisco José, dentre outros títulos.

Em 1861, entrou para a Faculdade de Medicina do Rio de Janeiro como opositor de Ciências Acessorias, sendo depois nomeado Lente de Botânica e Zoologia (1871), com a tese "Das plantas tóxicas do Brasil". Foi também nomeado Lente de história natural do Colégio Pedro II. Autor de inúmeros trabalhos importantes, dentre eles: "Elementos de botânica" (1877), "Família das Euforbiáceas" (1879), "Catalogue des plantes toxiques du Brésil" (1880), Considerações botânico médicas sobre a erva dita homeriana (1888), etc.. Caminhoá faleceu em 28 de novembro de 1896, no Rio de Janeiro.

A primeira obra redigida sobre Caminhoá que localizamos foi o verbete elaborado pelo médico e escritor BLAKE (1898) para o "Dicionário Bibliográfico Brasileiro", obra produzida no final do século XIX. O Dicionário de Augusto Victorino Alves Sacramento Blake é, por muitos autores e críticos especializados, considerada a mais completa bibliografia de autores brasileiros do período colonial até o século XIX. Esta obra apresenta a biografia de cada autor e faz uma compilação das obras por eles produzidas. A introdução narra os primeiros passos da tipografia no Brasil e a emergência das primeiras sociedades literárias no país. 0 "Dicionário Bibliográfico Brasileiro" tornou-se famoso e muito respeitado entre os intelectuais do período, além de ter sido tomado como uma forte referência literária da época. E é no quarto volume dessa obra, publicado em 1898, que Sacramento Blake se debruça sobre a vida de Joaquim Monteiro Caminhoá. O verbete de Blake se propõe a fazer uma análise biográfica de Caminhoá, chamando atenção para aspectos da vida do personagem, como: nascimento e morte, filiação, formação, serviços prestados, títulos, medalhas recebidas, sociedades médicas as quais pertenceu, além de uma enumeração das obras produzidas por Caminhoá. 
Já no século XX, no ano de 1932, o médico, professor, orador e ex-ocupante da cadeira 33 (trinta e três) da Academia Brasileira de Letras MAGALHÂES (1932) escreveu o livro do "Centenário da Faculdade de Medicina do Rio de Janeiro". Nessa obra comemorativa, Fernando Augusto Ribeiro Magalhães redigiu uma curta biografia sobre Joaquim Monteiro Caminhoá, que fora um dos mais notáveis pesquisadores das áreas de botânica, biologia e zoologia, no século XIX. No texto, Fernando Magalhães apresentou uma biografia que seguia o mesmo padrão do conjunto de dados biográficos apresentado por Blake, e apresentou como este último, uma lista das publicações de Caminhoá.

Por sua vez, na década de sessenta do século XX, o médico ARAÙJO (S/d.), patrono da Cadeira no 95 da Academia Nacional de Medicina, redigiu um artigo sobre Caminhoá. No estudo apresentado, Carlos da Silva Araújo comentou sobre a trajetória de vida do personagem enfatizando sua atuação como professor da Faculdade de Medicina do Rio de Janeiro, a admissão como sócio na Academia Imperial de Medicina e alguns de seus trabalhos realizados na mesma instituição, atividades que realizou como botânico, comentou sobre a mais importante o obra produzida por Caminhoá, "Elementos de Botânica Geral e Médica", a nomeação para a Cátedra de História Natural do Colégio Pedro II, e mencionou títulos, comendas e homenagens póstumas recebidas pelo estudioso. Portanto, esse estudo se diferiu dos demais até então apresentados pelo fato de Araújo ter escolhido alguns temas na trajetória do letrado, e não ter apresentado uma biografia de forma linear, que apresentasse uma narrativa que privilegiasse datas e fatos da vida do homem de ciência do Império.

No ano de 1971, o médico e professor LACAZ (1971) publicou também uma curta biografia sobre Caminhoá no livro "Vultos da medicina brasileira". Carlos da Silva Lacaz apresentou o mesmo tipo de informações biográficas sobre Caminhoá conforme as apresentadas por Blake e Fernando Magalhães, conforme acima comentamos. Listou apenas alguns trabalhos acadêmicos de Caminhoá. Um dos diferenciais do texto de Lacaz foi a anexação de uma matéria do Jornal do Comércio, que em alusão a morte de Joaquim Monteiro Caminhoá, escreve que o autor fora um dos mais notáveis botânicos brasileiros, cujas obras serviriam de referência para as gerações posteriores de estudantes, especialmente por conta da precisão e minúcia, além da escrita atraente de Caminhoá. O jornal considera que os escritos de Caminhoá marcam como um dos mais eficientes estudos das ciências naturais.

Outro autor analisado foi GIFFONNI (1972), médico e dedicado ao Magistério, sendo professor por longos anos. Orsini Carneiro Giffoni foi Professor de Antropologia da Faculdade de Filosofia, Ciências e Letras de Catanduva, interior de São Paulo, bem como Professor de Biologia do Instituto de Educação Padre Anchieta. Sua principal obra foi o "Dicionário BioBibliográfico brasileiro de escritores médicos - 1500-1899", publicada pela primeira vez em 1972. Na obra, o autor se dedica a apresentar uma biografia daqueles que eram considerados os mais importantes médicos escritores do período por ele escolhido (1500-1899). Apesar das muitas críticas, por deixar de fora do seu dicionário muitos importantes médicos escritores, o autor não deixou de citar Joaquim Monteiro Caminhoá. Giffoni apresenta uma curta biografia que salienta, especialmente, as publicações de Caminhoá.

Outro autor analisado foi SANTOS FILHO (1991), médico e professor universitário, e autor da obra "História Geral da Medicina Brasileira", composta por dois volumes, cuja 1a edição foi publicada em 1977. Esta publicação era a ampliação e reforma da obra "História da Medicina no Brasil do século XVI ao século XIX", que havia sido publica em 1947.

Lycurgo dos Santos Filho, juntamente com Carlos da Silva Lacaz, se insere numa tradição de pesquisa de médicos que se interessaram pela história da medicina brasileira e passaram a realizar pesquisas na área e a publicar livros e artigos. Registra-se que a história da medicina que a maioria destes médicos apresenta em suas obras tem um caráter memorialístico, preocupada especialmente em referir-se aos grandes vultos da área no Brasil, e mencionar 
seus feitos. Porém, é importante destacar que muitas destas obras igualmente informam sobre fontes para subsidiar futuras pesquisas. No volume dois da supracitada obra cujo conteúdo é centrado na história da medicina do Império, Lycurgo na parte referente à Botânica e Zoologia Médicas mencionou Joaquim Monteiro Caminhoá, apresentando um curto trecho sobre o personagem em que mencionava dados sobre sua formação, atuação e citação de alguns de seus títulos publicados.

Portanto, todos os trabalhos supracitados produzidos sobre Caminhoá foram produzid os por médicos, que redigiram curtas biografias, apresentadas de forma linear, privilegiando uma narrativa de datas e fatos, com exceção de Carlos da Silva Araújo, que selecionou alguns temas para comentar sobre a trajetória do estudioso. Contudo, toda a produção mencionada não se caracteriza por serem estudos de análise crítica profunda, que não contextualizam a produção científica do médico do Império do Brasil. Eles limitaram-se apenas a elencar uma lista das suas obras, sem apresentarem uma reflexão crítica das mesmas.

O primeiro estudo que localizamos realizado por um historiador sobre a trajetória de vida de Caminhoá foi da historiadora das ciências, pesquisadora do Departamento de Pesquisa da Casa de Oswaldo Cruz, professora do Programa de Pós-graduação em História das Ciência e da Saúde, FONSECA (2000). Maria Rachel Fróes da Fonseca é coordenadora do "Dicionário Histórico Biográfico das Ciências da Saúde no Brasil - 1832-1930", publicado em versão online no início do século XXI. O Dicionário apresenta a trajetória de médicos e cientistas, dos espaços onde estes se formavam e atuavam (como instituições de ensino, de pesquisa, e hospitalares e órgãos governamentais), e das instâncias de discussão e de socialização de seus estudos (associações profissionais e sociedades médicas). A pesquisa de Fonseca é também estritamente biográfica, no entanto, é a mais detalhada dentre as bibliografias pesquisadas.

A autora apresenta uma biografia mais detalhada da vida de Caminhoá, apresentando informações mais precisas e detalhadas sobre dados pessoais, trajetória profissional, e produção intelectual. Neste último item apresentou uma relação minuciosa das suas conferências, cursos, artigos, pareceres, teses, relatórios, entre outros. Por exemplo, Fonseca destacou, dentre outras coisas, os dez cursos de botânica popular proferidos por Caminhoá nas Conferências Populares da Glória, que eram realizadas na cidade do Rio de Janeiro desde 1973.

Inserido também no mesmo espaço institucional da pesquisadora supracitada Maria Rachel, o historiador BENCHIMOL (1999) na obra intitulada Dos Micróbios aos Mosquitos. Febre Amarela e a Revolução Pasteuriana no Brasil, analisou a trajetória de Domingos José Freire e João Batista de Lacerda, dois personagens que enfrentaram de forma teórica e prática a febre amarela e outros flagelos que grassavam as populações dos núcleos urbanos do sudeste do país durante o Império. $\mathrm{E}$, um dos homens que atuou com o primeiro citado foi Joaquim Monteiro Caminhoá, que integrou a Comissão de Estudos Sobre Febre Amarela (1883 a 1885), dirigidos por Freire, e depois foi também seu auxiliar na continuação dos referidos estudos. Jaime Larry Benchimol Benchimol também argumenta que Caminhoá foi o principal porta-voz de Domingos Freire na Academia Imperial de Medicina. O historiador utilizou diversas obras de Caminhoá como fonte de análise.

Prosseguindo, o primeiro trabalho acadêmico de pós-graduação que localizamos foi a dissertação de mestrado de SANTOS (2017), defendida no Programa de História da Ciência da Pontifícia Universidade Católica de São Paulo. Nesse estudo, Wandir Vieira Leal Santos analisou a principal obra de Caminhoá intitulada Elementos de Botânica Geral e Médica, publicada no ano de 1877, em quatro volumes, enfatizando a análise do conceito de espécie. O trabalho de Wandir ganha relevância pois insere-se numa perspectiva de analisar as obras do médico-botânico do Império brasileiro dentro do contexto sócio-científico de sua 
produção, observando com quais autores Caminhoá dialogava e quais ele refutava para a construção do conceito de espécie.

O trabalho que pretendemos realizar segue a linha dos três últimos autores supracitados. Reafirmamos o propósito em manter o envolvimento com estudos acerca da história das ciências ilustrada, o que encontra no perfil do médico e estudioso das ciências naturais Joaquim Monteiro Caminhoá perspectivas amplas de trabalho.

Joaquim Monteiro Caminhoá foi um dos mais importantes homens de ciência que atuou no Império do Brasil, tendo inclusive uma carreira consolidada e reconhecida internacionalmente. Ela atuou na Faculdade de Medicina do Rio de Janeiro, no Imperial Colégio Pedro II, e em diversas sociedades científicas, e publicou diversos livros e artigos. $\mathrm{O}$ estudioso se dedicou a produzir conhecimento científico sobre questões médicas e botânicas. Contudo, sua trajetória acadêmica ainda não foi devidamente estudada, e suas produções científicas ainda não foram analisadas profundamente. Dessa forma, há lacunas que precisam ser preenchidas pelos estudiosos que se dedicam a pesquisar as relações ciências e trajetórias, e caminhos amplos e profícuos que merecem ser explorados e estimulam novas reflexões.

Um dos artigos redigidos por Caminhoá intitula-se Utilidade das Ciências Naturais, publicado no Barão de Macahubas. Periódico Científico, Literário e Noticioso, na data de 09 de setembro de 1888. No estudo, o autor argumenta sobre a utilidade do estudo das ciências naturais, considerando que aqueles que as desconhecem "andam errantes em seu próprio país". (CAMINHOÁ, 1888, p. 2) E, a seguir, em tom bastante lamentoso, afirmou que "triste papel representam os homens de estado que desconhecem as riquezas naturais de seu país, graças as quais podem prosperar a agricultura e as indústrias que se alimentam com as matérias fornecidas pelos seres da natureza!" (Idem. Ibidem, p. 2)

Prosseguiu argumentando sobre a importância dos animais e vegetais para a vida do homem, e afirmou que era um "crime" em nosso país não se estudar as ciências naturais, uma vez que por aqui as "essências florestais estão por milhares". (Idem. Ibidem, p. 2) Um mineral, uma planta, um inseto, um verme, segundo Caminhoá, são assuntos que nos revelam as leis da natureza, esse mundo a ser decifrado pelo homem. Aquele que estuda o mundo natural é capaz de abrir para os seus semelhantes "o vasto cofre que guarda os imensos tesouros por Deus tão generosamente concedidos, tesouros que são eternos, que dão lucros incalculáveis a quem os sabe procurar...". (Idem. Ibidem, p. 2) Em outras palavras, para Caminhoá, a natureza é uma fonte de conhecimentos e de riquezas.

Na parte final do texto, Caminhoá definiu o que significa estudar a natureza: "É procurar aproximar-se do Fator dos mundos, porque é procurar decifrar as leis imutáveis e eternas que ele escreveu no seio da terra, nas entranhas dos animais, nas pétalas das flores, na atmosfera, e nas águas onde pululam os infinitamente pequenos, de cuja existência, ignorada até bem pouco, depende a saúde, e as vezes a vida dos inúmeros seres que cobrem a superfície da terra e as profundezas do oceano". (Idem. Ibidem, p. 2)

\section{Referências bibliográficas}

Publicações de Joaquim Monteiro Caminhoá:

CAMINHOÀ, Joaquim Monteiro. Utilidade das Ciências Naturais. Barão de Macahubas. Periódico Científico, Literário e Noticioso. Bahia, n. 32, ano III, 09 de setembro de 1808.

Artigos, Livros e Teses:

ARAÚJO, Carlos da Silva. Joaquim Monteiro Caminhoá. Patrono da Cadeira no 95. Datilografado. Arquivo pessoal da Academia Nacional de Medicina. [Rio de Janeiro]: [s.n.], [s.d.].

BENCHIMOL, Jaime Larry. Dos Micróbios aos Mosquitos. Febre Amarela e a Revolução Pasteuriana no Brasil. Rio de Janeiro: Editora FIOCRUZ; Editora UFRJ, 1999.

BLAKE, Sacramento. Dicionário Bibliográfico Brasileiro. Rio de Janeiro: Imprensa Nacional, 1898, Vol. IV. 
FONSECA, Maria Rachel Fróes da. Joaquim Monteiro Caminhoá. In: Dicionário Histórico-Biográfico das Ciências da Saúde no Brasil (1832-1930). Rio de Janeiro: Casa de Oswaldo Cruz/Fiocruz, 2000 - Disponível em: http://www.dichistoriasaude.coc.fiocruz.br. (acessado no dia 17/09/2017)

GIFFONI, Orsini Carneiro. Dicionário Bio-bibliográfico brasileiro de escritos médicos (1500-1899). São Paulo: Nobel, 1972.

LACAZ, Carlos da Silva. Vultos da medicina brasileira. São Paulo: Laboratório Pfizer do Brasil, 1971. MAGALHÃES, Fernando. Centenário da Faculdade de Medicina do Rio de Janeiro. Rio de Janeiro: Typ. A. P. Barthel, 1932.

SANTOS, Wandir Vieira Leal. A Concepção de espécie na visão do botânico brasileiro Joaquim Monteiro Caminhoá. Dissertação de Mestrado. São Paulo: PUC-SP, 2017.

SANTOS FILHO, Lycurgo de Castro. História Geral da Medicina Brasileira. vol.2. São Paulo: Editora Hucitec, Editora da Universidade de São Paulo, 1991. 


\title{
A IMPORTÂNCIA DA CRIATIVIDADE COMPUTACIONAL PARA A LITERATURA GENERATIVA: REFLEXÕES SOBRE ARTE, CIÊNCIA E TECNOLOGIA NA CIBERLITERATURA
}

\author{
Thalita Biazzuz Veronese - Doutoranda no HCTE/UFRJ - thalitabv@gmail.com
}

\section{Resumo}

Desde o surgimento da arte-técnica, a visão da arte como coisa exclusivamente humana alimenta as críticas em relação à interferência da ciência e da tecnologia sobre a criação artística. Mais recentemente, a arte gerada por computadores, aqui chamada arte generativa, trouxe novos elementos a essa discussão e tem levado, como em outros momentos da história, ao questionamento do papel do artista e de sua relação com a obra e com o público. Este artigo levanta perspectivas sobre a arte e, mais especificamente, a literatura generativa sob os aspectos da Criatividade Computacional.

Palavras-chave: Ciberartes. Literatura Generativa. Criatividade Computacional.

1 Ciência e técnica na história da arte

A visão da arte como coisa exclusivamente humana vem sendo desafiada desde o surgimento da arte-técnica, no século XIX, quando o advento da fotografia mecanizou uma tarefa até então dominada apenas pelos artistas. Esta visão, convertida em tecnofobia, foi, e ainda é, responsável por movimentos de resistência à aceitação das tendências surgidas ao longo da história da arte. Na fictícia Macondo, de Gabriel García Márquez, é esta visão que impossibilita seus habitantes de apreciar o gramofone, visto como um "truque mecânico que não se podia comparar com uma coisa tão comovedora, tão humana e tão cheia de verdade cotidiana como uma banda de música". De fato, como nota Gombrich (1999), "não existe obstáculo maior à fruição de grandes obras de arte do que a nossa relutância em descartar hábitos e preconceitos".

Se já há dois séculos esta resistência existia em relação ao uso das novas tecnologias pela arte, hoje ela se apresenta ainda mais forte diante das incursões da inteligência computacional pelas mais diversas manifestações artísticas, alimentando o complexo e dinâmico relacionamento entre a ciência e a arte. É importante notar, porém, como lembra Leonel Moura, que a criatividade artificial, embora possa ser questionada quanto a sua originalidade e independência, apenas acrescenta elementos à forma e ao conteúdo da arte: características tradicionais e propostas inovadoras coexistem no cenário híbrido contemporâneo, bem como não se extingue ou desvaloriza o papel do artista humano.

Desde o século XIX, com o surgimento da fotografia e do cinema, ícones da tecnicização da arte, o papel do artista vem sendo questionado e instigado a se ressignificar. Incorporado ao sistema de produção industrial, o campo artístico direcionou à valorização do espírito crítico e da criatividade seu processo de reconstrução. Já no século $X X$, o processo de desmaterialização da arte contemporânea é seguido pela desmaterialização da própria autoria, a partir do novo relacionamento com o público, provocado pela interatividade característica da cibercultura. Hoje, é justamente a supervalorização do ato criador como produto da inspiração e da intuição humana o que dificulta, muitas vezes, o reconhecimento do caráter artístico da arte gerada por computadores, aqui denominada arte generativa. 
2 Ciberartes e a criatividade artificial

No campo das ciberartes, inicialmente limitado às manifestações artísticas interativas ocorridas no ciberespaço, a tecnologia encontra-se cada vez mais naturalizada. Em sua instalação Pas de deux (traduzida como "O balé de tecidos"), Daniel Wurtzel explora os movimentos provocados por um vórtice de ar sobre um par de tecidos. A sequência de movimentos dos tecidos e seu efeito estético são aleatórios, em contraposição à intencionalidade que se imprimia nas obras de arte clássicas. Da mesma forma, os poemas gerados pelo algoritmo de Peter Howard, Peter's Haiku Generator, dependem do autor apenas como idealizador e/ou engenheiro em sua concepção inicial, apresentando-se independentes a cada nova composição do software gerador.

Em ambos os casos, entretanto, o caráter crítico e libertário da obra e de seu criador permanece, sujeito à participação e à sensibilidade do público no processo de análise crítica e estética. Como diz Leonel Moura, referindo-se ao seu robô poeta ISU, a ausência de racionalidade ou consciência dos seus atos não impede o artista artificial de "produzir deslumbramento e desencadear sentidos na mente do observador humano".

Em ISU, assim como em muitos artistas artificiais, o caráter aleatório é predominante, mas a ciência por trás deste processo criativo vem se sofisticando com o tempo. Esta é uma das muitas formas de reaproximação entre a ciência e a arte, cuja diferenciação se acentuou a partir do século XVII, com a apropriação da natureza pela ciência, e encontrou seu auge com o positivismo do século XIX. Atualmente, esta aproximação vem se fortalecendo também pelo caminho inverso, ou seja, na aplicação de teorias e práticas de arte à ciência da computação, como ocorre, por exemplo, nas áreas da Computação Estética (FISHWICK, 2006) e da Criatividade Computacional.

Ao discutir a possibilidade de criar máquinas que pensassem, Alan Turing (1950) sugeriu que fossem definidos, inicialmente, os termos "máquina" e "pensar". Da mesma forma, deveríamos, antes de questionar se computadores podem ser criativos, explorar o significado do termo "criatividade". Muitos autores têm se dedicado a esta tarefa, e, especialmente, ao estudo da conexão entre criatividade e inteligência. O surgimento e o crescimento da Criatividade Computacional, uma nova área de pesquisa voltada à modelagem e à simulação da criatividade, acrescenta novos elementos a essa discussão (TOIVONEN e GROSS, 2015).

Atualmente, pesquisas envolvendo cientistas e artistas buscam desenvolver robôs e softwares que sejam, mais do que simples ferramentas, capazes de produzir arte de caráter criativo e original. No projeto "bot or not", desenvolvido pelo escritor e pesquisador Oscar Schwartz, os leitores são convidados a julgar a autoria de poemas selecionados aleatoriamente: seria o poema apresentado escrito por um robô? Schwartz descreve sua experiência como um "teste de Turing para poesia". Assim, ao selecionar a opção "not" para um poema gerado computacionalmente, o leitor teria sido "enganado" pela máquina, ou seja, o poeta robô teria sido capaz de escrever um poema como se fosse um poeta humano.

Embora a iniciativa seja válida sob o aspecto da aceitação do público em relação à arte representada pela poesia generativa, "ser aprovado" no teste não é suficiente para que um software seja considerado criativo. Em primeiro lugar, a própria concepção do teste de Turing, na qual é inspirado o projeto "bot or not", não foi proposta como um método para efetivamente testar a inteligência de uma máquina (RIEDL, 2014). Além disso, uma análise mais sistemática em relação aos atributos linguísticos e estéticos do poema em questão seria necessária para concluir que, mais do que "enganar" o leitor, o software seja capaz de gerar uma estrutura textual poética. Por fim, ainda que tal análise levasse à conclusão de que a poesia robótica poderia ter sido escrita por um ser humano, isso não esgotaria a discussão sobre os limites da criatividade computacional. 
3 Afinal, é possível codificar a criatividade?

A Criatividade Computacional é definida por Simon Colton como uma subárea da Inteligência Artificial, na qual se estuda como construir softwares que exibam comportamentos que seriam considerados criativos se desempenhados por seres humanos. O objetivo é que estes softwares atuem de forma independente, não apenas como ferramentas que ajudem a aumentar a criatividade humana, e para isso os cientistas têm se concentrado tanto em melhorar técnicas de Inteligência Artificial existentes, como Mineração de Dados e Aprendizagem de Máquina, quanto em criar novas técnicas.

Embora inclua também teorias científicas inovadoras, conceitos matemáticos e projetos de engenharia, na maioria das vezes a Criatividade Computacional é aplicada principalmente ao universo artístico (BODEN, 2015), obtendo resultados interessantes nos campos da música e das artes visuais. O software AARON, por exemplo, gera desenhos que, aos olhos de um leigo, poderiam ter sido produzidos por um artista humano, apesar de apresentar uma série de limitações capazes de colocar em xeque sua criatividade quando expostas a um especialista. Mesmo entre os cientistas da computação - senão principalmente entre eles - ainda há, como lembra Mántaras (), um grande ceticismo em relação ao potencial criativo de um software. Mas a Criatividade Computacional vem quebrando este paradigma e amadurecendo como uma área de pesquisa interdisciplinar e promissora, especialmente se não restringirmos as expectativas à construção de réplicas de seres humanos criativos, e formos capazes de acolher a complexidade de contribuições às diversas áreas relacionadas, que vão desde a psicologia, com uma melhor compreensão de como funciona a criatividade humana, até a própria ciência da computação, com a possibilidade de desenvolver softwares mais sofisticados. Ao contrário do que profetiza Lev Manovich (1996), é possível encontrar uma intersecção entre os interesses dos territórios de Duchamp e Turing.

A controvérsia é ainda maior quando se trata das incursões da Criatividade Computacional no campo da Literatura. Acontece que, ao contrário das produções musicais e visuais, baseadas em regras bem conhecidas e relativamente fáceis de reproduzir, produções literárias estão apoiadas em um conjunto teórico que depende de uma série de conhecimentos ainda não dominados pelo ser humano, associados à Linguística e ao Processamento de Linguagem Natural. Se ensinar uma máquina a escrever um texto coerente é um desafio que não chegamos a superar de maneira satisfatória, adicionar criatividade a este texto é tarefa ainda mais difícil. Devemos considerar, além de regras gramaticais, uma extensa base de conhecimento que inclui o contexto cultural e o público alvo de uma produção literária.

A exceção se encontra na poesia. Apesar de ter forte apelo à criatividade, este gênero caracteriza-se por uma maior liberdade, gramatical e semanticamente, o que representa um obstáculo a menos para os softwares geradores de textos poéticos.

\section{Desafios e perspectivas para a Literatura Generativa}

Poderia o robô poeta ser considerado um artista? Dentro de suas limitações, essa nova arte surgida a partir da integração com o software, o hardware e a cibernética traz o elemento computacional possivelmente como mais um coautor para as obras e manifestações produzidas. Já a perspectiva de que as máquinas possam competir com as pessoas em esforço criativo ainda é uma questão sem resposta (ELTON, 1995).

A própria natureza da poesia de certa forma acompanha um afrouxamento das regras da linguagem, como, por exemplo, das restrições gramaticais, o que pode levar à conclusão de que é mais fácil construir um robô poeta do que um robô romancista. Talvez isso explique a maior proporção de trabalhos desenvolvidos sobre a poesia generativa, em relação à quantidade de trabalhos desenvolvidos na literatura generativa em geral, considerando gêneros literários em que haja menor liberdade sobre a estrutura da linguagem. 
O processamento de linguagem natural vem sendo usado de forma bem sucedida em diversas aplicações, como a tradução automática de textos, a geração procedural em jogos e a correção gramatical e ortográfica. Mas gerar automaticamente textos literários de forma autônoma, com mínima intervenção humana e máxima originalidade, exige mais do que a modelagem puramente estrutural da linguagem, e ainda depende, portanto, de avanços consideráveis nos métodos desenvolvidos por esta nova ciênia denominada Criatividade Computacional.

A arte generativa, assim como muitas das formas de aproximação com a ciência promovidas pela arte contemporânea, contribui, ainda, como observa Arlindo Machado, para a democratização da produção artística, possibilitada pela participação do público neste processo que as novas tecnologias proporcionam. Esse é um aspecto que não pode ser ignorado, se considerarmos o papel cultural da relação entre o público e a arte.

A arte, assim como a ciência, é uma forma de conhecimento, cuja evolução decorre de seu caráter experimental. No futuro, as resistências em relação à arte produzida por inteligência artificial deverão ser superadas, como o foram as resistências diante do advento da artetécnica. Afinal, como lembra Cristina Costa (1998), a arte produzida por computadores depende fortemente da capacidade de fruição do público. E, assim como soube, naquele momento, privilegiar a ideia criadora, o artista contemporâneo deve aprender agora a explorar as regiões nas quais a máquina não pode substituí-lo, ou reinventar seu papel no cenário artístico.

\section{Referências bibliográficas}

BOLDEN, M. Computational Creativity Research: Towards Creative Machines. Atlantis Press, 2015. Disponível em: https://doi.org/10.2991/2F978-94-6239-085-0.

COSTA, C. Arte, resistências e rupturas: ensaios de arte pós-clássica. São Paulo: Moderna, 1998. ISBN 8516019926. Citado na página 31.

ELTON, M. Artificial creativity: Enculturing computers. Leonardo, v. 28, n. 3, 1995

FISHWICK, P. Aesthetic computing. Cambridge, Mass: MIT Press, 2006. ISBN 9780262062503.

GOMBRICH, E. A história da arte. Rio de Janeiro: Livros Técnicos e Científicos Editora, 1999. ISBN 8521611854. HOWARD, P. Peter's Haiku Generator. 2017. Disponível em: http://peterhoward.org/haikugen/ framset1.htm. Acessado: 2017-10-08.

MANOVICH, L. The Death of Computer Art. 1996. Disponível em: http://rhizome.org/community/ 41703/. Acessado: 2017-10-08.

MÁNTARAS, R. L. Artificial Intelligence and the Arts: Toward Computational Creativity. The Next Step: Exponential Life, 2017.

MCCORMACK JON; D'INVERNO, M. Computers and creativity. Springer, 2012. ISBN 978-3-642-317262,364231726X,978-3-642-31727-9,3642317278. Disponível em: <http://gen.lib.rus.ec/book/index.php?md5=021b28ec7d2eb126efa195f28eafad57>.

MOURA, L. Notes on a new kind of art. Matlit, Coimbra University Press, v. 3, n. 1, p. 185-194, 2015. Disponível em: <https://doi.org/10.141952F2182-8830_3-1_11>.

MÁRQUEZ, G. Cem anos de solidão. Rio de Janeiro: Editora Record, 2010. ISBN 8501078891.

RIEDL, M. O. The lovelace 2.0 test of artificial creativity and intelligence. CoRR, abs/1410.6142, 2014.

Disponível em: <http://arxiv.org/abs/1410.6142>.

SCHWARTZ, O. Bot or not. 2017. <http://botpoet.com>. Acessado: 2017-10-08.

TOIVONEN, H.; GROSS, O. Data mining and machine learning in computational creativity. Wiley Interdisciplinary Reviews: Data Mining and Knowledge Discovery, Wiley Periodicals, Inc, v. 5, n. 6, p. 265-275, 2015. ISSN 1942-4795. Disponível em: <http://dx.doi.org/10.1002/widm.1170>.

TURING, A. M. Computing machinery and intelligence. Mind, LIX, n. 236, p. 433-460, 1950. Disponível em: $<+$ http://dx.doi.org/10.1093/mind/LIX.236.433>.

WURTZEL, D. Daniel Wurtzel. 2017. <http://www.danielwurtzel.com/>. Acessado: 2017-10-08. 


\section{MANOEL BOMFIM E CELSO FURTADO: PENSADORES ORIGINAIS DO BRASIL}

Wilson Vieira - Professor do IE-UFRJ - vieiraeco@gmail.com; wilson.vieira@ie.ufrj.br) Leila Almeida Barbosa - Doutoranda HCTE-UFRJ - leilaalmeidabarbosa@yahoo.com.br)

Resumo

O objeto deste trabalho é a análise da originalidade das reflexões de Manoel Bomfim (18681932) e Celso Furtado (1920-2004) para pensar o Brasil. Os objetivos são: i) apresentar a originalidade de cada um dos autores nas suas reflexões sobre o Brasil; ii) mostrar que a reflexão desses teóricos faz parte de um pensamento fundador brasileiro e autóctone, original. A hipótese de trabalho é a de que esses teóricos fazem parte do grupo de pensadores brasileiros que fundam um pensamento original, autóctone no Brasil.

Palavras-chave: Celso Furtado. Manoel Bomfim. pensamento político-social-econômico brasileiro.

\section{O Pensamento de Manoel Bomfim}

$\mathrm{Na}$ extensa obra de Bomfim, destacamos como objeto de estudo aquelas dedicadas a uma interpretação (ensaística) do Brasil e América Latina, nas quais, acreditamos, o autor contribui de forma inédita com formulações político-sociais e históricas a partir das realidades brasileira e latina. Dentre elas: "A América Latina: Males de Origem" (escrito em 1903 quando estava em Paris e publicado em 1905 pela Editora Garnier). Neste livro, segundo Botelho (2009, p. 120), ele enfrenta a teoria do racismo científico e esboça reflexões sobre educação, racismo e a construção da nação Brasil que irá complementar na trilogia "O Brasil na América": "Caracterização da Formação Brasileira" (escrito em 1925 e publicado em 1929), "O Brasil na História: Deturpação das Tradições, Degradação Política" (escrito em 1926 e editado em 1930), e "O Brasil Nação: Realidade da Soberania Brasileira" (escrito em 1928, com posfácio de agosto de 1931, ano da publicação).

Bomfim coloca-se os pioneiros da crítica ao racismo científico que, baseado no determinismo biológico como modelo explicativo da sociedade, dividia a humanidade em raças superiores e inferiores, civilizados ou bárbaros. Obviamente, nós, os latinos, estávamos no segundo grupo. Para ele, os problemas do atraso e da desqualificação não podiam estar embasados na raça; outrossim, deveriam ser diagnosticados no parasitismo social do qual eram vítimas e da dominação externa (colonizadores) e interna (elites) a que estavam submetidos estes povos (da América Latina, em geral, e de modo específico, o Brasil). Intentava ver tais dilemas superados pela educação e orientação adequada destes sujeitos, que constituiriam então a Nação Brasileira, em particular; e de modo geral, os povos latino-americanos. Esta posição crítica, quase ácida ao posicionamento político-filosófico de seus contemporâneos rendeu a Bomfim a pecha de utópico.

Outro aspecto do pensamento de Bomfim que podemos destacar é a sua defesa do desenvolvimento industrial como a melhor forma de superar a dependência (podendo nisso ser considerado um precursor do desenvolvimentismo), pois via as economias essencialmente agrícolas como sinônimas de economias colonizadas, podendo ser considerado nesse aspecto como um precursor de Caio Prado Júnior.

E a busca da superação da dependência passava também por não aceitar o imperialismo. No poderio norte americano, via uma ameaça à soberania dos países latino-americanos. 
Em seu último livro - "O Brasil Nação" (1931), Bomfim já não acreditava na transformação social somente pela educação popular, e cada vez mais influenciado pelas ideias socialistas afirma que "(...) a democracia, voz da maioria, converteu-se em regime de exploração da maioria trabalhadora. [...]. É esta uma situação que só pode resolver revolucionariamente" (BOMFIM, 1996, p. 566-567).

\section{A Originalidade do Pensamento de Celso Furtado}

Podemos observar a originalidade do pensamento de Celso Furtado tanto no período em que atuou na CEPAL (1949-1957) quanto no período em que esteve à frente da SUDENE (19591964).

No período cepalino de Furtado destacamos as obras "A Economia Brasileira" (1954), "Uma Economia Dependente" (1956) e "Perspectivas da Economia Brasileira" (1958), que analisamos sucintamente nos parágrafos que seguem.

Em "A Economia Brasileir"a (1954), é patente a preocupação em entender a economia brasileira no período em que é escrito o livro através do uso instrumental da história para compreender as características peculiares de uma economia subdesenvolvida como a brasileira. Esse livro se constitui na reunião das reflexões de Furtado em três frentes que ele trabalhava no período (como ele afirma em "A Fantasia Organizada" - 1985): i) teoria do desenvolvimento: gênese histórica e mecanismos de acumulação; ii) perspectiva histórica e problemas atuais da economia brasileira; iii) crítica das ideias sobre desenvolvimento econômico. Cabe destacar nesse livro a sua preocupação em mostrar que o sucesso da colonização no Brasil e o fracasso nos EUA se constituíram em raízes da situação de subdesenvolvimento que obstaculiza a construção da nação, mas também afirma o Brasil em suas potencialidades, dadas as semelhanças de recursos naturais e de tamanho de território entre esses dois países.

O livro "Uma economia Dependente" (1956) na verdade se constitui em partes dos capítulos 2, 3, 4 e 5 do livro de 1954.

O livro "Perspectivas da Economia Brasileira" (1958) se constitui em transcrição de conferências proferidas no ISEB em 1957, que giraram em torno de três temáticas:

I. Equacionamento do problema do desenvolvimento da economia brasileira na etapa vivida na década de 1950 (industrialização planejada a partir de 1956).

II. Análise de suas tendências fundamentais.

III. Tentativa de determinar os principais fatores que poderiam reduzir o ritmo desse desenvolvimento nos anos que se seguiriam.

Após sua saída da CEPAL em 1958, Furtado passa um período na Universidade de Cambridge (tal como vimos acima), local em que pesquisa e escreve o livro Formação econômica do Brasil - FEB (cuja primeira edição foi publicada em 1959), considerada pela maioria dos cientistas sociais e pelos estudiosos de seu pensamento como sua principal obra devido ao fato dela estar centrada na análise da evolução econômica do Brasil com a utilização do modelo keynesiano. Tal livro também se constitui numa ampliação da sua tese de doutorado de 1948 e do seu livro de 1954. Um outro ponto importante em FEB se encontra no fato de que a preocupação com as disparidades regionais se torna cada vez mais realçada nas reflexões de Furtado, apesar dos avanços na industrialização. Ele defende a necessidade de políticas de desenvolvimento que almejassem o fim de tal situação, para que a nação continuasse seu processo de formação e construção.

Ao mesmo tempo em que elaborava o diagnóstico do subdesenvolvimento brasileiro para compreender tal obstáculo para a construção da nação, Furtado propunha a solução para a superação de tal situação através do planejamento democrático estatal, para promover o 
desenvolvimento econômico, tomando parte de um debate intenso no Brasil e no mundo sobre o planejamento e a industrialização para a superação do subdesenvolvimento. Podemos afirmar que no período em que Furtado participa da CEPAL, ocorre a predominância do técnico sobre o político, na visão do planejamento como elemento de superação do subdesenvolvimento e construção da nação.

No período em que atuou na SUDENE (1959-1964), Furtado atua pelo desenvolvimento do Nordeste como uma forma de diminuir as disparidades regionais no Brasil, tendo enfrentado muitas dificuldades para levar à frente seus projetos devido à forte oposição da direita e dos EUA. Além dessa atuação, ele continua sua reflexão sobre o desenvolvimento e o subdesenvolvimento, destacando-se os seguintes livros: "A Pré-Revolução Brasileira" (1962) e "Dialética do Desenvolvimento" (1964), que analisamos sucintamente nas linhas abaixo.

"A Pré-Revolução Brasileira" (1962) se constitui numa compilação de estudos, cuja preocupação é, segundo Furtado, esclarecer à juventude universitária brasileira sobre as grandes transformações pelas quais o Brasil passava naquele momento. Destacamos do livro uma primeira crítica ao modelo de desenvolvimento econômico adotado pelo país e que ele defendia: não houve modificação nas condições de vida de $75 \%$ da população brasileira, muito pelo contrário, houve uma crescente concentração social e geográfica de renda, além de ter levado a um aumento relativo da renda da terra. No plano político-administrativo, a ampliação e a diversificação das funções do Estado não foi acompanhada das necessárias reformas de base do próprio Estado, o que colaborou para o enorme aumento do coeficiente de desperdício na ação administrativa pública. Dessa análise, podemos observar que o diagnóstico de Furtado acerca do desenvolvimento é dinâmico, significando para ele que durante a ação para superá-lo é possível reavaliá-la, reiterando sua defesa do planejamento democrático para o desenvolvimento econômico, dentro de sua defesa da socialdemocracia. No livro "Dialética do desenvolvimento" (1964) destacamos o fato de que o autor observa os fatores dinâmicos da economia brasileira se debilitarem devido à conformação das forças políticas no período (e que apoiariam o golpe de 1964), que impedem a superação dos obstáculos estruturais do subdesenvolvimento.

Após o golpe de 1964, Furtado é cassado e parte para o exílio, onde continua suas reflexões sobre o subdesenvolvimento, mantendo sempre o caminho dinâmico do pensar esse fenômeno e as propostas de sua superação para que a construção da nação Brasil continue.

\section{Considerações Finais}

Manoel Bomfim em suas principais obras, apresenta sua preocupação com a realidade nacional e latino-americana; a questão racial; a busca de uma concepção acerca do nacionalismo e a observação dos problemas da Latino-América - os conflitos entre seus países, o debate do socialismo e sua viabilidade, avançando para considerações políticas, econômicas e sociais que curiosamente, só encontrarão ênfase nas produções intelectuais de décadas depois. Estes fatos, somados, dão o tom da diferença e importância do pensamento bomfiniano neste período, e apontam para o que pensamos ser sua contribuição na formação de uma ciência social brasileira, autóctone, não importada nos seus vícios europeus ou norteamericanos, mas nascida da vivência social-histórica do autor, da realidade que matiza a sociedade de seu tempo. Salientada a importância do salto qualitativo de seu pensamento, nascido no seio do racismo científico, do cientificismo da época, para a crítica do mesmo e a proposição de novas reflexões na busca de soluções para os problemas da nação brasileira, e até da América Latina.

Celso Furtado, a partir de seu engajamento na CEPAL, faz um caminho original para diagnosticar o subdesenvolvimento brasileiro e propor alternativas à sua superação, 
elaborando uma reflexão que não faz um mero transplante das teorias originadas nos países centrais, mas sim adaptações à nossa realidade brasileira e latino-americana.

Por fim, podemos elencar como pontos em comum aos autores analisados a originalidade e a inovação dentro do contexto e do debate em que estão inseridos, além da crença na possibilidade de realizar a nação brasileira, comprovando nossa hipótese.

\section{Referências bibliográficas}

BOMFIM, Manoel. A América Latina: males de origem. Rio de Janeiro: Toopbooks, 1993 [1905]. $1997[1929]$.

O Brasil na América: caracterização da formação brasileira. 2a edição. Rio de Janeiro: Toopbooks,

O Brasil na história: deturpação das tradições, degradação política. 2a edição. Rio de Janeiro:

Toopbooks, 2013 [1930].

. O Brasil Nação: realidade da soberania nacional. 2ª edição. Rio de Janeiro: Toopbooks, 1996

[1931].

BOTELHO, André. Manoel Bomfim: um percurso da cidadania no Brasil. In.: BOTELHO, André; SCHWARTZ, Lilia Moritz. Um enigma chamado Brasil: 29 intérpretes e um país. São Paulo: Cia das Letras, 2009.

FURTADO, Celso. Economia Colonial no Brasil nos Séculos XVI e XVII. São Paulo: HUCITEC, ABPHE, 2001 (Tese de Doutorado, 1948).

. A economia brasileira. Rio de Janeiro: Editora A Noite, 1954.

. Uma economia dependente. Rio de Janeiro: Ministério da Educação e Cultura, 1956.

Perspectivas da economia brasileira. Rio de Janeiro: ISEB, 1958.

. Formação econômica do Brasil. 34ạ edição. São Paulo: Companhia das Letras, 2007 [1959].

. A pré-revolução brasileira. Rio de Janeiro: Fundo de Cultura, 1962.

Dialética do desenvolvimento. Rio de Janeiro: Fundo de Cultura, 1964.

. A fantasia organizada. Rio de Janeiro: Paz e Terra, 1985.

PRADO JR., Caio. Formação do Brasil contemporâneo: colônia. São Paulo: Brasiliense; Publifolha, 2000 [1942].

VIEIRA, Wilson. A construção da nação no pensamento de Celso Furtado. Campinas: IFCH-UNICAMP, 2010

(Tese, Doutorado em Sociologia). 


\section{OS ARQUIVOS PESSOAIS E A HISTÓRIA DA CIÊNCIA: A ORNITOLOGIA BRASILEIRA NO ARQUIVO DE HELMUT SICK}

Douglas Vieira Machado - Graduado em História/UFF e Arquivologia/UNIRIO - douglasmachado@mast.br Maria Celina Soares de Mello e Silva - Coordenadora do Mestrado Profissional em Preservação de Acervos de C\&T - MAST/MCTI - celina@mast.br

\section{Resumo}

O presente trabalho busca analisar e demonstrar questões relativas ao tratamento e organização Arquivo Helmut Sick, sob guarda do Museu de Astronomia e Ciências Afins. Por meio dos resultados parciais obtidos na identificação tipológica buscamos evidenciar a importância da organização de arquivos pessoais de cientistas para a História da Ciência, tendo como estudo o arquivo de Helmut Sick, e como fonte de pesquisa para entre outras áreas, como a Arquivologia e a Ornitologia.

Palavras-chave: História da Ciência. Arquivos pessoais. Tipologia documental. Identificação de documentos. Ornitologia.

\section{Introdução}

Os arquivos pessoais durante muito tempo foram negligenciados e colocados à margem do saber arquivístico, em um limbo onde em detrimento dos arquivos oficiais, nem eram considerados arquivos de fato. Contudo, atualmente gozam de prestígio por parte da Arquivologia, constituindo uma importante fonte de pesquisa equiparável (ou complementar) aos arquivos institucionais. Livres dos mecanismos que condicionam a acumulação institucional a acumulação de arquivos pessoais é pautada pela vontade de seu titular (SILVA, 2015). Se nos arquivos de organismos jurídicos é possível observar, entre outras, relações políticas, legais ou econômicas, em um arquivo pessoal pode-se ir mais além, uma vez que os documentos íntimos expressam não só as relações entre o indivíduo e Estado, mas também as relações entre o indivíduo e Instituições e o indivíduo e a Sociedade. Neste sentido este trabalho procura divulgar a pesquisa realizada no Plano de Trabalho "A ornitologia brasileira no arquivo Helmut Sick: identificação de documentos por meio de estudo tipológico" que está inserido no projeto "Estudo da espécie e tipologia documental de arquivos de ciência e tecnologia", coordenado pelo Arquivo de História da Ciência do MAST.

Identificação de documentos por meio de estudo tipológico

Iniciado em 2013, o projeto tem como objetivo o estudo da tipologia da produção documental arquivística oriunda das atividades de pesquisa de instituições científicas, visando a elaboração de procedimentos, recomendações e políticas de preservação, com foco no estudo da produção documental arquivística dos laboratórios científicos e tecnológicos no âmbito do Ministério da Ciência, Tecnologia, Inovações e Comunicações (MCTIC).

A fase atual tem como objeto de estudo os arquivos pessoais de cientistas sob a guarda do MAST, como o arquivo do antropólogo Luiz de Castro Faria. No âmbito do projeto já foram realizados o levantamento tipológico nos arquivos de Bernhard Gross e Joaquim da Costa Ribeiro. O presente Plano de Trabalho está dando continuidade aos estudos, tendo como objeto o arquivo do ornitólogo Helmut Sick. 
$\mathrm{O}$ arquivo já tem sido objeto de pesquisa, mesmo que ainda esteja em processo de organização. Uma vez que o arquivo pessoal encontra-se inteiro no MAST, o presente estudo, portanto, visa ampliar o conhecimento sobre o produtor e sua obra, de forma que as atividades sejam mapeadas e proporcionem contexto para a organização do arquivo. Desta forma, este arquivo poderá se tornar fonte de pesquisa para, entre outras áreas, a historiografia, a arquivologia e a ornitologia. No mesmo sentido, após sua organização, o arquivo poderá tornar-se fonte para a história da ciência, que busca nos arquivos pessoais, fatos e informações que complementem as fontes oficiais e que, eventualmente, possam fornecer um conhecimento voltado para a personalidade, a vida cotidiana e familiar do cientista em seu campo de atuação.

A pesquisa almeja estudar as espécies e tipos documentais do Arquivo Helmut Sick visando a organização do acervo, de forma a promover o acesso a este patrimônio da ciência brasileira, tornando-o fonte de pesquisa para a história da ciência. Os objetivos da pesquisa podem ser resumidos em três âmbitos: a identificação dos documentos; o tratamento do arquivo, com sua organização, produção de instrumentos de pesquisa, digitalização e alimentação na base de dados Zenith; e a difusão, por meio da produção de artigos e apresentação de comunicações em eventos, como também, a disseminação do conhecimento produzido sobre o acervo e sobre arquivos pessoais.

\section{Helmut Sick e seu Arquivo}

Heinrich Maximilian Friedrich Helmuth Sick nasceu em 10 de janeiro de 1910, em Leipzig, Alemanha. Estudou ciências naturais nas universidades de Koenigsberg, Munique, Leipzig e Berlim. Em 1937 obteve o título de Doutor em Filosofia pela Faculdade de Matemática e Ciências da Universidade Friedrich Wilhelm de Berlim, com a tese "A estrutura microscópica da pena da ave e sua função". Em 1939, viajou ao Brasil em expedição organizada e patrocinada pelo Museu Zoológico da Universidade de Berlim, em convênio com o Museu Nacional do Rio de Janeiro, para realizar pesquisas ornitológicas, com o objetivo de coletar material ornitológico e estudar espécies raras, como o mutum (Crax blumenbachii) e o jacude-estalo (Neomorphus geoffroyi).

Em 1942, com o rompimento das relações com a Alemanha e o ingresso do Brasil na Segunda Guerra mundial, por sua naturalidade alemã Sick foi preso, primeiro na Ilha das Flores e depois na Ilha Grande, onde continuou suas pesquisas até ser liberto após dois anos de regime prisional. Em 1946 foi contratado como naturalista da Fundação Brasil Central, realizou expedições às regiões Centro-Oeste e Norte, narradas no livro "Tukani". Naturalizado brasileiro em 1952, foi o primeiro a escrever, de maneira mais aprofundada, sobre as aves brasileiras ameaçadas de extinção. Trabalhou e colaborou com renomadas instituições como o Max Planck Institut e a Washington State University. Sick também foi membro de diversas associações e sociedades científicas, como o Comitê Ornitológico Internacional e a Academia Brasileira de Ciências. Durante toda sua vida planejou e integrou diversas expedições pelo país. Dentre elas está uma importante expedição realizada em dezembro de 1978 ao nordeste do Estado da Bahia, onde foi identificada a arara-azul-de-lear (Anodorhynchus leari), descoberta em 1823 e até então de localização desconhecida. De sua extensa e incansável produção, a mais importante obra de sua vida, o livro "Ornitologia Brasileira", publicado pela primeira vez em 1984, é uma importante referência bibliográfica até os dias atuais. A obra, de caráter pioneiro, é considerada o alicerce fundador do campo da ornitologia no Brasil. Durante cinquenta e dois anos de vida no Brasil, desde a chegada ao Estado do Espírito Santo, em 1939, até poucos dias antes de falecer, realizou intensa atividade científica. Sick faleceu na cidade do Rio de Janeiro no dia 5 de março de 1991. 
Por ser viúvo e não possuir filhos, seus bens pessoais, assim como todos os documentos produzidos e acumulados durante a sua vida, foram deixados para Ingeburg Kindel, brasileira, amiga e vizinha de Sick. Após negociação, a legatária doou o arquivo de Sick para MAST/MCTIC, que tem, dentre os seus objetivos, o de preservar, organizar e inventariar arquivos pessoais de cientistas para viabilizar o acesso a estudos e pesquisas relacionados à história da ciência. $\mathrm{O}$ acervo foi acondicionado em 21 caixas do padrão do Arquivo de História da Ciência - AHC/MAST, totalizando 2,73 metros lineares de documentos, entre textuais e iconográficos, que chegaram ao MAST sem acondicionamento adequado e não higienizados. A equipe do Arquivo de História da Ciência providenciou uma higienização superficial e acondicionamento provisório, com o objetivo de inseri-lo no depósito de guarda. O arquivo já tem sido objeto de pesquisa, mesmo ainda esteja em processo de organização.

\section{Metodologia}

A tipologia documental compreende o estudo de identificação dos tipos de documentos. Esta atividade constitui a etapa que antecede todo o tratamento arquivístico, pois é a partir da qual os documentos identificados serão classificados e descritos. Portanto, constitui-se a base para a organização do arquivo. Trata-se da análise da gênese do documento de arquivo, ou seja, dos motivos pelos quais o documento foi criado, com o objetivo de identificar a natureza da atividade e o objeto da ação, somado à espécie documental.

Desta maneira, a compreensão do contexto de produção e acumulação dos documentos se faz necessária, pois permite a identificação do produtor e dos tipos documentais que compõe o arquivo. Para identificar as espécies e tipos documentais do Arquivo Helmut Sick está em andamento o estudo de identificação da tipologia documental deste acervo. Para tanto, é imprescindível entender a biografia, história e trajetória pessoal do titular. Deste modo, a realização de uma pesquisa biográfica foi fundamental para a identificação das funções e atividades que o cientista desempenhou e para representá-las no futuro quadro de arranjo (ou classificação) do arquivo.

Os tipos documentais foram identificados a partir da suas características diplomáticas, com apoio do Glossário de Espécies e Tipos Documentais em Arquivos Pessoais do MAST (instrumento em fase de desenvolvimento), e separados de acordo com as atividades desempenhadas pelo cientista. Esta separação inicial constitui uma proposta inicial de quadro de arranjo, seguindo a metodologia do Arquivo de História das Ciências, como pode ser observado no Quadro 1:

Quadro 1 - Quadro de categorias de atividades pessoais e profissionais de cientistas

1.

ATI

VID

ADE

$S$

VIN

CUL

AD

AS

À

VID

A

PES

SOA

L

HCTE-UFRJ 
1.1 Documentos pessoais e de identificação

1.2 Relações familiares

1.3

Relações

sociais

1.4 Assuntos financeiros

1.5 Atividades de

lazer/entretenimento

1.6 Práticas religiosas

1.7 Educação

2. ATIVIDADES VINCULADAS À VIDA PROFISSIONAL

2.1

Formação

profissional

2.2

Ativ

idad

es

doc

ent

es

2.3

Ativ

idad

es

$\mathrm{ad}$

mini

stra

tiva

s de

uni

dad

es

de

pes

quis

a

2.4 Consultoria e assessoramento

2.5 Filiação

em

associações

e entidades

de classe 


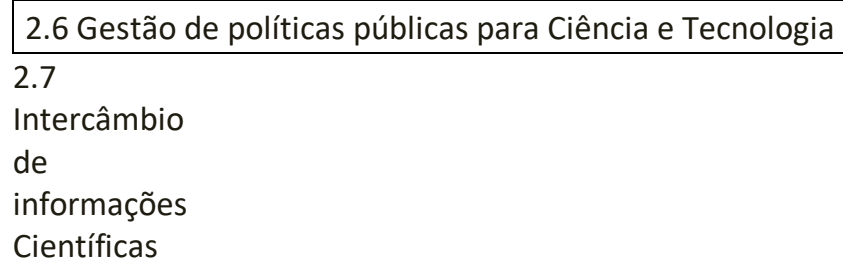

ATI

VID

ADE

$S D E$

PES

QUI

SA

EM

CIÊ

$\mathrm{NCl}$

A E

TEC

NOL

OGI

A

3.1

Ad

mini

stra

ção

da

pes

quis

a

3.2

Des

env

olvi

me

nto

da

pes

quis

3.3

Diss

emi

naç

ão

dos

resu

Itad

os

HCTE-UFRJ 
ÍTIC

AS

\author{
4.1 Relações e atividades políticas \\ 4.2 \\ Atuação \\ partidária
}

Fonte: Arquivo de História das Ciências - MAST/MCTIC

$\mathrm{O}$ arquivo pessoal de cientista como fonte de pesquisa

Os arquivos pessoais de cientistas são formados pela acumulação e produção de documentos resultados das atividades da vida de seu titular. Desta maneira, anos de pesquisas estão registrados em arquivos pessoais de cientistas. Os documentos presentes em tais arquivos possuem uma importância ímpar, pois documentam atividades que dificilmente seriam registradas por arquivos institucionais. Nesse sentido, a pesquisa em andamento busca identificar e organizar os documentos tendo como base o quadro de atividades exposto anteriormente. Compreendendo a identificação tipológica como mecanismo identificador da atividade produtora de um documento é possível compreender os conjuntos documentais, o contexto de produção e o modo de pensar a vida de seu titular.

No caso específico de Helmut Sick, o tratamento em curso já apresenta resultados preliminares. Quase noventa por cento dos documentos tratados até agora, as cartas, sendo as de intercâmbio de informação científica, são a espécie e o tipo mais recorrentes. Este tipo documental foi assim nomeado pela equipe do projeto por se tratar de correspondência entre cientistas, ou entre cientista e instituições, com o objetivo de trocar informações a cerca das pesquisas desenvolvidas, incluindo até dados científicos. Estes documentos registram não apenas o diálogo e troca de informações entre indivíduo-indivíduo, como também indivíduoInstituição. Estes documentos constituem um rico material de pesquisa, pois, além de outras possibilidades, permitem acompanhar (de forma quase íntima) o desenvolvimento do pensamento científico, ou mesmo, da produção científica do titular do arquivo. Além disso, até o momento, também identificamos anotações e desenhos estritamente relacionados com as pesquisas desenvolvidas por Helmut Sick, que, a pensar de seu pioneiro protagonismo na ornitologia brasileira, podem constituir material de pesquisa e desenvolvimento deste campo do conhecimento no Brasil.

Resultados parciais e considerações finais

HCTE-UFRJ 
O trabalho de identificação documental demonstra-se um grande desafio. O gênero carta é um exemplo: a primeira vista parece um documento de fácil identificação. Contudo, nem sempre há de forma clara, a fronteira entre o assunto principal (vinculada à atividade que promoveu a criação do documento) e outros assuntos diversos (SILVA, 2015). A julgar pela presença deste tipo documental no conjunto tratado até o momento (a lembrar, cerca de 90\%) é possível estimar a dimensão e complexidade que constitui a organização do Arquivo Helmut Sick. Soma-se a isso o fato de que a grande maioria dos documentos encontra-se em outros idiomas como inglês, francês e, sobretudo, alemão, a língua materna de Helmut Sick, que abarca o maior número de itens. Os documentos produzidos nesta última língua demandam mais tempo e cuidado em sua análise e identificação devido à soma da dificuldade causada pela falta de conhecimento do idioma alemão, à complexa atividade de estudo tipológico. Também foram identificados documentos manuscritos que oferecem um desafio a mais, uma vez que, além da barreira do idioma, requisitam conhecimentos avançados em paleografia.

O contato com um conjunto documental despertou a busca por novos conhecimentos no que tange às teorias de estudo e tratamento de arquivos pessoais. Além disso, foi observado o desenvolvimento de conceitos e concepções sobre tipologia documental, pelo contato com espécies e tipos de documentos dificilmente vistos em arquivos institucionais. Soma-se a isso o desafio proposto pelo contato com idiomas estrangeiros, fato que aciona conhecimentos adjacentes ao campo de formação.

Os documentos presentes no Arquivo Helmut Sick representam a incansável produção e prática científica de um cientista apaixonado pela natureza e por sua preservação. Para Sick, o intercâmbio de informações científicas foi um importante fator de construção de conhecimento e de desenvolvimento científico, constituindo assim, um valioso recurso que permite tanto o entendimento do contexto o qual pesquisador está situado, quanto do pensamento científico. Através deste conjunto documental é possível remontar a construção e afirmação da ornitologia enquanto campo científico no Brasil, não apenas pelos métodos, práticas e outros aspectos da ciência, mas também pelos aspectos exclusivos da práxis ornitológica. O estudo do Arquivo de Helmut Sick permite a compreensão de um fazer científico e a reconstrução de sua história, promovendo a valorização da História da Ciência. O trabalho de identificação de documentos realizado no arquivo estudado revela a relação não somente de um pesquisador com a ciência e do fazer científico, mas também a relação entre indivíduo e sociedade. É possível perceber, mesmo que de forma preliminar que a organização do acervo proporcionará uma valiosa fonte de pesquisa histórica, arquivística e científica.

Referências bibliográficas

BRASIL, Arquivo Nacional. Dicionário brasileiro de terminologia arquivística. Rio de Janeiro: Arquivo Nacional, 2005. 232p.

BELLOTTO, Heloísa Liberalli. Como fazer análise diplomática e análise tipológica de documento de arquivo. São Paulo: Associação de Arquivistas de São Paulo / Arquivo do Estado, 2002 (Projeto Como Fazer, 8).

CAMARGO, Ana Maria de Almeida; GOULART, Silvana. Da teoria à prática: tempo e circunstância: a abordagem contextual dos arquivos pessoais. São Paulo: Instituto Fernando Henrique Cardoso, 2007.

SILVA, Maria Celina Soares de Mello e; SANTOS, Paulo Roberto Elian dos. Arquivos pessoais: história, preservação e memória da ciência. Rio de Janeiro: Associação dos Arquivistas Brasileiros/FAPERJ, 2012. 192p.

. Os Arquivos Pessoais como Fonte: reconhecendo os tipos documentais. In: GRANATO, Marcus (org.). MAST: 30 ANOS DE PESQUISA. Rio de Janeiro: Museu de Astronomia e Ciências Afins, v. 1, p.177-203. 2015. 
Configuração e recuperação da informação em documentos de ciência e tecnologia: estudo tipológico no arquivo pessoal do físico Bernhard Gross. Perspectivas em Ciência da Informação, v. 18, n. 3, p. 160-174, jul./set. 2013a.

Identificação de tipos documentais em arquivos pessoais: estudo no arquivo do físico Joaquim da Costa Ribeiro. Arquivo \& Administração, Rio de Janeiro, v. 12, n. 2, p. 1-88, jul./dez. 2013b.

SANTOS, Paulo Roberto Elian dos. Arquivo pessoal, ciência e saúde pública: o arquivo Rostan Soares entre o laboratório, o campo e o gabinete. In: SILVA, Maria Celina Soares de Mello e; Santos, Paulo Roberto Elian dos.

Arquivos pessoais: história, preservação e memória da ciência. Rio de Janeiro : Associação dos Arquivistas Brasileiros/FAPERJ, 2012. p. 21-50.

TRANCOSO, Márcia Cristina. Tipologia documental no arquivo pessoal do Físico Joaquim da Costa Ribeiro: estudo tipológico e classificação. Monografia de especialização do Programa de Pós-Graducação em Preservação de Acervos de Ciência e Tecnologia - PPACT/MAST. Rio de Janeiro, 2012. 


\section{CRIATIVIDADE COMO UMA DÁDIVA DO REINO VEGETAL}

Daniella Villalta - Doutoranda em Artes Visuais -EBA/UFRJ - danvita@gmail.com

Resumo

Neste breve estudo exploro a noção de criatividade como uma dádiva oferecida por algumas plantas da ampla farmacopeia indígena da região amazônica, especialmente a ayahuasca. Para tanto, apresento um breve panorama sobre a importância das imagens como fonte de inspiração e conhecimento para os povos amazônicos, e sobre a pintura amazônica atual inspirada nos conhecimentos dessa medicina ancestral a partir da obra de seu mestre maior, o artista peruano Pablo Amaringo e de seu legado para a arte visionária amazônica.

Palavras-chave: Ayahuasca. Visões. Conhecimento. Criatividade. Arte Visionária. Pablo Amaringo.

As Visões da Ayahuasca: Imagens, Conhecimento e criatividade dos Povos com Desenho. No domínio da produção de imagens visionárias no contexto ritual da ayahuasca, chamadas também de mirações, Luís Eduardo Luna, antropólogo colombiano que realizou um importante estudo sobre o xamanismo dos ayahuasqueiros mestiços da Amazônia e produziu em coautoria com o artista peruano Pablo Amaringo uma valiosa obra sobre a iconografia da ayahuasca, esclarece que as plantas visionárias têm sido fundamentais na concepção do mundo de diversas culturas há milênios e na sua expressão criativa. Conforme explica no memorial de uma exposição de artistas ayahuasqueiros realizada em 1999, na St. Lawrence University,

Muitas vezes, é por meio do uso ritual de plantas visionárias que os xamãs se submetem a sua formação e adquirem suas habilidades. Plantas visionárias também podem gerar mitos e canções de poder que permitem a comunicação com o que é normalmente invisível e são instrumentos utilizados para navegar no reino visionário. Entre algumas culturas ameríndias, plantas visionárias são a fonte de inspiração dos ricos motivos iconográficos encontrados em pintura corporal e na decoração de objetos materiais. Canções e visões, assim como visões e sonhos, são reinos intimamente ligados, sendo a manifestação de experiências sintéticas simultaneamente percebidas em muitos níveis (LUNA, 1999. Disponível em https://www.stlavu.edu/gallery/pamaringo.htm Acesso em 07/05/17).

Os desenhos visionários da ayahuasca, segundo Angelika Gebhart-Sayer (1986), têm sido explicitamente referidos a padrões específicos em diversos estudos. Os Desana (ReichelDolmatoff, 1978. apud Sayer, 1986. p.208), percebem suas visões como padrões luminosos simétricos que se sobrepõem como superfícies, múltiplas imagens luminosas, agrupadas ou não, fazendo ziguezagues ou ainda formando desenhos de redes hexagonais e quadriculados, articulados aos estímulos sonoros que podem torná-las ainda mais brilhantes. Assim também são as visões descritas pelos xamãs Shipibo-Conibo: luminosas, melódicas (levando a estados de consciência sinestésica), com projeções que resplandecem em formas geométricas. A autora ressalta que isso exclui a afirmação de que padrões geométricos ou reticulados presentes nas visões de diversos grupos sejam de ordem subjetiva ou cultural, estando ligados a um estado fosfênico que se apresenta em outros estimulantes narcóticos. No caso da ayahuasca, deve-se a uma função neural da retina, estimulada pelo alcaloide harmina. 
Os kaxinawá, por exemplo, equiparam as imagens surgidas no estado alterado da consciência, especialmente aquele induzido pelo nixi pae aos sonhos e a capacidade de perceber a espiritualidade do mundo, sendo ambas "visões verdadeiras da realidade não ordinária, onde é possível travar contato com os yuxin (LUZ, 2004. p.39)". Lagrou (2012) explica que ao relacionar o estilo formal da arte gráfica kaxinawá com os contextos rituais de seu uso, observou a relação entre um estilo de pensar, um estilo de perceber e um estilo particular de mostrar que implica em ocultar a maior parte do que poderia ser visto. Uma arte de sugerir. No caso específico do ritual de ingestão da ayahuasca pelos homens caçadores, "o desenho não é materializado, mas ativamente visualizado. O desenho possui um papel crucial na experiência porque opera a passagem de uma percepção visual para uma percepção visionária (LAGROU, 2012. p.102)".

Assim se dá a transformação visual que leva do grafismo à figuração virtual, a quimera abstrata que marca a fluidez das imagens visionárias que nunca se deixam capturar.

Para os Ashaninka, do grupo Aruák, o kamarampi, termo advindo do verbo kamarank, vomitar, designa a bebida, ao lado da expressão hananeroca, que vem de Hananerite, o rio celestial, mais ca, o cipó. Luz (2004) afirma que entre os Ashaninka,

\begin{abstract}
"Banisteriopsis caapi proporciona àquele que a usa a capacidade de ver os espíritos como eles realmente são, ou seja, em sua forma humana (...) sob o efeito da bebida, as qualidades perceptíveis do mundo aparecem como uma ilusão criada pelos 'seres poderosos', sua forma intencionalmente ilusória (Luz, 2004. p.47)”.
\end{abstract}

Ester Langdon (2004) explora as experiências dos Siona da Colômbia com o yagé e suas narrativas, e ensina que as visões advindas do uso do cipó estão intimamente ligadas à aquisição de conhecimento. O mestre xamã lidera os ritos, sendo os poderes de ver e saber essenciais para acompanhar os outros nos caminhos xamânicos. Conforme cita, "Os Siona dizem que o xamã 'dá as dicas com seus cânticos, e a gente vai vendo' o 'outro lado': suas cenas, sua beleza, suas cores, seus cheiros, seus ritmos e seus sons se tornam realidade (LANGDON, 2004. p.72)", com uma forte tradição oral, poética e performativa que embelezam a experiência de contar e ouvir.

Ayahuasca e criatividade na Arte visionária amazônica

A arte visionária amazônica está calcada num modo de ser e de viver no mundo e não está contida apenas numa produção artística altamente imaginativa ou fantasiosa. Antes, trata-se de uma produção ancorada nas experiências dos pintores visionários, pinturas testemunhais, que conforme Belaunde (2013) assinala, "são narrações visuais das experiências vividas pelo pintor, no seio de diversas práticas culturais de transmissão e geração de conhecimentos, muitas vezes conduzidas em famílias e sustentadas por meio de plantas que ocupam um lugar chave na vida ritual da Amazônia do pie-de-monte andino; (...) Portanto, mais do que usar plantas para pintar, os artistas fazem ver visões que provêm das plantas, já que essas plantas são tidas como fontes de conhecimento, memória ancestral e criatividade imagética (BELAUNDE, 2013)".

A arte visionária amazônica tornou-se conhecida pela obra de Pablo Amaringo, ayahuasqueiro peruano que no final dos anos de 1980, em Pucallpa, no Peru, fundou com o antropólogo colombiano Eduardo Luna, a quem conheceu por intermédio do etnofarmacologista Dennis Mckenna, uma escola de pintura amazônica, a Usko Ayar, con el claro objetivo de enseñar artes plásticas y promover em los niños y jóvenes valores como el respecto a la naturaleza, conservación el medioambiente y el amor a la cultura amazónica (RIVERA, 2015, p.33)".

O interesse inicial de Luna e Mckenna era conhecer as plantas mágicas do Peru, mas Amaringo argumentou que não praticava mais o xamanismo, e vendo a decepção dos dois 
pesquisadores, propôs-se a pintar tudo que a ayahuasca o havia ensinado. Em uma entrevista, quando perguntado sobre a ayahuasca ser uma planta mestra também para a arte, Amaringo afirmou acreditar que sim e que isto se dá através da pessoa que quando, sentindo o desejo de beber ayahuasca, "lo hace y surge uma inspiración, brota la creatividad, la intuición, la inteligência, el discernimento y bueno, tantas otras cosas más (RIVERA, 2015. p.38)".
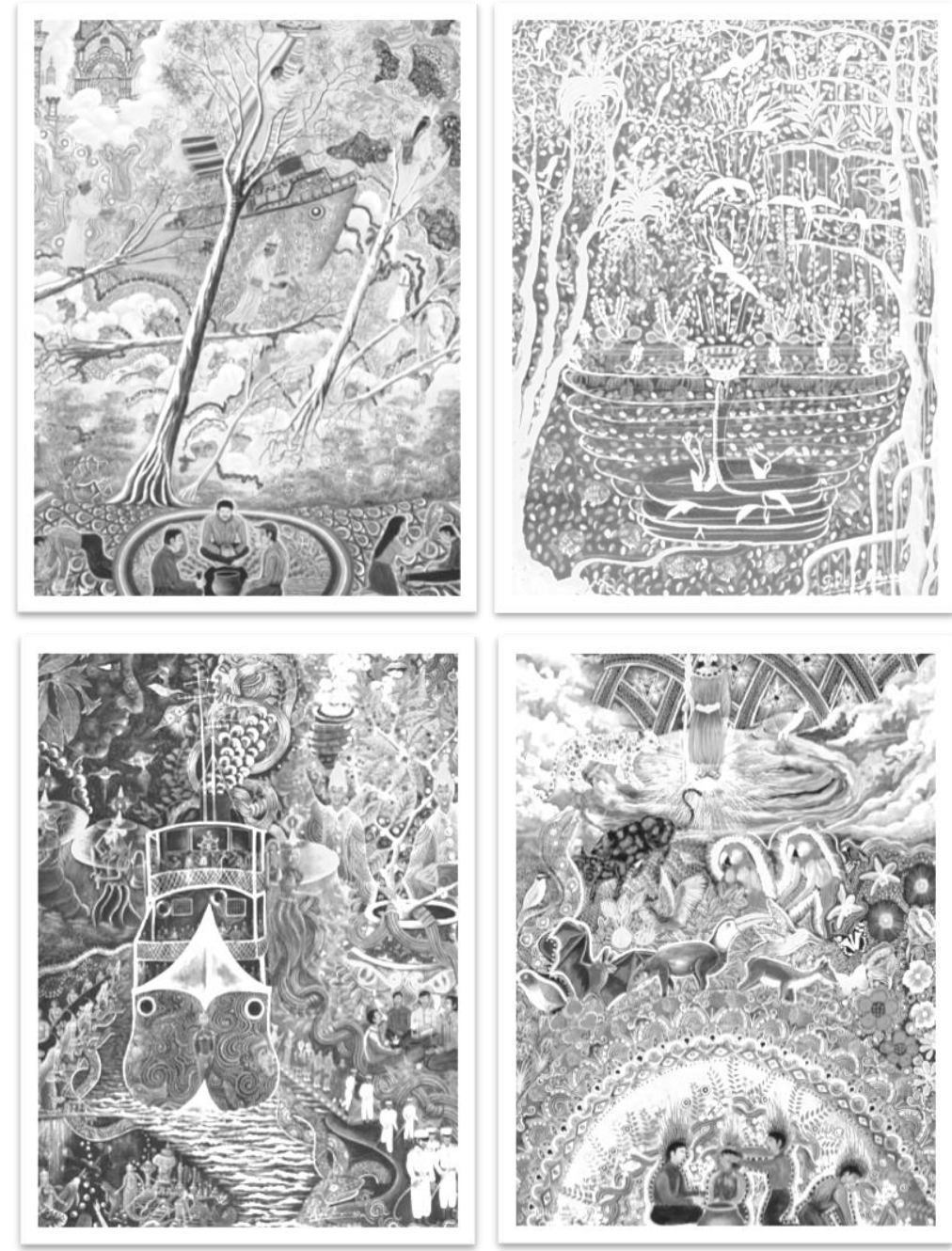

Ila, Yana Yacumama ,Barco Fantasma e Encantu Rumi - Pablo Amaringo

Um dos alunos fundadores da Usko Ayar, Anderson Debernardi é considerado um dos mais expressivos artistas da nova geração, e para alguns superou até mesmo seu mestre, Amaringo. Suas obras saíram do contexto amazônico também pelas mãos de Luna, e ganharam o mundo. Sobre uma possível relação entra suas visões, transes, criatividade e talento artístico com a ayahuasca, Debernardi relata em uma entrevista que a relação existe em tudo, que a ayahuasca é um todo, o centro de tudo para ele: o artístico, o visionário, o estético, a beleza. E acrescenta que o que ele próprio faz fisicamente é nada, pois a beleza (da experiência visionária, presumo) é enorme, com cores que não se pode comparar e com muita potencialidade para a criatividade. 

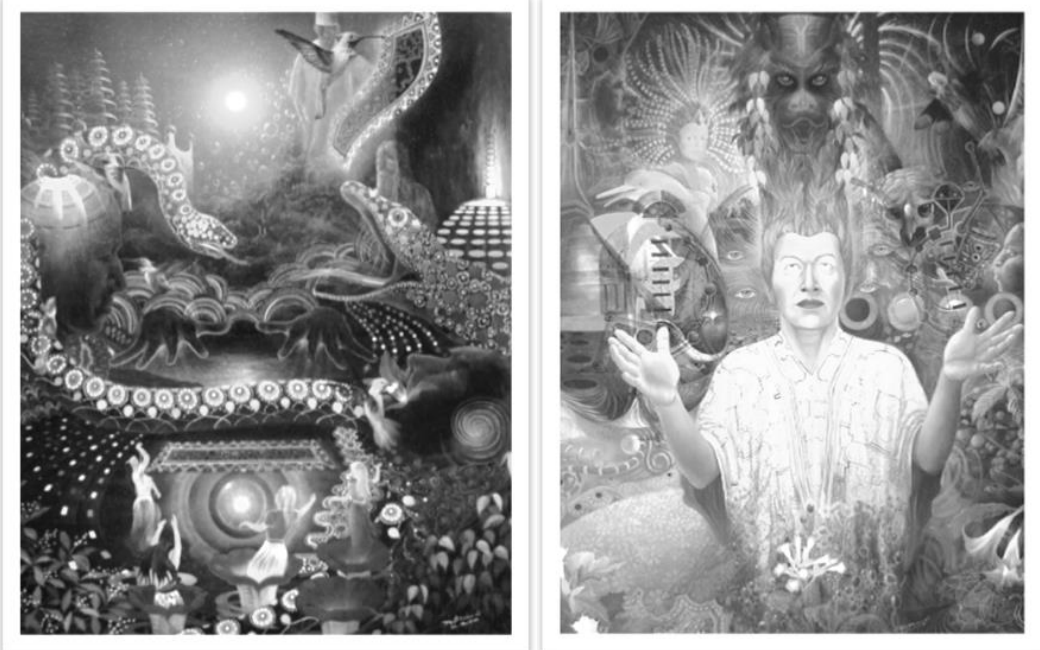

S/ título e Shaman Cosmico de Anderson Debernardi

Casilda Pinche Sánches, também artista da primeira geração na escola de arte Usko Ayar, é atualmente professora de arte em uma localidade próxima a Nauta, na região de lquitos. Em sua produção também afirma a influência advinda de suas experiências com a bebida, apresentando-a como uma arte espiritual concebida através da ayahuasca e também vinculada aos espíritos dos animais da terra, da água e do ar.
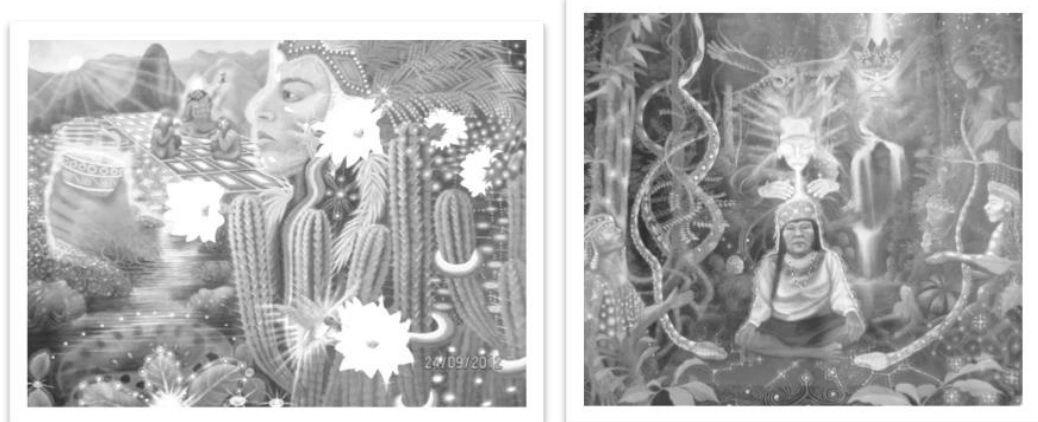

Obras sem título - Casilda Pinche Sánchez

Para Paolo del Águilla, aluno da segunda geração na escola de Amaringo, a criatividade é um dom das plantas e recorda que durante sua primeira experiência visionária, a ayahuasca personificada no corpo de uma anciã lhe entregou pincéis e um estilo próprio que o ajudou a se distinguir dos convencionalismos das escolas de arte ocidentais e também do próprio convencionalismo da escola de arte de Pucallpa. Conforme diz, lo que plasmo em mi expresión plástica es la espiritualidade , o artista chama então a sua arte de espiritual, pois afirma que la fuente de inspiración de mis trabajos es la ayahuasca y todo lo que sucede em mí cuando tomo ayahuasca (DEL ÁGUILLA, 2014). Abaixo duas de suas obras. 


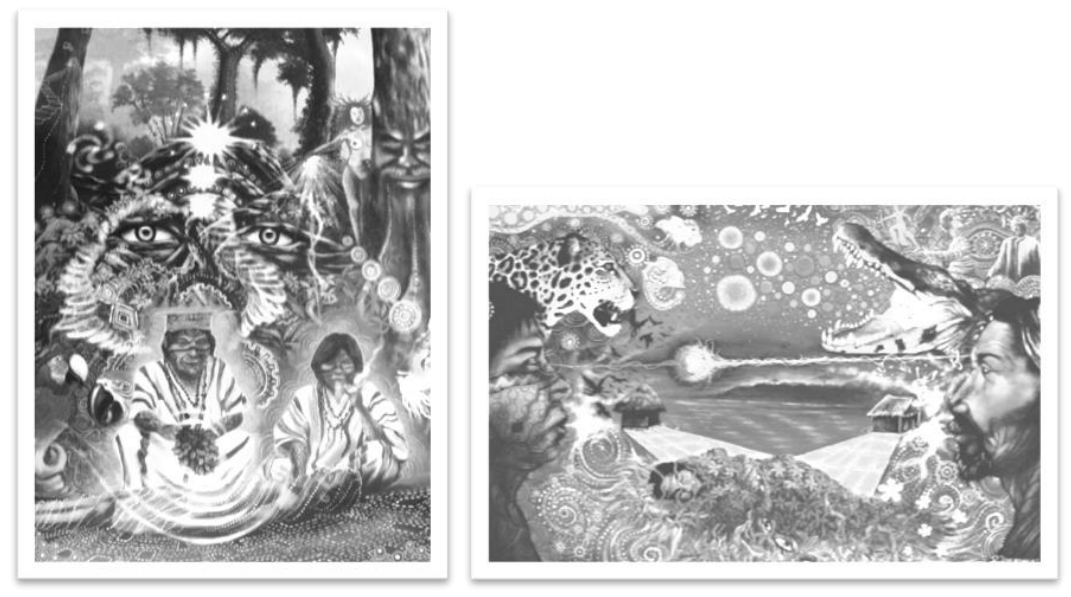

Sem título e Shamanes

Christian Bendayán, que também foi aluno de Amaringo, escreveu no prólogo de um livro comemorativo dos 25 anos da Escola que,

La creatividad y generosidad de Don Pablo no solo concebiría una infinidad de pinturas que nos invita al viaje cósmico, también nos revela los conocimientos de la medicina tradicional, detalladas ilustraciones de la naturaleza amazónica y un dogma de vida basado en valores ancestrales (BENDAYAN \& VILAR, 2013. p.6).

Um ponto que pode ser levantado é se uma planta pode tornar alguém mais criativo ou ainda, se pessoas ditas criativas podem aproveitar produtivamente suas experiências com estados alterados da consciência como fariam com eventos inspiradores do cotidiano. Gostaria de pensar a criatividade não somente como insights que rompem com modos convencionais de concepção do mundo, nem tão pouco como um dom reservados a alguns gênios. Mas gostaria de considerá-la como uma abertura ao conhecimento, àquilo que não se sabia, nem conhecia e no caso das plantas ditas professoras, a criatividade é também conhecimento que se revela e assim permite à pessoa que nela busca esse conhecimento novos arranjos, novos olhares e modos de perceber e se corresponder com a realidade, de modo a fazê-lo mais criativamente.

\section{Referências bibliográficas}

BELAUNDE. Luisa Elvira. Processos criativos na pintura visionária xamânica da Amazônia peruana: Roldán Pinedo y Enrique Casanto. 37을 Encontro Anual da ANPOCS. Disponível em http://www.anpocs.org/index.php/papers-37-encontro/st/st35?format=html Acesso em 01/jun/2017.

BENDAYAN, C. \& VILAR, A. Usko Ayar: la escuela de las visiones. Lima: PetroPeru, 2013.

GEBHART-SAYER, Angelika. "Una Terapia Estética: Los Diseños Visionarios del Ayahuasca entre los ShipiboConibo". América Indígena. XLVI:189-218,1986.

LAGROU, Els. Perspectivismo, animismo y quimeras. Mundo Amazônico 3:95-122, 2012. Disponível em http://pt.scribd.com/doc/142776735/Els-Lagrou-Perspectivismo-Anismismo-y-Quimera\#scribd Acesso em 7/set/2017.

LANGDON, Esther Jean. A tradição narrativa e aprendizagem com yagé (ayahuasca) entre os índios Siona da Colômbia. In: LABATE, Beatriz C.\&ARAÚJO, Wladimir S. (orgs.) O uso ritual da ayahuasca. Campinas: Mercado de Letras/FAPESP, 2004.

LUNA, Eduardo. Memorial de Exposição, 1999. Disponível em https://www.stlavu.edu/gallery/pamaringo.htm Acesso em 07/05/17.

LUNA, Luis Eduardo; AMARINGO, Pablo. Ayahuasca Visions: The Religious Iconography of a Peruvian Shaman. Berkeley: North Atlantic Books, 1991. 
X Congresso Scientiarum História: criatividade é a saída!

LUZ, Pedro. O uso ameríndio do caapi. In: LABATE, Beatriz C.\& ARAÚJO, Wladimir S. (orgs.) O uso ritual da ayahuasca. Campinas: Mercado de Letras/FAPESP, 2004.

RIVERA, Ronald Cachique. Arte con ayahuasca, entrevistas sobre procesos creativos. Lima: La Nave, 2015. 


\section{MUSEÓPOLIS: UM JOGO COMO CASO DE COLABORAÇÃO PARA A HISTÓRIA E FILOSOFIA DA CIÊNCIA}

WIENSKOSKI, Paula - Doutoranda no HCTE-UFRJ - Casa da Ciência da UFRJ, paula@casadaciencia.ufrj.br KOEHLER, Carlos Benevenuto Guisard - Professor do HCTE-UFRJ, cbgk@uol.com.br

\section{Resumo}

O presente trabalho apresenta como o processo de testagem de um jogo denominado Museópolis, elaborado para promover acervos encontrados em centros e museus brasileiros de várias áreas do conhecimento, deu margem à proposta de criação de outro jogo destinado à difusão de conhecimentos básicos fundamentais de Epistemologia, História e Filosofia da Ciência. Assim, esse jogo cumpriria com uma função paradidática de promover a discussão sobre temas relevantes da área, além de consolidar uma gama de novas informações pertinentes à essa área interdisciplinar de estudos.

Palavras-chave: Jogo. Divulgação Científica. Museus. Ciência. Epistemologia. História Da Ciência. Filosofia Da Ciência. Difusão De Conhecimentos. HCTE.

\section{Conhecendo museus do Brasil}

Na estruturação cultural da humanidade, o jogo é parte intrínseca da natureza do homem. Segundo o teórico Huizinga, o ser humano, que, em suas etapas evolutivas, foi denominado, pela sua capacidade de raciocínio, como Homo sapiens e, pelo fabrico de objetos, como Homo faber, é também, pela sua produção social relacionada aos jogos, o Homo ludens. Hoje, muito além do simples uso dos jogos como ferramenta educativa, o edutainment - corrente que explora recursos que educam e divertem - vem se afirmando cada vez mais como tendência na elaboração de jogos de veia comercial, oferecendo um conhecimento do qual os jogadores se apropriam voluntariamente.

Em sua segunda edição, publicada em 2009, o guia Centros e museus de ciência do Brasil foi ponto de partida para a proposta do Museópolis, um jogo elaborado como projeto final do curso de especialização em divulgação científica em parceria com a Casa da Ciência da UFRJ. O envolvimento no processo do jogo faz com que o despertar do aprendizado da ciência se dê através do conhecimento das peças reais de acervo dos museus brasileiros, organizadas em 14 áreas do conhecimento que se interrelacionam, com o intento de construir uma ideia mais abrangente de ciência. Para fazer um recorte dos acervos relacionado a este trabalho, optou-se por peças que demonstrassem as diversas manifestações da história, ciência e cultura brasileiras.

\section{Criação do jogo}

Em uma visão panorâmica, Museópolis pode ser definido como uma "corrida" entre quatro jogadores. para construir, cada um deles, um museu de uma área do conhecimento específica e dentro de determinadas condições estipuladas nos objetivos. Essas condições (tais como obter certo número de visitantes e de peças acervo, contratar pessoas de equipe etc.) são tarefas que os jogadores executam. No processo de construção do seu espaço, cada jogador é levado a conhecer as peças de acervo que vão ganhando, além das dos outros participantes, através das visitas aos outros museus. 
Os procedimentos metodológicos foram organizados em algumas etapas: elaboração da ideia geral do jogo; pesquisa de outros jogos com estruturas, dinâmicas e conteúdos similares ao do nosso jogo; criação das regras, levantamento de conteúdo; design das peças; formação de grupos focais para avaliação do jogo; entrevistas; análise dos resultados e reformulação dos protótipos e obtenção de um produto mais acabado.

A dinâmica do jogo se baseia em elementos de sorte (ganhos nas casas do tabuleiro, uso de dados e cartas de sorte ou revés), e na estratégia da montagem dos espaços expositivos (na escolha do acervo, na contratação de equipe etc.). Além disso, os participantes também ganham ao visitar os museus concorrentes, quando podem ganhar bônus ao responder a perguntas sobre as peças em exibição.

No desenvolvimento da pesquisa, procuramos conhecer alguns teóricos cujos trabalhos relacionados ao jogo e à sua temática forneceram diretrizes para a tomada de decisões no processo de elaboração do Museópolis. Buscamos a instrumentalização necessária - teórica e técnica -, para a criação da estrutura, do conteúdo e design do jogo. Este estudo experimental baseou-se em uma abordagem qualitativa definida pelo público-alvo e pela aplicabilidade dos testes.

\section{O conteúdo}

Primeiramente, foram escolhidos os temas aos quais as peças seriam vinculadas, a partir das áreas do conhecimento definidas pelo CNPq: antropologia; arte; astronomia; biologia; botânica; física; geociências; história; história natural; literatura; química e zoologia. Além dessas, foram criadas outras duas áreas: descobertas e personalidades.

Em seguida, realizou-se um levantamento dos museus e dos seus sítios na Internet, para a escolha dos objetos. Escolhidas as peças, foram realizadas pesquisas para elaboração dos textos, perguntas e respostas que deveriam constar nas cartas, com uso de linguagem acessível e evitando as simplificações.

Cada carta de acervo possui um texto que relata um pouco sobre a peça, além de seis perguntas e respostas múltipla-escolha, uma foto do objeto ou relacionada ao assunto e, ainda, a informação do local onde a peça pode ser visitada.

Os textos foram criados com o objetivo de funcionarem como uma espécie de etiqueta para as peças, com linguagem acessível, mas sem abrir mão dos conceitos teóricos mais importantes e evitando as armadilhas das simplificações. Esse trecho, escrito por Gouvêa (2005), referindo-se à abordagem dos textos sobre ciências para crianças, se aplica bem ao nosso pensamento:

[...] a apresentação de conceitos científicos [...] possibilita o contato das crianças com a linguagem e texto científicos, que têm estruturas próprias, tornando conhecidos vocábulos, processos, estruturas de pensamento, isto é, inserindo-as na cultura científica.

Design

Um dos maiores desafios encontrados durante o trabalho relaciona-se ao estigma que é geralmente atribuído à imagem de museu. Se, por um lado, várias pessoas se mostraram interessadas no tema, muitas acharam que não tinham "conhecimentos suficientes" para participar do jogo, imaginando que seria necessário um grande cabedal de conhecimentos gerais para ter um bom desempenho.

Por esse motivo, procuramos desenvolver um jogo que não medisse o nível de conhecimento dos jogadores, mas no qual as informações sobre o acervo integrassem a sua dinâmica. Para isso, foi importante criar um design atraente, que explorasse a tridimensionalidade do espaço museal e valorizasse as peças de acervo por meio de recursos gráficos refinados. 
Procurou-se explorar, gráfica e visualmente, a tridimensionalidade do espaço museal, reforçando a proposta do jogo. O principal recurso gráfico do jogo é o tabuleiro, por meio do qual se busca a imersão do jogador no espaço arquitetônico do museu, território que representa um ambiente urbano e social. A manipulação dos componentes colocados sobre o tabuleiro, a forma como ele é percorrido e a representação do elemento humano em seu interior reforçam essa intenção.

No desenrolar do jogo, cada participante, lançando dois dados, percorre um trajeto à volta do tabuleiro, onde estão localizados os museus concorrentes. Em cada casa, há uma ação a ser feita e ele pode avançar ou recuar casas; sortear cartas de sorte/revés ou, ainda, ganhar peças de acervo, notas de investimento (a moeda corrente do jogo) ou visitantes. As cartas de sorte/revés revelam algumas atividades do cotidiano de um museu, trazendo benefícios ou fazendo o jogador enfrentar problemas e desafios.

A avaliação foi feita através de rodadas do jogo com grupos focais de três ou quatro jogadores, seguida de entrevistas sobre a atividade. Após cada sessão, a entrevista abordava questões sobre o conceito, a jogabilidade e o design.

O resultado foi imensamente satisfatório, não apenas por chegar a uma proposta de produto, mas também porque o interesse demonstrado pelas peças de acervo sugere que o jogo pode contribuir para despertar o interesse pelos espaços que as preservam. Foi destacado o interesse pelas peças e pela abordagem do conteúdo, considerado um diferencial entre outros jogos voltados para o aprendizado de ciência.

Um desafio: integrar conceitos sobre História e Filosofia da Ciência

Com o jogo pronto, iniciou-se uma nova fase de testes, com o intuito de aperfeiçoar o protótipo e vários grupos de diferentes naturezas foram convidados a conhecer o jogo. Algumas pessoas, que eram (ou foram) alunos do Programa de Pós-graduação HCTE/UFRJ, levantaram questões interessantes sobre o conteúdo do jogo e compartilharam suas experiências pessoais ao ingressarem no programa de pós-graduação. Por não haver uma graduação específica em história, filosofia ou epistemologia da ciência, eles falaram das suas dificuldades ao entrar em contato pela primeira vez com conteúdos abordados nas disciplinas, nos textos, em palestras etc. independente de suas graduações originais.

Surgiu então o desafio de se criar um novo jogo (nome provisório: Aventuras na Ciência), partindo dos mesmos conceitos de jogabilidade do Museópolis, mas não sendo simplesmente uma "versão" do jogo com uma nova temática. A nova proposta é a de divulgar uma bibliografia básica existente nas temáticas relacionadas à história e filosofia da ciência, bem como da epistemologia, fazendo uso de um conteúdo baseado em algumas discussões básicas da temática. Foram levantados algumas questões a serem abordadas:

- Demarcação da Ciência;

- Formas de construção do conhecimento científico;

- Mitos e Citações populares na Ciência;

- Conceitos de revolução, paradigma e evolução de teorias científicas;

- Biografias de cientistas e filósofos da ciência;

- Concepções de conhecimento e suas formas de descrever o universo;

- Noções de ciência em outras culturas;

- Influências externalistas sócio-culturais na ciência;

- Abordagem de diferenças entre ciência e tecnologia;

- O papel do observador na concepção de ciência,

- Escolas epistemológicas

- Metodologia científica; 
- Criação e validação de teorias;

- Teoria x experimento;

- Marcos da ciência que mudaram as visões de mundo.

O objetivo principal do jogo é o de divulgar conceitos propostos por cientistas e filósofos através de suas obras. Alguns dos autores levantados para serem incluídos seriam: Platão, Aristóteles, Galileu Galilei, Isaac Newton, David Hume, Immanuel Kant, J.C. Maxwell, Albert Einstein, Niels Bohr, Werner Heisenberg, Paul Dirac, Karl Popper e Thomas Kuhn entre outros. A próxima etapa será constituir um grupo de pesquisa e trabalho para estruturar o jogo, levantar o conteúdo e levar à novas testagens com a finalidade de confirmar se esta atividade contribui para a compreensão pública do que seja a ciência, seu papel central na cultura universal e aspectos referentes à construção do conhecimento científico.

\section{Bibliografia}

Centros e Museus de Ciência do Brasil. Rio de Janeiro: Museu da Vida, Casa da Ciência e Associação Brasileira de Museus e Centros de Ciência, 2009.

EDITORA ABRIL. Os melhores jogos do mundo. São Paulo: Editora Abril, 1978.

GOUVÊA, Guaciara. A revista Ciência Hoje das Crianças e práticas de leituras do público infantil. In:

MASSARANI, L. (org.) O Pequeno Cientista Amador - a divulgação científica e o público infantil. Rio de Janeiro: Casa da Ciência/UFRJ, Museu da Vida/Fiocruz, Vieira \& Lent, 2005.

SCHALL, Virgínia Torres. Histórias, Jogos e brincadeiras: alternativas lúdicas de divulgação científica para crianças e adolescentes sobre saúde e ambiente. In: MASSARANI, L. (org.) O Pequeno Cientista Amador - a divulgação científica e o público infantil. Rio de Janeiro: Casa da Ciência/UFRJ, Museu da Vida/Fiocruz, Vieira \& Lent, 2005.

HALABAN, Sérgio; ZATZ, André. Conversa com Mário Seabra. In:

http://www.ludomania.com.br/Variedades/Seabra_Conversa.htm - acessado em 20/08/2009. 


\section{LITERATURA E QUÍMICA: POSSÍVEIS INTERAÇÕES}

Pablo Wolf Oliveira - Mestrando em Ensino de Química - PEQui - IQ-UFRJ - pablo.wolf1984@gmail.com Nadja Paraense dos Santos - Professora HCTE/ROFQUI - IQ/UFRJ,

Resumo

O presente trabalho mostra a importância de pensarmos no ensino de forma a buscar romper barreiras disciplinares e procurar entender o ser humano e o mundo em que ele vive através da integração de saberes de diferentes áreas do conhecimento. Pensando no livre trânsito de saberes entre as chamadas cultura científica e cultura humanística e em um ensino de Química integrado às duas culturas e que fomente o questionar por parte de estudantes e professores, selecionou-se três textos literários e pontuou-se brevemente algumas questões que podem ser levantadas a partir deles e alguns conteúdos de Química relacionados. O trabalho pontuou possibilidades relevantes para o ensino de Química na visão humanística.

Palavras-chave: Ensino. Química.Literatura.

1 Introdução

É fundamental a discussão sobre o significado que o ensino de ciências, e especificamente o ensino de Química, tem para o estudante. Muito se tem falado sobre um ensino limitado à apresentação e aplicação de conceitos, fórmulas e regras de nomenclatura, e que felizmente tem evoluído para o uso de exemplos do cotidiano, a contextualização e a interdisciplinaridade. Entretanto, também é importante buscar entender se o ensino apresentado ajuda o estudante a compreender o ser humano e o mundo em que ele vive e a perceber a complexidade que envolve esta relação.

Esse entendimento de mundo não pode ser conseguido se o conhecimento for dado apenas de forma compartimentada, como se não fosse preciso diferentes saberes para lidar com a realidade, que não é simples, mas complexa, e cujo entendimento depende de múltiplos fatores interligados.

Edgard Morin propõe a reforma do pensamento ao apresentar o problema da fragmentação dos saberes, ou seja, do isolamento desses em disciplinas, e coloca a necessidade de trabalhar esses saberes de forma transdisciplinar, o que condiz com o entendimento da realidade complexa.

Morin (2005) afirma que os desenvolvimentos disciplinares das ciências possibilitaram uma eficiência produtiva com a divisão do trabalho, entretanto, não possibilita que o aprendiz contextualize e integre esses conhecimentos.

O pensamento que recorta, isola, permite que especialistas e experts tenham ótimo desempenho em seus compartimentos, e cooperem eficazmente nos setores não complexos de conhecimento, notadamente os que concernem ao funcionamento das máquinas artificiais; mas a lógica a que eles obedecem estende à sociedade e às relações humanas os constrangimentos e os mecanismos inumanos da máquina artificial e sua visão determinista, mecanicista, quantitativa, formalista, e ignora, oculta ou dilui tudo que é subjetivo, afetivo, livre, criador (MORIN, 2005, p.15).

Castro (2015) aponta a época da globalização em que estamos vivendo caracterizando-a pelo domínio dos conhecimentos técnicos na sociedade e na vida das pessoas e expõe o paradoxo de como equilibrar o desenvolvimento técnico com a valorização do humano. Além disso, alerta sobre o lugar do ser humano nessa sociedade dominada pela técnica. 
O conhecimento dito técnico-científico nunca é neutro, embora nele o valor determinante seja a eficiência do funcional. Mas eficiência para quê? O perigo está em aliciar e tornar o ser humano apenas mais um instrumento funcional num mundo funcional, fazendo do ser humano apenas "recurso técnico" e um consumidor (CASTRO, 2015, p.25).

Nessa perspectiva, é possível fazer uma crítica à separação entre a cultura humanística, que para Morin (2005) é aquela que estimula a reflexão sobre as grandes interrogações humanas, e a cultura científica, que está relacionada à busca da verdade objetiva, exterior (MORA, 2003). Para esta autora, o fluxo de conhecimento e de compreensão deve circular entre as duas culturas.

Gurgel e Watanabe (2017) defendem o ensino da ciência como cultura, entendendo a primeira como parte da cultura de uma sociedade, e então fazem um trabalho envolvendo narrativas no ensino de Física, com o objetivo de levarem os alunos a reconhecerem a ciência como parte de sua cultura.

Castro, Fagundes e Ferraz (2014, p.19) apontam que "a realidade foi reduzida a disciplinas", mas para descobrirmos a essência do ser humano e da verdade, é preciso questionar, pois o questionar proporciona uma educação que traz liberdade ao ser humano, e destaca o papel da arte no sentido poético e dialético como convite ao questionar e ao pensar.

Na perspectiva da procura por um ensino humanista, de integração da ciência à cultura, da concepção da importância da integração de saberes e que leve o estudante a questionar, apresenta-se aqui a proposta de uso de textos literários no ensino de Química.

Silveira (2013) apresenta razões que corroboram para a defesa do potencial pedagógico de textos literários em aulas de Química, explicitando por exemplo: a possibilidade de humanizar a ciência; inserir o conhecimento científico em uma realidade complexa que vai além do conhecimento da disciplina de estudo; estimular a leitura e permitir a vivência de situações que vão além do conhecimento científico.

Sendo assim, o objetivo do presente trabalho é fazer uma breve explanação sobre o potencial pedagógico do uso de alguns textos literários no ensino de Química, pontuando questões que podem ser levantadas a partir da leitura de cada texto e conteúdos químicos que podem ser relacionados.

\section{Desenvolvimento}

A partir da pesquisa bibliográfica, procurou-se textos literários com potencial pedagógico para uso no ensino de Química. Buscou-se textos que permitam ao aluno e ao professor levantarem questões relevantes do ponto de vista humano, social, histórico, científico e também que possam servir como ponto de partida para trabalhar conteúdos de Química. Para este trabalho, foram selecionados três textos literários que serão apresentados nos três tópicos a seguir.

\subsection{Um trecho do livro "Uma aprendizagem, ou o Livro dos Prazeres".}

O romance "Uma aprendizagem ou o Livro dos Prazeres" (1969) é de autoria da escritora Clarice Lispector (1920-1977). A narrativa em terceira pessoa gira em torno da busca por si mesma da personagem Lóri, uma professora primária que se apaixona por Ulisses, professor de filosofia sábio e equilibrado, que espera o tempo necessário para que Lóri se sinta segura de se entregar a ele.

O trecho selecionado para este trabalho é uma passagem que descreve a intensa alegria de Lóri em sua passagem pelo mar. A seguir temos um pequeno trecho desta passagem: "O caminho lento aumenta sua coragem secreta - e de repente ela se deixa cobrir pela primeira onda! O sal, o iodo, tudo líquido deixam-na por uns instantes cega, toda escorrendo- 
espantada de pé, fertilizada. “(...) Com a concha das mãos cheias de água, bebe-a em goles grandes, bons para a saúde de um corpo" (LISPECTOR, 1998, p.79).

Percebe-se neste texto o potencial de se levantar questões como a composição da água do mar, a origem dos sais no mar, a possibilidade de benefícios do banho de mar para a saúde e o valor cultural da relação do ser humano com o mar.

A partir do texto, os conteúdos químicos sobre íons, compostos iônicos, soluções, soluções eletrolíticas e o estado físico do iodo podem ser trabalhados.

\subsection{Lixo}

A crônica Lixo foi escrita por Luís Fernando Veríssimo e publicada pela primeira vez em 1981 (ARAÚJO, 2014). É um diálogo entre dois vizinhos que conhecem aspectos da vida um do outro através da observação do lixo que cada um produz em suas casas.

Vale destacar aqui o seguinte trecho do diálogo:

“- Só não fiquei com eles porque, afinal, estaria roubando. Se bem que, não sei: o lixo da pessoa ainda é propriedade dela?

“-Acho que não. Lixo é domínio público.

“-Você tem razão. Através do lixo, o particular se torna público. O que sobra de nossa vida privada se integra com a sobra dos outros. O lixo é comunitário. É a nossa parte mais social. Será isso?" (VERÍSSIMO, 2013, p.90).

A partir do texto, é possível levantar questões sobre os tipos de lixo, as suas características, o seu aproveitamento pelo ser humano, o seu destino final, a sociedade de consumo que vivemos, a responsabilidade de cada um pelo lixo que gera e como o lidar com o lixo afeta a vida do ser humano.

Este texto serve como ponto de partida para a investigação dos diferentes materiais encontrados no lixo e a partir dessa investigação é possível trabalhar conteúdos químicos tais como propriedades específicas da matéria (temperatura de fusão e de ebulição, densidade, solubilidade), transformações físicas e químicas e processos de separação de misturas.

\section{3 Água de Nagasáqui}

O conto de ficção científica Água de Nagasáqui foi escrito por Domingos Carvalho da Silva em 1965 (CAUSO, 2007). Este conto apresenta a narração de um sobrevivente, de uma cidade próxima a Nagasáqui, do lançamento de bomba atômica na Segunda Guerra Mundial que bebe a água de um riacho da região e desde então passa a ser a causa da morte de várias pessoas por ter bebido a água " nagasaquiada". Assim, o personagem descreve:

"Meteram-me numa ambulância, talvez para que, confinado em alguma cela de cimento, eu acabasse os meus dias. (...) Num dos meus camarotes de classe geral eu repousava com este esqueleto radioativo que continuava a luzir dentro de mim" (SILVA, 2007, p. 71).

O texto permite o aparecimento de questões como as causas e consequências do uso das bombas atômicas, a contaminação radioativa e a recuperação dos locais atingidos, a forma como ocorre essa contaminação, a distinção entre os fenômenos descritos no texto que de fato são reais daqueles que só ocorrem em uma história de ficção científica.

A partir do texto e da discussão das questões levantadas, é possível trabalhar conteúdos de Química tais como estrutura atômica, emissões radioativas, fusão e fissão nuclear, energia nuclear.

\section{Considerações finais}

Este trabalho pontuou possibilidades de se trabalhar, a partir de textos literários, questões relevantes tanto dentro da cultura científica quanto na cultura humanística, questões essas 
que não fazem parte de apenas uma área de conhecimento, mas que precisam da colaboração e da integração de diferentes saberes. Mostrou-se também alguns conteúdos de Química relacionados ao texto e às possíveis questões levantadas que, embora não possam dar conta sozinhos da complexidade das questões levantadas, podem contribuir para uma melhor compreensão das mesmas.

Espera-se que o trabalho em aulas de Química com os textos literários aqui apresentados contribuam para uma formação humanística do estudante ao mesmo tempo em que os conteúdos científicos são construídos.

\section{Referências bibliográficas}

ARAÚJO, Lucy Aparecida Melo. As marcas de oralidade na crônica de Luís Fernando Veríssimo. Verbum: Caderno de pós-graduação, São Paulo, n. 6, p.69-82,2014. Disponível em:

https://revistas.pucsp.br/index.php/verbum/article/viewFile/19074/14485. Acesso em: 21 set.2017.

CASTRO, Manuel Antônio de; FAGUNDES, Igor; FERRAZ, Antônio Máximo (org.). O Educar poético. Rio de Janeiro: Tempo Brasileiro,2014.

CASTRO, Manuel Antônio de. Leitura: questões. Rio de Janeiro: Tempo Brasileiro,2015.

CAUSO, Roberto de Sousa (ed.). Os melhores contos brasileiros de ficção científica. São Paulo: Devir,2007.

GURGEL, Ivan. WATANABE, Graciella. A elaboração de narrativas em aulas de Física. A aprendizagem em Ciências como Manifestação Cultural. São Paulo: livraria da Física, 2017.

LISPECTOR, Clarice. Uma aprendizagem ou o livro dos prazeres. Rio de Janeiro: Rocco, 1998.

MORIN, Edgar. A cabeça bem-feita. Repensar a reforma. Reformar o pensamento. 11 ed. Rio de Janeiro: Bertrand Brasil,2005.

MORA, Ana María Sánchez. A divulgação da ciência como literatura. Rio de Janeiro: Casa da Ciência: Editora UFRJ,2003.

SILVA, Domingos Carvalho da. Água de Nagasáqui. In: CAUSO, Roberto de Sousa (ed.). Os melhores contos brasileiros de ficção científica. São Paulo: Devir,2007.

SILVEIRA, Marcelo Pimentel da. Literatura e Ciência: Monteiro Lobato e o ensino de Química.2013.297 f. Tese (Doutorado em Ciências) - Interunidades em Ensino de Ciências, Universidade de São Paulo, São Paulo.

VERÍSSIMO, Luis Fernando. Lixo. In: O melhor das comédias da vida privada. Rio de Janeiro: Objetiva, 2013. 


\section{HISTORICIDADE DO CONCEITO DA CONSCIÊNCIA QUÂNTICA}

Antônio Tadeu Zanotelli - Aluno especial Mestrado HCTE - antoniozanotelli@ig.com.br

Resumo

A proposta deste trabalho tem como linha central conceituar as discussões e os avanços sobre o conceito da teoria da mente e suas abordagens até o cenário da consciência quântica. $O$ problema da consciência trouxe ao longo de sua história vários conceitos, alguns deles bem divergentes. Uma das idéias deste texto é mostrar as possibilidades ou não da redutibilidade da consciência a fenômenos puramente físicos, baseada na lógica dos estados qualitativos das experiências percebidas da realidade objetiva, por exemplo, é possível que a atividade cerebral que dá suporte à consciência não seja uma função neuronal, como pregam alguns cientistas. Existe alguma relação entre consciência e a atividade cerebral? Neste breve ensaio, tento mostrar as possibilidades destes conceitos que evoluíram ao longo das décadas.

Palavras Chave: Consciência Quântica., Consciência. Microtúbulos. Neurônios. Penrose. Hameroff. Tubulinas.

\section{Abordando a Consciência}

O conceito de consciência é descrito como o estado de estar acordado e ciente do que está acontecendo ao redor, e no fato de ter um senso de si mesmo. Há uma compreensão que a Consciência implica da experiência subjetiva do mundo fenomenal interno e externo. A consciência é central também para a compreensão, significado e escolha volitiva (processo cognitivo pelo qual um indivíduo se decide a praticar uma ação em particular) com a experiência de livre arbítrio. A Consciência define nossa existência.

Camillo Golgi no séc. XIX foi o responsável por inventar uma técnica específica para corar neurônios, que ele denominou de La reazione nera (a reação negra). Como a técnica era incapaz de destacar uma separação clara entre os neurônios conectados, fez com que Golgi assumisse uma posição de que o sistema nervoso seria um reticulado no qual, sinais elétricos e químicos percorreriam de modo contínuo o tecido cerebral. A descoberta de Golgi permitiu que Wilhelm V. W. Haltz formulasse a hipótese de que as células nervosas são as unidades estruturais básicas do sistema nervoso, hipótese esta que seria demonstrada mais tarde por Cajal.

Em 1906, Santiago Ramón y Caja recebia o Prêmio Nobel por suas pesquisas a respeito da estrutura microscópica do cérebro. Uma de suas principais hipóteses era a "Doutrina do Neurônio", ele postulava que o neurônio seria a unidade funcional do sistema nervoso. Na visão clássica da atividade cerebral, as redes neuronais - formadas por neurônios conectados por meio de sinapses - seriam as responsáveis pelas diversas funções desempenhadas pelo cérebro, os processos cognitivos, afetivos, emocionais e motores. Cajal tinha o conhecimento que o cérebro contém outras células, mais numerosas que os neurônios, as chamadas "células gliais". Inicialmente conjecturava-se apenas que estas células eram mero suporte estrutural e metabólico para a atividade neuronal - daí o nome "glia". Hoje se sabe que, as células da glia, geralmente são células não neuronais do sistema nervoso central que proporcionam, suporte e nutrição dos neurônios. Os neurocientistas acreditaram por décadas que os neurônios eram os responsáveis por toda a comunicação no cérebro e sistema nervoso, e que as células gliais, embora nove vezes mais numerosas que os neurônios, apenas os alimentavam. Novas 
técnicas de imagem e instrumentos de "escuta" mostram que as células gliais se comunicam com os neurônios e umas com as outras, e têm a capacidade de modificar esses sinais nas fendas sinápticas entre os neurônios e podem até mesmo influenciar o local da formação das sinapses, conseqüentemente muitos acreditam que as células gliais podem ser essenciais para o aprendizado e para a construção de lembranças, além de importantes na recuperação de lesões neurológicas.

O advento da Física Quântica causou impacto na evolução da própria Física. Há toda uma controvérsia criada pelas dificuldades conceituais da interpretação dos fenômenos quânticos e a figura do observador é que dá sentido a várias medições.

Em geral, os enfoques quânticos não excluem o funcionamento do cérebro através de redes neurais, mas consideram que, complexidade somente não explica tudo e situam efeitos quânticos como centrais para a descrição da emergência ou geração do eu consciente. Há modelos inclusive que negam que a consciência seja uma propriedade emergente de redes neurais operando além de certo nível crítico de complexidade, mas consideram que a dinâmica cerebral, na verdade, organiza e faz aflorar algo que já é uma propriedade intrínseca da natureza. Uns dos modelos mais discutidos atualmente acreditam na possibilidade de que a própria consciência possa operar com base em princípios ou efeitos quânticos.

A seguir detalho alguns modelos e os mecanismos elaborados por seus pesquisadores:

\section{Modelo de Fröhlich-Marshall-Zohar}

Segundo Herbert Fröhlich (U. Liverpool, 1967), físico especialista em supercondutividade a altas temperaturas, seria possível ocorrerem estados quânticos coletivos em sistemas biológicos, ele argumenta que existiriam efeitos vibracionais dentro das células correspondentes a radiação eletromagnética na faixa de microondas, resultantes de um fenômeno de coerência quântica biológica que teria origem em grandes quantidades de energia disponibilizadas por atividades metabólicas. Em consequência disto, ele sugeriu a possibilidade de que estados de coerência quântica de grande alcance, semelhantes aos observados em supercondutividade e em lasers, chamados de condensados de Bose-Einstein, poderiam existir mesmo a temperaturas tão altas como as características de sistemas biológicos. Fröhlich identificou freqüências de excitação coerente da e as denominou transições acústico-conformacionais, ou fônons coerentes (bombeados). Tais estados coerentes são chamados 'condensados de Bose-Einstein' na Física Quântica. Marshall em 1989 sugeriu que eles fornecem os estados quânticos macroscópicos que suportam a integração (binding) da consciência.

\section{Modelo de Eccles e Beck}

Sir John Eccles, ganhador do prêmio Nobel de Fisiologia e Medicina de 1963, propôs um modelo, posteriormente aperfeiçoado em parceria com Frederick Beck, físico teórico, pelo quais os efeitos quânticos ocorreriam nos terminais sinápticos dos neurônios e seriam moduladores das funções cerebrais. O mecanismo central estaria relacionado à exocitose, processo pelo qual as moléculas neurotransmissoras contidas em minúsculas vesículas são expelidas através da passagem sináptica entre neurônios. A proposta era que a chegada de um impulso nervoso ao terminal de um axônio (prolongamento tubular através do qual os neurônios se comunicam) não induziria invariavelmente as vesículas a expelirem seus neurotransmissores através da sinapse, como se pensava. Isso seria controlado por uma espécie de "gatilho quântico", associado a transferências de elétrons através de um fenômeno denominado tunelamento, que promoveria alterações conformacionais nas membranas controladoras do mecanismo de deliberação de neurotransmissores. Com isso, efeitos 
quânticos seriam os controladores efetivos de toda a dinâmica cerebral, embora não fique claro como é que tal mecanismo implicaria na emergência da consciência.

\section{Modelo de Hameroff-Penrose}

Dois dos principais propositores da Consciência Quântica são: Stuart Hameroff, médico, e Roger Penrose, físico-matemático de Oxford que atua na área de Cosmologia e Gravitação e foi ganhador do prêmio Wolf juntamente com Stephen Hawking. Na década de 1980, Penrose e Hameroff (separadamente) começaram a abordar estas questões, contra os pontos de vista tradicionais. Hameroff havia ficado intrigado com as atividades organizadas aparentemente inteligentes dentro das células realizadas por polímeros de proteínas chamadas microtúbulos (HAMEROFF E WATT, 1982; HAMEROFF, 1987). Os principais componentes do citoesqueleto estrutural da célula, os microtúbulos também são os responsáveis na separação precisa dos cromossomos na divisão celular, um comportamento complexo do Paramecium, e regulação das sinapses dentro de neurônios do cérebro. A função inteligente e a estrutura de rede periódica dos microtúbulos sugeriram que podem funcionar como algum tipo de computador biomolecular. Quer individualmente, quer nessas matrizes maiores, os microtúbulos são responsáveis pelos movimentos celulares e intracelulares que requerem uma organização espaço-temporal inteligentes. Os microtúbulos têm uma estrutura cristalina comparável aos sistemas computacionais.

Anos mais tarde, Penrose, em parceria com Hameroff, formulou um modelo, procurando localizar as estruturas cerebrais onde ocorreriam os tais efeitos quânticos. Nesse modelo, eles principiam por correlacionar certas características da psique com atributos de sistemas quânticos. Por exemplo: 1) A sensação de um self unitário (the binding problem): isso é atribuído a coerência quântica e não-localidade; 2) Livre arbítrio: decorrência de um processo randômico, não determinístico; teria a ver com indeterminação quântica; 3) Intuição: processamento não-algorítmico, computação via superposição quântica; 4) Diferença e transição entre estados não-conscientes e consciência - colapso da função de onda.

O conceito deles é que a consciência poderia "emergir" como um estado quântico macroscópico a partir de certo nível crítico de coerência de eventos acontecendo em certas estruturas subneurais, denominadas microtúbulos, que compõem o esqueleto neuronal. Os ingredientes essenciais do modelo são os seguintes: 1 ) Coerência quântica e auto-colapso (redução objetiva, que ocorreria ao se atingir certo limiar de massa-energia críticos, relacionado à gravidade quântica) da função de onda são essenciais para a emergência de consciência e isto acontece nos microtubulos; 2) Tubulinas, subunidades dos microtúbulos, são acopladas por eventos quânticos internos e interagem cooperativamente entre si; 3) O citoesqueleto é uma rede de polímeros protéicos dentro dos neurônios que estabelece a sua forma, mantém conexões sinápticas e cumpre outras tarefas essenciais. Os microtúbulos são os componentes principais do citoesqueleto, são cilindros poliméricos ocos compostos de proteínas conhecidas como 'tubulinas'. 4) Deve ocorrer coerência quântica entre tubulinas através de um bombeamento de energia térmica e bioquímica, provavelmente a La Fröhlich; 5) Durante o processamento pré-consciente, ocorre um processo de computação/superposição quântica nos microtúbulos, até que um auto-colapso acontece em função de efeitos relacionados à Gravitação Quântica; 6) Conexões via MAPs (microtubuleassociated proteins) sintonizam e "orquestram" essas oscilações quânticas.

Um fato interessante é que comportamentos cognitivos de organismos unicelulares. Protozoários como Paramecium podem nadar, encontrar comida e companheiros, aprender, lembrar e fazer sexo, tudo isso sem a computação sináptica (SHERRINGTON, 1957).

Hameroff argumenta que o processamento quântico em microtúbulos dentro dos dendritos e as gap junctions entre os dendritos são a principal chave da consciência. O principal 
argumento contra o processamento quântico no cérebro sempre foi que qualquer coerência quântica no cérebro seria decoerente mais rápido do que o tempo necessário para qualquer processo biológico útil. Hameroff aceita que este é, em princípio, um argumento válido. No entanto, Hameroff alega que os microtúbulos podem ser resguardados a partir do seu ambiente por um estado gelatinoso não-líquido ordenado que surge no interior neuronal. Outra objeção ao processamento quântico é que mesmo se surgisse em um neurônio, seria difícil para ele se comunicar através do cérebro. Isso é contrabalançado pela sugestão de que poderia haver um túnel quântico em junções de gap entre os neurônios. Nos últimos anos, 'gap junctions' foram descobertos no cérebro e estes novos conceitos estão sendo muitos mais difundidos do que antes, também estão correlacionados com a sincronia gama de $40 \mathrm{~Hz}$. A sincronia está envolvida em uma série de atividades cerebrais, incluindo a percepção do som, SONHO REM (dormindo), atenção, memória de trabalho, reconhecimento facial e percepção somática. A sincronia gamma diminui durante a anestesia geral e retorna ao acordar a partir desta. Hameroff considera a sincronia gama como o melhor correlato geral da consciência. Muitos receptores pós-sinápticos enviam sinais para o citoesqueleto dendrítico. Gray e Singer, 1989, encontraram oscilações gamma coerentes no cérebro que dependiam da estimulação visual. Sugeriu-se que essa sincronia poderia resolver o problema de ligação (binding problem), que é o problema de como os diferentes inputs no cérebro são ligados em uma única experiência consciente. Sugeriu-se que a sincronia refletisse a atividade de uma assembléia relevante de neurônios. Sabe-se que a sincronia gama correlaciona-se com a atividade dendrítica ao invés do salto axonal.

Hameroff aponta para 'gap junctions' como uma alternativa para sinapses em conexões entre neurônios. Os neurônios que são conectados por gap junctions e criam-se de forma síncrona. As 'gap junctions' desempenham um papel mais importante no cérebro adulto do que se supunha anteriormente. Numerosos estudos mostram que 'gap junctions' mediam a sincronia gama. Um neurônio pode ter muitas conexões de junção de lacuna, mas nem todas elas são necessariamente abertas ao mesmo tempo. A abertura e o fechamento das junções podem ser regulados pelos microtúbulos.

O citoesqueleto dos dendritos é distinto daquele encontrado em células fora do cérebro e do citoesqueleto encontrado nos axônios dos neurônios. Os microtúbulos nos dendritos são mais curtos do que os dos axônios e têm uma polaridade mista, ao contrário, uniforme. Estudos demonstram que o citoesqueleto também está envolvido na transmissão do sinal. Sugere-se que a rede de microtúbulos seja bem projetada para representar e processar informações. A Tubulina deveria alternar entre duas conformações. Sugere-se que os estados conformacionais da tubulina possam interagir com a tubulina vizinha por meio de interações dipolares.

Os neurônios conectados por "junções gap" podem ser vistos como um único hiperneuron, e o hiperneuron podem ser visto como uma montagem de neurônio convencional. Em geral, Hameroff argumenta que a evidência emergente de neurobiologia se moveu em favor do modelo OR Orch durante a última década, não obstante a continuada impopularidade da teoria. Ele acha que a consciência surge nos dendritos dos neurônios que são conectados por 'gap junctions' para formar 'hiperneuron', e que estes estão relacionados com a sincronia gama. Picos axonais e sinapses na sua visão servem de entradas e saídas do processo microtubular como parte de um sistema interativo.

Assim, a sincronia detectada deriva de dendritos em vez de picos axonais.

A principal função dos dendritos é a manipulação do sinal de entrada no neurônio, o que pode resultar em um pico do axônio. No entanto, esta não é toda a história, uma vez que muitos neurônios corticais têm dendritos, mas não axônios. Aqui os dendritos interagem com outros dendritos. Também pode haver uma atividade dendrítica extensa sem picos. 
De acordo com Orch OR (Redução Objetiva Orquestrada), a redução (objetiva) não é um processo totalmente aleatório da teoria padrão, mas age de acordo com uma nova física nãocomputacional (PENROSE 1989, 1994). A idéia é que a consciência está associada com este processo OR (gravitacional), mas ocorre de forma significativa apenas quando as alternativas são parte de alguma estrutura altamente organizada, de modo que tais ocorrências de OR ocorrem em uma forma extremamente orquestrada. Só então é que um evento reconhecidamente consciente tem lugar. Por outro lado, podemos considerar que qualquer ocorrência individual de OR seria um elemento de protoconsciência (Consciência ligada à matéria. Parte de uma consciência. não se refere ao todo, o conhecimento cósmico e espiritual)

A partir de 2003, pesquisas publicadas começaram a demonstrar coerência quântica em sistemas biológicos quentes. Ouyang e Awschalom (2003) mostraram que a transferência quântica de spin através de anéis de fenilo (o mesmo que aqueles em bolsas hidrofóbicas da proteína) é aumentada a temperaturas cada vez mais quentes.

Conforme Hameroff, ele afirma que o critério para a proto-consciência é OR. Não seria razoável se referir a OR como critério para a consciência real, porque, de acordo com o esquema DP, processos OR iriam existir o tempo todo, e estariam fornecendo a aleatoriedade efetiva que é característica da medição quântica. Superposições quânticas irão continuamente atingir o limite limiar DP para OU em ambientes não-biológicos, bem como nos biológicos, e geralmente ocorrem no ambiente puramente aleatório de um sistema quântico sob medida. Em vez disso, o nosso critério para a consciência é Orch OR, condições para as quais são bastante rigorosas: superposição deve ser isolada dos efeitos de decoerência do meio aleatória por tempo suficiente para atingir o limiar DS. Eles acreditam que há evidências de que tais superposições poderiam ocorrer dentro suficientemente grandes coleções de microtúbulos no cérebro para $\tau$ ser uma fração de segundo.

Compreender a anestesia e consciência terá um significado existencial e filosófico, e fornecer novos alvos para o desenvolvimento de drogas e outras terapias destinadas a transtornos mentais, cognitivas e neurológicas.

Referências bibliográficas

PLACE, U.T (1956), "Is Consciousness a Brain Process?" British Journal of Psychology 47: 44-50. Reimpresso na coletânea BEAKLEY, B. \& LUDLOW, P. (orgs.) (1992), The Philosophy of Mind: Classical Problems /

Contemporary Issues, MIT Press, Cambridge, pp. 33-40.

HAMEROFF, S.; PENROSE, Consciousness in the Universe: Neuroscience, Quantum Space-Time Geometry and Orch OR Theory, 2014

MARTINS, Mirkos; VIZZOTO, JULIANA; LIBRELOTTO, GIOVANI - Simulando o modelo ORCH-OR através de autômatos celulares quânticos. Disponível em: http://seer.upf.br/index.php/rbca/article/viewFile/1322/1073 HAMEROFF, S.; PENROSE, R. Orchestrated reduction of quantum coherence in brain microtubules: A model for consciousness? In: Press, M., editor, Toward a Science of Consciousness - The First Tucson Discussions and Debates, p. 507-540. MIT Press. 1996.

BECK, F.;ECCLES, J.C. (1992): "Quantum Aspects of Brain Activity and the Role of Consciousness", Proceedings of the National Academy of Sciences U.S.A. 89, 11357- 61.

BECK, F.;ECCLES, J.C. (1992): "Quantum Aspects of Brain Activity and the Role of Consciousness", Proceedings of the National Academy of Sciences U.S.A. 89, 11357- 61.

HAMEROFF, S.; PENROSE, Consciousness in the Universe: Neuroscience, Quantum Space-Time Geometry and Orch OR Theory, 2014

HAMEROFF, S.; PENROSE, R. Orchestrated reduction of quantum coherence in brain microtubules: A model for consciousness? In: Press, M., editor, Toward a Science of Consciousness - The First Tucson Discussions and Debates, p. 507-540. MIT Press. 1996. 
MARTINS, Mirkos; VIZZOTO, JULIANA; LIBRELOTTO, GIOVANI - Simulando o modelo ORCH-OR através de autômatos celulares quânticos. Disponível em: http://seer.upf.br/index.php/rbca/article/viewFile/1322/1073

PLACE, U.T (1956), “Is Consciousness a Brain Process?” British Journal of Psychology 47: 44-50. Reimpresso na coletânea BEAKLEY, B. \& LUDLOW, P. (orgs.) (1992), The Philosophy of Mind: Classical Problems / Contemporary Issues, MIT Press, Cambridge, pp. 33-40. 


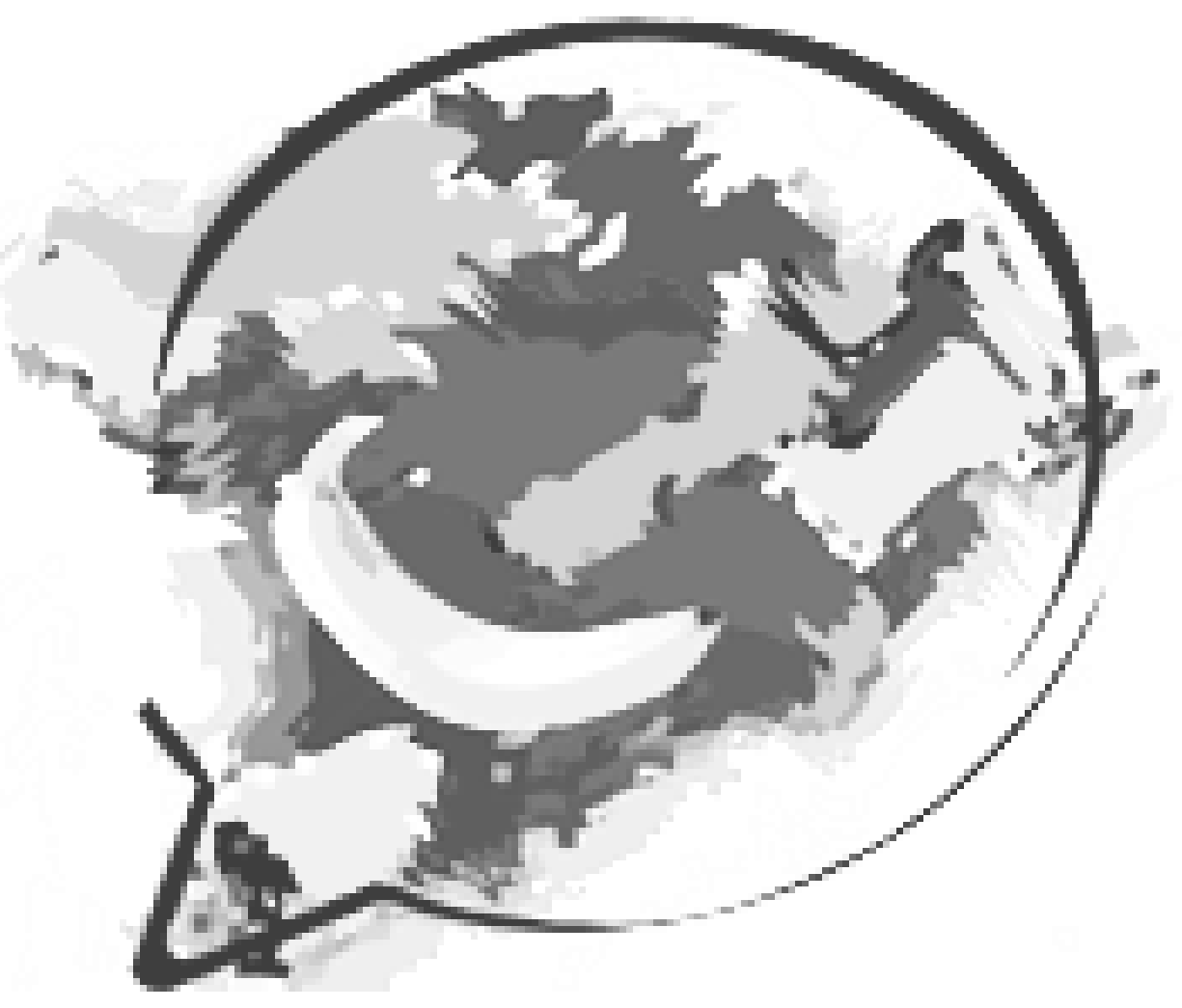

SH X - 2017

SCIENTIARUM HISTORIA $X$

Filosofia, Ciências e Artes: Conexões Interdisciplinares

Criatividade é a saída!

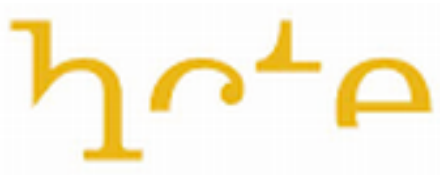

www.hcte.ufrj.br 